\title{
Metallogenesis and Tectonics of the Russian Far East, Alaska, and the Canadian Cordillera
}

\author{
U.S. Geological Survey Open-File Report 03-434
}

PREPARED IN COLLABORATION WITH:

ALASKA DIVISION OF GEOLOGICAL AND GEOPHYSICAL SURVEYS

GEOLOGICAL SURVEY OF CANADA

RUSSIAN ACADEMY OF SCIENCES

RUSSIAN MINISTRY OF NATURAL RESOURCES

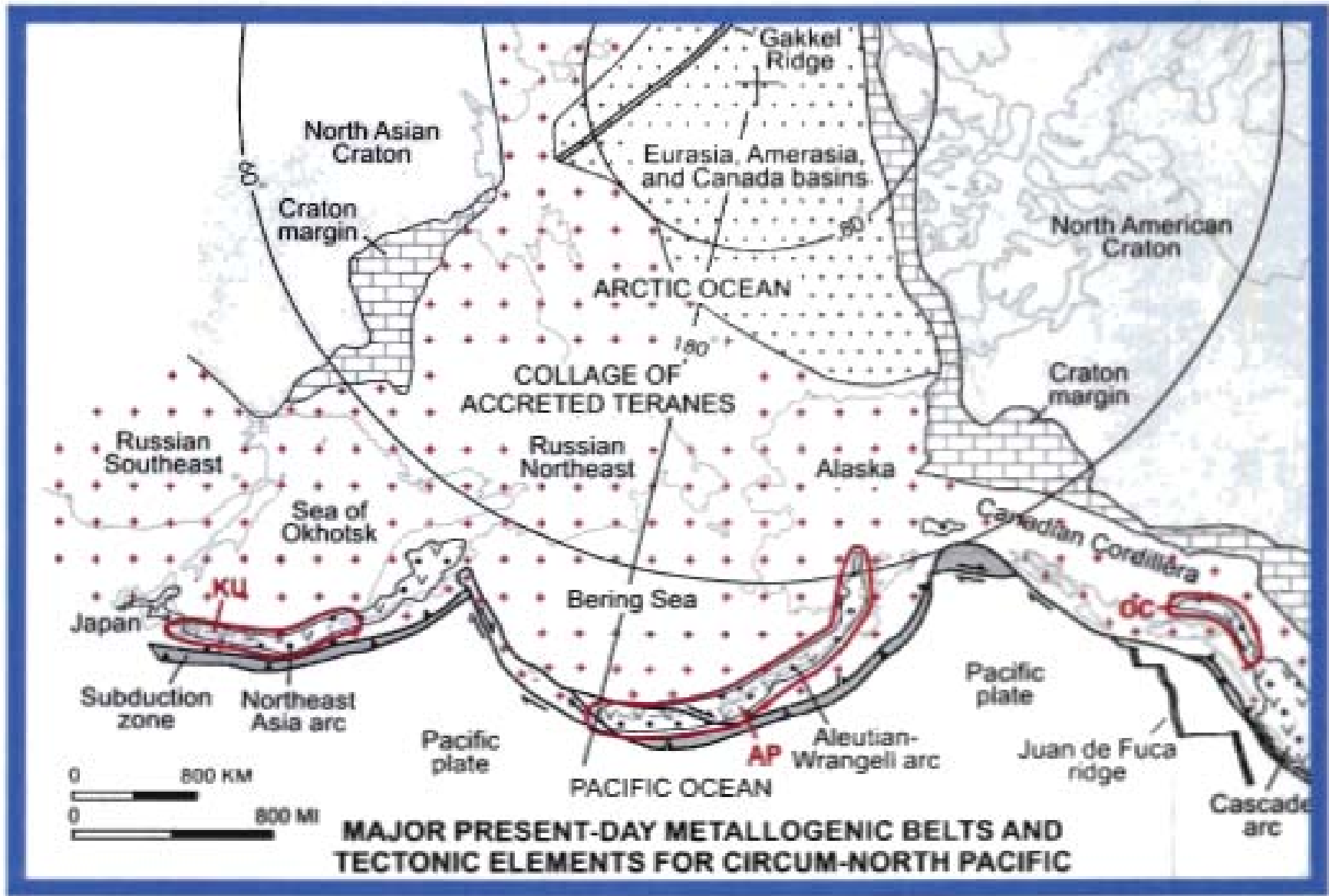

This repont is preliminary and has not been reviewed for conformity with U.S. Geological Survey

editorial tandards or with the North American Stratigraphic Code Any use of trade, firm, ot product names is for deseriptive purposes onily and does not imply endorsement by the U.S. Government

U.S. Department of the Interior

U.S. Geological Survey 


\title{
METALLOGENESIS AND TECTONICS OF THE RUSSIAN FAR EAST, ALASKA, AND THE CANADIAN CORDILLERA
}

\author{
By Warren J. Nokleberg', Thomas K. Bundtzen ${ }^{2}$, Roman A. Eremin', Vladimir V. Ratkin', \\ Kenneth M. Dawson', Vladimir I. Shpikerman" , Nikolai A. Goryachev', Stanislav G. Byalobzhesky', \\ Yuri F. Frolov", Alexander L. Khanchuk', Richard D. Koch', James W.H. Monger', Anany I. Pozdeev', \\ tlya S. Rozenblum', Sergey M. Rodionov', Leonid M. Parfenov ${ }^{9}$, Christopher R. Scotese ${ }^{10}$, and Anatoly A. Sidorov ${ }^{10}$
}

\section{OPEN-FILE REPORT 03-434}

\section{PREPARED IN COLLABORATION WITH: ALASKA DIVISION OF GEOLOGICAL AND GEOPHYSICAL SURVEYS GEOLOGICAL. SURVEY OF CANADA RUSSIAN ACADEMY OF SCIENCES RUSSIAN MINISTRY OF NATURAL RESOURCES}

'-U.S. Geological Survey, Menlo Park, California, USA

${ }^{2}$-Alaska Division of Geological and Geophysical Surveys, Fairbanks, Alaska, USA

-Russian Academy of Sciences, Magadan, Russia

-Russian Academy of Sciences, Vladivostok, Russia

-Geological Survey of Canada, Vancouver, Canada

-Russian Ministry of Natural Resourees, Geological Committee of Kamchatka, Petropavlovsk-Kamchatsky, Russia

2-Russian Ministry of Natural Resources, Geological Committee of Northeastem Russia, Magadan

"Russian Academy of Sciences, Khabarovsk, Russia

-Russian Academy of Sciences, Yakutsk, Russia

${ }^{10}$-University of Texas, Arlington, Texas, USA

"-Russian Academy of Sciences, Moscow, Russia

- Now at Pacific Rim Geological Consulting, Fairbanks, Alaska

'-Now at Russian Ministry of Natural Resources, St. Petersberg, Russia 


\section{CONTENTS}

Abstract _.................

Introduction.

Associated Project.

Metallogenic Bletts

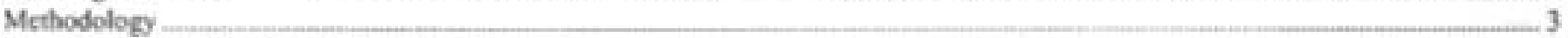

Tectonic Controls for Metallogenesis _.

Metallogenic and Tectonic Definitions _.

Mineral Deposit Models

Acknowledgements $\quad . \quad 7$

Introduction to Phanerozoic Metallogenic and Tectonic Model for the Russian Far East, Alaska, and the Canadian Cordillera tum.num... 7

Paleomagnetic Dilemma. Loci of Aceretion of Wrangellia Supenterrane _............... 8

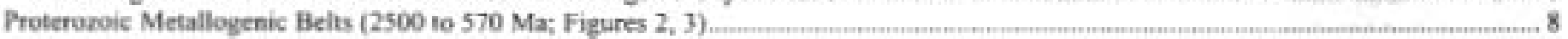

Overview - 8

Metallogenic Belts Formed During Proterozoic Rifting of North Asian Craton or Craton Margin $\ldots \ldots \ldots \ldots \ldots \ldots$

Oroek Metallogenic Beit of Ironstone and Sediment-Hosted Cu Deposits (Belt OK) West-Central Part of Russian Northeast...ini-i. 10

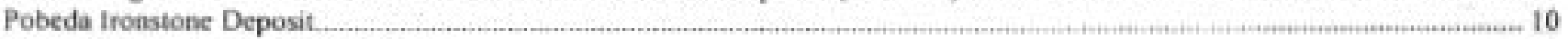

Oroek Sediment-Hosted Cu Deposit .......

Origin of and Tecionic Controls for Oroek Metallogenic Belt._._.__

Lantarsky-Dzhugdzhur Metallogenic Belt of Anortbosite Apatite-Ti-Fe and Gabbroic Ni-Cu (PGE) Deposits (Belt LD)

Central Part of Russian Far East)

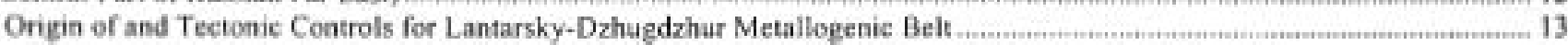

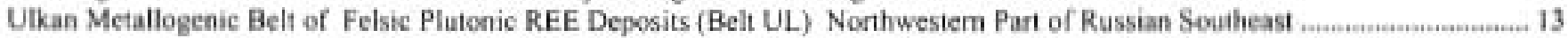

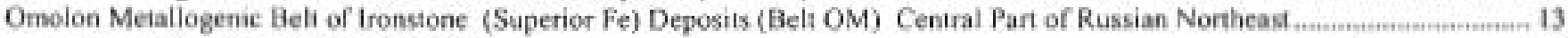

Verkhny-Omolon Ironstone Deposit ..................... 13

Origin of and Tectonic Controls for Omolon Metallogenic Belt........._........ 14

Bilyakchan Metallogenie Belt of Sediment-Hosted Cu and Basaltic Cu Deposits (Belt BI) Southwestern Part of

Russian Northeast _......... 16

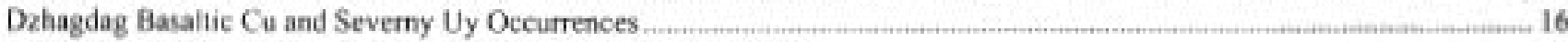

Origin of and Tectonic Controls for Bilyakchan Metallogenic Belt._._. 16

Kilbuck Metallogenic Belt of Ironstone (Superior Fe) Deposils (Belt KI) Southwestern Alaska. _ 16

Metallogenie Belts Formed During Proterozoic Sedimentation, Rifting, and Hydrothermal Activity Along Cratons or

Craton Margins -

Sinuk River Metallogenic Belt of Massive Sulfide-Bsrite and Stratabound Fe and Mn Deposiss (Belt SR) Nonthwestem Alaska... 17

Aurora Creek Massive Sulfide-Barite Deposit _._._........ 18

Origin of and Tectonic Controls for Sinuk River Metallogenic Belt.

Gillespie Metallogenic Belt of SEDEX Zn-Cu-Pb-Au-Ag Deposits (Belt GM) Northem Yukon Territory _......... 18

Biende SEDEX Za-Cu-Pb-Au-Ag Deposil.

Hart River SEDEX Zn-Cu-Ag Deposit - _... 18

Origia of and Tectonic Setting for Gillespic Metallogenic Belt

Wemecke Metallogenic Beli of U-Cu-Fe (Au-Co) Vein and Breccia Deposits (Beit WR) Central Yukon Territory .

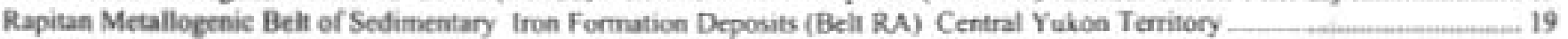

Crest Iron Formation Deposit 19

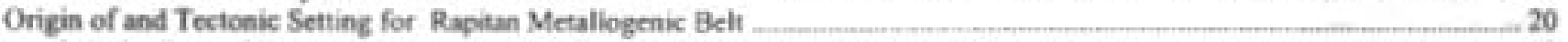

Metallogenic Belus Formed During Proterozoic Rifting of North American Craton or Craton Margin _................................20

Redstone Metallogenie Belt of Sediment-Hosted Ca-Ag Deposits (Belt RS) Central Yukon Territory _................................ 20

Costes Lake (Redstone) iediment-hosted Cu-Ag Deposit.

Origin of and Tectonic Controls for Rectabe Metallogenic Beh.

Churchall Metallogenic Belt of Cu Vein Deposits( Belt CH) Northern British Columbia ................................................... 20

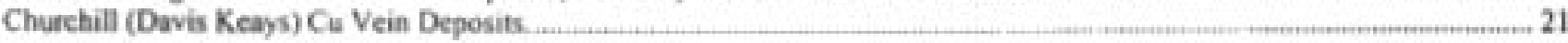

Origin of and Tectonic Controls for Churchill Metallogenic Bell _..._._._.

Monashee Metallopenie Belt of Sedimentary Exhalative (SEDEX) Zn-Pb-Ag Deposits (Belt MO) Southem British Columbia...... 21

Big Ledge SEDEX Zn-Pb Deposit ................. 21

Ruddock Creek SEDEXX Zn-Pb Deposit. 21

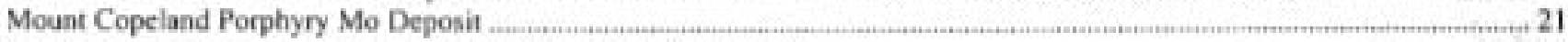

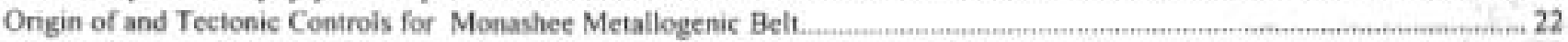

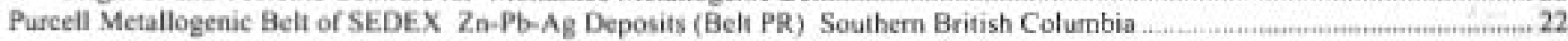

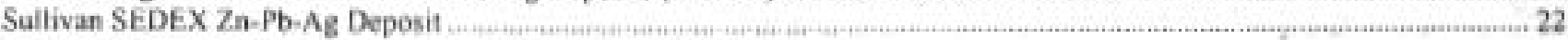

Origin of and Tectonic Seting for Purcell Metallogenic Belt _.....

Clark Range Metallogenic Beli of Sedimeni-Hosted Cu-Ag Deposits Southern British Columbia (Belt CR) ................................ 23

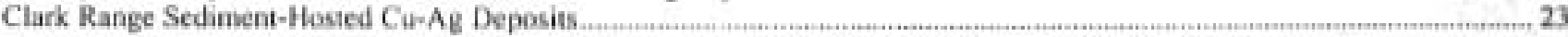


Origin of and Tectonic Conirols for Clark Range Metallogenic Belt.

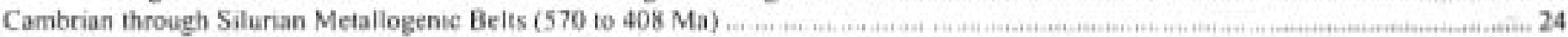

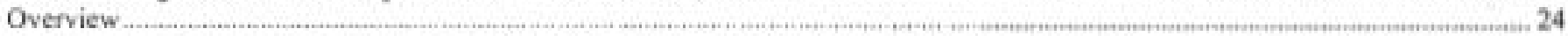

Metallogenic Beits Formed During Early Paleozoic Marine Sedimentation in Riffed Fragments of Gondwaadaland Supereontinent., 24

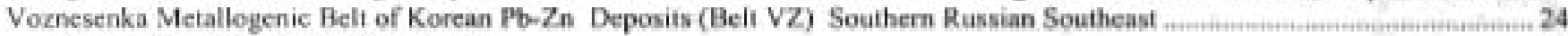

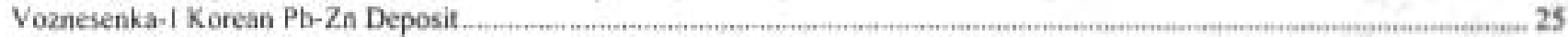

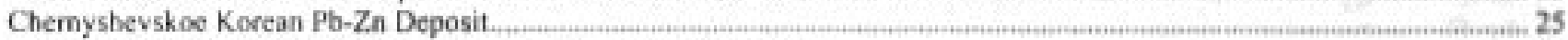

Origin of and Tectonic Controls for Voznesenka Metallogenic Belt ............

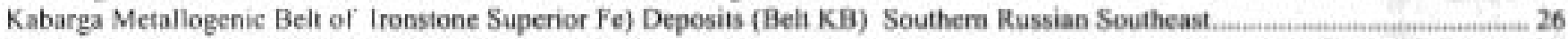

Metallogenic Belts Formed During Early Paleozoic Sedimentation or Marine Volcanism in Manchurid or Altaid Orogenic Systems 26

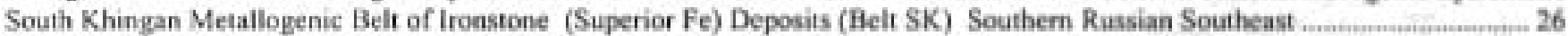

Gar Metallogenic Belts of Volcanogenic Fe Deposits and Stratiform Cu and Pb-Zn Deposits (Belt GR) Westem Part of

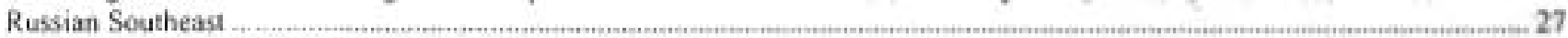

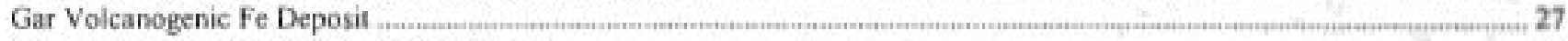

Kamenushinskoe Cu Massive Sulfide Deposit ............ 27

Chagoyan Stratiform Pb-Zn Deposit . 28

Origin of and Tectonic Controls for Gar Metallogenic Belts ... 28

Metallogenic Belts Formed During Early Paleonoic Sea-Floot Spreading. Regional Metamorphism, or Duriag Subduction-

Related Volcanism in Russian Far East Terranes . . 28

Galam Metallogenic Belt of Volcanogenic Fe, Volcanogenie Mn, and Sedimentary P Deposits (Belt GL) Central Part of

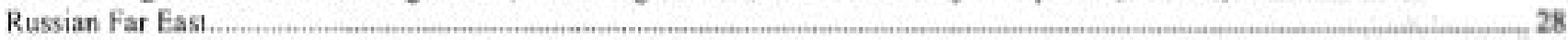

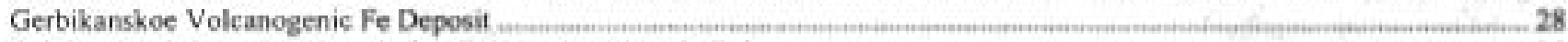

Origin of and Tectonic Controls for Galam Metallogenic Belt _. 29

Omulevka River Metallogenic Belt of Austrian Alps W and Kipushi Cu-Pb-Zn Deposits (Belt OR) Northwest Pan of Russian

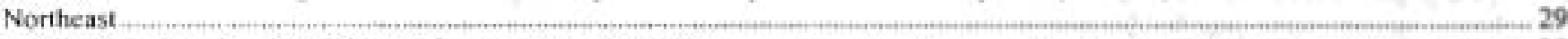

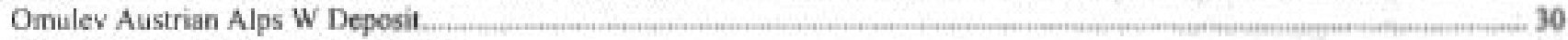

Vesnovka Kipushi Cu-Pb-Zn Deposit _._. _ _. 30

Origin of and Tectonic Controls for Omulevka River Metallogenic Belt._. 31

Rassokha Metallogenic Belt of Basaltic Cu and Sediment-Hosted Cu Deposits (Belt RA) Northern Part of Russias Northeast ..... 31

Agyndja Basaltic Cu and Sodiment-Hosted Cu Deposit.

Origin of and Tectonic Controls for Rassokha Metallogenic Belt.

Metallogenic Beits Formed During Early Paleozoic Rifting of Continental Margins or in Continental-Margin Are Terranes menmen 32

Dzhardzhan River Metallogenic Belt of Southeast Missouri Pb- $\mathrm{Zn}$, Sediment-Hosted Cu and Sandstone-Hosted U deposits (Belt DZ) Northern Part of Eastem Siberia.

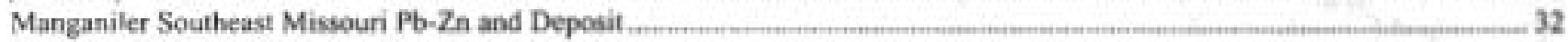

Kyongdyoi Sandstone-Hosted U Deposit _ _ 32

Origin of and Tectonic Controls for Dzhardzhan River Metallogenic Belt _.

Anvil Metallogenic Belt of SEDEX (SEDEX) Zn-Pb-Ag Deposits, Yukon Ternitory, Canada (Belt AN) _._. 33

Anvil District SEDEX Zn-Pb-Ag Deposits .... 33

Origin of and Tectonic Controls for Anvil Metallogenic Belt _. 33

Howards Pass Metallogenic Belt of Sedimentary Exhalative Zn-Pb Deposits (Belt HP) Eastem Yukon Territory _. 33

Howands Pass (XY) Zn- Pb SEDEX Deposit . _ _ 34

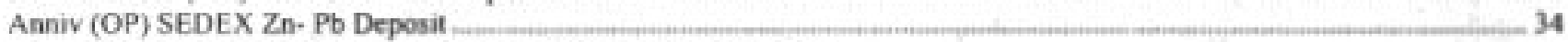

Origin of and Tectonic Setting for Howards Pass Mctallogenic Belt........ 35

Kootenay Metallogenic Belt of Carbonate of Sediment-Hosied Deposits (Belt KO) Southen British Columbia__...

Jersey SEDEX Pb-Zn Deposit. _ 36

H.B (Zincton) Pb-Zn SEDEX Deposit _. _- 36

Origin of and Tectonic Setting for Kootenay Metallogenic Belt _._. 36

Prince of Wales Island Metallogenic Belt of Continental-Margit Afc-Relaied Deposits (Belt PW) Southeastem Alaska. 36

McLean Arm Porphyry Cu-Mo District _._._ 37

Polymetallic Vein, Skam, and Disseminated Deposits in Paleozoic Plutons at Ktakas Inlet and Kassan Peninsula

Salı Chuck Zoned Mafic-Ultramafic Cu-Au-PGE Deposil .

Origin of and Tectonic Controls for Prince of Wales Island Metallogenic Belt.

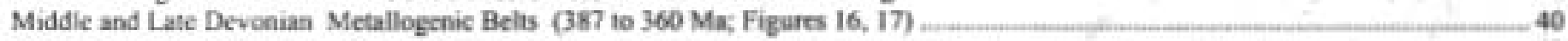

Overview - 40

Metallogenic-Tectouic Model for Middle through Late Devonian (387 to $360 \mathrm{Ma}$; figure 18 ) __. 40

Specific Events for Middle Through Late Devonian _._. 41

Metaliogenac Bell Formed During Collision ___ 45

Yaroslavka Metallogenic Belt of Flaorite and Sn Greisen Deposits (Beli YA) Southem Part of Russian Southeast _..

Voznesenka-II Fluorite Greisen Deposit _.__ 45

Yaroslavka Sa Greisen Deposit 46

Origin of and Tectonic Controls for Yaroslavka Metallogenic Belt.... 47

Metallogenic Belis Formed in a Middle Palecovoic Continental Are Along Nonth Asian and North American Craton Margins....47 
Kedon Metallogenic Belt of Au-Ag Epithermal Vein. Porphyry Mo, Fe Skarm, and Associated Deposits (Belt KE)

Central Part of Russian Northeasa

Kubaka Au-Ag Epithermal Vein Deposit.

Olecha Au-Ag Eputhermal Vein Deposit.

Origin of and Tectonic Controls for Kedon Metallogenic Beli

Eastem Seward Peninsala (Kiwalik Mounnain) Metallogenic Belt of Kuroko Massive Sulfide Deposits (Belt ES)

Northwestern Alaska.

Aretic Metallogenic Belt of Kuroko and Kipushu Massive Sulfide Deposits (Beli AT) Northern Alaska

Aretic Kuroko Massive Sulfide Deposat

Origin of and Tectonic Conuols for Arctic Metallogenic Beh.

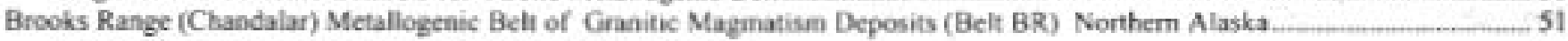

Vein, Skam, and Porphyry Deposats Ceniral Brooks Range w..... 51

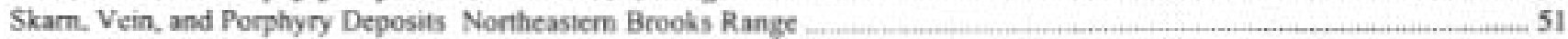

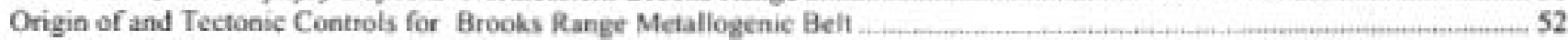

Alaska Range and Yukon-Tanana Upland Metallogenic Belt of Kuroko Massive Sulfide Deposits (Belt AKY) Central and

East-Central Alaska

Bonnifield District of Kuroko Massive Sulfide Deposits nuswa 52

Anderson Mountain Kuroko Massive Sulfide(7) Deposit _

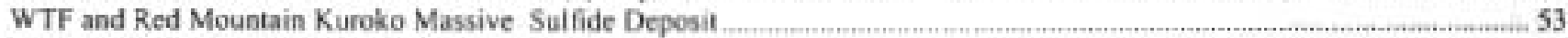

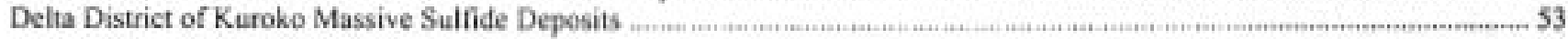

Origin of and Tectonic Controls for Alaska Range und Yukon-Tanana Upland Metallogenic Beit_............................................. 53

Dawson Metallogenic Belt of Volcanogenic Pb-2n-Cu Massive Sulfide and SEDEX Pb-Cu-Zn-Ba Deposits (Belt DA)

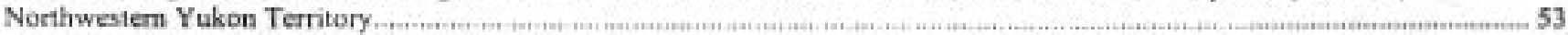

Frances Lake Metallogenic Beli of Volcanogenic Zn-Cu-Pb Massive Sulfide Deposits (Beh FR) Southem Yukon Territory ........ 55

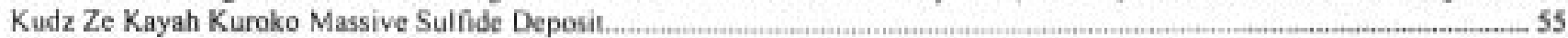

Wolverine-Lynx Kuroko Massive Sulfide Deposits _. _

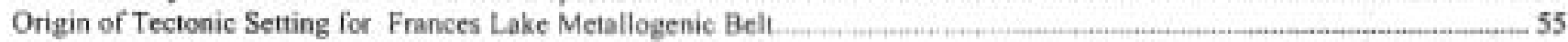

Tracy Metallogenic Belt of Kuroko Massive Sulfide Deposits (Belt TR) Southeastem Alaska and Weslem British Columbia....... 56

Sumdum Kuroko Zn-Cu Massive Sulfide Deposit .

Ecstall Kuroko Zn-Cu Massive Sulfide Deposit _ 56

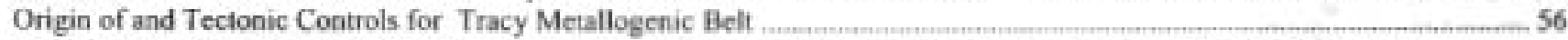

Mount Sicker Metallogenic Belt of Kuroko Volcanogenic Massive Sulfide Za-Cu-Pb-Au-Ag Deposits (Belt MS)

Vancouver lsiand

Mount Sicker (Lenora-Tyee, Twin J, Lara, Copper Canyon) Kuroko Massive Sulfide Zn-Cu-Pb-Au-Ag Deposit............. 57

Myra Falls (Buttle Lake, Myra, Lynx, H-W, Battle) Kuroko Massive Sulfide Zn-Cu -Aw-Ag Deposit ___..._. 57

Origin of and Tectonic Controls for Mount Sicket Metallogenic Belt . 57

Kootenay-Shuswap Metallogenic Belt of Volcanogenic Zn-Pb-Cu-Ag-Au Massive Sulfide Deposits(Beln KS) Southern

British Columbia _. 58

Homestake and Rea Gold Kuroko Zn-Pb-Cu-Au-Ag Deposits _ 58

Goldstrean Besshi Cu-Zn-Ag Deposit. 58

Harper Creek and Chu Chua Cu-2n-Ag・Au Deposits _ 58

Adams Plateau SEDEX Zn-Pb-Ag Deposits 59

Origin of and Tectonic Setting for Kootenuy-Shwwap Metallogenic Belt _....._._._. 59

Metallogenic Belts Formed During Middle Paleozoic Rifting of Nonth Asian Craton Margin

Khamna River Metallogenic Belt of Carbonatice-Related Nb, Ta, and REE Deposits (Belt KR) Southern Part of Eastern Siberia... 59

Khamna Carbonatite-Related REE Deposits ....

Gornoye Ozero Carbonatite-Related REE Deposit _...

Origin of and Tectonic Controls for Khamna River Metallogenie Belt .

Sette-Daban Range Metallogenic Beit of Southeast Missouri Pb-Zn, Sediment-Hosted Cu, and Basaltic Cu Deposits (Belt SD)

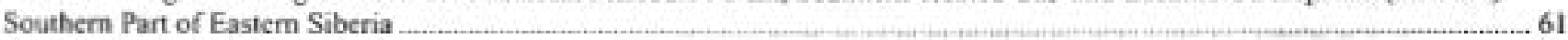

Sardana Missouri Pb-Zn Deposit. .

Urut Soubeast Missouri Pb-Zn Deposit_...

Kurpandzha Sediment-Hosted Ce Deposit _ 62

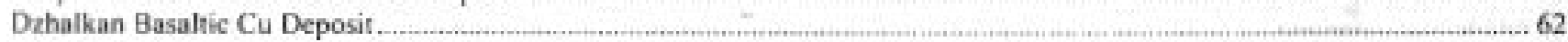

Origin of and Tectonic Controls for Sette-Daban Range Metallogenic Belt _...................................63

Selennyakh River Metallogenic Belt of Southeast Missoxiri Pb-Zn, Siratabound $\mathrm{Hg}$ and $\mathrm{Au}$, and Pb-Zn Vein Deposits

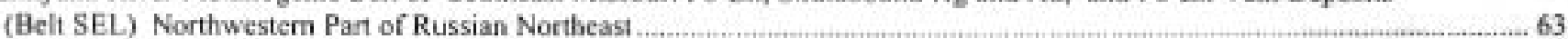

Gal-Khaya Carbonate-Hosied Hg Deposit _.

Kondakovskoe Southeast Missouri Pb-Zn Occurrence $\ldots 63$

Chistoe Pb-Zn Vein Deposit._........._._. 63

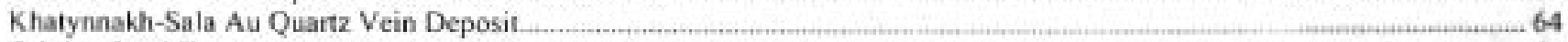

Origin of and Tectonic Controls for Selennyakh River Metallogenic Belt. 
Tommot River Metallogenic Belt of Carbonatite-Related Nb, Ta, and REE Deposits (Belt TO) North-Central Part of

Russian Northeast _.............................................................................. 64

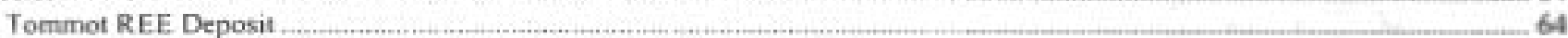

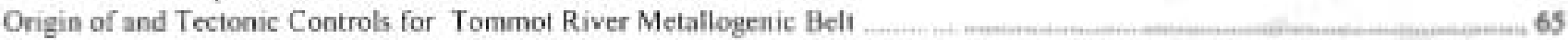

Urultun and Sudar Rivers Metallogenic Belt of Southeast Missouri Pb- $\mathrm{nn}$, Carbonate-Hosied Hg. Basaltic Cu, and

Volcanogenic Mn Deposits (Belt URS) West-Central Part of Russian Northeast n...m.n.m.

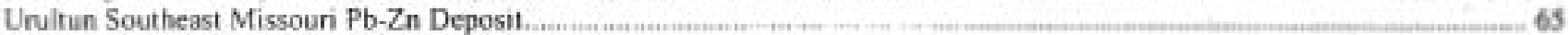

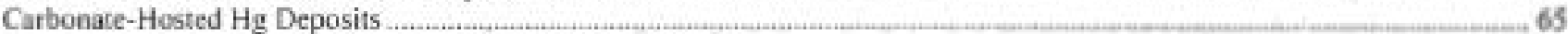

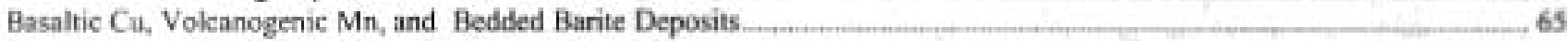

Origin of and Tectonic Controls for Urultun and Sudar Rivers Metallogenic Belts.

Yarkhodon Metallogena Belt of Southeast Missouri Pb-Zn Deposits (Belt YR) Wesi-Ceatral Pant of Russian Nontheast .

Slezovka Southeast Missouri Pb-Zn Deposit _......... 6 ?

Origin of and Tectonic Controls for Yarkhodon Metallogenic Belt .wirments. 67

Berezovka River Metallogenic Belt of Kuroko Massive Sulfide Deposits (Belt BE) Central Pant of Russian Nontheast merim-min 67

Berezovskoe Kuroko Massive Sulfide Oecurrence _............... 67

Origin of and Tectonic Controls for Berezovka River Metallogenic Bels _ _ 67

Metallogenic Belis Formed During Middle Paleozoic Rifting of North American Craton Margin or in Low-Temperature

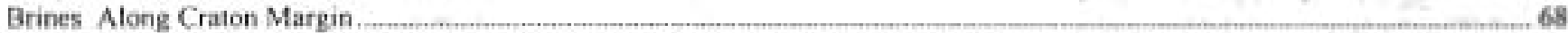

Mystic Metallogenic Belt of SEDEX Bedded Barite and Southeast Missouri Pb-Zn Deposits (Belr MY) West-Central Alaska...n.68

Bedded Banteand Southeast Missouri Pb- Zn Deposit.

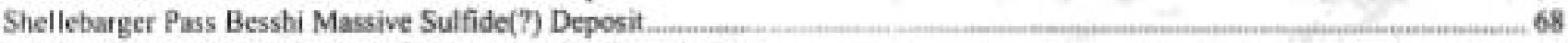

Origin of and Tectonic Controls for Mystic Metallogenic Belt

Northern Cordillera Metallogenic Belt of Southeast Missouri Zn-Pb Deposits (Belt NCO) Ceninal Yukon Territory ...ninmenen.men 69

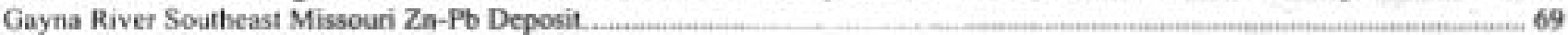

Goz Creek (Barrier Reef) Southeast Missoun Zn-Pb Deposit.

Bear-Twit Southeast Missouri Zn-Pb District. _ 69

Origis of abd Tecionic Controls for Northern Condallera Metallogenic Belt ___ _ 69

Dempster Metallogenic Beli of SEDEX Ba, Sedimentary-Exhalative (SEDEX), SEDEX Ni-Zn-PGE-Au, and Kuroko $\mathrm{Zn}$-Pb-Cu Massive Sulfide Deposits (Belt DE) Northwestern Yukoe Territory _ 70

Rein SEDEX Ba Deposits . _ 70

Marg Kuroko Volcanogenic Zn-Pb-Cu Deposit..__ 70

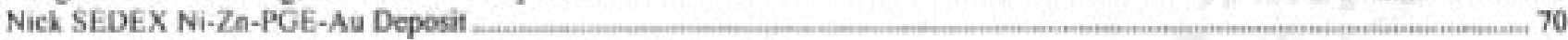

Origin of and Tectoenic Controls for Dempster Metallogenic Belt ___

Macmillan Pass Metallogenac Belt of Zn-Pb-Ag-Ba SEDEX Deposits, Central Yukon Territory (Belt MP) ....................................... 71

Tom, Jason Main, and Jason East Pb-Zn-Ag-Ba SEDEX Deposits _ 71

Moose Ba SEDEX Deposit n. _ 71

Origin of and Tectonic Setting for MacMillan Pass Metallogenic Belt.

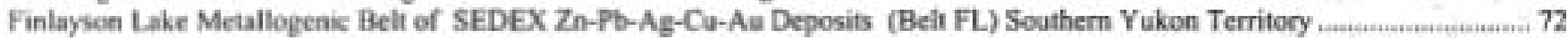

Maxi SEDEX Zn-Fb-Ag Occurrence _. 72

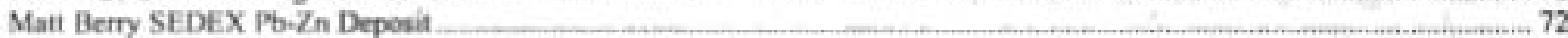

Origin of and Tectonic Setting for Finlayson Lake Metallogenic Belt.

Liard Metallogenic Belt of Southeast Missouri Ba.F Deposits (Belt Li) Northern British Columbia ................................... 72

Leguil Creek Bedded Ba Deposit.

Lower Liard Sonaheast Missouri Ba.F and Muncho Lake Ba Deposits _.

Ongin of and Tectonic Setting for L.iand Metallogenic Belt.

Gataga Metallogenic Belt of Zn-PB-Ag-Ba SEDEX Deposits (Belt GA) Northern British Columbia.

Cirçue (Stronay) Deposit. _ 73

Driftpile Creek SEDEX Zn-Pb-Ag-Ba Deposit.

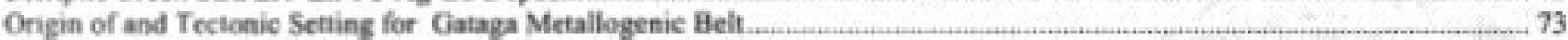

Robb Lake Metallogenic Belt of Soetheast Missouri Zn-Fb Deposits (Belt RL) Northern British Columbia ................................. 75

Robb Lake Southeast Missouri Zn-Pb Deposits _...m. 75

Origin of and Tectonic Controls for Robb Lake Metallogenic Belt _...... 75

Ingerika Merallogenic Belt of Soetheast Missouri Zn-Pb-Ag-Ba Deposits, and Manto Zn-Pb-Ag Deposits (Belt IN)

Northern British Columbia. 75

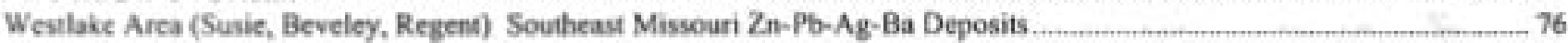

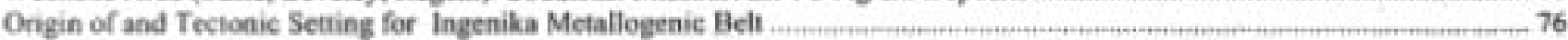

Cathedral Metallogenic Beh of Southeast Missouri Zn-Pb-Ag Deposits Southem British Columbia (Beh CA)..................... 76

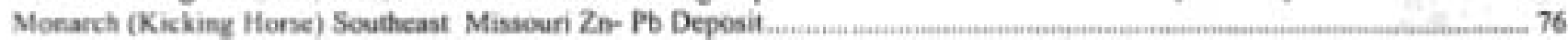

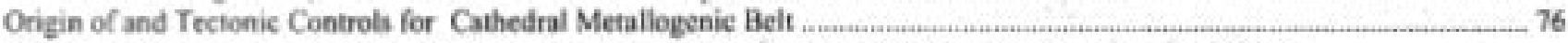

Southem Rocky Mountains Metallogenic Belt of Stratabound Barite-Magnesite-Gypsum Deposits (Belt SRM)

Soethem British Columbia. 76

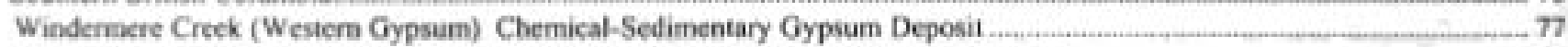

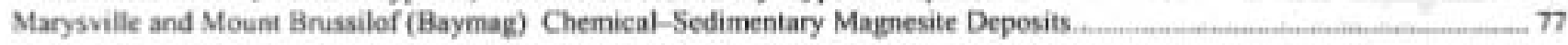


Parson and Brisco Barite Vein and Gypsum Deposits.

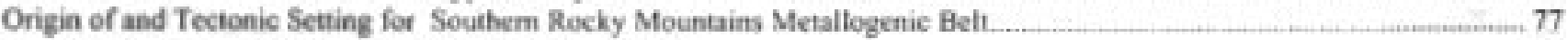

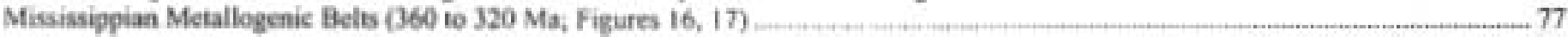

77

Metallogenic-Tectonic Model for Mississippian (360 to 320 Ma: Figure 29).

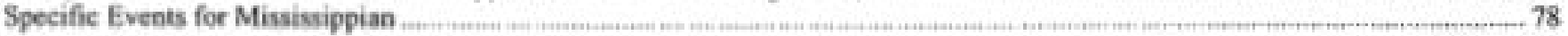

Metallogenic Belt Fonned During Mississippian-Pennsylvanian Back-Are Spreading Along North American Craton Margin.....m... 78

Northwestern Brooks Range Metallowenie Belt of SEDEX Zn-Pb, Bedded Barite, Kuroko Massive Sulfide, and Sulfide Vein

Deposits (Belt NBR) Northwestern Alaska.

Red Dog Crek SEDEX Zn-Pb Deposit . 79

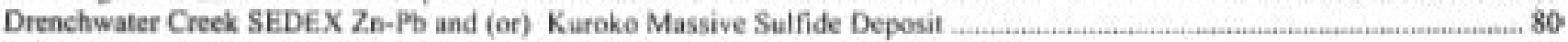

Origin of and Tectonic Controls for Northwestem Brooks Range Metallogenic Belt................................................................ 81

Pennsylvanian Metallogenic Belts (320 to 286 Ma; Figures 31, 32) _.. _.

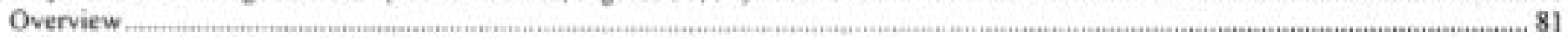

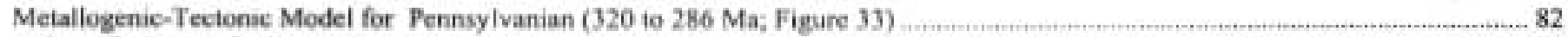

Specific Events for Pennsylvanian .

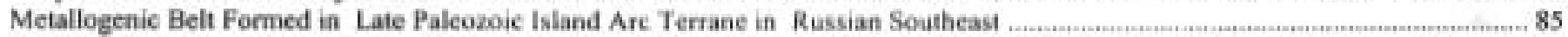

Laoelin-Grodekovsk Metallogenic Belt of Porphyry Cu-Mo and Au-Ag Epithermal Vein Deposits (Beli LG) Southern Part

of Russian Southeast _.....

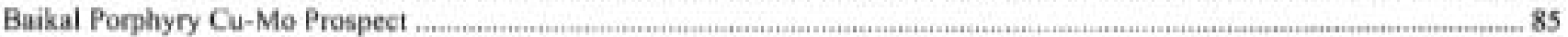

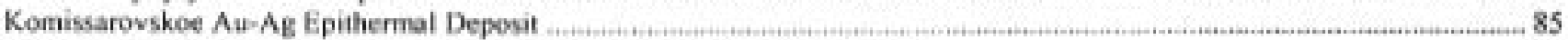

Origin of and Tectonic Controls for Laoelin-Grodekoysk Metallogenic Belf ...m.

Metallogenic Bels Fomed In Late Paleozoic Oceanic Lithosphere Preserved in Subduction Zones Terranes in Russian Northeast. 86

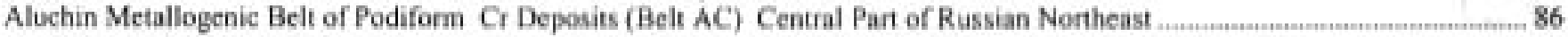

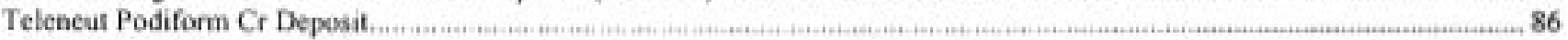

Origin of and Tectonic Controls for Aluchin Metallogenic Belt, .

Ust-Belaya Metallogenic Belt of Podiform Cr Deposits (Belt UB) Northeastern Part of Russian Northeast _...............n.m.n....86

Origin of and Tectonic Controls for Ust-Belaya Metallogenic Belf ,

Metallogenic Belts Formed in Late Paleocoic Skolai Island Are in Wrangella Stperterrane _.

Alaska Range-Wrangell Mounains Metallogenic Belt of Granitic Magmatism Deposits (Belı ARW) Central and Eastern-

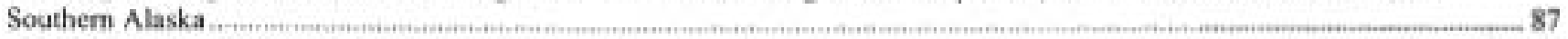

Rainy Creek Cu-Ag Skam Districi._...__._.

Chistochina District. . 87

Origin of and Tectonic Controls for Alaska Ranpe- Wrangell Mountains Metallogenic Beli__._. 87

Ketchikan Metallogenic Belt of Kuroko Massive Sulfide Deposits (Bell KK) Southeasiern Alaska._._._. 88

Late Triassic Metallogenic Belts (230 to $208 \mathrm{Ma}$; Figure 32) _.

Overview . 88

Metallogenic-Tectonic Model for Late Triassic (230 to $208 \mathrm{Ma}$; Figure 34)

Specific Events for Late Triassic (Camian through Norian) .

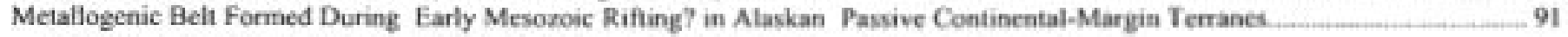

Farewell Metallogenic Belt of Gabbroic Ni-Cu-PGE Deposits (Belt EAR) Westem Alaska .......... 91 Roberts PGM Prospect _._._._._._._. 91

Origin of and Tectonic Controls for Farewell Metallogenic Belt _..._. 91

Metallogeaic Belts Formed in Middle Mesozoic Talkeetna-Bonrana Island Are in Wrangellia Superterrane _.... 92

Kodiak Istand and Border Ranges Metallogenic Belt of Podiform Cr Deposits (Belt KOD) Southern Coastal Alaska ............ 92 Red Mountain Podiform Cr Deposit. 92

Origia of and Tectocaic Controls for Kodiak Island and Border Ranges Metallogenic Belt ___ 92

Eastem Alaska Range Metallogenic Belt of Gabbroic Ni-Cu Deposits, Besshi Massive Sulfide, and Related Deposits

(Belt EAR) Southem Alaska and Northwestern Canadian Condillera. 93

Denali Cu-Ag Besshi(7) Massive Sulfide Deposil _..._. 93

Fish Lake Gabbroic Ni-Cu Deposit. . 94

Wellgreen Gabbroic Ni-Cu Deposit _. 94

Origin of and Tectonic Controts for Eastern and Western Alaska Range Metallogenic Beli _._._._._._._.

Alevander Metallogenic Belt of Volcanogenic Cu-Pb-Zn and Carbonate-Hosted Massive Sulfide Deposits. Southeastern Alaska (Belt AX) _______._. 95

Windy Crapgy Cu-Co Massive Sulfide Deposit._____. 95

Greens Creek Kuroko Zn-Pb-Cu Massive Sulfide Deposit _.

Castle Island Bedded Barite Deposit _.. 96

Origin of and Tectonic Controls for Alexander Metallogenic Beit of Massive Selfide Depenits___. 96

Metallogenic Belts Formed in Middle Mesozoic Stikinia-Quesnellia lsland Are _. 98

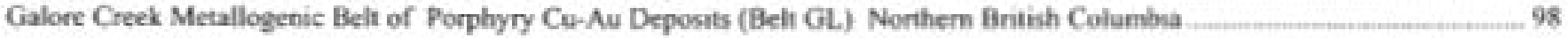

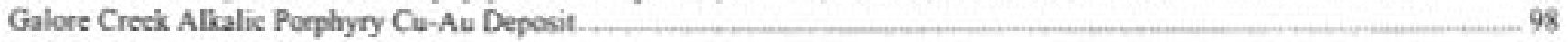

Red Chris Porphyry Cu-Au Deposit. 98 
Origin of and Tectonic Controls for Galore Creek Metallogenic Belt.

Sustur Metallogenic Belt of Basaltic Cu Deposits (Belt SU) Northern British Columbia.

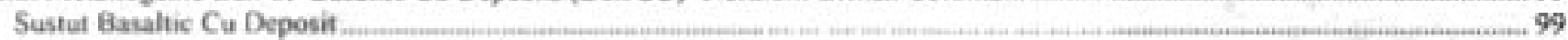

Origin of and Tectonic Controls for Sustut Metallogenie Belt .

Copper Mountain (North) Metallogenie Belt of Porphyry Cu-Au Deposits (Belt CMN) Northern British Columbia.................. 99

Lorraine Porphyry $\mathrm{Cu}-\mathrm{Au}$ Deposit . .

Mount Milligan Porphyry Cu-Au Deposit. _ 100

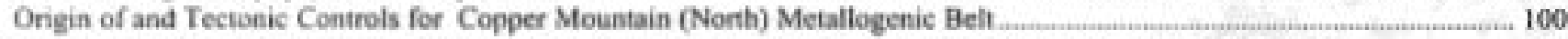

Copper Mountain (South) Metallogenic Belt of Porphyry Cu-Au Deposits (Belt CMS) Southem British Columbia..................... 100

Copper Mountain (Ingerbelle) Porphyry Cu-Au Deposit _.

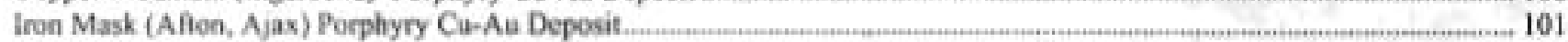

Mt. Polley (Cariboo-Bell) Porphyry Cu-Au Deposit ..._.

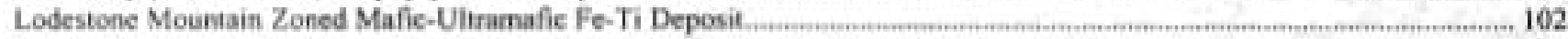

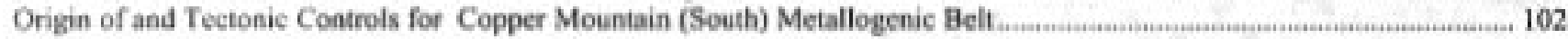

Guichon Metallogenic Belt of Porphyry Cu-Mo-Au and Au Skam Deposits (Belt GU) Southem British Columbia....................... 102

Highland Valley Distriet (Bethlehem, Valley Copper, Lomex, Highmsnt) of Porphyry Cu-Mo Deposits................................. 103

Valley Copper, Brenda, Axe, and Primer Porphyry Cu-Mo Deposits _...

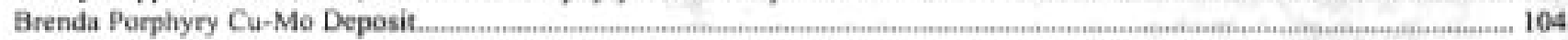

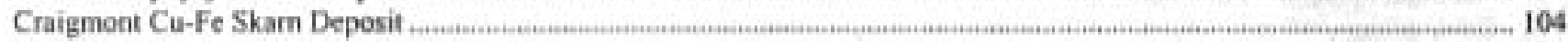

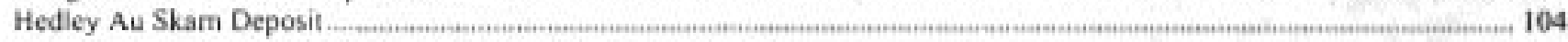

Origin of and Tectonic Controls for Guichon Metallogenic Belt _.....

Texas Creek Metallogenic Belı of Porphyтy Cu-Mo-Au, Au-Ag Polymetallie Vein and Au Quartz Vein Deposits (Belt TC)

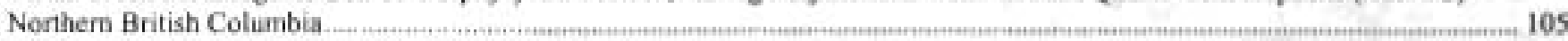

Texas Creek District Porphyry Cu-Mo-Au Deposits

Polaris Au Quartz Vein Deposit .........

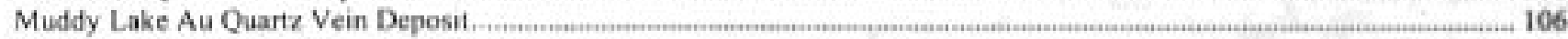

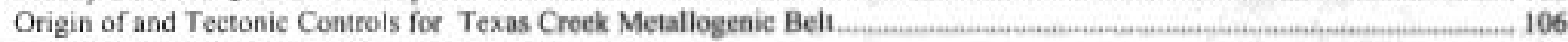

Early Jurassic Metallogenic Belis (208 $10193 \mathrm{Ma}$; Figure 42) _.m-106

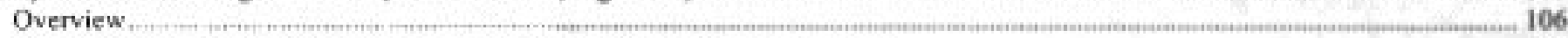

Metallogenic-Tectonic Model for Early Jurassic (208 to 193 Ma; Figure 43) _....n-

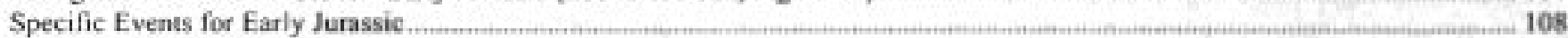

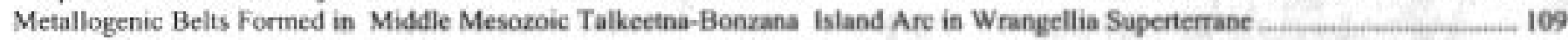

Alaska Peninsula Metallogenic Belt of Granitic Magnatism Deposits (Belt AP) Alaska Peninsula _._._........... 109

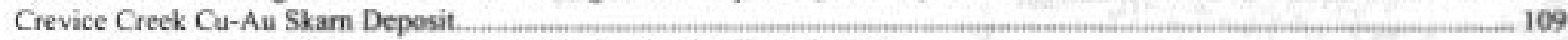

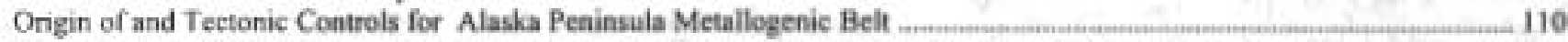

Talkeetna Mountains-Alaska Range Metallogenie Belt of Kuroko Massive Sulfide Deposits (Belt TM) Northern Part of Southem Alaska

Johnson River Massive Sulfide(7) Deposit.

Origin of and Tectonic Controls for Talkeetna Mountains-Alaska Range Metallogenic Belt.

Island Porphyry Metallogenic Belt of Porphyry Cu-Mo, Cu Skarn, Fe Skarn and Cu Skarn Deposits (Belt IP) Vancouver 1sland.

Island Copper Porphyry Cu-Mo-Au Deposit.

Fe and Cu-Fe-Au Sksms in Island Porphyry Metallogenic Belt .,

Texada Iron Fe Skarn Deposit______t 112

Origin of and Tectonic Controls for Island Porphyry Metallogenic Belt . .

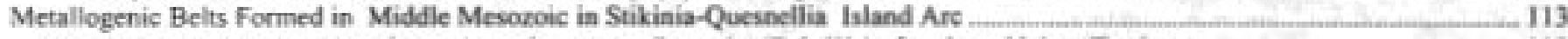

Klotassin Metallogenic Belt of Porphyry Cu-Au-Ag Deposits (Belt KL), Southem Yukon Territory __

Minto Copper and Williams Creek Porphyry Cu-Au-Ag Deposits.

Origin of and Tectonic Controls for Klotassin Metallogenic Belt.

Toodoggone Metallogenic Belt of Au-Ag. Epithermal Vein and Porphyry Cu-Au Deposits (Belt TO) Northem British

Columbia.

Toodoggone District of Au-Ag Epithermal Vein Deposits __ 114

Kemess North and South Porphyry Cu-Au Deposit.

Origin of and Tectonic Controls for Toodogene Metallogenic Belt

Coast Mountains Metallogenic Belt of Volcanogenic Cu-Zn-Av-Ag Massive Sulfide Deposits (Belr CM) Northern British

Columbia $\quad 115$

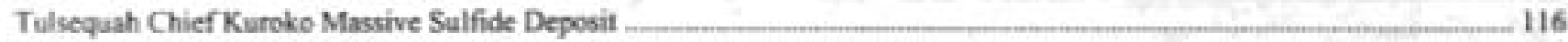

Granduc Besshi Massive Sulfide Deposit. 116

Eskay Creek Kuroko Massive Sulfide Deposit.__ 116

Alice Am Silver District of Massive Sulfide Deposits..._._._. 116

Amyox Cyprus Massive Sulfide Deposit _____. 116

Ongin of and Tectonic Controls for Coast Mountains Metallogenic Belt. _ _ 117

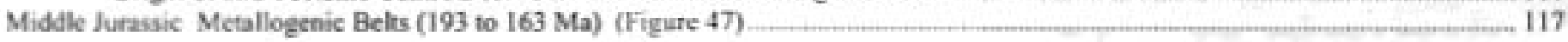


Overview

Metallogenic-Tectonic Model for Middle Jurassic (193 tol63 Ma, Figure 47)

Specific Events for Middle Jurassic

Late furassic Metallogenic Belts (163 to $144 \mathrm{Ma}$, Figures 48, 49)

Overview.

Metallogenic-Tectonic Model for Late Jurassic (163 to 144 Ma; Figure 50).

Specific Events for Late Jurassie.

Metallogenic Belt Formed Along Late Mesonoic Along Continental-Margin Transform Fault _..

Ariadny Metallogenic Beht of Zoned Mafic- Uliramafic Ti Deposits (Belt AR) Southern Part of Russian Far East................ 124

Metallogenic Belis Fonned in Late Mesozoic Continental Margin and Island Are Systems in Russian Far East.

North Burcya Metallogenic Belt of A $₫-A g$ Epithernal Veis and Granitoid-Related Au Deposits (Belt NB) Northwestern

Part of Russian Southeast.

Pokrowskee Au-Ag Epithermal Vein Deposit.

Pioneer Granitoid-Related Au Deposit. 125

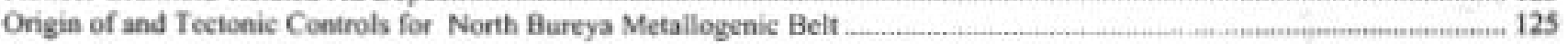

Chersky-Argatass Ranges Inferred Metallogenic Belt of Kuroko Massive Sulfide Deposits (Belt CAR) West-Central Part of

Ressian Northeast

Khotoidokh Kuroko Massive Sulfide Deposit

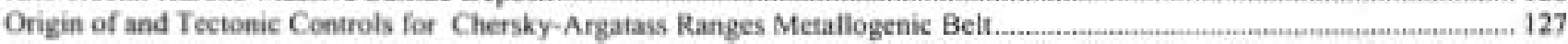

Yassachnaya River Metallogenic Bett of Pb-Zn Skam, Porphyry Cu, and Cu-Ag Vein Deposits (Belı YS) Western Part of

Russian Northeast …,

Terrassnoe Pb-2n Skam Deposit.

Kunarev Porphyry $\mathrm{Cu}$ and Pb-Zn-Cu-Ag Skarn Deposit .

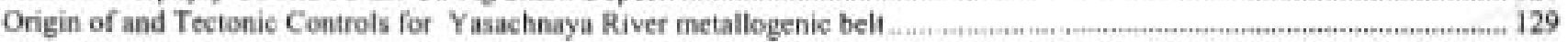

Oloy Metallogenic Beit of Porphyry Cu-Mo and Au-Ag Eputhermal Vein Deposits (Belt OL) North-Central Part of Russian

Northeast......

Peschanka Porphyry Cu-Mo Deposit . 130

Vesennee Au-Ag Epithermal Vein Deposit....

Origin of and Tectonic Controls for Oloy metallogenic belt

Pekulney Metallogenic Belt of Basalic Cu Deposits (Belt PK) Eastern Part of Russian Northeast ..................................... 131

Skalistaya Basaltic Cu Deposif. . . .

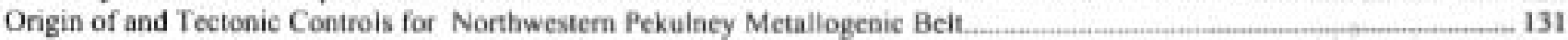

Tamvatney-Mainits Metallogenic Belt of Podiform Cr Deposits (Belt TAM) East-Central Part of the Russian Northeast.

Krasnaya Podiform Cr Deposit _...n. 132

Origin of and Tectonic Controls for Tanvatney-Mainits Metallogenic Belt._._. 132

Mainits Metallogenic Belt of Kuroko Massive Sulfide Deposits (Belt MA) Eastern Part of Russian Northeast....... 133

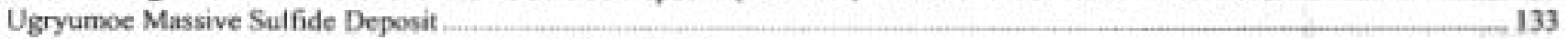

Origin of and Tectoric Controls for Mainits metallogenic belt. 133

Svyatoy-Nos Metallogenic Belt of Au-Ag Epithermal Vein Deposits (Belt SVN) Northern Part of Russian Northeast_.

Polevaya Av-Ag Polymetallic Veis Deposit _._._._. 133

Origin of and Tectonic Controls for Svyatoy-Nos Metallogenic Belt . 134

Kuyul Metallogenic Belt of Podiform Cr. FGE and Associated Deposits (Belt KUY) East-Central Part of Russian Northeast__- 134 Origin of and Tectonic Controls for Kuyul Metallogenic Belt - 134

Metallogenic Belts Formed in Late Mesozoic Koyukuk and Togiak Jsland Are Systems in Western and Southwestern Alaska. 134

Eastem Seward Peninsula and Marshall Metallogenic Belt of Podiform Cr Deposits (Beit ESM) Northwestem Alaska -

Kobuk Metallogenic Belt of Podiform Cr Deposits (Belt KB) Northern Alakka _. 135 Misheguk Mountain Podiform Cr Deposit ___ 135

Avan Podiform Cr Deposit. 135

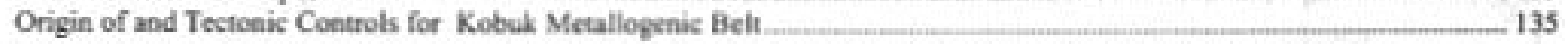

Southwestern Alaska Metallogenic Belt of Zoned Mafic-Ultramafie PGE Deposits (Belt SWA) Southwestern Alaska......... 136.

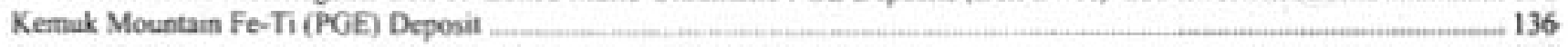

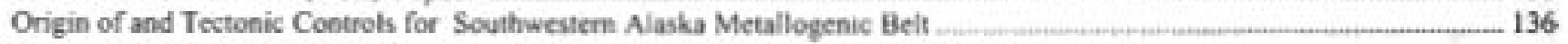

Yukon River Metallogenic Belt of Podiform Cr Deposits (Beht YR) West-Central Alaska...........................................

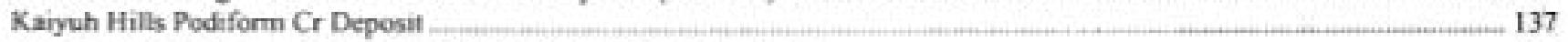

Onigin of and Tectonic Controls for Yukon River Metallogenic Belt _.

Metallogenic Belts Forned in Late Mesozoic Gravina Island Are in Souhern Alaska und Canadian Cordillera................................ 137

Eastern-Southern Alaska Metallogenic Belt of Granitic Magmatism Deposits (Belt ESA) Eastern-Soutbern Alaska ................... 137

Pebble Copper Porphyry Au-Cu Deposit ___ 138

Orange Hill and Bond Creek Porphyry Cu-Mo Deposits .

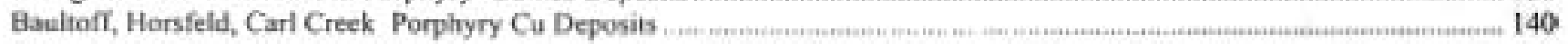

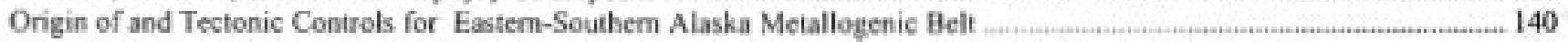

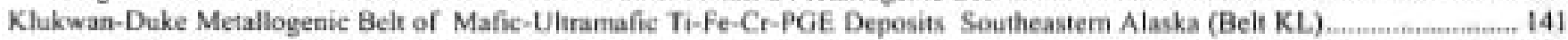

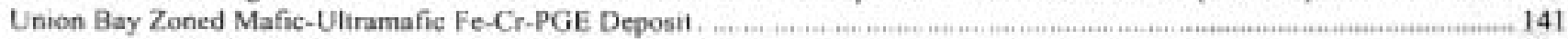


Klukwan Zoned Mafic-Ultramafic Fe-Ti Deposit.

Origin of and Tectonic Controls for Klukwan-Duke Melallogenic Belt .

Metallogenic Beits Formed in Late Mesozoic Collision and Overthrusting in Eastern Alaska and Canadian Cordillera ................... 142

Fortymule Metallogenic Belt of Serpentinite-Hosted Asbestos Deposits (Beh ECA) East-Central Alaska and Northwestern

Canadian Cordillera _..........._............ 142

Slate Creck Serpentinite-Hosted Asbestos Deposit ............ 142

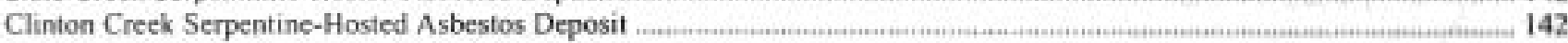

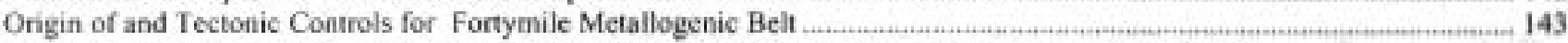

Cassiar Metallogenic Belt of Serpentinite-Hosted Astestos Deposits Northem British Columbia (Belt CS) ........................... 143

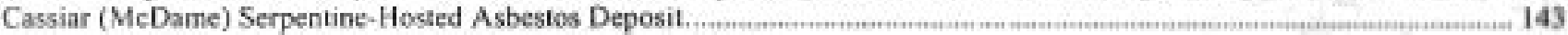

Origin of and Tectonic Controls for Cassiar Metallogenic Belt _.

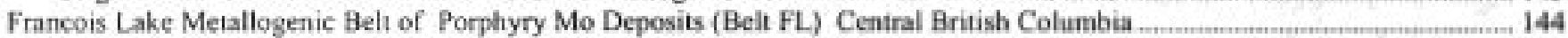

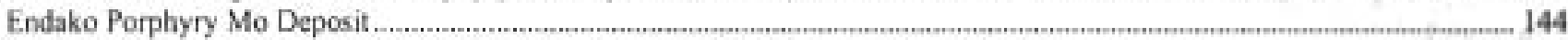

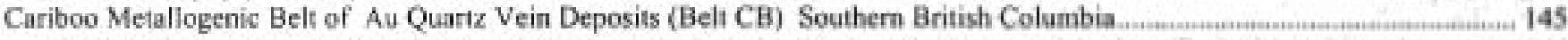

Cariboo-Barkerville District (Cariboo Gold Quartz, Mosquito Creek, Island Mountain) of Au Quartz Vein Deposits........... 145

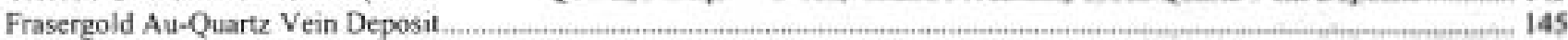

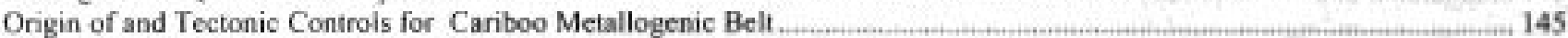

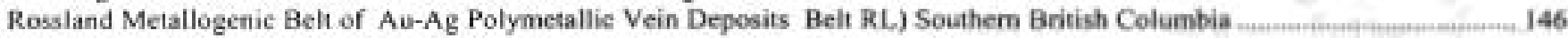

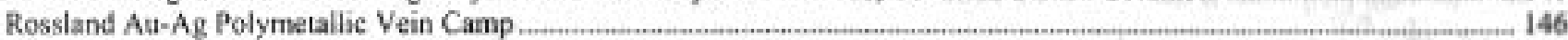

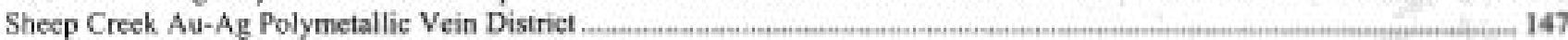

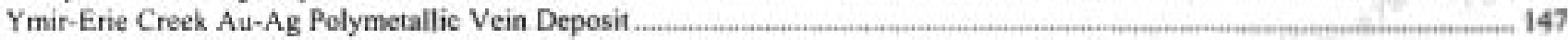

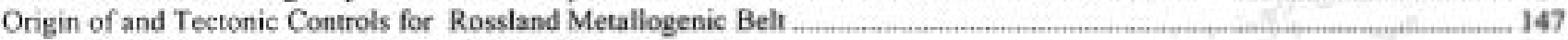

Early Cretaceous Metallogenic Belts (144 to 120 Ma; Figures 61, 62)

Overview .................................. 147

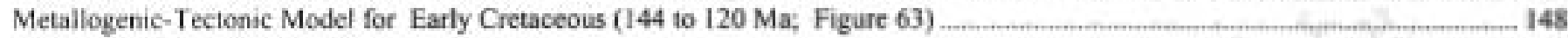

Specific Events for Early Cretaceous..............._.

Metallogenic Belts Formed Along Late Mesozoic Continental-Margin Transform Faults in Russian Southeast ....................... 152

Samarka Metallogenic Belt of W Skam, and Porphyry Cu-Mo Deposits (Belt SA) West-Central Part of Russian Southeast narmi.. 152

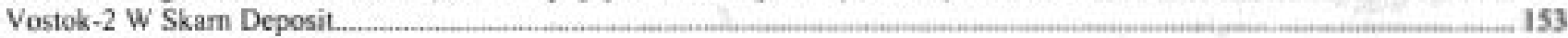

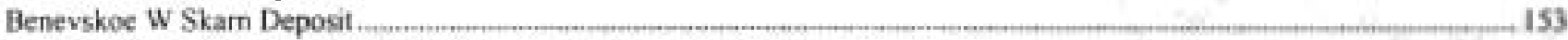

Origin of and Tectonic Controls for Samarka Metallogenic Belt.

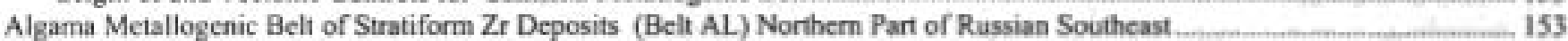

Kondyor Metallogene Belt of Zoned Mafic-Ultramafic Cr-PGE Deposits (Beit KO) Northern Part of Russian Southeast...... 154

Kondyot Zoned Mafic-Ultramafic Cr-PGE Deposit ____ 155

Origin of and Tectonic Controls for Kondyor Metallogenic Belt.

Metallogenic Belts Formed During Late Mesozoic Closure of Mongol-Okhotsk Ocean in Rassian Southeast

Selemdzha-Kerbi Metallogenic Belt of Au Quartz Vein Deposits and Granitoid-Related Au Deposits (Belt SK) Northwestem

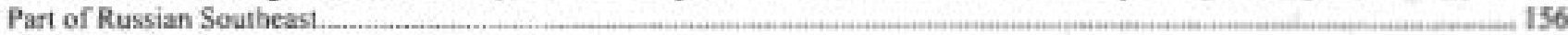

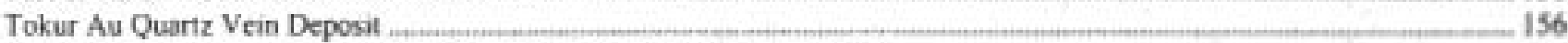

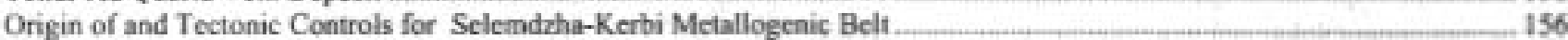

Stanovoy Metallogenic Belt of Granitoid-Related Au Deposits (Belı ST) Northern Part of the Russian Southeast.

Kirovskoe Granitoid-Related Au Deposit ...يum-157

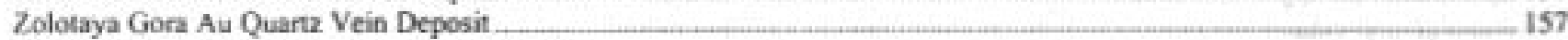

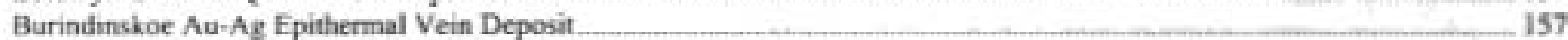

Origin of and Tectonic Controls for Stanovoy Metallogenic Belt. 157

Metallogenic Belts Formed During Late Mesozoic Accretion of Kolyma-Omolon Superterrane in Russian Northeast-.

Kular Metallogenic Belt of Au Quartz Vein, Granitoid-Related Au, and Sn Quartz Vein Deposits (Belt KV) Nonthem Part of

Eastem Siberia

Allakh-Yun Metallogeaic Belt of Au Quartz Vein Deposits, and Associated W-Sn Quartz Vein Deposits (Belk AY) Southem

Part of Russian Northeast.

Yur Au Quartz Vein Deposit. 160

Levo-Dybin Granitioid-Related Au Deposit ___ 160

Origin of and Tecionic Cottrols for Allakh-Yun Metallogenic Belt.

Yana-Polousnen Metallogenic Belt of Granitoid-Related Au, Sn Quartz Vein, W Vein, Sn Greisen, Co-, Av-, and Sn-Skarn,

Sn-Silicate Sulfide Vein and Related Deposits (Beit YP) Central Part of Russian Northeast._. 160

Polyarmoe Sn grensen and Vein Deposit.

Kandidatskoe Au Skam Deposit ___._. 161

Chistoe Granitoid-Related Au Deposit. 161

Ilin-Tas Se Silicate-Sulfide Vein Deposit___ 161

Origin of and Tectonic Centrols for Yana-Polousnen Metallogenic Belt. 161

Darpir Metallogenic Beli of Sn and Associaled Felsic-Magmatism Deposits (Beln DP) Westem Pant of Russian Nonheast.

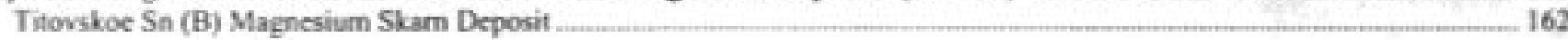


Chepak Granitoid-Related Au Deposit.

Origin of and Tectonic Controls for Darpir Metallogenic Belt

Tompon Metallogenic Belt of Cu, W, Sn Skam, and Sn Quartz Vein Deposits (Belt TO) West-Central Pant of Eastem Siberia.. 163

Shamanikha Metallogenic Belt of Au Quartz Vein and Cu-Ag Quartz. Vein Deposits (Belt SH) Central Part of the

Russian Northeast

Au Quartz Vein Deposits

Cu-Ag quartz Vein Deposits

Verkhoyansk Metallogenic Belt of Au Quartz Vein, Au-Sn Polymetallic Vein Deposits (Belt VK) Western Part of

Russian Northeasa

Nikolaevskoe and Otkrytoe Au Quartz Vein Deposits.

Chochimbal Au Polymetallic Vein Deposit.

Imtandata Sn polymetallic Vein Deposit.

Origin of and Tectonic Controls for Verkhoyansk Metallogenic Belt.

Yana-Kolyma Metallogenic Belt of Au Quartz Vein, Sn Vein and Greisen, W Vein. Granitoid-Related Au, and Clastic-

Sediment-Hosted Hg Deposits (Belt YA) Central Pant of Russian Northeast.

Host Granitoid rocks and Associated l.ode Deposits

Natalka Au Quartz Vein Deposit.

Svetloe and Kholodnoe Au Quartz Vein Deposits

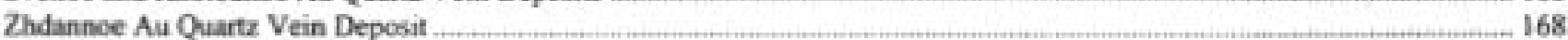

Utin Au Quartz Vein Deposit.

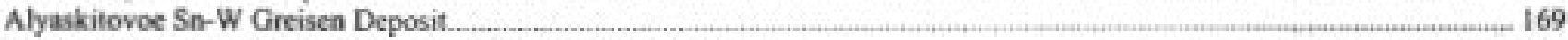

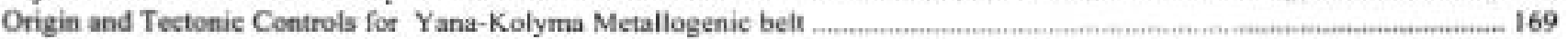

Metallogenic Belts Formed During Late Mesozoic Island Arcs in Russian Northeast and Southeastem Alaska, and Southem

Canadian Cordillera.

Left Omolon Belt of Porphyry Mo-Cu and Mo-Cu Skam Deposits (Belt LO) East-Central Part of Russian Northeast...mentuman+m 170

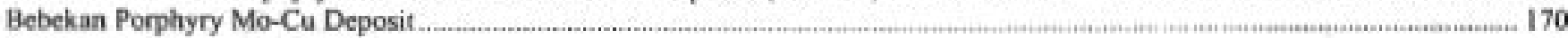

Medgora Mo-Cu skam Deposit.......,_.

Origin of and Tectonic Controls for Left Omolon Metallogenic Belt _._.

Westem-Southeastem Alaska Metallogenic Belt of Granitic-Magmatism-Related Deposits (Beli WSE) Southeastem Alaska ..... I7।

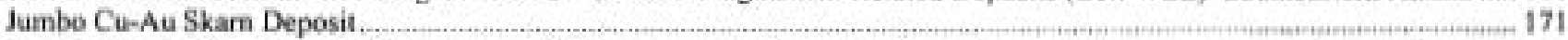

Bokan Mountain Felsic plutonic U-REE deposit _..m. 171

Origin of and Tectonic Controls for Western-Southeastem Alaska Metallogenic Belf.....

Britannia Metallogenic Belt of Kuroko Cu-Zn Massive Sulfide Deposits, Southern British Columbia (Bch BR) ...

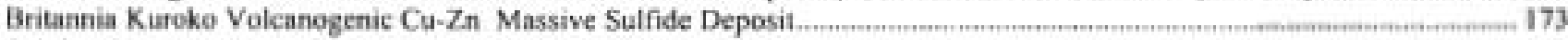

Origin of and Tectonic Controls for Britannia Metallogenic Belt.

Late Early Cretaceous Metallogenic Belts (120 to $100 \mathrm{Ma}$; Figures 61, 62) _._.........._._. 173

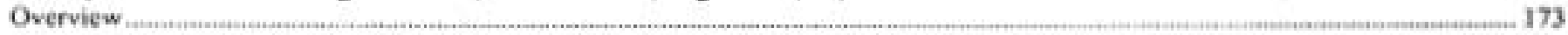

Metallogenic-Tecionic Model for Late Early Cretaceous (120 to $100 \mathrm{Ma}$; Figure 72)

Specific Events for Late Early Cretaceous _ _ 175

Metallogenic Beli Formed in Late Mesozoic Continental-Margin Arc, Russian Southeast Badzhal-Erop-Khingan Metallogenic

Bell of

Sn Greisen, Skam, and Sn Quarnz Vein Deposits (BZ-KH) Western Part of Russian Southeast

Solnechnoe Se Quartz Vein Deposit 176

Pravoarmiskoe Sn Greisen Deposit 176

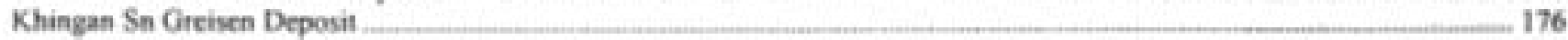

Verkhnebidzhankke So Quartz Vein Deposit ___ 178

Origin of and Tectonic Controls for Badzhal-Erop-Khingan Metallogenic Belt ___ 179

Metallogenic Belts Formed in Late Mesoroic Collision and Accretion of lsland Ares, and Transform Continetral-Margin

Faulting. Russian Northwest, Westem and Northern Alaska, and Northem Canadian Cordillera

Anadyr River Metallogenic Belt of Au Quartz Vein and Associated Deposits (Belt AD) Eastem Part of Russian Northeast. 180

Vacej As Quartz Vein Occurrence. 180

Nutekin Aw Quart2 Vein Occurrence.

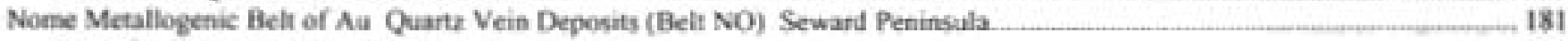

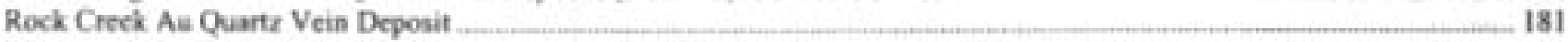

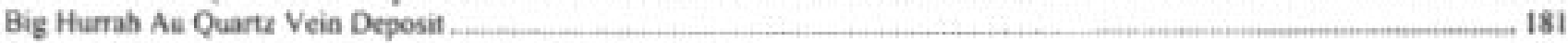

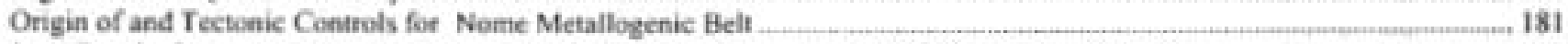

Southern Brooks Range Metallogense Belt of Au Quartz Vein Deposits (Belt SBR) Northern Alaska................................ 182

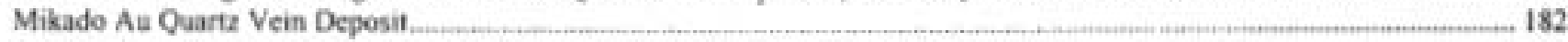

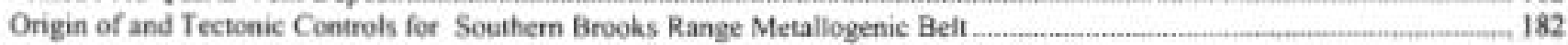

Fish River Metallogenic Belt of Sedimentary P and Fe Deposits (Belt FR) Northern Yukon Territory .................................... 183

Metallogenic Belts Formed in Late Mesozoic Collision and Accretion of Wrangellia Superterrane, and Generation of Omineca-

Selwyn Plutonic Belt, Canadian Cordillera. 
Selwyn Metallogenic Belt of W-Cu Skarn, Zn-Pb-Ag Skam, and Zn-Pb-Ag Manto Deposits, Eastern and Northeastem Yukon

Temitory (Belt SW)

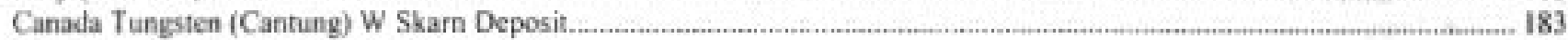

Macnillan Pass (Mactung) Skarm W Deposit.

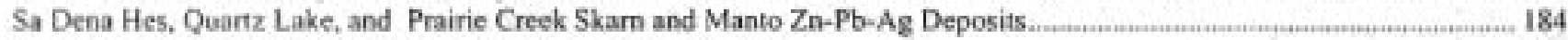

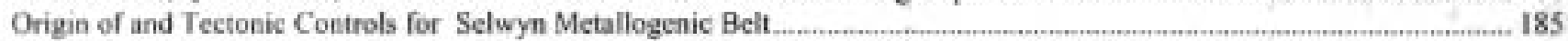

Tombstone Metallogenic Beit of Ag Polymetallic Vein, Au-Sb Vein, and W-Sn-Au and Cu-Au Skam Deposits, Central

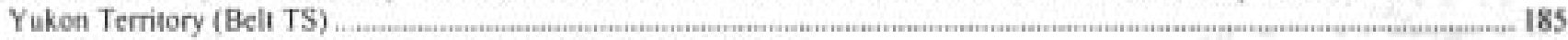

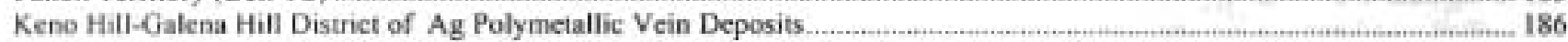

Brewery Creck Sb-Au Vein Deposit _. 186

Eagle (Dublin Gulch) Porphyry Au-W Deposit 186

Ray Gulch W Skam Deposit....__ 187

Origin of and Tectonic Controls for Tombstone Metallogenic beh.

Cassaar Metallogenic Belt of Porphyry Mo-W; W Skarn, Zn-Pb-Ag Manto, Sn Skarn, and Au Skam Deposits (Belt CA)

Northern British Columbia and Southem Yukon Territory 188

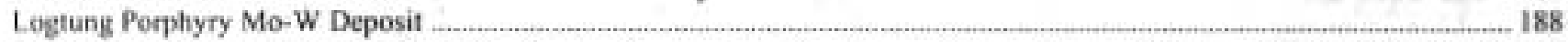

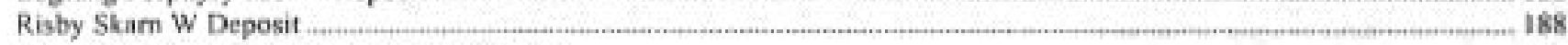

Midway (Silvertip) Manto Pb-Zn-Ag Deposit n...

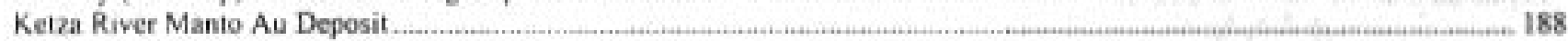

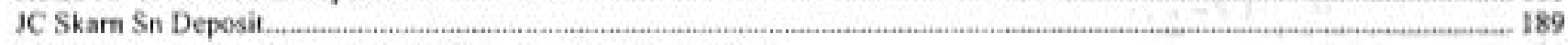

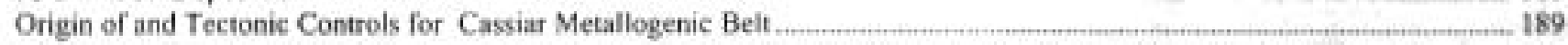

Whiteborse Metallogenic Belt of Cu-Fe Skarn, Porphyry Cu-Au-Ag, and Au-Ag Polymetallic Vein Deposits (Belt WH)

Southern Yukon Territory 189

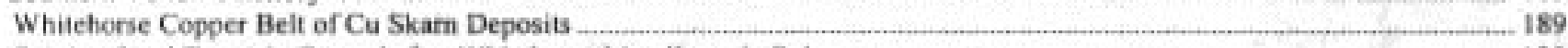

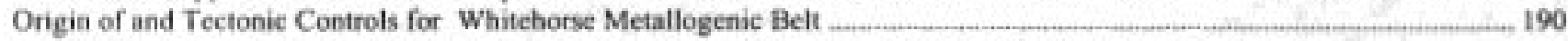

Bayonne Metallogenic Beit of Porphyry Mo and Cu-Mo-W-Zn Skam Deposits (Belt BA) Southern British Columbia

Boss Mountan Porphyry Mo Deposit _._..._._. 191

Trout Lake Porphyry Mo Deposit _._. 191

Red Mouniain Mo Skam Deposit. _ 191

Emerald-Invincible W-Mo Skam Deposit._____ 191

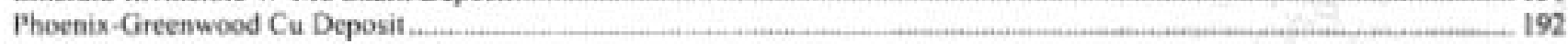

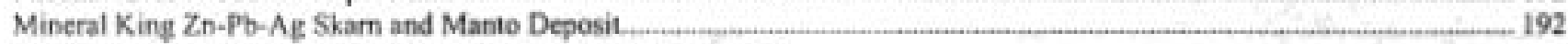

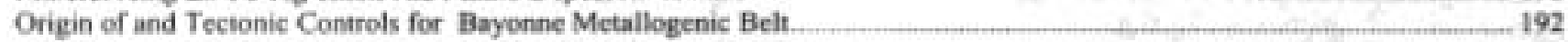

Early Late Cretaceous Metallogenic Belis (100 to $84 \mathrm{Ma}$; Figures 79, 80) _

Overview 192

Metallogenic-Tectonic Model for Early Late Cretaceous (100 to 84 Ma; Figure 81) _____ 194

Specific Events for Early Late Cretaceous.____ 194

Metallogenic Belt Formed in Late Mesozoic Part of East Sikhote-Aline Continental-Margin Are, Russian Southeast _.

Sergeevka Metallogenic Belt of Granitoid-Related Au Deposits (Belt SG) Southern Part of Russian Southeast

Progress Granitoid-Related Au Deposit _ 197

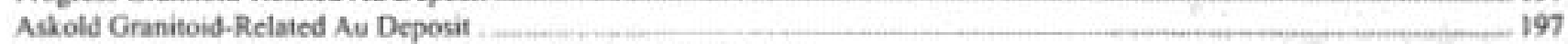

Origin of and Tectonic Controls for Sergeevka Metallogenic Belt _-_._. 197

Taukha Metallogenie Belt of B Skam, Pb-Zn Skam, Pb-Zn Polymetallic Vein, and Related Deposits (Belt TK) Eastem Part

of Russian Southeast. 197

Dalnegorsk B Skarn Deposit _..._._._._._._._. 199

Nikolaevskoe Pb-Ze Skam Deposit ___ 200

Partizanskoe Pb-Zn Skam Deposit _ 201

Krasnogonkoe Pb-Zn Polymetallic Vein Deposit. 202

Oriegn of and Tectonic Controls for Taukha Metallogenic Belt._._. 203

Kema Metaliogenic Belt of Ag-Au Epithermal Vein, and Porphyry Cu-Mo Deposits (Belt KM) Eastem Part of Russian

Southeast. 204

Glinyanes Ag Eputhermal Vein Deposit.____ 204

Sukhoi Creek Porphyry Cu-Mo Deposit ___ 204

Tayouhnoe Ag Epithermal Vein Deposit._. 205

Verkhnezolotoc Porphyry Cu Deposit. 205

Origin of and Tectonic Controls for Kema Metallogenic Belt . 205

Lerhkinsky Metallogenic Belt of Sn Greisen, Sn Polynietallic Vein, Sn silica-sulfide vein, and Porphyry Sn Deposits (Belt LZ)

Southem Part of Russian Southeast ..._. 205

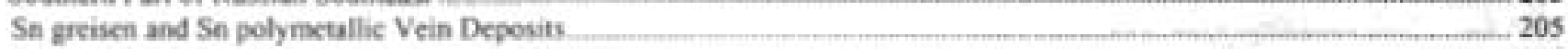

Tigrinoe Sn Greisen Deposit . 206

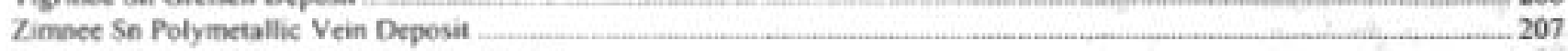

Anenyevikoe Sn Silica-Sulfide Vein Deposit _ _ _ 207

Yantamoe Porphyry So Deposit._. 209 
Lower Amur Metallogenic Belt of Au-Ag Epithermal Vein, Porphyry Cu, and Sn Greisen Deposits (Belt LA) Northern

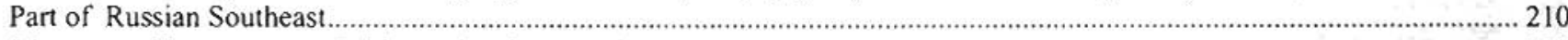

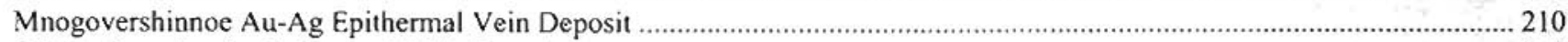

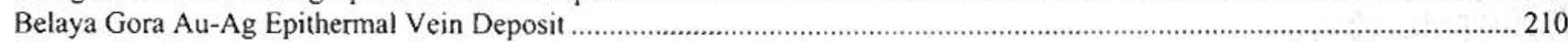

Origin of and Tectonic Controls for Lower Amur Metallogenic Belt .................................................................................... 211

Metallogenic Beit Formed in Late Mesozoic Oceanic Crust and Island Arc Terranes, Russian Southeast ...................................... 211

Aniva-Nabil Metallogenic Belt of Volcanogenic Mn and Fe and Cyprus Massive Sulfide Deposits (Belt ANN) Sakhalin

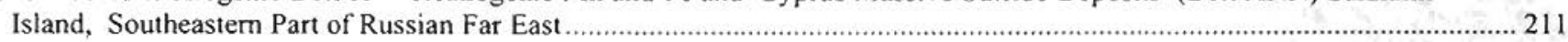

Metallogenic Belts Formed in Late Mesozoic and Early Cenozoic Olyutorka Island Arc, Russian Northeast ................................ 212

Koryak Highlands Metallogenic Belt of Zoned Mafic-Ultramafic PGE and Cu Massive Sulfide Deposits (Belt KH) East-

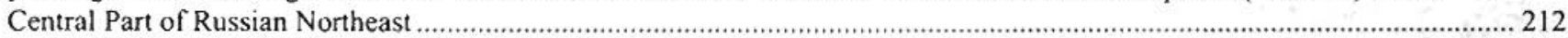

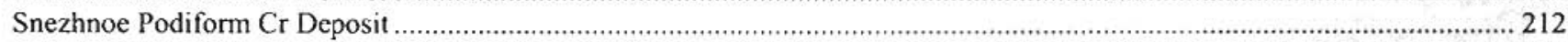

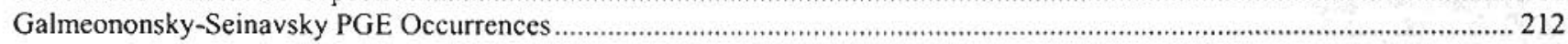

Origin of and Tectonic Controls for Koryak Highlands Metallogenic Belt........................................................................ 213

Vatyn Metallogenic Belt of Volcanogenic Mn and Fe Deposits (Belt VT) Southeastern Part of Russian Northeast.................... 213

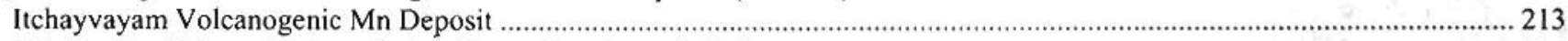

Origin of and Tectonic Controls for Vatyn Metallogenic Belt .......................................................................................2 214

Eastern Asia-Arctic Metallogenic Belt Formed in Late Mesozoic Part of Okhotsk-Chukotka Continental-Margin Arc, Russian

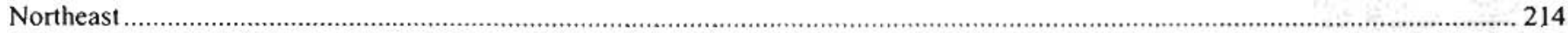

General Setting of Metallogenic Zones in Eastern Asia-Arctic Metallogenic Belt ....................................................................2 214

Origin of and Tectonic Controls for Eastern Asia-Arctic Metallogenic Belt ..............................................................................2 214

Eastern Asia-Arctic Metallogenic Belt: Dogdo-Erikit Metallogenic Zone of Au-Ag Epithermal Vein, Sn-polymetallic vein

(Southern Bolivian type?), and Volcanic-Hosted Hg (Plamennoe type) Deposits (Belt DE) West-Central Part of Russian

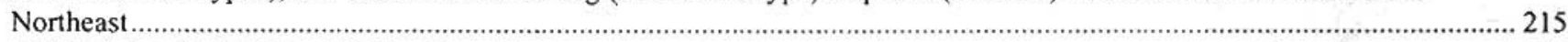

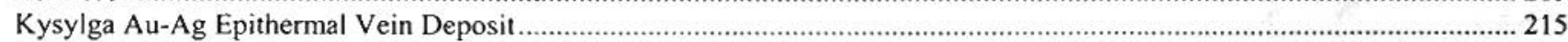

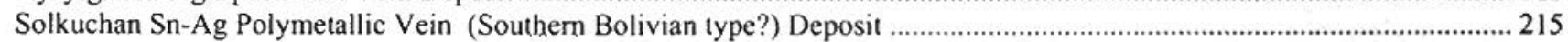

Dogdo Volcanic-Hosted Hg (Plamennoe type) Deposit .................................................................................................. 215

Eastern Asia-Arctic Metallogenic Belt: Okhotsk Zone of Au-Ag Epithermal Vein Deposits (Belt EAOH) Southeastern Part of

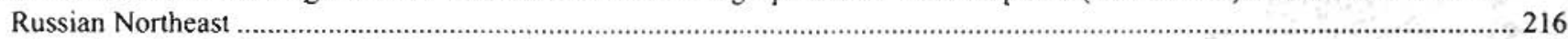

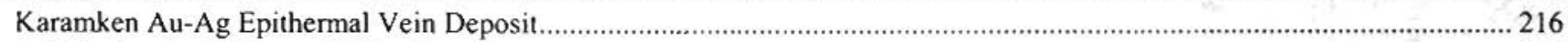

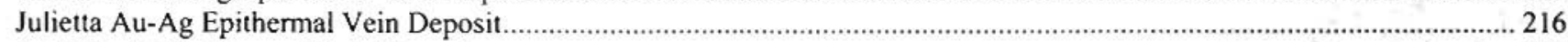

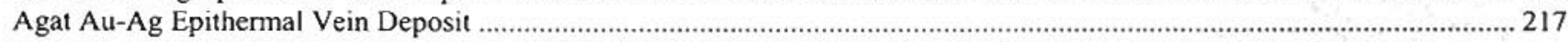

Eastern Asia-Arctic Metallogenic Belt: Koni-Yablon Zone of Porphyry Cu-Mo and Cu-Mo Skarn Deposits (Belt EAKY)

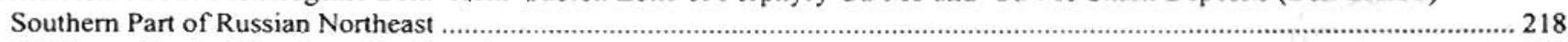

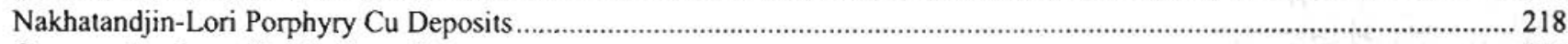

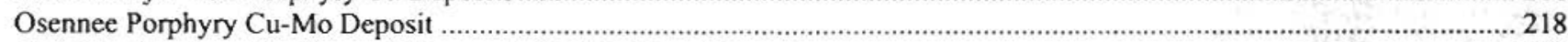

Etandzha Porphyry Cu-Mo and Muromets Cu-Mo Skam Deposits .....................................................................................2. 219

Eastern Asia-Arctic Metallogenic Belt: Korkodon-Nayakhan Zone of Porphyry Mo and Granitoid-Related Au Deposits

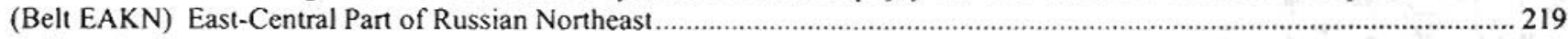

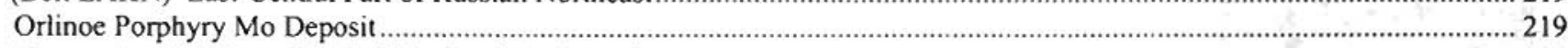

Khetagchan Porphyry Granitoid-Related Au Deposit ....................................................................................................... 219

Eastern Asia-Arctic Metallogenic Belt: Verkhne-Kolyma Zone of Sn-Ag Polymetallic Vein (Southern Bolivian type), Sn

Polymetallic Vein, Rhyolite-Hosted Sn, and Granitoid-Related Au Deposits (Belt EAVK) Southeastern Part of Russian

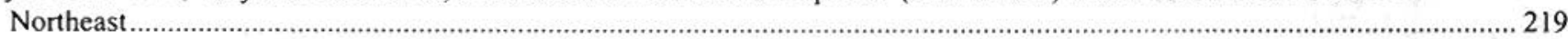

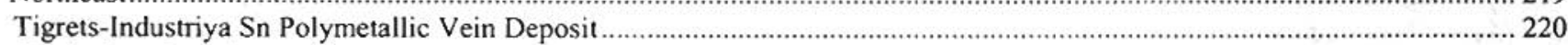

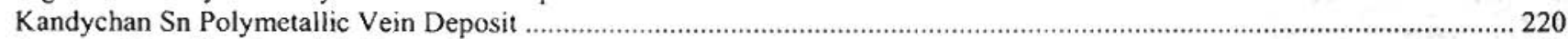

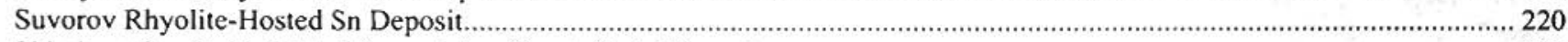

Shkolnoe Granitoid-Related Au and Au Quartz Vein Deposit .............................................................................................. 220

Eastern Asia-Arctic Metallogenic Belt: Vostochno-Verkhoyansk Zone of Ag Polymetallic Vein and Clastic Sediment-Hosted $\mathrm{Hg}$ Deposits (Belt VV) West-Central Part of Russian Northeast .................................................................................2 221

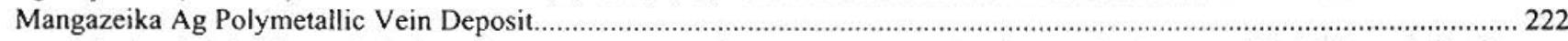

Eastern Asia-Arctic Metallogenic Belt: Adycha-Taryn Zone of Au-Ag Epithermal Vein, Ag-Sb Polymetallic Vein, and Clastic Sediment-Hosted Sb-Au Deposits (Belt AT) Western Part of Russian Northeast .................................................................222

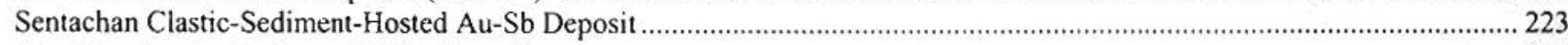

Ak-Altyn Au-Ag Epithermal Vein Deposit ................................................................................................................ 223

Eastern Asia-Arctic Metallogenic Belt: Omsukchan Zone of Sn Polymetallic Vein, Sn Silicate-Sulfide, Porphyry Sn, Au-Ag Epithermal Vein, Porphyry Mo-Cu, and Associated Deposits (Belt EAOM) Southeastern Part of Russian Northeast .............. 223

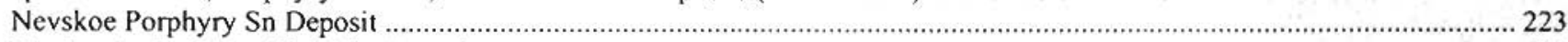

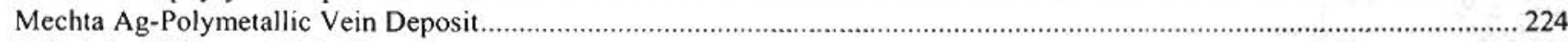

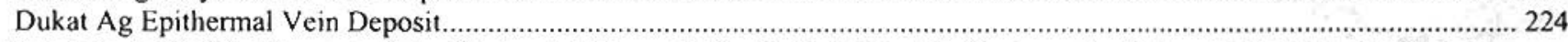

Eastern Asia-Arctic Metallogenic Belt: Chokurdak Zone of Granitoid-Related Sn Greisen, Sn-Polymetallic Vein, Sn Greisen, and Au-Ag Epithermal Vein Deposits (Belt EACD) Northern Part of Russian Northeast. 
Eastern Asia-Aretic Metallogenic Belt: Chaun Zone of Granitic-Magmatism-Related Deposits (Belt EACN) Northeastern

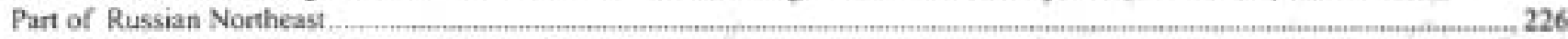

Jultin Sn-W Polymetallic Vein and Greisen Deposit._. 226

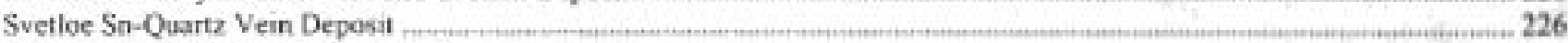

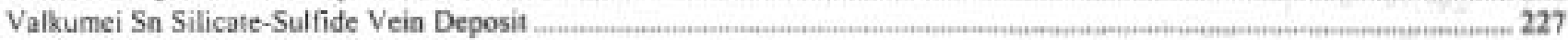

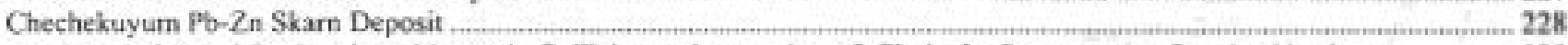

Metallogenic Belt Formed During Late Mesozoic Collision and Aceretion of Chukotka Superterrane, Russian Northeast.mumenum, 228

Chukotka Metallogenic Belt of Au Quartz Vein and Related Deposits (Belt CH) Northern Part of Russian Northeast .m.num..... 228

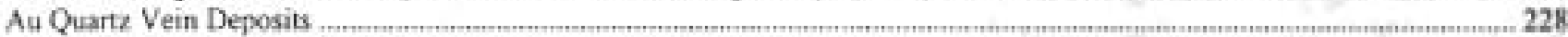

Karalveem Au Quartz Vein Deposit.

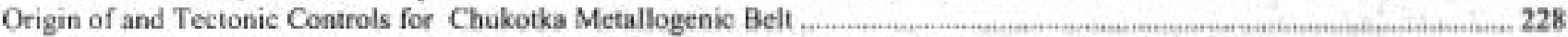

Metallogenic Belts Formed in Late Mesozoic Collision and Accretion of Wrangellia Superterrane, Southem Alaska............... 229

East-Central Alaska Metallogenic Belt of Granitic Magmatism Deposits (Older, Mid-Cretaceous Part; Belt ECA)

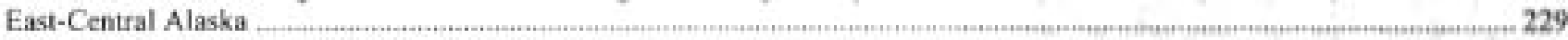

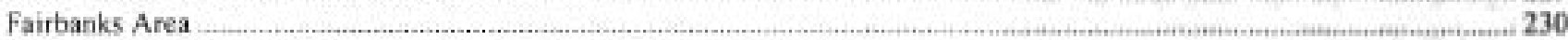

Fort Knox Granitoid-Related Au Deposit.

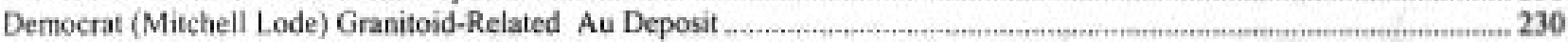

Pogo Granitoid-Related Au Quartz Vein Deposit ......... 232

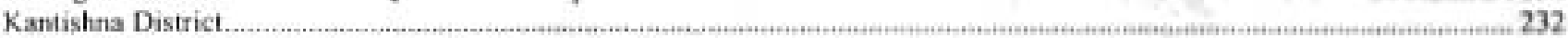

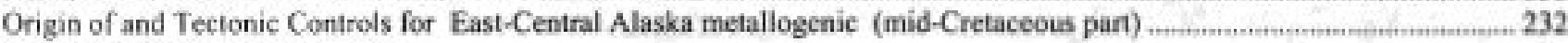

Misused Name: Tintina Gold Belt ....... 233

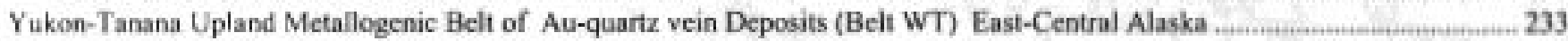

Purdy Au Quartz Vein Deposit.

Origin of and Tectonic Controls for Yukon-Tanana Upland Metallogenie Belt ......................................................................... 233

Wrangell Mountains Metallogenic Beli of Cu-Ag Quartz Vein and Kennecoti Cu Deposits (Belt WR) Eastern-South Alaska m...233

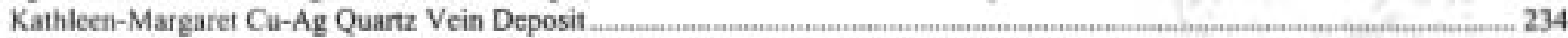

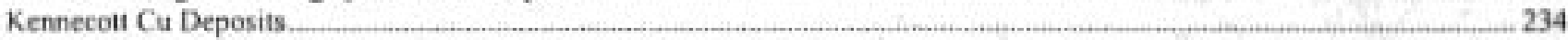

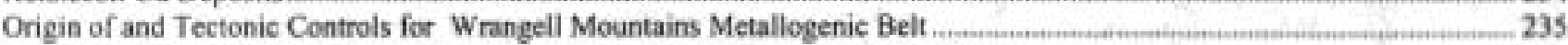

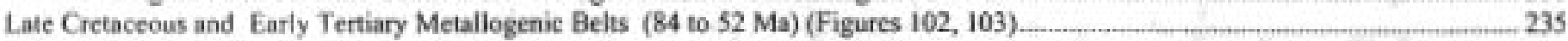

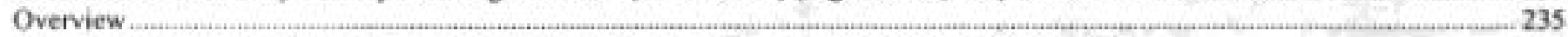

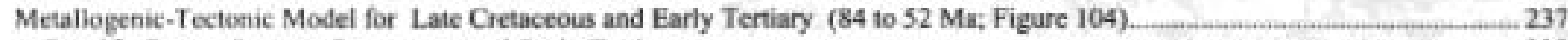

Specific Events for Late Cretaceous and Early Tertiary _.

Metallogenic Belt Formed in Late Mesozoic and Early Cenozoic Olyutorka Island Arc, Russian Northeast......................... 240

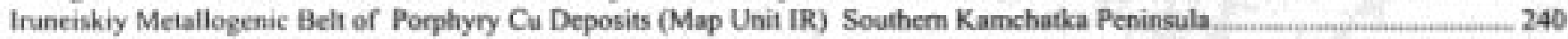

Metallogenic Belts Formed in Late Mesozoic and Early Cenozoic Part of Okbotsk-Chukotka Continental-Margin Are,

Russian Nontheast and Western Alaska.

Eastem Asia-Aretic Metallogenic Belt: Verkhne-Yudomsky (Yuzhno-Verkhoyansk) Zone of Sn and Ag Polymetallic Vein (Southem Bolivian type) Deposits (Belt VY) West-Central Part of Russian Northeast.

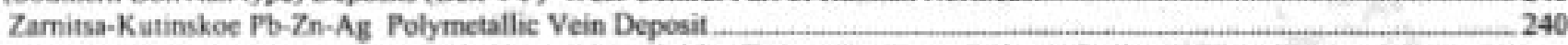

Easiem Asia-Arctic Metallogenic Belt: Verkhoyansk-Indigirka (Dulgalak) Zone of Clastic Sediment-Hosted Hg and Sb-Au Vein

Deposits (Belt EAV1) Westem Part of Russian Northeast. 241

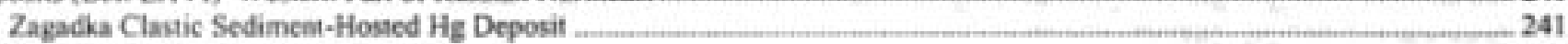

Kyuchyus Sb-Au-Hg Vein Deposit. 241

Eassem Asia-Arctic Metallogenic Belt: Anuyi-Beringoviky Zone of Au-Ag Epithermai Vein and Disseminated Au Sulfide Deposits (Belt EAAB) Northeastem Pant of Russian Northeasi 241

Valunistoe Au-Ag Eputhernal Vein Deposit _._._._._._._._._. 243

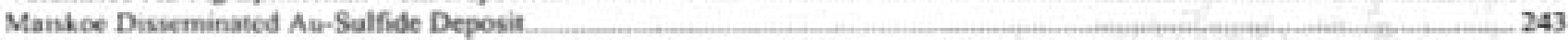

Easlem Asia-Arctic Metallogenic Belt: Chukodka Zone of Igneous-Related Hg Deposits (Belt EACH) Northeastem Part of Russian Northeast 243

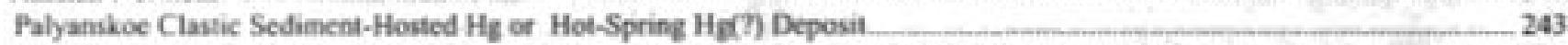

Seward Peninsula Metallogenic Belt of Granitic Magmatism Deposits (Belt SP) Northwestem Alaska._._. 244

Losa River Sn-W Skarn and Sn Greisen Deposit. 245

Felsic Plutonic U and Sandstone U deposits ___ 245

Origin of and Tectonic Controls for Sewand Peninsula Metallogenic Belt._._. 245

Nonthwestern Koyukuk Basia Metallogenic Belt of Felsic Plutonic U and Manto-Replacement (Polymetallic Pn-Zn, Au)

Deposits (Beli NWK) West.Central Alata. 245

Whecler Creek, Clear Creek, and Zane Hills Felsic Plutonic U Deposits._._. 247

Ilisoss Creek Manto-Replacement (Polymetallic Pn-Zn, Aa) Deposit. 247

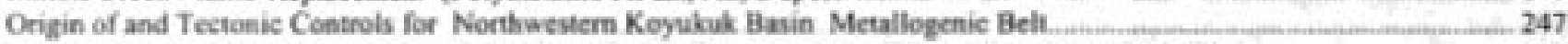

West-Central Alaska Metallogenic Belt of Porphyry Cu-Au Deposits (Belt WCA) West-Central Alaska.

Indian Mountain and Purcell Mountain Porphyry Cu-Au Deposits _ 247 
Origin of and Tectonic Controls for West-Central Alaska Metallogenic Beit.

Metallogenic Beits Formed in Late Mesozoic and Early Cenozoic Kluane Continental-Margin Are, Southern Alaska......mem...men.. 248

Kuskokwim Mountains Metallogenic Belt of Granitic-Magmatism-Related Deposits (Beit SWK) Southwestem Alaska...r...m... 248

Geologic Setting of Kuskokwim Mountains Metallogenic Belt .

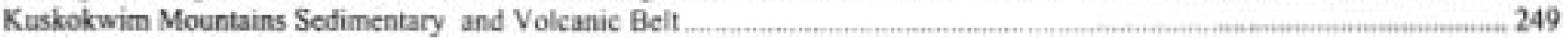

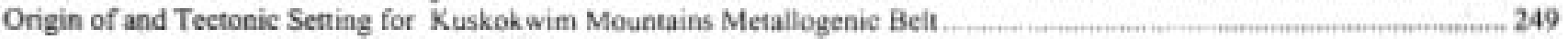

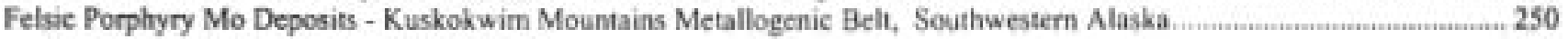

MeL.eod Porphyry Molybdenum Prospect. . 250

Molybdenum Mountain Porphyry Molybdenum Prospect _._. 250

Alkalic-Calcic Porphyry Cu-Au Prospects - Kuskokwim Mountains Metallogenje Belt.

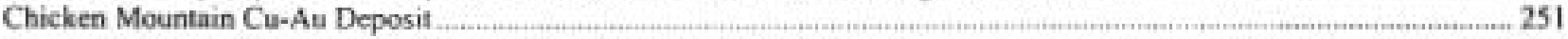

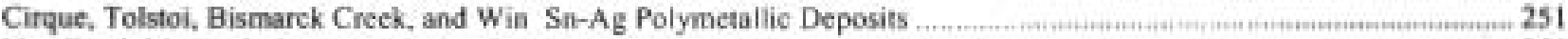

Von Frank Mountain Porphyry Cu-Au Prospect. 251

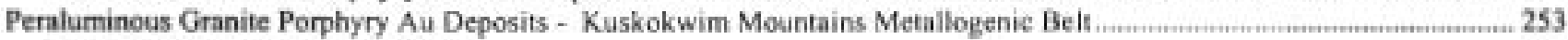

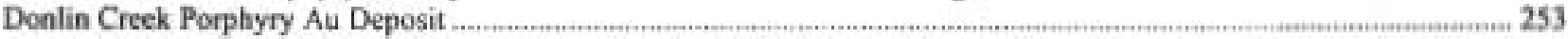

Vinasale Granitodd-Related (Porphyry) Au Deposit.... .

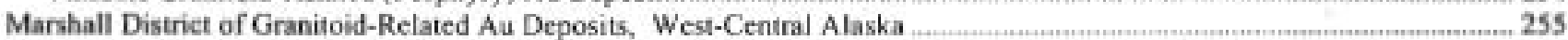

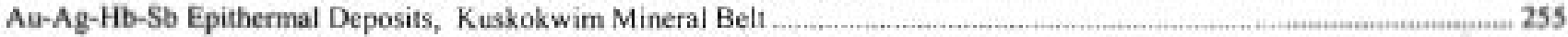

Other Significant Deposits in the Kuskokwim Mineral Belt .......... 256

East-Central Alaska Metallogenic Belt of Granitic Magmatism Deposits (Younger, Late Cretaceous and Early Tertiary Part;

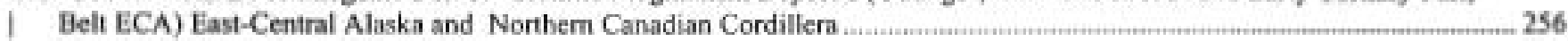

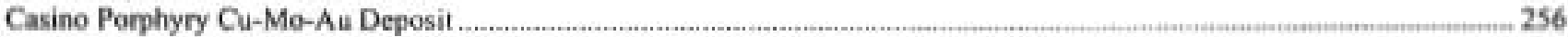

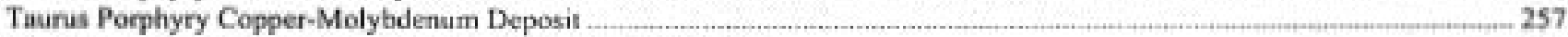

Road Metal Tourmaline-Topaz-Quartz-Sulfide Greisen Deposit 257

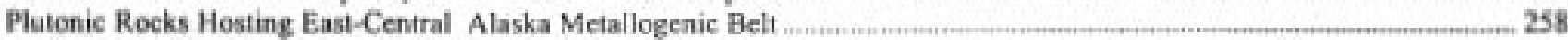

Origin of and Tectonic Setting for East-Central Alaska Metallogenic Belt (Younger Late Cretaceous and Early Tertiary

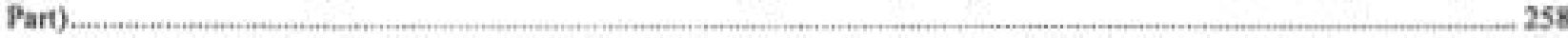

Southern Alaska Metallogenic Belt of Granitic Magmatism Deposits (Belt SA) Central and Northern Part of Southern Alaska... 258

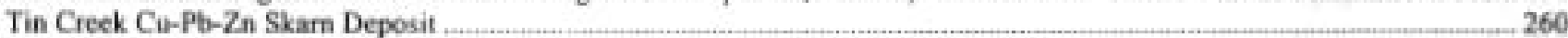

Kijik River Porphyry Cu Deposit ..._. _ 260

Golden Zone Deposit w.

Nabesna Glacier polymetallic vein(?) deposit.

Sn and Mo Lode Deposits Hosted by Granitoid plutons of McKinley Sequence _._._._._._._. 260

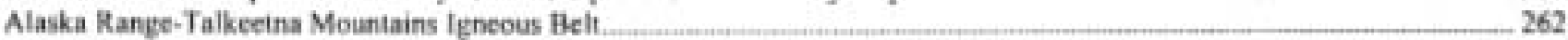

Origin of and Tectonic Setting for Southem Alaska Metallogenic Belt._._._._. 262

Metallogenic Beles Formed During Early Tertiary Oblique Subduction of Kula-Farallon Oceanic Ridge Under Margin of

Southem and Southeastem Alaska 262

Maciaren Metallogenic Belt of Au Quartz Vein Deposits (Belt MC) Northern Part of Eastern-Southern Alaska._................

Lucky Hill and Timberline Creck Au Quartz Vein Deposits. 262

Origin of and Tectonic Controls for Maclaren Metallogenic Belt _._. 263

Talkectna Mouatains Metallogenic Belt of Au Quartz Vein Deposits (Belı TM) Northern Part of Southern Alaska. Independence Au Quartz Vein Deposit ____. 263

Origin of and Tectonic Contools for Talkeetha Mountains Metallogenic Belt ____ 263

Chugach Mountains Metallogenic Belt of As Quartz Vein Deposits (Bels CM) Southern Alaska._. 263

Chiff Au Quarte Vein Deposit._._._._._. 264

Ongin of and Tectonic Controls for Chagach Mountains Metallogenic Beli____ 264

Baranof Metallogenic Belt of Au Quartz Vein Deposits Southeastem Alaska (Belt BN) ___... 264

Chichagoff and Hirst-Chichagof Au Quartz Vein Deposit_____._. 264

Apex and El Nido Av Quartz Vein Deposit _______alogenie Beth 264

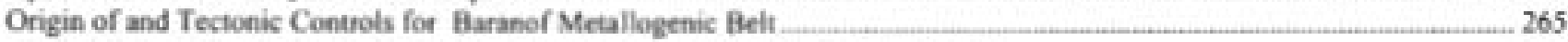

Juneau Metallogenic Beht of Au Quartr. Vein Deposits (Belt JU) Southeastern Alaska. 265

Alaska-Juneau Au Quarte Vein Deposit___. 265

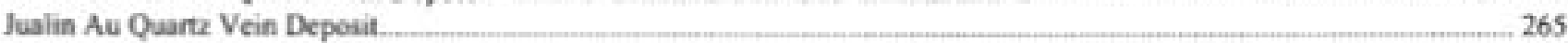

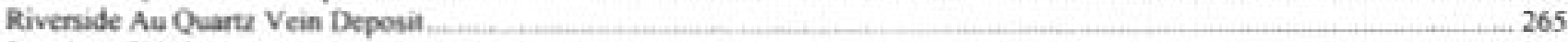

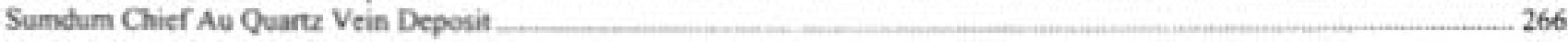

Treadwell Au Quarz Vein Deposit ...__..... 266

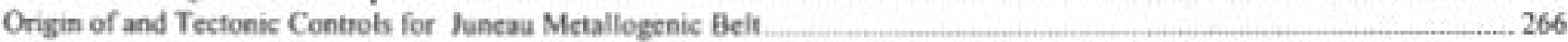

Metallogenic Belts Formed During Early Teniary Spreading Along Kula-Farallon Oceanic Ridge, Southern and Southeastern

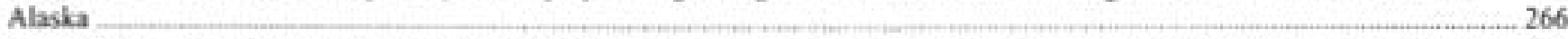

Prince William Sound Metallogenic Belt of Besshi and Cyprus Massive Sulfide Deposits (Belt PW) Eastern-Southern Alaska... 266

Beatson (Latouche) and Ellamar Besshi Massive Sulfide Deposits _ _ 267

Midas Besshi Massive Sulfide Deposit _._. 267

Copper Bultion (Rua Cove) Cyprus Masswe Sulfide Deposit _._. 267 


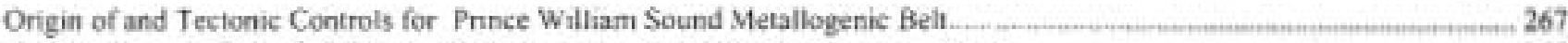

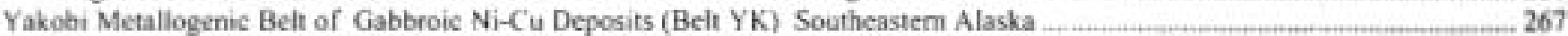

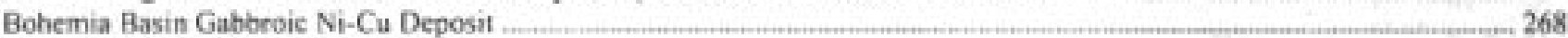

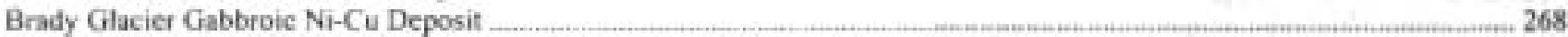

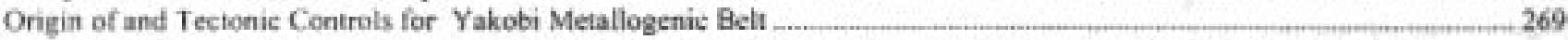

Metallogenic Belts Formed in Late Cretaceous and Early Tertiary Coast Continental-Margin Arc, Southeastem Alakka, and

Southern Canadian Cordillera

Surprise Lake Metallogenic Belt of Porphyry Mo-W-Cu, and Au-Ag Polymetallic Vein Deposits (Belt SL) Northem British

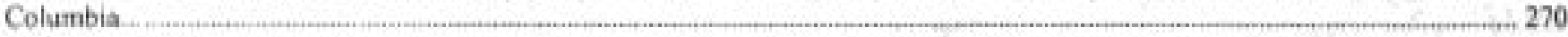

Adanac-Adera Porphyry Mo Deposit__._._. 270

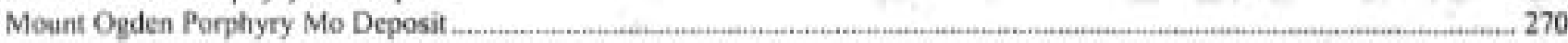

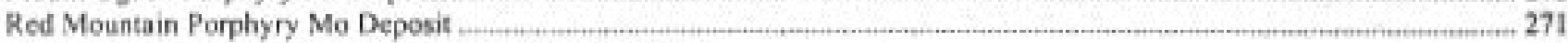

Surprise Lake Polymetallic and Epithermal Au-Ag Veins. .... 271

Origin of and Tectonic Controls for Surprise Lake Metallogenic Belt . 271

Central-Southeastern Alaska Melallogenic Belt of Porphyry Mo and Cu Deposits (Belt CSE) Southeastern Alaska ....................... 272

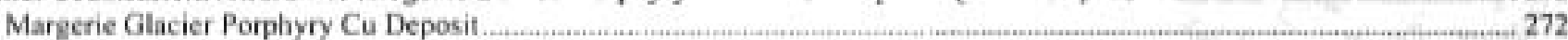

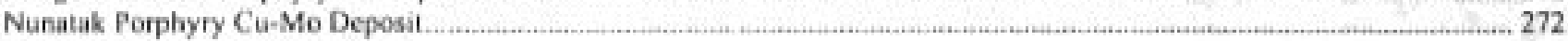

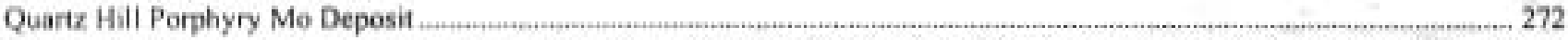

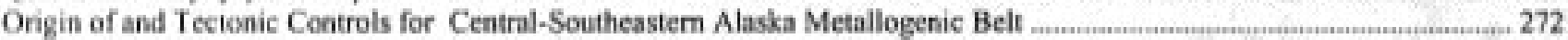

Bulkley Metallogenic Belt of Porphyry Cu-Mo and Polymetallic Vein Deposits (Belt BK) Central British Columbia ................ 273

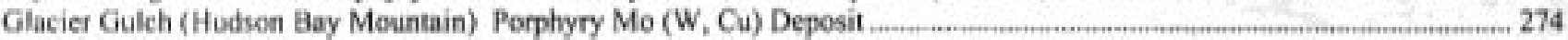

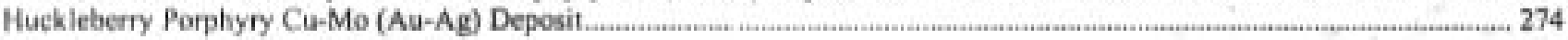

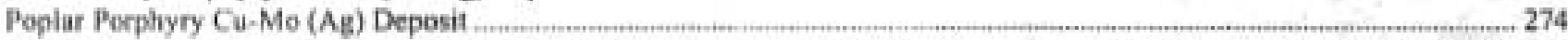

Red Rose W-Au-Cu-Ag Polymetallic Vein Deposit .

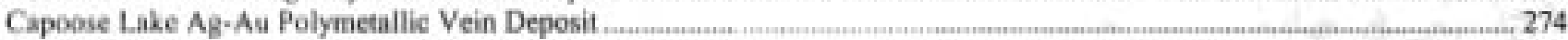

Nadisa (Silver Queen) Ag Polymetallic Vein Deposit 275

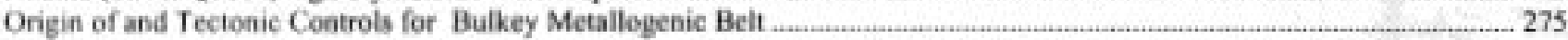

Fish Lake-Bralome Metallogenic Belt of Porphyry Cu-Mo, Porphyry Cu-Au, Au Quartz Vein, Au-Ag Polymetalic Vein, and

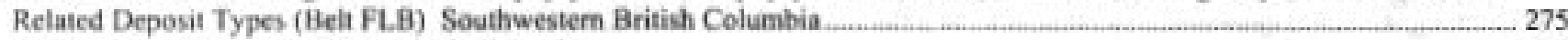

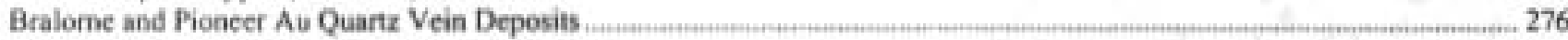

Fish Lake Porphyry Cu*Au (Ag-Mo-Zn) Deposit._._._._. 276

Maggie Porphyry Cu-Mo Deposit _____._. 276

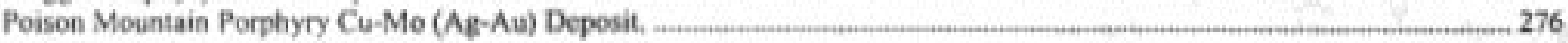

Origin of and Tectonic Controls for Fish Lake-Bralome Metallogenic Belt._._. 277

Tyaughton-Yalakom Metallogenic Belt of W-Sb Folymetallic Vein and Hg-Sb Vein Deposits (Belt TY) Southern British Columbia 277

Gambuer Metallogenic Belt of Porphyry Cu-Me and Za-Pb-Cu Skam Deposits (Belt GB) Southem British Columbia.

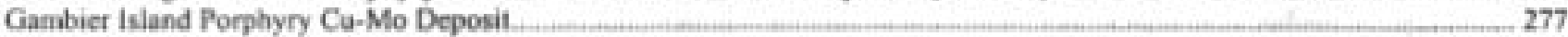

Ho-Mars Porphyry Cu-Mo Deposit. 278

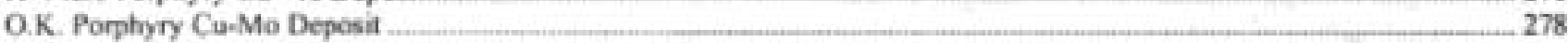

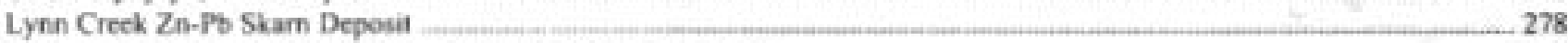

Origin of and Tectonic Coatrols for Gambier Metallogenic Belt

Catface Metallogeaic Belt of Porphyry Cu-Mo-Au and Au-Ag Polymetallic Vein Deposits (Belt CF) Vancouver Island. 278

Porphyry Cu-Mo and Polymetallic Veia Deposits ___ 278

Origin of and Tectoaic Controls for Catface Metallogenic Belt.

Metallogenic Belis Fonned in Backare Part of Earty Tertiary Coast Continental-Margin Are, Southem Canadian Condillera. 279

Skeena Metallogenic Beli of Porphyry Cu-Mo, Porphyry Mo: Az Polymetallic Vein and Au-Ag Epithermal Vein Deposits

(Belt SK) Central British Columbia

Porphyry Mo and Cu-Mo Deposits Associated with Nanika Intrusions of Nanila Plutonic Suite...280

Berg Porphyry Cu-Mo (Pb-Za-Ag-Au) Deposit. 280

Mount Thomlinson Porphyry Mo Deposit .__ 280

Redbird Porphyny Mo Deposit _. 280

Porphyry Mo Deposits Associated with Alice Arm Intrusions of Nanika Plutonic Suite....... 280

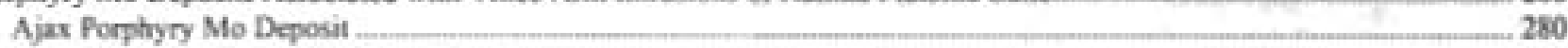

Bell Moly Porphyry Mo-W Deposit _._._. 280

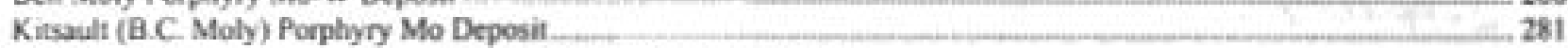

Ag Polymetallic Vein Deposits Associated with Goosly Plutonic Suite .___. 281

Equity Silver (Sam Goosly) Ag Polymetallic Vein Deposit._._._. 28 i

Prospenty-Poner ldaho Ag Polymetallic Vein Deposit. 281

Porphyry Cu-Au-Ag Deposits Associated with Babine Plutonic Suite _._. 281

Bell Copper Porphyry Cu-Au (Mo) Deposit _._._. 281

Ciranesle Porphyry Cu-Au (Mo) Deposil. 282

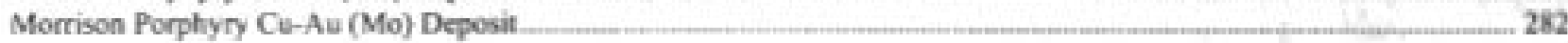


Au-Ag Epithermal Vein Deposits Associated with Quanchus Plutonic Suite

Origin of and Tectonic Controls for Skeera Metallogenic Belt.

Nelson Metallogenic Belt of Ag Polymetallic Vein, Ag-Pb-Zn Manto, Au-Ag Epuhermal Vein, Porphyry Mo, Palecplacer U.

and Related Deposits (Bell NS) Southem British Columbia 283

Blucbell (Riondel) Zn-Pb-Ag Skam and Manto Deposit _ _ 283

Highland Bell (Beaverdell) Ag-Polymetallic Vein Deposit ___ 284

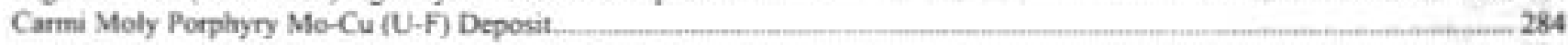

Lassie Lake and Hydraulic Lake Paleoplacer U deposits 284

Origin of and Tectonic Controls for Netson Metallogenic Belt._. 284

Early to Middle Tertiary Metallogenic Belts 52 to 23 Ma; Figures 102, 103) _.___ 285

Overview - 285

Metallogenic-Tectonic Model for Early to Middle Tertiary (52 to23 Ma; Figure 123) ....._.

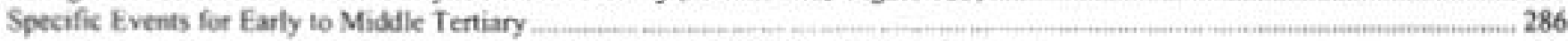

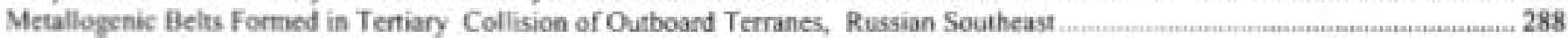

Central Sakhalin Metallogenic Belt of Au Quartz. Vein and Talc Deposits (Beit CS) Sakhalin Island, Soutbeastern Part of

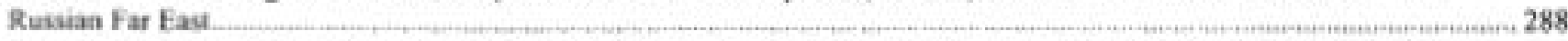

Sredinny Metallogenic Belt of Au Quartz Vein and Metamorphic REE Vein(?) Deposits (Belt SR) Southern Kamehatka Peninsula 288

Tumannoe Au quartz vein deposit .

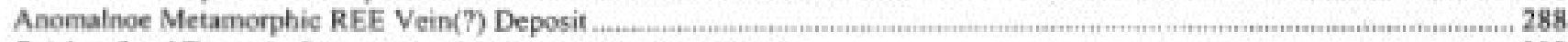

Origin of and Tectonic Controls for Sredinny Metallogenic Belt .....................................

Metallogenic Beits Formed in Tertiary Backare Rifting and Continental-Margin Transform, and Transcurrent Fuulting.

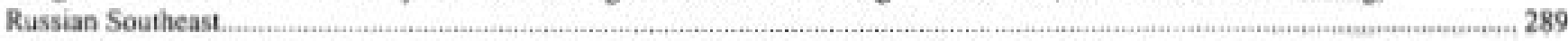

Kvinumaky Metallogenic Belt of Hornblende Peridotite and Gabbroic Cu-Ni Deposits (Belt KV) Southern Kamehatka

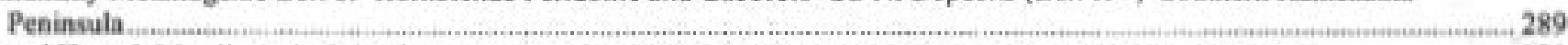

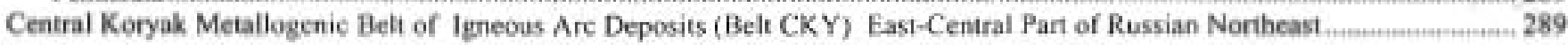

Sn polymetallic Deposits ...._. 289

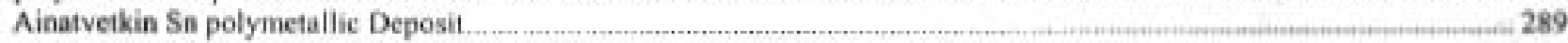

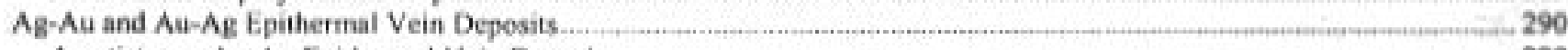

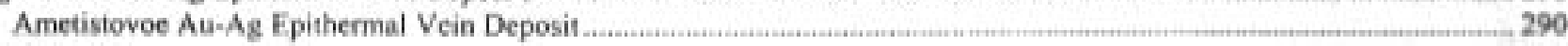

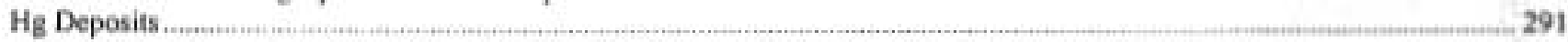

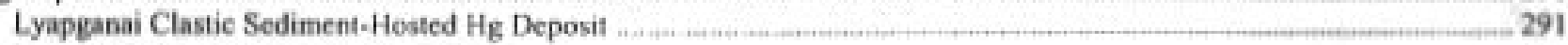

Lamut Volcanic-Hosted Hg Deposit .

Tamvataey Silica-Carbonate $\mathrm{Hg}_{\mathrm{g}} \mathrm{Deposit} \ldots$

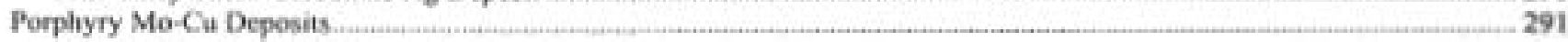

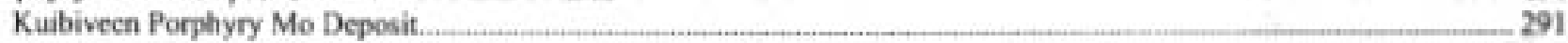

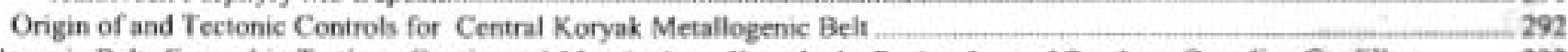

Metallogenic Belts Formed in Tertiary Continental-Margin Arcs, Kamchatka Peninsula, and Southem Canatian Cordillera

Olyutor Metallogenic Belı of Igneous-Arc-Related Deposits (Belt OT) Karnchatka Peninsula ____. 292

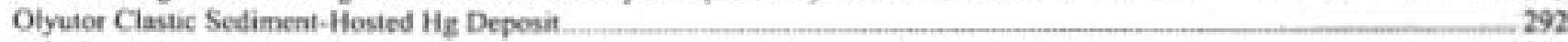

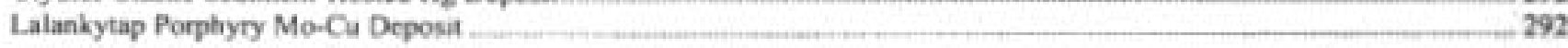

Maletoivayam Sulfur-Sulfide Deposit_______. 293

Ongin of and Tectonic Controls for Olyutot Metallogenic Belt

Pinchi Lake Metallogenic Belt of Hg Epithermal Vein, Sb-Aw Vein, and Silica-Carbonate Hg Deposits (Belt PC) Central

British Columbia 293

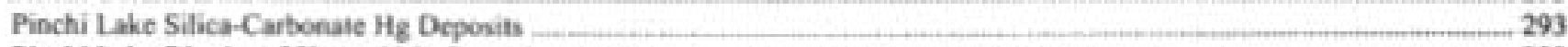

Pinchi Lake District of Sb-Au Vein Deposits. _ _ 293

Origin of and Tectonic Controls for Pinchi Lake Metallogenic Belt

Owl Creck Metallogenic Belt of Porphyry Cu-Mo. Porphyry Mo. and Au Polymetailic Vein Deposits (Belt OC) Southem

Bntish Columbia. 294

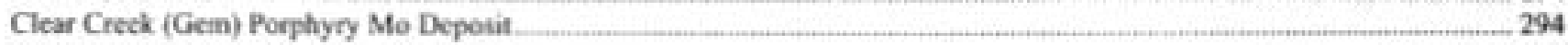

Owl Creek Porphyry Cu-Mo District ..._. 294

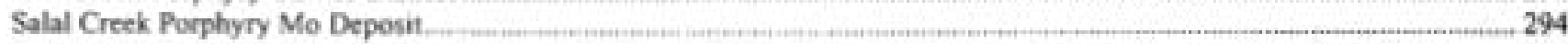

Origin of and Tectonic Controls for Owl Creek Metallogenic Belt.

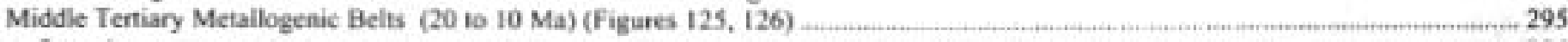

Overview. . 295

Metallogenic-Tectonic Model for Middle Tertiary (20 tol0 Ma, fig. 127) _.

Specifie Events for Middle Tertiary _. 295

Metallogenic Belts Formed in Tertiary Continental-Margin Arcs, Kanchatka Peninsula, Southem Alaska, and Southern

Canadian Cordillera .....

East Kamchatka Metallogenic Belt of Au-Ag Epithermal Deposits (Belt EK) Eastern and Southern Kamchatka Peninsula wewnen 299

AsachinskoeAu-Ag Epithermal Vein Deposit ...

Mutnovskoe Au-Ag Epithermal Vein Deposit . 


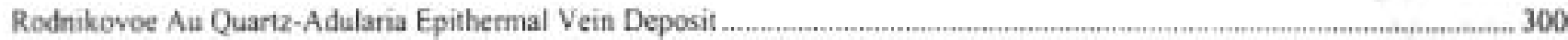

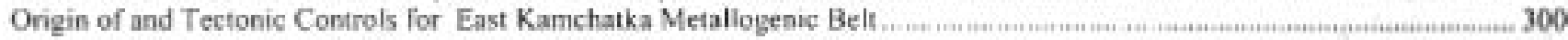

Central Kamchatka Metallogenic Belt of Au-Ag Epithermal and Porphyry Cu-Mo Deposits (Belt CK) Kamchatka Peninsula..... 300

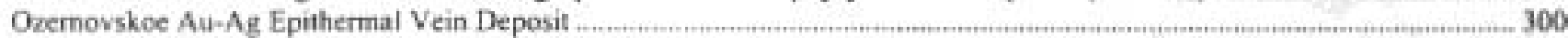

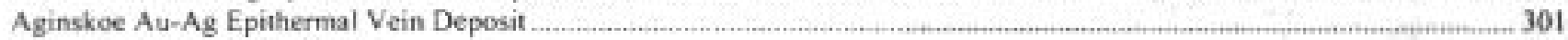

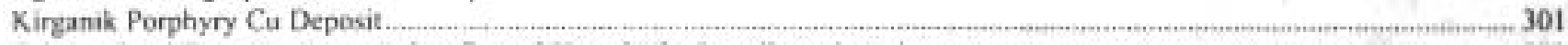

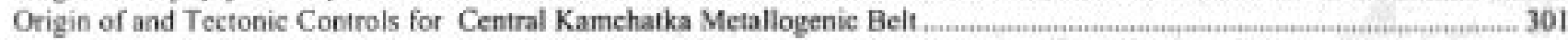

Alaska Peninsula and Aleutian Islands Metallogenic Belt of lgneous Are Deposits (Belt AP) Western-Southern Alaska .nwernen. 301

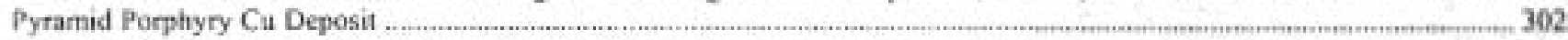

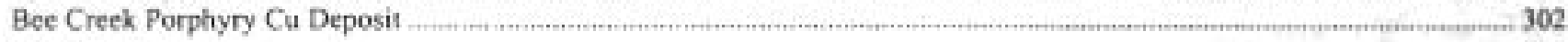

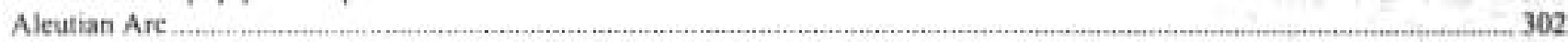

Tectonic Setting for Alaska Peninsula and Aleutian islands Metallogenic Belt.

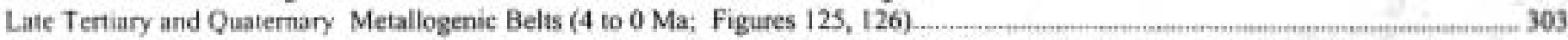

Overview ...........................

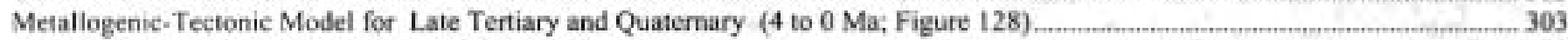

Specific Events for Late Tertiary and Quatemary ......

Metallogenic Belts Formed in Late Tertiary and QuaternaryContinental-Margin Ares, Kamehatka Peninsula, Southern Alaska, and Southem Canadian Cordillera .................................

Sakhalin Island Metallogenic Belt of Siljea-Carbonate or Volcanic-Hosted Hg Deposits (Belt SH) Sakhalin Island,

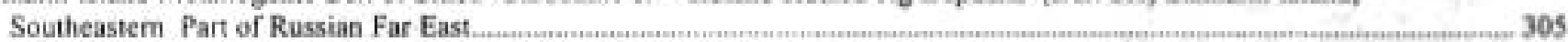

Kuril Metallogenic Beht of Au-Ag Epithermal Vein, Cu-Pb-Zn Polymetallic Vein, Sn silica-sulfide vein, Sn Vein, Sulfur-sulfide

(volcanic S), Kuroko Massive Sulfide, and Porphyry Mo Deposits (Belt KU) Kuril Islands, East-Central Pant of Russian

Far East . 305

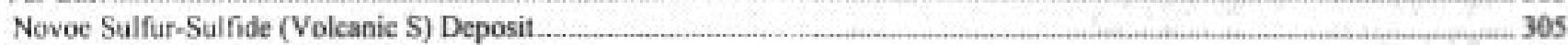

Prasolovskoe Au-Ag Epithermal Vein Deposit .

Koshikina Cu-Pb-Zn Polymetallic Vein Deposit....._._._. 306

Valentinovskee Kuroko Cu-Pb-Zn Deposit.... 306

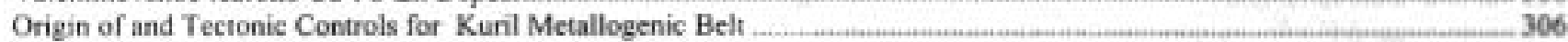

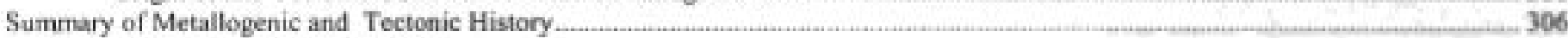

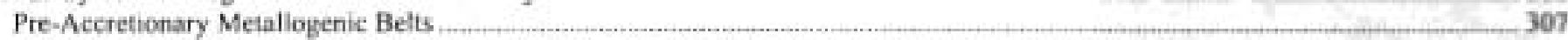

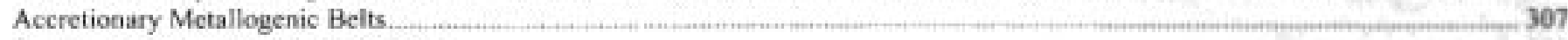

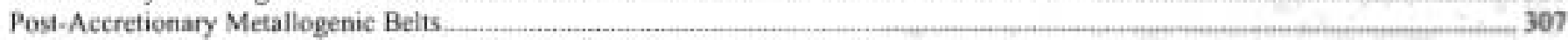

Conclusions _. 308

References Cited . _. 309

Cover Figure. Major present-day metallogenic and tectonic elements for the Circum-North Pacific and geographic names for major regions. The major features, continued from the Neogene are: (1) a series of continental-margin arcs and companion subduction-zone assemblages around the Circum-North Pacific; (2) continuation of opening of major sedimentary basins behind major arcs; (3) in the eastern part of the Circum-North Pacific, dextral transpression between the Pacific Ocean plate and the present-day Canadian Cordillera margin; and (4) sea-floor spreading in the Arctic and eastern Pacific Oceans. Refer to text for detailed explanation of tectonic events (section on Pliocene to Present) and to figure 18 for explanation of abbreviations, symbols, and patterns. The major metallogenic belts are: (1) the Kuril (KU) metallogenic belt which is hosted in the Kuril volcanic-plutonic belt; (2) the Alaska Peninsula and Aleutian islands (AP) metallogenic belt which contains granitic-magmatism-related deposits and is hosted in the Aleutian volcanic belt; and (3) the OWl Creek (OC) metallogenic belt which is hosted in the Cascade volcanic-plutonic belt. 


\section{Metallogenesis and Tectonics of the Russian Far East, Alaska, and the Canadian Cordillera}

\section{Abstract}

The Proterozoic and Phanerozoic metallogenic and tectonic evolution of the Russian Far East, Alaska, and the Canadian Cordillera is recorded in the cratons, craton margins, and orogenic collages of the Circum-North Pacific mountain belts which separate the North Pacific from the easterm North Asian and western North American Cratons. The collages consist of tectonostratigraphic terranes and contained metallogenic belts which are composed of fragments of igneous arcs, accretionarywedge and subduction-zone complexes, passive continental margins, and cratons. The terranes are overlapped by continentalmargin-arc and sedimentary-basin assemblages and contained metallogenic belts. The metallogenic and geologic history of terranes, overlap assemblages, cratons, and craton margins has been complicated by post-accretion dismemberment and translation during strike-slip faulting which occurred subparallel to continental margins.

Seven processes overlapping in time were responsible for most of metallogenic and geologic complexities of the region. (1) In the Early and Middle Proterozoic, marine sedimentary basins developed on major cratons and were the loci for ironstone (Superior Fe) deposits and sediment-hosted Cu deposits which occur along both the North Asia Craton and North American Craton Margin (2) In the Late Proterozoic, Late Devonian, and Early Carboniferous, major periods of rifting occurred along the ancestral margins of present-day Northeast Asia and northwestern North American. The rifling resulted in fragmentation of each continent, and formation of cratonal and passive continental-margin terranes which eventually migrated and accreted to other sites along the evolving margins of the original or adjacent continents. The rifting also resulted in formation of various massive-sulfide metallogenic belts. (3) From aboul the late Paleozoic through the mid-Cretaceous, a succession of island arcs and contained igneous-arc-related metallogenic belts, and tectonically parred subduction zones formed near continental margins. (4) From about mainly the mid-Cretaceous through the present, a succession of continental-margin igneous arcs (some extending offshore into island arcs) and contained metallogenic belts, and tectonically paired subduction zones formed along the continental margins. (5) From about the Jurassic to the present, oblique convergence and rotations caused orogen-parallel sisistral, and then dextral displacements within the plate margins of the Northeast Asian and North American cratons. The oblique convergences and rotations resulted in the fragmentation, displacement, and duplication of formerly more continuous arcs, subduction zones, passive continental margins, and contained metallogenic belts. These fragments were subsequently accreted along the margins of the expanding continental margins. (6) From the Early Jurassic through Tertiary, movement of the upper continental plates toward subduction zones resulted in strong plate coupling and

accretion of the former island ares, subduction zones, and contained metallogenic belts to continental margins. In this region, the multiple are accretions were accompanied and followed by crustal thickening, anatexis, metamorphism, formation of collisionrelated metallogenic belts, and uplift; this resulted in the substantial growth of the North Asian and North American continents. And (7) in the middle and late Cenozoic, oblique to orthogonal convergence of the Pacific Plate with present-day Alaska and Northeast Asia resulted in formation of the present ring of volcanoes and contained metallogenic belts around the Circum-North Pacific. Oblique convergence between the Pacific Plate and Alaska also resulted in major dextral-slip faulting in interior and Southem Alaska and along the westem part of the Aleutian-Wrangell arc. Associated with dextral-slip faulting was crustal extrusion of terranes from Western Alaska into the Bering Sea.

\section{Introduction}

This report provides an analysis of the metallogenesis and tectonics of significant metalliferous lode deposits, selected major nonmetalliferous lode deposits, and host rocks in the Russian Far East, Alaska, and the Canadian Cordillera. The report is based on a series of published terrane and overlap assemblage maps, mineral deposit and metallogenic belt maps, and mineral deposit databases, and interpretive articles for the region (Nokleberg and others, 1987, 1993, 1994a, b, c, d, 1995a, 1996, 1997a, b, c, 1988a, b, 1989a, b, 2000). For the analysis, this report synthesizes and combines coeval and genetically-related groups of significant lode mineral deposits into metallogenic belts. Eacb section on a specific metallogenic belt contains: (1) a description of the significant mineral deposits; (2) a description of the host rocks for the significant lode deposits; and (3) an interpretation of the origin of, and tectonic controls for the host rocks and contained deposits and metallogenic belt(s). The report also provides: (1) metallogenic and tectonic definitions; (2) explanation of methodology; (3) list of mineral deposits models; (4) an integrated metallogenic and tectonic model for the Phanerozoic geologic history of the region; and (5) an extensive list of cited references for the geology, mineral deposits, metallogenesis, and tectonics of the region. The descriptions of significant mineral deposits in this report are adapted from Nokleberg and others (1997a), with additional data and revision from the authors. For British Columbia (southwest Canadian Cordillera), descriptions of significant mineral deposits are also tevised with new data from MINFILE (2002).

The Russian Far East, Alaska, and the Canadian Cordillera are commonly regarded as frontier areas in the world for the discovery of metalliferous lode and placer deposits. During the late 1800's and early 1900 's, the region was subject to recurring nushes or stampedes to sites of newly discovered deposits. During the last few decades, the region has been substantially explored 

for lode and placer deposits, and geologically mapped and assessed for mineral resource potential at various scales. These activities have resulted in abundant new information on lode and placer deposits, geology, and patterns of mineral resources. In addition over the last three decades, various lectonic analyses have interpreted the region as being composed of numerous faultbounded assemblages of rocks defined as tectono-stratigraphic terranes (Jones and others, 1987; Monger and Berg. 1984, 1987; Zonenstain and others, 1990; Silberling and others, 1992; Nokleberg and others, 1994c, 1997c; 2000; Parfenov, 1995a; Monger and Nokleberg, 1996).

This report defines, describes, synthesizes, and interprets the major metallogenic belts and contained signifieant lode mineral deposits according to tectonic origins. This paper contains five types of information and interpretation: (1) an introduction and discussion of terms, methods, and concepts applied to the metallogenesis and tectonics of the region; (2) descriptions and interpretations of metallogenic belts and their notable or significant lode deposits; (3) description of the host rocks for the major metallogenic belts; (4) interpretation of the tectonic origin of metallogenic belts and host rocks; and (5) a model for the Phanerozoic metallogenic and tectonic evolution of the region. The method of metallogenic analysis utilized in this study is modeled after that employed for a metallogenic and tectonic analysis of porphyry copper and molybdenum (gold, silver), and granitoid-hosted gold deposits of Alaska (Nokieberg and others, 1995). Related recently-published articles are: (1) a dynamic computer model, which illustrates the metallogenesis and tectonics of the Circum-North Pacific (Scotese and others, 200I); and an article interpreting the Phanerozoic tectonic evolution of the Circum-North Pacific by Nokleberg and others (2000).

\section{Associated Project}

This study is the concluding part of a project on the significant mineral deposits, metallogenesis, and tectonics of the Russian Far East, Alaska, and the Canadian Cordillera. The project provides critical information on bedrock geology and geophysics, tectonics, major metalliferous mineral resources, metallogenic patterns, and crustal origin and evolution of mineralizing systems of the region. The major scientific goals and benefits of the project are to: (1) provide a comprehensive international data base for the mineral resources of the region in English; (2) provide major new interpretations of the origin and crustal evolution of mineralizing systems and their host rocks, thereby enabling enhanced, broad-scale tectonic reconstructions and interpretations; and (3) promote trade, scientific, and technical exchanges between North America and the Russian Far East. The project provides sound scientific data and interpretations for commercial firms, governmental agencies, universities, and individuals which are developing new ventures and studies in the project area, and also for land-use planning studies which deal with mineral-resource potential issues. Vast potential for known and undiscovered mineral deposits exists in the western part of the study area; however, prior to this study, little information existed in English in the West.

Major companion studies already published are: $(1)$ a compilation and analysis of the regional metallogenesis of the Circum-North Pacific (Nokleberg and others, 1993); (2) a tectono-stratigraphic terrane map of the Circum-North Pacific at a scale of 1:5,000,000, including a detailed explanation of map units and stratigraphic colurnas (Nokleberg and others, 1994c; digital venion is Grenninger and others, 1999); (3) a surnmary terrane map of the Circum-North Pacific at a scale 1:10,000,000 (Nokleberg and others, 1997e), (4) detailed tables of mineral deposits and placer districts for the Russian Far East, Alaska, and the Canadian Cordillera in paper format (Nokleberg and others, 1996) and in CD-ROM format (Nokleberg and others, 1997a); (5) a GIS compilation of the summary lerrane map, mineral deposit maps, and metallogenic beli maps of the Russian Far East, Alaska, and the Canadian Cordillera (Nokleberg and otbers, 1998); (6) a study of the Phanerozoic tectonic evolution of the Circum-North Pacific (Nokleberg and others, 2000); and (7) a dynamic computer model for the metallogenesis and tectonics of the Circum-North Pacific (Scotese and others, 2001). These articles, tables, and maps contain the full suite of mineral deposit data, mineral deposit location maps, metallogenic belt maps, and tectonic interpretations which are utilized in this study.

A complete listing of the project goals, and methods are available on the Internet/Web at hitp:ilminerals.er.usgs.gov/ ws/projects/majdeps.html. Major recent articles for the project (Nokleberg and others, 1993, 1994a, 1996, 1997a, b, c, 1998, 2000) are available on the Intemet/Web at hitp:i/wrgis.wr.usgs.gow/. This project was started at the invitation of the Soviet Academy of Sciences to the U.S. Geological Survey in 1988 . Subsequently, several organizations and many individuals volunteered to work on various aspects of the project which has produced a large variety of articles and maps. Other organizations participating in the project include the Russian Academy of Sciences, Russian Ministry of Natural Resources (former Ministry of Geology and ROSKOMNEDRA), Alaska Division of Geological and Geophysical Surveys, Geological Survey of Canada, Geological Survey of Japan, Exxon Exploration Company, University of Alaska, and Michigan State University.

This project represents a major joint attempt of a large group of geologists from Russia, Alaska, and the Canadian Cordillera to compile, synthesize, interpret, and publish major studies on the mineral resources, metallogenesis, and tectonies of this vast and geologically complicated region of the earth. The project includes a number of geologists who have each gathered field data and observations in their respective parts of the Russian Far East, Alaska, and Canadian Cordillera over many years and who have come together as a large intemational team to compile and synthesis a vast amount of data for a large region of the earth. Other recent metallogenic synthesis of parts of the Russian Far East, Alaska, and the Canadian Cordillern include those by Dawson and othen (1991), Sidorov and Eremin (1994), Goncharov (1995a, b), Goryachev (1995, 2003), Nekrasov (1995), Parfenov (1995d), Popeko (1995), Ratkin (1995), Ratkin and Khanchuk (1995), Nokleberg and others (1984, 1987, 1988, 1993, 1994a, b, 1995a, 1996, 1997a, b), Sidorov and Eremin (1995), Goldfarb (1997), Goldfarb and others (1997, 1998, 2000), and Young and others (1997). A volume containing papers on the geology and mineral deposits of the Russian Far East was edited by Bundtzen and others (1995), A volume containing papers on the stratiform ore deposits in northeastern Asia was edited Goryachev 
and Byalobahesky (1996). A volume containing papers on the mineral deposits of Alaska was edited by Goldfarb and Miller (1997). A volume on the geology of Mesozoic gold quartz veins in Northeastern Asia was published by Goryachev (1998), A volume on the pre-Cretaceous metallogeny of Nortbeastem Asia was published by Shpikerman (1998). A volume containing papers on the Tintina Gold Belt in Alaska and the Yukon-Territory, Canada was edited by Tucker and Smith (2000).

\section{Metallogenic Belts}

In this study, the regional metallogenesis of the Russian Far East, Alaska, and the Canadian Cordillera is synthesized, compiled, and interpreted in terms of metallogenic belts. This synthesis and compilation is based on data for about 1,079 significant lode deposits and 144 major metallogenic belts for the region (Nokleberg and others 1997a, b, 1998). A key element for this type of analysis is definition of metallogenic belt which is defined on the basis of a geologic unit (area) which either contains or is favorable for a group of coeval and genetically related, significant lode mineral deposit types (defined in the below section on definitions). A metallogenic belt may be of irregular shape and variable size; the size is partly a function of the scule of the analysis; in this study, metallogenic belts were synthesized and compiled at a scale of $1: 10,000,000$ scale (Nokleberg and others 1997a, b, 1998). In this report for each time span, metallogenic belis are described in a clockwise geographic succession, according to similar tectonic environments, around the Circum-North Pacific, from the Russian Far East to Alaska to the Canadian Cordillera.

For definition and outline of metallogenic belts, the following eriteria were used. (Nokleberg and others, 1995a). (1) Mineral Deposit Association. Each metallogenic belt includes a single mineral deposit type or a group of coeval, closely-located and genetically-related mineral deposits types for the region, as listed in Table 1. (2) Tectonic Event for Formation of Mineral Deposits. Each belt includes a group mineral deposits which formed in a specific tectonic event (e.g., collision, accretion, rifting. etc.). And (3) favorable Geological Environment. Because a metallogenic belt is underlain by a geological host rock and (or) structure which is favorable for a particular suite of mineral deposit types, a belt is predictive for undiscovered deposits. Consequently, the synthesis and compilation of metallogenic belts can be useful for mineral exploration, land-use planning, and environmental studies.

In this study, a metallogenic belt is essentially synonymous with the term mineral-resource tract as originally defined by Pratt (1981) and used for assessment of mineral resource potential in the USA, as exemplified in Ludington and Cox (1996). The metallogenic belt maps and underlying regional geologic (terrane and overlap assemblage) maps constitute a basic part of the three-part methodology of quantitative mineral resource assessment as described by Cox (1993) and Singer (1993, 1994).

\section{Methodology}

The methodology for the analysis of the complex metallogenic and tectonic history of the Russian Far East, Alaska, and the Canadian Cordillera consists of the following steps. (1) The significant lode deposits are described and classified according to defined mineral deposit models (table 1). Description of the mineral deposit models for the region, and descriptions of the 1,079 significant lode deposits and 161 placer districts for the region are contained in Nokleberg and others (1996, 1997a); (2) Metallogenic belts are delineated (Nokleberg and others, 1997b). (3) Tectonic environiments (Tables 2, 3) for the cralons, craton margins, orogenic collages of terranes, overlap assemblages, and contained metallogenic belts are assigned from regional compilation and synthesis of stratigraphic, structural, metamorphic, isotopic, faunal, paleomagnetic, and provenance data. The tectonic environments include cratonal, passive continental margin, metamorphosed continental margin, continental-margin arc, island arc, transform continental-margin arc, oceanic crust, seamount, ophiolite, accretionary wedge, subduction zone, turbidite basin, and metarnorphic (Nokleberg and others, 1994c, 1997c; Greninger and others, 1999). (4) Correlations are made between terranes, fragments of overlap assemblages, and fragments of contained metallogenic belts. (5) Coeval ternines and their contained metallogenic belts are grouped into those that formed in a single metallogenic and tectonic origin, for instance, into a single island are or subduction zone. (6) Igneous-are and subduction-zone ternanes, which are interpreted as being tectonically linked, and their contained metallogenic belts, are grouped into coeval, curvilinear arc-subduction-zone-complexes. (7) Geologic, faunal, and paleomagnetic data are employed io interpet the original geographic positions of terranes and their metallogenic belts. (8) The paths of tectonic migration of terranes and contained metallogenic belts are constructed. (9) The timing and nature of accretion of various terranes and contained metallogenic belts are determined from geologic, age, and structural data. (10) The nature of collision-felated geologic units and their contained metallogenic belts are determined from geologic data. (11) The age and nature of post-accretionary overlap assemblages and contained metallogenic belts are determined from geologic and age data. The part of this methodology, that enables the correlation of belts of related lode deposits to the tectonic origin of host rock units, was first cmployed for Northern and Central America by Albers and others (1988).

For additional information on the fectonic analysis of the region, including correlations of terranes and tectonic linkages between terranes and overlap assemblages, the reader is referred to Table 2 (derived from Nokleberg and others, 2000), For a summary of the tectonic setting (environment) of the major Proterozoic and Phanerozoic metallogenic belts in the region, the mineral deposit models, and the significant mineral deposits in each belt, the reader is referred to Table 3 . For a listing of the significant mineral deposits in each major metallogenic belt, locations of deposits, major metals in each deposit, refer to Table 4. Most significant mineral deposits for British Columbia (southwest Canadian Cordillera) have deposit numbers from MINFILE (2002). These deposit descriptions can be accessed from the MINFILE Web site at www.em.gov.bc.ca/mining/geolsurv/minfile/ 
A theoretical example of the first steps of the methodology for the metallogenic and tectonic analysis is provided is figure 1. Figure IA illustrates a theoretical suite of metallogenic belts which are hosted in several geologic units cratons, terranes. and overlap assemblages, or along major faults between terranes. Figure IB illustrates the siratigraphic and metallogenic history of the map area. The steps in this theoretical example are as follows. (1) Key terms are defined or cited from previous studies (e.g.s Nokleberg and others, 1997a), (2) A regional geologic base map is constructed which illustrates two major cratons (A, B), several fault-bounded terranes $(1,2,3,4)$, one accretionary assemblage (a), and four post-accretion overlap assemblages (b, $c$, d, e), (3) A series of mineral deposit models are defined and described, and a high-quality mineral deposit data base is compiled. For this theoretical example, the major mineral deposit types are low-sulfide Au quartz vein, ironstone, epithermal Au vein, porphyry Cu, bedded barite, and kuroko massive sulfide. (4) Metallogenic belts are delineated. For simplicity in this example, each metallogenic belt contains only a sinele mineral deposit type. The two cratons (A, B) each contain distinctive, pre-acctetionary metallogenic belis (ironstone and bedded barile deposits) which formed early in their geologic history, and an island are assemblage (terrane 4) contains a pre-accretionary metallogenic belt of kuroko massive sulfide deposits. A collisional granitic pluton with a porphyry Cu metallogenic belt formed during accretion of terrane 3 against terrane 4 . A metallogenic belt containing Au quartz vein deposits formed during aceretion of terrane 1 against terrane 2. Overlying all terranes and both cratons is a post-accretion overlap assemblage which contains a metallogenie belt of epithermal Au vein deposits. (5) The genesis of formation of bedrock geologie units and (or) structures and contained mineral resource tract or metallogenic belt is interpreted using modem tectonic concepts (fig. IB). Examples include: kuroko massive sulfide deposits forming in an island arc environment; porphyry Cu and low-sulfide Au quartz vein deposits forming in an accretionary environment, and epithermal Au vein deposits forming in a continental-margin igneous-are environment. And (6) by carefully defining each metallogenic belt to be the geologically-favorable area for a group of coeval and genetically-related mineral deposits, a predictive character is established within the belt for undiscovered deposits. Hence, regional metallogenic analysis should be valuable for mineral exploration, land-use planning, and environmental studies.

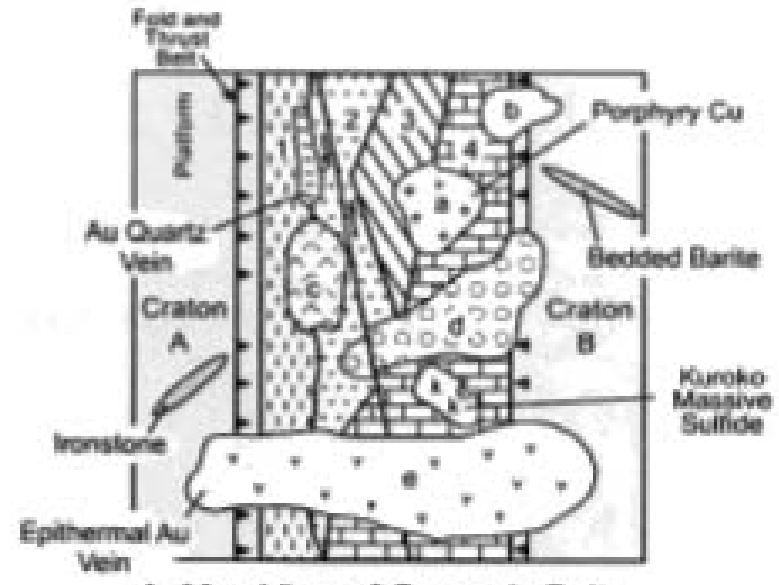

A. Map View of Orogenic Belt

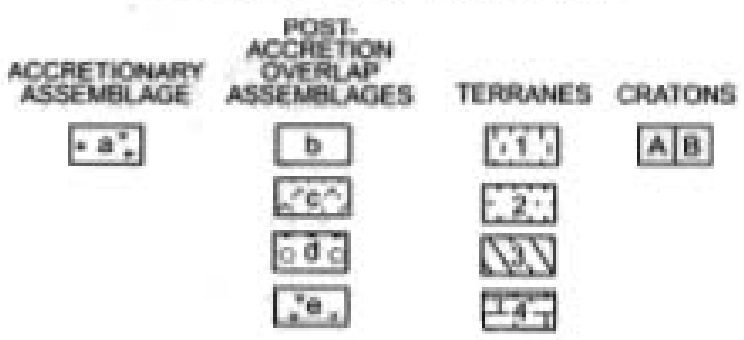

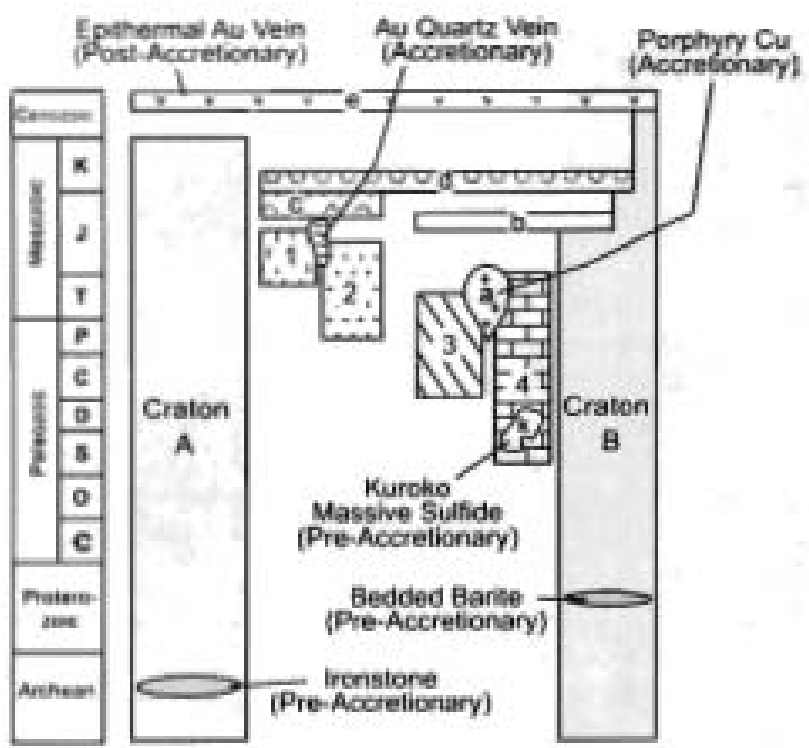

B. Stratigraphic Columns for Orogenic Belt

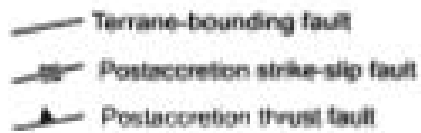

Figure 1. Generallzed theoretical example ilustrating the methodology for metaliogenic analysis of cratons, terranes, accretionary assemblages, overlap assemblages, and contained metallogenic belts. A. Map view example of orogenic belt. B. Stratigraphic columns for example orogenic belt. Refer to text for discussion.

\section{Tectonic Controls for Metallogenesis}

Interpretation of the comprehensive data base of mineral deposits (Nokleberg and others, 1997a), mineral-resource tract maps (Nokleberg and others, 1997b, 1998), terrane and overlap assemblage maps (Nokleberg and others, 1997c, 1998), and the companion metallogenic and tectonic model for the Russian Far East, Alaska, and the Canadian Cordillera, reveals seven major tectonic environments for the Phanerozoic metallogenesis of the region: (1) subduction-related arc; (2) collisional (anatectic)related are; (3) post-collisional extension; (4) oceanic rift; (5) continental rift; (6) back-are rift; and (7) transform continentalmargin are. Each tectonic environment provides a unique interpretation for the origin of the 144 major metallogenic belts and 
1,079 significant mineral deposits in the region. Examples of metallogenic belts associated with each of the seven tectonic eovironment are as follows; (1) An example of a subduction-related are tectonic environment is the mid- and Late Cretaceous Eastern Asa metallogenic belt of mainly epithermal and polymetallic vein deposits which is hosted by the Okhotsk-Chukotka volcanic-plutonic belt. (2) An example of a collisional (anatectic)-related are tectonic environment is the Late Jurassic-Early Cretaceous Yana-Kolyma metallogenic belt of mainly Au quartz vein deposits which is hosted along the suture boedering KolymaOmolon superterrane. (3) An example of a post-collisional extension tectonic environment is the Late Cretaceous and early Tertiary Chugach Mountains metallogenic belt of Au quartz vein deposits which is associated with underthrusting of KulaFarallon oceanic ridge and post-underthrusting extension. (4) An example of an oceanic rifting tectonic environment is the Early Tertiary Prince William metallogenic belt of Besshi and Cyprus massive sulfide deposits which is associated with the KulaFarallon oceanic ridge. (5) An example of a continental rifting tectonic environment is the Late Devonian Selennyakh metallogenic beit of Southeast Missouri Pb-Zn deposits which is associated with rifting of North Asian craton margin. (6) An example of a back-arc rifting teetonic environment is the Late Triassic Alexander metallogenic belt of Cyprus massive sulfide deposits associated with the back afe of Talkeetna-Bonanza arc. And (7) an example of a transform continental-margin are tectonic environment is the Early Tertiary Central Koryak metallogenic belt of polymetallic and epithermal vein deposits associated with the Kamchaika-Koryak igneous belt. The tectonic controls for each of the metallogenic belts of the region are listed in Table 3 and described in more detail in the below sections on descriptions and interpretations of origins of metallogenic belts.

The tectonic classification of lode mineral deposits has been a topic of considerable debate (Sawkins, 1990); however classification of lode mineral deposits by mineral deposit types and tectonic environment can be extremely useful. These classifications are useful for regional mineral exploration and assessment, for research on the critical or distinguishing characteristics of metallogenic belts, and for synthesizing of metallogenic and tectonic models. For this report in describing the metallogenic belts of the region, the significant lode deposits are classified both according to mineral deposit type and tectonic environment.

\section{Metallogenic and Tectonic Definitions}

Definitions for mineral deposit, metallogenic, and tectonic terms used in this report were adapted from Coney and others (1980), Jones and others (1983), Howell and others (1985), Monger and Berg (1987), Nokleberg and others (1987, 1994a, c, 2000), and Wheeler and others (1988), In alphabetical order, these terms and their definitions are as follows.

Accretion. Tectonic juxtaposition of two or more terranes, or tectonic juxtaposition of terranes to a craton margin.

Accretionary wedge and subduction-zone terrane, Fragment of a mildly to intensely deformed complex consisting of varying amounts of turbidite, hemipelagic, and pelagic deposits, and oceanic crust and upper mantle. This type of terrane is divided into units composed predominantly of turbidite deposits of predominantly of oceanic rocks. Units are interpreted to have formed during tectonic juxtaposition in a zone of major thrusting of one lithospheric plate over another, generally along the margin of a continent or an island arc. The terrane may include large fault-bounded units which contain a coherent intemal stratigraphy. Many subduction-zone terranes contain fragments of oceanic cnust and associated rocks which exhibit a complex structural history, occur in a major thrust zone, and possess blueschist-facies metamorphism.

Collage of terranes. A composite group of tectonostratigraphic terranes.

Craton. Regionally metamorphosed and deformed shield assemblages of Archean and Early Proterozoic sedimentary, volcanic, and plutonic rocks, and overlying platform successions of Late Proterozoic, Paleozoic, and local Mesozoic and Cenozoic sedimentary and lesser volcanic rocks.

Craton margin. Chiefly Late Proterozoic through Jurassic miogeoclinal units deposited on a continental shelf or slope. Locally has, or may have had an Archean and Early Proterozoic cratonal basement.

Cratonal terrane. Fragment of a craton.

Continemtal-murgin arc terrame. Fragment of an igneous belt of coeval plutoenic and volcanic rocks, and asueciated sedimentary rocks which formed on or close to a continent, above a subduction zone dipping beneath a continent. Inferred to possess a sialic basement.

Deposit. A general term for any lode or placer mineral occurrence, mineral deposit, prospect, and (or) mine.

lsland-are terrane. Fragenent of a belt of plutonic rocks, coeval volcanic rocks, and associated sedimentary rocks which formed above an intraoceanic subduction zone.

Metallogemic beit. A geologic unit (area) which either contains or is favorable for a group of coeval and genetically-related, significant lode and placer deposit models. Using this definition, a metallogenic belt is a predictive lool for undiscovered deposits.

Metamorphic nerrane. Fragment of a highly metamorphosed or deformed assemblage of sedimentary, voleanic, and (or) plutonic rocks which cannot be assigned to a single tectonic environment because the original stratigraphy and strucfure are obscured. Includes intensely-deformed structural melanges which contain fragments of two or more ternanes.

Metamorphosed continental margin ferrane. Fragment of a passive continental margin, in places moderately to highly metamorphosed and deformed, which cannot be linked with certainty to the nearby craton margin. May be derived either from a nearby craton margin or from a distant site. 
Mine. A site where valuable minerals have been extracted.

Mineral deposit. A site where concentrations of potentially valuable minerals for which grade and tonnage estimates have been made.

Mineral occturrence or prospect. A site of potentially valuable minerals on which no known exploration has occurred, or for which no grade and tonnage estimates have been made.

Oceanic crust, seamount, and ophiolite terrane. Fragment of part or all of a suite of eugeoclinal deep-marine sedimentary rocks, pillow basalt, gabbro, and ultramafic rocks which are interpreted as a fragment of oceanic sedimentary and volcanic rocks and the upper mantle. Includes both inferred offshore oceanic and marginal ocean basin rocks, minor volcaniclastic rocks of magmatic are derivation, and major marine volcanic accumulations formed at a hotspot, fracture zone, or spreading axis.

Overlap assemblage. A postaccretion unit of sedimentary or igneous rocks deposited on, or intruded into two or more adjacent terranes. The sedimentary and volcanic parts either depositionally overlie, or are interpreted to have originally depositionally overlain two or more adjacent terranes, or terranes and the craton margin. Plutonic rocks, which may be coeval and genetically related to overlap volcanic rocks, may stitch together adjacent terranes, or a terrane and a craton margin.

Passive continental margin terrane. Fragment of a craton margin.

Post-accretion rack unit. Suite of sedimentary, volcanic, or plutonic rocks which formed late in the history of a terrane, after accretion. May occur also on adjacent terranes or on the craton margin either as an overlap assemblage or as a businal deposit. A relative-time term denoting rocks formed after tectonic juxtaposition of one terrane to an adjacent terrane.

Pre-accretion rock unit. Suite of sedimentary, volcanic, or plutonic rocks which formed early in the history of a terrane, before accretion. Constitutes the unique stratigraphy and igneous geology of a terrane. A relative-time term denoting rocks formed before tectonic juxtaposition of one terrane to an adjacent terrane.

Prospect. A site of potentially valuable minerals at which exploration has occurred.

Significant mineral deposit. A mine, mineral deposit, prospect, or occursence which is judged as important for the metallogenesis of a geographic region.

Subterrane. A fault-bounded unit within a terrane which exhibits similar, but not identical geologic history relative to another fault-bounded unit in the same terrane.

Supprterrane. An aggregate of terranes which is interpreted to share either a similar stratigraphic kindred or affinity, of a common geologic bistory prior to accretion (Moore, 1992). An approximate synonym is composite terrane (Plafker and Berg, 1994).

Tectonic linkage. The interpreted association of a suite of coeval tecionic units which formed in the same region and as the result of the same tectonic processes. An example is the linking of a coeval continental-margin arc, foreare deposits, a back-are rift assemblage, and a subduction-zone complex, all related to the underthrusting of a continental margin by oceanic crust.

Tectonostratigraphic terrane. A fault-bounded geologic entity or fragment which is characterized by a distinctive geologic history which differs markedly from which of adjacent terranes (Jones and others, 1983; Howell and others, 1985).

Transform continental-margin arc. An igneous belt of coeval plutonic and volcanic rocks, and associaled sedimentary rocks which formed along a transform fault which cuts the margin of a craton, passive continental margin, and (or) collage of terranes accreted to a continental margin.

Turbidite basin terrane. Fragment of a sedimentary basin filled with deep-marine elastic deposits in either an orogenic foreare or backare setting. May include continental-slope and continental-rise turbidite, and submarine-fan turbidite deposited on oceanic crust. May include minot epiclastic and volcaniclastic deposits.

\section{Mineral Deposit Models}

For the metallogenic analysis of the Russian Far East, Alaska, and the Canadian Cordillera, metalliferous and selected non-metalliferous lode deposits are classified into various models or types as described in Nokleberg and others (1996, 1997a) and as listed in Table 1. This classification of mineral deposits was chiefly derived mainly from the minetal deposit types of Eckstrand (1984), Cox and Singer (1986), Bliss and others (1992), and Eckstrand and others (1995), but includes some modifications. The mineral deposit types are systematically arranged to describe the essential properties of a class of mineral deposits. Some mineral deposit models are descriptive (empirical), in which instance the various attributes are recognized as essential, even though their relationships may not be known. An example of a descriptive mineral deposit type is the basaltic Cu type in that the essential autribute is empirical datum of a geologic association of Cu sulfides with relatively Cu-ricb metabasalt or greenstone. Other deposit typen are genetic (theoretical), in which case the attributes are felated through some fundamental concept. An example is the W skam deposit type in which the essential attribule is the genetic process of contact metasomatism is the essential attribute. For additional information on the methodology of mineral deposit types, the reader is referred to the discussions by Eckstrand (1984), Cox and Singer (1986), and Bliss (1992). The lode deposit models which are utilized in this report and previous, related publications (Nokleberg and others, 1996, 1997a) are listed in Table 1, and are grouped according to host rock lithologies and (or) origia. Lode deposit models which share a common origin, such as contact metasomatic deposits, or porphyry deposits, are grouped together under a single heading. 


\section{Acknowledgements}

We thank the many geologists with whom we have worked for their valuable expertise is each region of Alaska, the Russian Far East, Hokkaido lsland of Japan, the Canadian Cordillera, and the U.S.A. Pacific Northwest. We also thank our managers who have so kindly supported our project studies. Specifically, we thank J.N. Aleinikoff, Yu.V. Arkhipov, H.C. Berg. R.B. Blodgett, S.E. Box, D.A. Brew, M.D. Bulgakova, Ch. B. Borukaev, D.C. Bradley, Howard Brooks, J. Decker, J.M. Duke, Cynthia Dusel-Bacon, Robert B. Forbes, H.L. Foster, J.M. Franklin, V.V. Gaiduk, B.M. Gamble, V.V. Golozubov, Arthur Grantz. D.G. Howell, C.W. Jefferson, D.L. Jones, S.M. Karl, S.V. Kovalenko, W.C. MoClelland, E.M. MacKevett, Jt., A.V. Makhinin, M.V. Martynyuk, M. L. Miller, T.P. Miller, L.Ph. Mishin, E.J. Moll-Staleup, T.E. Moore, S. W. Nelson, V.S. Oxman, S.A. Palanjan, I.V. Panchenko, T.L. Pavlis, L.I. Popeko, A.V. Prokopiev, J.C. Reed, Jr., D.H. Richter, S.M. Roeske, N.J. Silberling, the late G.M. Sosunov, A.B. Till, F.F. Tret'yakov, A.N. Vishnevskiy, I.G. Volkodav, W.K. Wallace, G.R. Winkler, the late L.P. Zonenshain, and Yu.P. Zmievsky for their many beneficial discussions. We thank the late Ch.B. Borykaev, the late William R. Greenwood, Donald Grybeck, B.A. Morgan III, L.Ya. Nekrasov, A.T. Ovenshine, P.P. Hearn, T.E. Smith, D.J. Templeman-Kluit, and W.H. White for their encouragement and support of the project. We thank S.G. Byalobzhesky, A. Grantz, K.G. Mackey, B.A. Natal'in, L.M. Natapov, G. Plafker, W.W. Patton, Jr. S.D. Sokolov, G.M. Sosunov, R. W. Tabor, N.V. Tsukanov, and T.L. Vallier for their very fine work on the detailed terrane and overlap assemblage map of the Circum-North Pacific (Nokleberg and others, 1994a) and for many discussions of the tectonics of the region. We thank various Russian interpreters, including the late Lidiya $\mathrm{L}$. Kovbas, Tatyana L. Koryakina, Tatyana N. Velikoda, Elena P, Burak, and Elena V. Alekseenko for their skilled assistance during long and complex scientific dialogues, and for translation of complex geologic descriptions and references. We thank B.A. Natal'in for participation in the compilation and synthesis of a portion of the Russian Soutbeast part of the terrane map of the Circum-North Pacific. We thank Julie A. Nokleberg for computer drafting of most of the metallogenic belt figures, and for the most of the mineral deposit figures for Alaska and the Russian Far East. We thank Richard D. Lancaster and Kim Nguyen of the Geological Survey of Canada for computer drafting of the lode mineral deposit figures for the Canadian Cordiliera. We thank Dani Alldrick, Chris Ash, Derek Brown, Larry Diakow, Fil Ferri, Trygve Hõy, Dan Hora, David Lefebure, Jim Logan, Donald Maclntyre, Bill McMillan, Mitch Mihalynuk, JoAnne Nelson, Andre Panteleyev, Robert Pinsent, Gerry Ray, Paul Schiarizaa, and George Simandl for revisions of mineral deposit descriptions for British Columbia, Canada. We also thank Marti L. Miller. Suzanne Paradis for their constructive and very helpful reviews.

\section{Introduction to Phanerozoic Metallogenic and Tectonic Model for the Russian Far East, Alaska, and the Canadian Cordillera}

In the below Phanerozoic (Devonian through Recent) time-span sections on metallogenesis of the region, an interpretative model is presented for the Phanerozoic metallogenic-lectonic evolution of the Russian Far East, Alaska, and the Canadian Cordillera. The model is derived from the below descriptions of metallogenic belts and host rocks, and from a detailed analysis of the Phanerozoic tectonic evolution of the region (Nokleberg and others, 2000). The metallogenic-tectonic model attempts to: (1) integrate stratigraphic, age, structural, and paleomagnetic data and field relations for the region; (2) integrate data on metallogenic belts and contained lode deposits with host-rock geology and structures; and (3) portray the regional metallogenic-lectonic interactions between the North Asian and North American continents. The model concentrates on the Devonian through the Present. For more descriptions of the regional geology and tectonies of the region, a detailed analysis was published by Nokleberg and others $(2000)$.

The metallogenic-tectonic model illustrates: (1) major metallogenic belts superposed, at approximate scale, over major units, including cratons, craton margins, lerranes, and overlap assemblages; (2) geologie units which are proportional to those on detailed terrane and overlaps assemblage maps (Nokleberg and others, 1994a, 1997b,c; Monger and Nokleberg, 1996); and (3) known or interpreted displacements along major strike-slip and thrust faults. In most cases, however, the tectonic model does not incorporate internal deformation of terranes or tectonic erosion of terrane margins. In the following descriptions of the metallogenic-tectonic model, the tectonic features of the model are condensed. For complete description of tectonic features, refer to the separate publication on Phanerozoic tectonic evolution of the Circum-North Pacific (Nokleberg and others, 2000). A dynamic (computer) version of the metallogenic-tectonic model is published by Scotese and others (2001).

The metallogenic-tectonic model provides a guide for future research by: (1) integrating geologic, mineral deposit, metallogenic belt. paleontologic, isotopic, and paleomagnetic data from the Russian Far East, Alaska, the Canadian Cordillera, the Pacific Ocean, and the Arctic Ocean; (2) proposing a new, unified interpretation which spans the area from northeastem part of the North Asian Craton to the northwestem part of the North American Craton; and (3) identifying problems with data and interpretations. Because of a lack of abundant Proterozoic and older rock units exterior to the craton margins, the model starts with the Devonian. For various published tectonic reconstructions for the Proterozoic, which illustrate highly different global interpretations, the studies of Hoffman (1989, 1991), Moores (1991), Ross and otbers (1992), Scotese (1997), Unnug (1997), and Karlstrom and others (1999) are recommended.

An important complication of ternane recognition and analysis is that the margins of terranes and parts of their preaccretionary metallogenic belts, have been tectonically removed, either by dislocation of ternanes from distant locations, or by 
tectonic erosion of the margins of terranes. In the case of dislocation, detailed analysis of each terrane with respect to in-place overlap assemblages, passive continental-margin ussemblages, and cratonal assemblages should provide the original site of origin. In the case of tectonic erosion, as in the case of subduction-zone terranes, large parts of the original unit (such as an oceanic plate) may have been thrust to great depths and thereby may essentially have disappeared.

An important interpretation in the metallogenic-tectonic model is that a succession of coeval single ares and companion subduction zones, and their contained, pre-accretionary metallogenic belts formed on or near the margins of the North Asian and North American Plates. One consequence of this interpretation is that many of the complexities of the collage of acereted terranes and contained metallogenic belts in the region are the results of oblique subduction and resultant strike-slip displacements within active continental margins, rather than the migration of island-are systems across ocean basins to accrete eventually to the margins of plates. Substantiation of this interpretation will require: (1) determination of the facing directions of the ures with resipect to cratons; (2) correlation of coeval arc and tectonically linked (companion) subduction zones to establish them as different parts of a former, single, curvilinear are/subduction-zone system; and (3) determination of the linkage of ares to cratons. This interpretation is reasonably well established for most of the Mesozoic and Cenozoic, but less so for the Paleozoic. For each time interval (stage) in the metallogenic-tectonic model, specific (numbered) tectonic events are described in a clockwise order, according to similar tectonic environments, starting with the area of the Russian Southeast and ending with the area of the southem Canadian Cordillera. The time scale used for the tectonic model is from Palmer (1983).

\section{Paleomagnetic Dilemma: Loci of Accretion of Wrangellia Superterrane}

A major paleomagnetic dilemma exists for the loci of accretion of superterranes to the margin of the North American Craton in the mid-Cretaceous to early Tertiary. The dilemma consists of two conflicting hypotheses for the loci of aceretion of the Wrangellia superterrane, which constitutes most of the Insular superterrane, and the Intermontane superterrane which consists of the Stikinia, Quesnellia, and Cache Creek terranes (Cowan, 1994; Cowan and others, 1997). One hypothesis, based on geologic evidence, including magmatic, stratigraphic, and faunal ties, interprets the Wrangellia superterrane as accreting at a northerly paleolatitude, approximately at its present latitude. The other hypothesis, based on paleomagnetic data for both continental voleanic rocks and coeval plutonic rocks, interprets the Wrangellia superterrane and the western part of the Intermontane terrane as acereting at a paleolatitude approximately $3,000 \mathrm{~km}$ fartber south. This hypothesis is informally named the Baja British Columbia controversy, in reference to accretion of the Wrangellia superterrane at the approximate latitude of Baja California (Umhoefer, 1987; Cowan and others, 1997; Dickinson and Butler, 1998). For the synthesis of the lectonic evolution of the Circum-North Pacific, these two hypothesis are called the northerm-accretion interpretation and southern-accretion interpretation. For the metallogenic analysis of the Wrangellia superierrane in the Mesozoic and early Cenozoic, only the northern-accretion interpretation is considered. For additional information and references for both interpretations, please refer to the discussion and references in Nokleberg and others $(2000)$.

\section{Proterozoic Metallogenic Belts (2500 to 570 Ma; Figures 2, 3)}

\section{Overview}

The major Proterozoic metallogenic belis in the Russian Far East, Alaska, and the Canadian Condillera are summarized in table 3 and portrayed on figures 2 and 3 . The major beits (and their major mineral deposit types) are as follows. (1) In the central and southeastern part of the Russian Northeast, are the Bilyakchan (BI) (basaltic Cu), Oroek (OK) (ironstone and sediment-bosted Cu), Omolon (OM) (Ironstone (Superiot Fe)), and Ulkan (UL) (Felsic Plutonic REE and related deposits) metallogenic belts. These belts are interpreted as forming during incipient rifting of the passive contineatal margin of the North Asian Craton or Craton Margin. (2) In the same region are the Lantarsky-Dzhugdzhur (LD) metallogenic belis of anorthosite-hosted apatite Tr-Fe and gabbroic $\mathrm{Cu}-\mathrm{Ni}$-Co-PGE that is interpreted as forming during Mesoproterozoic rifting of passive continental margin of North Asian Craton. (3) On the Seward Peninsula in Western Alaska, the Sinuk River (SR) metallogenic belt, which contains massive sulfide-barite and stratabound Fe-Mn deposits, is hosted in Proteroeoic or older metavolcanic and sedimentary rock. The belt is interpreted as forming during marine volcanogenic rifting(?) of the North American Continental Margin. (4) in Southwestern Alaska, the Kilbuck (KI) metallogenie belt, which contains mainly ironstone (Superior Fe) deposits, is hosted in the KilbuckIdono cratonal terrane and is interpreted as forming during rifing of the North Asian Craton. (5) In the northem part of the Canadian Cordillera is the Wemecke (WR) metallogenic bett of U.Cu.Fe (Au-Co) vein and breccia deposits. This belt is hosted in the North American Craton Margin and is interpreted as forming during hydrothermal activity along a Paleoproterozoic passive continental margin. 


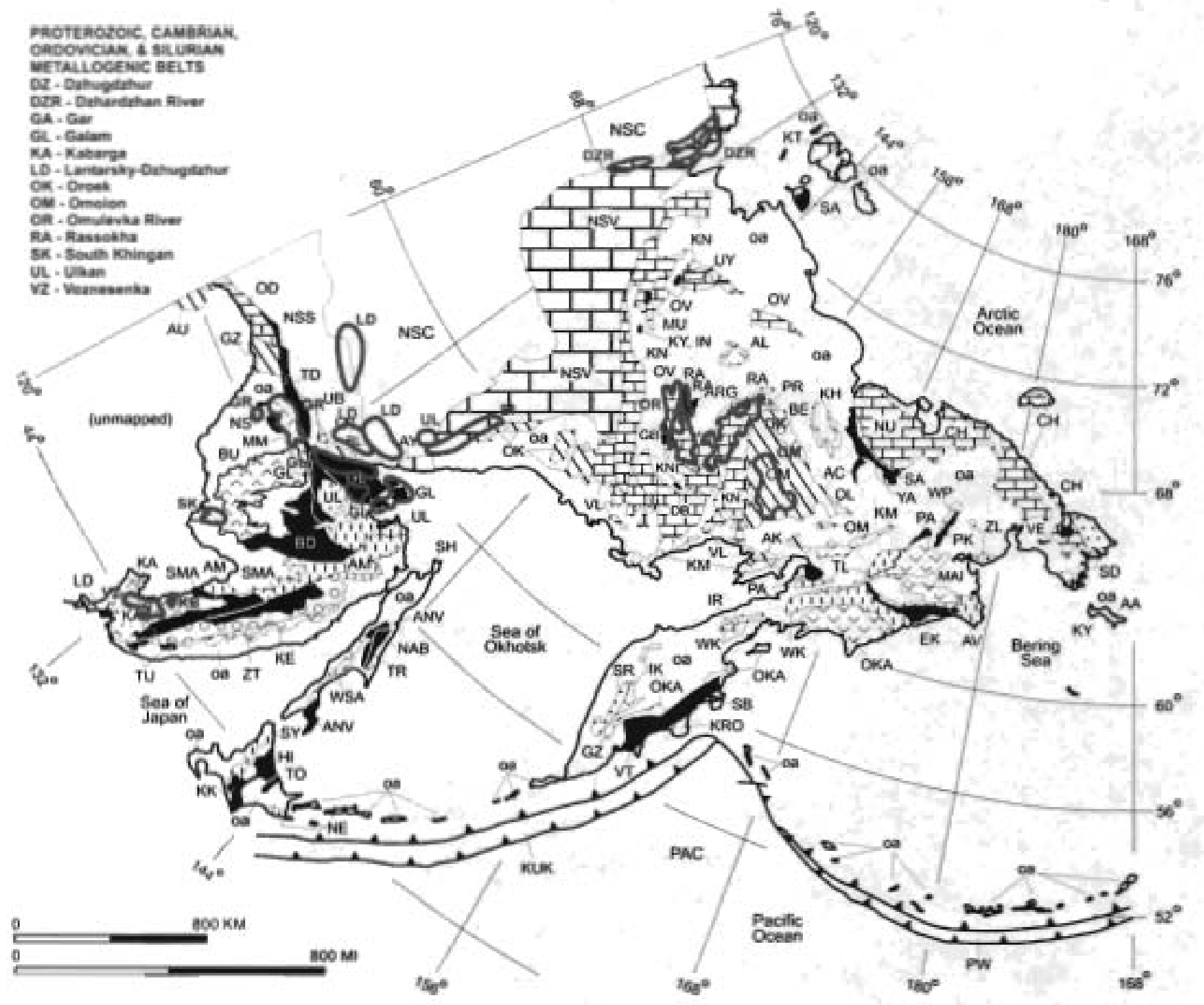

Figure 2. Generalized map of major Proterozoic and Cambrian through Sturian metalogenic belts and terranes for Russian Far East, northern Japan, and adjacent offshore areas. Refer to text for description of metallogenic belts. Adapted from Nokleberg and others (1997b, 1998)

(6) In the same region is the Gillespie (GE) metallogenic belt of SEDEX Pb-Zn deposits that is hosted in the North American Craton Margin and is interpreted as forming during Intrusion of gabbro and diorite sills during Paleoproterozoic rifting. (7) In the same region is the Rapitan (RA) metallogenic belt of iron formation deposits that is hosted in the North American Craton Margin. This bell is interpreted as forming during marine exhalation along Mesoproterozoic North American Craton Margin. (8) In the same region is the Redstone (RD) metaliogenic belt of sediment-hosted Cu-Ag deposits that is hosted in the North American Craton Margin. This belt is interpreted as forming during incipient Neoproterozoic rifting of the North American Craton Margin. (9) In the southern Canadian Cosdillera is the Monashee (RD) metallogenic belt of SEDEX Zn-Pb-Az deposits. This belt, that is hosted in the Monashee lerrane, is interpreted as a fragment of North American Craton and formed during Late Proterozoic rifting of North American Craton. (10) In the same region, the Purcell (PR) belt of massive sulfide deposits is hosted in the North American Craton Margin, and is interpeted as forming during incipient rifting of the craton. And (11) in the same region, the Clark Range (CR) belt of sediment-hosted Cu-Ag deposits is hosted in the North American Craton Margin, and is interpreted as forming during incipient rifting of the craton margin. In the below descriptions of metallogenic belts, only notable examples of significant lode. deposits are described for each belt. Table 4, which is adapted and revised from Nokleberg and others (1997a), lists the significant lode deposits in each metallogenic belt. 


\section{EXPLANATION}

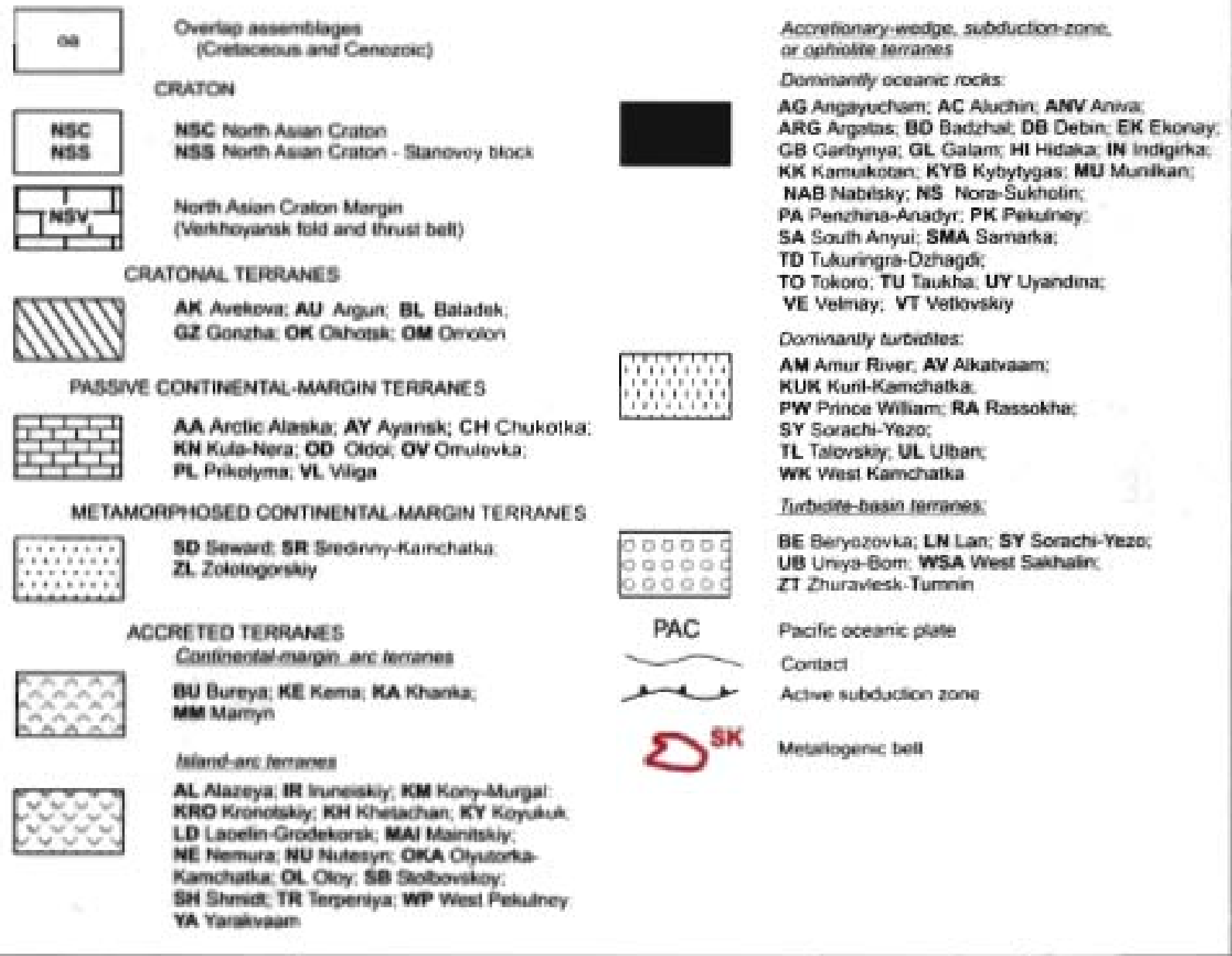

\section{Metallogenic Belts Formed During Proterozoic Rifting of North Asian Craton or Craton Margin}

\section{Oroek Metallogenic Belt of Ironstone and Sediment Hosted Cu Deposits (Beit OK) West-Central Part of Russian Northeast}

The Oroek metallogenic belt of ironstone and sediment-hosted Cu deposits (fig. 2; tables 3, 4)occurs mainly in the Shamanikha River basin in the central part of the Russian Northeast (Shpikerman, 1998). The belt is hosted in the Shamanikha subterrane of the Prikolyma passive continental margin terrane of the Kolyma-Omolon superterrane (Nokleberg and others, 1994c, $1997 \mathrm{c}$ ). The belt trends nortb-south for $400 \mathrm{~km}$ along the axis of the Prikolyma terrane and has a maximum width of $100 \mathrm{~km}$. The ironstooe deposits oceur in the Lale Proterozoic Spiridon and Gorbunov Formations. The significant deposits are at Pobeda and Oroek (Nokjeberg and others 1997a, b, 1998). The Oroek metallogenic belt is herein interpreted as a faulted fragment of the Bilyakchan metallogenic belt, described below, which is hosted in the North Asian Craton Margin (Verkhoyansk fold belt, unit NSV).

\section{Pobeda Ironstone Deposit}

One part of the Pobeda ironstone deposit (fig. 4) occurs in the Spiridon Formation consists of stratiform hematite (Z.G. Potapova, writtea conmun., 1954; A. G. Kats, written commun., 1979) and is interpreted as a fossil littoral zircon-titaniummagnetite placer deposit. The other part of the deposit occurs in Late Proterozoic dolomitic marble of the Gorbunov Formation in a zone of imbricated thrust faults. This part of the deposit consists of gabbro and gabbro-amphibolite bodies and with hematite masses which occur along thrust fault planes. The deposit contains massive, brecciated, and stockwork ores. Massive ores contain 


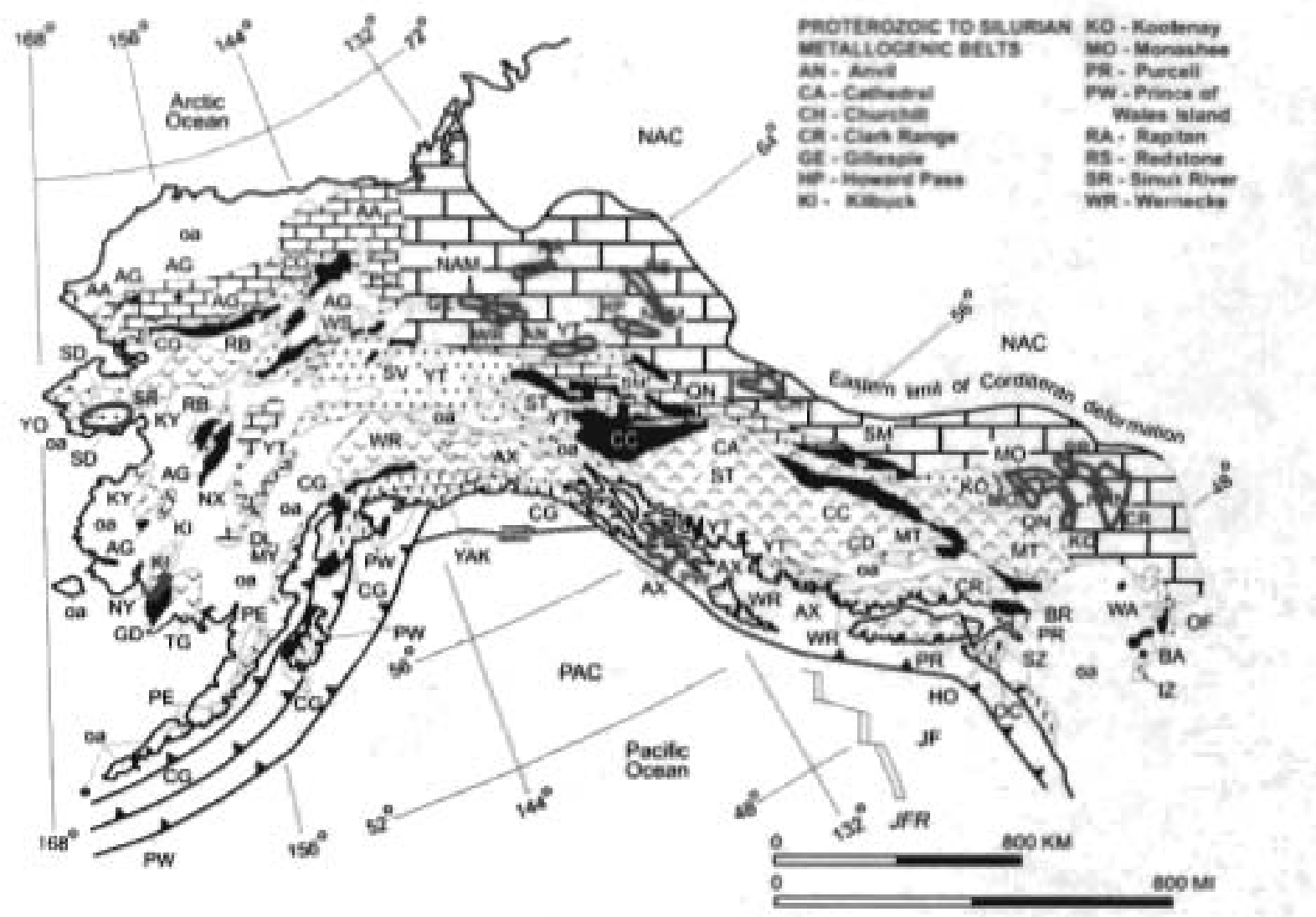

Figure 3. Generalized map of major Proterozoic and Cambrian through Silurian metallogenic beits and terranes for Alaska, Canadian Cordiliera, and adjacent offshore areas. Reler to text for description of metaliogenic belts. Adapled from Nokleberg and others $(1997 b, 1998)$.

up to $70 \% \mathrm{Fe}$. The brecciated ores are composed of clasts of dolomite and gabbro-amphibolite cemented by hematite. The stockwork is defined by separate, halo-shaped bodies which are located around the massive and brecciated ores. Ore minerals also include calcite, quartz, barite, chlorite, pyrite, chalcopyrite, galena, and malachite. The ore-bearing horizon extends for $18 \mathrm{~km}$, but the best defined stratiform hematite deposit is 150 to $600 \mathrm{~m}$ long and 2 to $20 \mathrm{~m}$ thick. A related dolomite-hosted Fe deposit in theGorbunov Formation is interpreted as forming during chemical deposition of Fe from seawater.

\section{Oroek Sediment-Hosted Cu Deposit}

The sediment-hosted Cu Oroek deposit (fig. 5) (1.G. Volkodav and Korobitsyn, A. V, written commun., 1979, Shpikerman and Shpikerman, 1996) occurs in the Oroek Formation which consists of an Late Proterozoic volcaniclastic rock sequence which varies between $150-180 \mathrm{~m}$ thick. The sequence consists mainly of quartrite, quartz-chlorite and graphite-chlorite schist, and phyllite and thin conformable beds of basalt and ruffaceous rocks. The major ore minerals are chalcocite, bornite, and chalcopyrite which occur in metamorphosed sandstone, siltstone, and shale. Local abundant quartz bodies also contain chalcopyrite, bornite, and bematite. Later cross-cutting quartz veins also contain minor malachite, chalcocite, axurite, chrysocolla, bormite, and native copper. Mineralized rocks are deformed and form an overtumed. isoclinal fold whose limbs dip southeast at $40^{\circ} 1090^{\circ}$.

\section{Origin of and Tectonic Controls for Oroek Metallogenic Belt}

The sediment-hosted $\mathrm{Cu}$ deposits of the Oroek metallogenic belt are hosted mainly in the Middle Riphean Oroek Formation which consists of metamorphosed sedimentary rocks with a thickness of 1300 to $1500 \mathrm{~m}$ (Shpikerman, 1998). The Cu deposits occur only in two lithologies: quartz-chloritoid and quartz-chlorite schist. The quartz-chloritoid schist locally contains polimictic siltstone and sandstone with parallel and oblique laminations. The chlorite schists contain dark green chloritoid porphyryblasts, dark green chlorite, quartz, epidote, mica, and rutile, and have a dark color, fine-grain composition, and a laminated shaley and lenticular lexture. The ore-bearing rocks of the Oroek Formation are derived from subaqueous, polimictic sandstone, siltstone and shale (pelite) which contain considerable volcanic rock fragments (L.A. Shpikerman, written commun. 


\section{EXPLANATION}

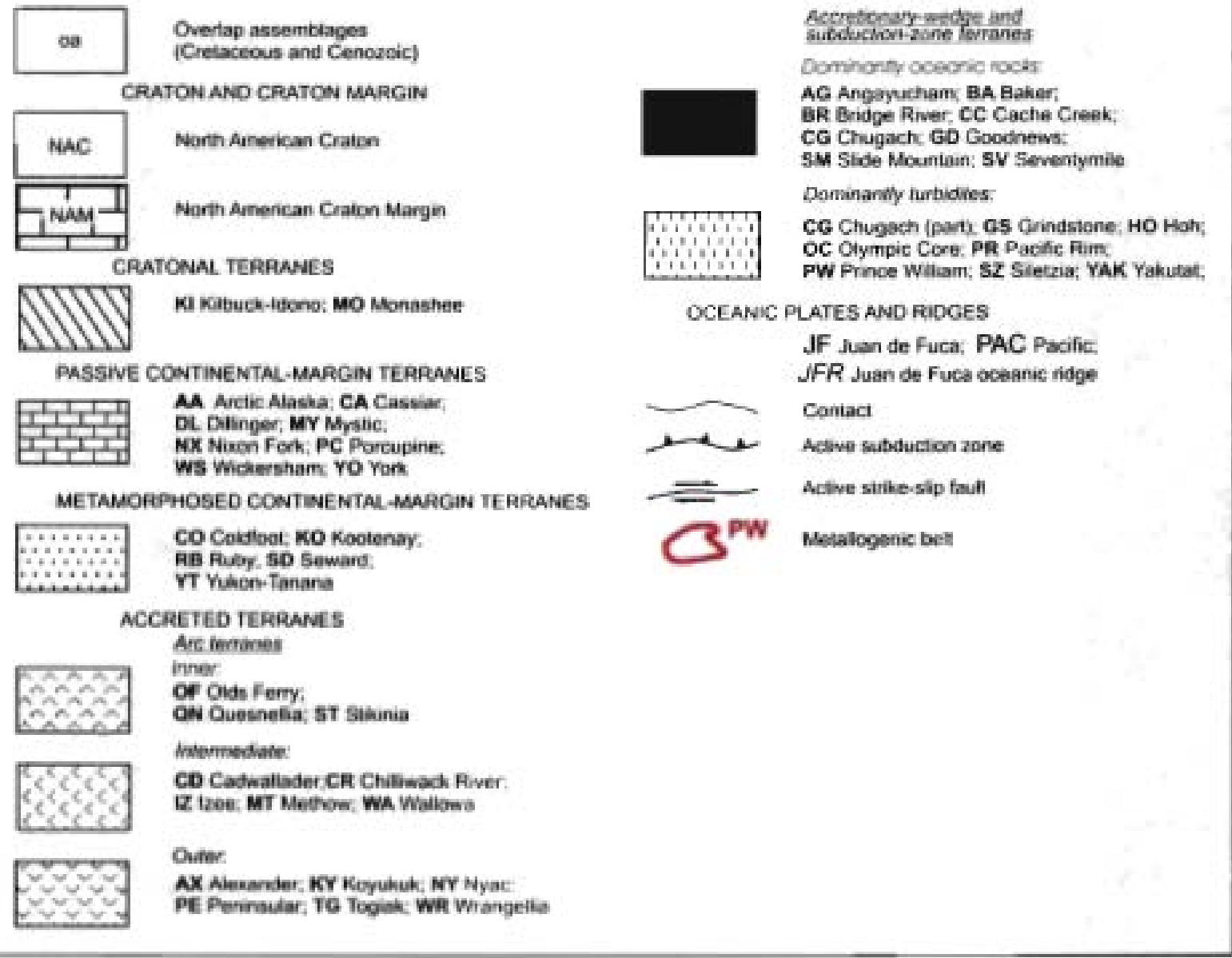

1999). Metamorphism occurred at quartz-albite- epidote-biotite subfacies, and the age of metamorphism is probably Pre-Vendian (Shpikerman, 1998). The sediment-hosted Cu deposits and host rocks are interpreted as forming in rifl-related troughs in a sublittoral and sheif area during the early history of the Prikolyma passive continental margin terrane, during Middle or Late Proterozoic incipient rifting of the North Asian Craton Margin (Shpikerman, 1998). The ironstone deposits of the Oroek metallogenic belt (Pobeda deposit and others) oceur in the Vendian Syapyakane suite which ranges from 300 to $800 \mathrm{~m}$ thick and is composed of mainly feldspathic-quartz sandstones with thin interbeds and lenses consisting of hematite (martite), magnetite. titanic magnetite, ilmenite, rutile, and zircon (Shpikerman. 1998). The sandstones are typical occurrences of Vendian beach placers and are similar to sandstones in the Middle Riphean Spiridonova Formation which occurs to the west, also in the Prikolyma terrane. However, these formations are underlain by the Gorbunova Formation which contains beds of dolomite and stratiform hematite-carbonate iron deposits. The Prikolyma terrase is interpseied as a rifted fragment of the North Asian Craton Margin (Verkhoyansk fold belt, unit NSV; Nokleberg and others, 1994c, 1997c; Shpikerman, 1998).

\section{Lantarsky-Dzhugdzhur Metallogenic Beit of \\ Anorthosite Apatite-T-Fe and \\ Gabbroic NI-Cu (PGE) Deposits (Beit LD) \\ Central Part of Russian Far East)}

The Lantarsky-Dzhugdehur metallogenic belt of anorthosite apatite-Ti-Fe and gabbroic Cu-Ni-Co-PGE deposits is hosted in the co-named igneous beli of layered gabbro and anorthosite complexes in one of a linear series of mafie plutons which crop out along in the Stanovoy block along the southern flank of the North Asian Craton (fig. 2; tables 3. 4) (Nokleberg and others, 1997b, 1998).. The belt occurs in the northern Khabarovsk Province in the central part of the Russian Far East and in southem Yakutia. $\mathrm{U}-\mathrm{Pb}$ and $\mathrm{Sm}-\mathrm{Nd}$ isotopic ages for the bost anorthosite intrusions range from 1.7 to $1.9 \mathrm{Ga}$ (Sukhanov and others, 1989; Neimark and others, 1992).

The Lantarsky-Dehugdehur igseous belt consists of five gabbroic Cu-Ni-Co-PGE deposits that are hosted in anorthosite and gabbro bodies that oceur along the $1,000 \mathrm{~km}$-long Stanvoy suture (collisional) zone between the Archean Aldan shield of the North Asian Craton to the North and the Proterosoic Stanovoy block to the south. The Archean rocks to the nonth consist of gneiss and schist intruded by Paleozoie to Mesozoic granitic rock (Lennikov, 1979). The rocks south of the suture zone consist of 
Archean granulite facies metamorphic rock, and Paleozoic greenschist to amphibolite facies metamorphic rock. The LantraskyDzhugdzhur anorthosite complex is elongated along the Stanvoy suture zone, is $170 \mathrm{~km}$ long, varies from 5 to $34 \mathrm{~km}$ wide, and covers and areas of approximately $2,700 \mathrm{~km}^{2}$. The complex is composed of approximately 70 percent anorthosite, and 30 percent gabbro, norile, and ultramafic rock. The complex contains a clussic layered series of anorthosite plutons, including those in Finland, Canada, and South America (Papunen, 1986; Ryan and others, 1995). The five gabbroic Cu-Ni-Co-PGE prospects, that have been identified since 1990, are at Avlandzhinsky, Kontaktovy, Nyandomi, Ozerny, and Odorin. These prospects oceur near the contact between anorthosite and gabbro layers, and REE-bearing alkali granitic rock. The two largest prospects at the Kontaktovy and Nyandomi are 300 to $600 \mathrm{~m}$ wide and range up to several $\mathrm{km}$ long. Surface samples of massive sulfides contain up to $3.4 \% \mathrm{Cu}, 0.74 \% \mathrm{Ni}, 0.17 \% \mathrm{Co}, 5.43 \mathrm{~g} / \mathrm{Pt}, 2.8 \mathrm{~g} / \mathrm{Pd}$, and $0.85 \mathrm{~g} / \mathrm{Rh}$ (Pollack, 1997; Panskikh, 1978), These prospects are geological and geochemical analogs to the $\mathrm{Cu}-\mathrm{Ni}-\mathrm{Co}-\mathrm{PGE}$ deposits in the layered Svecokarelian complexes of Finland and Western Russia, and Cu-Ni-PGE depesits in the Nain plutonic suite at Voisey Bay, Canada (Papunen, 1986; Pollack, 1997). The deposits in the Lantasky-Dzhugdzhur belt have been explored by Vostok Gold Corporation.

Another similar group of anorthosite Apatite-Ti-Fe deposits are the Bogidenskoe, Gayumskoe, Maimakanskoe, and Dzhaninskoe deposits. These deposits oceur to the south of the above-described deposits generally consist of apatite, ilmenite, and titanium magnetite which are hosted in melanocratic olivine gabbro, gabbrosyenite, gabbro-pyroxenite, and pyroxenite. These mafic and ultramafic rock often forms stock-like bodies in the Geransky anorthosite massif (Lennikov and others, 1987) that has a $\mathrm{Pb}-\mathrm{Pb}$ isotopic age of 2.2 to $1.8 \mathrm{Ga}$. The deposits occur on the southern, southwestem, and western margins of the Geransky unorthosite massif. The four largest deposits are spaced about 15 to $30 \mathrm{~km}$ between each other, and together contain an estimated 350 million tonnes $\mathrm{P}_{2} \mathrm{O}_{5}$ (Panskikh and Gavrilov, 1984). Together, the deposits in the belt contain approximately one billion tonnes of $\mathrm{P}_{2} \mathrm{O}_{4}$, an amount which is comparable with deposits in the Kola province in northwestern Russia near Sweden.

\section{Origin of and Tectonic Controls for}

Lantarsky-Dzhugdzhur Metallogenic Beit

The Lantasky-Dzhugdzhur metallogenic belt is interpreted as forming during Mesoproterozoic rifting along the edge of the North Asian Craton. During rifting, coeval, large anorthosite plutons intruded the Stanovoy suture and adjacent area for a distance of more than $1,000 \mathrm{~km}$, and adjacent region to the south.

\section{Uikan Metallogenic Beit of Felsic Plutonic REE Deposits (Beit UL) \\ Norttwestern Part of Russian Southeast}

The Ulkan metallogenic belt of felsic plutonic REE deposits occurs in the northwestern part of the Russian Southeast (fig. 2; tables 3, 4) (Nokleberg and otbers, 1997b, 1998). The belt occurs mainly in the Paleoproterozoic Ulkan volcano-lectonic basin that has isotopic ages of 1.9 to $1.5 \mathrm{Ga}$, and which overlies folded Archean basement rocks of the North Asian Craton (unit NSC) The REE, Be, U-Mo, Nb-Ta and related deposits are interpreted as forming in two periods.

\section{Omolon Metallogenic Beit of ironstone (Superior Fe) Deposits (Belt OM) \\ Central Part of Russian Northeast}

The Omolon metallogenic belt of ironstone (Superior Fe) deposits (fig 2; tables 3,4) occurs in the central part of the Russian Northeast. The belt is hosted in Archean metamorphic rocks of the Omolon cratonal terrane of the Kolyma-Omolon superterrane (Nokleberg and others, 1994c, 1997c; Shpikerman, 1998). More than ten local ironstone deposits are known in the bell (table 4) (Nokleberg and others, 1997a, b, 1998). The significant deposit is at Verkhny-Omolon.

\section{Verkhny-Omolon tronstone Deposit}

The significant Verkhny-Omolon ironstone deposit (fig. 6) consists of sheet-like and podiform bodies of banded iron formation which occur in Archean migmatite, amphibole and biotite-amphibole plagiogneiss, amphibolite, and mafic schist (Gelman, Titov, and Fadeev, 1974; Fadeev, 1975; Zhulanova, 1990; Milov, 1991). The banded iron ore consists of medium- to coarse-grained masses or layers of magnetite and quartz which is intergrown with apatite and actinolite. The deposit extends for 3.5 


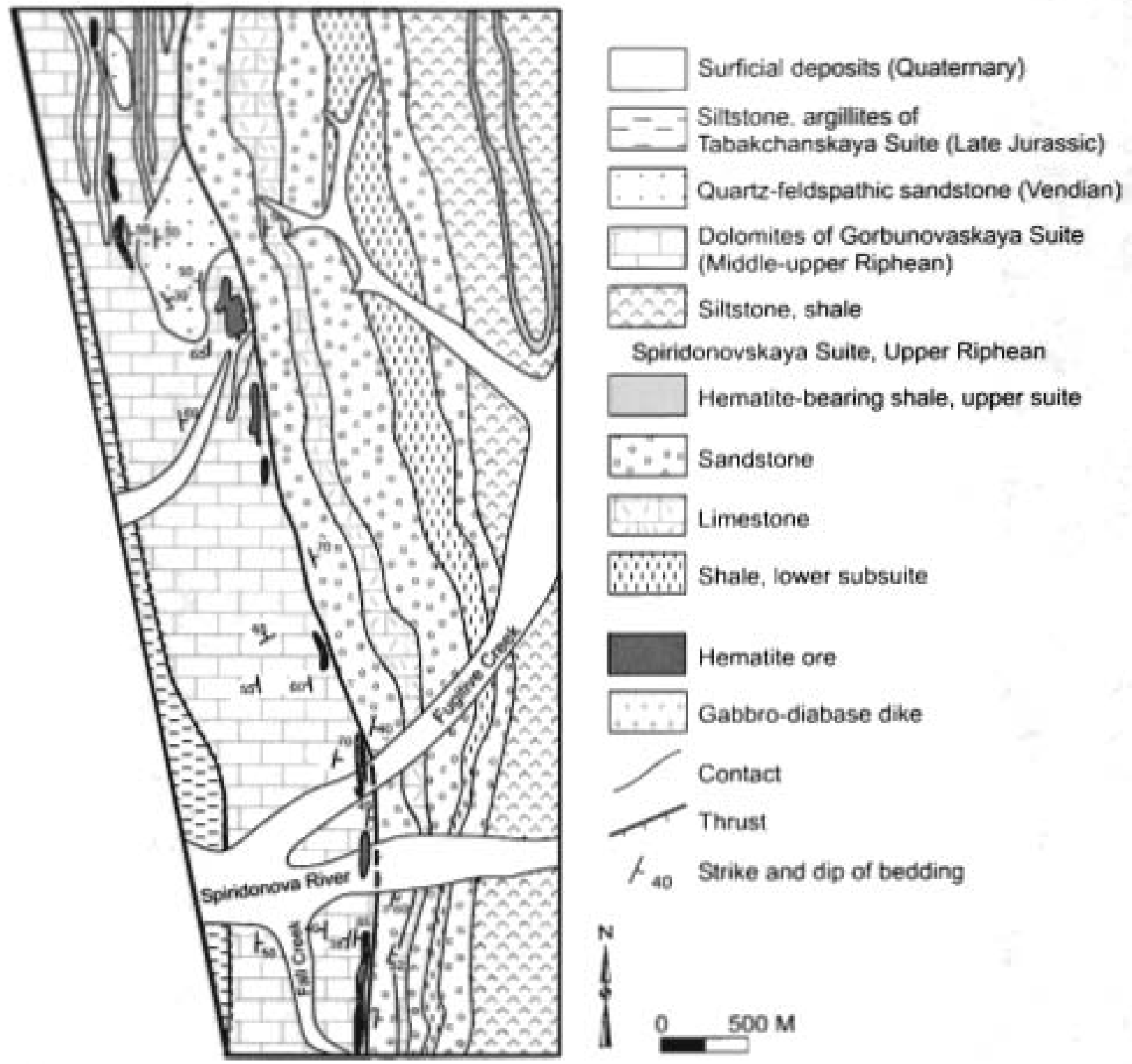

Figure 4. Pobeda ironstone deposit, Oroek metallogenic belt. Russian Northeast. Adapted from Shplkerman (1998).

$\mathrm{km}$, averages $250 \mathrm{~m}$ thick in the central portion, and locally consists of aliemating, nearly conformable ore bodies and horizons in the country rock. The original quartzite and possibly the ironstone deposits may be derived from marine sedimentary rocks which originally contained ironstone (Superior Fe) deposits. The host rocks are extensively granitized. Rb-Sr isotopic data reveal polymetamorphisms of the Archean basement. Granulite facies metamorphism occurred at 3.4 to $3.8 \mathrm{Ga}$, regional granitization occurred approximately at $2.0 \mathrm{Ga}$; and low grade metamorphusm and deformation occurred approximately at $1.0 \mathrm{Ga}$ (Zhulanova, 1990; Milov, 1991).

\section{Origin of and Tectonic Controls for Omolon Metallogenic Belt}

The Omolon metallogenic belt is hosted in various outcrops of the Archean crystalline basement of the Omolon metamorphic assemblage in the Omolon cratonal terrane (Zhulanova. 1990: Shpikernan, 1998). These crystalline rocks consist of Archean to Early Proterozoic sedimentary, volcanic, and magmatic rocks which are metamorphosed at granulite and amphibolite facies into gneiss, granitic gneiss, and amphibolite. Isotopic ages range from 2.3 to $1.7 \mathrm{Ma}$. The assemblage exhibits granulite facies of metamorphism, including amphibole, clinopyroxene-amphibole, and hypersthene-bearing schist, and biotite-hypersthene plagiogneiss and garnet-clinopyroxene gneiss. Leucocratic migmatites prevail in the assemblage and formed from multiple 

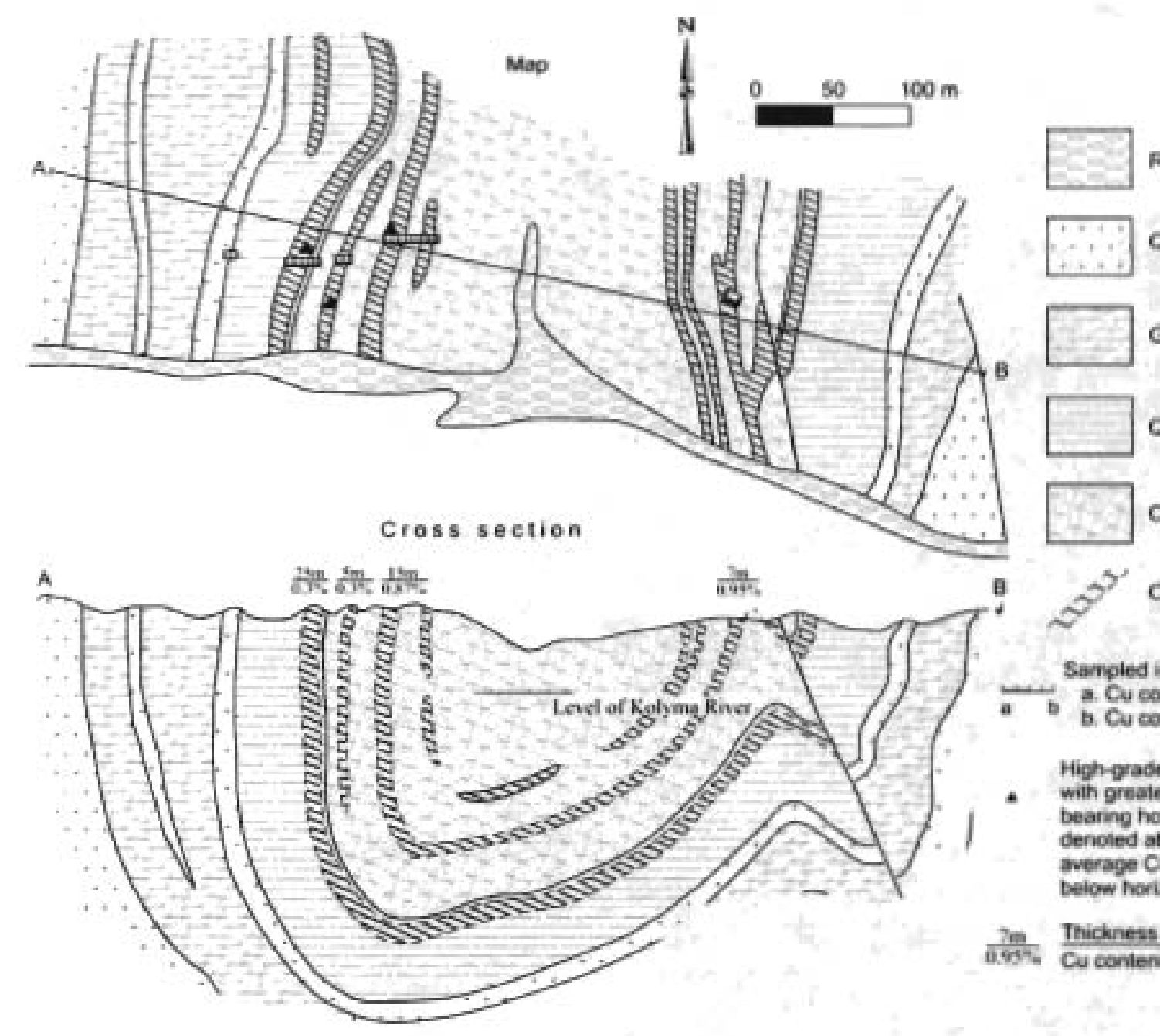

River gravel

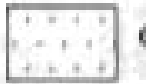

Quartzite

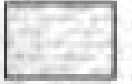

Graphite-chlorite schist

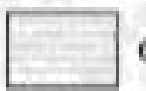

Ouartz-chloritoid schist

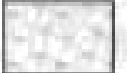

Chierite schist and phyllite

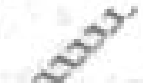

Cu-bearing horizons

Sampled intervals

a. Cu content $>0.1 \%$
b. Cu content $<0.1 \%$

High grade composhe samples with greater than $3 \%$ Cu. For orebearing horizons, Bickness denoled above horizontal line: average Cu grade for the section below horizontal line.

$\frac{7 .}{1.55 \%} \frac{\text { Thickness }}{\text { Cu content }}$

Figure 5. Oroek sediment-hosted Cu deposit, Oroek metallogenic belt, Russian Northeast. Schematic geologic map and cross section for southern part of deposit. Adapted from Shpikerman (1996).

granitization. The crystalline basement is unconformably overlain by a gently-dipping sedimentary and volcanic rock sequence of Riphean and younger age. The Omolon terrane is interpreted as a rifted fragment of the North Asian Craton (unit NSC; Nokleberg and others, 1994c, 1997c). Riffing is interpreted as occurring in the Late Devonian and Early Carboniferous (Nokleberg and others, 2000). The Omolon terrane and contained ironstone metallogenic belt are herein interpreted as possibly correlative with the Kilbuck-Idono terrane and contained Kilbuck ironstone metallogenic belt in southwestern Alaska (fig. 3) (Nokleberg and others, 1998, 2000)

An older group of $\mathrm{Be}, \mathrm{Ce}, \mathrm{La}, \mathrm{Y}, \mathrm{Nb}$, and Ta deposits is related to Rapakivi-type graniles with isotopic ages of 1.65 to $1.7 \mathrm{Gl}$. The granites intrude subalkalic siliceous volcanic rocks. The Be deposits, as at Burgundiy and Nygvagan, oceur in albitegenthevite-bearing zones within granite intrusions. The $\mathrm{Ce}, \mathrm{La}, \mathrm{Y}, \mathrm{Nb}$, and Ta deposits, as at Albititovoe and Gurjanouskoe, occur within zones of quartz, microcline, albile, riebeckile, aegirine along a linear zone of altered volcanic rocks. For both types of deposits, the main ore minerals are zircon, monazile, gagarinite, cassiterite, bastnasite, columbite, xenotime, and pytochlore.

A younger group of $\mathrm{Y}, \mathrm{Ce}, \mathrm{U}, \mathrm{Mo}, \mathrm{Nb}$, and Ta deposits exhibit isotopic ages of 1.1 to $\mathrm{I} .3 \mathrm{Ga}$, but show no clear connection with igneous rocks. Coeval dikes of alkalic basalt, with up to $12 \% \mathrm{~K}_{2} \mathrm{O}$, occur in the area. The large $\mathrm{Y}$-Ce deposit at Uzhnoe consists of metasomatic albite and apatite which occur in a fault zone. The apatite contains $\mathrm{Ce}$ and up to $1 \% \mathrm{Y}$. Other ore minerals are zircon, syochysite, monozite, xenotime, thorite, and brannerite. The U-Mo deposits, as at Mezhdurechnoe and Zapadnoe, are associated with altered beresite formed of muscovite, sericite, hydromica, pyrite, and $\mathrm{Ca}-\mathrm{Fe}-\mathrm{Mg}$ carbonate minerals. The chief ore minerals are mainly molybdenite, native gold and $\mathrm{Cu}$-, $\mathrm{Zn}$-, and $\mathrm{Pb}$-sulfides. The $\mathrm{Nb}-\mathrm{Ta}$ deposits, as at Krasnogorskoe, occur in zones of argillaceous-altered volcanic rocks now mainly quartz, hydromica, and clay. The chief ore minerals are $\mathrm{Nb}$-bearing gematite (up to $1 \% \mathrm{Nb}$ ), euxenite, and molybdenite. The deposits of the Ulkan metallogenic belt are similar to those in the Pikes Peak, Colorado region in the U.S.A. The metallogenic belt is isolated, distant from roads, and has only 
recently been studied (Kirillov, 1991,1993). Insufficient data preclude determining the ongin of the Ulkan metallogenic belt. The Ulkan belt is coeval anorthosite to the south which is interpreted as forming in a Mesoproterozoic rif-related voleanic-plutonic center.

\section{Bilyakchan Metallogenic Belt of \\ Sediment-Hosted $\mathrm{Cu}$ and \\ Basaltic Cu Deposits (Belt BI) \\ Southwestern Part of Russian Northeast}

The Bilyakchan metallogenic belt of sediment-hosted $\mathrm{Cu}$ and basalt Cu deposits (fig. 2; tables 3,4) occurs in the southwestern part of the Russian Northeast in Proterozoic rocks of the Verkhoyansk fold belt (unit NSV) that constitutes the North Asian Craton Margin (Nokleberg and others, 1994c, 1997b, c, 1998; Shpikerman, 1998). The beli strikes north-northeast for 350 $\mathrm{km}$ along the western folded margin of the Okhotsk cratonal terrane and is about $50 \mathrm{~km}$ wide. The deposits occur in metamorphosed sandstone and basalt of the Riphean and Vendian Bilyakchan sequence with a thickness of 3,100 m (Kutyrev and others, 1986). The Bilyakchan metallogenic belt is correlated with the tectonically-displaced Oroek metallogenic belt of ironstone and sediment-hosted $\mathrm{Cu}$ deposits which is described above.

\section{Dzhagdag Basaltic Cu and Severmy Uy Occurrences}

Basaltic Cu occurrences, as at Dzhagdag, occur in the lower part of the sequence. The Dzhagdag deposit consists of two layers of late Riphean (Vendian) amygdalotdal basalt, intercalated with tuff and sandstone, which contain Cu-bearing horizons which are 0.4-5 m thick and contain finely disseminated to small masses of chalcocile, bornite, native copper, cuprite, covellite, and malachite (Kutyrev and others, 1988). The basaltic Cu deposits and the hosting basalts are interpreted as forming during rifting on a shallow-submerged scarp of the western Okhotsk cratonal terrane. The sediment-bosted (sandstone) Cu occurrences, as at Severny Uy and Borong, occur at higher stratigraphic levels. The Severny Uy deposit consists of Cu-bearing horizons from 1 to $3 \mathrm{~m}$ thick and occur in Late Riphean (Vendian) quartz-and polymictic sandstone and siltstone (Kutyrev and others, 1986). The deposit contains fine disseminations and pockets of massive pyrite, chalcopyrite, borrite, chalcocile, and hematite. The sedimentbosted $\mathrm{Cu}$ deposits and the host sandstones are interpreted as forming during erosion of volcanic rocks with basaltic $\mathrm{Cu}$ deposits.

\section{Origin of and Tectonic Controls for Bllyakchan Metallogenic Belt}

The southwestern part of the North Asia Craton Margin (Verkhoyansk fold belt, unit NSV), which hosts the Bilyakchan metallogenic belt, consists of the following major units: (1) Middle to Late Riphean shelf limestone, sandstone, and shale with a combined thickness of more than $3 \mathrm{~km}$, and (2) Late Riphean to Late Vendian clastic and volcanic rocks, including variegated conglomerate, sandstone, siltstone, basalt, and rare rhyolite. The late Riphean (Vendian) sedimentary and volcanic rock which host the $\mathrm{Cu}$ deposits are interpreted as forming in a riff-related depression which formed in the transition between a continental shelf and adjacent onshore area, within the Siberian paleocontinental passive margin. The riff-related sedimentary rocks and $\mathrm{Cu}$ deposits were subsequently deformed into gentle folds and metamorphosed at greenschist facies. Sedimentary rocks of the fold beli are apparently tectonically detached from crystalline basement of craton. In this region, the Verkhoyansk fold belt is separated from the North Asian Craton by a west-verging thrust fault.

\section{Kilbuck Metallogenic Belt of Ironstone (Superior Fe) Deposits (Beit Kr) Southwestern Alaska}

The Kilbuck metallogenic belt of ironstone (probable Superior Fe type) deposits (fig. 3; tables 3, 4) occurs in southwestern Alaska. The metallogenic belt is bosted in the Kilbuck-Idono cratonal terrane which occurs in two discontinuous fragments separated along the dextral-slip Nixon Fork fault (fig. 3). The one known occurrence is at Canyon Creek (table 4) (Nokleberg and others 1997a, b, 1998).

The Canyon Creek ironsione (Superior Fe) oceurrence consists of rhythmically-layered hematite, magnetite, and siderite in layers up to $4 \mathrm{~cm}$ thick which occur in bleached Early Proterozoic quartzite (Bruce Hickok. T.K. Bundtzen, and M.L. Millet, written commun., 1992). The host rocks are mainly quartzile, garnet-biotite schist, meta felsic volcanic rocks, and amphibolite which are metamorphosed at amphibolite facies. The occurrence is about $150 \mathrm{~m}$ long, but is poorly exposed.

The Kilbuck-Idono terrane which hosts the Canyon Creek ironstone (banded Fe formation) oceurrence consists chiefly of metamorphosed diorite, tonalite, trondhjemile, and granite orthogneiss, subordinate amphibolite, and minor metasedimentary rocks (Box and others, 1993; Miller and others, 1991). The metasedimentary rocks of the terrane are mainly quartz-mica schist, marble, garnet amphibolite, and minor banded iroe formation. The metaplutonic rocks of the terrane yield Early Proterozoic (2.06 to $2.07 \mathrm{Ga}$ ) U.Pb zircon ages of emplacement (Box and others. 1990. Miller and others. 1991). The Kilbuck-ldono termane may be a displaced cratonal fragment of either the North America Cratos or the North Asian Craton. The Kilbuck-Idono terrane is possibly 


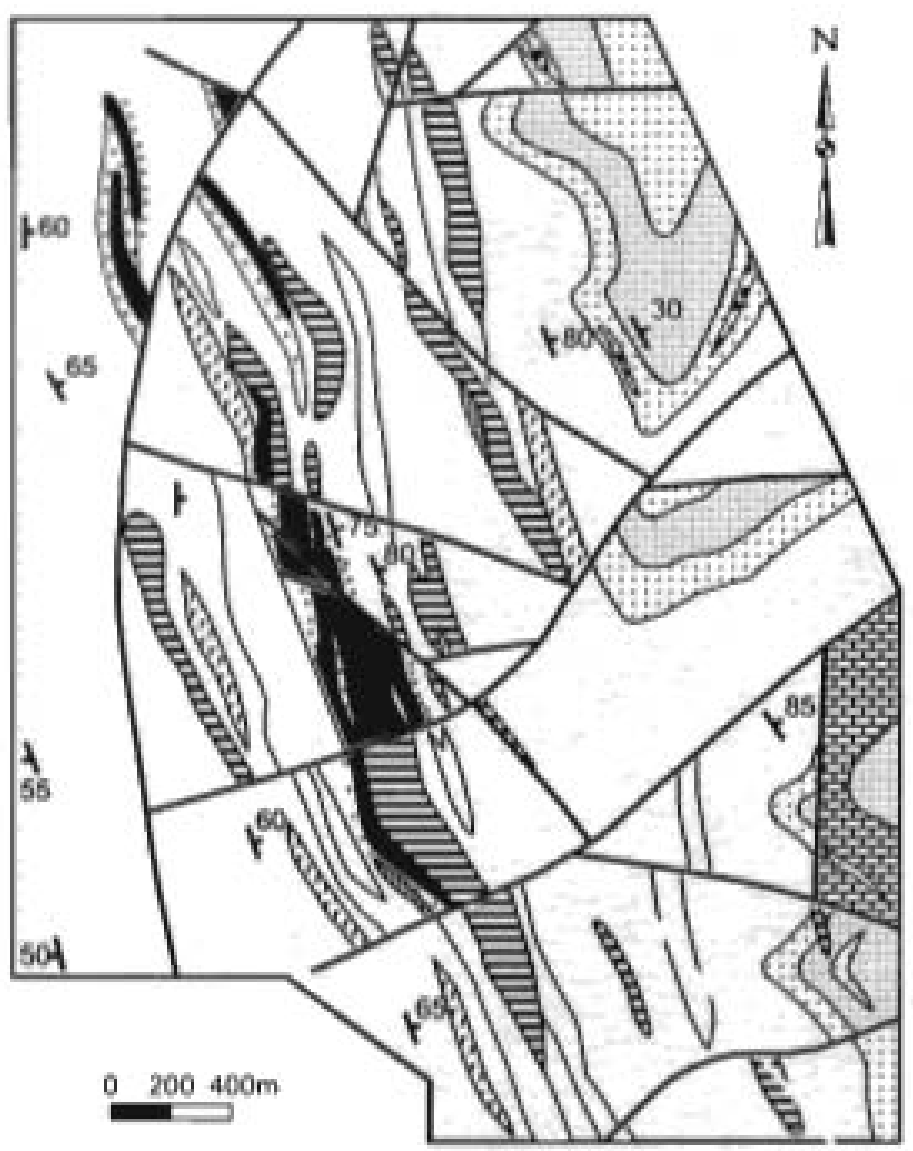

a b a - Quartz-rich sandstone b - Conglomerate lenses in sandstone

Sedimentary and metamorphic rock

Sericite-chlorite schist (Late Proterozoic Riphean)

Marl

$\square$ Migmatite

Migmatite

Amphibolite

[IIIII Schist

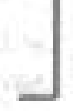

(and

Archean

crystalline

rock

F37 Gabbro and diorite (Late Proterozoic)

I크 Ore bodies: a - known;

b - indicated by geophysical data

2 Mineralized host rock

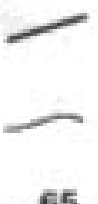

Fault

\section{Contact}

$\uparrow^{65}$ Strike and dip of schistosity

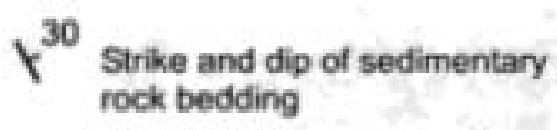

Figure 6. Verkhny-Omolon ironstone deposih, Omolon metallogenic belt, Russian Northeast. Schemalic geologic map. Adapted from Geiman and Fadeev (1983).

correlative with the Omolon terrane of the Kolyma-Omolos superierrane, or the Okhotsk terrane, both in the Russian Northeast and interpreted as rifled fragments of the North Asian Craton (fig. 2) (Nokleberg and others, 1994c, 1997c, 2000). The Omolon terrane has a somewhat similar stratigraphy and also contains ironstone deposits in the Omolon metallogenic belt.

\section{Metallogenic Beits Formed During Proterozoic \\ Sedimentation, Rifting, and Hydrothermal Activity \\ Along Cratons or Craton Margins}

\section{Sinuk River Metallogenic Belt of \\ Massive Sulfide-Barite and \\ Stratabound Fe and Mn Deposits (Beit SR) \\ Northwestern Alaska}

The Sinuk River metallogenic belt of stratiform massive sulfide-barite and stratabound Fe deposits occuns in the Sinuk River area in the southwestern part of the Seward Peningula in northwestern Alaska (fig. 3; tables 3,4) (Nokleberg and othern, $1997 \mathrm{~b}, 1998$ ). The metallogenic belt occurs in a $250 \mathrm{~km}$ region of metamorphosed, upper Paleozoic, carbonate-dominated rocks of the Seward metamorphosed continental margin ternane (Nokleberg and others, 1994c, 1997c), about $30 \mathrm{~km}$ west of Nome (Herreid, 1968; Hudson and others, 1977; Bundizen and others, 1994, 1995; Newberry and others, 1997). At least 15 separate occurrences of massive to disseminated galena, sphalerite, fluorite, and barite, and massive hematite occur in the area. The deposits vary widely in morphology and size and consist of: (1) disseminated to massive barite sulfide lenses (Aurora Creek, Nelson, Rocky Mountain Creek, Quarry) which are bosted in felsic metavolcanic achist, carbonate rock, and metamorphosed mafic flows(7), and which are interpreted as kuroko massive sulfide and replacensent deposits; and (2) massive, stratabound 
segregations of hematite, magnetite, and pyrolusite, interpreted as volcanogenic(?) Fe and Mn deposits (American, Bear, Cub, Monarch) which are hosted in calc-schist and marble.

\section{Aurora Creek Massive Sulfide-Barite Deposit}

The Aurora Creek massive sulfide-barite deposit (Herreid, 1968, 1970; Bundizen and others, 1994, 1995; Schmidt, $1997 \mathrm{~b}$ ) consists of disseminated to massive sphalerite, galena, barite, pyrite, magnetite, and minor chalcopyrite in muscovitefeldspar metavolcanic schist of Aurora Creek sequence, which is part of the Late Proterozoic and early Paleozoic Nome Group. Sulfide minerals occur for $2,400 \mathrm{~m}$ along strike. Significant dolomite formation is interpreted to have accompanied sulfide deposition. The deposit has been explored by with limited drill cores and trenches. Intense alteration to tourmaline occurs in feldspar-rich metavolcanic schists near massive sulfides and barite occurrences. Limited sulfur isotopic analyses indicate which heavy sulfur probably formed in a seawater-contaminated, marine volcanogenic setting. Lead isotope analyses from the Aurora Creek, Quarry, and Rocky Mountain Creek suggest either a kuroko massive sulfide and SEDEX deposit type (Bundtzen and others, 1995). One zone in one drill core contains an average of $15.9 \% \mathrm{Zn}, 1.38 \% \mathrm{~Pb}, 0.07 \% \mathrm{Cu}, 35 \% \mathrm{Ba}, 2.6 \mathrm{~g} / \mathrm{t} \mathrm{Au}, 45 \mathrm{~g} / \mathrm{t} \mathrm{Ag}$. Similar, but smaller occurrences are located at the Nelson. Rocky Mountain Creek, and Quarry prospects. The Aurora Creek and nearby deposits are interpreted as similar to the Ansil mine and related deposits in the Noranda area of Quebec.

\section{Origin of and Tectonic Controls for Sinuk River Metallogenic Belt}

The Sinuk River metallogenic belt, which contains the Aurora Creek, Quarry, Nelson, and Rocky Mountain Creek ZnPb-barite-Ag deposits, is bosted in the Aurora Creek sequence of the Nome Group (Bundizen and others, 1994; Schmidt, 1997b). The Monarch, Quarry, American, and Cub Bear Fe-Mn deposits are hosted in the overlying Mount Distan sequence. New U-Pb zircon isotopic ages of 675 and $681 \mathrm{Ma}$ were oblained from orthogneiss which intrudes the Mount Distan sequence (T.K. Bundtzen, this study). This relation suggests which both the stratiform massive sulfide-barite and stratabound Fe and Mn deposits of the Sinik River metallogenic belt are probably of Late Proterozoic or older age (Bundtzen and others, 1994, 1995; Patrick and McClelland, 1995). Sulfur isotopic analyses of sulfides from the massive sulfide-barite deposits suggest formation in a seawatercontaminated, marine volcanogenic rift(?) environment. The Aurora Creek sequence and the hosting Nome Group are part of the Seward metamorphosed continental margin terrane that is interpreted as part of the North American Continental Margin (Nokleberg and others, 2000). The Sinuk River metallogenic belt is interpreted as forming during marine volcanogenic rifting(?) of the North American Continental Margin.

\section{Gillespie Metallogenic Belt of SEDEX Zn-Cu-Pb-Au-Ag Deposits (Belt GM) Northern Yukon Territory}

The Gillespie metallogenic beit of SEDEX $\mathrm{Zn}-\mathrm{Cu}-\mathrm{Pb}-\mathrm{Au}-\mathrm{Ag}$ deposits occurs in the northern Yukon Territory (fig. 3; tables 3, 4) (Nokleberg and others, 1997b, 1998). The belt is hosted in the Gillespie Lake Group which is the uppermost unit of the Early Proterozoic Wernecke Supergroup of the North American Craton margin. The group is about $1 \mathrm{~km}$ thick and consists mainly of dolostones and dolomitic clastic rocks (Mustard and others, 1990). The major SEDEX occurrences are Blende in the eastem Ogilvie Mountains, and Hart River.

\section{Blende SEDEX Zn-Cu-Pb-Au-Ag Deposit}

The East and West Zones of the Blende deposit consist primarily of galena, sphalerite and pyrite, with lesser chalcopyrite and tetrahedrite, in vein and breccia zones with siderite-dolomile-quartz gangue (NDU Resources, press release, 1993; Robinson and Godwin, 1995). The deposit contains an estimated resource of 19.6 million tonnes grading $3.04 \% \mathrm{Zn}, 2.81 \% \mathrm{~Pb}, 1.6 \% \mathrm{Cu}, 56$ $\mathrm{g} / \mathrm{Ag}$ and $2.75 \mathrm{~g} / \mathrm{t} \mathrm{Au}$. Ore borizons extend over $700 \mathrm{~m}$ vertically and $6 \mathrm{~km}$ along strike along a structural zone of shears and breccia. The mineralization is multistage. The deposits are hosted in stromatolite-bearing dolostone of the Middle Proterozoic Gillespie Lake Group in the Wernecke Supergroup. Stocks, plugs, and dikes of homblende gabbro intrude the dolostone and appear to be associated with mineralization (Robinson and Godwin, 1995).

\section{Hart River SEDEX Zn-Cu-Ag Deposit}

The Hart River SEDEX $\mathrm{Zn}-\mathrm{Cu}-\mathrm{Ag}$ deposit consists of pyrite and pyrrhotite and minor sphalerite, galena and tetrahedrite which occur as a tabular mass along a facies change from dolomite to calcareous black argillite of the Early Proterozoic Gillespie Lake Group (EMR Canada, 1989; Macintyre, 1991). The host rocks are cut by numerous diabase sills and dikes which metamorphose the dolomite to serpentinite-talc and the argillite to hornfels. The footwall is silicified and contains a stockwork of sulfide veinlets, whereas the hanging wall contains thinly layered sulfides. The deposit has estimated reserves of 1.1 million tonnes grading $3.6 \% \mathrm{Zn}, 1.45 \% \mathrm{Cu}, 0.9 \% \mathrm{~Pb}, 49.7 \mathrm{~g} / \mathrm{Ag}$, and $1.4 \mathrm{~g} / \mathrm{t}$ Au (Maclntyre, 199l; Abbott and others. 1994). 
The Gillespic metallogenic belt SEDEX deposits is hosted in the Wernecke Supergroup which is part of a shelf assemblage, at least $14 \mathrm{~km}$ thick and is part of the North American Craton Margin. The assemblage consist of fine-grained, turbidite clastic rocks which grade upward into carbonate rocks, and is broadly correlated with the Purcell Supergroup of the southern Canadian Cordillera (Young and others, 1979). The major SEDEX occurrences in the Gillespie metallogenic belt at Blende (and the Carpenter Ridge prospect) may be related to Proterozoic gabbro-diorite sills (Robinson and Godwin, 1995), of may be possibly related to correlative overlying mafic volcanic flows as at Hart River (Abbott and othen, 1994). Other SEDEX Zn-Pb occurrences, as at Cord, which is hosted by the upper Gillespie Lake Group in the Wernecke Mountains, and other stratabound $\mathrm{Zn}-\mathrm{Pb}-\mathrm{Ag}$ vein occurrences, as at $\mathrm{Oz}$. Monster, and Tart, may also be related to this mafic igneous activity. Similar mineralization ages occur at Blende (1.4 Ga; Robinson and Godwin, 1995), Hart River (1.24 to 1.28 Ga; Morin, 1978), and Sullivan (1.43 Ga, LeCouteur, 1979). These ages and host rock setting indicate sedimentary exhalation oecurred in a distal sedimentary shelf facies and was possibly related to a widespread Middle Proterozoic event, including faulting, rifting, and associated mafic intrusion (Dawson and others, 1991). This rifting is interpreted as influencing sedimentation in the Wernecke and Purcell Supergroups and the Muskwa Ranges Assemblage.

\section{Wernecke Metallogenic Beit of U-Cu-Fe $(A u-C o)$ Vein and Breccia Deposits (Belt WR) Central Yukon Territory}

The Wernecke metallogenic belt of U-Cu-Fe (Au-Co) vein and breccia deposits (fig. 3; tables 3,4) occurs in the central Yukon Territory and is hosted in the Early Proterozoic Wernecke Supergroup in the North American Craton Margin. In this area, the Early Proterozoic Wernecke Supergroup consists of a thick sequence of dominantly fine-grained clastic rocks (Delaney, 1981). More than forly deposits of $\mathrm{Cu}, \mathrm{U}$ and $\mathrm{Fe}$ are associated with extensive heterolithic breccias, as veins, and disseminations in the matrices and elasts, and in adjacent hydrothermally altered rock (Nokleberg and others 1997a, b, 1998). The significant deposits ure at Dolores, Igor, Irene, Pagisleel. Porphyry, and Slab (table 4). Chalcopyrite, brannerite, hematite and magnetite are associated with alteration assemblages of $\mathrm{Na}$ and $\mathrm{K}$-feldspar, silica, chlorite and carbonate (Dawson and others, 1991). No definitive tonnage and grade data exist for the deposits and oocurrences in the Wernecke metallogenic belt; however, resource estimates exist for fwo significant eccurrences which contain varying proportions of $\mathrm{Cu}, \mathrm{U}, \mathrm{Au}$, Fe and $\mathrm{Co}$. The Igor occurrence contains an estimated resource of 0.5 million tonnes grading $1.0 \% \mathrm{Cu}$, and the Pagisteel occurrence contains an estimated resource of I tonne grading $29 \%$ Fe (Archer and others, 1986; Hitzman and others, 1992; Abbott and others, 1994). Other significant occurrences are at Slab, Irene. Porphyry, Dolores, Athens, and Olympic (table 4).

Formation of the vein and breccia deposits in spatial relationship to associated mafic dikes and minor diorite intrusions was proposed by Abbott and others (1994). Similarities between these deposits in the Wernecke belt and those in the better known Kinuna-Olympic Dam deposit type were discussed by Gandhi and Bell (1996), but evidence of coeval, large-scale magmatic activity, regarded as an important feature of the later deposit type, is lacking. A deep-seated magmatic bydrothermal source for the formation and mineralization of the breccias was proposed for both the Kinuna-Olympic Dam deposit type and the deposits in the Wernecke belt (Hitzman and others, 1992; Thorkelson and Wallace, 1993). A recent, unpublished U-Pb zircon isotopic age of 1.72 Ga for a post-deposit dike suggests an Early Proterozoic age for both the Wernecke Supergroup and the mineraliration (D. S. Thorkelson, personal communication, 1994).

\section{Rapitan Metallogenic Belt of Sedimentary Iron Formation Deposits (Beit RA) Central Yukon Territory}

The Rapitan metallogenic belt of iron formation deposits (fig. 3; tables 3, 4) occurs in the central Yukon Territory and is hosted in the Rapitan Sedimentary Assemblage, the lowest and easternmost unit of the Windermere Supergroup which is part of the North American Craton Margin. The Rapitan assemblage is interpreted as forming in a rift environment which exhibits rapid facies and thickness changes, and contains a suite of rift-related igneous intrusions and extrusions with isotopic ages of about 770 Ma (Gabrielse and Campbell, 1991). Diamictite, in part glaciogenic, oceurs at several localities and stratigraphic levels, notably at two well defined horizons in eastem Mackenzie Mountains. The largest deposit of hematite-jaspilite iron deposit in North America occurs in one of these horizons at Snake River (Crest; table 4) (Nokleberg and others 1997a, b, 1998).

\section{Crest tron Formation Deposit}

The Crest Iron (Snake River) formation deposit consists of a main zone of banded, laminated or nodular jasper hematite which occurs along a siratigraphic interval about $130-\mathrm{m}$ thick near the base of the "ice marginal' glacial diamictite complex of the Shezal Formation. The richest part of the deposit oceurs in the top $80 \mathrm{~m}$ which contains little or no interbedded sedimentary rocks. Estimated resources are 5.6 billion tonnes grading $47.2 \%$ Fe. Numerous smaller regional occurrences are also hosted in the 'proglacial' siltstone facies of the underlying Sayunei Formation (Eisbacher, 1985; Yeo, 1986). This type of banded iron 
formation mineral deposit is named the Rapitan-type by Gross (1996). This type iron of deposit exhibits distinctive lithological features, including association with diamictites (tillite) which contain dropstone, sandstone, conglomerate, and argillite. The Crest Iron deposit and the Jacadigo iron formation in Brazil are interpreted as having been deposited in Late Proterozoic or early Paleozoic rocks grabens and fault-scarp basins along the rifted margins of continents or ancient cratons (Gross, 1996),

\section{Origin of and Tectonic Setting for}

Rapitan Metallogenic Belt

An origin of marine exbalation along synsedimentary faults was proposed for this type of hematite-jaspilite iron formation by Gross (1965), with modifications by Yeo (1986) to include brine transport by currents generated by the thermal gradients between cold glacial and warm hydrothermal waters. The iron deposits in the Rapitan assemblage are correlated with hematite-jasper iron formation in silistone and diamictile of the Late Proterozoic Tindir Group near Tatonduk River in eastern Alaska (Payne and Allison, 1981; Young, 1982). Dawson and others (1994) correlate the iron deposits in the Rapitan Assemblage and Tindir Group with Late Proterozoic tillite and hematite iron units of the Prikolyma terrane of the Kolyma region in eastern Siberia (Furduy, 1968). This interpretation tentatively supports juxtaposition of Siberia and Laurentia in the Late Proterozoic.

\section{Metallogenic Belts Formed During Proterozoic Rifting of North American Craton or Craton Margin}

\section{Redstone Metallogenic Beit of Sediment-Hosted $\mathrm{Cu}-\mathrm{Ag}$ Deposits (Belt RS) Central Yukon Territory}

The Redatone metallogenic belt of sediment-hosted Cu-Ag deposits (fig 3; tables 3, 4), which occurs in the western Mackenzie district in the central Yukon Territory, is hosted in the dominantly clastic rocks of the Late Proterozoic Windermere Supergroup which is part of the North American Craton Margin (Gabrielse and Campbell, 1991; Nokleberg and others, $1997 \mathrm{~b}$. 1998). The largest deposits is at Coates Lake (Redstone); the other deposit in the belt is the June Creek (Baldwin-ShelI) deposit (table 4) (Nokleberg and others 1997a, b, 1998).

\section{Coafes Lake (Redstone) sediment-hosted Cu-Ag Deposit}

The Coates Lake (Redstone) sediment-hosted Cu-Ag deposit consists of chalcopyrite, bornite, digenite, chalcocile and covellite as disseminations stratabound in eight repetitive algal carbonateievaporite sabkha sequences along a transgressive contact with underlying continental redbeds of the Redstone River Formation (Chartrand and others, 1989). The deposit contains estimated reserves of 37 million tonnes grading $3.9 \% \mathrm{Cu}$ and $11.3 \mathrm{~g} / \mathrm{Ag}$. Other deposits in the belt are at June Creek, Haybook Lake, and Per.

\section{Origin of and Tectonic Controls for Redstone Metallogenic Beit}

The Coates Lake deposit is the largest and best-documented example of Kuperschiefer-type, syngenetic mineral deposit in Canada. Typically Kuperschiefer deposits are zonally distributed and contain disseminated sulfides at oxidation-reduction boundaries in anoxic marine sedimentary rock at the base of a marine or large-scale saline lacustrine transgressive cycle. The host struta either overlie or are interbedded with continental redbeds. The redbeds, along with characteristically-associated evaporites, are a probable source of evaporite-derived ore fluid and copper (Kirkham, 1996a).

The Redstone metallogenic belt of sediment hosted Cu-Ag deposits and hosting Windermere Supergroup are interpreted as forming during a period of major Late Proterozoic rifting along the westem continental margin of North America (Gabrielse and Campbell, 1991). The Coates Lake Group which hosts the Coates Lake deposit is an unconformity-bounded rift assemblage which occupies several faul-controlled embayments over a $300 \mathrm{~km}$-long trend which is located along the eastern limit of Late Proterozoic strata in the Mackenzie Mountains (Jefferson and Ruclic, 1986)

\section{Churchill Metallogenic Belt of \\ Cu Vein Deposits( Beit CH) \\ Northern British Columbia}

The Churchill metallogenic Belt of $\mathrm{Co}$ vein deposits occurs in the Muskwa Ranges assemblage in northern British Columbia (fig. 3; tables 2, 3) (Nokleberg and others, 1997b, 1998). This assemblage consists of a platformal succession, about 6km-thick, of quartzite, carbonate rocks, and flysch which are tentatively correlated with the Purcell (Belo) Supergroup which was deposited along the passive continental margin of the North American Craton (Bell, 1968; Anken and McMechan, I991). The Muskwa Ranges assemblage consists of a lower sequence of platformal quartrite and carbonate rocks which is about $3.5 \mathrm{~km}$ thick. and an upper sequence of shaley flysch which is about $2.5 \mathrm{~km}$ thick. In this area are fwelve significant Cu vein deposits which 
occur in clastic and impure carbonate rocks of the Aida and Gataga formations in the Racing River-Gataga River region (Taylor and Stott, 1973). The significant deposit is at Churchill. Other Cu vein deposits in the Churchill metallogenic belt are at Davis Keays. Gatage, and Fram.

\section{Churchill (Davis Keays) Cu Vein Deposits.}

The major Churchill (Davis Keays) Cu vein deposit oceurs along the Magnum vein system. The deposit consists of chalcopyrite, pyrite, quartz, and ankerite in a zone which is $100 \mathrm{~m}$ wide (Preto und Tidsbury, 1971: Dawson and others, 1991). The deposit oecurs in strongly folded Late Proterozoic dolomites and slates of the Aida Formation (with K-Ar isotopic age 780 $\mathrm{Ma}$ ), and is intruded by diabase dikes and sills. Overtying Cambrian basal conglomerate contains clasts of mineralized vein material. The deposit age is interpreted as Late Proterozoic. From 1971 to $1974,498,00$ tonnes grading $3.43 \% \mathrm{Cu}$ were produced. The grade is highly variable and discontinuous.

\section{Origin of and Tectonic Contro/s for Churchill Metallogenic Belt}

The $\mathrm{Cu}$ vein deposits in the Churchill metallogenic belt are associated with a northwest-striking diabase dike swarm whicb crosscuts folded sedimentary rocks in the Purcell (Belt) Supergroup which were deposited along the passive continental margin of the North American Craton. The Cu vein deposits are partly concordant with and intruded by genetically-related diabase dikes. However, no diabase dikes occur in the Late Proterozoic Windermere Group to the west, indicating an early Late Proterozoic age for dike emplacement and formation of associated $\mathrm{Cu}$ vein deposits (Dawson and others, 1991). The Churchill metallogenic belt is interpreted as forming in a major, Mesoproterozoie rifting event which is reflected in the sedimentary assemblages of the Purcell and Wernecke Supergroups and the Muskwa Ranges assemblage.

\section{Monashee Metallogenic Belt of Sedimentary Exhalative (SEDEX) Zn-Pb-Ag Deposits (Beit MO) Southern British Columbia}

The Monashee belt of sedimentary exhalative (SEDEX) Zn-Pb-Ag deposits (fig, 3; tables 3,4), located in southem British Columbia in the southeastern Canadian Cordillera, is hosted in the Monashee cratonal terrane. The major SEDEX deposits (table 4) are Big Ledge, Ruddock Creek, Cottonbelt, and River Jordan (King Fiasure), as well as the Neoproteroroic Mount Copeland porphyry Mo deposit which is herein included in the metallogenic belt because the porphyry systems are part of the Monashee cratonal terrane (Nokleberg and others 1997a, b, 1998). The SEDEX deposits and prospects are within the upper paragneiss part of the terrane. Estimated resources range from less than 1 million to 6.5 million tonnes.

\section{Big Ledge SEDEX Zn-Pb Deposit}

The Big Ledge SEDEX Zn-Pb deposit consists of sphalerile, pynhotile, galena, and pyrite in lenses (Hey, 1982a; MINFILE, 2002). The deposit contains estimated reserves of 6.5 million tonnes grading $4 \% \mathrm{Zn}$. The deposit is in a dark. pyntotite and pyrite-rich, graphitic, calcarcous schist which extends along strike for approximately $10 \mathrm{~km}$. The schist is part of paragneiss which is interpreted as the amphibolite-grade metamorphic equivalent of the Late Proterosoic Windermere Group.

\section{Ruddock Creek SEDEX Zn-Pb Deposit}

The Ruddock Creek SEDEX Zn-Pb deposit consists several layers with banded sphalerite, pyrnhotite, galene, pyrite and minor chalcopyrile and local barite and fluorite which occur in discontimuous lenses and layers along strike length for several kilometers (Drwson and others, 1991; Hoy, 1982a, 2001; MINFILE, 2002). The deposit has estimated reserves of approximately 5.0 million tonnes grading $7.5 \% \mathrm{Zn}, 2.5 \% \mathrm{~Pb}$ and is hosted in possibly Paleoproterozoic schist, cale-silicate gneiss, quartzite and marble.

\section{Mount Copeland Porphyry Mo Deposit}

The Mount Copeland porphyry Mo deposit consists of molybdenite, pyrite, pyrnhotite, bomite, chalcopyrite and galena which occur along the northern boundary of a large mass of nepheline syenite gneiss flanking the southem boundary of the Frenchmas's Cap Dome, one of several gneissic domes flanking the eastern margin of the Shuswap Metamorphic Complex (McMillan, 1973; Okulitch and others, 1981; MINFILE, 2002). The deposit has estimated reserves of 180,000 tonnes grading $1.82 \%$ MoS2 and production of 171.145 tonnes grading $0.75 \% \mathrm{MoS2}$. The deposit is hosted in irregular lenses of aplite and pegmatite syenite. U. $\mathrm{Pb}$ zircon isotopic analysis suggests an age of $773 \mathrm{Ma}$. This age indicates the porphyry deposit formed in the early history of the Monashee cratonal terrane prior to fragmentation and migration. 
The SEDEX $\mathrm{Zn}-\mathrm{Pb}$ deposits in the Monashee metallogenic belt, which are interpreted as Broken Hill type $\mathrm{Pb}-\mathrm{Zn}-\mathrm{Ag}$ deposits by Høy (2001), consist of extensive, thin, sulfide layers which are folded and metamorphosed along with their predominantly calcareous and schistose host rock (Fyles, 1970; Høy, 1982a, 2000; Dawson, and others, 1991). A correlation of the SEDEX $\mathrm{Zn}-\mathrm{Pb}$ deposits and host rocks of the Monashee terrane with those in the Kootenay terrane may exist (Dawson and others, 1991; Høy, 2001). The Monashee terrane is interpreted as a displaced fragment of the North American Craton which consists of a core of basement paragneiss (with a Late Archean and Paleoproterozoic isotopic age of 2.8 to $1.96 \mathrm{Ga}$ ), intruded by orthogneiss $(2.1 \mathrm{Ga})$, and mantled by paragneiss which is intruded by a syenite pluton which may be as old as $1,852 \mathrm{Ma}$ (Scammell and Brown, 1990; Nokleberg and others, 1994c, 1997c; Crowley. 1997). In the area of the Mount Copeland porphyry Mo deposit, minor occurrences of pyrochlore and columbite-tantalite in carbonatite associated with syenite gneiss (McMillan, 1973) suggest a genetic relationship of these alkaline intrusions to a rifting event which resulted in the separation of the Monashee terrane from the craton in the Late Proterozoic (Monger and Nokleberg, 1996).

\section{Purcell Metallogenic Belt of SEDEX $\mathrm{Zn}-\mathrm{Pb}$-Ag Deposits (Belt PR) Southern British Columbia}

The Purcell metallogenic belt of sedimentary exhalative (SFDEX) $\mathrm{Zn}-\mathrm{Pb}-\mathrm{Ag}$ deposits (fig 3; tables 3,4) occurs in the southern Canadian Cordillera and is hosted in sedimentary rocks of the Mesoproterozoic Purcell Supergroup. The sedimentary rocks of the supergroup comprise a dominantly passive margin depositional sequence of fine-grained, basinal clastic rocks at least $11 \mathrm{~km}$ thick. This basinal sequence thins eastward into platformal sedimentary rocks toward the North American Craton (Aitken and McMechen, 1991). The Purcell Supergroup is correlated with the Belt Supergroup in the western and northern USA. The major SEDEX deposit is Sullivan; other significant deposits in the belt are the Moyie (St. Eugene) and Vine Ag-Au polymetallic vein deposits (table 4) (Høy, 1991, 2001; Nokleberg and others 1997a, b, 1998).

\section{Sullivan SEDEX Zn-Pb-Ag Deposit}

The Sullivan SEDEX $\mathrm{Zn}-\mathrm{Pb}$-Ag deposit (fig. 7) consists of a laminated sulfide assemblage of galena, sphalerite and pyrite which has undergone metamorphic recrystallization, and tectonically-induced mechanical and chemical remobilization (Leitch and Turner, 1991, 1992; Lydon, 1995). The deposit occurs near a north-trending rift axis at an intersection with the eastwest-trending, proto-Kimberley fault. The Sullivan deposit originally contained 170 million tonnes of ore with a grade of $5.5 \% \mathrm{Zn}$, $5.8 \% \mathrm{~Pb}$, and $59 \mathrm{~g} / \mathrm{Ag}$. About $70 \%$ of the deposit occurs in a massive pyrthotite-galena-spbalerite vent complex which overlies a heavily tourmaline-altered bydrothermal upflow zone. The remaining $30 \%$ of the deposit occurs in concordant laminated pyrthotitesphalerite-galena "ore bands" which extend eastwards from the vent complex (Lydon, 1995). Ongoing hydrothermal activity from marine brines generated successive chlorite-pyrnbotite-muscovite and albite-chlorite-pyrite-sericite-calcite assemblages in ore zone and hanging wall and footwall, all coincident with gabbro dikes and sills. The deposit is hosted conformably within folded, Middle Proterozoic turbidite of the Early Aldridge formation of the Purcell Supergroup. The turbidites fill an intracontinental extensional rift marine basin which is extensively intruded by tholeutic Mesoproterozoic Moyie Sills series. The sulfide deposition is interpreted as predating the Mine Sill series, part of the Moyie Sills series, and was accompanied by extensive boron (tourmaline) alteration of marine sedimentary origin. Related, smaller $\mathrm{Zn}-\mathrm{Pb}-\mathrm{Ag}$ deposits are at Fors, Stemwinder, North Star, and Vine.

\section{Origin of and Tectonic Setting for Purcell Metallogenic Belt}

The Purcell metallogenic belt of SEDEX Zn-Pb-Ag deposits (fig. 3; tables 3,4) is hosted in the Purcell Supergroup which ranges up to $10 \mathrm{~km}$ thick to the west, but thins eastward into platformal sedimentary rocks. The Supergroup is overlain by shallow marine and non-marine rocks (Aitken and McMechan, 1991), is underlain by basement rocks older than $1.7 \mathrm{Ga}$, and is intruded by the tholeitic Moyie Sills with a U-Pb zircon isotopic age of 1.467 Ma (Anderson and Davis, 1996). Up to 30\% of outcrops of the turbidite sequence consists of the tholeitic sills which were emplaced before significant consolidation of the sedimentary rocks. The sills are interpreted as forming during rifting (Hey, 1989; Lydon, 1995). The SEDEX Zn-Pb-Ag deposits of the Purcell metallogenic belt are interpreted as forming at the beginning of major period of mid-Purcell (middle Paleozoic) rifting which consisted of exhalation of $\mathrm{Zn}-\mathrm{Pb}-\mathrm{Ag}$-bearing fluids and associated hydrothermal alternation which was followed by intrusion of the abundant Moyie Sills series. Several other similar metallogenic belts of Mesoproterozoic stratiform massive sulfide deposits occur in parts of the North American Craton Margin and are interpreted as forming during a major period of Middle Proterozoic rifting along the passive continental margin of the North American Craton (Stewart, 1975). These belts include: (1) Churchill belt of Cu vein deposits; (2) Clark Range belt of sediment-hosted Cu-Ag deposits; and (3) Gillespie belt of SEDEX deposits. The SEDEX deposits are interpreted as directly associated with mafic volcanic rocks and hydrothermal activity. 


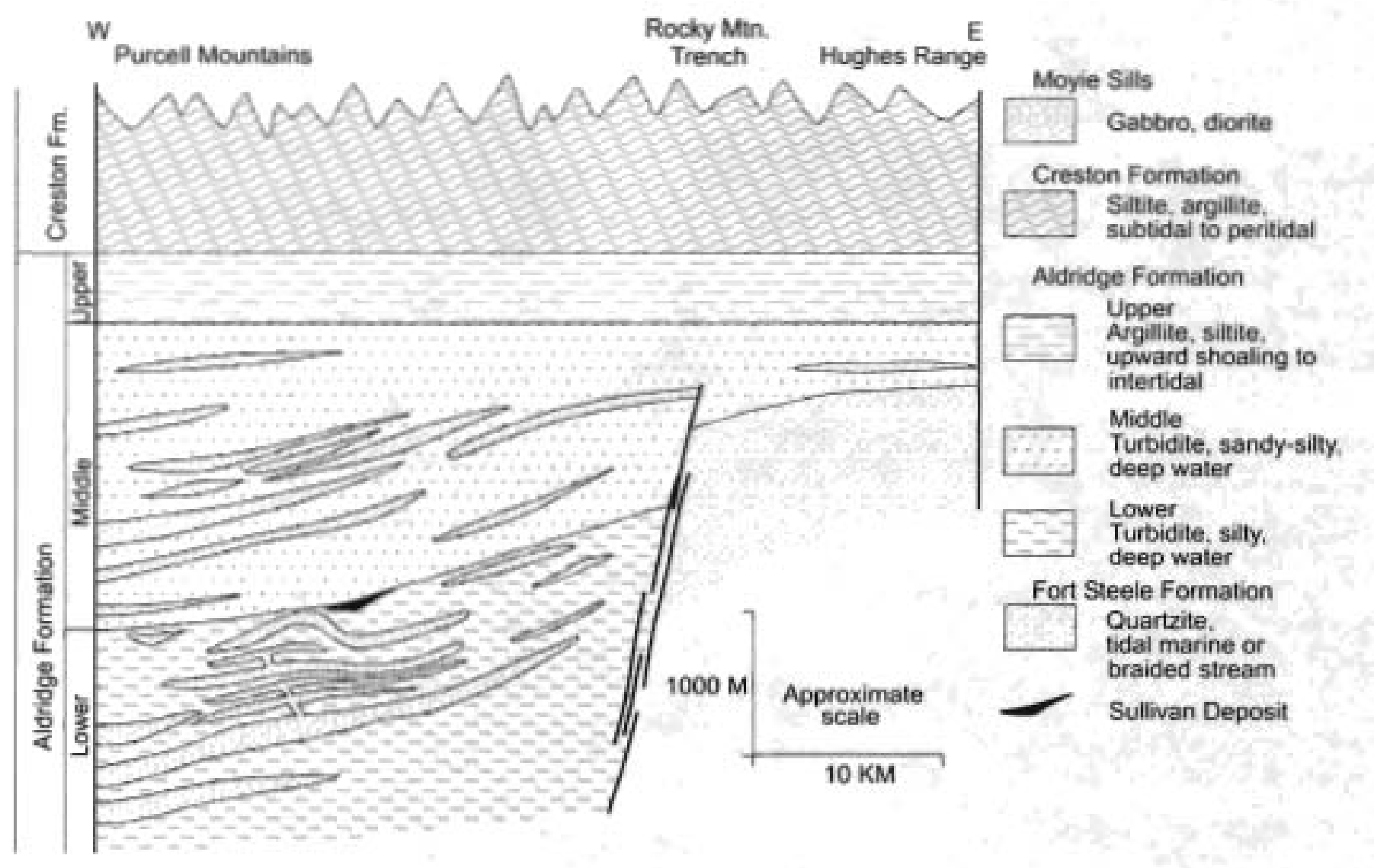

Figure 7. Sullivan sedimentary-exhaiative $\mathrm{Zn}-\mathrm{Pb}-\mathrm{Ag}$ deposit, Purcell metallogenic belt, Canadian Cordiliera. Schematic restored cross section. Adapted from Lydon (1995).

\section{Clark Range Metallogenic Beit of Sediment-Hosted Cu-Ag Deposits Southern British Columbia (Belt CR)}

The Clark Range metallogenic belt of sediment-hosted Cu-Ag deposits occurs in the Clark Range of southeastem British Columbia and southwestern Alberta (fig3; tables 3, 4) (Nokleberg and others, 1997b, 1998). The belt is hosted in the predominantly clastic rocks of the Appekuny, Grinell, and Siych Formations of the lower Purcell Supergroup which was deposited along the passive continental margin of the North American Craton. The metallogenic belt contain numerous, minor occurrences of sediment-hosted Cu-Ag and less common Zn-Pb-Cu deposits (Kirkham, 1974; Morton and others, 1974 ; Collins and Smith, 1977; Binda and others, 1989). The sedimentary rocks of the Mesoproterouroic Purcell Supergroup comprise a dominantly passive margin depositional sequence of fine-grained, basinal clastic rocks at least $11 \mathrm{~km}$ thick. They thin eastward into platformal sedimentary rocks toward the North American Craton. The supergroup is correlated with the Belt Supergroup in the westem and northern USA The metallogenic belt contains no significant mineral deposits (Nokleberg and others, $1997 \mathrm{a}, \mathrm{b})$.

\section{Clark Range Sodiment-Hosted Cu-Ag Deposits}

The sediment-bosted $\mathrm{Cu}-\mathrm{Ag}$ sulfide occurrences in the Clark Range metallogenie belt are most abundant in the Grinnell Formation. The deposits typically consist of erratically disseminated chalcocite, bomite, and less common Cu sulfides which are hosted in relatively permeable white quartz-arenite inlerlayered with red argillite. Larger Canadian occurrences include Kinshena Creek and Bull River, and an extensive occurrence in the Akamina syncline along the contact between the Grinnell and Siyeh Formations (Binda and others, 1989). None contain measured reserves or resources. The Grinnell Formation is the stratigraphic equivalent of the Revent Formation of Montana which hosts the important Spar Lake Cu (Ag) deposit (Hayes and others, 1989). In this area is a 75-km-long belt of sediment-hosted $\mathrm{Cu}-\mathrm{Ag}$ and $\mathrm{Zn}-\mathrm{Pb}$ occurrences that are located in the Spokane and Helena Formations in the eastern Belt basin of western Montana. These units are the equivalents to the Siyeh Formation in Canada (Lange and others, 1989). 
The Clark Range metallogenic belt is hosted by sedimentary rocks which are interpreted as part of Proterozoic through middle Paleozoic passive margin along the North American Craton (Nokleberg and others, 1994c, 1997b, c, 1998, 2000; Monger and others, 1996). The sediment-hosted Cu occurrences in the Clark Range metallogenic belt, which occur in quartz-arenite beds in dominantly red argillite, were interpreted by Kirkham (1974) as forming during late diagenetic mineralization of eolian beds in a sabkha sequence. In contrast, the oceurrences are interpreted by Collins and Smith (1977) as the product of cyclically-controlled redox conditions during short-lived, fluvial to lacustrine episodes. Alternatively. Morton and others (1974) interpret the metalbearing fluids forming from exhalations along faults.

Deposition of a prograding wedge of Purcell (Belt) sedimentary rocks is interpreted as the result of major Mesoproterozoic rifting along the passive continental margin of the North American Craton (Monger and others, 1972). A riftrelated, exhalative origin for the sediment-hosted copper deposits in the Clark Range metallogenic belt is supported by analogous, similar deposits elsewhere in the North American Craton Margin: (1) Cap Mountains deposit in the southern Franklin Mountains, Northwest Territories (Aitken and others, 1973); (2) Churchill belt of Cu vein deposits; (3) Gillespie belt of SEDEX deposits; and (4) the Purcell belt of SEDEX deposits. Many of the metallogenic belts with SEDEX deposits are directly associated with mafic volcanic rocks and hydrothermal activity.

\section{Cambrian through Silurian Metallogenic Belts (570 to $408 \mathrm{Ma}$ )}

\section{Overview}

The major Cambrian through Silurian metallogenic belts in the Russian Far East, Alaska, and the Canadian Cordillera are summarized in table 3 and portrayed on figures 2 and 3 . The major belts, although with disparate origins, are as follows. (1) In the Russian Southeast, Voznesenka (VZ) and the Kabarga (KA) belts, which contain Korean $\mathrm{Pb}-\mathrm{Zn}$ and Ironstone (Superior $\mathrm{Fe}$ ) deposits, are hosted in the Khanka continental-margin arc superterranes. These belts are interpreted as forming during marine sedimentation in rifted fragments of the Gondwandaland supercontinent. (2) In the same region, the South Khingan (SK), and Gar (GA) belts, which contain ironstone (Superior Fe), volcanogenic Fe, Cu massive sulfide, and stratiform $\mathrm{Zn}-\mathrm{Pb}$ deposits, are hosted in the Bureya or Khanka continental-margin arc superterranes. These belts are interpreted as forming These belts are interpreted as forming during early Paleozoic sedimentation or marine volcanism in Manchurid and Altaid orogenic systems. (3) In the central part of the Russian Far East, Galam (GL) belts, Omulevka River (OR), Rassokha (RA), which contain Volcanogenic Fe and Mn; sedimentary, Austrian Alps W, Kipushi $\mathrm{Cu}-\mathrm{Pb}-\mathrm{Zn}$, and Basaltic $\mathrm{Cu}$, sediment-hosted $\mathrm{Cu}$ deposits, are interpreted as during early Paleozoic sea-floor spreading, regional metamorphism, or during subduction-related volcanism. (4) In the Russian Northeast, Dzhardzhan River (DZR) belt, which contains Southeast Missouri $\mathrm{Pb}-\mathrm{Zn}$, sediment-hosied $\mathrm{Cu}$, and sandstone-hosted $\mathrm{U}$ deposits, is interpreted as forming during incipient rifting of early Paleozoic (Cambrian) continental-margin. (5) In the Canadian Cordillera, the Anvil (AN), Howards Pass (HP), and Kootenay (KO) belts, which contain SEDEX Zn-Pb-Ag deposits, are hosted in the North American Craton Margin, or in the Yukon-Tanana and Kootenay continental-margin terranes which are interpreted as having been rifted from the North American Craton Margin. These belts are interpreted as forming during rifting of early Paleozoic (Cambrian) North American Continental-Margin. And (6) in Southeastem Alaska, the Prince of Wales Island (PW) porphyry Cu and polymetallic vein deposits, which are hosted in the Alexander sequence of the Wrangellia superierrane, are interpreted as forming in a short-lived continental-margin arc. In the below descriptions of metallogenic belts, a few of the notable or significant lode deposits are described for each belt. Table 4, which is adapted and revised from Nokleberg and others (1997a), provides a complete listing of significant lode deposits in each metallogenic belt.

\section{Metallogenic Belts Formed During Early Paleozoic Marine Sedimentation in Rifted Fragments of Gondwandaland Supercontinent}

\section{Voznesenka Metallogenic Belt of Korean Pb-Zn Deposits (Beit VZ) \\ Southern Russian Southeast}

The Voznesenka metallogenic belt of Korean $\mathrm{Pb}-\mathrm{Zn}$ massive sulfide deposits (fig, 2; tables 3,4) oceurs in the southem part of the Russian Southeast. The belt is hosted in the Voznesenka terrane of the Khanka superterrane, a fragment of a Paleozoic active continental-margin arc (Androsov and Ratkin, 1990; Nokleberg and others, 1994c, 1997c; Khanchuk and others, 1996, 1998; Ryazantseva, 1988). The significant deposits are at Voznesenka-1 and Chernysherskoe (table 4) (Nokleberg and others 
1997a, b, 1998). The massive sulfide ores generally oceur conformable to organic-rich, bituminous limestones near a contact with overlying marl, Banded magnetite ore associated with algae bioherms is a peculiarity of the stratiform deposits of the Voznesenka metallogenic belt.

\section{Vornesenka-1 Korean Pb-Zn Deposit}

The Voznesenka-1 (Korean Pb-Zn deposit (fig. 8) (Androsov and Ratkin, 1990; Ryazantseva, 1988) consists of massive and thick-banded sphalerite and magnetite-sphalerite layers in bedded Early Cambrian limestone turbidite. The ore bodies are lenticular, 1-2 m thick, 20 to $100 \mathrm{~m}$ long, and oceur in dolomitie limestone and mart. The sulfide bodies and host rocks are folded and regionally metamorphosed. The sulfide bodies were locally altered to skam und greisen during emplacement of a Silurian granitic stock which intrudes the carbonate unit. The deposit is of medium size with an average grade of $4 \% \mathrm{Zn}$.
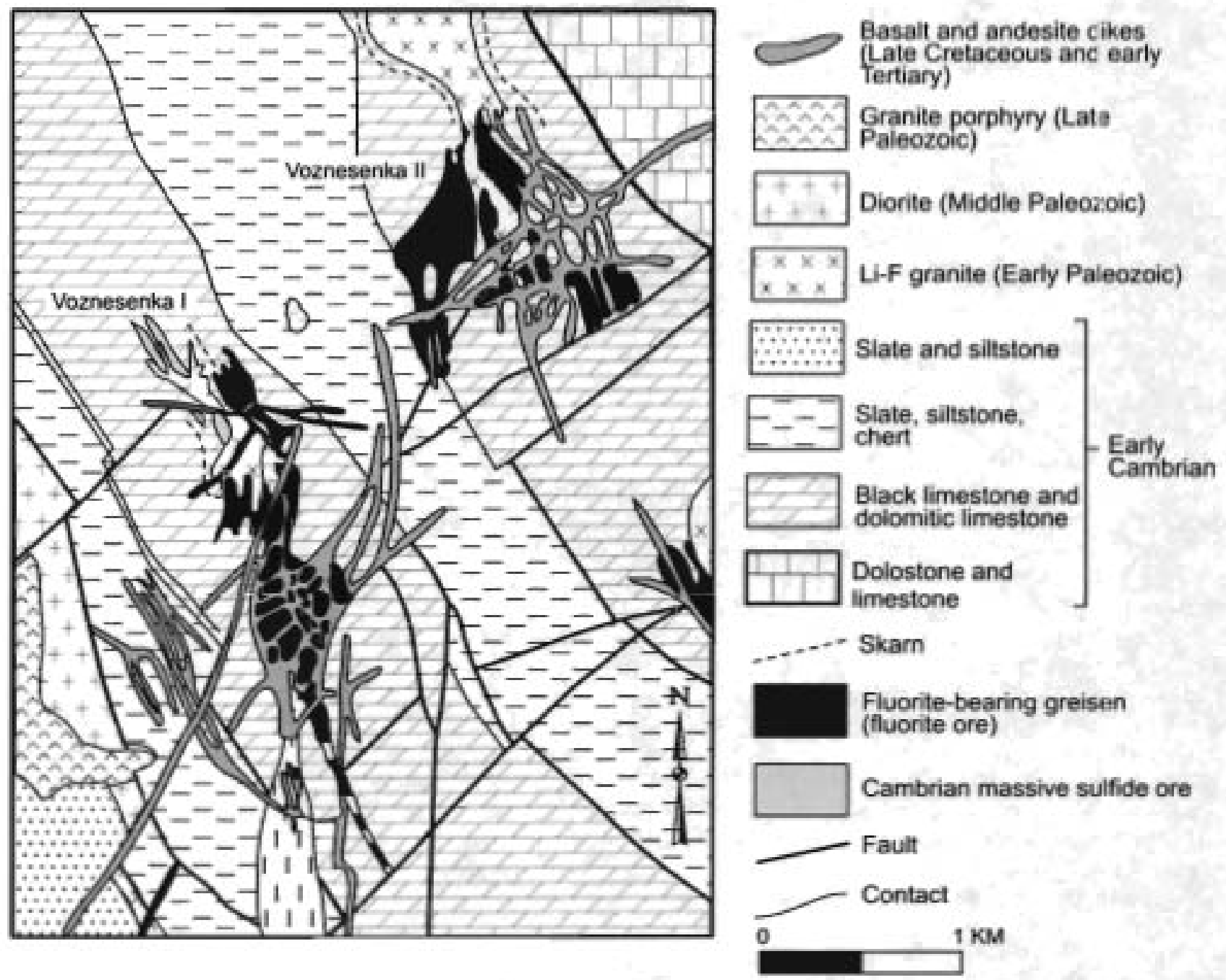

Figure 8. Voznesenka-1 Korean Zn massive sulfide deposit (Voznesenka metallogenic belt) and Voznesenka-ll fluorite greisen deposit. Yarosiavka metalogenic belt, Russian Southeast. Schematic geologic map. Adapled from Ratkin (1995).

\section{Chernyshevskoe Korean Pb-Zn Deposit}

The nearby Chernyshevskoe Korean Pb-2n deposit (Bashanov, 1988; Ryarantseva, 1988) consists of sheeted pynhotiteanenopyrile-pyrite-galeni-sphalerile bodies which occur at the contact of a limestone sequence with overlying Early Cambrian siltstone. Rare conformable zones of disseminated sulfide mineralization occur within the limestone away from the contact. The sulfide bodies are 1 to $2 \mathrm{~m}$ thick, with a surface exposure 100 to $200 \mathrm{~m}$ long. The deposit was drilled to a depth of about $100 \mathrm{~m}$. The deposit is small with an average grade of $1.5-6.5 \% \mathrm{~Pb}$ and $0.7-2.5 \% \mathrm{Zn}$. Both the Voenesenka-I and Chernyshevskoe deposits wese formerly interpreted as skams and were previously not evaluated properly. Locally abundant sedimentary-exhalative siliceous rocks have anomalously high $\mathrm{F}, \mathrm{B}$, and $\mathrm{Zn}$ values. 
The Cambrian through Silurian units of the Voznesenka ierrane consists are (Nokleberg and others, 1994c, 1997e; Khanchuk and others, 1996, 1998): (1) Cambrian sandstone, pelitic schist, rhyolite, feisic fuff, and limestone and dolomite which together are up to several thousand meters thick, are intensely deformed; (2) Ordovician collision-related biotite and Li-F protolithionite granitoid rocks with Rb-Sr and Sm-Nd ages $450 \mathrm{Ma}$ (Belyatsky and others, 1999); and (3) Ordovician to Early Silurian conglomerate and sandstone with questionable-age flora. The limestone turbidites bosting the Voznesenka-I and Chemyshevskoe Korean $\mathrm{Zn}-\mathrm{Pb}$ deposits are interpreted as forming on the upper pan of an Early Cambrian continental slope. The limestone turbidite and other Cambrian sedimentary and volcanic units of the Voznesenka terrane are interpreted as a fragment of a Late Proterozoic to early Paleozoic carbonate-rich sedimentary rock sequence which formed on a passive continental margin. Archaeocyathid fauna in Cambrian limestone is related to the Australia paleogeographic province. The Voznesenka terrane probably was a part of the passive continental margin of Gondwanaland (Khanchuk and others, 1998). Similar stratiform Cambrian $\mathrm{Zn}$ deposits occur in fragments of Gondwanaland in Africa and South America.

\section{Kabarga Metallogenic Belt of Ironstone Superior Fe) Deposits (Belt KB) Southern Russian Southeast}

The Kabarga metallogenic belt of ironstone (Superior Fe) deposits (fig. 2; tables 3, 4) occurs in the southem part of the Primorye province in the Russian Southeast and is hosted in the Kabarga terrane of the Khankha superternune (Nokleberg and others, 1994c, 1997c). The belt is defined principally by a group of ironstone deposits at Ussuri which consist of beds of magnetite- and hematite-magnetite-bearing chert which occur in a sequence of Early Cambrian clastic-carbonate rocks which overlie Early Cambrian dolomite (Denisova, 1990; Nokleberg and others 1997a, b, 1998). Magnetite and hematite Layers also occur along the layering planes between chert and intercalated with quartz-sericite-chlorite and quartz-sericite schist and dolomite. The upper part of the Fe deposit is oxidized, and contains $\mathrm{Mn}$ deposits, mainly pyrolusite, which occur in addition to the $\mathrm{Fe}$ deposits. Mineralogic and geochemical studies suggest an exhalative-sedimentary origin. The deposits are generally small, with $\mathrm{Fe}$ contents which range from 24 to $39 \%$ ).

The Kabarga metallogenic belt of ironstone (Superior Fe) is bosted in the Kabarga terrane of Khanka supenterrane (Nokleberg and others, 1994c, 1997c). The ironstone deposits occur in Cambrian siliceous limestonc, limestone, graphitic pelitic shale, ferromanganese and phosphate layers, and dolomite. The rocks are intensively deformed. The stratigraphic thickness ranges up to I km. The older units of the Kabarga terrane, which underlie the deposits described above, consist of highly metamorphosed and deformed marble, cale-schist, gneiss, and quartzite which exhibit granulite and amphibolite-facies metamorphism, and yield a Rb-Sr whole-rock isotopic age of greater than $1,517 \mathrm{Ma}$. Younger units consist of Silurian sandstone, limestone, Silurian collisional-related granitoid plutons, Permian basalt, andesite, and rhyolite, and Early Triassic sandstone. The Khanka supenterrane is interpreted as a fragment of a Paleozoic continental-margin arc (Nokleberg and others, 1994c, 1997c). In the Early Cretaccous, the Khanka superterrane was accreted to the eastern margin of Asia.

\section{Metallogenic Belts Formed During Early Paleozoic Sedimentation or Marine Volcanism in Manchurid or Altaid Orogenic Systems}

\section{South Khingan Metallogenic Belt of Ironstone (Superior Fe) Deposits (Belt SK) Southern Russian Southeast}

The South Khingan metallogenic belt of ironstone (Supenor Fe) deposits (fig. 2; tables 3,4) occurs in the southwestern parts of the Khabarovsik province in the Russian Soutbeast in the Malokhingansk terrane of the Bureya superterrane. The belt contains a group of significant deposits at South Khingan (table 4) (Nokleberg and others 1997a, b, 1998).

The South Khingan deposit (fig. 9) consists of Fe- and Mn-bearing beds which are composed of magnetite-, hematiter, and magnetite-bematite-bearing quartzile in beds 18 to $26 \mathrm{~m}$ thick which are interlayered with chlorite-dolomite breccia (Kazansky, 1972). Underlying sedimentary rocks contain braunute-haussmanite-rhodochrosite layers between 2 and $9 \mathrm{~m}$ thick. The $\mathrm{Fe}$ - and Ma-bearing layers are overlain by a dolomite sequence which is overlain in turn by shale, limestone, and dolomite which all occur in the lower portion of the Early Cambrian Khingan series. The deposit has not been developed because of the difficulties with ore concentration and steeply-dipping beds. The largest deposits at Kimkanskoe, Kastenginskoc, and South Khingan are estimated as containing approximately 3 billion tomnes of Fe and Mn minerals. Mineralogic and geochemical studies suggest an sedimentary-exhalative origin. The Early Cambrian Khingan series is part of the Bureya superterrane which is interpreted as a fragment of a continental-margin ate which was accreted to Sino-Korean Craton during the Paleozoic (Nokleberg and others, 1994c, 1997c). The supertemane contains Late Proterozoic and Devonian granitoid rocks with K-Ar isotopic ages of 604 and 301 
Ma which locally form extensive plutons and batholiths. The metallogenic belt is interpreted as forming in volcanic and sedimentation basin along an unstable proto-continental margin, or in a fragment of Archean craton which was incorporated into an accretionary wedge lerrane.
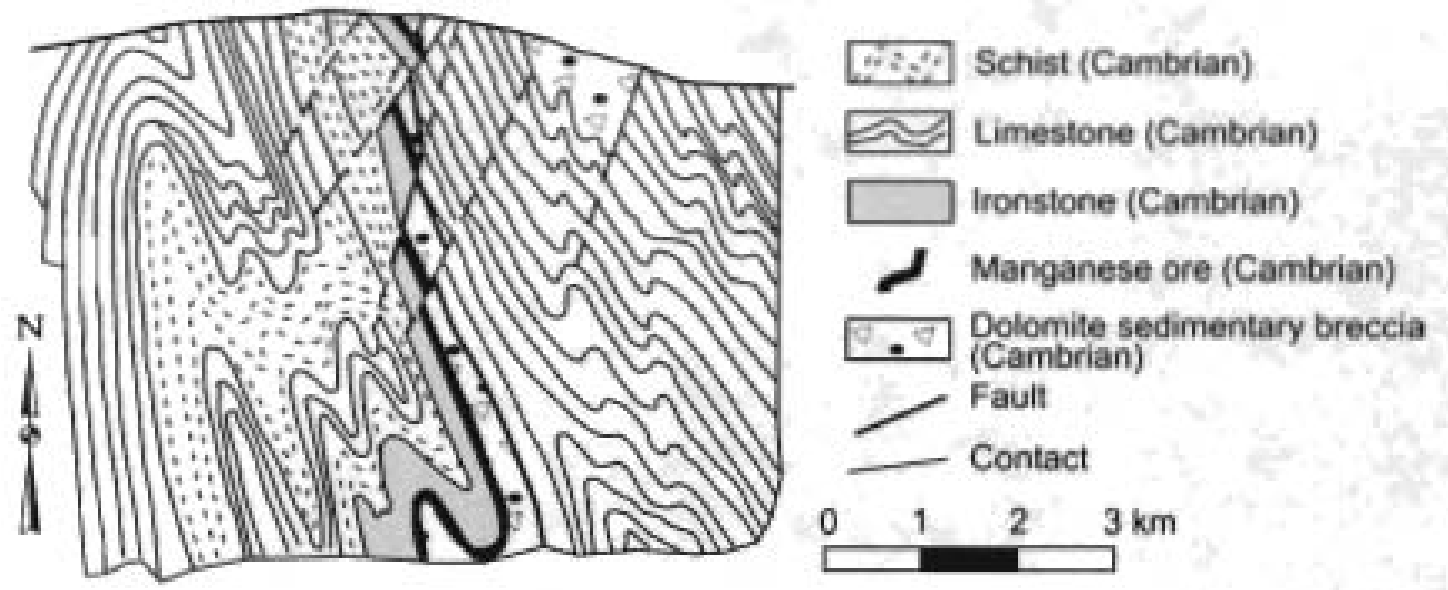

Figure 9. South Khingan ironstone deposit, South Khingan metallogenic belt, Russian Southeast. Schematic geologic map and cross section. Adapted from Korostelev and others (1990).

\section{Gar Metallogenic Belts of Volcanogenie Fe Deposits and Stratiform $\mathrm{Cu}$ and Pb-Zn Deposits (Beit GR) Western Part of Russian Southeast}

Two Gar metallogenic belts of volcanogenic $\mathrm{Fe}$ and stratiform $\mathrm{Cu}$ and $\mathrm{Pb}$ - $\mathrm{Zn}$ deposits (fig. 2; tables 3, 4) occur in the northwestem part of the Russian Southeast. The belts are hosted in the Mamyn continental-margin are terrane (unit MM, fig. 2) (Nokleberg and others, 1994c, 1997c). The Fe deposits generally consist of lenses and beds of magnetite which is spatially associated with basalt and limestone. A large deposit occurs at Gar, coincidental with the Gar of volcanogenic Fe deposits is a metallogenic belt of $\mathrm{Cu}$ and $\mathrm{Pb}-\mathrm{Zn}$ stratiform sulfide deposits (Nokleberg and others 1997a, b, 1998). The belt also contains (table 4): (1) small massive Cu sulfide deposits, as at Kamenushinskoe, which occur in rtyolite which underlies a sequence of magnetitebearing basalt; and (2) a small stratiform $\mathrm{Pb}-\mathrm{Zn}$ vein deposit at Chagoyan.

\section{Gar Volcanogenic Fe Deposit}

The large Gar volcanogenic Fe deposit (Zimin, 1985; Zimin and Konopiev, 1989) consists of sheeted iron ore bodies which occur in metamorphosed, Early Cambrian(7) felsic and mafic volcanogenic rocks with limestone lenses part of the Gar terrane. The iron ore beds occur chiefly in the upper Early Cambrian(?) section composed mainly of mafic volcanic rocks. The ore occurs within a section 220 to $250 \mathrm{~m}$ thick, but most of the ore, about 75 percent, occurs within an interval ranging from 156 to $184 \mathrm{~m}$ thick. The ore horizon oecurs for $4 \mathrm{~km}$ along strike. The deposit has estimated reserves of 389.1 million tonnes grading $41.7 \%$ Fe. Total inferred reserves in the metallogenic belt are 4 billion tonnes (Zimin and Konoplev, 1989). The Gar deposit has not been mined. The deposit is intruded by early Paleozoic gabbro, diabase, and plagiogranite and is locally metamorphosed to skam. Magnetite is the dominant ore mineral. Similar volcanogenie iron deposits oceur nonth of the Gar deposit and need further exploration.

\section{Kamenushinskoe Cu Massive Sulfide Deposit}

The small Kamenushinskoe Cu massive sulfide deposit (P.N. Radchevsky, written commun, 1956, V.V. Ratkin, this study) consists of lenses, from 100 to $800 \mathrm{~m}$ long and 2 to $12 \mathrm{~m}$ thick, which occur conformable to bedding. Eleven ore bodies have been explored by drilling to a depth of $300 \mathrm{~m}$. Pyrite is the most common ore mineral; however, some ore bodies consist of hematite-magnetite-pyrite ore. Chalcopyrite locally comprises up to 1 to $2 \%$. The deposit is locally contact-metasomatized into skam by Paleozoic granite. The deposit is interpreted as of sedimentary-exhalative origin which was associated with felsic seafloor volcanism. The Kamenushinskoe deposit occurs in Cambrian rtyolite of the Mamyn terrane. The rhyolite underlies a basaltic and limestone sequence which contains the volcanogenic Gar deposit. 
The Chagoyan stratiform Pb-Zn deposit (1.G. Khelvas, written commun, 1963; V, V, Rakin, this study) consists of a galena-sphalerite ageregate which occurs as cement between grains in sandstone. Veinlets are also common. The deposit is about $270 \mathrm{~m}$ long and $1.0 \mathrm{~m}$ thick, and is hosted in quartz-feldspar sandstone which underlies Cambrian(?) limestone and dolomite. Galena and sphalerite are the dominant ore minerals, with subordinate pyrite, pynhotite, and chalcopyrite. Post-ore dikes and stocks of Early Cretaceous diorite and granodiorite cut the deposit. The Mesozoic igneous nocks and the contained stratiform ore bodies locally exhibit hydrothermal alteration to quartz, sericite, and tourmaline. The deposit occurs on the northern bank of the Zeya River and is small. Average grades are $1.42 \% \mathrm{~Pb}, 5.16 \% \mathrm{Zn}$, and up to $3,000 \mathrm{~g} / \mathrm{Ag}$. The deposit contains estimated reserves of 65 thousand tonnes zinc.

\section{Origin of and Tectonic Controls for Gar Metallogenic Belts}

The rocks hosting the two Gar metallogenic beits are interpreted as forming in a Late Proterozoic volcanic-tectonic basin in which marine basalt to thyolite volcanism occurred (V.V. Ratkin, this study). The volcanogenic Fe deposits of the Gar metallogenic belt consist of sheeted Fe layers, mainly magnetite, which are hosted in metamorphosed Early Cambrian(?) felsic and mafic volcanic rocks and limestone. The stratiform $\mathrm{Cu}$ and $\mathrm{Pb}-\mathrm{Zn}$ deposits of the Gar metallogenic belt are hosted in Cambrian rhyolite ( $\mathrm{Cu}$ deposits) and quartz-feldspar sandstone ( $\mathrm{Pb}-\mathrm{Zn}$ deposits) which underlies Cambrian(?) basalt and calcareous rocks. These stratified units comprise part of the Mamyn continental-margin are terrane (fig. 2). These stratigraphic units and stratiform deposits are (Nokleberg and others, 1994c, 1997c): (1) underlain by Archean(?) gneiss and schist, granite-gneiss, gabbro, and amphibolite which exhibit granulite facies metamorphism, and Proterozoic(?) and Early Cambrian sequence consists of greenschist, metasandstone, marble, quartzite, felsites, sandstone, and siltstone; and (2) are overlain by Silurian clastic rocks and Middle Devonian siltstone, sandstone, and limesione which are gently folded. The tectonic origins of the stratiform sulfide deposits are poorly understood and need further study.

\section{Metallogenic Belts Formed During Early Paleozoic Sea-Floor Spreading. \\ Regional Metamorphism, or During \\ Subduction-Related Volcanism in \\ Russian Far East Terranes}

\section{Galam Metallogenic Belt of Volcanogenic Fe, Volcanogenic Mn, and Sedimentary P Deposits (Belt GL) Central Part of Russian Far East}

The Galam metallogenic belt of volcanogenic Fe, volcanogenic Mn, and sedimentary P deposits (fig. 2; tables 3,4) occurs in the central part of the Russian Far East in the Galam accretionary wedge terrane (Shkolnik, 1973). The significant deposit is the Gerbikanskoe volcanogenic Fe deposit; other deposits are: the North-Shantarskoe, Nelkanskoe, Ir-Nimiiskoe-2, and Lagapskoe sedimentary P deposits; and the Ir-Nimiiskoe-1, Milkanskoe, Galamskoe, Gerbikanskoe, Kunumskoe, and Itmatinskoe volcanogenic Fe and Mn deposits (table 4) (Nokleberg and others 1997a, b, 1998). The Fe and Mn deposits occur in Cambrian beds and lenses with chert in seafloor basins and are interpreted as forming during seafloor hydrothermal activity which was associated with mafic volcanism.

The sedimentary $\mathbf{P}$ deposits are phosphorites which formed in limestone caps which formed in two stages on accreted seamounts, atolls, and guyots. The older stage consisted of siliceous deposition of phosphate coquina (inarticulate brachiopods, trilobites, etc) in the section of those atolls. Abrasion resulted in the formation of fragmentary trains, including phosphorite fragments. The younger stage consists of accumulations of phosphorite fragments. The deposits are interpreted as being subsequently deformed and metamorphosed during subsequent accretion of the Galam terrane.

\section{Gerbikanskoe Volcanogenic Fe Deposit}

The Gerbikanskoe volcanogenic Fe deposit (fig 10) (Shkolnik, 1973) consists of two zones separated by a sequence of sandstone and siltstone. The two zones contain approximately 30 steeply-dipping sheets and lenses of magnetite and hematite. Individual bodies are several tens of $m$ to 5 to $7 \mathrm{~km}$ long, and locally occur in a closely-spaced en-echelon pattem. Thickness varies from 5 to $50 \mathrm{~m}$ and is commonly 8 to $28 \mathrm{~m}$. Fe-rich zones vary from banded to thinly-banded, lenticular-banded, and bedded, and consists of finely-dispersed hematite, magnetite, and rare pyrite and chalcopyrite. The deposit is large with an average grade of $42-43 \% \mathrm{Fe}$ (soluble Fe $33-53 \%$ ), $1.8 \% \mathrm{Mn}$, and $9.6 \% \mathrm{P}$. 


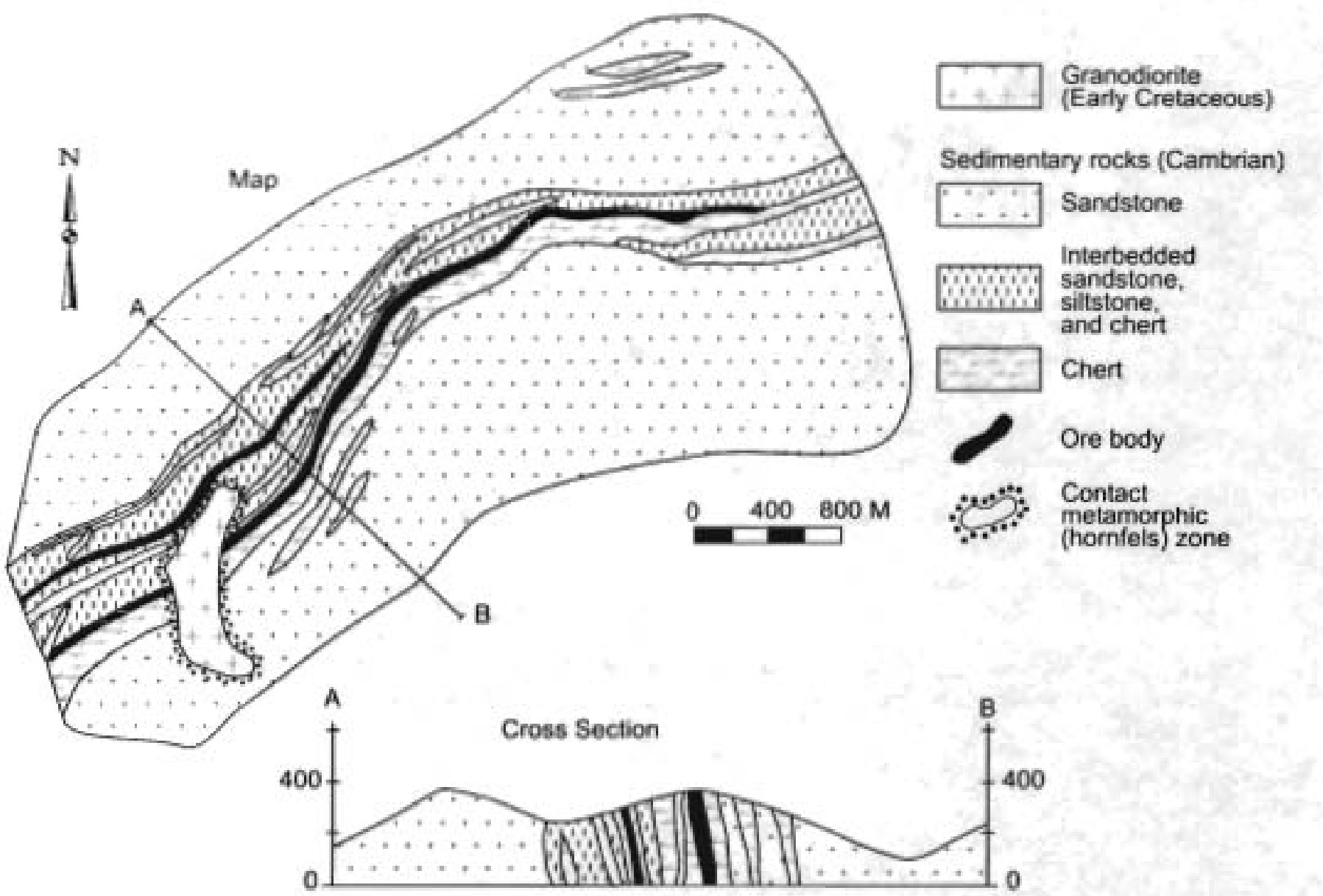

Figure 10. Gerbikanskoe volcanogenic Fe deposit, Galam metallogenic belt, Russian Southeast. Schematic geologic map and cross section. Adapted from Shkolnik (1973).

\section{Origin of and Tectonic Controls for Galam Metaliogenic Belt}

The volcanogenic Fe deposits in the Galam metallogenic belt consist of numerous lenticular and sheeted magnetite bodies which consist of conformable, stecply-dipping bodies of complex composition. Magnetile bodies occur in a layer up to $600 \mathrm{~m}$ thick which consists of aliernating, weakly metamorphosed Cambrian dark gray jasper, schist, shale, spilite, basalt, and basaltic tuff which is interiayered with rare sandstone, siltstone, sedimentary breccia, limestone, and dolomite. The volcanogenic Mn deposits consist of partly metamorphosed, stecply-dipping. lenticular and sheeted, bedded Mn bodies which occur in a diverse Lower Cambrian sequence of jasper, shale, schist, spilite, basalt, and basaltic tuff which overlays a carbonate reef complex with seamounts. The Fe and $\mathrm{Mn}$ deposits occur in long beds and lenses and are interpreted as forming during seafloor hydrothermal activity and associated with basaltic volcanism which was accompanied by chert deposition in seafloor depressions. The sedimentary P deposits are hosted in complex, stecply-dipping and folded sequence of jasper and volcanic rocks which represent a reef edifice. The deposits consist of carbonate beds which contain phosphorite-bearing breccia with Cambrian fossils. The sedimentary breccia is interpreted as forming in atoll fans and seamounts (Khanchuk, 1993).

The Galam terrane consists of a complexly-built accretionary prism with numerous regional-size olistoliths of early Paleozoic (Cambrian and Ordovician) marine basalt, chert, and clastic rocks (Khanchuk, 1993). The matrix consists of late Paleozoic turbidite and olistostrome. The early Paleozoic strata and overlying middle to late Paleozoic sedimentary rocks are interpreted as forming in a marine basin (Shkolnik, 1973; Khanchuk, 1993).

\section{Omulevka Rlver Metallogenic Beit of Austrian Alps W and Kipushi Cu-Pb-Zn Deposits (Belt OR) \\ Northwest Part of Russian Northeast}

The Omulevka River metallogenic belt of stratabound Austrian Alps W and Kipushi Cu-Pb-Zn deposits (fig. 2; tables 3, 4) occurs in the northwest part of the Russian Northeast (Shpikerman, 1998). The belt occurs between the Moma and Omulevka Rivers, and is hosted in the northeastem part of the Omulevka passive continental margin terrane of the Kolyma-Omolon superterrane (Nokleberg and others, 1994c, 1997c). The belt is greater than $300 \mathrm{~km}$ long and ranges up to $100 \mathrm{~km}$ wide. The 
significant deposits are the Omulev stratabound Austrian Alps W deposit, and the Vesnovka Kipushi Cu-Pb-Zn deposit (table 4) (Nokleberg and others 1997a, b, 1998)

\section{Omulev Austrian Alps W Deposit}

The Omulev Austrian Alps W deposit (fig. 11) (Shpikeman and others, 1986) consists of veiniets in Middle Ordovician black, carbonaceous, calcareous siltstone. The main ore mineral is scheelite with lecal pyrite, antimony realgar, orpiment, galena, and chalcopyrite. The ore minerals are restricted to a conformable, thin layer which is intricately foided along with adjacent sedimentary rocks, The ore minerals and sedimentary rocks exhibit greenschist-facies metamorphism. The deposit occurs in the core of a large, open, northwest-trending anticline, and covers an area of about $100 \mathrm{~km}^{2}$. The deposit is small and has an average grade of up to $1 \% \mathrm{WO}_{3}$.
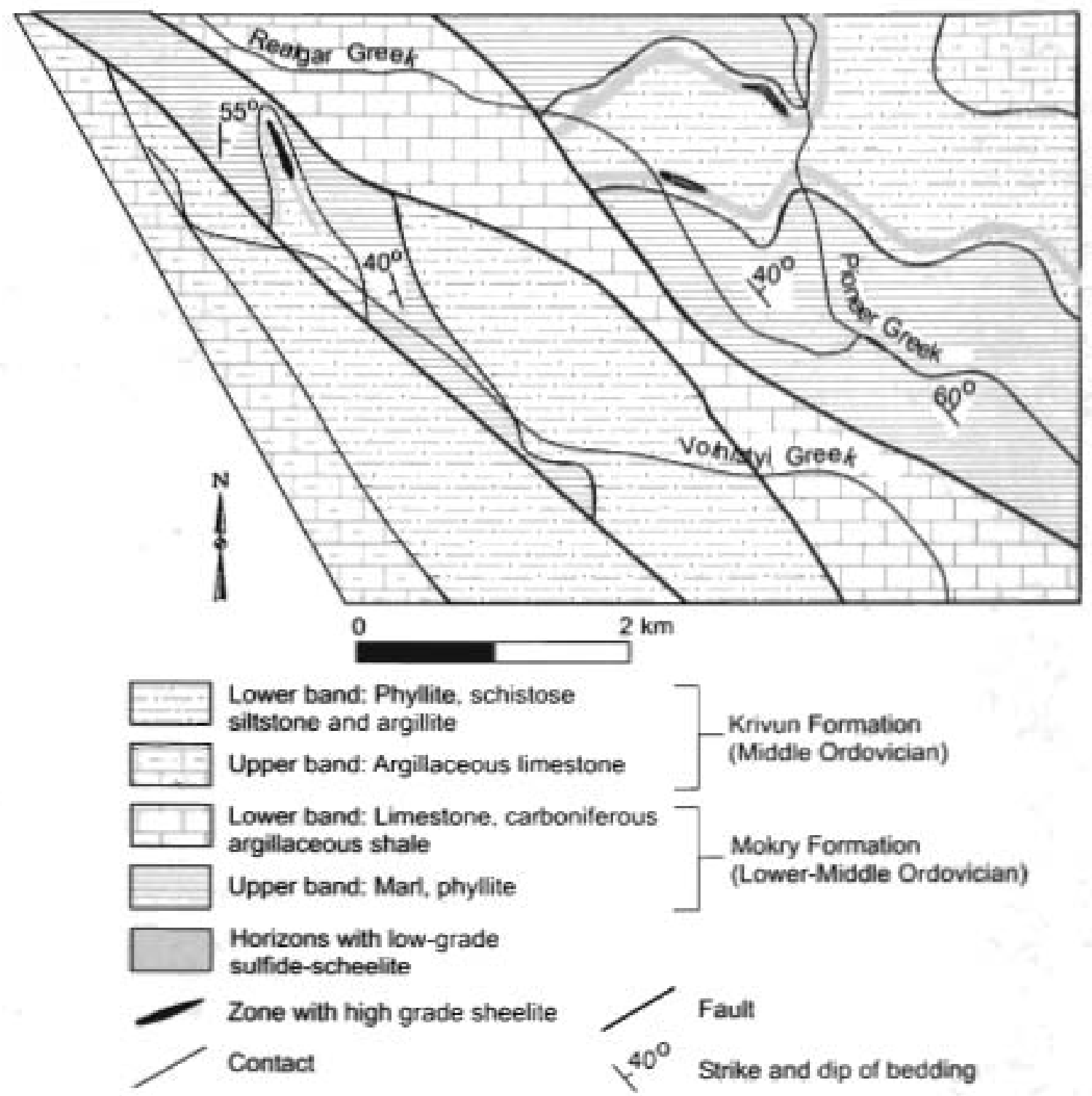

Figure 11. Omulev Austrian Alps W deposit, Omulevka River metallogenic bell, Russian Northeast. Schematic geologic map. Adapted fromShpikerman and others (1986).

\section{Vesnovka Kipushi Cu.Pb-Zn Deposit}

The Vesnovka Kipushi Cu-Pb-Zn deposit (Shpikerman, 1998) consists of veinlets and disseminated sulfides in Middle Ordovician limestone, shale, and siltstone. The ore bodies trend east-west and form metasomatic replacements conformable to bedding. The chief ore minerals are sphalerite, galena, chalcopyrite, and renierite(?). The calcareous siltstone which hosts the ore bodies is silicified and cut by calcite veins. Local tuff beds in these formations suggest which a volcanic island are occurred along the margin of an Early and Middle Ordovician continental-margin sedimentary basin (Bulgakova, 1986). 
The Omulevka River metallogenic belt of stratabound Austrian Alps W and Kipushi $\mathrm{Cu}-\mathrm{Pb}-\mathrm{Zn}$ deposits consists mainly of vein deposits which are hosted in the Omulevka passive continental margin terrane (Shpikerman, 1998).

The stratabound Austrian Alps W mineralization deposits are hosted in the lower part of the Middle Ordovician (Llanvimian) Krivun Formation which ranges froen 600 to $700 \mathrm{~m}$ thick and consists of flysch composed of thythmicallyioterbedded black clay-carbonaceous limestone, calcareous siltstone and phyllite. The ore-bearing rock horizon ranges from 10 to $15 \mathrm{~m}$ thick and is composed of black calcareous siltstone with clastic, round grains of calcite ( $65-70 \%)$, quartz ( $20-30 \%)$, and graphite (3-5\%). Metamorphism has produced a fine-grained granoblastic and lepidogranoblasic texture. Former interstitial clay is metamorphosed to a fine-grained epidote aggregate.

The Vesnovka and related Kipushi $\mathrm{Cu}-\mathrm{Pb}-\mathrm{Zn}$ deposits are hosted in the Middle Ordovician Minutka Formation which is about $325 \mathrm{~m}$ thick and consists of thythmically interlayered black clay limestone and shale wit beds of siltstone and calcareous sandstone. The sulfide deposits are beds of sandstone and calcareous siltstone. The deposits and host rocks are interpreted as having been regionally metamorphosed in the Late Silurian for several reasons. (1) The Ordovician und Silurian sedimentary rocks of Rassokha terrane and the northern part of the Omulevka terrane are unconformably overlapped by Lower Devonian conglomerates, and pebbles of the metamorphic rocks occur in these conglomerates. And (2) a model Pb age of 410 to $432 \mathrm{Ma}$ is obtained for the galena from the sulfide ores of the Omulevka Austrian Alps W deposit (Shpikerman, 1998).

Because the stratabound Austrian Alps W and Kipushi $\mathrm{Cu}-\mathrm{Pb}-\mathrm{Zn}$ deposits occur as veins and replacements, the Omulevka River metallogenic belt is interpreted as forming during regional metamorphism. The regional metamorphism is interpreted as occurring during accretion of the small Rassokha oceanic crust terrane to the North Asian Craton Margin (NSV) in the Late Silurian (Shpikerman, 1998). The host Omulevka continental margin terrane is interpreted as a rifled fragment of the North Asian Craton Margin (Nokleberg and others, 1994c, 1997c). Rifting is interpreted as occurring in the Late Devonian and Early Carboniferous.

\section{Rassokha Metallogenic Belt of Basaltic Cu and Sediment-Hosted Cu Deposits (Belt RA) Northern Part of Russian Northeast}

The Rassokha metallogenic belt of basaltic $\mathrm{Cu}$ and sediment-hosted Cu deposits (fig. 2; tables 3,4) oceurs in the northern part of the Russian Northeast (Shpikerman, 1998). The belt is $80 \mathrm{~km}$ long and $20 \mathrm{~km}$ wide and is bosted in the Rassokha passive continental-margin terrabe of the Kolyma-Omolon superierrane (Nokleberg and others, 1994c, 1997c). The metallogenic belt also contains sparse $\mathrm{Pb}-\mathrm{Zn}$ vein deposits which oceur in the Middle and Late Ordovician Bulkut Formation. This volcanic-rockdominated unit consists of potassic trachybasalt, trachyandesite, basalt, and trachyle flows, interbedded tuff, siliceous shale, red sandstone, conglomeraies and gray limestone, and hypabyssal shoshonite bodies. The $\mathrm{Pb}-\mathrm{Zn}$ vein deposits are interpreied as forming during a period of post-volcanic, hydrothermal activity. The Bulkut Formation is interpreted as part of a distal(?) oceanic island arc volcanic assemblage. The significant deposit is the basaltic $\mathrm{Cu}$ and sediment-hosted Cu Agyndja deposit (table 4) (Nokleberg and others 1997a, b, 1998).

\section{Agyndja Basaltic Cu and Sediment-Hosted Cu Deposit}

The basaltic $\mathrm{Cu}$ and sediment-hosted Cu Agyndja deposit (Shpikerman and others, 1988) consists of disseminated and vein-like ore bodies, and sparse breccia ores which are hosted in amygdaloidal trachybasalt and sandstone of Middle to Late Ordovician age. The ore minerals are bornite, chalcocite, chalcopyrite, covellite, and local native copper. The lower part of the stratified deposit is commonly composed of mineralized trachybasalt which overlain by Cu-bearing sandatone. The Cu minerals in trachybasalt occur in amygdules and synvolcanic fissures in the upper portion of lava flows. The Cu minerals also occur both as cement and as clasts in sandstone. The deposit occurs over an area of about $100 \mathrm{~km}^{2}$. Individual ore horizons are 1 to $30 \mathrm{~m}$ thick and trend northwest. The Cu sulfide deposits occur in submarine lava flows, subvolcanic porphyry intrusions, and shallow-water sandstones. The Agyndja deposit is large with an average grade of about $1 \% \mathrm{Cu}$.

\section{Origin of and Tectonic Controls for Rassokha Metallogenic Belt}

The Rassokha passive continental-margin terrane, which host the Rassokha metallogenic belt, consist of two structural complexes (Shpikennan, 1998). A lower complex consists mainly of Ondovician marine sedimentary and volcanic rock is about $5.000 \mathrm{~m}$ thick. The major lithologies are Cambrian sandstone and conglomenate with round clasts of serpentinite, trachybasalt, tuff, volcaniclastic sandatone, minor trachyle. The basaltic $\mathrm{Cu}$ and sediment-hosted $\mathrm{Cu}$ deposits of the Rassokha metallogenic belt are hosted in the Middle and Late Ordovician Agyndja Formation which contains sedimentary and volcanic rocks and ranges from 800 to $1000 \mathrm{~m}$ thick. The major lithologies in the formation are interbedded lava flows ( $10-30 \mathrm{~m}$ thick), mainly red porphyry trachybasalt, rare trachyrc, trachyandesite, tuff, volcaniclastic sandstone, and conglomerate. Local limestone and dolomite with marine fauna occur ( Shpikerman, 1998). The lower complex is intruded by sills of K-rich basalt, monzonite, and syenite porphyry 
which are interpreted as comagmatic with the flows. The igneous rocks are interpreted as forming during rifting of an island are complex located close to a continent. The unconformably overlying upper complex consists of marine and abyssal sedimentary rock, including coarse clastic rock, carbonate, volcaniclastic rock, and black sbale. Based on Devonian graptolites, the age of the upper complex ranges from Devonian to Triassic. The upper complex is interpreted as having been deposited along the middle Paleozoic passive continental margin in the Verkhoyansk fold belt (North Asian Craton Margin). The basaltic Cu and sedimenthosted $\mathrm{Cu}$ deposits of the Rassokha metallogenic belt are interpreted as forming during Ordovician rifting of an island are (Shpikerman, 1998).

\title{
Metallogenic Belts Formed During Early Paleozoic Rifting of Continental Margins or in Continental-Margin Arc Terranes
}

\author{
Dzhardzhan River Metallogenic Belt of \\ Southeast Missouri Pb-Zn, Sediment-Hosted $\mathrm{Cu}$ \\ and Sandstone-Hosted $U$ deposits (Belt DZ) \\ Northern Part of Eastern Siberia
}

The Dzhardzhan River metallogenic belt of Southeast Missouri Pb-Zn, sediment-hosted Cu, and sediment-hosted U deposits (fig. 2; tables 3,4) occurs in two areas in the northern part of eastern Siberia in the portheastern North Asian Craton Margin (Verkhoyansk fold belt, unit NSV; Nokleberg and others, 1994c; Shpikerman, 1998). The two parts of the belt trend for more than $400 \mathrm{~km}$ from the Dzardzhan River in the south to the Laptev Sea in the north. The Dehardzhan River metallogenie belt contains sparse stratabound deposits in Vendian, Early Cambrian, Late Devonian, and Early Carboniferous sedimentary rocks. The major Southeast Missouri $\mathrm{Pb}-\mathrm{Zn}$ deposits are at Manganiler and Aga-Kukan, and the major sediment-hosted U deposit is at Kyongdyoi (table 4) (Nokleberg and others 1997a, b, 1998).

\section{Manganiler Southeast Missouri Pb-Zn and Deposit}

The Manganiler Southeast Missouri Pb- $\mathrm{Zn}$ and similar deposits generally consist of layers of concordant, lenticular galena-sphalerite ore bodies which occur in Early Cambrian dolomite (Shpikerman, 1998). The ore bodies vary from 0.4 to $3.6 \mathrm{~m}$ thick and are up to $135 \mathrm{~m}$ long. Disseminated sulfides are locally replaced by massive, predominuntly sphalerile in the lower portion of the deposit. The sulfides are banded locally. The major ore minerals are sphulerite and lesser galena. Subordinate ore minerals are pyrite, marcasite, and smithsonite. The occurrences also exist to the south, as at the Agu-Kukan deposit, is a Southeast Missouri Pb-Zn occurrence, and is bosted in Early Carboniferous limestone. Nearby Late Devonian sandstone and shale contain sediment-bosted Cu occurrences.

\section{Kyongdyoi Sandstone-Hosted U Deposit}

The Kyongdyoi sandstone-hosted U deposit consists of uraninite crust which occurs in Late Proterozoic (Vendian) and Early Cambrian sandstone and limestone (unit NSV, Verkhoyansk fold belt, Yu.M. Arsky and others, written commun, 1963). Uranium occurs in disseminated sulfides such as pyrite and sphalerite, and in bitumen (kerite) inclusions. The deposit occurs in various stratigraphic levels of anticlinal domes and in lens-shaped bodies which range from 0.3 to $2.3 \mathrm{~m}$ thick and from 100 to 400 $\mathrm{m}$ long. The uranium-bearing zone ranges up to $50 \mathrm{~km}$ long.

\section{Origin of and Tectonic Controls for Dzhardzhan River Metailogenic Belt}

The southeast Missouri Pb-Zn deposits of the Dzhartzhan River metallogenic belt occur two stratigraphic horizons, in the lower part of a Cambrian sedimentary rock sequence, and in the Early Carboniferous Aga-Kukan suite. The Lower Cambrian sedimentary rocks, about $110 \mathrm{~m}$ thick, consist of bituminous and clay limestone and sandstone, conglomerate, basalt flows, tuff (Natapov and Shuligina, 1991). The Early Carboniferous Aga-Kukan suite is about $150 \mathrm{~m}$ thick and consists of limestone and sandstone (Melnikov and lzrailev, 1975). The sediment-hosted Cu deposits are hosted in the Late Devonian and Early Carboniferous Artygan suite which is about $800 \mathrm{~m}$ thick and is stratigraphically beneath the Aga-Kukan suite. The suite is composed of red limestone, siltstone, and sandstone (Melnikov and lerailev, 1975). The sandstone-hosted U deposits are hosted in Vendian sandstone which contain local bitumen (kerite).

The Southeast Missouri Pb- $\mathrm{Zn}$ and sediment-hosted U deposits in the Dahardzhan River metallogenic belt are herein interperted as forming during prolonged action of subsurface water in carbonate and sandstone along the passive margin of the North Asian Cratoe Margin (Verkhoyansk fold beli, unit NSV; Shpikerman, 1998). The sediment-hosted Cu deposits are interpreted as forming during migration of $\mathrm{Cu}$ from the craton to a shallow sea during both Riphean and Late Devonian rifting of the North Asian Craton Margin. This unit is chiefly a thick wedge of continental margin deposits which range up to $20 \mathrm{~km}$ thick (Nokleberg and others. $1994 \mathrm{c}, 1997 \mathrm{c}$ ). The sedimentary rocks of the Verkhoyansk fold belt are apparently tectonically detached 
from crystaline basement of craton. The fold belt is separated from the Siberian platform by the Late Cretaceous, weat-verging Lena thrust belt (fig. 2).

Anvil Metallogenic Belt of SEDEX (SEDEX) Zn-Pb-Ag Deposits.

Yukon Territory, Canada (Belt AN)

The Anvil metallogenic belt of sedimentary exhalative (SEDEX) Zn-Pb-Ag deposits (fig. 3; tables 3,4) occun in the Anvil district in the westem Selwyn Basin, Yukon Territory, Canada. The deposits are hosted in the passive continental margin rocks of the Nonth American Craton which represent the transition from shelf to off-shelf facies. The SEDEX deposits oceur in calcareous and non-calcareous phyllites which are correlated (Jennings and Jilson, 1986) with Early Cambrian to Silurian strata in the Howards Pass region (Gordey and Anderson, 1993) which contain Early Silurian SEDEX deposits (Howards Pass metallogenic belt described below). The major deposits are in the Anvil district are the Faro, Vangorda Creek, Grum, Firth, DY, and Swim (table 4) (Nokleberg and others 1997a, b, 1998).

\section{Anvill District SEDEX Zn-Pb-Ag Deposits}

The Anvil district contains six pyrite-bearing, stratiform $\mathrm{Zn}-\mathrm{Pb}-\mathrm{Ag}$ ( $\mathrm{Au}-\mathrm{Cu}-\mathrm{Ba}$ ) deposits and two stratiform pyritic $\mathrm{Cu}-\mathrm{Zn}$ occurrences which extend southeastward along strike for $45 \mathrm{~km}$. The deposits and occurrenees are hosted in distinctive, Early Cambrian graphitic phyllite which forms a district-wide metallotect. Ore from the three principal deposits (Faro, Vangorda, and Grum) consists of massive pyrite, pyrrhotite, sphalerite, galena and marcasite with patchy barite in a siliceous gangue. Higher ore grades are associated with barite. Pyrite-bearing massive sulfides are overlain by barite-bearing massive sulfides, and are underlain by pyrite-bearint quartzite which grades laterally into ribbon-banded graphitic quartzite und graphitic phyllite. The Faro deposit (fig. 12) occurs approximately 100 metres stratigraphically below the contact between phyllite and quartzite of the Early Cambrian Mount Mye Formation and calcareous rocks of the Cambrian and Ordovician Vangorda Formation. At the northern end, the deposit is intruded and contact metamorphosed by the Cretaceous Anvil batholith and related dikes. For the district, the combined, pre-mining reserves were 120 million tonnes grading $5.6 \% \mathrm{Zn}, 3.7 \% \mathrm{~Pb}$, and $45-50 \mathrm{~g} / \mathrm{Ag}$ (Jennings and Jilson, 1986). Faro, the largest depesit, ceased production in 1997. The Vangorda deposit, a smaller mine, containing 7.1 million tonnes of ore, was largely exhausted between 1990 and 1993 (Brown and MeClay, 1993), and the Grum mine produced 16.9 million tonnes of ore from 1993 to 1996.

\section{Origin of and Tectonic Controls for Anvil Metallogenic Beft}

The Anvil metallogenic belt is hosted by sedimentary rocks of western Selwyn basin which are part of the Cambrian through Devonian passive margin of the North American Cralon (Nokleberg and others, 1994c, 1997c; Monger and Nokleberg. 1996). The host sedimentary stratu represent a transition from shelf to slope facies. The coincidence of southwestward thickening in the graphitic phyllite with a linear array of alkaline basalt volcanism centers suggests which rift-related synsedimentary faults may have served as conduits for the SEDEX fluids. However, demonstrable feeder zones have not been observed. The elongale subbasins hosting the deposits are interpreted as forming during Middle Cambrian to Early Ordovician extension and faulting (Jennings and Jilson, 1986). The resulting structural conduits provided concentrated exhalative metalliferous brines in a reducing environment in which the deposits formed. Related extensional faulting and emplacement of Middle Ordovician alkalic basalt dikes, which occur along the eastern margin of Selwyn Basin and southward to Gataga Trough, may have served both as a tectonic control on the development of the sedimentary basins in the Anvil and Howards Pass areas, and a source of both heat and metalliferous brines.

The mineral assemblages, bost rock age, and geologic setting for the Anvil metallogenie belt are similar to those for the Howards Pass and Kootenay metallogenic belts of the Canadian Cordillera (described below). All three metallogenic belts are interpreied as forming from $\mathrm{Pb}$ - and $\mathrm{Zn}$-rich fluids resulting during rifting, volcanism, basinal subsidence, local marine transeressoon, and related hydrothermal activity along the passive continental margin of the North American Craton. Rifting is interpreted to have formed the Misty Creek Embayment in the Early to Middle Cambrian (Cecile, 1982), the Selwyn Basin in the Late Proterozoic to Ordovician (Gabrielse, 1963), and the Meilleur River Embayment in the Early to Middle Ordovician (Morrow, 1984), with the latter event marked by alkalic basaltic voleanism (Fritz and others, 1991), SEDEX oceurrences also formed during these events mainly in the Anvil and Howards Pass metallogenic belts, and to a minor extent in the Misty Creek and Meilleur River embayments.

\section{Howards Pass Metallogenic Beit of Sedimentary Exhalative Zn-Pb Deposits (Belt HP) Eastem Vukon Territory}

The Howards Pass metallogenic belt of sedimentary exhalative (SEDEX) Zn-Pb deposits (fig. 3; tables 3, 4) occurs in the easiem Yukon Territory. The belt is hosted in the Selwyn Basin which constitutes part of a Cambrian to Devonian passive margin 
of the North American Craton Margin. The major deposits are at Howards Pass and Anniv (table 4) (Nokleberg and others 1997a, b, 1998).

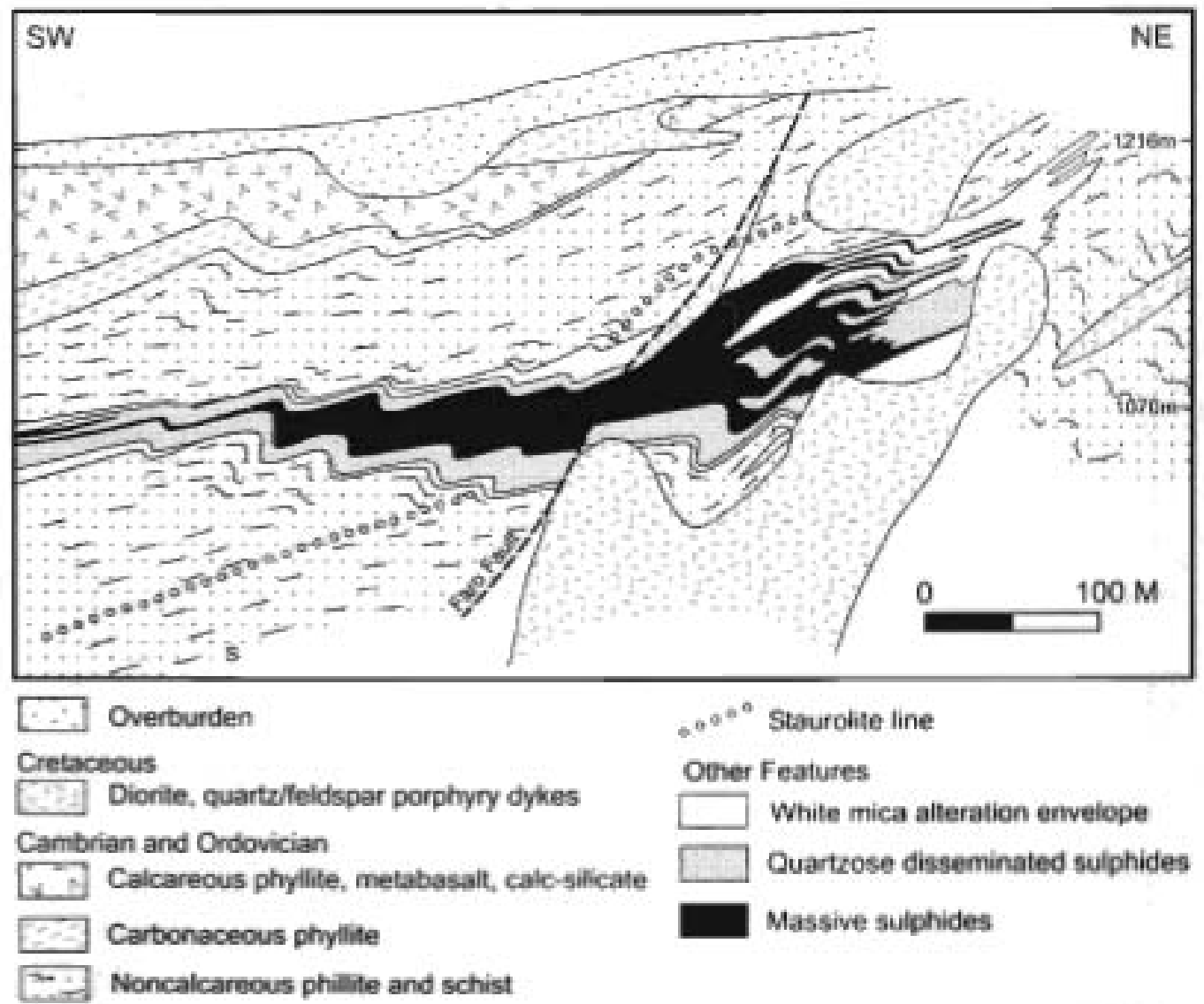

Figure 12. Faro sedimentary-exhalative Zn-Pb-Ag deposit, Anvil metallogenic beit, Canadian Cordillera. Schematic cross section. Adapted from Jennings and Jilson (1986).

\section{Howards Pass (XY) Zn-PB SEDEX Deposit}

The Howards Pass (XY) sedimentary exhalative (SEDEX) Zn- Pb deposit (fig. 13) consists of fine-grained, well-bedded sphalerite and galena with pyrite as stratiform and stratabound massive bodies, up to 50 meters thick and 3 to $4 \mathrm{~km}$ long, which are interlaminated with carbonaceous, cyclical, limy mudstone and chert of the rift-related Early Silurian "Active Zone" of the Ordovician to Devonian Road River Group (Yukon Minfile, 1984; Abbott and others, 1986a, b; Abbott and others, 1994; Maclntyre, 1991). The deposit is one of three related Zn-Pb SEDEX deposits which occur in an elongate, 20 km-wide sub-basin in the eastern Selwyn Basin. The deposits are interpreted as forming at the base of the continental slope, about $10 \mathrm{~km}$ to $20 \mathrm{~km}$ seaward of a carbonate platform margin. Total reserves and resources are estimated at about 500 million tonnes grading $5 \% \mathrm{Zn}$. and 2\% Pb (Placer Developenents Lid. Annual Report, June 1982).

\section{Annlv (OP) SEDEX Zn-Pb Deposit}

The Anniv (OP) SEDEX $\mathrm{Zn}$ - Pb deposit consists of sphalerite and galena which occur in saucer-shaped stratiform and stratabound bodies in Early Silurian cyclic, rift-related carbonaceous mudstone and chert of the Ordovician to Silurian Road River Group (Morganti, 1981; Yukon Minfile, 1984; EMR Canada, 1989; Macintyre, 1991). The host rocks interpreted as part of a Cambrian and Devonian passive margin of the North American Craton Margin. The deposit averages $13 \mathrm{~m}$ thick (maximum $45 \mathrm{~m}$ ) over a $1.5 \mathrm{~km}$ strike length. 


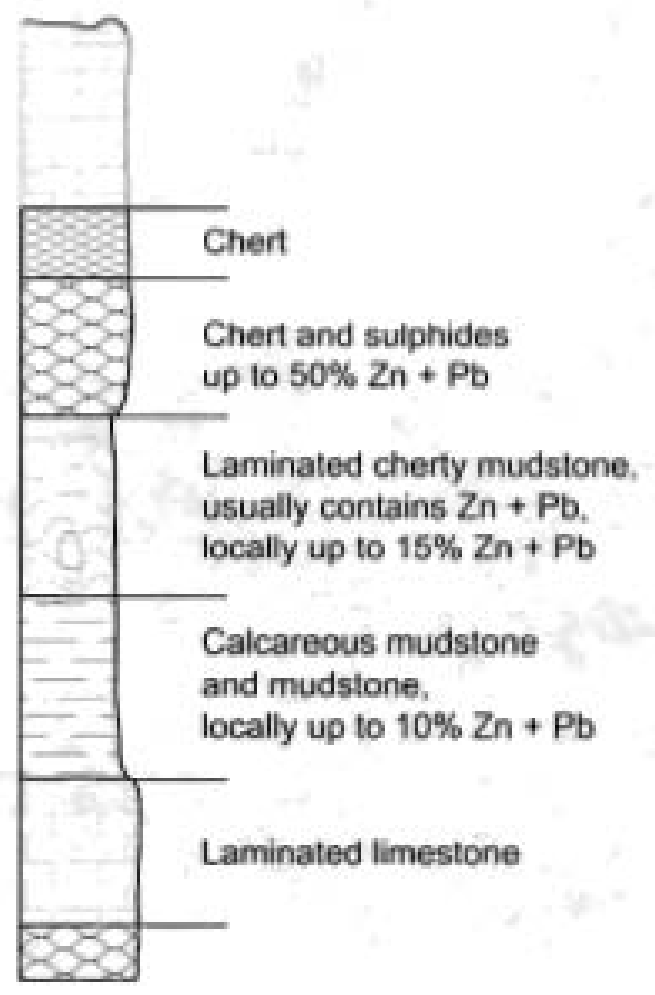

Figure 13. Howards Pass sedimentary exhalative Zn- Pb deposit, Howards Pass metallogenic belt, Canadian Cordillera. Schematic stratigraphic column illustrating major stratiform sulfide zones. Adapted from Morganti (1981).

\section{Origin of and Tectonic Setting for Howards Pass Metallogenic Beit}

The Zn-Pb SEDEX deposits of the Howands Pass metallogenic belt are hosted Selwyn Basin which contains a sequence of late Precambrian to Middle Devonian, turbiditic sandstone, deep water limestone, shale and chert. The basin is the offshore equivalent of the shallow-water carbonate and sandstone of Mackenzie Platform (Gordey and Anderson, 1993). A major SEDEX event was localized in eastern Selwyn Basin at Howards Pass where large stratiform bodies of Zn-Pb-Fe sulfides were deposited synchronously with Early Silurian (Norford and Orchard, 1983) carbonaceous and limy mudstone and chert. The Howards Pass metallogenic belt is interpreted as forming from $\mathrm{Pb}$ - and $\mathrm{Zn}$-rich fluids resulting during rifting, volcanism, basinal subsidence, local marine transgression, and related bydrothermal activity (Goodfellow and Jonasson, 1986; Dawson and others, 1991). The fluids were discharged episodically into a stable, starved marine basin during restricted seawater circulation and resultant formation of sulphidic, anoxic bottom waters. The mineral assemblages, host rock age, and geologic setting for the Howards Pass metallogenic belt are similar to those for the Anvil and Kootenay metallogenic belts of the northern and southem Canadian Cordillera (described above and below, respectively). All three belts are interpreted as forming from $\mathrm{Pb}$ - and $\mathrm{Zn}$-rich fluids resulting during rifting, voleanism, basinal subsidence, local marine transgression, and related hydrothermal activity along the passive continental margin of the North American Craton.

\section{Kootenay Metallogenie Belt of Carbonate of Sediment Hosted Deposits (Belt KO) Southern British Columbia}

The Kootenay metallogenic belt of carbonate or sediment-hosted (SEDEX) Zn-Pb deposits (fig. 3; tables 3, 4) occurs in southeastem British Columbia. The deposits are hosied in metamorphosed and intensely deformed siliceous clastic, carbonate, volcanic, and plutonic rocks of the Kootenay metamorpbosed continental margin terrane. This metarnorphosed continental margin terrane occurs between the North America Craton Margin and to the east, and the accreted island are Quesnellia terrane to the west (fig. 3). Some of the older sedimentary rock units, notably the middle Paleozoic Eagle Bay Assemblage in Kootenay and Shuswap regions of southeastem British Columbia, can probably be stratigraphically correlated with units in the North America Craton Margin (Monger and Nokleberg. 1996). The significant deposits in the metallogenic belt are the Mastadon, Jersey, Duncan Lake area. H. B. (Zincton), and Reeves-MacDonald (Reemac) deposits (table 4) (Nokleberg and others 1997a, b, 1998). 
Mastadon SEDEX Pb-Zn(?) Deposit

The Mastadon SEDEX Pb-Zn (?) deposit consists of pyrite, arsenopyrite, sphalerite, galenat and sulfosalts which occur in bands, lenses and stringers from 0.1 to 12 meters wide (Mining Review, 1992). The hanging wall part of deposit consists of disseminated sphalerite, galena and pyrite; footwall part of deposit consists of massive arsenopyrite, sphalerite and pyrite. Ore minerals are concentrated along the contact between phyllite and limestone. Au is refractory and associated with arsenopyrite. The deposit contains estimated production and reserves of 12.27 milhon tonnes grading $4.9 \% \mathrm{Zn}, 2.3 \% \mathrm{~Pb}$, and $62 \mathrm{~g} / 1 \mathrm{Au}$. The deposit is bosted in Early Cambrian Hamill Formation quartzite and Badshot Formation with limestone forming the footwall. The deposit origin is poorly understood.

\section{Jersey SEDEX Pb-Zn Deposit}

The Jeney deposit consists of fine grained sphalerite and galena with pyrite, pyrthotite and minor arsenopyrite in five ore bands ranging from 0.30 to 9 meters thick (Fyles and Hewlett, 1959; Sangster, 1986; Maclotyre, 1991). Sulfides oceur more abundantly in fold troughs relative to fold crests. Cd is associated with sphalerite, $\mathrm{Ag}$ with galena. The deposit has produced 7,7 million tonnes grading $3.49 \% \mathrm{Zn}, 1.65 \% \mathrm{~Pb}, 3.08 \mathrm{~g} / \mathrm{Ag}$. The deposit is hosted in the folded Reeves Member dolomite of the Early Cambrian Luib Formation, and may be a SEDEX Pb-Zn deposit.

\section{H.B. (Zincton) Pb-Zn SEDEX Deposit}

The H.B. (Zincton) Pb-Zn SEDEX deposit consists of pyrite and sphalerite which occur in narrow bands, irregular lenses or disseminations in dolomite of the Early Cambrian Reeves Fommation (Sangster, 1986; Macintyre, 1991; Hoy, 1982b; MINFIL.E. 2002), Local cross-zones contain fine-grained massive sulfides which commonly occur as matrix in a coarse breccia. The breccia zones are related to thrust faults and are interpreted as secondary structures. Much of the dolomite in the West orebody is altered to talc. The deposit has produced 6.7 million ionnes grading $3.91 \% \mathrm{Zn}, 0.74 \% \mathrm{~Pb}, 4.42 \mathrm{~g} / \mathrm{Ag}$.

\section{Origin of and Tectonic Setting for Kootenay Metallogenic Beit}

The Kootenay metallogenic belt of Zn-Pb SEDEX deposits is hosted in platformal, Early Cambrian earbonate rocks in the Kootenay metamorphosed continental margin terrane. The deposits commonly consist of bands and lenses of sphalerite, galena and pyrite both conformable and discondant to often isoclinally folded and regionally metamorphosed dolostone of the Badshot, Reeves and Luib formations. Along with their host rocks, these deposits were deformed prior to deposition of unconformably overlying strata of the Carboniferous Milford Assemblage (Monger and others, 1991). The age of the carbonate-hosed deposits is not known with certainty, and may be either SEDEX, of highly-deformed replacement deposits in Early Cambrian carbonate rock. The mineral assemblages, host rock age, and geologic setting for the Kootenay metallogenic belt are similar to those for the Anvil and Howards Pass metallogenic belts of the northem Canadian Cordillera as described above. All three belts are interpreted as forming from $\mathrm{Pb}$ - and $\mathrm{Zn}$-rich fluids resulting during rifting, volcanism, basinal subsidence, local marine transgression, and related hydrothermal activity along the passive continental margin of the North American Craton. Episodic rifting in the Cambrian through Ordovician is interpreted as opening several sedimentary basios in the Canadian Cordillera, such as the Selwyn Basin, with related formation of $\mathrm{Zn}$ - $\mathrm{Pb}$ SEDEX deposits which are similar to those in the Kootenay metallogenic belt.

\section{Prince of Wales island Metallogenic Beh of Continental-Margin Arc-Related Deposits (Belt PW) Southeastem Alaska}

The Prince of Wales lsland metallogenic belt occurs in Southeastern Alaska and consists mainly of a suite of porphyry Cu-Mo, polymetallic vein, and skam deposits (fig. 3; tables 3, 4) which occur mainly in alkalic Orodovian and Silurian plutons in the Alexander sequence of the Wrangellia superterrane. The deposits and metallogenic belt occur on central and southera Prince of Wales Island, and to a much lesser extent on Chichagof. Annette, and Gravina Islands in central-southeastern Alaska (Nokleberg and others, 1995a). These alkalic plutons range in age from Late Ordovician to Early Silurian. The plutons intrude the metamorphosed Devonian(7) St. Joseph Island Voleanics (Eberlein and others, 1983; D.A. Brew, oral commun., 1995), Early and Middle(7) Devonian Karheen Formation (Gełuels, 1992; D.A. Brew, oral commun, 1995), Middle to Late Ordovician to Early Silurian Descon Formation (Herreid and others, 1978; D.A. Brew, oral comrun., 1995), and metamorphosed Late Proteroeoic and Eurly Cambrian(7) Wales Group (Gehrels and Berg, 1992; D.A. Brew, otal commun., 1995). The plutons and metasedimentary rocks form the older part of the Alexander sequence in the region. The major granitic-magmatism-related deposits are represented by deposits in four areas: (1) several deposits in the McLean Arm porphyry Cu-Mo district; (2) the Klaka lnlet polymetallic skam and vein deposit; (3) the Kassan Peninsula Cu-Fe skam deposit; and (4) the major zoned mafic-ultramafic Cu-Au-PGE deposit at Salt Chuck (table 4) (Nokleberg and others 1997a, b, 1998). 
The Mclean Arm porphyry Cu-Mo district (fig. 14) contains a group of porphyry copper-molybdenum deposits which consist of precious metal stockworks and veins at Poison, Ickis, Veta, Apex, and Stone Rock Bay prospects in the central part of a nonthwest-irending belt of middle Paleozoic, multi-phase plutons composed of pyroxenite, syenite, quartz monzonite, and mixed intermediate-composition igneous rocks. The plutonic rocks intrude the clastic rocks of the Descon Formation on the extreme tip of southem Prince of Wales lsland. The central part of the complex which contains the deposits is mainly syenite. The altered and mineralized syenite at Stone Rock Bay has a a U-Pb zircon age of $436 \mathrm{Ma}$ (Gehrels, 1992). The sulfide deposits occur mainly in stockwork which occurs along joints and faults which strike $25^{\circ}$ or $295^{\circ}$ and dip steeply. The deposits and their host joints and faults appear to be related to a concentric alteration zone, of about $5 \mathrm{~km} 2$ area, with a carbonate-albite center, and an albite and sericite rim. The higher grade veins and stockwork range from 0.4 to $5.6 \% \mathrm{Cu}, 0.01$ to $0.08 \% \mathrm{Mo}$, and 2.1 to $11.0 \mathrm{~g} / \mathrm{Au}$. Anomalous Ag. Pt. Bi, Te, and base metals also oceur in the deposits (MacKevett, 1963; F.D. Forgeron and L.W. Leroy, written commun., 1971; T.K. Bundtzen, unpublished data, 1990; Nokleberg and others, 1995a). Soil sampling, trenching, and limited diamond drilling done in 1972 suggests a potential for 40 million tonnes of $\mathrm{Cu}$-Mo ore at the Apex zone.

\section{Polymetallic Voin, Skarn, and Disseminated Deposits in Paleozoic Plufons at Klakas Inlef and Kassan Peninsula}

A suite of polymetallic vein, skarn, and disseminated deposits, which form part of the Prince of Wales Island metallogenic belt, are associated with Silurian or older alaskite and granodiorite in Klakas Inlet. The granodiorite, with a minimum K-Ar isotopic age of $428 \mathrm{Ma}$ (Tumer and others, 1977), contains sericite-altered veinlets of chalcopyrite, molybdenite, and galena in a $100 \mathrm{~m}^{2}$ area. The deposit contains up to $0.23 \% \mathrm{Cu}, 0.06 \%$ molybdenum, $0.05 \% \mathrm{Co}, 0.05 \% \mathrm{Sn}$, and $0.01 \%$ W, The high Sn and $\mathrm{W}$ values occur adjacent to the main $\mathrm{Cu}$ and Mo deposits (Herreid and others, 1978).

A suite of polymetallic Cu vein, Cu-Fe (magnetite) skarn, and disseminated deposits also occurs in or near altered Late Ordovician to Early Silurian, intermediate-composition plutons on Kasaan Peninsula. About 607,690 tonnes of Fe and $\mathrm{Cu}$ ore were mined in this area prior to World War II (Wamer and Goddard, 1961). Most of the deposits consist of irregular bodies of magnetite, chalcopyrite, and pyrite, and contain lesser amounts of sphalerite and galena. The deposits contain minor $\mathrm{Au}$ and $\mathrm{Ag}$. and generally occur in skarn associated with alkali gabbro, diorite, and granodiorite. The plutonic rocks exhibit U-Pb zircon isoiopic ages ranging from the Late Ordovician to the Early Silurian (Gehrels and Berg, 1992). The largest skam deposit in the area occurs at the Mount Andrew-Mamie mine, the biggest Cu producer in the district (Bundtzen, 1978). The deposits in this area are associated with peripheral polymetallic veins and stockworks which contain chalcopyrite and pyrite, and Au values. Concentric magnetic anomalies in the area are interpreted by Warner and Goddard (1961) as reflecting as a buried porphyry Cu deposit.

\section{Salt Chuck Zoned Mafic-Uitramafic Cu-Au-PGE Deposit}

The Salt Chuck zoned mafic-ultramafic Cu-Au-PGE deposit (fig. 15) consists of irregularly and randomly distributed veiniets of bornite and associated minor chalcopyrite, chalcocile, covellite, native copper, and magmatic magnetite (Donald Grybeck and David A. Brew, written commun., 1985; Loney and others, 1987; Loney and Himmelberg, 1992; Foley and others, 1997). The deposit produced about 300,000 ionnes grading $0.95 \% \mathrm{Cu}, 1.2 \mathrm{~g} / \mathrm{Au}, 5.8 \mathrm{~g} / \mathrm{Ag}, 2.2 \mathrm{~g} / \mathrm{PGE}$ (mainly Pd and Pu), and produced $610,400 \mathrm{~g}$ PGE from 1907 to 1941 . The sulfides and oxides occur as disseminations and along cracks and fractures in pipe-like late Paleozoic or Mesozoic gabbro-clinopyroxenile stock intruding Silurian metagraywacke. Clinopyroxenite and gabbro grade integularly into one another. Bomile, the principal sulfide; occurs mainly as interstitial grains in clinopyroxenite in amounts up to Is percent. Extensive, late magmatic or hydrothermal epidote veins occur in gabbro and clinopyroxenite. Low- $\mathrm{K}$, altered biotite from clinopytoxenite has a K-Ar isotopic age of $429 \mathrm{Ma}$. The deposit is interpreted to be magmatic, however, considerable hydrothermal remobilization of sulfides has occurred. 


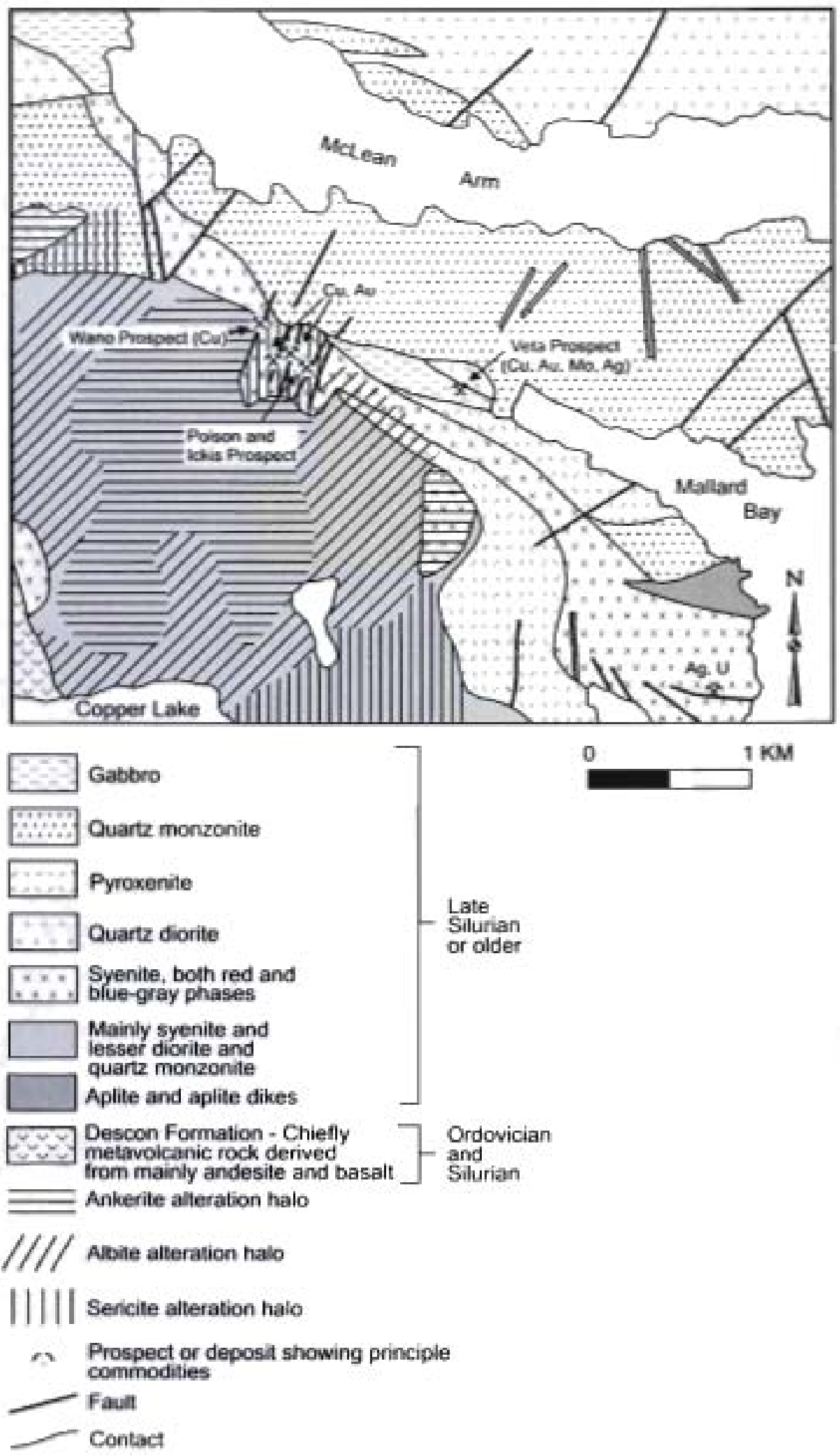

Figure 14, Mctean Arm porphyry Cu-Mo district, Prince of Wales Isiand metallogenic belt, Southeastem Alaska. Adapted from Mackevett (1963), Gehrels (1992), T.K. Bundtzen, F. . Forgeran, and L.W. LeRoy (written comm., 1993), and Nokleberg and others (1995). 


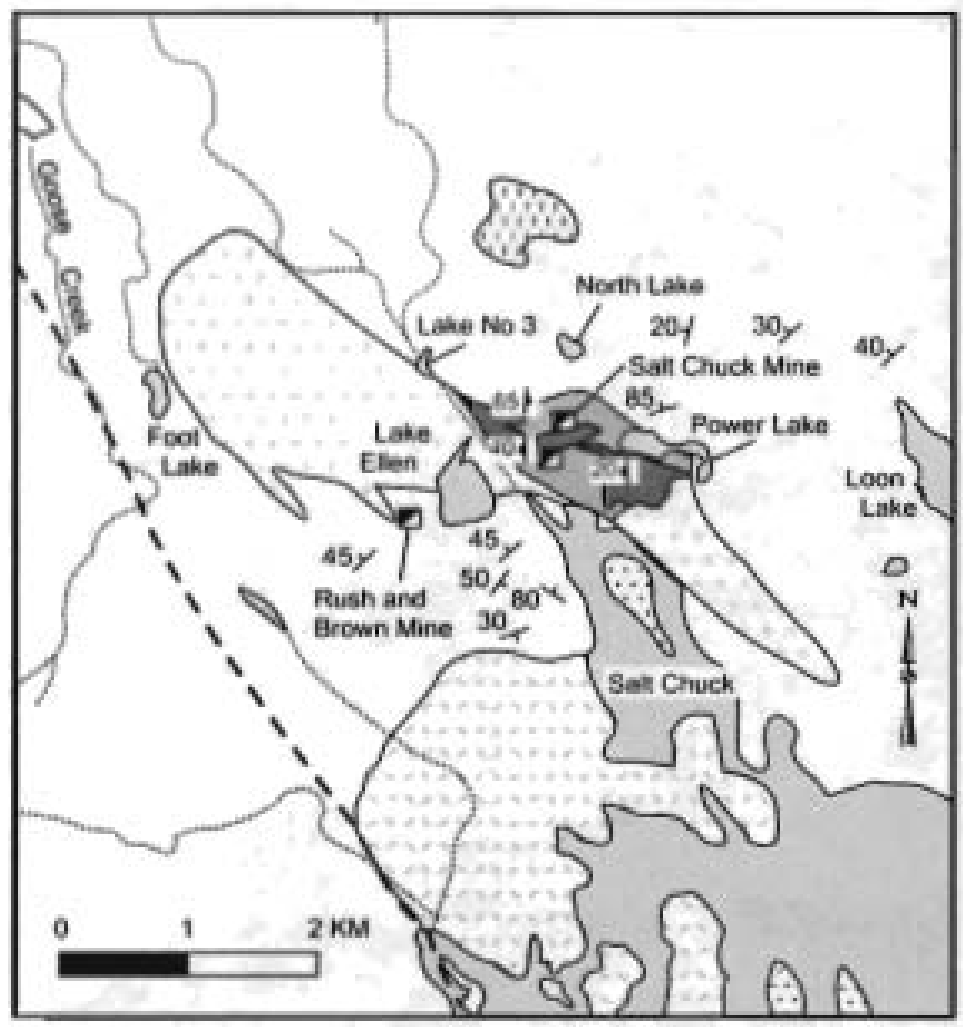

Lakes, tide-water, and tidal zones (Holocene)

$\ldots \ldots$ Surficial deposits (Holocene). Chiefly alluvium,

2..... tidal mudflat, and glaciofluvial deposits

W.6. Quartz diorite porphyry (Cretaceous?). Contains large plagioclase phenocrysts

Metaigneous complex (Early Devonian to Early

Ordovican). Chiefly hornblende and (or) quartz

chloritic magmatite, leucogabbro, trondhjemite, and

minor pyroxenite. Cut by mafic and felsic dike swarms

Salt Chuck intrusion (Early Devonian? to Earty Ordovician).

Chiefly sulfide-bearing clinopyroxenite and gabbro.

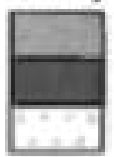

Gabbro

Clinopyroxenite

Undivided gabbro and clinopyroxenile

$\square$ Descon Formation (Lower Silurian and Ordovician).

***..... Stream

Contact, approximately located

...... Fault approximately located

$40 \mathrm{y}$ Strike and dip of cumulate layering

45. Strike and dip of bedding

D. Mine shan

Figure 15. Sait Chuck zoned mafio-utramafic Cu-Au-PGE deposit, Prince of Wales island metallogenic belt, Southeastern Alaska. Schematic geologic map. Adapted trom Loney and Himmelberg (1992). 
The continental-margin arc-related deposits deposits of the Prince of Wales Island metallogenic belt are mainly bosted in Orodovician and Silurian granitoid rocks which intrude early Paleozoic stratified rocks of the Alexunder sequence of the Wrangellia superterrane (Nokleberg and others. 1995a). The stratified rocks consist of felsic to mafic volcanic and associated marine sedimentary rocks. The known porphyry $\mathrm{Cu}$ and associated deposits occur in plutons which range from 472 to $432 \mathrm{Ma}$ in age (Turner and others; 1977; Herreid and others, 1978; Eberlein and others, 1983: Gehrels, 1992; Gehrels and Berg. 1992). The zoned mafic-ultramafic Salt Chuck deposit, one of a series of mafic-ultramafic bodies intruding the Descon Formation (Loney and Himumelberg, 1992), has a K-As isotopic age of $429 \mathrm{Ma}$ (Loney und others. 1987). This suite of deposits and host rocks are interpreted as forming during Ordovician and Silurian, subduction-related, island-are magmatism in the Alexander sequence of the Wrangellia superterrane (Gehrels and Berg. 1994; Nokleberg and others, 1994c, 1995a, 1997c, Goldfurb, 1997). The granitoid plutons and associated plutons are herein interpreted as forming at intermediate levels of the are, whereas the Salt Chuck zonedmafic-ultramafic deposit is herein interpreted as forming from magmas which intruded into the deeper levels of the arc.

\section{Middle and Late Devonian Metallogenic Belts (387 to $360 \mathrm{Ma}$; Figures 16,17 )}

\section{Overview}

The major Middle and Late Devonian metallogenic belts in the Russian Far East, Alaska, and the Canadian Cordillera are summarized in table 3 and portrayed on figures 16 and 17. The major belts are as follows. (1) In the Russian Southeast, the Yaroslavka (YA) belt, whicb contains F and $\mathrm{Sn}$ greisen deposits, is hosted in the Khanka continental-margin are terrane. The beli is interpreted as forming during anatectic granitic plutonism which occurred during terrane accretion. (2) In the Russian Northeast. Northern Alaska, and the Canadian Cordillera, the Arctic (AT), Brooks Range (BR), Dawson (DA) Frances Lake (FR), Kedon (KE), Kootenay-Shuswap (KS), and Tracy (TR) belts contain deposits associaled with felsic to mafic marine volcanism or with granitic magmatism. These belts are hosted in the North Asjan or North American Cratons or Craton Margins, or in cratonal or continental-margin (arc) terranes which were derived from those craton margins. These belts are interpreted to be associated with formation of a short-lived continental-margin arc (Kedon arc in the Russian Northeast) along the margin of the North Asian Craton and Craton Margin and the North American Craton Margin. And (3) in Southern Alaska and the Canadian Cordillera, the Mount Sicker belt, which contains kuroko massive sulfide deposits, is bosted in the Wrangellia island-are superterrane. This belt is interpreted as forming during subduction-related volcanism in the short-lived Sicker island arc.

In the Russian Northeast, Alaska, and Canadian Cordillera, the Berezovka River (BE), Cathedral (CA), Dempsier (DE). Finlayson Lake (FL); Gataga (GA), Ingenika (IN), Liard (LI), Northem Cordillera (NCO), Macmillan Pass (MP), older part of Mystic (MY), Robb Lake (RL), Selennyakh River (SEL), Sette-Daban (SD), Southern Rocky Mountain (SRM). Tommot River (TO), Urultun and Sudar Rivers (URS), and Yarkhodon (YR) belts, which contsin massive sulfide, bedded barile, carbonatiterelated $\mathrm{Nb}, \mathrm{Ta}$, and REE, and related deposits, are hosted either in the North Asian or North American Craton Margins, or in passive continental margin terranes derived from those craton margins. These belts are interpreted as forming during late Late Devonian and (or) Early Mississippian rifting of either the North Asian or the North American Craton Margins (table 3), or during generation of low-temperature brines from adajacent shale basins. In the below descriptions of metallogenic belts, a few of the noteable or significant lode deposits (table 4) are described for each belt.

\section{Metallogenic-Tectonic Model for Middle through Late Devonian (387 to 360 Ma; Figure 18)}

During the Middle to Late Devonian ( 387 to $360 \mathrm{Ma}$ ), the major metallogenic-tectonic events were (fig 18; table 3); (1) formation of a discontinuous continental-margin are (Kedon arc in Russian Northeast) and contained metallogenic belts, and associated subduction zone along the North Asian and North American Craton Margins; (2) in the late Late Devonian, inception of rifling of the North Asian and North American Cratons and Craton Margins, resulting in formation of new terranes and associated metallogenic belts (table 3); and (3) formation of the Sicker are and contained metallogenic belts, and associated subduction zone in the Wrangellia superterrane. Sedimentation continued along the North Asian and North American Craton Margins. Out of the field of view of figure 18 was formation of the Yaroslavka (YA) belt which contains $F$ and Sn greisen deposits. The belt is hosted in the Voznesenka terrane in the Khanka continental-margin arc superterrane and is interpreted as forming during anatectic granitic plutonism which occurred during accretion of the Voznesenka terrane with other parts of the Khanka superierrane in the early Paleocoic. 


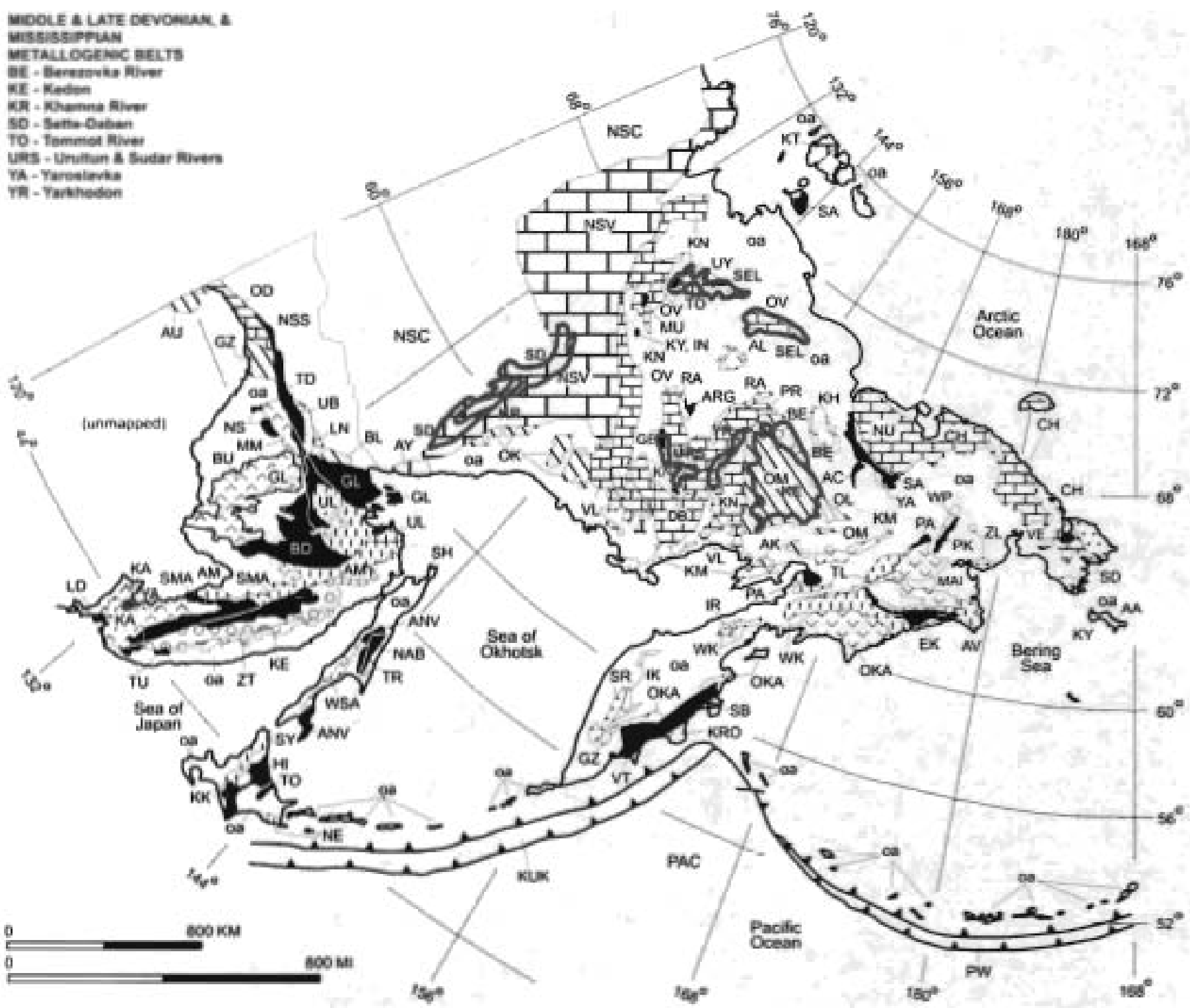

Figure 16. Generalized map of major Middle and Late Devonian and Mississippian metallogenic belts and terranes for Russian Far East, northern Japan, and adjacent offshore areas. Refer to text for description of metallogenic belts. Adapted from Nokleberg and others (1997b. 1998). Refer to foure 2 for explanation.

\section{Specific Events for Middle Through Late Devonian}

(1) In the early Paleozoic, on the basis of paleomagnetic data, the North Asian Craton and Craton Margin (NSC, NSV, KN) migrated to a position adjacent to the North American Craton and Craton Margin (NAC, NAM) along a pre-Devonian sinstral-slip suture.

(2) The Kedon continental-margin are and associated subduction zone formed along the margin of the North Asian Craton and Craton Margin (NSC, NSV, KN) and along the margin of the North American Craton Margin (NAM). The relative positions of the two cratons (NSC, NAC) and their craton margin units (NSC, NSV, KN, NAM) are determined from paleomagtic data for the cratons (see Nokleberg and others, 2000). In the North Asian Craton Margin and outboard terranes, the are is preserved today in: 


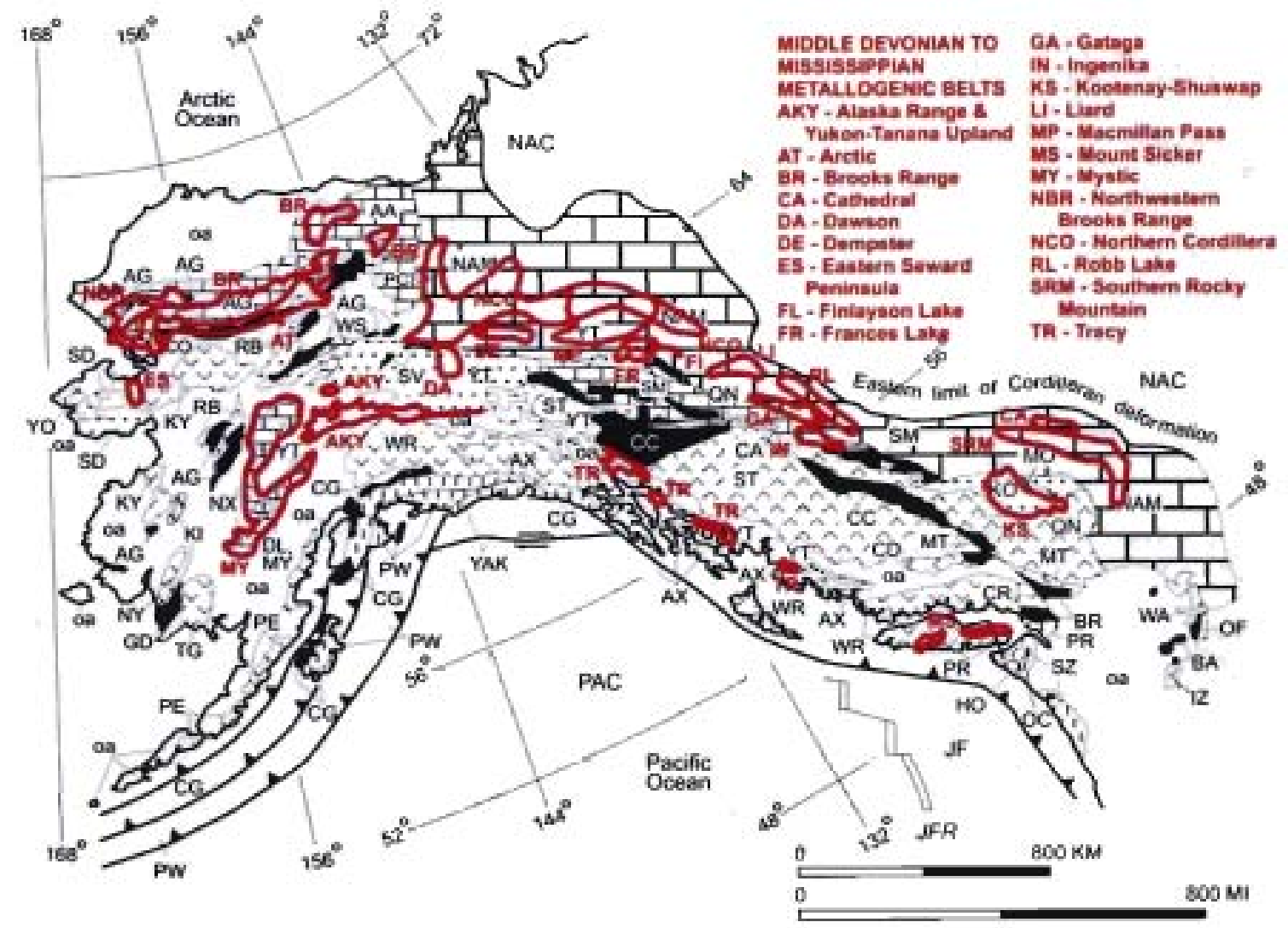

Figure 17. Generalized map of major Middle and Late Devonian metallogenic and Mississippian belts and terranes tor Alaska, Canadian Cordillera, and adjacent offshore areas. Refer to text for description of metallogenic belts Adapted from Nokleberg and others (1997b, 1998). Refer to figure 3 for explanation.

(1) sporadic occurrences of marine and continental volcanic and associated rocks and subduction-related granitic rocks in the southern part of the craton margin (NSV); (2) units which overlie parts of the Okhotsk (OK). Akekova (AK), Omolon (OM) cratonal terranes; (3) the Oloy (OL) and Yarakvaam (YA) island-arc terranes; and (4) the Beryozovka (BE) turbidite-basin terrane. Associated with this arc was the subduction of the older part of the Galam (GL) accretionary-wedge terrane along the margin of the North Asian Craton and Craton Margin (NSC, NSV), and subduction of the Angayucham and ancestral Pacific Oceans along the margin of the North American Craton Margin (NAM). Forming in part of the North Asian Craton Margin, from which the Omolon terrane was rifted, was the Kedon metallogenic belt which contains deposits related to felsic to mafic marine volcanism or to granitic magmatism in the Kedon arc.

In the Alaska and the Canadian Cordillera, the arc is preserved today in sporadic occurrences of marine volcanic and associated rocks and shallow- to deep-level subduction-related granitic rocks in various parts of the Arctic Alaska (AA), Coldfoot $(\mathrm{CO})$, Ruby (RB), Seward (SD), Yukon-Tanana (YT), and Kootenay (KO) terranes. Occurring in this arc, now preserved in various continental-margin terranes, were the Arctic (AT), Brooks Range (BR), Dawson (DA), Frances Lake (FR), KootenayShuswap (KS), and Tracy (TR) metallogenic belts, which contain deposits related to felsic to mafic marine volcanism or to granitic magmatism. The Devonian are is interpreted as extending discontinuously from Arctic Alaska to northern California (Rubin and others, 1991; Mortensen, 1992; Smith and Gehrels, 1992; Nokleberg and others, 1994a; Plafker and Berg, 1994).

(3) In the late Late Devonian, rifting of the North Asian and North American Cratons and Craton Margins oceurred. Derived from the North Asian Craton (NSC) and Craton Margin (NSV) were the Kotelnyn (KT), Omulevka (OV), Prikolyma (PR), Nixon Fork-Dillinger-Mystic (NX, DL, MY), Viliga (VL), and Zolotogorskiy (ZL) passive continental-margin terranes, the Avekova (AK), Kilbuck-Idono (KJ), Okhotsk (OK), and Omolon (OM) cratonal terranes. Derived from the Devonian continentalmargin arc which formed along the margins of the North Asian Craton Margin were the Beryozovka (BE), Oloy (OL), and Yarakvaam (YA) terranes (fig. 18). The newly-created terranes migrated into the Angayucham Ocean. Derived from the North American Craton Margin (NAM) were the Kootenay (KO) and Yukon-Tanana (YT) passive continental-margin terranes. The following metallogenic belts, which contain massive sulfide, carbonatite-related $\mathrm{Nb}$, Ta, and REE, or related deposits, formed during rifting: Berezovka River (BE); Cathedral (CA), Dempster (DE), Finlayson Lake (FL); Gataga (GA), Ingenika (IN), Liard (LI), older part of Mystic (MY), Northern Cordillera (NCO), Macmillan Pass (MP), Robb Lake (RL), Selennyakh River (SEL), Sette-Daban (SD), Southem Rocky Mountain (SRM), Tommol River (TO), Urultun and Sudar Rivers (URS), and Yarkhodon $(Y R)$. 


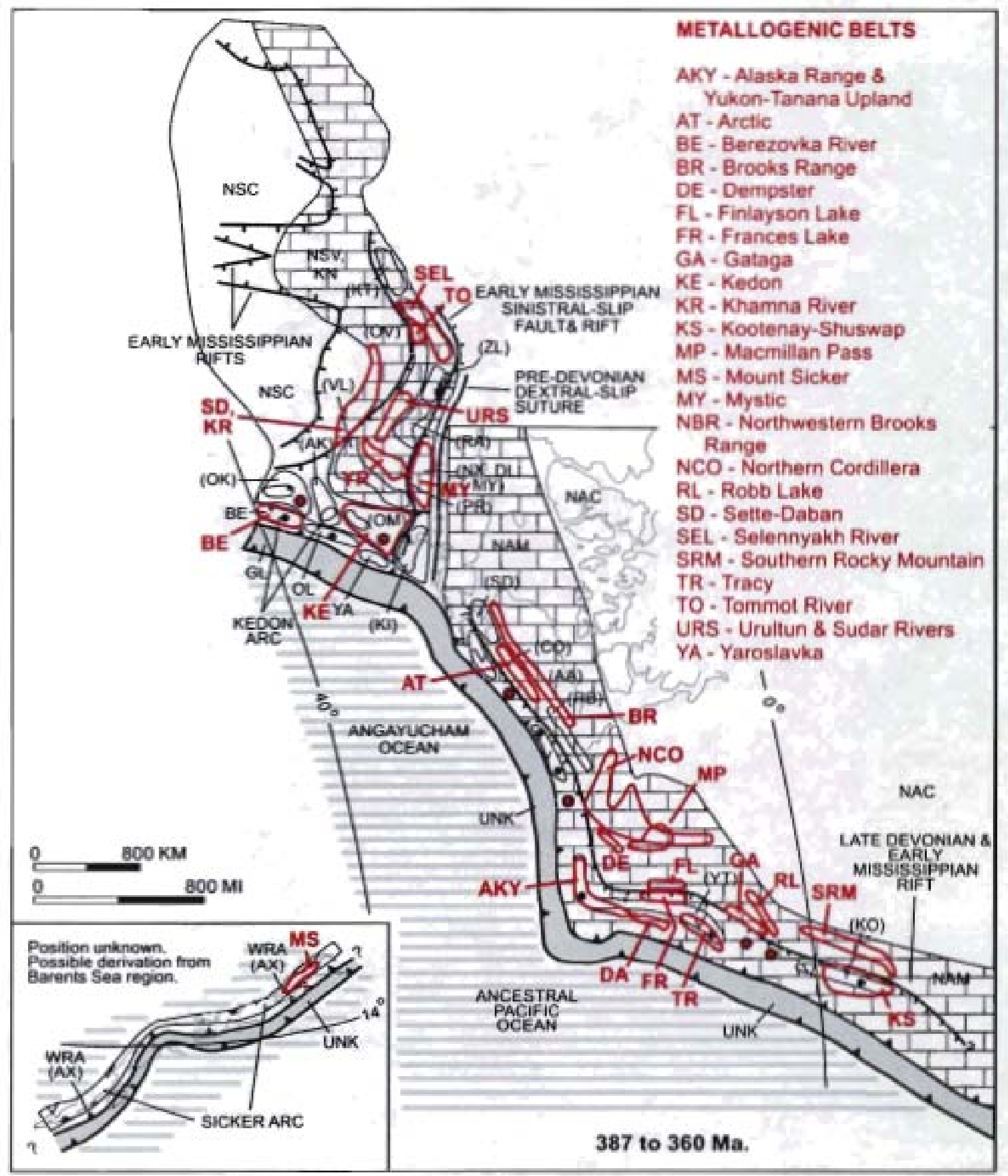

Figure 18. Middle through Late Devonian ( 387 to $360 \mathrm{Ma}$ ) stage of metallogenic-tectonic model and explanation. Refor to text for explanation of metallogenic-tectonic events, and to tables 3 and 4 for descriptions metalogenic belts and signilicant deposits. Adapted from Nokleberg and others (1997b, 1998, 2000). 


\section{EXPLANATION}

\section{TECTONIC ENVIRONMENTS AND} GEOLOGIC UNITS

CRatomuL

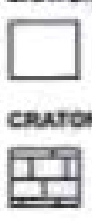

Cratons (No patterns): NAC, North American; NSC, North Asian; NSS, Stanovoy block:

couros waeca

Craton Margins: NAM, North American; NSV, North

Asian (Verkhoyansk foldoelt:

NSS, North Asian (Stanovoy block)

Passive continental-margin terranes (derived from craton

margins): AA. Arctic Alaska; AP, Artis Plateau; CA.

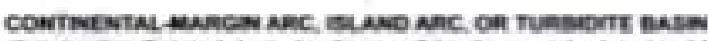

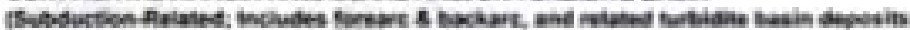

Continental-margin arcs: al, Aleutian; at, Alaska Range-

Talkeetna Mountains; bw, Bowers Ridge; ca, Cascade; ck, Central Kamchatka; cn, Coast-North Cascade; ej, East Japani.

ek, East Kamchatka; es, East Sikhote-Alin; 99. Gravina-

Nutzotin-Gambier, io, Indigirka-Oloy; ka, Kamloops; kc,

Central Kamchatka; kk, Kamchatka-Koryak; kh, Kahiltna; km, Kuskokwim Mountains; ko, Khingan-Okhotsk; ku, Kuril; mo, Monakin; no, North Okhotsk; oc, Okhotsk-Chukotka; ol, Oloy; os, Oloy-Svyatov Nos; pn, Penzhina; ns Nelson; sb Spences Bridge; sh Shirshov Ridge; sv, Svyotoy-Nos: tt, Tahtsa-Twin

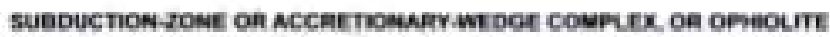

AG, Angayucham; AM, Amur River; AC, Aluchin; AGR, Argatas; ANV, Aniva; AV, Alkatvaam; BA, Baker; BD, Badzhal; BR, Bridge River; CC, Cache Creek; CG, Chugach: DB, Debin; EA, Easton; EK, Ekonay; GB, Garbyn'ya. GD, Goodnews; GL, Galam; GS, Grindstone; HI, Hidaka; HO, Hoh: KB, Khabarowsik; KK, Kamulkotan; KLM, Kiselevka-Manoma;

\section{BACKAHC SPREADEV OQ HOT-SPOT UNTS}

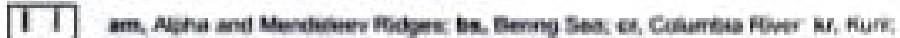

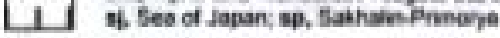

oceanac

Plates: FAR, Faralion; JF, Juan de Fuca; KULA, Kula; PAC,

ROST ACCGE TON OVEMLAP SEDRAENTAUV AHO VOL CANAC UNT, sunMarume rake on ocean Busat benosir

$\because$ ab, Amerasia Basin;ar, Anadyr; atb, Aleutian-Bowers; bo. Bowser; bu, Bureya; cb, Canada Basin; cf, Cordilleran

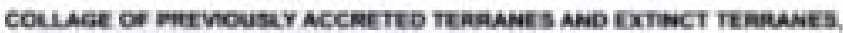

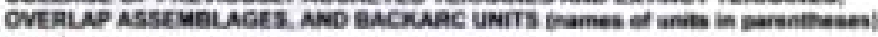

COLL, Collages of various accreted terranes (some labeled);
CONTACTS AND FAULTS

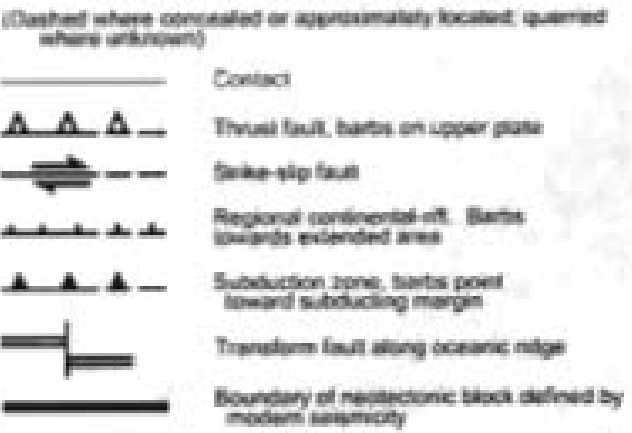

SYMBOLS

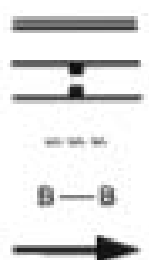

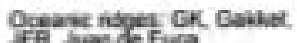

Tre $\sin$ de Fute

Backars aprading barts bos sweiktry batih

Zone of actus invarnoptian and Caformition of combenta marpm

Zone of Bueschis bopes metsmophiom

Relative direction and motion of oceanic plate

DE $\quad$ Falt name abbevition

(ch) Nebreviabons for eviensive extinct hasin. prevosisy actovited temanes, of inacove prewon paremitieses:

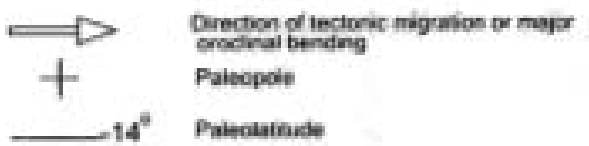

\section{PLUTONIC BELTS}

(4) Colloional granie tels ma, Man, no, Northerm

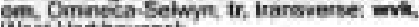
West Wenhoyansk

(4) Subducton-ietated conanental margn plutonic rocks

(0) Scowiondqe-reished ptutoric rocka: sab,

\section{FAULT NAMES}

\section{AO Mopcha- Taryn}

Ac. Nectien mogatinuse

CA Coneral Sahete-Aien

CC Cascada megathusi

co Contac

DE Dorual

FS Fiaserswavht Civet

ha bermoon

KA Katag

WE Kortanga

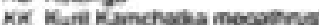

kO Kebsh South For

LE Lena

IS Lyahev-5euts

No Mengat-Othotsk

MY Myatrsh

NE Nison fort

I. Alosa Lake

OC Queen Chartone

SH Sabhain Hobkado

TE Tesin

$n$ Tirent.

ix. UEan

UM Ulaknay

\section{METALLOGENIC BELT}

OH hetakogerk beit mh aborewason

(4) The Sicker island are was active along most of the length of the Wrangellia superterrane (WRA), which at this time was composed only of the Alexander sequence $(\mathrm{AX})$ of the Wrangellia superternane. Associated with the Sicker are was an unknown subduction zone (UNK). In the southern Canadian Cordillera today, the Sicker are is defined by the Sicker Group which consists of Late Devonian arc-related volcanic and sedimentary strata, having a U-Pb zircon age of $367 \mathrm{Ma}$, and coeval intrusions (Muller, 1980; Parish and McNicoll, 1992). Occurring in the Alexander sequence (AX) was the Mount Sicker metallogenic belt of kuroko massive sulfide deposits which formed in the subduction-related, shon-lived Sicker arc. Insufficient data exist lo ascertain the relative positions of the Wrangellia superterrane (WRA) and associated subduction zone. On the basis of paleomagnetic, geologic, geochronologic, and faunal data, the Wrangellia superterrane (Alexander sequence, AX) may have been derived from the Ruasian platform (Baltica) in the Barents Sea region (Bacard and others, 1993, 1994) or possibly from Australia (Gehrels and Saleeby, 1987). 
Yarostavma Metallogenic Beit of Fluorite and

Sn Greisen Deposits (Belt YA)

Southern Part of Russian Southeast

The Yaroslavka metallogenic belt of fluorite and Sn greisen deposits (fig. 16; tables 3,4) occurs in the southwestern part of the Primorye province of the Russian Southeast (Ryazantseva. 1998). The deposits occur in numerous early Paleozoic granitoid plutons which intrude Cambrian clastic and limestone units in the Vosensenka continental-margin are terrane of the Khanka superterrane. The major fluorite greisen deposit is at Voznesenka-II; the major Sn greisen deposit is at Yaroslavka (table 4) (Nokleberg und others 1997a, b, 1998).

\section{Voznesenka-ll Fluorite Greisen Deposit}

The major Voznesenka-1l fluorite greisen deposit (fig. 19) (Androsov and Ratkin, 1990, Ryazantzeva, 1998) consists of fluorite which oecurs above the apex of a $1.5 \mathrm{~km}$-wide Late Cambrian intnasion of lithium-fluorine alaskite granite with Rb-Sr isotopic ages of about $512-475 \mathrm{Ma}$. The fluorite is interpreted as forming from metasomatic replacement and alteration of Early Cambrian, black organic limestone to greisen along a north-south-trending fault into which the alaskite granite intruded. An aggregate of muscovite and fluorite occurs at the peripbery of the ore zone whereas the greisen occurs in the middle of the zone. The greisen is oflen brecciated into fragments of mica and fluorite, fluoritized limestone, greisen, and greisenized granite which are cemented by an aggregate of quartz, topaz, and micaceous-fluorite. The deposit is very large and contains an estimated 450 million tons fluorite ore averaging $30-35 \% \mathrm{CaF}_{2}$. The Voznesenka-ll deposit has been mined since 1960's, is the sole producer of Russian fluorspar, and is currently one of the largest fluorine producen in the world.

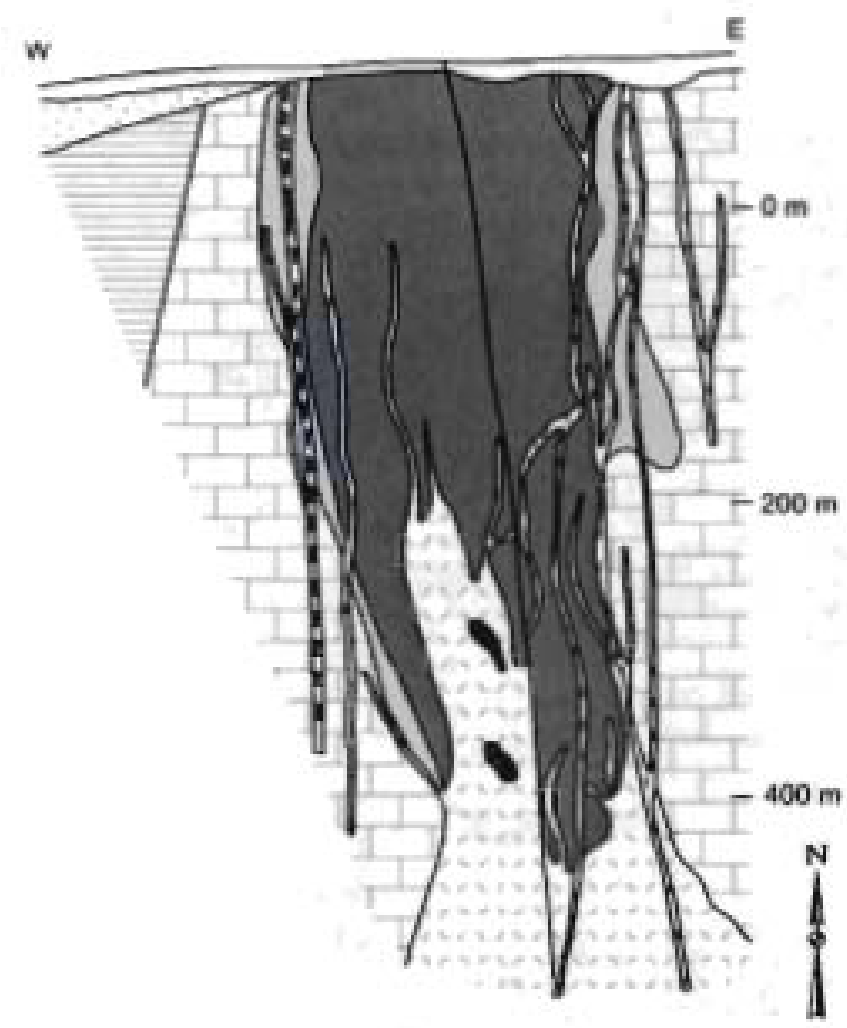

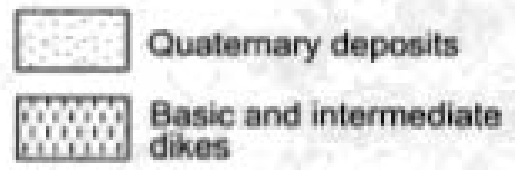

…3 Greisenized granite

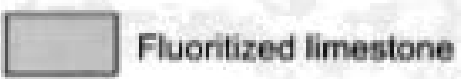

Fluorite ore
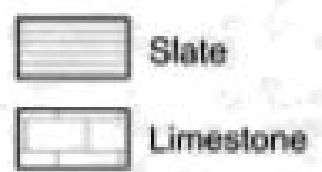

12 Tectonic fault and zone

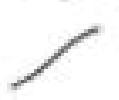

Contact

0

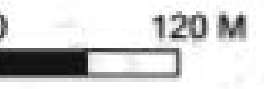

Figure 19. Voznesenka II F greisen deposit, Yaroslavka metallogenic beit, Russian Southeast. Schematic cross section through Glavnoe deposit. Adapted from Androsov and Ralkin (1990) and Ryazantzeva (1998).

The formation of the greisen fluorspar deposits is interpreted as related to intrusion of Late Cambrian leucogranite (Ryazantzeva and Shurko, 1992). The high fluorine content of the granitic intrusions is related to the presence of Precambrian accumulations of boros, fluorine, and sufur, and other metals in the zone in the host sedimentary rocks. lsotopic analyses of boron in tourmaline from leucogranite suggests which evaporites were the source for the boron, and which florine may be derived from associated dolomite. 
The major Yaroslavka Sn greisen deposit (fig. 20) (Govorov, 1977; Ryazantzeva, 1998) occurs mainly in greisen which mainly replaces skam, limestone, and schist; and to lesser extent in granite and granite porphyry with a Rb-Sr isotopic age of 408 $\mathrm{Ma}$ and an initial Sr ratio of 0.7136 (Rayazantseva and others, 1994). Tin-bearing quartz and quartz-tourmaline veins, related to replacement of skarn by greisen, are classified into: (1) mineralized fracture zones; (2) ore veins; (3) veialets and ore pods; and (4) saddle-shaped and sheeted ore. The Sa ores are classified into three types based on mineral associations: (1) tourmaline-quartz; (2) tourmaline-fluorite; and (3) sulfide-toumaline-quartz with subordinate cassiterite-polymetallic and chlorite-sulfides. The sulfide minerals are dominantly pyrite, arsenopyrite, galena, and sphalerite. The deposit occurs along the contact of a early Paleozoic biotite granite (approximately $400 \mathrm{Ma}$ ) which intrudes Early Cambrian shale, siltstone, sandstone, and limestone. The pre-ore pyroxene-scapolite, vesuvianite-gamet, and epidote-amphibole skarn occurs in limestone and shale along the granite contacts, and in rare limestone inclusions within the granite. The deposit is of medium size. The average grade is $0.52 \% \mathrm{Sn}$. The deposit was mined from the 1950's through the 1970's. Over forty occurrences of and vein deposits are known in the Yaroslavka metallogenic belt.

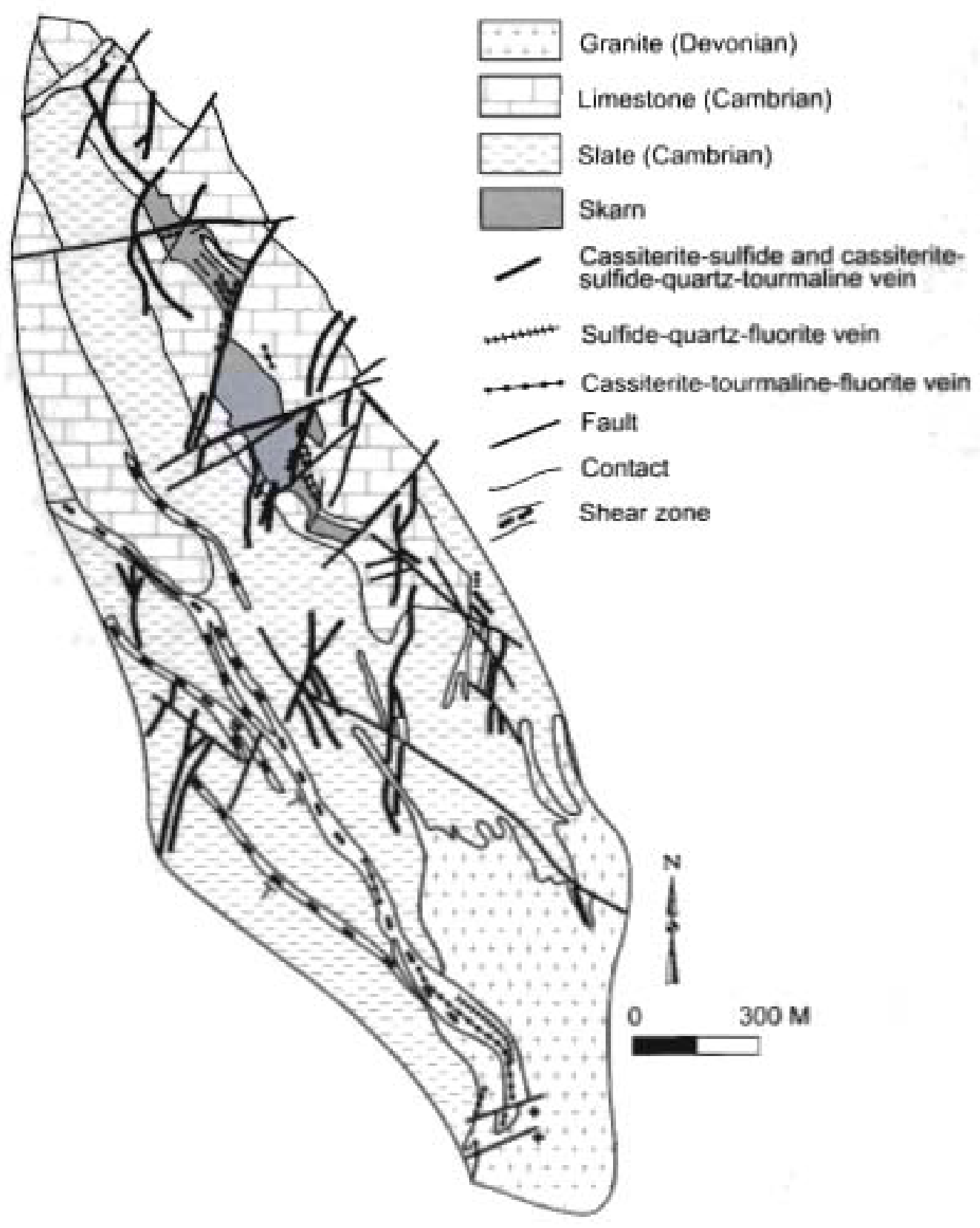

Figure 20. Yaroslavka Sn greisen deposit. Yaroslavka metallogenic belt. Russian Southeast. Schematic geologic map. Adapted from Govorov \{1977) and Ryazantzeva (1998) 
The leucogranites bosting the Yaroslavka metallogenic belt of fluorite and Sn greisen deposits are lithium-fluorine-REE enriched (Ryarantseva, 1998). The extensive deposits occur in the apical parts of plutons, altered to quarta-mica-fluorite-REE greisen) which intruded Early Cambrian limestone of the Vounesenka passive continental-margin terrane. The leucogranites are interpreted as forming during anatectic melting of older granitic gneisses and Cambrian sedimentary rocks (Khetchikov and others, 1992) presumably during collision of the Voznesenka and Kabarga terranes in the early Paleozoic (Nokleberg and others, $1994 \mathrm{c}, 1997 \mathrm{c}$, Khanchuk and others, 1996, 1998). The Voznesenka terrane bosting the Yaroslavka metallogenic belt consists of four major units. (1) Cambrian sandstone, pelitic schist, thyolite, felsic tuff, and limestone and dolomite comprise a section up to several thousand meters thick with thyolite which yields a Rb-Sr whole-rock isotopic age of $512 \mathrm{Ma}$. (2) Ordovician to Early Silurian conglomerate and sandstone which contains a questionable flon. (3) Early Devonian rhyolite and felsic tuff, Middle to Late Devonian rhyolite, felsic tuff, and rare basalt. And (4) Late Permian basalt, andesite, thyolite, sandstone. The stratified Cambrian rocks are intensely deformed and intruded by collision-related Devonian granitoid rocks with isotopic ages of 440 to $396 \mathrm{Ma}$ (Ryazantseva and others, 1994. The Cambrian sedimentary and volcanic units of the Voznesenka terrane are interpreted as a fragment of a Late Proterozoic to early Paleozoic carbonate-rich sedimentary rock sequence which formed on a passive continental margin. Archacocyathid in Cambrian limestone is related to the Australia paleogeographic province. The Voznesenka terrane is interpreted as a fragment of the passive continental margin of Gondwanaland (Khanchuk and others, 1998).

\section{Metallogenic Belts Formed in a \\ Middle Paleozoic Continental Arc \\ Along North Asian and North American \\ Craton Margins}

\section{Kedon Metallogenic Belt of Au-Ag Epithermal Vein, Porphyry Mo, Fe Skarn, and Associated Deposits (Belt KE) Central Part of Russian Northeast}

The Kedon meiallogenic belt of Au-Ag epithermal vein, porphyry Mo, Fe skarn and associated deposits (fig. 16; tables 3. 4) occurs in the central part of the Russian Northeast. The belt is hosted in early and middle Paleozoie granite, and coeval rhyolite, andesite, trachyandesite, silicic tuff, and associated sedimentary rocks of the Omolon cratonal terrane of the Kolyma-Omolon superierrane (Nokleberg and others, 1994c, 1997c). The areal extent of the Kedon metallogenic belt is approximately $40,000 \mathrm{~km}{ }^{2}$.

The Au-Ag epithermal vein deposits occur in subaerial extrusive rocks and subvolcanic equivalents, and in fuff of Middle Devonian through Early Carboniferous age. The significant deposits are at Olcha, Kubaka, and Zet (table 4) (Nokleberg and others 1997a, b, 1998). These deposits occur in trachyandesite-trachydacite volcanic rocks of Early Carboniferous age (Igor N. Kotlyar, written commun., 1995). Small deposits, such as at Tumannaya, Obyknovennoe, and Yolochka, occur in felsic volcanic rocks of Late Devonian age. Some epithermal vein deposits, as at Grisha, also oecur in early(?) Paleozoic syenite. Porphyry Mo$\mathrm{Cu}$ deposits, as at Vechernee and elsewhere, occur in middle Paleozoic, potassic granitoid rocks and subvolcanic rhyolites. Fe skarn deposits, as at Skarnovoe and elsewhere, occur in early Paleozoic granite which intrude Archean iron formation which provided Fe for the Fe skarn deposit (Fadeev, 1975). The available field, isotopic, and paleoflora data indicate that the magmatic rocks of the Kedon metallogenic belt formed mainly in the Middle Devonian through the Early Carboniferous (Lychagin and others, 1989).

\section{Kubaka Au.Ag Epithermal Vein Deposit}

The Kubaka Au-Ag epithermal vein deposit (fig. 21) (Savva and Vortsepnev, 1990;, Stepanov and others, 1991; V.A. Banin, oral commun, 1993; L.N. Kotlar, writlen commun., 1986; Layer and others, 1994) consists of veins and zones of adularia. quarz and adularia-chalcedony-hydromica-quartz veinlets which contain fluorite, barite, and carbonate. The veins occur in a borthwest-trendiag elongate caldera $4 \mathrm{~km}$ in diameter. The caldera lies transverse to the northeast trend of the main regional structural trend. The caldera is rimmed by Middle to Late Devonian voleanic rocks and voleanogenic sediments and is filled with Late Devonian to Early Carboniferous volcanic rocks. The Au-bearing veins occur within the caldera, and are localized in subvolcanic trachydacite in a stratified, Middle to Late Devonian volcaniclastic sequence composed of ignimbrite, pumiceous rhyoline to dacise, trachyandesite and rhyolite-dacite sills, and tephra and agglomerate tuff of various compositions. The veirs die out in the overlying Early Carboniferous carbonaceous shale and siltstone. The most intensely mineralized veins trend about east. west and west-northwest. The host rocks are intensely silieified, adularized, and sericitized; with the development of much hydromica. Initial stage of mineralization was marked by a gold-chalcedony association with colloidal gold ( with electrum and küstelite). A later adularia-quartz stage contains coarser, recrystallized native gold and scattered, disseminated pyrite, arsenopyrite, galens, freibergite, acanthite, aguilarite, naumannite, argentopyrite, and Au-Ag sulfides in fine-grained aggregates. Native gold predominates markedly over sulfide-bound gold. The Au.Ag ratio is 1:1 to 1:2. The deposit is medium size with proven reserves of about 100 tonnes Au and an average grade of about $17 \mathrm{~g} / \mathrm{Au}$ and $15.7 \mathrm{~g} / \mathrm{Ag}$. Since 1996, the Kubaka deposit has been 
developed under a joint venture agreement between the Kinross Gold Corporation of Canada and a consortium of Russian firms under the Omolon Mining Company. The joint venture is the first Western and Russian mining venture to succeed in the Russian Federation.
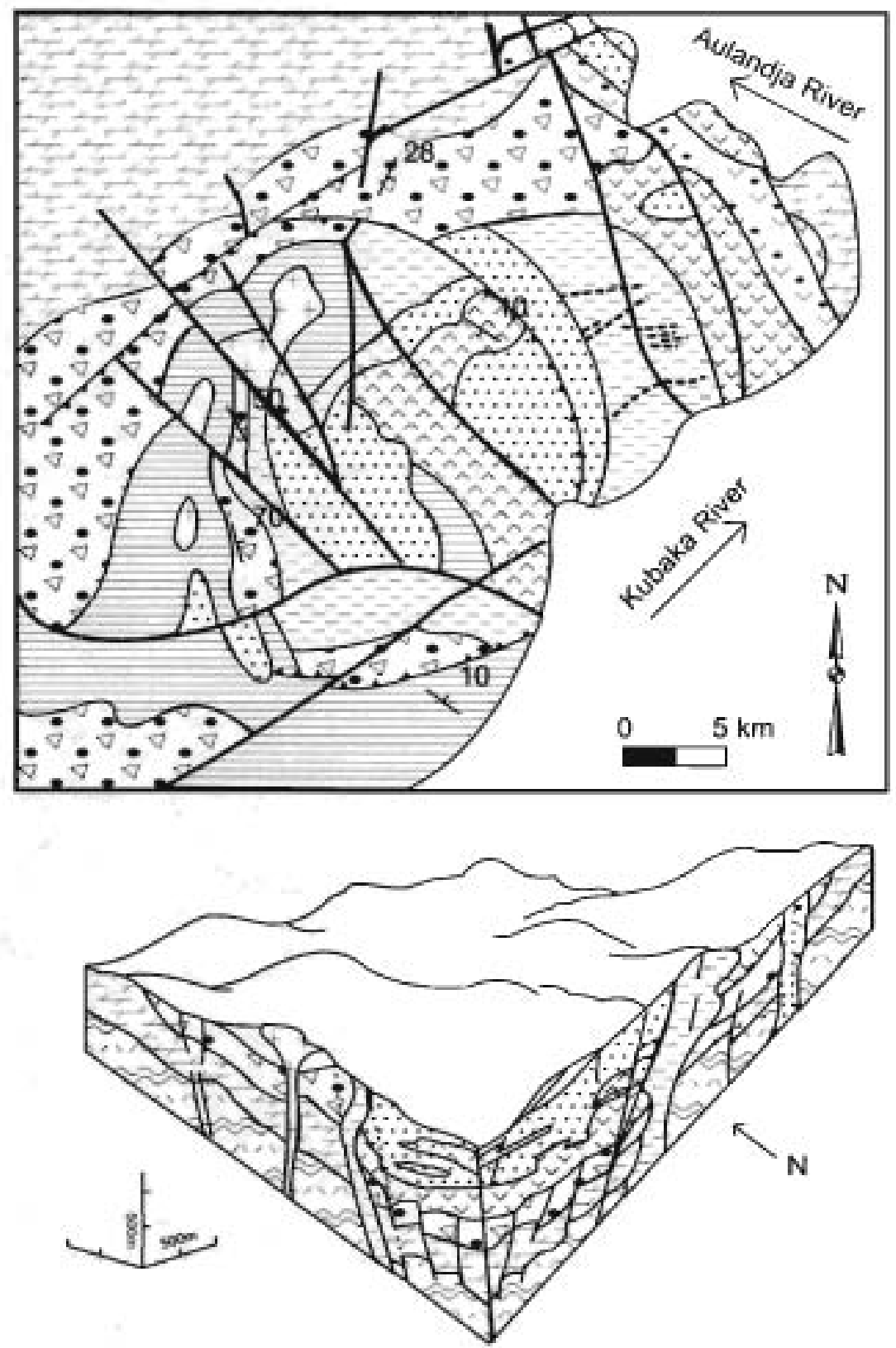

$+\ldots$ Alkalic gabbro

Korbin Formation, Coaly shale (Lower Carboniferous)

..P. Kubaka Sequence, trachy basaltic tuff, and trachyandesite (Lower Carboniferous)

Trachydacite

Rhyolite

7.9 Tuffaceous sandstone

27 Rhyolite ignimbrite and tuff (Devonian)

Biotite-amphibolite gneiss (Archean)

\#... Ore bodies

Fault

12. Thrust fault

Contact

10 Strike and dip of bedding

Figure 21. Kubaka Au-Ag epithermal vein deposit. Kedon metallogenic belt. Russian Northeast. Schematic geologic map and oblique view cross sections. Adapted from I.N.Kotlyar and N.E. Savva (written comm. 1994) and Sidorov and Goryachev (1994).

The stratified volcanic rocks and subvolcanic caldera rocks yield $\mathrm{Rb}-\mathrm{Sr}$ isochron ages of are 332-344 Ma. Post-ore alkalic basalt dikes exhibit K-Ar isotopic ages of 124-155 Ma. Adularia from ore vein samples exhibit Ar-Ar ages which range from 110 to $175 \mathrm{Ma}$, with plateau ages ranging from 110-130 Ma. Cretaceous thyolite and alkalic basalt dikes occur within and beyond the mineralized tectonic block. Basalt dikes cross the mineralized veins and are themselves cut by later, Au-poor quartz-carbonate veins and veinlets. The age of mineralization is interpreted as Late Devonian to Early Carboniferous because fragments of Aubearing calcedonic quartz occur in the adjacent conglomerates which contain Early-Middle Carboniferous fossils.

\section{Olcha Au-Ag Epithermal Vein Deposit}

The Olcha Au-Ag epithermal vein deposit (Zagruzina and Pokazaniev, 1975; Pokazaniev, 1976a, b; I.N. Kotlar, written commun., 1984) consists of steeply dipping quartz, carbonate-quartz, and adularia-quartz veins and stockwork zones ranging from 
several tens of meters to $1,300 \mathrm{~m}$ long. The veins and stockworks are hested in Middle to Late Devonian or Early Carboniferous volcanic rocks of the Kedon series. The veins occur along fractures, mainly in extrusive andesite breccia of a volcanic vent, and more rarely, in hypabyssal dacite-porphyry bodies and felsic extrusive rocks. The ore minerals include gold, chalcopyrite, argentite, polybasite, galena, sphalerite, pyrite, hematite, Mn-oxides, stromeyerite, tetrahedrite, native silver, and tellurides. The gangue minerals are quarnz and adularia, with lesser calcite, dolomite, rhodochrosite, and barite. Au and $\mathrm{Ag}$ is associated with $\mathrm{Hg}$. $\mathrm{Cu}_{1}, \mathrm{Mo}, \mathrm{Pb}, \mathrm{Zn}, \mathrm{Mn}$, and $\mathrm{As}$. The deposit exhibits propylitic and quartz-sericite alteration. The Au-Ag ore bodies are controlled by arcuate faults which occur around a volcano-tectonic depression over a basement composed of Archean metamorphic rocks and early Paleozoic(?) carbonate and clastic sedimentary rocks. Adularia from quartz veins has been dated by K-Ar isotopic studies as $268 \mathrm{Ma}$ and by $\mathrm{Rb}$-Sr isotopic studies as $251 \mathrm{Ma}$. More recent $\mathrm{K}$-Ar duting of adularia from Au-bearing veins yields an age of 318 Ma. The deposit is medium size, and grade ranges from 0.5 to $273 \mathrm{~g} / \mathrm{t}$ Au and 26.3 to $4,978 \mathrm{~g} / \mathrm{t} \mathrm{Ag}$.

\section{Origin of and Tectonic Controls for Kedon Metallogenic Beit}

The Omolon cratonal terrane, which hosts the Kedon metallogenic belt, consists of a long-lived succession of Archean to Early Proterozoic crystalline basement, Middle Proterozoic through middle Paleozoic miogeoclinal sedimentary rocks (Nokleberg and others, 1994c, 1997c). The younger part of the stratigraphy consists of unconformably overlying, widespread, gently-dipping Middle and Late Devonian cale-alkulic lava, and thyolite tuff, and Early Carboniferous trachyte, trachyandesite, and basalt which are interlayered with nonmarine sandstone, conglomerate, and siltstone. These rocks constitute the Kedon are of Shpikerman (1998). The felsic-magmatism-related lode deposits and host rocks of the Kedon metallogenic belt are interpreted as forming in the Kedon continental-margin magmatic are which formed in the Late Devonian. Subsequent to the Kedon arc, the Omolon terrane is interpreted baving been rifted from the North Asian Craton (Nokleberg and others, 2000; Shpikerman, 1998).

\section{Eastem Seward Peninsula (Kiwalik Mountain) Metallogenic Belt of Kuroko Massive Sulfide Deposits (Beit ES) Northwestern Alaska}

The Eastern Seward Peninsula metallogenic belt of kuroko massive sulfide deposits occurs in the Kiwalik Mountain region of the Seward Peninsula in northwestern Aluska (fig. 17; tables 3, 4) (Nokleberg and others, 1997b, 1998, Sheet 4). The metallogenic belt is bosted in a thin, tectonically-transposed unit of middle Paleozoic(?) felsic schists and metavolcanic rocks of the Seward metamorphosed continental margin ierrane (Nokleberg and others, 1994c, 1997e). Two small oceurrences on the west flank of Kiwalik Mountain consist of chalcopyrite, galena, tetrahedrite, and sphalerite in layers and as disseminations. The layers range from 0.2 to $2 \mathrm{~m}$ thickand occur parallel to compositional layering in a 200 meter-thick section of metafelsite, "button schist". and metatuff. The Kiwalik Mountain belt are interpreted as the extension of the Arctic metallogenic belt of kuroko massive sulfide deposits described below (T.K. Bundtzen and Thomas Crafford, written commun, 1991).

\section{Arctic Metallogenic Beit of Kuroko and Kipushi Massive Sulfide Deposits (Belt AT) Northein Alaska}

The extensive Arctic metallogenic belt of major kuroko massive sulfide deposits (tables 3, 4), which contains the Ambler district, and one Kipushi $\mathrm{Cu}-\mathrm{Pb}-\mathrm{Zn}$ deposit, occurs along an east-west trend for about $260 \mathrm{~km}$ along the southem flank of the Brooks Range in northern Alaska (fig. 17). The metallogenic belt is hosted in a sequence of metavolcanic and sedimentary rocks which occur in both the Coldfoot metamorphosed continental-margin terrane of the southem Brooks Range, and in the Nome Group in the southern Seward Peninsula in the Seward metamorphosed continental-margin terrane (Nokleberg and others, 1994c. $1997 \mathrm{c}$; Schmidi, 1997b). The Arctic kuroko massive sulfide and the Ruby Creek Kipushi Cu-Pb-Zn (fig, 22)deposits oceur in the Ambler district (Hitzman and others, 1986); other kuroko massive sulfide deposits of the district are at Smucker, Michigan Creek, BT, Jerri Creek. Sun, and Rooseveli Creek prospects (table 4) (Nokleberg and others 1997a, b, 1998).

\section{Arctic Kuroko Massive Sulfide Deposit}

The Arctic kuroko massive sulfide deposit (Wiltse, 1975; Sichermann and others, 1976; Hitzman and others, 1982; Schmidt. 1983; Schmidt. 1986, 1988; Hitrman and others, 1986) consists of stratiform, semi-massive to massive chalcopyrite and sphalerite accompaniod by lesser pyrite, minor pyrrhotite, galena, letrahedrite, arsenopyrite, and inces of bornite, magnetite, and hematite. The deposit oceurs in a thick horizon which has an areal extent of about 900 by $1.050 \mathrm{~m}$, and in fwo thinner horizons above the main horizon. The sulfides form multiple lenses up to $15 \mathrm{~m}$ thick over stratigraphic interval of 6 to $80 \mathrm{~m}$. The gangue minerals are mainly calcite, dolomite, barite, quartz, and mica. Locally abundant chlorite, phlogopite-talc-barite, and pyritecalcite-white mica occur in bydrothermally-altered wall rocks overlying, underlying, and interlayered with sulfide mineralization. The alteration is interpreted as occurring during tapid influx of cold seawater into a hot hydrothermal vent system. The deposit contains an estumated 37 million tonnes grading $4.0 \% \mathrm{Cu}, 5.5 \% \mathrm{Zn}, 0.8 \%, \mathrm{~Pb}, 47 \mathrm{~g} / \mathrm{Ag}, 0.62 \mathrm{~g} / \mathrm{Au}$. The deposit is hosted in part of the 


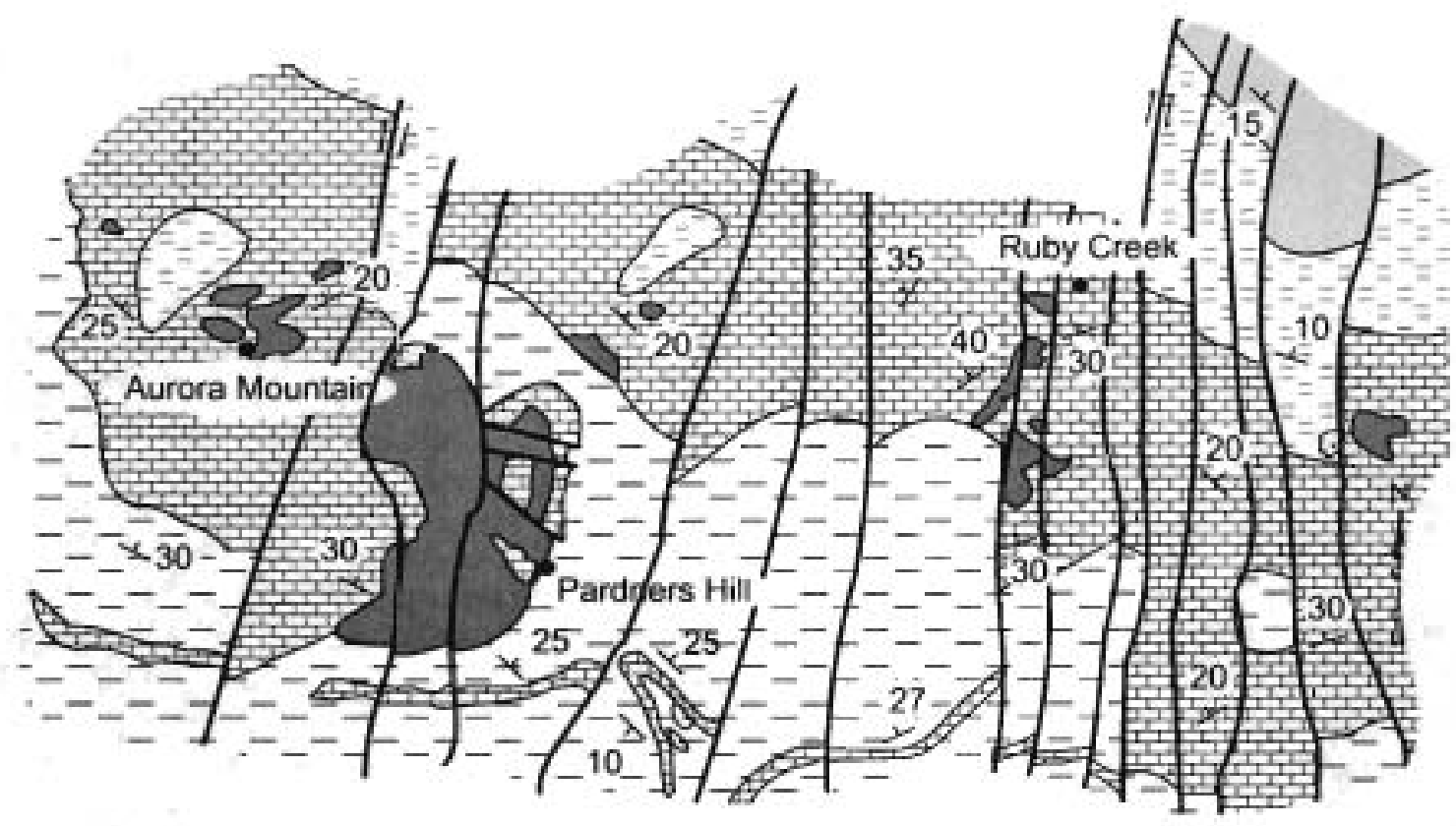

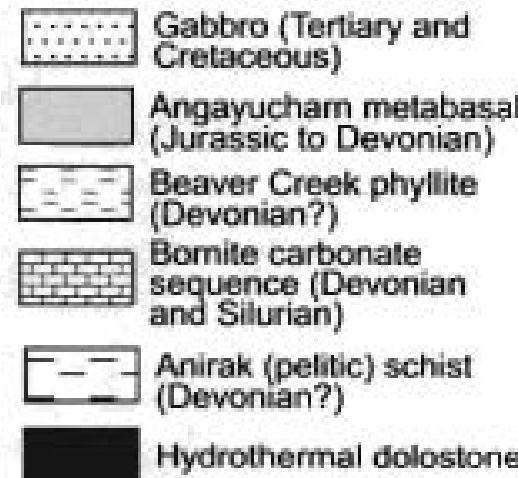

Figure 22. Ruby Creek (Bornite) Kipushi Cu-Pb-Zn deposit and related deposits, Cosmos Hills area, Arctic metallogenic belt, Northem Alaska. Schematic geologic map. Except where noted, all faults are downthrown to the east. Adapted from Hitzman (1986) and Schmidt (1997).

Devonian and Mississippian Ambler sequence. The main horizon of sulfides is hosted in mainly graphitic pelitic schist and metarhyolite porphyry derived from submarine ash-flow tuff.

\section{Origin of and Tectonic Controls for Arctic Metallogenic Belt}

The kuroko massive sulfide deposits in the Arctic metallogenic belt are hosted in, or occur adjacent to submarine mafic and felsic metavoleanic rocks and associated carbonate, pelitic, and graphitic metasedimentary rocks of the Devonian and Mississippian Ambler sequence (Hitzman and others, 1982, 1986; Newberry and others, 1997) which forms part of the informally named Ambler schist belt or Coldfoot metamorpbosed continental margin terrane of the southern Brooks Range (Moore and others, 1992; Nokleberg and others, 1994c, 1997c). On the basis of local birnodal voleanic rocks, a back-arc rift environment is interpreted by some workers in the southern Brooks Range belt for the origin of kuroko massive sulfide deposits and host rocks (Hitzman, 1986; Newberry and others, 1997; Schmidt, 1986; Moore and others, 1994; Goldfarb, 1997). However, this belt shares many characteristics with the broadly coeval Eastern Alaska Range belt of kuroko massive sulfide deposits, described below, which is interpreted as forming in a submerged continental-margin arc environment (Lange and others, 1993). In addition, regional tectonic analyses interpret the Devonian submarine and associated volcanic rocks of the southern Brooks Range and the belt of Devonian granitoid plutons, which oceur along the southem flank of the Brooks Range, are part of a discontinuous Devonian continental-margin are which extended along the margin of the North American Cordillera (Rubin and others, 1991; Plafker and Berg, 1994; Goldfarb, 1997; Nokleberg and others, 2000). The Arctic metallogenic belt is herein interpreted as forming in the back-are of the same continental-margin arc in which formed the Brooks Range metallogenic belt of granitic magmatism deposits, described below (fig. 17). With this interpretation, the SEDEX deposits formed later in the Late Mississippian and Early Pennsylvanian, and in a distinctly different tectonic environment. This interpretation differs from, 
Goldfarb (197) who interprets that the Arctic metallogenve belt as forming during a long-protracted, 100-m.y.-long event which included formation of SEDEX zinc-lead deposits in the Northwestern Brooks Range metallogenic belt (described below).

\section{Brooks Range (Chandalar) Metallogenic Beit of Granitic Magmatism Deposits (Belt BR) Northern Alaska}

The Brooks Range metallogenic belt of granitic magmatism deposits (fig. 17; tables 3,4), mainly porphyry, polymetallic vein, and skarn deposits, occurs in the core of the Brooks Range in northern Alaska (Nokleberg and others, 1995a, 1997b, 1998), The metallogenic belt is hosted in the Coldfoot, Hammond, and North Slope terranes of the Arctic Alaska superterrane (Moore and others, 1992, 1994; Nokleberg and others, 1994c, 1997c). The belt is discontinuous, but extends for over $900 \mathrm{~km}$ along the length of the Brooks Range. The significant deposits in the belt are: the Mount Igikpak and Arrigetch Peaks polymetallic vein, Au quartz vein, Sn skam, Cu-Pb-Zn skam deposits; the Ann (Emie Lake), Galena Creek, Porcupine Lake, and Romanzof Mountains polymetallic vein deposits; the Jim-Montana Cu-Zn skarn deposit; the Sukakpak Mountain Sb-Zu vein deposit; the Victor, Venus, Evelys Lee, and Ebo porphyry $\mathrm{Cu}$ and $\mathrm{Cu}$ skarn deposits; the Geroe Creek porphyry Cu-Mo deposit; the Esotuk Glacier Pb-Zn skarn and fluorite vein deposit; and the Bear Mountain porphyry Mo deposit (table 4) (Nokleberg and others 1997a, b, 1998). These significant deposits oceut in two groups described below: a major group in the central Brooks Range, and a minor group in the northeastern Brooks Range. In the northeastern Brooks Range, the belt is sometimes referred to as the Chandalar belt (Newberry and others, 1997a, b).

\section{Vein, Skarn, and Porphyry Deposits Central Brooks Range}

Significant deposits in the central Brooks Range part of the belt are at Mount Igikpak and Arrigetch Peaks, Sukakpak Mountain, Victor, and Geroe Creek. These deposits include polymetallic quartz veins containing base-metal sulfides, Sn skarns containing both disseminated cassiterite and base-metal sulfides, $\mathrm{Cu}-\mathrm{Pb}-\mathrm{Zn}$ skams containing disseminated $\mathrm{Fe}$ and base-metal sulfides, and porphyry Cu and Mo deposits (Nokleberg and others, 1995a).

The Victor and associated porphyry Cu and Cu skam deposits at Venus, Evelyn Lee, and Ebo (DeYoung, 1978; Donald Grybeck, written commuin., 1984; Newberry and others, 1997a) consist of veinlet and disseminated chalcopyrite, bornite, molybdenite, and pyrite in schistose Devonian granodiorite porphyry which inirudes either the Silurian and Devonian Skajit Limestone or older marble, calc-schist, and pelitic schist. The skarn minerals are mainly garnet, magnetite, and diopside, and retrograde vein and replacement epidote, amphibole, chlorite, calcite, and quartz. The skarns were subsequently regionally metamorphosed during the Mesozoic. Skarns in marble adjacent to plutonic rocks contain vugs containing interstitial bornite, chalcopyrite, bornite, chalcocite, pyrite, magnetite, and some digenite. Zones in granitoid rocks up to $30 \mathrm{~m}$ wide contain up to $0.4 \% \mathrm{Cu}$. Grab samples of skarn contain up $105.5 \% \mathrm{Cu}, 0.41 \mathrm{~g} / \mathrm{Au}$, and $0.29 \mathrm{~g} / \mathrm{Ag}$.

The felsic-magmatism-related deposits in the central Brooks Range are hosted in a structurally complex and polymetamorphosed assemblage of Devonian or older carbonate rocks, including Silurian and Devonian polymetamorphosed limestone, calc-scbist, quartz-mica schist, and quartzite, which is intruded by mainly Late Devonian gneissic granitoid rocks which together with the metasedimentary rocks constitute the Hammond passive continental margin terrane of the Aretic Alaska superterrane (Moore and others, 1992).

\section{Skam, Vein, and Porphyry Deposits Northeastern Brooks Range}

Significant deposits in the Brooks Range metallogenic belt in the northeastern Brooks Range are a cluster of $\mathrm{Pb}-\mathrm{Zn}$ skam, fluorite vein, polymetallic vein, and porphyry Cu deposits at Esotuk Glacier, Porcupine Lake, Romanzof Mountains, and Galena Creek (Nokleberg and others, 1995a). This part of the belt is sometimes referred to as the Chandalar belt (Newberry and others, $1997 \mathrm{a}, \mathrm{b})$.

The Romanzof Mountains polymetallic vein and Pb-Zn skam deposit (Brosge and Reiser. 1968; Grybeck, 1977; Sable, 1977; W. P. Brosge, oral commun, 1984; Newberry and others, 1997a) consists of numerous scattered mineral oceurrences of polymetallic sulfides. The most common types of deposits are: (1) zones of disseminated galena, sphalerite, chalcopyrite and pyrite, locally with $\mathrm{Au}$ and $\mathrm{Ag}$. in Devonian(7) granite; (2) $\mathrm{Pb}-\mathrm{Zn}$ skarn in marble with disseminated magnetite, pyrite, pyrthotite, sphalerite, and galena in gangue of carbonate, clinopyroxene, epidote, amphibole, beryl, tourmaline, and fluorite; (3) disseminated galena, sphalerite, chalcopyrite, and (or) molybdenite in quartz veins along sheared contact in in Devonian(?) granite, and (4) local fluorite greisen in in Devonian(7) granile. Grab samples contain up to $0.15 \% \mathrm{Sn}$. The skams and quartz veins occur in Precambrian marble and calc-schist of the Neruokpuk Quartzite at the periphery of the Silurian or Early Devonian Okpilak (granite) batholith.

These felsic-magmatism-telated deposits are hosted in a variety of Paleozoic and late Proterozoic metasedimentary rock which consisa mainly of marble, calc-schist, limestone, quartzite, and greenstone of the North Slope passive continental margin terrane (part of the Arctic Alaska superterrane) where intruded by Devonian gneissose granite plutons (Newberry and others, 1997a). The paucity of deposits in the northeastem Brooks Range most likely reflects the limited geological exploration of the 
area. Although not part of this metallogenic belt, a nearby porphyry Mo deposit in this area at Bear Mountain consists of molybdenite- and wolframite-bearing Tertiary(7) granite porphyry stock (Barker and Swainbank, 1986). The stock intrudes the Late Proterozoic(?) Nenuokpuk(?) Quartzite, and the Tertiary(?) isotopic age for the stock may be a reset Devonian age. If so, the Bear Mountain deposit would be part of the Brooks Range metallogenic belt.

\section{Origin of and Tectonic Controls for}

Brooks Range Metallogenic Belt

Field, chemical, and isotope data indicate the granitic magmatism deposits in the Brooks Range metallogenic belt formed during intrusion of the Devonian gneissic granitoid rocks (Dillon and others, 1987; Nokleberg and others, 1995a). High initial $\mathrm{Sr}$ ratios (about 0.715), and $\mathrm{Pb}$ and $\mathrm{Sm}-\mathrm{Nd}$ isotopic studies indicate the presence of an older, inherited erustal component (about 1,000 to $800 \mathrm{Ma}$ ) and involvement of Proterozoic or older continental crust in the genesis of the plutons (Dillon and others, 1987; Nelson and others, 1993; Miller, 1994; Moore and others, 1994). U- $\mathrm{Pb}$ zircon and Rb-Sr isotopic studies indicate intrusion from about 402 to $366 \mathrm{Ma}$ (Dillon and other, 1987; Moore and others, 1994). Most of the gneissic granitoid plutons contain a moderately- to intensely-developed, subhorizontal to gently-dipping schistosity which formed at lower greenschist facies. K-Ar, and incremental Ar studies indicate which mid-Cretaceous greenschist metamorphism was superposed on older blueschist facies metamorphism (Dusel-Bacon and others, 1993; Moore and others, 1994).

These field, petrologic, chemical, and isotopic data indicate that the Brooks Range metallogenic belt and associated Devonian gneissic granitoid plutons formed along a Devonian continental-margin are which developed above a subduction zone (Newberry and others, 1997a; Nelson and others, 1993; Miller, 1994; Moore and others, 1994; Nokleberg and others, 1995a, 2000). U-Pb zircon isotopic ages indicate that the Devonian gneissic granitoid rocks intruded about 30 to 40 m.y. after the eruption of the submarine volcanic rocks which host the kuroko massive sulfide deposits to the west in the Arctic metallogenic belt (Newberry and others, 1997a; Nokleberg and others, 1997a) described above. Herein the Brooks Range metallogenic belt is interpreted as the axial arc part of a continental-margin are in which the Arctic metallogenic belt of kuroko massive sulfide and associated deposits formed in the back arc. Regional tectonic analyses also suggest that the Devonian igneous of the Brooks Range are part of a discontinuous Devonian continental-margin arc which extended along the margin of the North American Cordillera (Rubin and others, 1991; Nokleberg and others, 1994c, 1997c, 2000; Plafker and Berg, 1994; Goldfarb, 1997). An alternative interpretation by Goldfarb and others $(1997,1998)$ proposes which some of the deposits in the Aretic metallogenic belt formed during subsequent rifting, as indicated by $\mathrm{Pb}$ isotope data reported by Dillon and others (1987).

\section{Alaska Range and Yukon-Tanana Upland \\ Metallogenic Belt of Kuroko Massive \\ Sulfide Deposits (Beit AKY) \\ Central and East-Central Alaska}

The Alaska Range and Yukon-Tanana Upland metallogenic beli of kuroko massive sulfide deposits (fig. 17; tables 3,4) occurs in the central and eastern Alaska Range in the southern part of the Yukon-Tanana metamorphosed continental margin terrane. The massive sulfide deposits extend for $350 \mathrm{~km}$ along strike on the northern flank of the Alaska Range, and constitute one of the longer belts of massive sulfide deposits in Alaska. The significant deposits are WTF. Red Mountain, Sheep Creek, Liberty Bell, Anderson Mountain, Miyaoka, Hayes Glacier, MeGinnis Glacier, and in several deposits in the Delta district (table 4) (Newberry and others, 1997; Nokleberg and others 1997a, b, 1998).

\section{Bonnifield District of Kuroko Massive Sulfide Deposits}

In the Bonnifield district along the Wood River drainage, the best-studied deposits are at Anderson Mountain and WTF. and Red Mountain. Twenty sulfur isotopic analyses from seven stratiform deposits in the Bonnifield district indicate enrichment by heavier sulfur during deposition, typical of many volcanogenic massive sulfide deposits (Gilbert and Bundtuen, 1979; Newberry and others, 1997). One lead isotopic analysis from the Anderson Mountain deposit yielded a single-stage lead age of $370 \mathrm{Ma}$ (Devonian).

\section{Anderson Mountain Kuroko Massive Sulfide(7) Deposit}

The Anderson Mountain kuroko massive sulfide(?) deposit (Gilbert and Bundtzen, 1979; Curtis J. Freeman, written commun., 1984; Newberry and others, 1997a) consists of massive sulfide layers with pyrite, chalcopyrite, galena, sphalerite, enargite, and arsenopyrite in gangue of quartz, sericite, chlorite, calcite, barite and siderite. The deposit is hosted in metamorpbosed marine tuffaceous rhyolite and metamorphosed calcareous clastic rocks which are correlated with the Moose Creek Member of the Mississippian(?) Totatlanika Schist. Numerous high-angle faults cut the deposit. The massive sulfide beds lie on an irregular paleosurface in footwall with domal sulfide accumulations. The absence of footwall alteration and stringer mineralization suggests off-vent deposition. Grab samples contain up to $19 \% \mathrm{Cu}$, up to $5 \% \mathrm{~Pb}, 28 \% \mathrm{Zn}$, and 171 g/t Ag. High geochemical values of $\mathrm{As}, \mathrm{Sb}, \mathrm{Hg}$, and $\mathrm{W}$ may be derived from underlying schist. 
The WTF and Red Mountain Kuroko massive suifide deposits (Gilbert and Bundtzen, 1979; David R. Gaard, written commun. 1984) consist of massive pyrite, sphalerite, galena, and chalcopyrite in a quartz-rich gangue. The sulfides are hosted in in felsic metavolcanic rock derived from crystal and lapilli tuff, minor flows, and metasedimentary rock. The stratiform massive sulfide layers oceut on both sides of a large, east-west trending syncline. The massive sulfide layers at Red Mountain occur in a proxumal setting on the south limb of the anticline, and occur in a sulfide-silica exhalite which ranges up to $130 \mathrm{~m}$ thick. An older, southem borizon contains sphalerite and coarse pyrite in black chlorite schist. The WTF deposit occurs on the north limb of the antiform and consists of a thin blanket of fine-grained sulfides which are interpreted as having formed in a distal setting relative to the vent. The WTF depost contains an estimated 1.10 million tones grading $0.15 \% \mathrm{Cu}, 2.5 \% \mathrm{~Pb}, 7.9 \% \mathrm{Zn}, 270 \mathrm{~g} / \mathrm{Ag}$, and 1.9 git Au. The deposits occur immediately below the Sheep Creek Member and above the Mystic Creek Member of the Mississippian(?) Totatlanika Schist.

\section{Delta District of Kuroko Massive Sulfide Deposits}

The best-known kuroko massive sulfide deposits of the Alaska Range and Yukon-Tanana Upland metallogenic belt are part of the Delta district in the eastem part of the Alaska Range (fig. 23). The district and large massive sulfide deposits have been described by several authors (Nauman and others, 1980; Lange and Nokleberg, 1984; C.R. Nauman and S.R. Newkirk, written commun., 1984; Lange and others, 1990, 1993; Newberry and others, 1997a). The district comprises an area of about 1,000 km². The district contains about 26 deposits, many of which are stratiform or transposed and some of which are replacement deposits which occur along four regional trends. The deposits consist of varying amounts of pyrite, chalcopyrite, galena, sphalerite, and lesser malachite and bornite. The gangue minerals are mainly quartz, carbonate, and white mica. Hydrothermal alteration consists of chlorite, quartz, sericite, pyrite, and $\mathrm{Zn}$-Ag-Au sulfide minerals. The massive sulfides and adjacent disseminated sulfide layers occur in zones which average $500 \mathrm{~m}$ long, $200 \mathrm{~m}$ wide, and $15 \mathrm{~m}$ thick. The deposits are hosted in metamorphosed Devonian spilite, andesite, and keratophyre suite, which initially formed in flows, tuff, and breccia, and in metamorphosed shallow- to deepmarine sedimentary rocks; now mainly quartz schist, quartz-chlorite-feldspar schist, calc-schist, and marble. The host rocks are part of the extensive Devonian and Mississippian Yukon-Tanana terrane. Intruding the deposits are numerous tholeitic greenstone sills which are interpreted as Triassic(?) to Cretaceous(?). The largest deposit contains an estimated 18 million tonnes grading 0.3 to $0.7 \% \mathrm{Cu}, 1$ to $3 \% \mathrm{~Pb}, 3$ to $6 \% \mathrm{Zn}, 34$ to $100 \mathrm{~g} / \mathrm{Ag}, 1$ to $3.4 \mathrm{~g} / \mathrm{Au}$.

\section{Origin of and Tectonic Controls for Alaska Range and Yukon-Tanana Upland Metallogenic Belt}

The Alaska Range and Yukon-Tanana Upland metallogenic belt of kuroko massive sulfide deposits is hosted in Devonian metavolcanic and interlayered metasedimentary rocks of the southern Yukon-Tanana terrane which which is interpreted as a fragment of metarnorphosed Devonian and Mississippian continental-margin are (Lange and others, 1990, 1993; Nokleberg and others, 1994c, 1997, 2000). The metavoleanic rocks, which host most of the major base and precious metal deposits, are derived from a volcanic suite which varies in composition from spilite to andesite to keratophyre. Most studies of kuroko massive sulfide deposits interpret a back-are or are-related rift origin for the deposits (Sawkins, 1990); bowever, in the eastern Alaska Range, the lack of coeval mafic plutonic or volcanic rocks appears to preclude a nift origin. The Yukon-Tanana ternane in east-central Alaska, Southeastern Alaska, and the Canaduan Cordillera, and the correlative Kootenay Ierrane in southern British Columbia are interpreted to be fragments of the herein, informally named, Kootenay arc, a discontinuous Devonian continental-margin are which extended along the margin of the North American Cordillena from Arctic Alaska to California (Grantz and others, 1991; Rubin and others, 1991: Mortensen, 1992; Plafker and Berg. 1994; Nokleberg and others, 1994c, 1997c; Monger and Nokleberg. 1996: Nokleberg and others, 2000). Fragments of the Kootenay arc include several metallogenic belts which host kuroko massive sulfide and related deposits (Nokleberg and others, 1997a, b, c): (1) The Arctic metallogenic belt in the Coldfoot terrane in Arctic Alaska; (2) the Frances Lake metallogenic belt (Murpby and Piercey, 1999) in the Yukon-Tanana ternane in the southem Yukon Territory. (3) the Tracey metallogenic belt in the Yukon-Tanana Ierrane in Southeastem Alaska and westem British Columbias and (4) the Kootenay-Shuswap belt in the Kootenay ierrane in the southern Canadian Cordillera.

\section{Dawson Metallogenic Belt of Volcanogenic Pb-Zn-Cu Massive Sulfide and SEDEX Pb-Cu-Zn-Ba Deposits (Belt DA) Northwestern Yukon Territory}

The Dawson metallogenic belt of volcanogenic $\mathrm{Pb}-\mathrm{Zn}-\mathrm{Cu}$ massive sulfide and SEDEX $\mathrm{Pb}-\mathrm{Cu}-\mathrm{Zn}-\mathrm{Ba}$ oceurrences is located in the Yukon-Tanana terrane in the southem Yukon Territory (fig. 17; tables 2. 3) (Nokleberg and others, 1997b, 1998). Stratiform massive sulfide occurrences exist in three sequences within the terrane. With more detailed study, each of the three sequences and contained massive sulfide deposits might be designated as separate metallogenic belts. 

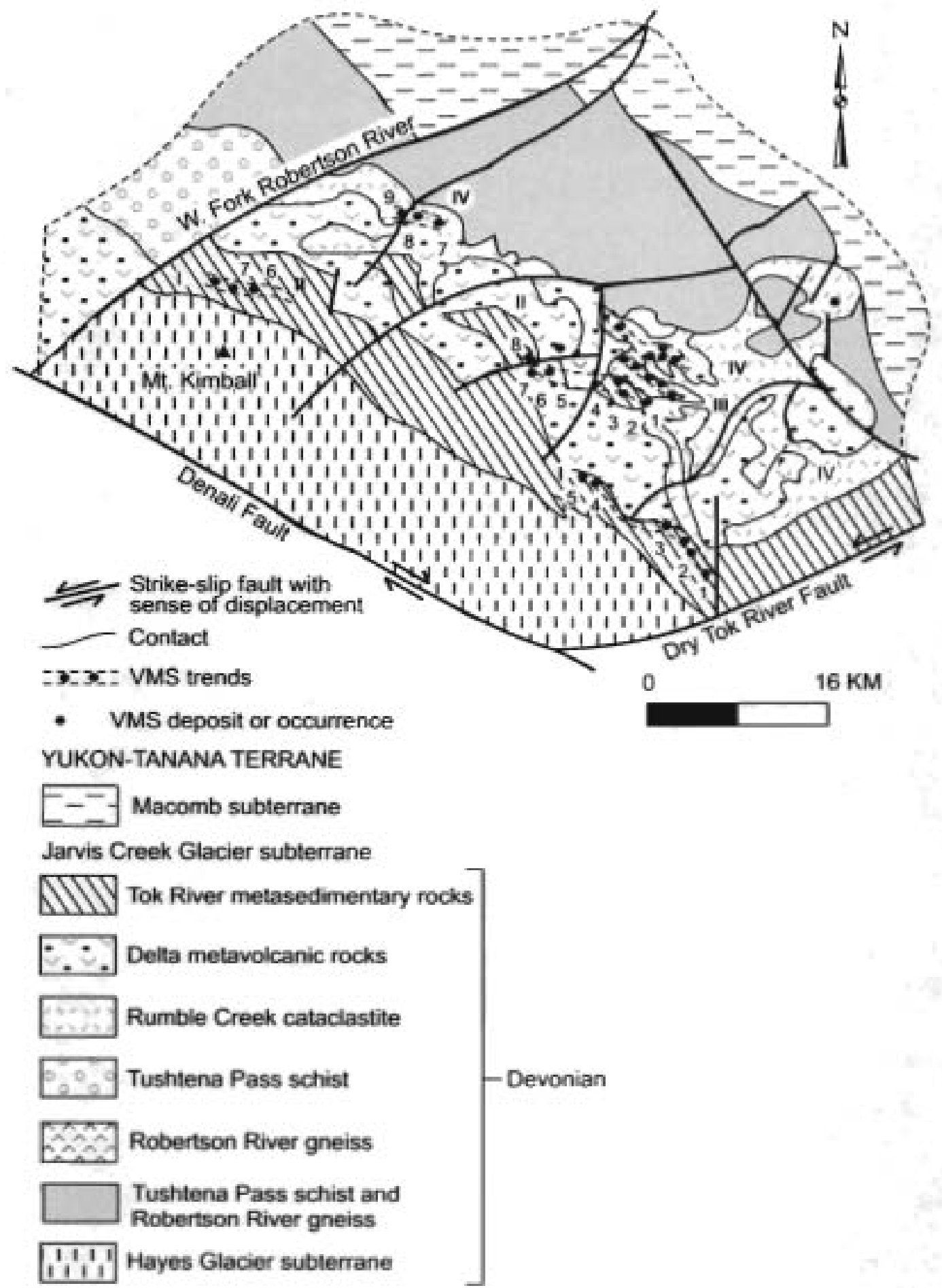

Figure 23. Delta district of kuroko massive sulfide deposits, Alaska Range and Yukon-Tanana Upland Metallogenic East-Central Alaska. Schematic geologic map. Roman numerals denote mineralization trends; arabic numerals denote deposits within a trend. Deposits: PP.LZ Trend (i), 1-LBB, 2-PPD, 3-UPP, 4-LZ East, 5-ZZ, 6-RC East, 7-RC; DD-Rum Trend (ii), 1-LBB, 2-Rum South, 3Rum North, 4-Lower Rum, 5-DDS, 6-DDX, 7-DDY, 8-DDN; PG-Trio-HD Trend (IV), 7-PGX, 8-PG, 9-PGW; VMS-volcanogenic massive sulfide. Modifled from Lange and others (1993).

Besshi Cu-Zn-Pb massive sulfide occurrences, such as Lucky Joe (Mortensen, 1992), are hosted in Devonian and Mississippian mafic metavolcanic and carbonaceous metasedimentary rocks. The occurrences are Kuroko and Beschi deposits which are associated with calc-alkaline and tholeiitic volcanic rocks, respectively. The bost rocks are part of the Late Proterozoic to early Paleozoic Nisling assemblage which consists of continental margin metasedimentary rocks. These deposits and host rocks are correlated with similar, larger deposits of the Delta district in Alaska Range and Yukon-Tanana Upland metallogenic belt of Kutoke volcanogenie massive sulfide deposits described above. These extensive middle Paleozoic volcanics and granitoids are 
interpreted by and as part of a exiensive continental-margin are in the Late Devonian and Early Mississippian which formed along the margin of the North American Craton Margin (Lange and others, 1985; Montensen, 1992; Nokleberg and others, 2000).

Small pyrite-bearing Pb-20-Bs lens-shaped occurrences, as at Mickey (Mortensen, 1992), are hosted in carbonaceous schist and quartzile and Middle Mississippian felsic metatuff. These deposits are interpreted as SEDEX Zn-Pb deposits may be correlated with similar-age SEDEX deposits of the Gataga metallogenic belt $1,000 \mathrm{~km}$ to the southeast, across the Tintina fault (fig. 17) (Johnston and Mortensen, 1994). However, the Dawson metallogenic belt is hosted in the Yukon-Tanana terrane which is interpreted as a nifted fragment of the North American Craton Margin (Montensen, 1992; Monger and Nokleberg, 1996; Nokleberg and others, 2000) whereas these metallogenic belts to the east containing SEDEX deposits are hosted in a Devonian-Mississippian clastic wedge deposited on the North American Craton Margin (Nokleberg and others, 1997b, 1998, Sheet 4). The host rocks for this part of the Dawson metallogenic belt are part of the Nasina assemblage which consists of Late Devonian to Middle Mississippian mafic to felsic metavolcanic rocks, quartzite, schist, and metaplutonic rocks. The tectonic origin of this group of deposits is unclear.

Pyrite-bearing Kuroko $\mathrm{Pb}-\mathrm{Zn}-\mathrm{Cu}$ (Au-Ba) massive sulfide occurrences, as at Lone Star (Mortensen, 1992), are hosted in middle Permian felsic metavoleanic rocks. The host rocks are part of the Klondike schist and associated units which consist mainly of middle Perman felsic metavoleanic and metaplutonic rocks (Mortensen, 1992). Structurally interleaved with the metavoleanic rocks are blueschist and eclogite which are interpreted as remnants of a former subduction zone which was tectonically linked to the volcanic arc which formed the metavoleanic rocks and associated oceurrences.

\section{Frances Lake Metallogenic Beit of Volcanogenic \\ Zn-Cu.Pb Massive Sulfide Deposits (Belt FR) Southern Yukon Territory}

The Frances Lake metallogenic belt of volcanogenic massive sulfide deposits (fig. 17; tables 3,4) occurs in the southeastern Yukon Territory and is hosted in Early Mississippian felsic metavolcanic rocks and meta volcaniclastic units is the Yukon-Tanana terrane. The kuroko massive sulfide deposits, which occur northeast of the Tintina Fault and southwest of Finlayson Lake, are interpreted as equivalent to: (1) smaller kuroko massive sulfide occurrences in the Dawson metallogenic beli (as at Mickey) which oecur southwest of the Tintina fault and are hosied in the Nasina Assemblage (Johnston and Mortensen 1994); and (2) major kuroko volcanogenic massive sulfide deposits which occur across the Tintina fault in the Alaska Range and Yukon-Tanana Upland metallogenic belt in East-Central Alaska. The significant deposits are at Kudz Ze Kayah and Wolverine (table 4). Local Besshi and Cyprus volcanogenic massive sulfide deposits also occur in the belt.

\section{Kudz Ze Kayah Kuroko Massive Sulfide Deposit}

The Kudz Ze Kayah kuroko Zn-Cu-Pb massive sulfide deposit consists of pyrite-bearing massive sulfide bodies which are associated with deformed, subvolcanic domes or thick sills which occur within felsic metavolcanic units. The deposit contains mineable reserves of 11.3 million tonnes grading $5.9 \% \mathrm{Zn}, 0.98 \% \mathrm{Cu}, 1.5 \% \mathrm{~Pb}, 133 \mathrm{~g} / \mathrm{Ag}$, and $1.34 \mathrm{~g} / \mathrm{Au}$ (Mining Review, summer, 2000). The deposit and similar oecurrences are hosted in felsic metavolcanic rocks of the Late Devonian to Middle Mississippian Nasina Assemblage which constitutes the middle structural sequence of the Yukon-Tanarna terrane (Mortensen, 1992).

\section{Wolverine-Lymx Kuroko Massive Sulfide Deposits}

The Wolverine-Lyax kuroko $\mathrm{Zn}-\mathrm{Cu}-\mathrm{Pb}-\mathrm{Ag}-\mathrm{Au}$ massive sulfide deposits consist of massive sulfides in a fragmental thyolite unit which is capped by an extensive magnetile iron formation and limy exhalite. The deposit contains estimated reserves (Wolverine and $\mathrm{Lynx}$ ) of 6.2 million tonnes grading $12.66 \% \mathrm{Zn}, 1.3 \% \mathrm{Cu}, 1.5 \% \mathrm{~Pb}, 350 \mathrm{~g} / \mathrm{Ag}$, and $371 \mathrm{~g} / \mathrm{Au}$ (Mining Review, summer 2000). The deposit occurs in the Yukoo-Tanana terrane about $135 \mathrm{~km}$ southeast of Ross River, Yukon Territory. It is hosted by interbedded felsic volcanics and argillite of Devonian and Mississippian age.

\section{Origin of Tectonic Serting for Frances Lake Metallogenic Belt}

The eastern Frances Lake belt of kuroko massive sulfide deposits is hosted subvoleanic felsic domes or sills (Johnston and Mortensen, 1994) which form lensoidal metavolcanic units which interfinger with fine-grained quartzite and carbonaceous schist of the Devonian and Mississippian Nasina Assemblage or Nisutlin subterrane of the Yukon-Tanana terrane. The Nasina Assemblage consists of earbonaceous quartzite, quartz-mica schist, marble, mafic and felsic metavolcanic rocks and lesser amounts of metaplutonic rocks. These units are interpreted as part of the extensive Kootenay continental-margin igneous are which formed along the margin of the North American Craton Margin, subsequent to rifting of the Yukon-Tanana and related terranes (Mortensen, 1992; Nokleberg and others, 2000). Remnants of the extensive middle Paleozoic Kootenay continental margin arc and associated lode deposits exiend for several thousand $\mathrm{km}$ in various metamorphosed continental margin termanes in Northem Alaska, East Central Alaska, the northem and southem Canadian Cordillera, and Southeastem Alaska (Rubin und others, 1991; Plafker and Berg, 1994; Nokleberg and others, 1994c, 1997c; Monger and Nokleberg, 1996; Nokleberg and others, 2000). Fragments of the 
Kootenay arc include the following metallogenic belts, in addition to the frances Lake belt, which host kuroko massive sulfide and related deposits (Nokleberg and others, 1997a, b, c): (1) The Arctic metallogenic belt hosted in the Coldfoot terrane in Arctic Alaska; (2) Alaska Range and Yukon-Tanana Upland metallogenic bell hosted in the Yukon-Tanana terrane in central and eastern Alaska; (3) Tracy metallogenic belt bosted in the Yukon-Tanana tertane in Scutheastern Alaska and westem British Columbia; and (4) Kootenay-Shuswap metallogenic belt hosted in the Kootenay terrane in the southern Cunadian Cordillera.

Tracy Metallogenic Beit of Kuroko Massive

Sulfide Deposits (Beit TR) Southeastern

Alaska and Western British Columbia

The Tracy metallogenic belt of kuroko massive sulfide deposits (fig. 17; 1ables 3, 4) extends from Southeastern Alaska into western British Columbia and is bosted in Devonian and Mississippian interlayered metavolcanic and metasedimentary rocks of the Yukon-Tanana terrane. In this region, the Yukon-Tanana metamorphosed continental margin terrane occurs as two, colinear, narrow fault-bounded fragments which extend discontinuously north-northeast for several hundred $\mathrm{km}$ west of the Stikinia islandare terrane. The significant deposits are at Alamo, Ecstall, Packsack, Red River. Scotia, Sumdum, and Sweetheart Ridge (table 4) (Nokleberg and others 1997a, b, 1998).

\section{Sumdum Kuroko Zn-Cu Massive Sulfide Deposit}

The Sumdum kuroko $\mathrm{Zn}$-Cu massive sulfide deposit consists of massive lenses and disseminated zones containing pyrrhotite, pyrite, chalcopyrite, sphalerite, and lesser bornite, malachite, azurite, and galena in bodies up to $15 \mathrm{~m}$ wide (Brew and Grybeck, 1984; Kimball and others, 1984). The deposit contains an estimated 24 million tonnes grading $0.57 \% \mathrm{Cu}, 0.37 \% \mathrm{Zn}$, and 10.3 to $103 \mathrm{~g} / \mathrm{t} \mathrm{Ag}$, assuming deposit continues beneath the Sumdum Glacier. The zones occur parallel to layering along the crest and flanks of an isoclinal fold in Paleozoic or Mesozoic metasedimentary schist and gneiss at the western edge of the informally named Coast plutonic-metamorphic complex of Brew and Ford (1984), Local sulfide-bearing veins(?) and fault breccia, which may postdate the stratabound deposit, may represent remobilization of the original deposit.

\section{Ecstall Kuroko Zn-Cu Massive Sulfide Deposit.}

The Ecstall kuroko Zn-Cu massive sulfide deposit, which consists of pyrite, chalcopyrite, sphalerite, pyrrhotite, marcasite, and galena, occurs in two tabular massive stratabound lenses in Middle Devonian schist, quartzite which are intruded by granitoid gneiss. These units are part of the Nisling assemblage of the Yukon-Tanana terrane in the Coast Plutonic Complex of British Columbia, Canada (EMR Canada, 1989; Hoy, 1991; Allrick and others, 2001; MINFILE, 2002), The deposit contains estimated reserves of 6.9 million tonnes grading $0.65 \% \mathrm{Cu}$, and $2.5 \% \mathrm{Zn}$. The deposit occurs in a metavolcanic sequence which is overprinted by an intense hydrothermal alteration assemblage of chlorite, sericite, and silica.

\section{Origin of and Tectonic Controls for Tracy Metallogenic Belt}

The Tracy metallogenic belt of kuroko massive sulfide deposits is hosted in metavolcanic and interlayered metasedimentary rocks of the Cambrian to Devonian Nasina and Nisling assemblages and equivalent rocks of the Yukon-Tanana terrane. The assemblage consists of carbonaceous quartzite, quartz-mica schist, marble, mafic and felsic metavolcanic rocks and lesser amounts of metaplutonic rocks. Locally large parts of the terrane occur in pendants and screens within plutons of the Coast Plutonic Complex. These units are interpreted as part of the extensive continental-margin igneous arc which formed along the North American Craton Margin, prior to rifting of the Yukon-Tanana and related terranes (Nokleberg and others, 1994c, 1997c). Remnants of the extensive middle Paleozoic Kootenay continental margin arc and associated lode deposits extend for several thousand $\mathrm{km}$ in various metamorphosed continental margin terranes in Northem Alaska, East Central Alaska, the northem Canadian Cordillera, and Southeastern Alaska (Rubin and others, 1991; Plafker and Berg, 1994; Nokleberg and others, 1994c, 1997c; Monger and Nokleberg, 1996; Nokleberg and others, 2000). Fragments of the Kootenay are include several metallogenic belts hosting the kuroko volcanogenic massive sulfide and related deposits (Nokleberg and others, 1997a, b, c): (1) The Arctic metallogenic belt in the Coldfoot terrane in Aretic Alaska; (2) Alaska Range and Yukon-Tanana Upland metallogenic belt in the Yukon-Tanana terrane in central and eastem Alaska; (3) the Tracy metallogenic belt hosted in the Yukon-Tanana terrane in Southeastern Alaska and westem British Columbia; and (4) the Frances Lake belt in the Yukon-Tanana terrane in the southern Yukon Territory; and (5) the KootenayShuswap belt in the Kootenay terrane in the southem Canadian Cordillera, and the Frances Lake metallogenic belt in the southem Yukon Territories. 
Mount Sicker Metallogenic Belt of Kuroko

Volcanogenic Massive Sulfide

Zn-Cu-Pb-Au-Ag Deposits (Belt MS)

Vancouver hland

The Mount Sicker metallogenic belt of kuroko massive sulfide Zn-Cu-Pb-Au-Ag deposits (fig 17; tables 3, 4) occurs in southwestem British Columbia on Vancouver Island. The belt is hosted by the Late Devonian to Early Permian Sicker Group, a sequence of are-felated voleanic and sedimentary strata in the southem Alexander sequence of the Wrangellia superterrane. The significant deposits are at Mount Sicker near Duncan (Lenora-Tyee, Twin J, Lara, Copper Canyon), and Myra Falls (Buttle Lake, Lynx, H-W, Battle; table 4) (Nokleberg and others 1997a, b, 1998).

\section{Mount Sicker (Lenora-Tyee, Twin L, Lara, Copper Canyon) Kuroho Massive Sulfide Zn-Cu-Pb-Au-Ag Deposit}

The Mount Sicker (Lenorn-Tyee, Twin J. Lara, Copper Canyon) kuroko massive sulfide Zn-Cu-Pb-Au-Ag deposit consists of massive pyrite, chalcopyrite, sphalerite, galena with barite hosted in Late Devonian felsic volcanic tuffs of the McLaughlin Ridge Formation (Juras, 1987; Sicker Group; Hoy, 1991; Robinson and others, 1994). The combined estimated reserves and production for the Lenora-Tyee-Twin J deposit are 594,852 tonnes grading $2,46 \%, \mathrm{Cu}, 3.85 \% \mathrm{Zn}, 0.37 \% \mathrm{~Pb}, 117.0$ el $\mathrm{Ag}$, and $2.5 \mathrm{gt}$ Au. Estimated reserves for the Lara deposit are 529,000 tonnes grading $1.01 \% \mathrm{Cu}, 5.87 \% \mathrm{Zn}, 1.22 \% \mathrm{~Pb}, 100.1$ $8 / \mathrm{Ag}$, and $4.73 \mathrm{~g} / \mathrm{Au}$. Estimated reserves for the Copper Canyon deposit are 32.4 million tonnes grading $0.75 \% \mathrm{Cu}, 8.57 \mathrm{~g} / \mathrm{Ag}$. and $1.17 \mathrm{~g} / \mathrm{Au}$ (Dawson and others, 1991).

\section{Myra Falls (Buttle Lake, Myra, Lynx, H.W, Battle) Kuroko Massive Sulfide Zn-Cu -Au-Ag Deposit}

The Myra Falls (Lyax-Myra, Price, H-W, Battle) kuroko volcanogenic massive sulfide $\mathrm{Zn}-\mathrm{Cu}$-Au-Ag deposit (fig. 24)consists of massive sphalerite, chalcopyrite, pyrite and lesser galena and barite with minor tennantite, bornite, pyrrhotite, digenite, covellite and stromeyerite which occur in a number of lenses along an east-west trend (Juras, 1987; Juras and Peanon, 1991; Dawson and others, 1991; Hoy, 1991; George Cross Newsletter no. 30, February 12, 1993; Pearson, 1993). The deposits contain an estimated combined production and reserves of 30.3 million tonnes grading $2.23 \mathrm{~g} / \mathrm{Au}, 54.5 \mathrm{~g} / \mathrm{Ag}, 2.12 \% \mathrm{Cu}$, and $7.1 \% \mathrm{Zn}$. The deposit is hosted within felsic voleanies of the Late Devonian Myra Formation in the Sicker Group. The deposits occur at two stratigraphic levels; the H-W horizon, at the base of the Myra Formation, and the Lymx-Myra-Price horizon, in the central portion of the Myra Formation. Under the H-W deposit, the stratigraphic footwall consists of greater than $300 \mathrm{~m}$ of basaltic andesite of the Price Fomation which in tensely altered to to quartz-sericite-pyrite.
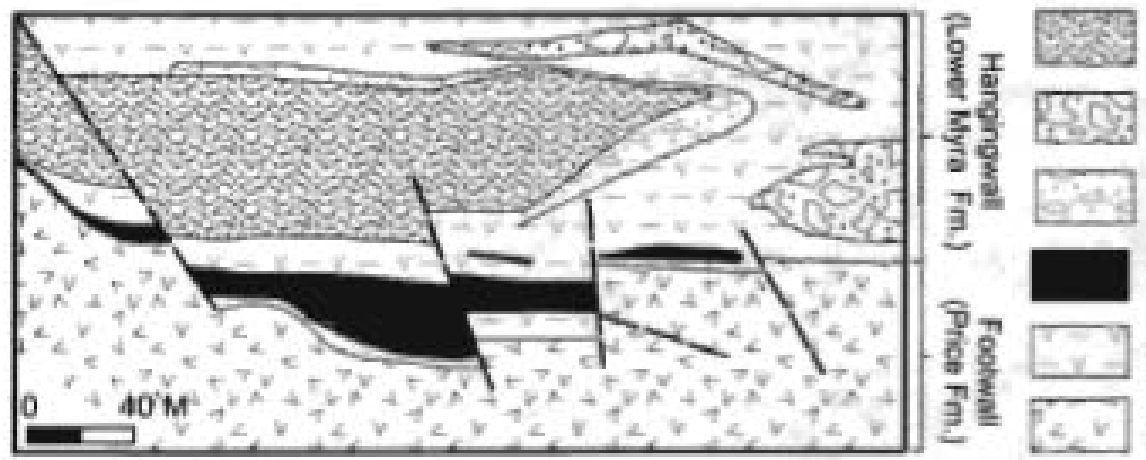

Quartz - feidspar phyric rhyolie Massive to in - situ breccialed

Hangingwall mafic sil: Massive to in - situ beccciated

Zone of intersction between mafic sill and felsic volcaniclastic debris Massive to semimassive sulphide Interbedded quartz - feldspar phyric volcaniclastic beds and black mudstone

Footwall mafic volcanic rock

Figure 24. H.W kuroko massive sulphide Zn-Cu-Au-Ag deposit, Mount Sicker metallogenic belt, Canadian Cordillera. Schematic cross section. Adapted from Barrett and Sheriock (1996b).

\section{Origin of and Tectonic Controls for Mount Sicker Metallogenic Belt}

The kuroko volcanogenic massive sulfide Zn-Cu-Pb-Au-Ag deposits in the Mount Sicker metallogenic belt occur mainly in fragmental basaltic andesite, lesser dacite and andesite, intermediate pillow lava, and epiclastic volcanic rock. The host rock and deposit distribution are defined by three fuulf-bounded uplifs. The voleanic rocks are 310 to $440 \mathrm{~m}$ thick and exhibit an U-Pb zircon isotopic age of $370 \mathrm{Ma}$ (Juras, 1987). Underlying pillow basaltic flows of the Price Formation formed during a nonexplosive effusive event which was succeeded by rifting, felsic volcanism, and formation of massive sulfide deposits. The volcanic rocks are overlain by Carboniferous sedimentary rocks which contain bioclastic crinoidal limestone in the Buttle Lake Formation. Significant kuroko massive sulfide deposits occur in felsic volcanics of the upper part of the Sicker Group in domal 
culminations. The calc-alkaline volcanic rocks hosting the Mount Sicker metallogenic belt are interpreted as part of the minor, middle Paleozoie Sicker island are which forms the oldest part of the Alexander sequence of the Wrangellia superternae (Monger and Nokleberg, 1996; Nokleberg and others, 1994c, 1997c). In this paper, following Nokleberg and others (1994c. 2000), the Wrangellia superternane is subdivided into three sequences, from west to east to southeast, the Peninsular, Wrungellia, and Alexinder sequences. These sequences are interpreted as form the once continuous core of the superterrane and have heen subsequently lectonically dismembered.

\section{Kootenay-Shuswap Metallogenic Belt of \\ Volcanogenic Zn-Pb-Cu-Ag-Au \\ Massive Sulfide Depesits(Belt KS) \\ Southern British Columbia}

The Kootenay-Shuswap metullogenic belt of voleanogenic $\mathrm{Zn}-\mathrm{Pb}-\mathrm{Cu}-\mathrm{Ag}$-Au massive sulfide deposits (fig. 17: tables 3. 4) occurs in Southern British Columbia. The belt is hosted in is a discontinuous assemblage of metamorphosed and intensely deformed siliceous clastic, carbonate, volcunic, and plutonic rocks of the Kootenay terrane in the Shuswap region. This metamorphosed continental margin terrane excurs between the North America Craton Margin to the east, and the accreted island are Quesnellia ternune to the west (fig. 17). The belt contains Kuroko, Besshi, Cyprus, SEDEX Zn-Pb, Southeast Missouri, and bedded barite deposits (table 4) (Nokleberg and others (1997a, b). Four types of volcanogenic massive sulfide deposits are recognized by Preto and Schiarriza (1985). The significant deposits in the metallogenic belt are the Cyprus-type Chu Chua and Harper Creek Cyprus massive sulfide deposits, the kuroko-type Homestake and Rea (Hilton) kuroko sulfide deposits, the Goldstream Besshi massive sulfide deposit, the Adams Plateau Zn-Pb-Ag SEDEX deposits (Spar, Lucky Coon. King Tutt, Mosquito King), and the Rexspar (Birch Island) felsic plutonic U-REE deposit (Nokleberg and others 1997a, b, 1998).

\section{Homestake and Rea Gold Kuroko $\mathrm{Zn}$-Pb-Cu-Au-Ag Deposits}

The Homestake kuroko $\mathrm{Zn}-\mathrm{Pb}-\mathrm{Cu}-\mathrm{Au}-\mathrm{Ag}$ deposit consists of two tabular sulfide-barite horizons which occur in intensely quartz-sericite-pyrite altered sericite schist derived from felsic to mafic tuffaceous units of the Devonian Eagle Bay Assemblage (Dawson and others, 1991; Hoy, 1991). Sulfide minerals are ietrabedrite, galena, sphulerite, pyrite, and chalcopyrite, Estimated reserves are 919.420 tonnes grading $248 \mathrm{~g} / \mathrm{Ag}, 2.5 \% \mathrm{~Pb}, 4 \% \mathrm{Zn}, 0.55 \% \mathrm{Cu}$, and 275,500 tonnes grading $36.7 \% \mathrm{Ba}$. The deposit is overlain by intermediate to felsic voleanics of Eagle Bay Assemblage. The Rea Gold volcanogenic sulfide deposit occurs about $4 \mathrm{~km}$ to the norwest, and contains contains mining reserves of 376,385 tonnes grading $2.2 \% \mathrm{~Pb}, 2.3 \% \mathrm{Zn}, 6.1 \mathrm{~g} / \mathrm{Au}$, and $76 \mathrm{~g} / \mathrm{l}$ Ag.

\section{Goldstream Besshi Cu-Zn-Ag Deposit}

The Goldstream Besshi Cu- $\mathrm{Zn}-\mathrm{Ag}$ volcanogenic massive sulfide deposit occurs in the easiern part of the Kootenay terrane and consists of massive pyrmotite, chaicopyrite and sphalerite oflen exhibiting gneissic texture with sub-rounded quartz, phyllite and carbonate inclusions (Høy, 1991; MINFILE, 2002). The deposit occurs as a thin, conformable sheet (400 × $1500 \times 1$ $3 \mathrm{~m}$ thick) and as several other borizons in sericile quartzite and calcareous and chloritic phyllite in the lower Index Formation of the Cambrian Lardeau Group. The host metavolcanic-phyllite unit consists of mafic tholeintic volcanic rocks, massive greenstone, chloritic phyllite, ultramafic pods and dark calcareous to pelitic schist. In 1983 and 1984, 427,886 tonnes were mined averaging $8.9 \mathrm{~g} / \mathrm{Au}, 4.43 \% \mathrm{Cu}$, and $0.12 \% \mathrm{Zn}$. Production restarted in 1992; estimated reserves are 3.2 million tonnes grading $4.5 \% \mathrm{Cu}$, $3.1 \% \mathrm{Zn}$, and $20 \mathrm{~g} / \mathrm{Ag}$.

\section{Harper Creek and Chu Chua Cu-Zn-Ag-Au Deposits}

The Harper Creek Cu-Ag-Au volcanogenic massive sulfide deposit consists of disseninated pyrite, pymhotite and chalcopyrite with minor molybdenite, galena, sphalenite, and tetrahedrite which occur in tabular zones in mafic metavolcanic rocks and quartz-sericite phyllite of the Devonian Eagle Bay Formation (Preto and Schiarizza, 1985; Schiariza and Preto, 1987; Hoy, 1997. The deposit occurs in two parts: (1) the East Zone with reserves of 42.5 million tonnes grading $0.3946 \mathrm{Cu}, 2.4 \mathrm{glt} \mathrm{Ag}$, and $0.044 \mathrm{~g} / \mathrm{Au}$; and (2) the West Zone with reserves of 53.5 million tonnes grading $0.42 \% \mathrm{Cu}, 2.6 \mathrm{~g} / \mathrm{Ag}$ and $0.047 \mathrm{gl} / \mathrm{Au}$. The deposit has estimated reserves of 96 million tonnes grading $0.41 \% \mathrm{Cu}, 2.5 \mathrm{~g} / \mathrm{Ag}, 0.04 \mathrm{~g} / \mathrm{Au}$, and $0.016 \% \mathrm{Mo}$. A skarn or porphyry origin was interpreted by Schiariza and Preto (1987) with a relation to Devonian intrusive rocks which are now metamorphosed to orthogneiss and are interpreted as derived from bimodal, calcalkaline volcanic rocks. The deposit is herein interpreted as a kuroko massive sulfide deposit.

The Chu Chua Cyprus $\mathrm{Cu}-\mathrm{Zn}$ volcanogenic massive sulfide consists of pyrite with chalcopyrite and minor sphalerite which occur in two major and several smaller stratiform massive sulfide lenses associaled with pyritic, cherty sediments and pillow basalt of the late Paleozoic (Devonian to Permian) Fennel Formation (McMillan, 1980; Schiarizza and Preto, 1987). Chalcopyrite and sphalerite occur interstitially to pyrite. Basalt is locally extensively altered to talc and carbonate in structures 
interpeted as vents. The deposit contains estimated reserves of 2.5 million tonnes grading $2 \% \mathrm{Cu}, 0.5 \% \mathrm{Zn}, 0.5 \mathrm{~g} / \mathrm{Au}, 9 \mathrm{~g} / \mathrm{Ag}$. The deposit is interpreted as a Cyprus(7) massive sulfide deposit (Hoy, 1991).

\section{Adams Plateau SEDEX Zn.Pb-Ag Deposits}

Several SEDEX Zv-Pb-Ag deposits, which occur in the Adams Plateau area, are hosted in clastic metasedimentary sequences of probable Cambrian age and lower Eagle Bay Assemblage (Schiariza and Preto, 1987; Hoy, 1991) in the Kootenay terrane, and Devonian and older magmatic are rocks in the Yukon-Tanana terrane in the Canadian Cordillera. The assemblage is correlative in part with the Nisutlin Assemblage of the Yukon-Tanana terrane (Wheeler and McFeely, 1991). The significant deposits ure two previously-producing, small mines at Mosquito King and Lucky Coon.

\section{Origin of and Tectonic Setting for Kootenay-Shuswap Metallogenic Belt}

A diverse group of volcanogenic and related mineral deposits occur in the Kootenay-Shuswap metallogenic belt. Because of a wide range of age of host rocks and deposits, this metallogenic belt may be divided into two metallogenic belts, one of Cambrian age and the other of Devonian and Mississippian age.

The Kuroko massive sulfide deposits in the Kootenay-Shuswap metallogenic belt are hosted in Devonian and Mississippian felsic to intermediate metavolcanic units. The calc-alkaline igneous-are rocks are interpreted as part of the extensive middle Paleozoic continental-margin are which extends for several thousand $\mathrm{km}$ along the North American Craton Margin (Grantz and others, 1991; Rubin and others, 1991; Plafker and Berg, 1994; Nokleberg and others, 1994c, 1997c; Monger and Nokleberg. 1996). Fragments of the continental-margin are include several metallogenic belts hosting the kuroko massive sulfide and related deposits (Nokleberg and others, $1997 \mathrm{a}, \mathrm{b}, \mathrm{c}$ ): (1) The Arctic metallogenic belt hosted in the Coldfoot terrane in Arctic Alaska; (2) Alaska Range and Yukon-Tanana Upland metallogenic belt hosted in the Yukon-Tanana terrane in central and eastern Alaska; and (3) the Frances Lake and Finlayson Lake metallogenies belt hosted in the Yukon-Tanana terrane in the southern Yukon Territory.

The Cyprus massive sulfide deposits in the Kootenay-Shuswap metallogenic belt are hosted in Devonian mafic volcanic and associated metasedimentary rocks. The deposits and bost oceanic assemblages, together with SEDEX sulfide deposits and their host rocks, oceur in imbricaled thrust sheets within other assemblages in the Kootenay terrane. These oceanic assemblages and deposits, which are interpreted to have formed in the back-are of the Kootenay arc, and were subsequentally structurally emplaced within shelf and continental-margin are parts of the Kootenay terrane during accretion of the outboard Slide Mountain oceanic terrane in the Jurassic (Monger and Nokleberg, 1996; Nokleberg and others, 2000).

The Besshi $\mathrm{Cu}-\mathrm{Zn}-\mathrm{A}_{\mathrm{E}}$ deposits in the Kootenay-Shuswap metallogenic belt are hosted in Cambrian tholeitic metavolcanic and associated rocks which constitutes the older part of the Kootenay terrane. The Besshi $\mathrm{Cu}-\mathrm{Zn}$-Ag deposits in the KootenayShuswap metallogenic belt are herein interpreted as forming in a short-lived Cambrian continental-margin arc.

The Adams Plateau SEDEX Zn-Pb-Ag deposits in the Kootenay-Shuswap metallogenic belt are bosted in Cambrian metasedimentary rocks. The deposits are correlated with similar SEDEX deposits in the Kootenay metallogenic belt to the east. and with deposits in the Anvil and Howards Pass metallogenic belts to the north in the Selwyn Basin of the northem Canadian Cordillera. All three metallogenic belts are interpreted as forming from $\mathrm{Pb}$ - and $\mathrm{Zn}$-rich fluids during rifting, volcanism, basinal subsidence, local marine transgression, and related hydrothermal activity along the passive continental margin of the North American Craton.

\section{Metallogenic Belts Formed During Middle Paleozoic Rifting of North Asian Craton Margin}

\section{Kharnna River Metallogenic Belt of Carbonatite-Related $\mathrm{Nb}, \mathrm{Ta}$, and REE Deposits (Beit KR) Southern Part of Eastern Siberia}

The Khamna River metallogenic belr of carbonatite-related $\mathrm{Nb}, \mathrm{Ta}$, and REE deposits (tables 3,4) oceurs in the southem part of eastem Siberia in the North Asian Craton Margin (fig. 16; Verkhoyansk fold belt, unit NSV) (Nokleberg and others, 1994c). The belt strikes north-south, is about $300 \mathrm{~km}$ long, and varies from 20 to $60 \mathrm{~km}$ wide. The significant deposits are at Khamna and Gomoye Ozero (table 4) (Nokleberg and others 1997a, b, 1998). These deposits consist of pyrochlore, orthite, perovskite, and monozite which occur in halos adjacent to or around alkalic igneous rocks. The Khamna River metallogenie belt is similar to the Tommot River metallogenic belt, described below, oceurs in the passive continental margin Omulevka terrane of the Kolyma-Omsolon superterrane in the western part of the Russian Northeast. 
The Khamna deposit (Elyanov and Moralev. 1973; N.D. Kobtseva and T.G. Devyatkina, written commun., 1988) consists of steep fluorite-carbonate veins and stockworks which occur in Late Proterozoic metasomatic carbonate in the vicinity of dikes and stocks of probable Late Devonian alkalic syenite and alkalic magmatic breccia. The veins range from 0.1 to $1.5 \mathrm{~km}$ long and from 1.4 to $30 \mathrm{~m}$ thick. Individual stockworks are $100-500 \mathrm{~m}^{2}$ in size. The main ore minerals are bastnaesite, parisite, and galena. Disseminated mineralization also oceurs. The average grade is $0.2-1.93 \%$ REE; $0.03-0.26 \% \mathrm{Nb}_{2} 0_{3}$. The syenite exhibits $\mathrm{U}$ Th- $\mathrm{Pb}$ isotopic ages of which range from 240 to $417 \mathrm{Ma}$ (V.I. Shpikerman and N.A. Goryachev, this study).

\section{Gornoye Ozero Carbonatite-Related REE Deposit}

The majot Gornoe Ozero Nb-Ta-REE deposit (fig 25) (Korostylyov, 1982; N.D. Kobtseva and T.A. Devyatkina, written commun., 1988) occurs in a middle Paleozoic (Late Devonian) ellipsoid intrusion of alkalic rocks, with a surface area of $10.3 \mathrm{~km}^{2}$. The alkalic intrusion exhibits a zoned structure. The core consists of nepheline-cancrinite syenite and small relic pyroxenite and melteigite pockets. Carbonatite comprises up to $90 \%$ of the intrusion and occurs mostly in the periphery. The host rocks are limestone, shale, and siltstone of the middle Riphean Lakhandin suite which is altered to fenite near the intrusion. The carbonatite consists of dominate calcite, along with ankerite-calcite and dolomite-calcite. Other parts of the carbonatite contain aegirine, amphibole, chlorite, pyroxene, magnetite, biotite and barite. Relatively older parts of the intrusion contain pyroxenite are in association with perovskite, magnetite, spinel and apatite. Pyrochlore, apatite and magnetite occur in syenite which formed after pyroxenite. The relatively younger carbonatite formed during two stages: (1) un earlier stage of pyrochlore-hatchettolit; and (2) a later stage of REE minerals including bastnasite, parisite and monazite, and also pyrochlore and columbite). The average grade is $0.35 \%$ REE oxides; $0.09-0.36 \% \mathrm{Nb}_{2} 0_{9} ; 0.011 \% \mathrm{Ta}_{2} \mathrm{O}_{5}$. The complex exhibits $\mathrm{K}$ - $\mathrm{Ar}$ isotopic ages of 280 to $350 \mathrm{Ma}$ and the age of mineralization is interpreted as probably $290 \mathrm{Ma}$.
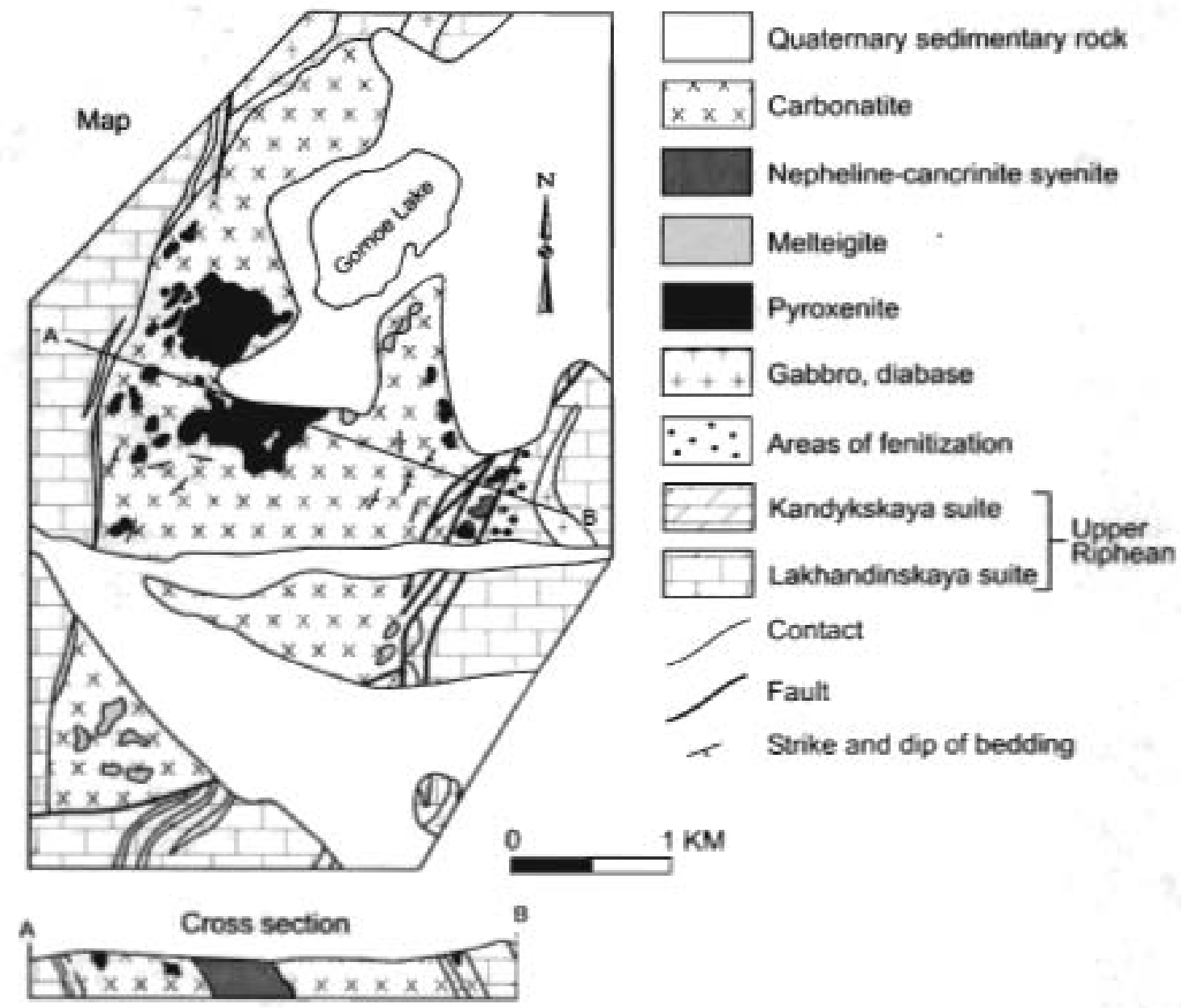

Figure 25. Gomoye Ozero carbonatite-related REE deposit, Khamna metallogenic beit, Russian Southeast. Adapted from Korostelev (1982). 
The carbonatjes and alkalic igneous rocks of the Khamna River metallogenic belt intrude Late Proterozoic and early Paleozoic sedimentary deposits of the folded margin of the North Asian Craton Margin (Shpikerman, 1998: Verkhoyansk fold belf, unit NSV). U-Pb isolopic studies of the carbonaties and ores yield an age of $41710240 \mathrm{Ma}$, and K-Ar isotopic studies yield an age of 350 to $280 \mathrm{Ma}$ (Ellyanov and Moralev, 1973). Because coeval, rift-telated basaltic rocks formed in adjacent areas neighboring areas, the Khamna River metallogenic beit is inierpreted as forming during rifting of the North Asian Craton during the Late Devonian to Early Mississippian. The sedimentary rocks of the Verkhoyansk fold belt are apparently tectonically detached from crystaline basement of craton. The fold belt is separated from the Siberian platform by a Late Cretaceous, westverging thrusi belt

\section{Sette-Daban Range Metallogenie Belt of Southeast Missouri Pb-Zn, Sediment-Hosted $\mathrm{Cu}$, and Basaltic $\mathrm{Cu}$ Deposits (Belt SD) \\ Southern Part of Eastern Siberia}

The Sette-Daban Range metallogenic belt of Southeast Missouri $\mathrm{Pb}-\mathrm{Zn}$, sediment-hosted $\mathrm{Cu}$, and basaltic $\mathrm{Cu}$ deposits (fig. 16; tables 3, 4) occurs in the southem part of eastern Siberia (Nokleberg and others, 1994c, 1997c; Shpikerman, 1998) in the North Asian Craton Margin (Verkhoyansk fold belt, unit NSV). The metallogenic belt trends south to north for more than $700 \mathrm{~km}$ along the Sente-Daban Mountain Range. The deposits, of Late Proterozoic to Early Carboniferous age, occur at different stratigraphic levels of the North Asian Craton Margin (Verkhoyansk fold belt, unit NSV). The major Southeast Missouri Pb-Zn deposits are at Lugun, Sakyryr., Segenyakh, and Uruí, the major sediment-bosted Cu deposit is at Kurpandzha; and the major basalitic Cu deposit is at Dzhalkan (table 4) (Nokleberg and others 1997a, b, 1998). The Southeast Missouri Pb-Zn deposits are the dominate deposit type in the metallogenic belt. The Southeast Missouri Pb-Zn deposits at Unui and Lugun occur in Vendian dolomile of the Udom Formtation and the Southeast Missouri Pb-Zn-fluorite occurrences at Segennyak and Sakyryr are hosted by Late Silurian dolomile of the Oron Formation. The sediment-hosted Cu deposits are associated with basaltic Cu deposits which usually occur at the same or nearby stratigraphic levels. The sediment-bosted $\mathrm{Cu}$ deposits are hosted in Late Devonian and Early Carboniferous sandstone and shale.

\section{Sardana Missouni Pb-Zn Deposit}

The Sardana Missouri Pb-Zn deposit (fige. 26) (Kuznetsov and Yanshin, 1979; Ruchkin and others, 1979; Kutyrev and others, 1989) consists of disseminated, banded, massive, and breecia and ore and stringers which oecur within and adjacent to a dolomite bioherm which ranges from $50-80 \mathrm{~m}$ thick. The bioherm is hosted in the Late Proterozoic (Late Vendian) dolomite of the Yudom Formation. The ore bodies are lenticular, ribbon-like, and cylindrical in form, and are mostly confined to the overturned limb of a syncline. The limb dips eastward at $75-85^{\circ}$. The ore bodies range up to $40 \mathrm{~m}$ thick and are 200 to $300 \mathrm{~m}$ long at depth. Drilling indicates additional ore bodies occur at a depth of 200 to $300 \mathrm{~m}$. Most of the ore is associated with metasomatic, sugartextured dolomite and zebra (brown and white striped) dolomite. The main ore minerals are sphalerite, galena, calcite, and dolomite, and subordinate ore minerals are pyrite, mareasite, arsenopyrite, quartz, and anthraxolite. Oxidized ore minerals include smithsonite, cerussite. anglesite, goethite, hydrogoethite, and aragonite. Low-grade disseminations occur in Late Proterozoic (Late Vendian) dolomite for many kilometers in both limbs, and in the axis of a north-south-trending syncline which is $3 \mathrm{~km}$ wide and more than $10 \mathrm{~km}$ long. The deposit is medium to large with reserves of more than 1.0 million tonnes $\mathrm{Pb}+\mathrm{Zn}$, and a $\mathrm{Pb}: \mathrm{Zn}$ ratio of 1:3-4. The dolomite of Yudom Formation is $200 \mathrm{~m}$ thick and transgressively overlies Late Proterozoic (Late Riphean) quartz and quartz-feldspar sandstone and siltstone which in turn is conformably overlain by Early Cambrian variegated clay and carbonate rocks. The deposit intruded by sparse diabase and dolerite dikes.

\section{Urui Southeast Missouri Pb-Zn Deposit}

The Urui Southeast Missouri Pb-Zn deposit (Ruchkin and others, 1977; Volkodav and others, 1979; Bogovin and others, 1979; N.D. Kobtseva and T.G. Devyatkina, written commun., 1988) consists of stratified ribbon-like deposits, from $2-3$ to $40 \mathrm{~m}$ thick and 0.5 to $1.2 \mathrm{~km}$ long, which occur in metamorphosed Late Proterozoic (Vendian) dolomite. The ore bodies are conformable to host rocks and strike $30-45^{\circ} \mathrm{NW}$; and commonly wedge out at a depth of $30-40 \mathrm{~m}$. The deposits vary from massive, pocket-stringer-disseminated, to banded. Galena and sphalerite are the $\mathrm{m}$ ain ore minerals; pyrite, marcasite, arsenopyrite are secondary; and pyrthotite, chalcopyrite, and electrum are scarce. Calcite, quartz, and anthraxolite also occur. The deposit is medium to large with an average grade of 9.9-25.6 Pb; 6.4-21.3\% $\mathrm{Zn} ; 6.8-200 \mathrm{~g} / \mathrm{Ag}$; up to $10 \mathrm{~g} / \mathrm{Ge}$. The deposit is associaled with a significant recrystallization of dolomite and formation of peculiar zebra dolomite rocks. The general structural pattern of deposit conirolled by monoclinal strike of sedimentary rocks to the west and by numerous post-ore faults which trend roughly east-west and strike northwest. Local Paleozoic diabase dikes in area. 

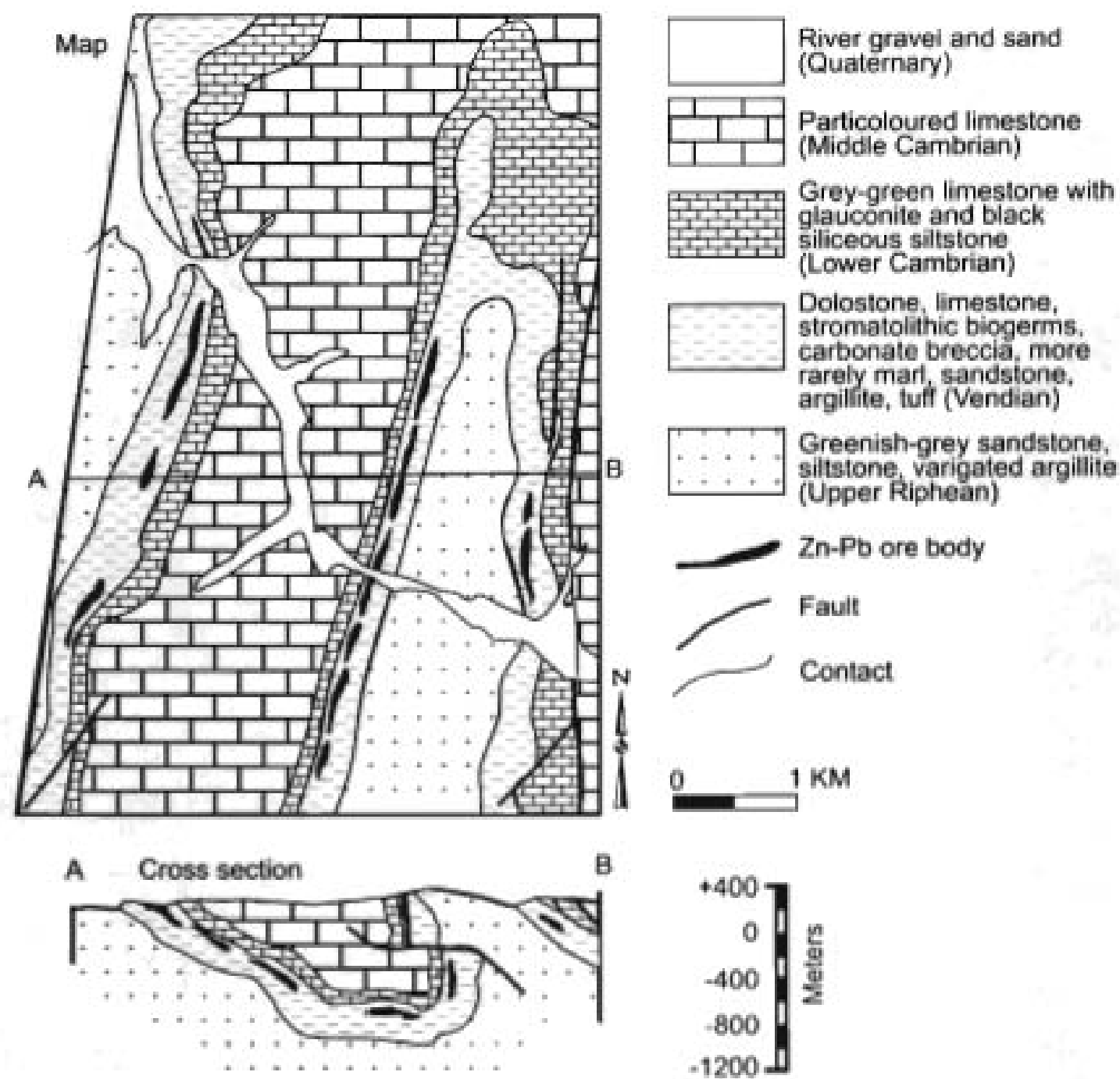
.... Greenish-grey sandstone. siltstone, varigated argillite (Upper Riphean)
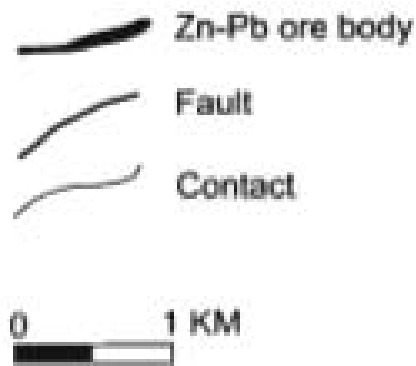

B

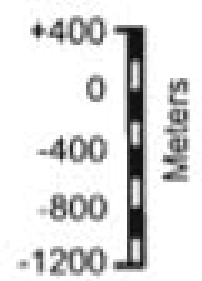

Figure 26. Sardana Southeast Missouri Pb-Zn deposit, Sette-Daban metallogenic belt, Russian Northeast Schematic geclogic map and cross section. Adapted from Shpikerman (1998) using materials of A.I. Starnikov and A.V. Prokopiev.

\section{Kurpandzha Sediment-Hosted Cu Deposit}

The Kumandaha Southeast sediment-hosted Cu deposit (Kutyrev, 1984; loganson, 1988) eonsists of more thun three stratified horizons of finely disseminaled to massive copper ore which is hosted in Late Devonian to Early Carboniferous coastal and deltaic sandstone. The main ore minerals are chalcocite, bomite, chalcopyrite, and pyrite, Ore bodies range from 0.2 up to $4 \mathrm{~m}$ thick and up to $1.5 \mathrm{~km}$ long. The host polymictic sandstone contains pyroclasts of volcanic rock. The deposit occurs in a stratigraphic interval from 50 up to $300 \mathrm{~m}$ thick which is underlain by famennian basalt which also contains copper mineralization. The deposit oecurs within a major syncline which has an amplitude of up to $4 \mathrm{~km}$. Ore bodies and host rocks strike at 40 to $70^{\circ}$ on syncline limbs.

\section{Dzhalkan Basaltic Cu Deposit}

The well-known basaltic Cu deposit at Dahalkan (Kutyrev, 1984; Kutyrev and others, 1988) occurs in a Famennian amygdaloidal basalt flow and near the Kurpandzha sediment-hosted $\mathrm{Cu}$ deposit. The deposit consists of disseminated $\mathrm{Cu}$ in a sequence of basalt flows with a lotal thickness of $180 \mathrm{~m}$. The deposit is mostly confined to horizons which range from 0.3 to $2.0 \mathrm{~m}$ thick and contain both cinden and anyzdules at the top of flows. The ore minerals include native copper and cuprite, with lesser bornite, chalcocite, and chalcopyrite. Epidosite (epidote-quartz) wallirock alteration occurs locally. The ore bodies range from 0.3 to $1.0 \mathrm{~m}$ thick and up to $100 \mathrm{~m}$ long. Artas of copper mineralization are separated by unmineralized areas of up to several kilometers. The deposit is small with average grades of 0.3 up to $4.5 \% \mathrm{Cu}$. The basalt flows erupted into shallow water and subaerial environments. The host basalts are folded, with fold limbs dipping 40 to $60^{\circ}$. 
The Sette-Daban metallogenic belt occurs within the Sette-Daban horstianticlinorium in the southwestern part of the North Asia Craton Margin (the Verkhoyansk fold belt, unit NSV; Shpikerman, 1998). The local units which host the Sette-Daban metallogenic belt consist of mainly thick, shelf carbonate and clastic rocks, and volcaniclastic deposits of Riphean, Vendian, and Cambrian age with a combined thickness of up to $13 \mathrm{~km}$. The major lithologies are limestone, dolomite, marl, mudstone, shale, mudstone, siltstone, sandstone, quartzite, conglomerate, basalt, tuff, Cu-bearing sandstone, and Cu-bearing basalt. Rare mafic and ultramafic dikes oceur. The units are metamorphosed to lower greenschist facies. The sulfide deposits, as at Sardana, are interpreted as syngenetic.

The Southeast Missoun Pb-Zn deposits are located in the upper part of the Oron Formation of Ludlovian age (350-500 m thick) which consists of large black and thin bedded dolomites and bydrogenic dolomite breccia. Hiod unit is overlapped by the Hurat Formation which consists mainly of marl. The Southeast Missouri Pb- $\mathrm{Zn}$ deposits of the Selte-Daban Range metallogenic belt are interpreted as forming from artesian thermal waters which circulated through the carbonate rocks of the North Asia passive continental margin. The sediment-hosted $\mathrm{Cu}$ deposits of the Sette-Daban belt are hosted in voleanic sedimentary rocks of Givetian, Fronian, Famenian and Turonian age. The significant deposits are in the upper Famenian and Turonian Menkule suite which ranges from 100 to $550 \mathrm{~m}$ thick and contains coastal-marine and continental sandstone, tuffaceous sandstone, siltstone, and dolomite. The basaltic $\mathrm{Cu}$ and sediment-hosted $\mathrm{Cu}$ deposits are interpreted as forming during rifting, mainly in the Middle Devonian to Early Curboniferous (Shpikerman, 1998).

\section{Selennyakh River Metallogenic Beit of Southeast Missouri $\mathrm{Pb}-\mathrm{Zn}$, Stratabound $\mathrm{Hg}$ and $\mathrm{Au}$, and $\mathrm{Pb}-\mathrm{Zn}$ Vein Deposits (Belt SEL) \\ Northwestern Part of Russian Northeast}

The Selennyakh River belt metallogenic belt of diverse lode deposits, including Mississippi $\mathrm{Zn}-\mathrm{Pb}$, stratabound $\mathrm{Hg}$ and $\mathrm{Au}$, and $\mathrm{Pb}-\mathrm{Zn}$ vein deposits (fig 16; tables 3, 4) occurs in the northwestern part of the Russian Northeast (Shpikerman, 1998). The metallogenic belt is bosied in the Omulevka terrane of the Kolyma-Omolon superierrane in early through late Paleozoic, passive continental margin carbonate and shale (Nokleberg and others, 1994c, 1997c; Shpikerman, 1998). The significant deposits are (table 4) (Nokleberg and others 1997a, b, 1998): (1) stratabound Hg deposits sucb the Gal-Khaya carbonate-hosted Hg deposit; (2) small Southeast Missouri type $\mathrm{Pb}-\mathrm{Zn}$ occurrences as at Kondakovakoe; (3) $\mathrm{Pb}-\mathrm{Zn}$ vein deposits as at Chistoe; and (4) Au quartz vein deposits as at Khatynnakh-Sala. This metallogenic belt, which needs further study, occurs along a sublatitudinal strike for more tban $600 \mathrm{~km}$ (fig. 16).

\section{Gal-Khaya Carbonate-Hosted Hg Deposit}

The Gal-Khaya carbonate-hosted $\mathrm{Hg}$ deposit (Bubkin, 1975) consists of a zone of quartz-carbonate breocia and veins which occurs along the contact of Early Silurian limestone and calcareous shale. The zone is $600 \mathrm{~m}$ long, 60 to $80 \mathrm{~m}$ wide, dips $75^{\circ}$, and is concordant to host rock bedding. The ore occurs in cylindrical ore shoots, mainly in carbonate breccia cemented with calcite and quartz-calcile. The main ore mineral is cinnubar. Also present are metacinnabar, galkhaite (Hg, $\mathrm{Cu}, \mathrm{Zn} ; \mathrm{As}$, Sb). stibnite, realgar, orpiment, pyrite, chalcopyrite, fluorite, barite, native gold, tennantite, sphalerile, bornite, chalcocite, covellite, malachite, and azurite. Gangue minerals include quartz, calcite, dolomite, barite, dickite, kaolinite, and bitumen (anthraxolite). The (syngenetic) deposit is interpreted as forming in the Late Devonian or Carboniferous (Shpikerman, 1998), or as an epigenetic deposit which formed in the Late Cretaceous (Galkin, 1968).

\section{Kondakovskoe Southeast Missouri Pb-Zn Occurrence}

The Kondakovskoe Southeast Missouri Pb-Zn deposit (Bakharev and others, 1988) consists of sulfide disseminations and pockets in Devonian limestone which is locally metamorphosed to marble. The deposit is localized along the southem contact of the Early Cretaceous Ulakhan-Siss granodiorite intrusion. The mineralized layer is several hundred meters long and consists of two mineral assemblages: (1) galena-sphalerite; and (2) less common pyrite-tetrahedrite. The deposit contains up to $0.1 \%$ Cd, $0.05-1 \% \mathrm{~Pb}, 0.08-1.5 \% \mathrm{Zn}$, and $0.01-0.3 \% \mathrm{Sb}$.

\section{Chistoe Pb-Zn Vein Deposit}

The Chistoe Pb-Zn vein deposit (Shpikerman, 1998) consists of a galena vein which occurs in a shear zone in Ordovician limestone locally metamorphosed to marble. The vein varies from 10 to $20 \mathrm{~m}$ thick and is about ten meters long. The ore minerals include galena, which is predominant, and also pyrite, sphalerite, chalcopyrite, cenussite, and smithsonite, Oxidized minerals are locally abundant. 
The Khatynnakh-Sala Au quartz vein deposit (Nekrasov, 1959, 1962, O.G. Epov and others, written commun., 1964) occurs in anticlinal domes and is controlled by bedding-plane faults. The ore bodies include 30 veins, lenses, lenticular bodies, and stockworks. The veins are generally not more than $1 \mathrm{~m}$ thick, generally $15-20 \mathrm{~m}$ long, and not more than $30-40 \mathrm{~m}$ long. Most of the veins and host rocks ure isoclinally folded. The host rocks include Ordovician and Silurian amphibole-mica-carbonate shale and limestone locally metamorphosed to marble. Two levels of intensely sulfidized shale, from $0.4-6 \mathrm{~m}$ thick and up to $250 \mathrm{~m}$ long, also occur in the deposit. Post-mineralization diabase and diorite porphyritic dikes are present, which are probably Late Jurassic-to-Early Cretaceous in age. Besides pyrite and pyrrhotite, the ore minerals are arsenopyrite, galena, fahlore, sphalerite, and gold. Gangue mineruls constitute $95 \%$ of the deposit and include quarzz albite, ankerite, burite, and fluorite. Pyrite is altered to pyrrhotite, and metamorphic actinolite, zoisite, biotite, sphene replace gangue minerals along with recrystallization of quartz. A late Paleozoic age is interpreted for the deposit and associated metamorphism. The deposit averages 0.2 to $2 \mathrm{~g} / \mathrm{Au}$.

\section{Origin of and Tectonic Controls for Selennyakh River Metallogenic Beit}

The Selennyakh River metallogenic belt is hosted in the Omulevka passive continental margin terrane. The local units which host the Selennyakh River metallogenic belt consist of a continuous succession of Ordovician, Early Carboniferous, and Permian sedimentary rocks which are about 10,000 to $12,000 \mathrm{~km}$ thick. The major lithologies are continental-shelf carbonate rocks with layers of deep-marine limestone and shale. The stratabound $\mathrm{Hg}$ and $\mathrm{Au}$ deposits, which are the major element of the Selennykh River belt, are hosted in Middle Ordovician and Lower Silurian limestone and dolomite which ranges from 300 to 500 $\mathrm{m}$ thick. The ore-bearing carbonate stratum is overlapped by calcareous shale (Shpikerman, 1998). Local middle Paleozoic mafic and syenite intrusions also occur. The younger, Carboniferous and Permian stratiform deposits are interpreted as forming during a short-lived rifting event within the Omulevka terrane.

The diversity of deposit types in the Selennyakh River metallogenic belt is interpreted as the result of a complex metallogenic history (Shpikerman, 1998) of the terrane which consisted of: (1) subsurface mineralization occurring in artesian thermal basins associated with Late Devonian rifting, thereby forming Southeast Missouri $\mathrm{Zn}-\mathrm{Pb}$ and stratabound $\mathrm{Hg}$ deposits; and (2) subsequent formation of veins during intrusion and regiotal metamorphism of the stratabound deposits, thereby forming $\mathrm{Hg}$. $\mathrm{Au}$, and $\mathrm{Pb}-\mathrm{Zn}$ vein deposits. The local units which host the Selennyakb River metallogenic belt consist of a continuous suecession of Middle Ordovician to Middle Devonian sedimentary rocks which are about $10,0001012,000 \mathrm{~km}$ thick. The major lithologies are continental-shelf carbonate rocks with layers of calcareous shale. Local, rift-related, middle Paleozoic alkali-mafic and syenite intrusions also occur and have ${ }^{40} \mathrm{Ar} \cdot{ }^{19} \mathrm{Ar}$ isotopic ages of 300 and $141 \pm 02 \mathrm{Ma}$, respectively (Trunilina and others, 1996). The host Omulevka terrane is interpreted as a rifted fragment of the North Asian Craton Margin (Verkhoyansk fold belt, unit NSV; Nokleberg and others, 1994c, 1997c; Shpikerman, 1998)-

\section{Tommot River Metallogenic Belt of \\ Carbonatite-Related $\mathrm{Nb}$, Ta, and \\ REE Deposits (Belt TO) \\ North-Central Part of Russian Northeast}

The small Tommot River metallogenic belt of carbonatite-telated $\mathrm{Nb}$, Ta, and REE deposits occurs in the north-central part of the Russian Northeast (fig. 16; tables 3,4) (Nokleberg and others, 1997b, 1998). The belt is hosted in the passive continental margin Omulevka terrane of the Kolyma-Omolon superterrane (Nokleberg and others, 1994c, 1997e), extends almost $50 \mathrm{~km}$, and varies between 20 to $30 \mathrm{~km}$ wide. The Tommot River metallogenic belt is herein correlated with the Khamna River metallogenic belt which is hosted in the North Asian Craton Margin (unit NAV, Verkhoyansk fold beli). This interpretation suggests that the Omulevka terrane is a faulied fragment of the North Asian Craton Margin.

\section{Tormmot REE Deposit}

The one significant deposit in the belt at Tommot (Nekrasov, 1962; L.M. Parfenov, P.W. Layer, written commun, 1994) consists of $\mathrm{REE}, \mathrm{Ta}$, and $\mathrm{Nb}$ minerals which occur in fenite, metasomatic alkalic pegmatite, and acgirine granite and in country rock adjacent to a zoned Late Devonian (?) alkalic gabbroic-syenite pluton. These igneous rocks intrude early Paleozoic slate. The 20 ore bodies at the deposit include metasomatic veins and lenses which vary from several to $25 \mathrm{~m}$ thick and range up to a hundred meters long. The most important elements in the deposit are $\mathrm{Y}, \mathrm{Ce}, \mathrm{L} . \mathrm{a}, \mathrm{Ta}$, and $\mathrm{Nb}$. Some rock samples contain $0.1-0.2 \%$ $\mathrm{Y} ; 0.1-0.5 \% \mathrm{Zn}$; and $0.01-0.5 \% \mathrm{Nb}$. K-Ar isotopic studies indicate a Permian to Carboniferous age whereas U-Pb isotopic studies indicate an age of $368 \mathrm{Ma}$ (Nekrasov, 1962). 
The intrusion of alkalic igneous rocks which host the $\mathrm{Nb}$, Ta and REE deposits of the Tommot River metallogenic belt are interpreted as forming during Late Devonian rifting of the North Asian Craton and the formation of the Omulevka Omulevka passive continental margin terrane (Nokleberg and others, 1997b, 1998). The alkalie igneous rocks, that host the Tommot River metallogenic belt, are part of a sequence of Mississippian igneous rocks in the terrane. The Omulevka terrane is herein interpreted as rifted fragment of the Paleozoic passive continental margin of North Asian Craton (Nokleberg and others, 1994c, 1997c, 2000) which in the Khamna River area contains a possibly similar belt of carbonatite-related $\mathrm{Nb}$, Ta, and REE deposits.

Urultun and Sudar Rivers Metallogenic Belt of
Southeast Missouri Pb-Zn, Carbonate-Hosted $\mathrm{Hg}$.
Basaltic Cu, and Volcanogenic Mn Deposits
(Belt URS) West-Central Part of Russian Northeast

The Urultun and Sudar Rivers metallogenic belt of Southeast Missouri Pb-Zn, voleanogenic-sedimentary Mn, basaltic $\mathrm{Cu}$, bedded barite, and carbonate-hosted $\mathrm{Hg}$ deposits (fig. 16; tables 3,4) occurs in three discontinuous fragments which extend northwesterly for $170 \mathrm{~km}$ in the west-central part of the Russian Northeast (Shpikerman, 1998. The southeastern portion of the belt is in the Sudar River basin, and the northwestern portion of the belt is in the Late Taskan and Uniltun Rivers. The deposits occur in various parts of the Paleozoic Sudar rift sequence in the Omulevka passive continental margin terrane (Nokleberg and others, 1994c, 1997c). Southeast Missouri Pb-Zn-fluorite deposits, as at Urultun, are most prevaleat, and occur in Late Ordovician through Middle Devonian strata (Shpikerman, 1987, 1988). The significant deposits are the Unultun Southeast Missouri Pb-Zn deposit; the Uochat carbonate-hosted $\mathrm{Hg}$ deposit, the Batko basaltic Cu deposit, the Lyglykhtakh volcanogenic Mn deposit, and the Prizovoe bedded barite deposit (table 4) (Nokleberg and others 1997a, b, 1998).

\section{Urultun Southeast Missouri Pb-Zn Deposit}

The Urultun Southeast Missouri Pb-Zn deposit (fig. 27) (Shpikerman, 1987, 1998) consists of disseminaled veinlets and brecciated ore which oecur in Early Devonian dolomite overlain by Middle Devonian (Givetian) marl. The ore bodies are composed of dolomite, calcite, fluorite, galena, sphalerite, and anthruxolite. Barite, pyrite, and cinnabar are present locally. The deposit is interpreted as forming in two stages: (1) an early sphalerite-fluorite stage which resulied in disseminaled metasomatic ore; and (2) a galena-fluorite-calcite stage which resulted in breccialed and veinlet ores. The ore-bearing dolomite sequence is up to $240 \mathrm{~m}$ thick and occurs along a synclinal limb of a fold which generally trends northwesterly. Two to five conformable ore horizons, varying in thickness from 1 to $10 \mathrm{~m}$, oceur in the dolomile sequence. The ore bodies are sporadic within a given horizon. The deposit occurs over an area of about 20 by $4 \mathrm{~km}$. This and other deposits and bost rocks are stratigraphically overlapped by deep-sea argillaceous and carbonaceous sedimentary rocks. The deposit contains an estimated resource of 23 million tonnes with an average grade of about $2.85 \% \mathrm{~Pb}, 6.74 \% \mathrm{Zn}$, and $10 \%$ fluorite.

\section{Carbonate-Hosted Hg Deposits}

The carbonate-hosted Hg deposits of the Urultun and Sudar Rivers metallogenic belt are interpreted as forming in the same event as the Southeast Missouri Pb-Zn deposits. The significant deposit at Uochat (Babkin, 1975) consists of disseminated, cinnabar-bearing veinlets which occur in brecciated Early(?) Devonian dolomite along a major north-south-trending fault. The deposit is about $20 \mathrm{~m}$ long and 4 io $7 \mathrm{~m}$ thick. The main ore mineral is cinnabar, which occurs with calcite in masses and irregular veinlets. Pyrite. quartz, sphalerite, and anthraxolite also occur. The deposit formed in several stages: (1) pre-ore silicification; (2) pre-ore calcite alieration; (3) deposition of cinnabar and calcite; and (4) post-ore deposition of calcite. The deposit is small.

\section{Basaltic Cu, Volcanogenic $\mathrm{Mn}$, and} Bedoded Barite Deposits

The stratabound basaltic $\mathrm{Cu}$ deposits occur in rift-related trachybasalt flows of the Givetian Formation which formed in a shallow marioe envitonment. The significant deposit is at Batko.

The Batko basaltic Cu deposit (Shpikerman and others, 1991) consists of disseminated and irregular masses of sulfides which occur in subalkalic, amygdaloidal basalt flows up to $200 \mathrm{~m}$ thick, within folded red beds of Middle Devonian (Givetian) age. The ore minerals are bomile, chalcocite, and covellite. The deposit oceurs at the tops of the basalt flows. The adjacent trachybasalt is inensely epidotized and carbonatized. The upper mineralized horizon is no more than $2-3 \mathrm{~m}$ thick. The deposit is small with grab samples which contain up to $3.1 \% \mathrm{Cu}$ and $13.7 \mathrm{~g} / \mathrm{Ag}$. Ag and Ba are associated with the $\mathrm{Ca}$.

The stratiform volcanogenic Mn deposits, as at Lyglykhtakh, and the bedded barite deposits occur in folded Early Carboniferous (Mississippian) through Late Permian siliceous shales, cherts and siliceous-carbonate rocks which are intercalated with tuff and diabase bodies. The Prizovoe bedded barite deposit occurs in the Early and Middle Carboniferous Batko Formation. Associated stratiform rhodochrosite deposits, at Lyglykhtakh and elsewhere in the Sudar and nearby river basins, oceur in the lower part of the Late Permian Turio Formation. Stratigraphic breaks may exist between these formations of sedimentary rocks. 

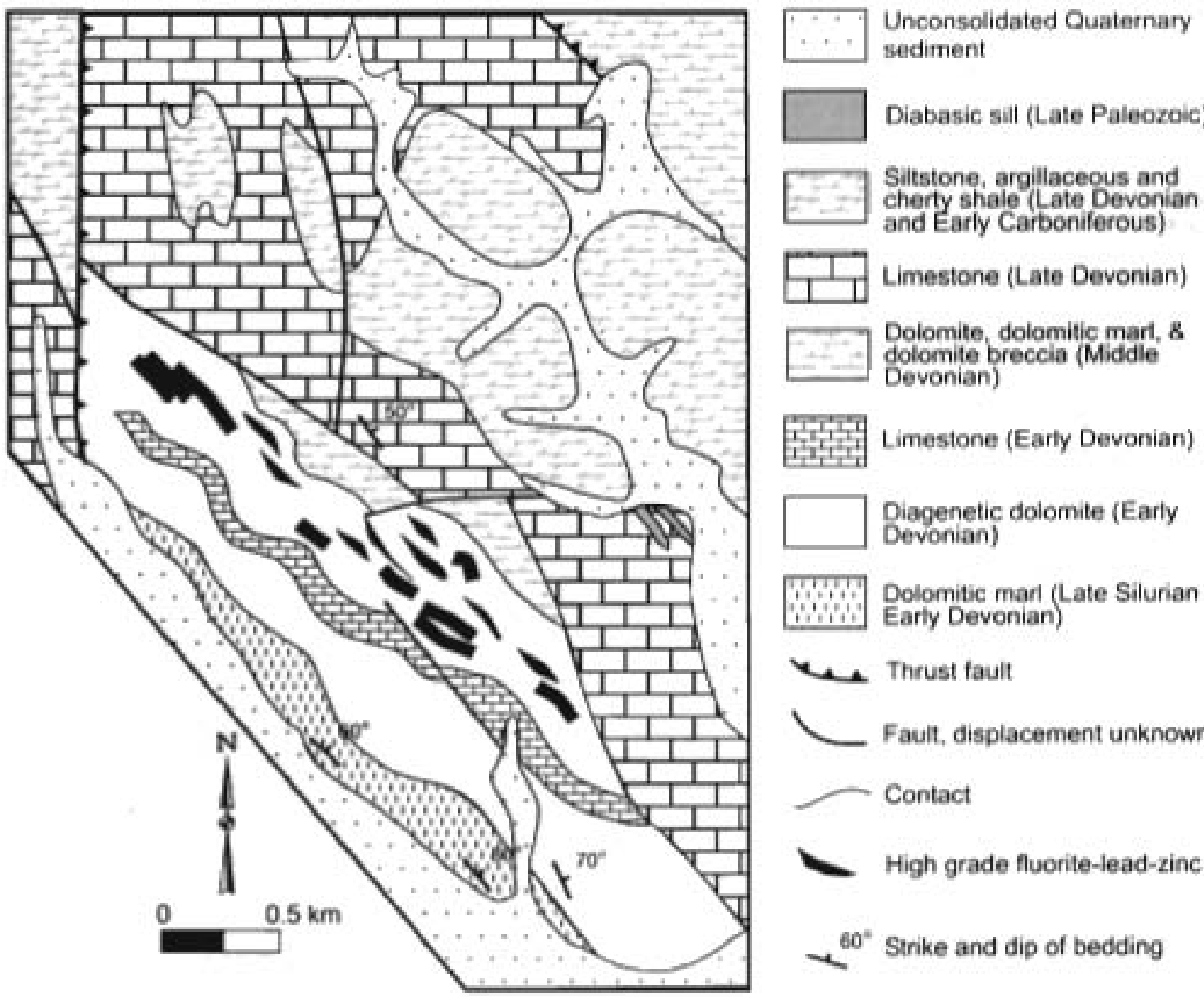
…… Dolomitic marl (Late Silurian and

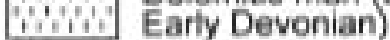

W. Thrust fault

$\checkmark$ Fault, displacement unknown

Contact

High grade fluorite-lead-zinc ore

$2^{60^{*}}$ Strike and dip of bedding

Figure 27. Urultun Southeast Missoun Pb-Zn deposih, Urultun and Sudar Rvers metallogenic beit, Russian Northeast. Generalized geologic map of the Bitum.Sdvig area of stratabound F.Pb-Zn deposit. Adapted from Shpikeman (1987).

\section{Origin of and Tectonic Controls for Unultun and Sudar Rivers Metallogenic Belts}

Both the Southeast Missouri Pb-Zn and carbonate-hosted $\mathrm{Hg}$ deposits are interpreted as forming in a middle Paleozoic thermal artesian paleobasin in a majot petroleum area (Shpikerman, 1998). Early and middle Carboniferous rifting is interpreted as the source of mineralizing fluids. Similarly, the deep-marine sedimentary and mafic volcanic rocks which host the busaltic Cu, volcanogenic Mn, and associated deposits of the Unultun and Sudar Rivers metallogenic belt are interpreted either as allochthonous blocks of oceanic-floor sedimentary rocks, or as sedimentary and volcanic rocks which were deposited during Devonian rifting of the North Asian Craton Margin to form the Omulevka terrane (NokJeberg and others, 1994c, 1997c).

Characteristic pyroclastic debris in the sedimentary rocks indicates which submarine volcanism and was associated with these SEDEX deposits. This inlerptetation is supported by anomalous values of $\mathrm{Pb}, \mathrm{Zn}, \mathrm{Cu}, \mathrm{Ag}$, and $\mathrm{Hg}$ in the host rocks. In spite of the variety of mineral deposit types in this belt, a genetic relation is interpreted between most of the deposits. The sedimentaryexhalative accumulation of $\mathrm{Mn}$ and barite ores, and anomalous $\mathrm{Pb}, \mathrm{Zn}, \mathrm{Cu}, \mathrm{Ag}$, and $\mathrm{Hg}$ concentrations are interpreted as forming during deposition of the Southeast Missouri Pb-Zn deposits in artesian horizons. The younger parts of the Omulevka terrane consists of Carboniferous and Permian fossiliferous tuff, chert, shale, limestone, siltstone, and sandstone, and Triassic fossiliferous siltstone, mudstone, marl, and shaley limestone.

\section{Yarkhodon Metallogenic Belt of}

Southeast Missouri Pb-Zn Deposits (Belt YR)

West-Central Part of Russlan Northeast

The Yarkhodon metallogenic belt of Southeast Missouri Pb-Zn-bante deposits oceurs mainly in the Yarkhodon River basin in the west-central part of the Russian Northeast (fig. 16, tables 3, 4) (Nokleberg and others, 1997b, 1998). The belt is 
hosted in the Yarkhodon subterrane in the eastem part of the Prikolyma passive continental margin terrane. The belt is $330 \mathrm{~km}$ long and up to $50 \mathrm{~km}$ wide. Most of the deposits oceur in the same stratigraphic level of the Yarkhodon Formation of Givetian age and are hosted in diagenetic dolomite and dolomitized limestone, Rare deposits occur in Proterozoic dolomite. The depositional environment for the original limestone is interpreted as a carbonate bank formed on a passive continental shelf. The significant deposits are at Slezovka and Gomoe.

\section{Slezovka Southeast Missouri Pb-Zn Deposit}

The Slezovka Southeast Missouri Pb-Zn deposit (A.V. Artemov and others, written commun., 1976; Davydov and others, 1988) consists of vein, disseminated, and breccia sulfides which occur in Middle Devonian a mineralized dolomite sequence which occurs in a sequence of clastic sedimentary rocks and carbonate rocks. The deposit contains up to five mineralized beds, each 3 to $5 \mathrm{~m}$ thick which separated by barren interbeds ranging from 3 to $10 \mathrm{~m}$ thick. The ore minerals are mainly galena, sphalerite, pyrite, and barite. The deposit is cut by quartz and calcite veinlets. The deposit is small.

\section{Origin of and Tectonic Controls for Yarkhodon Metallogenic Beit}

The Yarkhodon subterrane of the Prikolyma passive continental margin terrane, which hosts the Yarkodon metallogenic belt, consists of the follow major units: (1) Givetian limestone, dolomite, marl, and siltstone; (2) Fumennian to Early Permian argillite, silistone, volcaniclastic sandstone, rhyolite tuff, and basalts. The sedimentary rocks are very thick are inierpreted as forming along continental-slope base of a rift-related trough within a passive continental-margin area. The Prikolyma terrane is interpreted as a riff-related fragment of the North Asia Craton (unit NSC; Nokleberg and others, 1994c, 1997c). The Southeast Missouri $\mathrm{Pb}$ - $\mathrm{Zn}$-barite deposits of the Yarkodon metallogenic belt are interpreted as forming during rifting during the Late Devonian through the Mississippian.

Berezovka River Metallogenic Belt of Kuroko Massive Sulfide Deposits (Belt BE) Central Part of Russian Northeast

The Berezovka River metallogenic belt of kuroko massive sulfide and sulfide vein deposits in the Berezovka River basin in the west-central part of the Russian Northeast (fig. 16; tables 3,4) (Nokleberg and others, 1997b, 1998). The belt is hosted in the Late Devonian through Late Permian turbidite deposits which are part of the Beryozovka turbidite basin terrane of the Kolyma-Omolon superterrane (Nokleberg and others, 1994c, 1997c). The northwest-trending belt is $120 \mathrm{~km}$ long and up to 100 $\mathrm{km}$ wide. The belt occurs in four areas separated by units of post-accretionary volcanic rocks. In addition to kuroko massive sulfide deposits, the belt also contains numerous stratiform vein and veinlet-disseminated $\mathrm{Au}$ - and $\mathrm{Ag}$-bearing $\mathrm{Ba}$ - $\mathrm{Pb}$ - $\mathrm{Zn}$ deposits. The significant deposit at Berezovskoe and other similar deposits are hosted in the Tynytyndzhin formation of Late Devonian (Frasnian and Famennian) age.

\section{Berezovskoe Kuroko Massive Sulfide Occurrence}

The Berezovskoe deposit consists of tuffaceous sandstone and siltstone, and rhyolite and basalt flows (Gorodinsky and others, 1974: N.A. Bobrov, written commun_ 1976; Shpikerman, 1998). The Berezovskoe deposit consists of quartz-sulfide veins and stratiform barite-sulfide bodies which are conformable to bedding in the host rocks. The major sulfide minerals are galena and sphalerite. Some of the vein deposits are interpreted as forming during late Mesozoic magmatism which remobilized and redeposited the volcanic-rock-hosted massive sulfide deposits (Davydov and others, 1988). Because of a bimodal assemblage of basalt and thyolite has recently been recognized in the Devonian rocks of the Berezovka terrane (Dylevsky, 1992), potential exists for the discovery of new stratiform massive sulfide deposits.

\section{Origin of and Tectonic Controls for} Berezovka River Metallogenic Bett

The Beryogovka turbidite basin ternane occurs in a series of lectonic sheets which are thrust southward over the northem margin of the Omolon terrane (Nokleberg and others, 1994c, 1997c). The Beryozovka terrane consists of: (1) a basal section of deep- and shallow-marine basalt, rhyolite, siliceous siltstone, chert, sandstone, and conglornerate which formed in a rift setting and which contains Late Devonian conodonts and radiolarians, and Early Carboniferous forminiferas, conodonts, and macrofossils; and (2) Middle and Late Carboniferous to Early Jurassic chert, siltstone, mudstone, and shale with pelitomorphic limestone layers and argillaceous-calcareous concretions. The Late Devonian Kuroko massive sulfide deposits and associated bimodal voleanic rocks are herein interpreted as forming during rifting which was the earliest interpreted event for the Beryozovka terrane (Nokleberg and others, 1994c, 1997c). 
Metallogenic Belts Formed During Middle
Paleoxoic Rifting of North American Craton
Margin or in Low-Temperature Brines
Along Craton Margin

\section{Mystic Metallogenic Beit of SEDEX Bedded Barite and Southeast Missouri Pb-Zn Deposits (Beit MY) West-Central Alaska}

The Mystic metallogenic belt of SEDEX massive bedded barite and Southeast Missouri Pb- $\mathrm{Zn}$ deposits occurs in WestCentral Alaska (fig. 17; tables 3, 4) (Nokleberg and others, 1997b, 1998). The belt is hosted in the Mystic and Nixon passive continental margin terranes (Nokleberg and otbers, 1994c, 1997c). The significant deposits are at Gagaryah and Reef Ridge. The belt also contains younger a younger Besshi massive sulfide(?) deposit at Shellebarger Pass. In addition, very high Cu background values ( 350 to $450 \mathrm{ppm} \mathrm{Cu}$ ) occur in Late Triassic basalt, and several small syngenetic Cypris-type chalcopyrite deposits occur within interstices of pillow structures and in aquagene tuff of the Mystic terrane in the McGrath quadrangle (T.K. Bundtzen, written commun., 1992).

\section{Bedded Bariteand Southeast Missouri Pb-Zn Deposit}

A sedimentary-exhalative (SEDEX) bedded barite deposit is hosted Gagaryah at in Late Devonian (Frasnian) shales and elastic rock host barite mineralization in the Lime Hills D-4 Quadrungle (Bundtzen and Gilbert, 1991). The deposit consists of nodular, laminated, composite, and massive, light gray barite in Frasnian (early Late Devonian) shale, limestone, and minor chert of Mystie Terrane. The deposit extends along strike for 640 metern, has an average thickness of 20 meters, and an estimated downdip extension of 300 meters. The deposit contains slightly elevaied levels of Av, V, Sr (in celestite), but no lead or zine. Sulfide isotopic analyses of +20 and +24 determined from nodular and massive barite respectively. The deposit contains 2.3 million tones grading $51 \%$ barite. The barite is interpreted as deposited syngenetically into host shale basin with barite rapidly precipitating from low temperature hydrothermal fuids distal from exhalative vents. Barite nodules and spheroids are also commonly encountered in either Devonian or Mississippian strata at other localities in the Mystic terrane to the northeast.

A Southeast Missouri Pb-Zn deposit at Reef Ridge consists of stringers of brown sphalerite and minor galena in hydrothermal breccia in carbonate rocks of the Silurian and Devonian Whirlwind Creek Formation in the Nixon Fork terrane (Harold Noyes, written commun., 1984). The deposit extends along strike for $2,000 \mathrm{~m}$ and ranges up $1015 \mathrm{~m}$ thick. The sulfides pinch and swell along strike. The deposit is the best known of ten similar nearby occurrences, and contains bout 181,000 tonnes of $15 \%$ combined $\mathrm{Zn}$ and $\mathrm{Pb}$.

\section{Shellebarger Pass Besshi Massive Suifide(7) Deposit}

The younger Shellebarger Pass Besshi massive sulfide(7) deposit (Reed and Eberlein, 1972; Bundtzen and Gilbert, 1983) consists of a very fine grained mixture of mainly pyrite and marcasite and lesser sphalerile, chalcopyrite, galena, and pyrnhotite in a gangue of siderite, calcite, quartz, and dolomite. The sulfides and gangue occur in massive, lenticular sulfide bodies, as replacements of carbonate-rich beds, and as fracture fillings, mainly in chert and siltstone. The host rocks are a Triassic and (or) Jurassic age sequence of chert, dolomite, siltsione, shale, volcanic graywacke, conglomerate, aquagene tuft, and overlain by an upper sequence of pillow basalt, agglomerale, and breccia. At least six individual sulfide bodies are known. The main sulfide bodies may be proximal to basaltic flow fronts. The highest chalcopyrite concentrations occur in the basal parts of bodies. Minor sphalerite occurs in or near the hanging wall. Extensive hydrothermal alieration occurs in the footwall, but is to absent in hanging wall. The basalt displays high background Cu values of 250 to $300 \mathrm{gl}$. The deposit contains an estimated several hundred thousand tonnes of unicnown grade. Individual samples contais up to $5 \% \mathrm{Cu}$ and average about $2 \% \mathrm{Cu}$ and $1 \% \mathrm{Zn}$.

\section{Origin of and Tectonic Controls for Mystic Metallogenic Belt}

The Mystic metallogenic belt is hosted in the Mystic and Nixon passive continental margin terranes which consist of a complexly deformed but partly coberent, long-lived stratigraphic succession, including Devonian through Pensylvanian carbonate and clastic sedimentary rock, Permian flysch and chert, and Triassic(?) pillow basalt (Nokleberg and others, 1994c, 1997e): Recent studies report carly to middle Paleozoic fauna in these terranes that are typical of taxa that occur in similar age units in the Kolyma region in the Russian Northeast and suggest that these three terranes were rifled from the Siberian continent (North Asian Craton Margin) (Blodgett and Brease, 1997; Blodgett, 1998; Fryda and Blodgett, 1998; Dumoulin and othern, 1998, 1999; Blodgett and Boucot, 1999). The Mississippian and older parts of these terranes and a stratigraphy that is similar to the North Asian Craton Margin (NSV). Accordingly, these Mississippian and older parts of these terranes and their Mississippian and older lode SEDEX bedded barite deposits and metallogenic belts are herein interpreted as being derived from rifting of the North Asian Craton Margin (NSV) (Nokleberg and others, 2000). Coeval metallogenic belts with similar origin deposits residing in the Russian Northeast include the Urultun and Sudar Rivers, Selennyakh River, and Sette-Daban, and Yarkhodon belts (table 3). The tectonic 
origin of the younger Triassic(?) Besshi(7) and Cyprus massive sulfide deposits in the Mystic metallogenic belt, as at Shellebarger, is not cleat

Northern Cordiliera Metallogenic Belt of

Southeast Missouri Zn-Pb Deposits (Beit NCO)

Central Yukon Territory

The Northem Cordillen metallogenic belt of Proterozoic and early Paleozoic Southeast Missouri Zn-Pb deposits (fig. 17; tables 3,4$)$ occurs in the east-central Yukon-Territory and western Northwest Territories and is hosted in an extensive pericratonic platformal sequence in the North American Craton Margin. The major Proterozoic deposits are at Gayna River and Goz Creek. The major early Paleozoic deposit is at Bear-Twit; other examples are at Guyna River, Goz Creek area (Barrier Reef), and Rusty Springs (Termuende) (table 4) (Nokleberg and others 1997a, b, 1998).

\section{Gayna River Southeast Missouri Zn-Pb Deposit.}

The Gayna River Southeast Missouri $\mathrm{Zn}-\mathrm{Pb}$ deposit consists of sphalerite with minor pyrite and galena which occur in breccias and as tabular replacement bodies in Late Proterozoic shallow water carbonate of the Little Dal Group (Mackenzie Mountain Assemblage; Hardy, 1979; Aitken, 1991; Hewton, 1982; EMR Canada, 1989). Sphalerite and lesser galena occur as disseminations in breccias which formed as slumps over the flanks of stromatolitic reefs. Sphalerite is also concentrated in solutioa-collapse and fault-related crackle breceias. The Gayna River district contains 18 deposits and more than 100 occurrences. Several deposits exceed I million tonnes grading $10 \%$ combined $\mathrm{Zn}$ and $\mathrm{Pb}$.

\section{Goz Creek (Barrier Reef) Southeast Missouri Zn-Pb Deposit}

Deposits in the Goz Creek area consist of sphalerite with minor galena, pyrite and boulangerite which occur as fracture and breccia filling and disseminations (EMR Canadn, 1989; Dawson and others, 1991; Fritz and others, 1991). The deposit contains estimated reserves of 2.49 million tonnes grading $11 \%$ combined $\mathrm{Zn}$ and $\mathrm{Pb}$. The deposits occur in both stratigraphically and tectonically controlled zones in pervasively silicified sandy dolostone. Smithsonite occurs as weathering product of sphalerite. The deposit age is interpreted to be Late Proterozoic. Other Southeast Missouri Pb-Zn districts hosted by Late Proterozoic dolostone include Nadaleen Mountain, south of Goz Creek, and Coal Creek Dome, north of Dawson.

\section{Bear-Twit Southeast Missourl Zn-Pb District.}

The Bear-Twit Southeast Missour $\mathrm{Zn}-\mathrm{Pb}$ district consists of galena and sphalerite with minor tetrahedrite which oecur in brecciated dolomitized shallow water (reef) carbonates of the Early Devonian Whittaker, Delorme and Camsell Formations (Dawson, 1975; Archer Cathro and Associates, unpublished company report, 1978; EMR Canada, 1989). The deposit contains estimated reserves of 8 million tonnes grading $5.4 \% \mathrm{Zn}, 2.6 \% \mathrm{~Pb}$, and $0.5 \mathrm{~g} / \mathrm{Ag}$. The deposit occurs in cross-cutting fractures, breccia matrices, fossil replacement, and also as disseminations in dolomite. The deposit age is interpreted as Early Devonian. In the Godlin Lakes region, are numerous deposits are hosted by orange-weathering ferroan dolostone of the Early Cambrian Sekwi Formation (Dawson, 1975). The Rusty Springs deposit in northwestern Yukon is an Ag-rich Southeast Missouri Pb-Zn deposit bosted by breccialed dolostone of the Middle Devonian Ogilvie Formation.

\section{Origin of and Tectonic Controls for Northern Cordillera Metallogenic Beit}

The deposits in the Northem Cordilleran metallogenic belt are classic Southeast Missouri Pb-Zn deposits composed of sphaierite, galena, and pyrite, with a gangue of dolomite, quartz, calcite and barite, and lesser gypsum, fluorite, chalcopyrite, and pyrobitumen. These minerals occur in vugs, pores, burrows, various sedimentary and lectonic breceias, and minor to major fractures. Secondary dolomite commonly accompanies mineralization. $\mathrm{Zn}$ : $\mathrm{Pb}$ ratios average 10:1, and $\mathrm{Ag}$ and $\mathrm{Fe}$ contents are low. The deposit form is highly irregular and usually discondant on a local scale, but stratabound on a district scale. The deposit sizes range from a few tens of thousands to about 10 million tonnes, and grades range from 3 to $10 \%$ combined $\mathrm{Zn}$ and $\mathrm{Pb}$ in larger deposits to about $50 \%$ combined $\mathrm{Zn}$ and $\mathrm{Pb}$ in small bodies (Dawson and others, 1991). Remote location and lack of infrastructure has limited drilling and development to only a few of the several hundred known occurrences.

The Late Proterozoic to Middle Devonian passive part of the North American Craton Margin consists of a miogeoclinal sedimentary prism which is segmented into two contrasting facies belts. To the northeast are shallow water sandstone, dolostone and limestone which define the Mackenzie Platform, whereas to the southwest are turbiditic sandstone, deep-water limestone. shale and chert which define the Selwyn Basin. Sedimentary lithofacies exerted a primary control upon the localization of preaccretionary sedimenl-hosted mineral deposits. Minor occurrences of Southeast Missouri Pb-Zn deposits are a common feature of carbonate rocks of all ages in the Nonth American miogeocline; however, significant deposits commonly are localized along the carbonate-shale facies changes near the tectonically-unstable, western margin of Late Proterozoic to early Paleozoic platformal carbonate successions. 
The apparent spatial relationship of mineralization to extensional structures suggests formation of the Southeast Missouri $\mathrm{Zn}-\mathrm{Pb}$ deposits during major rifting and basinal subsidence along the passive North American Craton Margin. These structures include rift-induced, synsedimentary and block faulting, uplift, basinal subsidence, resultant facies changes, reefal development, development of karsts, brecciation, and basinal brine migration (Dawson and others, 1991). The common association of bydrocarbons with $\mathrm{Zn}-\mathrm{Pb}$ deposits in carbonate focks suggests a genetic relationship between mineralization and oil maturation, migration, and entrapment (Jackson and Beales, 1967). Although the timings of mineral deposition commonly are not well known (Sangster, 1986), the two major age groups of Southeast Missouri $\mathrm{Zn}-\mathrm{Pb}$ deposits are herein interpreted as forming during two major periods of incipient rifting of the North American Continental Margin, the Late Proterozoic and early Paleozoic.

Other metallogenic belts in the Canadian Cordillera, which contain stratiform or stratabound massive sulfide deposits which are hosted in parts or rifted fragments of the North American Craton Margin, are (in order of decreasing age): (1) Monashee belt of Late Proterozoic SEDEX deposits; (2) Redstone belt of Late Proterozoic sediment-hosted Cu deposits (3) Cathedral belt of Cambrian Southeast Missouri $\mathrm{Zn}-\mathrm{Pb}$ deposits; (4) Churchill beit of Late Proterozoic $\mathrm{Cu}$ vein deposits; (5) Kootenay belt of Cambrian SEDEX deposits; and (6) Anvil belt of Cambrian through Silurian SEDEX deposits. An important distinction occurs between some of the metallogenic belts. Many metallogenic belts with SEDEX deposits are directly associated with mafic volcanic rocks and bydrothermal activity whereas the metallogenic belts containing Southeast Missouri $\mathrm{Zn}-\mathrm{Pb}$ deposits are not.

\section{Dempster Metallogenic Belt of SEDEX Ba, Sedimentary-Exhalative (SEDEX),

The Dempster metallogenic belt of SEDEX Ba, SEDEX Ni-Zn-PGE-Au, and Kuroko Zn-Pb-Cu massive sulfide deposits occurs in the northwestern Yukon Territory (fig. 17; tables 3, 4) (NokJeberg and others, 1997b, 1998). The belt is hosted in the North American Craton Margin in a sequence Devonian and Mississippian clastic strata which are part of the Earn assemblage, in the region north of Tintina Fault and south of Dawson Fault. The significant deposits are the Rein SEDEX, Marg Kuroko massive sulfide, and the Nick SEDEX deposits.

\section{Rein SEDEX Ba Deposits}

The Rein and several other large SEDEX deposits in the region contain barite, barylocalcite, and witherite and are hosted in Early to Middle Devonian (late Emsian to early Eifelian) sedimentary rocks which crop our near Dempster Highway (M.J. Orehard, written communication, 1985). None of the occurrences has measured reserves. The upper Earn Assemblage includes beds between the Tombstone and Robert Service thrust faults previously interpreted to be Mesozoic, including the Keno Hill quartzite, which bost the large polymetallic silver vein district of Keno Hill in the Tombstone metallogenic belt.

\section{Marg Kuroko Volcanogenic Zn-Pb-Cu Deposit}

The Marg kuroko $\mathrm{Zn}-\mathrm{Pb}-\mathrm{Cu}-\mathrm{Au}-\mathrm{Ag}$ massive sulfide deposit consists of pyrite, sphalerite, chalcopyrite and galena with minor arsenopyrite and tetrahedrite which occur in a quartz and barite gangue (Eaton, written commun., Archer, Cathro, and Associates, 1989; Yukon Minfile, 1991). The deposit occurs in four stacked massive sulfide lenses which occur at the contact of quartz-sericite-chlorite phyllite and graphitic phyllite. The deposit contains an estimated 2.097 million tonnes grading $5.0 \% \mathrm{Zn}$, $2.7 \% \mathrm{~Pb}, 1.8 \% \mathrm{Cu}_{1}, 65 \mathrm{~g} / \mathrm{Ag}, 1.2 \mathrm{~g} / \mathrm{Au}$. The host rocks are tectonically interleaved with, and overlain by the Keno Hill quartzite of the Late Eam Assemblage, part of a Devonian and Mississippian clastic wedge (Mortensen and Thompson, 1990; Turner and Abbott, 1990). The felsic metavoleanic rocks are interpreted as part of a Carboniferous continental-margin arc form along the North American Craton Margin.

\section{Nick SEDEX NI-Zn-PGE-Au Deposit}

The Nick SEDEX Ni-Zn-PGE-Au deposit consists of pyrite, vaesite, melnikovite-type-pyrite, sphalerite and wurtzite which occur in a gangue of phosphatic-carbonaceous chert, amorphous silica and intergrown bitumen (Hulbert and others, 1992; Yukon Minfile, 1992). The deposit has reserves of 900,000 tonnes grading $5.3 \% \mathrm{Ni}, 0.73 \% \mathrm{Zn}$, and $0.8 \mathrm{~g} / \mathrm{t}$ PGE, along with minor Au. The deposit forms a thin, conformable unit at the contact between Middle and Late Devonian Earn Group. The deposit extends laterally over a $80 \mathrm{~km}^{2}$ basin (Hulbert and others, 1992). The host rocks are the basinal sedimentary part of a Devonian and Mississippian clastic wedge exposed in an east-west trending syncline. The basin is interpreted as a local trough or embayment on the eastern margin of the Selwyn Basin. The only known deposits similar to this rare SEDEX deposit are the $\mathrm{Ni}$ Mo sulfide beds of the Yangtze Platform. China (Coveney and others, 1994). 
In the Middle Devonian, a dramatic change in sedimentation pattems occurred throughout the North American Craton Margin when continental shelf platform assemblages of carbonate and clastic rocks were drowned and starved of clastic sediments before being inundated by mainly turbidite and chert-ricb clastic rocks derived from the west and north. The abrupt change from passive-margin to variably coarsening-upward clastic sedimentation represented by the Eam Assemblage is interpreted as the result of local block uplift as a consequence of regional extension or strike-slip faulting (Gordy, 1991; Gordey and Anderson, 1993), of as interpreted herein, related to syndepositional faults which bounded a westerly trending, rif-related trough. The formation of the Dempster metallogenic belt and the similar Macmillan Pass and Gataga metallogenic belts is interpreted as occurring during deposition of the clastic wedge.

\section{Macmillan Pass Metallogenic Belt of Zn-Pb-Ag-Ba SEDEX Deposits, Central Yukon Territory (Beit MP)}

The Macmillan Pass metallogenic belt of SEDEX Zn-Pb-Ag-Ba deposits (fig 17; tables 3,4) occurs in the central Yukon Territory and is hosted in the Devonian and Mississippian sedimentary rocks of Eam Group, part of the North American Craton Margin in the northern Canadian Cordillera. The significant deposits are at Cathy (Bar, Walt, Hess), Gravity (BA), Jeff (Naomi, Baroid), Macmullan Pass (Tom, Jason Main, Jason East), Moose (Spartan, Racicot), Oro (Buc, Mar, Dar, Tang), and Tea (Brock) (table 4) (Nokleberg and others 1997a, b, 1998).

\section{Tom, Jason Main, and Jason East Pb-Zn-Ag-Ba SEDEX Deposits}

Tom, Jason Main, and Jason East SEDEX Pb-Zn-Ag-Ba deposits occur in two or more stratigraphic intervals in the Middle to Late Devonian lower Earn Group. interpreted as part of a Devonian and Mississippian clastic wedge in the MacMillan Pass area. The deposits are interpreled as spatially related to syndepositional faults bounding a rift-related trough filled with fineto coarse-grained siliceous turbiditic clastic rocks(Maclntyre, 1991; Mining Review, 1992). Estimate reserves are 9.3 million tonnes grading $7.5 \% \mathrm{~Pb}, 6.2 \% \mathrm{Zn}$, and $69.4 \mathrm{~g} t \mathrm{Ag}$ for the Tom deposit, and 14.1 million tonnes grading $7.09 \% \mathrm{~Pb}, 6.57 \% \mathrm{Zn}$, and $79.9 \mathrm{~g} / \mathrm{Ag}$ for the Jason deposits (Maclntyre, 1991; Mining Review, 1992). The distribution of ore facies consists of: (1) a Cuand $\mathrm{Ag}$-rich footwall stockwork which is overlain by $\mathrm{Pb}$ - and $\mathrm{Zn}$-rich massive sulfide facies; (2) an upward and lateral gradation into a $\mathrm{Zn}$ - and Fe-rich, laminated sulfide facies; and (3) a distal gradation into Ba-rich ore. This distribution is interpreled as forming during a zonal deposition from low-temperature brines exhaled into an anoxic sub-basin (McClay and Bidwell, 1986; Large, 1983). The Jason deposits, $5 \mathrm{~km}$ southwest of Tom, possess similar ore facies but occur closer to a graben margin and are characterized by slump and debris flows and discordant, replacement ore textures.

\section{Moose Ba SEDEX Deposit}

The Moose Ba SEDEX deposit consists of finely laminated barite which occurs in two beds from 25 to 45 meters thick and exposed for 200 to 250 meters along strike (Dawson and Orchard, 1982; Yukon Minfile, 1992). The deposit has estimated reserves of 3.0 million tonnes grading $84 \% \mathrm{BaSO}_{4} 12 \%$ to $14 \% \mathrm{SiO}_{2}$. The deposit occurs near the base of a shale member of the Middle to Late Devonian lower Eam Group, immediately above an underlying chert pebble conglomerate. The host rocks are interpreted as pan of a Devonias and Mississippian clastic wedge.

\section{Origin of and Tectonic Setting for Mackillan Pass Metallogenic Belt}

The MacMillan Pass metallogenic belt of Zn-Pb-Ag-Ba SEDEX deposits is hosted mainly in Late Devonian (Frasnian) units of the North American Craton Margin (Dawson and Orchard, 1982). Most of the SEDEX deposits in the metallogenic belt are related to syndepositional faults which bound a westerly trending, rift-related trough filled with turbiditic siliceous clastic rocks of the lower Earn Group (Abbot, 1986b). The Devonian and Mississippian Earn Group, which hosts the metallogenic belt, represents a dramatic change in sedimentation patterns. The change consisted of drowning of shelf carbonate-clastic platforms and subsequent inundation by nubidite- and chert-rich clastic rock derived from the west and north (Gordey and others, 1991). The abrupt change from passive continental margin sedimentation to variable, coarsening-upward clastic sedimentation is interpreted as the result of local block uplift as a consequence of regional extension related to rifting or strike-slip faulting (Gordey, 1992), or a consequence of ensialic arc magmatism, uplift and foreland clastic wedge deposition (Gabrielse and others, 1982). 
The Finlayson Lake metallogenic belt of SEDEX Zn-Pb-Ag-Cu-Au deposits (fig. 17; tables 3,4) occurs in the Selwyn Basin of the North American Craton Margin in the Yukon Territory. The significant deposits at Maxi and Matt Berry (table 4) (Nokleberg and others 1997a, b, 1998) are hosted in deformed sedimentary rocks of the Road River Group. The stratigraphic position and age of the host rocks at Maxi are better known than at Matt Berry.

\section{Maxi SEDEX Zn-Pb-Ag Occurrence}

The Maxi SEDEX Zn-Pb-Ag occurrence consists of galena, sphalerite, and quartz which occur as penetratively-deformed and transformed lamellae and bands in black phyllite in the basal Road River Group (Biusson, 1978). The sulfides are commonly coarse-grained and concentrated in minor fold hinges, indicating mobilization during pre-Late Devonian, regional metamorphism. A second stage of folding and thermal metamorphism is interpreted as related to Cretaceous granitoid plutons in the area (Blusson, 1978). No reserves or resources are reported.

\section{Matt Berry SEDEX Pb-Zn Deposit}

The Matt Berry SEDEX deposit consists of massive galena, sphalerite, pyrthotite and chalcopyrite which occur with minor antimony-silver minerals (Ostler, 1979; Bremner and Ouellette, 1991). The deposit contains estimated reserves of 533,434 tonnes grading 6.81\% $\mathrm{Pb}, 4.8 \% \mathrm{Zn}$, and $102.9 \mathrm{~g} / \mathrm{Ag}$ (Northem Miner, August 5, 1980). The sulfides are concentrated with quartz, in fold noses, and in discontinuous en-echelon lenses over a strike length of $500 \mathrm{~m}$. The rocks have undergone at least three periods of deformation and metamorphism, including thermal metamorphism along the contacts of a Cretaceous granitoid pluton. The deposits constitute a zone of sulfide lenses up to $10 \mathrm{~m}$ thick hosted by deformed black phyllite and quartz-sericite phyllite, probably of the Paleozoic Road River Group in eastern Selwyn Basin, Yukon. The copper and antimony minerals are interpreted as related to local Cretaceous intrusive activity which overprints the Paleozoic SEDEX mineralization which formed along a Devonian and Mississippian passive continental margin.

\section{Origin of and Tectonic Setting for Finlayson Lake Metallogenic Belt}

The Maxi and Matt Berry deposits are interpreted as originally stratiform SEDEX sulfides deposits which were deposited with black shale in the Ordovician and Silurian Road River Group and are provisionally correlated with the adjacent Howards Pass metallogenic belt to the northeast. The Maxi and Matt Berry deposits were attenuated, deformed, remobilized, and contact metamorphosed during mid-Cretaceous magmatism, uplift and deformation.

\section{Liard Metallogenic Belt of Southeast Missouri Ba-F Deposits \\ (Belt L) Northern British Columbia}

The Liard metallogenic belt of Southeast Missouri Ba-F deposits occurs in northern British Columbia and is hosted mainly in early to middle Devonian shelf carbonate rocks in the North American Craton Margin (fig. 17; tables 3,4) (Nokleberg and others, 1997b, 1998). The deposits are epigenetic stockworks, breccia-fillings, replacements, and (or) veins which exhibit stratigraphic and structural controls similar to those of Southeast Missouri $\mathrm{Zn}-\mathrm{Pb}$ deposits. The large deposits exhibit a southward lateral gradation towards several, small $\mathrm{Zn}-\mathrm{Pb}$ vein and breccia occurrences which are hosted in a dolomite-barite-fluorite gangue (Dawson, 1983). The Ba-F deposits are herein interpreted as analogous to Southeast Missouri $\mathrm{Pb}$-Zn deposits. However, local epigenetic barite deposits occur in the area without fluorspar and $\mathrm{Pb}-\mathrm{Zn}$ sulfides.

\section{Leguil Creek Bedded Ba Deposit}

The Leguil Creek (Letain) bedded Ba deposit consists of three stratabound zones of veins and lenses of barite which are hosed in Cambrian to Devonian shale and siltstone (MINFILE, 2002). The barite and host rocks are gently folded. Discordant, fault-controlled barite vein zones range from I $104 \mathrm{~m}$ thick. Barite sulphur isotopic analysis indicate a Devonian age of mineralization (K.M. Dawson, unpublished data, 1995). A SEDEX barite origin, similar to that for the adjacent Gataga SEDEX metallogenic belt, with subsequent tectonic remobilization, is herein proposed.

\section{Lower Liard Southeast Missouri Ba-F and Muncho Lake Ba Deposits}

The Lower Liard Southeast Missouri Ba-F deposit consists of fluorite with barite, witherite, barytocalciite, quartz and calcite which occurs as veins, lenses and breccia-fillings at the contact between limestone of the Middle Devonian Dunedin Formation and shale of the Besa River Formation (EMR Canada, 1989; MINFILE, 2002). Fission-track dating suggests a 
Mississippian age of mineralization (MINFILE, 2002). Massive stratabound Ba deposits, which occur in the same region at Muncho Lake, northern British Columbia, are not hosted by the same strata, and may be spatially related to fluorite-free barite replacements and breccias. The Muncho Lake Ba deposit in northern British Columbia consists of mssive, stratabound barite which is devoid of fluorite. The barite layer overlies the Waknash Formatoin and is bedded and contains local abundant sandstone, and may exhibit evaporite textures (Dan Hora, written commun, 2000). Also oceurring in the atea area barite veins (Butnerchuk and Hancock, 1997; MINFILE, 2002).

\section{Origin of and Tectonic Serting for} Liard Metallogenic Beit

The Liard metallogenic belt of Southeast Missouri(7) Ba-F deposits is hosted in Devonian passive continental margin sedimentary rocks of the North American Craton Margin. The deposits exhibit characteristies similar to Southeast Missouri Pb- $\mathrm{Zn}$ deposits in the Robb Lake metallogenic belt of Southeast Missouri Pb-Zn deposits (described herein), and to the Gataga metallogenic belt of SEDEX deposit (described herein). Sulphur isotope analyses exhibit heavy values for barite sulfur in all three metallogenic belts (K.M. Dawson, unpublished data, 1995). These data and a similar geologic setting suggest a genetic relation between the two deposit types and three metallogenic belts. A similar rifling origin is interpreted for all three metallogenic belts. The rifting is interpreted as oceurring during the Late Devonian and Early Mississippian rifting event when the Yukon-Tanana and Kootenay metamorphosed continental margin terranes separated from the North American Craton Margin (Nokleberg and others, 1994c, 1997c, 2000; Monger and Nokleberg, 1996). During the rifting, volcanism, plutonism, related hydrothermal activity, and sedimentary exhalations occurred in the North American Craton Margin and in the Yukon-Tanana and Kootenay terranes (Paradis and others, 1998).

\section{Gataga Metallogenic Belt of Zn-Pb-Ag-Ba SEDEX Deposits (Beit GA) Northern British Columbia}

The Gataga metallogenic belt of $\mathrm{Zn}-\mathrm{Pb}-\mathrm{Ag}$-Ba SEDEX deposits (fig. 17; tables 3, 4) occurs in northeastem British Columbia. The deposits are hosted in basinal sedimentary strata of the Kechika Trough, a southeastern extension of Selwyn Basin (Fritz and others, 1991). The belt contains eight significant deposits and extends for $180 \mathrm{~km}$ southeastward from Driftpile Creek to Akie River. The deposits are localized in inferred euxinic sub-basins in a structurally controlled trough which was partly flanked by carbonate reefs (Maclntyre, 1982, 1998). The significant deposits are at Akie, Cirque (Stronsay), and Driftpile Creek (Saint, Roen; table 4) (Nokleberg and others 1997a, b, 1998). The deposits and host rocks are part of a sequence of Late Devonian (Famennian) turbiditic shale and cherty argillite of the Earn Group (Pigage, 1986; Paradis and othen, 1998).

\section{Cirque (Stronsay) Deposit}

The Cirque (Stronsay) Zn-Pb-Ag-Ba SEDEX deposit (fig. 28), the largest in the Gataga belt, consists of stratiform, laminar banded, massive barite with pyrite, galena and sphalerite which occur in turbidite shale, chert, and cherty argillite of the Late Devonian Gunsteel Formation (Jefferson and others, 1983; Gorzynski, 1986). The host rocks are siliceous and contacts between sulfide bodies and sediments are sharp. The deposit forms a 1000 by $300 \mathrm{~m}$ tupering, wedge-shaped lens which is about 10 to $60 \mathrm{~m}$ thick. The Cirque and adjacent South Cirque deposits contain estimated reserves of $52.2 \mathrm{million}$ tonnes grading $896 \mathrm{Zn}$, $2 \% \mathrm{~Pb}$, and $47 \mathrm{~g} / \mathrm{Ag}$ (Mining Review, 1992).

\section{Driftpile Creek SEDEX}

Zn-Pb-Ag-Ba Deposit.

The three sulfide bodies at the Driftpile SEDEX Zn-Pb-Ag-Ba deposit consist of stratiform pyrite, sphalerite, galena, and barite in siliceous black turbiditic shale of Famennian (Late Devonian) age (Paradis and others, 1998). The deposit has estimated reserves of 18.1 million lonnes geding $2.38 \% \mathrm{Zn}+\mathrm{Pb}$ (Insley, 1991; Paradis and others, 1995). The sulfide bodies occur in three stratigraphic levels in the Gunsteel Formation of the Earn Assemblage in different thrust-bounded panels. The host sedimentary rocks are interpreted as part of a Devonian-Mississippian clastic wedge-

\section{Origin of and Tectonic Setting for Gataga Metallogenic Beit}

The SEDEX $\mathrm{Zn}-\mathrm{Pb}-\mathrm{Ag}$ - Ba deposits of the Gataga metallogenic belt are interpreted as forming during deposition of basinal elastic rocks of the Earn Assemblage during the early to late Famennian over a time span of not more than 7 million years. This relatively brief episode occurred during or immediately after a period of continental-margin are formation and subsequent rifting of the North American Craton Margin in the early Mississippian (Paradis and others, 1998). The rifting is interpreted to have influenced sedimentation and volcanism in the Yukon-Tanana and Kootenay terranes (Nokleberg and others, 1994c, 1997c; 

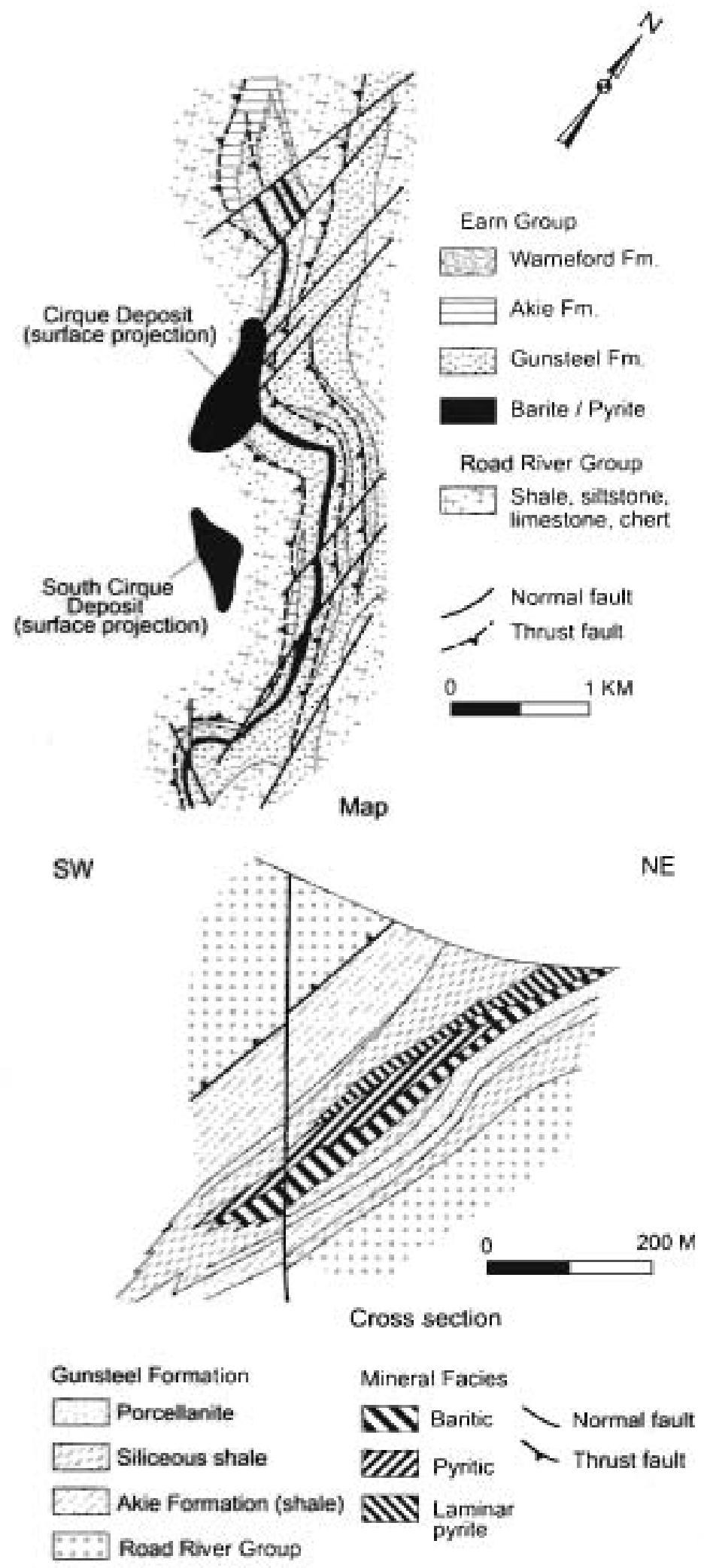

Figure 28. Cirque (Stronsay) sedimentary-exhalative $\mathrm{Zn}-\mathrm{Pb}-\mathrm{Ag}-\mathrm{Ba}$ deposit, Gataga metallogenic belt, Canadian Cordillera. Schematic map and cross section. Adapted from Jefferson and others (1983). 
Monger and Nokleberg. 1996; Nokleberg and others, 2000). The SEDEX deposits of the Gataga metallogenic belt are interpreted as forming during a relatively brief period immediately afler rifling (Paradis and others, 1998; this study). However, other metallogenic belts containing Devonian-Mississippian SEDEX deposits are interpreted as forming over a longer age range, from Frasnian (early Late Devonian) at Macmillan Pass to Tournasian (Early Mississippian) in the Cassiar ternane.

\section{Robb Lake Metallogenic Belt of}

Southeast Missouri Zn-Pb Deposits (Belt RL)

Northern British Columbia

The Robb Lake metullogenic belt of Southeast Missouri Zn-Pb deposits eccurs in northem British Columbia (fig. 17; tables 3. 4) (Nokleberg and others, 1997b, 1998; Nelson and others, 2002) and is hosted in the Proterozoic to Devonian passive continental units of the Rocky Mountains which constitute part of North American Craton Margin. The Southeast Missouri Pb- $\mathrm{Zn}$ deposits in the Robb Lake metallogenic belt oceur in secondary breccias of either solution or tectonic origin in folded dolostones mainly of the Silurian and Devonian Muncho-MoConnel Formation (Taylor and others, 1975; Nelson and othes, 2002).

Occurrences also are located in the underlying Silurian Wokkpash and overlying Devonian Stone.Dunedin, Pine Point, and Slave Point Formations (Macqueen and Thompson, 1978; Nelson and others, 1999; Paradis and others, 1999). The significant deposit is at Robb Lake.

\section{Robb Lake Southeast Missouri Zn-Pb Deposits}

The Robb Lake deposit consists of sphalerite, galena and pyrite which occur primarily in tabular and lenticular zones parallel to bedding in dolomite collapse breccias of the Silurian and Devonian Muncho-McConnel Formation (EMR Canada, 1989; Dawson and others, 1991; Mining Review, 1992; Nelson and others, 2002). The deposit occurs on the west limb and crest of a large south plunging anticline. The deposit occurs in an $8 \mathrm{~km}^{2}$ area, and consists of a series of interconnected, beddingparallel and crosscutting breccia bodies with a matrix of dolomite, sphalerite, galenu, pyrite, quartz, calcite, and pyrobitumen, and peripheral veins and stockwork. (Nelson and others, 2002). Estimated reserves ure 7.1 million tonnes grading $4.7 \% \mathrm{Zn}$ and $1.5 \%$ $\mathrm{Pb}$ (Mining Review, summer, 2000). A significantly larger, but less defined resource for the district and belt is an estimated 20.1 million tonnes grading 5.1\% combined $\mathrm{Pb}$ and $\mathrm{Zn}$ (Dawson and others, 1991).

\section{Origin of and Tectonic Controls for Robb Lake Metallogenic Beit}

The southern part of the Robb Lake metallogenic belt occurs along a Devonian carbonate facies front in shales of the Besa River Formation to the west for $250 \mathrm{~km}$, extending from Mount Burden on the south to the CTV and DODO deposits near Tuchodi Lakes on the north. The stratigraphic setting for these occurrences, that consists of a carbonate front adjacent to the major Great Slave Lake basin, is interpreted as analogous to that at Pine Point (Nelson, 1991). Some oceurrences in the nonthern part of the Robb Lake metallogenic belt contains fluorite, barite, and pyrobitumen and are poor in sphalerite, galena, and pyrite. This feature suggests continuity with the southern end of the Liard metallogenic belt of Southeast Missouri Bs-F deposits which occurs in similar Devonian host rocks (Nelson and others, 2002). The timing of mineralization is poorly constrained, but is interpreted as pre-early Tertiary (pre-Laramide) on the basis of rotated geopetal structures (Manns, 1981) or as Devonian or Missippian on the basis of isotopic studies (Nelson and others, 2002).

The Robb Lake metallogenic belt exhibits characteristics similar to the Liard metallogenic belt of Southeast Missouri(7) Ba-F deposits (described above), and to the Gataga Lake metallogenic belt of SEDEX deposit (described above). Sulphur isotope analyses exhibit heavy values for barite in all three metallogenic belts (K.M. Dawson, unpublished data, 1995). These data and a similar geologic setting suggest a genetic relation between the two deposit types and three metallogenic belts. A similar rifting origin is interpreted for all three metallogenic belts. A major period of Late Devonian and Early Mississippian rifting along the North American Craton Margin is interpreted with rifting away of the Yukoo-Tanana and Kootenay continental margin terranes and formation of the Robb Lake and coeval metallogenic belis (Nokleberg and others, 1994c, $1997 \mathrm{c}$; Monger and Nokleberg. 1996; Nokleberg and others, 2000). Nelson and others (2002) propose a somewhat contrasting inlerpretation of back-are and intra: are spreading, and exhalative activity for the genesis of the Robb Lake and related, coeval metallogenic belts. This back-arc and intra-are spreading would be coeval with the slightly older Kootenary are as interpreted by Nokleberg and others (2000).

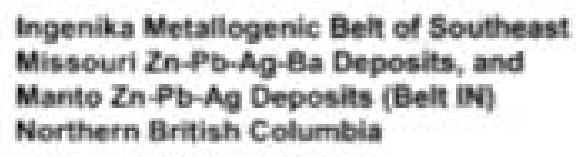

The Ingenika metallogenic belt of Southeast Missouri $\mathrm{Zn}-\mathrm{Pb}-\mathrm{Ag}-\mathrm{Ba}$ deposits and manto $\mathrm{Zn}-\mathrm{Pb}-\mathrm{Ag}$ deposits oceurs in central British Columbia. The belt is hosted in Late Proterozoic to Devonian carbonate-dominated strata of the proximal pericratonic Cassiar terrane (fig. 17; tables 2, 3) (Noklebere and others, 1997b, 1998). The significant deposits are in the Wasi Lake area at Susic, Beveley, and Regent. 
The Susie, Beveley and Regent Southeas Missouri $\mathrm{Zn}-\mathrm{Pb}-\mathrm{Ag}$-Ba deposits consist of sphalerite, galena and barile in four zones of vein and breccia-filling which are hosted in Late Proterozoic to Devonian platformal dolostones (EMR Canada, 1989; Ferri and others, 1992). The deposits contain estimated resources of 2.82 million tonnes grading $2.24 \% \mathrm{Zn}, 1.42 \% \mathrm{~Pb}$, and $36.3 \mathrm{~g} / \mathrm{t}$ $\mathrm{Ag}$. The deposit age is interpreted as Cambrian to Devonian, similar to the host rocks. A series of probably eurly Tertiary foliated felsic dikes occur along the top of Bevely Mountain. The dikes range up to $200 \mathrm{~m}$ wide.

\section{Origin of and Tectonic Setting for Ingenika Metallogenic Belt}

The Southeast Missouri $\mathrm{Zn}-\mathrm{Pb}-\mathrm{Ag}$-Ba deposits and Manto $\mathrm{Zn}-\mathrm{Pb}-\mathrm{Ag}$ deposits in the Ingenika metallogenic belt possess an ore mineral assemblage and morphology characteristic of manto replacement (Nelson, 1991). The deposits in the belt ure interpreted as forming during deposition of metal from low temperature brines which may have originated within an adjacent shale basin. The Ingenika metallogenic belt is herein interpreted us a displaced part of the Cathedral metallogenic belt of Southeast Missouri Zn-Pb-Ag deposits (Dawson, 1996a; Nokleberg and others, 1997b, 1998) wbich occurs mainly in the western margin of the North American Craton Margin. Rock sequences in the Cassiar terrane are similar to those in the western North American Craton Margin to the south, thereby suggesting a dextral, northward displacement of Cassiar terrane about $700 \mathrm{~km}$ along the Tintina-Rocky Mountain Trench fault system in the Late Cretaceous and early Tertiary, as proposed by Gabrielse (1985). Restoration of this displacement would juxtapose the Ingenika and Cathedral metallogenic belts of Southeast Missouri Pb- $\mathrm{Zn}$ deposits,

\section{Cathedral Metallogenic Belt of Southeast Missouri Zn-Pb-Ag Deposits Southem British Columbia (Belt CA)}

The Cathedral metallogenic belt of Southeasi Missouri Zn-Pb-Ag deposits occurs in southern British Columbia (fig. 17; tables 2, 3) (Nokleberg and others, 1997b, 1998). The metallogenic belt is hosted in the Middle Cambrian Cathedral and Jubilee Formations which contain dominantly carbonate rocks which are part of a shallow-water, carbonate-clastic shelf which was deposited along the passive continental margin of the North American Craton Margin. The deposits in the Cathedral metallogenic belt contain the only Southeast Missouri $\mathrm{Pb}-\mathrm{Za}$ deposits in the Canadian Cordillera with significant production. The significant deposit is at Monarch (Kicking Horse).

\section{Monarch (Kicking Horse) Southeast Missouri Zn- Pb Deposit}

The Monarch Southeast Missouri $\mathrm{Zn}-\mathrm{Pb}$ - $\mathrm{Ag}$ deposit extends along strike for of over $1,370 \mathrm{~m}$ in folded, breceiated and dolomitized limestone of the Cathedral Formation (Hey, 1982; MINFILE, 2002). The deposit consists of argentiferous galena, sphalerite, and pyrite which occur as fillings in north-south striking, vertical fissures along the east limb of an anticline. Combined production and reserves are 820,000 tonnes grading $5.63 \% \mathrm{~Pb}, 8.85 \% \mathrm{Zn}, 31 \mathrm{~g} / \mathrm{Ag}$. The deposit age is interpreted as Middle Cambrian. Minor similar oceurrences are at Hawk Creek, Steamboat and Shag, to the southeast of the Monarch (Kicking Horse) deposit.

\section{Origin of and Tectonic Controls for Cathedral Metallogenic Beft}

The age of mineralization for the Catbedral metallogenic belt is not known precisely, and the genesis of Southeast Missouri-type deposits is debatable. Faults, breccias and other open spaces in the host shelf limestone are filled by an assemblage of sulfide minerals and calcite-dolornite-fluorile gangue. The ore metals probably were transported and deposited by low temperature brines which may have originated within the adjacent shale basin. The Cathedral metallogenic belt is correlated with the Devonianl(f) Ingenika metallogenic belt in central British Columbia, described above. This relation suggests dextral. northward displacement of about $700 \mathrm{~km}$ along the Tintina fault system (Gabrielse (1985).

\section{Southern Rocky Mountains Metallogenic Belt of Stratabound Barite-Magnesite-Cypsum Deposits (Belt SRM) Southern British Columbia}

The Southern Rocky Mountains metallogenic belt of stratabound barite-magnesite-gypsum deposits (fig. 17; tables 3,4) occurs in southeastern British Columbia and is hosted in passive continental margin sedimentary rocks of the North American Craton Margin. The significant deposits are at Brisco, Forgetmenot Pass, Kootenay River Gypsum, Lussier River (United Gypsum), Marysville, Mount Brussilof, Parson, and Windermere Creek (Western Gypsum) (table 4) (Nokleberg and others 1997a, b. 1998). Most of the deposits range in age from Cambrian to Devonian; a few formed in the Triassic (Nokleberg und others, 
1997a, b). Most of the magnesile and barite deposits in the belt are hosted primarily in Cambrian carbonate units. In southeastern British Columbia, the belt contains a major group of gypsum mines which are hosted in Devonian stmata. Also occurring in the belt are local magnesite, and $\mathrm{Zn-Pb}$ deposits, as at Kicking Horse.

Windermere Creek (Western Gypsum)

Chemical-Sedimentary Cypsum Deposit

The Windermere Creek (Western Gypsum) chemical-sedimentary gypsum deposit consists of gypsum and anhydrite which underlie basal carbonate strata of the Devonian Burnais Formation (British Columbia Department of Mines and Petroleum Resources, 1991; MINFIL.E, 2002). The deposit and related occurrences form a belt which extends $80 \mathrm{~km}$ from Windermere Creek southeastward to Kootenay River and Lussier River. Estimated reserves range from 7 to 12 million tonnes of ore grading $90 \%$ gypsum. About 6.8 million tonnes of ore has been produced at four open-pit operations. A synsedimentary evaporite origin is interpreted for the deposits and for gypsum in concordant beds in dolostone of the Late Triassic Whitehorse Formation at Forgetmenot Pass.

\section{Marysville and Mount Brussillof (Baymag)}

Chemical-Sedimentary Magnesite Deposits

These chemical-sedimentary magnesite deposits consist of conformable, interbedded magnesite which is bosted within quartzites of the upper $100 \mathrm{~m}$ of the Early Cambrian Cranbrook Formation (Grant, 1987; Simandl and Haneock, 1999; MINFIL.E, 2002). The thickest beds range up to approximately 15 meters thick and are exposed over a strike length of $5.5 \mathrm{~km}$. The average grade is 40 to $45 \% \mathrm{MgO}$. Chemical-sedimentary magnesite forms extensive replacements of carbonates of the Middle Cambrian Cathedral Formation at the Mount Brussilof (Baymag) deposit (Grant, 1987; Simandl and Hancock, 1991; MINFILE, 2002). Estimated reserves are 40.7 million tonnes grading $92.4 \%$ to $95 \% \mathrm{MgO}$.

\section{Parson and Brisco Barite Vein and Gypsum Deposits}

The Parson barite vein deposit consists of barite and lesser gypsum in vein and breccia fillings in Early Cambrian quartzite which is underlain by dolostone and shale (Leitch, 1991; MINFILE, 2002). The mine at Parson produced 75,000 tonnes of barite at unspecified grade from two parallel veins between 1957 and 1988. The Brisco vein and breccia deposit occurs in a breccia zone in Ordovician dolostone (Reesor, 1973; MINFILE, 2002). Between 1947 and 1973 the mine at the deposit produced 140,000 tonnes grading $98 \%$ barite. In both cases, early Paleozoic replacement is interpreted.

\section{Origin of and Tectonic Setting for \\ Southern Rocky Mountains Metallogenic Belt}

The Southern Rocky Mountains metallogenic belt contains a diverse age group of large, stratabound and stratiform deposits of gypsum-anhydrite, barite, and magnesite. From oldest to youngest, the ages and modes of formations of the significant deposits are: (1) early Paleozoic replacement for formation of Parson Ba vein deposit; (2) Cambrian synsedimentary deposition of stratiform Marysville chemical-sedimentary magnesite deposit; (3) Middle Cambrian replacement for formation of Mount Brussilof chemical-sedimentary magnesite deposit; (4) Ordovician replacement for formation of Brisco Ba vein deposit; and (5) Devonian synsedimentary deposition of stratiform Windermere Creek chemical-sedimentary gypsum deposit. A few deposits are also interpreted as forming in either the late Paleozoic or Triassic (Nokleberg and others, 1997a, b). From this short list, at least two major origins exist, either stratiforn evaporate-related deposits, or replacement vein deposits which formed over a long geologic history. With further study, the Southem Rocky Mountains metallogenic belt may be divided into several metallogenic belts which formed during several lectonic events which affected the passive continental margin sedimentary rocks of the North American Craton Margin.

\section{Mississippian Metallogenic Belts (360 to 320 Ma; Figures 16, 17)}

\section{Overview}

The Mississippian metallogenic belts in the Russian Far East, Alaska, and the Canadian Cordillera are summarized in table 3 and portrayed on figures 16 and 17. The major belt was the Northwestern Brooks Range (NBR) belt of SEDEX Zn-Pb and bedded barite deposits which is hosied in the Aretic Alaska superterrane. This belt is interpreted as forming during MississippianPennsylvanian back-are spreading along North American Craton Margin. Continuing on from the Middle and Late Devonian were the Berezovka River (BE), Selennyakh River (SEL), Sette-Daban (SD), Urultun and Sudar Rivers (URS), Kedon (KE), Yarkhodon (YR), Northern Cordillera (NCO), Macmillan Pass (MP), Finlayson Lake (FL), and Gataga (GA) metallogenie belts. In the below descriptions of metallogenic belts, a few the noteable or significant lode deposits (rable 4) are described for each belt. 
During the Mississippian (360 to $320 \mathrm{Ma}$ ), the major metallogenic-tectonic events were (table 3): (1) separation of North Asian and North American Cratons and Cratons Margins along a series of oblique-sinistral rifts; (2) ending of rifting of fragments from cratons and their margins and formation of associated metallogenic belts; (3) continuation of the Sicker are and associated subduction in the Wrangellia superterrane. Sedimentation continued along the North Asian and North American Craton Murgins.

\section{Specific Events for Mississippian}

(1) From the late Devonian and to the Early Mississippian, rifting oceurred along the eastern margin of the North Asian Craton Margin (NSV, KN). This event formed the Kotelnyi (KT), Omulevka (OV), Prikolyma (PR), Nixon Fork-Dillinger-Mystic (NX, DL, MY), Viliga (VL), and Zolotogorskiy (ZL) passive continental-margin terranes, the Avekova (AK), Kilbuck-Idono (KI), Okhotsk (OK), and Omolon (OM) cratonal terranes, and the Beryozovka (BE), Oloy (OL), and Yarakvaum (YA) terranes. Before the rifting, these terranes were parts of either the North Asian Craton (NSC), the North Asian Craton Margin (NSV), or the Devonian continental-margin arc which formed along the margins of the North American and North Asian Craton Margins (fig. 29). The newly-created terranes remained into the Angayucham Ocean. Derived from the North Asian Craton (NSC) and Cratoa Margin (NSV) were the Kotelnyi (KT), Omulevka (OV), Prikolyma (PR), Nixon Fork-Dillinger-Mystic (NX, DL, MY), Viliga (VL), and Zolotogorskiy (ZL) passive continental-margin terranes, the A vekova (AK), Kilbuck-Idono (KI), Okhotsk (OK), and Omolon (OM) cratonal terranes. Derived from the Devonian continental-margin are which formed along the margins of the North Asian Craton Margin were the Beryozovka (BE), Oloy (OL), and Yarakvaam (YA) terranes (fig. 29). Derived from the North American Craton Margin (NAM) were the Kootenay (KO) and Yukon-Tanana (YT) passive continental-margin terranes. Accompanying the rifting was formation of the Northwestert Betezovka River (BE), Brooks Range (NBR), Dempster (DE), Finlayson Lake (FL), Gataga (GA), Northern Cordillera (NCO), Macmillan Pass (MP), older part of Mystic (MY), Selennyakh River (SEL), Sette-Daban (SD), Southern Rocky Mountain (SRM), Tommot River (TO), and Urultun and Sudar Rivers (URS) metallogenic belts which all contain massive sulfide, carbonatie-related $\mathrm{Nb}, \mathrm{Ta}$, and RFE, and related deposits.

(2) Movement along a series of oblique-sinistral rifts resulted in the separation of North Asian and North American Cratons and Cratons Margins.

(3) The Kedon continental margin are and associated subduction zone continued activity along the margin of the North Asian Craton and Craton Margin (NSC. NSV) until about the late Early Mississippian. Associated with the are was subduction of the older part of the Galam (GL) accretionary wedge terrane. Remnants of the arc are preserved in the in part of the North Asian Craton and Craton Margin (NSC, NSV, KN (2) units which overlie parts of the Okhotsk (OK), Akekova (AK), Omolon (OM) cratonal terranes; (3) the Oloy (OL) and Yarakvaam (YA) island-are terranes; and (4) the Beryozovka (BE) turbidite-basin terrane.

(4) The Sicker island arc, which formed in the Devonian along most of the length of the Wrangellia superterrane (WRA) ceased activity. Insufficient data exist to ascertain the relative positions of the Wrangellia superterrane.

\section{Metallogenic Beit Formed During \\ Mississippian-Pennsylvanian Back-Arc \\ Spreading Along North American \\ Craton Margin}

\section{Northwestern Brooks Range \\ Metallogenic Beit of SEDEX Zn-Pb, Bedded Barite, Kuroko Massive Sulfide, and Sulfide Vein Deposits (Beit NBR) Northwestern Alaska}

The major Northwestem Brooks Range metallogenic belt of large SEDEX Zn-Pb-Ag (SEDEX), kuroko massive sulfide, bedded barite, and sulfide vein deposits (fig. 17; tables 3, 4) occurs in northwestern Alaska. The metallogenic belt is hosted in the Kagvik sequence in the Endicott Mountains passive continental margin terrane of the Arctic Alaska superterrane (Nokleberg and others, 1994c, 1997c). The belt extends along strike for more than $200 \mathrm{~km}$. Locally associated with the SEDEX deposits are vein sulfide deposits. The larger SEDEX Zn-Pb-Ag deposits are at Lik and the Red Dog Creek deposit, a world-class mine of zine and lead (Schmidt, 1997a), and the Drenchwater Creek kuroko-massive sulfide deposit (Nokleberg and Winkler, 1982; Lange and othen, 1985), Other deposits in the belt are the Hannum Creek metamorphosed SEDEX Zn-Pb? deposit, the Omar Kipushi Cu-Pb$\mathrm{Zn}$ deposit, the Frost, Story Creek, and Whoopee Creek Cu-Zn-Pb-Ba sulfide vein deposits, and the Nimiuktuk bedded barite deposit (table 4) (Nokleberg and others 1997a, b, 1998). 


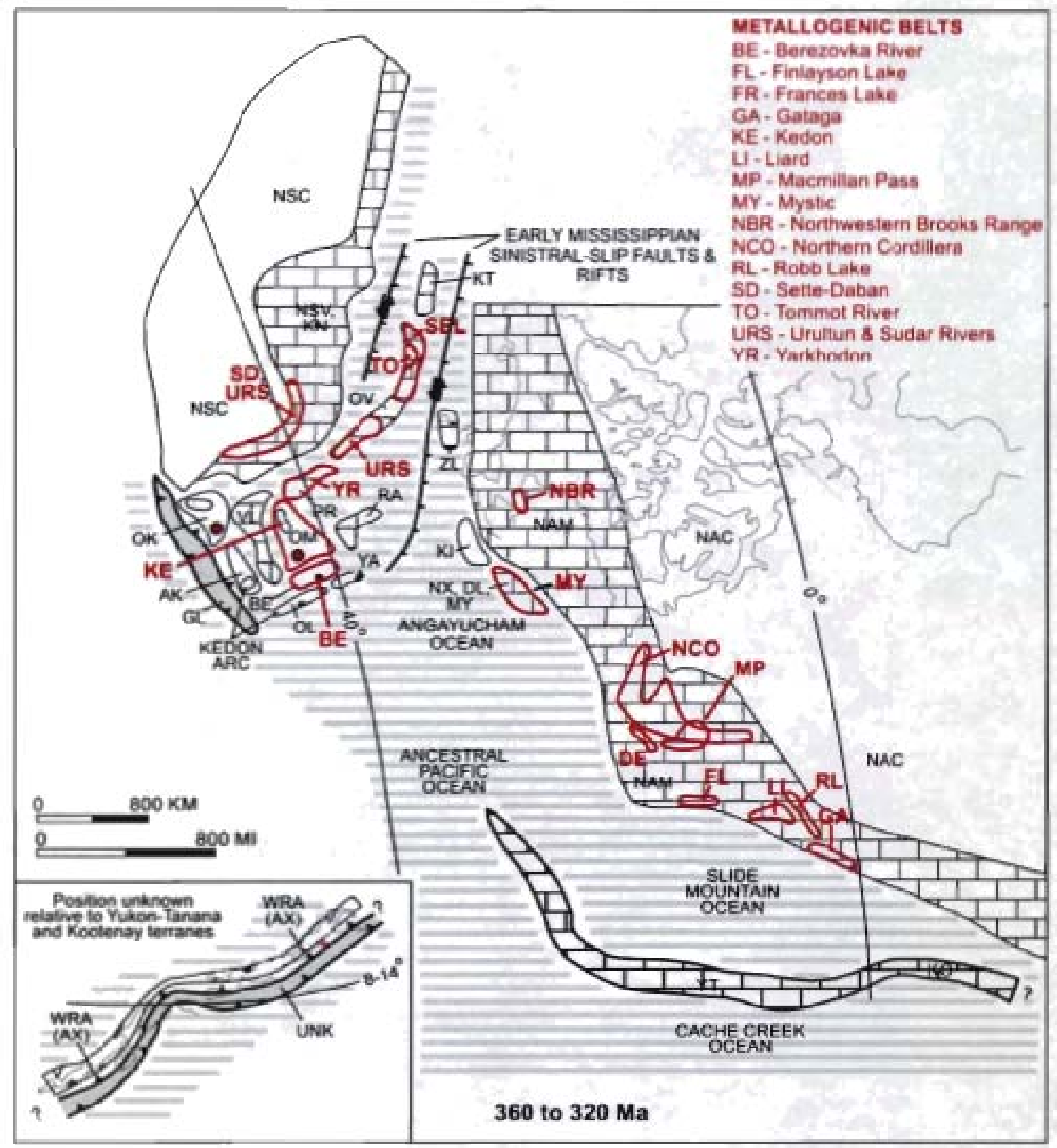

Figure 29. Mississippian (360 to $320 \mathrm{Ma}$ ) stage of metalogenic-tectonic model. Refer to text for explanation of metallogenio-lectonic events. Refor to text for explanation of metallogenic-tectonic events, to tables 3 and 4 for descriptions metallogenic beits and significant deposits, and to figure 18 for explanation of abbreviations, symbois, and patterns. Adapted from Nokleberg and others (1997b, 1998, 2000)

\section{Red Dog Creck SEDEX Zn-PB Deposit}

The Red Dog Creek SEDEX Zn-Pb-Ag deposit (fig. 39) (Tailleur. 1970; Plahuta, 1978; Booth, 1983; Joseph T. Plahuta, L.E. Young, J.S. Modene, and D.W. Moore, written commun., 1984; Lange and others, 1985; Moore and others, 1986; Schmidt, $1997 \mathrm{a}$; Schmidt and Zierenberg. 1988; Bundtzen and others, 1996) consists of disseminated and massive sphalerile, galent, pyrite, and barite in Mississippian and Pennsylvanian shale, chert, and silica exhalite of the Kuna Formation. The deposit is $1,600 \mathrm{~m}$ long and up $10150 \mathrm{~m}$ thick and occurs near the base of the Kuna Formation. Barite-rich lenses, up to $50 \mathrm{~m}$ thick locally cap the deposit. The sulfide minerals occur as: disseminated sulfides in organic-rich siliceous shale; coarse-grained sulfide veins, fine-grained, fragmental-lextured to indistinctly bedded sulfides; and silica exhalite lenses. Minor hydrothermal alieration consists of 
silicification and decarbonatization of shale, A small, propylitically altered diorite plug or hydrothermally altered pyroxene andesite flow occurs at north end of deposit. Proor to mining, which began in 1990, the Main deposit was estimated to contain 85 million tonnes grading $17,1 \% \mathrm{Zn}, 5 \% \mathrm{~Pb}$, and $82 \mathrm{~g} / \mathrm{Ag}$. By the end of 1999, the four SEDEX deposits at Red Dog (Main. Aggaluk, Hill Top, Anarrag) contained an estimated 142.3 million tonnes grading $15.8 \% \mathrm{Zn}, 4.3 \% \mathrm{~Pb}$, and $83 \mathrm{~g} / \mathrm{Ag}$ (Swainbank. and Szumigla, 2000) The host rocks and deposit are extensively structurally imbricated along many subborizontal thrust faults. Graywacke of the Cretaceous Okpiknak Formation structurally underlies deposit,

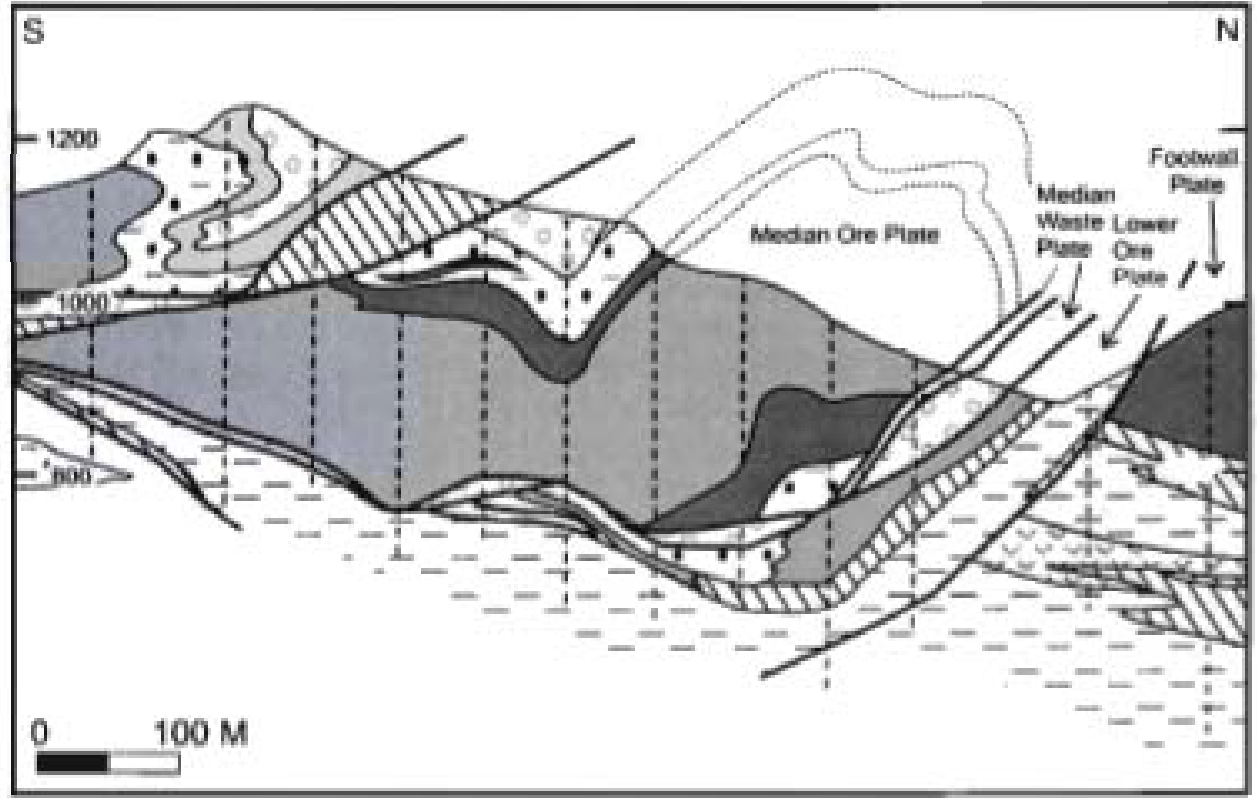

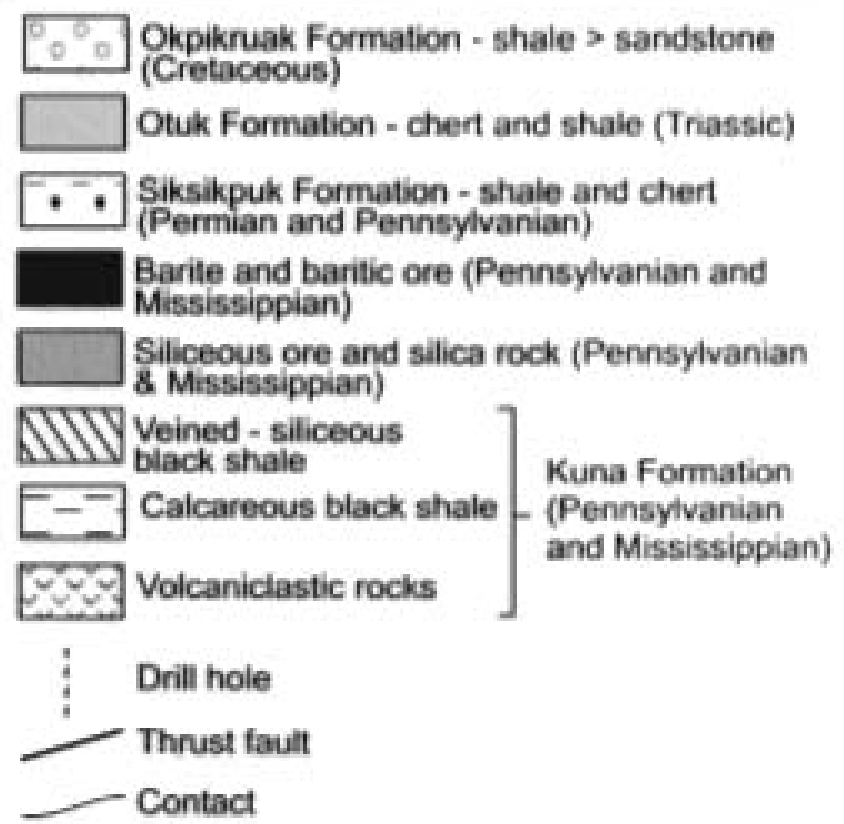

Figure 30. Red Dog Creek sedimentary exhalative Zn-Pb-barte deposit, Northwestem Brooks Range metalogenic belt, Northern Alaska. Schematic geologic cross section through the Main deposit showing the structural interpretation of thrust plates and the overturned foid related to thrust faults. Section along N 40 E. Adapted from Schmidt (1997).

\section{Drenchwater Creek SEDEX Zn-Pb and (or) Kuroko Massive Sulfide Deposit}

The Drenchwater Creek SEDEX Zn-Pb and (or) kuroko massive sulfide deposit consists of disseminated and massive sphalerite, galena, pynite, and barite in Mississippian shale, chert, tuff, and quartz-exhalite of the Kagvik sequence (Nokleberg and Winkler, 1982; Lange and others, 1985). Volcanic sandstone and keratophyre are locally abundant. The salfides occur as 
disseminations in chert, disseminations and massive aggregates in quartz-exhalite, and as sparse, remobilized disseminations in sulfide-quartz veins crosseuiting cleavage in shale and chert. Locally exiensive hydrothermal alteration of chert and shale is accompanied by extensive replacement by kaolinite, montmorillonite, sericite, prehnite, fluorite, actinolite, chlorite, calcite, and quartz. Grab samples contain more than $1 \% \mathrm{Zn}, 2 \% \mathrm{~Pb}$, and $150 \mathrm{~g} / \mathrm{Ag}$. The deposit ranges up to $1,800 \mathrm{~m}$ long and up to $50 \mathrm{~m}$ thick. The host rocks and deposit are extensively faulted and structurally imbricated by many thrust faults which dip moderately south

Origin of and Tectonic Controls for Northwestern Brooks Range Metallogenic Beit

The Northwestern Brooks Range metallogenie belt of Zn-Pb-Ag SEDEX, bedded barite, kuroko massive sulfide, and vein deposits is hosted in a tectonically disrupted and strongly folded assemblage of Mississippian and Pennsylvanian chert, shale, limestone turbidite, minor tuff, and sparse intermediate to silieic volcanic rocks, mainly keratophyre, named the Kuna Formation by Mull and others (1982). The Kuna Formation is the basal unit of the Kagvik sequence of Churkin and others (1979) and the Kagvik terrane of Jones and others (1987), and part of the DeLong Mountains ierrane of the Aretic Alaska superterrane of Moore and others (1994). This unit, and younger, late Paleozoic and early Mesozoic cherts and sbales are interpreted either as a deepwater, allochthonous oceanic assemblage (Churkin and others, 1979; Nokleberg and Winkler, 1982; Lange and others, 1985), or as an assemblage deposited in an intracratonic basin (Mull and others, 1982; Mayfleld and others, 1983; Schmidt, 1997a). Herein, the SEDEX Zn-Pb-Ag, bedded barite, and kuroko volcanogenic massive sulfide deposits in the Northwestern Brooks Range belt are interpreted as forming during a short-lived period of Late Mississippian and Early Pennsylvanian rifting or back-are spreading that was possibly associated with a short-lived continental-margin arc.

South of the main east-west-trending belt of SEDEX $\mathrm{Zn}-\mathrm{Pb}$-Ag and bedded barite deposits are a group of sulfide vein deposits at Story Creek, Whoopee Creek, and Frost, and a Kipushi Cu-Pb-Zn deposit at Omar. The vein deposits generally consist of sphalerite and galena in association with quartz and minor curbonate gangue in veins and fractures (Ellersieck und others, 1982; Mayfield and others, 1983; Schmidt, 1997b). The vein deposits occur in the middle Paleozoic continental-margin sedimentary rocks of the Arctic Alaska superterrane. The veins and fractures occur in 1.5-3-km long linear zones which cross tightly folded strata, indicating an epigenetic origin (Schmidt, 1997b). No tonnage and grade data are availuble. Insufficient data preclude assignment of these deposits to a specific mineral deposit type. The vein deposits are interpreled by some workers as the possible feeders to the Zn-Pb SEDEX deposits and as having possibly formed during dewatering of the same source basin (Schmidt, 1993). However, this interpretation is contradicted by the field relation in which the vein deposits cross tightly-folded strata, indicating formation of veins after Cretaceous deformation of the strata.

\section{Pennsylvanian Metallogenic Belts (320 to $286 \mathrm{Ma}$; Figures 31, 32)}

\section{Overview}

The major Pennsylvanian metallogenic belts in the Russian Far East, Alaska, and the Canadian Cordillera are summarized in table 3 and portrayed on figures 29 and 30. The major belts are as follows, (1) In the Russian Southeast, the Laoelin-Grodekovsk (LG) belt, which contains granitic-magmatism-related deposits, is hosted in the Laoelin-Grodekovsk islandare terrane. This belt is interpreted as forming during subduction-related granitic plutonism that formed the Laoelin-Grodekovsk island arc, part of Khanka superterrane. (2) In the Russian Northeast, the Aluchin (AC) and Ust-Belaya (UB) belts contain podiform $\mathrm{Cr}$ deposits and are hosted mainly in fragments of ophiolites that are preserved in the Aluchin, and Penzhina-Anadyr subduction-zone terranes, respectively. The Aluchin belt is interpreted as forming in Oceanic lithosphere preserved in Aluchin subuction zone that was tectonically linked to Alazeya island arc. The Ust-Belaya belt is interpreted as forming in Oceanic lithosphere preserved in Penzhina Anadyr subuction zone that was tectonically linked to Koni-Murgal continental margin and island arc. (3) In northwestem Alaska, the Northwestern Brooks Range metallogenic belt, which contains SEDEX Zn-Pb-Ag. kuroko volcanogenic massive sulfide, bedded barite, and sulfide vein deposits, continued to form. (4) In Southern Alaska, the Alaska Range-Wrangell Mountains (ARW) and Ketchikan (KK) belts, which contain granitic-magmatism-related deposits and buroko massive sulfide deposits, are hosted in the Wrangellia superterrane, and are interpreted as forming in the short-lived Skolai island arc. In the below descriptions of metallogenic belts, a few of the noteable or signficant lode deposits (table 4 ) are described for each belt. 


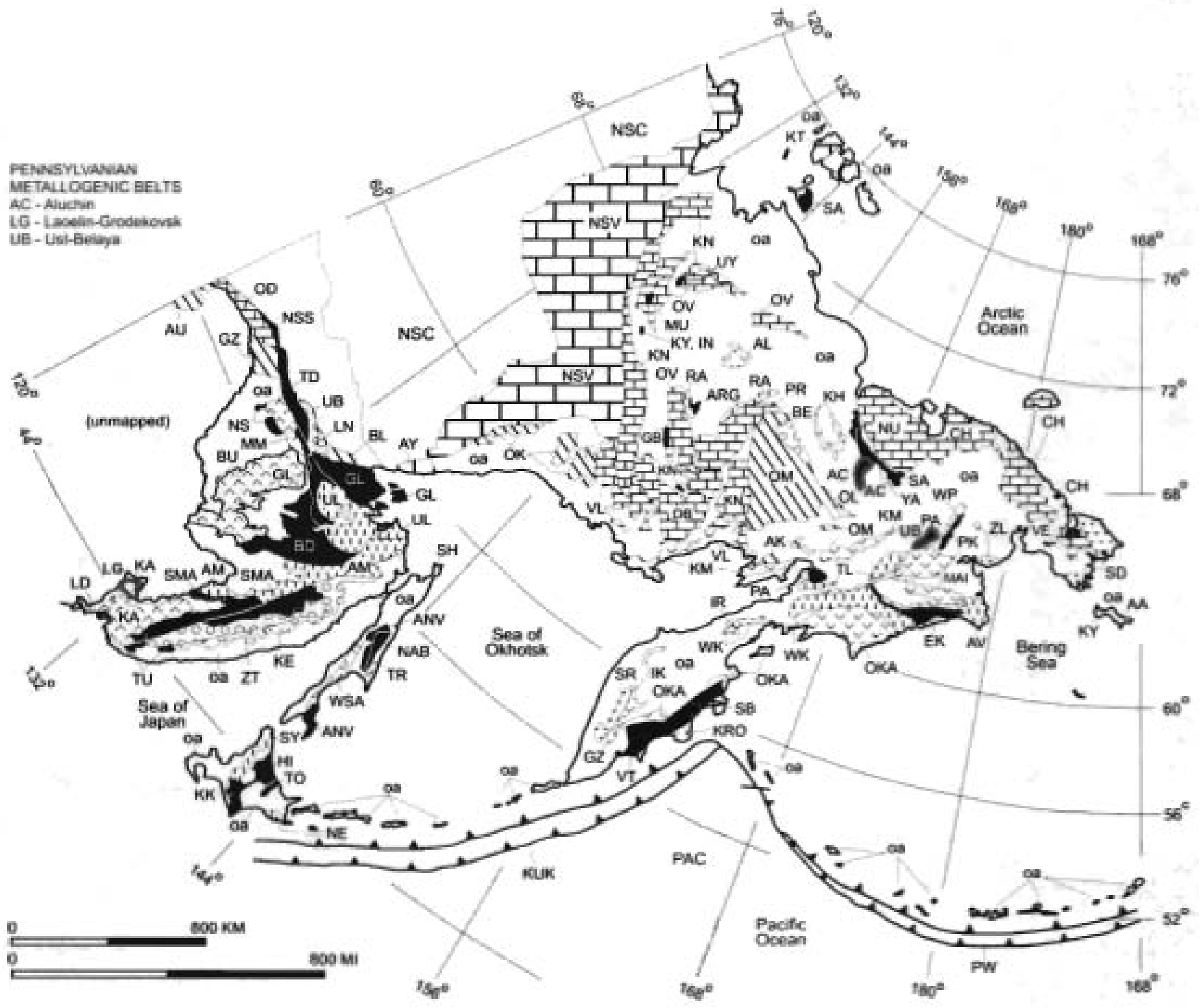

Figure 31. Generalized map of major Pennsylvanian metallogenic belts and terranes for Russian Far East, northem Japan, and adjacent offshore areas. Refer to text for description of metallogenic belts. Adapied from Nokieberg and others (1997b, 1998). Refer to figure 2 for explanation.

\section{Metallogenic-Tectonic Model for Pennsylvanian (320 to $286 \mathrm{Ma}$; Figure 33)}

During the Pennsylvanian ( 320 to $286 \mathrm{Ma}$ ), the major metallogenic-tectonic events were (table 3): (1) inception of the older parts of Stikinia-Quesnellia are (Stikinia and Quesnellia lerranes) and associated subduction zone in the Yukon-Tanana (YT) and Kootenay (KO) terranes is an area offshore of the North American Craton Margin (NAM); and (2) formation of the Skolai island are and associated metallogenic belt, and associaled subduction zone in the Wrangellia superterrane. Sedimentation continued along the passive continental margias of North A sia and North America. Out of the field of view of figure 33 was formation of the Laoelin-Grodekovsk (LG) metallogenic belt, which contains granitic-magmatism-related deposits and which formed in the Laoclin-Grodekovik island-are terrane. 


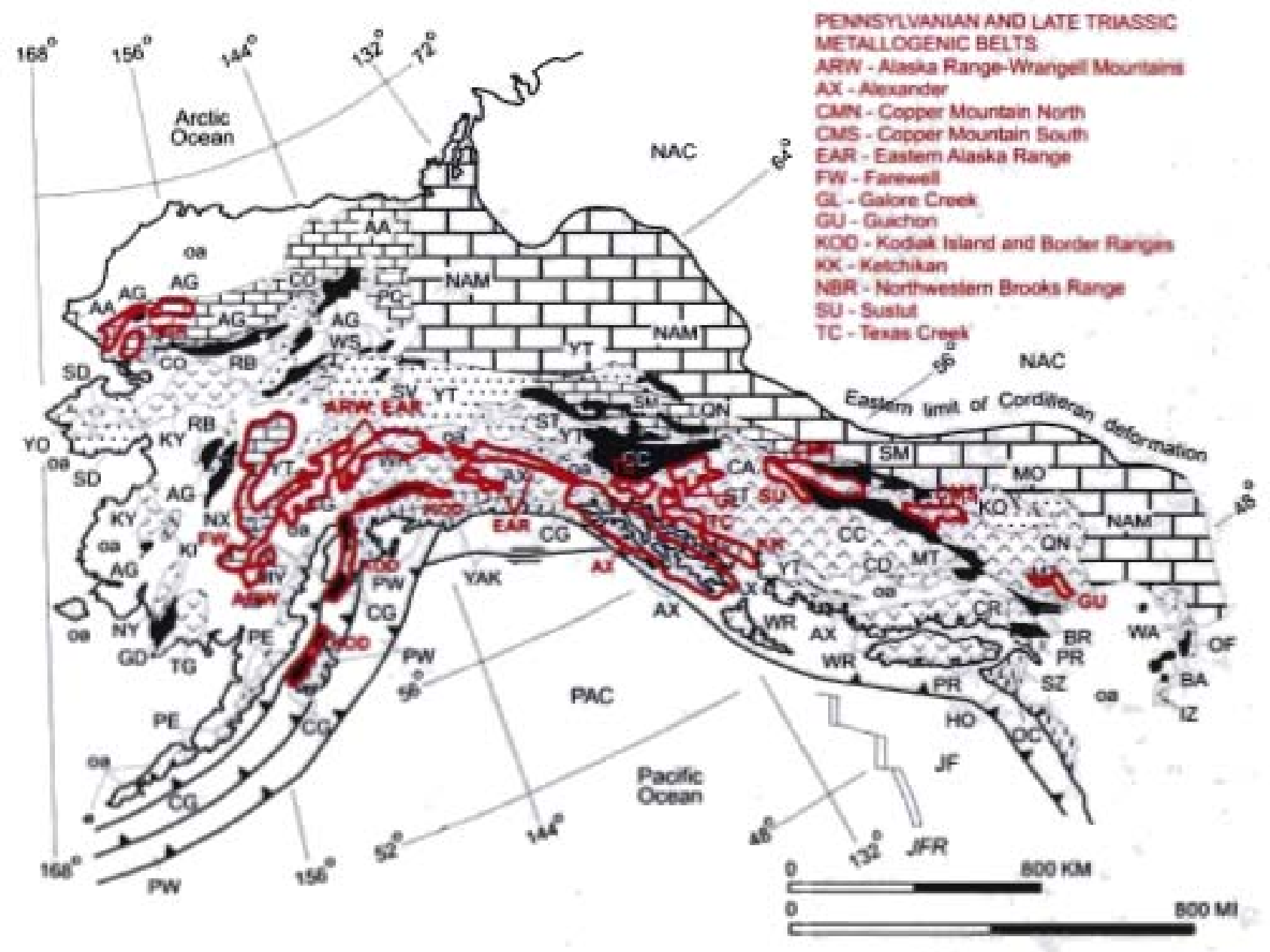

Figure 32. Generalized map of major Pennsyivanian and Late Triassic metallogenic belts and terranes for Alaska, Canadian Cordillera, and adjacent oftshore areas. Refer to text for description of metallogenic belts. Adapted from Novleberg and others (1997b, 1998). Refer to foure 3 for explanation.

\section{Specific Events for Pennsylvanian}

(1) Along the margis of the North Asian Craton (NSC), dextral-slip occurred along the Mongol-Okhotsk suture (MO). resulting in displacement of its southern margin relative to the Mongol-Okhotsk Ocean.

(2) Between the North Asian and North American Cratons, sporadic sea-floor spreading is interpreted as having enlarged the ancestral Pacific Ocean and formed the Oimyakon, Angayucham, and Goodnews Oceans. Forming during this event were the Aluchin (AC), and Ust-Belaya (UB) metallogenic belts which contain podiform Cr deposits and are hosted mainly in fragments of ophiolites which are sow preserved in the Aluchin, and Penzhina-Anadyr, subduction-zone terranes. Fragments of the Oimyakon Ocean are preserved in the Debin and Garbyn'ya terranes (fig. 33). Fragments of the Angayucham and Goodnews Oceans are preserved in the Angayucham and Goodnews terranes, respectively (fig. 33).

Within the Angayucham Ocean were the Kilbuck-Idono cratonal terrane (KI), derived from the North Asian Craton (NSC), and the Nixon Fork-Dillinger-Mystic passive continental-margin ternanes (NX, DL, MY), derived from the North Asian Craton Margin (NSV). During this time span, before accretion to the present Nenth American continent, the Nixon Fork-DillingerMystic terrane may have experienced several post-rifting events which formed additional units, such as the siliciclastic rocks of the Sheep Creek Formation and the Mt. Dall Conglomerate.

(3) The intraoceanic Omulevka Ridge, which separated the Oimyakon and ancestral Pacific Oceans, consisted of the Omulevka (OV), Prikolyma (PR), and Omolon (OM) terranes. These terranes were previously riffed from North Asian Craton and Craton Margin in the Early Mississippian. The Paleozoic Yarakvaam (YA), Oloy (OL), and the Alazeya (AL) island-are terranes, together with the Beryozovka turbidite-basin terrane (BE), are interpreted as parts of an active island are on an extension of the Omulevka Ridge.

(4) Along the margin of the Angayucham Ocean, between the North Asian and North American Cratons and Cratoe Margins, was the Taymyr Peninsula collage (TA; Vernovskiy and others (1998) which is interpreted as a series of Late 
Proterozoic ophiolite, island-are, and passive continental-margin terranes which were displaced along dextral-slip faults along the margin of the

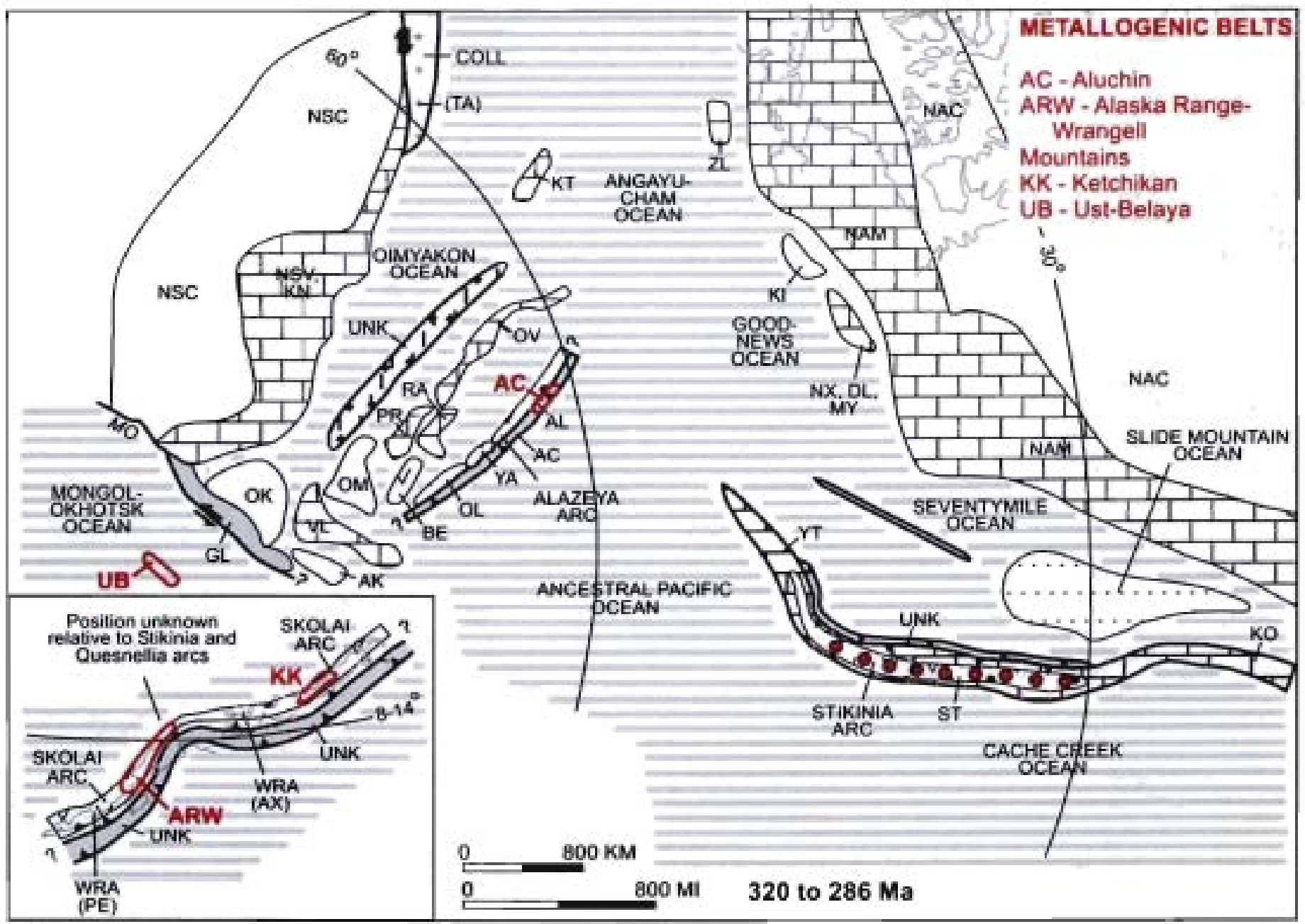

Figure 33. Pennsytvanian ( 320 to $286 \mathrm{Ma}$ ) stage of metallogenic-tectonic model. Refer to text for explanation of metallogeniclectonic events, to tables 3 and 4 for descriptions metallogenic belts and significant deposits, and to figure 18 for explanation of abbreviations, symbols, and patterns. Adapted from Nokleberg and others (1997b, 1998, 2000).

North Asian Craton (NSC) and North Asian Craton Margin (NSV, KN) (Zonenshain and others, 1990; Vernikovsky and others, 1998).

(5) Fragments of the North American Craton Margin (NAM), including the Yukon-Tanana (YT) and Kootenay (KO) terranes, which formed offshore during Early Mississippian rifting, occurred offshore from the North American Craton Margin (NAM). Towards the North American Craton Margin were the Slide Mountain and Seventymile Oceans. An extensive but thin submarine fan was deposited in the Slide Mountain Ocean (Anvil Ocean of Templeman-Kluit, 1979) between the Yukon-Tanana (YT) and Kootenay (KO) continental-margin terranes and the North American Craton Margin (NAM).

(6) At an unknown location, the Skolai island are was active along the length of the Wrangellia superterrane (WRA). Associated with the are was a presumed (unknown) subduction zone (UNK). The Skolai are deposits consist mainly of Early to Middle Pennsylvanian plutons and Pennsylvanian and Permian marine volcanic and volcaniclastic rocks that are interpreted as forming at high latitudes (Nokleberg and others, 1994b, 2000). Forming with the arc was the Alaska Range-Wrangell Mountains (ARW) metallogenic belt which contains granitic-magmatism-related deposits and the Ketchikan (KK) metallogenic belt which contains kuroko massive sulfide deposits. The basement for the Skolai arc may in part be the Alexander terrane which contains a fragment of an early and middle Paleozoic continental-margin are (Nokleberg and others, 1994b). Insufficient data exist to ascertain the relative positions of the Wrangellia superterrane (WRA; and contained Skolai arc), and its associated subduction zone, with respect to the Stikinia and Quesnellia island-arc terranes and their associated subduction zones. Fauna in the Slana Spur and Eagle Creek (former Mankommen) Formations of the eastern Alaska Range indicate a high-latitude environment (Petocz, 1970).

(7) Subsequently in the Permian, the major part of the Stikinia-Quesnellia are overlapped part of the Yukon-Tanana terrane after weak initiation of the arc in the Mississippian. This arc, defined by Permian granitic plutons in the Yukon-Tanana 
terrane, and by the Stikine Assemblage in the Stikinia terrane, may have been tectonically linked to subduction of part of the Seventymile Ocean. Evidence in the Yukon Territory frvors the Stikine part of the are facing toward the North American Craton Margin (NAM, Monger and Nokleberg. 1996). Along strike, the extension of the are occurs in the Harper Ranch Group of the Quesoellia (QN) island are terrane. Part of the are was probably linked tectonically to subduction of part of the Cache Creek Ocean (Monger and Nokleberg. 1996).

(8) Fauna of the Quesnellia and Stikinia terranes (QN and ST) are elosest to those southwestem United States and northem Andean regions; the terranes probably formed along the continental margin at lower latitudes than their present positions. Estimates suggest which Stikinian fauna were located anywhere from near 0 to $8,000 \mathrm{~km}$ away from the craton (Belasky and Runnegar, 1994)

\section{Metallogenic Belt Formed in Late Paleozoic Island Are Terrane in Russian Southeast}

\section{Laoelin-Grodekovsk Metallegenic Belt of Porphyry Cu-Me and Au-Ag Epithermal Vein Deposits (Beit LG) \\ Southern Part of Russian Southeast}

The Laoelin-Grodekovsk metallogenic belt of porphyry Cu-Mo and Au epithermal vein deposits (fig, 31; tables 3, 4) occurs in the late Paleozoic Laoelin-Grodekovsk island-arc terrane in the southern part of the southern Russia Far East. The porphyry Cu-Mo deposits and Au-Ag epithermal vein deposits occur in, or are associated with a thick Permian marine sequence of felsic and mafic voleanic rocks which may also be favorable for undiscovered kuroko massive sulfide deposits. Small lenses of sphalerite ore occur conformable to shales in this sequence. The principal deposit porphyry $\mathrm{Cu}$-Mo deposit is at Baikal, and the significant Au-Ag epithermal vein deposit is at Komissarovskoe (table 4) (Nokleberg and others 1997a, b, 1998). The region and metallogenic belt is poorly exposed and poorly studied.

\section{Balkal Porphyry Cu-Mo Prospect}

The Baikal porphyry Cu-Mo prospect (Petrachenko and Petrachenko, 1985) consists of veinlets and disseminations along contacts of gabbro-diorite and gabbro-syenite, both within and adjacent to the intrusive rocks. The mineralization occurs over an area of $150-200 \mathrm{~m}^{2}$ in hydrothermally altered biotite-K-feldspar rock which is surrounded in turn by propylitic epidote-chlorite alteration. The ore minerals are chalcopyrite, bomite, pyrite, and molybdenite. The hydrothermally altered area exhibits anomalous Au. The host rocks are metamorphosed Silurian and Devonian sedimentary and siliceous volcanic rocks, and Permian(?), subalkaline, gabbro-diorite, gabbro-syenite, and granile porphyry which intrude the sedimentary sequence. The gabbro-diorite highly alkaline. The gabbro-syenite and granite porphyry hosting the deposit are K-enriched. The deposit is small. Because the ore is highly oxidized, the $\mathrm{Cu}$ is content low $(0.01 \%$. Cu. Molybdenum grade is about $0.01 \%$.

\section{Komissarovskoe Au-Ag Epithermat Deposit}

The Komissarovskoe Au-Ag epithermal deposit (A.N. Rodionov, written commun., 1991) consists of low-grade, short Au-Ag-pyrite veins which occur in dacite volcanic rocks, presumably part of a Permian volcanic sequence. The veins contain minor galena and sphalerite, occur in metasomatic sericite-biotite-quartz bodies in fracture zones, and are conformable to, and crosscut bedding. The epithermal deposits may be related to areas of higher carbon contents in thin-bedded siltstone and argillite. Associated Au placer deposits occur in adjacent parts of China. The deposit is small. Average grades are $1.92 \mathrm{~g} t$ Au and 49-52 g/t As

\section{Origin of and Tectonic Controls for} Laoelin-Grodekovsk Metallogenic Belt

The Laoelin-Grodekovak metallogenic belt of porphyry Cu-Mo and Au-Ag epithermal vein deposits is hosted by the Laoelin-Grodekonsk island-arc ternane which consists chiefly of two units (Nokleberg and others, 1994c, 1997e). (1) A lower tectonic melange unit is composed of fragments of Early Silurian granite-pebble-bearing conglomerate, sandstone, siliceous mudsione and lesser interbedded basalt, andesite, rhyolite, and tuff. The sedimentary are locally intensely deformed and metamorphosed to middle amphibolite facies. And (2) an upper unit is composed of Permian basalt, andesite, rhyolite, conglomerate, sandstone, mudstone, and shale and lesser interbedded limestone lenses which contain Late Permian Tethyan fusulinids. The structural thickness is about several thousand meters. The Permian rocks are intruded by zoned duniteclinopyroxenite-gabbro intrusions which form Alaskan-Unalian zoned mafic-ultramafic plutons, and local tonalite and plagiogranite. The zoned dunite-clinopyroxenite-gabbro intrusions may be favorable for undiscovered zoned mafic-ultramafic $\mathrm{Cr}$ PGE deposits (V, V. Ratkin, this study). The Permian igneous rocks that host Laoelin-Grodekovsk metallogenic belt are part of the 
younger Permian sequence of the Laoelin-Grodekovsk terrane that is interpreted a Permian island arc (Nokleberg and otbers, $2000)$.

\section{Metallogenic Belts Formed In Late Paleozoic Oceanic Lithosphere Preserved in Subduction Zones Terranes in Russian Northeast}

\section{Aluchin Metallogenic Beit of Podiform \\ Cr Deposits (Beit AC) \\ Central Part of Russian Northeast}

The Aluchin metallogenic belt of podiform $\mathrm{Cr}$ deposits (fig 31; tables 3, 4) occurs in the Big Anui River basin in the central part of the Russian Northeast. The belt is hosted in the Aluchin ophiolite terrane of the Kolyma-Omolon superterrane (fig. 31) (Nokleberg and others, 1994c, 1997e). The podiform $\mathrm{Cr}$ deposits, as at Teleneut, are hosted by dunite and serpentinite, and oecur in the north-eastem and southern portions of the metallogenic belt in a large, linear mass of dunite and harzburgite which extends for over $100 \mathrm{~km}$ (Nokleberg and others 1997a, b, 1998).

\section{Teleneut Podiform Cr Deposit}

The Teleneut podiform $\mathrm{Cr}$ deposit (Aksenova and others, 1970) occurs in serpentinite rocks at the southern end of the Aluchin alpine-type ultramafic body where ultramafic rocks crop out on the surface as a fault-bound lens which is $7 \mathrm{~km}$ long by $2.5 \mathrm{~km}$ wide with a north-south trend. The ultramafic rocks consist of serpentinite (70\%) and subordinate little-altered dunite and pyroxenite. The Teleneut podiform $\mathrm{Cr}$ occurrence occurs in the central part of the lens which contains mostly serpentinite. The chromite occurrence $1500 \mathrm{~m}$ long and $700 \mathrm{~m}$ wide along a north-south trend. The occurrence contains rare disseminations and massive accumulations with up to $70 \%$ chromite. The structure is usually banded or lensoidal, or rarely massive. The main ore minerals are chromite, magnetite and spinel which are associated with $\mathrm{Ni}, \mathrm{Fe}$, and $\mathrm{Cu}$ sulfides, and pentlandite, millerite, bravoite, violarite, pyrrhotite and chalcopyrite. Sulfides occur both in high-chromite-ores and in low-chromite ores and listvenites. Sulfide grains usually occur between chromite grains and serpentinite-altered silicates and are xenomorphic.

\section{Origin of and Tectonic Controls for Aluchin Metallogenic Belt}

The ultramafie rocks hosting the deposits of the Aluchin metallogenic belt are part of a faulted succession of the Aluchin subduction-zone terrane (AC) which consists chiefly of (Lychagin and others, 1989; Byalobzhesky and others, 1990; Seslavinskiy and Gedko, 1990) of. (1) dismembered ophiolites of presumed middle Paleozoic age, including harzburgite, pyroxenite, dunite, therzolite, gabbro, plagiogranite, a mafic dike suite, basalt, and local glaucophane schist; (2) tectonic lenses of Middle Carboniferous to Early Permian island-are elastic-tuffaceous deposits, basalt, and andesitic basalt which are intruded by diorite and tonalite; and (3) unconformably overlying Late Triassic (Norian) shallow-marine volcanic and sedimentary rocks, and Early Jurassic clastic deposits which contain pebbles of the underlying diorite and tonalite. In the inner part of the Kolyma-Omolon superterrane, the subduction zone linked to the Alazeya arc can be traced beneath Cenozoic deposits along a borseshoe-like magnetic high (Parfenov, 1995c). The Aluchin subduction-zone ierrane is interpreted as a small part of an elongate subduction zope which was tectonically linked to the mainly Late Triassic and Early furassic Alazeya island arc (Nokleberg and others, 2000).

\section{Ust-Belaya Metallogenic Belt of Podiform Cr Deposits (Beit UB) Northeastern Part of Russian Northeast}

The Ust-Belaya metallogenic belt of podiform $\mathrm{Cr}$ deposits (fig. 3; tables 3, 4) occurs in the Ust-Belaya dunite-haraburgite subterrane of the Penzhina Anadyr accretionary wedge-oceanic terrane in the northeastem part of the Russian Northeast (Nokleberg and others, 1994c, 1997a, b, c, 1995). The one significant deposit at Ust-Belaya consists of zones of closely spaced, banded chromite (10-30\%/ chromite) which occur as lenses, schlieren, and vein-like bodies of disseminated and massive chromite (Silkin, 1983). The chromite occurs in layers up to $1,300 \mathrm{~m}$ long and $400 \mathrm{~m}$ wide in the dunite of the Ust-Belaya alpine-type ultramafic body. The chromite oceurrences extend northward for $13 \mathrm{kn}$ along a belt more than $2 \mathrm{~km}$ wide. The chromite is of economic, low- and medium-Cr metallurgical grade (Sikin, 1983). Associated PGE placer deposits are dominated by Os, Ir, and Ru minerals which are typical of dunites and harzburgiles, particularly in the Koryak Highlands (Denitrenko and others, 1990). 
The Ust-Belaya metallogenic belt is hosted in ophiolite which is a tectonic fragment in the Ustbelaya aceretionary wedge or subduction zone subterrane which forms the northem part of the Penzhina-Anadyr' terrunę (fig. 31). This Ust-Beluya subterrane consists mainly of a large early Paleozoic ophiolite with an areal extent exceeding $1,000 \mathrm{~km}$. Extensive zones of chromite deposits are confined to dunites which occur together with peridotite, metagabbro, amphibolite, and gabbro. The subterrane consists of the following tectonic sheets which are distinguished by contrasting lithologies (Nokleberg and others, 1994c, 1997c). (1) The Otrozhnaya sheet is composed of an ophiolite which contains metamorphosed ultramafic rocks, gabbro, diabase, basalt, and volcanic breccia, and an overlying sequence of chert, calcareous sandstone, tuff, and limestone which yield Middle and Late Devonian and Early Carboniferous faunas. The Otrozhnaya sheet is intruded by diabase, plagiogranite, and diorite dikes which yield $\mathrm{K}$-Ar ages of 180 to $304 \mathrm{Ma}$. (2) An unnamed sheet is composed of serpentinite melange. (3) The Mavrina sheet is composed of shallow-marine sandstone and siltstone and interlayered conglomerate and limestone which yield a Middle Jurassic fauna. And (4) an uppermost sheet is composed of interlayered sandstone, siltstone, and mudstone which yield an Late Jurassic to Early Crefaceous fauna. The Penzhina-Anadyr' terrane is interpreted as accretionary wedge or subduction zone unit which contains fragments of oceanic lithosphere, now preserved as ophiolites. The Penzhina-Anadyr' subduction zone terrane is tectonically linked to the Late Jurassic part of the Kony-Murgal island-arc terrane (Nokleberg and others, 2000).

\section{Metallogenic Belts Formed in Late Paleozoic Skolai Island Arc in Wrangellia Superterrane}

\section{Alaska Range-Wrangell Mountains Metallogenic Belt of Granitic Magmatism Deposits (Beit ARW) Central and Eastern- Southern Alaska}

The Alaska Range-Wrangell Mountains metallogenic belt of granitic magmatism deposits (fig, 32; tables 3, 4) (mainly porphyry, polymetallic vein, and skarn deposits) oceurs in the Alaska Range and the Nutzotin and Wrangell Mountains in central and eastern-southern Alaska (Nokleberg and others, 1995a). The metallogenic belt is hosted in the late Paleozoic part of the Wrangellia sequence of the Wrangellia island-are terrane which contains late Paleozoic volcanic and granitoid rocks (Nokleberg and others, 1994c, 1997c). The significant deposits are the Rainy Creek Cu-Ag skarn deposit, and the Chistochina deposits, and smaller eccurrences or prospects as the Rainbow Mountain and Slate Creek porphyry Cu deposits (table 4) (Nokleberg and others $1997 \mathrm{a}, \mathrm{b}, 1998$ ). Farther to the southeast in the Nutzotin and Wrangellia Mountains, similar small, subvolcanic intrusions occur in the Permian and Pennsylvanian Slana Spur, Hazen Creek, and Station Creek Formations, and in the Tetelna Volcanics (Richter, 1975; MacKeveth, 1978).

\section{Raimy Croek Cu-Ag Skarn District}

The Rainy Creek Cu-Ag skam deposit (Rose, 1966; Lange and others, 1981; Nokleberg and others, 1984, 1991) comprises a zone about $10 \mathrm{~km}$ long and up $105 \mathrm{~km}$ wide which contains scattered garnet-pyroxene skam bodies which have disseminated to small masses of chalcopyrite and bornite, minor sphalerite, galena, magnetite, secondary Cu-minerals, and sparse gold. The deposits occur in faulted lenses of marble of the Pennsylvanian and Permian Slana Spur Formation adjacent to late Paleozoic(7) metagabbro, metadiabase, and hypabyssal meta-andesite intrusive rocks. Local disseminated sulfides also occur in meta-andesite. The sulfide-bearing bodies and adjacent wall rocks are locally intensely faulted Grab samples contain up to $5.6 \%$ $\mathrm{Cu}, 300 \mathrm{~g} / \mathrm{Ag}, 1.2 \mathrm{~g} / \mathrm{Au}, 0.07 \% \mathrm{Zn}$

\section{Chisfochina District}

The Chistochina porphyry Cu and polymetallic vein deposit (Richter, 1966; Rainier J. Newberry, written commun, 1985) contains several small areas containing galena, pyrite, chalcopyrite, letrahedrile, and gold in quartz veins, small masses, and disseminations is margins of the Pennsylvanian and Permian Ahtell quartz diorite pluton and in adjacent volcanic and sedimentary rocks of the Pennsylvaniaa and Permian Slana Spur Formation. The quartz veins range up to $10 \mathrm{~m}$ wide, locally contain massive barite, calcite, and cenussite, and occur over an area about $5 \mathrm{~km}$ long and $3 \mathrm{~km}$ wide. The district also contains small $\mathrm{Cu}-\mathrm{Au}$ and $\mathrm{Pb}-2 \mathrm{n}$ skams. Grab samples contain up to $20 \% 6 \mathrm{~Pb}, 1.4 \% \mathrm{Cu}, 21 \mathrm{~g} / \mathrm{Ag}, 1.4 \mathrm{~g} / \mathrm{Au}$.

\section{Origin of and Tectonic Controls for Alaska Range- Wrangell Mountains Metallogenic Belt}

The Alakk Range-Wrangell Mountains metallogenic belt is bosted by granitoid plutons and associated volcanic rocks of the Pennsylvanian and Early Permian Skolai are (Nokleberg and others, 1984, 1985; 1995a; Nokleberg and Lange, 1985, 1994d; Plafket and others, 1989). The Skolai are forms a lithologically variable suite of volcanic and plutonic rocks which is 
discontinuously exposed in the Wrangellia and Alexander sequences of the Wrangellia supertermae which extends from eastemsouthem Alaska into adjacent parts of the western Canada Cordillera. The granitoid rocks in this arc are Early to Middle Pennsylvanian plutons of granodiorite and granite which were preceded by gabbro and diorite, and succeeded by shoshonite (Beard and Barker, 1989; Barker, 1994). U-Pb zircon isotopic age studies reveal ages of 290 to $316 \mathrm{Ma}$ (late Paleozoic) for this suite of plutons and volcanic rocks (Richter and others, 1975a; Barker and Stern, 1986; A leinikoff and others, 1987; Gardner and others, 1988; Plafker and others, 1989). Common $\mathrm{Pb}$ isotopic compositions for the granitoid rocks yield low radiogenic $\mathrm{Pb}$ values and suggest derivation from a mixture of oceanic mantle and pelagic sediment leads, without an older continental component (Aleinikoff and others, 1987). Rb-Sr isotopic data, and REE volcanic and plutonic whole-rock chemical analyses suggest an intraoceanic island are origin (Barker and Stem, 1986; Beard and Barker, 1989; Barker, 1994; Miller, 1994). A marine origin for the Skolai arc is supported by submarine deposition of the volcanic flows, tuff, and breccia, and associated volcanic graywacke and argillite (Richter and Jones, 1973; Bond, 1973, 1976). The principal data for an island arc origin are: (1) the absence of abundant continental erustal detritus in late Paleozoic stratified rocks; (2) little or no quarts in the volcanic rocks and associated shallowintrusive bodies; (3) high-latitude fauna; and (4) isotopic data summarized above.

\section{Ketchikan Metallogenic Beit of Kuroko Massive Sulfide Deposits (Belt KK) Southeastern Alaska}

The Ketchikan Metallogenic Belt of kuroko massive sulfide deposits occurs in Southeastern Alaska (fig. 32; tables, 3, 4) (Nokleberg and others, 1997b, 1998). The belt strikes north-south, is about $300 \mathrm{~km}$ long, and varies from 20 to $60 \mathrm{~km}$ wide. The significant kuroko massive sulfide deposit at Moth Bay consists of discontinuous lenses and layers of massive pyrite and pyrrhotite, minor chalcopyrite and galena, and local disseminated pyrite (Berg and others, 1978; Newberry and others, 1997). The deposit contains an estimated 91,000 tonnes grading $7.5 \% \mathrm{Zn}$ and $1 \% \mathrm{Cu}$ and an additional 181,000 tonnes grading $4.5 \% \mathrm{Zn}$ and $0.75 \% \mathrm{Cu}$. The host rocks are light brown-gray, upper Paleozoic of Mesozoic muscovite-quartz-calcite schist, subordinate pelitic schist and quartz-feldspar schist, and possibly metachen. Layers and lenses of massive sulfides, up to $1 \mathrm{~m}$ thick, occur parallel to compositional layering in the schist.

The Motb Bay deposit is hosted in the former Tuku terrane, now designated as part of late Paleozoic sedimentary and volcanic rocks of the Wrangellia sequence of the Wrangellia superterrane which consists of a poorly-understood sequence of mainly Permian and Triassic marble, pelitic phyllite, and felsic metavolcaniclastic and metavolcanic rocks which are overlain by Late Jurassic to mid-Cretaceous units of the Gravina belt (Gehrels and Berg. 1994). The Ketchikan metallogenic belt and host rocks are berein interpreted as a fragment of a late Paleozoic Skolai island are which formed early in the history of the Wrangellia superterrane (Nokleberg and others, 1994c; 2000).

\section{Late Triassic Metallogenic Belts (230 to $208 \mathrm{Ma}$; Figure 32)}

\section{Overview}

The major Late Triassic metallogenic belts in the Alaska and the Canadian Cordillera are summarized in table 3 and portrayed on figure 32. No major Late Triassic metullogenic belis exist in the Russian Far East. The major belts in Alaska and the Canadian Cordillera are as follows. (1) In the same region is the Farewell belt of gabbroic Ni-Cu-PGE deposits that is hosted in the Dillinger, Mystic, and Nixon Fork passive continental margin terranes. The iectonic origin of this belt is uncertain. (2) In Southern Alaska, three belts are interpreted as forming in the middle Mesozoic Talkeetna-Bonzana island are in Wrangellia Superterrane. These belts are the: (a) the Kodiak Island and Border Ranges (KOD) belt of podiform Cr deposits, that is interpreted as forming in the roots of the Talkeetna-Bonzana arc; and (b) Eastern and Western Alaska Range (EAR) belt of gabbroic Ni-Cu, Besshi massive sulfide, and related deposits, and the Alexander (AX) belt of massive sulfide and related deposits. Both belts are interpreted as forming during back-are rifting of the Talkeetna-Bonzana are preserved in the Wrangellia island-are superternane. And (3) in the Canadiun Cordallera, the Copper Mountain (North; CMN), Copper Mountain (South; CMS), Galore (GL), Guichon (GU), and Texas Creek (TC) belts which all contain granitoid magmatism-telated deposits, are interpreted as forming in the axial parts of the Stikinia-Quesnellia island ares. The Stikinia and Quesnellia island-are terranes are interpreted as foming on the deformed continental margin strata of Yukon-Tanana terrane which was previously riffed from the North American Craton Margin (Gehrels and others, 1990; Monger and Nokleberg. 1996; Nokleberg and others, 1994c, 1997c, 2000). Mineralization in all these belts continued into the Early Jurassic. And (4) also in the Canadian Cordillera, the Sustut metallogenic belt of basaltic Cu deposits, that is hosted in the Stikinia island ave terrane, formed in the upper oxidized parts of an island are volcanic pile during shallow burial metamorphism and diagenesis. In the below descriptions of metallogenic belts, a few of the noteable signficant lode deposits (table 4) are described for each belt. 
During the Late Triassic (Carnian to Norian - 230 to $208 \mathrm{Ma}$ ), the major metallogenic-tectonic events were (table 3): (1) inception of contunental-margin ares and associated subduction along the North Asian Craton Margin; (2) continued formation of the Stikinia and Quesnellia island arcs and inception of subduction-related Talkeetna and Bonanza island are in the Wrangellia superterrane, and associated metallogenic belts in these island are systems; and (3) beginning of sinistral-slip imbrication of the Stikinia-Quesnellia island are and metallogenic belts, and associated subduction zones. Sedimentation continued along the passive continental margins of North Asia and North America.

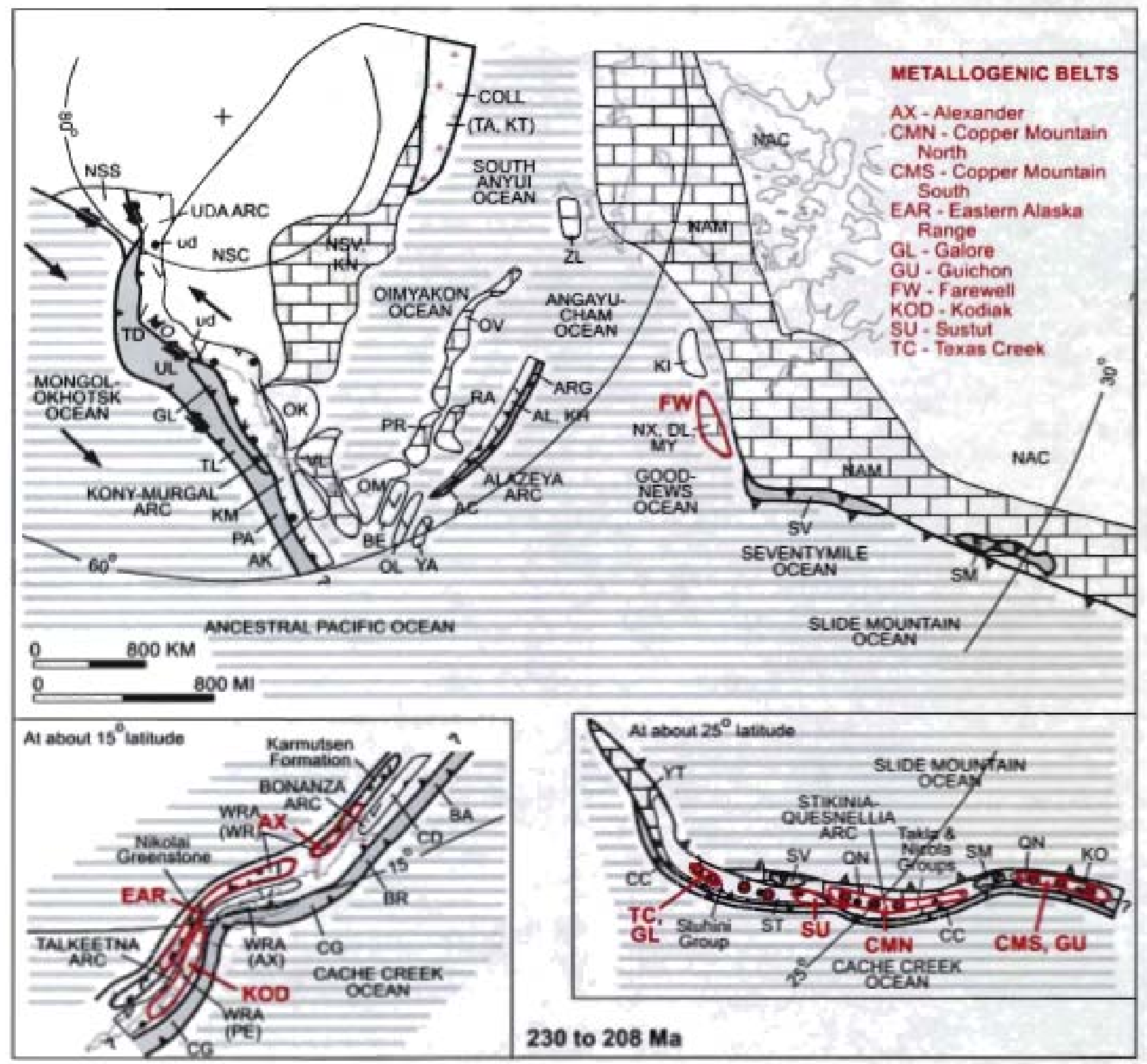

Figure 34. Late Triassic (Camian through Norian - 230 to $208 \mathrm{Ma}$ ) stage of tectonic model. Refer to text for explanation of metalogenic-tectonic events, to tables 3 and 4 for descriptions metallogenic belts and significant deposits, and to figure 18 for explanation of abbreviations, symbols, and patterns. Adapted from Nokleberg and others (1997b, 1996, 2000). 
(1) The continental-margin Uda are, defined by the Uda volcanic-plutonic belt (ud) and associated units, commenced activity and was associated with subduction and sinistral transpression of the Mongol-Okhotsk Ocean plate to form the Turkuringra-Dzhagdi (TD), Ulban (UL), and older part of Galam (GL) terranes, Both subduction and sinistral transpression oceurred along the Mongol-Okbotsk suture (MO)

(2) The extensive Kony-Murgal island are (KM) commenced activity as an offshore extension of the Uda are. Associated with the are was subduction of part of the ancestral Pacific Oceas plate to form the Talovskiy (TL) and Penzhina-Anadyr (PA) terranes, Inboard of the Kony-Murgal arc, the Okhotsk (OK) cratonal terrane was accreted to the North Asian Craton (NSC) and Craton Margin (NSV), together with the Viliga (VL) passive continental-margin terrane, and the Omolon (OM) and Avekova (AK) cratonal terranes. The Kony-Murgal terrane (KM) contains Triassic, Jurassic, and Neocomian Boreal fauna (Dagis and others, 1979, Dagis and Dagis, 1984; Zakharov and others, 1984). The Viliga ternane contains Carboniferous, Permian, Triassic, and Jurnssic Boreal fauna.

(3) The Alazeya are, consisting of the Alazeya ( $\mathrm{AL}$ ) and Khetachan (KH) island-are terranes, continued activity and moved toward the Omulevka Ridge. Associated with the Alazeya arc was subduction of part of the Ancestral Pacific Ocean to form the Aluchin (AC) and Argatas (ARG) accretionary-wedge terranes. These terranes can be iraced by magnetic anomalies under extensive Cenozoic deposits of the Russian Northeast (Parfenov and others, 1999). Behind the are were fragments of prior Devonian to Pennsylvanian island ares, including the Beryozovka turbidite-basin (BE), and the Oloy (OL), and Yarakvaam (YA) island-are terranes.

(4) The Kotel'nyi passive continental-margin terrane (KT) was aecreted and becume part of the Taimyr Peninsular collage (TA). Within the Angayucham, Goodnews, and Seventymile Oceans were previously rifted terranes, including the Kilbuck-Idono eratonal (KI), and the combined Nixon Fork-Dillinger-Mystic passive continental-margin terrane (NX, DL, MY). During this time span, before accretion to the North American continent, the Dillinger, Mystic, and Nixon Fork terranes may have experienced several post-rifting events which formed additional units, such as the Triassic basaltic rocks which occur in the Tatina River area, Coeval mafic-ultramafic sills and dikes and cogenetic alkali-olivine basalt flows host gabbroic Ni-Cu-PGE deposits of the Farewell (FW) metallogenic belt.

(5) The complex Stikinia-Quesnellia island are and associated subduction zones were active. The Stuhini Group is preserved in the Stikinia (ST) terrane, whereas the Takla and Nicola Groups are preserved in the Quesnellia (QN) terrane. Forming with the Stikinia-Quesnellia island are were the Copper Mountain (North; CMN), Copper Mountain (South; CMS), Galore (GL), Guichon (GU), and Texas Creek (TC) belts which contain granitic magmatism-related deposits. Also in the Stikinia island are terrane is the Sustut (SU) metallogenic belt of basaltic $\mathrm{Cu}$ deposits that is interepreted as forming in in the upper oxidized parts of an island are volcanic pile during shallow burial metamorphism and diagenesis. The Stikinia-Quesnellia are is interpreted as forming stratigraphically on the Yukon-Tanana (YT) and Kootenay (KO) terranes, previously rifled fragments of the North American Craton Margin (NAM; Mihalynuk and others, 1994). On the outboard side of the ares was subduction of part of the Cache Creek Ocean plate to form the Cache Creek terrane (CC). The Cache Creek terrane and similar subduction-zone assemblages, which were tectonically linked to the Talkeetna and Bonanza arcs, along with the Chugach (CG), possibly Bridge River (BR), and Baker (BA) terranes, all contain exotic Permian Tethyan faunas in carbonate blocks in matrices of mainly early Mesozoic age. The Cache Creek terrane contains detritus probably derived from the Stikinia-Quesnellia arc (Monger and Nokleberg, 1996).

(6) Parts of the Seventymile (SV) and Slide Mountain (SM; Anvil Ocean of Templeman-Kluit, 1979) Ocean plates were obducted onto the Yukon-Tanana (YT) and Kootenay (KO) terranes, and onto the North American Craton margin (NAM). Part of the obduction occurred by the Late Triassic and (or) Early Jurassic when granitic plutons of the Stikinia-Quesnellia arc intruded across an intervening fault.

(7) The beginning of dextral-slip imbrication of the Stikinia-Quesnellia arc occurred along the Tally Ho shear zone (Hansen and others, 1990; Hart, 1995; inset, fig. 34). Alternatively, the present-day configuration of the Stikinia-Quesnellia island-are and associated subduction zone terranes may have formed by oroclinal warping and counter-elockwise fotation of the Stikinia-Quesnellia are in response to a combination of oblique convergence, and arc migration toward the companion subduction zone of the Cache Creek terrane (fig. 34) (Milalynuk and others, 1994). Migration of the Stikinia-Quesnellia arc and associated ternanes toward North America was accomplished by subduction and (or) obduction of the Seventymile terrane along the continental margin.

(8) The Talkeetna and Bonanza ares formed along the length of the Wrangellia superterrane. Forming with the ares were: (a) the Kodiak lsland and Border Ranges (KOD) metallogenic belt which contains podiform $\mathrm{Cr}$ deposits and is interpreted as forming in the roots of the arc; (b) the Eastern and Westem Alaska Range (EAR) metallogenic belt which contains gabbroic Ni$\mathrm{Cu}$, Besahi massive sulfide, and related deposits, and (c) the Alexander (AX) metallogenic belt which contains deposits related to felsic to mafie marine volcanism. The Talkeetna are is preserved in the Late Triassic(?) and Jurassic Talkeetna Formation and coeval granitic plutonic rocks of the Peninsular sequence (PE) of the Wrangellia superterrane (WRA), and the Bonzana are is preserved in the Cadwallader island-afe terrane (CD). Associated with the island ares was subduction of part the Cache Creek Ocean plate to form the Chugach (CG), possibly Bridge River (BR), and Baker (BA) terranes. These terranes locally contain early Mesozoic blueschist (Plafker and others, 1994). 
(9) During subduction of the Cache Creek Ocean plate to form the Talkeetna, Bonanza, and Stikinia-Quesnellia ares. limestone blocks containing mainly Pernian Tethyan faunas were accreted, locally in thick and extensive blocks in the subduction-zone compleses of the Chugach (CG) and Cache Creek (CC) terranes (Monger and Berg, 1987; Monger and Nokleberg, 1996). Teihyan faunas are generally interpreted as being derived from the late Paleozoic and early Mesozoic Tethys Ocean, remnants of which occur in the present-day Mediternanean region, Middle East, Himalayas, Southeast Asia, eastern China, Russian Southeast, and Japan (Monger and Ross, 1971; Monger and others, 1972; Stevens and others, 1997).

(10) In the Wrangella superternane (WRA), back-are rifting or bot-spot activity formed the widespread basalt fields of the Nikolai Greenstone and Karmutsen Formation (Barker and others, 1989; Richards and others, 1991; Lassiter and others, 1994). The mafic magmatism forming those rocks was first interpreted as forming in a rift setting (Barker and others, 1989). Alternatively, the mafic magmatism may have formed in a short-lived mantle-plume setting similar to which in Java (Richards and others, 1991; Lassiter and others, 1994).

\section{Metallogenic Belt Formed During Early Mesozoic Rifting? in Alaskan Passive Continental-Margin Terranes}

\section{Farewell Metallogenic Belt of Gabbroic Ni-Cu-PGE Deposits (Beit EAR) Western Alaska}

The Farewell metallogenic belt of gabbroic Ni-Cu-PGE deposits (fig. 32; tables 3,4) is hosted in the the Dillnger, Nixon Fork, and Mystic subterranes of the Farewell composite terrane of Decker and others (1994) in Western Alaska. The belt contains the Farewell gabbroic Ni-Cu district (Foley and others, 1997; Bundtzen and others, 2003a, b; Bundtzen, Sidorov, and Chubarov, 2003) in the west-central Alaska Range. The deposits in the district are hosted in the informally-named Farewell mafic-ultramafic suite that consists of differentiated, tholeitic, peridotite, clinopyroxenite, and gabbro sills, and cogenetic alkali-olivine basalt flows that intrude or overlie: (1) silty limestone and shale of the Cambrian to Ordovician Lyman Hills Formation; and (2) calcareous sandstone and shale of the Permian-Pennsylvanian Sheep Creek Formation. The mafic-ultramafic suite are enstatite rich, orthopyroxene poor, and contain Ti-chromitite. REE and other trace element data from the Farewell suite suggests a magma mixing model with local crustal contamination. "Ar/" Ar isotopic ages for three sills range from 225.6-10-233.7 Ma (Norian). The Farewell district contains three prospects at Gargaryah, Roberts, and Straight Creek.

\section{Roberts PGM Prospect}

The Roberts PGM prospect consists of disseminated to semi massive pyrthotite, chalcopyrite, pentlendite, speerylite, and bravoite that occur in the lower part of an enstatite-rich ultramafie sill that intrudes the Lyman Hills Formation. Surface channel sampling yields grades of up to $16.9 \mathrm{~g} / \mathrm{PGE}, 1.48 \mathrm{~g} / \mathrm{Au}, 2.27 \% \mathrm{Ni}, 1.31 \% \mathrm{Cu}$, and $0.14 \% \mathrm{Co}$, A 5-meter-thick dnill interval yields grades of up to $4.13 \mathrm{~g} / \mathrm{PGE}, 0.67 \% \mathrm{Ni}, 0.32 \% \mathrm{Cu}$, and $298 \mathrm{ppm} \mathrm{Co}$. The Straight Creek and Gargaryah River deposits, discovered in 2001 , consists of sills with up to $1.59 \mathrm{~g} / \mathrm{PGE}, 1.00 \% \mathrm{Co}, 0.87 \% \mathrm{Ni}$, and $250 \mathrm{ppm} \mathrm{Co}$. Several sills containing these PGE-Ni-Cu-Co prospects in the Farewell district exhibit a strong magnetic signature with maximum intensities of up to 4,300 milligals. Trace element data obtained for the sill intrusions hosting the prospects and PGE element ratios (Pt, Pd, Ir, Rh, Ru, Os) are similar to those reported from sulfide-bearing mafic intrusions in the Paxson-Canwell Glacier in the Eastern Alaska Range, and Kluane Lake area in the Yukon Territory. These deposits are part of the Eastem Alaska Range metallogenie belt, described below, that is bosted in the Wrangellia superierrane.

\section{Origin of and Tectonic Controls for}

Farewell Metallogenic Belt

The Farewell metallogenic belt is bosted in the Dillinger, Mystic, and Nixon Fork passive continental margin terranes of Nokieberg and others (1997c) (Dillinger, Mystic, and Nixon Fork subterranes of the Farewell (composite) terrane of Decker and others, 1994 and Bundtzen and others, 1997). North of the Farewell district in the Dillinger ternane are similar, deformed maficultramafic sills in the Nixon Fork terrane at St. Johns Hill (McOrath quadrangle) and in the Babybasket Hills (Medfra quadrangle). Geological mapping and paleontological data indicate that the Nixon Fork and Dillinger terranes were coeval, continental margin platform sections that were overlain by the Mystic lerrane. These three terranes are interpreted as having been rifted from the North Asian Craton Margin in the Late Devonian and Early Mississippian (Blodgett and Brease, 1997; Blodgett, 1998; Fryda and Blodgett, 1998; Dumoulin and others, 1998, 1999; Blodgett and Boucot, 1999) when the North Asian and North American Crasons (and their margins) are interpreted as having been adjacent (Nokleberg and others, 2000). The early to middle Paleozoic fauna in the Dillnger, Nixon Fork, and Mystic terranes are typical of taxa that eccur in similar age units in the Kolyma region of the North Asian Craton Margin (Verkhoyansk fold beli) in the Russian Northeast.

The tectonic origin of the Farewell metallogenic belt is uncertain. The Late Triassic gabbroic Ni-Cu deposits of the Farewell metallogenic belt and host rocks are similar to the deposits and host rocks of the Late Triassic Eastem Alaska Range 
metallogenic belt, now located a few bundred $\mathrm{km}$ to the east in Southem Alaska. However, available paleomagnetic data (table 3 in Nokleberg and others (2000)), indicate that the Wrangellia superterrane, that hosts the Eastern Alaskan Range metallogenic belt, was within a few degrees of the Late Triassic paleoequator. In contrast, the three subterranes (Dillnger, Nixon Fork, and Mystic), constituting the Farewell terrane, are interpreted as having been located several thousand km away, near the North American Craton Margin (fig. 34) (Nokleberg and others, 2000). Additional work is needed to determine the tectonic origin of the Farewell metallogenic belt, contained deposits, and host rocks. Herein, the Farewell metallogenic belt is interpreted as forming during incipient Late Triassic rifting of Dillinger and adjacent passive continental margin terranes

\section{Metallogenic Belts Formed in Middle Mesozoic Talkeetna-Bonzana Island Arc in Wrangellia Superterrane}

\section{Kodiak Island and Border Ranges \\ Metallogenic Belt of Podiform $\mathrm{Cr}$ Deposits \\ (Belt KOD) Southern Coastal Alaska}

The Kodiak Island and Border Ranges metallogenic belt of podiform Cr deposits and one gabbroic Ni-Cu deposit (fig. 32; tables 3, 4) occurs along the northern margin of Kodiak Island, on the Kenai Peninsula, and along the northern flank of the Chugach Mountains in southern coastal Alaska (Foley, 1985; Foley and others, 1997). This belt occurs discontinously along a strike distance of several hundred kilometers from Kodiak Island pn the southwest to the eastern Chugach Mountains on the east. The metallogenic belt is hosted in the Border Ranges ultramafic-mafic assemblage which forms the southern part of the Talkeetna part of the Talkeetna-Bonzana island are in Wrangellia superierrane (Burns, 1985; Plafker and others, 1989; Nokleberg and others, 1994c, 1997c, 2000). The significant deposits are at Halibut Bay, Claim Point, Red Mountain, and Bernard and Dust Mountains; a possibly related gabbroic Ni-Cu deposit at Spirit Mountain (table 4) (Nokleberg and others 1997a, b, 1998).

\section{Red Mountain Poditorm Cr Deposit}

The Red Mountain podiform Cr deposit (fig. 35) (Guild, 1942; Bundtzen, 1983b; Burns, 1985; Foley and Barker, 1985; Foley and others, 1985, 1997) consists of layers and lenses of chromite in dunite tectonite; the layers and lenses range up to several hundred meters long and $60 \mathrm{~m}$ wide. The largest chromite layer is about $190 \mathrm{~m}$ long and up to $1.5 \mathrm{~m}$ wide, and more than 10 smaller ore bodies exist. The host Late Triassic to Early Jurassic dunite tectonite is interlayered with subordinate pyroxenite in zones about $60 \mathrm{~m}$ thick. Serpentinite is locally abundant along contacts of bodies. Exploration and development occurred sporadically from about 1919 to the $1980^{\circ} \mathrm{s}$. Several hundred meters of underground workings and trenches were constructed. An estimated 26,000 tonnes of ore, ranging from 38 to $42 \% \mathrm{Cr}_{2} \mathrm{O}_{3}$, was produced from 1943 to 1957. The two largest remaining deposits are estimated to contain 87,000 tonnes grading about 25 to $43 \% \mathrm{Cr}_{7} \mathrm{O}_{3}$. An additional, low-grade deposit contains an estimated 1.13 million tonnes $\mathrm{Cr}_{2} \mathrm{O}_{3}$. The nearby Windy River chromite placer deposit, which occurs downstream from Red Mountain deposit, in hosted in glaciofluvial sand and gravel deposits and is estimated to contain 15.6 million m' grading about $1.33 \% \mathrm{Cr}_{2} \mathrm{O}_{2}$.

\section{Origin of and Tectonic Controls for}

Kodiak Istand and Border Ranges Motallogenic Belt

The Kodiak Island and Border Ranges metallogenic belt of podiform $\mathrm{Cr}$ and associated deposits oceurs in the Late Triassic to Early Jurassic Border Ranges ultramafic and mafic assemblage (Bums, 1985; Plafker and others, 1989, DeBari and Coleman, 1989; Foley and others, 1997). The assemblage is a major belt of ultramafic tectonite, cumulate gabbro, and norite which occurs along the southem, faulied margin of the Peninsular sequence of the Wrangellia island arc superiernane directly north of the Border Ranges fault system (unit WR, fig. 32) (MacKevett and Plafker, 1974; Burns, 1985; Plafker and others, 1989; Nokleberg and others, 1994c, 1997c). In this region, the ultramafic and mafic rocks are interpreted as the deep-level root of the Late Triassic to Jurassic Peninsular sequence (Talkeetna part of the Talkeetna-Bonanza island arc) of the Wrangellia superterrane (Bums, 1985; Debari and Coleman, 1989). This sequence consists of the Late Triassic(?) and Early Jurassic marine andesite volcanic rocks of the Talkeetna Formation and the Middle Jurassic plutonic rocks of the Alaska-Aleutian Range batholith. The age of the Talkeetna part of the Talkeetna-Bonanza island are is interpreted as about 180 to $217 \mathrm{Ma}$ (Newberry and others, 1986a; Roeske and others, 1989). These data indicate that the Kodiak Istand and Border Ranges metallogenie belt are a deep-level suite of lode deposits formed in the root of the Talkeetna-Bonanza island are along the margin of the Wrangellia superterrane (Nokleberg and others, 1994d, 2000). 
The Eastern Alaska Range metallogenic belt of gabbroic Ni-Cu, Besshi massive sulfide, and related deposits (fig. 32: tables 3,4) occurs in the eastern Alaska Range and Wrangell Mountains in southern Alaska and in the nonthwestem Canadian Cordillera (Foley, 1982; Foley and others, 1997) and is equivalent to the Kluane- Nikolai belt (Mortensen and Hulbert, 1991: Hulbert, 1995; Hulbert and Carne, 1995), Bundtzen and others (2000) named this belt as the Kluane-Nikolai mafic-ultramafic belt.

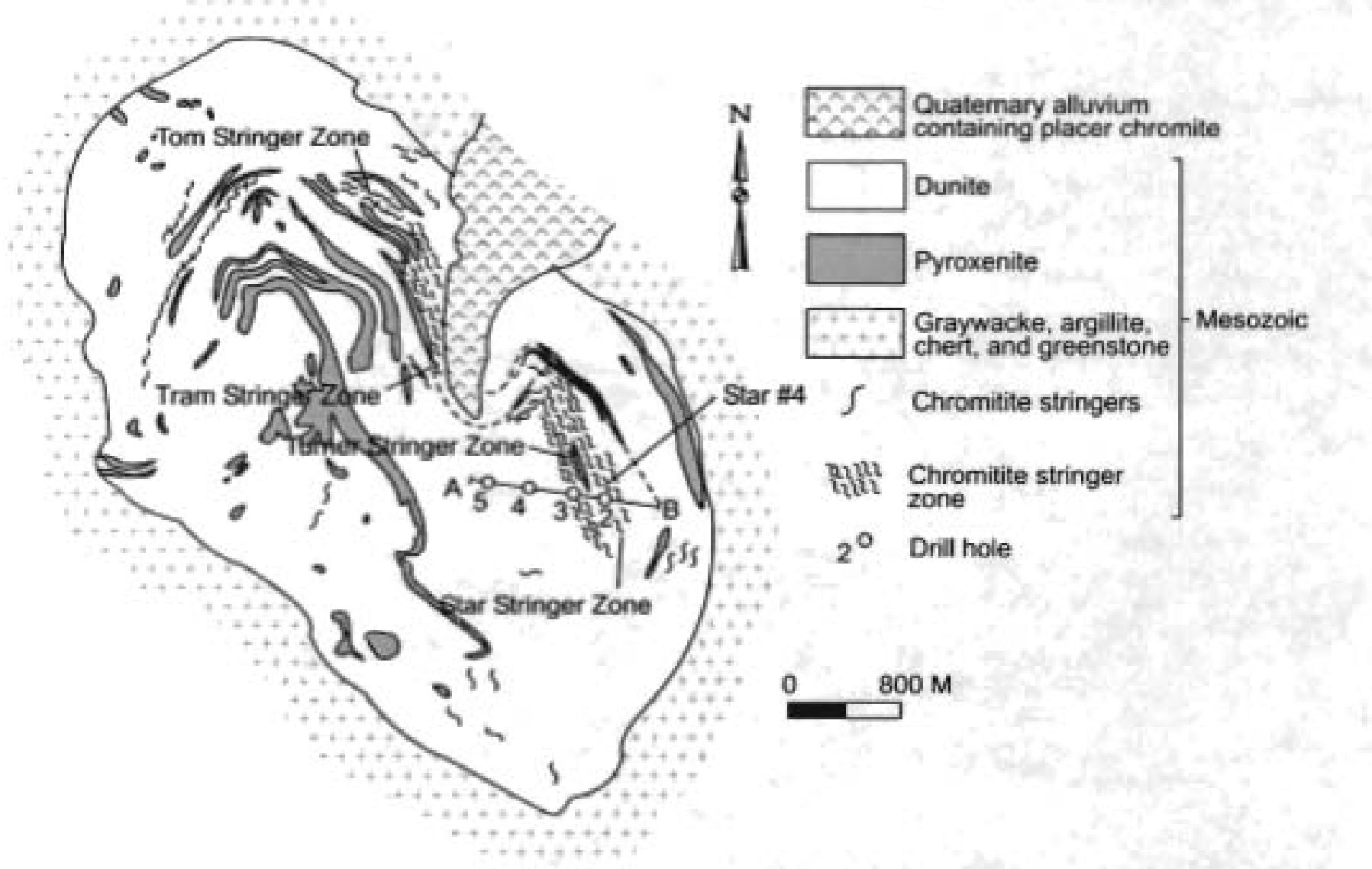

Figure 35. Red Mountain podiform Cr deposit, Kodiak Island and Border Ranges metallogenic belt, Southem Alaska. Schematic geologic map showing locations of the larger chromite deposits. Modified from Guild (1942), and Foley and others (1997).

In Alask, Barker (1987) first recognized that the differentiated, Triassic sill-like plutons contained significant PGE in addition to $\mathrm{Cu}$ and $\mathrm{Ni}$. These mafic-ultramafic bodies are the focus of intense exploration for PGE. The metallogenic belt occurs in the Wrangellia sequence of the Wrangellia superterrane. This sequence contains the areally extensive, Late Triassic Nikolai Greenstone and coeval mafic and ultramfic sills, dikes, and plutons (Nokleberg and others, 1994c, 1997c). The significant deposits are at Denali, Fish Lake, and Wellgreen (table 4) (Nokleberg and others 1997a, b, 1998). The metallogenic belt is hosted in Late Triassic marine pillow basalt and interlayered marine clastic metasedimentary rock of the Wrangellia sequence of the Wrangellia superterrane.

\section{Denali Cu-Ag Besshi(?) Massive Suifide Deposit}

The Denali Cu-Ag Besshi(?) massive sulfide deposit (Stevens, 1971; Seraphim, 1975; Smith, 1981) contains at least six stratiform bodies of very fine grained and rhythmically layered chalcopyrite and pyrite laminations in thin-bedded, shaly. carbonaceous, and limy argillite enclosed in the Late Triassic Nikolai Greenstone. The largest body is about $166 \mathrm{~m}$ long and $9 \mathrm{~m}$ wide, and extends at least $212 \mathrm{~m}$ below surface. The massive sulfide layers contain abundant $\mathrm{Cu}$ and up to $13 \mathrm{~g} / \mathrm{Ag}$. The sulfide deposits and host rocks are metarnorphosed at lower greenschist facies and locally moderately folded. The deposit contains several hundred meters of underground workings which were developed from 1964 to 1969, but never put into production. The deposit is 
interpreted as forming in a submarine volcanic environment of a reducing or euxinic marine basin containing abundant organic matter and sulfate reducing bacteria.

\section{Fish Lake Gabbroic Ni-Cu Deposit}

The Fish Lake gabbroic Ni-Cu deposit (Stout, 1976; Nokleberg and others, 1984; I.M. Lange and W.J. Nokleberg. written commun., 1985; Nokleberg and others, 1991) consists disseminated and wispy-layered chromite, in serpentinized olivine cumulate. The deposit occurs in a zone up to $15 \mathrm{~km}$ long along strike, and ranges up to $2 \mathrm{~km}$ wide. Isolated grab samples contain greater than $0.5 \% \mathrm{Cr}$ and up to $0.3 \% \mathrm{Ni}$, and local anomalous $\mathrm{Cu}$ and $\mathrm{Ni}$ in stream-sediment and rock samples. The gabbroic $\mathrm{Ni}$ Cu deposit is hosted in small- to moderate size gabbro plutons and local cumulate mafic and ultramafic rocks. The mafic and ultramafic rocks intrude the Nikolai Greenstone and older rocks, and are interpreted as co-magmatic with the mafic magmas which formed the Middle and Late Triassic Nikolai Greenstone (Nokleberg and others, 1994d, 2000).

\section{Wellgreen Gabbroic Ni-Cu Deposit}

The Wellgreen gabbroic Ni-Cu deposit (fig. 36) (Campbell, 1976; Hulbert and others, 1988; EMR Canada, 1989; Mining Review, 1991) consists of massive pyrrhotite, pentlandite, chalcopyrite and magnetite lenses which are scattered along the footwall contact of a steeply dipping fault zone in gabbroic rocks of the Late Triassic Quill Creek Complex. In the Yukon Territory, the belt includes the Canalask deposit at White River (Bremes, 1994) in which Cu-Ni sulfides generally occur as disseminations in mafic dikes and peridotite. The deposit is medium size and bas estimated reserves of 50 million tonnes grading $0.36 \% \mathrm{Ni}, 0.35 \% \mathrm{Cu}, 0.51 \mathrm{~g} / \mathrm{Pt}, 0.34 \mathrm{~g} / \mathrm{Pd}$. The deposit oceurs in a $130-\mathrm{km}$-long belt of $\mathrm{Ni}-\mathrm{Cu}-\mathrm{Co}-\mathrm{PGE}$ occurrences which, along with host gabbroic bodies, are interpreted as Late Triassic.

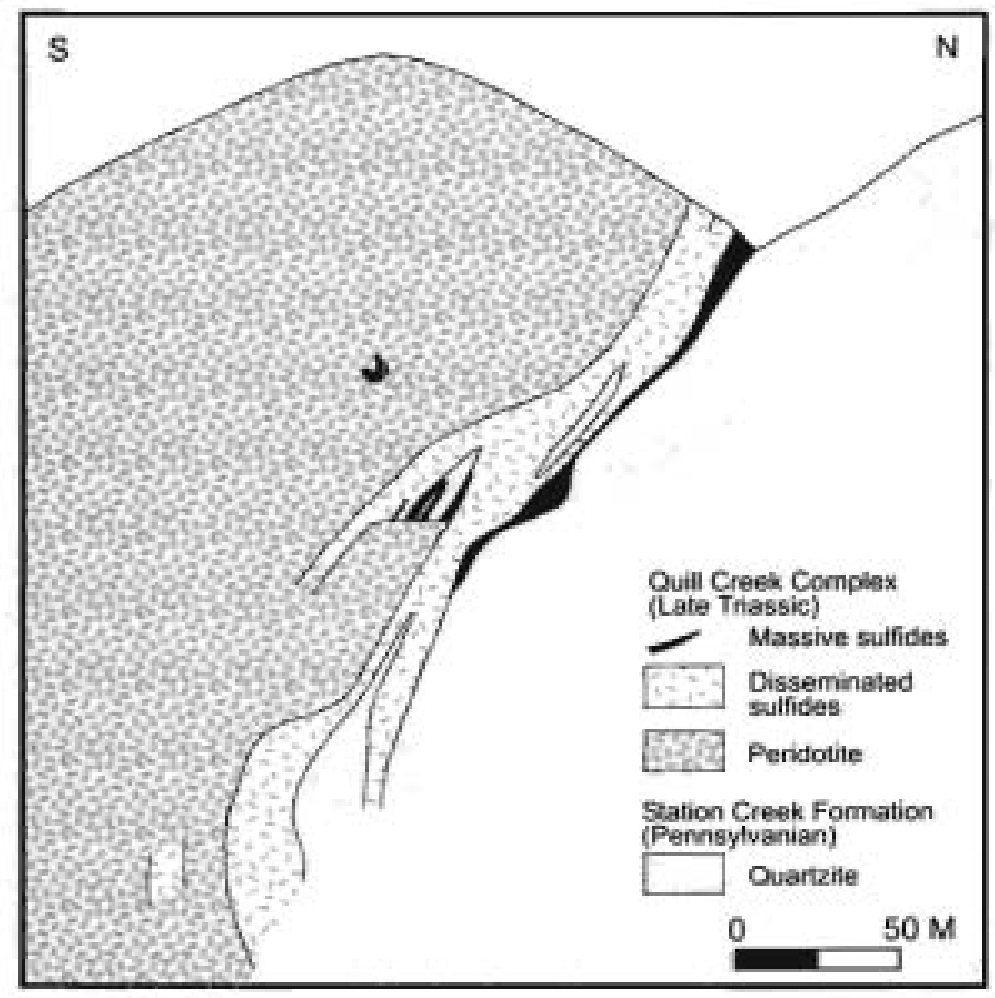

Figure 36. Wellgreen gabbroic Ni-Cu deposit, Eastern Alaska Range metallogenic beit. Schematic cross section through East Zone. Adapted from Hulbert and others (1998).

\section{Origin of and Tectonic Controls for Eastern and Western Alaska Range Metallogenic Beit}

The gabbroic Ni-Cu and PGE deposits in the Eastern Alaska Range metallogenic belt are hosted in gabbro and ultramafic sills and plutons which are interpreted as coeval with, and genetically related to the mainly Late Triassic Nikolai Nikolai Greenstone (Nokleberg and others, 1994d). The Nikolai Greenstone, which forms a major part of the Wrangellia superterrane, consists mainly of massive, subaerial, amygdaloidal basalt flows, lesser pillow basalt flows, and thin beds of argillite, chert, and mafic volcaniclastic rocks which are up to $4,350 \mathrm{~m}$ thick (Nokleberg and others, 1994c, d, 2000). The flows are predominantly intermixed aa, pahoehoe, and pillow basalt flows with minor interlayered chert and argillite (Nokleberg and others, 1994d); 
individual flows range from $5 \mathrm{~cm}$ to more than $15 \mathrm{~m}$ thick. The Late Triassic mafic volcanic and sedimentary rocks of the Nikolai Greenstone also host the Beschi massive sulfide deposit at Denali.

In the southwesternmost Yukon Territory, the Weligreen und associated deposits of the Eastern and Western Alaska Range metallogenic belt oceur in gabbroic bodies which intrude the Pennsylvanian Skolai assemblage, part of the Wrangellia sequence of the Wrangellia superterrane (Campbell, 1960; Read and Monger, 1976; Nokleberg and othen, 1994c, 1997e; Hulbert, 1994). The Skolai assemblage is overlain by mainly Late Triassic basalt of the Nikolai Greenstone and by Late Triussic carbonate rock (Nokleberg and others, 1994c, 1997c). In this area, the gabbro bodies hosting the Wellgreen deposit, and similar gabbroic Ni$\mathrm{Cu}$ deposits in the same area, are also interpreted as coeval with the Late Triassic Nikolai Greenstone. This suite of mafic flows and related units, and mafic and ultramafic shallow intrusive to plutonic rocks are interpreted as forming during either a shortlived period of back-arc rifting or hot spot (oceanic plume) activity within the Talkeetna-Bonanza island arc in Wrangellia superterrane (Nokleberg and Lange, 1985a; Nokleberg and others, 1985a; 1987, 1994c, d, 2000; Plafker and others, 1989).

Also occurring in part of the Eastem Alaska Range metallogenic belt in the Yukon Territory are generally subeconomic volcanic redbed $\mathrm{Cu}$ deposits which are hosted in the predominantly subaerial tholeitic basalt of the Late Triassic Karmutsen Formation, part of the Wrangellia sequence of the Wrangellia superterrane (Read and Monger, 1976). Significant volcanic redbed Cu-Ag deposits at Silver City and Johobo consist of stratabound lenses of native $\mathrm{Cu}$, chalcocite, bornite, chalcopyrite and pyrite (Sinclair and others, 1979; Carriere and others, 1981). The origin of these deposits is not well understood. Kirkham (1996a, b) proposed that the deposits formed during early-stage burial metamorphism, analogous to diagenesis in sedimentary Cu deposits. Also in the Yukon Territory, the Eastern and Western Alaska Range metallogenic belt contains sparse stratiform gypsum deposits, as at Bullion Creek, which are hosted in limestone of the Late Triassic Nizina Formation, also part of a structurally displaced fragment of the Alexander sequence of the Wrangellia superterrane (Monger and others, 1991; Nokleberg and others, 1994c, 1997e).

\section{Alexander Metallogenic Belt of Volcanogenic Cu-Pb-Zn and Carbonate-Hosted Massive Sulfide Deposits, Southeastern Alaska (Belt AX)}

The Alexander metallogenic belt of volcanogenic and carbonate-hosted massive sulfide and associated deposits (fige 32; tables 3, 4) occurs for about $750 \mathrm{~km}$ along the length of Southeastern Alaska. The metallogenic belt is hosted in the early Paleozoic (and older) to Late Triassic Alexander sequence of the Wrangellia superterrane (Nokleberg and others, 1994c, 1997c). The belt contains volcanic- and carbonate-hosted massive sulfide deposits, and bedded barite deposits. The significant deposits in the belt (tables 3,4): are the Windy Craggy massive sulfide deposit (Alsek River area, British Columbia): the Glacier Creek, Greens Creek, Khayyam, Kupreanof Island, Niblack, and Orange Point kuroko massive sulfide deposits (Dawson and others, 1991: Nokleberg and others, 1994c, 1997a, b, 1998, 2000; Newberry and others, 1997); the Castle Island, Haines, and Lime Point bedded barite deposits (Nokleberg and others, 1994c, 1997a, b, 1998; Schmidt, 1997b); and the Moonshine carbonate-hosted massive sulfide deposit (Herreid and others, 1978; Nokleberg and others 1997a, b. 1998).

\section{Windy Craggy Cu-Co Massive Sulfide Deposit}

The world-class Windy Craggy deposit (fig. 37) oecurs in the Tatshenshini River area, northern British Columbia, Canada, and consists of one or more pyrrhotite, pyrite and chalcopyrite massive sulfide bodies which are hosted in Late Triassic submarine, tholeitic to calcalkaine basalt flows, with lesser intercalated siltstone, chert, argillite, and limestone, and numerous diorite dikes and sills which cut footwall units (EMR Canada, 1989; Schroeler and Lane, 1991; G. Harper, writlen commun, 1992; Macintyre and others, 1993). Both zones have adjacent sulfide stringer stockworks. The deposit contains reserves of 265 million tonnes grading $1.44 \% \mathrm{Cu}, 0.07 \% \mathrm{Co}$ and $0.20 \mathrm{gt}$ Au. Five additional stratiform $\mathrm{Cu}$ occurrences were discovered in the area in 1992. The deposit age is interpreted as Late Triassic on the basis of Norian conodonts in limestone from the deposit (M. Orchard, written commun., 1983). The host rocks are intruded by calc-alkaline diorite sills and dikes, and overlain by calc-alkaline pillow basalt at least $1,300 \mathrm{~m}$ thick. The large. Cu-bearing pyrite-pyrthotite massive sulfide bodies are folded, faulted, and sheared. The deposit is transitional between Cyprus and Besshi volcanogenic massive sulfide deposit types.

\section{Greens Creek Kuroko Zn-Pb-Cu Massive \\ Sulfide Deposit}

The Greens Creek Kuroko Zn-Pb-Cu massive sulfide deposit (fig. 38) oecurs on Admiralty Island and consists of sphalerite, galena, chalcopyrite, and tetrahedrite in a pyrite-rich matrix. The sulfides occur in massive pods, bands, laminations, and disseminations, and are associated with pyrite-carbonate-chert exhalite (Berg. 1984; Wells and others, 1986; Brew and others, 1991: Newberry and others, 1997 . The struchural hanging wall contains chlorite- and sericite-bearing metasedimentary rocks. The structural footwall contains black graphitic argillite. "Black ore" forms an extensive blanket deposit, and is composed of fine. grained pynte, sphalerile, galena, and Ag-rich sulfosalts in laminations in black carbonaceous exhalite and argillite. "White ore" occurs along edges of massive sulfide pods and is composed of minor tetrahedrite, pyrite, galena, and sphalerite in laminations, stringers, or disseminations in massive chent, carbonate rocks, or sulfate-rich exhalite. Local veins occur below the massive sulfides and contain bornite, chalcopyrite, and gold. The veins may constitute brine conduits. The sulfides and host rocks are 
underlain by serpentinized mafic voleanic flows and tuffs. An incremental Ar age of $211 \mathrm{Ma}$ was obtained for hydrothermal mariposite from a small massive sulfide occurrence near Greens Creek (Taylor and others, 1995). The host rocks are part of a Triassic suite of metasedimentary and metavoleanic rocks in the Wrangellia sequence which overlies the early to middle Paleozoic rocks of Alexander sequence. Both are part of the Wrangellia superterrane (Nokleberg and others, 1994c, 1997c). The host rocks are tightly folded into a southeast-plunging, overturned antiform. The deposit is interpreted as forming during marine exhalation in a Triassic back-arc or wrench fault extensional basin during deposition of the arc. From 1989-1999, the Greens Creek mine produced 299,480 tonnes zinc, 122,400 tonnes lead, 1,896 tonnes silver, and 10,617 kg gold from 2,924,294 tonnes of ore (Swainbank and Szumigala, 2000).

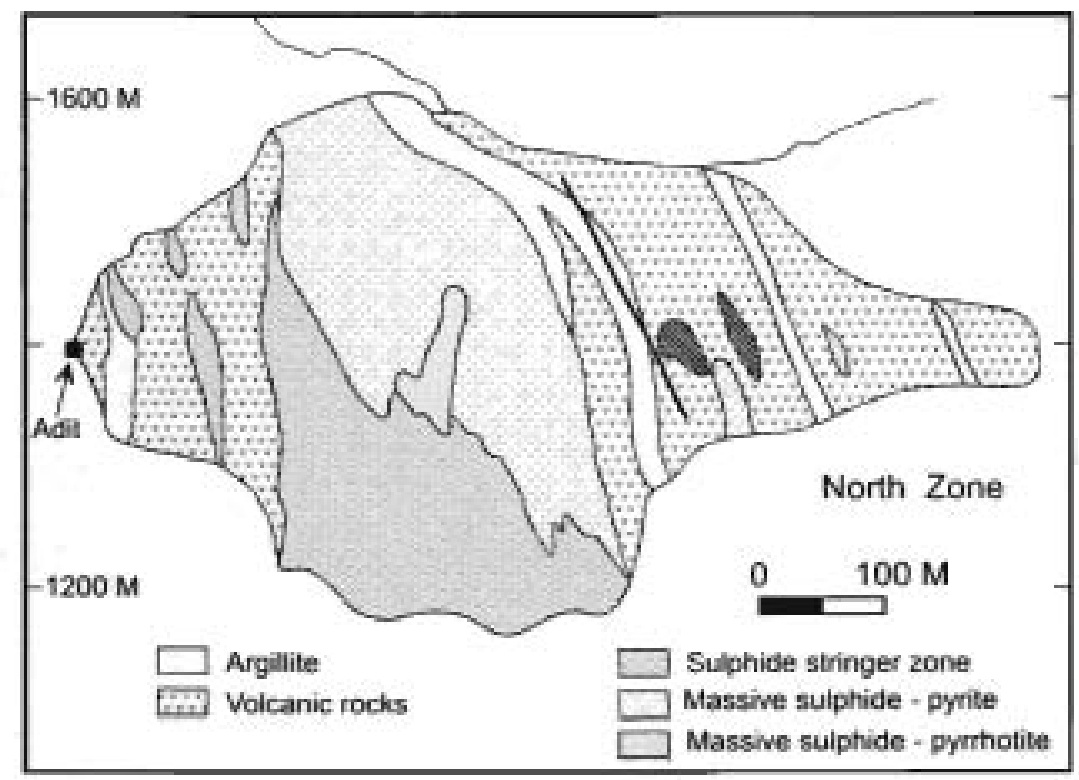

Figure 37. Windy Craggy Cyprus massive sulfide deposit, Alexander metallogenic belt, northern British Columbia, Canadian Cordillera. Schematic cross section through North Zone. Adapted from Downing and others (1990).

\section{Castle Island Bedded Barite Deposit}

The Castle Island bedded barite deposit consists of lenses of massive barite interlayered with metamorphosed limestone of probable Triassic age, and with metamorphosed calcareous and tuffaceous clastic rock (Berg and Grybeck, 1980; Berg, 1984; Grybeck and others, 1984; Brew and others, 1991). Sulfide-rich interbeds contain spbalerite, galena, pyrite, pyrrhotite, bornite, tetrahedrite, and chalcopyrite. The deposit produced 680,000 tonnes of ore grading $90 \%$ barite. Sulfide-rich layers contain up to $5 \%$ galena and sphalerite, and $100 \mathrm{~g} / \mathrm{Ag}$.

\section{Origin of and Tectonic Controls for Alexander Metallogenic Belt of Massive Sulfide Deposits}

The deposits in the Alexander metallogenic belt of massive sulfide and associated deposits (tables 3,4 ) are hosted in a variety of rocks. At the Windy Craggy deposit, the basalt flows hosting the massive sulfide deposit consist of a thick unit of dominantly alkaline to sub-alkaline composition, and abundant interleaved, craton-derived clastic sedimentary rocks which are more characteristic of a Besshi-type deposit. Hosting the Greens Creek and other kuroko massive sulfide deposits are suites of Triassic metasedimentary rocks, argillite, and siliceous metavolcanic rocks. Hosting the Castle Island bedded barite deposit is Triassic(?) limestone, and calcareous and tuffaceous clastic rocks. The Triassic units constitute the younger part of the Wrangellia sequence in Southeastern Alaska which in this area overlies the early to middle Paleozoic Alexander sequence; together the two sequences form the Wrangellia superterrane in the region (Nokleberg and others, 1994c, d, 1997c, 2000)

In Southeastern Alaska, in addition to marine basalt, the Triassic part of the Wrangellia sequence contains siliceous (meta)volcanic rocks (rhyolite and tuff), limestone, argillite, and conglomerate in a relatively narrow belt on the eastem side of the terrane (Gehrels and Berg, 1994). In contrast, in southern Alaska, the Triassic part of the Wrangellia sequence consists of thick unit of marine and subaerial basalt in the Nikolai Greenstone, and lesser limestone (Nokleberg and others, 1994c, 1997c). In southern British Columbia on Vancouver Island, similar thick marine basalt forms the Karmutsen Volcanics (Nokleberg and others, 1994c, 1997c).

The Triassic strata and contained massive sulfide deposits of the Alexander metallogenic belt are interpreted as forming in a back-are rift environment on the basis of (Dawson, 1990; Gehreis and Berg. 1994; Nokleberg and others. 1994c, 1997c): (1) the presence of bimodal voleanic rock (basalt and rhyolite); (2) a variety of deposit types (Cyprus to Besshi, kuroko, and carbonate-hosted massive sulfide deposits, and bedded barite deposits) which are generally related to rifting: and (3) the 
occurrence of turbiditic clastic rocks. On the basis of geochemical data, either back-arc rifting or bot-spot activity is interpreted to have formed the widespread basalt fields of the Nikolai Greenstone and Karmutsen Formation and coeval mafic and ultramafic sills and plutons (Barker and others, 1989; Richards and others, 1991; Lassiter and others, 1994). Herein, back-arc rifting is interpreted as the tectonic environment for the Triassic strata and contained massive sulfide deposits. The rifting is tectonically linked to the coeval Bonzana-Talkeetna island are which occurs along the length of the Wrangellia superterrane for several thousand $\mathrm{km}$ (Nokleberg and others, 2000).

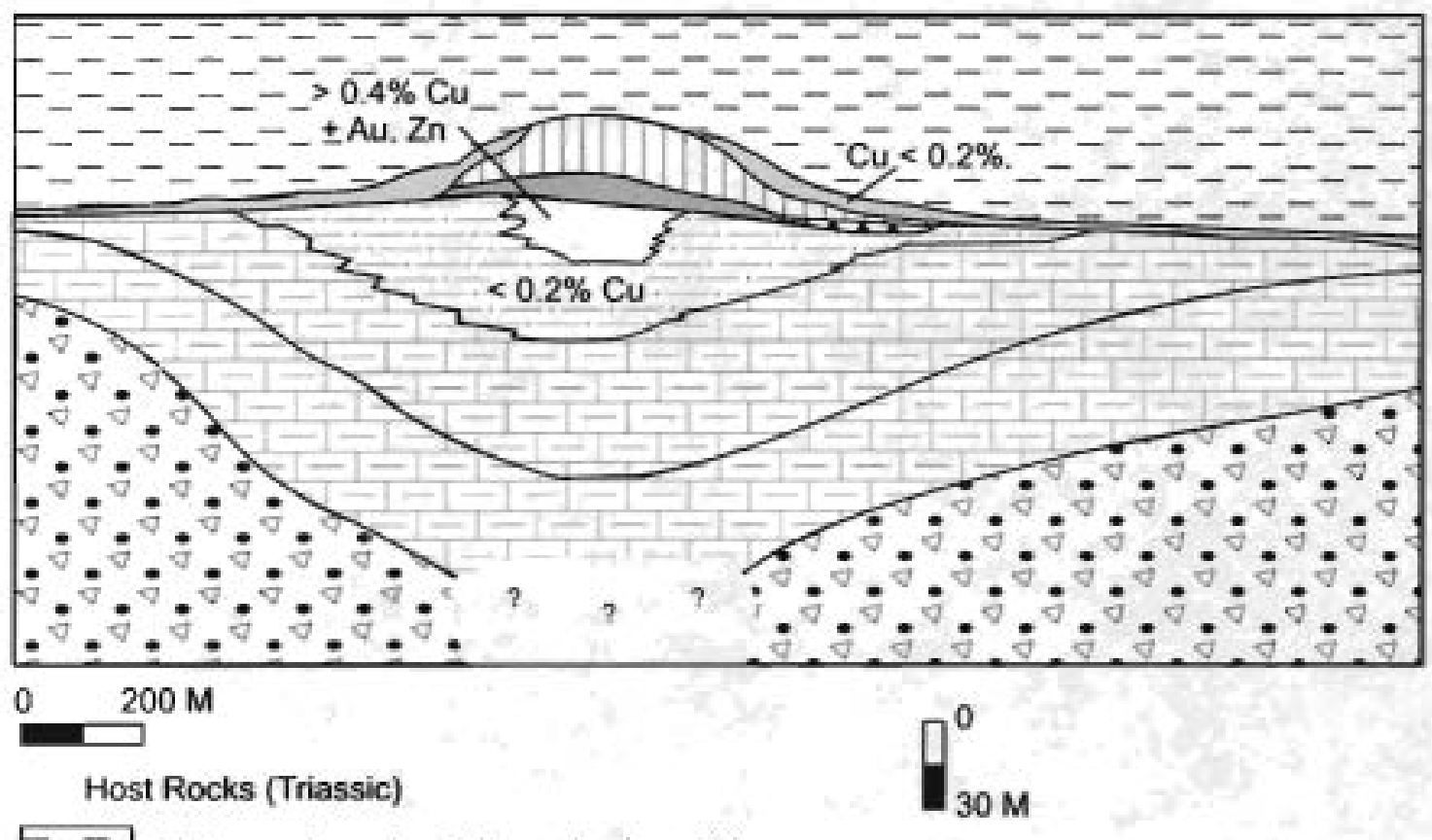

-_- Metamorphosed argillite and calc-argillite

Quartz-pyrite-sericite-carbonate phyllite

- Chlorite-calcite phyllite

$\because . ;$ Greenstone

Sulfide Assemblages \& Related Units (Triassic)

[IDW White ore carbonate and locally barite rich

$\square$ Massive sulfide, base-metal rich

Massive sulfide, fine-grained chiefly pyrite

White massive sulfides, silica-rich

¿ Siliceous, carbonate breccia

Contact

Figure 38. Greens Creek kuroko massive sulfide deposit, Alexander metallogenic belt, Southeastem Alaska, Schematic, predeformation, cross-section model based on drill core logging and underground and surface mapping. Modified from Newberry and others (1997). 


\section{Metallogenic Belts Formed in \\ Middle Mesozoic Stikinia-Quesnellia \\ Istand Arc}

\section{Galore Creek Metallogenic Beit of Porphyry Cu-Au Deposits (Beit GL) Northern British Columbia}

The Galore Creek metallogenic belt of porphyry Cu-Au deposits (fig 32; tables 3,4) occurs in northern British Columbia and is hosted in alkaline granitoid plutons which are coeval and comagmatic with volcanic, volcaniclastic and subordinate sedimentary rocks of the Late Triassic Stuhini Group of the northern Stikinia terrane. The significant deposits are the Galore Creek, Gnat Lake, and Red Chris porphyry $\mathrm{Cu}$, porphyry $\mathrm{Cu}-\mathrm{Au}$, and $\mathrm{Cu}-\mathrm{Au}$ skarn deposits (table 4) (Nokleberg and others 1997a, b, 1998).

\section{Galore Creek Alkalic Porphyry Cu-Au Deposit}

The Galore Creek alkalic porphyry Cu-Au deposit consists of chalcopyrite, pyrite, bornite and magnetite which occur as disseminations, skams, coarse replacements, and fracture fillings in syenitic porphyry and breccias and the Late Triassic Stuhini Group metasedimentary and metavolcanic rocks (Allen and others, 1976; EMR Canada, 1989; Dawson and others, 1991; Mining Review, 1992, J. Mortensen, written commun., 1993; Enns and others, 1995). The deposit contains estimated reserves of 125 million tonnes grading $1.06 \% \mathrm{Cu}, 7.7 \mathrm{~g} / \mathrm{Ag}$, and $0.4 \mathrm{~g} / \mathrm{t}$ Au. Approximately $80 \%$ of deposit consists of altered skam and replacements along contacts between syenite intrusives and Triassic voleanic and sedimentary rock. A U-Pb zircon isotopic age of $210 \mathrm{Ma}$ is reported for the intramineral syenite porphyry. The porphyry is typical of undersaturated, feldspathoid-bearing subelass of alkalic porphyry deposits.

The Galore Creek deposit is hosted in volcanic rocks of the Stuhini Formation. The rocks are dominantly augite and plagioclase phyric basalt and andesite flows, fragmental rocks and less abundant feldspathoid-bearing fows. Prograde Cu skarns, which occurs in calcareous pyroclastic, volcaniclastic, and shoshonite volcanic rocks adjacent to contacts of pseudoleucite-phyric syenite dikes, constitutes about $80 \%$ of ore reserves in the Central Zone. Potassic alteration assemblages of orthoclase and biotite, which occur in or adjacent to potassic host rocks, are replaced by a calcic skarn assemblage of zoned andradite, diopside, Fe-rich epidote, and vesuvianite along with chalcopyrite, bornite, pyrite, and magnetite, and minor chalcocite, sphalerite, and galena. Retrograde assemblages consist of anhydrite, chlorile, sericite, calcite, gypsum, and fluorite (Dawson and Kirkham, 1996).

The Southwest Zone consists of disseminated chalcopyrite in a late-stage, diatreme breccia and adjacent orthoclase porphyry. The North Junction and other satellite deposits consist of disseminated chalcopyrite and bornite in volcanic rocks. Reserves calculated in 1992 are: Central Zone -233.9 million tonnes grading $0.67 \% \mathrm{Cu}, 0.35 \mathrm{~g} / \mathrm{Au}$, and $7 \mathrm{~g} / \mathrm{Ag}$; Southwest Zone -42.4 million tonnes grading $0.55 \% \mathrm{Cu}, 1.03 \mathrm{~g} / \mathrm{Au}$, and $7 \mathrm{~g} / \mathrm{Ag}$; and North Junction -7.7 million tonnes grading $1.5 \% \mathrm{Cu}$.

\section{Red Chris Parphyry Cu-Au Deposit}

The Red Chris alkalic porphyry Cu-Au deposit consists of a stockwork and a set of sbeeted-veins containing quartz, pyrite, chalcopyrite, and increasing bornite at depth. The deposit is hosted in an elongate porphyritic monzonite stock emplaced within the Late Triassic alkaline volcanic and volcaniclastic rocks of either the Stuhini, Group (EMR Canada, 1989; American Bullion Minerals Lid., news release, Jan. 1995; Newell and Peatfield, 1995; Ash and othen, 1997). The monzonite exhibits an isotopic age of 203+1.3 Ma (Friedman and Ash, 1997). An early K-Na alteration stage of orthoclase-albite-biotite with variable quartz-sericite, was succeeded by pervasive quartz-ankerite-sericite-pyrite alteration. Pyrite occurs as a halo to the steeply dipping deposit which is both controlled and offset by east-northeast trending subvertical fults. The deposit contains estimated resources of 320 million tonnes grading 0.38\% Cu and $0.30 \mathrm{~g} / \mathrm{Au}$ (American Bullion Minerals, news release, Jan., 1995). A minimum K. Ar isotopic age of mineralization of $195 \mathrm{Ma}$ (Early Jurassic) is obtained from a post-mineral dike (Newell and Peatfield, 1995). Subvolcanic complexes similar to the Red stock occur at the Rose and Groat Creck porphyry Cu-Au prospects which are located $10 \mathrm{~km}$ northwest, and $25 \mathrm{~km}$ southwest of Red Chris, respectively (Newell and Peatfield, 1995). Porphyry Cu-Au prospects at June and Stikine in the Gnat Lake area are hosted in quartz monzonite and granodiorite phases of the Hotailuh Batholith (Panteleyev, 1977).

\section{Origin of and Tectonic Controls for Galore Croek Metallogenic Belt}

The Galore Creek metallogenic belt of porphyry $\mathrm{Cu}$-Au deposits is hosted in and adjacent to a Late Triassic (210 Ma) center of alkaline volcanism, conlemporaneous witb multi- phase intrusion and magmatic- hydrothermal activity, and late diatreme breccias, which together probably contributed to the high Cu and Au contents at Galore Creek relative to other alkaline porphyry systems as at Cat Face in British Columbia (Enns and others, 1995). The Galore Creek metallogenic belt is part of the subduction related Stikinia island are (Monget and Nokleberg. 1996; Nokleberg and others, 2000). Isotopic ages indicate intrusion of host granitoid plutons and formation of associated mineral deposits from the Late Triassic to the Farly Jurassic. This age represents the main and final part of subduction-related igneous building of the Stikinia island arc, just before accretion of the Stikinia terrane, 
along the with tectonically-related Quesnellia island are and Cache Creek subduction-zone ternanes, onto the North American Craton Margin (Monger and Nokleberg. 1996, Nokleberg and others, 2000).

Sustut Metallogenic Beit of

Basaltic Cu Deposits (Belt SU)

Northern British Columbia

The Sustut metallogenic belt of basalic Cu deposits, which occurs in northem British Columbia, is hosted in fragmental volcanic rocks of intermediate composition and interlayered sedimentary rocks of the Late Triassie Takla Group in the northeastern part of the Stikinia island-are terrane (fig. 32; tables 3, 4) (Nokleberg and others, 1997b, 1998). A more extensive, but less coherent belt could be defined to the south and west which would include minor volcanic redbed Cu occurrences in the overlying Hazelton Assemblage and the Nicola Assemblage in southem Quesnellia island-are terrane. In each case, the deposits are located within emergent, subaerial parts of island-are terranes. The significant deposit is at Sustut.

\section{Sustut Basaltic Cu Deposit}

The Sustut basaltic Cu deposit consists of a stratabound assemblage of hematite, pyrite, chalcocite, bomite, chalcopyrite and native copper which occurs as disseminations and as blebs and grains in the mutrix of sandstone, conglomerate, tuff breccia and lahar of the Late Triassic Takla Group (EMR Canada, 1989; Dawson and others, 1991). The deposit is a large concordant body which is strongly zoned inward from an outer zone of pyrite, chalcopyrite, and bornite into a core of chalcocite, native copper and hematite. The zonation is interpreted as reflecting the mignation of ore fluids along permeable aquifers. The host rocks are sandstone, conglomerate, lahar, and red/green or grey tuff breccia of subaerial origin. Estimated resources are 21 million tonnes grading $1.11 \% \mathrm{Cu}$ (Kirkham, 1996b; Harper, 1977; Mining Review, summer 2000). The grade increases in finer grained units. Pyrite forms an incomplete envelope around $\mathrm{Cu}$-bearing lenses, and bematite is ubiquitous. The deposit age is interpreted as Late Triassic. The Northstar deposit to the south of Sustut is a faulted block of lower-grade, chalcocite-bearing sedimentary rocks which are apparently interlayered within volcanic flows of the Takla Group (Sutherland Brown, 1968).

\section{Origin of and Tectonic Controls for Sustut Metallogenic Belt}

The origin of basaltic Cu deposits hosted in volcanic rocks is interpreted as analogous to that for diagenetic sedimentary $\mathrm{Cu}$ deposits in sedimentary sequences. However, the common presence of low-grade metamorphic minerals may also supports a melamorpbic origin (Kirkham, 1996b). In the Sustut metallogenic belt, the deposits are interpreted as forming in the upper oxidized parts of volcanic piles during shallow burial metamorphism and diagenesis (Kirkham, 1996b) which was coeval with Late Triassic island-are volcanism in the Stikinia and Quesnellia terranes.

\section{Copper Mountain (North) Metallogenic Belt of Porphyry Cu-Au Deposits (Belt CMN) \\ Northern British Columbia}

The Copper Mountain (North) metallogenic belt of porphyry Cu-Mo-Au deposits (fig. 32; tables 3,4) occurs in northem British Columbia and is hosted in graniloid plutonic rocks of the mainly in intermediate-cornposition granitoid plutons in the Copper Mountain suite in the Quesnellia island-are terrane. Most plutens in the suite are small, equant stocks with diameters ranging up to a few kilometers. The significant deposits are the Lorraine and Mount Mulligan porphyry Cu-Au deposits (table 4) (Nokleberg and others 1997a, b, 1998).

\section{Lorraine Porphyry Cu-Au Deposit}

The Lotraine porphyry Cu-Au deposit consists of two fault-bounded zones of ehalcopyrite, bornite and magnetite which occur as disseminations in the 30-by 5-km-wide Middle Jurassic Duckling Creek Syenite Complex which is part of the largest pluton in the Hogem Bstholith of the alkaline Copper Mountain Suite (EMR Canada, 1989; Dawson and others, 1991; Woodsworth and others, 1991; Bishop and others, 1995; MINFILE, 2002). The sulfides are dominantly disseminated, but also occur in veins. In the Lower Zone, sulfides occur in mafic-rich lenses and are zoned from chalcopyrite + pyrite at the rim, through chalcopyrite with minor bomite to bornite with minor chalcopyrite at the core. Magnetite is common in veinlets and as an accessory mineral. The deposit coetains an estimated resource of 9.1 million tonnes grading $0.70 \% \mathrm{Cu}$ and $0.27 \mathrm{~g} / \mathrm{Au}$ (MINFIL.E, 2002). An Upper Zone is similar but is highly exidized (Garnett, 1978). The Cu-Au deposit exhibits chanacteristics of both hydrothermal and magmatic origins, and is related to orthomagmatic-hydrothermal fluid flow contemporaneous with magmatism and development of migmatitic fabrics(Bishop and others, 1995). Cu minerals are associated with elevated intensity of biotite, chlorite, potassiem feldspar and sericite alteration. A K-Ar isotopic age of $175+1.5 \mathrm{Ma}$ (Middle Jurassic) for the syenite at Lorrine is interpreted as a reset age; a U.Pb zircon age is about $181 \mathrm{Ma}$ (Bishop and others, 1995). 
The Mount Milligan Porphyry Cu-Au deposit consists of pyrite, chalcopyrite, bornite and magnetite which occur as disseminations and in quartz, veinlets (Delong and others, 1991; McMillan, 1991; Nelson and others, 1991; Barrie, 1993; Sketchley and others, 1995). The deposit has estimated reserves of 298.4 million tonnes grading $0.22 \% \mathrm{Cu}$ and $0.45 \mathrm{~g} / \mathrm{Au}$. The deposit is hosted in augite porphyntic andesite of the Witch Lake (informal) formation of the Late Triassic to Early Jurassic Takla Group which is intruded by severai small brecciated diorite and monzonite porphyry dikes and stocks. Cu-Au mineralization in the Main deposit accompanied the emplacement of the MBX stock and Rainbow dyke; the Southern Star deposit surrounds the stock of the same name. A U-Pb ziroon isotopic age of $183+1 \mathrm{Ma}$ is obtained for the Southem Star monzonite. $\mathrm{Cu}$ and $\mathrm{Au}$ minerals are associated with moderate to intense potassic alteration around intrusive contacts. Potassic alteration, which is ubiquitous in mineralized stocks and surrounding volcanic rocks, is surrounded by propylitic alteration which decreases in intensity outward from intrusive. A well-developed mineral zoning consists of a biotite-rich core in the potassic zone which contains most of the $\mathrm{Cu}$ and Au. Numerous polymetallic veins are hosted by the propyliyic alteration zone immediately beyond the limits of the porphyry deposit.

\section{Origin of and Tectonic Controls for Copper Mountain (North) Metallogenic Belt}

The Copper Mountain (North) metallogenic belt is hosted mainly in intermediate-composition granitoid plutons in the Copper Mountain suite which are part of the subduction-related Quesnellia island arc (Nokleberg and others, 1994a, b; Monger and Nokleberg, 1996; Nokleberg and others, 2000). Emplacement of plutons was apparently along faults and intersections of faults. In both the Copper Mountain (North) and Copper Mountain (South) metallogenic belts, many of the porphyry Cu-Au deposits occur in alkaline plutons. Isotopic ages indicate intrusion of host granitoid plutons and formation of associated mineral deposits from about 175 to $185 \mathrm{Ma}$ in the Middle Jurassic in the Copper Mountain (North) metallogenic belt. This age represents the end of subduction-related igneous building of Quesnellia island arc, just before accretion of the Quesnellia terrane, along the with tectonically-related Stikinia island arc and Cache Creek subduction-zone terranes, onto the North American Craton Margin (Monger and Nokleberg, 1996; Nokleberg and others, 2000).

\section{Copper Mountain (South) Metallogenic Belt of Porphyry Cu-Au Deposits (Belt CMS) Southern British Columbia}

The Copper Mountain (South) metallogenic beit of porphyry Cu-Au deposits (fig. 32; tables 3, 4) occurs in southern British Columbia and is hosted in the Copper Mountain alkalic plutonic suite in the Quesnellia island-are terrane. The significant deposits are the Copper Mountain, Iron Mask area (Afton, Ajax), and Mt. Polley (Cariboo-Bell) porphyry Cu-Au deposits, and the Lodestone Mountain zoned mafic-ultramafic Fe-V deposits (table 4) (Nokleberg and others 1997a, b, 1998).

\section{Copper Mountain (Ingerbelle) \\ Porphyry Cu-Au Deposit}

The Copper Mountain (Ingerbelle) alkalic porphyry Cu-Au deposit (fig. 39) consists of mainly of chalcopyrile and bornite which occur as disseminations and in stockworks in Early Jurassic alkaline intrusive rocks of the Copper Mountain Suite and similar age volcanic and volcuniclastic rocks of the Nicola Assenblage (Preto, 1972; McMillan, 1991; P. Holbeck. Cordilleran Roundup, written commun, 1995; MINFILE, 2002). This and similar deposits in the Copper Mountan area occur along a northwest trend for over $4 \mathrm{~km}$. The main ore bodies are the Copper Mountain Pits 1-3, Ingerbelle East, Ingerbelle, Virginia and Alabama. Production up to 1994, was 108 million tonnes containing 770,000 tonnes Cu and 21.8 tonnes Au. Estimated reserves are 127 million tonnes grading $0.38 \% \mathrm{Cu}, 0.16 \mathrm{~g} / \mathrm{Au}$, and $0.63 \mathrm{~g} / \mathrm{Ag}$ (MINFILE, 2002). Estimated resources are 200 million tonnes grading $0.4 \%$ Cu equivalent. Significant values in $\mathrm{Pt}$ and $\mathrm{Pd}$ were reported from assays of chalcopyrite- and bornite-rich concentrates.

The Copper Mountain (Ingerbelle) deposit consists of a silica-deficient, chalcopyrile-pyrite-bornite stockwork hosted almost entirely by fragmental andesitic volcanic rocks, calcareous volcaniclastic rocks and minor carbonate strata (Fahrni and others, 1976). Intrusive rocks are equigranular diorile stocks, and more siliceous dikes, sills, and irregular plags of the Lost Horse Intrusive Complex, a porphyritic unit which is offen closely associated with bornite-chalcopyrite-pyrite-magnetite mineral deposits and occurrences. A K-Ar biotite isotopic age of 197 to $200 \mathrm{Ma}$ is interpreted as an Early Jurassic age for the deposit. Alteration mineral assemblages at the Copper Mountain Pits 1 io 3, and the Alabarna and Virginia ore bodies are early albite-diopsideepidote-calcite; and potassium feldspar-biotile-epidole-magnetite; and a later propylitic assemblage of chlorite-pyrite-epidotescapolite-calcite (Preto, 1972; Stanley and others, 1995).

At the Ingerbelle deposit. skarn-like ore and gangue mineral zonation occurs along the contact of the Lost Horse stock where it intrudes agglotnerate, tuff, tuff-breccia, and sedimentary rocks of the Nicola Assemblage (Sutheriand Brown and others. 1971; Preto, 1972; Macauley, 1973; Fahmi and others, 1976; and Dawson and Kirkham, 1996). In these areas, early biotite hornfels was overprinted by prograde albite-epidote, chlorite, andradite, diopside, and sphene, then both the stock and prograde 


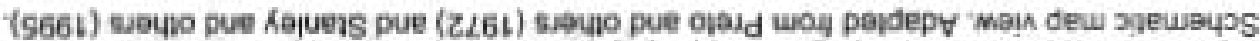

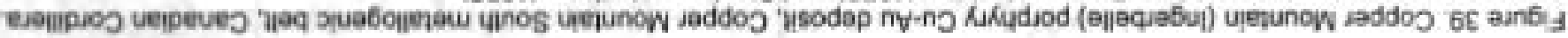

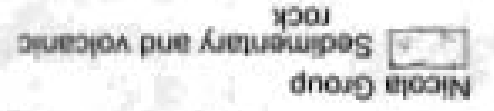

auvexoskd jo osqueg

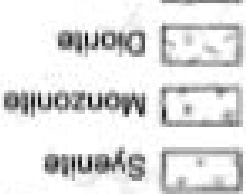

sypois oxer sonews

\section{epoasq pue anuaksopiu

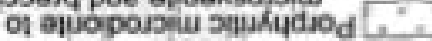 \\ xajduos assoH 1507 \\ suojsnalu| ulęunow jaddo}

msseul reddn

anuozuow zuenb жаељ ериел

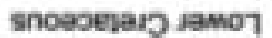

pou suespan sursapur [....?

dnoip vosasulid

aueoog apow

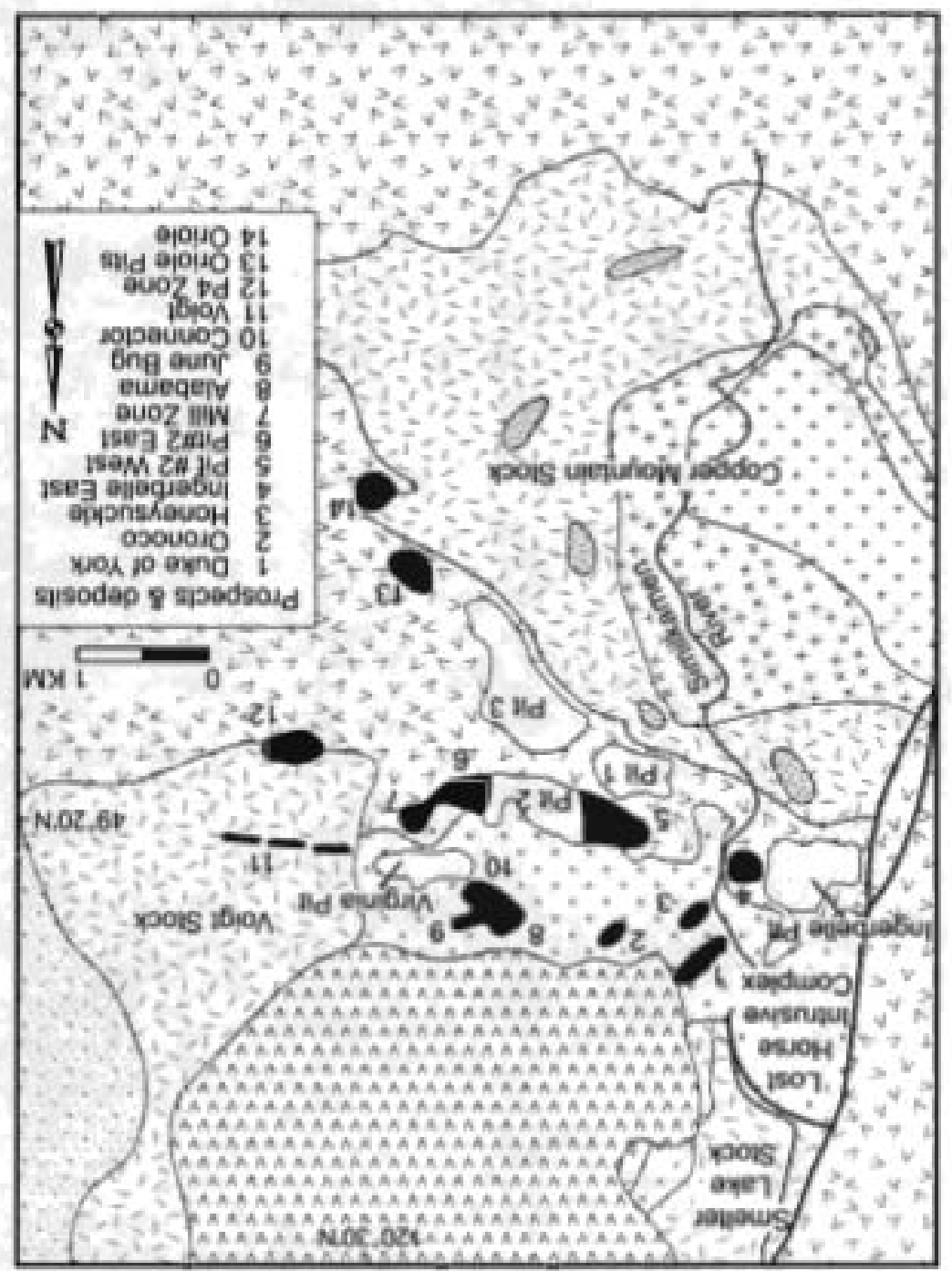

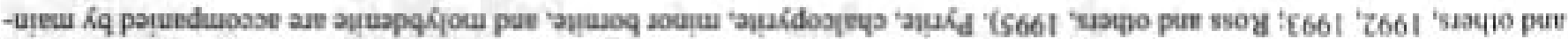

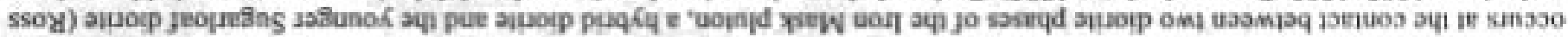

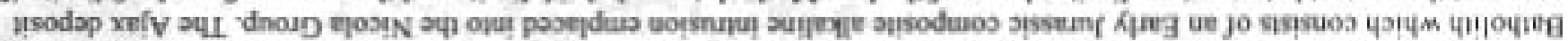

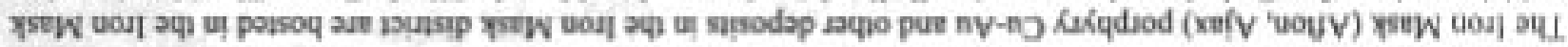

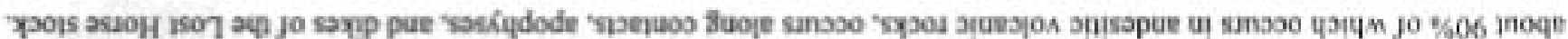
'ao эฺฺ 
stage albite and peripheral propylitic alteration. Potassic and scipolitic alteration crosscuts albite and propylitic alteration (Ross and others, 1992, 1993, 1995). The Afton deposit consists of a tabular-shaped body of chalcopyrite and bornite which is hosted in fractured diorite of the Cherry Creek pluton. A deeply penetrating supergene zone contains native copper and lesser chalcocite. Aggregate pre-production reserves and production for the Ajax East and West deposits and for the Afton deposit are 66 million tonnes grading $0.77 \% \mathrm{Cu}$ and $0.56 \mathrm{~g} / \mathrm{Au}$. The common occurrence of picrite intrusions along fauts which cut the Nicola Group und their association with the porphyry deposits in the lron Mask pluton indicate which regional, steeply-dipping faults controlled emplacement of the plutons in the batholith and also served as conduits for mineralizing fluids. An U.Pb zircon isotopic age of $207 \mathrm{Ma}$ (Late Triassic) for the Cherry Creek pluton.

Deep drilling in 2001-2002 southwest of and below the Afton orebody by DRC Resources Corporation has proven a resource of 34.3 million tonnes of $1.55 \% \mathrm{Cu}, 114 \mathrm{~g} / \mathrm{Au}, 3.42 \mathrm{~g} / \mathrm{Ag}$ and $0.125 \mathrm{~g} / \mathrm{Pd}$ in the Main Zone, and an additional 1.1 million tonnes of similar material in the Northeast Zone. The roughly tabular body is $850 \mathrm{~m}$ long, $750 \mathrm{~m}$ deep, and $70 \mathrm{~m}$ wide, and is open to length and depth. The deposit exhibitsboth hydrothermal and magmatic characteristics (DRC Resources Corp, news release April 2003).

\section{Mt. Polley (Cariboo-Beli) Porphyry Cu-Au Deposit}

The Mt. Polley (Cariboo-Beil) Porphyry Cu-Au deposit consists of magnetite, chalcopyrnte and minor pyrite which occur in several intrusive phases and three distinct breccias in an Early Jurassic pseudoleucite-bearing alkaline complex which intrudes Upper Triassic Nicola alkaline volcanic and volcaniclastic rocks of the Quesnel trough (EMR Canada, 1989; McMillan, 1991; Mining Review, 1991; Gosh, 1992; Fraser and others, 1993; MINFILE, 2002). Some skarn and vein occurs in tuff and flows of the Nicola Assemblage. Supergene mineralization includes malachite, native copper, cuprite, chalcocite and covellite. The deposit contains proven reserves of 76.5 million tonnes grading $0.30 \% \mathrm{Cu}, 0.47 \mathrm{~g} / \mathrm{t}$ Au. Production through 1999 was 15.26 million tonnes with $341,000 \mathrm{~g} \mathrm{Ag}, 6,858,448 \mathrm{~g} \mathrm{Au}$, and $31,637,173 \mathrm{~kg} \mathrm{Cu}$ (MINFILE, 2002). A U-Pb zircon isotopic age of $200 \pm 1.5$ Ma for diorite and a monzonite porphyry indicates an Early Jurassic age for intrusion of the host granitoid rocks.

\section{Lodestone Mountain Zoned Mafic-Uitramafic Fe-Ti Deposit}

The Lodestone Mountain zoned mafic-ultramafic Fe-Ti deposit consists of titaniferous magnetite and ilmenite which occur in pods and lenses and as disseminated grains in pyroxenite of the Tulameen zoned mafic-ultramafic (Alaskan type) complex (St. Louis and others, 1986; Nixon and others, 1997). The deposit contains estimated reserves of 81.65 million tonnes grading $17.56 \% \mathrm{Fe}$ (EMR Canada, 1989). Minor Pt and Pd are reported. Reported Ti content of magnetite is 1\%. An additional 249 million tons of possible and inferred ore is estimated. The deposit is interpreted as forming primarily by magmatic differentiation. The Late Triassic Tulameen layered mafic-ultramafic (Alaskan-type) complex is coeval, and in part cogenetic with adjacent gabbro plutons of the Lost Horse intrusive complex (Findlay, 1969). The complex inirudes basaltic andesite of the Nicola Group. Several lode and placer Pl-Pd deposits occur at Grasshopper Mountain in the Tulameen Complex (Findlay, 1969).

\section{Origin of and Tectonic Controls for \\ Copper Mountain (South) Metallogenic Belt}

The Copper Mountain (South) metallogenic belt is bosted in the Copper Mountais plutonic suite. Syenite, monzonite, and monzodiorite are most common, but diorite, monzogranite, clinopyroxenite occur locally. The porphyry Cu-Au deposits are hosted in the felsic plutons, whereas the major Fe-Ti deposit at Lodestone Mountain is hosted in zoned mafic-ultramafic rocks. Many felsic plutons are lithologically and texturally complex, with multiple phases of intrusion and potassic metasomatism, characterized by abundant aputite and magnetie. Soene plutobs are aepheline-and leucite-normative; others are both quartzsaturated and quartz-undersaturated (Woodsworth and others, 1991). The deposits in the Copper Mountain (South) and (North) metallogenic belts are part of the subduction related Quesnellia island are (Monger and Nokleberg. 1996; Nokleberg and others, 2000). In both the Copper Mountain (North) and Copper Mountain (South) metallogenic belts, many of the porphyry Cu-Au deposits occur in alkaline plutons. Isotopic ages indicale intrusion of host granitoid plutons and formation of associated mineral deposits occurred from about 207 to $197 \mathrm{Ma}$ in the Late Triassic and Early Jurassic (Ross and others, 1995; Stanley and others, 1995). This age represents the end of subduction-related igneous building of Quesnellia island arc, just before aceretion of the Quesnellia terrane, along the with Iectonically-related Stikinia island arc and Cache Creek and Slide Mountain subduction-zone terranes, onto the North American Craton Margin (Monger and Noklebere. 1996; Nokleberg and others, 2000).

\section{Guichon Metallogenic Belt of Porphyry Cu-Mo-Au and Au Skam Deposits (Belt GU) Southem British Columbia}

The Guichon metallogenic belt of porphyry Cu-Mo-Au and Au skarn deposits (fig. 32; tables 3,4) occurs in southern British Columbia and is associated with the Guichon Suite of numerous large calc-alkaline granitoid plutons hosted by the westem Quesnellia island-arc terrane. The Guichon Suite has close spatial and temporal affinities with the Late Triassic and Early Jurassic 
island-are volcanic rocks of the Nicola Assemblage of the Quesnellia island-arc terrane (Woodsworth and others, 1991), Parallel facies belts define a west-facing are which progresses compositionally from cale-alkaline on the west to alkaline on the east for both volcanic and comagmatic granitond plutonic rocks (Mortimer, 1987). The significant deposits in the belt are: (1) porphyry Cu-Mo deposits in the Highland Valley district (Bethlehem-JA, Valley Copper. Lornex, Highmont (Gnawed Mountain)): (2) porphyry Cu-Mo deposits at Axe (Summers Creek), Brenda (Peachland area), and Gibraltur (Pollyanna, Granite Mo); (3) porphyry Cu deposits at Primer (North Zone); (4) the Craigmont Cu-Fe skam deposit; and (5) the Hedley Camp (Nickel Plate, Mascot) Au skam deposit (table 4) (Nokleberg and others 1997a, b, 1998).

Highland Valley District (Bethlehem, Valley Copper, Lornex, Highmont ) of Porphyry Cu-Mo Deposits

The Highland Valley district contains large porphyry Cu-Mo deposits which occur in the calc-alkaline, composite Guichon Creek Batholith is the southern Quesnellia terrane. Associated with the youngest, innermost, and most leucocratic phases of the batholith are late-stage dike swarms (McMillan, 1985Casselman and others, 1995). The batholith ranges from diorite and quartz diorite at the border, to younger granodiorite in the center. Although much variation occurs, individual deposits typically exhibit concentric zonation alteration which grades from central silicic alteration, to potassic, phyllic, and argillic alteration in an intermediate zone, and to peripberal propylitic alteration (McMillan and others, 1995). The principal deposits in the district at Bethlehem, Valley Copper, Lornex, and Highmont have combined production and reserves of about 2,000 million tonnes grading $0.45 \% \mathrm{Cu}$. The Highland Valley district is the largest porphyry Cu district in the Canadian Cordillera (McMillan, 1985).

\section{Valley Copper, Brenda, Axe, and Primer Porphyry Cu-Mo Deposits}

The Valley Copper porphyry Cu-Mo deposit (fig. 40) consists of fracture-controlled chalcopyrite (potassic alteration) and bomite (phyllic alteration) with minor digenite, covellite, pyrite, pyrrhotite, molybdenite, sphalerite and galena (McMillan, 1985. 1991; Highland Valley Copper Lid., annual report, 1991; MINFILE, 2002). The linkages between sulfide minerals and alteration types are not clear because chalcopyrite also occurs in the phyllic zone and bornite occurs in the potassic zone. Combined estimated production and reserves are 716 million tonnes grading approximately $0.47 \% \mathrm{Cu}$, and $0.006 \% \mathrm{Mo}$. The deposit is hosted in granodiorite and quartz monzonite of the Bethsaida phase of the Guichon Creek Batholith. Minor amounts of Fe-Sb sulfide (gudmundite) and native gold are reported. An oxidized halo ranging in thickness from 0.3 to 100 meters consists of limonite, malachite, pyrolusite, digenite, native copper and tenorite. The average thickness of the oxidized zone is 33 meters.

The smaller Brenda, Axe, and Primer porphyry Cu-Mo deposits are hosted in calc-alkaline Jurassic stocks south of Highland Valley. The Gibraltar porphyry Cu-Mo deposit (Bysouth and others, 1995) is hosted in the calc-alkaline Granite Mountuin granodiorite pluton which intruded the Cache Creek terrane during accretion with the tectonically-linked Stikinia Quesnellia island-are terranes to the east and west, respectively. This accretion is interpreted as occurring during oroclinal warping of these terranes in the Early Jurassic (Drummond and others, 1976; Dawson and others, 1991).

\section{Brenda Porphyry Cu-Mo Deposit}

As another example, the Brenda porphyry Cu-Mo deposit consists of chalcopyrite and molybdenite with minor pyrite and magnetite which occur within veins and fractures (McMillan, 1991; Weeks and others, 1995; MINFILE, 2002). The deposit contains estimated combined production and reserves of 164.0 million tonnes grading $0.16 \% \mathrm{Cu}, 0.04 \% \mathrm{Mo}, 0.031 \mathrm{~g} t \mathrm{Au}$, and $0.63 \mathrm{~g} / \mathrm{Ag}$. The deposit is hosted in granodiorite and quartz diorite of the Middle Jurassic Brenda Stock. Mineralization is interpreted as occurring during at least five stages of vein emplacement, each with unique attitudes and overall mineralogy developed in fractures. Grade is a function of fracture density and mineralogy of the veins. Potassic alieration (K-feldspar and biotite) accompanies sulfide mineralization. K-Ar homblende ages are $176 \mathrm{Ma}$ for the Brenda Stock and K-Ar biotite ages of 146 $\mathrm{Ma}$ is interpreted as the age of deposit.

\section{Craigmont Cu-Fe Skarn Deposit}

The Craigmont Cu-Fe skarn deposit occurs $30 \mathrm{~km}$ south of Highland Valley and consists of magnetite, hematite and chalcopyrite which occur as massive pods, lenses and disseminations within a calc-silicate skam assemblage which replaces carbonate of the Nikola Assemblage (Dawson and others, 1991; MINFILE, 2002). Combined production and reserves are estimated at 34.9 million tonnes grading $1.21 \% \mathrm{Cu}$ and $19.6 \% \mathrm{Fe}$. The host rocks are calcareous volcaniclastic and reefoid carbonate rocks of the western facies belt of the Nicola Assemblage, at their embayed contacts with the border phase of the Guichon Creek Batholith. Younger intrusive phases in the core of the batholith host the large Highland Valley porphyry Cu-Mo district (Dawson and others, 1991). Production between 1962 and 1982 was 33.4 million tonnes grading $1.21 \% \mathrm{Cu}, 0.002 \mathrm{~g} / \mathrm{t}$ Au and $0.007 \mathrm{~g} / \mathrm{Ag}$. Reserves are estimated at 1.5 million tonnes grading $1.13 \% \mathrm{Cu}$. A 500,000 tonne stockpile of magnetite ore exists, from which approximately 45,000 tonnes per year are shipped to coalfields for use in heavy media separation. The deposit age is interpreted as Early Jurasic. 


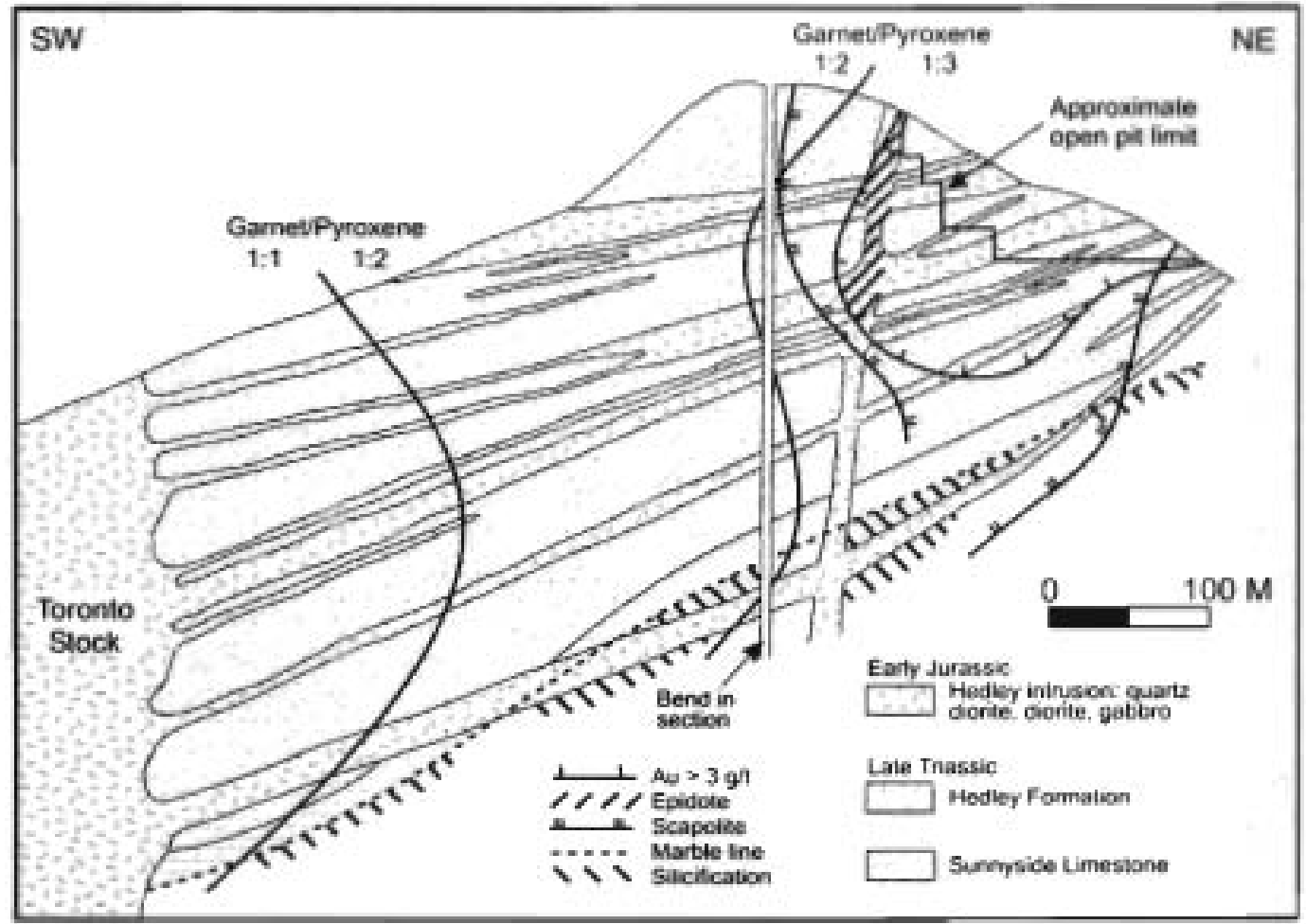

Figure 40, Valley Copper porphyry Cu-Mo deposit, Guichon metaliogenic belt, Canadian Cordiliera. Schematic cross section. Adapted from McMilian and others (1995).

\section{Hediley Au Skam Deposit}

The Hediey Au-Ag skarn deposit consists of pyrrbotite, arsenopyrite, pyrite, chalcopyrite and sphalerite with trace galena, native Bi, native Au, electrum, tetrahedrite, native Cu, molybdenite and cobaltite (Ray and Webster, 1991; Ettlinger and others, 1992; Ray and others, 1993; Ray and Dawson, 1994) (fig. 41 for Nickel Plate part of deposit). The deposit is hosted in cale-silicate skam associated with contact metumorphism of limestone of the eastem sedimentary facies of the Late Triassic Nicola Assemblage adjacent to the Early Jurassic Hedley diorite and gabbro intrusives. Production 1904 to 1991 was 8.43 million tonnes of ore from which was extracted 62.68 tonnes Au and 14.74 tonnes Ag from the Nickel Plate, Mascot, French, Goodhope and Canty parts of the deposit. Remaining reserves are 5.07 million tonnes grading $3.0 \mathrm{~g} / \mathrm{Au}, 2.5 \mathrm{~g} / \mathrm{Ag}$, and $0.1 \% \mathrm{Cu}$. The ore bodies are semiconformable, tabular sulfide zones developed near the skam-marble boundary, where alternating layers of garnetrich and diopside-hedenbergite-rich prograde skarn follow bedding. $\mathrm{Au}$ together with anomalous amounts of $\mathrm{Ag}$. $\mathrm{Bi}, \mathrm{Te}$, and $\mathrm{Co}$ are concentrated with anenopyrite, pyrhotite, and pyrite in the latest stage, a retrograde quartz-calcite-epidote-sulfide assemblage (Ettlinger and others, 1992). The deposit age is interpreted as Early Jurassic.

The intrusions associaled with Au skams in the Canadian Cordillera constitute a distinctive suite of calc-alkaline to alkaline plutons of syoorogenic to late orogenic timing. At Hedley, intrusions are enriched in Fe, depleted in total alkalies and silica, and have low ferric/ferrous iron ratios, i.e. are reduced, relative to other types of skarn deposits (Ray and Webster, 1991 : Dawson, 1996b).

\section{Origin of and Tectonic Controls for Guichon Metallogenic Beht}

The Guichon metallogenic belt of porphyry Cu-Mo deposits is bosted in and adjacent to Late Triassic to Early Jurassic plutonic rocks of the Quesnellia island are (Monger and Nokleberg, 1996; Nokleberg and others, 2000). The eale-alkaline Guichon Creek batholith, which hosts the porphyry Cu-Mo deposits in the Highland Valley district, was emplaced at about 210 Ma, approximately contemporaneous with the intrusion of the composite alkaline Iron Mask and Copper Mountain plutons, 40 and 120 kilometers away to the bortheast and southeast, respectively (McMillan and others, 1995). About $100 \mathrm{~km}$ to the south, the Alaskan-type, ultramafic-mafic Tulameen Complex was emplaced. The Quesneilia island-are is interpreted as forming on the deformed continental margin strata of Yukon-Tanana ierrane, as a rifted fragment of the North American Craton Margin (Gehrels and others, 1990; Monger and Nokleberg. 1996; Nokleberg and others, 1994c, 1997c, 2000). 


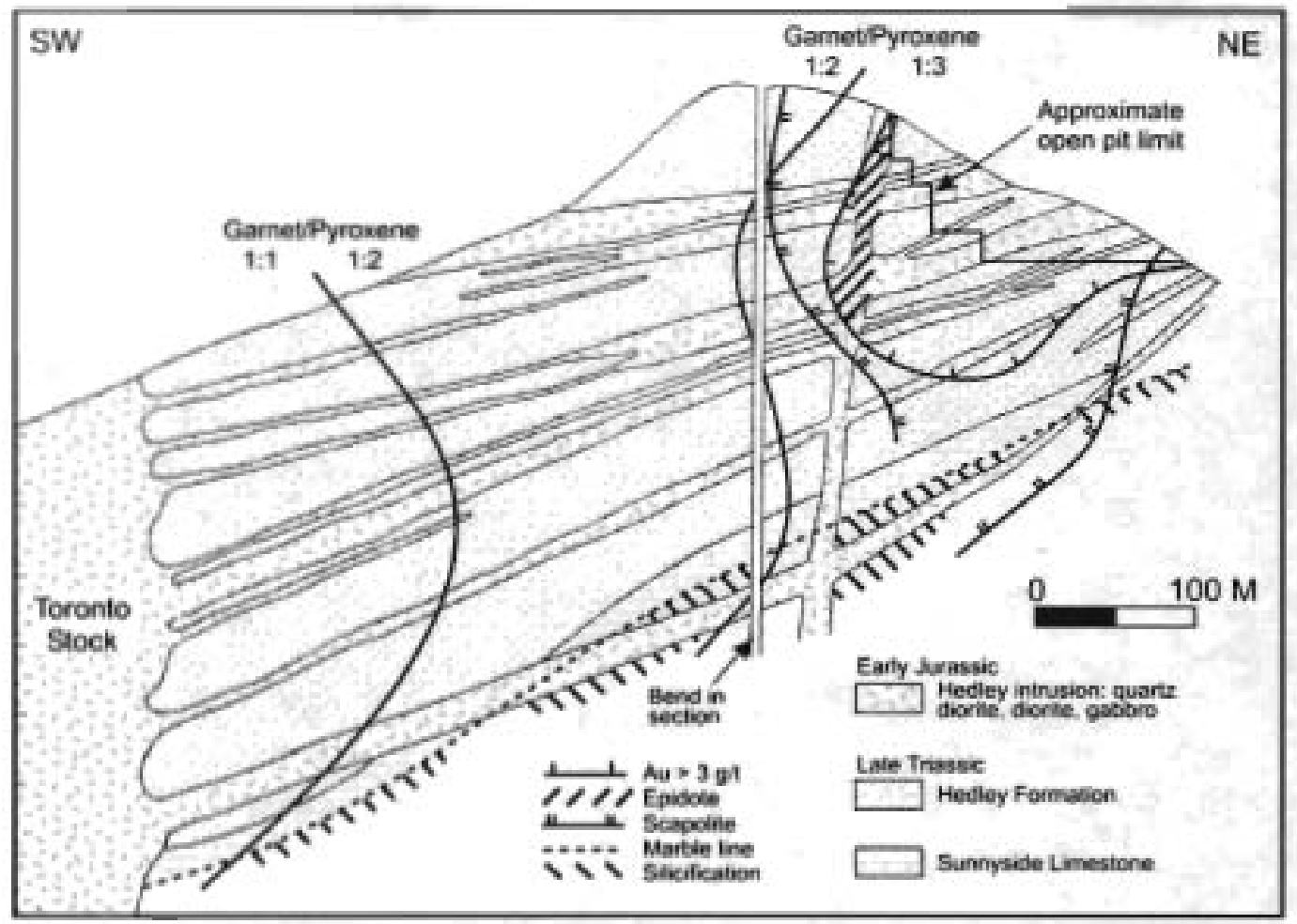

Figure 41. Nickel Plate Au skam deposit, Hedley Camp, Guichon metallogenic belt, Canadian Cordillera. Schematic cross section. Adapted from Dawson (1996b)

Texas Creek Metaliogenic Belt of Porphyry Cu-Mo-Au, Au-Ag Polymetallic Vein and Au Quartz Vein Deposits (Belt TC) Northern British Columbia

The Texas Creek composite metallogenic belt of porphyry Cu-Mo-Au, Au-Ag polymetallic vein, and Au quartz vein deposits (fig. 32; tables 3, 4) oocurs in northem British Columbia and is hosted in Late Triassic to Middle Jurassic granitoid plutons which intrude coeval marine and subaerial mafic to felsic volcanic, volcaniclastic, and sedimentary rocks of the Stuhini and Hazelton Groups in the Stikinia island-are terrane. The major porphyry Cu-Mo-Au deposits are at Schaft Creek (Liard Copper), Ker (Main Zone), and Sulphurets (Gold Zone) (table 4) (Nokleberg and others 1997a, b, 1998). The major polymetallic vein deposits are at Brucejack Lake (West Zone, Shore Zone), Snip (Shan), Red Mountain, Silbak-Premier (Premier Gold), and Snowfields. Other significant deposits are the Polaris-Taku (Whitewater) and Muddy Lake (Golden Bear, Totem) Au quartz vein deposits, and the E \& L gabbroic Ni-Cu deposit atSnippaker Creck.

\section{Texas Creek District Porphyry Cu-Mo-Au Deposits}

The Texas Creek district contains significant porphyry Cu-Mo and polymetallic vein deposits. The large Schaft Creek (Liard Copper) porphyry Cu-Mo deposit is hosted mainly in Triassic andesile which is intruded by diorite and granodiorite of the Middle Jurassic Hickman batbolith. The deposit consists of a quartz-vein stockwork with potassic alteration in a low-grade core, an insermediate zone of bornite, chalcopyrite, and molybdenile associated with chlorite-sericite alteration which contains the bulk of the ore, and epidote in the periphery (EMR Canada, 1989; Spilsbury, 1995; MINFIL.E, 2002). Estimated reserves are 971.5 million tonnes grading $0.298 \% \mathrm{Cu}, 0.033 \% \mathrm{MoS}_{2}, 1.20 \mathrm{~g} / \mathrm{Ag}$, and $0.14 \mathrm{~g} / \mathrm{Au}$. The Hickman batholith has an isotopic age of 182 $\mathrm{Ma}$.

The Kerr and Sulphurets porphyry Cu-Au deposits (Ditwon and others, 1995; Fowler and Wells, 1995; Kirkham and Margolis, 1995) occur in intermediate volcanic rocks, volcaniclastic and sedimentary rocks of the Early Jurassic Unuk River formation of the Hazelton Assemblage. The Kerr deposit consists of an elongate shear zone, about $2 \mathrm{~km}$ long by $900 \mathrm{~m}$ wide. The deposit contains estimaled reserves of 134.9 million tonnes grading $0.76 \% \mathrm{Cu}$ and $0.34 \mathrm{~g} / \mathrm{Au}$ (Ditson and others, 1995). The Sulphurets deposit consists of a $1.5 \mathrm{~km}$ northeast-trending halo which surrounds the Kerr (Main Zone) deposit, and consists of a quartz-pyrite-sericite halo and associated stockwork of chalcopyrite and bomite surrounding the main copper deposit (Fowler and Wells, 1995). Estimated reserves are 18.2 million tonnes grading 0.82 glt Au and $0.35 \% \mathrm{Cu}$.

The Snip (Au), Red Mountain (Aw-Cu), Soowfields Au-Ag, and Brucejack Lake Au-Ag polymetallie vein deposits are hosted in clastic, volcaniclastic, and volcanic rocks of the Early Jurassic Haxelton Assemblage and adjacent plutons of the Texas Creek plutonic suite. The Snip deposit, the only mine in the group, consists of a shear-vein system with high Au values which 
crosscuts graywacke and siltstone adjacent to a contact with a porphyritic quartz monzonite stock. Estimated combined production and reserves are 1.9 million tonnes grading $29.5 \mathrm{~g} / \mathrm{Au}$ (Rhys and Godwin, 1992; Rhys and others, 1995). The Red Mountain deposit (Brown and Kahlert, 1995) consists of a semi-tabular stockwork of pyrite-pyrrhotite which contains high $\mathrm{Au}$ and $\mathrm{Ag}$ values (up to $20 \mathrm{~g} / \mathrm{Au}$ ), disseminated sphalerite-pynhotite mineralization, and iniense sericite alteration. The deposit occurs above a quartz-molybdenite stockwork at the top of a Early Jurassic monzodiorite and quartz monzodiorite stock and sill which intrude sedimentary and volcanic rocks of the Triassic Stuhini Group and the Early and Middle Jurassic Hazelton Group. Estimated resources at Red Mountain are 2.5 million tonnes of $12.8 \mathrm{~g} / \mathrm{Au}$ and $38.1 \mathrm{~g} / \mathrm{Ag}$ (Rhys and others, 1995).

The Silbak Premier Au-Ag-Pb-Zn epithermal vein deposit is hosted by volcanic and volcaniclastic rocks of the Hazelton Assemblage. The deposit consists of argentite and electrum which occur both in low-sulfide and base-metal sulfide ore. The veins are related to subvolcanic, quartz-K-feldspar porphyry dikes which form part of the Texas Creek plutonic suite. Between 1918 and 1987, about 56.1 tonnes of $\mathrm{Au}$ and 1,270 tonnes of $\mathrm{Ag}$ were produced. Estimated reserves are 6.1 million tonnes grading $2.33 \mathrm{~g} / \mathrm{t}$ Au and $90.5 \mathrm{~g} / \mathrm{Ag}$ (Alldrick and others, 1987).

\section{Polaris Au Quartz Vein Deposit}

The Polaris Au quartz vein deposit consists of native gold associated with arsenopyrite and stibnite in quartz-ankerite veins (Marriott, 1992; Mihalynuk and Marrioth, 1992). The deposit has produced approximately 231,000 oz Au from 760,000 tons of ore, with a recovered grade of $0.30 \mathrm{oz}$ Au/t. The deposit contains estimated resources of 2.196 million tonnes grading $14.74 \mathrm{~g} / \mathrm{t}$ Au. The deposit is underlain by late Paleozoic to Triassic Stuhini Group volcanic and sedimentary rocks. The volcanic rocks composed of andesite and basalt flows and pyroclastic rocks host gold in an assemblage of arsenopyrite, ankerite, sericite, pyrite, fucbsite, and stibnite. The structures bosting the deposit are splays of the Tulsequah River shear zone.

\section{Muddy Lake Au Quartz Vein Deposit}

The Muddy Lake (Golden Bear, Totem) Au quartz vein deposit consists of disseminations and fracture-fillings of extremely fine-grained pyrite which occur along faul contacts of tuffite and limestone (Melis and Clifford, 1987; Osatenko and Britton, 1987; Schroeter, 1987; Dawson and others, 1991; North American Metals Corp, news release, February 1995). The deposit contains estimated reserves of 720,000 tonnes grading $5.75 \mathrm{~g} / \mathrm{t} \mathrm{Au}$. The deposit has been interpreted as a mesothermal Auquartz veins hosted by silicified limestone, dolostone and tuff of the Permian Asitka Assemblage, and mineralization is probably related to an unexposed pluton of the Texas Creek suite. The deposit occurs in a north-trending, 20-km-long fault zone. Four deposits occur on the property at Bear, Fleece, Totem, and Kodiak. Recent studies interpret the deposit as a Carlin-type deposit (Poulsen, 1996; Lefebure and others, 1999), which contains both oxidized and primary ore.

\section{Origin of and Tectonic Controls for Texas Creek Metallogenic Beit}

The Texas Creek metallogenic belt occurs in a suite of dominantly calc-alkaline granitoid, but in part, gabbroic and alkalic, plutons which intruded mainly in the Early Jurassic as part of the Stikinia are and the flanking Cache Creek subductionzone terrane, prior to accretion to North America in the Middle Jurassic (Dawson and others, 1991; Kirkham and Margolis, 1995; Mihalynuk and others, 1994; Monger and Nokleberg, 1996; Nokleberg and others, 2000). The Stikinia island-are lerrane is interpreted as forming on the deformed continental margin strata of Yukon-Tanana terrane which is interpreted as a rifled fragment of the North Americar Craton Margin (Gehrels and others, 1990; Monger and Nokleberg, 1996; Nokleberg and others, $1994 \mathrm{e}, 1997 \mathrm{e} ; 2000)$. Several metallogenic bels formed during granitic magnatism associated with formation of the Stikinia and Quesnellia island ares. The metallogenic belts which formed in conjunction with the Stikinia island arc are the Copper Mountain (North), Galore Creek, Guichon, KJotassin, Texas Creek, and Toodoggone belts. The Copper Mountain (South) and Guichon metallogenic belts formed in conjunction with the Quesnellia island arc.

\section{Early Jurassic Metallogenic Belts (208 to $193 \mathrm{Ma}$; Figure 42)}

\section{Overview}

The major Early Jurassic metallogenic belts in Alaska and the Canadian Cordillera are summarized in table 3 and portrayed on figure 40. No majoe Early Jurassic metallogenic belts existed in the Russian Far East. The major belts in Alaska and the Canadian Cordillera are as follows. (1) Three belts are hosted in the Wrangellia island-arc superterrane These belts are the Talkeetna Mountains-Alaska Range belt (TM), which contains kuroko massive sulfide deposits, the Alaska Peninsula (AP) belt, which contains granitic magmatism deposits, and the lsland Porphyry (IP) belt, which contains granitic-magmatism-related deposits, These belts are interpreted as forming in the Talkeetna-Bonzana arc preserved in the Wrangellia superterrane. (2) In the Canadian Condillera, continuing on from the Late Triassic, commencing in the Early Jurassic were the Coast Mountains (CM), Copper Mountain (North; CMN), Copper Mountain (South; CMS), Galore (GL), Guichon (GU), Klotassin (KL), and Texas Creek 
(TC), and Toodoggone (TO) belts which contain granitic magmatism-related deposits and are interpreted as forming in the axial parts of the Stikinia-Quesnellia island arc. In the followiung descriptions of metallogenic belts, a few of the noteable signficant lode depesits (table 4) are described for each belt.

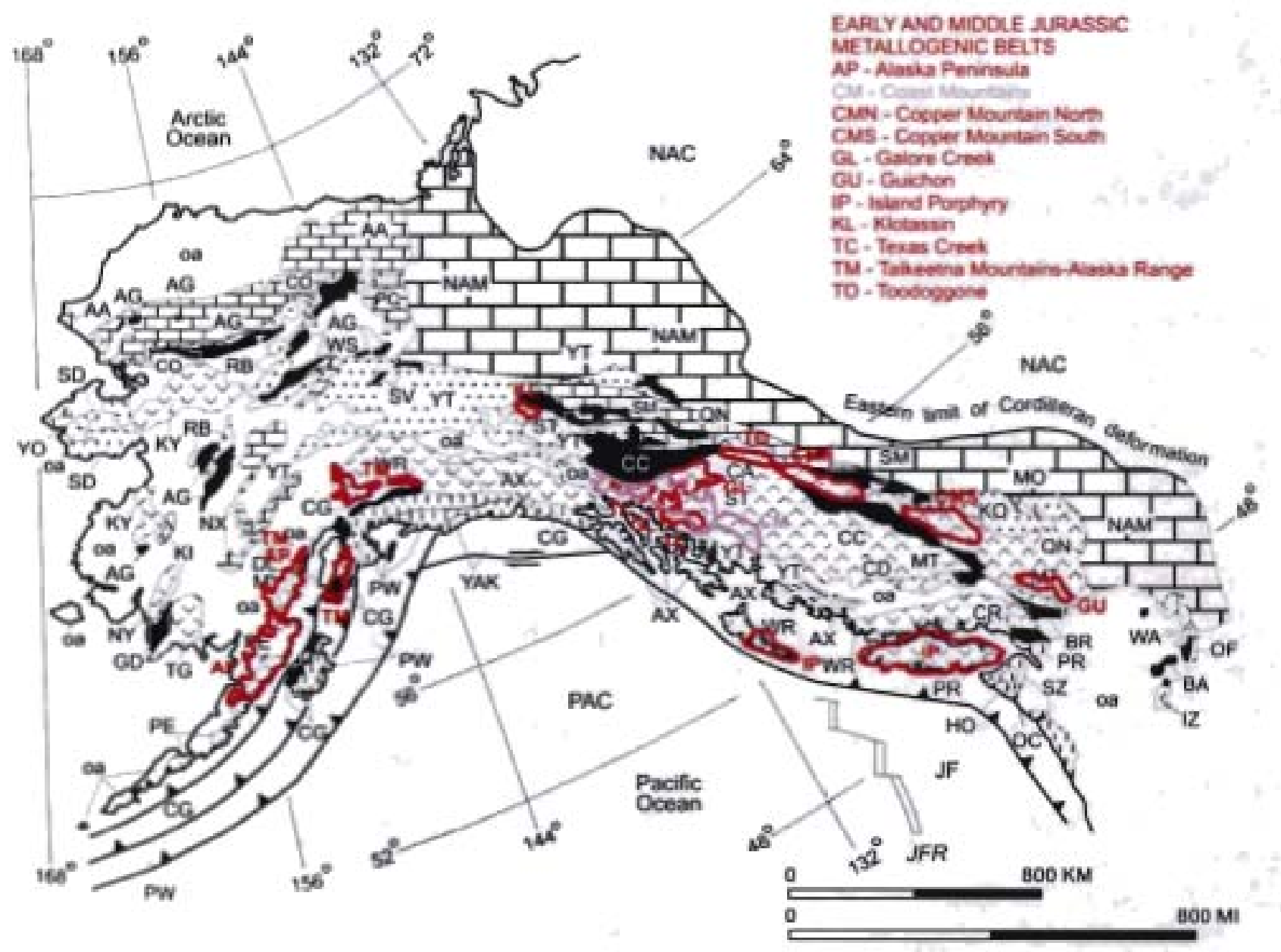

Figure 42 Generalized map of major Early and Middle Jurassic metallogenic belts and terranes for Alaska, Canadian Cordillera, and adjacent offshore areas. Refer to toxt for description of metallogenic belts. Adapted from Nokleberg and others (1997b, 1998). Refer to foure 3 for explanation.

\section{Metallogenic-Tectonic Model for \\ Early Jurassic (208 to 193 Ma; Figure 43)}

During the Early Jurassic (Hettangian to Pleinsbachian - 208 to $193 \mathrm{Ma}$ ), the major metallogenic-tectonic events were (fig. 43; table 3): (1) continuation of continental-margin arcs and associated subduction near the North Asian Craton in the Rusaian Far East; (2) beginning of assembly of previously rifted cratonal, passive continental-margin, and island-are terranes between which eraton and the ancestral Pacific Ocean to form the Kolyma-Omolon superterrane; (3) continuation of the Talkectna, Bonanza, and Stikinia-Quesnellia ares and associated metallogenic belts, and formation of companion subduction zones; (4) continued sinistral-

slip imbrication of the Stikinia-Quesnellia island are, contained metallogenic belts, and associated subduction zones during oblique-sinistral convergence between the ancestral Pacific Ocean plate and the North American Craton Margin; and (5) with the beginning of aceretion of the Stikinia-Quesnellia are at about $185 \mathrm{Ma}$, the start of mountain building in the North American Cordillera. Sedimentation continued along the passive continental margins of North Asian and North American Cratons. 


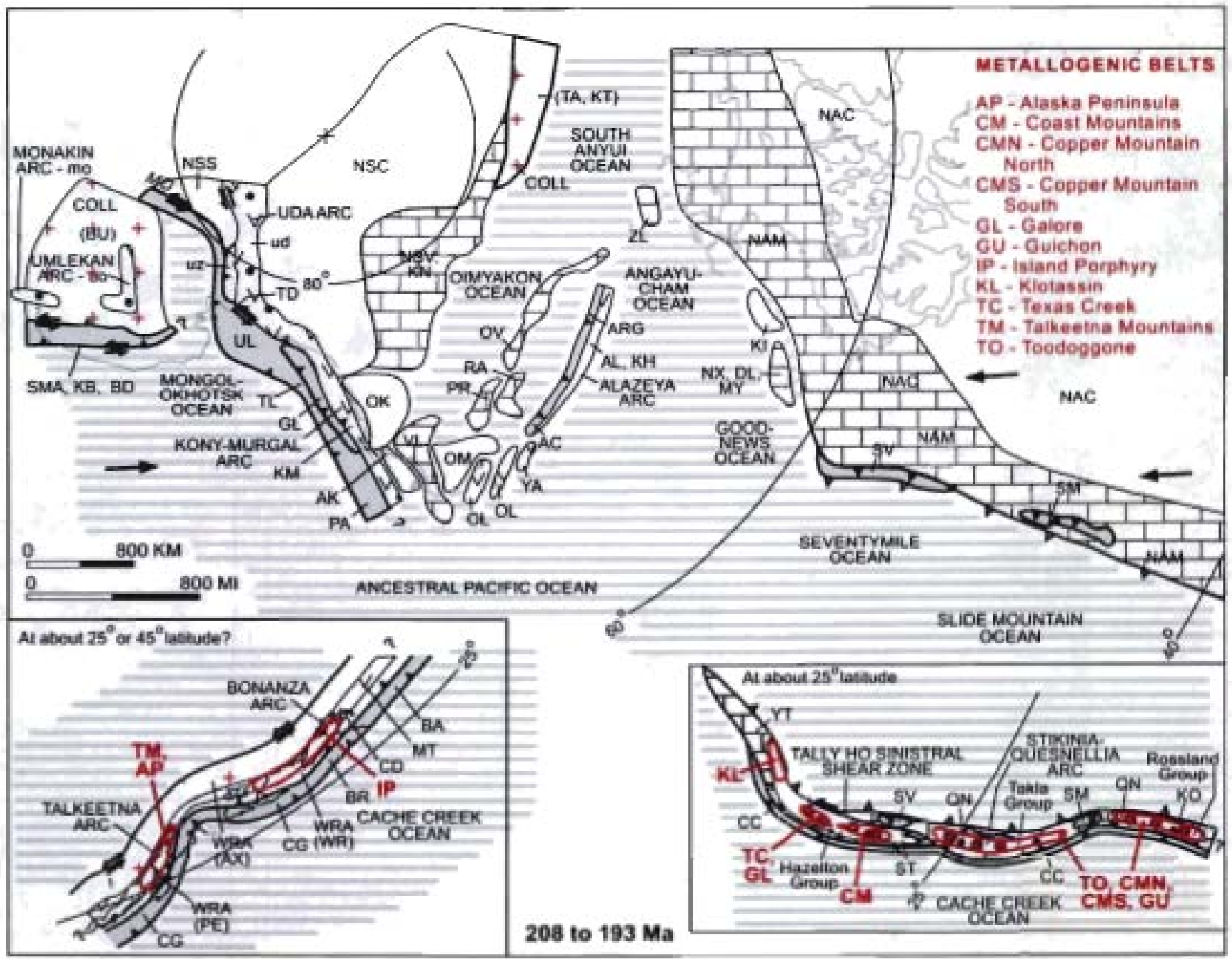

Figure 43. Early Jurassic (Hettangian through Pliensbachian - 208 to $193 \mathrm{Ma}$ ) stage of metaliogenic-lectonie model. Refer to text for explanation of metallogenic-tectonic events, to tables 3 and 4 for descriptions metallogenic belts and significant deposits, and to figure 18 for explanation of abbreviations, symbols. and pattems. Adapted from Nokleberg and others (1997b, 1998, 2000).

\section{Specific Events for Early Jurassic}

(1) The Monakin continental-margin arc, consisting of the Monakin volcanic-plutonic belt (mo) and the Umiekan continentalmargin arc, consisting of the Umiekan-Opodzhin volicanic-plutonic beit (uo) and associated units, commenced activity. Associated with this are was oblique (sinstral) subduction of part of the Ancestral Pacific Ocean plate to form the Samarka (SMA), Khabarovik (KB), and Badzhal (BD) terranes.

(2) The continental-margin are Uda are (consisting of the Uda volcanic-plutonic belt (ud) and Uda-Zeya sedimentary basin (uz) continued to form. Associated with the are was subduction and sinistral transpression of part of the Mongol-Okhotsk Ocean plate to form the Turkuringra-Dahagdinski (TD), Ulban (UL), and Galam (GL) terranes. Subduction and sinistral transpression occurred along the Mongol-Okhotsk suture (MO).

(3) The extensive Kony-Murgal island afe (Kony-Murgal terrane (KM)) continued to form as an offahore extension of the Uda arc. Associated with the are was subduction of part of the Ancestral Pacific Ocean plate to form the Talovskiy (TL) and Penzhina-Anadyr (PA) terranes. Inboard of the Kony-Muryal island are (KM) were the Okbotsk (OK), Avekova (AK), and Omolon (OM) cratonal terranes which were previously rifted from the North Asian Craton (NSC), and the Viliga (VL) passive continental-margin terranes which was previously rifted from the North Asian Craton Margin (NSV). Behind the are were fragments of prior Devonian to Pennsylvanian island-are terranes, including the Beryozovka tarbidite-basin (BE), and Oloy (OL), and Yarakvaam (YA) island-are terranes. 
(4) The Angayucham Ocean (Kobuck Sea of Plafker and Berg, 1994), along with the South Anyui Ocean, continued to receive sparse continental-derived detritus. Previously rifled terranes, including the Kilbuck-ldono cratonal (KI) and the combined Nixon Fork-Dillinger-Mystic passive continental-margin (NX, DL. MY) terranes were near the North American Craton Margin.

(5) The dexiral-slip imbrication of the Stikinia-Quesnellia are and associated subduction-zone terranes continued along the Tally Ho shear zone (Hansen and others, 1990; Hart. 1995) (inset, fig. 43). Part of the Tally Ho shear zone may occur be defined by a string of fault-bounded(?) ultramafic rocks whicb occur within the Yukon-Tanana terrane in northern Southeastern Alaska (Himmelberg and others, 1985). Alternatively, the present-day configuration of the Stikinia-Quesnellia island-arc and associated subduction zone terranes may have formed by oroclinal warping in response to a combination of oblique convergence and are migration toward the companion subduction zone of the Cache Creek terrane (Mihalynuk and others, 1994) (not depicted in fig. 43). Oroclinal warping is interpreted as forming in response to: (1) oblique-sinstral convergence between the ancestral Pacific Ocean plate and the Stikinia-Quesnellia are; and (2) are migration toward the companion subduction zone (trench rollback), similar to tectonics of the present-day Banda are in Southeast Asia (McCaffrey and Abers, 1991; Mihalynuk and others, 1994). Migration of the Stikinia-Quesnellia are and associated terranes toward North America was accomplished by subduction and (or) obduction of the Seventymile Ocean plate along the continental margin.

(6) The Stikinia part of the are consisted of the extensive suite of the subduction-related volcanic and plutonic are rocks of the Hazelton Group which also formed in response to subduction of the Cache Creek Ocean plate (CC). In central part of the Stikinia-Quesnellia island arc, coeval subduction-related granitic plutonic rocks also intruded the previously-accreted passive continental-margin Yukon-Tanana terrane (YT), which may have been the stratigraphic basement for part of the Stikinia island are (Mihalynuk and others, 1994). The plutonic rocks also intrude the structurally overlying Slide Mountain (SM) and Seventymile (SV) terrunes. The subduction-related volcanic and plutonic are rocks of the Quesnellia part of the arc, consisting of the Takla and Rossland Groups, and the coeval igneous belts formed in response to continued subduction of part of the Cache Creek Ocean plate (CC; Mihalynuk and others, 1994).

(7) In the axial parts of the Stikinia-Quesnellia island are, continuing on from the Late Triassic, were the Coast (CM). Copper Mountain (North; CMN), Copper Mountain (South; CMS), Galore (GL), Guichon (GU), Klotassin (KL), and Texas Creek (TC), and Toodoggone (TO) belts which contain granitic magmatism-felated deposits

(8) Also occurring was obduction of parts of the Seventymile and Slide Mountain Ocean plates onto the North American Craton Margin (NAM; Mihalynuk and others, 1994). Part of the obduction oceurred by the Late Triassic and (or) Early Jurassic when granitic plutons of the Stikinia-Quesnellia island are intruded across an intervening fault. During the final stage of obduction of the Slide Mountain terrane (SM) over the Kootenay metamorphosed continental-margin terrane (KO), these terranes started to obduct onto the North American Craton Margin (NAM). Migration of the Stikinia-Quesnellia are and associated terranes toward the North American Craton Margin was accomplished by subduction of the Seventymile Oeean plate along the continental-margin and by obduction.

(9) Outboard and perhaps at a lower paleolatitude (either $25^{\circ}$ or $45^{\circ}$ ), the Talkeetna and Bonanza ares continued activity in the Wrangellia superterrane (WRA). This extensive are formed along most of the length of the Wrangellia superierrane with coeval equivalents in the Cadwallader (CD) island are and Methow (MT) turbidite-basin terranes. Forming in the ares were the Talkeetna Mountains-Alaska Range metallogenic belt, which contains kuroko massive sulfide deposits, the Alaska Peninsula metallogenic belt (AP), which contains Cu- and Fe-skam deposits, and the Island Porphyry metullogenic belt (IP), which contains granitic-magmatism-related deposits. Associated with the Talkeetna and Bonanza arcs was subduction of part of the Cache Creek Ocean plate to form the Chugach (CG), Bridge River (BR), and possibly Baker (BA) terranes.

\section{Metallogenic Belts Formed in \\ Middle Mesozoic Talkeetna-Bonzana \\ Island Are in Wrangellia Superterrane}

\section{Alaska Peninsula Metallogenic Beit of Granitic Magmatism Deposits (Belt AP) Alaska Peninsula}

The Alaska Peninsula metallogenic belt of granitic magmatism deposits (fig, 42; tables 3, 4), mainly $\mathrm{Cu}-\mathrm{Au}, \mathrm{Cu}-\mathrm{Zn}$, and Fe skarn deposits, occurs on the northeastem Alaska Peninsula. The metallogenic belt is hosted in the central and northwestem part of the Peninsular sequence of the Talkeetna-Bonarza island in the Wrangellia superterrane where intruded by Jurassic granitoid plutons (Nokleberg and others, 1994c, 1997c). The significant deposits in the belt are the Crevice Creek, Glacier Fork, Kasna Creek Cu-Fe skarn deposits, and the Magnetite lsland Fe skam deposit (table 4) (Nokleberg and others 1997a, b, 1998).

\section{Crevice Creek Cu-Au Skarn Deposit}

The Crevice Creek Cu-Au skam deposit (Martin and Katz, 1912; Richter and Herreid, 1965) consists of at least ten epidote-gamet skam bodies which occur in limestone over a $2 \mathrm{~km}^{2}$ area adjacent to the Jurassic(7) granodiorite stock of Pilot Knob. The skam bodies vary from 3-800-m long and from a few centimeters to $60 \mathrm{~m}$ wide. Local magnetite-rich skam occurs in isolated pods in nearby metavolcanic rocks, and local disseminated magnetite zones occur in epidole-garnet skarns. The gamet 
skam bodies occur in limestone, chert, and argillite of the Late Triassic Kamishak Formation and in overlying metavolcanic rocks of the Late Triassic(?) to Early Jurassic Talkeetna Formation (Nokleberg and others, 1994d). The largest skarn body at Sargent Creek contains epidote, gamet, actinolite, quartz, pyrite, and chalcopyrite. Lenses up $101 \mathrm{~m}$ wide and $10 \mathrm{~m}$ long average $7 \% \mathrm{Cu}$. Numerous airborne magnetic anomalies occur in the area surrounding the granodiorite stock. The Crevice Creek deposit produced 11 tonnes of ore from high-grade zones, with an average grade of $4.5 \mathrm{~g} / \mathrm{Au}, 514 \mathrm{~g} / \mathrm{Ag}$, and $17.5 \% \mathrm{Cu}$.

\section{Origin of and Tectonic Controls for}

Alaska Peninsula Metaliogenic Belt

The $\mathrm{Cu}-\mathrm{Au}$ and $\mathrm{Cu}-\mathrm{Zn}$ skam deposits of the Alaska Peninsula metallogenic belt occur in areas where Jurassic(?) quartz diorite and tonalite intrude calcareous sedimentary rock, and generally consist of epidote-garnet skarn in limestone or marble, containing disseminations and layers of chalcopyrite, sphalerite, and pyrrhotite. The Fe skarn deposits occur in dolomite or marble and generally consist of magnetite skarn containing lesser garnet, amphibole, and rare chalcopyrite. The Fe skarns occur in areas where Jurassic(?) quartz diorite and tonalite intrude calcareous sedimentary rocks. These skarn deposits occur in marine sedimentary rocks of the Late Triassic Kamishak Formation, in Early Triassic marble, and in volcanic and volcaniclastic rocks of the Late Triassic(?) to Early Jurassic Talkectna Formation.

The Alaska Peninsula metallogenic belt occurs in, or adjacent to, the Late Triassic(?) and Early to Middle Jurassic, Talkeetna part of the Talkeetna-Bonanza island are which extends for several hundred $\mathrm{km}$ along the strike length of the Alaska Peninsular part of the Wrangellia superterrane (Burns, 1985; Plafker and others, 1989; Nokleberg and others, 1994c, 1997c; DeBari and Coleman, 1989). Abundant field, chemical, and isotopic data indicate that the Talkeetna arc is mainly gabbro, diorite, and tonalite, and rarely granodiorite, has calc-alkaline composition and lower initial $\mathrm{S} r$ ratios, and is interpreted as having formed in an island arc above a subduction zone (Reed and others, 1983; Burns, 1985; Plafker and others, 1985). The Jurassic(?) plutonic rocks, which host the Alaska Peninsula metallogenic belt, form the older part of the Alaska-Aleutiun Range batholith, which along with the Late Triassic(?) and Early Jurassic Talkeetna Formation and Border Ranges ultramafic-mafic complex, collectively define the Talkeetna arc which is a key comlonent of the Peninsular sequence (Nokleberg and others, 1994a).

\section{Talkeetna Mountains-Alaska Range \\ Metallogenic Belt of Kuroko Massive \\ Sulfide Deposits (Beit TM) Northern Part of Southern Alaska}

The Talkeetna Mountains-A laska Range metallogenic belt of kuroko massive sulfide deposits (fig. 42; tables 3,4) occurs in the northem part of southem Alaska. The metallogenic belt is hosted in submarine fuff, andesite, and dacite of the Late Triassic(?) and Early Jurassic Talkeetna Formation, which is a major unit in the Peninsular sequence and Talkeetna-Bonanza islanc arc of the Wrangellia superterrane (Nokleberg and others, 1994c, 1997c). The one significant deposit is the Johnson River prospect (table 4) (Nokleberg and others 1997a, b, 1998).

\section{Johnson River Massive Sulfide(7) Deposit}

The Johnston River kuroko massive sulfide(?) deposit (R. L. Detterman, oral commun,, 1984; Steefel, 1987; Madelyn Moltholyn, written commun., 1988; J. Proffett, written commun., 1991) consists of quark-sulfide veins and massive sulfide lenses containing chalcopyrite, pyrite, sphalerite, galena, and gold which occur in discordant pipe-like bodies of silicified volcanic rock. Veins of chlorite, sericite, and anhydrite, and a cap of barite occur proximal to the four ore horizons. The deposit occurs in pyroclastic and volcaniclastic rocks of Portage Creek Agglomerate in the Talkeetna Formation; similar mineralized horizons have been found along strike to the northeast. Local stockworks, which cut the metavolcanic rock, suggest either mobilization or additional deposition. The deposit is interpreted as forming from deposition of sulfides directly over a capped submarine vent system during Jurassic volcanism. The deposit contains an estimated 997,540 tonnes grading $10.35 \mathrm{~g} / \mathrm{Au}, 7.84 \mathrm{~g} / \mathrm{t} \mathrm{Ag}, 8.3 \% \mathrm{Zn}$, $1.1 \% \mathrm{~Pb}$, and $0.76 \% \mathrm{Cu}$ (Bundtzen and others, 1994). In the same region, in the Oshetna River drainage of the Nelchina district, northeast of Anchorage, tuff in the Talkeetna Formation contains disseminated chalcopyrite and barite. Also in this region, Auenriched massive sulfide deposits in the Eskay Creek district contain many similar morphological features to those described at Johnson River.

\section{Origin of and Tectonic Controls for}

\section{Talkeetna Mountains-Alaska Range Metallogenic Beit}

The Late Triassic(?) and Early Jurassic Talkeetna Formation (fig. 42) which hosts the Talkeetna Mountains-Alaska Range metallogenic belt consists mainly of bedded andesitic volcaniclastic sandstone and tuff, ignimbrite, breccia, and agglomerate; andesite and lesser rhyolite and basalt flows; and shale (Plafker and others, 1989; Nokleberg and others, 1994a). The Talkeetna Formation is linked to Middle Jurassic plutonic rocks which form the older part of the Alaska-Aleutian Range batholith, which along with the Border Ranges ultramafic-mafic complex, define the Talkeetna are (Nokleberg and others, 1994a). The Peninsular sequence forms a major part of the Talkeetna-Bonanza island arc, and is one of three major sequences in the Wrangellia superterrane. The Talkeetna are is tectonically linked to a discontinuous series of Early Triassic to Jurassic(?) 
blueschist units and the McHugh Complex which form a partly coeval subduction zone complex which oceurs along the northern margin of the Chugach terrane (Nokleberg and others, 2000).

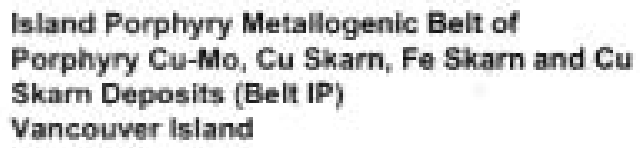

The Island Porphyry metallogenic belt of porphyry Cu-Mo; and Fe and Cu-Fe-Au skarn deposits (fig, 42; tables 3, 4) occurs on Vancouver Island and Queen Charlotte Islands in southern British Columbia and is hosted in the Island Plutonic Suite rocks that are part the Gambier overlap assemblage of the Wrangellia superterrane (Woodsworth and others, 1991; Anderson and Reichenbach, 1991). On Vancouver Island, the plutons are mainly Early to Middle Jurassic, whereas on Queen Charlotte Island, the plutons are mainly Middle to Late Jurassic. The significant deposits are the Island Copper (Rupert Inlet), Hushamu, Red Dog. porphyry Cu-Mo and porphyry Cu deposits, the Burnaby Iron (Jib), Jedway (Magnet, Jessie), Kennedy Lake (Brynnor), Tasu Sound (Wesfrob, Tasu, Garnet), Texada Iron, and Zeballos Iron (Ford) Fe skarn deposits, the Benson area (Empire, Coast Copper) Cu-Fe skam deposits, and the Texada (Vananda, Marble Bay) Cu-Au skam deposit (table 4) (Nokleberg and others 1997a, b, 1998).

\section{Island Copper Porphyry Cu-Mo-Au Deposit}

The 1stand Copper (Rupert Inlet) porphyry Cu-Mo-Au deposit (fig. 44) consists of pyrite, chalcopyrite and molybdenite which occur as fracture fillings and disseminations (EMR Canada, 1989; Perello and others, 1995; MINFILE, 2002). The main part of the deposit, which occurs in a carapace which surrounds a quartz-feldspar porphyry dike, is tabular shaped, ranges from 60 to 180 meters wide, 1700 meters long and 300 meters deep, and strikes $290^{\circ}$ and dips $60^{\circ} \mathrm{N}$, parallel to the dike. Between 1971 and 1994, the mine at the deposit produced 345 million tonnes with an average grade of $0.41 \% \mathrm{Cu}, 0.017 \% \mathrm{Mo}, 0.91$ g/t Au, and $1.4 \mathrm{~g} / \mathrm{Ag}$ (MINFILE, 2002). The deposit contains additional estimated reserves of 257 million tonnes grading $0.52 \% \mathrm{Cu}$ and 0.22 $g / t$ Alt. The deposit is hosted in andesite and basalt tuff in the Middle Jurassic Bonanza Group which are intruded by a quartz feldspar porphyry dike.

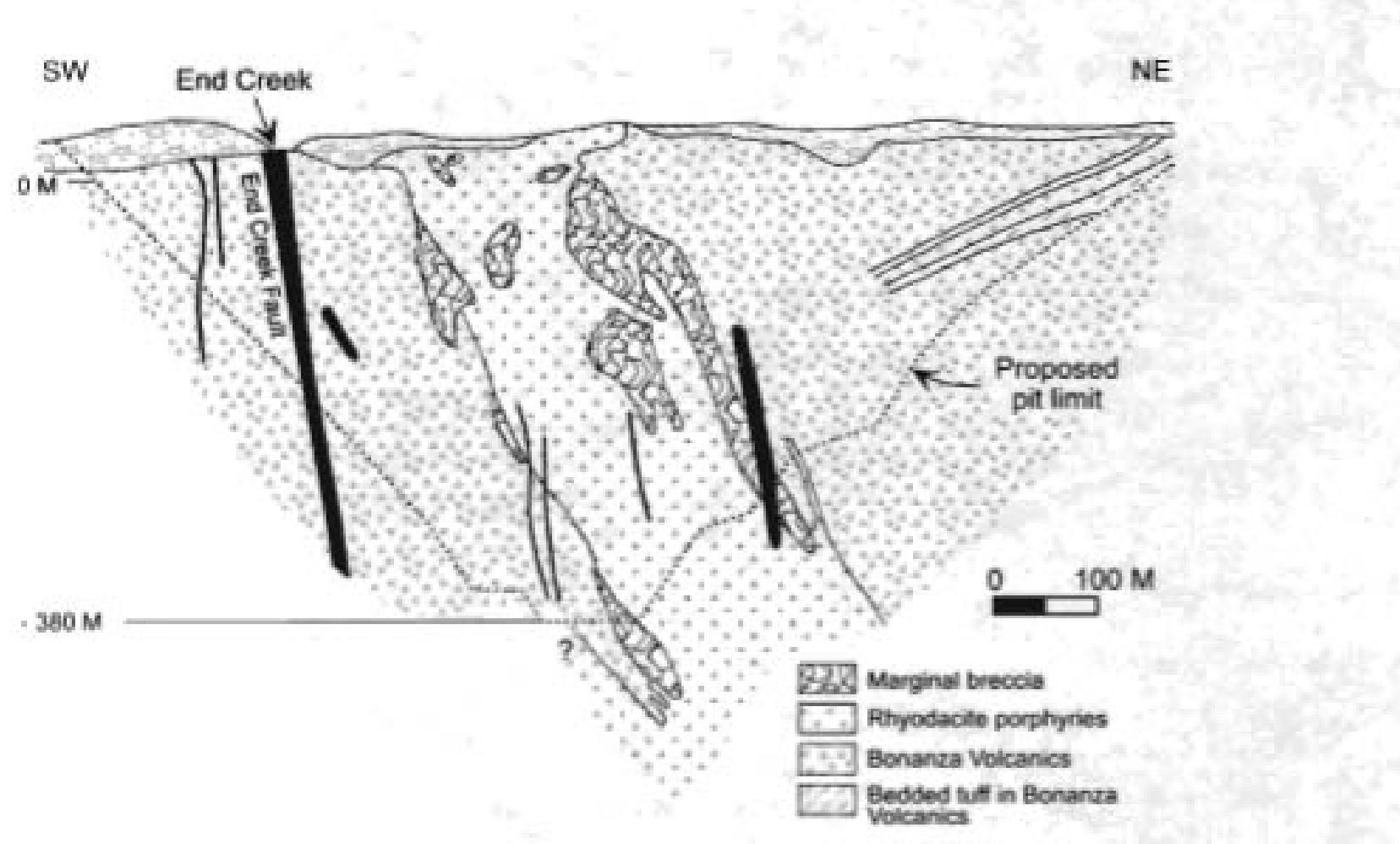

Fipure 44 island Copper porphyry Cu-Mo deposit, Island Copper metallogenic belt, Canadian Cordiliera. Schematic cross section. Adapled from Perello and others (1995).

Al Island Copper, early, intramineral and late stages of quartz-feldspar porphyry dike intrusions, which exhibit a U-Pb zircon isotopic age of 168.5 Ma (Ross and others, 1996), are mantled by breccias and concentrically enveloped by early-stage 
biotite-magnetite-chalcopyrite-molybdenite, main-stage quartz-chalcopyrite-molybdenite and magnetite-actinolite-plagioclase veining, and a late-stage, peripheral assemblage of chlorite-sericite-clay-epidote-chalcopyrite-pyrite (Leitch and others, 1995). The mineralized dikes are interpreted as coeval and cogenetic with the adjacent Rupert stock to the east (Ross and others, 1996). Late stage porphyry dikes and associated breccia contain an advanced argillic alteration assemblage of kaolinite, pyrophyllite, sericite and dumortierite, similar to advanced alteration assemblages of silica, clay, pyrophyllite, diaspore, zunyite, and alunite in volcanic rocks of the Bonanza Group at Mount Mclntosh and Pemberton Hills. These units are interpreted by Panteleyev and Koyanagi (1994) as high levels of alteration related to a stock hosting porphyry Cu-Mo deposits as at Hushamu (Dasler and others, 1995).

\section{Fo and Cu-Fe-Au Skarns in Island Porphyry Metallogenic Belt}

Significant skam Fe and skarn Cu deposits are hosted mainly by limestone of the Late Triassic Quatsino Formation on Vancouver and Texada Islands, the equivalent Kunga Formation on the Queen Charlotte Islands, and to a lesser degree, by volcanic rocks of the underlying Karmutsen Formation. Skarn deposits rich in iron and some deposits containing significant copper and precious metals, commonly occur along contacts of the above strata with granitoid plutons of the Jurassic island Suite. Magnetite, chalcopyrite, bornite, pyrite, pyrrhotite and molybdenite are associated with the prograde skam assemblage of grandite gamet, diopside, wollastonite and epidote. Significant concentrations of base and precious metals may be associated with the retrograde assemblage of actinolite, tremolite, epidote, quartz, chlorite and calcite (Dawson and Kirkham, 1996). The deposit size ranges up to 30 million tonnes grading $40-50 \% \mathrm{Fe}$. Important past iron producers were Tasu, Jedway, Burnaby Iron, Brynnor, and Texada Island. Significant copper skarns are Coast Copper and Marble Bay.

\section{Texada Iron Fe Skam Deposit}

Texada Iron Fe skarn deposit consists of massive magnetite skarn mineralization which occurs as replacement bodies at the Prescott (fig. 45), Yellow Kid, and Paxion mines (Webster and Ray, 1990; Ray and Webster, 1997; MINFILE, 2002). The deposits produced an estimated 17.6 million tonnes grading $61 \% \mathrm{Fe}$. The deposits are hosted in limestone of the Late Triassic Quatsino Formation, at or near contacts with quartz monzonite of the Middle Jurassic Gillies Stock which bas an U-Pb zircon isotopic age of $178 \mathrm{Ma}$. The deposits consist of massive magnetite and associated gamet, pyroxene, epidote, amphibole, minor calcite, and sporadic pyrite and pyrrhotite. Rare arsenopyrite and sphalerile also occur. Sampling of Fe-skam magnetite from the Texada Iron Mines by Webster and Ray (1990) indicate grades of 3.14\% Cu, $46.6 \mathrm{~g} / \mathrm{t} \mathrm{Ag}$, and $2.8 \mathrm{~g} / \mathrm{t} \mathrm{Au}$.

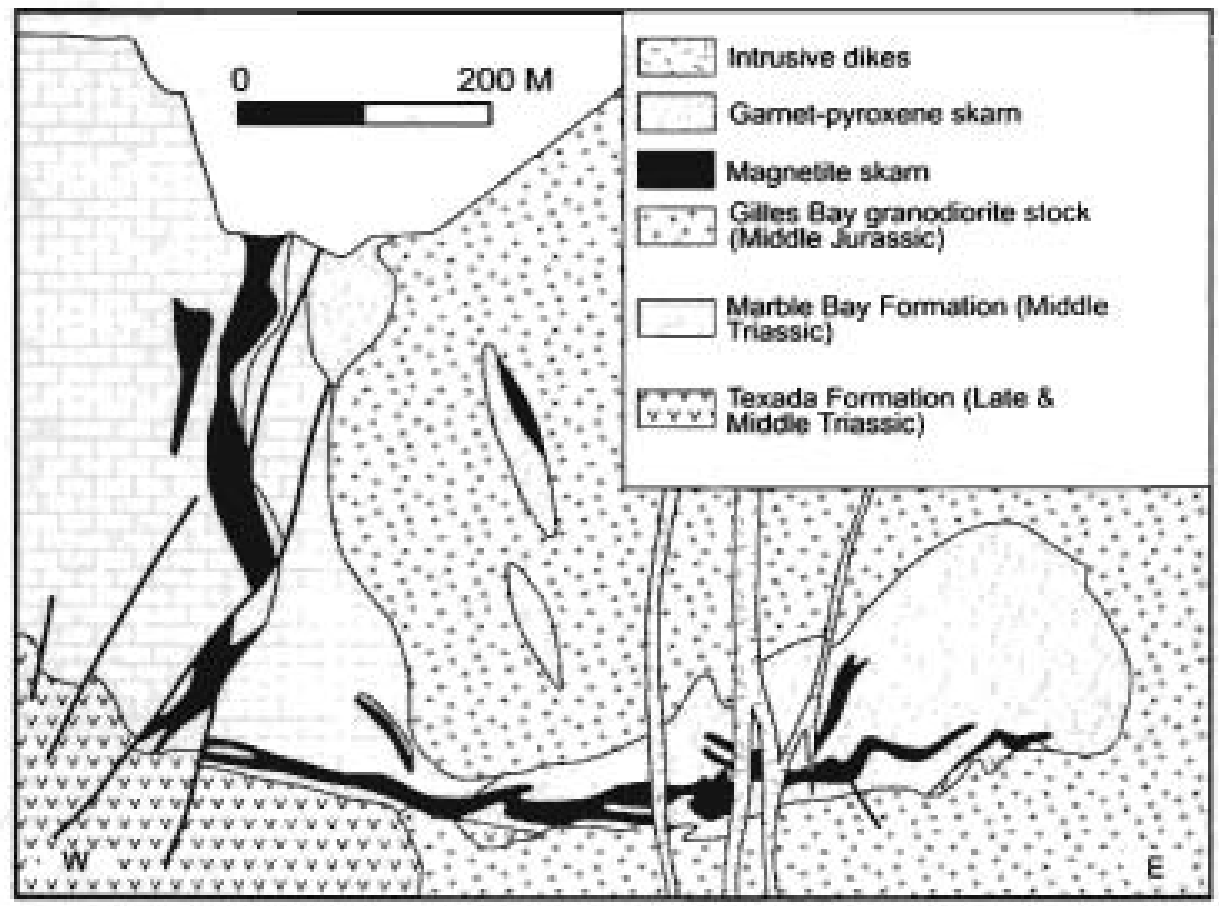

Figure 45. Prescott body, Texada Fe skam deposit, Island Porphyry metallogenic belt, Canadian Cordillera. Schematic cross section. Adapted from Webster and Ray (1990). 
The Island Porphyry metallogenic belh is hosied in the Jurassic volcanic and plutonic rocks which form part of the Gambier overlap assemblage in southern Britisb Columbia. This group is part of the Talkeetna-Bonanza are in the Wrangellia superterrane (Nokleberg and others, 2000). In southern British Columbia, the host rocks on northern Vancouver lsland consist of the Bonanza Group, and on Queen Charlone Island, the bost rocks consist of the correlative Yakoun Group. The Middle Jurassic volcanic and plutonic rocks, with isotopic ages of 165 to $170 \mathrm{Ma}$, which host the Island Copper metallogenic belt are the youngest part of the Bonanza arc which was initiaied in the Early Jurassic (Monger and Nokleberg, 1996; Ross and others, 1996). The Middle to Lute Jurassic plutons of the Bumaby Island suite and coeval volcanic rocks of the Yakoun Group are a younger and northern part of the are

The younger, Late Jurassic pan of the Island Porphyry metallogenic belt is coeval with: (1) the Western-Southeastern Alaska metallogenic belt which is hosted in the Late Jurassic and Early Cretaceous Gravina belt of the Wrangellia superterrane in Southeastern Alaska; and (2) the Eastern Alaska Range metallogenic belt which is hosted in the Kahiltna and Nutzotin overlap assemblages in southem Alaska. Together, the granihoid plutonic and andesitic volcanic rocks of the Gravina-Nutzotin-Gambier overlap assemblage, and the Kahiltna overlap assemblage define the Gravina island are which is interpreted as forming on the northem, or leading edge of the Wrangellia island-are ternane during migration towards North America (Nokleberg and others, 1984, 1985, 2000; Nokieberg and Lange, 1985a; Plafker and others, 1989; Plafker and Berg, 1994; Nokleberg and others, 2000). The Gravina are and associated granitic magmatism deposits are tectonically linked to the younger part of the McHugh Complex which forms the northem pant of the Chugach subduction zone and accretionary wedge complex (Nokleberg and others, 2000).

\section{Metallogenic Belts Formed in Middle Mesozoic in Stikinia-Quesnellia Island Arc}

\section{Klotassin Metallogenic Beit of Porphyry Cu-Auvg Deposits (Belt KL). Southern Yukon Territory}

The Klotassin metallogenic belt of porphyry Cu-Au-Ag deposits (fig. 42; tables 3,4) occurs in the southern Yukon Territory and is bosted in the Klotassin Batholith. This batholith consists of a talc-alkaline granitoid pluton which forms part of the more extensive Klotassin Plutonic Suite which intrudes the Stikinia island-are terrane in southwestern Yukon Territory (Woodsworth and others, 1991). The significant deposits are metamorphosed and deformed porphyry Cu-Au-Ag deposits at Minto Copper and Williams Creek (table 4) (Nokleberg and others 1997a, b, 1998). Both deposits are hosted in a foliated Early Jurassic granodiorite pluton. Significant POE prospects occur in mafic and ultramafie plutons at Pyroxene Mountain (Mortensen and others, 1994).

\section{Minto Copper and Williams Creek Porphyry Cu-Au-Ag Deposits}

The Minto Copper porphyry Cu-Au-Ag deposit consists of an assemblage of disseminated chalcopyrite, bomite, magnetite and pyrite with minor bessite and native gold which occur in zones of moderate to strong gneissic foliation in diorite of the Early Jurassic Klotassin Batholith (EMR Canada, 1989; Minto Explorations Lad, aews release, January 25, 1994). Estimated reserves are 6.55 million tonnes grading $1.87 \% \mathrm{Cu}$ and $0.51 \mathrm{~g} / \mathrm{Au}$. The deposit is interpreted as a metamorphosed porphyry $\mathrm{Cu}$ deposit. The deposit age is interpreted as Early Jurassic (Mortensen and others, 1994).

The Williams Creek porphyry $\mathrm{Cu}-\mathrm{Au}-\mathrm{Ag}$ deposit consists of chalcopyrite, bornite, pyrite and minor arsenopyrite and molybdenite which occur as interstitial grains parallel with the gaeissic foliation is granodionile of the Triassic Klotassin Batholith (EMR Canada, 1989; Westem Holdings Lid., annual report, 1992). Estimated reserves are 14.2 million tonnes grading $1.01 \% \mathrm{Cu}$ and $0.51 \mathrm{~g} / \mathrm{Au}$. Jurassic regional metamorphism destroyed much of the original features of the deposit. An oxidized zone, up to 200 meters deep, contains malachite and azurite which replaces copper sulfides. The deposit age is interpreted as Early Jurassic (Mortensen and others, 1994).

\section{Origin of and Tectonic Controls for Klotassin Metallogenic Belt}

The Minto Copper and Williams Creek porphyry $\mathrm{Cu}-\mathrm{Au}-\mathrm{Ag}$ deposits are similar, pre-aceretionary porphyry $\mathrm{Cu}-\mathrm{Au}-\mathrm{Ag}$ deposits which are hosted in foliated, gneissic granodionite and dionite of the Klotassin pluton (Pearson and Clark, 1979). The original textures of the deposits were mostly destroyed during Middle to Late Jurassic regional metamorphism and associated deformation. These events are interpreted as occurring during accretion of the Stikinia ialand are and associated terranes onto the North American Craton Margin (Le Couteur and Tempelman-Kluit, 1976) after oroclinal warping of the Stikinia-Quesnellia island are and tectonically-linked Cache Creek subduction-zone terrane (Mihalynuk and othen; 1994; Monger and Nokleberg, 1996; 
Nokleberg and others, 2000). Before accretion, the Stikinia island are is interpreted as forming on the Yukon-Tanana terrane, a rifted and deformed fragment of the North American Craton Margin (Monger and Nokleberg. 1996; Nokleberg and others, 2000). Several metallogenic belis formed during granitic magmatism associated with formation of the Stikinia and Quesnellia island arcs. The metallogenic belts which formed in conjunction with the Stikinia island arc are the Copper Mountain (North), Galore Creek, Guichon, Klotassin, Texas Creek, and Toodoggone belts. The Copper Mountain (South) and Guichon metallogenic belts formed in conjunction with the Quesnellia island arc.

Toodoggone Metallogenic Belt of Au-Ag

Epithermal Vein and Porphyry Cu-Au

Deposits (Belt TO) Northern Eritish Columbia

The Toodoggone metallogenic belt of Au-Ag epithermal vein and porphyry Cu-Au deposits (fig. 42; tables 3, 4) occurs in northern British Columbia and is hosted by: (1) the Toodoggone Formation, a Early Jurassic suecession of subaerial, intermediate, calc-alkaline to alkaline, predominantly pyroclastic rocks (Diakow and others, 1991, 1993; Monger and others, 1991); (2) and the coeval and comagmatic cale-alkaline plutons of the Black Lake Suite (Woodsworth and others, 1991). The belt and bost rocks occur in the eastern part of the Stikinia island-are terrane along the southwestern flank of the Stikine Arch. The Toodoggone Formation forms part of the Early Jurassic, cale-alkaline part of the Stikinia terrane and were deposited on the alkalinesubalkaline, Late Triassic Takla Group. The Toodoggone Formation is correlated with the Hazelton Group to the south and west. The significant deposits are Au-Ag epithermal vein deposits in Toodoggone district, and the Kemess porphyry Cu-Au deposit (table 4) (Nokleberg and others 1997a, b, 1998).

\section{Toodoggone District of Au-Ag Epithermal Vein Deposits}

The Toodoggone district contains significant Au-Ag epithermal vein deposits, with production from four principal deposits; Cheni (Lawyers, Cliff Creek), Chappelle (Baker), Shas, and AI.

The Lawyers Au-Ag epithermal vein deposit (fig. 46) consists of native gold, silver and electrum, with amethystine quartz, calcite and barite occurring in veins, stockworks und breccia. The deposit is hosted in silicified, propylitized and argillized intermediate volcaniclastic rocks which are proximally associated with plutons of the Black Lake Suite and with regional faults. The current resource is estimated at 1.76 million tonnes grading $6.8 \mathrm{~g} / \mathrm{Au}$ and $242.7 \mathrm{~g} / \mathrm{Ag}$ (Schroeter, 1983; Vulimin and others, 1986; Dawson and others, 1991). This and other deposits in the district display higher sulfide conient and higher-temperature alteration assemblages in relation to decreasing distance from contacts with granitoid stocks and plutons.

The Chappelle (Baker) Au-Ag epithermal vein deposit consists of a $\mathrm{Zn}$-Pb-Fe-sulfide-rich mineral assemblage bosted in calcareous sedimentary rocks of the Takla Group along the contact with the Black Lake stock (Barr, 1980). The Shasta Au-Ag epithermal vein deposit lacks sulfides and any evidence of underlying plutons, but exhibit advanced argillic alieration assemblages which indicate high-level deposition (MINFILE, 2002).

\section{Kemess North and South Porphyry Cu-Au Deposit}

The Kemess North, a developed prospect, and the Kemess South mine are porphyry Cu-Au deposits which consist of pyrite, chalcopyrite, magnetite, hematite, molybdenite and digenite which occur in stockwork veialets and fractures and as disseminations (Diakow and others, 1991, 1993; Rebagliati and others, 1995, Diakow, 2001). The deposits are hosted in equigranular intrusions which cut mainly mafic volcanic rock of the the Late Triassic Takla Group. At the Kemess South mine, mineralization is related to a felsic to intermediate, mainly monzodiorite pluton of Early Jurassic age which is probably related to the Black Lake Suite and coeval with the Toodoggone Formation. At the Kemess North prospect, several large hydothermal alteration zones enclose six major zones of porphyry-style $\mathrm{Cu}$-Au deposits, as well as several vein and skarn deposits. Oxidation of these deposits and subsequent development of a supergene blanket are interpreted as an Early Jurassic event which occurred in Early Junssic volcaniclastic and epiclastic rock (Diakow, 2001). The Late Cretaceous sedimentary rock of the Sustut Group are interpreted as capping the supergene zone.

The Kemess South porphyry Cu-Au deposit is hosted by the relatively flat-lying Maple Leaf quartz monzodionile sill. Higher $\mathrm{Cu}$ and $\mathrm{Au}$ grades correlate with zones of intense quartz-pyrite-chalcopyrile stockwork which contains intenselydeveloped K-feldspar vein selvages and magnetite stringers. A supergene zone, which formed contemporaneously with the Late Cretaceous Sustut Basin, forms about $20 \%$ of the deposit, and contains elevated $\mathrm{Cu}$ grades and contains chalcocite and native $\mathrm{Cu}$. Production commenced at Kemess South in 1998, based on estimated reserves of 442 million tonnes of hypogene and supergene ore grading 0.23\% Cu and 0.4 gt Au (Rebagliati and others, 1995; El Condor Resources Lid., news release, July 19, 1993).

The Keness North porphyry Cu-Au deposit is bosted in potassic-altered, mafic volcanic rocks of the Takla Group. The deposit is centered on Early lurassic porphyritic monzodiorite dikes. Higher grade Cu-Au mineral assemblages in volcanic host rocks are associated with hydrothermal biotite alteration, whereas potassium feldspar and propylitic alteration decrease zonally outwards from these centers, along with decreasing $\mathrm{Cu}$ and $\mathrm{Au}$. Estimated reserves are 116 million tonnes grading $0.19 \% \mathrm{Cu}$ and $0.38 \mathrm{~g} t \mathrm{Au}$ (Rebagliati and others, 1995; Northern Miner, March 10, 2003). 


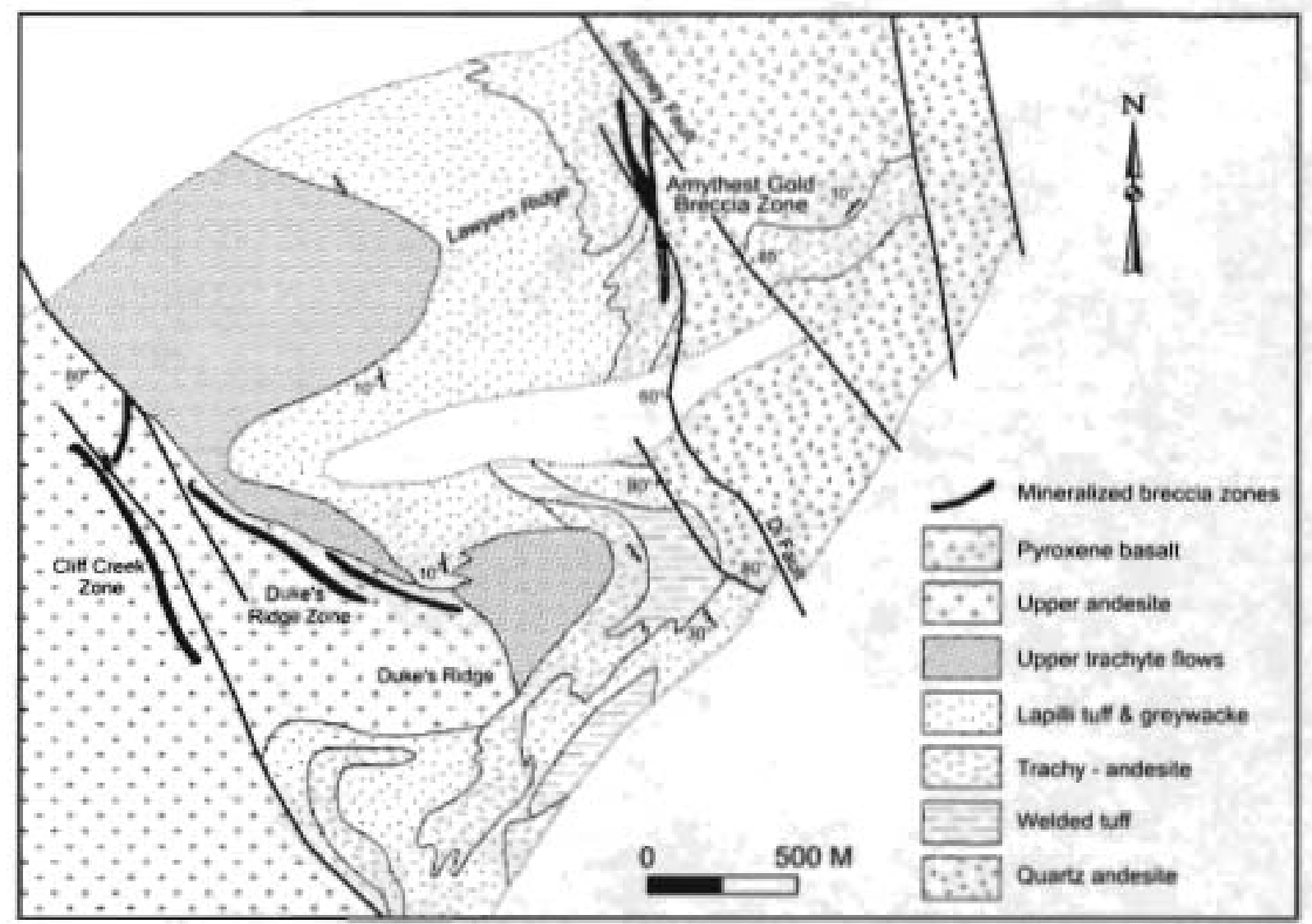

Figure 46. Lawyers Au-Ag epithermal vein deposit, Toodoggone metallogenic belt, Canadian Cordiliera. Schematic geologic map showing various zones. Adapted from Vulimin and others (1986).

\section{Origin of and Tectonic Controls for Toodoggone Metallogenic Belt}

The Toodoggone metallogenic belt is hosted in the Toodoggone Formation, a Early Jurassic succession of subacrial, intermediate, calo-alkaline to alkaline, predominantly pyroclastic rocks, and coeval and comagmatic calc-alkaline plutons of the Black Lake Suile which oceur on the outer limb of the oroclinal warp of the Stikinia and Qvesnellia island are and associated Ierranes. The transition from alkaline to calo-alkaline magnatism is interpreted as forming during the final stages of the oroclinal warp in the Early Jurassic, before accretion of the Stikinia-Quesnellia are and associated Cache Creck subduction-zoene terrane in the Middle Jurassic (Mihalynuk and others, 1994; Monger and Nokleberg. 1996; Nokleberg and others, 2000). The volcanic rocks of the Hazelton Group and correlative units, such as the Toodoggone Formation, and associated granitoid plutonic rocks, represcnt emergence of the are and a transition from marine to subaerial deposition in the Early Jurassic. The Toodoggone Formation consists exclusively of bigh-K, calc-alkaline volcanic rock which was deposited in high-energy subaerial flows, associated air-fall tuff, and lesser lava flows bertween about 200 to $190 \mathrm{Ma}$.

The Stikinia island-are terrane is interpreted as forming on the deformed continental margin strata of Yukon-Tanana lerrane which may be a rifled fragment of the North American Craton Margin (Gehrels and others, 1990; Monger and Nokleberg. 1996; Nokleberg and others, 1994c, 1997c, 2000). Several other metallogenic belts are herein interpreted as forming during granitic magmatism associated with formation of the Stikinia and Quesnellia island ares, including the Copper Mountain (North), Galore Creek, Guichon, Klotassin, Texas Creek, and Toodoggone belts.

\section{Coast Mountains Metallogenic Belt of Volcanogenic Cu-Zn-Au-Ag Massive Sulfide Deposits (Belt CM) Northern British Columbia}

The Coast Mountains metallogenic belt of voleanogenic massive sulfide deposits (fig, 42; tables 3, 4) occurs in the western limb of the oroclinally-warped Stikinia island-are terrane. To the west, the belt and terrane are border by, and in part, intruded by plutons along the eastem edge of the Coast Plutonic Complex. The metallogenic belt contains a vuriety of significant kuroko. Cyprus, and Besshi massive sulfide deposits (Nokleberg and others, 1997a, b). The significant deposits are the Tulsequah Chief and Eskay Creek kuroko Zn-Cu-Pb-Au-Ag massive sulfide deposits, the Granduc Besshi massive sulfide deposit, and the Alice Arm Silver and Anyox distriets of Cyprus massive sulfide deposits (table 4) (Nokleberg and others 1997a, b. 1998). 
The Coast metallogenic belt contains a variety of volcanogenic massive sulfide deposits of various ages. Following are the major rock sequences which host volcanogenic massive sulfide deposits in the Stikinia terrane: (1) the middle to upper Paleozoic Stikine assemblage which contains interbedded volcanic arc, carbonate and fine-grained clastic rocks; (2) the Late Triassic Stuhini Group and Takla Group, which unconformably overlie the Stikine assemblage, and contain voleanic are rocks and interfingering clastic rocks which are intruded by coeval granitoids; and (3) the unconformably-overlying. Early Jurassic Hazelton and Spatzizi Groups, and the Takwahoni Formation which contain andesitic volcanic rocks and intercalated sedimentary rocks. The Stikinia island-arc terrane is interpreted as forming on the deformed continental margin strata of Yukon-Tanana terrane which may be a rifted fragment of the North American Craton Margin (Gehrels and others, 1990; Monger and Nokleberg, 1996; Nokleberg and others, $1994 \mathrm{c}, 1997 \mathrm{c}$ ).

\section{Tulsequah Chief Kuroko Massive Sulfide Deposit}

The Tulsequah Chief kuroko $\mathrm{Zn}-\mathrm{Cu}-\mathrm{Au}-\mathrm{Ag}-\mathrm{Pb}$ volcanogenic massive sulfide deposit consists of massive to disseminated pyrite, sphalerite, chalcopyrite, and galena, with minor tennantite and tetrahedrite in conformable lenses which occur between a hanging wall of dacite tuff and a footwall sequence of basalt and andesite flows. The volcanic rocks constitute a bimodal sequence within the Devonian and Mississippian Mount Eaton series of the Stuhini Group. The occurrence of several stacked ore lenses, with repeated bimodal volcanic and sedimentary rocks indicate which several rifting events occurred in a local basin which was part of a mature island arc (Sebert and Barrett, 1996). Production from 1951 to 1957 was 574,000 tonnes. The deposit has reserves of 8.8 million tonnes of ore grading $6.42 \% \mathrm{Zn}, 1.3 \% \mathrm{Cu} .1 .21 \% \mathrm{~Pb}, 2.1 \mathrm{~g} / \mathrm{t} \mathrm{Au}$ and $106.4 \mathrm{~g} / \mathrm{Ag}$. (Dawson and others, 1991 ; Redfern Resources Lid., summary report,1995)

\section{Granduc Besshi Massive Sulfide Deposit}

The Granduc Besshi Cu (Ag-Au-Co) deposit consists of several overlapping, tabular sulfide lenses hosted in pelagic sedimentary rocks and turbidites which are underlain by basalt and andesite flows, within the Late Triassic Stuhini Group (Grove, 1986; Dawson and others, 1991; MINFILE, 2002). The host rocks are intruded by Jurassic to Tertiary granitoid plutons of the Coast Plutonic Complex. The deposit contains reserves of 32.5 million tonnes grading $1.93 \% \mathrm{Cu}, 7 \mathrm{~g} / \mathrm{Ag}$ and $0.13 \mathrm{~g} / \mathrm{t} \mathrm{Au}$. A Besshi-type exhalative origin is supported by laterally extensive, well-bedded ore lenses, dominantly sedimentary host rock, and ore minerals. The deposition is interpreted as occurring in a sedimentary basin adjacent to the Stuhini island are.

\section{Eskay Creek Kuroko Massive Sulfide Deposit}

The Eskay Creek Ag-Au polymetallic kuroko massive sulfide deposit consists of sphalerite, tetrahedrite, boulangerite, and boumonite with minor pyrite and galena which occur as stratabound and stratiform massive, semi-massive and disseminated layers in carbonaceous and tuffaceous mudstone of the Lower Jurassic Mount Dilworth Formation of the Hazelton Assemblage (EMR Canada, 1989; Prime Equities Inc., 1991; MacDonald, 1992; Sherlock and others, 1999; MINFILE, 2002). Gold and silver occur as electrum grains ( 5 to 80 microns) within fractured sphalerite, commonly in contact with galena. The deposit has estimated reserves 3.9 million tonnes grading $26 \mathrm{~g} / \mathrm{t} \mathrm{Au}$ and $986 \mathrm{~g} / \mathrm{t} \mathrm{Ag}$. The $21 \mathrm{~B}$ zone has reserves 1.04 million tonnes grading $63.8 \mathrm{~g} / \mathrm{t}$ Au and $2567 \mathrm{~g} / \mathrm{Ag}$, and the 109 zone, a coeval epitbermal vein deposit, has reserves of 0.97 million tonnes grading $9.6 \mathrm{~g} / \mathrm{Au}$ and $127 \mathrm{~g} / \mathrm{Ag}$.

\section{Alice Arm Silver District of Massive Sulfide Deposits}

The Alice Arm Silver district, which contains the Dolly Varden, North Star, and other kuroko $\mathrm{Ag}-\mathrm{Pb}-\mathrm{Zn}$ deposits, is hosted in Early Jurassic calc-alkaline volcanic rocks of the Hazelton Group. The deposits consists of pyrite, sphalerite, galena, tetrahedrite, pyrargyrite and some native silver in barite-Ag-rich sulfide lenses (Devlin and Godwin, 1986; EMR Canada, 1989; Mining Review, 1992). The various deposits are interpreted as structurally displaced parts of a once continuous massive sulfide zone. The combined production and reserves for the Alice Arm Silver district are 2.91 million tonnes grading $390 \mathrm{~g} / \mathrm{t} \mathrm{Ag}$, $0.53 \%$ $\mathrm{Pb}$, and $0.82 \% \mathrm{Zn}$.

\section{Anyox Cyprus Massive Sulfide Deposit}

The Anyox Cyprus Cu-Ag-Au district contains the Hidden Creek and Bonanza deposits, and five other occurrences. The deposits and occurrences consist of lenticular to sheet-like ore bodies of pyrite and pyrrhotite, lesser chalcopyrite, and minor sphalerite and magnetite (Grove, 1986; EMR Canada, 1989; Hoy, 1991; Smith, 1993). Combined production and reserves are 26.7 million tonnes grading $1.48 \% \mathrm{Cu}, 9.6 \mathrm{~g} / \mathrm{Ag}$, and $0.17 \mathrm{~g} / \mathrm{t} \mathrm{Au}$. The deposits and occurrences are located near the contact between volcanic and sedimentary rocks in a roof pendant of tholeiitic mafic volcanic rocks and overlying turbidites which are intruded by the Coast Plutonic Complex. Host rock geochemistry indicates formation along an ocean ridge, The host strata are interpreted as Eariy and Middle Jurassic volcunic and sedimentary units of the Stikinia terrane (Macdonald and others, 1996). 
The Coast Mountains metallogenic belt contains a variety of volcanogenic massive sulfide deposits which occur in three age-range groups of volcanic and associated rocks in the Stikinia island-arc terrane. The following three age-range sequences of massive sulfide deposits and host rocks are identified. (1) The middle to upper Paleozoic Stikine assemblage contains interbedded volcanic are, carbonate and fine-grained clastic rocks. The Tulsequah Chief kuroko massive sulfide deposit and associated occurrences formed in this age-range of the island arc. (2) The Late Triassic Stuhini Group and Takla Group, which unconformably overlie the Stikine assemblage, contains volcanic are rocks and interfingering clastic rocks which are intruded by coeval granitoids. The Granduc Besshi massive sulfide deposit formed in this age-range of the island arc. And (3) the unconformably-overlying Early Jurassic Hazelton and Spatzizi Groups, and the Takwahoni Formation contain andesitic volcanic rocks and intercalated sedimentary rocks. The kuroko massive sulfide deposits in the Alice Arm Silver district, and the Cyprus massive sulfide deposits in the Anyox district formed in this age-range of an island are. Each of the three age-range groups of volcanic and associated rocks are interpreted as parts of a long-lived volcanic arc which were deposited on Yukon-Tanana continental margin terrane, a rifted fragment of the North American Craton Margin (Gehrels and others, 1990; Monger and Nokleberg. 1996; Nokleberg and others, 1994c, 1997c). With more detailed study, each of the three age-range groups of voleanic rocks and associate massive sulfide deposits might be designated as sepurate metallogenic belts.

\section{Middle Jurassic Metallogenic Belts (193 to $163 \mathrm{Ma}$ ) (Figure 47)}

\section{Overview}

The major Middle Jurassic metallogenic belts in Alaska and the Canadian Cordillera are summarized in table 3 and portrayed on figure 47. No significant Middle Jurassic metallogenic belts exist in the Russian Far East. The major belts are as follows. (1) In Southem Alaska and the Canadian Cordillera, continuing on from the Early Jurassic, are the Talkectna MountainsAlaska Range belt, which contains kuroko massive sulfide deposits, the Alaska Peninsula (AP) belt, which contains Cu-and Feskarn deposits, and the Island Porphyry (IP) belt, which contains granitic-magmatism-related deposits. These belts are hosted in the Wrangellia islund-are superterrane and are interpreted as forming in the Talkeetna-Bonzana arc preserved in the superterrane. And $(2)$ in the Canadian Cordillera, continuing on from the Early Jurassic were the Coast Mountains (CM), Copper Mountain (North; CMN), Copper Mountain (South; CMS), Galore (GL), Guichon (GU), Klotassin (KL), Texas Creek (TC), and Toodoggone (TO) belts which contain either granitic magmatism-related deposits or deposits related io felsic to mafic marine volcanism. These belts are interpreted as forming in the axial parts of the Stikinia-Quesnellia island arc.

\section{Metallogenic-Tectonic Model for Middle Jurassic (193 to $163 \mathrm{Ma}$; Figure 47)}

During the Middle Jurassic (Toarcian through Callovian - 193 to $193 \mathrm{Ma}$ ), the major metallogenic-tectonic events were (fie 47; table 3): (1) continuation of continental-margin arcs and associated subduction near the North Asian Craton in the Russian far East; (2) beginning of assembly of previously rifted cratonal, passive continental-margin, and island-are ternanes between which craton and the ancestral Pacific Ocean to form the Kolyma-Omolon supernerrane; (3) continuation of the Talkeetna, Bonanza, and Stikinia-Quesnellia arcs, associated metallogenic belts, and formation of companion subduction zones; (4) continued sinistral-slip imbrication of the Stikinia-Quesnellia island are and associated subduction zones during obliquesinistral coavergence between the ancestral Pacific Ocean plate and the North American Craton Margin; and (5) with the beginning of accretion of the Stikinia-Quesnellia are at about $185 \mathrm{Ma}$, the start of mountain building in the North American Cordillera. Sedimentation continued along the passive continental margins of North Asian and North American Cratons.

\section{Specific Events for Middle Jurassic}

(1) The Monakin continental-margin arc, consisting of the Monakin volcanic-plutonic belt (mo) and the Umlekan continental-margin are, consisting of the Umlekan-Ogodzhin volcanic-plutonic belt (uo) and associated units, commenced activity. Associated with this are was oblique (sinstral) subduction of part of the Ancestral Pacific Ocean plate to form the Samarka (SMA), Khabarovsk (KB), and Badehal (BD) terranes. 


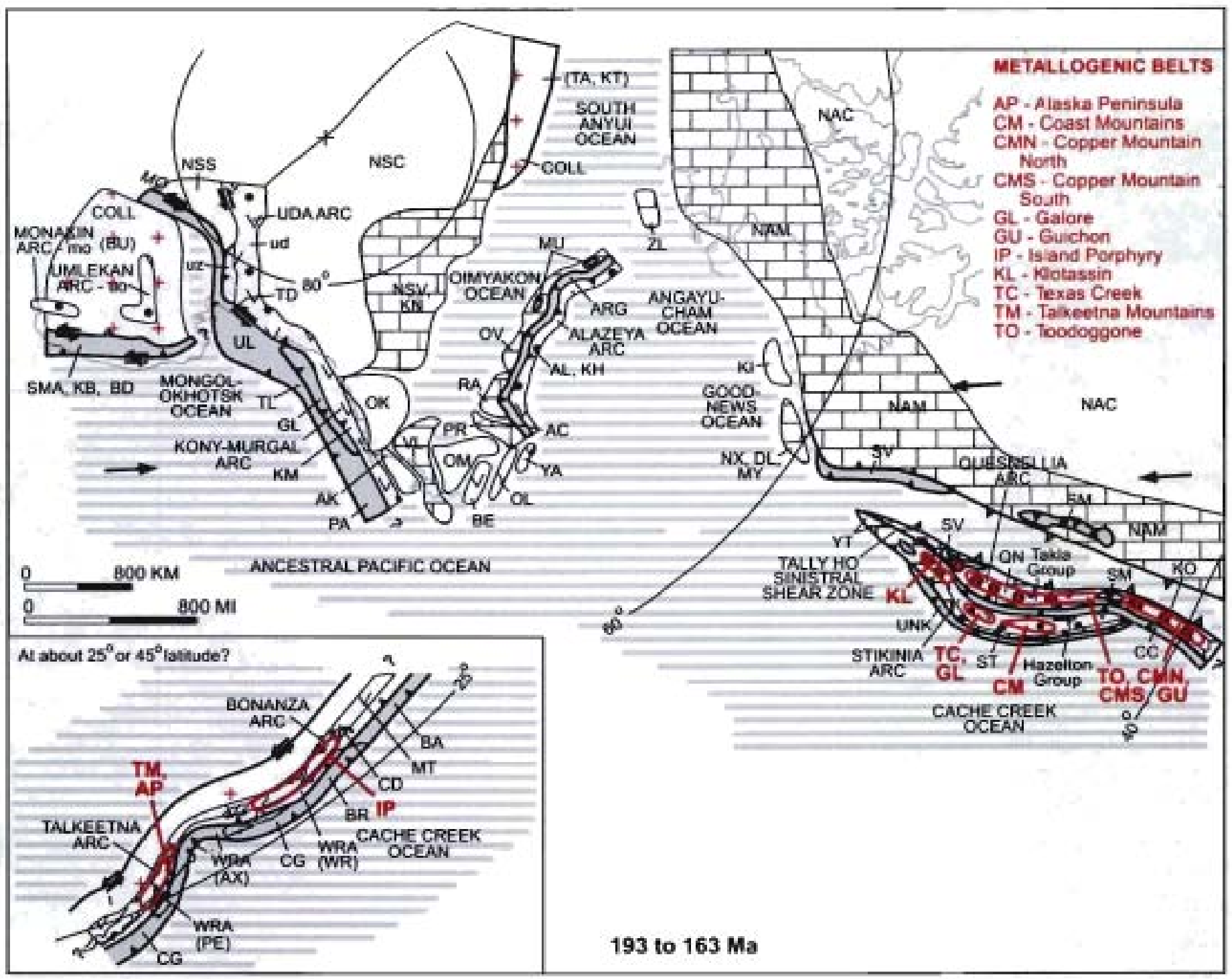

Figure 47. Middle Jurassic (Toarcian through Callovian - 193 to $163 \mathrm{Ma}$ ) stage of metallogenic-tectonic model, Refer to text for explanation of metallogenic-tectonic events, to tables 3 and 4 for descriptions metallogenic belts and significant deposits, and to figure 18 for explanation of abbreviations, symbols, and patterns. Adapted from Nokleberg and others (1997b, 1998, 2000).

(2) The continental-margin arc Uda arc (consisting of the Uda volcanic-plutonic belt (ud) and Uda-Zeya sedimentary basin (uz) continued to form. Associated with the are was subduction and sinistral transpression of part of the Mongol-Okhotsk Ocean plate to form the Turkuringra-Dzhagdinski (TD), Ulban (UL), and Galam (GL) terranes. Subduction and sinistral transpression occurred along the Mongol-Okhotsk suture $(M O)$.

(3) The extensive Kony-Murgal island arc (Kony-Murgal terrane (KM)) continued to form as an offshore extension of the Uda are. Associated with the arc was subduction of part of the Ancestral Pacific Ocean plate to form the Talovskiy (TL) and Penzhina-Anadyr (PA) terranes. Inboard of the Kony-Murgal island arc (KM) were the Okhotsk (OK), A vekova (AK), and Omolon (OM) cratonal terranes which were previously rifted from the North Asian Craton (NSC), and the Viliga (VL) passive continental-margin terranes which was previously rifted from the North Asian Craton Margin (NSV). Behind the are were fragments of prior Devonian to Pennsylvanian island-arc terranes, meluding the Beryozovka turbidite-basin (BE), and Oloy (OL), and Yarakvaam (YA) island-arc terranes.

(4) During the Bathonian, the Alazeya island arc, consisting of the Alazeya (AL) and Khetachan (KH) island-arc terranes, as a result of flip of the associated subduction zone, migrated towards the terranes forming the Kolyma-Omolon superterrane. The southern part of the Kolyma structural loop was formed during the convergence of the Alazeya are toward the terranes forming the Kolyma-Omolon superterrane. The major terranes in the superlerrane are the Alazeya (AL), Aluchin (AC), Argatas (ARG), Beryozovka (BE), Khetachan (KH), Munilkan (MU), Oloy (OL), Omolon (OM), Omulevka (OV), Prikolyma (PL), Rassokha (RA), Uyandina (UY), and Yarakvaam (YM) lerranes. During this collision, fragments of the older part of the Angayucham Ocean plate were obducted onto the Omulevka terrane to form the Munilkan (MU) ophiolite terrane, and the Uyandina, Kybytygas, and Indigirka ophiolite terranes of Oxman and others (1995). 
(5) The Angayucham Ocean (Kobuck Sea of Plafker and Berg, 1994), along with the South Anyui Ocean, continued to receive sparse continental-derived detritus. Previously rifted terranes, including the Kilbuck-Idono cratonal (KI) and the combined Nixon Fork-Dillinger-Mystic passive continental-margin (NX, DL, MY) terranes were near the North American Craton Margin.

(6) The dextral-slip imbrication of the Stikinia-Quesnellia arc and associated subduction-zone terranes was completed along the Tally Ho shear zone (Hansen and others, 1990; Hart, 1995). Or alternatively, the oroclinal warping of the StikiniaQuesnellia island-are and associated subduction zone terranes was completed (not depicted in fig. 47; Mihalynuk and others, 1994). For either interpretation, migration of the Stikinia-Quesnellia are and associated terranes toward North America was accomplished by subduction and (or) obduction of the Seventymile Ocean plate along the continental margin.

(8) The subduction-related volcanic and plutonic arc rocks of the Quesnellia part of the are, consisting of the Takla Group and the coeval igneous belts formed in response to continued subduction of part of the Cache Creek Ocean plate (CC; Mihalynuk and others, 1994). The Stikinia part of the are consisted of the extensive suite of the subduction-related volcanic and plutonic arc rocks of the Hazelton Group which also formed in response to subduction of part of the Cache Creek Ocean plate. Remrants of this oceanic plate may be preserved in the terrane of ultramafic and related rocks which occurs discontinuously along the Denali strike-slip fault (DE, fig. 47) for several hundred kilometers (Nokleberg and others, 1994b).

(9) Forming in the Stikinia-Quesnellia are and continuing on from the Early Jurassic were the Coast Mountains (CM), Copper Mountain (North; CMN), Copper Mountain (South; CMS), Galore (GL), Guichon (GU), Klotassin (KL), Texas Creek (TC), and Toodoggone (TO) belts which contain either granitic magmatism-related deposits or deposits related to felsic to mafic marine volcanism.

(10) Also completed was obduction of parts of the Seventymile and Slide Mountain Ocean plates onto the North American Craton Margin (NAM; Mihalynuk and others, 1994). Migration of the Stikinia-Quesnellia are and associated terranes toward the North American Craton Margin was accomplished by subduction of the Seventymile Ocean plate along the continentalmargis and by obduction.

(11) Outboard and perbaps at a lower paleolatitude (either $25^{\circ}$ or $45^{\circ}$ ), the Talkeetna and Bonanza ares continued activity in the Wrangellia superterrane (WRA). This extensive are formed along most of the length of the Wrangellia superterrane with coeval equivalents in the Cadwallader (CD) island arc and Methow (MT) turbidite-basin terranes. Forming in the are and continuing on from the Early Jurassic were the Talkeetna Mountains-Alaska Range metallogenic belt, which contains kuroko massive sulfide deposits, the Alaska Peninsula (AP) metallogenic belt, which contains $\mathrm{Cu}$ - and Fe-skam deposits, and the Island Porphyry (IP) metallogenic belt, which contains granitic-magmatism-related deposits. Associated with the Talkeetna and Bonanza ares was subduction of part of the Cache Creek Ocean plate to form the Chugach (CG). Bridge River (BR), and possibly Baker (BA) terranes.

\section{Late Jurassic Metallogenic Belts (163 to 144 Ma; Figures 48,49 )}

\section{Overview}

The major Lute Jurassic metallogenic belts in the Russian Far East, Alaska, and the Canadian Cordillera are sumuarized in table 3 and portrayed on figures 48 and 49. The major belts are as follows. (1) In the Russian Southeast, the Ariadny (AR) belt, which contains zoned mafic-ultramafie Ti deposits, is bosted in zoned mafic-ultramafic plutons intruding the Samarka subductionzone terrane. The belt is interpreted as forming along a transform continental margin. (2) Also in the Russian Southeast is the North Bureya (NB) belı of granitic-magmatism-related deposits which is interpreted as forming in the Umlekan continentalmargin arc. (3) In the central part of the Russian Far East is the Stanovoy (ST) belt which contains analectic, granitic-magmatismrelated deposits and is interpreted as forming during accretion of the Bureya superterrane to North Asian Craton. (4) In the Russian Northeast is the Chersky-Argatass Ranges (CAR) belt of kuroko massive sulfide deposits, and the Yasachnaya River (YS) belt of granitic-magmatism-related deposits. Both metallogenic belts are hosted in the Indigirka-Oloy volcanic-plutonic assemblage and are interpreted as forming in the Uyandina island are. (5) In the Russian Northeast, the Oloy (OL) belt contains granitic-magmatism-related deposits and is bosted in the Oloy island are. (6) In the same region, the Pekulney (PK) belt, which contains basaltic $\mathrm{Cu}$ deposits, is bosted in Late Jurassic oceanic crustal rocks which were subsequently tectonically incorporated inio the Pekul'ney subduction-zone lerrane; ( 7 ) In the same region, the Tamvatney-Mainits (TAM) belt, which contains podiform $\mathrm{Cr}$ deposits, is hosted in zoned mafic-ultramafic plutons, and the Mainits $(\mathrm{MA})$ bell, which contains kutoko massive sulfide deposits, are both interpreted as forming in the Mainitskiy island arc. (8) Also in the same region, the Svyatoy-Nos (SVN) belt, which contains Au-Ag epithermal vein deposits, is hosted in the Svyatoy-Nos volcanic belt which is interpreted as forming in the co-named island arc. (9) In the Russian Northeast, Alaska, and the northem Canadian Cordillera, the Eastern Seward Peninsula and Marshall (ESM), Kobuk (KB), Kuyul (KUY), Southwestem Alaska (SWA), and Yukon-River (YR) belts, which contain podiform 


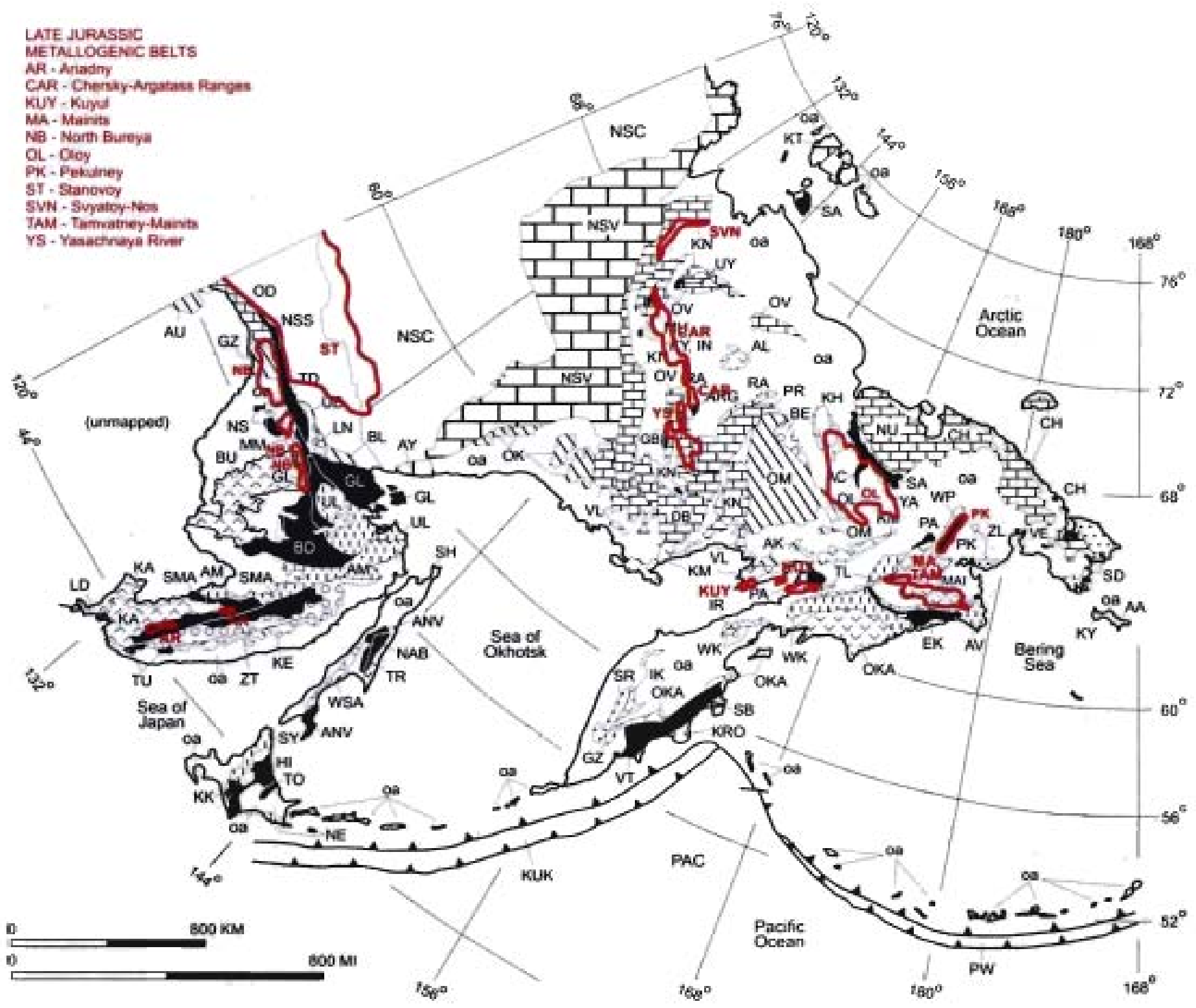

Figure 48. Generalized map of major Late Jurassic metallogenic belts and terranes for Russian Far East, northern Japan, and adjacent offshore areas. Refer to text for description of metallogenic belts. Adapted from Nokleberg and others (1997b, 1998). Refer to figure 2 for explanation.

$\mathrm{Cr}$ and related deposits, and also zoned mafic-ultramafic PGE deposits, are bosted in mafic-ultramafic plutons which intruded into the basal parts of various island ares. These ares include the Svyatoy-Nos, Kony-Murgal, Koyukuk, and Togiak ares, (10) In Southern Alaska, the Eastern-Southern Alaska (ESA) belt, which contains granitic-magmatism-related deposits, is bosted in the Gravina-Nutzotin-Gambier belt which overlies the Wrangellia superterrane, and is interpreted as forming along the axial part of the Gravina arc. In Southeastern Alaska, the KJukwan-Duke (KL) belt, which contains oned mafic-ultramafic Ti-Cr-PGE deposits, is hosted in subduction-related, zoned mafic-ultramafic plutons which are associated with basal part of Gravina island arc on the Wrangellia superterrane. (11) In East-Central Alaska and central Canadian Cordillera, the Fortymile (FM) and Cassiar (CS) belts, which contain serpentinite-hosted asbestos deposits, are hosted in ultramafic rock of the Seventymile subduction zone and Slide Mountain accretionary wedge terrane. These belts are interpreted as forming during regional metamorphism which occurred during obduction and overthrusting of oceanic lithosphere of oceanic terranes onto the North American Craton Margin. (12) In the Canadian Cordillera, the Cariboo (CB) belt of Au quartz vein, the Francois Lake (FL) of porphyry Mo, and the Rossland (RL) belt of $\mathrm{Au}-\mathrm{Ag}$ polymetallic vein deposits, are hosted in various island-arc and subduction-zone terranes. These metallogenic belts are both interpreted as forming during regional metamorphism and anatectic granitic plutonism associated with obduction of the Stikinia-Quesnellia are and associated subduction zone complexes onto the North American Craton Margin. And (13) in the southem Canadian Cordillera, the continuity of the Island Porphyry (IP) belt of granitic-magmatism-felated deposits is hosted in 


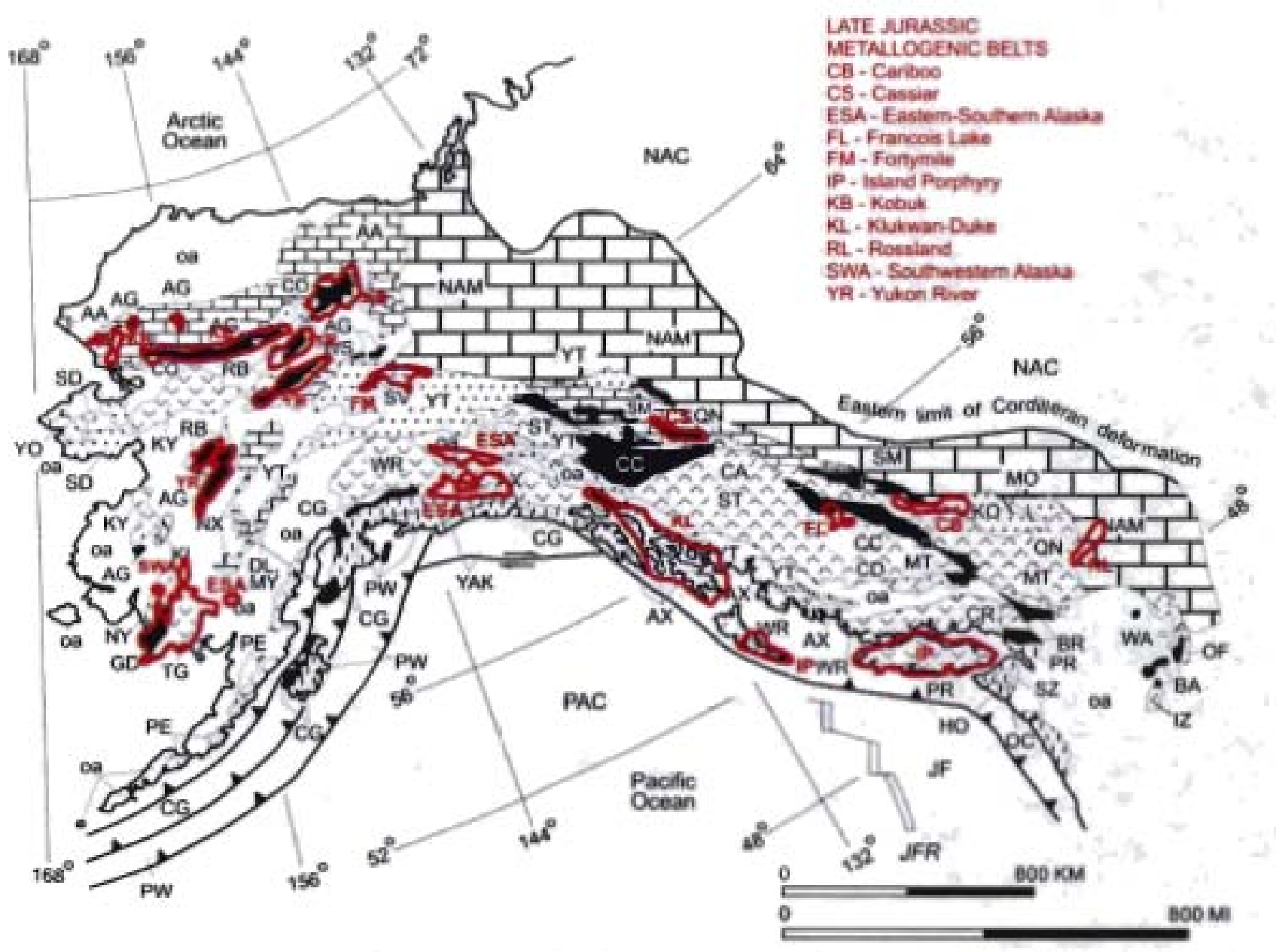

Figure 49. Generalized map of major Late Jurassic metallogenic belts and terranes for Aaska, Canadian Cordllera, and adjacent offshore areas. Refer to text for description of metallogenic belts. Adapted trom Nokbeberg and others (1997b, 1998$)$. Refer to figure 3 for explanation.

the Wrangellia island-are superterrane. This belt is interpreted as forming in the Gravina are which overlies the superterrane. In the below descriptions of metallogenic belts, a few of the noteable or signficant lode deposits (table 4 ) are described for each belt.

\section{Metallogenic-Tectonic Model for Late Jurassic (163 to $144 \mathrm{Ma}$; Figure 50)}

During the Late Jurassic (Oxfordian through Kimmeridgian; 163 to $144 \mathrm{Ma}$ ), the major metallogenic-tectonic events were (fig. 50; table 3): (1) beginning of accretion of the Bureya superterrane against the North Asian Craton along the Mongol. Okhotsk suture and formation of associated metallogenic belts; (2) establishment of a series of continental-margin arcs, and formation of associaled metallogenic belts companion subduction-zones around the Circum-North Pacific; (3) initiation of rift grabens which subsequently formed the Amerasia and Canada Basins and also resulied in inception of the Koyukuk arc; (4) obduction of the Stikinia-Quesnellia are and associated terranes onto the North American Craton Marginc and (5) ending of the previous long-lived period (Late Proterozoic through Early Jurassic) of passive sedimentation on the North Asian and North American Cratons.

\section{Specific Events for Late Jurassic}

(1) Far to the south at about $60^{\circ}$ paleolatitude, the Mainitskiy island are (Mainitskiy terrane, MAI) commenced activity. Forming in the arc were the Tamvatney-Mainits (TAM) belt of podiform $\mathrm{Cr}$ deposits which is hosted in zoned mafie-ultransfie plutons, and the Mainits (MA) belt of kuroko massive sulfide deposits. Tectonically linked to the are was the Alkatvaam accretionary-wedge terrane (AV) which formed from subduction of part of the adjacent oceanic plate. This are and companion subduction zone migrated northward toward the Kony-Murgal island are.

(2) The Monakin are (Monakin volcanic-plutonic belt, mo) and the Umlekan arc (Umlekan-Ogodzhin volcanic-plutonic belt, vo and associated units) continued activity. Forming in the are was the North Bureya (NB) metallogenic belt, which contains subduction-related granitic-magmatism deposits. Associated with formation of the arcs was oblique (sinstral) subduction of part of 


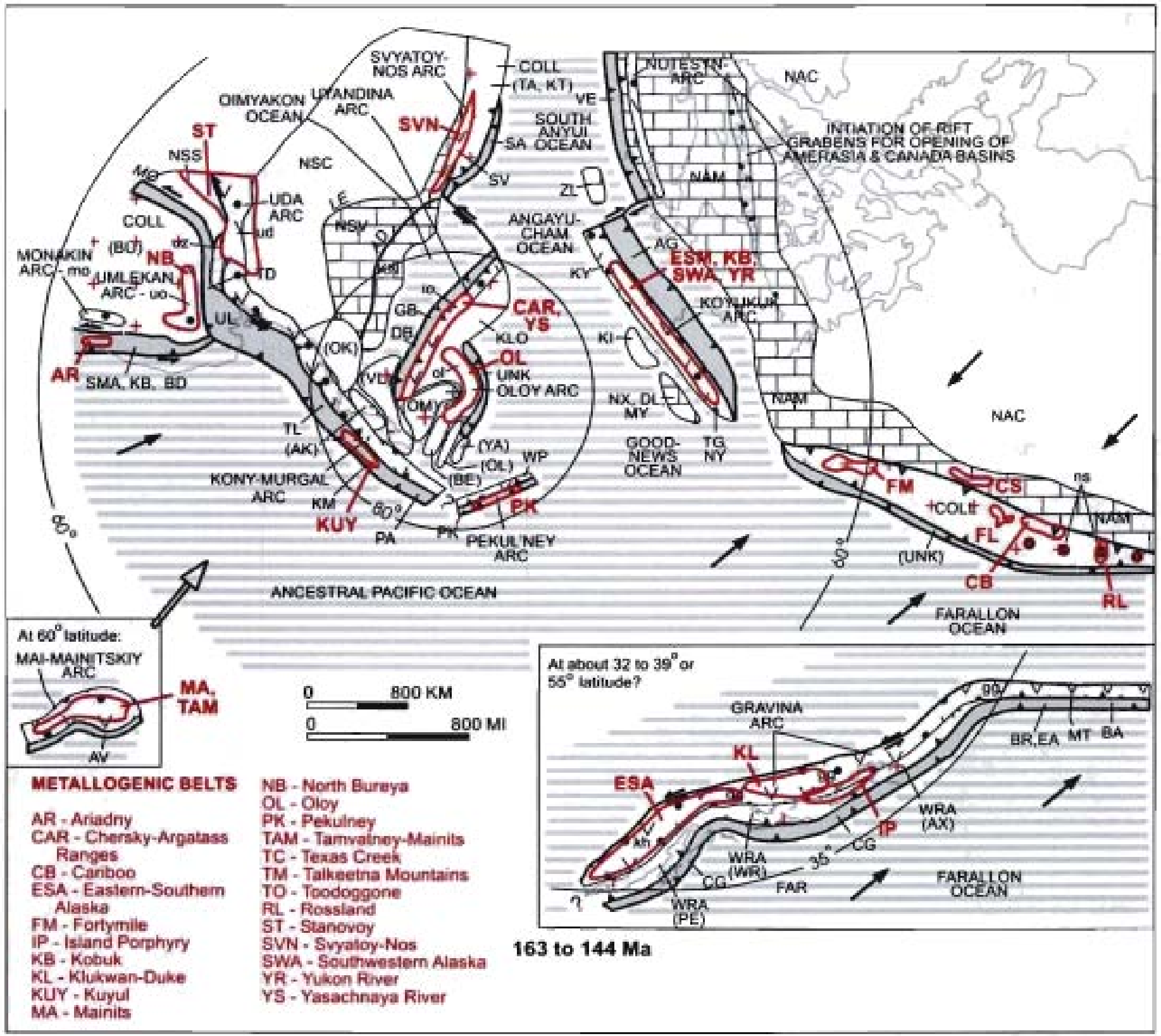

Figure 50. Late Jurassic (Oxtordian through Kimmeridigian - 163 to 144 Ma) stage of metallogenic-lectonic model, Refer to text for explanation of metallogenic-tectonic events, to tables 3 and 4 for descriptions metallogenic belts and significant deposits, and to figure 18 for explanation of abbreviations, symbols, and patterns. Adapted from Nokleberg and others (1997b, 1998, 2000).

the Ancestral Pacific Ocean plate to continue forming the Samarka (SMA), Khabarovsk (KB), and Badzhal (BD) terranes.

Forming along the transform continental margin was the Ariadny (AR) belt of zoned mafic-ultramafic Ti deposits which is hosted in zoned mafic-ultramafic plutons intruding the Samarka subduction-zone terrane.

(3) In the same region, the Bureya (BU) superterrane accreted against the Ulban accretionary-wedge terrane (UL) along the Mongol-Okhotsk suture $(M O)$ thereby closing the Mongol-Okhotsk Ocean. Forming during accretion was the Stanovoy (ST) metallogenic belt which contains anatectic, granitic-magmatism-related deposits.

(4) The Uda continental-margin arc (Uda volcanic-plutonic belt, ud, and Uda-Zeya sedimentary basin, uz) continued to form. Associated with the arc was subduction and sinistral transpression of part of the Mongol-Okhotsk Ocean plate to form the Turkuringra-Dzhagdinsk (TD), and Ulban (UL) terranes. Subduction was associated with sinistral transpression along the Mongol-Okhotsk suture (MO).

(5) The extensive Kony-Murgal continental-margin and island-arc terrane (KM) continued to form as an extension of the Uda continental-margin arc (ud). Associated with the arc was continued subduction of part of the ancestral Pacific Ocean plate to form the Talovskiy (TL) and Penzhina-Anadyr (PA) terranes. The Kony-Murgal island are overlapped the Okhotsk (OK) and Avekova (AK) cratonal terranes which were previously rifted from the North Asian Craton (NSC), and the Viliga (VL) passive 
continental-margin ierranes which were previously rifted from the North Asian Craton Margin (NSV). As a transform extension of the Kony-Murgal terrane, the West Pekul'ney island-are lernane (WP) was initiated. Associated with the are was subduction of part of the ancestral Pacific Ocean plate to form the Pekul'ney terrane (PK).

(6) The Kolyma-Omolon superternane (KLO) continued to migrate toward the North Asian Craton Margin (NSV). During migration, the Uyandina are (consisting of Uyandina-Yasachnaya volcanic belt in the western part of the long IndigirkaOloy sedimentary-volcanic-plutonic assemblage (io)) started to form along the leading edge of the superternane. Forming in the Uyandina arc was the Chersky-Argatass Ranges (CAR) metallogenic belt, which contains kuroko massive sulfide deposits, and the Yasachnaya River (YS) metallogenic belt, which contains granitic-magmatism-related deposits. Tectonically linked to the Uyandina arc was subduction of the oceanic crustal rocks preserved in the Garbyn'ya (GA) and Debin (DB) ophiolite belt (and corresponding tertanes, fie 48) of Oxman and others (1995) which are berein interpreted as a reminants of the Oimyakon Ocean plate.

(7) On the opposite side of the Kolyma-Omolon superterrane (KLO), the Oloy island arc (ol) formed in response to subduction of part the South Anyui Ocean plate. Forming in the are was the Oloy (OL) metallogenic belt which contains graniticmagmatism-related deposits. Along one part of the North Asian Craton Margin (NSV), the Svyotoy-Nos continental-margin are formed along the margin of the Taymyr Peninsula collage (TA) in response to subduction of another part of the South Anyui Ocean plate to form the South Anyui subduction-zone terrane (SA). Forming in the are was the Svyatoy-Nos (SVN) metallogenic belt which cootains Au-Ag epithemal vein deposits and is hosted in the Svyatoy-Nos volcunic belt. The Angayucham Oceun continued to exist along with the South Anyui Ocean.

(8) Outboard of the Oloy are was the minor Pekul'ney island arc. Incorporated into the tectonically-linked Pekul'ney subduction zone terrane was the basaltic Cu deposits of the Pekulney metallogenic belt that formed in a primitive island arc and neighboring sea-floor environment.

(9) Adjacent to the North American Craton Margin (NAM), two extensive ares formed. The Nutesyn continental-margin are formed in response to subduction of part of the South Anyui Ocean plate to form the Velmay subduction-zone terrane (VE). The Koyukuk (KY), Togiak (TG), and Nyac (NY) island-arc terranes formed in response to subduction of an (inner) Angayucham Ocean plate to extend the Angayucham (AG) subduction-zone terrane and opening of the Acrasia and Canada Busins. Outbourd of the island are were the outer Angayucham and the Goodnews Oceans. Forming in the basal parts of the Koyukuk (KY), Togiak (TG), and Nyac (NY) island ares were the Eastern Seward Peninsula and Marshall (ESM), Klukwan-Duke (KL), Kobuk (KB), Kuyul (KUY), Southwestern Alaska (SWA), and Yukon-River (YR) metallogenic belts which contain podiform Cr and related deposits, and zoned mafic-ultramafic PGE deposits and are hosted in mafic-ultramafic plutons. The polarity of the island are was continentward, toward the North American Craton Margin (NAM).

(10) The Kilbuck-Idono cratonal (K1) and the Nixon Fork-Dillinger-Mystic passive continental-margin terranes (NX, DL, MY) accreted onto the North American Craton Margin (NAM) at about the same time as obduction of the Stikinia-Quesnellia island are described below.

(11) Rift grabens, depicted as rifting associated with sea-floor spreading, began to open the Amerasia and Canadu Basins (Grantz and otbers, 1998). These grabens were an early stage of creation of new oceanic crust in the Early Cretaceous, as described below.

(12) A subduction zone (UNK) having a component of oblique sinistral-slip is inferred to have formed along, and parallel to the continental margin in order to accomplish migration of the Wrangellia supernerrane toward the North American Craton Margin. Remnants of the subduction zone may be preserved in the terrane of ultramafic and related rocks which occurs discontinuously along the Denali strike-slip fault (DE, fig. S0) for several hundred kilometers (Nokleberg and others, 1994b). The mafic and ultramafic rocks may in part be derived from the Farallon Ocean plate (FAR) which separated the Wrangellia superterrane from the North American Craton Margin.

(13) Regional thrust faulting oceurred with obduction of the Stikinia (ST), Quesnellia (QN), Cache Creek (CC), Slide Mountain (SM), Yukon-Tanana (YT), Seventymile (SM), and Kootenay (KO) terranes over the Cassiar (CA) terrane and the North American Craton Margin (NAM). This compressional event marked the beginning of a major orogenic event, including regional metamorphism, deformation, crustal thickening, anatectic magmatism, and uplift in the core of the Canadian Cordillera (Monger and Nokleberg. 1996). Forming during the regional metamorphism, or during younger hydrothermal alteration, were the serpentinite-hosted asbesios deposits of the Cassiar (CS) and Fortymile metallogenic belts (FM) that are hosted in ultramafic rock in the Slide Mountain (SM) and (or) Seventymile (SV) terranes. The Nelson plutonic suite (ns, fig. 50), which intrudes the Stikinia, Quessellia, Kootenay, Cache Creek, and Slide Mountain terranes, and the coeval Francois Lake plutonic suite formed during this compressional event. The Nelson plutonic suite consists chicfly of granodiorite, quartz monzonite, and local monzonite plutons which yield isotopic ages mainly of 185 to $155 \mathrm{Ma}$ and exhibit local crustal inheritance (Parrish and others, 1988; Woodsworth and others, 1992). Formed in the Nelson plutonic suite was the Rossland (RL) metallogenic belt of Au-Ag polymetallic vein deposits. Forming nearby in the Francois Lake plutonic suite was the Francois Lake (FL) metallogenic belt of porphyry Mo deposits. Forming in the nearby Kootenay terrane was the Caribeo (CB) belt of Au quartz vein deposits. By the Late Jurassic (about $155 \mathrm{Ma}$ ), detritus from this emergent orogenic welt in the eastem Canadian Corfillera was stied eastwards onto the North American Craton Margin (Cant, 1989).

(14) The extensive Gravina island are was initiated along the length of the Wrangellia superterrane. Remnants of the are are preserved in the Kahiltna (kh) and Gravina-Nutzotin-Gambier (gg) overlap assemblages which occur only on the Wrangellia 
superternane. Forming in the Gravina are were the Eastern-Southern Alaska (ESA) metallogenic belt, which contains graniticmagmatism-related deposits, and the continuing 1sland Porphyry (IP) belt, which contains granitic-magmatism-related deposits. Tectonically linked to the are was subduction of part of the Farallon Ocean plate (FAR) to form the Chugach (CG), Bridge River $(B R)$, Easton (EA), and Baker (BA) terranes.

\section{Metallogenic Beit Formed Along Late Mesozoic Along Continental-Margin Transform Fault}

\section{Ariadny Metallogenic Belt of Zoned Mafic- Uitramafic Ti Deposits (Beit AR) Southern Part of Russian Far East}

The Ariadny metallogenic belt of zoned mafic-ultramafic Ti deposits (fig, 48; tables 3,4) occurs in the southern part of the Russian Southeast only in the Samarka accretionary-wedge terrane. The principal Ti deposits are at Katenskoe, Ariadnoe, and Koksharovskoe (table 4) (Nokleberg and others 1997a, b, 1998), and consist mainly of disseminated to massive ilmenite which is hosted in layen in gabbro and pyroxenite. Titanium-magnetite and apatite are rare. The deposits also contains sparse PGE minerals, and sparse PGE minerals oceur in stream-sediment samples. The bodies are several tens of $\mathrm{m}$ thick and several hundred $\mathrm{m}$ long. K-Ar isotopic studies yield ages of 160 to $170 \mathrm{Ma}$. The petrochemical features and mineral composition of the gabbro and pyroxenite intrasions hosting the zoned mafic-ultramafic Ti deposits are similar to those bosting the Kondyor PGE deposit (A.I. Khanchuk, written commun., 1992).

The zoned intrusions which host the Ariadny metallogenic belt consist of Late Jurassic ultramafic and gabbroic complexes with K-Ar isotopic ages of about $160 \mathrm{Ma}$ age (Shcheka and Vrzhosek, 1985). The complexes are interpreted as synvoleanic intrusives which intruded into the turbidite deposits of the Samarka accretionary-wedge terrane immediately before accretion of the terrane in the Early Cretaceous (A.1. Khanchuk, written commun., 1993; Nokleberg and others, 1994c, 1997c). Intrusion of the Samarka terrane may have occurred in the final stages of accretion during seaward migration of the subduction zone (Khanchuk and Ivanov, 1999). The Middle and Late Jurassic clastic matrix of the terrane consists of parautochthonous turbidite and olistostromal deposits rocks which contain fragments of mainly middle and late Paleozoic ophiolitic rocks and greenstone, Middle Triassic chert, Early Jurassic schist and shale, and Triassic to Jurassic clastic rocks, Olistostromes, particularly in the northern part of the terrane, consist of large fragments of Carboniferous to Early Permian limestone. A fragment of the terrane occurs near the town of Bikin, where meimechite and picrite flows occur in a Late Jurassic (?) matrix (Philippov; 1990). The Sumarka accretionary-wedge terrane and correlative subduction zone units in Japan are tectonically linked to Jurassic granitoid rocks in Korea, and with a major Jurassic to Cretaceous volcanic-plutonic belt in southeastem China (Nokleberg and others, 1994c, 1997c). These subduction-related units are interpreted as offset from their tectonically-linked igneous ares by leftlateral movement during the Cretaceous and Cenozoic (Nokleberg and others, 1994c, 1997c).

\section{Metallogenic Belts Formed in Late Mesozoic Continental Margin and island Arc Systems in Russian Far East}

\section{North Bureya Metallogenic Beit of Au-Ag Epithermal Vein and Granitoid-Related Au Deposits (Belt NB) Northwestern Part of Russian Southeast}

The North Bureya metallogenic belt of Au-Ag epithermal vein and granitoid-related Au deposits (fig. 48; tables 3, 4) (Radkevich, 1984) occurs in the northwestem part of the Russian Southeast. The deposits are hosted in Early Cretaceous felsie and intermediate volcanic rocks which occur: (1) mainly in the Late Jurassic and Cretaceous Umickan-Ogodzhin volcanic-plutonic belt; and (2) in the borthem part of the Late Jurassic to Cenozoic Late Amur sedimentary assemblage. These units overlie the Malokhingansk and Turan terranes of the Bureya superterrane, and the Gonzha, North Sukhotinsk, Marmyn, and TukuringraDahagdi terranes. The volcanic rocks extend along the boundary of the Tukuringra-Dzhagdi lerrane with the North Asia Stanovoy cratonal block. The major Av-Ag epithermal vein deposits ate at Barnskoe, Burindinskoc, and Poktovskoe (table 4) (Nokleberg and others $1997 \mathrm{a}, \mathrm{b}, 1998$ ). A granitoid-related Au deposit is at Pioncer. Only a few Au-Ag epithermal vein deposits are known. Several poorly-explored deposits are known in the area, but are unexplored because of exiensive Cenozoic surficial deposits and swamps (Melnikov, 1974). Numerous placer Au mines occur within the North Bureya metallogenic belt. The gold in the placer mines is interpreted by Gurov (1978) as being mainly derived from Au-bearing quarte veins hosted in Late Jurassic to Early Cretaceous sedimentary and volcanic rocks. The North Burcya metallogenic belt is assessed to be promising for Au resources and needs further study. 
The Pokrovskoe Au-Ag epithermal vein deposit (Khomich and others, 1978; Mel'nikov, 1984; V.D. Melnikov, written commun. 1993; Khomich, 1990) occurs in Late Cretaceous andesite, dacite andesite, and related fuff. This volcanic sequence overties a Jurassic coal-bearing sequence of sandstone, silitstone, and argillite. The ore bodies consist of gently-dipping quartz veins and zones of hydrothermal altenation. Main alteration types are propylitization (albite, sericite, calcite, chlorite, and pyrite), berezitization (quart2, sericite, and hydromica), and argillization (kaolinite, montmorillonite, hydromica, carbonates, quartz, and pynte). The largest ore bodies are gently-dipping zones of altered rock, located near the lower contact of andesitic sequence with a granodiorite porphyry sill. Hydrothermally altered rocks consist of quartz $(25-85 \%)$, carbonate $(2-5 \%)$, hydromica $(5-12 \%)$, adularia (up to $5 \%$ ), kaolinite (5-7\%), and sulfides (less than $1 \%$ and mostly pyrite). Gold is fine-grained $(0.0005$ to $0.032 \mathrm{~mm}$ ), is associated with quartz. and is virtually not associated with sulfides. Silver grains (0.002 to $0.016 \mathrm{~mm})$ were observed in Fehydroxide alteration. The deposit is medium size with reserves of 15 million tonnes grading $4.4 \mathrm{~g} / \mathrm{Au}$ and $15 \mathrm{~g} / \mathrm{Ag}$. The deposit is interpreted as forming in the Late Cretaceous.

\section{Pioneer Granitold-Related Au Deposit}

The Pioneer granitoid-related Au deposit (N.E. Malyamin and V.E, Bochkareva, written commun., 1990, V.N. Akatkin, written commun. 1991) occurs near the margin of an Early Cretaceous granodiorite intrusion, both within the intrusion, and in adjacent country rock of contact-metamorphosed Jurassic sandstone and siltstone. The ore bodies consist of quartz, quartzfeldspar, quartz-tourmaline, and quartz-carbonate veins and zones of altered quartz-potassium feldspar-sericite-albite rocks. The ore bodies vary from I to $50 \mathrm{~m}$ thick, and in plan branch with variable trends. The ore bodies are large, have low Au content, and have no visible boundaries. The extent of mineralization is determined by geochemical sampling. Both gold and Au-sulfide bodies are recognized. The gold ore type consists of quartz-adularia-carbonate veins, and the Au-sulfide type consists of quartz veins with pyrite, galena, stibnite, and Ag-sulfosalts. The deposit is small, with estimated reserves of 17.1 tonne Au, 20.1 tonne Ag, and average grades of grade $2.7 \mathrm{~g} / \mathrm{Au}$, and $5.2 \mathrm{~g} / \mathrm{Ag}$.

\section{Origin of and Tectonic Controls for North Bureya Metallogenic Belt}

The Umlekan-Ogodzhin voleanic-plutonic belt (Volsky, 1983; Kozlovsky, 1988) which hosts the North Bureya metallogenic belt consists chiefly of: (1) Early Cretaceous sandstone, conglomerate, and mudstone with sparse flora and freshwater fauna; (2) Early Cretaceous calc-alkalic andesite, dacite, and tuff which yield $\mathrm{K}$-Ar isotopic ages of 112-135 Ma; and (3) Late Cretaceous alkalic basalt and rhyolite. The belt is intruded by coeval Early Cretaceous granite, granodiorite, diorite, and monzodiorite. Some granitoid plutons are probably Late Jurassic, or oldet because derived detritus occurs in the Early Cretaceous part of section of the Umlekan-Ogodzhin igneous belt. This belt was deposited on Gonzha terrane, and on Mamyn and Turan terranes of Bureya superterrane after collision of these terranes with the Tukuringra-Dzhagdinsk terrane (Nokleberg and others, $1994 \mathrm{c}, 1997 \mathrm{c})$.

The Umlekan-Ogodzhia volcanic-plutonic belt belt constitules part of the Umiekan continental-margin are which is interpreted as forming from subduction of part of the ancestral Pacific Ocean plate which is now preserved as tectonically interwoven fragnents of the Badzhal (BD), older Jurassic, part part of the Khabarovsk (KB), and Samarka (SMA) terranes. This tectonic pairing is based on: (1) occurrence of the aceretionary-wedge terranes outboard (oceanward) of the Umiekan are (fig. 48); (2) formation of melange structures during the Jurassic and Early Cretaceous (Nokleberg and others, 1994a; Khanchuk and others, 1996); and (3) where not disrupted by extensive Cretaceous and early Cenozoic movement along the Central Sihote-Aline strikeslip fault, the melange structures and bounding faults dip toward and beneath the igneous units of the are. Subduction is genenally interpreted as ending in the Early Cretaceous when extensive sinstral faulting occurred along the subduction zone (Khanchuk and others, 1996).

\section{Chersky-Argatass Ranges Inferred \\ Metallogenic Beit of Kuroko Massive \\ Sulfide Deposits (Belt CAR) \\ West-Central Part of Russian Northeast}

An inferred metallogenic belt of kuroko massive sulfide deposits (fig 48; tables 3,4) occurs in the west-central part of the Russian Northeast. The metallogenic belt is hosted in Late Jurassic volcanic rocks in the Chersky and Argatass Ranges in the Indigirka-Oloy sedimentary-volcanic assemblage (unit io, fig .48) (Nokleberg and others, 1994c, 1997c). The belt extends northwest for nearly $700 \mathrm{~km}$ and occurs in four areas which are up to 35 to $30 \mathrm{~km}$ wide each (Danilov and others, 1990). The significant deposit is at Khotoidokh in the northwest part of the belt (table 4) (Nokleberg and others 1997a, b, 1998). 
The Khotoidoh Kuroko massive sulfide deposit (fig. 51) (G.G. Naumov, written commun., 1987; Danilov and others., 1990; Dylevsky and others, 1996) consists of a steeply-dipping stratiform body of massive sulfides in a lens which ranges up to 13 $\mathrm{m}$ wide and $450 \mathrm{~m}$ long. The lens is hosted in Late Jurassic sedimentary and volcanic rocks. The deposit is underlain by thyolite and overlain by siltstone. The main ore minerals are pyrite, chaleopyrite, sphalerite, galena, tetrahedrite, and barite. Also occurring are bornite, native $\mathrm{Au}$, native $\mathrm{Ag}$ and matildite. The ores vary from massive to thin-banded. The ore is regionally metamorphosed, and wallrock metasomatic alteration includes propylitic, and late-stage silica and sericite alternation. The host rocks are the

\section{Map}
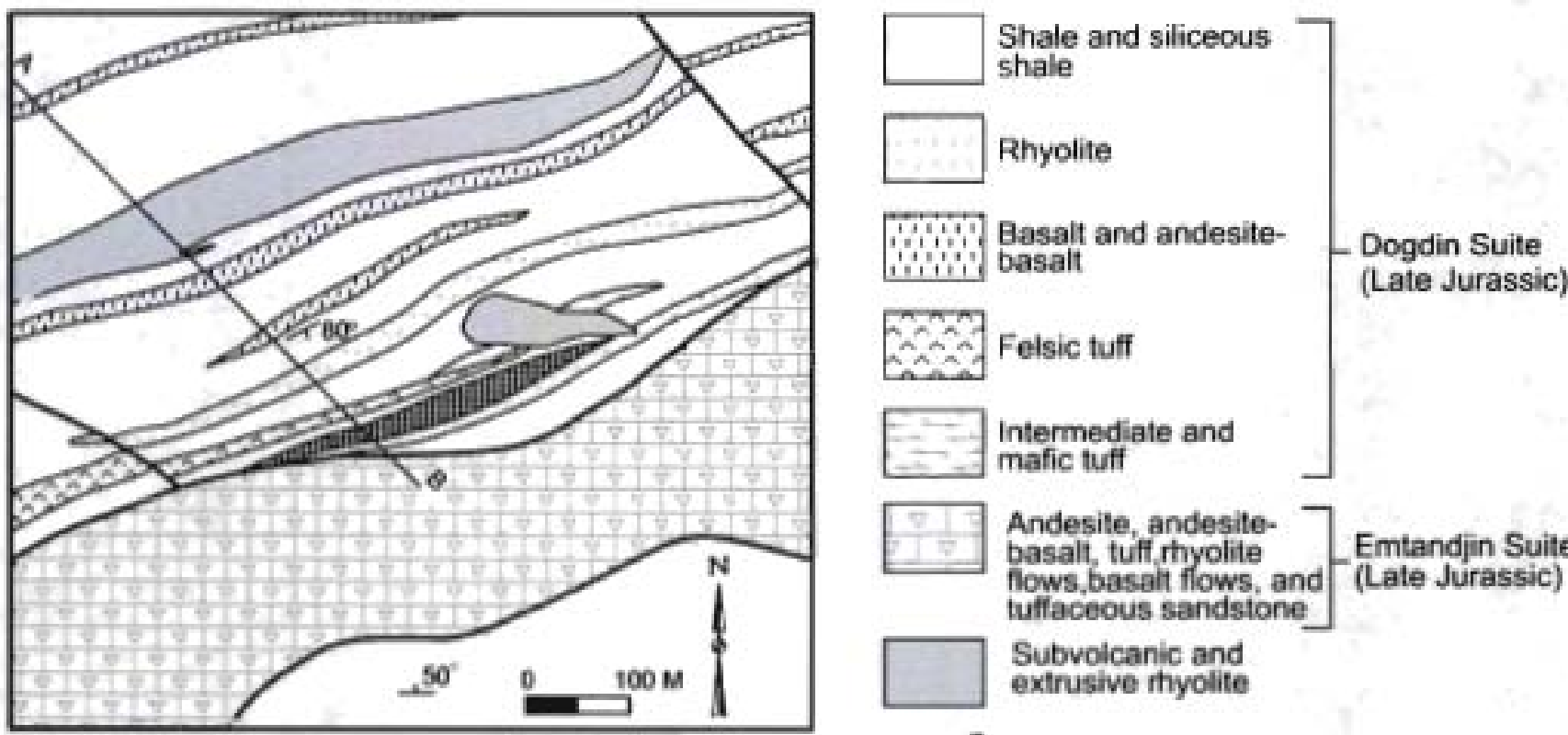

Andesite, andesitebasalt, tuff, rhyolite flows, basalt flows, and tuffaceous sandstone

Emtandjin Suite

Subvolcanic and extrusive thyolite

Ore body

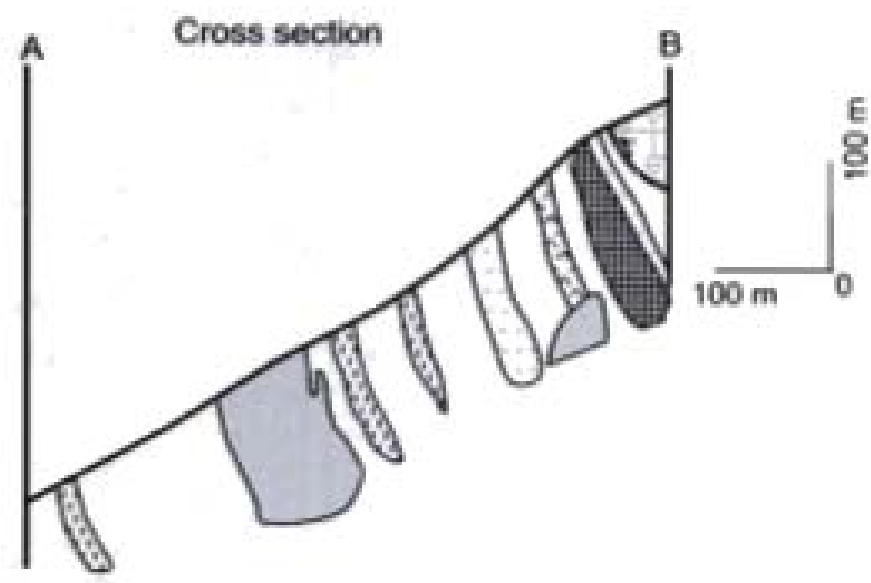
(fift:
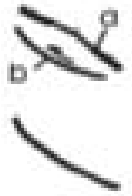

$\sim$

$\Upsilon^{80}$
Thrust fault (a, plan view; b, Cross section)

Fault, sense of displacement unknown

Contact

Strike and dip of bedding

Figure 51. Khotoidokh kuroko Po-Zn massive sullide deposil, Schematic geologic map and cross section. Adapted from Dylevsky. Zuyev, Chersky-Argatass Ranges metallogenic beit, Russian Northeast Schematic geologic map and cross section. Adapted from Dylevsky, Zuyev, and Shpikerman (1996).

Kimmeridgian Dogdin Formation which is about $450 \mathrm{~m}$ thick. This formation consists of marine, thin-bedded clastic sedimentary rocks which are interbedded with rhyolite lava and tuff and, to a smaller extent, with basalt and andesite-basalt. The volcanic rocks in the deposit are a bimodal rhyolite-basalt assemblage similar to which of island ares. The environment of formation of the deposit is similar to which of the Miocene Kuroko massive sulfide deposits of the Green Tuff belt in Japan. The known reserves are $180,000 \mathrm{tPb}, 900,000 \mathrm{Zn}, 150,000 \mathrm{t} \mathrm{Cu}$, and about $1,000 \mathrm{t} \mathrm{Ag}$. The average grades are $5.15 \% \mathrm{~Pb}, 14.9 \% \mathrm{Zn}, 0.796 \mathrm{Cu}, 0.5$ $1.0 \mathrm{~g} / \mathrm{Au}$ and more than $100 \mathrm{~g} / \mathrm{tg}$. 
The Chersky-Argatass Ranges metallogenic belt is hosted in the Indigirka-Oloy sedimentary-voleanic assemblage which consists chiefly of shallow-marine and nonmarine late Middle Jurassic to Neocomian formations which overly various accreted terranes of the Kolyma-Omolon superterrane (Nokleberg and others, 1994c, 1997o). The Indigirka-Oloy is composed mainly of sandstone, siltstone, shale, conglomerate, and volcanic rocks of varying composition. The igneous rocks of the indigirka-Oloy assemblage include coeval plutonic rocks and mainly shallow-marine, rarely nonmarine basalt, andesite, rhyolite, and tuff with interlayered sandstone, conglomerate, siltstone, and shale. The belt also contains small bodies of granite, granodiorite, and monzogranite. The igneous rocks of the Indigirka-Oloy sedimentary-volcanic assemblage are interpreted as part of the Jurassic Uyandina island arc which formed on margin of the Kolyma-Omolon superterrane during final stages of migration towards, but before accretion the northeastern North Asian Craton (Nokleberg and others, 2000).

\section{Yassachnaya River Metallogenic Belt of Pb-Zn Skarn, Porphyry $\mathrm{Cu}$, and $\mathrm{Cu}-\mathrm{Ag}$ Vein Deposits (Belt YS) Western Part of Russian Northeast}

The Yasachnaya River metallogenic belt of $\mathrm{Pb}$ - $\mathrm{Zn}$ skam, porphyry $\mathrm{Cu}$, and $\mathrm{Cu}-\mathrm{Ag}$ vein deposits (fig. 48; tables 3,4) occurs in the Yasachnaya River basin in the western part of the Russian Northeast. The belt extends in two branches to the northwest for nearly $500 \mathrm{~km}$ and ranges up to $100 \mathrm{~km}$ wide. The deposits are hosted in or near Late Jurassic granitic and subvolcanic intrusive bodies which are associated with the Uyandin-Yassachny volcanic-plutonic belt, part of the Indigirka-Oloy overlap assemblage (unit io, fig. 48) (Nokleberg and others, 1994c, 1997c). The significant $\mathrm{Pb}-\mathrm{Zn}$ skam deposits are at Terrassnoe and Kunarev (tuble 4) (Nokleberg and others 1997a, b, 1998). A porphyry Cu stockwork deposit at Datsytovoe is spatially associated with the $\mathrm{Pb}-\mathrm{Zn}$ skarn deposit at Kunarev. These relations define a complex mineral deposit district where $\mathrm{Pb}-\mathrm{Zn}$ skam and porphyry $\mathrm{Cu}$ deposits are closely associated.

\section{Terrassnoe Pb-Zn Skam Deposit}

The Terrassnoe Pb-Zn skars deposit (Shpikerman, 1987; V.1. Shpikerman and others, written commun., 1988) occurs along a fault between Late Devonian (Frasnian) limestone and late Paleozoic pelitic and chert in the bottom of a Late Jurassic volcanic depression intruded by hypabyssal dikes which overly a buried late Mesozoic granitic intrusion. The skam consists of hedenbergite, gamet (andradite-grossular), and ilvaite. The main ore minerals are sphalerite, galena, chalcopyrite, and magnetile. Silver occurs mainly with sulfide minerals and Ag-polymetallic minerals predominate. Ag mineralization was later than the skam formation. The deposit contains a probable resource of 5.2 million tonnes with an average grade of about $1 \% \mathrm{~Pb}, 5 \% \mathrm{Zn}$, and 140 gt Ag. The deposit extends for $700 \mathrm{~m}$.

\section{Kunarev Porphyry Cu and Pb-Zn-Cu-Ag Skarn Deposit}

The Kunarev deposit (fig. 52) (Shpikerman, 1987; V.I. Shpikerman and N.E. Savva, written commun., 1988) is a composite deposit containing both porphyry $\mathrm{Cu}, \mathrm{Pb}-\mathrm{Zn}-\mathrm{Cu}-\mathrm{Ag}$ skam, and polymetallic replacement deposits. In the middle of the host volcanic sequence is a $\mathrm{Ag}$-Cu-Bi stockwork related to a porphyry trachyrhyolite dike and to a quartz diorite stock. Quartzcarbonate veinlets in the stockwork contain pyrite, chalcopyrite, sphalerile, galena, freibergite, and $\mathrm{Ag}$ - $\mathrm{Pb}$-Bi sulfosalts. The host rhyolite and quartz diorite exhibit an intense pyrite alteration, and the quartz diorite is propylitically altered. This part of the deposit is known as the Datsytowoe porphyry Cu occurrence.

To the west and south is the Kunaryov Pb-Zn-Cu-Ag skam deposit. The skams occurs as sheet-like replacements in Middle and Late Jurassic calcareous conglomerate, and in fissure veins above and beneath the conglomerate. The skams conaists of hedenbergite and garnet, along with pymhotite, sphalerite, and chalcopyrite. The central part of the deposit consists of relatively younger quartz-carbonate veins and veinlets which contain sphalerile, galena, chalcopyrile, pyrite, cobaltile, matildite, and galena: bismuthite. Average grades are $0.7-1.1 \% \mathrm{~Pb}, 1.15-10.5 \% \mathrm{Zn}$, and $47-170 \mathrm{~g} / \mathrm{Ag}$. Further to south, skams in the conglomerate are replaced by epidote- and jasper-bearing metasomatic rocks. In addition are polymetallic replacements with a thickneas from 10 to $25 \mathrm{~m}$ which occur in several places at the southern end of the deposit. The ore minerals are pyrite, sphalerite, chalcopyrite, and marcasile. 


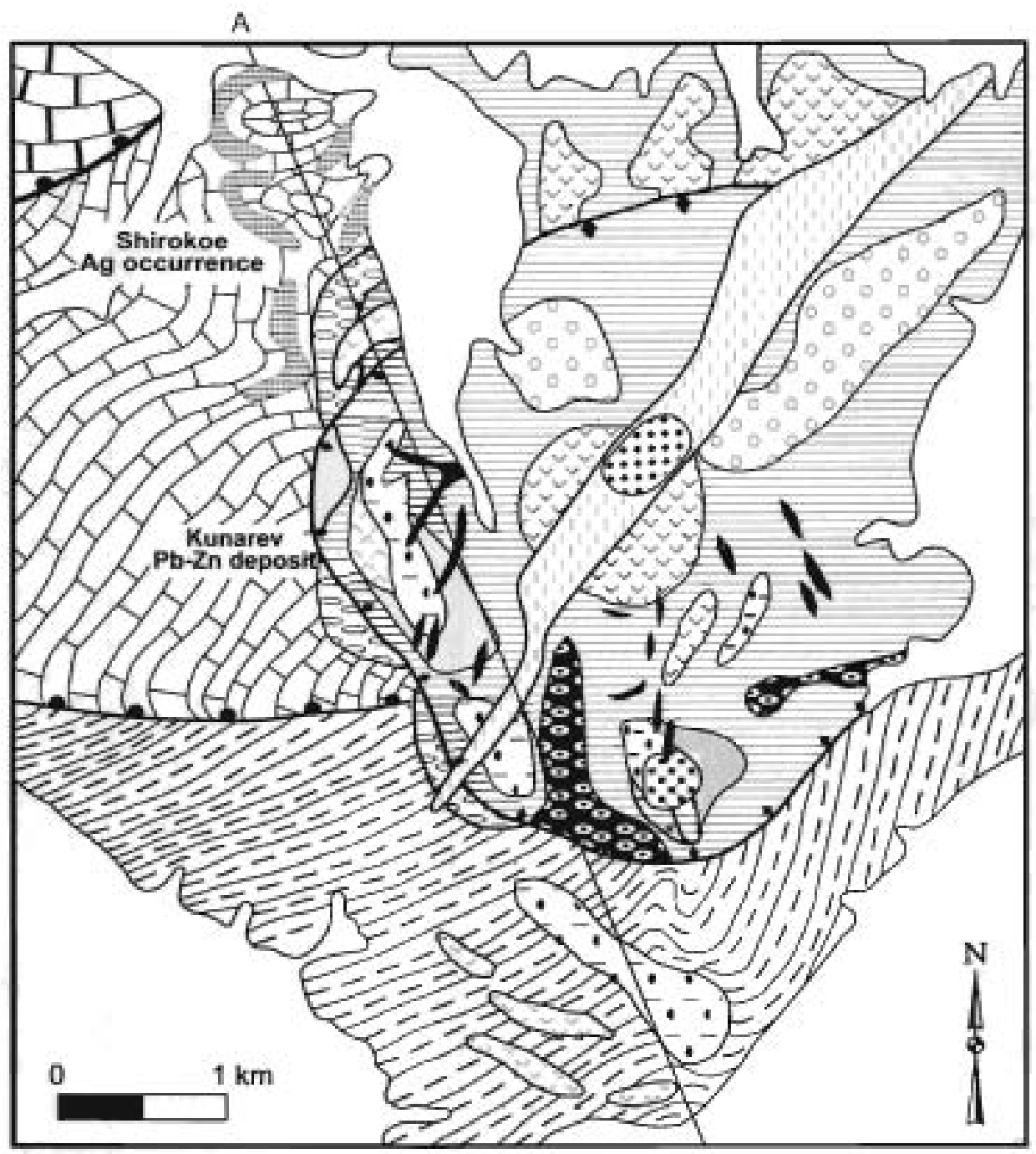

A

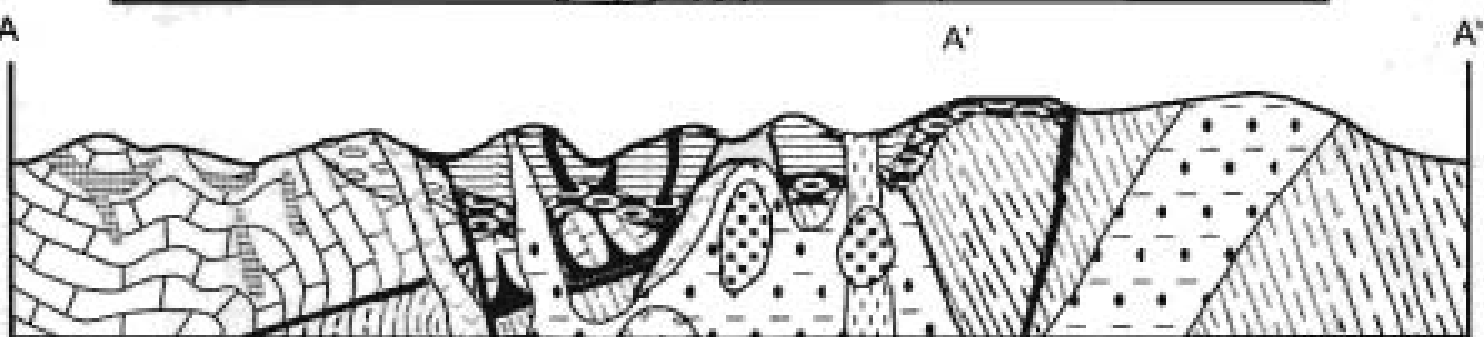

Figure 52. Kunarev $\mathrm{Pb}-\mathrm{Zn}-\mathrm{Cu}-\mathrm{Ag}$ skam deposit, Yasachnaya River metaliogenic belt, Russian Northeast. Schematic geologic map and cross section. Adapted from Shpikerman (1998).

The nearby Shirokoe Ag occurrence occurs farthest from the central part of the volcanic structure at the northwestern end of the ore field. The deposit oceurs in the lower volcanic sequence and consists of quartz-carbonate-sulfide stockwork and veins which are hosted in Early and Middle Devonian limestone. The stockwork and veins form conformable and crossing ore bodies with a complex morphology. The ore minerals are galena, $\mathrm{Pb}$ sulfostibnites, sphalerite, $\mathrm{Ag}$ sulfosalts, freibergite, acanthite, betechtinite, bournonite, native silver, and stibnite (N.E.Savva, written commun., 1989). The average grade of high-grade ore is $1,100 \mathrm{~g} / \mathrm{Ag}, 1.3 \% \mathrm{~Pb}, 0.6 \% \mathrm{Zn}$, and $0.4 \% \mathrm{Sb}$.

The Kunarev $\mathrm{Pb}-\mathrm{Zn}-\mathrm{Cu}-\mathrm{Ag}$ skarn deposit is hosted in an eroded, oval-shaped, late Mesozoic voleanic structure. At the base of the volcanic sequence are faulted Paleozoic clastic and carbonate rocks. The main part of the volcanic sequence consists of gently-lying, Late Jurassic volcanic and sedimentary rocks. The lower part the volcanic sequence contains calcareous conglomerates, up to $150 \mathrm{~m}$ thick, overlain by argillite which is about $350 \mathrm{~m}$ thick. The upper part consists of a mixed tuff member, with a thickness of about $80 \mathrm{~m}$. In the central part of the volcanic sequence is downdropped caldera with a diameter of about 4-5 km which extends into the folded Paleozoic basement. The caldera is filled with the upper volcanic sequence. Intrusive rocks include subvolcanic stocks composed of andesite, dacite, diorite, and granite-porphyries. Explosive breccias also occur. A 


\section{Explanation}

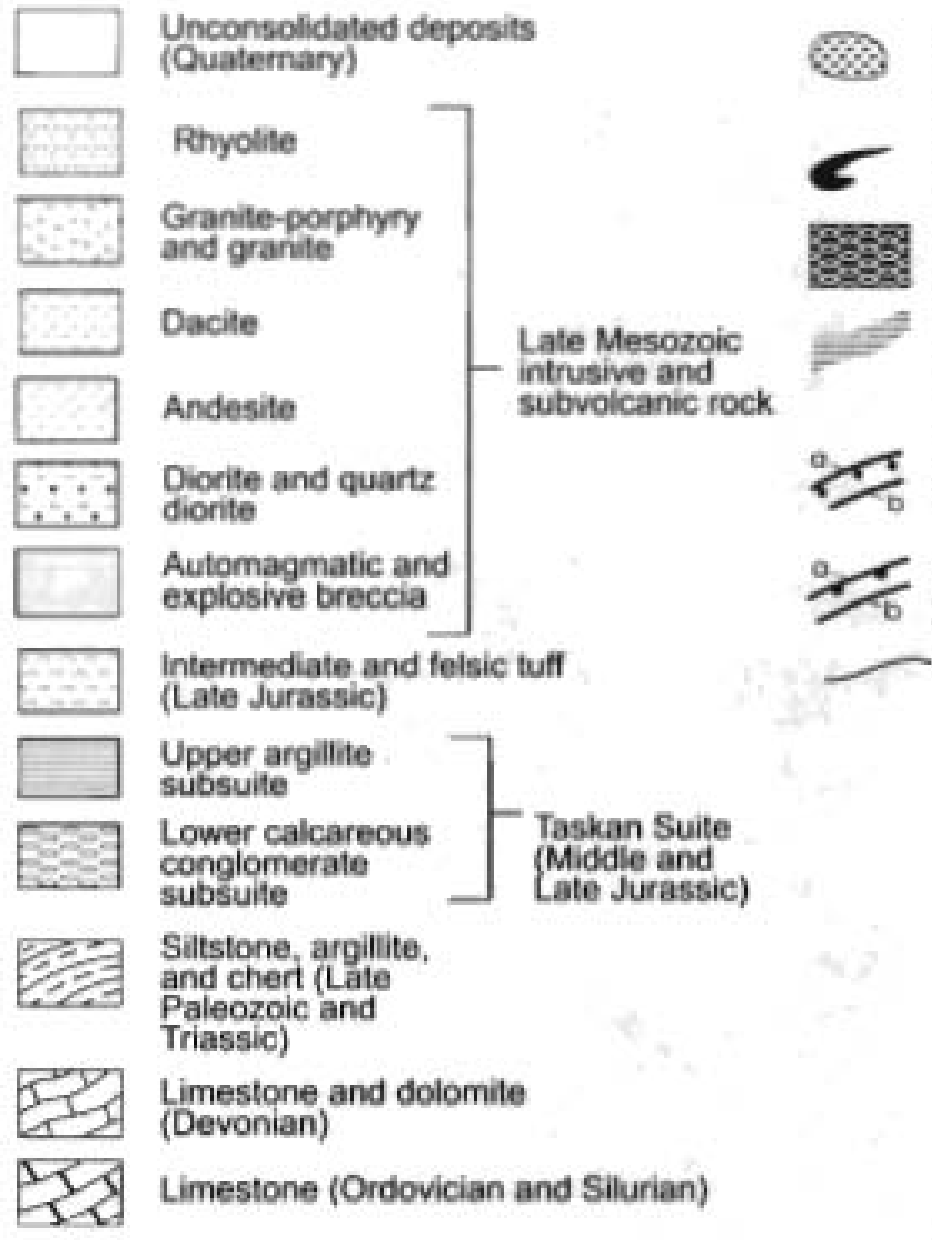

Copper and polymetallic minerals in veinlets and disseminations in subvolcanic rocks

Polymetallic skarn-sulfide veins and melasomatic replacement bodies

Conglomerate partly altered to skam and epidote-bearing polymetallic sulfides

Quartz-carbonate-sulfide veins, veinlets and disseminations with high $\mathrm{Ag}_{9}$

Arc-shaped fault bounding volcanotectonic structure ( $a$, plan view; $b$, cross section view)

Thrust fault (a, plan view; $b$. cross section view)

Contact

trachyrhyolite dike is the youngest intrusive and trends northeast. Rb-Sr isotopic ages for the subvolcanic rocks are $141.5 \pm 6.5 \mathrm{Ma}$ (E.F. Dylevsky, written commun., 1988).

\section{Origin of and Tectonic Controls for Yasachnaya River metallogenic beit}

The $\mathrm{Zn}-\mathrm{Pb}$ skams and associated deposits of the Yasachnaya River metallogenic belt occur mainly in Paleozoic carbonate rocks of the Omulevka passive continental margin lerrane of the Kolyma-Omolon supenterrane where intruded by Late Jurassic granite, diorite, and rhyolite of the Uyandin-Yassachny volcanic-plutonic belt, part of the Indigirka-Oloy overlap assemblage (fig. 48). Petrochemical zonation of the Uyandina-Yassachny volcanic-plutonic belt suggests that the igneous rocks of this magmatic afe and associated metallogenic belt formed over a subduction zone which dipped towands the core of the Omulevka terrane. The Uyandin-Yassachny volcanic-plutonic belt and associated lode deposits of the Yasachnaya River metallogenic belt are interpreted as forming in the Late Jurassic Uyandina igneous arc which formed along the margin of the Kolyma-Omolon superterrane, immediately before acctetion of the supenterrane to the North Asian Craton (Nokleberg and others, 2000).

Oloy Metallogenic Belt of Porphyry Cu-Mo and

Au-Ag Epithermal Vein Deposits (Belt OL)

North-Central Part of Russian Northeast

The Oloy metallogenic belt of porphyry Cu-Mo and Aw-Ag epithermal vein deposits (fig 48; tables 3, 4) oceurs mainly in the Oloy volcanic-plutonic island are belt mainly in the drainages between the Oloy and Bolshoy Anyui rivers in the northcentral part of the Russian Northeast. The belt extends for $400 \mathrm{~km}$; the central part ranges up to $160 \mathrm{~km}$ wide. The numerous porphyry Cu-Mo-Au deposits and Au-Ag epithermal deposits in the belt are hosted in the Oloy volcanic belt which forms the northeastem part of the Indigirka-Oloy sedimentary and igneous assemblage (table 4) (Nokleberg and otherk, 1994c, 1997c). The significant porphyry Cu deposits are at Asket, Dalny, Innakh, and Peschanka (table 4) (Nokleberg and others 1997a, b, 1998). The significant Au-Ag epithermal deposits are at Vesennee and Klen. Associated Cu-Mo stockwork deposits occurs mainly in stocks and small bodies of the gabbro-monzonite-syenite series (Gorodinsky and others, 1978). In some areas, a zonation of felsio- 
magmatism-related deposits occurs in the Oloy metallogenic belt. Au-Ag epithermal veins generally occur peripheral to granitic intrusions which host porphyry Cu-Mo deposits whereas Au quartz-carbonate-sulfide polymetallic vein deposits occur in intermediate sites between the Au-Ag epithermal vein and porphyry Mo deposits.

\section{Peschanka Porphyry Cu-Mo Deposit}

The Peschanka porphyry Cu-Mo deposit (fig, 53) (Gorodinsky and others, 1978; Volchkov and others, 1982; Kaminskiy and Baranov, written commun., 1982; Migachev and others, 1984; V.V. Gulevich and others, written commun., 1993) occurs in the eastern portion of the Late Jurassic to Early Cretaceous Egdegkych multiphase pluton which is composed of monzodiorite and quartz monzodiorite which are intruded by planar bodies of quartz monzonite and granodiorite porphyry. The deposits consists of sulfide veinlets and disseminations, with pervasive $\mathrm{Cu}$ and Mo minerals which occur throughout the entire elongated quartz monzonite and granodiorite porphyry body and which extend into the wall rock. The main ore minerals are pyrite, chalcopyrite, bornite, tetrahedrite-tennantite, and molybdenite. Minor or rare minerals are magnetite, hematite, sphalerite, galena, chalcocite, native gold Au-tellurides, enargite, arsenopyrite, pyrrhotite, and marcasite. The gangue minerals are quartz, carbonate, and anhydrite. Four mineral associations occur. (1) molybdenite which is associated with the quartz-sericite subzone of phyllic alteration; (2) pyrite and chalcopyrite which are associated with quartz-sericite-chlorite alteration; (3) chalcopyrite, bornite, and tetrahedrite which are associated with quartz-sericite and biotite alteration; and (4) polysulfide minerals which occur with all alteration types. Mineralization was preceded by wide-spread pyritization in the peripheral propylitic zone. The deposit contains an estimated resource of 940 million tonnes with an average grade $0.51 \% \mathrm{Cu}, 0.019 \% \mathrm{Mo}, 0.42 \mathrm{~g} / \mathrm{t} \mathrm{Au}$, and $1.4 \mathrm{~g} / \mathrm{Ag}$.
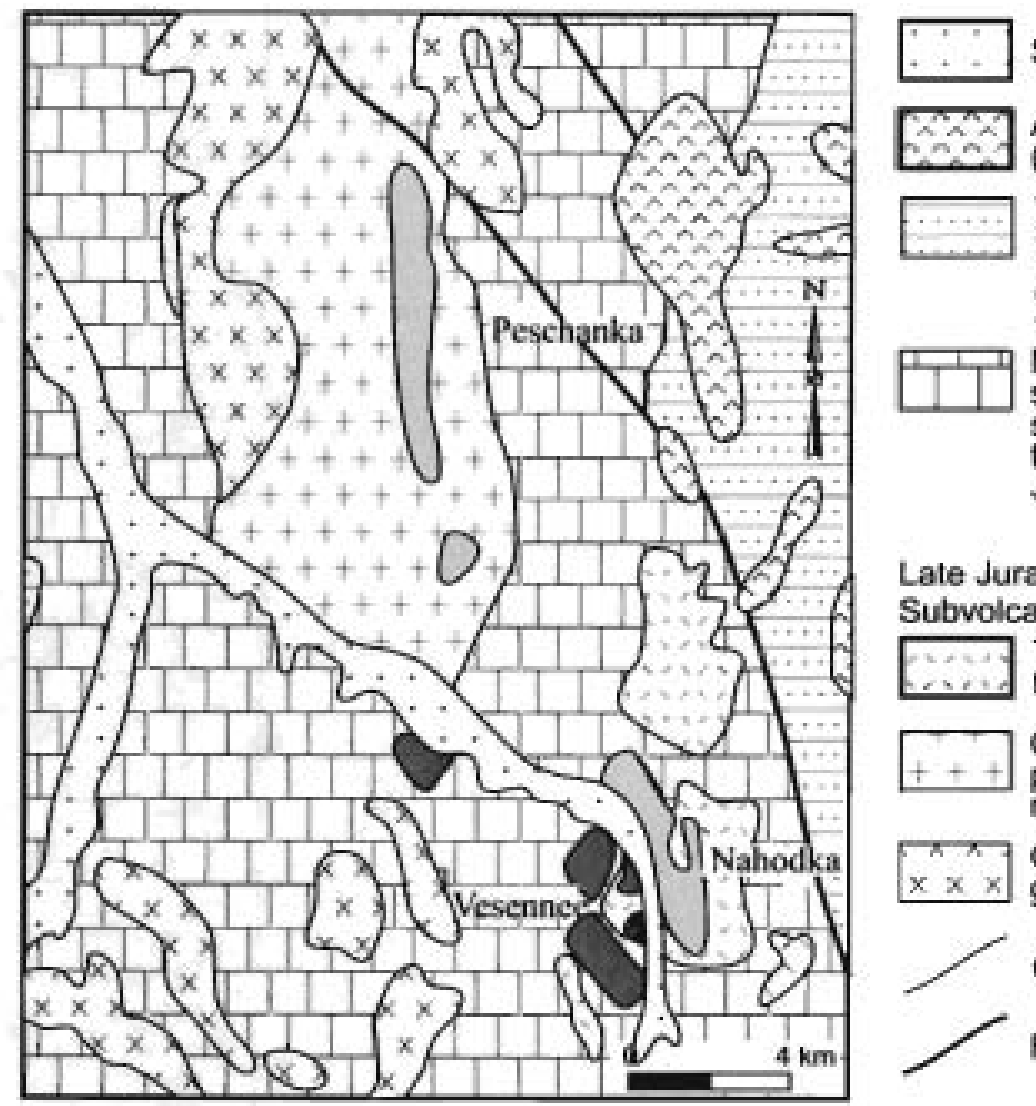

Surficial rock (Quatemary)

Andesite and dacite (Late Cretaceous)

Continental sedimentary rocks: sandstone \& siltstone with interlayered gritstone. conglomerate, and coal (Early Crelaceous)

T11 Marine sedimentary rocks: siltstone, mudstone, sandstone, conglomerate. tuff, and lava (Late Jurassic)

Late Jurassic-Early Cretaceous Subvolcanic and Intrusive rock Trachydacite, trachyrhyolite, …. trachyandesite

+ Quartz syenite, granosyenite+++ porphyry, quartz monzonite, monozonite-porphyry $\begin{array}{llll}x & x & x & \text { Gabbro, monzodionite, } \\ \text { gabbro-monzonite }\end{array}$

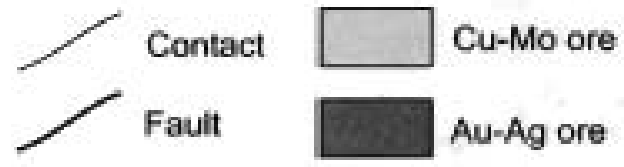

Figure 53. Peschanka porphyry Cu deposit, Oloy metallogenic belt, Russian Northeast. Schematic geologic map. Adapted from Migachev and others (1984) using materials of V.V. Gulevich and E.F. Dylevsky.

\section{Vesennee Aus-Ag Epithermal Vein Deposit}

The Vesennee Au-Ag epithermal vein deposit (Gorodinsky and others, 1974; Shilo and others, 1975; Shapovalov, 1976; Sidorov, 1978; V.V. Gulevich and others, written commun., 1993) consists of carbonate-quartz veins, altered veinlets, and mineralized breceias which oecur in structurally complex forms. The veins are controlled by northeast- and approximately eastwest-trending fractures which cut northwest-trending zones of associated granitoid rocks. Individual ore bodies range from 150 to $500 \mathrm{~m}$ long. The ore minerals are sphalerite, galena, pyrite, chalcopyrite, tetrahedrite, tennantite, bournonite, and electrum, with minor Ag-sulfides and sulfosalts, stannite, and matildite. The main gangue minerals are quartz, calcite, and thodochrosite with 
subordinate adularia, dolomite, celestite, and gypsum. Au:Ag ratio varies from 1:5 10 1:30. The deposit occurs mainly in propylitically-altered trachyandesite which is part of an Late Jurassic volcaniclastic sequence which is intruded by hypabyssal bodies und dikes of gabbro rocks, syenite, granodiorite porphyry, and andesite-dacite, all of Late Jurassic to Late Cretaceous age. The deposit is of medium size and grade ranges from 0.1 to $48 \mathrm{~g} / \mathrm{Au}$ and up to $300 \mathrm{~g} / \mathrm{Ag}$.

\section{Origin of and Tectonic Controls for Oloy metallogenic belt}

The age of mineralization age for the Oloy metallogenic belt is interpreted as Late Jurassic (Gulevich, 1974). However, some K-Ar isotopic data indicate an Early Cretaceous age for some of the associated intrusions, and some deposits occur in Early Cretaceous wall rocks (Gorodinsky and others, 1978). Some, still younger porphyry and epithermal vein deposits may be related to remobilization during post-accretionary magmatism in the Late Cretaceous. The porphyry deposits in the Oloy metallogenic belt contain characteristic, widespread magnetite, Co, and PGE minerals which are interpreted as being derived from hosting oceanic terranes into which igneous rocks of the Oloy volcanic-plutonic belt intruded.

The Oloy metaliogenic belt is hosted in the younger (Neocomian) part of Late Junssic-Neocomian Oloy-Svyatoy Nos volcanic belt (Nokleberg and others, 1994c, 1997c). This igneous belt occurs along the northeastern margin of the KolymaOmolon superterrane and is part of the Indigirka-Oloy sedimentary-volcanic-plutonic assemblage. The volcanic belt occurs along the northeastern margin of the Kolyma-Omolon superterrane and consists of shallow-marine and nonmarine mafic, intermediate, and siliceous volcanic rocks and tuff, associated sedimentary rocks, and small plutons of granite, granodiorite, and monzogranite (Shul'gina and others, 1990; Natapov and Shul'gina, 1991). The volcanic belt also contains small bodies of granite, granodiorite, and monzogranite. The Oloy volcanic belt is interpreted as forming the upper part of the Oloy island are during a short-lived period of Early Cretaceous subduction of part of the South Anyui terrane beneath the northeastern margin of the Kolyma-Omolon superterrabe, after accretios of the Kolyma-Omolon superterrane to the North Asian Craton Margin (Nokleberg and others, 1994c, $1997 \mathrm{c}, 2000)$.

\section{Pekuiney Metallogenic Beit of Basaltic Cu Deposits (Belt PK) Eastern Part of Russian Northeast}

The Pekulney metallogenic belt of basaltic $\mathrm{Cu}$ deposits occurs in a north-east-trending belt which extends along the Pekulney Range in the eastem parn of the Russian Northeast (fig 48; tables 3,4) (Nokleberg and others, 1997b, 1998). The belt exiends for aboul $170 \mathrm{~km}$ and nnges up to $20 \mathrm{~km}$ wide. The belt is hosted in the Late Jurassic and Early Cretaceous rocks of the Pekul'ney subduction-zone terrane (Nokleberg and others, 1994c, 1997e). The significant deposit is at Skalistaya.

\section{Skatistaya Basaitic Cu Deposit}

The Skalistaya deposit (Shkursky and Matveenko, 1973) consists of a network of prehnite-pumpellyite-silica-carbonate and epidote-carbonate veinlets which vary from 2 to $20 \mathrm{~cm}$ thick and which contain disseminated native copper. The veinlets occur is basalt and consist mostly of prehnite and low-Fe pumpellyite. The secondary minerals consist of laumontite, calcite, dolomile, chlorite, quartz, epidote, and adularia. Native copper intergrowths, ranging from 0.5 to $8 \mathrm{~mm}$ in diameter, occur in prehnite aod pumpellyite masses and in wall rocks. Cu content of the ore is about 1 to $2 \%$, and the native copper contains up to $100 \mathrm{gll}$ Ag The ore bodies oecur in amygdaloidal basalt and associated tuff in a Late Jurassic to Early Cretaceous volcaniclastic sequence which exiends over an area of about 1.0 by $0.6 \mathrm{~km}$. Similar occurrences of native copper are knowa along a zone which is up to $18 \mathrm{~km}$ long. The deposit is small with Cu grading about $1-2 \%$.

\section{Origin of and Tectonic Controls for Northwestern Pekulney Metallogenic Belt}

The Pekul'ney subduction-zone lerrane, which hosts the Pekulney metallogenic belt, is divided into western and eastem units (Nokleberg and others, 1994c, 1997e). The western unit consists of: (1) a basal serpentinite matrix melange which contains fragments of metamorphic rocks, including greenschist, glaucophane schist, and picritic basalt; (2) a metamorphic complex which is composed of amphibolite and schist which are derived from dunite, spinel peridotile, clinopyroxenite and which yields $\mathrm{Pb}-\mathrm{Pb}$ isotopic ages of 1,600 to L,800 Ma, and eclogite inclusions which yield isotopic ages of $2,400-1,900 \mathrm{Ma}$; and (3) the Late Jurassic and Early Cretaceous Pekulneyveem Formation which is composed of basalt, tuff, hyaloclastite, radiolarian chert, siltstone, and sandstone. The basalt flows range up to 60 to $80 \mathrm{~m}$ thick and are interbedded with tuff, and cherty shale, all with abundant hematite (Shkursky and Matveenko, 1973). The eastern Televeem unit consists of a thick flysch sequence of Early Cretaceous (Aptian to Albian) and Late Cretaceous (Cenomanian to Turonian) age. The basaltic $\mathrm{Cu}$ deposits occur in the Pekulneyveem Formation and are interpreted as forming in a primitive island arc and neighboring sea-floor environment with subsequent incorporation of the host rocks and deposits into a subduction zone, now preserved in the Pekul'ney subduction-zone iemane that was tectonically linked to the Pekulney island arc. 
The Tamvatney-Mainits metallogenic belt of podiform $\mathrm{Cr}$ deposits (fig. 48; tables 3,4) occurs in the Tamvatney ophiolite and other similat units in the east-central part of the Russian Northeast. The Tamvatney ophiolite is tectonically interiayered with other units in the Mainitskiy island-arc terrane (Nokleberg and others, 1994c, 1997c). The depostts consist of sparse localities of massive chrome spinel with accessory Os-Ru-Ir minerals in dunite, pyroxenite, and associated rocks (Dmitrenko and others, 1987. 1990). The significant deposits at Krasnaya and Chirynai occur in dunites and layered complexes of gabbro, dunite, and peridotite (table 4) (Nokleberg and others 1997a, b, 1998).

\section{Krasnaya Podiform Cr Deposit}

The Krasnaya podiform Cr deposit (fig. 54) (Dmitrenko and Mochalov, 1986; Dmitrenko and others, 1987) consists of two borizons with numerous chromite bodies occur within the Krassnaya Gora alpine-type ultramafic body. An upper horizon occurs at the contact of dunite and an overlying intergrown pyroxenite-dunite-harzburgite assemblage. Chromite occurs in dunite bands. Podiform and schlieren occurrences of nearly massive to massive chromite extend for $35-70 \mathrm{~m}$ with a thickness of up to several meters. Several large podiform chromite bodies at the base of dunite layers contain massive and concentrated chromite for $60-100 \mathrm{~m}$ along strike and are more than $1 \mathrm{~m}$ thick. Zones of disseminated chromite up $22 \mathrm{~m}$ thick also occur. PGE associated with chromite oceur as solid solution in the sulfides with Os, Ir, and $\mathrm{Ru}$ in hexagonal sites, and Ir, Os, Pt, Ru, and Rh in cubic sites. Some secondary, nare, platinum, rhodium, and palladium arsenides and sulfoarsenides are also identified.
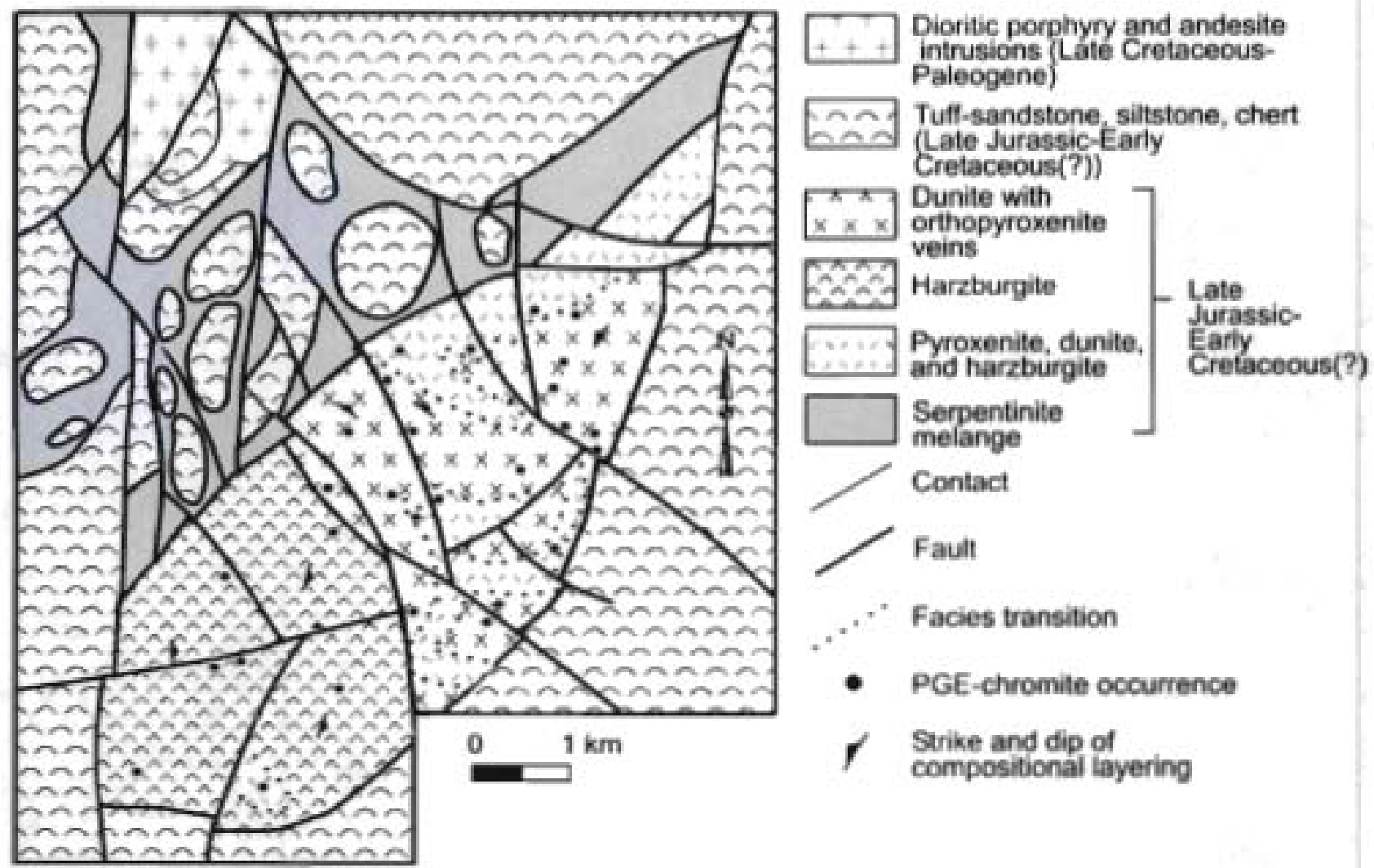

Figure 54. Krasnaya Gora podilorm $\mathrm{Cr}$ deposit. Tamvatney-Mainits metallogenic belt, Russian Northeast. Schematic geologic map. Adapted from Dmitrenko and others (1987).

\section{Origin of and Tectonic Controls for \\ Tanvatney-Mainits Metallogenic Belt}

The Tamvatney ophiolite which hosts the Tarnvatney-Mainits metallogenic belt consists of a large, steeply-dipping tectonic block composed of an older assemblage of mainly serpentinite melange with peridotite and lherrolite, and a younget assemblage of Late Jurassic to Early Cretaceous (Neocomian) basalt, andesite, and mafic volcaniclastic rocks (Dmitrenko and others, 1990). The serpentinile melange has a complex structure and consists of ultramafic rocks, gabbro, chert, Paleozoic and Early Mesozoic limestone, amphibolite, green and glaucophane schist, and eclogite. The younger assemblage consists of jasper. 
shale, basalt. plagiorhyolite, siltstone, and sandstone age (Tilman and others, 1982; Markov and others, 1982). Lower structural assemblage is an accretionary prism dominated by former oceanic lithosphere, whereas the upper assemblage is interpreted as the base of the Late Jurassic and Early Cretaceous Mainitskiy island are (Palandzhyan and Dmitrenko, 1990). The podiform Cr deposits in the metallogenic belt (Krassnaya Gora and other deposits) are hosted in the older assemblage whereas the minor Cyprus massive sulfide deposits are hosted in the younger assemblage. The Mainitskiy terrane is tectonically linked to the Alkatvaam accretionary-wedge terrane (Nokleberg and others, 2000).

Mainits Metallogenic Belt of Kuroko

Massive Sulfide Deposits (Beit MA)

Eastern Part of Russian Northeast

The Mainits metallogenic belt of Kuroke massive sulfide deposits (fig. 48; tables 3, 4) occurs in the eastern part of the Russian Northeast. The east-west-trending belt is $170 \mathrm{~km}$ long, up to $40 \mathrm{~km}$ wide, and is hosted in the Late Jurassic and Early Cretaccous Mainitskiy island-arc terrane (Nokleberg and others, 1994c, 1997c). The significant deposit in the belt is at Ugryumoe (table 4) Nokleberg and others 1997a, b, 1998).

\section{Ugryumoe Massive Sulfide Deposit}

The Ugryumoe deposit consists of massive sulfides which contain high concentrations of $\mathrm{Cu}, \mathrm{Zn}$, $\mathrm{Pb}$, and $\mathrm{Au}$ which occur along a silicified zone up to $3 \mathrm{~km}$ long (Oparin and Sushentsov, 1988). The sulfide horizons consists of massive pyrite, and chalcopyrite, pyrite, and quartz. The sulfides occur in a Mesozoic sequence of interbedded basalt, plagiothyolite, tuff, and siliceous tuffaceous siltstone. The deposit is interpreted as a possible kuroko massive sulfide deposit and occurs in the Hettangian and Sinemurian Lazov sequences. The sequences contain interbedded basalt, plagiorhyolite, tuffs, and tuffaceous siltstone. Intrusive rocks include granite, plagiogranite, and gabbro. Abundant geological data suggest significant potential for additional massive sulfide deposits in this beli.

\section{Origin of and Tectonic Controls for Mainits metallogenic beit}

The Mainitskiy island-are terrane which hosts the Mainits metallogenic belt consists of older and a younger sequences (Nokleberg and others, 1994c, 1997c). The older sequence consists of: (1) a lower unit of serpentinite and serpentinite mélange which contain fragments of late Paleozoic and early Mesozoic ophiolites, and limestone with spilite and bedded jasper which contain Middie and Late Jurassic radiolarians; and (2) an upper unit of graywacke, siltstone, fuff, bedded chert which contain rare Berriasian and Valanginian Buchia. Local olistoliths are common and are composed of ophiolite, limestone, plagiogranite, andesite, and rhyolite which are all metarnorphosed to pumpellyite facies. The younger sequence consists of a thick assemblage of Late Jurassic and Early Cretaceous island are volcanic and sedimentary rocks composed of tholeiitic basalt, andesitic basalt, rhyolite, tuff, breccia, chert, siltstone, and sandstone. The younger sequence is interpreted as primitive island are sequence and contains the Lazov sequence which hosts the massive sulfide deposits of the Mainits metallogenic belt. The Late Jurassic and Early Cretaceous pan of the Mainitskiy terrane is interpreted as forming in a island are which was tectonically linked to the Alkatvaam accretionary-wedge terrane (Nokleberg and others, 2000).

\section{Svyatoy-Nos Metallogenic Belt of Au-Ag Epithermal Vein Deposits (Beit SVN) Northern Part of Russian Northeast}

The Svyatoy-Nos metallogenic bell of Au-Ag epithermal vein deposits (fig, 48; tables 3,4) occurs in the northern part of the Russian Northeast. The deposits are closely related to inlermediate and felsic dikes with K-Ar isotopic ages of $149 \mathrm{Ma}$. which are part of Late Jurassic Svyatoy Nos volcanic belt (Bakharev and others, 1998). The epithermal Au-Ag deposits in the metallogenic belt, as at Polevaya, are associaled with dikes and small bodies of Early Cretaceous subvoleanic rhyolite, monzonite, and quartz syenite-porphyry (Nokleberg and others 1997a, b, 1998). The Svyatoy-Nos metallogenie belt is partly overlain by Cenozoic sedimentary rocks of the Primorskaya lowland. The sole significant deposit is at Polevaya (table 4).

\section{Polevaya Au-Ag Polymetallic Vein Deposit}

The Polevaya Au-Ag polymetallie vein deposit (Nekrasov, 1962; Bakharev and others, 1988) consists of two thin, subparallel zones of inlensely silicified and sericitized granodiorite and quartz diorite. The zones range from 1 to $2 \mathrm{~m}$ thick and up to $500 \mathrm{~m}$ long. The zones occur along and near the contact of an Early Cretaceous pluton which forms the core of a complex, Late Jurassic to Late Cretaceous volcanic-plutonic structure. The major minerals are chalcedony-like cryptocrystalline quartz, caleite, pyrite, galena, sphalerite, chalcopyrite, and gold. The sulfide content is about $2-3 \%$. The deposit contains up to $10 \mathrm{~g} / \mathrm{Au}$, $10 \mathrm{~g} / \mathrm{t}$ $\mathrm{Ag}, 0.020-1 \% \mathrm{~Pb}, 0.050-1 \% \mathrm{Zn}, 0.005 \cdot 0.3 \% \mathrm{Cu}$, and $0.5 \% \mathrm{Sn}$. 
The Svyatoy-Nos metallogenic belt is bosted in the younger (Neocomian) part of Late Jurassic and Early Cretaceous Oloy-Svyatoy Nos volcanic belt (Nokleberg and others, 1994c, 1997c). This igneous belt occurs along the northeastem margin of the Kolyma-Omolon superterrane and is part of the Indigirka-Oloy sedimentary-volcanic-plutonic assemblage. The belt contains mainly andesite, rhyolite, and tuff with interlayered shallow-marine sandstone, conglomerate, and siltstone (Parfenov, 1995a, b). The Oloy-Svyatoy Nos voleanic belt occurs adjacent to and southwest of the South Anyui terrane (fig. 48 ) and consists of mainly shallow-marine, rarely nonmarine basalt, andesite, rhyolite, and tuff with interlayered sandstone, conglomerate, siltstone, and shale. The volcanic belt also contains small bodies of granite, granodiorite, and monzogranite. The belt is interpreted as possibly related to a short-lived period of Late Jurassic Early Cretaceous subduction of the part of the South Anyui oceanic terrane beneath the northeastem margin of the Kolyma-Omolon superterrane, after accretion of the Kolyma-Omolon superterrane to the North Asian Craton Margin (Nokleberg and others, 1994c, 1997c, 2000).

\section{Kuyul Metallogenic Belt of Podiform $\mathrm{Cr}$, PGE and Associated Deposits (Belt KUY) East-Central Part of Russian Northeast}

The Kuyul metallogenic belt of podiform $\mathrm{Cr}$ and associated PGE deposits (fig. 48; tables 3,4) occurs in the southern part of the major nappe and thrust belt of the Koryak Highlands in the east-central part of the Russian Northeast. The belt extends for more than $900 \mathrm{~km}$ from the Taigonoss Peninsula to the northern spurs of the Pekulney Range. The metallogenic belt is hosted in the Kuyul ophiolite, part of the Gankuvayam and Elistratov units of the Kuyul subterrane (unit TLK) of the Talovskiy subduction zone-oceanic terrane (Nokleberg and others, 1994c, 1997c). The Kuyul ophiolite contains about 20 poorly-prospected $\mathrm{Cr}$ deposits in serpentinized peridotites which occur in about 50 mainly small, discontinuously-exposed ultramafic bodies. The significant deposits in the belt are at Talov and Tikhorechen (table 4) (Nokleberg and others 1997a, b, 1998). These deposits consist of chromite and accessory chromium spinel which occur with PGE minerals in dunite and associated ultramafic rocks, PGE minerals, in association with gold, is hosted in serpentinite and rodingite adjacent to peridotite and dunite. Local $\mathrm{Cu}-\mathrm{Zn}-\mathrm{Co}-\mathrm{Ag}$ sulfide minerals occur in carbonate breccias (Gorelova, 1990).

\section{Origin of and Tectonic Controls for Kuyul Metallogenic Belt}

The Kuyul subterrane of the Talovskiy terrane consists chiefly of tectonic sheets composed of (Nokleberg and others, 1994c, 1997c); (1) serpentinite melange with blocks of: (a) ultramafic rock, gabbro, plagiogranite, dike suites of oceanic and subduction zone origin, and amphibolite; (b) island are volcanic and sedimentary deposits composed mainly of andesite, dacile, tuff; and glaucophane schist; and (c) foreatc tuff and sedimentary tocks; (2) Kuyul ophiolite composed of harzburgite, gabbro, troctolite, wehrlite, plagiogranite, sheeted dikes, and pillow lava of Bathonian and Tithonian age (Chekov, 1982; Markov and others, 1982); (3) Kingiveem complex composed of oceanic volcanic, siliceous, and carbonate rocks of Permian, Middle and Late Triassic, and Middle Jurassic age; and (4) the Kuyul subduction-zone melange composed of Late Jurassic and Early Cretaceous turbidite deposits which contain Buchia and Middle Jurassic rodiolarian chert.

The Kulul ophiolite assemblage which hosts the Kuyul metallogenic belt is interpreled as forming either: (1) during spreading of a marginal-sea basin during the early stages of island arc formation; or (2) adjacent to a transform fault along the margin of an ocean basin (Palandzhyan and Dmitrenko, 1990). The Talowskiy subduction-zone terrane is tectonically linked to the mainly Late Jurassic and Early Cretaceous Koni-Murgal island-are terrane (Nokleberg and others, 2000).

\section{Metallogenic Belts Formed in Late Mesozoic Koyukuk and Togiak island Arc Systems in Western and Southwestern Alaska}

\section{Eastern Seward Peninsula and Marshall Metallogenic Belt of Podiform Cr Deposits (Belt ESM) Northwestern Alaska}

The Eastern Seward Peninsula and Marshall metallogenic belt of podiform $\mathrm{Cr}$ deposits occurs in the eastem Seward Peninsula and in the Marshall (Andreatsky River) area to the south in northwestern Alaska (fig. 49; tables 3,4) (Nokleberg and others, 1997b, 1998). No significant lode deposits are known from the belt, but small, isolated occurrences of nickel sulfide minerals are found in ultramafic rocks in the region. These occurrences are interpreted as the sources of PGE minerals which have been recovered in placer mines in Sheep Creek and Dime Creek, and in the Ungalik River in the Koyuk district. The metallogenic belt is hosted in a complexly-deformed, fault-bounded unit of ophiolite and related tocks which occur discontinuously in five small areas (Foley and others, 1982). In the eastern Seward Peninsula area, the units consists of fault-bounded slivers of ultramafic 
rocks and serpentinite which occur along the tectonic boundary between the Koyukuk island-are terrane to the east and the Seward metamorphosed continental margin terrane to the west (Nokleberg and others, 1997b, 1998, Sheet 3). In the Marshall (Andreatsky River) area, the unit consists of pillow basalt, chen, diorite, gabbro, serpentinite, and harzburgite. In both areas, the ophiolite and related rocks are interpreted as small, isolated klippen or faulted slivers of the upper part of the Angayucham oceanic and subduction-zone terrane. The thrust slices of ultramafic rocks in the highest structural level of the Angayucham terrane are interpeted lower part of an ophiolite which consitutes the base of the Koyukuk istand arc (Loney and Himmelberg, 1989, Patton and Box, 1989). This interpretation suggests that the Eastern Seward Peninsula and Marshall metallogenie belt of pediform $\mathrm{Cr}$ deposits formed during subduction-related intrusion of mafic-ultramafic plutons into the basal part of the Late Jurassic Koyukuk island are (Nokleberg and others, 1993; Goldfarb, 1997; Nokleberg and others, 2000).

\section{Kobuk Metallogenic Beit of \\ Podiform Cr Deposits (Beit KB) \\ Northern Alaska}

The Kobuk metallogenic belt of podiform $\mathrm{Cr}$ and associated PGE deposits, and one serpentine-hosted asbestos deposit (fig. 49; tables 3, 4), occurs for several hundred kilometers along the southern flank of the Brooks Range in northern Alaska. The metallogenic belt is hosted in the upper structural of the Angayucham oceanic and subduction-zone terrane (Jones and othern, 1987: Nokleberg and others, 1994c, 1997c) which is interpreted as the basal part of the Koyukuk island arc (Patton and others, 1994). The major podiform Cr deposits are at Iyikrok Mountain, Avan, Misheguk Mountain, and Siniktanneyak Mountain (table 4) (Nokleberg and others 1997a, b, 1998). The serpentine-hosted asbestos deposit is at Asbestos Mountain.

\section{Misheguk Mountain Podiform Cr Deposit}

The Misheguk Mountain Podiform Cr deposit (Roeder and Mull, 1978; Degenhart and others, 1978; Zimmerman and Soustek, 1979; Foley and others, 1984, 1982, 1997) consists of disseminated fine- to medium-grained chromite in Jurassic or older, locally serpentinized dunite and peridotite tectonite. The dunite and harzburgite layers are intensely deformed into minor folds. Grab samples contain up $1027.5 \% \mathrm{Cr}$ and $0.31 \mathrm{~g} / \mathrm{PGE}$, and the deposit contains an estimated 110,000 to 320,000 tonnes chromite. Chromite-bearing zones have surface dimensions of 31 by $107 \mathrm{~m}$. The deposit is interpreted as part of a dismembered ophiolite.

\section{Avan Podiform Cr Deposit}

The Avan podiform Cr deposit (Roeder and Mull, 1978; Degenhart and others, 1978; Zimmerman and Soustek, 1979; Mayfield and others, 1983; Foley and others, 1985, 1982) consists of disseminated fine- to medium-grained chromite in Jurassic or older dunite and harzburgite tectonite which is locally aliered to serpentinite. Zones of chromite in dunite are up to a few meters wide and a few hundred meters long, the host dunite and harzburgite layers exhibit intense minor folds. Grab samples contain up to $43 \% \mathrm{Cr}$ and $0.48 \mathrm{~g} / \mathrm{PGE}$. The deposit contains an estimated 290,000 to 600,000 tonnes chromite.

The dunite and harzburgite tectonite host rocks at Avan and elsewhere are bosted by which occur as fauli-bounded slabs in the Misheguk igneous sequence which also contains pillow basalt, gabbro, chert, and minor limestone (Roeder and Mull, 1978; Zimmerman and Soustek, 1979; Nelson and Nelson, 1982; Foley and others, 1982). The age of the ultramafic rocks hosting the podiform $\mathrm{Cr}$ deposits is probably Jurassic (Patton and ethers, 1994). This sequence is part of the Angayucham subduction zone terrane (Patton and others, 1994). The ultramafic rocks hosting the Asbestos Mountain deposit also occur as fauli-bounded slabs in the upper part of the Angayucham terrane.

\section{Origin of and Tectonic Controls for Kobuk Metallogenic Beit}

The Kobuk metallogenic belt occurs in highly-deformed mafic and ultramafic rock that forms the upper structural level of the Angayucham subduction zone ternane along the southern margin of the Brooks Range (fig, 49; tables 3, 4). The belt occurs mainly is a major east-west-striking, south-dipping thrust sheet which extends for several hundred km, and in sparse isolated klippen. These Angayucham terrane occurs along south-dipping faults over the highly deformed metamorphosed, middle Paleozoic and older metasedimentary, metavoleanic, and lesser metagranitoid rocks of the Coldfoot metamorphosed continental margin terrane to tbe north, and in tarn are overthrust by the mainly island-are, Late Jurassic and Early Cretaceous Koyukuk island-are ierrane to the south (Moore and others, 1992; Patton and others, 1994). The thrust slices of ultramafic rocks in the highest structural level of the Angayucham ternane are interpeted lower part of an ophiolite which consitutes the base of the Koyukak island are (Loney and Himmelberg. 1989, Patton and Box, 1989; Patton and others, 1994). This interpretation suggests that the Kobuk metallogenic belt of podiform $\mathrm{Cr}$ and related deposits formed during subduction-related intrusion of maficultramafic plutons into the basal part of the Late Jurassic Koyukuk island arc (Nokleberg and others, 1993; Goldfarb, 1997; Nokleberg and others. 2000). 
The Southwestern Alaska metallogenic belt of zoned mafic-ultramafic PGE deposits (fig. 49; tables 3.4) are hosted in the Goodnews subduction zone and Togiak island-arc terranes (Nokleberg and others, 1994c, 1997c). The significant deposits in the beit are: (1) a concealed Fe-Ti (PGE) deposit at Kemuk; and (2) a zoned mafic-ultramafic PGE occurrence at Red Mountain (fig. 55 ) in ultrumafic rocks at Goodnews Bay which is interpreted as the source of the extensive placer PGE deposits in the region (table 4) (Southworth and Foley, 1986; Foley and others, 1997; Nokleberg and others 1997a, b, 1998). The ultramafic plutons which host the deposits in both areas are a part of a belt of similar zoned mafic to ultramafic plutons which intrude both the Goodnews oceanic terrane and the adjacent Togiak island-arc terrane (Nokleberg and others, 1994c, 1997c).

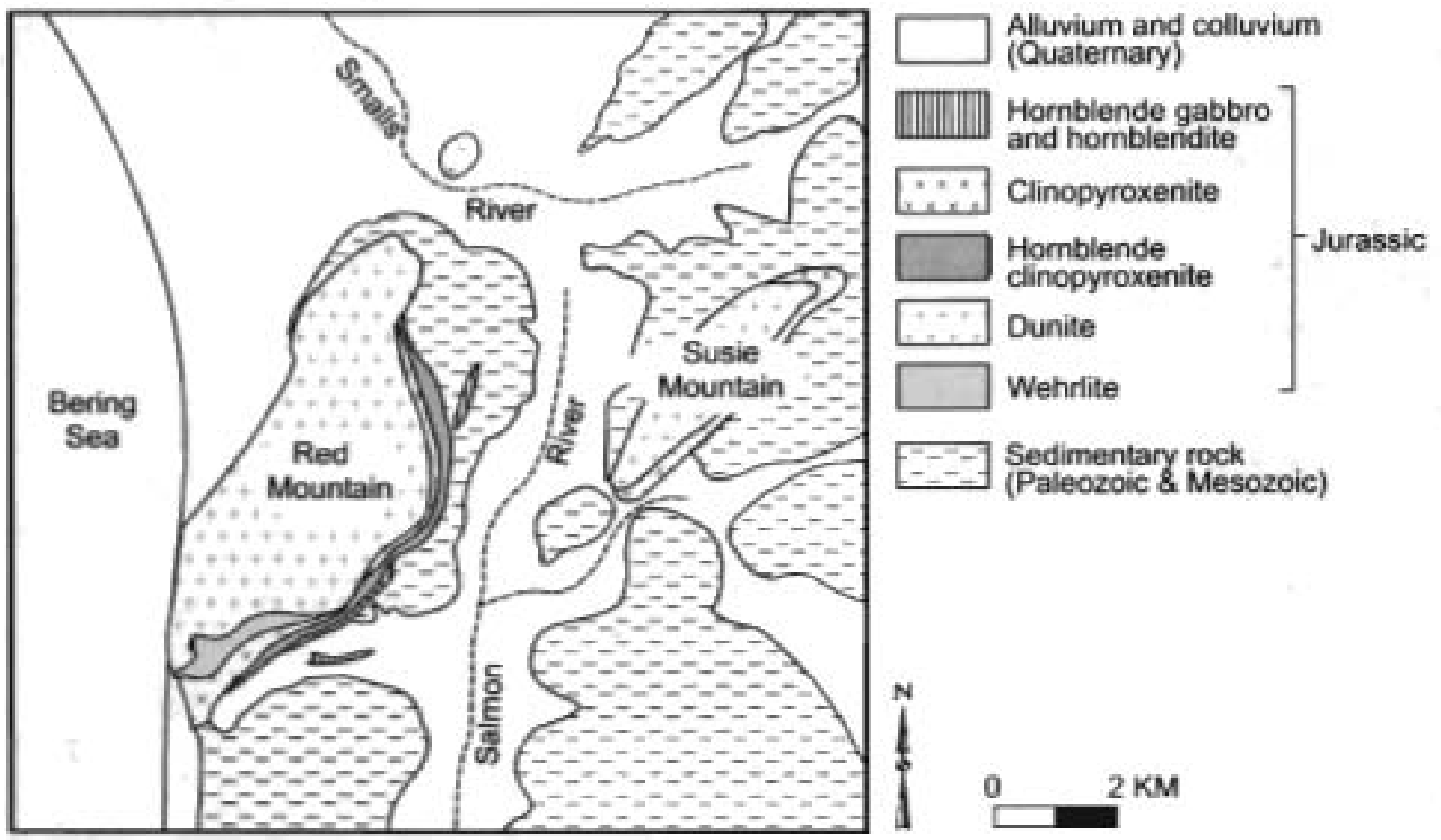

Figure 55. Red Mountain mafic-ultramafic PGE occurrence, Southwestern Alaska metallogenic beit, Southwestem Alaska. Occurrence is hosted in Goodnews Bay mafio-ultramafic complex. Schematic geologic map. Adapted from Southworth (1986) and Foley and others (1997).

\section{Kemuk Mountain Fe-TI (PGE) Deposit}

The Kemuk Mountnin Fe-Ti (PGE) deposit (Humble Oil and Refining Company, written commun, 1958; Eberlein and others, 1977: C.C. Hawley, written comumun, 1980; Foley and others, 1997) consists of a buried titaniferous magnetite deposit in cnudely zoned pyroxenite which is interpreted as part of a zoned Alaskan-lype ultramafic pluton. A steeply-dipping, hightemperature, contact metamorphic zone occurs in adjacent Permian quartzite and limestone. An aeromagnetic survey indicates the concealed pluton is about $1,500 \mathrm{~m}$ thick, and underlies about $6 \mathrm{~km}^{2}$ area. Based on Humble Oil and Refining Company drill data (written commun., 1988; Bundtzen and others, 1994), the deposit is estimated to contain 2,200 million tonnes grading 15 to $17 \%$ Fe, and 2 to $3 \% \mathrm{TiO}_{2}$.

\section{Origin of and Tectonic Controls for Southwestern Alaska Metallogenic Belt}

The ultramafic plutons which host the Kernuk Mountain and Red Mountain deposits are a part of a belt of similar zoned mafic to ultramafic plutons which intrude both the Goodnews oceanic terrane and the adjacent Togiak island-are terrane. These plutonic rocks are interpreted as the oldest known remnants of the Togiak island arc which consists chiefly of two major sequences (Box, 1985; Nokleberg and others, 1994c, 1997c); (1) a lower ophiolite sequence at the southwestern end of the terrane which consists of Late Triassic midocean-ridge pillow basalt, drabase, gabbro, and ultramafic rocks; and (2) a coherent upper sequence of Early Jurassic to Early Cretaceous marine volcaniclastic sandstone, conglomenate, shale, tuffaceous chert, minor argillaceous limestone, and marine to nonmarine andesite and basalt flows, and flow breccia, and tuff. The Togiak island are is 
interpreied as forming in the Jurassic and Early Cretaceous and is tectonically linked to the Goodnews subduction-zone terrane (Box and Patton. 1989; Decker and others, 1994; Plafker and Berg. 1994; Nokleberg and others, 2000).

Yukon River Metallogenic Beit of

Podiform Cr Deposits (Belt VR)

West-Central Alaska

The Yukon River metallogenic belt of podiform $\mathrm{Cr}$ deposits (fig, 49; tables 3, 4) œccurs along the southern flank of the Yukon-Koyukuk Basin in west-central Alaska (Foley and others, 1982, 1997). As in the Southern Brooks Range metallogenic belt of podiform $\mathrm{Cr}$ deposits to the north, the metallogenic belt is hosted in the upper structural level of the Angayucham oceanic and subduction-2one terrane which is interpreted as the basal part of the Koyukuk island are (Nokleberg and others, 1994c, 1997c, 2000, Patton and others, 1994). The Yukon River metallogenic belt extends for several hundred kilometers. The principal deposits in the northeastern part of this belt are at Caribou Mountain, Lower Kanuti River, and Holonada, and the significant deposits in the southwestern part of this belt at Mount Hurst and Kaiyuh Hills are in the Tozitna and Innoko areas (table 4) (Nokleberg and others 1997a, b, 1998).

\section{Kalyuh Hilts Podiform $\mathrm{Cr}$ Deposit}

The Kaiyuh Hills podiforn Cr deposit (Loney and Himmelberg, 1984; Foley and others, 1984, 1997) consists of banded and disseminated chromite from $1 \mathrm{~cm}$ to $1 \mathrm{~m}$ thick which occur in fresh and serpentinized Jurassic(?) dunite of the Kaiyuh Hills ultrumafic belt. The dunite interlayered with harzburgite tectonite. The largest deposit covers an area of 1 by $100 \mathrm{~m}$, and consists of massive chromite containing an estimated 5,000 tonnes $\mathrm{Cr}_{2} \mathrm{O}_{3}$. Lesser oceurrences consist of banded nodular pods of chromite. Metallurgical grade chromite containing $46 \% \mathrm{Cr}_{2} \mathrm{O}_{3}$ is present. The deposit contains an estimated 15,000 to 34,000 tonnes $\mathrm{Cr}_{3} \mathrm{O}_{3}$ in one deposit. Surface samples from the largest deposit average $60 \% \mathrm{C}_{2} \mathrm{O}_{2}$.

\section{Origin of and Tectonic Controis for Yukon River Metallogenic Beit}

Along the southern margin of the Brooks Range, the Angayucham oceanic terane occurs mainly in a major east-weststriking, south-dipping thrust sheet which extends for several hundred $\mathrm{km}$, and in sparse isolated klippen that forms the upper structural level of the Angayucham subduction zone termane in West-Central alaska (fig. 49; tables 3,4). These thrust sheets and klippen are thrust along north-dipping fuults over the highly deformed metamorphosed, middle Paleozoic and older metasedimentary, metavolcanic, und lesser metagranitoid rocks of the Ruby metamorphosed continental margin terrane to the south. To north is the Late Jurassic and Early Cretaceous Koyukuk island-are ternane (Moore and others, 1992; Patton and others, 1994). The thrust slices of ultramafic rocks in the highest structural level of the Angayucham terrane are interpeted lower part of an ophiolite which consitutes the base of the Koyukuk island are (Loney and Himmelberg, 1989, Patton and Box, 1989; Pattern and others, 1994). This interpretation suggests that the Yukon River metallogenic belt of podiform Cr deposits formed during subduction-related intrusion of mafic-ultramafic plutons into the basal part of the Late Jurnssic Koyukuk island are (Nokleberg and others, 1993; Goldfarb, 1997; Nokleberg and others, 2000).

\section{Metallogenic Belts Formed in Late Mesozoic Gravina Island Arc in Southern Alaska and Canadian Cordillera}

\section{Eastern-Southern Alaska Metallogenic Belt of Granitic Magmatism Deposits (Beit ESA) Eastern-Southern Alaska}

The major Eastern-Southem Alaska metallogenic belt of granitic magmatism deposits (fig. 49; tables 3, 4) contains porphyry $\mathrm{Cu}, \mathrm{Mo}$, and $\mathrm{Au}$, polymetallic vein, and Fe-Au skam deposits (Nokleberg and others, 1995a). The metallogenic beit is bosted in the northern purt of the Wrangellia island-are superterrane, in and adjacent to the area underiain by the Late Jurassic to mid-Cretaceous Gravina-Nutzotin belf and coeval granitoid plutonic rocks (Nokleberg and others, 1994c, 1995a, 1997e). This igneous belt was designated as part of a volcanic-plutonic are by Richter and others (1975), has been called the NutzotinChichagof belt by Hudson (1983), the Chisana are by Plafker and others (1989), and the Gravina are by Stanley and others (1990). This igneous beli exiends for a few hundred kilometers within and parallel to the northern margin of the Wrangellia island are superterrane. The deposits of the Eastem-Southern Alaska metallogenic belt are associaled with Early to mid-Cretaceous granitoid rocks, mainly granite and granodiorite (Miller, 1994). Most of the granitoid rocks are calc-alkaline and intermediate in composition. The significant deposits are the Nabesina (fig 56) and Rambler Fe-Au skarn deposits, the Pebble Copper porphyry Au-Cu deposit, the Bond Creek-Orange Hill, and London and Cape, porphyry Cu and Mo deposits, and the Midas Cu-Au sikam deposit (table 4) (Nokleberg and others 1997a, b, 1998). 


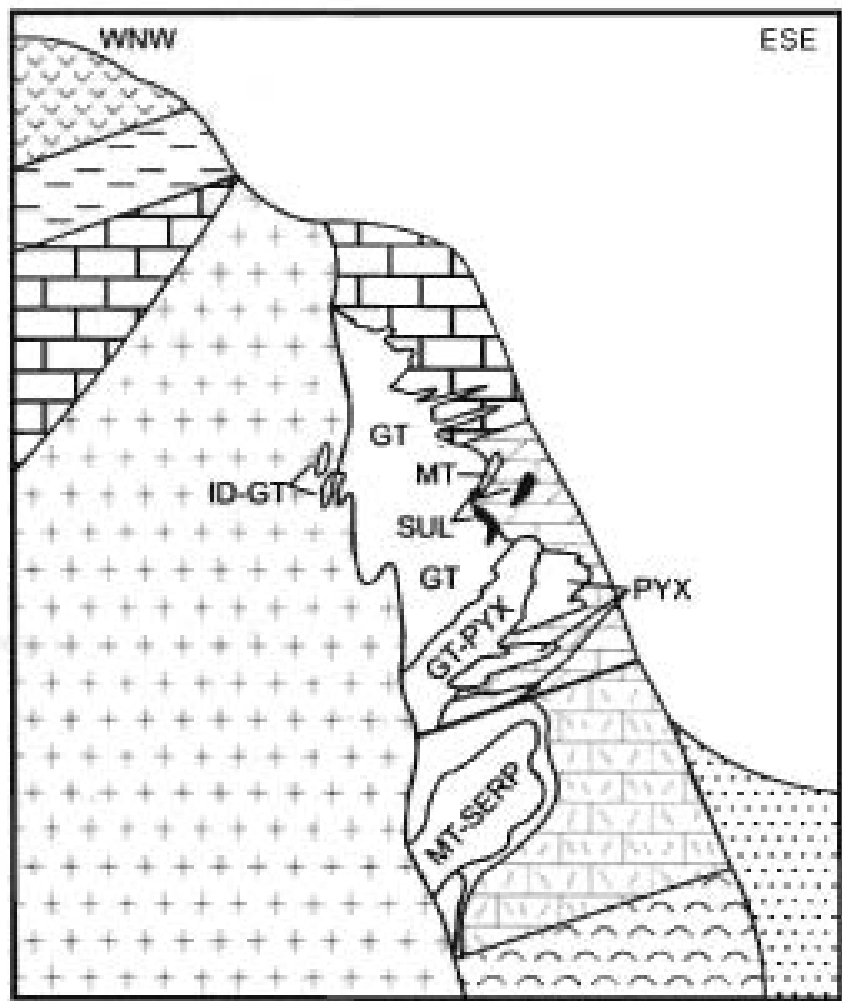

$\therefore \ldots$ Colluvium (Holocene)

[C.] Wrangell Lava (Quaternary)

++7 Nabesna Stock (mid-Cretaceous)

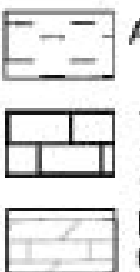

Argillite

Thin-bedded limestone metamorphased to calc-silicate hornfels

Massive limestone metamorphosed to marble Late

Algae marker bed Triassic

GT Garnet skarn GT-PYX Garnet-pyroxene skarn PYX Pyroxene skarn
ID-GT Idocrase-gamet skam

\section{MT-SERP Magnetite-serpentine skam}

\section{MT Magnetite bodies}

\section{SUL Sulfide ore}

Figure 56. Nabesna Fe-Au skarn mine, Eastern-Southem Alaska metallogenic belt, Southern Alaska. Schematic cross section showing sulfide-magnetite-skarn relations. Magnetite-rich ore replaces dolomite. Gold-rich ores form small marble front replacements. The chief ore mineral is chalcopyrite in garnet-pyroxene skarn. Adapted from Wayland (1953), Weglarz (1991), and Newberry and others (1997).

\section{Pebble Copper Porphyry Au-Cu Deposit}

The Pebble Copper porphyry Au-Cu deposit occurs in the western part of soutbern Alaska (Phil St. George, written commun., 1991; Bouley and others, 1995; Young and others, 1997). The deposit consists of disseminated chalcopyrite, pyrite, and molybdenum, accompanied by minor to trace galena, sphalerite, and arsenopyrite, in a stockwork vein system. The deposit contains an inferred reserve of 430 million tonnes grading $0.35 \% \mathrm{Cu}, 0.4 \mathrm{~g} / \mathrm{Au}$, and $0.015 \% \mathrm{Mo}$. Recent data indicates 1.0 billion tonnes grading $0.61 \% \mathrm{Cu}$ equivalent, or $0.4 \% \mathrm{Cu}$ and $0.30 \mathrm{~g} / \mathrm{Au}, 0.015 \% \mathrm{Mo}$ (Northem Dynasty news release, September 25 . 2003). The deposit is hosted in a mid-Cretaceous granodiorite porphyry and its adjacent homfels aureole. The sulfide minerals formed during a late-stage intense hydrofracturing which followed potassic, silicic, and sericitic alteration events. Tourmaline breccias also exist locally. K-Ar ages for hydrothermal sericite and igneous K-feldspar are 90 and $97 \mathrm{Ma}$, respectively. The granodiorite hosting the deposit is part of a larger, composite $40 \mathrm{~km}$ volcanic-plutonic complex which also includes pyroxenite, alkali gabbro, and granite, and overlying dacite volcanic rocks. The volcanic and plutonic rocks are alkalic-calcic and quartz alkalic in composition. The granodiorite porphyry intrudes the Late Jurassic and Early Cretaceous Kahiltna overlap assemblage, and is overlain by Tertiary volcanic rocks.

\section{Orange Hill and Bond Creek Porphyry Cu-Mo Deposits}

The Orange Hill and Bond Creek porphyry Cu-Mo deposits (fig. 57) (Van Alstine and Black, 1946; Richter and others, $1975 \mathrm{a}, \mathrm{b}$; Nokleberg and others, 1995a) occur in the northern Wrangell Mountains. The deposits consist of pyrite, chalcopyrite, and minor molybdenite which occur in quartz veins which contain $\mathrm{K}$-feldspar and sericite, and as disseminations in the Cretaceous Nabesna pluton. The pluton, which has K-Ar isotopic ages of II2-1]4 Ma, forms a complex intrusion of granodiorite and quart2 diorite intruded by granite porphyry. The deposits exhibit abundant biotite-quartz, quartz-sericite, and chlorite-sericite-epidote 


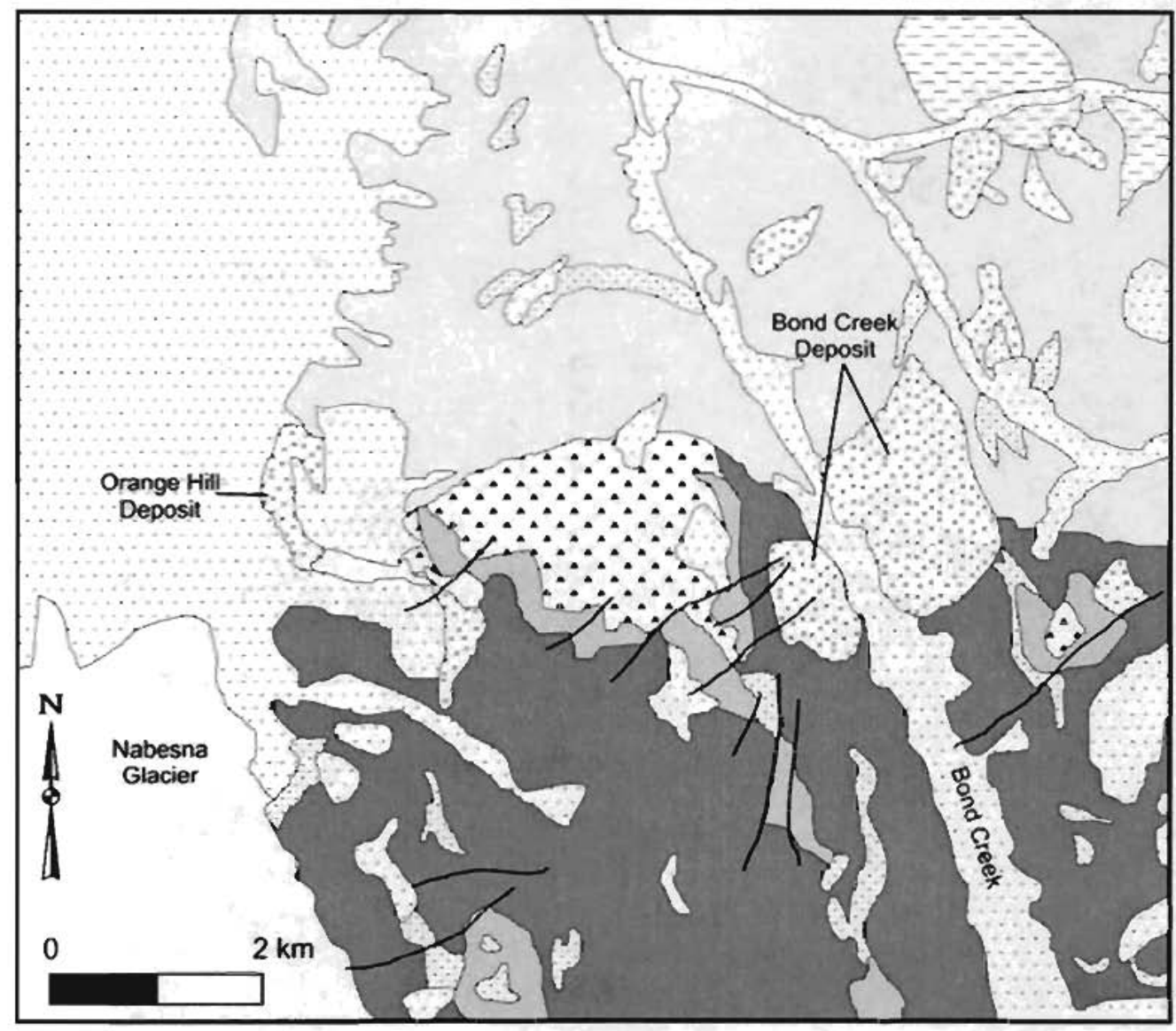

$\{$ lce (Holocene)

..... Undifferentiated surficial deposits (Quaternary)

Homblende porphyry dikes and sills (Tertiary)

Potassic, phyllic. silicic, and argillic alteration

zones with limonite staining

$\square$ Granodiorite and quartz monzonite of

Nabesna batholith (Cretaceous)

- Ttondhjemite (Cretaceous)

$\because \because$ Subaerial basalt of Nikolai Greenstone

(Upper Triassic)

Fine-grained sedimentary rocks and limestone (Middle Permian to Middle Triassic)

Volcaniclastic rocks, tuffs, and flows

(Pennsylvanian to Permian)

- Fault Contact

Figure 57. Bond Creek and Orange Hill porphyry Cu-Mo deposits, Eastern-Southern Alaska metallogenic belt, Eastern-Southern Alaska. Schematic geologic map. Adapted from Richter (1973) and Nokleberg and others (1995).

alteration, and late-stage anhydrite veins (R.J. Newberry, written commun., 1985). Widespread, late-stage chlorite-sericite-epidote alteration also occurs in the Nabesna pluton. The altered areas associated with the deposit have dimensions of about $1.0 \mathrm{by} 3.0 \mathrm{~km}$ at Orange Hill, and 2.0 by $3.0 \mathrm{~km}$ at Bond Creek. 
The Orange Hill deposit contains an inferted reserve of 320 million tonnes grading $0.35 \%$ Cu and $0.02 \% \mathrm{Mo}$, and the Bond Creek deposit contains an inferred reserve of 500 million tonnes grading $0.30 \%$ Cu and $0.02 \% \mathrm{Mo}$ (Richter and others, 1975a, b). The Nabesna pluton intrudes Late Jurassic and Early Cretaceous flysch of the Gravina-Nutzotin belt. Associated skarn deposits contain disseminated andradite garnet, pyroxene, pyrite, chalcopyrite, bornite, and magnetite, and massive pyrrhotite, pyrite, chalcopyrite, and sphalerite. Also associaled with the Nabesna pluton are the mined Nabesna Fe-Au and the Rambler FeAu skarn deposits (Weyland, 1943; Nokleberg and others, 1987; Newberry and ochers, 1997a).

\section{Baultoff, Horsfeld, Carl Creek Porphyry Cu Deposits}

The Baultoff, Horsfeld, and Carl Creek porphyry Cu deposits (Richter and others, 1975b) occur in three nearby areas in the northern Wnangell Mountains. The deposits consist of pyrite and chalcopyrite which occur both in veinlets and as disseminations in altered Cretaceous granitoid plutons composed of quartz diorite, quartz diorite porphyry, or granile porphyry. The altered areas associated with the deposits have dimensions up to 1,000 by $2,000 \mathrm{~m}$. Alteration minerals are chlorite, sericite, albite, pyrite, local actibolite veins and disseminations also oceur. The deposits contain an estimated resource of 240 million tonnes grading $0.2 \% \mathrm{Cu}, 80.01 \% \mathrm{Mo}$, and trace Au (Richter and others, 1975b). The host granitoid rocks form part of the Cretaceous Klein Creek batholith which intrudes Late Jurassic and Eariy to mid-Cretaceous flysch of the Gravina-Nutzotin belt.

\section{Origin of and Tectonie Controls for}

Eastem-Southern Alaska Metallogenic Beit

The Eusiem-Southern Alaska metallogenic belt occurs in the central and northern part of the Wrangellia island-are terrune, in and adjacent to the area underlain by the Late Jurassic and Early Cretaceous Gravina-Nutzotin belt, and by the partly coeval Kahiltna overlap assemblage (Nokleberg and others, 1995a) (fig. 49). In the Nutzotin Mountains between the Alaska Range and Wrangell Mountains, the Gravina-Nutzotin belt consiats chiefly of argillite, graywacke, and conglomerate, and a lesser unit of andesite and basalt volcanic and volcaniclastic rocks in the Chisana Formation (Berg and others, 1972; Richter, 1976; Richter and others, 1976). Sedimentary rocks range in the from deep marine turbidites to shallow-water and nonmarine deposits. The coarse clastic rocks in the Nutzotin part of the Gravina-Nutzotin beli are interpreted as derived locally from the underlying Wrangellia superterrane and from unknown metamorpbic source terranes. Metamorphism is lower greenschist facies (DuselBacon and others, 1993).

The granitoid rocks of the Gravina ate are partly coeval with the andesitic and basaltic volcanic and volcaniclastic rocks of the Early Cretaceous Chisana Formation which oceurs in the upper part of the Gravina-Nutzotin belt in the Nutzotin Mountains in eastern-southern Alaska. The igneous rocks of the Chisana Formation are $\mathrm{Al}_{2} \mathrm{O}$, rich, exhibit pronounced light-REE enrichment, are classified as tholeitic-transitional to calc-alkalic, and are interpreted as subduction-related by Barker (1994), The Chisana Formation is interpreted as forming in the axial part of the Gravina ure with voleanic-rock-derived flysch of the Kahiltna overlap assemblage and Gravina-Nutrotin belt as forming along the are flanks.

To the west, in the central and western Alaska Range and adjacent areas, the Kahiltna overlap assemblage, which is partly coeval with the Gravina-Nutzotin belt, consists chiefly of structurally-disrupted, deep marine, partly volcaniclastic, flyschoid graywacke and argillite, with minor amounts of chert, limestone, conglomerate, and andesite (Csejtey and others, 1986; Jones and others, 1982, 1987; Wallace and others, 1989; Nokleberg and others, 1994d). The assemblage is mostly Early Cretaceous in age, but includes rocks ranging in age from Late Jurassic to locally early Late Cretaceous (Cenomanian). Metarnorphism is lower greenschist facies, but locally ranges from zeolite to amphibolite facies (Dusel-Bacon and others, 1993). The occurrence of locally abundant volcanic rock detritus in the flysch of the Kahiltna overlap assemblage indicates that the Gravina arc occurred sporadically across most of southem Alaska.

Together, the granitic and andesitic rocks of the Gravinu-Nutzotin belt and the Kahiltna overlap assemblage define the Gravina island arc, which is inlerpreted as forming on the northern, or leading edge of the Wrangellia island-arc superierrane during migration towards North America (Nokleberg and others, 1984, 1985, 2000; Nokleberg and Lange, 1985a; Plafker and others, 1989; Plafker and Berg, 1994; Nokleberg and others, 2000). The Gravina arc and associated granitic magmatism deposits are tectonically linked to the younger part of the McHugh Complex which forms the northern part of the Chugach subduction zone and accretionary wedge complex (Nokleberg and others, 2000). These relations reveal the long and complex history of the Wrangellia island-arc superterrane (Nokleberg and others, 1984, 1985, 2000, Nokleberg and Lange, 1985a). The Eastern-Southern Alaska metallogenic belt is herein interpreted as partly coeval with: (1) the Western-Southeastem Alaska metallogenic belt, described below, which is also bosted in the Late Jurassic and Early Cretaceous Gravina overlap assemblage of the Wrangellia superterrane in Southeastern Alaska; and (2) the Island porphyry metallogenic belt, described above, which is bosted in the Gambier overlap assemblage in southern British Columbia. 
The Klukwan-Duke metallogenic belt of zoned mafic-ultramafic Ti-Fe-Cr-PGE deposits (fig. 49; tables 3, 4) occurs along the length of Southeastern Alaska from Klukwan, near Haines, in the north, to Duke lslund in the south (Taylor, 1967; Brew, 1993; Himmelberg and Loney, 1995; Foley and others, 1997). The deposits occur in a suite of zoned, Alaskan-oype maficultramafic plutons of mainly mid-Cretaceous age (100 to $110 \mathrm{Ma}$ ) which constitute a long, discontinuous suite of zoned plutons which intrude the flysch of the Late Jurassic and Early Cretaceous Gravina-Nutzotin-Gambier volcanic-plutonic-sedimentury belt. This belt, which forms a major overlap assemblage, occurs along the length of the Wrangellia island arc superierrane (Nokleberg and others, 1994c, 1997c). The significant deposits (table 4) are at Union Bay, Klukwan, and Huines, and lesser deposits are at Funter Bay, Duke Island, Snettisham, and Union Bay (Nokleberg and others 1997a, b, 1998).

\section{Union Bay Zoned Mafic-Ultramafic Fe-Cr-PGE Deposit}

The Union Bay zoned mafic-ultramafic Fe-Cr-PGE deposit (fig. 58) (Ruckmick and Noble, 1959; Berg, 1984; Brew and others, 1991; Himmelberg and Loney, 1995; Foley and others, 1997) consists of magnetite and chromite which are disseminated in dunite; chromite also occur as discontinuous stringers in dunite. The deposit is bosted in a mid-Cretaceous, concentrically zoned mafic-ultramafic complex which has a dunite core, named the Union Bay ultramafic pluton. The dunite occurs in a pipe and a lopolith in center of the ultramafic pluton. Peridotite also occurs with dunite; pyroxenite and homblende pyroxenite on the periphery of the pluton. The pluton intrudes the Late Jurassic and Early Cretaceous flysch of Gravina-Nutzotin overlap assemblage. Magnetite and chromite form primary segregations, and PGE also occurs with chromite and magnetite in dunite. Hand-picked specimens of chromite average $0.093 \mathrm{~g} / \mathrm{PL}, 0.200 \mathrm{~g} / \mathrm{Pd}, 0.062 \mathrm{~g} / \mathrm{Rh}$ and $0.215 \mathrm{~g} / \mathrm{lt}$. The deposit is large and contains an estimated 1,000 million tonnes grading 18 to $20 \%$ Fe. The deposit may also contain $\mathrm{V}$.

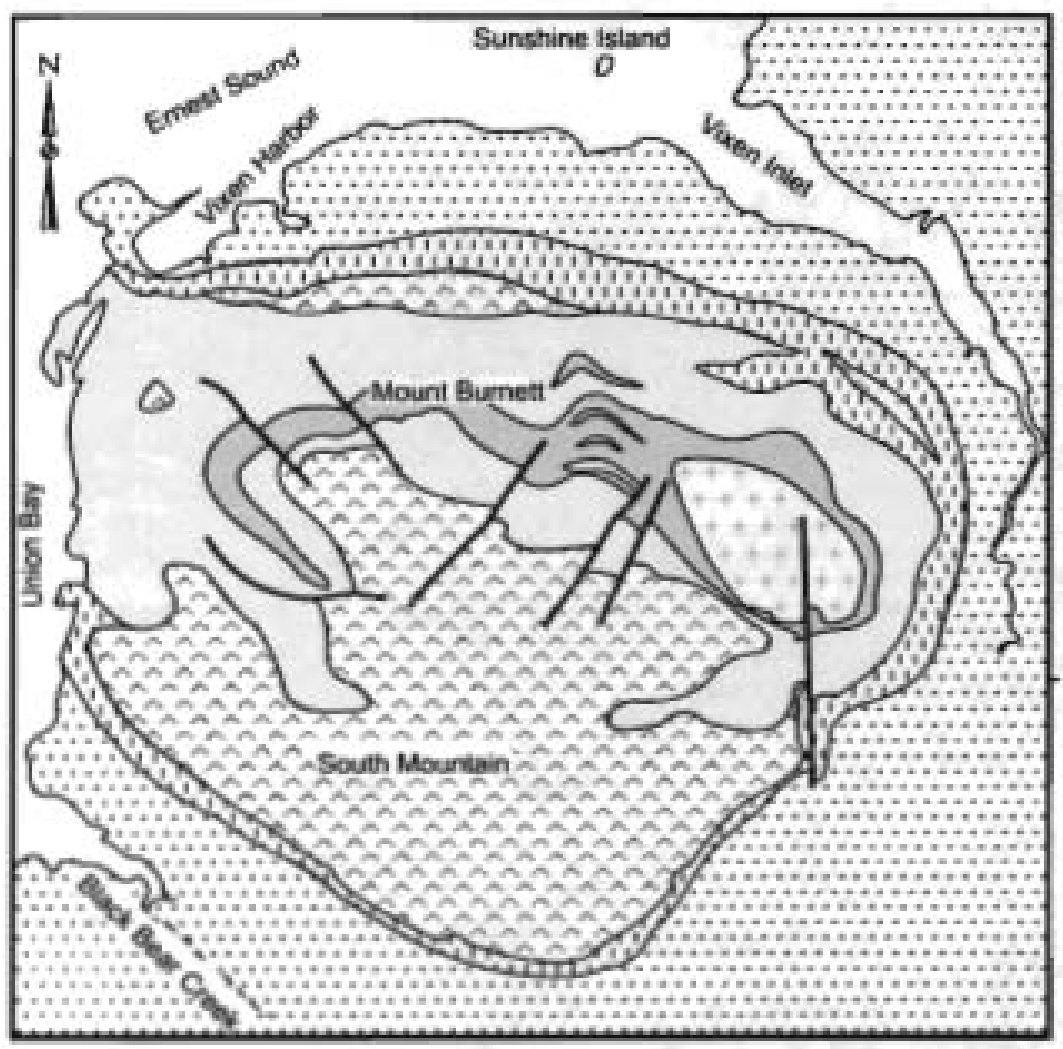

Union Bay Mafic-Utramafic Complex
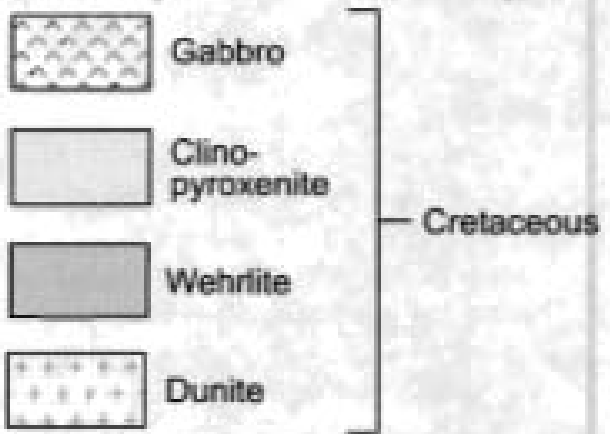

Wehrlite

Gravina Sequence
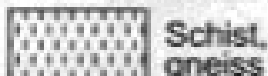

gneiss

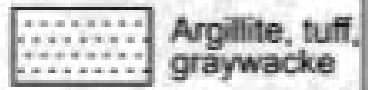

Late Jurassic graywacke

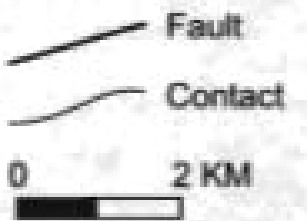

Figure 58. Union Bay zoned mafioultramafic Fe-Cr-PGE deposit, Kukwan-Duke metalogenic belt, Southeastern Alaska. Schematic geoiogic map. Adapted from Hirnmelberg and Loney (1995)

\section{Kilukwan Zoned Mafic-Ulitramafic Fe-TI Deposit}

The Klukwan Zoned mafic-ultramafic Fe-Ti deposit (Wells and Thome, 1953; Robertson, 1956; MacKevett and others, 1974; Berg. 1984; Still, 1984; Wells and others, 1986; Brew and others, 1991; Foley and others, 1997) consists of titaniferous magnetite accompanied by minor chalcopyrite, hematite, pyrite, pynthotite, spinel, and leucoxene which occur either as 
disseminations or in tabular zones in a pyroxemite body surrounded by diorite. Magnetite occurs interstitial to pyroxene and is idiomorphic against hornblende. The host pyroxenite and diorite are Cretaceous and intnude Triassic or older rock of the Wrangellia superterrane. Associated with the lode deposit is the nearby Klukwan magnetile placer deposit at Takshanuk Mountain which contains an estimated 453 million tonnes grading $10 \%$ titaniferous magnetite. The placer deposit occurs in an alluvial fan at the foot of the mountain slope below the Klukwan deposit.

\section{Origin of and Tectonic Controls for}

Klukwan-Duhe Metallogenic Beit

The zoned mafic-ultramafic Fe-Ti-PGE deposits of KJukwan-Duke metallogenic belt occur mainly in concentrically zoned, Alaskan-type, mafic and ultramafic plutons (fig. 49; tables 3,4) (Foley and others, 1997). These plutons are part of the Gravina arc and intrude mainly Late Jurassic to Early Cretaceous flysch of the Gravina-Nutzotin-Gambier volcanic-plutonicsedimentary belt, and adjacent units of the Wrangellia island arc superterrane (Plafker and Berg. 1994; Nokleberg and others, 1994c, 1997e; Himmelberg and Loney, 1995). In southeastern Alaska and the Canadian Cordillera, the Gravina-Nutzotin-Gambier belt consists chiefly of intercalated volcanic rocks and sedimentary rocks (Gravina, Dezadeash, and Gambier units) which range in age from Late Jurassic (Oxfordian) through Early Cretaceous (Albian) (Berg and others, 1972; Monger and Berg, 1987; MeClelland and others, 1992). Coarse clastic rocks in the Gravina part of assemblage were largely derived from the stratigraphically underlying Wrangellia superterrane which lies mainly to west, but may also have been derived in part from the Stikinia and Yukon-Tanana terranes to the east.

The Gravina-Nutzotin-Gambier volcanic-plutonic-sedimentary belt (Berg and others, 1972; Monger and Berg, 1987; MeClelland and others, 1992) forms a major Late Jurassic and Early Cretaceous overlap assemblage. The assemblage is generally interpreted as an island are which was deposited on, and intruded into the Wrangellia island are superterrane in Southeastern Aluska. British Columbia, and Eastern-Southem Alaska (Nokleberg and others, 1994c, 1997c). The zoned mafic and ultramafic plutons and associated zoned mafic-ultramafic Fe-Cr-PGE deposits of the Klukwan-Duke metallogenic belt are generally interpreted as the plutonic feeders to the island are (Plafker and Berg. 1994; Nokleberg and others, 2000; Monger and Nokleberg, 1996). Cessation of the island are is generally interpreted as coincident with accretion of the Wrangellia island superterrane to the North American continental margin in the mid-Cretaceous.

\section{Metallogenic Belts Formed in Late Mesozoic Collision and Overthrusting in Eastern Alaska and Canadian Cordillera}

\section{Fortymile Metallogenic Belt of Serpentinite-Hosted Asbestos Deposits \\ (Beit ECA) East-Central Alaska and \\ Northwestem Canadian Cordiliera}

The Fortymile metallogenic belt of serpentinite-hosted usbestos deposits (fig. 49, tables 3, 4) occurs in the Yukon-Tanana Upland in east-central Alaska and in the northwestern part of the Canadian Cordillera (Foley, 1982). The metallogenic belt is bosted in the Seventymile oceanic and subduction-zone terrane which occurs in a discontinuous klippen thrust over the eastern part of Yukon-Tanana metamorphosed continental margin terrane in the Yukon-Tanana Upland (Jones and others, 1987; Foster and others, 1987: Nokleberg and others, 1994c, 1997c). The significant deposits are a large serpentinite-hosted asbestos deposit at Slate Creek, Alaska and at Clinton Creek, northwestern Canadian Cordillera (table 4) (Nokleberg and otbers 1997a, b, 1998).

\section{Slate Creek Serpentinite-Hosted Asbestos Deposit}

The Slate Creek serpentinite-hosted asbestos deposit (Foster and Keith, 1974; Robert K. Rogers, written commun, 1984) consists of antigorite with minor clinochrysotile, chrysotile, magnetite, brucite, and magnesite in serpentinized harzburgite. The chrysotile asbestos occurs in zones of fracturing near centers of thicker serpentinite, primarily as cross-fiber asbestos in randomly oriented veins about 0.5 to $1 \mathrm{~cm}$ thick. The veins contain aliemating zones of chrysotile and magnetile, and commonly exhibit magnetite selvages. Some chrysotile is altered to antigorite. The haraburgite occurs as tabular iectonic lenses, generally from 60 to $150 \mathrm{~m}$ thick and up to $800 \mathrm{~m}$ long. The deposit contains an estimated 58 million tonnes grading 6.496 fiber.

\section{Clinton Creek Serpentine-Hosted Asbestos Deposit}

In the northwestem Yukon Terntory, northwestera Canadian Cordillera, the Fortymile metallogenic belt contains a significant asbestos deposits at Clinton Creek (EMR Canada, 1989). The asbestos occurs mainly in fractures zones in faultbounded lenses of serpentinite in sheared metavedimentary rocks of the iectonically-imbricated Slide Mountain and YukonTanana (Nisling) terranes (Abbott, 1983). The chrysotile occurs as cross-fiber asbestos veinlets. The deposit has estimated reserves of 6.8 million lonnes grading $4.37 \%$ fibre. Approximately 0.94 millon tonnes of fibre were prodaced from 15.9 million 
tonnes of ore mined between 1967 and 1978. A maximum Permian age of chrysotile formation is suggested by K-Ar and Rb-Sr isotopic ages which are interpreted as the age of metamorphism (Hioon, 1981).

\section{Origin of and Tectonic Controis for Fortymilie Metallogenic Beft}

In east-central Alaska, the Seventymile subduction zone ternine, which contains the serpentinite-hosted asbestos deposits of the Fortymile metallogenic belt, occurs as discontinuous remnants of thrast sheets of uliramafic and associated rocks which are structurally thrust onio the subjacent Yukon-Tanana terrane. The Seventymile terrane contains serpentinized harzburgite and associated ultramafic rocks, gabbro, pillow basalt, chen, argillite, andesite, and graywacke of Permian to Triassic age (Foster and others, 1987; Nokleberg and others, 1994c, 1997e). The Seventymile terrane is interpreted as a dismembered ophiolite which formed during a Permian to Triassic period of sea-floor spreading (Foster and others, 1987; Nokleberg and others, 1989a, 1994c, 1997e). The Seventymile terrane is interpreied as a possible root to the Stikinia(?) island are terrane in east-central Alaska (Nokleberg and others, 2000). In the northern Canadian Cordillera, the Slide Mountain accretionary wedge ternane is also interpreted as part of the root of the Jurassic Stikinia-Quesnellia island are terranes.

The serpentinite-hosted asbestos deposits in the Fortymile metallogenic belt are the products of low-grade metamorphism and alteration of ultramafic rock in both the Seventymile and Slide Mountain terranes. The metamorphism and alteration are herein interpreted as occurring during either Jurassic thrusting of these ternnes onto the North American Craton Margin, or more likely, during younger hydrothermal activity associated with extensive Late Cretaceous granific magnatism.

\section{Cassiar Metallogenic Belt of Serpentinite-Hosted Asbestos Deposits Northern British Columbia (Beit CS)}

The Cassiar thetallogenic belt of serpentinite-hosted asbestos (and local jade) deposits occurs in northern British Columbia in the east-central part of the Canadian Cordillera (fig. 49; tables 2, 3) (Nokleberg and others, 1997b, 1998). The metallogenic belt is bosted in the altered ulinamafie rocks of the Slide Mountain subduction-zone terrane. The two significant deposits are at Cassiar and adjacent McDame.

\section{Cassiar (McDame) Serpentine-Hosted Asbestos Deposit}

The Cassiar (McDame) serpentine-hosted asbestos deposit (fig. 59) (Burgoyne, 1986; Leaming. 1978; Northern Miner, December 12, 1987) consists of a chrysotile asbestos stockwork hosted in serpentinized alpine ultramafic intrusive rocks which occur along the fault contact of the Slide Mountain lerrane and structurally underlying shelf sedimentary rocks of the passivecontinental margin Cassiar Ierrane (Nokleberg and others, 1997b, 1998). The deposit consists of two-fibre vein type chrysotile with magetite which occurs in vein partings and in wall rocks, accompanied by some pyrite and jade. About 2.05 million fonnes of fibre were produced between 1953 and 1984 from 23.3 million tonnes of ore mined between 1953-1984. The deposit age is uncertain, but probably Cretaceous. The deposit is large and contains pre-production reserves of 55 million tonnes with high quality chrysotile.

\section{Origin of and Tectonic Controls for Cassiar Motallogenic Belt}

The chrysotile asbestos deposits of the Cassiar metallogenic belt occur in sheared and altered serpentine lenses and bodies which occur along the contacts between alpine ultramafic intrusions of the Slide Mountain terrane and the structurally underlying sedinentary rocks of the Cassiar passive continental-margin terrane (Nokleberg and others, 1997b, 1998, Sheet 3). Chrysotile veinlets, along with lizardite, antigorite, magnetite, pyrite and nephrite, formed as infiltrational replacements of serpentinite in and along shear zones (O'Hanley and Wicks, 1995). An incremental ${ }^{60} \mathrm{Ar}-{ }^{30} \mathrm{Ar}$ isotopic age of $94 \mathrm{Ma}$ on phlogopite in the orebody footwall (Nelson and Bradford, 1993) is interpreted as a minimum age of serpentinization. Phlogopite formation apparently post-dates metamorphism related to emplacement of the Sylvester allochthon of the Slide Mountain terrane in the Middle to Late Jurassic (Harms, 1986; Monger and others, 199I).

The Slide Mountain terrane consists mainly of a fault-bounded oceanic assemblage of Devonian to Permian and locally Late Triassic marine volcanic and sedimentary rocks, and local mafic and ultramafic plutonic rocks (Nokleberg and others. 1994c). The terrane oecurs for about $2,000 \mathrm{~km}$ aleng the length of the Canadian Cordillern (Nokleberg and others, 1997b, 1998, Sheet 1). The Slide Mountain terrane is interpreted as a sequence of oceanic crustal rocks which formed adjacent to, and were subducted under a late Paleozoic and early Mesozoic island arc now preserved as two fragments in the Quesnellia and Stikinia terranes (Nokleberg and others, 1994c; Monger and Nokleberg. 1996; Nokleberg and others, 2000). The Slide Mountain terrane occurs in large blocks to small, discontinuous remnanis which are thrust over and (or) tectonically imbricated onto the YukonTanana, Kootenay, and Cassiar continental-margin terranes, and onto the North American cralon margin (Nokleberg and others, 1997b, 1998, Sheet 1). The Slide Mountain terrane is interpreted as being emplaced onto the North American craton and craton margin, along with the Stikinia, Quesnellia, and Cache Creek terranes during a major period of Jurassic accretion (Monger and 
Nokleberg, 1996). The serpentinite-hosted asbestos deposits in the Cassiar metallogenic belt are the products of low-grade metamorphism and alteration of ultramafic rock in the Slide Mountain terranes. The metamorphism and alteration are herein interpreted as occurring during either Jurassic thrusting of these terranes onto the Nortb American Craton Margin, or more likely, during younger hydrothermal activity associated with extensive Late Cretaceous granitic magrnatism.

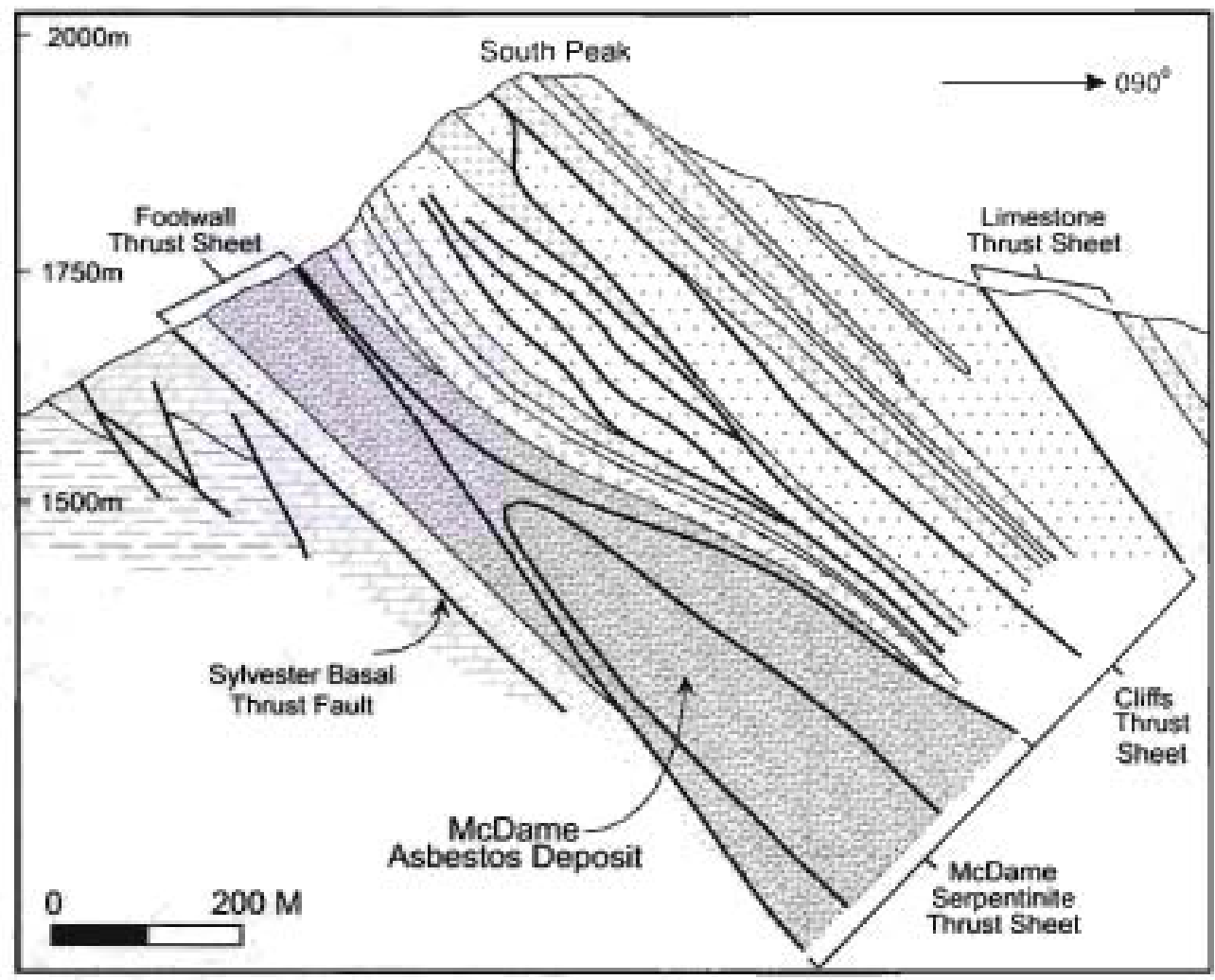

Slide Mountain Terrane Sylvester Group

Serpentinite

Limestone

Argillite, chert, greywacke

Diorile, gabbro

Volcanic (greenslone)

Graphitic argillite

North American Continental

Margin

Sandpile Group

$\square$ Dolomite, limestone

Kechika Group

$\square$ Argillite

Faull

Figure 59. Cassiar (McDame) serpentine-hosted asbestos deposit, Cassiar metallogenic belt, northern British Columbia. Schematic cross section. Adapted from Burgoyne (1986).

\section{Francois Lake Metallogenic Belt of Porphyry Mo Deposits (Beit FL) Central British Columbia}

The Francois Lake metallogenic belt (fig. 49; tables 3, 4) (Nokleberg and others, 1997b, 1998) is defined by the distribution of porphyry Mo deposits in felsic plutons of the Francois Lake Suite (Carter, 1982) which intrude the Stikinia, Quesnellia and Cache Creek terranes along the eastern part of the Skeena Arch in central British Columbia. The Middle and Late Jurassic plutons of the Stag Lake (171-163 Ma) and Francois Lake (157-145 Ma) Suites (White and others, 1970; Whalen and others, 1998), with no identified coeval volcanic rocks, may correlate with the Nelson Plutonic Suite (170-155 Ma) in the southeastern part of the Canadian Cordillera. Both suites of intrusive rocks are herein interpreted as emplaced during major accretion and collision of the Stikinia-Quesnellia island arc and associated subduction zone complexes to the west with the North American Craton Margin.

\section{Endako Porphyry Mo Deposit}

The Endako quartz monzonite pluton of the Francois Lake Suite hosts the Endako porphyry Mo deposit, the largest Mo deposit in Canada with initial reserves of 280 million tonnes grading $0.08 \% \mathrm{Mo}$. The deposit is essentially a stockwork of quartz molybdenite, pyrite and magnetite veins about $350 \mathrm{~m}$ wide, which extends for about $3.3 \mathrm{~km}$ along a west-northwesterly axis. The Endako pluton is flanked to the north and south by the younger Casey Alaskite and Francois Granite plutons, respectively. Potassic and phyllic assemblages envelope quartz-molybdenite and other vein assemblages, and the host rocks are pervasively kaolinized (Dawson and Kimura, 1972; Dawson and others, 1991; Bysouth and Wong, 1995). Similar, but smaller, Mo deposits oecur at Nithi Mountain, Owl Lake and to the north and northwest of Endako deposit (Dawson, 1972). 
The Cariboo metallogenic beit of Au quartz vein deposits (fig. 49; tables 3,4) occurs in eastem-central British Columbia and is hosted by the Early Cambrian Downey Creek Formation of the Barkerville subterrane of Kootenay terrane. The belt consists of metamorphism-related, Au-quartz-sulfide lenses which are emplaced concordantly with limestone of the Baker Member of the Downey Creek Formation and cut by discordant quartz-sulfide-gold veins which oceur mainly in the Rainbow Member of the Downey Creek Formation (Robert and Taylor, 1989). The significant deposits in the belt are in the CaribooBarkerville district and at Frasergold (table 4) (Nokleberg and others 1997a, b, 1998). The Cariboo-Barkerville district also contains major placer gold deposits (Nokleberg and others, 1997a).

\section{Cariboo-Barkerville District \\ (Cariboo Gold Quartz, Mosquito Creok, Island Mountain) of Au Quartz Vein Doposits}

The Cariboo-Barkerville district contains three principal mines (Cariboo Gold Quartz, Mosquito Creek, and Island Mountain Mines) which consists of quartz-sulfide veins and pyritic replacement lenses (Robert and Taylor, 1989; Schroeter and Lane, 1991; MINFILE, 2002). The quartz-sulfide veins occur in phyllite and quartzite of the Rainbow Member, usually within $100 \mathrm{~m}$ of the contact with mafic volcanic rocks and limestone of the Baker Member of the Downey Creek Formation. Pyrite-gold lenses, which occur discontinuously in marble bands within the Baker Member, pre-date brittle deformation, are cut by quartz: sulfide-Au veins, and are interpreted as synmetamorphic (Robert and Taylor, 1989; Dawson and others, 1991). From 1933-1987. the three principal mines produced 38 tonnes of Au from 2.7 million tonnes of ore grading $13.94 \mathrm{~g} / \mathrm{Au}$ and $1.87 \mathrm{~g} / \mathrm{Ag}$. Recent exploration of the Mountain and Bonanza Ledge deposits indicates a probable reserve of 3,109,800 tonnes grading $2.95 \mathrm{~g} / \mathrm{Au}$ (International Wayside Gold Mines 2003 Annual Report). The associated Wells-Barkerville placer Au district also produced 64.8 tonnes of Au between 1850 and 1990. The deposit age is interpreted as Middle Jurassie through Early Cretaceous.

\section{Frasergoid Au-Quartz Vein Deposit}

The Frasergold Au quartz vein deposit consists of pyrnhotite, pyrite and coarse-grained gold, and minor galena, sphalerite, and chalcopyrite whicb occur in deformed quartz-carbonate veins and stockwork stratabound in at least three stratigraphic horizons in porphyroblastic phyllite (Eureka Resources Inc., annual report,1990; Mining Review, 1992; MINFILE, 2002). Estimated resources are 12.7 million tonnes grading $1.87 \mathrm{~g} / \mathrm{Au}$. The prospect occurs $25 \mathrm{~km}$ south of Quesnel Lake in eastern British Columbia and consists of a 8-km-long zone of deformed, stratabound quartz-carbonate-pyrite-Au veins which are hosted in Late Triassic phyllite of the Quesnellia island-are terrane near the suture with the adjacent Kootenay terrane (Dawson and others, 1991).

\section{Origin of and Tectonic Controls for Cariboo Metallogenic Belt}

The Cariboo metallogenic belt occurs near the margin of the Kootenay terrane near the suture (major fault) with the Quesnellia island-are terrane (fig. 49, tables 3,4). The deposits in the Cariboo-Barkerville district are interpreted as forming during chlorite- to sillimanite-grade regional metarnorphism mainly in the Middle Jurassic to Early Cretaceous (Andrew and otbers, 1983). This event is related to the successive overthrusting of Kootenay terrane by Cassiar, Slide Mountain, and Quesnellia lerranes during a major accretionary event (Struik, 1986). Similarly, the Frasergold Au quartz vein prospect is interpreted as forming early in the metamorphism of the area as metamorphic segregations related to the accretion of the Quesnellia island-are terrane (Bloodgood, 1987).

The deposits in the Cariboo metallogenic belt are interpreted as forming during accretion of the Quesnellia and adjacent ierranes to the North American Continental Margin because of: (1) the occurrence of the deposits near a major fault; (2) the metamorphic lextures and structures of the deposits, and (3) an age of formation which approximates the interpreted age of accretion of the Quesneilia and adjacent terranes, which constitute the Intermontane Superterrane (Monger and others, 1972. 1992), to the North American Continental Margin. A Middle to Late Jurassic period of regional metamorphism and associated deformation is interpreted as the age of accretion of the Quesnellia and Stikinia island-arc terranes, and associated terranes, to the North American Craton Margin, after oroclinal warping of the Stikinia-Quesnellia island-are terranes and tectonically-linked Cache Creek and Slide Mountain subduction-zone terranes (Monger and others, 1972, 1992; Mihalynuk and others; 1994; Monger and Nokleberg, 1996; Nokleberg and others, 2000). Before accretion, the Quesnellia island are may have formed on the Kootenay terrane, a rifled and deformed fragment of the North American Craton Margin, and the coeval Stikinia island are may have formed on the Yukoo-Tanana Ierrane, another rifted and deformed fragment of the North American Craton Margin (Monger and Nokleberg. 1996; Nokleberg and others, 2000). 
The Rossland metallogenic belt of Au-Ag polymetallic vein deposits (fig, 49; tables 3, 4) occurs in southern British Columbia is hosted in or near granitoid plutons of the Middle Jurassic Nelson Plutonic Suite. This granitic suite represents the oldest continental-margin are in the Canadian Cordillera. The plutons and vein deposits intrude the Quesnellia, Kootenay, and Cassiar terranes, and the North American Craton Margin (Hoy and Dunne, 1992; Hey and Andrew, 1988). The significant deposits in the belt are at Rossland Camp (Le Roi, War Eagle), Sheep Creek (Kootenay Belle), and Ymir-Erie Creek (Yankee Girl; table 4) (Nokleberg and others 1997a, b, 1998).

\section{Rossland Au-Ag Polymetallic Vein Camp}

The Rossland Au-Ag polymetallic vein camp (fig. 60) occurs in three ureas, the North belt, Main veins, and South belt. Most production ( $>80 \%$ ) has been from the Le Roi, Center Star, Nickel Plate, War Eagle, and Josie mines which oceur in the Main vein system (Dawson and others, 1991; Schroeter and Lane, 1991: Hoy and Dunne, 1992; MINFILE, 2002). The Main vein deposits consist of pyrrhotite and chalcopyrite in a gangue of quartz and calcite with an average ore grade of $1 \% \mathrm{Cu}$. The pyrrhotite-chalcopyrite veins are located along the margins of the intrusions, are disseminated and associated with K and Si skarn alteration at deep levels, grade to massive veins with minor gangue and alteration envelopes at higher levels, and in uppermost levels, brittle fracture-controlled veins with $\mathrm{Pb}-\mathrm{Zn}-\mathrm{Ag}$ and quartz-carbonate gangue predominate. The veins in the Main vein system form an en-echelon set which occurs between two large north-trending lamprophyre dikes. The veins dip stecply north and strike $070^{\circ}$. A structural control is inferred by growth faults which were active during deposition of Rossland Group, Total production from Rossland Camp between 1894 and 1941 was 7.62 million tonnes of ore grading $15.2 \mathrm{~g} / \mathrm{Au}, 19 \mathrm{~g} / \mathrm{Ag}$, resulting in extraction of 84 tonnes of $\mathrm{Au}$ and 105 tonnes of $\mathrm{Ag}$. The timing of vein emplacement with respeet to the plutons in the district is not known precisely (Files, 1984; Hoy and others, 1998).

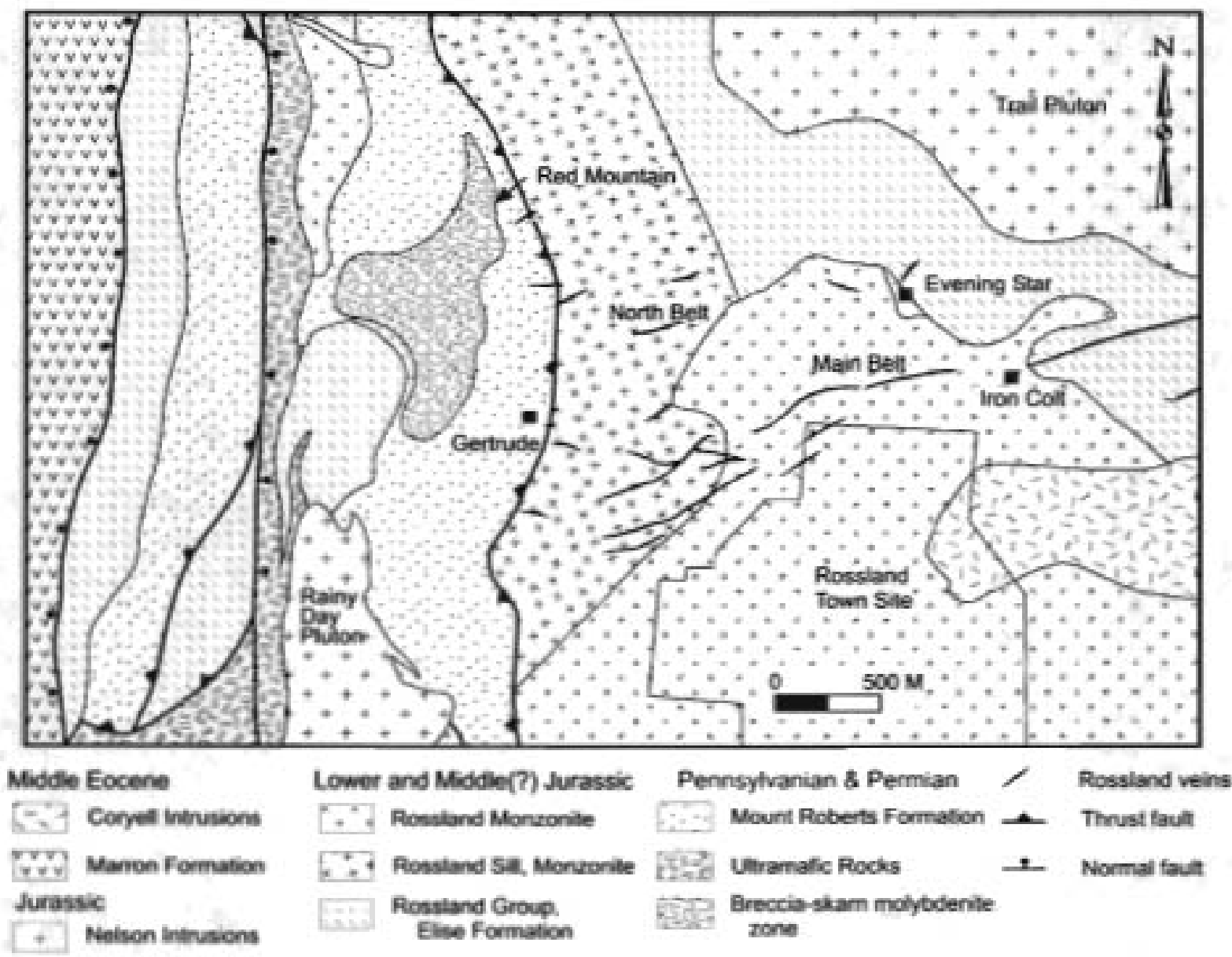

Figure 60. Rossland Au.Ag polymetallic vein and related deposits, Rossland metallogenic belt, Canadian Cordiliera. Schematic geclogic map. Adapted from Hoy and Andrew (1988). 
The deposits in the Sheep Creek Au-Ag polymetallic vein district (Kootenay Belle and others) consist of an assemblage of pyrite, sphalerite, galena, and chalcopyrite which occurs in quartz veins within quartzite, argillite, and argillaceous quartzite of the Nevada and Nugget members of the Earty Cambrian Quartzite Range Formation of the North American Craton Margin (Panteleyev, 1991; Schroeter and Lane, 1991). Estimated combined production and reserves are 1.8 million tonnes grading $15 \mathrm{~g} / \mathrm{t}$ Au and $6 \mathrm{~g} / \mathrm{Ag}$. The veins are controlled by northeast-trending faults which are particularly productive where they cross the axes of two north-trending anticlines. The deposits are interpreted as related to local dikes of the Middle Jurassic Nelson Plutonic Suite.

\section{Ymin-Erie Creek Au-Ag Polymetallic Vein Deposit}

The Ymir-Erie Creek (Yankee Giri) Au-Ag polymetallic vein deposits which consist of pyrite, galena, sphalerite and native gold, in a gangue of quartz, calcite and siderite which occur along northeast-trending shear zones in folded metasedimentary rocks of the Late Triassic Ymir and Early Jurassic Rossland groups (Schroeter and Lane, 1991). The veins occur near contacts of metasedimentary rocks intruded by granitoid dikes of the Middle Jurassic Nelson Plutonic Suite to which the deposits may be related (Hoy and Andrew, 1988; Hoy and others, 1998).

\section{Origin of and Tectonic Controls for Rossland Metallogenic Belt}

The Rossland metallogenic belt occurs in the southem Canadian Cordillera, and, on the basis of spatial, structural, and age data, is interpreted as forming during intrusion of dikes and plutons of the Middle and Late Jurassic Nelson Plutonic Suite (Parrish and others, 1988; Woodsworth and others, 1991). The Nelson plutonic suite consists chiefly of granodiorite, quartz. monzonite, and local monzonite plutons which yield isotopic ages mainly of 155 to $170 \mathrm{Ma}$ with local crustal inheritance. On the basis of structural and temporal relations, the Nelson Plutonic Suite is interpreted as forming immediately after a period of regional thrusting associated with accretion and obduction of the Stikinia, Quesnellia, Cache Creek, and Slide Mountain terranes, and obduction of the latter two terranes over the Yukon-Tanana, Kootenay, and Cassiar terranes, and over the North American Craton Margin (Monger and Nokleberg, 1996; Nokleberg and others, 2000). This major compressional orogenic event included regional metamorphism, deformation, crustal-thickening, anatectic magmatism, and uplift in the core of the Canadian Cordillera. By the Late Jurassic (about $155 \mathrm{Ma}$ ), detritus from this emergent orogenic welt in the eastern Canadian Cordillera was shed eastwards onto the North American Craton Margin (Cant, 1989).

\section{Early Cretaceous Metallogenic Belts (144 to 120 Ma; Figures 61, 62)}

\section{Overview}

The major Early Cretaceous metallogenie belts in the Russian Far East, Alaska, and the Canadian Cordillera are summarized in table 3 and portrayed on figures 61 and 62 . The major belts are as follows. (1) In the southern part of the Russian Fat East is the Samarka metallogenic belt (SA) which contains W skarn and porphyry Cu-Mo deposits. This belt is interpreted as forming during anatectic granitic plutonism occurring during subduction of Kula oceanic ridge along the transform continental margin of the Russian Southeast. (2) In the same region are Algama (AL) belt which contains stratiform $\mathrm{Zr}$ deposits, and the Kondyor (KO) belt which contains zoned mafic-ultramafic Cr-PGE deposits. The latter belt is hosted in zoned mafic-ultramafic plutons introding Stanovoy block of the North Asian Craton, and the former belt is interpreted as related alkali igneous rock associated with the zonod mafic-ultramafic plutons that intrude the Stanovoy block. These two belis are interpreied as forming duriag plutonic intrusion related to continental-margin transform faults. (3) In the central part of the Russian Far East are the Selemdzhu-Kerbi (SK) and Stanovoy (ST) belts, which contain Au-quartz vein and anatectic granitic-magmatism-related deposits and are hosted in veins and plutons which iatruded various temanes and the Stanovoy block of the North Asian Craton. The belts are interpreted as forming during collision of the Bureya aod Khanka continental-margin are supenterranes with the North Asian Cratos and and closure of the Mongol-Okhotsk Ocean. (4) In the Russian Northeast are the Allakh-Yun (AY), Darpir (DP), Kular (KU), Shamanikhu (SH), Tompon (TO), Verkhoyansk (VK), Yana-Kolyma (YA), and Yana-Polousnen (YP) belts which contain a large suite of Au quartz vein, and granitic-magmatism-related deposits. These belts are hosted in the Verkhoyansk granite belt which intrudes the Kolyma-Omolon superterrane and the North Asian Craton Margin and are interpreted as forming during regional metamorphism and anatectic granitic plutonism associated with accretion of Kolyma-Omolon superterrane onto the North Asian Craton Margin. (5) In the Russian Northeast, continuing on from the Late Jurnssic, were: (a) the Oloy (OL) belt, which contains granitic-magmatism-related deposits and is hosted in the Oloy island arc; (b) the Tamvatney-Mainits (TAM) belt, which contains podiform $\mathrm{Cr}$ deposits and is hosted in zoned mafic-ultramafic plutons; and (c) the Mainits (MA) belt which contains kutoko massive sulfide deposits. In the Canadian Cordillera, also continuing on from the Late Jurassic, was the Cariboo (CB) belt of Au quartz vein deposits. (6) Also in the Russian Northeast was the Left Omolon (LO) belt, which contains porphyry Mo-Cu, 


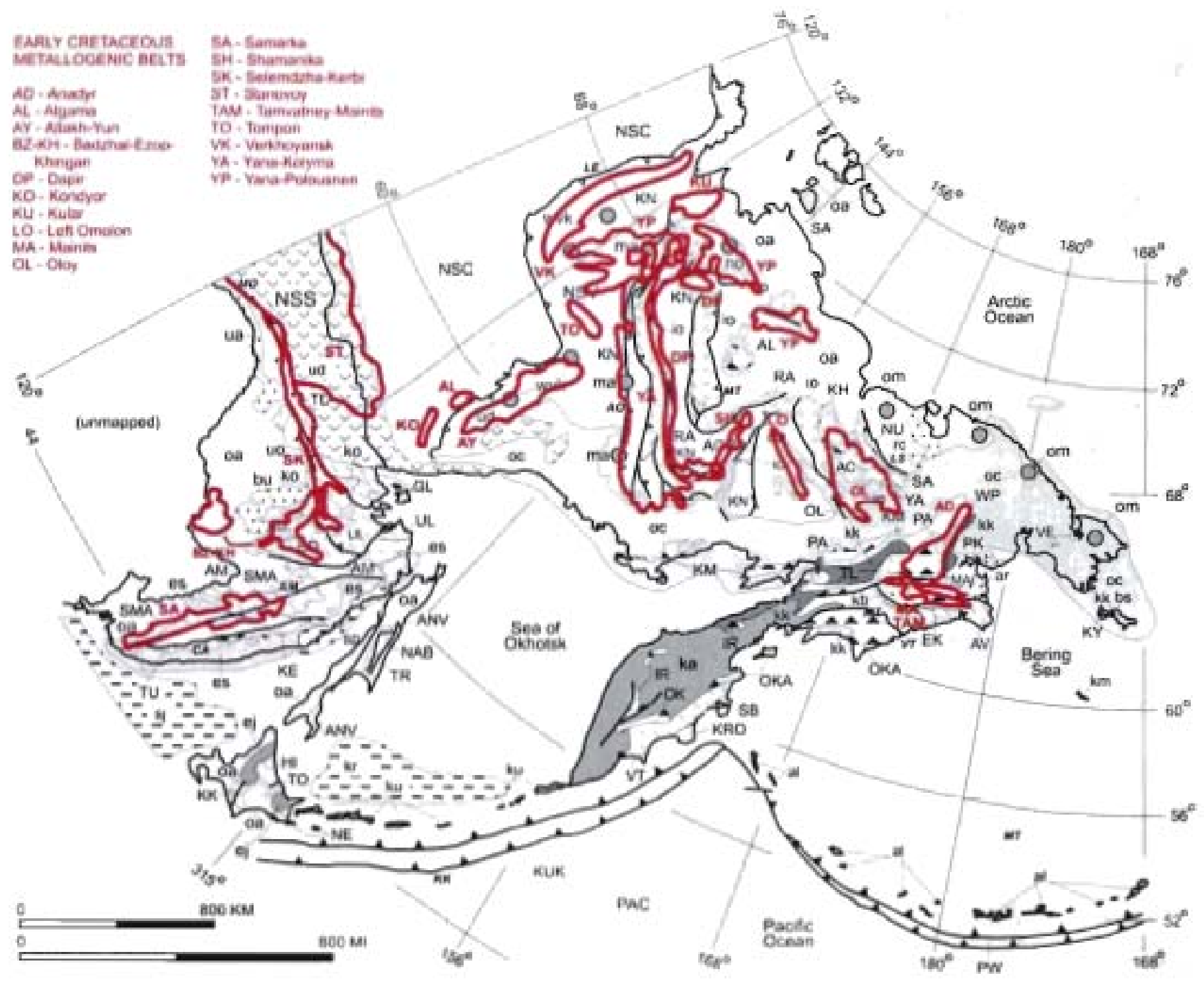

Figure 61. Generalcred map of major Early Cretaceous metallogenic belis, oventap assembiages, and tectonically-linked subductionzone or accretionary-wedge assemblages for Russian Far East, northern Japan, and adjacent offshore areas. Reler to text for description of melallogenic belts. Adapted from Nobleberg and others (1997b, 1985).

Mo-Cu skarn deposits and is hosted in the the Oloy arc island are. (7) in Southeastem A laska and the southern Canadian Cordillera are two metallogenic belts that formed during granitic plutonism that formed the Gravina island arc on the Wrangellia superterrane. These belts are the (a) the Western-Southeastern Alaska (WSE) bell, which containa granitic-magmatism-related deposits, and (b) the Britannia bell that contains Kuroko massive sulfide deposits. In the below descriptions of metallogenic belts, a few of the noteable or signficant lode deposits (table 4 ) are described for cach belt.

\section{Metallogenic-Tectonic Model for Early Cretaceous (144 to $120 \mathrm{Ma}$; Figure 63)}

During the Early Cretaceous (Neocomian - 144 to $120 \mathrm{Ma}$ ), the major metallogenic-tectonic events were (fig, 63 ; table 3): (1) completion of accretion of the Bureya supernerrane against the North A sian Craton along the Mongol-Okhotsk suture and formation of associated metallogenic belts; (2) continuation of the continental margin and island arcs, and formation of associated metallogenic belts and companion subduction zone assemblages around the Circum-North Pacific; (3) aceretion of the major Kolyma-Omolon superterrane and formation of associated metallogenic belts in the Russian Northeast; (4) initiation of subduction 
of the Nontb American Continental Margin under the Angayucham subduction-zone terrane; (5) continuation of opening of the Amerasia, Canada, and Eurasia Basins in response to sea-floor spreading in the Arctic Ocean; (6) the beginning of aceretion of the

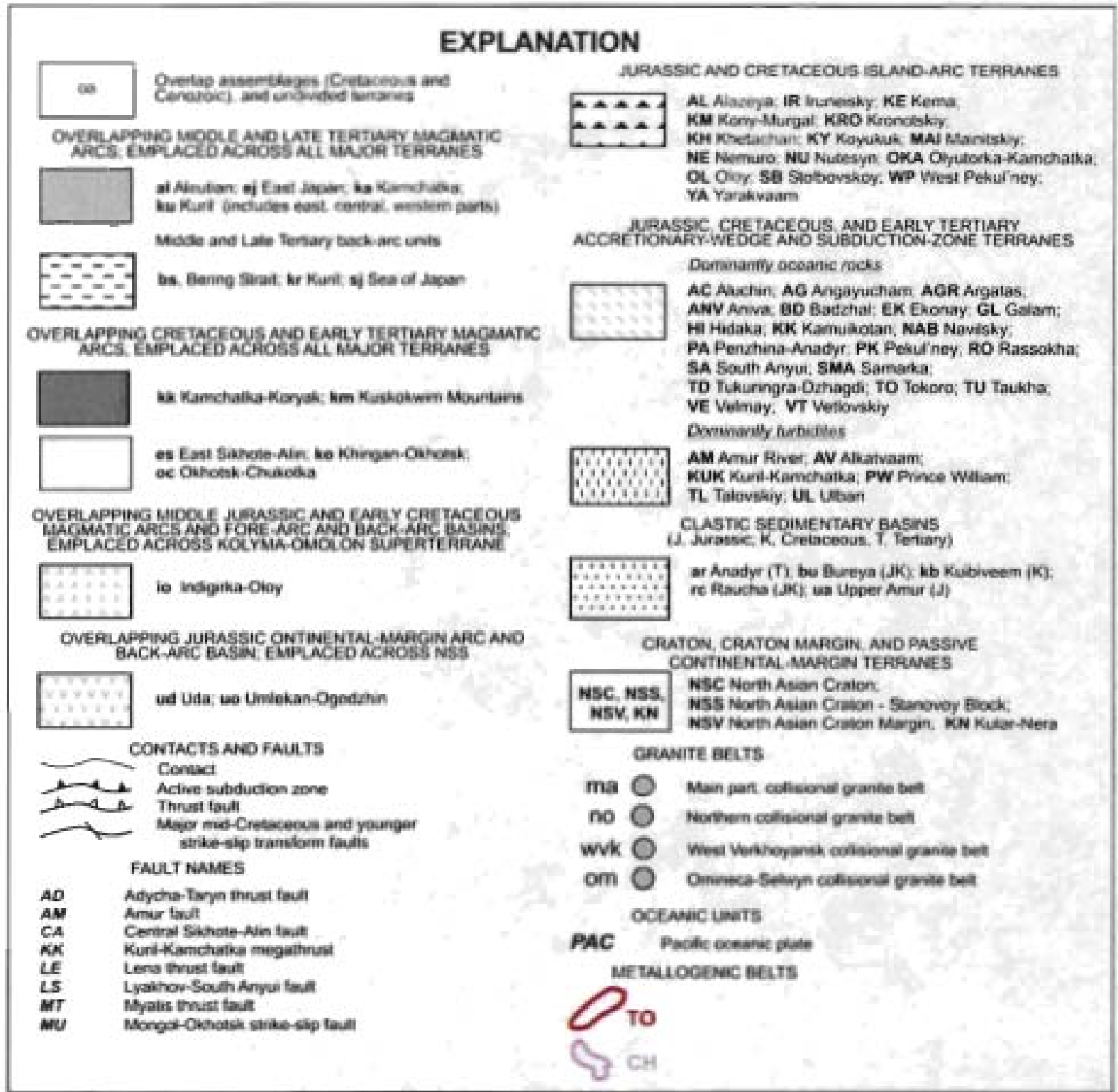

Wrangellia superterrane in the Southem Cansdian Cordillera; and (7) around the Circum-North Pacific, continued sinstral transpression between oceanic plates and continents.

\section{Specific Events for Earty Cretaceous}

(1) Far to the south at about $32^{\circ}$ paleolatitude, the Mainitskiy island are (Mainitskiy terrane, MAI) commenced activity. Forming in the are were the Tarnvatney-Mainits (TAM) belt, which contains podiform $\mathrm{Cr}$ deposits, is hosted in zoned maficultramafic plutons, and the Mainits (MA) belt, which contains kuroko massive sulfide deposits. Teetonically linked to the are was the Alkatvaam accretionary-wedge terrane (AV) which formed from subduction of part of the adjacent oceanic plate. This are and companion subduction zone migrated northward toward the Kony-Murgal island are.

(2) The Umlekan are (Umlekan-Ogoctzhin volcanic-plutonic belt (uo) and associated units) continued activity. Associated with this belt was subduction of part of the Ancestral Pacific Ocean plate to form the Amur (AM) and Badzhal (BD) terranes.

(3) In the same region, the accretion of the Bureya (BU) superterrane against the Ulban accretionary-wedge terrane (UL) was completed along the Mongol-Okhotsk suture $(M O)$, thereby closing the Mongol-Okhotsk Ocean. Forming during accretion was the Stanovoy (ST) metallogenic belt which contains anatectic, granitic-magmatism-related deposits, and the Selemdzha-Kerbi 
(SK) metallogenic belt which contains Au-quartz vein deposits. In the same region is the Kondyor (KO) metallogenic belt which contains zoned mafic-ultramafic Cr-PGE deposits and is hosied in zoned mafic-ultramafic intrusions intruding Stanovoy block of

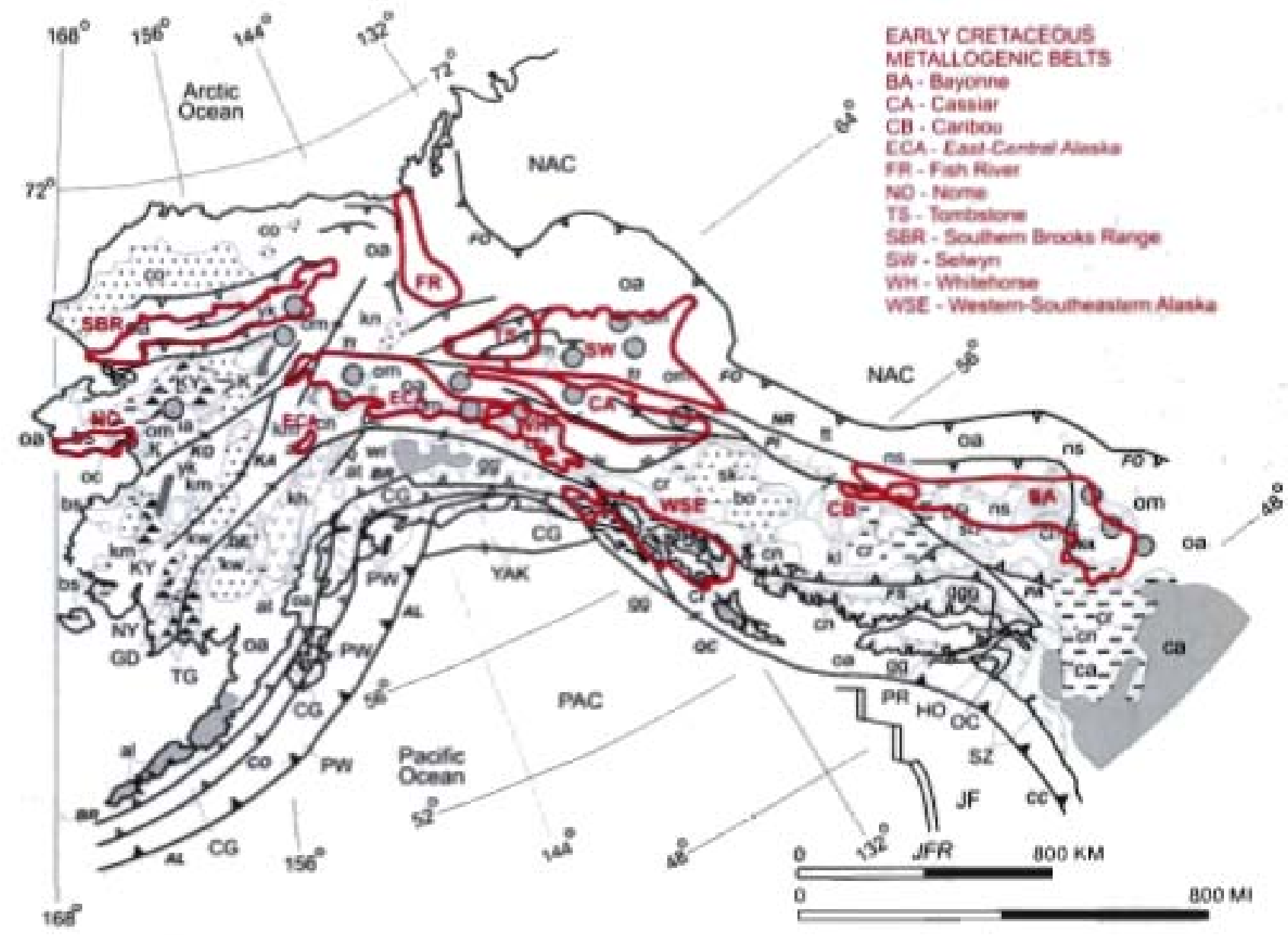

Figure 62. Generalized map of major Earfy Cretaceous metallogenic beits and overlap assemblages for Alaska, Canadian Cordiliera, and adjacent offshore areas. Refer to text for description of metallogenic belts. Adapted from Nokieberg and others (19970, 1998).

the North Asian Craton. Also in the same region is the Algama (AL) metallogenic belt which contains stratiform Zr deposits These two metallogenic belt are interpreted as forming during plutonic intrusion related to continental-margin transform faults when the margin of the North Asian Craton was being deformed during collision and aceretion of outboard terranes.

(4) The continental-margin Uda arc (Uda volcanic-plutonic belt, ud, and Uda-Zeya sedimentary basin, uz) continued to form. Associated with the are was subduction and sinistral transpression of the final remnant of the Mongol-Okbotsk Ocean plate, thereby forming the Ulban (UL) terrane. Sinistral transpression continued along the Mongol-Okhotsk suture (MOO).

(5) The extensive Kony-Murgal continental-margin and island arc and Pekulney island are continued to form. Associated with these ares was subduction of part of the ancestral Pacific Ocean plate to form the Talovikiy (TL), Penzhina-Anadyr (PA), and Pekulney (PK) terranes.

(6) Behind the Kony-Murgal are, the Kolyma-Omolon superterrane (KL.O) was acereted between at about 140 to $100 \mathrm{Ma}$. During the early stage of accretion, the Main collisional granite belt (ma; 144 to $134 \mathrm{Ma}$ ) formed (Layer and others, 1995; Fujita and others, 1997). At about the final stage of accretion, the subduction-related Northern granite belt (no) formed at about 127 to $120 \mathrm{Ma}$ (Fujita and others, 1997). In contrast to the Main granite belt, the coeval Northern granite belt is interpreted as forming in response to subduction related to closure of an inlet of the South Anyui Ocean. As a result, the northera bend of the KolymaOmolon structural loop formed (Sengor and Natal'in, 1996a). As a continuation of the structural loop, the extensional Transverse granite belt (tr) formed (Parfenov, 1995c). Associated with accretion of the Kolyma-Omolon superterrane (KLO) and intrusion of anatectic granites were formation of the Allakh-Yun (AY), Darpir (DP), Kular (KU), Sharaanikha (SH), Tompon (TO), Verkhoyansk (VK), Yana-Kolyma (YA), and Yana-Polowsnen (YP) metallogenic belts which contain a large suite of Au quartz vein and granitic-magmatism-related deposits.

(7) The Oloy island arc and the opposing Nutesyn and Koyukuk island ares continued to be active on the opposite sides of the South Anyui and Angayucham Oceans. Forming in the Oloy arc were the Oloy (OL) and Left Omolon (LO) metallogenic 


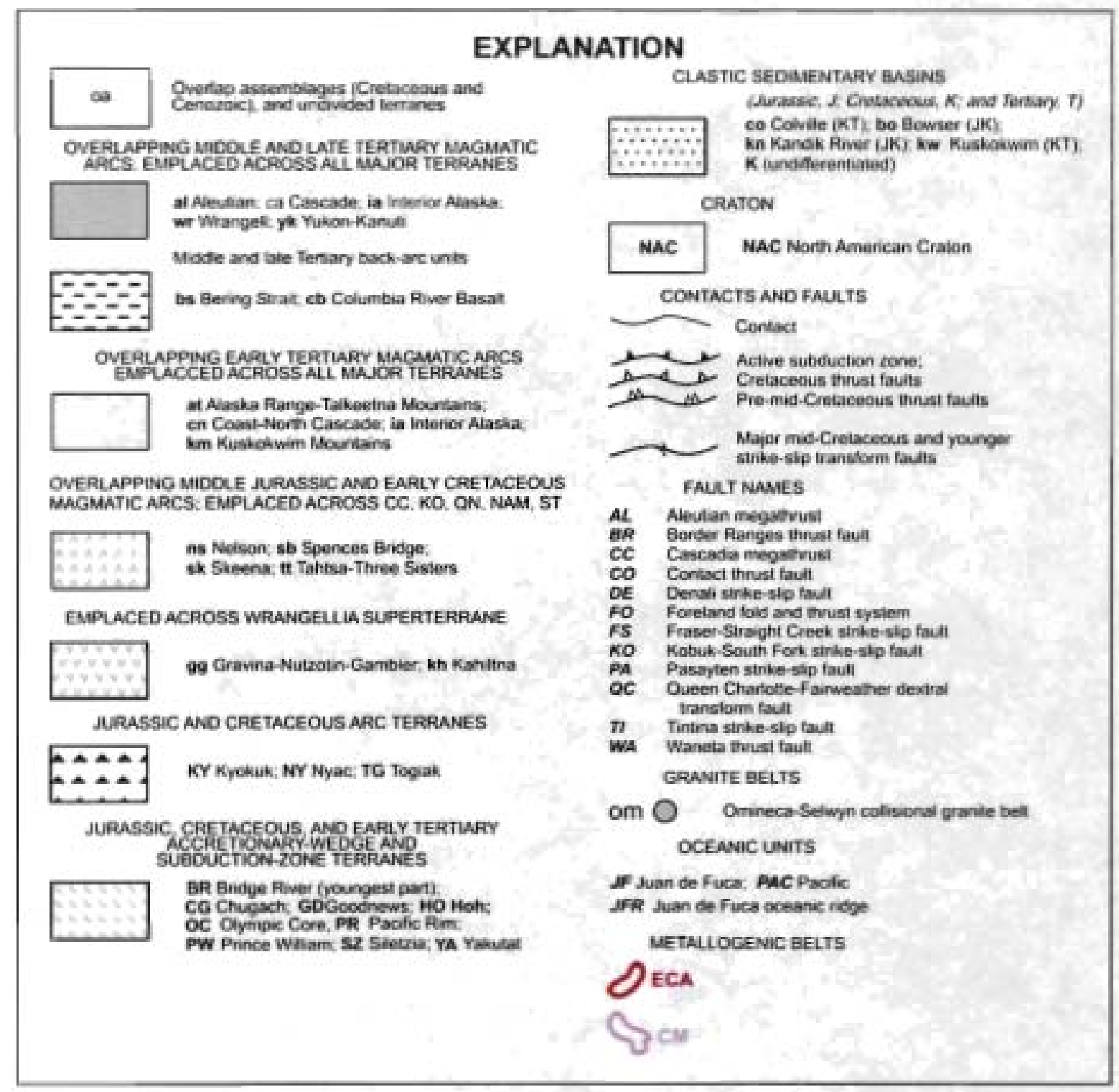

belts, which contains granitic-magmatism-related deposits. Parts of the Oloy, Nutesyn, and Koyukuk island arcs are preserved in the Nutesyn (NU), Koyukuk (KY), Togiak (TG), and Nyac (NY) terranes. Associated with these ares was subduction of parts of the Seuth Anyui and Angayucham Ocean plate, thereby forming the South Anyui (SA), Velmay (VE), and (inner) Angayucham (AG) terranes, and subduction of the outboard margin of the Arctic Alaska terrane. An exiensive zone of blueschist facies metamorphism occurs in this region in both the Angayucham and Aretic Alaska terranes. Affer initial accretion of the Koyukuk are with the Artic

Alaska superterrane, beginning in the Late Jurassic at about 160 to $145 \mathrm{Ma}$ (Moore and others, 1994a, b), subduction flipped to outboard of the new continental margin of this part of Alaska.

(8) At about 140 to $135 \mathrm{Ma}$, sea-floor spreading and associated rifling, which started with the formation of grabens in the Late Jurassic or earlier (Lawver and Scotese, 1990; Grantz and others, 1990, 1991, 1998) formed: (1) new oceanic crust and the large proto-Amerasia (ab) and proto-Canada ( $\mathrm{cb}$ ) basins; and (2) a collage of passive continental-margin terranes derived from the North American Craton Margin (Artis Plateau (AP), Chukchi Cap (CK), Chukchi Spur (CS), and Northwind Ridge (NR) terranes). Sea-floor spreading and opening of the Amerasia and Canada Basins is herein interpreted as causing: (1) closure of the inner Angayucham Ocean; (2) subduction of the North American continental margin (Chukotka terrane, $\mathrm{CH}$, and the Aretic Alaska superierrane, AA); (3) beginning of closure of the South Anyui Ocean; (4) intense deformation and metamorphism of the southern margin of the eastern Chukotka ternane (CH) and southem Arctic Alaska superternane (AA) to form the Seward (SD), Coldfoot (CO), and Ruby (RB) terranes; (5) formation of an extensive blueschist facies belt in both the subducted continental margin (Arctic Alaska superterrane (AN), and Seward (SD), Coldfoot (CO), and Ruby (RB) terranes) and in the overthrust Angayucham terrane (AG); and (6) deposition of synorogenic Early to mid-Cretaceous flysch in the Koyukuk basin in what became western 
Alaska. For additional information the opening of the Canada Basin, whether by rifting and rotation, or by strike-slip translation, or by a combination of the two processes, please refer to the analyses by Grantz and others (1990, 1998) or Lane (1994, 1997).

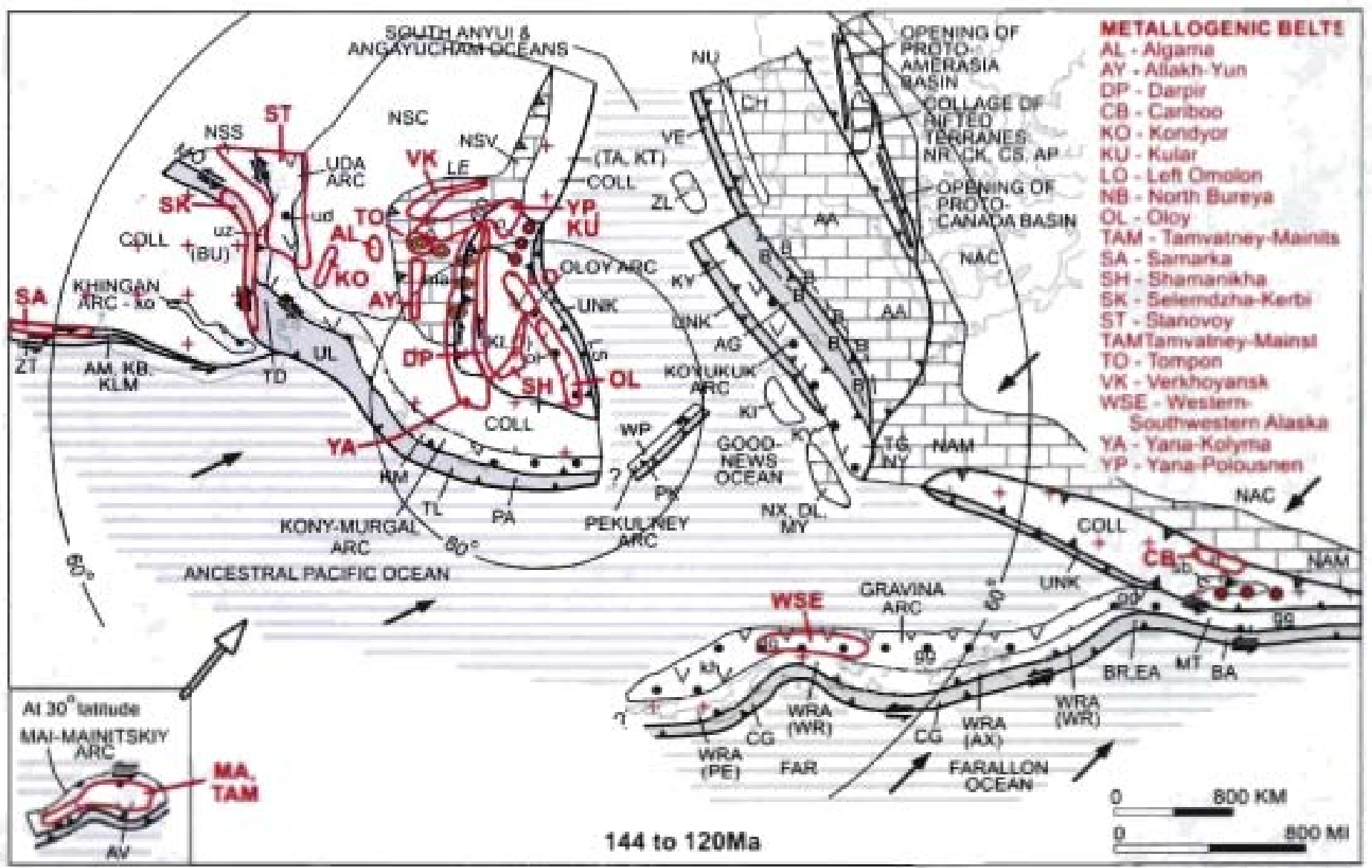

Figure 63. Earty Cretaceous (Neocomian - 144 to $120 \mathrm{Ma}$ ) stage of metaliogenic-tectonic model. Refer to text for explanation of metallogenic-tectonic events, to tables 3 and 4 for descriptions metallogenic belts and significant deposits, and to figure 18 for explanation of abbreviations, symbols, and patterns. Adapted from Nokleberg and others (1997b, 1998, 2000).

(9) Underthrusting in a subduction zone along the North American Craton Margin (NAM) resulted in consumption of the Farallon Ocean plate (FAR). Small lectonic lenses of terranes of alpine ultramafic and related rocks, which occur along the ancestral Denali fault (fig. 63) (Nokleberg and others, 1985, 1994a), may be remants of the subduction-zone assemblages which may have been mostly thrust under the margin of what is now North America.

(10) The Gravina are continued io form. Associaled with the Gravina are was subduction of part of the Farallon Ocean plate to form the Chugach (CG), Bridge River (BR), Easton (EA), and Baker (BA) lerranes. The are is preserved in the Kahiltna (kh) and Gravina-Nutzotin-Gambier (gg) assemblages which occur obly on the Wrangellia superterrane. Forming in the Gravina are was the Westem-Southeastem Alaska (WSE) metallogenic belt which contains granitic-magmatism-related deposits.

(11) The Wrangellia superterrane (WRA) started to accrete at about $60^{\circ}$ paleolatitude. The continentward part of the Wrangellia superterrane impinging onto a collage of terranes previously accreted to the North American Craton Margin (NAM). During accretion, the are was extended to the south during the formation of two major overlap assemblages, the coeval TahtsaThree Sisters magmatic assemblage (it) and the Spences Bridge volcanic-plutonic belt (sb).

\section{Metallogenic Belts Formed Along \\ Late Mesozoic Continental-Margin \\ Transform Faults in Russian Southeast}

\section{Samarka Metallogenic Beit of W Skam, and Porphyry Cu-No Deposits (Belt SA) West-Central Part of Russian Southeast}

The Samaka metallogenic belt of $W$ and Sn skam and porphyry Cu-Mo deposits (fig. 61: tables 3, 4) occurs in aluminous, mainly S-type granisoid rocks of Early to mid-Cretaceous age which intrude the Sarnarka accretionary-wedge terrane 
in the west-central part of the Russian Southeast. The belt contains major W skarn deposits at Benevskoe and Vostok-2, small porphyry Cu-Mo deposits at Khvoshchovoe, Kafen, and Malakhitovoe, and a porphyry Mo deposit at Skalistoe (table 4) (Nokleberg and others 1997a, b, 1998). The deposits are hosted in Early to mid-Cretaceous granodiorite porphyry, granite, and gabbro-diorite. The southern-most part of the Samarka metallogenic belt occurs in a displaced fragment of the Samarka terrane which is displaced along a left-lateral, north-east-trending strike-slip fault (fig. 61). The small W skarn deposit at Benevskoe occurs in this displaced fragment. Also possibly part of the same Samarka metallogenic belt is a younger, Paleocene porphyry CuMo deposit at Skalistoe (fig, 61). This deposit consists of veinlet molybdenum ore and wolframite which oceur in a subvolcanic granite porphyry. Alternatively, the Skalistoe deposit may be part of post-aceretionary Luzhkinsky metallogenic belt described below.

\section{Vostok-2 W Skarn Deposit}

The major productive Vostok-2 deposit (fig. 64) (Stepanov, 1977; Rostovsky and others, 1987) consists of vein and sheet skarn which formed in several stages. An older stage consists dominantly of pyroxene, plagioclase, amphibole, and garnet. A subsequent stage consists of greisen alteration of skam and granitoid rocks with formation of quartz, feldspar, and muscovite, along with minot chlorite and biotite which contains scheelite and apatite, and minor arsenopyrite, pyrrhotite, and chalcopyrite. A late stage consists of scheelite and quartz with followed by crystallization of low temperature scheelite and arsenopyrite. The deposit occurs along the flat to steeply-dipping contacts of granitoid plutons which intrude olistostromes of large, CarboniferousPermian limestone and calcareous-shale. Successive skarn and greisen altemation of limestone preceded the deposition of scbeelite and other minerals, including gold and apatite, locally up to a few tens of percent. Plagiogranite with an approximate K. Ar age of $110 \mathrm{ma}$ is interpreted as forming with the deposit. The deposit is large with average grades of $0,65 \% \mathrm{~W}_{2} \mathrm{O}_{3}$ and $1.64 \%$ $\mathrm{Cu}$. The deposit has been mined since the 1980's.

The olistostromes which bost the Samarka belt of Sn and W skarn deposits are derived from the caps of guyots which are enclosed in a matrix host of highly-deformed Jurassic sedimentary rocks in the accretionary wedge complex of the Samarka terrane. The skarns are hosted in limestone layers und occur along the contacts of calcareous and alumosilicate clastic rock.

\section{Benevskoe W Skarn Deposit}

The small Benevskoe W skam deposit (V.D. Shlemchenko and others, written commun., 1983) occurs along the margin of an Early Cretaceous biotite, peraluminous granite which intrudes olistoliths of Permian sedimentary shales and interbedded with limestone. The skarn occurs in altered limestone. Various mineral assemblages are magnetite, gamet, pyroxene-gamet, garnet-epidote, and garnet-orthoclase. Late-stage quartz-feldspar and quartz-amphibole overgrowths which replace the skams and locally contain disseminaled scheelite. Late-stage quartz-sericite and zeolite alierations also occur. The major ore minerals are scheelite with minor magnetite, arsenopyrite, pyrite, and rare cassiterite. Gangue minerals are quartz, feldspar, amphibole, epidote. biotite, and tourmaline. Easily-concentrated apatite also exists. The deposit is small with average grades of 0.44 to $3.15 \% \mathrm{~W}_{2} \mathrm{O}_{3}$. As to the north, small porphyry $\mathrm{Cu}-\mathrm{Mo}$ occurrences also occur in this part of the metallogenic belt.

\section{Origin of and Tectonic Controls for Samarka Metallogenic Belt}

The W skarn deposits of the Samarka metallogenic belt occur near maialy Early Cretaceous, S-type granitoid rocks which intrude the Samarka accretionary-wedge terrane. The host granitoid rocks and associated deposits are herein interpreted as forming in underthrusting of the Kula oceanic ridge and resultant genesis of bimodal igneous activity along the transform continental margin of the Russian Southeast (A.1. Khanchuk, written commun., 1997; Khanchuk and others, 1998). K-Ar isotopic studies indicate intrusive ages of 110 to $115 \mathrm{Ma}$ for the granitoid rocks hosting the deposits (Rostoviky, 1987; Stepanov, 1977).

\section{Algama Metallogenic Beit of Stratiform Zr Deposits}

(Belt AL) Northern Part of Russian Southeast

The Algama metallogenic belt of stratiform $\mathrm{Zr}$ deposits (fig. 61: tables 2, 3) occurs to the north of the Kondyor massif at Algama in the southeastern part of the Stanovoy block of the North Asian Craton (unit NSS; Nokleberg and others, 1997b, 1998). in the western part of the Khabarovsk province of the Russian Southeast. The deposits are hosted in Vendian carbonate rock. The belt contains many small occurrences and a significant deposit at Algaminskoe which has been drilled and explored by underground workings (Nekrasov and Korahinsky, 1991). The Algaminskoe deposit consists of hydrozircon and baddeleyite which oecurs with a colloform texture. The ore occurs in long lenses, conformable to a layer of cavemous dolomite marble which ranges up to about $40 \mathrm{~m}$ thick, and in zones which crosscut metamorphosed Vendian metasedimentary rocks. The baddeleyite deposits are interpreted as forming during hypogene and supergene alteration which was associated with karst formation. The U$\mathrm{Pb}$ zircon isotopic age of baddeleyite is approximately $100 \mathrm{Ma}$ (J.N. Aleinikoff, written commun, 1992). The origin of the stratiform $\mathrm{Zr}$ deposits is interpreted as related to alkalie igneous rocks, possibly including carbonatite, which were associated with the late stage intrusion of the zoned mafic-ultramafic rocks, possibly part of the same belt of Late Jurassic to mid-Cretaceous intrusives at Kondyor. With this interpretation, the Algama belt formed during intrusion of alkali igneous rock associated with 
mafic-ultramafic plutons that intruded along major continental-margin transform faults during subduction of terranes along Mongol-Okhotsk fault system.
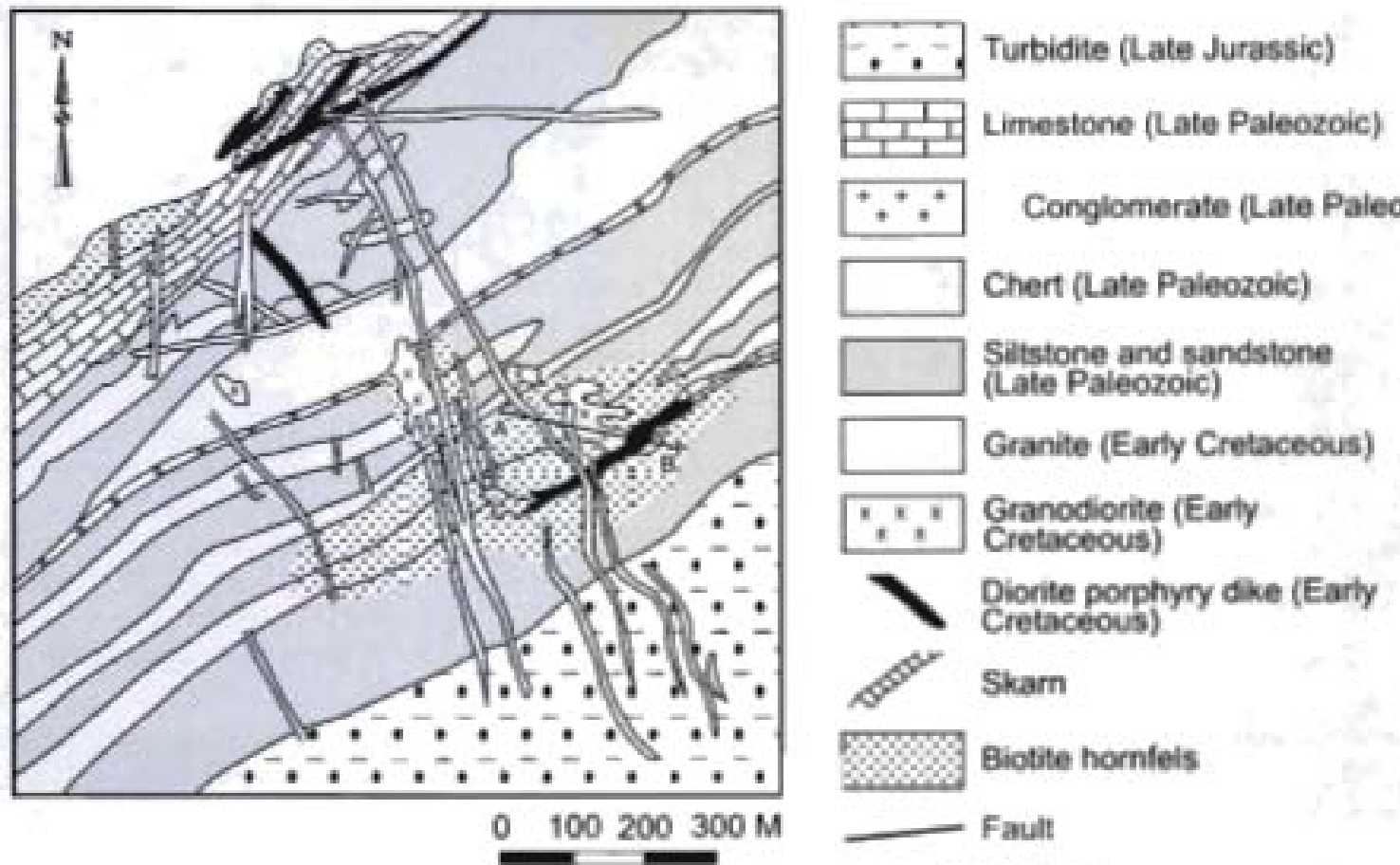

\section{$\because *$ Conglomerate (Late Paleozoic)}

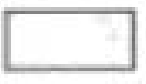

Chert (Late Paleozoic)

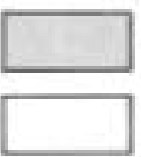

Silstone and sandstone (Late Paleozoic)

$" x x^{x}$ Granodiorite (Early

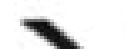

Dionite porphyry dike (Early

Granite (Early Cretaceous)

A

B

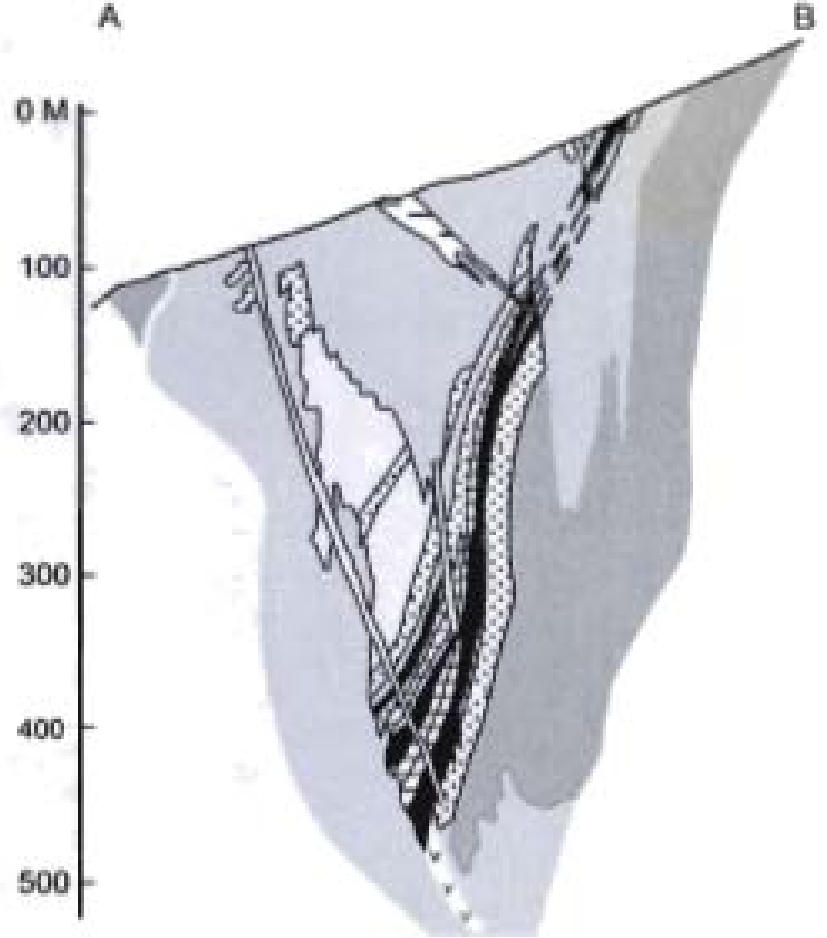
Cretaceous)

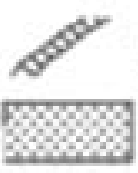

Skarn

Biotite hornfels

Fault

Contact

Figure 64, Vostok-2 W skam deposit, Luzhkinsky metallogenic belt, Russian Southeast. Schematic geologic map and cross section. Adapted from Stepanov (1977).

\section{Kondyor Metallogenic Beit of \\ Zoned Mafic-Ultramafic Cr-PGE \\ Deposits (Beit KO) Northern Part of \\ Russian Southeast}

The Kondyor metallogenic belt of zoned mafic-ultramafic PGE-Cr deposits (fig 61; tables 3, 4) occurs in several zoned intrusions (Kondyor, Chad, Ingagli, Sy-Bakn, Usmun-Dara, Arbarastakh) which in a linear direction across Khabarovsk territory 
for about $850 \mathrm{~km}$ (Zalishchak and others, 1993). The deposits are interpreted as occurring along a northwest-trending, deepseated, buried fault which cuts the southeastem part of the Stanovoy block of tbe North Asian Craton (unit NSS). This area is in the northem part of the Khabarovsk province of the Russian Southeast. The belt contains a single large zoned mafic-ultramafic $\mathrm{Cr}$ PGE deposit at Kondyor und Chad (table 4) (Nokleberg and others 1997a, b, 1998). In a generalized plan view, the zoned complexes consist of circular-shaped plutonic bodies of dunite which are successively rimmed by pyroxenite, peridotite, gabbro, ojolite, and nepheline syenite (Murakushev and others, 1990).

\section{Kondyor Zoned Mafic-Uitramafic Cr-PGE Deposit}

The productive Kondyor (fig. 65) (Marakushev and others, 1990) and Chad PGE-Cr deposits contain two types of lode deposits: (1) semi-massive to massive lenses of chromite which range from 2 to $50 \mathrm{~m}$ thick; and (2) oval-shaped, roughly equadimensional metasomatic deposits which range from $20010300 \mathrm{~m}$ thick. The first type consists of PGE minerals which occur as intergrowths with chromite and olivine; and as small inclusions. Isoferroplatinum is the major PGE mineral. The second type consists of PGE minerals which form intergrowths with magnetile, pyroxene, and narely with metasomatic phlogopite, chrome diopside, and magnetite. This deposit is cut by veins and dikes of alkalic igneous rocks including nepheline syenite, lujavrite, ijolite, and urtite. In addition to isoferroplatinum and tetraferroplatinum, this type of deposit commonly contain up to 5 to $8 \%$ sulfide and arsenide minerals. At Kondyor approximately 13.5 tones FGE were prodoced from 1984-1993 (Bundtzen and Sidorov, 1998). Annual production has averaged about 2.5 to 3.0 tonnes PGE since 1993. In 1999, approximately 2.9 tonnes PGE were produced (Bakulin and others, 1999). Beginning in 1999, PGE production was started at the Chad zoned complex (Bakulin and others, 1999; N.L. Lysyuk and N.P. Romanoviky, written commun, 2000). By-product gold, which is also recovered from the Kondyor deposit, contains up to 10 percent Pd and 40 percent Cu (Zaliahchak and others, 1993; V. Molchanov and V. Sapin, written commun., 1993) All production is from placer deposits, not lode deposits. The Kondyor placer deposits have produced 3.1 and $2.2 \mathrm{~kg}$ platinum nuggest which rank as some of the world's largest native platinum specimens. In 1998 and 1999 , about $75 \mathrm{~kg}$ PGE were recovered from chromite lodes during pilot tests studies The Kondyor deposit is one of the most important sources of platinum in the Russian Federation.
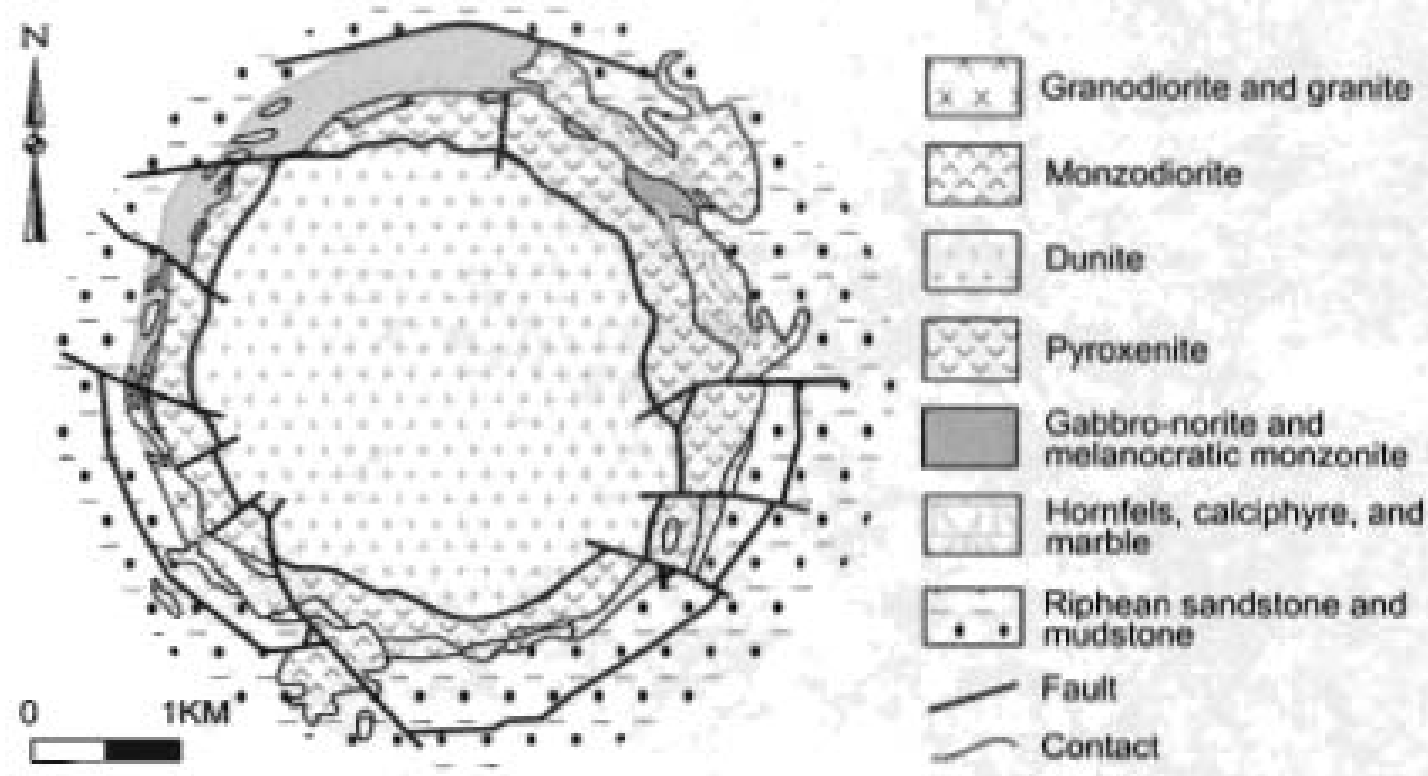

Figure 65. Kondyor zoned mafic-ultramafic PGE-Cr deposit, Kondyor metallogenic belt, Russian Southeast. Adapted from Nekrasov and others (1994).

\section{Origin of and Tectonic Controls for Kondyor Metallogenic Belt}

Controversy exists about the age and tectonic environment for the mafic and ultramafic rocks which host the Kondyor and similar deposits. The host rocks were originally interpreted as an integral part to the Late Proterozoic and older cratonal rocks of the Stanovoy block of the North Asian Craton. However, A.I. Khanchuk (written commun., 1994) interprets the mafic and ultramafic rocks as Jurassic, because the intrusions are similar in composition to other Jurassic massifs of the Ariadny igneous belt. However, this belt is herein interpreted as forming in the mid-Cretaceous along with the Algama metallogenic belt, described above. Unpublished K-Ar isotopic ages for the zoned mafic-ultramafic intrusions in the Kondyor metallogenic belt range from 60 to 110 to $160 \mathrm{Ma}$ (A.M. Lennikov, written commun, 1993), An Ar-Ar isotopic age of $127 \mathrm{Ma}$ (Early Cretaceous) was recently obtained for the alkalic mafic and ultramafic igneous rocks at Ingagli (Dalrymple and others, 1995) which may be part of the same igneous belt which hosts the Kondyor metallogenic belt. The interplate intrusions of the Kondyor metallogenic belt are herein 
interpreted as having been emplaced along a deep-seated, continental-margin transform fault during the Early Cretaceous, when the margin of the North Asian Craton was being deformed during collision and accretion of outboard terranes.

\title{
Metallogenic Belts Formed During Late Mesozoic Closure of Mongol-Okhotsk Ocean in Russian Southeast
}

\author{
Selemdzha-Kerbi Metallogenic Belt of \\ Au Quartz Vein Deposits and Granitoid-Related \\ Au Deposits (Beit SK) \\ Northwestem Part of Russian Southeast
}

The Selemdzha-Kerbi metallogenic belt of Au quartz vein, granitoid-related Au deposits, and the Talaminskoe clasticsediment-hosted Sb-Au deposit (fig. 61; tables 3, 4) occurs in the northwestem part of the Russian Southeast. The belt is hosted in the Tukuringra-Dzhagdi subduction-zone terrane and in the Nilan subterrane of the Galam accretionary-wedge terrane (Nokleberg and others, 1994c, 1997c).

The Au quartz vein deposits, as at Afanas'evskoe, Kharga, Ingagli, Malomyr, Sagurskoe, Tokur, and Zazubrinskoe, occur throughout the metallogenic belt, but are mainly in three large and remote areas, the Verkhne-Selemdzha, Sophiisky, and Kerbi mining districts which comprise an area of over 1,000 $\mathrm{km}^{2}$ (Eirish, 1991; (Nokleberg and others 1997a, b, 1998). The deposits are interpreted as forming during regional metamorphism. In this area, Au was probably derived from black shale which commonly contains disseminated Au in very small quartz veinlets and rarely in small veins (Moiseenko, 1977). In the Kerbi mining district, an exhalative origin for primary gold is interpreted because gold is concentrated near eruptive centers composed mainly of Paleozoic marine basalt. Placer gold mines, common in all three mining districts, bave been active for many decades. The Au quartz vein mines at Tokur, the significant deposit in the belt, and at Petrovsko-Eleninsky occur near dike swarms where gold is interpreted as

presumably forming just before dike intrusion. The belt also contains the Poiskovoe granitoid-related Au deposit and the Talaminskoe Sb-Au vein deposit (table 4).

\section{Tokur Au Quartz Vein Deposit}

The Tokur Au quartz vein deposit (Radkevich E.A., Moiseenko V.G., Molchanov P.Ya., Melnikov V.D., and Fat'yanov 1.1., 1969; Eirish, 1972; Melnikov V.D, and Far'yanov 1.I., 1970; Layer, Ivanov, and Bundtzen, 1994) consists of Au-bearing veins. The ore minerals comprise $3 \%$ of the veins and consist of pyrite, arsenopyrite, gold, sphalerite, galena, chalcopyrite, pyrrhotite, tetrahedrite, tennantite, and scheelite. Sphalerite and arsenopyrite increase with depth. The gangue minerals are quartz, adularia, sericite, chlorite, and calcite. Gold fineness ranges from 650 to 800 . Vein zones normally range from 25 to $90 \mathrm{~m}$ thick and carbonaceous material occurs along vein margins. The veins commonly occur conformable to bedding of host rocks and are locally discordant. The veins range up to $800 \mathrm{~m}$ in length and vary from 0.2 to $0.7 \mathrm{~m}$ thick. The maximum depth of deposit is 500 $\mathrm{m}$. The host rocks are argillite, sandstone, and quartzite, part of a structurally-deformed middle Paleozoic sequence of sandstone and schist. The deposit is medium size; 27.1 tonnes of Au were mined between 1933 and 1940. Ar-Ar isotopic study of vein adularia indicate an age of $114 \mathrm{Ma}$ or Early Cretaceous which is interpreted as the age of mineralization (P.H. Layer, Ivanov, and Bundtzen, 1994). Diorite dikes and stocks cut the veins. The dikes are interpreted as forming during the late stage of accretion with Au having been derived from the host black shale which is also the source for placer gold.

\section{Origin of and Tectonic Controls for Selemdzha-Kerbi Metallogenic Belt}

The Selemdzha-Kerbi metallogenic belt is interpreted as forming during Late Jurassic and Early Cretaceous collision of the Bureya and Khanka continental-margin arc superterranes with the North Asian Craton and closure of the Mongol-Okhotsk Ocean (Nokleberg and others, 2000). During this collision, the middle to late Paleozoic passive continental-margin clastic rocks of the craton to the north were thrust onto the Bureya superterrane to the south. The Paleozoic clastic rocks and the lesser oceanic tholeiite, chert, limestone, and black shale of the Tukuringra-Dzhagdi and Galam subduction zone-accretionary-wedge terranes occur in large nappes. During collision and regional thrusting, these rock units underwent greenschist facies regional metamorphism with late-stage formation of Au quartz vein deposits formed. Local higher-grade metamorphism occurred in metamorphic domes. 
The Stanovoy belt of granitoid-related Au deposits (fig. 61; tables 3.4) occurs in northem part of the Russian Southeast in the Stanovoy block of the North Asian Craton (unit NSS) in the northwestem part of the Russian Soutbeast. The granitoidhosted Au deposits generally consist of quartz and quartz-carbonate veins which are spatially associated with Jurassic to Early Cretaceous granite and granodiorite which are generally interpreted as forming in a collisional setting (Parfenov, 1995a, b; Nokleberg and others, 2001). The single, large granitoid-related Au deposit in the belt is ut Kirovskoe, a small Au quartz vein deposit is at Zolotaya Gora, and Au-Ag epithermal vein deposits are at Bamskoe and Burindinskoe (table 4) (Nokleberg and others 1997a, b, 1998). Also occurring in the area are numerous placer Au mines, as at Dzhalinda, Yannan, and Ingagli Rivers, which constitute some of the largest placer Au mines in the west-central part of the Russian Far East.

\section{Kirovskoe Granitoid-Related Au Deposit}

The Kirovskoe granitoid-related Au deposit (Gurov, 1969; G.P. Kovtonyuk, written commun., 1990) consists northweststriking Au-quartz-sulfide veins hosted in an Early Cretaceous granodiorite stock. The veins occur mainly along the contacts of diabase porphyry dikes which cut the granodiorite. The contacts of veins are generally sharp, although host rocks are hydrothermally altered. The veins are 0.5 to $1.0 \mathrm{~m}$ thick, and the surrounding altered rock range from 5.0 to $9.0 \mathrm{~m}$ thick. The altered rocks consist mainly of quartz ( 40 to $95 \%$ ), and albite, sericite, and hydromica. The main sulfide minerals are pyrrhotite, arsenopyrite, and chalcopyrite along with common galena, sphalerite, bismuthite, and tennantite-tetrahedrite. Fineness of gold ranges from 844 to 977 . The deposit is small, was mined until 1961, and about 10 tonnes Au were produced.

\section{Zolotaya Gora Au Quartz Vein Deposit}

The Zolotaya Gora Au quartz vein deposit (Melnikov, 1984) consists of quartz veins and zones of hydrothermally altered metamorphic rocks which occur conformably to host rock layering. Alteration is predominantly sericite-quartz and chloriteamphibole-quartz. The main mineral assemblage is sulfides-biotite-quartz, sulfide-sericite-quartz and biotite-quartz-amphibolechlorite. Less common are amphibole-quartz-feldspar mineral assemblages. Four successive stages of mineralization are identified: (1) magnetite-chalcopyrite-pyrthotite-quartz; (2) Au-carbonate-sulfide; (3) zeolite; and (4) supergene. Gold occurs both in early and late quartz, and in hydrothernally-altered rocks. Gold generally forms films and fine plates in fractures, and is concentrated in selvages of quartz and quartz-pyrite veins. Gold fineness is high (985). The deposit is small, has an average grade of grade $52 \mathrm{~g} / \mathrm{Alu}$, and was intermittently mined from 1917 to 1948 , and about 2.5 tonnes Au were produced. The deposit is hosted in gneissic granite, granulite, calcareous shale, and quartzite of the Stanovoi block of the North Asian Craton.

\section{Burindinskoe Au-Ag Epithermal Vein Deposit}

The Burindinskoe Au-Ag epithermal vein deposit (V.A. Taranenko, written commun, 1991; G.P. Kovtonyuk, written commun. 1993) occurs in steeply-dipping quartz and quartz-carbonate gold-bearing veins. The veins range up to $200 \mathrm{~m}$ length, with an average thickness of about $10 \mathrm{~m}$, and are hosted in an Early Cretaceous volcanic sequence overlying the Gonzhinsky terrane of the Burea-Khanka superterrane. The deposit is small with an average grade of $9.5 \mathrm{~g} / \mathrm{Au}, 42.6 \mathrm{~g} / \mathrm{Ag}$. Ore reserves are about 827,400 tonnes with inferred $6,230 \mathrm{~kg}$ Au and $38,200 \mathrm{~kg}$ silver.

\section{Origin of and Tectonic Controls for Stanovoy Metallogenic Beft}

The largest number of granitoid-related Au deposits and relased large placer deposits occur in the soutbers part of the metallogenic belt, near a major fault between Precambrian gneisses of the Stanovoy block to the north with the Paleozoic rocks of the Tukuringra-Dzhagdi subduction-zone terrane to the south (fig. 61). The laner is metamorphosed to greenschist facies. The Paleozoic rocks contain beds of Au-bearing, pyritized graphitic shale (V1. Sukhov and others, written commun, 1979). Because of these relations, the placer Au mines and the associated gramitoid-related Au deposits, mainly Au-bearing veins and veinlets in collisional granitic intrusions and adjacent metamorphic rocks (Gurov, 1978), are herein interpreted as forming during the Late Jurassic and Early Cretaceous(?) accretion of the Bureya superterrane to the south with the North Asian Craton to the north, and closure of the Mongol-Okhotsk ocean (Nokleberg and others, 2000). 
Kular Metallogenie Beit of

Au Quartz Vein, Granitold-Related Au, and

Sn Quarta Vein Deposits (Beit KV)

Northern Part of Eastern Siberia

The Kular metallogenic belt of Au quartz vein, granitoid-related Au, and Sn-W quartz vein deposits (fig. 61; tables 3, 4) occurs in the northern part of eastern Siberia. The belt may extend under extensive Cenozoic deposits of the Primorskaya Lowland. The deposits of the Kular belt occur in or near Early Crelaceous collisional (anatectic) granitoid rocks of the Verkhoyansk collisional granite belt (unit vk) which intrude Late Permian and Triassie sandstone and shale of the Verkhoyansk complex within the Kular-Nera terrane of the Kolyma-Omolon superterrane (Nokleberg and others, 1994c, 1997c). Most of the deposits occur adjacent to, or in granite and adamellite of the informally-named Kular batholith (lvensen and others, 1975). The significant deposits in the belt are the Burguat and Drhuotuk Au quartz vein deposits, the Novoe and Solur granitoid-related Au deposits, and the Tirekhtyak district (Nagomoe, Podgornoe, Poputnoe) with Sn quartz vein deposits (table 4) (Nokleberg and others 1997a, b, 1998).

The major Au quartz vein deposits, as at Burguat and Dahuotuk, typically consist of lenticular veins of quartz and carbonate-quartz with gold and scarce ( $1-2 \%)$ sulfide minerals including pyrite, galena, sphalerite, and chalcopyrite. Minor granitoid-related Au deposits, as at Solur and Novoe, typically consist of quartz and white mica-quartz veins. The veins and mineralized shear zones occur in Late Permian clastic rocks adjacent to an Early Cretaceous granitic intrusion. Also in this area are associated placer Au deposits in the Kular district. Small, non-economic occurrences of Sn und W occur in $\mathrm{Sn}$ quartz vein deposits, as at Nagornoe and Poputnoe in the Tirekhtyak district, and are also associated with Early Cretaceous granitoid plutons.

The lode deposits of the Kular metallogenic belt are related mainly to the Early Cretaceous collisional (anatectic) granitoid rocks of the Verkhoyansk collisional granite belt (fig. 61) (Nokleberg and others, 1994c, 1997c). The Verkhoyansk belt, of Late Jurassic and Early Cretaceous age consists chiefly of two major belts, the Main granite belt of Late Jurassic to early Neocomian age, and the Northem granite belt of Neocomian age. The Northem granite belt, which hosts the Kular metallogenic belt, extends for about $600 \mathrm{~km}$ along northwestem margin of the Kolyma-Omolon superierrane. The Northern belt consists of inclined sheet-like plutons, up to $200 \mathrm{~km}$ long, which are generally conformable with major folds. Major lithologies are tonalite, granodiorite, and, less commonly, two mica leucogranite. These granitoid rocks are interpreted as forming immediately after the Late Jurassic accretion of the Kolyma-Omolon superternune to the North Asian Craton (Nokleberg and others, 2000).

\section{Allakh-Yun Metallogenic Belt of Au Quartz Vein Deposits, and Associated \\ W-Sn Quartz Vein Deposits (Belt AY) \\ Southern Part of Russian Northeast}

The Allakh-Yun metallogenic belt Au of quartz vein deposits, $W$ and $S n$ quartz vein deposits (fig. 61; tables 3, 4) occurs in the southern part of the Russian Northeast. The deposits are hosled in late Paleozoic to early Mesozoic carbonate and clastic rocks of the North Asian Craton Margin (Verkhoyansk fold belt, unit NSV; Nokleberg and others, 1994c, 1997c; Goryachev, 1998, 2003). The sedimentary rocks are regionally metamomposed to greenschist facies, locally to staurolite grade along major fault zones (Simanovich, 1978). Regional metamorphism is interpreted as occurring prior to the development of Au quartz vein deposits. Sparse intermediate-composition granitic dikes and major granodiorite plutons, with $\mathrm{K}$-Ar ages of 140 -110 Ma, occur in the region (Nenashev, 1979). The Au-quartz vein deposits occur along a linear trend along the western boundary of the belt of granitoid plutons and dikes. The significant depesits in the belt are the Bular, Devt, Malyutka, Nezhdaninka, Novinka, Onello (Lider), Svetly, Voskhod, Yur, and Zaderzhnoe Au quartz vein deposits, the Dies and Muroenets Cu-Mo skarn deposits, the Burgali porphyry-Mo (W) deposit, the Levo-Dybin granitoid-related Au deposit, and the It-Yuryak W vein and Sn (W)-quartz vein deposit (table 4) (Nokleberg and others 1997a, b, 1998).

The Av quartz vein deposits consist of three types. (1) Concordant deposits, as at Bular, Yur, and Duet, are interpreted as metamorphic and have K-Ar isotopic ages of 170 to $140 \mathrm{Mz}$ (Nenashev, 1979; Goryachev, 1998, 2003). (2) Crosscutting. postmetamorphic Au-quartz veins and mineralized shear zones, as at Voskhod, Novinka, Zaderzhnoe, and Nezhdanin, are closely related to the early stage granitic dikes and are interpreted as igneous (Ivensen, Levin, 1975; Gamyanin and others, 1985; Goryachev, 1998, 2003). And (3) quartz granitioid-related Au deposits, as at Levo-Dybin, and W-Sn quartz vein deposits, as at Yh-Yuryak, are associated with and interpreted as related to late-stage granitoid rocks. The deposit sizes range from small to large. Related placer Au deposits are widespread in the southem portion of the metallogenic belt.

\section{Nezhdanin Au Quartz Vein Deposit}

The major Nezhdanin Au quartz vein (shear zone Au) deposit (fig. 66) (V.I. Korostolev, written commun., 1963; Silichev and Skobelev, 1970; Grinberg and others, 1970; Gamyanin and others, 1985; G.N. Gamyanin and others, written commun., 1990. 
Goryachev, 1995, 1998, 2003) consists of disseminated gold in: (1) steeply-dipping shear zones up to $40 \mathrm{~m}$ thick and $5.4 \mathrm{~km}$ long: (2) related tension-gash quartz veins up to $200 \mathrm{~m}$ long and $1.2 \mathrm{~m}$ thick; and (3) quartz lenses within the shear zones. Vein minerals include quartz, carbonate, arsenopyrite, galena, sphalerite, scheelite, sericite, albite, chalcopyrite, tetrahedrite, lead and copper sulfosalts, stibnite, and gold. Wallrock alteration includes silicification, sulfidization, and sericitization. Quartz-silver-polymetallic ore bodies both cross-cut and post-date the feathered quartz-vein mineralization. The ore bodies are located along a deep fault which cuts the core of a doubly-plunging anticline in Late Carboniferous to Early Permian sandstone and shale. The deposit extends more than $1,000 \mathrm{~m}$ vertically. Workings include boreholes and seven levels of adits. The deposit is major with proven reserves of 475 tonnes $\mathrm{Au}$, and an estimated additional resource of more than 500 tonnes Au. The average minimum grade is $5 \mathrm{~g}$ t Au with up to $6,748 \mathrm{~g} / \mathrm{t} \mathrm{Au}$, and up to $8,300 \mathrm{~g} / \mathrm{Ag}$ in veins.

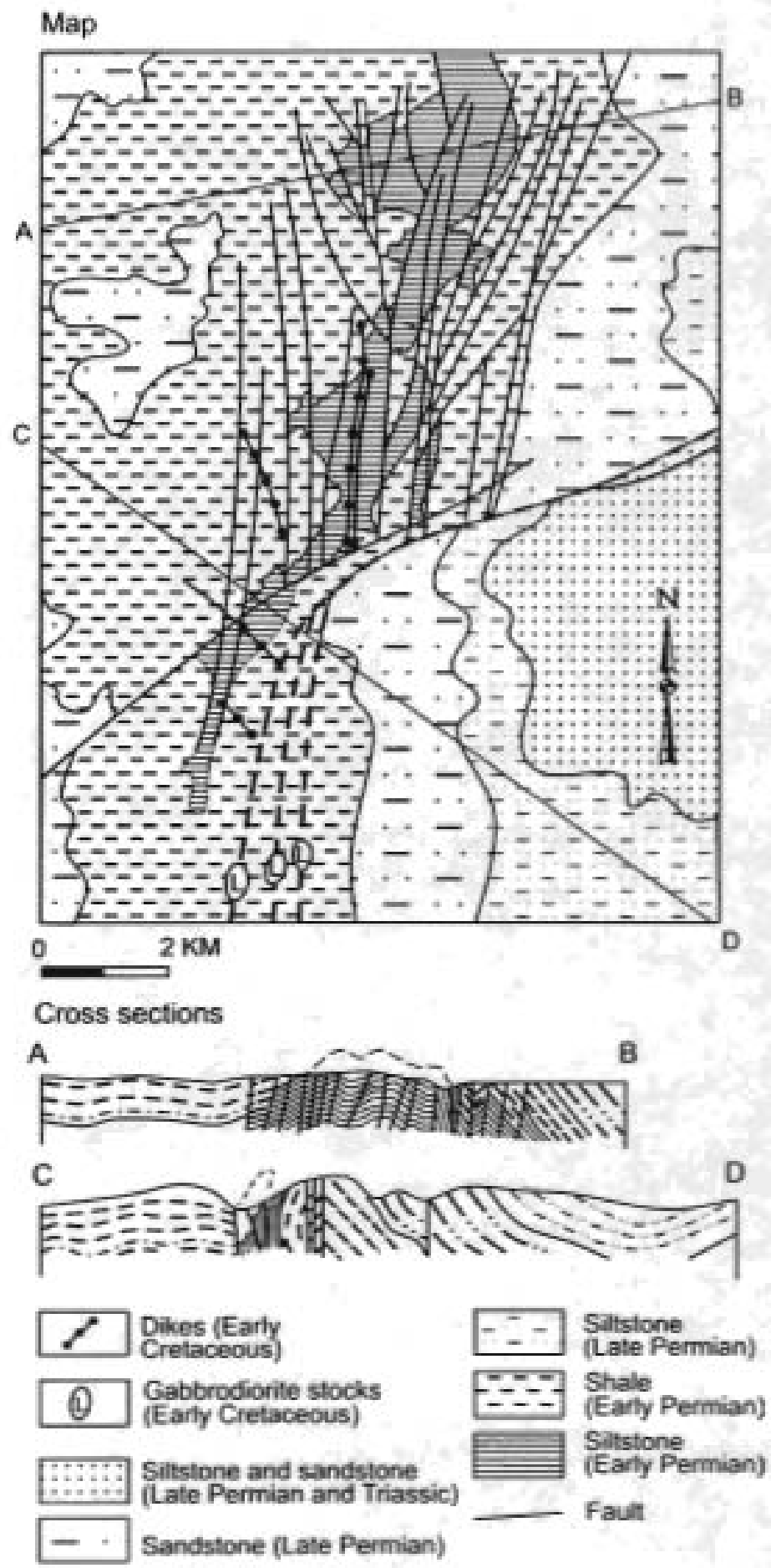

Figure 66. Nezhdaninka Au-Ag-quartz vein deposit, South Verkhoyansk metallogenic belt, Russia, East-Central Yakufia (Verkhoyansk area). Schematic geologic map and cross sections. Adapted from Shour (1985). 
The small Yur Au quartz vein deposit (Strona, 1960, N.D. Kobtseva, written commun., 1988) consists of four interbedded quartz veins which occur in a zone of meridional faults in middle Carboniferous sandstone-shale. The veins range from $0.3-0.4 \mathrm{~m}$ thick and are 100-500 $\mathrm{m}$ long. The main ore minerals are gold, arsenopyrite, galena, pyrite, and sphalerite. The ore minerals comprise up to $2 \%$ of veins. The gangue minerals are quartz, ankerite, and albite. Wallrock alteration is insignificant, but includes sericite, silica, and arsenopyrite alteration. The deposit is small with an average grade of 3.5-5.7 g/t Au.

\section{Levo-Dybin Granitioid-Related Au Deposit}

The Levo-Dybin granitioid-related Au deposit (A.V, Kokin, written commun., 1978; Zubkov, 1984; Goryachev, 1998, 2003 ) consists of abundant quartz stringers, from 0.2 to $0.3 \mathrm{~m}$ thick, which form peculiar sheet stockworks in contact metamorphosed, Late Permian sandstone beds, which range from $51020 \mathrm{~m}$ tbick. The stringers consists of quartz (90-95\%). muscovite, potassium feldspar, scheelite, molybdenite, arsenopyrite, niccolite, löllingite, pyrrhotite, bismuth, gold, bismuthine, bismuth tellurides and sulfotellurides, and maldonite. The deposit occurs for $800-1,000 \mathrm{~m}$ along the strike of the bedding; and also occurs above an Early Cretaceous granitoid body and in adjacent country rocks. The deposit contains up to $3 \%$ As, 7-13 g't Au, up to $2.5 \% \mathrm{WO}_{3}$, up to $1 \% \mathrm{Bi}$, and up to $0.6 \% \mathrm{Te}$.

\section{Origin of and Tectonic Controls for Allakh-Yun Metallogenic Belt}

The vein deposits of the Allakh-Yun metallogenic belt are interpreted as forming during two major tectonic events (Goryachev, 1998, 2003). The relatively older, metamorphic-related Au quartz vein deposits are interpreted as forming during the early stages of thrusting and associated metamorphism of the southern part of the North Asian Craton Margin (unit NSV. Verkhoyansk fold belt) during accretion of the Okhotsk terrane and Kolyma-Omolon superterrane onto the North Asian Craton Margin. Accretion of the Okhotsk terrane may have been accentuated by the coeval accretion of the outboard Kony-Murgal island-arc terrane. The relatively younger, crosscutting, Au-quartz vein deposits, and granitioid-related Au and W-Sn quartz vein deposits of the Allakh-Yun metallogenic belt are interpreted as forming during intrusion of the Early Cretaceous anatectic granitoid rocks of the Verkhoyansk collisional granite belt (unit vk; Nokleberg and others, 1994c, 1997c). This Late Jurassic and Early Cretaceous granite belt consists of two main belts, the Main granite belt of Late Jurassic to carly Neocomian age, and the Northern granite belt of Neocomian age. The Main granite belt, which hosts the Allakh-Yun metallogenic belt, extends for about $110 \mathrm{~km}$ along southwest border of the Kolyma-Omolon superterrane and stilches the superterrane to North Asian Craton margin. The granites occur as inclined, sheet-like plutons, up to $200 \mathrm{~km}$ long, which are generally conformable with major folds. Ar-Ar ages of granitoid rocks range from 134 to $144 \mathrm{Ma}$ (Parfneov, 1995). These granitoid rocks are interpreted as forming immediately after the Late Jurassic accretion of the Kolyma-Omolon superterrane to the North Asian Craton Margin (Nokleberg and others, $1994 \mathrm{c}, 1997 \mathrm{c}, 2000)$.

\section{Yana-Polousnen Metallogenic Belt of Granitoid-Related Au, Sn Quartz Vein, W Vein, Sn Greisen, Co-, Au-, and Sn-Skarn, Sn-Silicate Sulfide Vein and Related Deposits (Belt YP) Central Part of Russian Northeast}

The Yana-Polousnen metallogenic belt of granitoid-related Au, Sn quartz vein, W vein, Sn greisen, Co-, Au-, and Snskarn, Sn-silicate sulfide vein and related deposits (fig. 6I; tables 3, 4) occurs in an enormous, discontinuous wide zone, about $1000 \mathrm{~km}$ and up to $200 \mathrm{~km}$ wide in the northwestern part of the Russian Northeast (Shpikerman and Goryachev, 1995, 1996, 2003). The belt trends from the lower part of the Alazeya River in the southwest to the headwaters of the Yana River in the northeast. The belt is locally extensively overlain by unconsolidated Cenozoic sedimentary deposits. The granitoid-related deposits occur in or near granitoid rocks which intrude: (1) the North Asian Craton Margin (Verkhoyansk fold belt, unit NSV); (2) carbonate, clastic, and igneous rocks of the Omulevka, Munilkan, and Kular-Nera terranes of the Kolyma-Omolon superterrane; and (3) the overlapping Polousnen flysch of the Indigirka-Oloy sedimentary-volcanic assemblage (unit io; Nokleberg and others, $1994 \mathrm{c}, 1997 \mathrm{c})$.

Several types of lode deposits occur in the Yana-Polousnen metallogenic belt (table 4) (Nokleberg and others 1997a, b, 1998). (1) Medium to major Sn and W quartz vein, and Sn greisen mines und deposits, some of which are now mostly exhausted, occur at Argin, Kester, Balyktaah, Ploskoe, Odinokoe, Polyarnoe, and Takalkan. These deposits generally occur in the apical portions of granitoid plutons and are associated with placer $\mathrm{Sn}$ and $\mathrm{W}$ placer deposits. (2) Co, Au, and Sn skarn deposits, as at Kandidatskoe and Arbatskoe, and granitoid related Au quartz vein deposits, as at Chistoye and Tuguchak-2, generally occur along the contacts of granitoid plutons. (3) Sn-silicate-sulfide and Sn polymetallic vein deposits, usually associated with Ag, occur at Alys-Khaya, Anomalinoe, Bugdogar, Burgachan, Ege-Khaya, Khoton-Khaya, Ilin-Tas, Sigilyakh, and Ulakhan-Egelyakh. These deposits generally occur adjacent to intrusions along contacts, often adjacent to mafic and intermediate dikes, and are associated with the late stage mineralization and associated granitic magmatism. And (4) $\mathrm{Sb}, \mathrm{Pb}$, and $\mathrm{Zn}$ polymetallic vein deposits, as at 
Altinskoe, Aragochan, Dalnee, Dokhsun, and Verkhne-Naanchan, are associated with granitoid plutons. Isotopie studies indicate the deposits and associated grantoid roeks formed from about 130-110 Ma (Nenashev, 1979; Goryachev, 1998, 2003; Parfenov, 1995; Parfenov and others, 1999).

\section{Polyamoe Sn greisen and Vein Deposit}

The Polyarnoe Sn greisen and vein deposit (Nekrasov, 1962; O.G. Epov and G.S. Sonin, written commun., 1964; Flerov. $1974)$ consists of quartz and quartz-topaz veins which dip gently to moderately $\left(5-40^{\circ}\right)$ near and within a stock of apogranite at the top of the major Cretaceous Omchikandin leucogranite batholith. The veins range from 0.1 to $3.5 \mathrm{~m}$ thick, are up to $300 \mathrm{~m}$ long. and extend up to 260 m down-dip. The main minerals are quartz, 1opaz, fluorite, muscovite, zinnwaldite, wolframite, cassiterite, arsenopyrite, molybdentite, tourmaline, sphalerite, galena, pyrite, chalcopyrite, stibnite, bismuth, bismuthine, and bismuth sulfosalts. No size or grade data are available. The deposit is associated with quartz-topaz greisen.

\section{Kandidatskoe Au Skarn Deposit}

The Kandidatskoe Au skarn deposit (Nekrasov, 1962; Bakharev and others, 1988) consists of zones of garnet-pyroxene, pyroxene-wollastonite, pyroxene, and epidote-pyroxene skam which range up to 100 to $150 \mathrm{~m}$ long and up to $50 \mathrm{~m}$ thick. The skarn zones occur in a block of Devonian carbonate and Permian clastic rocks located between granodiorite of the Early Cretaceous Ulakhan-Tass pluton and monzonite of the mid-Cretaceous Kandidatsky stock. The main (No. 1) ore body occurs as a steeply-plunging, funnel-shaped pipe of massive and disseminated ore with an outcrop area of $150 \mathrm{~m}$ long and up to $20 \mathrm{~m}$ wide. The main minerals are arsenopyrite, lollingite, pyrthotite, molybdenite, glaucodot, cobaltite, gold, bismuth, bismuthine, maldonite, hedleyite, and A and B joseite. The gold is fine-grained ( $98 \%$ less than $0.08 \mathrm{~mm}$ ) and has a fineness of $650-1,000$. At the adit level $(50 \mathrm{~m})$, the thickness of the ore body is half of which at surface. The deposit contains up $1055 \mathrm{~g} / \mathrm{Au}, 3 \% \mathrm{Co}, 20 \% \mathrm{As}, 0.5 \% \mathrm{Bi}$, $3 \% \mathrm{Zn}, 0.5 \% \mathrm{Ni}, 0.1 \% \mathrm{Te}$.

\section{Chistoe Granitoid-Related Au Deposit}

The Chistoe grantitoid-felated Au deposit (Bakharev and others, 1988) consists of a set of quartz veins which range from $101050 \mathrm{~m}$ long and from 0.1 to $0.5 \mathrm{~m}$ thick. The veins occur in two steep-lying northeast-striking shear zones which range up to $500 \mathrm{~m}$ long and are hosted in contact metamorphosed Late Jurassic sandstone and in Early Cretaceous granodiorite stocks. The main minerals are muscovite, quartz, tourmaline, arsenopyrite, cobaltite, calcite, wolframite, native bismuth, native gold (fineness 500-1000), bismuthine, joseite (A, B, M, L types), and maldonite. The veins are associated with greisen zones which range up to I to $2 \mathrm{~m}$ wide. The deposit contains up to $20 \mathrm{gtt} \mathrm{Au}, 0.9 \% \mathrm{~W}, 0.5 \% \mathrm{Bi}$, and $1 \% \mathrm{As}$.

\section{Min-Tas Sn Sillicate-Suifide Vein Deposit}

The llin-Tas Sn silicate-sulfide vein deposit (Shur and Flerov, 1979; T.N. Spomior and others, written commun, 1985) consists of complex veins and less common shear zones and stringers which occur in contact metamorphosed Late Triassic sandstone and siltstone adjacent to the Bezymyanny granitoid pluton. Granodiorite of the early magmatic phase has an Rb-Sr isotopic age of $170 \mathrm{Ma}$ with an initial Sr isotopic age of 0.7035 , and fine-grained granite of the second phase has a Rb-Sr isotopic age of $143 \mathrm{Ma}$ with an initial Sr ratio of 0.0761 (Nenashev and others, 1985). The ore bodies dip steeply, range from 0.01 to $6 \mathrm{~m}$ thick. and are about $100 \mathrm{~m}$ long. The veins are most dense at a distance of $500-1,000 \mathrm{~m}$ from the intrusive contact. The major minerals are quart, tourmaline, cassiterite, stannite, wolframite (ferberite), pyrrhotite, pyrite, arsenopyrite, and chalcopyrite. Also occurring are $\mathrm{Bi}$ and Te minerals. The deposit is major with an average grade of 0.7-2.5\% Sn; 0.3-1.0\% W0,; up to $10 \mathrm{~g} / \mathrm{Au}$.

\section{Origin of and Tectonic Controls for Yana-Polousnen Metallogenic Beht}

The lode deposits of the Yana-Polousnen metallogenic belt are related mainly to the Early Cretaceous collisional (anatectic) granitoid rocks of the Northern part of the Verkhoyansk granite belt (unit vk) (Nokleberg and others, 1994c, 1997c; Goryachev, 1995, 1998, 2003). The Northem part of this granite belt, which extends for about $600 \mathrm{~km}$ along northwestern margin of the Kolyma-Omolon superterrane, consists of inclined sheet-like plutons, up to $200 \mathrm{~km}$ long, which are generally conformable with major folds. Major lithologies are granodiorite, granite, and, less commonly, leucogranite. These granitoid rocks are interpreted as forming immediately after the final, Early Cretaceous stage of accretion of the Kolyma-Omolon superterrane to the North Asian Craton (Nokleberg and others, 2000).

\section{Darpir Metallogenic Belt of Sn and}

Associated Felaic-Magmatism Deposits

(Beit DP) Western Part of Russian Northeast

The Darpir metallogenic belt of Sn and associated felsic-magmatism-related deposits (fig. 61; tables 3,4) occurs in the western part of the Russian Northeast. The belt is hosted in a zone of Early Cretaceous granitic intrusions which trends northwest 
along the southwest boundary of the Omulevka passive continental margin terrane of the Kolyma-Omolon superterrane (Nokleberg and others, 1994c, 1997c). The belt extends for more than $1,000 \mathrm{~km}$ (fig. 61). The metallogenic belt and zone of granitic intrusions is transverse, or nearly orthogonal to the trend of the younger Okhotsk-Chukotka voleanic-plutonic belt to the southeast. A diverse group of granitic-intrusive-related mineral deposit types oceur in the Darpir metallogenic belt (table 4). The significant deposits in the belt are the Botshoy Kanyon Sn skarn deposit (fig. 67), the Bastion Sn greisen deposit, the Titovskoe Sn (B) magnesian skam deposit, the Chibagalakh Sn-B skarn deposit, the Darpir and Lazo Sn silicate-sulfide deposit, the VerkhneSeimchan Co-arsenide polymetallic vein deposit, and the Chepak granitoid-related Au deposit (Nokleberg and others 1997a, b, 1998). The belt also contains a few $\mathrm{Pb}-\mathrm{Z}$ n skam deposits.

The significant felsic-magma-associated deposit of the Darpir metallogenic belt occur in diverse geologic settings. The Sa skam deposits at Titovskoe and Bolshoy Kanyon occur in Paleozoic carbonate rocks near Early Cretaceous granitoid plutons. The Sn greisen deposit at Bastion occurs in leucocratic granite. Sn polymetallic vein and Sn silicate-sulfide deposits, such as the Darpir and Lazo deposits, commonly occur in or near Early Cretaceous granite plutons which intrude contact-metamorphosed, Early and Middle Jurassic siltstone. Bi-, Co-, and As-vein deposits, as at Verkhny Seimchan, and granitoid-related Au deposits, as the Chepak deposit, occur in a similar setting.

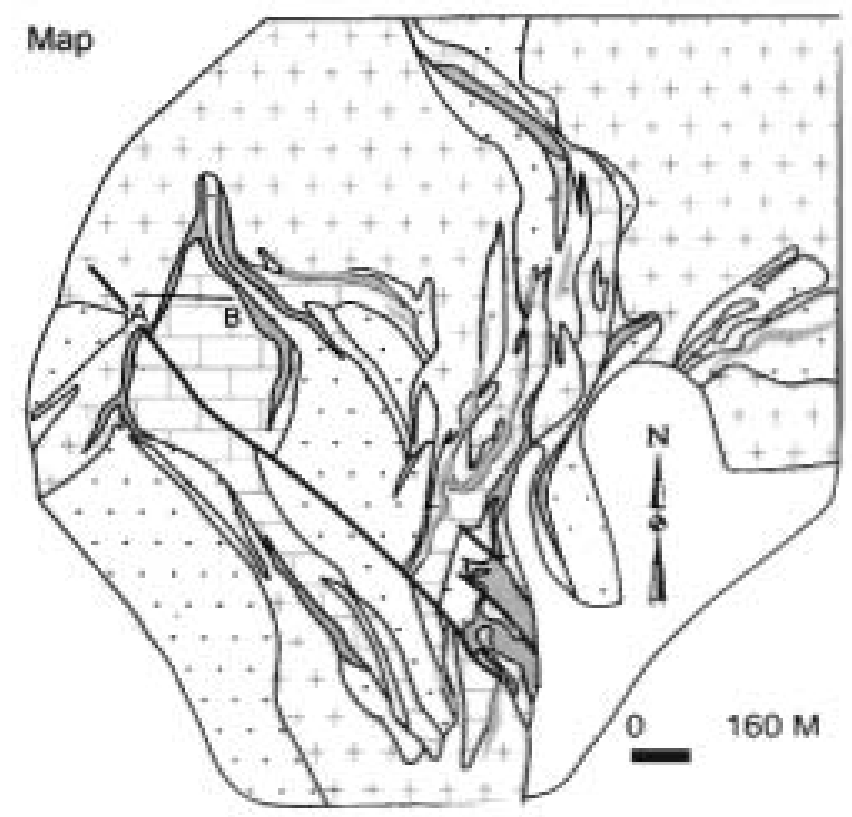

Cross section

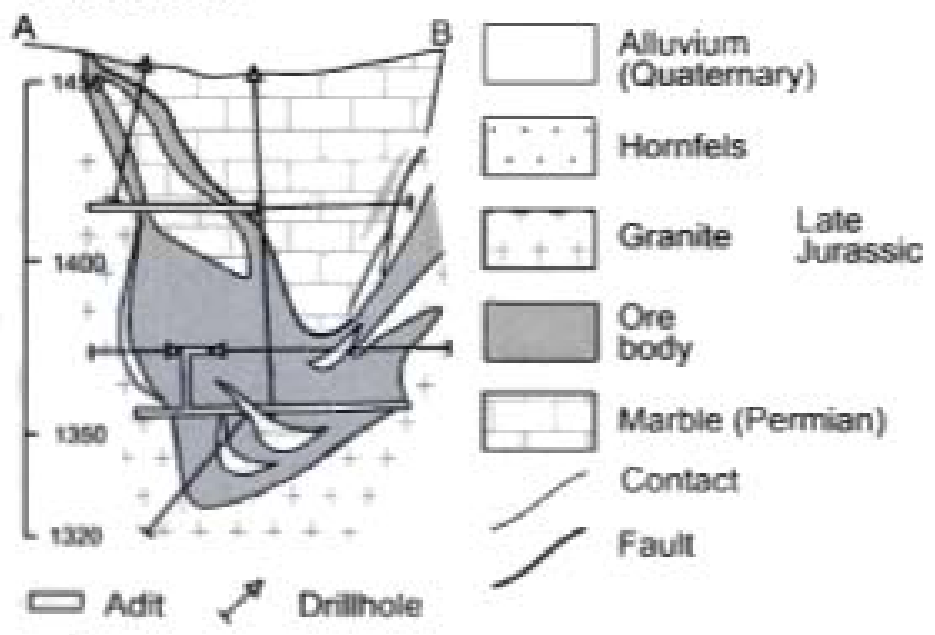

Figure 67. Bolshoy Kanyon Sn skarn deposit, Darpir metallogenic belt, Russian Northeast. Schematic geologic map and cross section, Adapled from Politov (1983).

\section{Thtorskoe Sn (B) Magnesium Skarn Deposit}

The Titovikoe Sn (B) magnesium skam deposit (Dorofeev, 1979) consists of forty ore bodies which occur along the contact between the quartz monzonite phase of an Early Cretaceous granitoid intrusion and Silurian and Devonian dolomite and limestone. The ore bodies range from $5 \mathrm{~cm}$ to $20 \mathrm{~m}$ thick and from 50 to $1,000 \mathrm{~m}$ long. The main ore mineral is ludwigite, which 
comprises up to 70-80\% in some ore bodies. The ore minerals also include ascharite, kotoite, datolite, harkerite, monticellite, nuoborite, clinohumite, calcite, periclase. forsterite, diopside, vesuvianite, brucite, garnet, axinite, lourmaline, biotite, phlogopite, serpentine, spinel, homblende, pyroxene, feldspar, quartz, and magnetite. Sn occurs as an isomorphous admixture in ludwigite. Ludwigite is often repiaced by sulfide minerals (pymhotite, sphalerite, pyrite, arsenopyrite, and chalcopyrite). Kotoite veins occur along the margins of ludwigite bodies. The contact between the intrusion and carbonate is highly irregular. Most of the skams occur where the contact forms embayments (pockets) into the intrusion. The deposit covers a 3 by $6 \mathrm{~km}$ area, and is of medium to major size. The average grades are $9.5 \% \mathrm{~B}_{2} \mathrm{O}_{2} ; 0.3 \% \mathrm{Sn}$.

\section{Chepak Granitoid-Related Au Deposit}

The Chepak granitoid-related Au deposit (P.I. Skomyakov, written commun, 1951; V.1. Shpikerman and N.A. Goryachev, written commun., 1995) consists of steeply dipping, quartz-sulfide veinlets, replacement veins, and associated alteration zones which are both concordant with, and cut intensely contact-metamorphosed Late Triassic sandstone and shale which overlie a buried granitoid pluton. The Au ore bodies occur in zones of nortbeast-trending veins. The host rocks are intruded by dikes of diorite porphyry, lamprophyre, and dolerite; and by small intrusive bodies of Late Jurassic-Early Cretaceous granite porphyry, granodiorite porphyry, and dacite. Disseminated veinlets are also occur in the magmatic rocks and in hornfels. The wall rocks are silicified, chloritized, and sericitized. The veins are composed mainly of quartz (30-60\%), sericite, feldspar, chlorite, carbonate, apatite, arsenopyrite, liellingite, scheelite, pyrrhotite, and pyrite. Less common or rare are chalcopyrite, bismuth, bismuthinite, marcasite, wolfrumite, magnetite, ilmenite, rutile, sphene, tourmaline, epidote, and fluorite. Arsenopyrite and löellingite make up to 20 to $40 \%$ of the veins. Most gold is finely dispersed in arsenopyrite, löellingite, and pyrrhotite. The deposit is medium size. The Au content ranges from 5 to $50 \mathrm{~g} / \mathrm{Au}$, with values as high as $200 \mathrm{~g} / \mathrm{t}$ Au. Proven reserves are 30 tonnes $\mathrm{Au}$ with an average grade of 7 to $8 \mathrm{~g} / \mathrm{Au}$.

\section{Onigin of and Tectonic Controls for Darpir Metallogenic Belt}

The Eurly Cretaceous granitic intrusions which host the Darpir metallogenic belt are part of the Main part of the Verkhoyansk collisional granite belt (fig, 61 ) which intrudes Paleozoic and early Mesozoic bedrock of the Kolyma-Omolon superterrane and the adjacent North Asian Craton Margin (Nokleberg and others, 1994c, 1997c). The Main part of the collisional granite belt is of Late Jurassic to early Neocomian age. The Main part of the granite belt occurs along southwest border of the Kolyma-Omolon superterrane and stitches the superterrane to North Asian Craton Margin (Verkhoyansk fold belt, unit NSV). The Main part of the granite belt occurs as inelined, sheet-like plutons, up to $200 \mathrm{~km}$ long, which are generally conformable with major folds. Younger differentiates are biotite, two-mica, and amphibole-biotite granitoid rocks. Ar-Ar ages of granitoid rocks range from 134 to $144 \mathrm{Ma}$. The Main part of the Verkboyansk collisional (anatectic) granitic belt and associated Darpir metallogenic belt are interpreted as forming during a period of anatectic granitic magmatism which occurred immediately after the Late Jurassic accretion of the Kolyma-Omolon superierrane to the North Asian Craton Margin (Nokleberg and others, 1994c, 1997c).

\section{Tompon Metallogenic Belt of}

Cu, W, Sn Skarn, and Sn Quartz Vein Deposits (Belt TO)

West-Central Part of Eastern Siberia

The small Tompon metallogenic belt of $\mathrm{Cu}$, W, and $\mathrm{Sn}$ skarn deposits (fig. 61; tables 3, 4) occurs in the west-central part of eastern Siberia. The belt exiends for about $150 \mathrm{~km}$ in the North Asian Craton margin (Verkhoyansk fold belt, unit NSV; NokJeberg and others, 1994c, 1997e). The deposits are hosted in altered Triassic limestone which is interlayered with sandstone and shale. The major deposits in the belt are the Khunkhada Sn-W skam, Agylki W skam, and Erikag Sn quartz vein deposits (table 4) (Nokleberg and others 1997a, b, 1998). The deposits generally occur above the apical portions of unexposed granitoid intrusions. $W$ in the skam deposits occurs as scheelite which is associated with chalcopyrite. The deposits contain anomalous Bi. The deposits are of small 10 medium size and are not economic. Older K-Ar isotopie studies yield an Early Cretaceous age of 125 $130 \mathrm{Ma}$ for the associated granitoid rocks. Newer Ar-Ar isotopic ages of granitoid rocks range from 134 to $144 \mathrm{Ma}$ (Layer and others, 1995).

The lode deposits of the Tompon metallogenic beli are associated with intrusion of the Main part (Late Jurassic to early Neocomian) of the Verkhoyansk collisional granite belt (unit vk; Nokleberg and others, 1994c, 1997e). The Main collisional granite beli extends for about $110 \mathrm{~km}$ along southwest border of the Kolyma-Omolon superterrane and stitches the superterrane to North Asian Craton margin. The granites in the belt ocear as inclined, sheef-like plutons, up to $200 \mathrm{~km}$ long, which are generally conformable with major folds. These granitoid rocks are interpreted as forming immediately after the Late Jurassic accretion of the Kolyma-Omolon superterrane to the North Asian Craton Margin (Nokleberg and others, 1994c, 1997c). 
The Shamanikha metallogenic belt of $\mathrm{Au}$ quartz and $\mathrm{Cu}-\mathrm{Ag}$ quartz vein deposits (fig. 61 ; tables 3,4 ) occurs in the Shamanikha River basin in the west-central part of the Russian Northeast. The belt is hosted in a zone of metamorphic rocks in Paleozoic and older rocks in the western part of the Sharnanikha subterrane of the passive continental margin Prikolyma terrane of the Kolyma-Omolon superterrane (fig. 61). The zone of melamorphic rocks and vein deposits is adjacent to the Late Jurassic voleanic and plutonic rocks of the Indigirka-Oloy overlap assemblage (unit io, Nokleberg and others, 1994c, 1997c). The major deposits in the belt are the Glukhariny and Kopach $\mathrm{Au}$ quartz vein deposits, and the Opyt $\mathrm{Cu}-\mathrm{Ag}$ quartz vein deposit (table 4) (Nokleberg and others $1997 \mathrm{a}, \mathrm{b}, 1998$ ). The metallogenic belt extends north-south for about $350 \mathrm{~km}$ and varies in width from 5 to $50 \mathrm{~km}$.

\section{Au Quartz Vein Depesits}

The Au quartz vein deposits generally oceur as thin quartz veins in late Proterozoic sedimentary rocks metamorphosed to greenschist facies. The significant Au quartz vein deposits are at Glukharny and Kopach. The Glukhariny occurrence (E. Ya. Lutskin, written commun., 1964; V.A. Semenov, written commun., 1974) consists of gold in quartz veins in Late Proterozoic quartz-chlorite-epidote schist, quartzite, and metarbyolite; and in quartz-cemented breceias in these rocks. The wall rocks are metamorpbosed to upper greenschist fieies. The ore minerals are native gold, galena, chalcopyrite, arsenopyrite, and hematite. The deposit oceurs in three east-west trending zones which range up to $1,200-4,000 \mathrm{~m}$ long and vary from 400 to $900 \mathrm{~m}$ wide. The deposit is small. Grab samples contain up to $25 \mathrm{~g} / \mathrm{h} \mathrm{Au}$ and up to $50 \mathrm{~g} / \mathrm{Ag}$.

\section{Cu-Ag quartz Vein Deposits}

The $\mathrm{Cu}-\mathrm{Ag}$ quartz vein deposits occur in Late Proterozoic Cu-bearing sandstone metamorphosed to greenschist facies. The significant deposit at Opyt (E. Ya. Lyaski, written commun., 1937; V.A. Erzin, written commun, 1946; A.N. Ruchkin and S.L. Tsykarev, written commun., 1984) occurs as veins and zones of massive, disseminated, and brecciated veinlets. The ore minerals are pyrite, chalcopyrite, bornite, galena, sphalerite, cuprite, native copper, chalcocite, arsenopyrite, and electrum. The gangue minerals are quartz, calcite, dolomite, graphite, and chlorite. The veins are hosted in Late Proterozoic, Cu-bearing. graphite-sericite-chlorite-quartz schist, and also in Late Jurassic silistone and sandsione. The deposit is located at the intersection of a Late Jurassic depression and a block of old metamorphic rocks near a barely eroded granite body. The main ore body is about $2 \mathrm{~km}$ long; the entire deposit trends northwest-southeast for about $3 \mathrm{~km}$. The deposit contains a probable resource of 14 million tonnes of reserves grading $1.5 \% \mathrm{Cu}, 1.2 \% \mathrm{~Pb}, 0.5 \% \mathrm{Zn}, 180 \mathrm{~g} / \mathrm{Ag}$, and up to I g/t $\mathrm{Au}$. The $\mathrm{Cu}-\mathrm{Ag}$ quartz vein deposits of the Shamanikha metallogenic belt occur adjacent to the Late Jurassic Uyandin-Yassachny volcanic-plutonic belt which forms the southwestern part of the Indigirka-Oloy sedimentary and igneous assemblage (unit io, fig. 61). The Cu-Ag quartz vein deposits exhibit a more diverse mineral composition compared to the Au quartz vein deposits in the same belt.

\section{Origin of and Tectonic Controls for Shamanikha Metallogenic Belt}

Because the metamorphic vein deposits of the Shamanikha metallogenic belt occur partly in Late Jurassic sedimentary rock, the veins are interpreted in forming in the latest Jurassic or Early Cretaceous (Nokleberg and others, 2000; this study). The metamorphism, associated deformation, and formation of the $\mathrm{Au}$ and $\mathrm{Cu}-\mathrm{Ag}$ quartz vein deposits are interpreted as occurring during one of two major lectonic events (Nokleberg and others, 2000): (1) the latest Jurassse and Early Cretaceous accietion of the Kolyma-Omolon superterrane, including accretion of the Prikolyma passive continental margin terrane, to the North Asian Craton margin (unit NSV, fig. 61); or (2) the Early to mid-Cretaceous accretion of the Chukotka superterrane against the South Aayui and Velmay subduction-zone terranes, and the Nulesyn island-arc terrane which were in turn were colliding with the Kolyma-Omolon superterrane to the southwest. Herein, the first inserpretation is favored.

\section{Verkhoyansk Metallogenic Belt of \\ Au Quartz Vein, Au-Sn Polymetallic Vein \\ Deposits (Belt VK) Western Part of \\ Russian Northeast}

The Verkboyansk metallogenic belt of Au quartz vein and Au polymetallic vein, and $\mathrm{Sn}$ vein deposits (fig. 61; tables 3. 4) occurs in the westem part of the Russian Northeast (Goryachev, 1998, 2003). The deposits are hosted in the North Asian Craton Margin (Verkhoyansk fold belt, unit NSV) (Nokleberg and others, 1994c, 1997c). The belt extends for about $1000 \mathrm{~km}$ from the Tompo River basis to the Arctic Ocean in a narrow band which occurs in the axial portion of the Verkhoyansk meganticlinorium. The major Au quartz vein deposits are at Anna-Emeskhin, Enichan-Tolono, Galochka, Nikolaevskoe, Otkrytoe, Syncha-I \& II, and Syugyunyakh-Kende, and the major Au-Sn polymetallic vein deposits are at Balbuk, Bochiyskoe, Chochimbal, Dyabkhanya, and limtandzha (table 4) (Nokleberg and others 1997a, b, 1998). A Pb polymetallic vein deposit is at Balbuk. 
The Au quartz vein deposits are interpreted as synmetamorphic and formed relatively earlier than the nearly coeval Aupolymetalte vein deposits (Goryachev, 1998, 2003). The Au quartz vein deposits are controlled by diagonal and longitudinal faults and anticlinal domes (Amuzinsky, 1975) and occur both as sheeted ore bodies and sometimes as stockworks.

An example of in Au polymetallic vein deposit is at Chochimbal. An example of a Sn polymetallic vein deposits is at Imtandzha. The polymetallic vein deposits occur in the southem half of the metallogenic belt and are closely associated with Cretaceous granitoid rocks. The Au-Sn polymetallic vein deposits are relatively older than associated granitoid rocks (Ivensen and others, 1975; Goryachev, 1998, 2003).

\section{Nikolaevsikoe and Otkrytoe Au Quartz Vein Deposits}

The Au quartz vein deposits at Nikolaevskoe and Otkrytoe (Abel and Slezko, 1988) consist of conformable and crosscuating quartz veins with gold, galena, arsenopyrite, pyrite, tetrahedrite, sulfosalts, carbonates, and albite which are hosted in Early Permian sandstone beds. The veins occur in anticlinal hinges, are up to $1 \mathrm{~km}$ long, and range from 0.2 to $1 \mathrm{~m}$ thick, sometimes up to $10 \mathrm{~m}$ thick. Sulfides comprise up to $5 \%$ of the veins. The Au quartz vein deposits are not economic, but the source for the placer Au mines of the Verkhoyansk district.

\section{Chochimbal Au Polymetallic Voin Deposit}

The Au polymetallic vein deposit at Chochimbal (Goryachev, 1994, 2003) consists of interbedded shallow-dipping. steeply-dipping, cross-cutting carbonate-quartz-sulfide veins which are hosted in mid-Carboniferous clastic rocks. The ore bodies vary from 0.1 to $2.8 \mathrm{~m}$ thick and from 400 to $500 \mathrm{~m}$ long. The major minerals are quartz, siderite, sulfides, pyrite, arsenopyrite, Fe-sphalerite, and galena. Less common minerals are chalcopyrite, pyrrhotite, tetrahedrite, bournonite, native gold, and boulangerite.

\section{Imtandzha Sn polymetallic Vein Deposit}

The Imtandzha Sn polymetallic vein deposit occurs in a zone of an intense fissures along the axis of an anticline which is about $500 \mathrm{~m}$ wide and $2 \mathrm{~km}$ long. Coeval granodiorite porphyry dikes which both cut a and are cut by the polymetallic vein deposits (Goryachev, 1998, 2003). Early-stage polymetallic veins are mostly conformable whereas late stage, cross-cutting veins are less common. The early-stage veins range from 0.01 to $0.85 \mathrm{~m}$ thick. The major minerals are galena, sphalerite, and siderile; minor minerals are quartz, tetrahedrite, pyrite, arsenopyrite, and boulangerite. The laie stage veins contain quartz, chlorite, pyrile, arsenopyrite, galena, cassiterite, tourmaline, and stannite and range from 0.1 to $0.6 \mathrm{~m}$ thick.

\section{Origin of and Tectonic Controls for Verkhoyansk Metallogenic Belt}

The Verkhoyansk metallogenic belt is bosted in rocks late Paleozoic to early Mesozoic clastic sedimentary rocks which are weakly metamorphosed, lower greenschist facies with development of metamorphic chlorite and rare biotite. Permian and Triassic diabase dikes are wide-spread along with isolated Cretaceous granitoid plutons and variable-composition dikes. The Au quartz vein deposits of the Verkhoyansk metallogenic belt are interpreted as forming during regional deformation and metamorphism associated with accretion of the Kolyma-Omolon superterrane to the Verkhoyanak fold belt of the North Asian Craton Margin (Goryachev, 1998, 2003). The slightly younger Au and Sn polymetallic vein deposits of the Verkhoyansk metallogenic belt are interpreted forming during the Main part of the Early Cretaceous Verkhoyansk collisional granitic belt (vk) (Nokleberg and others, 1994c, 1997c). The belt is interpreted as forming immediately after the Late Jurassic accretion of the Kolyma-Omolon superterrane to the North Asian Craton Margin (Nokleberg and others, 1994c, 1997c).

\section{Yana-Kolyma Metallogenic Belt of Au Quartz Vein, Sn Vein and Greisen, W Vein, Granitoid-Related Au, and Clastic-Sediment-Hosted $\mathrm{Hg}$ Deposits (Beit YA) Central Part of Russian Northeast}

The Yana-Kolyma metallogenic belt of mainly Au quartz vein, lesser Se vein, Sn geisen, granitoid related Au, W vein deposits, and clastic-sediment-hosted Hg deposits (fig. 61; tables 3,4) oceurs in the central part of the Russian Northeast (Goryachev, 1998, 2003). The Yana-Kolyma belt is hosted in the upper Paleozoic through middle Mesozoic rocks of the KularNera accretionary-wedge ierrane of the Kolyma-Omolon superterrane (Nokleberg and others, 1994c, 1997c). Major, wide shear zones, distinct folds, and numerous granitic intrusions characterize the host rocks of the metallogenic belt. These structures and intrusions are interpected as forming during collision of continental blocks in the Late Jurassic to Early Cretaceous. The collisional zone contains a major belt of Early Cretaceous granitoid plutons which are mainly high alumina and S-type with lesser I-type plutons (Shkodzinsky and others, 1992). The latter are associated with numerous andesite and granitic porphyry dike suites.

The numerous Au quartz vein lode and related placer Au deposits in the Yana-Kolyma metallogenic belt are sites of extensive Russian Northeast Au production (Shilo, 1960; Firsov, 1957, 1985; Goryachev, 1998, 2003), The total production has been more than 2,570 tonnes of placer Aus, and about 100 tonnes of lode Au. The most important lode Au deposits in the 
metallogenic belt are: (1) the Natalka deposit, in production since 1945, which has produced about 75 tonnes of Au; (2) the Igumen deposit, with a production of 11 tonnes $\mathrm{Au}_{4}$ (3) the Redionov, Vetrenskoye, and Utin deposits with combined production about 8 tonnes Au; and (4) other deposits at Srednikan, and Shturm. Mining has ceased at all lode deposits except at Natalka and Svetloye. However, the majority of the deposits are not thoroughly prospected. The significant deposits in the belt are (tables 3,4$)$ : (I) Au quartz vein deposits at Aleshkino, Buzovskoe, Badran, Burkhala, Chai-Yurya. Chelbanya, Daika Novaya, Darpir, Degdekan, Dirin-Yuryak, Djelgala-Tyellakh, Dorozhnoe, Ekspeditsionnoe, Goletsov (Golets), Igumen, Imtachan, Kamenistoe, Khangalass, Khaptagai-Khaya, Kholodnoe, Kontrandya, Laryukcov, Lazzo, Maldyak, Mitrei. Natalka, Nadezhda, Pavlik, Pil, Rodionov, Sana, Srednekan, Stakhanov, Shturm, Sokh, Svetloe, Tabogu, Talalak. Tokichan, Tumannoe, Tunguss, Tuora-Tas, Uchui, Utinka (fig. 68), Verkhne-Khakchan, Vetrenskoe, Yugler, Yukhondja, Zatessnoe, and Zhdannoe; (2) granitoid-related Au deposits at Delyuvialnoe and Ergelyakh; (3) Sn and Sn-W greisen deposits at Alyaskitovoe, Baryllyelakh, Bekkem, and KereYuryak; (4) Sn quartz vein deposits at Butugychag, Burgavli, Burkat, Medvezhje, and Svetloc, (5) a Sb-Au vein deposit at Krokhalin; (6) a W vein and greisen deposit at Bokhapcha; and (7) a clastic sediment-hosted $\mathrm{Hg}$ or hot-spring $\mathrm{Hg}$ deposit at Kuzmichan (Nokleberg and others 1997a, b, 1998).

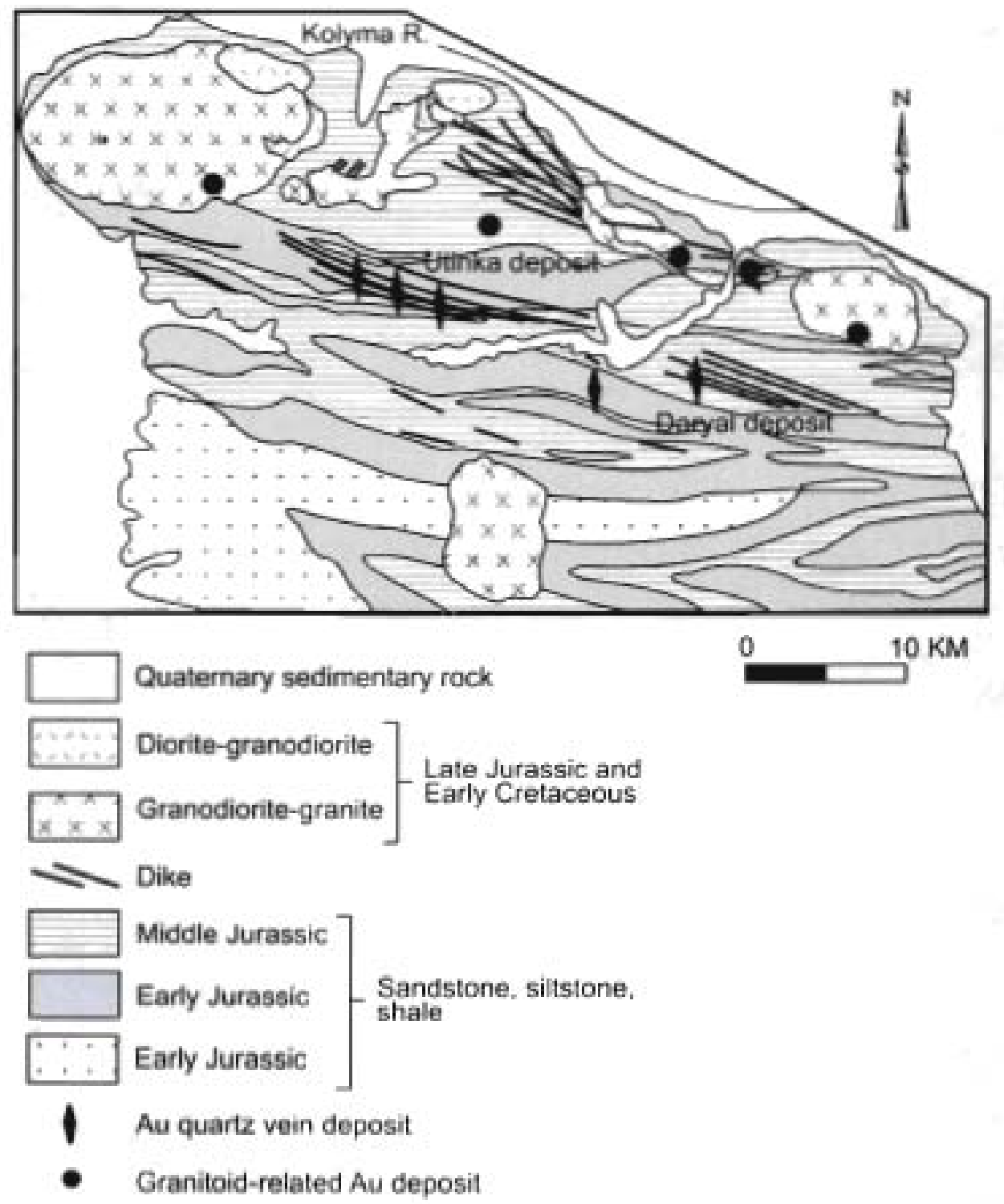

Figure 68. Utinka Au-quartz vein deposit, Yana-Kolyma metallogenic belt, Russian Northeast. Schematic geologic map showing geologic setting of the Utinka lode deposih. Adapted from Goryachev (1998).

\section{Host Granitoid rocks and Associated Lode Deposits}

Hosting and associated with the lode deposits of the Yana-Kolyma metallogenic belt are various collisional plutons composed of diorite-granodiorite, granodiorite-granite, and granite-leucogranite (Goryachev, Goncharov, 1995, Goryachev, 1998 , 2003). The granitoid plutons are interpreted as forming at various depths. The Late Jurassic and Early Cretaceous granite- 
leucogranite plutons form large, homogeneous, batholith-like intrusions with surface areas as large as $7,000 \mathrm{~km}^{2}$. The granitoid rocks occur in an axial portion of the Yana-Kolyma collision zone and consist of biotite and two-mica granites with accessory sillimanite, andalusite, cordierite and garnet. Higb Rb contents are characteristic, the granites are typical S-type collisional granites which have initial Sr ratios ranging up 0.7045 to 0.7111 (Goryachev and Goncharov, 1995; Goryachev, 1998, 2003). Small Sn occurrences are associaled with these graniles.

The Late Jurassic and Early Cretaceous diorite-granodiorite intrusions form numerous dikes and small stocks which are oceur as separate suites in central portions of these zones. Diorite-porphyries, granodiorite-porphyries, and granite-porphyries are most prevalent as dikes; stocks are composed of two and three rock types, from diorite to biotite-amphibole granodiorite or granite. These igneous rocks are cale-alkaline, with some predominance of $\mathrm{Na}$ over $\mathrm{K}$, and locally contain accessory garnet (up to $20.5 \%$ pyrope), and initial Sr ratios of 0.7045 to 0.7087 (Goryachev and Goncharov, 1995; Goryachev, 1988, 2003). These granites are typical 1-type granites of the ilmenite-series, Au-quartz vein deposits are usually associated with these intrusions.

The Early Cretaceous granodiorite-granite intrusions occur in small plutons (with surface areas of up to $300 \mathrm{~km}^{2}$ ) in the same area occupied by the diorite-granodiorite intrusions. The granodiorite-granite plutons are composed of granodiorite and mostly bootite granite rocks, are characterized by relatively high $\mathrm{CaO}$, low alkali content, with some predominance of $\mathrm{K}$ over $\mathrm{Na}$, and with initial $\mathrm{Sr}$ rations of 0.7057 to 0.7087 . Accessory minerals are ilmenite, gamet, zircon and sulfide minerals (Gamyanin and others, 1991). Associated with these plutons are Au lode and W vein deposits.

Also part of the Yana-Kolyma metallogenic belt are suite of Sn quartz vein and greisen, W vein, Sb-Au and clasticsediment-hosted $\mathrm{Hg}$ occurrences (fig. 61). Notable examples are Sn quartz vein and greisen deposits at Alaskitovoye and Burgavli, the Krokhalin Sb-Au vein occurrence, and the clastic-sediment-hosted $\mathrm{Hg}$ at Kuzmichan. Most of the Sn deposits are small, except for Alaskitovoye.
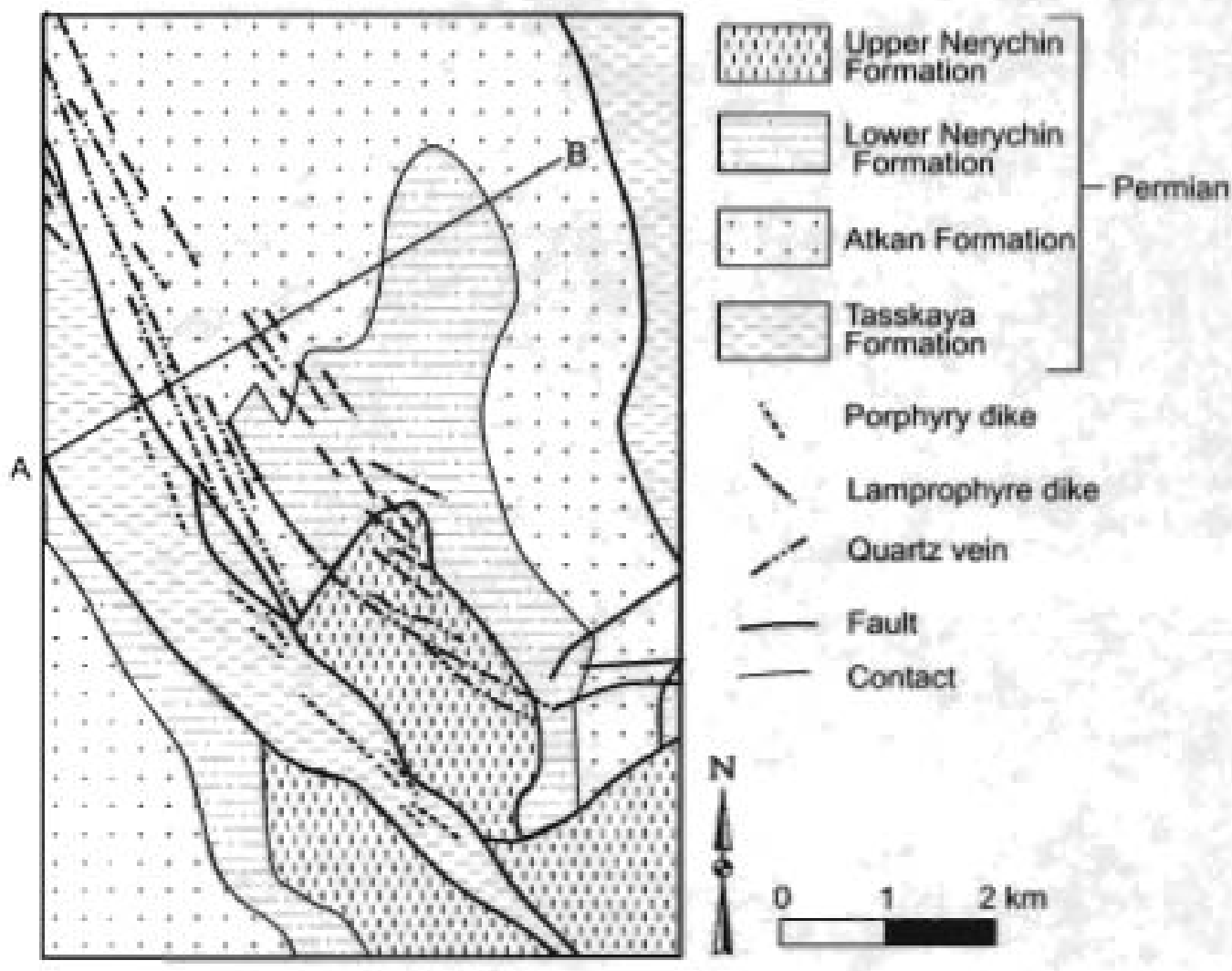

Porphyry dike

- Lamprophyre dike

Quartz vein
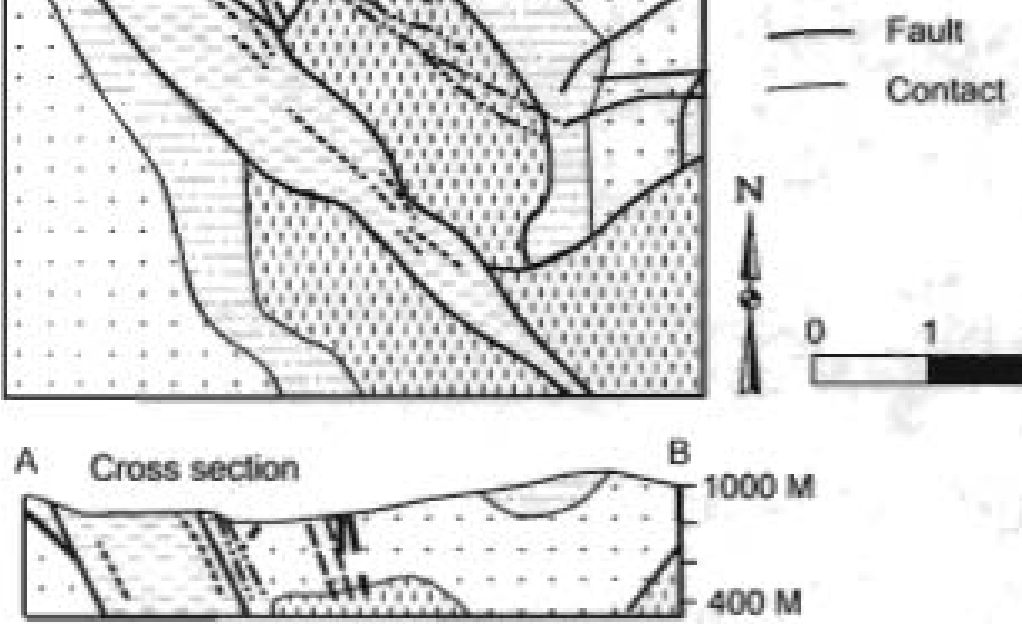

Figure 69 Natalka Au quartz vein deposit, Yana-Kolyma metallogenic belt, Russian Northeast. Schemafic geologic map and cross section. Adapted from Eremin (1995).

\section{Natalka Au Quartz Vein Deposit}

The Natalka Au quartz vein deposit (fig. 68) (Firsov, 1957a; Shilo, 1960; Voroshin and others, 1989; Goncharov, 1995; Eremis and others, 1994) consists of zones of subparallel and reticulate quarz veinlets which can be grouped into two or three 
systems which converge locally along strike into podiform and platy veins. The ore minerals cement schistose, brecciated, cataclastic, and graphite-altered Late Permian tuffaceous sedimentary rocks. The deposit occurs along the Tenka strike-slip fault. The ore deposit is deformed with synclines and anticlines which occur near the fault zone. The deposit is intruded locally by abundant pre-ore and post-ore dikes of felsic to intermediate composition. The zone of mineralized veinlets is approximately 300 $\mathrm{m}$ wide; individual ore bodies occur in zones ranging from 50 to $300 \mathrm{~m}$ long and from 1 to $15 \mathrm{~m}$ thick. The gangue in the veinlets are composed mainly of quartz (90-95\%), albite, anorthoclase, carbonate, chlorite, and sericite; with lesser kaolinite, barite, apatite, and graphite. The ore minerals are dominated by fine-grained disseminated arsenopyrite intergrown with pyrite in wall rocks. Subordinate and rare minerals include galena, sphalerite, chalcopyrite, pyrrhotite, bournonite, boulangerite, tetrahedritetennantite, scheelite, rutile, ilmenite, and stibnite. Fine-grained and microscopic, low-grade Au is commonly associated with arsenopyrite and galena in the veins and veinlets. A considerable proportion of the gold is intergrown in arsenopyrite in the wall rock adjacent to the veins. The Natalka deposit is large with total reserves of $450 \mathrm{t}$ Au. From 1945 to 1994, the Natalka mine has produced 75 tonnes $\mathrm{Au}$ and 22 tonnes $\mathrm{Ag}$. The annual production is $8 \mathrm{t} \mathrm{Au}$ and $4 \mathrm{t} \mathrm{Ag}$. The lower grade ores average $4 \mathrm{~g} t$. More recent production data are not available.

\section{Svetloe and Kholodnoe Au Quartz Vein Deposits}

The Svetloe Au quartz vein deposit (fig. 70) (P.I. Skornyakov, written commun., 1953; Fedotov, 1960b, 1967, Goryachev, 1998, 2003) consists of subparallel quartz veins $600-1500 \mathrm{~m}$ long average $0.2-0.5 \mathrm{~m}$ thick, and 20-80 m apart. The veins occur as conformable bodies or in acute fractures in the limbs of an asymmetric anticline and dip $70^{\circ}$ to $85^{\circ}$. The ore bodies trend mainly northwest, but range from east-west to north-south. Hosting the Au quartz veins is Late Triassic and Early Jurassic sandstone and shale which are intruded by a transverse set of dikes of felsic and intermediate composition. The ore minerals are mainly arsenopyrite, pyrite, and galena containing gold ( 858 fine). Subordinate ore minerals are sphalerite, chalcopyrite, scheelite, pyrnotite, and native gold. The deposit is small and has proven feserves 3.61 Au with grade ranging from 1.0 to $100 \mathrm{~g} / \mathrm{Au}$. The nearby Kholodnoe deposit, which occurs to the south, is made up of three sets of quartz veins and mineralized fracture zones which trend northwest. Some veins occur within the dikes. Gold occurs as very small inclusions or irregular masses.

\section{Zhdannoe Au Quartz Vein Deposit}

The Zhdannoe Au quartz vein deposil (Gavrikov and Zharova, 1963; Rezhkov and others, 1971; Yu. A. Vladimirtseva, written commun., 1987; V.A. Amuzinskyi, G.S. Anisimova, and $Y_{a}$. Yu. Zhdanov, written commun., 1992) consists of a set of 13 interbedded veins which range from 0.1 io $3 \mathrm{~m}$ thick and to $500 \mathrm{~m}$ long. Some ore bodies occur in cross-cutting fissures. Ore minerals are arsenopyrite, pyrite, galena, sphalerite, native gold (fineness 848 ), and very scarce boulangerite and chalcopyrite. Premineral content of quartz veins is 1 to $3 \%$. Veins accompanied by minor walltock alieration to bersite. The deposit is judged to be exhausted and was small with an average grade of $221095 \mathrm{~g} / \mathrm{Au}$. The deposit occurs in the hinge of a brachyanticline at its periclinal closure and is hosted Late Triassic (Carnian) silty shale and sandstone.

\section{Utin Au Quartz Vein Deposit}

The Utin Au quartz vein deposit (I.R. Yakushev, written commun., 1950; P.I. Skomyakov, written commun., 1953; Goryacbev, 1995, 1998, 2003) occun in a Late Jurassic suite of ore-bearing dikes which extend for about $35 \mathrm{~km}$. The dikes cuts a Middle Jurassic sedimentary sequence at an acute angle to bedding. The host sedimentary rocks are isoclinally folded into westnorthwest trending structures. The main ore body extends $12 \mathrm{~km}$ and occurs in a steeply dipping dike, 0.4 to $1.3 \mathrm{~m}$ thick, which consists of hydrothermally altered andesite porphyry. The dike is intensely crushed and deformed. The Au quartz veins form complicated, often diagonally cross-cutting systems within the dike. Some quartz veins also cut the dikes obliquely, and extend into the surrounding sedimentary rocks. Arsenopyrite, pyrite, and pyrthotile comprise up to several per cent of the veins. Also occurring are gold, galena, sphalerite, chalcopyrite, jamesonite, Bi-boulangerite, tetrahedrite, scheelite, marcasite, and stibnite. The gold distribution is quite irregular; individual ore shoots extend from 5 to $30 \mathrm{~m}$ in strike and are up to several hundreds of meters in width. The small deposit was discovered in 1929 and produced 12 tonnes Au with grade ranging from 0.1 to 3,923 glt Au. The grade of ore shoots ranges from 5 to $3.923 \mathrm{~g} / \mathrm{Au}$.

\section{Alyaskitovoe Sn-W Greisen Deposit}

The Alyaskitovoe Sn-W greisen deposit Shur, 1985; Yu. A. Vladimirtseva and V.M. Vladimirtsev, written commun. 1987 ) consists of veins and greisen which occur inside and adjacent to a stock of two-mica granite which intrudes Late Triassic sandstone and shale. The veins are gressen are variable in thickness and length and occur in fissures which strike nonth-northeast and dip northwest at 75-85. The veins have complex morphology with en-echelon lenses which altemate with thin stringers. The Main ore minerals are wolframite, cassiterite, and arsenopyrite. The gangue minerals are mainly quartz, muscovite, tourmaline, and apatite. A complex combination of sulfosalts of lead, silver, and bismuth occur in the veins. The wallrocks exhibit quartzmuscovite, muscovite-apatite, and tourmaline greisen alteration. The deposit is small and has average grades of 0.45 to $1.33 \%$ $\mathrm{WO}_{3}$ and up to $0.38 \% \mathrm{Sn}$. 

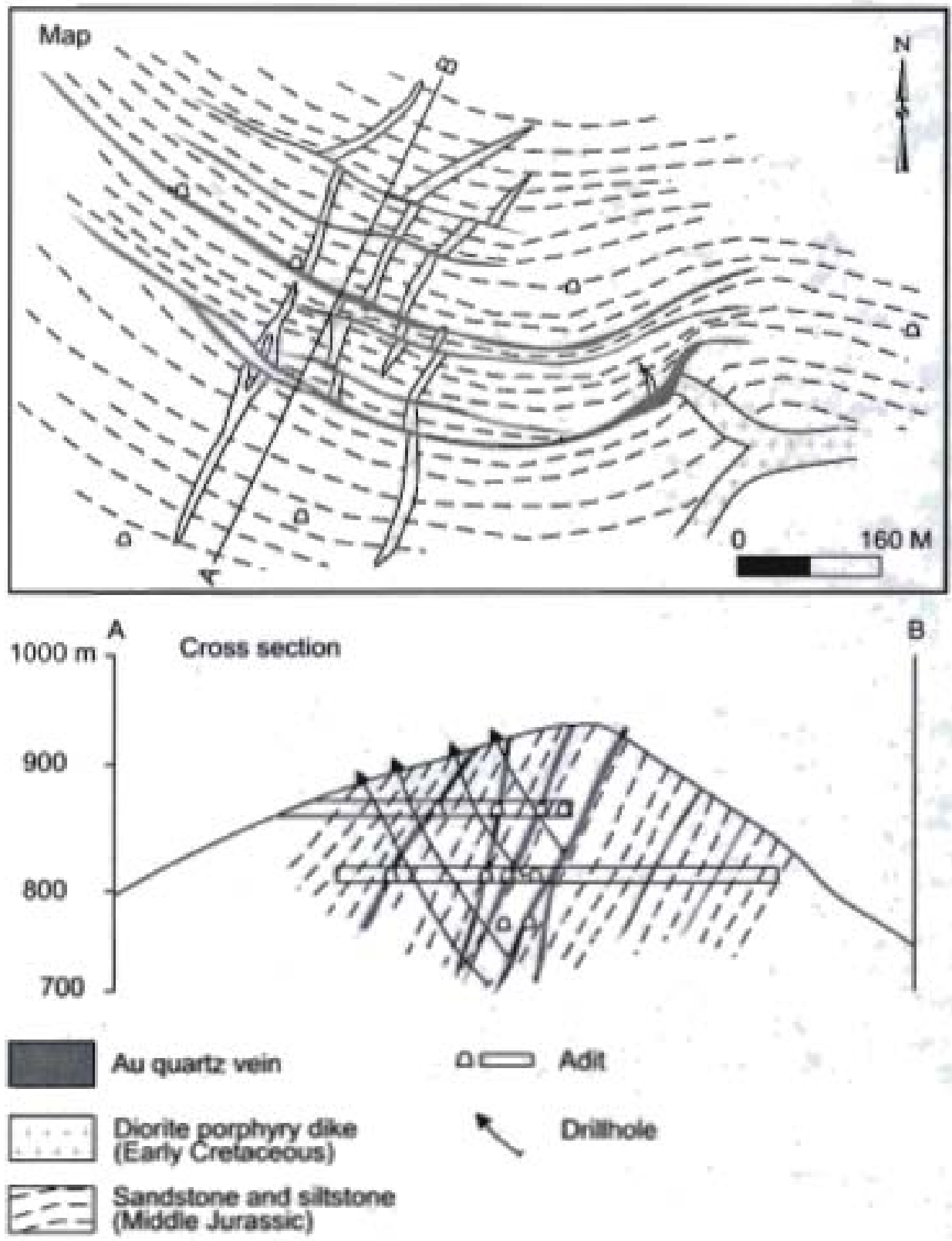

B

Figure 70. Svetioe Au quartz vein deposit, Yana-Kolyma metallogenic belt, Russian Northeast. Schematic geologic map and cross section. Adapled from Goryachev (1998).

\section{Origin and Tectonic Controls for Yana-Kolyma Metallogenic belt}

The Au quartz vein and associated deposits of the Yana-Kolyma metallogenic belt oceur as linear bands and clusters which are controlled by two major sets of strike-slip fault tones which trend northwest for over $500-600 \mathrm{~km}$ (Goryachev, 1995 . 1998, 2003). Secondary controlling structures are less extensive, diagonal and transverse fault zones which are bounded by northwest-trending strike-slip fault. The larger Au quartz vein deposits generally oceur in the northwest-trending zones. The main types of the Au deposits occur in: (1) mineralized shear zones (linear stockworks) with low-gnde ores which are not as widespread as the other types of ore, but contain approximately half of the Au reserves in the region; (2) quartz veins which commonly contain bigh-grade ores and coarse gold which are most favorable for milling, but contain smaller reserves; (3) Awbearing, quartz stockworks in altered dikes, with low-grade ores, but they contain high-grade ore shoots, and medium reserves; and (4) granitoid-related Au quartz veins and greisens with low-grade $A$ u and arsenic enriched ores

The bost rocks for the Au quartz vein deposits of the Yana-Kolyma metallogenic belt are Permian to Jurassic black shale and tuffaceous sedimentary rocks which form part of the Kular-Nera accretionary-wedge terrane. The shales locally contain anomalous syngenetic carbonaceous matter. Au mineralization is associated with burial and low-grade greenschist facies metamorphism which consists of both contact and regional, penetrative metamorphism, and hydrothermal activity (Geiman, 1976). The Au quartz vein deposits of the Yana-Kolyma metallogenic belt are similar to other deposits of this type throughout the world. 
The main features of this deposit type are: (1) predominance of quartz; (2) minot amounts of subordinate sulfide minerals, mainly arsenopyrite and pyrite, but a telluride minerals are absent; (3) less than $3-5 \%$ sericite, albite, carbonate minerals, and chlorite; and (4) in many places, a considerable down-dip extension of ore with little or no vertical zonation.

Most of the Au quartz vein deposits ure associated with the low-grade greenschist facies regional metamorphism. They formed during collision event after small dikes and stocks diorite-granodiorite intrusive suites, and before intrusion of the granitoid plutons granodiorite-granite suites, and were subsequently thermally metamorphosed. Consequently, the Yana-Kolyma Au quartz vein deposits are interpreted as being genetically or paragenetically related to the coeval, 1-type, diorite dikes and small granitoid plutons. The Au is interpreted as forming of two stage: (1) from the hydrothermal fluid generated during metamorphism of sediment-hosted Au which in turn was derived from an older period of multi-stage redeposition of Au from auriferous zones of pyrnhotite and pyrite in SEDEX deposits; and (2) from hydrothermal fluid generated during intrusion of the I-type granitoids. The granitoid-related Au quartz vein deposits ure strongly genetically connected to the Late Jurassic and Early Cretaceous granodiorite-granite and granite-leucogranite plutons (Goryachev, 1998, 2003).

The Yana-Kolyma metallogenic belt is hosted in rocks upper Paleozoic through middle Mesozoic age of the YanaKolyma fold belt in the Kular-Nera aceretionary wedge terrane of the Kolyma-Omolon superterrane (Nokleberg and others, $1994 \mathrm{c}, 1997 \mathrm{e}$; Goryachev, 1998, 2003). These units are weakly metamorphosed to lower greenschist facies with development of metamorphic chlorite and biotite. The Au quartz vein, granitoid-related Au, and associated deposits of the Yana-Kolyma are interpreted as forming during syn-collisional regional deformation, metamorphism, and granitoid magmatism related with accretion of the Kolyma-Omolon superterrane to the North Asian Craton Margin (unit NSV, Verkboyansk fold belt; Nokleberg and others, 2000). The Sn vein, Sn greisen, W vein deposits, and clastic-sediment-hosted Hg deposits of the Yana-Kolyma metallogenic belt are interpreted as forming during intrusion of the Early Cretaceous late-collisional (anatectic) granitoid rocks (granodiorite-granite and granite-leucogranite associations) of the Main part of the Verkhoyansk collisional granite belt (unit vk; Nokleberg and others, 1994c, 1997e). Alternatively, Babkin (1975) and Berger (1993) interpret that the clastic-sediment-hosted $\mathrm{Hg}$ deposits of the Yana-Kolyma metallogenic belt formed during a younger event in the Paleocene.

\section{Metallogenic Belts Formed During Late Mesozoic Island Arcs in Russian Northeast and Southeastern Alaska, and Southern Canadian Cordillera}

\section{Left Omolon Belt of Porphyry Mo-Cu and Mo-Cu Skarn Deposits (Beit LO) East-Central Part of Russian Northeast}

The Left Omolon metallogenic belt of igneous-are-related deposits is associated with a chain of Early Cretaceous granodiorite stocks and small bodies which trend northwest for nearly $300 \mathrm{~km}$ along the left side of the Omolon River Basin (fig. 61; tables 3,4) (Nokleberg and others, 1997b, 1998). The major deposit types in the belt are porphyry Mo-Cu and related Mo-Cu skarn deposits. The significant deposits are at Bebekan and Medgora. The porphyry Mo-Cu deposits are associated with $\mathrm{Au}-\mathrm{Ag}$ and $\mathrm{Pb}-\mathrm{Zn}$ vein deposits.

\section{Bebekan Porphyry Mo-Cu Deposit}

The Bebekan porphyry Mo-Cu deposit (Alekseenko, Korobeinikov, and Sidorov, 1990) consists of a stockwork of sulfide-quartz veinlets with disseminated molybdenite, chaleopyrite, pyrite, sphalerite, pyrrhotite, arsenopyrite, bornite, and covellite. The deposit oceurs in an Early Cretaceous stock of porphyritic granodiorite. The ore body is confined to silicified and sericitized rocks marked by biotite, quartz, and orthoclase. The ore body is about $1.5 \mathrm{~km}$ by $400-500 \mathrm{~m}$ in size and coincides with the intrusion. A pyrite aureole extends about $1 \mathrm{~km}$ from the intrusioe and coincides with a zone of propylitic alteration of the host Late Jurassic volcanic-sedimentary sequence. The deposit is of small to medium size and on the average contains about $0.5 \%$ Mo and $0.7 \% \mathrm{Cu}$ with minor $\mathrm{Pb}, \mathrm{Zn}$, W, Au, and $\mathrm{Ag}$.

\section{Medgora Mo-Cu skarn Deposit}

The Medgora Mo-Cu skam deposit (Gorodinsky, Gulevich, and Titov, 1978) consists of disseminated veinlets in skam which is associated with the Early Cretaceous Medgora granite and granodiorite pluton. The metallic minerals are pyrite. chalcopyrite, molybdenite, pyrthotite, magnetite, bematite, and sphalerite. The skarns are composed of gamet, pyroxene. actinolite, scapolite, calcite, quartz, chlorite, epidote, and green mica. Individual ore zones extend from 30 to $160 \mathrm{~m}$. The deposit is of medium size with grades of 0.1 to $0.64 \% \mathrm{Mo}, 0.94$ to $2.94 \% \mathrm{Cu}$, and $0.4 \mathrm{~g} / \mathrm{Au}$. The Cu conient of the ore varies from hundredths of a percent to over $2 \%$. 
The Left Omolon metallogenic belt occurs along the northeast marginal of the Omolon cratonal terrane. Two possible tectonic settings are interpreted for the Early Cretaceous granitic intrusions bosting this metallogenic belt: (1) The Early Cretaceous granitic intrusions may be a transverse, nearly orthogonal brasch of the Cretaceous Okbotsk-Chukotka volcanicplutonic belt; or (2) the Early Cretaceous granitic intrusives, as interpreted berein, are part of the Oloy-Svyatoy Nos volcanic belt that constitute part of the Early Cretaceous Oloy continental-margin magmatic arc which occurs to the northeast of the Omolon cratonal terrane (fig, 61) (Nokleberg and others, 1994c, 1997b, c, 1998; 2000).

\section{Western-Southeastern Alaska Metallogenic Beit of Granitic-Magmatism-Related Deposits (Belt WSE) Southeastern Alaska}

The Western-Southeastem Alaska metallogenic belt of granitic-magmatism-related deposits (fig. 62; tables 3,4) occurs in Southeastern Alaska, and is hosted in Early to mid-Cretaceous granitoid plutons of the Muir-Chichagof plutonic belt which intrude the Wrangellia superterrane (Nokleberg and others, 1995a). The significant deposits are in the Jumbo $\mathrm{Cu}$-Au skam district, and the Bokan Mountain felsic plutonic U-RFE deposit (table 4) (Nokleberg and others 1997a, b, 1998).

\section{Jumbo Cu-Au Skarn Deposit}

The Jumbo Cu-Au skarn distriet includes significant deposit at Jumbo, several small deposits at Magnetite Cliff, Copper Mountain, and Corbin, and lesser deposits at Late Magnetite, Gonnason, Houghton, Green Monster, and Hetta. All of the deposits occur within a few kilometers of the Jumbo deposit. The Jumbo district contains an estimated 280,000 tonnes of ore grading $45 \%$ $\mathrm{Fe}$ and $0.73 \% \mathrm{Cu}$, and has produced 4.6 million $\mathrm{kg} \mathrm{Cu}, 220,000 \mathrm{~g} \mathrm{Aus}$, and 2.73 million $\mathrm{g} \mathrm{Ag}$ from 111,503 tonnes of ore (Kennedy, 1953; Herreid and others, 1978; Newberry and others, 1997). The deposits are hosted in, or lie adjacent to eurly Paleozoic marble and pelitic metasedimentary rocks of the Wales Group of the Alexander sequence where intruded by midCretaceous hornblende-biotite granodionite which exhibit concondant homblende and biotite K-Ar isotopic ages of $103 \mathrm{Ma}$. The Jumbo deposit consists of chalcopyrite, magnetite, sphalerite, and molybdenite in skarn which occurs at the contact between marble and a granodiorite stock. Gangue is mainly diopside and garnet. The deposit has been explored by more than $3.2 \mathrm{~km}$ of underground workings and is the largest in the district. The Magnetite Cliff deposit consists of a 25-m-thick shell of magnetite which mantles granodiorite in contact with garnet-diopside skarn. The skarn contains $2 \%$ to $3 \%$ chalcopyrite, estimated resources of 335,600 tonnes grading $46 \% \mathrm{Fe}$ and $0.77 \% \mathrm{Cu}$. The Copper Mountain deposit consists of scattered chalcopyrite and copper carbonate in diopside endoskarn which contains veins and masses of epidote, garnet, magnetite, and scapolite near granodiorite. This deposit has produced $101,800 \mathrm{~kg} \mathrm{Cu}, 321,300 \mathrm{~g} \mathrm{Ag}$, and $4,510 \mathrm{~g} \mathrm{Au}$, and has about $410 \mathrm{~m}$ of tunnels and shafts.

\section{Bokan Mountain Fetsic plutonic U-REE deposit}

The Bokan Mountain felsic plutonic U-REE deposit (fig. 7I) consists of disseminated U. Th, REE, and niobate minerals, including uranothorite, uranoan thorianite, uraninite, xenotime, allanite, monazite, pyrite, galena, zircon, and fluorite which occur in an irregular, steeply-dipping pipe of Jurassic peralkaline granite (Warner and Barker, 1989; Brew and others, 1991; Berg, 1984; Foley and others, 1997; Thompson, 1997). The deposit produced about 109,000 tonnes grading about $1 \% \mathrm{U}_{3} \mathrm{O}_{4}$; Th was not recovered. Most of ore was produced from a crudely cigar-shaped upper part of the pluton. The central zone which contains the deposit grades outward into normal granite. Associated pegmatite and vein REE, Nb, Th, and U deposits occur in the outer parts of granite or adjacent country rock, which consists of metamorphosed early Paleozoic granitic and sedimentary rocks of Alexander sequence.

\section{Orlgin of and Tectonic Controls for Western-Southeastern Alaska Metallogenic Beit}

The Western-Southeastem Alaska metallogenic belt is hosted in the Jurassic(?) and Farly to mid-Cretaceous granitoid plutons of the Muir-Chichagof plutonic belt which are interpreted by Plafker and others (1989b) as part of the granitoid roots of the Late Jurassic to Early and mid-Cretaceous Gravina arc. The U-REE deposits in the belt, as at Bokan Mountain, may have formed in extensional senting (Goldfarb, 1997), possibly in a back-arc environment. The Western-Southeastem Alaska metallogenic belt is interpreted as a northern extension of the Island metallogenic belt to the south, and as the southeastern extension of the Eastern-Southern Alaska metallogenic belt. All three metallogenic belts are bosted in the Late Jurassic through mid-Cretaceous Grivina island are which was built on the Wrangellia superterrane. The Gravina island are is interpreted as forming on the northern, or leading edge of the Wrangellia island-are terrane during migration towards North America (Nokleberg and others, 1984, 1985, 2000; Nokleberg and Lange, 1985a; Plafker and others, 1989; Plafker and Berg. 1994). The Gravina are and associated granitic magmatism deposits are tectonically linked to the younger part of the MeHugh Complex which forms the northem part of the Chugach subduction zone and accretionary wedge complex (Nokleberg and others, 2000). 


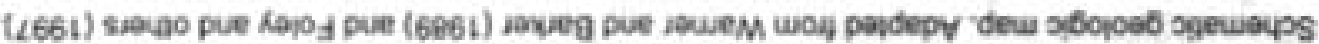

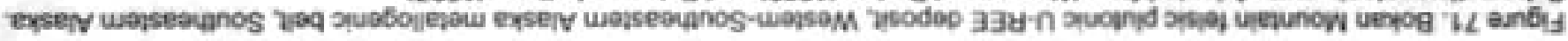
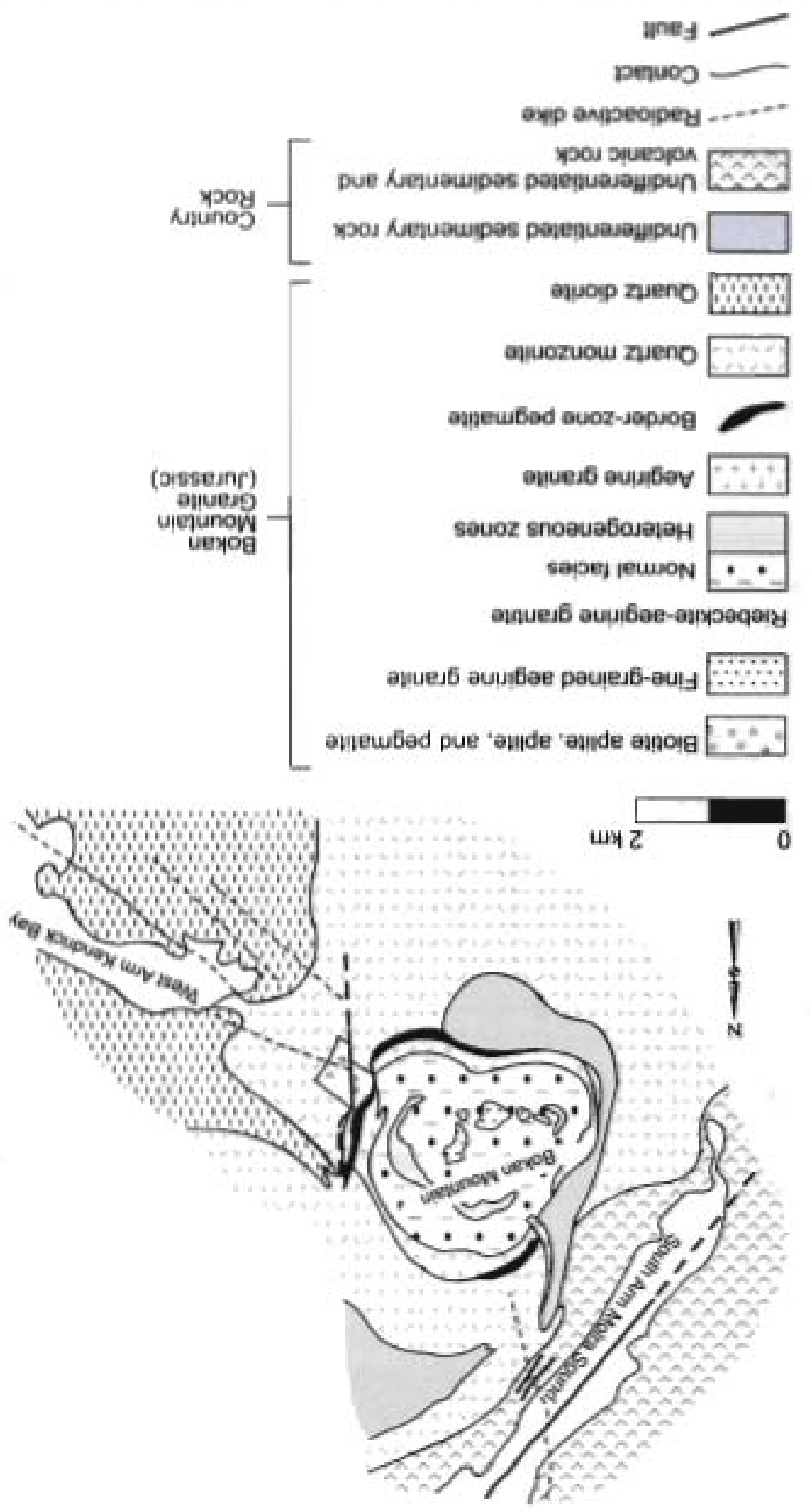
The Britannia metallogenic belt of kuroko $\mathrm{Cu}-\mathrm{Zn}$ massive sulfide deposits is hosted in the Late Jurassic to Early Cretaceous Gravina-Nutzotin-Gambier voleanic-plutonic-sedimentary belt which forms an overlap assemblage on the inward margin of Wrangellia superterane (fig, 63; tables 3, 4) (Nokleberg and others, 1997b, 1998, 2000). The significant deposit is at Britanna. The metallogenic belt also includes the Maggie, Northair, and Niffy deposits.

\section{Britannia Kuroko Volcanogenic Cu-Zn Massive Sulfide Deposit}

The Britannia deposit consists of a series of kuroko $\mathrm{Cu}-\mathrm{Zn}(\mathrm{Ag}-\mathrm{Au})$ ore bodies hosted a roof pendant of dacite tuff and breccia. The massive sulfide bodies consists of massive pyrite, chalcopyrite, sphalerite with minor galena, tennantite, tetrahedrite. barite and fluorite which occur in numerous discrete, concentrically zoned siliceous ore bodies (EMR Canada, 1989; Dawson and others, 1991: MINFILE, 2002). A U-Pb zircon age for a feldspar porphyry dike which cuts the deposit indicates a Middle Jurassic or older age for the deposit (Ray and Webster, 1994). The host rocks are metamorphosed dacite to andesite pyroclastic rocks. The massive sulfides consist mainly of stringers which oceur in the upper of two major mafic to felsic metavolcanic layers which are separated by, and overlain by metasedimentary rock. From 1905 to 1974 , the mine at the deposit produced $47,884,558$ tonnes of ore from which 15.3 tonnes $\mathrm{Au}, 180.8$ tonnes $\mathrm{Ag} .517$ tonnes $\mathrm{Cu}, 15.6$ tonnes $\mathrm{Pb}$ and 125.3 tonnes $\mathrm{Zn}$ were recovered. The nearby Northair deposits near Whistler are interpreted as volcanogenic massive sulfide deposits remobilized during emplacement of adjacent plutons (Miller and Sinclair, 1985). The Early Cretaceous metavolcanic host rocks form pendants and screens within granodiorite of the Coast Plutonic Complex. The deposit and host rocks are thinned and partially remobilized by the northwest. trending Britannia shear zone (Payne and others, 1980).

\section{Origin of and Tectonic Controls for Britannia Metallogenic Beft.}

The Britannia metallogenic belt is hosted in the Middle and Late Jurassic and Early Cretaceous sedimentary and calcalkaline volcanic rock of the Gambier Group which is intruded by partly coeval plutons which range in age from 130 to $94 \mathrm{Ma}$ (Nokleberg and others, 1994c, $1997 \mathrm{c}$; Monger and Nokleberg, 1966). The aro-related cale-allkaline volcanic and sedimentary rocks of the Gambier Group overlie Jurassic and older plutonic, volcanic and sedimentary rocks of the Const Plutonic Complex and Harrison terrane on the east, and Middle to Late Jurassic plutons of Wrangellia Superternane on the west. The Gambier Group and coeval plutonic rocks are part of the extensive Gravina-Nutzotin-Gambier volcanic-plutonic-sedimentary belt which forms a major middle Mesozoic sequence of voleanic, sedimentary, and plutonic rocks deposited on and intruded into the Wrangellia superterrane. The belt is interpreted as an elongate island are which extended for several thousand $\mathrm{km}$ along the inner margin of the Wrangellia supertemne (sheet 3; Nokleberg and others, 1994c, $1997 \mathrm{c}$ ). This Middle Jurassic to Early Cretaceous island arc, which was built ce the Wrangellia superterrane, is interpreted as forming immediately before accretion of a of the supenterrane to the accretionary margin of the North American Cordallera in the mid-Cretaceous (Monger and others, 1994; Monger and Nokleberg. 1996; Nokleberg and others, 2000). The volcanic exhalative activity deposited Kuroko-type massive sulfides in several centers in the Gambier Group. Mineral deposits and their host rocks were sheared and attenuated along faults active during and after the accretion of the Wrangellia superterrane.

\section{Late Early Cretaceous Metallogenic Belts (120 to $100 \mathrm{Ma}$; Figures 61, 62)}

\section{Overview}

The major Lale Early Cretaceous metallogenic belts in the Russian Far East, Alaska, and the Canadian Cordillera are summarized in table 3 and portrayed on figures 61 and 62 . Six major belts are identified. (1) In the Russian Southeast, the Badzhal-Ezop-Khingan (BZ-KH) bell of granitic-magmatism-related deposits, which is hosted in the Khingan-Okbotsk voleanicplutonic belt, is interpreted as forming in the Khingan continental-margin arc. (2) In the Russian Southeast, continuing on fim the Early Creteacoues was the Samarka (SA) belt of granitic-magmatism-related deposits. (3) In the Russian Northeast, continuing on from the Early Cretaceous, was the Kular (KU) metallogenic belt which contains Au quartz vein, and granitic-magmatism-related deposits. (4) Also in the Russian Northeast, was the Anadyr River (AD) metallogenic belt of Au quartz vein deposits, which is hosted in the Mainitskiy, West Pekulney, and (or) Penzhina-Anadyr terranes. The belt is interpreted as forming during regional metamorphism and generation of hydrothermal fluids associated with aceretion and collision of Mainitskiy island are onto North Asian Craton margin. (5) In Northern Alaska, the Nome (NO) and Southern Brooks Range (SBR) belis, which contain Au quartz vern deposits, are hosted in metamorphosed continental-margin ternanes and are interpreted as forming during regional 
metamorphism associated with extension which oecurred afler overthrusting of Angayucham subduction zone terrane. (6) In the northem Canadian Cordillera, the Fisb River (FR) metallogenic belt, which cootains stratabound sedimentary P and Fe deposits and is hosted in the North American Craton Margin, is interpreted as forming during Late Mesozoic, dextral movement along the Kaltag-Porcupine fault system. (7) In the Canadian Cordillera, continuing on from the Early Cretaceous was the Western-

Southeastern Alaska (WSE) belt, which contains granitic-magmatism-related deposits which are hosted in the Gravina-NutzotinGambier belt which overlies the Wrangellia superterrane. And (8) also in the Canadian Cordillera, the Bayonne (BA), Cassiar (CA), Selwyn (SW), Tombstone (TS), and Whitehorse (WH) belts, which contain granitic-magmatism-related deposits, are also hosted in or near anatectic granitic plutons of the Omineca-Selwyn plutonic belt which is interpreted as forming during final accretion of Wrangellia superterrane to North American continental margin. In the below descriptions of metallogenic belis, a few of the noteable or signficant lode deposits (table 4) are described for each belt.

\section{Metallogenic-Tectonic Model for Late Early Cretaceous (120 to $100 \mathrm{Ma}$; Figure 72)}

During the late Early Cretaceous (Aptian through Albian - 120 to $100 \mathrm{Ma}$ ), the majof metallogenic-tectonic events were (table 3): (1) inception of the short-lived Khinghan continental margin arc, and formation of associated metallogenic belts and companion subduction zone in the Russian Southeast; (2) accretion of the Mainitskiy island arc and associated Alkatvaam (AV) accretionary-wedge terranes to the active continental margin; (3) completion of accretion of the major Kolyma-Omolon superterrane in the Russian Northeast and formation of associated metallogenic belts; (4) obduction of Angayucham subductionzone terrane onto the Arctic Alaska terrane and formation of metallogenic belts during extension which succeded obduction; (5) continued opening of the Amerasia, Canada, and Eurasia Basins; and (6) continuation of the Gravina are and formation of associated metallogenic belts during continuing accetion of the Wrangellia superterrane, and inception of collision-related metallogenic belts.

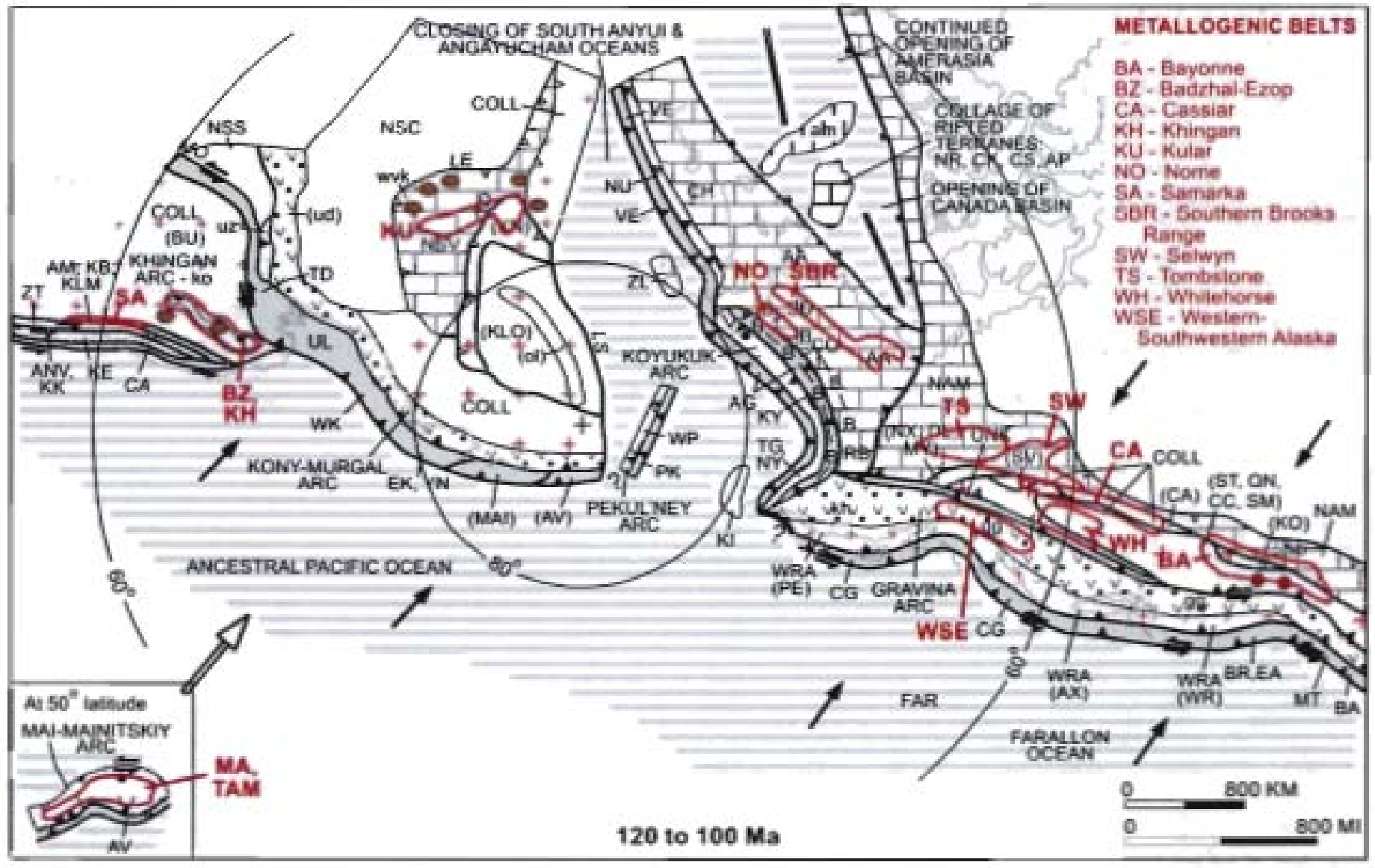

Figure 72. Late Early Cretaceous (Aptian through Albian - 120 to $100 \mathrm{Ma}$ ) stage of metallogenic-tectonic model. Refer to text for explanation of metaliogenic-tectonic events, to tables 3 and 4 for descriptions metallogernic bells and significant deposits, and to figure 18 for explanation of abbreviations, symbols, and patterns. Adapted from Nokleberg and others (1997b, 1998, 2000). 
(1) At about $50^{\circ}$ paleolatitude, the Mainitskiy island are (Mainitskiy terrane, MAI) continued activity. Associated with this are was subduction of part of the adjacent oceanic plate to form the Alkatvaam aceretionary-wedge terrane (AV). This arc and companion subduction zone continued to migrate northwards towards the North Asian Craton Margin and outboard terranes and was acereted to the active continental margin at the end of the Early Cretaceous (about $100 \mathrm{Ma}$ ). During this aceretion, the Au quartz vein and associated deposits of the Anadyr River (AD) metallogenic belt formed. The accretion is interpreted as oceuring by the beginning of the Albian with deposition of the overlying Kuibiveem sedimentary assemblage (kb), which is interpreted as a foreare unit to the Okhotsk-Chukotka continental margin are (oc). Subduction stepped outboard during accretion.

(2) At the end of the Neocomian, oblique subduction was replaced by sinistral-slip faulting purallel to the continental margin. This faulting resulied in structural interleaving of the previously active subduction-zone terranes. This structurat interleaving is interpreted as similar to the present-day region of Southern California and resulted in formation of the faultbounded basin of marine turbidites now preserved in the Zhuravlesk-Tumnin turbidite-basin terrane (ZT) (Golozubov and Khanchuk, 1996).

(3) The Khingan continental margin are (ko) started to form. Forming in the arc was the Badzhal-Ezop-Khingan (BZ$\mathrm{KH}$ ) belt of granitic-magmatism-related deposits. Tectonically linked to the are was oblique subduction of part of the Ancestral Pacific Ocean plate to form the Amur River (AM), Khabarovsk (KB), and Kiselevka-Manoma (KLM) subduction-zone and aceretionary-wedge terranes. Also in the same region, the Samarka (SA) belt of granitic-magmatism-related deposits, which is bosted in the Samarka island-arc terrane (SA), is interpreted as forming during anatectic granitic plutonism ussociated with thrusting of Kula-Farallon oceanic ridge under margin of southern Russian Far East.

(4) The continental margin Uda are and associated subduction zones ceased activity with accretion of the Burcya superterrane and closure of the Mongol-Okhotsk Ocean along the Mongol-Okhotsk suture (MO).

(5) The extensive Kony-Murgal continental-margin and island arc and Pekulney island are continued to form. Associated with these arcs was subduction of part of the ancestral Pacific Ocean plate to form the Talovskiy (TL), Penzhina-Anadyr (PA), and Pekulney (PK) terranes.

(6) The final stages of accretion of the Kolyma-Omolon superterrane is interpreted as causing a second phase of deformation in the Verkhoyansk fold and thrust-belt and formation of the West Verkhoyansk collisional granite belt (wk; 90 to $120 \mathrm{Ma}$ ) along the Lena fault $(L E)$. Forming in the associated Verkhoyansk granite belt and continuing on from the Early Cretaceous was the Kular (KU) metallogenic belt which contains Au quartz vein and granitic-magmatism-related deposits.

(7) The Nutesyn and Koyukuk island ares continued activity on the opposite sides of the South Anyui and Angayucham Oceans. Parts of these ares are preserved in the Nutesyn (NU), Koyukuk (KY), Togiak (TG), and Nyac (NY) ierranes. Associated with these ares was subduction of parts of the South Anyui and Angayucham Ocean plate thereby forming the Velmay (VE); and (outer) Angayucham (AG) terranes, and subduction of the outboard margin of the Arctic Alaska terrane. An extensive zone of blueschist facies metamorphism occurs in this region in both the Angayucham and Arctic Alaska terranes. Forming during extension which succeeded obduction were Nome (NO) and Southern Brooks Range (SBR) metallogenic belts which contain Au

quartz vein deposits, and are hosted in metamorphosed continental-margin terranes. These belts are interpreted herein as forming during regional metamorphism associated with extension.

(8) In the Arctic, sea-floor spreading and associated rifting continued with formation of large sedimentary basins, creation of a collage of passive continental-margin terranes derived from the North American Craton Margin (NAM; Lawver and Scotese, 1990; Grantz and others, 1990, 1991, 1998). Continuing was closure of the Angayucham Ocean, subduction along the North Americas continental margin, intense thrusting in the passive continental margin terranes, and deposition of Early to midCretaceous flysch.

(9) On the edge of the Wrangellia supentrrane (WRA), the Gravina arc continued to form. Associated with the Gravina are was subduction of part of the Farallon Ocean plate io form the Chugach (CG), Bridge River (BR), Easton (EA), and Baker (BA) terranes. Part of the are was preserved in the Kahiltna (kh) and Gravina-Nutzotin-Gambier (g8) assemblages which oceur obly on the Wrangellia superterrane. The Gravina arc extended into the southern Canadian Cordillera with the formation of the Spences Bridge volcanic-plutonic belt (sb). Forming in the Gravina are, and continuing on from the Farly Cretaceous was the Western-Southeastern Alaska (WSE) belt which contains granitic-magmatism-related deposits.

(10) The central and northern parts of the Wrangellia superterrane (WRA) accreted to the Northern Canadian Cordillera and southern Alaska. Along the accreting edge of the superternane, the intervening oceanic plate and the Kahiltna overlap assemblage were thrust during the active continental margin of the Southem Alaska and the northem Canadian Cordillera (Stanley and others, 1990). The small tectonic lenses of ierranes of alpine ultramafic and related rocks along the ancestral Denali fault (unit UM; Nokleberg and other, 1985, 1994a) may be remnants of this oceanic lithosphere.

(11) Coeval with accretion of the Wrangellia supernernane was intrusion of the Onineca-Selwyn anatectic granite belt (om) which occurs along the length of Canadian Cordillera and Alaska. Forming in or near the granite belt were the Bayonne (BA), Cassiar (CA), Selwyn (SW), Tombstone (TS), and Whitehorse (WH) metallogenic belts which contain granitic-magmatismrelated deposits. 
Sn Greisen, Skam, and Sn Quartz Vein Deposits (BZ-KH) Western Part of Russian Southeast

The Badzhal-Ezop-Khingan metallogenic belt of Sn greisen and Sn quartz vein deposits (fig. 61; tables 3, 4) occurs in the westem part of the Russian Southeast. The belt consists of the Badzhal-Ezop and Khingan parts and is hosted in granitoid rocks of the Early and mid-Cretaceous Khingan-Okbotsk volcanic-plutonic belt (fig. 61; Nokleberg and others, 1994c, 1997c). The significant deposits in the belt are the Festivalnoe, Ippatinskoe, Loshadinayadgriva, and Solnechnoe Sn quartz vein deposits, the Olgakanskoe and Pravourmiskoe Sn greisen deposits, the Kapral porphyry Mo deposit, and the Ezop Sn polymetallic vein deposit (table 4) (Nokleberg and others 1997a, b, 1998).

The Badzhal-Ezop part, which occurs in the northern part of the metallogenic belt, consists of Sn greisen, Sn skarn, and Sn quartz vein deposits. Sn minerals are predominant; $\mathrm{Pb}, \mathrm{Zn}, \mathrm{Ag}, \mathrm{Bi}, \mathrm{Cu}$, and $\mathrm{W}$ minerais are less prevalent. The distribution of the Sn deposits is zoned. Quartz-cassiterite deposits (mainly greisen with rare Sn skam and Sn quartz vein deposits, as at VerkhneIppatinskoe, Shirotnoe, Ezop, and Pravourmiiskoe) oceur along the contacts of large, crustal-origin granite and leucogranite intrusions. These occur mainly in the western part of the metallogenic belt adjacent to the craton. K-Ar isotopic studies indicate the Sn deposits and associated Sn granites formed between 75 to $100 \mathrm{Ma}$. The Badzhal-Ezop metallogenic belt contains Sn quartz vein deposits at Ezop, Festivalnoe, Ippatinskoe, Loshadinayadgrive, and Solnechnoe. Sn greisen and polymetallic vein deposits, as at Ezop, Olgakanskoe, and Pravourmiiskoe generally occur in veins.

Disseminated manto replacement deposits, as at Shirotnoe, also occur in the Badzhal-Ezop part of the belt. In this and similar deposits, a major and relatively older assemblage of ore minerals consists of quartz, cassiterite, topaz, fluorite, muscovite, tourmaline, arsenopyrite, molybdenite, and wolframite. A relatively younger and minor assemblage of ore minerals consists of sphalerite, galena, chalcopyrite, bismuthite, pyrrhotite, stannite, fluorite, and rare scheelite. This younger assemblage is more dominant to the east, away from source granitic intrusions, thereby illustrating a lateral zoning. This zoned change of mineral composition of ore from east to west is clearly observed in the Badzhal and Ezop mining districts, In addition to Sn, the greisen deposits often contain molybdenite and wolframite; locally each mineral is dominant.

The Khinghan part, which occurs in the southern part of the metallogenic belt, contains Sn deposits are mainly associated with potassic granitic intrusions with a K-Ar isotopic ages of 80 to $90 \mathrm{Ma}$ (Ognyanov, 1986), and a Rb-Sr whole-rock isochron age of $78 \mathrm{Ma}$ (Gonevchuk and others, 1998). Common in the belt are both Sn greisen deposits, with topaz-muscovite-quartz greisen which formed adjacent to plutons (as at Khingan, Nizhnee, Obeshchayushchee, and Verkhnebidzhanskoe deposits), and volcanic wood tin deposits (as at Dzhalinda) which formed in the upper part of felsic vents or calderas, The major Sn quartz vein deposits is at Verkhnebidzhanskoe.

\section{Solnechnoe Sn Quartz Vein Deposit}

The Solnechnoe Sn quartz vein deposit (fig. 73) (Ognyanov, 1986, 1shibara and others, 1997) consists of highly altered quartz-tourmaline veins with numerous apophyses is related to a long north-south, left-lateral, strike-slip fault. The deposit varies from 0.5 to $15 \mathrm{~m}$ thick, $800 \mathrm{~m}$ long, and extends to the depth more than $500 \mathrm{~m}$ below the surface. Five vertically-zoned mineral assemblages are distinguished, from bottom to top: (1) quartz-tourmaline; (2) quartz-arsenopyrite-cassiterite with wolframite, bismuthinite, and scheelite; (3) quartz-sulfide (pyrnhotite, chalcopyrite, and marcasite); (4) quartz-galena-sphalerite; and (5) quartz-carbonate. The deposit is closely related to a $\mathrm{K}$-rich granite phase of a gabbro-diorite-granodiorite complex with $\mathrm{K}$-Ar isotopic ages of 75 to $86 \mathrm{Ma}$. The deposit is medium with an average grade of $0.56 \% \mathrm{Sn}, 0.05 \% \mathrm{~W}$, and $0.1 \% \mathrm{Cu}$. The deposit has been mined since 1960 s(?) and is mostly exhausted.

\section{Pravourmiskoe Sn Greisen Deposit}

The Pravourmiskoe Sn greisen deposit (fig. 74) (Ognyanov, 1986) consists of disseminations and in veins which occur in a linear area over $1500 \mathrm{~m}$ long, 5 to $25 \mathrm{~m}$ thick, and extends several hundred $\mathrm{m}$ down dip. An earlier ore assemblage consists of quartz-topaz-cassiterite with fluorite, and a later assemblage consists of quartz-arsenopyrite-chalcopyrite, and quartz-tourmaline with cassiterite and stibnite. In addition to $\mathrm{Sn}, \mathrm{W}$, and $\mathrm{Cu} ; \mathrm{Bi}, \mathrm{Pb}$, and $\mathrm{Sb}$ also occur. The gangue is composed of quartzsiderophyllite (zwitters) with quartz-topaz greisen. The deposit is large with an average grade of $0.1-5 \% \mathrm{Sn}, 0.05 \% \mathrm{WO}_{3}$, and $0.5 \% \mathrm{Cu}$. The deposit occurs along an east-west-trending thrust fault with small offset. The deposit is hosted in and genetically related to Late Cretaceous felsic volcanic rocks which overlie the large, shallow, granite and leucogranite complex of the Verkhneurmiisky batholith with $\mathrm{K}$-Ar isotopic ages of 75 to $85 \mathrm{Ma}$. The granite has a long-ranging Rb-Sr age of 95 to $83 \mathrm{Ma}$ with an initial Sr ratio of 0.703 to 0.708 (Lebedev and others, 1994). 


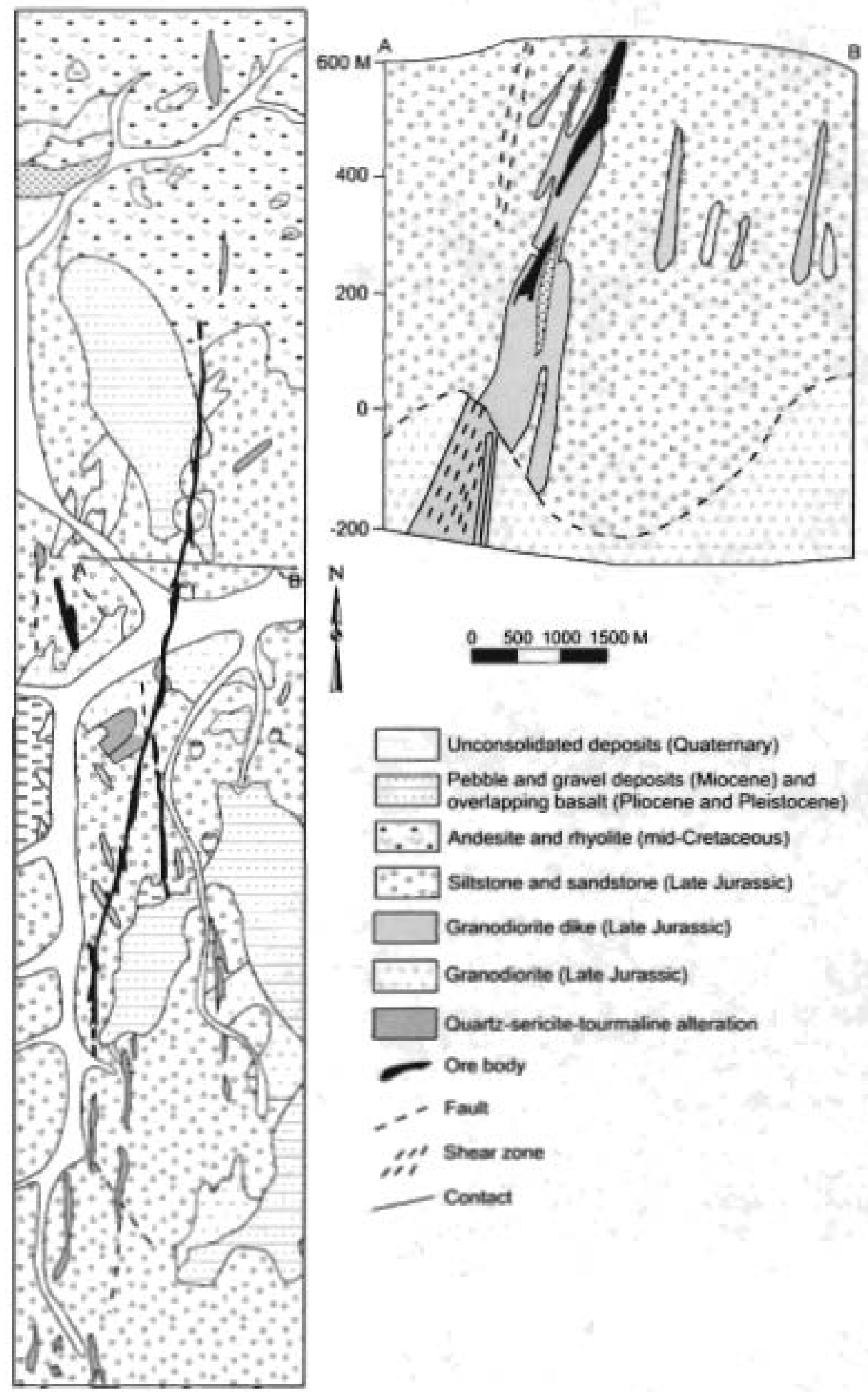

Figure 73. Solnechnoe Sn quartz vein deposit, Badzhal-Ezop-Khingan metallogenic belt, Russian Southeast. Schematic geologic map and cross section. Adapted from Vedernikov and Peltsman (1980). 

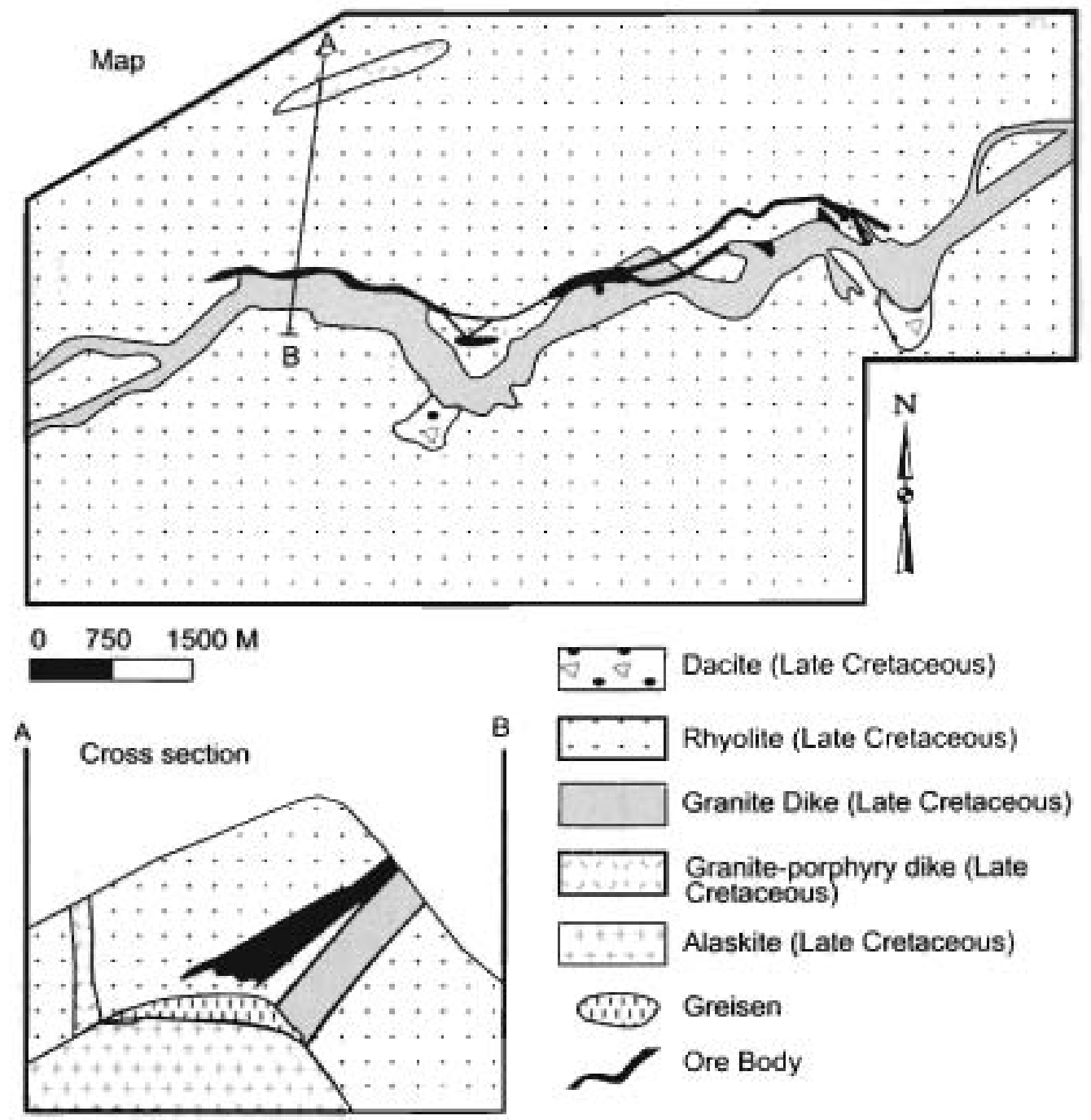

Rhyolite (Late Cretaceous)

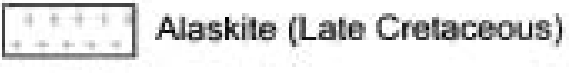

\section{(iiv) Greisen}

Ore Body

Figure 74. Pravourmiskoe Sn greisen deposit, Badzhal-Ezop-Khingan metallogenic belt, Russian Southeast. Adapted from Semenyak and others (1988).

\section{Khingan Sn Greisen Deposit}

The large and well known Khingan Sn greisen deposit (fig. 75) (Ognyanov, 1986) is of hypabyssal origin and occurs in a pipe-shaped ore bodies of hydrotbermal explosion breccia which cut a sequence of felsic volcanic rocks. The deposit contains over 15 ore zones from 10 to $50 \mathrm{~m}$ across and 100 to $400-500 \mathrm{~m}$ which are concentrated down-dip in a symmetrical breccia zone about $250-300 \mathrm{~m}$ across. The zone has been traced to depths of over $1200 \mathrm{~m}$. At the upper levels of the deposit, the breccia is replaced by chlorite, and at the depths of $700-800 \mathrm{~m}$, the breccia is replaced by quartz-muscovite (sericite)-topaz, greisen. Most of the ore zone is quartz-fluorite-cassiterite. Arsenopyrite, marcasite, loellingite, chalcopyrite, and Bi-minerals are subordinate. The deposit is interpreted as probably genetically related to subalkaline potassium granite with a $\mathrm{K}$-Ar age of $80-90 \mathrm{Ma}$ and a $\mathrm{Rb}-\mathrm{Sr}$ wholerock isochron age of $78 \mathrm{Ma}$ with an initial $\mathrm{Sr}$ isotopic ratio of 0.7123 (Gonevchuk and others, 1991). The deposit has been mined since the 1970 s. The deposit is of large and averages $0.6-0.7 \% \mathrm{Sn}$.

\section{Verkhnebidzhanskoe Sn Quartz Vein Deposit}

The Verkhnebidzhanskoe Sn quartz vein deposit (Ognyanov, 1986) is hosted in Late Proterozoic dolomite adjacent to a rhyolite porphyry stock. The deposit occurs at a tectonic contact of the dolomite with Late Proterozoic schist. The deposit consists of metasomatic quartz-sulfide lenses which range from 50 to $80 \mathrm{~m}$ along strike, and extend up to $70 \mathrm{~m}$ downdip with a maximum thickness of 10 to $12 \mathrm{~m}$. The deposit extends for about $1,300 \mathrm{~m}$. The dominate late-stage ore minerals are mainly sulfosalts (boulangerite, jamesonite) The subordinate, earlier-stage ore-minerals are quartz, cassiterite, and arsenopyrite. Alteration minerals include tale, caleite, siderite, and dolomite. Both the sedimentary and volcanic rocks are extremely rich in Sn (up to 10 clarkes). A Late Cretaceous thyolite porphyry stock, which contains geochemically anomalous $\mathrm{Sn}$ (about $0.005 \%$ ), is interpreted as the source for the vein $\mathrm{Sn}$ which formed during hydrothermal alteration. The deposit is small and contains an average of $0.3-2.0 \% \mathrm{Sn}$. 
The Sn deposits of the Badzhal (northern) part of the Badzhal-Ezop-Khingan metallogenic belt are hosted in, or near the Early and mid-Cretaceous Khingan-Okhotsk volcanic-plutonic belt (unit ko, fig. 61) (Nokleberg and others, 1994c, 1997c). The deposits occur mainly around the outcrops of large intrusions of crustal-derived granite and leucogranite or crustal- to mantlederived granitoid rocks which intrude mainly along older, elongate, east-west-striking faults which were subduction zones in the Middle Jurassic to Early Cretaceous. The Cretaceous Khingan-Okhotsk volcanic-plutonic belt is divided into two main sequences: (1) Barremian to Cenomanian andesite and minor basalt, with coeval gabbro, diorite, and granodiorite. Andesite exhibits calcalkalic composition, whereas basalt exhibits tholeitic composition. And (2) Late Cretaceous (mainly pre-Senonian) suite of K-rich felsic volcanic rocks, tuff, ignimbrite, and coeval subvolcanic intrusive and granitoid rocks. These Cretaceous granitoid rocks include granite, leucogranite, and composite gabbro-diorite-granodiorite plutons (Ognyanov, 1986). The plutonic units are coeval and comagmatic with volcanic rocks; both suites exhibits high potassium contents. The Khingan-Okhotsk belt overlies the Turan and Malokhingask terranes of the Bureya continental-margin arc superterrane, and Badzhal and Ulban accretionary-wedge terranes (Nokleberg and others, 1994c, 1997c). The belt defines the Khingan continental margin arc in the Russian Southeast (fig. 61) (Nokleberg and others, 2000).
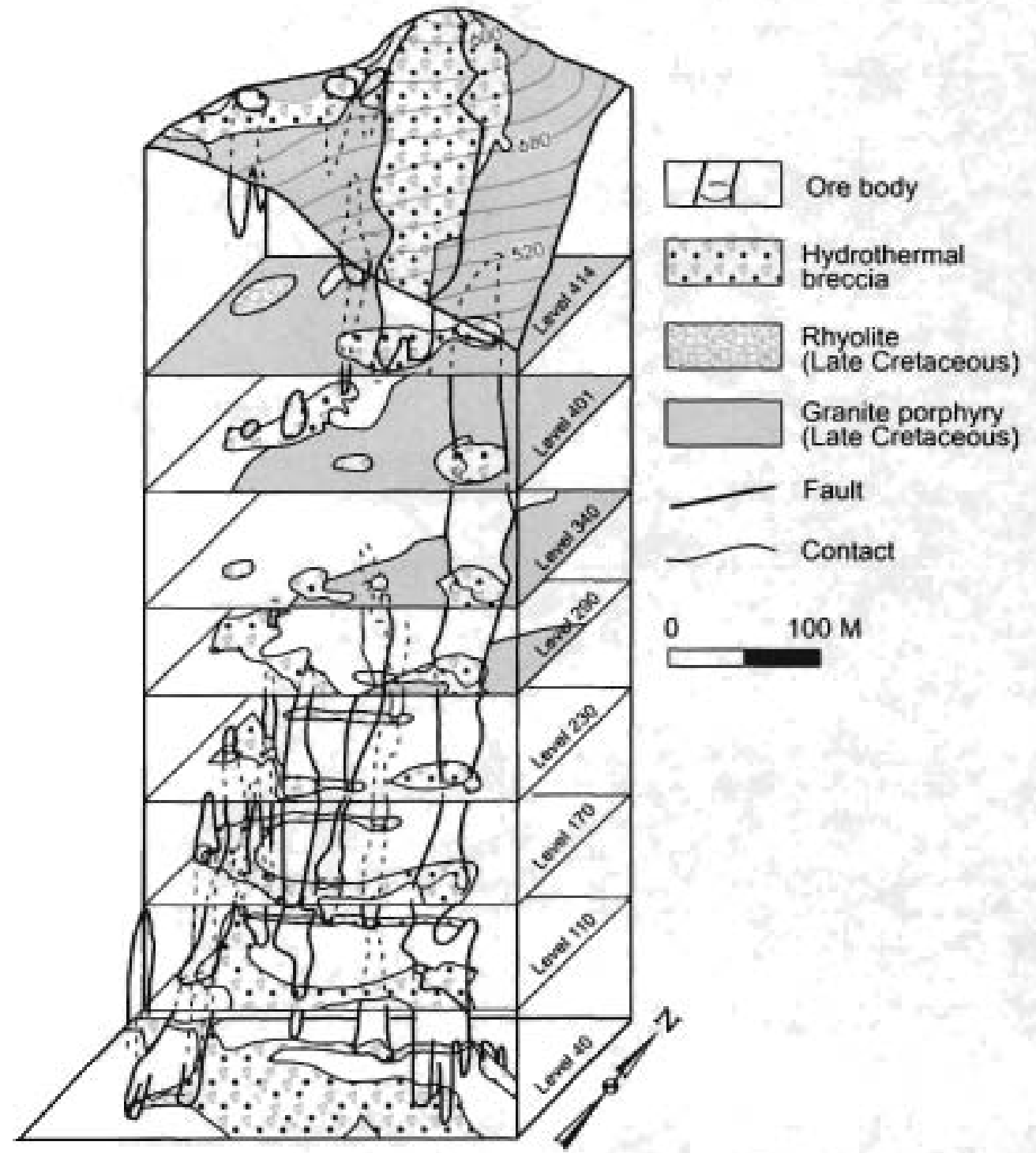

Figure 75. Khingan Sn greisen deposit, Badzhal-Ezop-Khingan metallogenic belt, Russian Southeast. Schematic three-dimensional figure. Levels and contours in meters. Adapted from Ore Deposits of the U.S.S.R. (1978).

The Khingan (southern) part of the Badzhal-Ezop-Khingan metallogenic belt is also hosted in the Khingan-Okhotsk volcanic-plutonic belt (isotopic age of $\mathrm{I} 34$ to $88 \mathrm{Ma}$ ). In the area underying the Khingan part of the metallogenic belt, these igneous rocks occur in a post-accretionary Cretaceous volcanic-lectonic depression in the eastern part of Bureya continental- 
margin are superterrane. The volcanic-tectonic depression is filled with mid-Cretaceous, intermediate-composition volcanic rocks and overlying Late Cretaceous tuff and rhyolite lava. The volcanic rocks range from 1.5 to $3.0 \mathrm{~km}$ thick. The volcanic rocks rest on a basement Proterozoic metamorphic rocks of the Bureya supenterrane. The intrusive rocks of the Khingan-Okhotsk belt in this area are dominantly granite and are comagmatic with the voleanic rocks. The granitoid rocks of the Khingan-Okhotsk belt are interpreted as subduction-related, calc-alkalic igneous focks, which include both S- and 1-type granites.

The Khingan continental-margin are (ko) is berein interpreted as forming from oblique subduction of the ancestral Pacific Ocean plate. Fragments of this plate are interpreted as occurring in tectonically interwoven fragments of the Amur River (AM). Khabarovsk (KB; younger Early Cretaceous part), and Kiselevka-Manoma accretionary-wedge terranes (Natal'in, 1991, 1993; Nokleberg and others, 1994a; Sengör and Natalin, 1996a, b). This tectonic pairing is based on: (1) occurrence of aceretionarywedge terranes outboard (oceanward) of, and parallel to the various parts of the Khinghan are; (2) formation of melange structures during the Early and mid-Cretaceous (Natal'in, 1991; Nokleberg and others, 1994a; Vrublevsky and others, 1988; Nechaev and others, 1996); and (3) where not distupted by extensive Cretaceous movement along the Central Sihote-Aline strike-slip fault, dipping of mélange structures and bounding faults toward and beneath the igneous units of the are (Natal'in, 1993). Formation of the Khingan are and associated subduction is generally interpreted as ending in the late mid-Cretaceous when oblique subduction changed into sinistral-slip faulting along the outboard margin of the are (Nokleberg and others, 2000).

\section{Metallogenic Belts Formed in Late Mesozoic \\ Collision and Accretion of island Ares, and \\ Transform Continetnal-Margin Faulting, \\ Russian Northwest, Western and \\ Northern Alaska, and Northern \\ Canadian Cordillera}

\section{Anadyr River Metallogenic Belt of Au Quartz Vein and Associated Deposits (Belt AD) Eastern Part of Russian Northeast}

The Anadyr metallogenic belt of sparse Au quartz vein deposits oceurs in the eastern part of the Russian Northeast in the Anadyr region (fig. 61, tables 3,4) (Nokleberg and others, 1997b, 1998). The significant deposits are at Vaegi and Nutekin. Significant associated placer Au districts occur at Kenkeren, Otrozhny, and Pekulncy (Nokleberg and others, 1997b, 1998). The knowledge of associnted lode deposits is poor, although placer Au deposits were discovered in the Zolotoy Range in 1902. The placer Au districts overlie island arc and oceanic crust terranes which occur in intricate fold, thrust, and nappe structures.

The lode sources for the placer Au deposits are interpreted as: (1) various Au quartz and sulfide-quartz vein which containing feldspar, carbonate minerals, epidote, chlorite, and other minerals; and (2) various mineralized zones in Paleozoic and Mesozoic clastic rocks, chert, volcanogenic rocks which are introded by Late Cretaceous calc-alkaline magmatism. Some Au occurrences are associated with PGE deposits which occur in silica-carbonate metasornatic rocks is serpentinite melange. Two small Au quartz vein occurrences are at Vaegi and Nutekin. Both are hosted in the Mainitskiy island-afe terrane (Nokleberg and others, 1997b, 1998).

The lode Au deposits of the Anadyr metallogenic belt are tentatively interpreted as forming mostly during late Early Cretaceous accretion and associated metamorphism and deformation of the Mainitskiy are that includes the Mainitskiy and West Pekulney island-are terranes and the Penzhina-Anadyr accretionary wedge or subduction-zone terranes (Nokleberg and others, 1994c, 1997c; 2000).

\section{Vaegl Au Quartz Vein Occurrence}

The small Vaegi Au quartz vein oceurrence (M.N. Zakharov and V.P. Vasilenko, written commun., $197 \mathrm{~m}$ ) consists of thin quartz and carbonate-quartz veins and veislets which contain disseminated gold, bematite, pyrite, and chalcopyrite with spare arsenopyrite. The deposit is hosted in Paleocoic and supposed Proterozoic intermediate metavolcanic rocks. Gold-cinnabar intergrowths occur in nearby heavy mineral placers which have been mined. The deposit occurs in a nappe of early Paleozoic and possibly older metavolcanic rocks which display both greenschist facies metamorphism and extensive host rock replacement by sulfide minerals and quartz, and which may have potential for vein and disseminated Au deposits (Ivanov and others, 1989).

\section{Nutekin Au Quartz Vein Occurrence}

The small Nutekin Au quartz vein oceurrence (V.P. Vasilenko, written commun, 1977) consists of steeply-dipping quartz and quartz-carbonate veins which grade into zones of silicified and sulfidized veinlets along strike. The deposits trend northwest and are up to $500 \mathrm{~m}$ long. The Au-bearing veins occur in early Mesozoic, and less frequently Early Cretaceous, clastic sedimentary rocks. The highest Au contents are in veins within Paleogene dolerite dikes. The Au is associated with rare disseminated pyrite and arsenopyrite, and is marked by high $\mathrm{Hg}$ content. The deposit occurs in the axial portion of a horstanticlinotium structure. 
The Nome metallogenic belt of Au-bearing quartz vein deposits (fig. 62; tables 3, 4) forms a $200 \mathrm{~km}$ long, east-westtrending belt along the southem part of the Seward Peninsula. The metallogenic belt occurs along the southern margin of the Seward metarnorphosed continental margin terrane (Nokleberg and others, 1994c, 1997c). The most favorable mineralized areas are associated with upper greenschist facies metamorphic rocks. Two major concentrations of deposits occur at (table 4) (Nokleberg and others 1997a, b, 1998): (1) Bluff and Big Hurrah in the Solomon District; and (2) Rock Creek, Mount Distin, and Sophia Gulch in the Nome District. In both areas, the deposits consist mainly of mesothermal, sulfide-poor, Au-quartz deposits in individual high grade veins or in zones of multiple, more-or-less en-echelon, sheeted veins which generally contain lower Au grades. The quartz veins, which typically contain minor carbonate, albite, and oligoclase, cut shallow-dipping metamorphic foliation. The best studied deposits in the Nome district are at Rock Creek and Mount Distin, both immediately north of Nome (Gamble and others, 1985; Apodaca, 1992). These newly evaluated lodes may be examples for the rich placer Au deposits mined in the Nome District.

In the Nome district, Bundtzen and others (1994) recognize three major mineral deposit types: (1) early-stage chalcopyrite-sphalerite-gold-quartz-carbonate veins, which appear as boudins which are rolled around early fold axes (Banger deposit): (2) Au-quartz polysulfide veins which crosscut schistosity at low angles (Rodine, McDuffy, and Twin Mountain deposits); and (3) brittle, Au-polysulfide-quartz-albite-carbonate veins which crosscut schistosity at high angles (Rock Creek, Sliscovish, Sophies Gulch deposits). The Au deposits are thought to have formed during various stages of dewatering of a metamorphic pile during Barrovian-type, greenschists facies regional metamorphism and associated plutonism, as interpreted for the Rock Creek deposit (Apodaca, 1992), and for the Mt. Distin and Bluff and deposits (Ford, 1990). However, recent Ar-Ar isotopic studies indicate the vein mica from quartz veins at the Bluft deposit formed at about $109 \mathrm{Ma}$, about 30 m.y. after metamorphic mica in the area reached closure temperature (Ford and Snee, 1996).

\section{Rock Creek Au Quartz Vein Deposit}

The Rock Creek Au quartz vein deposit (Ted Eggelston and R.V. Bailey, written commun, 1990-1991; A podaca, 1992) consists of arsenopyrite, scheelite, galena, stibnite, and pyrite which occur in a northeast-trending, sheeted, quartz vein system. At the surface, the deposit extends for 1,200 meters along strike, averages 70 meters width, and extends up to 150 meters in depth. The host rocks are phyllite and schist of the Paleozoic Nome Group. Fluid inclusion studies indicate ore deposition oceurred in the mesothermal range $\left(240^{\circ} \mathrm{C}-320^{\circ} \mathrm{C}\right)$. The ore minerals occur along selvages of quartz vein-host rock contacts. Vein mica yields an Ar-Ar isotopic age of 109 to $104 \mathrm{Ma}$ (T.K. Bundtzen and P.W. Layer, written commun., 1995). The deposit is interpreted as forming by hydrofracturing and dewatering during the waning stage of a mid-Cretaceous metamorphic event. The deposit contains an estimated 10.2 million tonnes grading $2.4 \mathrm{~g} / \mathrm{Au}$ and about $0.43 \% \mathrm{~W}$ (Swainbank and Szumigala, 2000). At Mount Distin, several similar, en-echelon Au quartz veins oceur along an east-west-trending thrust fault for at least $3 \mathrm{~km}$.

\section{Big Hurrah Au Quartz Vein Deposit}

The Big Hurrah deposit (Collier and othen, 1908; Cathcart, 1922; Asher, 1969; Mullen, 1984; Gamble and others, 1985; Read. 1985; Read and Meinert, 1986) consists of four major quartz veins, and zones of ribbon quartz. The major veins and ribbon zones range from 1 to $5 \mathrm{~m}$ thick and are a few hundred meters long. The veins contain sparse gold, pyrite, and arsenopyrite, and minor scheelite, chalcopyrite, and sphalerile, in a gangue of quartz, carbonate, and feldspar. These veins are intermixed with older, concordant, non-Au-bearing, metamorphic quartz veins. The Au-bearing veins range from discordant lension veins to discontinuous quartz lodes which occur in shear zones crossing foliation. The Au-bearing veins range from 0.5 to $5 \mathrm{~m}$ wide and extend to a depth of at least $90 \mathrm{~m}$. Most of the veins are less than $1 \mathrm{~m}$ wide. The veins and ribbon quartz zones are hosted in quartz-rich. graphitic, quartz-mica schist or quartzile of the Paleozoic Nome Group. The veins are interpreted as forming during shearing and uplift associaled with metamorphic dehydration in the mid-Cretaceous. Mining occurred at the deposit from 1903 . 1909, and from 1953-1954. The deposit has produced about $839 \mathrm{~kg}$ Au, averaging about $34.3 \mathrm{~g} / \mathrm{Au}$ (Reed and Meinhart, 1986). Recent assays range from 25 to $65 \mathrm{gl} \mathrm{Au}$.

\section{Origin of and Tectonic Controls for Nome Metallogenic Belt}

The Big Hurrah and Bluff deposits in the Solomon district and the deposits in the Nome district exhibit several similarities, including low-sulfide mineral concentration, fault localization, and confinement to low-grade, greenschist facies metarnorphic rocks. In all the deposits, a post-metamorphic fluid origin is suggested for the deposits by (Gamble and others, 1985): (1) the discordance of the veins to metamorphic foliations; (2) oxygen isotope and fluid inclusion data; and (3) the lack of coeval intrusions in the bell. These relations indicate that the Au deposits formed from fluids which equilibrated with the sedimentary and (or) volcanic protoliths of the None Group under greenschist facies regional metamorphism. Subsequently, the fluids moved upward during a later, post-kinematic event to deposit the vein minerals. As in the southern Brooks Range, regional 
metamorphism of the Seward metamorphosed continental margin terane occurred during two stages. A relatively older blueschist facies event in the Jurassic was followed by: (1) thrusting of oceanic units of the Angayucham terrane onto the passive continental-margin arctic Alaska supenterrane, and (2) subsequent, Early to mid-Cretaceous extensional, retrograde, greenschist metamorphism (Armstong and others, 1986; Moore and others, 1994; Miller and Hudson, 1991; Till und Dumoulin, 1994).

The Nome metallogenic belt is interpreted as forming in the waning stages of extension, which is defined by Early to mid-Cretaceous greenschist facies metamorphism and companion penetrative deformation (Miller and Hudson, 1991; Moore and others, 1992; Nokleberg and others, 1994c, 1997c; Goldfurb, 1997). In a few areas, the Nome Group exhibits an older, relict blueschist facies metamorphism which is interpreted as forming in a Jurassic or older period of convergent deformation and metamorphism (Armstrong and others, 1986; Moore and others, I994; Till and Dumoulin, 1994). The convergent deformation and blueschist facies metamorphism is interpreted as forming during Late Jurassic and Early Cretaceous subduction of the Seward terrane under the oceanic Angayucham terrane, resulting in formation of the Koyukuk island-arc terrane to the south (present-day coordinates) (Moore and others, 1994; Patton and others, 1994; Plafker and Berg. 1994; Nokleberg and others, 2000). Incremental Ar isotopic studies suggest quartz vein formation at about 109 to $104 \mathrm{Ma}$ (Ford and Snee, 1996), and which quartz vein formation was temporally related to a thermal pulse. This thermal pulse is also interpreted as causing high-grade metamorphism and anatectic plutons to the north in the Kigluaik Mountains, and to the east in the Bendeleben and Darby Mountains (Ford and Snee, 1996). The Au quartz vein deposits of the Nome metallogenic belt are interpreted as coeval with the Au quartz vein deposits in the Southern Brooks Range metallogenic belt to the northeast.

\section{Southern Brooks Range Metallogenic Bett of Au Quartz Vein Deposits (Beit SBR) Northern Alaska}

The Southern Brooks Range metallogenic belt of Au-bearing quariz vein deposits (fig. 62; tables 3, 4), which includes the Chandalar district, lies in the southern Brooks Range. The metallogenic belt is hosted in both the Hammond terrane (Aretic Alaska superterrane) and the Coldfoot terrane to the south (Nokleberg and others, 1994c, 1997c). The significant deposits are at Little Squaw and Mikado in the Chandalar district (table 4) (Nokleberg and others 1997a, b, 1998). Recent work on Au-bearing quartz vein deposits in the Wiseman area is summarized by Eden (2000).

\section{Mikado Au Quartz Vein Deposit}

The Mikado Au quartz vein deposit (Chipp, 1970; DeYoung, 1978; Dillon, 1982; Ashworth, 1983; J.T. Dillon, oral commun., 1986; Rose and others, 1988) consists of several quartz veins up to $3 \mathrm{~m}$ thick in a zone about $4.0 \mathrm{~km}$ long and $1.6 \mathrm{~km}$ wide. The veins contain scattered, minor arsenopyrite, galena, sphalerile, stibnite, and pyrite and spane gold. The veins occur along steeply dipping normal faults in Devonian or older quartz-muscovite schist, phyllite, and quartzile. The Little Squaw Mining Company drove more than 1,000 m of underground workings from 1980 10 1983. Minor production and several episodes of exploration activity have occurred, notably during the 1920's and 1960's. The Mikado deposit contained an estimated 12,000 tonnes averaging $75 \mathrm{~g} / \mathrm{Au}$, and produced about $542 \mathrm{~kg}$ Au from ore averaging about $30 \mathrm{~g} / \mathrm{Au}$ (Bundtzen and others, 1994). The Mikado deposit and surrounding district contains an estimated remaining 45,000 tonnes grading $30 \mathrm{~g} / \mathrm{Au}$.

\section{Origin of and Tectonic Controls for Southern Brooks Range Metallogenic Belt}

The Au quartz vein deposits occur along stecply dipping normal faults in greenschist facies metasedimentary rocks that are part of a structurally complex, polymetamorphosed, and poly-deformed assemblage of Devonian or older carbonate rocks, including the Skajit Limestone, calc-schist, quartz-mica schist, and quartzite, which are intruded by Proterozoic and Late Devonian gneissic granitoid rocks. These early Paleozoic metasedimentary rocks and Devonian metagranitoid rocks form a major part of the Hammond passive continental margin terrabe of the Arctic Alaska superterrane (Jones and others, 1987; Moore and others, 1992).

Field relations indicate the deposits, that were deposited from hydrothermal fluids, were deposited during normal faulting. The normal faulting may be associated with a period of regional extension which was associated with the waning stages of greenschist facies regional metamorphism and companion penetrative deformation in the Early to mid-Cretaceous (Moore and others, 1992; Nokleberg and others, 1994c, 1997c). This period of regional metamorphism is interpreted as the last major metamorphic event in the Hammond and Coldfoot terranes. In a few areas, the Coldfoot and Hammond ternanes exhibit reliet blueschist facies minerals which are interpreted as forming in a Jurassic or older period of convergent deformation and metamorphism (Moore and others, 1994). The convergent deformation and blueschist facies metamorphism probably occurred during Late Jurassic and Early Cretaceous subduction of the Coldfoot and Hammond terranes under the Angayucham subduction zone iernane, and Koyukuk island-arc terrane to the south (Moore and others, 1994; Pattou and others, 1994; Plafker and Berg. 1994; Nokleberg and others, 2000). As in the Nome region, the regional blueschist facies metamorphism was followed by: (1) thrusting on oceanic units of the Angayucham terrane onto the Coldfoot and Hammond terranes, and other parts of the passive continental-margin artic Alaska superterrane; and (2) extensional, Early to mid-Cretaceous retrograde, greensehist metamorphism and formation of Au quartz vein deposits (Armstong and others. 1986; Moore and others, 1994; Till and Dumoulin, 1994). The Au 
quartz vein deposits of the Southern Brooks Range metallogenic belt only occur in a small portion of the greenschist facies metasedimentary tocks of the southern Brooks Range. However, the more extensive placer Au deposits along the Brooks Range may be derived from undiscovered, or now totally eroded Au quartz vein deposits. The Au quartz vein deposits in the Southern Brooks Range metallogenic belt are interpreted as coeval with the Nome metallogenic belt to the southwest.

Fish River Metallogenic Belt of Sedimentary P and Fe Deposits (Belt FR) Northern Yukon Ternitory

The Fish River metallogenic belt of sedimentary P and Fe deposits oceurs in the northern Yukon Territory (fig, 62; tables 3, 4) (Nokleberg and others, 1997b, 1998)and is hosted in the Early Cretaceous Blow River Formation. The significant deposits are at Big Fish River and Alto. The Fish River metallogenic belt is herein tentatively interpreted as forming during Late Mesozoic, dextral movement along the Kaltag-Porcupine fault system.

The Fish River (Big Fish, Boundary, Rapid) stratabound Fe-P deposit consists of siderite and phosphatic ironstone which occur in shale in an Early Cretaceous (Albian) elastic wedge (Yukon Minfile, 1988; Butrenchuk, 1996). The ironstone consists of phosphate-siderite pellets and granules in a matrix of detrital quartz and mudstone. Rare phosphate minerals occur in epigenetic fracture veins and to a lesser degree in vugs, bedding plane partings, and fault breccia. The deposit is the well-known type locality of lazulite, the official Yukon gemstone. Estimated resources are over 1 billion tonnes grading $40 \% \mathrm{Fe}$

The Alto oolitic magnetite iron formation is hosted in black shale of the Jurassic and Cretaceous Kingak Formation (Nomis, 1976; Yukon Minfile, 1987). The deposit consists of olitic magnetite which occurs in a 45-m-thick bed, which occurs for a strike length of $350 \mathrm{~m}$, and is part of a recessive-weathering black shale which is about $50 \mathrm{~m}$ above the base of the Kingak Formation. Estimated resources are 50 million tonnes grading $55 \%$ Fe (Norris, 1976).

The Early Cretaceous Blow River Formation is part of a thick, clastic wedge deposited in the Blow Trough which is interpreted as forming during late Mesozoic, dextral movement along the Kaltag-Porcupine fault system (Norris and Yorath, 1981). The sideritic ironstone and phosphorites are interpreted to be distal, reworked deep water pellet packstone deposits within a thick silt and conglomerate unit with a westerly elastic souree (Yeo, 1992). The Blow River Formation contains an estimated $\mathrm{P}_{2} \mathrm{O}_{3}$ resource of approximately 7 billion tonnes, in addition to a larger resource of low-grade iron ore Young (1977b).

\section{Metallogenic Beits Formed in Late Mesozoic Collision and Accretion of Wrangellia \\ Superterrane, and Generation of Omineca-Selwyn Plutonic Belt, Canadian Cordillera}

\section{Selwyn Metallogenic Beit of W-Cu Skarn, \\ Zn-Pb-Ag Skarn, and Zn-Pb-Ag Manto Deposits, Eastern and Northeastern Yukon Territory (Belt sW)}

The Selwyn metallogenic belt W-Cu skam, Zn-Pb-Ag skarn, and $\mathrm{Zn}$-Pb-Ag manto deposits (fig- 62; tables 3, 4) occurs in the eastern and northeastern Yukon Territory and consists primarily of an arcuate belt of W-Cu (Zn-Mo) skams, and $\mathrm{Zn}-\mathrm{Pb}-\mathrm{Ag}$ ( $\mathrm{Cu}$-W) skarns and manto deposits which are hosted in or near the related granitoid stocks of the mid-Cretaceous Selwyn Plutonic Suite (Anderson, 1983b). This suite is part of the Omineca-Selwyn plutonic belt which extends from southeastern Yukon Territory and southwestern Northwest Territories, northwestward into the Mayo district. The major W skam deposits are at Bailey (Pat), Canada Tungsten (Cantung), Lened (Rudi, Godfrey), MacTung (MacMillan Tungsten), and the major Pb-Zn skam and manto deposits are at Su Dena Hes (Mt. Hundere), McMillan (Quartz Lake), and Prairie Creek (Cadillac; table 4) (Nokleberg and others $1997 \mathrm{a}, \mathrm{b}, 1998)$. Other potentially economic skam tungsten deposits in the belt include, from southeast to northwest, Bailey with an estimaled resource of 405,454 tonnes grading $1.0 \%$ WO, Baker-Lened with an estimated resource of 750,000 tonnes grading $1.2 \% \mathrm{WO}_{\text {, }}$ and Clea (Dawson, 1996c).

\section{Canada Tungsten (Cantung) W Skarn Deposit}

The Canada Tungsten (Cantung) W skam deposit (fig. 76) consists of pyrrhotite, scheelite and chalcopyrite with minor sphalerite in diopside skam bodies which replace two memben of Early Cambrian limestone (Sinclair, 1986; EMR Canada, 1989, Yukon Minfile, 1990, Dawson and otbers, 1991). The host rocks are the Cambrian to Devonian part of the North American Continental Margin. The skams are related to intnaion of a Late Cretaceous quartz monzonite (K-Ar age of $94.6 \mathrm{Ma}$ ) of the Selwyn Plutonic Suite. Prograde gamet-pyroxene skam is overprinted by a hydrous, retrograde, pyrrhotite-andradite-amphibolebiotite-scheelite skarn. The deposits include the Pit orebody which produced 1.51 million tonnes of ore yielding 40,087 tonnes of WO between 1962 and 1986 , and the E-Zone orebody with reserves of 4.2 million lonnes grading $1.6 \%$ WO and $0.23 \% \mathrm{Cu}_{4}$, with associated Bi (Dawson, 1996c; Matheison and Clark, 1984). The large, high-grade E-zone scheelite orebody contains estimated combined reserves and resouces of 7 million lonnes grading $1.5 \% \mathrm{WO}_{3}$ and $0.2 \% \mathrm{Cu}_{2}$. Production, that ceased in 1986, resumed in 
2001 on mineable reserves of 630,00 tonnes of $1.82 \%$ WO3.(North American Tungsten Corporation news release, January 21 , 2001).

\section{Macmillan Pass (Mactung) Skarn W Deposit}

The Macmillan Pass (Mactung) skarn W deposit consists of scheelite, pyrnhotite and minor chalcopyrite in several pyroxene-gamet skams which replace Cambrian to Ordovician limestone and limestone breccia (Sinelair, 1986; EMR Canada, 1989; Dawson and others, 1991; Mining Review, 1992). The host rocks are part of a folded Cambrian and Devonian outer-shelf sequence of carbonate and pelitic rocks of the North American Continental Margin. The host rocks are flanked by and inferred to be underlain by the Late Cretaceous quartz monzonite Macrung stock (with a K-Ar isotopic age of $89 \mathrm{Ma}$ ) of the Selwyn Plutonic Suite. Hydrothermal alteration has produced three distinct concentric skarn zones: a peripheral zone of garnet-pyroxene skarn; an intermediate zone of pyroxene skarm; and a central zone of pyroxene-pyrrhotite skarn. Estimated combined reserves and resources are 32 million toanes grading 0.92 WO, (Atkinson and Baker, 1986; Dawson and others, 1991).
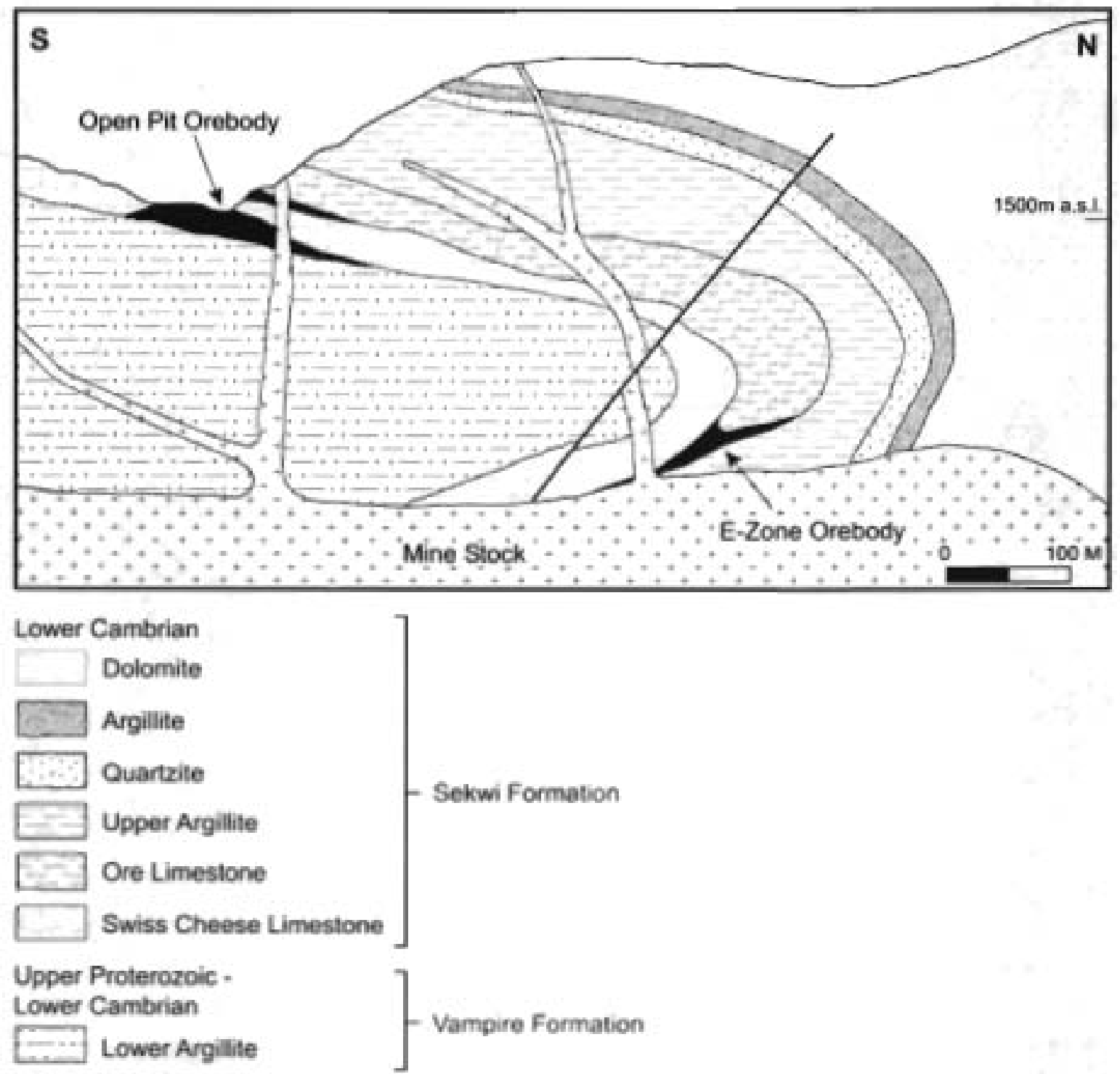

Figure 76. Canada Tungsten W skam deposit. Selwyn metallogenic beit, Canadian Cordillera. Schematic cross section. Adapted from Gordey and Anderson (1993).

\section{Sa Dena Hes, Quartz Lake, and Prairie Creek Skarn and Manto Zn-Pb-Ag Deposits}

$\mathrm{Zn}-\mathrm{Pb}-\mathrm{Ag}$ skam deposits oceur in several belts adjacent to the Mount Billings batholith in southeastem Yukon Territory. and the Flat River and smaller stocks in southwestern Northwest Territories. The associated granitoid plutonic rocks are part of the 
Selwyn Plutonic Suite. The host rocks are mainly Early Cambrian limestone; the associated granitoid plutons range from highsilica leucogranite and topaz granite to syenite. Diorite dikes also occur. In most cases, $\mathrm{Zn}$ skams oceur distally with respect to associated igneous rocks (Dawson, 1996a).

The Sa Dena Hes deposit at Mount Hundere, near Watson Lake, Yukon Territory consists of at least four tabular skarn and manto ore bodies (Abbott, 1981; Bremner and Ouellette, 1991; Northern Miner, October 7, 1991). The ore bodies are concordant to bedding in a deformed, Late Proterozoic and Early Cambrian craton margin sequence of limestone and phyllite. No nearby igneous rocks are exposed. The limestone is replaced by coarse-grained actinolite-hedenbergite-grossularite skarn, with pyrrhotite, magnetite, sphalerite, pyrite, and galena, and retrograde quartz and fluorite. The deposit has pre-production reserves of 4.8 million tonnes grading $12.7 \% \mathrm{Zn}, 4 \% \mathrm{~Pb}$, and $59 \mathrm{~g} / \mathrm{Ag}$ (Dawson and Dick, 1978; Dawson, 1996a).

The Quartz Lake (McMillan) deposit is a pyrite-bearing Zn-Pb-Ag manto which is probably related to small, nearby Cretaceous plutons. The deposit oceurs in southeastern Yukon and consists of a series of tabular and concordant bodies, lenses, and disseminations which replace limy quartzite and argillite of the Late Proterozoic to Early Cambrian Hyland Group of the North American Craton Margin. The deposit consists pyrite, galena, and sphalerite, with minor arsenopyrite, boulangerite, tetrahedrite, and chalcopyrite. Galena-lead isotopes indicate an age of $\mathrm{ca} .100 \mathrm{Ma}$, similar to which of intrusives of the Selwyn suite (Godwin and others, 1988). Estimated reserves are 1.5 million tonnes grading $6.6 \% \mathrm{Zn}, 5.5 \% \mathrm{~Pb}$, and $102 \mathrm{~g} / \mathrm{Ag}$ (Morin, 1981: Vaillancourt, 1982).

Recent exploration at the Prairie Creek (Cadillac) prospect, which oceurs near the South Nahanni River, Northwest Territories, reveals a stratabound deposit with characteristics of a $\mathrm{Zn}-\mathrm{Pb}-\mathrm{Ag}$ manto which occurs at depth beneath an extensive vein zone. No plutons are associated with the deposit which consists of galena and sphalerite, with minor tetrahedrite and chalcopyrite hosted in a quartz-carbonate gangue. The deposit occurs along a strike length of $10 \mathrm{~km}$ in 12 lenticular, stratabound vein zones which are hosted in shale and dolomite of the Middle Devoniun Amica Formation. Six deeper concordant ore lenses in the subjacent Ordovician Whittaker Formation are over $22 \mathrm{~m}$ thick. An estimated resource of 6.2 million tonnes grades $13 \% \mathrm{Zn}$, $12 \% \mathrm{~Pb}$, and $180 \mathrm{~g} / 4 \mathrm{Ag}$ (San Andreas Resources Corp., News Releases, 1992, 1993, 1994, 1995; Dawson, 1996a).

\section{Origin of and Tectonic Controls for Serwyn Metallogenic Belt}

The Selwyn metallogenic belt contains one of the world's largest reserves und resources of W skam deposits. The associated plutons, part of the Selwyn Plutonic Suite, are mainly equant, high level bodies of granite, granodiorite and quartz syenite with pronounced S-type characteristics, which discordantly intrude Late Proterozoic to early Paleozoic carbonate and pelitic rocks of the North American Craton Margin (fig. 62). The Selwyn Plutonic Suite is interpreted to have formed from thickening and melting of the continental crust in the outer part of a miogeoclinal sedimentary wedge during regional compression (Woodsworth and others, 1991). Skam W deposits commonly are associated with marginal or satellite phases of two-mica granites with aluminous accessory minerals (Anderson, 1983b). Radiometric ages for the plutonic suite range from 88 to $114 \mathrm{Ma}$, but most skarns are associated with early-phase plutons which range in age between 112 and $100 \mathrm{Ma}$ (Moriensen and others, 1994).

The Selwyn Plutonic Suite is part of the collisional mid-Cretaceous Omineca-Selwyn plutonic belt which extends from the southern part of the Canadian Cordillera, across Interior Alaska, northwestward into the Russian Northeast, and consists chiefly of granodiorite, granite, quarte syenile and minor syenite plutons of Early to mid-Cretaceous age (110-90 Ma) (Monger and Nokleberg. 1996; Nokleberg and others, 1994c; 2000). The spatial location of the belt, about $200 \mathrm{~km}$ west of the eastem limit of Cordilleran deformation, and chenistry suggests an anatectic origin of partial melting of cratonic crust during thickening caused by Cretacoous contraction (Monger and Nokleberg. 1996; Nokleberg and others, 2000) which was associated with orthogonal convergence between the Farallon Oceanic Plate and North America (Englebretson and others, 1985; 1992), and subsequent regional extension (Pavlis and others, 1993). Other metallogenic belts of granitic-magmatism-related deposits hossed in the Omineca-Selwyn plutonic belt in the Canadian Cordillera, Alaska, and the Rusvian Northeast include the Bayonne, Cassiar, Tombstone, and Whitehorse belts (fig. 62; tables 3, 4) Two other interpretations for the origin of the Omineca-Selwyn plutonic belt and related metallogenic belts are: (1) formatios during A-type subduction of the miogeocline and transtensional tectonics (Woodsworth and others, 1991; or (2) formation in the rear of a single broad, mid-Cretaceous, Cordillern-wide, subduction-related arc (Amustrong. 1988).

Tombstone Metallogenic Belt of Ag Polymetallic Vein, Au-Sb Vein, and W-Sn-Au and Cu-Au Skarn Deposits. Central Yukon Territory (Belt TS)

The Tombstone metallogenic belt of Ag polymetallic vein, Au-Sb vein, and W-Sn-Au and Cu skam deposits (fig 62; tables 3, 4) occurs in the central Yukon Territory, and is associated with late Early Cretaceous mafic to intermediate, alkalie plutons of the Tombstone Plutonic Suite which occurs in the Tombstone and Syenite Ranges of the northwestern Yukon Territory (Woodsworth and others, 1991; Mortensen and others, 1994). The belt contains major Ag polymetallic vein deposits at Keno Hill (Galena Hill). Craig (Tara, Nadaleen Mountain), and Rusty Mountain (Vera, Val, Cavey), a Sb-Au vein at Brewery Creek (Loki Gold), and a W skam deposit at Ray Gulch (Potato Hills. Mar; table 4) (Nokleberg and others 1997a, b, 1998). An exploration model for intrusion-related Au systems has been developed from the Tombstone Plutonic Suite by Lang and others (2000). 
The Keno Hill-Galena Hill district of Ag polymetallic vein deposits (fig. 77) consists of argentiferous galena, freibergite, and pyrargyrite with minor polybasite, stephanite, argentite and native silver which oceur in fault veins, breccias and sheeted zones (Watson, 1986; Lynch, 1989; Murphy and Roots, 1992; Yukon Minfile, 1992). The deposit is hosted predominantly within the Keno Hill Quartzite of the Early Mississippian Upper Earn Group which forms part of a Devonian and Mississippian clastic wedge in the North American Craton Margin. Two stages of veining occur: an earlier stage of quartz-pyrite-arsenopyritesulphosalts and trace Au which formed prior to movement on fault veins; and a post-fault set of siderite-galena-sphalerite-pyritefriebergite-pyrargyrite. A K-Ar isotopic age of $90 \mathrm{Ma}$ age, which is interpreted as age of deposit, may be related to granitoid intrusions of similar age to the north and south of Keno Hill. Between 1921 and 1988, estimated production was 6769 t of $\mathrm{Ag}$, half of which came from the Elsa, Keno No. 9, Lucky Queen, Silver King, Sadie-Ladue, and Husky Mines. Total production was 4.87 million tonnes of ore of average grade $1412 \mathrm{~g} / \mathrm{Ag}, 6.8 \% \mathrm{~Pb}, 4.6 \% \mathrm{Zn}$ and $0.02 \mathrm{~g} / \mathrm{Au}$ (Yukon Minfile, 1992). More than 65 ore deposits and prospects occur in the district. The Keno Hill-Galena Hill district is the second largest silver producer in Canada. Similar Ag polymetallic vein districts oceur to the west and northwest of Keno Hill at Nadaloen Mountain, Rusty Mountain, Kathleen Lakes, and McKay Hill.

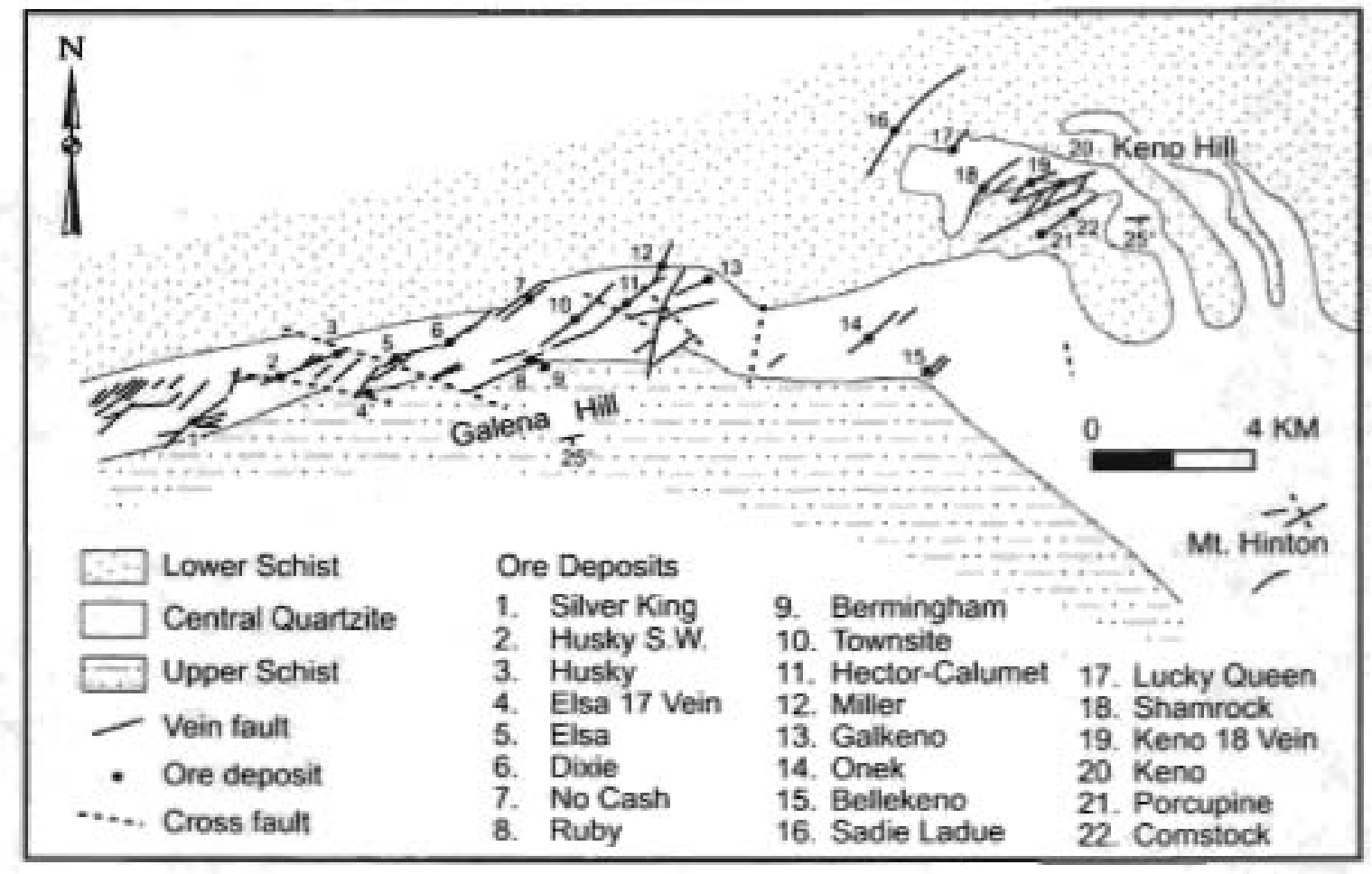

Figure 77. Keno Hill (Galena Hill) Ag polymetallic vein deposit, Tombstone metallogenic belt, Canadian Cordillera. Schematic regional geologic map showing locations of major deposits. Adapted from Watson (1986).

\section{Brewery Creek Sb-Au Vein Deposit}

The Sb-Au vein deposits at Brewery Creek (Loki Gold) are hosted by sheared clastic rocks of the Earn Group and adjacent porphyry sills (Bremner, 1990). Eight separate deposits occur over a strike length of $5.5 \mathrm{~km}$ along a shear zone between a sill of quartz monzonite, syenite and latite of the Tombstone suite, and graphitic argillite, chert, sandstone, conglomerate and bedded barite. The deposits consist of gold which occurs in fine-grained chalcedony-pyrite-arsenopyrite stockworks. About $90 \%$ of the deposit is oxidized at depths of $10-110 \mathrm{~m}$. Narrow quartz-stibnite veins post-date the Au veins. An open pit, heap-leach mine started at the deposit in 1995 with estimaled pre-production reserves of 19.2 million tonnes grading $1.53 \mathrm{~g} / \mathrm{Au}$ (Bremner, 1990; Loki Gold Corp.. News Release, January 11, 1994). Otber Au-Sb (W-Pb-Ag) veins in the region are at Antimony Mountain, West Ridge, and Spotied Fawn.

\section{Eagle (Dublin Gulch) Porphyry Au-W Deposit}

The Eagle (Dublin Guleh) porphyry Au-W deposit consists of granitoid-related Au vein stockworks which are similar to the Fort Knox deposits near Fairbanks, Alaska (Mortensen and others, 1994; Hitchins and Orssich, 1995). The Late Cretaceous Dublin Gulch biotite granodiorite stock, with a $\mathrm{K}$-Ar isotopic age of $95-87 \mathrm{Ma}$, contains: (1) sheeted Au-As-Cu-Bi-W quartz veins 
along the western end in the Eagle Zone; (2) scheelite-quartz veins in the east-central part; and (3) Au-sulfide quartz veins along the norithem contact and to the west. The ussociated Ray Gulch (Mar) W skam deposit occurs on the south side of the Dublin Gulch stock, and cassiterite breccia deposits occur $2 \mathrm{~km}$ north of the stock. The Au quartz veins in the Eagle Zone range from 1 to $2 \mathrm{~cm}$ wide, and are associated with potassic and phyllic envelopes which coalesce to form pervasive alteration which contain the closely-spaced quartz veins. Vein mineral assemblages, in addition to free gold grains up to $1 \mathrm{~mm}$ in diameter, are arsenopyrite, pyrnotite, chalcopyrite, pyrite, bismuthinite, tetradymite, tellurobismuthinite, native bismuth, and nare molybdenite and scheelite. Estimated resources are 64.5 million tonnes grading 1.03 g/ Au (Hitchins and Orssich, 1995).

\section{Ray Gulch W Skarn Deposit}

The Ray Gulch W skarn deposit consists of scheelite which occurs as disseminations and tabular layers in sulfide-free diopside-amphibole-epidote skarn. The deposit is hosted in calcareous metasedimentary rocks and tuff of the Late Proterozoic Hyland Group which is intruded by quartz monzonite sills which dip gently northward towards the Potato Hills stock, part of the mid-Cretaceous Tombstone Plutonic Suite. Eight separate skam zones comprise a resource of 5.44 million tonnes of material grading 0.82\% WO, (Lennan, 1986). Other W skams are at Scheelite Dome, Lugdush, und Rhosgobel. Sn skarns occur in the Keno Hill-McQuesten River region, and include Oliver Creek, Boulder Creek, East Ridge, and Barney Ridge. Also occurring in the area are several vein and breccia Sn-W deposits which are hosted by Late Proterozoic to Mississippian metasedimentary rocks and associated felsic granitoid stocks of the Tombstone Plutonic Suite (Emond and Lynch, 1992). Small Cu-Au skams deposits occur at Marn, Brenner, and lda.

\section{Origin of and Tectonic Controls for Tombstone Metallogenic belt}

The Tombstone metallogenic belt is hosted in the mid-Cretaceous Tombstone Plutonic Suite which intrudes the Proterozoic Hyland and Cambrian through Devonian Rocky Mountain Assemblage, and the Devonian and Mississippian clastic wedge rocks of Earn Group of the North American Craton Margin (fig. 62). The Tombstone Plutonic Suite, which has isotopic ages of 95-89 Ma, consists mainly of alkaline plutons which include syenite, hornblende-biotite granodiorite, quartz monzonite, and quartzfeldspar porphyry. The plutonic suite includes some felsic, peraluminous, two-mica granite and quartz monzonite plutons which were previously included in the slightly older Selwyn Plutonic Suite which has isotopic ages of 97 to $112 \mathrm{Ma}$. The granitoid rocks of the Tombstone Plutoaic Suite, which are part of the Ominecu-Selwyn plutonic suite, are similar in age, geochemistry, and petrology to mid-Cretaceous plutons whicb intrude the Yukon-Tanana terrane to the west in Alaska across the Denali fault, and the suites of lode deposits associated with each suite of granitoid rocks are similar. The Tombstone metallogenic belt contains Ag polymetallic vein, granitoid-related Au, Sb-Au vein, W-Sn-Au skam, and Cu-Au skam deposits. The older (mid-Cretaceous) part of the East-Central Alaska metallogenic belt contains granitoid-related $\mathrm{Au}$, Sb-Au vein, $\mathrm{Pb}-\mathrm{Ag}-\mathrm{Zn}$-Au polymetallic vein, and W-Au skam deposits. In recent years, the name Tintina Gold Bell (Tucker and Smith, 2000) has been used for granitoid-related Au deposits and occurrences which occur throughout the Yukon Territory and in the East-Central Alaska metallogenic belt (described below) of Nokleberg and others (1995a, 1996, 1997a), and in the correlative Tombstone metallogenic belt of Nokleberg and others (1995a, 1996, 1997a) which occurs to the east in the central Yukon Territory. Because the term Tintina Gold Belt includes deposits of several ages and differening origins, the term is not used in this study. Bundtzen and others (2000) introduced the term Timtina Gold Province to denote Mesozoic and Tertiary plutonic-related gold deposits which are related to which occur throughout the Yukon Territory and Interior Alaska.

As described above for the correlative East-Central Alaska metallogenic belt (mid-Cretaceous), the polymetallic, Sb-Au vein, and granitoid-related Au deposits of the Tombstone metallogenic belt are generally bosted in, or near mid-Cretaceous granitoid plutons (Nokleberg and others, 1995a; McCoy and others, 1997; Smith, 1999; Smith and others, 1999, 2000; Goldfarb and others, 2000). In both East-Central Alaska and the Central Yukon Territory, these plutons are interpreted as intruding during the waning stages of a major mid-Cretaceous collision of the Wrangellia superterrane with the previously-accreted Yukon-Tanana termane (Stanley and others, 1990; Dusel Bacon and others, 1993; Pavlis and others, 1993; Nokleberg and others, 2000). The collision and associated metamorphism and deformation is interpreted as forming in two phases: (1) a relatively older period of collision and thrusting, associated with higb-temperature and high-pressure metamorphism; and (2) a slightly younger period of extension associated with lower greenschist facies metamorphism. The mid-Cretaceous graniloid rocks and relatively younger quartz veins intrude and crosscut both the relatively older, higher-grade, and relatively younger, lower grade metamorphic fabrics in the region (Dusel Bacon and others, 1993; Pavlis and others, 1993). These relations suggest that the the Tombstone metallogenic belt formed in the waning stages of this complex deformation event (Nokleberg, 1997e, 2000). Other metallogenic belss of granitic-magmatism-related deposits hosted in the Omineca-Selwyn plutonic belt in the Canadian Cordillera, Alaska, and the Russian Northeast include the Bayonne, Cassiar, Selwyn, and Whitehorse beits (fig 62; table 3). 
Cassiar Metallogenic Belt of Porphyry Mo-W;

W Skarn, Zn-Pb-Ag Manto, Sn Skarn, and

Au Skarn Deposits (Beit CA) Northern British

Columbia and Southern Yukon Territory

The Cassiar metallogenic belt of porphyry Mo-W: W skarn, Zn-Pb-Ag manto, Sn skarn, and Au skarn deposits (fig, 62; tables 3,4) oceurs in northem British Columbia and southern Yukon Territory. The belt contains a variety of mineral deposit types which are related to granitoid plutons of the mid-Cretaceous Cassiar Plutonic Suite which forms a narrow, linear belt of dominantly biotite granite and granodiorite plutons which is part of the Omineca-Selwyn plutonic belt (fig. 62). The significant deposits in the belt are a Porphyry W-Mo deposit at Logtung (Logjam Creek), a Pb-Zn-Ag skarn and manto deposit at Midway (Silver Tip), a W skarn deposit at Risby (Cab), a Zn-Ag polymetallic vein deposit at Logan, and a Sn skarn deposit at JC or Viola (table 4) (Nokleberg and others 1997a, b, 1998). The Logan polymetallic $\mathrm{Zn}-\mathrm{Ag}$ vein deposit is hosted by the Marker Lake Batholith (Dawson, 1996a).

\section{Logtung Porphyry Mo-W Deposit}

The large Logtung (Logjam Creek) porphyry Mo-W deposit consists of disseminated scheelite, molybdenite and powellite with minor associated fluorite and beryl in garnet-diopside skarn, quartz vein stockwork and fractures (EMR Canada, 1989; Dawson and others, 1991; Yukon Minfile, 1991; Noble and others, 1995). The deposit contains estimated reserves of 230 million tonnes grading $0.104 \% \mathrm{WO}_{3}, 0.05 \% \mathrm{MoS}_{2}$. The deposit is bosted in a large quartz porphyry dike which is related to a nearby mid-Cretaceous quartz monzonite stock with a K-Ar isotopic age of $109 \mathrm{Ma}$ which is part of the Cassiar Plutonic Suite. The Logtung deposit is typical of a group of deposits (as at Stormy and Molly) which contain a molybdenite-rich stockwork in a granitoid pluton and a seheelite-rich garnet-diopside skam assemblage in the wall rocks (Dawson, 1996c). At the Logtung deposit, early quartz-scheelite veins are related to a monzogranite stock, a later stage of quartz-scheelite-molybdenite-pyrite-fluorite veins is related to a felsic dyke complex, and a final stage of polymetallic W-Mo veins which form a large zone is centered on the dyke complex (Noble and others, 1984). Both mid-Cretaceous intrusives are part of the Cassiar Plutonic Suite. The wall rocks are Mississippian and Pennsylvanian chert, argillite, and quartzite of the Cassiar continental margin terrane.

\section{Risby Skarn W Deposit}

The significant, but undeveloped Risby (Cab) skarn W deposit consists of two diopside-gamet skams which occur in Early Cambrian carbonates which are intruded by granitoid sills of the Cassiar Plutonic Suite (EMR Canada, 1989; Yukon Minfile, 1990; Mining Review, 1992). The No. I zone has a high pyrrhotite and low chalcopyrite content, whereas the No. 2 zone, which is intruded by a sill, has higher WO, mineralization and low sulfide content (Sinclair, 1986). The deposit has a drilled resource of 3.2 million tonnes grading $0.82 \% \mathrm{WO}_{3}$. The mineral assemblage is typical of W skarn deposits associated with plutons of the Omineca-Selwyn plutonic belt

\section{Midway (Silvertip) Manto Pb-Zn-Ag Deposit}

The Midway (Silvertip) manto $\mathrm{Pb}-\mathrm{Zn}-\mathrm{Ag}$ deposit consists of generally coarse-grained assemblage of sphalerite-galenapyrite which contains elevated $\mathrm{Ag}_{\mathrm{g}}$, and minor $\mathrm{Au}, \mathrm{Sb}$ and $\mathrm{Bi}$ values which occur as irregular, pipe-like, open-space filling and replacement bodies in limestone of the Middle Devonian McDame Group of the Cassiar continental margin termane (Bradford and Godwin, 1988; EMR Canada, 1989). The nearest intrusive rock, interpreted as the source of mineralizing fluids, is a group of quartz-feldspar porphyry dikes which are about $2 \mathrm{~km}$ from the deposit. The dikes intrude clastic sedimentary rocks of the Earn Group which unconformably overlie the McDame Group. The wall rocks exhibit sericite alteration. The dikes exhibit a K-Ar isotopic age of $66 \mathrm{Ma}$. Estimated reserves are 2.6 million tonnes grading $8.8 \% \mathrm{Zn}, 6.4 \% \mathrm{~Pb}$, and $3258 \mathrm{~g} t \mathrm{Ag}$ according to drilling and underground exploration (Bradford and Godwin, 1988; Mining Review, summer 2000; Penuvian Gold/Imperial Metals release, February 10, 2000). The deposit does not contain a calc-silicate gangue typical of skarn Zn deposits, and exhibits only minor amounts of a silica and carbonate gangue adjacent to replacement bodies, similar to the alteration in the large $\mathrm{Ag}-\mathrm{Zn}-\mathrm{Pb}$ manto deposits of northern Mexico. At both the Midway and the nearby YP manto deposits, a crude zonation in metal distribution exists wherein $\mathrm{Au}$ is concentrated commonly in massive sulfide zones which are rich in $\mathrm{Fe}, \mathrm{Cu}$, and $\mathrm{Zn}$, nther than in more distal $\mathrm{Pb}$ - and $\mathrm{Ag}$-rich zones (Dawson, 1996a). An origin similar to which of $\mathrm{Sa}$ Dena Hes $\mathrm{Zn}-\mathrm{Pb}$ - $\mathrm{Ag}$ manto deposit near Watson Lake, Yukon is proposed, where mantos are developed distally to an intrusion inferred to underlie the deposit at depth (Dawson, 1996a).

\section{Ketra River Manto Au Deposit}

The Ketza River mante Au deposit consists of Au-quartz-sulfide veins and massive pyrthotite-arsenopyrite-pyritechaloopyrite-Au mantos which occur in a central part; and (2) mantos and veins of similar mineralogy which contain lower amounts of sulfide minerals which occur in a outer part; and (3) $\mathrm{Ag}$ - $\mathrm{Pb}$ veins and mantos which occur in the periphery (Cathro, 1990). The deposit is hosted by Early Cambrian sedimentary rocks of Cassiar continental margin terrane. The district is interpreter as underlain by a mid-Cretaceous pluton of the Cassiar Plutonic Suite which is interpreted as emplaced along the Ketza-Seagull Arch, a major structural feature (Abbott, 1986a). Homfels underlies the deposit and exhibits a K-Ar whole-tock isotopic age of 
$101 \mathrm{Ma}$ (K.M. Dawson, unpublsshed data, 1986). The mine at the deposit operated between 1988 and 1990 with initial oxide ore reserves of 282,000 tonnes averaging 13.45 g/ Au (Canamax Resources Inc., 1988 Annual Report).

\section{JC Skarn Sn Deposit}

The JC Sn skam deposit consists of malayite, stannite, stanniferous tetrahedrite and cassiterite in hedenbergite-diopside skam which occur along the contact betwoen Devonian and Mississippian carbonate rocks and porphyritic granite of the midCretaceous Seagull Batholith (Layne and Spooner, 1986; EMR Canada, 1989; Yukon Minfile, 1991). The Seagull Batholith consists of a two-mica A-type granite which is also associated with the F-, Cl-, and B-rich, Sn skarn deposits at Val A and Viola, and with $\mathrm{Zn} \cdot \mathrm{Pb}-\mathrm{Ag}$ skam deposits at Atom, Bom, and Bar (Dawson and Dick, 1978). At the JC deposit, hedenbergite-diopsideandradite prograde skam contains elevated $\mathrm{Sn}$ in a distinctive green gamet skarn, and is replaced by a retrograde assemblage of cassiternte, stannite, tetrahedrite, sphalerite, and malayite. Axinite and fluorite fill interstices in a pipe-like breccia. Estimated resources are 1.25 million tonnes grading 0.54\% Sn (Layne and Spooner, 1986).

\section{Origin of and Tectonic Controls for Cassiar Metallogenic Belt}

The Cassiar metallogenic belt is hosted in the Cassiar Plutonic Suite which is lithologically similar to the Bayonne Plutonic Suite, but the generally elongate plutons of the Cassiar Suite exhibit post-emplacement deformation (Woodsworth and others, 1991). The plutons and most of the associated deposits are hosted by the Cassiar terrane which is interpreted as a displaced fragment of North American Craton Margin (Monger and others, 1972, 1992; Monger and Nokleberg, 1996; Nokleberg and others, 2000) and is composed of Proterozoic to Carboniferous sedimentary rocks. The Cassiar Plutonic Suite is part of the collisional mid-Cretaceous Omineca-Selwyn plutonic belt which extends from the southem part of the Canadian Cordillera, across Interior Alaska, and northwestward into the Russian Northeast, and consists chiefly of granodiorite, granite, quartz syenite and minor syenite piutons of Early to mid-Cretaceous age (110-90 Ma; Monger and Nokleberg, 1996; Nokleberg and others, 1994c; 2000). The spatial location of the belt, about $200 \mathrm{~km}$ west of the eastern limit of Cordilleran deformation, and chemistry suggests an anatectic origin of partial melting of cratonic crust during thickening caused by Cretaceous contraction (Monger and Noklebere. 1996; Nokleberg and others, 2000) which was associated with orthogonal convergence between the Farallon Oceanic Plate and North America (Englebretson and others, 1985; 1992), and subsequent regional extension (Pavlis and others, 1993). Other metallogenic belts of granitic-magmatism-related deposits hosted in the Omineca-Selwyn plutonic belt in the Canadian Cordillera, Alaska, and the Russian Northeast include the Bayonne, Selwyn, Tombstone, and Whitehorse belts (fig. 62; table 3).

Whitehorse Metallogenic Belt of

Cu-Fe Skam, Porphyry Cu-Au-Ag, and

Au-Ag Polymetallic Vein Deposits (Belt WH)

Southern Yukon Territory

The Whitehorse metallogenic belt of $\mathrm{Cu}$-Fe skarn, porphyry $\mathrm{Cu}-\mathrm{Au}-\mathrm{Ag}$, and $\mathrm{Au}-\mathrm{Ag}$ polymetallie vein deposits (fig, 62; tables 3,4) occurs in the southern Yukon Territory, and is hosted in the Whiteborse Plutonic Suite. These plutonic rocks intrude a large area of the northem Stikinia and Cache Creek terranes, and Yukon-Tanana ternane in the northern Canadian Cordillera (fig. 62). The Whitehorse Plutonic Suite, which is part of the Omineca-Selwyn plutonic belt, consists predominantly of midCretaceous, granodiorite plutons (Woodsworth and others, 1991). The significant deposits in the belt are Cu skam deposits near Whitehorse (Little Chief. War Eagle), and Hopkins or Giltana (table 4) (Nokleberg and others 1997a, b, 1998).

\section{Whitehorse Copper Belt of Cu Skarn Deposits}

The Whitehorse Copper Belt (fig. 78) comprises thirty-two $\mathrm{Cu}$-Fe (Mo-Au-Ag) cale-silicate skarn deposits hosted by both calcarcous and dolomitic units of the upper Triassic Lewes River Group of Stikinia terrane (Dawson and Kirkham, 1996). The skarms contain bornite, magnetite, and chalcopyrite, and minor native copper, tetrahedrite, and molybdenite. The skarns oecur in a $30-\mathrm{km}$-long belt along irregular contacts of the Whitehorse Batholith which consists of a composite calc-alkaline granodiorite pluton with a dionile margin (Meinert, 1986; Dawson and others, 1991; Yukon Minfile, 1991). The calcic or magnesian skarn mineralogy is a largely a function of the skam protolith (Morrison, 1981). The bulk of sulfide minerals and highest average Au and $\mathrm{Ag}$ grades occur in structurally controlled retrograde sham alteration assemblages (Meinert, 1986). From 1898 to 1982 estimated production was 142,000 tonnes $\mathrm{Cu}, 7,090 \mathrm{~kg}$ Au and $90,000 \mathrm{~kg} \mathrm{Ag}$ from 5.2 million tones ore. Combined production and reserves are 13.2 million tonnes grading an average of $1.4 \% \mathrm{Cu}, 0.7 \mathrm{~g} / \mathrm{Au}$, and $8.9 \mathrm{~g} / \mathrm{Ag}$ (Dawson and others, $199 \mathrm{I}$; Watson, (1984).

Two small skarns are the $\mathrm{Cu}(\mathrm{Mo}-\mathrm{Ag}-\mathrm{Au})$ Hopkins and the $\mathrm{Zn}$ (Cu-Ag) Sekulmun skarns (Dawson and others, 1991) which occur in carbonate rocks of the Cambrian through Devonian Nasina Assemblage of the Yukon-Tanana terrane where intruded by the Nisling Range granodiorite pluton (Dawson and others, 1991). Significant Au-Ag polymetallic vein deposits which occur at Mount Nansen and Mount Freegold (Dawson and others, 1991) are hosted in intermediate to felsic voleanic rocks of the Mount Nansen Group which are interpreted as coeval and probably comagmatic the Whitehorse Suite (Woodsworth and 
others, 1991). Small, polymetallic Au-Ag veins are hosted by granitioid plutons in the Moosehom Range on the border between Alaska and the Yukon Territory.

\section{Origin of and Tectonic Controls for Whitehorse Metallogenic Belt}

The Whitehorse metallogenic belt is bosted by the Whitehorse Plutonic Suite which bas an isotopic age range 103 to 112 Ma. The suite includes the Coffee Creek Plutonic Suite south of Dawson (Mortensen and others, 1994). The Whitehorse Plutonic Suite is part of the collisional mid-Cretaceous Omineca-Selwyn plutonic belt which extends from the southern part of the Canadian Cordillera, across Interior Alaska, and northwestward into the Russian Northeast (figs. 61, 62). The belt consists chiefly of granodiorite, granite, quartz syenite and minor syenite plutons of Early to mid-Cretaceous age (1 10-90 Ma; Monger and Nokleberg. 1996; Nokleberg and others, 1994c; 2000). The spatial location of the belt, about $200 \mathrm{~km}$ west of the eastem timit of Cordilleran deformation, and chemistry suggests an anatectic origin of partial melting of cratonic crust during thickening caused by Cretaceous contraction (Monger and Nokleberg, 1996; Nokleberg and others, 2000) which was associated with orthogonal convergence between the Farallon Oceanic Plate and North America (Englebretson and others, 1985; 1992), and subsequent regional extension (Pavlis and others, 1993). Other metallogenic belts of granitic-magmatism-related deposits hosted in the Omineca-Selwyn plutonic belt in the Canadian Cordillera, Alaska, and the Russian Northeast include the Bayorine, Cassar, Selwyn, and Tombstone belts (fig. 62).

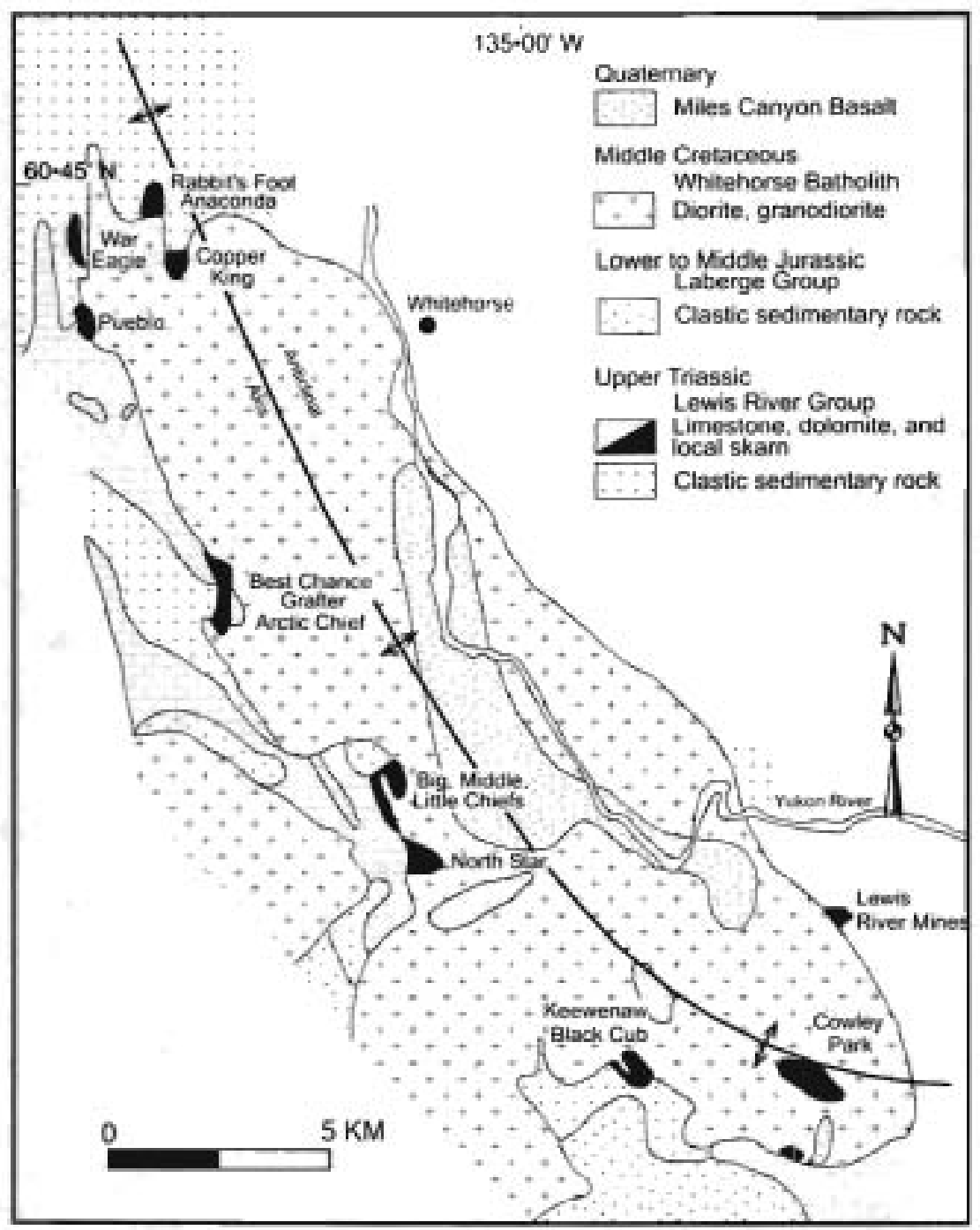

Figure 78. Whitehorse Copper Belt of Cu skarn deposits, Whitehorse metallogenic belt, Canadian Cordillera, Schematic map showing location of major Cu-Fe skarn deposits. Adapted from Dawson and Kirkham (1996). 
The Bayone metallogenic belt of porphyry Mo and Cu-Mo-W-Zn skam deposits (fig. 62; tables 3.4) oceurs in southem British Columbia and is hosted in the mid-Cretaceous Bayonne Plutonic Suite which is the extreme, southem part of the OminecaSelwyn plutonic belt. The intrusions typically are S-type, felsic, enriched in large-ion lithophile elements, and have initial Sr ratios in the range 0.710 to 0.740 (Armstrong, 1988). Most of the suite forms roughly equant, plutons and large stocks of mainly granodiorite or granite; the stocks are strongly discordant with the wall rocks of the Quesnellia and Kootenay terranes and the North American Craton Margin. The significant deposits in the belt are porphyry Mo deposits at Boss Mountain and Trout Lake, a W skam deposit at Emerald-Invincible, a $\mathrm{Zn}$-Pb skam and manto deposit at Mineral King, a Mo skam deposit at Red Mountain Moly (Coxey, Novelty, Nevada), and a Cu-Au skam deposit at Phoenix-Greenwood (table 4) (Nokleberg and others 1997a, b, 1998).

\section{Boss Mountain Porphyry Mo Deposit}

The Boss Mountain porphyry Mo deposit consists of molybdenite in quartz veins, fracture zones and in collapse breccias which are hosted by a granodiorite phase of the composite Early Jurassic Takomkane batholith which is intruded by the midCretaceous Boss Mountain stock (Soregaroli and Nelson, 1976; MacDonald and others, 1995). The emplacement of the stock was accompanied by rhyolite dikes, brecciation and multiple stages of veining and Mo deposition. Molybdenite was mined from a sheeted vein system which describes a partial annulus centered upon the apical region of the stock. Alteration assemblages consists of garnet, homblende, biotite, sericite, potassium feldspar, chlorite and talc. Pyrite forms a $1.5 \mathrm{~km}$-wide halo. Between 1965 and 1971 , about 2.97 million tonnes were milled with an average grade of $0.26 \%$ Mo. Between 1974 and $1980,3.6$ million tonnes were milled with an average grade of $0.188 \%$ Mo. Estimated remaining reserves are 3,84 million tonnes grading $0.135 \%$ Mo (Soregaroli and Nelson, 1976; MacDonald and others, 1995).

\section{Trout Lake Porphyry Mo Deposit}

The Trout Lake porphyry Mo deposit consists of molybdenite and pyrite in quartz veins, and also scheelite, pyrnotite, chalcopyrite, with lesser amounts of galena, sphalerite and tetrahedrite in peripheral skams (Boyle and Leitch, 1983; Linnen and others, 1995). The deposit is hosted mainly in limestone, schist, and quartzite of the Paleozoic Lardeau Group. A minor part of the deposit is hosted in altered granodiorite and tonalite of the Late Cretaceous Trout Lake stock which forms part of the Bayonne Plutonic Suite. Skarn calc-silicate alteration includes prograde clinopyroxene-gamet, and retrograde tremolite-clinozoisite with scheelite. Potassic (biotite) alteration overprints retrograde skarn and forms envelopes around quartz-albite Mo veins in skam and homfels, whereas $\mathrm{K}$-feldspar replaces plagioclase in the intrusion. The highest Mo grades are associated with the later quartz-Kfeldspar-muscovite alteration. Estimated resources are 49 million tonnes I grading 0.19\% Mo (Boyle and Leitch, 1983; Linnen and others, 1995).

\section{Red Mountain Mo Skarn Deposit}

The Red Mountain Mo skarn deposit (Coxey, Novelty, Giant) consists of molybdenite, pyrrhotite, chalcopyrite, arsenopyrite, scheelite, pyrite, magnetite, bismuthinite, galena and sphalerite which occur in veins, disseminations and shears within skarn and contact-metamorphosed siltstone and breccia of the Pennsylvanian to Permian Mount Roberis Formation (Ray and Webster, 1991; Ray and Dawson, 1998). The small porphyritic intrusions of granite and granodiorite are interpreted to be associated with, and a late phase of the Early to Middle Jurnssic subvolcanic, monzonite Rossland intrusion which is associated with large Au-bearing pyrrhotite-chalcopyrite vein deposits of the adjacent Rossland district (Hoy and others, 1998). An alternative interpretation is that the intrusions associated with the deposit are part of the mid-Cretaceous Bayonne Plutonic Suite. At Coxey, molybdenite and minor scheelite are associated with a prograde assemblage of pyroxene-garnet-vesuvianite and a retrograde assemblage of epidote-actinolite-chlorite. The Novelty and Giant Mo skarns contain abundant arsenopyrite, and minor pyrrhotite, pyrite, chalcopyrite, cobaltite, bismuthinite, native Bi, and Au. The Novelty deposit also contains some uraninite. Estimated production and reserves are 1.31 million tonnes grading 0.20\% Mo (Ray and Websier, 1991; Ray and Duwson, 1998).

\section{Emerald-Invincible W-Mo Skam Deposit}

The Emerald-Invincible W-Mo skam deposit consists of seheelite, wolframite, molybdenite, pyrnhotite, pyrite and chalcopynite which generally occur as disseminations, but locally occur as massive lenses with pyrite and pyrnhotite with associated gold (Ray and Webster, 1991: Dawson and others, 1991). The deposit is hosted in the Early Cambrian Laib Formation along the contact of the Reeves Member Limestone with the Emerald Member argillite, as well as along the contact of the limestone with the Cretaceous Emerald and Dodger Stocks. The skam consists of gamet, diopside, tourmaline, powellite, calcite, biotite, and K-feldspar. Sericite alteration is predominant; but kaolinite, tremolite and silica alteration also occur. The Emerald deposit has produced approximately 7,416 tonnes of Mo-W concentrate. The Pb- $\mathrm{Zn}$ deposits at the nearby Jersey and Emerald 
mines are interpreted as distal skarns relative to the W skam, however others have interpreted the Pb-Zn deposits as syngenetic (Dawson, 1996a).

\section{Phoenì-Greenwood Cu Deposit}

The Phoenix-Greenwood Cu-Au skarn deposit consists of chalcopyrite, pyrite, pyrrbotite, magnetite plus minor sphalerite and galena which occur in a garnet-rich calc-silicate skarn assemblage of andradite, elinozoisite, diopside and quartz (Church, 1986: Schroeter and Lane, 1991: MINFILE, 2002). The skarn hosted by Trussic carbonate, clastic, and volcanic rocks of the previously-accreted Quesnellia terrane in proximity to contacts with Middle Jurassic and mid-Cretaceous granitoid intrusive rocks. Production from 1893 to 1985 was 270,000 tonnes $\mathrm{Cu}, 36$ tornes $\mathrm{Au}$, and 117 tonnes $\mathrm{A}$. The deposit age is interpreted as Middle Jurassic to Early Cretaceous.

\section{Mineral King Zn-Pb-Ag Skam and Manto Deposit}

The Mineral King deposit consists of sphalerite, galena and pyrite with boumonite and rare meneghinite which occur in steeply-dipping pipes or as manto-style replacements along steeply dipping shear zones associated with a synclinal wedge between two faults. The deposit is hosted in the Middle Proterozoic Mount Nelson Formation composed of dolomite and dolomitic quartzite. The mine at the deposit produced an estimated 2.1 million tonnes grading $4,12 \% \mathrm{Zn}, 1.70 \% \mathrm{~Pb}$, and $24.8 \mathrm{~g} / \mathrm{Ag}$ (Fyles, 1960). Estimated current reserves are 72,576 tonnes grading $34.3 \mathrm{~g} / \mathrm{Ag} .2 .5 \% \mathrm{~Pb}$, and $4.5 \% \mathrm{Zn}$. No intrusive rock is exposed, but the deposit is interpreted as a $\mathrm{Zn}-\mathrm{Pb}$ skarn and manto distally related to a buried intrusion (Dawson and others, 1991) of the Bayonne Plutonic Suite.

\section{Origin of and Tectonic Controls for Bayonne Metallogenic Beft}

The Bayonne metallogenic belt is hosted in the extreme, southern part of the Omineca-Selwyn plutonic belt (fig. 62). The lithophile geochemistry of the plutonic suite is reflected in the abundance of porphyry Mo and related skarn deposits. The Omineca-Selwyn plutonic belt extends from the southern part of the Canadian Cordillera, across interior Alaska, and northwestward into the Russian Northeast, and consists chiefly of granodiorite, granite, quartz syeaite and minor syeaite plutons of Early to midCretaceous age (110-90 Ma; Monger and Nokleberg, 1996; Nokleberg and others, 1994e; 2000). The plutons in the belt form an extensive linear array of discrete intrasions, and many plutons exhibit S-type character. Extrusive equivalents (such as the South Fork Volcanics in the Yukon Territory) are rare. The plutons commonly huve high initial strontium ratios (about 0.710 ), indicating purtial derivation from old cratonic crust (Armstrong, 1988: Wondsworth and others, 1991). The spatial location of the beh, about $200 \mathrm{~km}$ west of the eastern limit of Cordilleran deformation, and chemistry stuggests an anatectic origin of partial melting of cratonic crust during thickening caused by Cretaceous contraction (Monger and Nokleberg. 1996; Nokleberg and others, 2000) which was associated with orthogonal convergence between the Farallon Oceanic Plate and North America (Englebretson and others, 1985; 1992), and subsequent regional extension (Pavlis and others, 1993). Other metallogenic belts of granitic-magmatism-related deposits hosted in the Omineca-Selwyn plutonic belt in the Canadian Cordillera, Alaska, and the Russian Northeast include the Cassiar, Selwyn, Tombstone, and Whitehorse belts (fig, 62; table 3).

\section{Early Late Cretaceous Metallogenic Belts (100 to $84 \mathrm{Ma}$; Figures 79, 80)}

\section{Overview}

The major early Late Cretaceous metallogenic belts in the Russian Far East, Alaska, and the Canadian Cordillera are summarized in table 3 and portrayed on figures 79 and 80. The major belts are as follows. (I) In the Russian Southeast, the Kema (KM), Lowet Amur (LA), Luzhkinsky (LZ), Sergeevka (SG), and Taukha (TK) belts, which contain a large array of graniticmagmatism-related deposits, are bosted in or near the East Sikbote-Aline volcanic-plutonic belt and are interpreted as forming during subduction-felated granitic plutonism which formed the East Sikhote-Aline continental margin arc. (2) in the same region was the Aniva-Navil (ANN) metallogenic bell of volcanogenic Mn and Fe and Cyprus massive sulfide deposits that are interpreted as forming in guyots, and oceanic crustal and island are assemblages that were subsequently lectonically incorporated into the Aniva and Nabilsky lerranes accretionary wedge and subduction zone terranes. (3) Also in the same region, continuing on from the late Early Cretaceous was the Badzhal-Ezop-Khingan (BZ-KH) belt of granitic-magmatism-related deposits, which is hosted in the Khingan-Okhotsk volcanic-plutonic belt, and is interpreted as forming in the Khingan continental-margin arc. (4) In the Russian Northeast are the Chaun (CN), Dogdo-Erikit (DE), Korkodon-Nayakhan (KN), Koni-Yablon (KY), Okhotsk (OH), Omsukchan (OM), Verkhne-Kolyma (VK) zones which constitute various parts of the Eastern Asia belt. In the same region and also part of the are the Eastern Asia metallogenic belt are the Adycha-Taryn (AT), Chokurdak (CD), and Vostochno-Verkhoyansk 
(VV) belts. These zones and belts all contain a rich array of granitic-magmatism-related deposits which are interpreted as forming during

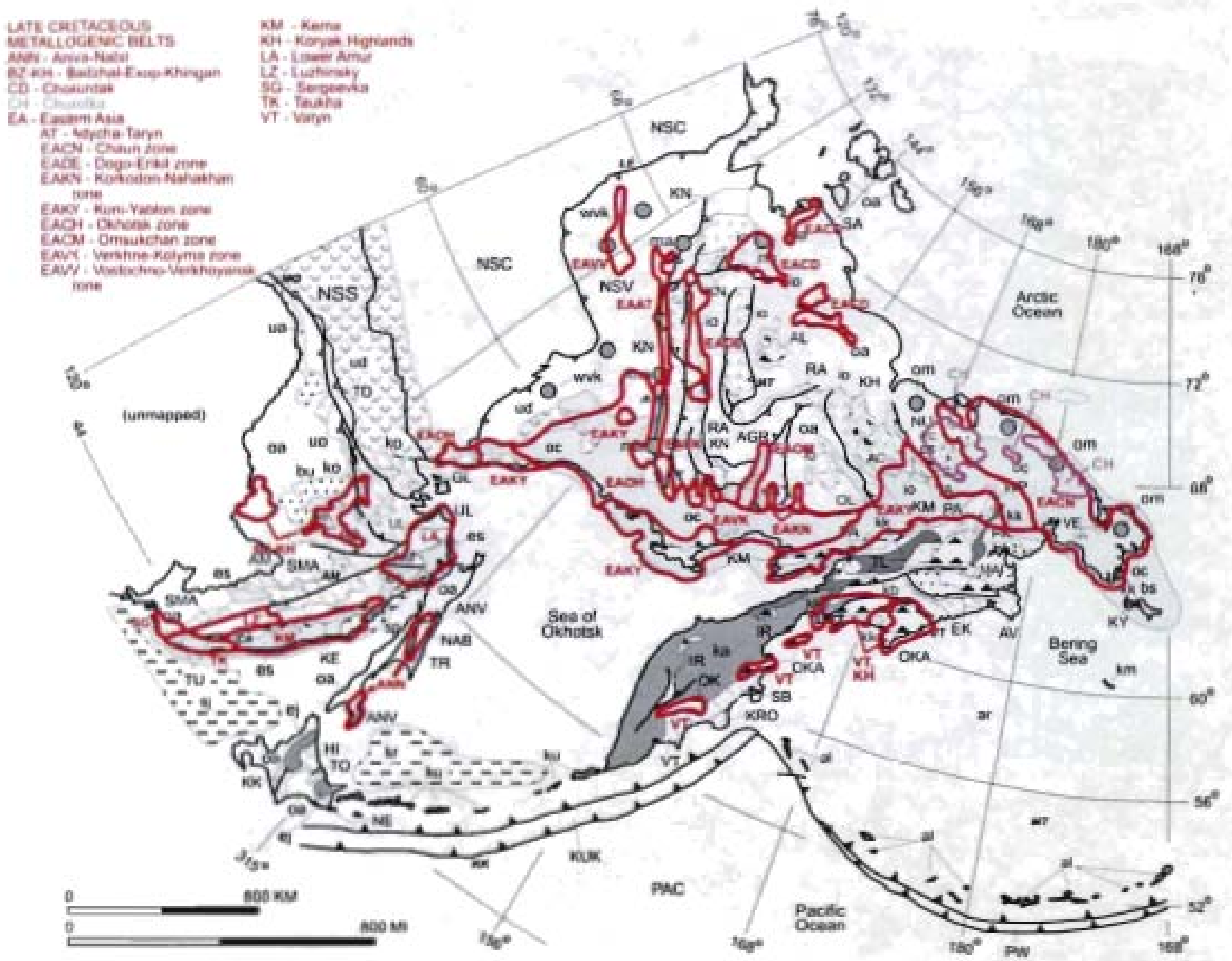

Figure 79. Generalized map of major Late Cretaceous metallogenic belts, overtap assemblages, and tectonically-linked subductionzone or accretionary-wedpe terranes for Russian Far East, northem Japan, and adjacent offshore areas. Refer to text for description of metallogenic belts. Adapted from Novleberg and others (1997b, 1998). Refer to figure 59 for explanation.

subduction-related granitic plutonism which formed the Okhotsk-Chukotka continental-margin are. The Eastern Asia metallogenie beli of granitic-magmatism-related deposits contains a complex array of zones (fige 79, table 3). Each zone contains a characteristic suile of mineral deposit types which are herein interpreted as reflecting the underlying terranes through which the granitic magmas ascended. (5) On northem Kamchatka Peninsula, in the Koryak Highlands in the Russian Far East are two metallogenic belts which are hosted in the Olyutorka-Kamchatka island-are terrane. The Koryak Highlands (KH) belt contains zoned mafic-ultramafic PGE and Cu massive sulfide deposits, and the Vatyn (VT) belt contains volcanogenic Mn and Fe deposits. Both belts are interpreted as forming in different parts of the Olyutorka island are. (6) In the Russian Northeast, the Chukotka (CH) belt, which contains mainly Au quartz vein deposits, is hosted in the Chukotka passive continental-margin terrane and is interpreted as forming during regional metamorphism and anatectic granitic plutonism associated with accretion of the Chukotka passive continental-margin terrane to the North Asian Craton Margin. (7) In East-Central and Southem Alaska, are three metallogenic belts which are interpreted as forming during regional metamorphism associated with accretion of Wrangellia superterrane to southern Alaska. These belis are the: (a) the Yukon-Tanana Upland (YT) belt, which contains Au quartz vein deposits and is hosted in the metamorphosed continental-margin Yukon-Tanana terrane; (b) the East-Central Alaska (older part) (ECA) belt, which contains granitie-magmatism-related deposits and is hosted in the Yukon-Tanana terrane; and (c) the Wrangell Mountains (WR) belt, which contains $\mathrm{Cu} \cdot \mathrm{Ag}$ quartz vein and Kennecott $\mathrm{Cu}$ deposits and is hosted the Wrangellia island-are 
superterrane. And (8) in the Canadian Cordillera, continuing on from the late Early Cretaceous were the Bayonne (BA), Cassiar (CA), Selwyn (SW), and Whitehorse (WH) belts, which contain granitic-magmatism-related deposits, and are hosted in or near anatectic granitic plutons of the Omineca-Selwyn plutonic belt which is interpreted as forming during final accretion of Wrangellia superterrane to North American continental margin. In the below descriptions of metallogenic belts, a few of the noteable or signficant lode deposits (table 4 ) are described for each belt.

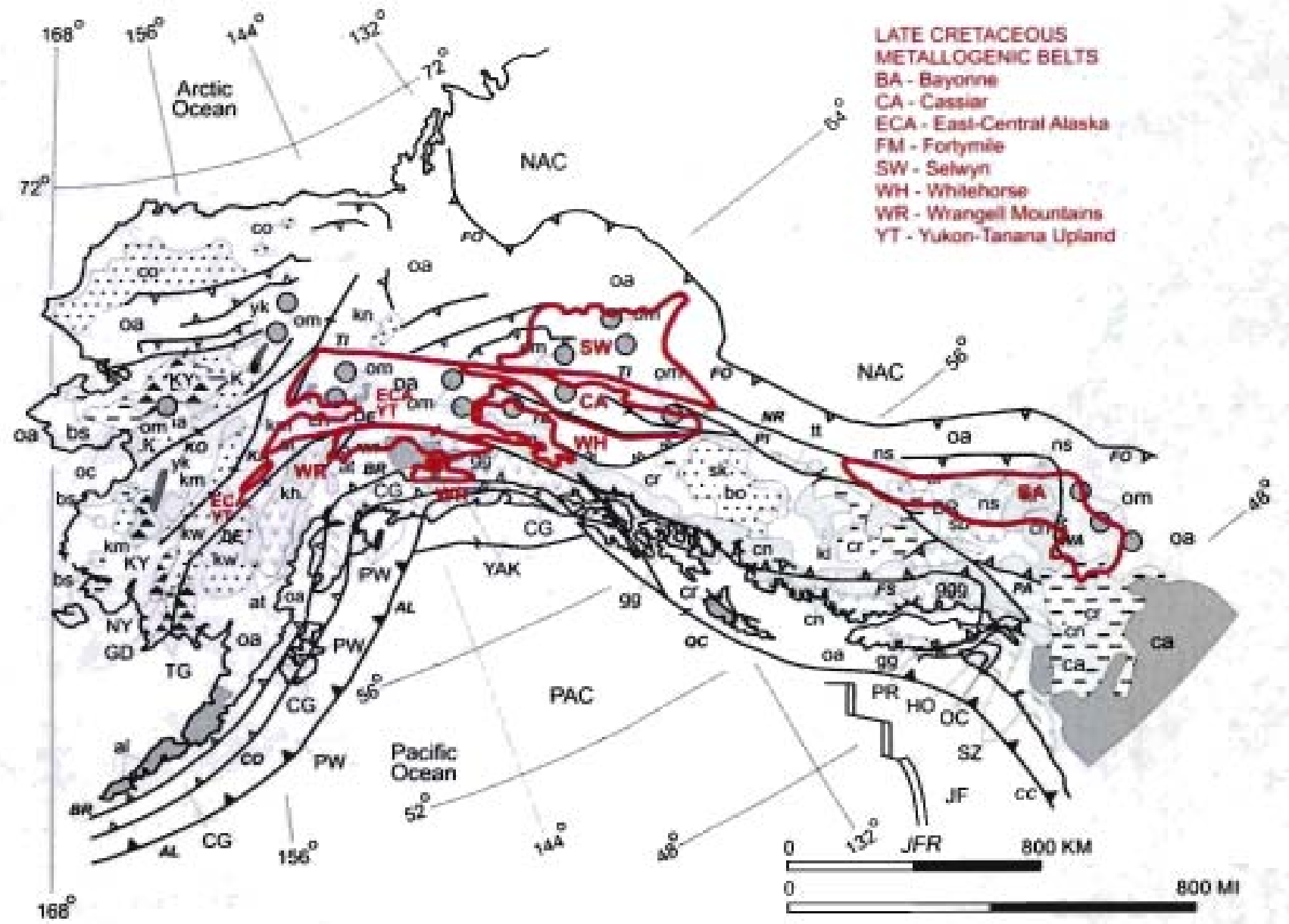

Figure 80. Generalized map of major Late Cretaceous metallogenic belts, overlap assemblages, and tectonically-linked subductionzone or accretionary-wedge terranes for Alaska, Canadian Cordillera, and adjacent offshore areas. Refer to text for description of metallogenic belts. Adapted from Nokleberg and others (1997b, 1998). Refer to figure 60 for explanation.

\section{Metallogenic-Tectonic Model for Early Late Cretaceous (100 to 84 Ma; Figure 81)}

During the early Late Cretaceous (Cenomanian though Santonian - 100 to $84 \mathrm{Ma}$ ), the major metallogenic-tectonic events were (fig. 81; table 3): (1) establishment of a series of continental-margin arcs and associated metallogenic belts, and companion subduction-zone assemblages almost continuously around the Circum-North Pacific; (2) continued opening of an ocean which would become the Amerasia, Canada, and Eurasia Basins; (3) completion of accretion of the Wrangellia superterrane and formation of associated metallogenic belts; and (4) in the eastern part of the Circum-North Pacific, a change to orthogonal compression between the Farallon Ocean plate and North America.

\section{Specific Events for Early Late Cretaceous}

(1) At about $32^{\circ}$ to $60^{\circ}$ paleolatitude, the Olyutorka island arc commenced activity. Parts of the arc are preserved in the Nemuro (NE), Kronotskiy (KRO), and Olyutorka-Kamchatka (OKA), Iruneisky (IR), Shmidt (SHT), and Terpeniya (TR) terranes. Forming in the Olyutorka arc were the Koryak Highlands metallogenic belt, which contains zoned mafic-ultramafic PGE and $\mathrm{Cu}$ massive sulfide deposits, and the Vatyn (VT) metallogenic belt, which contains volcanogenic $\mathrm{Mn}$ and Fe deposits. Also associated with the are was subduction of part of adjacent oceanic plate to form the Vetlovskiy (VT) terrane. This are and companion subduction zone migrated northward toward the Okhotsk-Chukotka continental-margin arc. 
(2) The East Sikhote-Alin (es) continental-margin are was initiated. This major Andean-type are overlapped previously accreted adjacent Ierranes in both the Russian Southeast and to the south. This arc extended for a distance of over 1,600 km along the active Russian Southeast continental margin. Forming as part of the are was the West Sakhalin (WSA) turbidite basin terrane. Forming in the East-Sikhote are were the Kema, Lower Amur, Luzhkinsky, Segeevka, and Taukha metallogenic belts. Also associated with the East-Sikhote are was oblique subduction of part of the Ancestral Pacifie Ocean plate (PAC) to form the Hidaka (HI). Aniva (ANV), and Nabilsky (NAB) ternanes. Incorporated into the Aniva and Nabilsky terranes were the volcanogenic Fe and

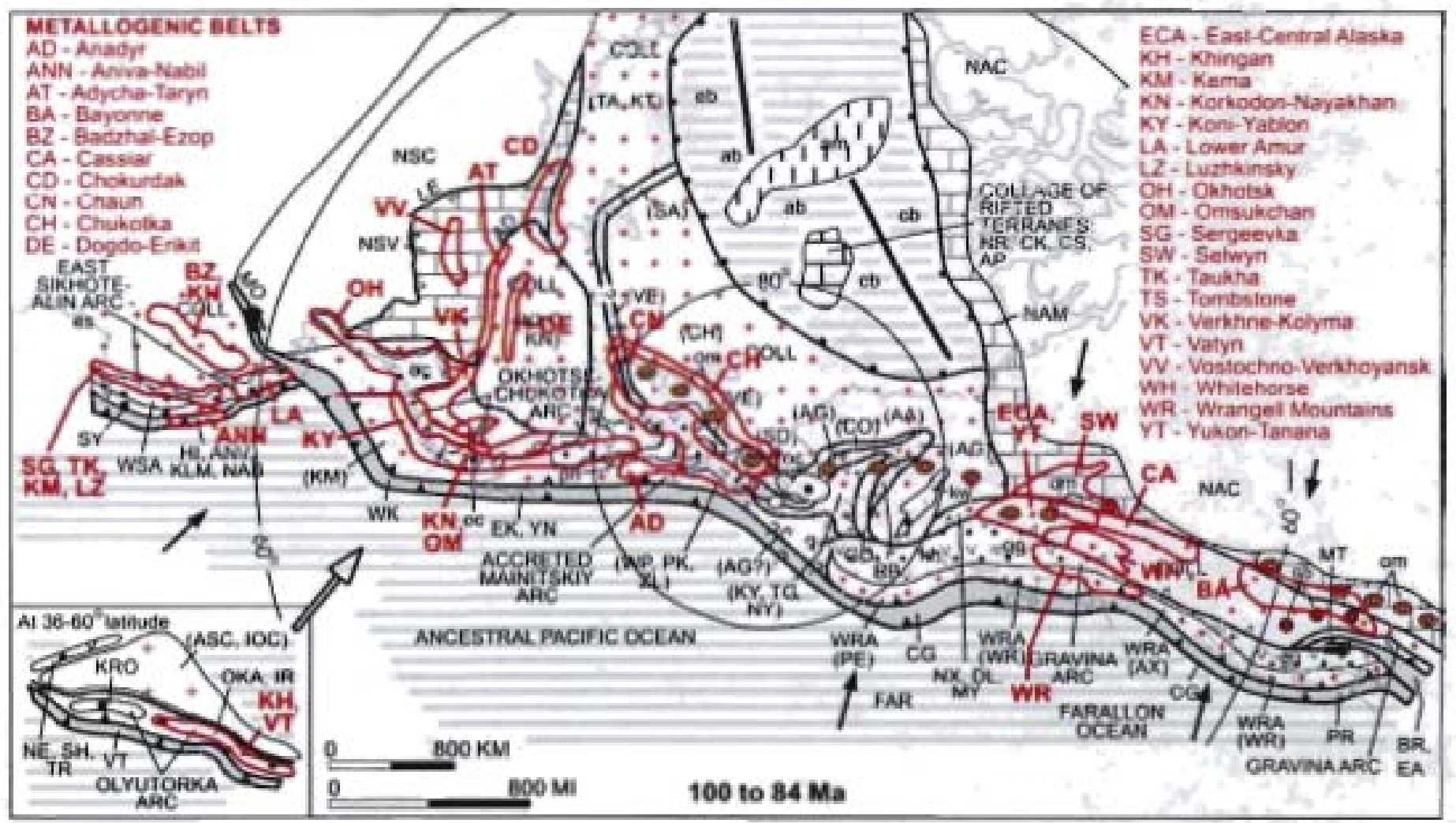

Figure 81. Earty Late Cretaceous (Cenomanian theough Santonian - 100 to B4 Ma) stage of metallogenic-tectonic model. Refer to text for explanation of metallogenic-tectonic events, to tables 3 and 4 for descriptions metalogenic belts and significant deposits, and to figure 18 for explanation of abbreviations, symbols, and pattems. Adapted from Nokleberg and others (19970, 1998, 2000).

Mn and Cyprus massive sulfide deposits of the Aniva-Nabil (ANN) metallogenic belt that formed in Late Cretaceous oceanic crust and island urc rocks.

(3) The Khingan continental margin are (ko) continued activity. Continuing in the are was the Badrhal-Ezop-Khingan (BZ-KH) belt of granitic-magmatism-related deposits.

(4) Subduction stepped seaward, after the accretion of the Mainitskiy are with the consequent inception of the OkhotskChukotka continental-margin arc (oc) and related Penzhina (forearc) sedimentary basin (pn) along the new continental margin. This major Andean-type are overlapped the previously accreted Kolyma-Omolon superterrane, part of the North Asian Craton Margin (NSV), and adjacent terranes in Russian Northeast and Western Alaska, and extended for about 3,500 km along an active continental margin. Associated with the are was oblique subduction of pant of the ancestral Pacific Ocean plate to form the West Kamchatka (WK), Ekonay (EK), and Yanranay (YN) terranes. Forming in the Okhotsk-Cbukotka are was the Eastern Asia metallogenic belt of granitic-magnatism-related deposits which contained a complex amay of zones. The zones were the Chaun $(\mathrm{CN})$, Dogdo-Erikit (DE), Korkodon-Nayakhan (KN), Koni-Yablon (KY), Okhotsk (OH), Omsukchan (OM), and VerkhneKolyma (VK) zones, Each zone contains a characteristic suite of mineral deposit types which are herein interpreted as reflecting the geochemical signature of the underlying lernanes through which the granitic magmas ascended. Also forming in the OkhotskChukotka volcanic-plutonic belt, and peripherally related to the Eastem Asia metallogenic belt, were the Adycha-Taryn (AT), Chokurdak (CD), and Vostochno-Verkhoyansk (VV) metallogenic belts.

(5) In the Arctic Ocean, sea-floor spreading and associated rifting continued (Lawver and Scotese, 1990; Grantz and others, 1990, 1991, 1998) with the formation of new oceanic cnust and the combined Alpha and Mendeleev Ridges (am) which are interpreted as large piles of hot-spot basalt and associated deposits (Giantz and others, 1990, 1991, 1998). The large Amerasia (ab), Canada (cb) and Eurasia (eb) Basins continued to form. During the opening of the basin, North American continental margin terranes, including the Arctic Alaska superterrane (AA) and the Chukotka terrane (CH), and outboard oceanic and island terranes 
migrated towards the North Asian Craton and previously accreted Kolyma-Omolon superterrane (KLO). The opening of the Amerasia (ab), Canada (cb) and Eurasia (eb) Basins is interpreted as causing oroclinal warping of Northern Alaska and the northern part of the Russian Far East.

(6) Also during the opening of the Amerasia (ab), Canada (cb), and Eurasia (eb) Basins, the South Anyui and Angayucham Oceans were closed, and the Chukotka (CH) and Arctic Alaska terranes (AA) were accreted to Northeast Asia. During accretion, the Chukotka metallogenic belt, which contains Au and Se quartz vein deposits, was formed. Also during accretion, the major Nutesyn and Koyukuk island ares and companion subduction zones were thrust onto the continental margin Chukotka terrane (CH) and Aretic Alaska superterrane (AA) in thrust aheets which are up to $150 \mathrm{~km}$ wide in Northern Alaska. The overthrust subduction zone termanes include the South Anyut (SA), Velmay (VE), Angayucham (AG), and Goodnews (GD) terranes. The overthrust island are ternunes include the Nutesyn (NU), Koyukuk (KY), and Togiak (TG) terranes. A final stage of blueschist-facies metamorphism of oceanic and continental-margin terranes occurred during thrusting. The lack evidence of a huge Himalayan-type mountain range in the Russian Northeast suggests either which: (1) strike-slip translation was more dominant than rifting in formation of the Canada Basin (Lane, 1994, 1997); and (or; 2) a major part of the rift migration of the Russian Northeast away from the Canada Basin was absorbed in the subduction zone associated with formation of the OkhotskChukotka are.

(7) During accretion, the southern margin of the eastem Chukotka terrane (CH), southern part of the Aretic Alaska superterrane (AA), and the outboard Seward (SD), Coldfoot (CO), Goodnews (GD), and Ruby (RB) terranes continued to be intensely deformed and metamorphosed. At the end of accretion, a period of extensional deformation occurred along the southern margin of the Arctic Alaska superternane (AA; Miller and Hudson, 1991).

(8) Back-arc continental-margin sedimentation in Kuskokwim basin ( $\mathrm{kw}$ ) occurred in a dextral wrench-fault setting (Bundtzen and Miller, 1997).

(9) The final stage of accretion of the Wrangellia superterrane (WRA) was completed at about $95 \mathrm{Ma}$. Forming during the final stage of accretion in Alaska were: (a) the Yukon-Tanana metallogenic belı (YT) which contains Au quartz vein deposits; (b) the East-Central Alaska metallogenic belt (older part, ECA) which contains granitic magmatism-related deposits; and (c) the Wrangell Mountains metallogenic belt (WR) which contains Cu-Ag quariz vein and Kennecott Cu deposits. Several major geologic events are interpreted as caused by the accretion of the Wrangellia superierrane. (a) The exiensive Gravina island are, which formed along the leading edge of the superterrane, and the Spences Bridge voleanic-plutonic belt (sb) ceased activity after accretion. (b) The Kahiltna (kh) and Gravina-Nutzotin-Gambier (ge) assemblages were thrust under the North American continental margin (Stanley and others, 1990; McClelland und others, 1991, 1992a, b; Nokleberg and others, 1994a) and were intensely deformed during a major period of orthogonal convergence which replaced the previous sinistral convergence. (c) The northeastern-most boundary of the accreted Wrangelliu superierrane became the locus of Late Cretaceous high-grade metamorphism, plutonism, contractional deformation, cnustal thickening, uplif, and erosion which characterizes the Coast Mountains of the Canadian Cordillera, Southeastem Alaska, and South-Central Alaska (McClelland and others 1991, 1992a, b; Pavlis and others, 1993; Plafker and Berg. 1994; Monger and Nokleberg, 1996). (d) A regional core complex formed in the previously-accreted Yukon-Tanana terrane (part of the collage in present-day Alaska) and developed a subborizontal fabric, imbricate thrusting of large subhorizontal nappes, and subsequent extension and removal of as much as $10 \mathrm{~km}$ of crust (Pavlis and others, 1993). (c) The southern part of Gravina arc and companion subduction zone was doubled during the latest stage of sinistral-slip faulting during accretion of the Wrangellia superterrane (McClelland and others 1991, 1992a, b; Monger and others, 1994; Monger and Nokleberg, 1996). The Methow turbidite-basin ternane (MT), an Early and mid-Cretaceous forearc part of the Gravina are, and the companion Bridge River (BR) and Easton (EA) subduction-zone terranes were structurally imbricated behind the southern part of the Gravina-Nutzotin-Garnbier (gg) assemblage (Monger and others, 1994). (f) The mainly onthogonal convergence and accretion of the Wrangellia superterrane initiated eastward thrusting of the North American Craton Margin (NAM) over the North American Craton (NAC). (g) Coeval with thrusting, and occurring along the axis of thrusting was intrusion of the Omineca-Selwya granitic belt (om) which occurs along the length of Canadian Cordillera, Alaska, and the northern part of the Russian Northeast. The belt was generated during an intense period of anatectic meiting, major regional thrusting, and erustal shortening and thickening, all related to orthogonal convergence. Continuing to form in or near the Omineca-Selwyn granite belt were the Bayone (BA), Cassiar (CA), Selwyn (SW), and Whitehorse (WH) metallogenic belts which contain graniticmagmatism-related deposits. Altematively, the Wrangellia superterrane accreted far to the south at about $35^{\circ}$ paleolatitude along the margin of Baja British Columbia (latitude of present-day Baja California). 
Metallogenic Belt Formed in Late Mesozoic Part of

East Sikhote-Aline Continental-Margin Arc,

Russian Southeast

Sergeevka Metallogenic Beit of

Granitoid-Related Au Deposits (Belt SG)

Southern Part of Russian Southeast

The Sergeevka metallogenic belt of granitoid-related Au deposits (fig. 79; tables 3,4) occurs in the southern part of the Russian Far East. The Au deposits occur in or near Late Cretaceous, post-accretionary granitoid plutons and dikes which intrude gneissic gabbro and Cambrian metamorphosed sedimentary rocks in the western part of the Sergeevka continental-margin are terrane of the Khanka superterrane (fig. 79). The principal deposits are at Askold, Balykovskoe, Krinichnoe, Porozhistoe, and Progress (table 4) (Nokleberg and others 1997a, b, 1998). The deposits are small and generally consist of Au-bearing quartz veins with minor sulfides, mainly pyrite and arsenopyrite. The deposits are generally small.

\section{Progress Granitold-Related Au Deposit}

The Progress granitoid-related Au deposit (A.N. Rodionov, written commun., 1991) consists of sulfide-poor veins and small veinlets which contain pyrite, arsenopyrite, quartz, and gold. In addition the deposit contains poorly mineralized fracture zones, mylonite zones, and zones of metasomatically-altered carbonate-chlorite-sericite rock. Mineralization occurs in a near a Late Cretaceous granitoid pluton and dikes which intrude Cambrian granitic and gabbro rocks of Sergeevka Complex. The average grade is $5.89 \mathrm{~g} / \mathrm{t}$ Au. The deposit is also the source for local placer Au mines.

\section{Askold Granitoid-Related Au Deposit}

The Askold granitoid-related Au deposit (fig. 82) (M.I. Efimova and others, written commun, 1971; Efimova and others, 1978) consists of a Au-quartz vein stockwork in a greisenized Mesozoic granite which intrudes Paleozoic volcanic and sedimentary rocks. A K-Ar muscovite age for alteration associated with the vein is $83.2 \mathrm{Ma}$ (lshihara and others, 1997). The deposit is prospected to depths of more than $100 \mathrm{~m}$. The deposit is of medium size with an average grade of $5.9-7.6 \mathrm{~g} / \mathrm{Au}$.

\section{Origin of and Tectonic Controls for Sergeevka Metallogenic Boit}

The Sergeevka metallogenic belt is hosted in or near Cretaceous granitoid plutons and dikes which intrude the complex continental-margin arc Sergeevka terrane which consists of: (1) migmatized, Cambrian gneissic gabbro and quartz diorite with a U-Pb zircon isotopic age of 500 to $527 \mathrm{Ma}$ (J.N. Aleinikoff, writien commun., 1992) which contain large xenoliths of amphibolite, quartzite, marble, and calc-schist; and (2) the Early Ordovician biotite-muscovite Taphuin Granite with a muscovite Ar-Ar age of $491 \mathrm{Ma}$. Along with other units of the Khanka superterrane, the Sergeevka terrane is overlapped by Devonian continental-rifrelated volcanic and sedimentary rocks, middle Paleozoic granitoid rocks, late Paleozoic granitoid rocks, and Permian back-arcrift-related volcanic rocks.

The Cretaceous granitoid rocks hosting the Sergeevka metallogenic belt are probably part of the East Sikhote-Aline voleanic-plutonic belt (fig. 79) of Late Cretaceous and early Tertiary age (Nokleberg and others, 1994c. These igneous belt consists chiefly of five major units (Nokleberg and others, 1994c): (1) Early Cenomanian rhyolite and dacite; (2) Cenomanian basalt and andesite; (3) thick Turonian to Santonian ignimbrite sequences; (4) Mastrichtian basalt and andesite; and (5) Maastrichtian to Danian (early Paleocene) rhyolite. The East Sikhote-Alin belt also contains coeval, mainly intermediatecomposition granitoid plutons. The East-Sikhote-Alin belt is equivalent to Okhotsk-Chukotka volcanic-plutonic belt on strike to the north in Russian Northeast, and is tectonically linked to the Amiva, Hidaka, and Nabilsky accretionary wedge and subductionzone terranes (Nokleberg and others, 2000). Other related, coeval metallogenic belts hosted in the East-Sikhote-Aline volcanic bell are the Ketna, Luzhkinsky, Lower Amur, and Taukha, belts (fig. 79; table 3).

Taukha Metallogenic Beit of B Skarn, Pb-Zn Skarn, Pb-Zn Polymetallic Vein, and Related Deposits (Beit TK) Eastern Part of Russian Southeast

The Taukha metallogenie belı of B skam, Pb-Zn skarn, Pb-Zn polymetallie vein, and related deposits (fig. 79; tables 3,4) occurs in the eastern part of the Russian Southeast (Vasilenko and Valuy, 1998). The deposits in the metallogenic belt are mainly $\mathrm{B}$ skam, and $\mathrm{Pb}-\mathrm{Zn}$ skarn, and $\mathrm{Pb}-\mathrm{Zn}$ polymetallie vein deposits which are hosted in or near mid-and Late Cretaceous and early Tertiary granitoid rocks of the East Sikhote-Alis volcanic-plutonic belt (Radkevich, 1991). This granitoid rocks of this belt intrude the intensely-deformed Taukha accretionary-wedge terrane (Nokleberg and others, 1994c, 1997c). The major B skarn deposit is at Dalnegorsk: Pb-Zn skams occur at Nikolaevskoe, Partizanskoe, polymetallic vein deposits occur at Fasolnoe, Krasnogorskoe (table 4), Lidovskoe. Novo-Monastyrskoe (fig. 83; table 4), and Shcherbakovskoe, and a Fe skam deposit oceurs at Belogorskoe 
(fig. 84; table 4) (Nokleberg and others 1997a, b, 1998; Valuy and Rostovsky, 1998). An isolated porphyry Cu deposit occurs at Plastun, and an isolated Au-Ag epithermal vein deposit occurs at Soyuz (Valuy and Rostovsky, 1998),

The B skarn deposits of the Taukha metallogenic belt are interpreted as forming early in the history of the East SikhoteAlin igneous belt, from about 90 to $70 \mathrm{Ma}$ when part of the Taukha terrane was overlapped by ignimbrite sequences. Pb- $\mathrm{Zn}$ skarn deposits occur in the central part of the Taukha metallogenic belt, mainly in the Dalnegorsk district has produced about forty percent of Russia's zinc and lead. The $\mathrm{Pb}-\mathrm{Zn}$ skam deposits afe interpreted as forming after the B skam deposits during a later stage of post-accretion volcanism, with K-Ar ages of 70-60 Ma, and composed mainly of rhyolite and dacite. The skam deposits generally occur in large limestone blocks enclosed in Early Cretaceous olistostromes. The skams occur along the contacts between limestone and clastic rocks and chert, and between limestone and overlying post-accretion volcanic rocks which overlie the Early Cretaceous olistostrome.

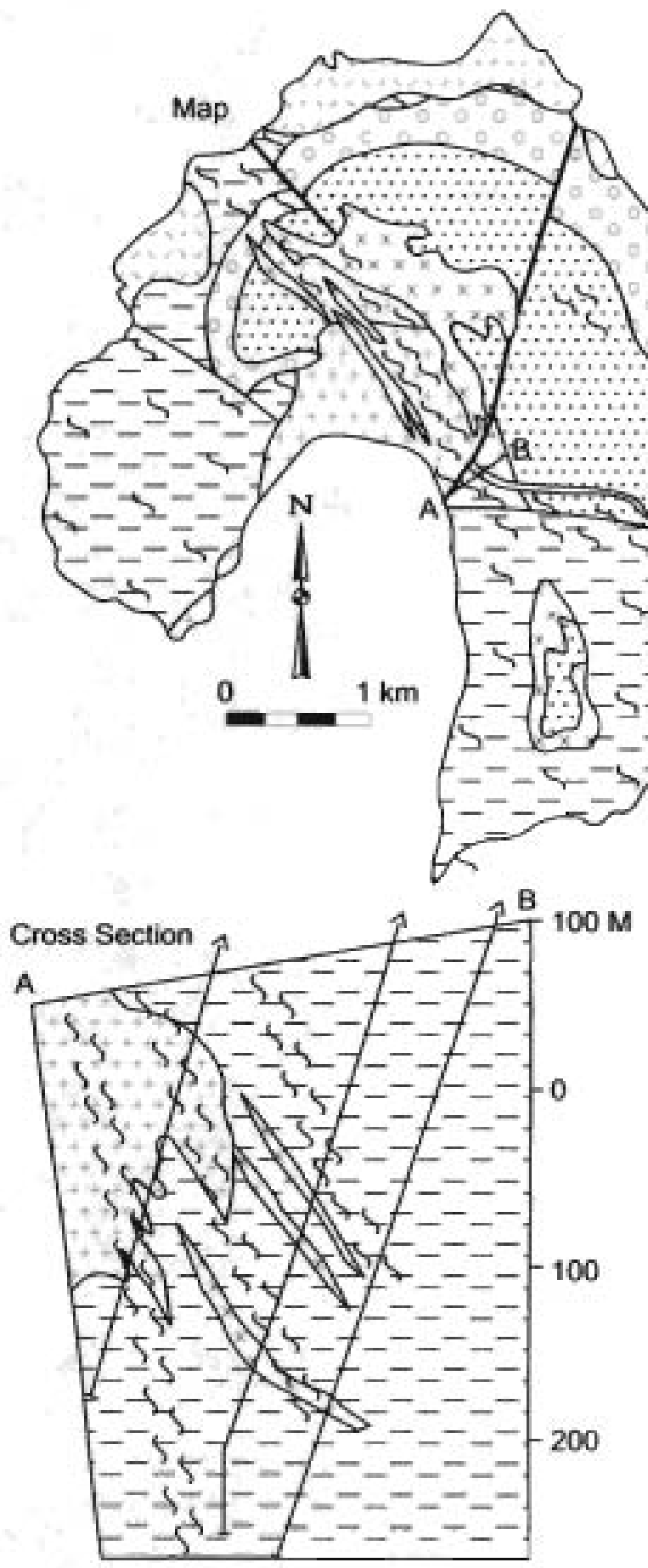

Figure 82. Askold Au granitoid-related Au deposit, Sergeevka metallogenic belt, Russian Southeast. Schematic geologic map and cross section. Adapted from Goryachev (1995a). 
The $\mathrm{Pb}-\mathrm{Zn}$ polymetallie vein deposits are coeval with the $\mathrm{Pb}-\mathrm{Zn}$ skam deposits, but oceur only in clastic and voleanic rocks. Unlike the skam deposits, the polymetallic vein deposits contain stannite and lesser cassiterite, in addition to mainly galena, sphalerite, and chalcopyrite. The lower levels of the polymetallie vein deposits contain about $3 \% \mathrm{Ag}$ in galena, with much less $\mathrm{Ag}$ in the upper levels. Some polymetallie vein deposits, as at Lidovskoe, oceur in the apices of granodiorite intrusions omagmatic with dacite. The polymetallic vein deposit at Krusnogonkoe are associated with volcanie breceias which are spatially related to a voleanic vent. The breccias also contain syngenetic disseminated galena, sphalerite, pyrite, and cassiterite. This relation suggests a gradation from $\mathrm{Pb}$-Zn polymetallic vein into porphyry Sn deposits (Ratkin and others, 1990). K-Ar isotopic studies indicate an age of about $60 \mathrm{Ma}$ for the voleanic rocks hosting the $\mathrm{Pb}-\mathrm{Zn}$ polymetallic vein deposits. Sparse disseminated and porphyry Cu deposits, as at Plastun, occur in Maastrichtian to Danian (early Paleocene) volcanic rocks. A small Au-Ag epithermal quartz vein deposit at Soyuz contains Ag-sulfosalts and is bosted in Late Creiaceous rhyolite and tuff.

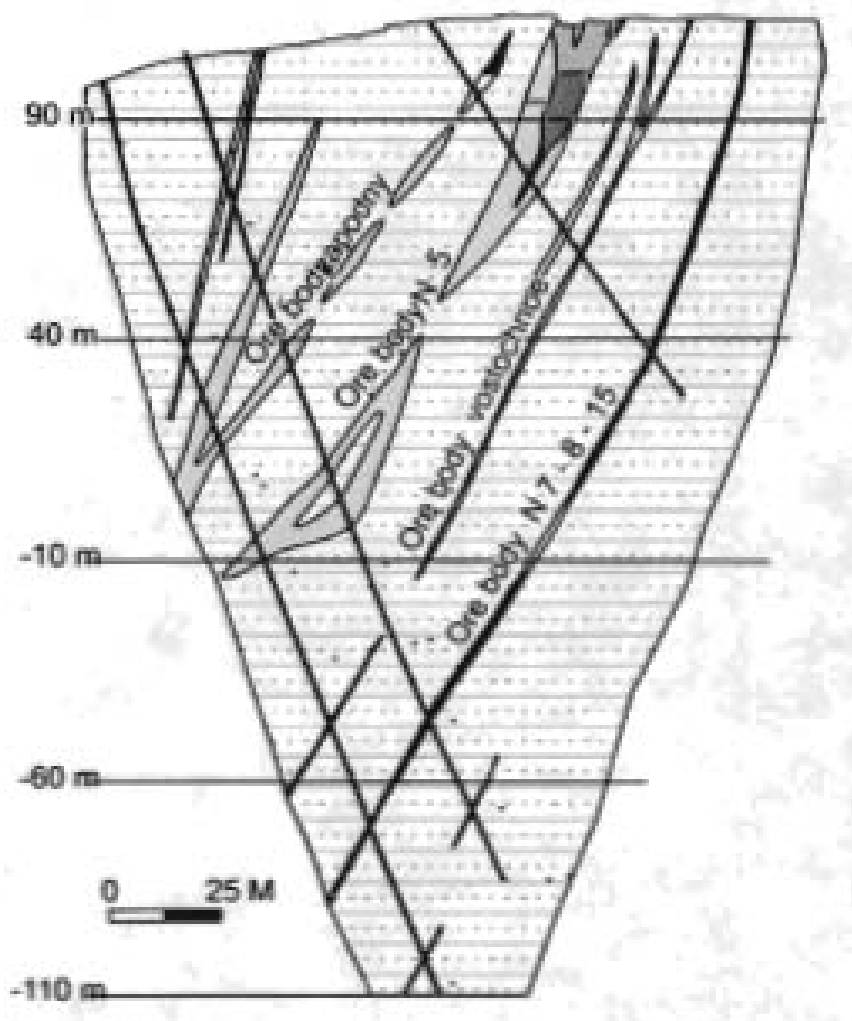

Oxidized sulphide ore

Massive primary ore

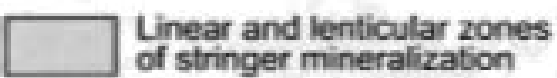

of stringer mineralization

W...... Dionite porphyry and diabase

……… dikes

Light gray silty shale

Figure 83. Novo-Monastyrakoe Pb-Zn polymetallic vein deposit, Taukha metallogenic belt. Russian Southesst. Schematic cross section. Adapted from Valuy and Rostovsky (1998).

\section{Dalnegorsk B Skarn Deposit}

The major, world-class B deposit at Dalnegorsk (fig 85) (Ratkin, 1991; Ratkin and Watson, 1993; Layer, Ivanov, and Bundtzen, 1994; Vasilenko and Valuy, 1998; Shkolnik and others, 2003) occurs in a thick skarn formed in a large, upturned olistolith of bedded Triassic limestone enelosed in Early Cretaceous clastic sedimentary rocks. The skarn extends to a depth of approximately I km, where it is cut off by a granitic intrusion. The skam formed in two stages, with a second-stage skarn overprinting an earlier skarn. The two stages of skam formation are separated in time by intrusion of intermediate-composition 
magmatic bodies (with approximate K-Ar ages of $70 \mathrm{Ma}$ ). The first stage consists of grossular-wollastonite skarn and concentrically zoned, finely banded aggregates with numerous finely crystalline datolite and druse-like aceumulations of danburite crystals in paleohydrothermal cavities. The second stage skam consists predominantly of long, radiated bedenbergite and andradite with coarsely-crystalline datolite, danburite, quartz, axinite, and calcite. The arcuate nature of metasomatic mineral zonation in the skam is interpreted by Shkolnik and others (2003) as replacement of stromatolite build-ups in the host Triassic Limestone. The complex layering are relict biogenic features of the stomatolite-bearing limestone. An Ar-Ar age for orthoclase indicates an age for the late-stage skarn assemblage of $57 \mathrm{Ma}$. The silucate mineralogy of the early-stage skarn is similar to which in $\mathrm{Pb}-\mathrm{Zn}$ skarn deposits in this same region. B isotopic studies indicate a magmatic source for boron (Ratkin and Watson, 1993). The deposit is

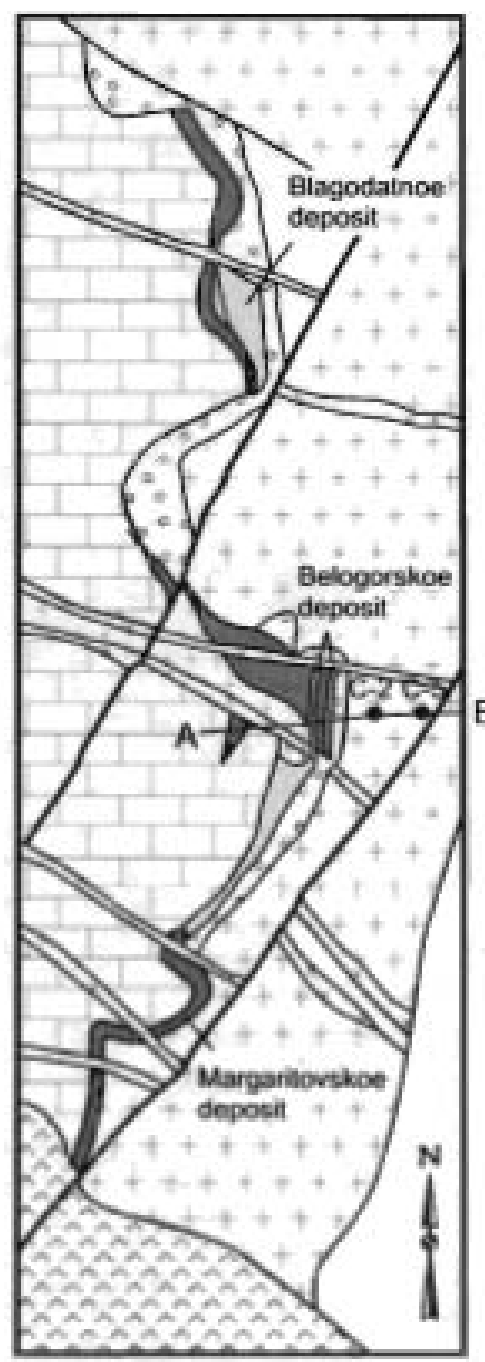

$\square$ Quatemary alluvial deposits

2ind Rhyolitic tuff

$\square$ Aplite dike

$\therefore \ldots$ Andesite and diabase dike

Rhyodacite

$\because \ldots$ Granite

$\square$ Limestone

B $\square$ Magnetite-garnet, garnet-magnetite skarn

$\square$ Garnet, garnet-pyroxene, garnet-pyroxenevesuvianite, and gamet-magnetite-cuspidine skarn

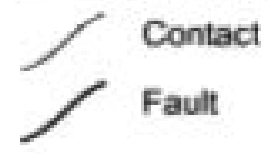

- C2. $^{\text {. Borehole }}$
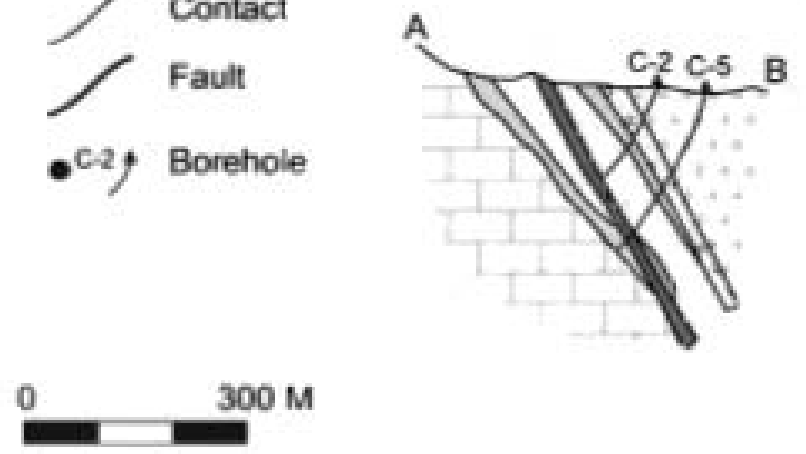

Figure B4. Beiogorskoe Fe skarn deposit, Taukha metallogenic bell. Russian Southeast. Adapted from Valuy and Rostovsky (1998).

very large and had been mined from 1970 s to present. The deposit produces over $90 \%$ of all borate in Russia. The Dalnegorsk open-pit mine at the deposit is prospected to the depth of $1 \mathrm{~km}$.

\section{Nikolsevskoe Pb-Zn Skam Deposit}

The Nikolaevskoe Pb-Zn skam deposit (fig. 86) (Garburov and others, 1987; V. V. Ratkin, this study; Vasilenko and Valuy, 1998) consists of large, layered ore bodies formed in a giant olistolith of Triassic limestone which is pant of an Early Cretaceous accietionary-fold complex. The skarn occurs at the contacts of limestone with bosting siltstone and sandstone, and with overlying felsic volcanic rocks of a Late Cretaceous to Paleogene post accretionary sequence. Small ore bodies also occur in limestone blocks in the volcanic rocks which were torn off the underlying basement. The ore minerals are dominantly galena and sphalerite which replace an earlier bedenbergite skam near the surface, and, at depth, replace a garnet-hedenbergite skam. Subordinate ore minerals are chalcopyrite, arsenopyrite, pyrite, pyrrhotite, fluorite, and $\mathrm{Ag}$-sulfosalts. $\mathrm{K}$-Ar isotopie studies indicate which an age of mineralization between 60 and $80 \mathrm{Ma}$. A $60 \mathrm{~K}$-Ar Ma isotopic age is obtained for an unmineralized basalt dike which cuts the deposit, and a K-Ar age of $70-80 \mathrm{Ma}$ is obtained for a mineralized ignimbrite which overlies the 
olistolith. The deposit is currently being mined. Average grades are $62 \mathrm{~g} / \mathrm{Ag} .1 .5-8.7 \% \mathrm{~Pb}$, and, 1.36-10.5\% $\mathrm{Zn}$. The deposit has been mined from 1970 's to present. The main shaft is about $500 \mathrm{~m}$ deep.

\section{Partizanskoe Pb-Zn Skarn Deposit}

The Partizanskoe Pb-Zn skam deposit (fig. 87) (Ratkin, Simanenko, and Logvenchev, 1991) consists of numerous small steeply-dipping ore bodies which occur at the contact of a Triassic limestone olistolith surrounded by Early Cretaceous clastic

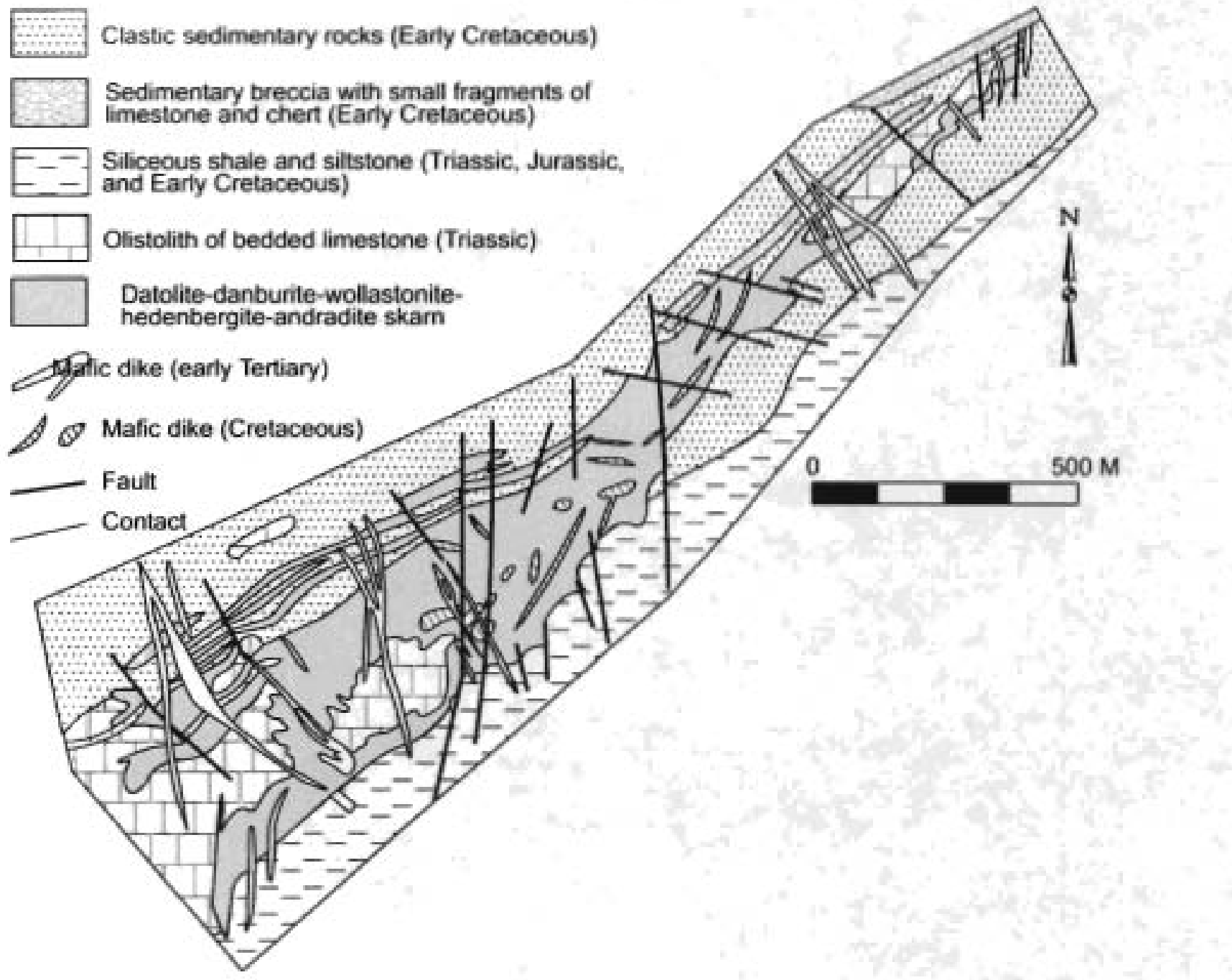

Figure 85. Dainegorsk B skam deposit, Taukha metallogenic belt, Russian Southeast. Schematic geologic map. Adapted from Nosenko and Chernyshov (1987).

rocks. The ore bodies merge and form a single skarn deposit about $400 \mathrm{~m}$ below the surface, and pinch out at a depth of approximately $600 \mathrm{~m}$. The ore and skam assemblages are vertically zoned; higher iemperature assemblages occur deeper. Massive, densely disseminated $\mathrm{Ag}-\mathrm{Pb}-\mathrm{Zn}$ ore $(\mathrm{Pb} / \mathrm{Zn}$ ratio of about 1.0$)$ occurs above a quartz-calcite ageregate in the upper part of the deposit. Massive, densely-disseminated $\mathrm{Pb}-\mathrm{Zn}$ ore ( $\mathrm{Pb} / \mathrm{Zn}$ ratio of about 0.8 ) is associated with Mn-hedenbergite skam and occurs at the middle part of the deposit. And disseminated $\mathrm{Zn}$ ore ( $\mathrm{Pb} / \mathrm{Zn}$ ratio of about 0.5$)$ occurs in ilvaite-garnet-bedenbergite skarn in the lower part of the deposit. Galena and sphalerite are the dominant ore minerals; chalcopyrite and arsenopyrite are common; minot magnetite, pymthotite, and marcasile also occur. Silver-bearing minerals are $\mathrm{Ag}$-and $\mathrm{Sb}$-sulfosalts is the upper part of the deposit and galena in the lower part. Galena contains Ag as a solid solution of matildite. The age of mineralization is bracketed between 60 and $70 \mathrm{Ma}$ by basalt dikes, with $\mathrm{K}-\mathrm{Ar}$ isotopic ages of $60-70 \mathrm{Ma}$, which cut the deposit at the contact of olistolith, and by the lower part of the overlying volcanic strata, with $\mathrm{K}$-Ar ages of $70-80 \mathrm{Ma}$, which are cut by ore body. The deposit consists of four or more related ore bodies which occur over about $5 \mathrm{~km}$ strike length, including the Soviet 2, Partizansk East, Partizansk West, and Svetlotvod ore bodies. The underground workings for the ore bodies follow contacts, and have a total length of about $11 \mathrm{~km}$. The deposit is of medium size. Average grades are $67.6 \mathrm{glt} \mathrm{Ag.} 1.5 .3 \% \mathrm{~Pb}$, and $0.6-4 \mathrm{Zn} \%$. The deposit has been mined from the 1950's to present. 


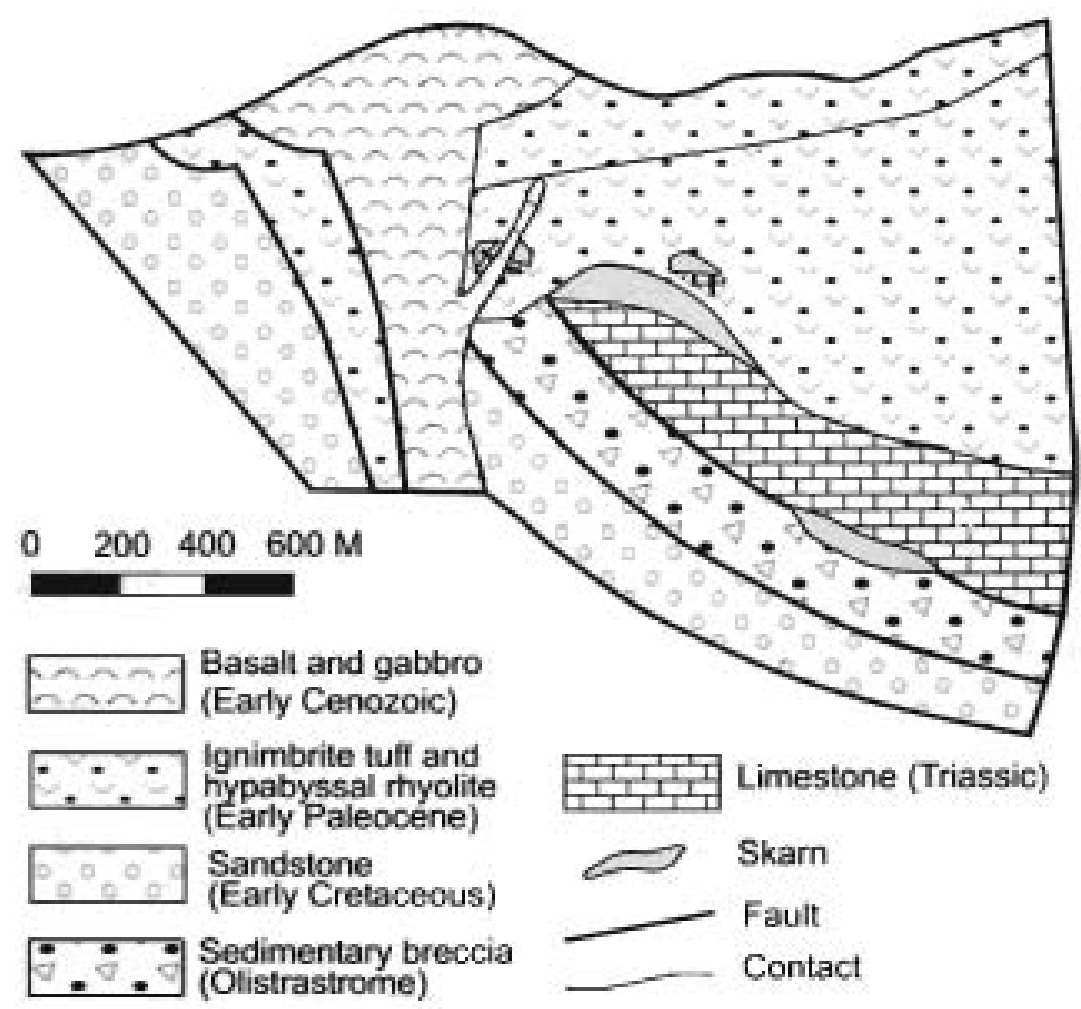

Figure 86. Nikolaevskoe Pb-Zn skam deposit, Taukha metallogenic belt, Russian Southeast. Schematic cross section adapted from Ratkin (1995).

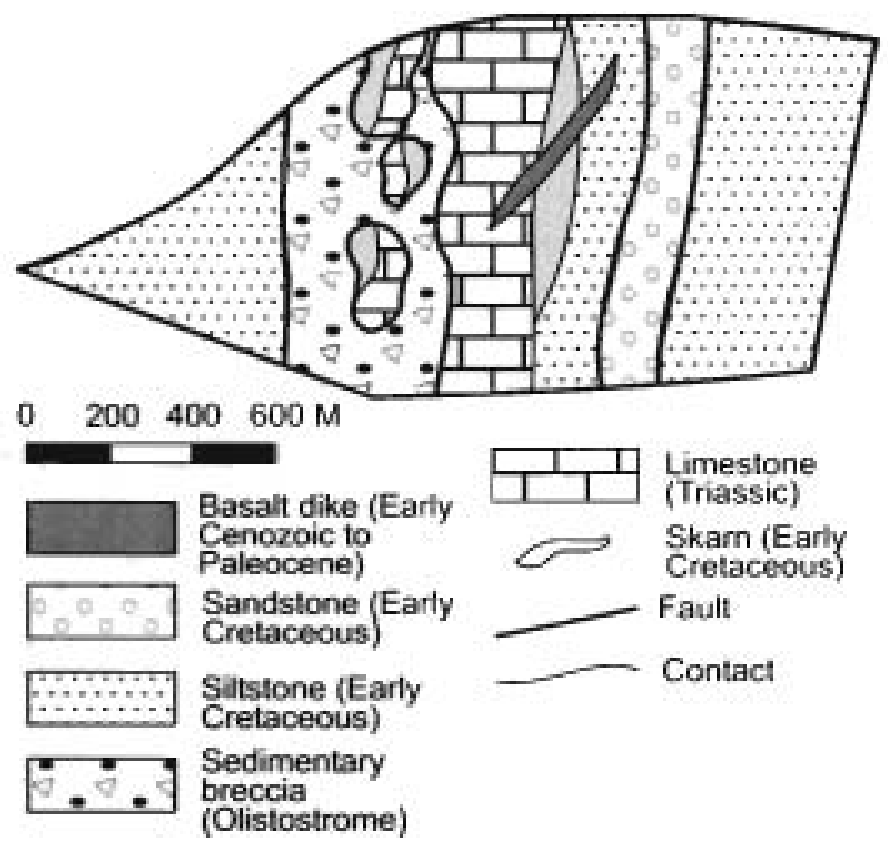

Figure 87. Partizanskoe Pb-Zn skarn deposit, Taukha metallogenic belt, Russian Southeast. Schematic cross section adapted from Ratkin (1995).

\section{Krasnogorskoe Pb-Zn Polymetallic Vein Deposit}

The Krasnogorskoe Pb-Zn polymetallic vein deposit (fig. 88) (Ratkin and otbers, 1990) consists of steeply-dipping quartz-sulfide veins, up to several hundred m length along sirike and from 0.2 to $1.5 \mathrm{~m}$ thick, wbich cut a sequence of Late Cretaceous (Cenomanian to Turonian) ash flow tuff. Sphalerite and galena are the dominant ore minerals; the flanks of veins contain pyrite-marcasite-pyrrhotite, with lesser Sb-Ag-sulfosalts. At the deeper levels of the ore bodies, galena contains up to several percent $\mathrm{Ag}$ and $\mathrm{Bi}$ in matildite. The volcanic rocks adjacent to the polymetallic veins are altered to guartz and chlorite. In 
the core of the veins, chlorite, Mn-calcite, thodochrosite, rhodonite, and spessartine occur with quartz gangue. The veins occur near an Late Cretaceous-Paleocene (Maastrichtian to Danian) volcanic vent. The vent breccia also contains disseminated sphalerite, gulena, and cassiterite. The veins formed immediately after mineralization of vent breceia, which were dated as approximately $65 \mathrm{Ma}$ by $\mathrm{K}$-Ar irotopic studies. The deposit is of medium size. Average grades are $62 \mathrm{~g} / \mathrm{Ag}, 5 \% \mathrm{~Pb}, 0.26 \% \mathrm{Sn}$, and $6.77 \% \mathrm{Zn}$.

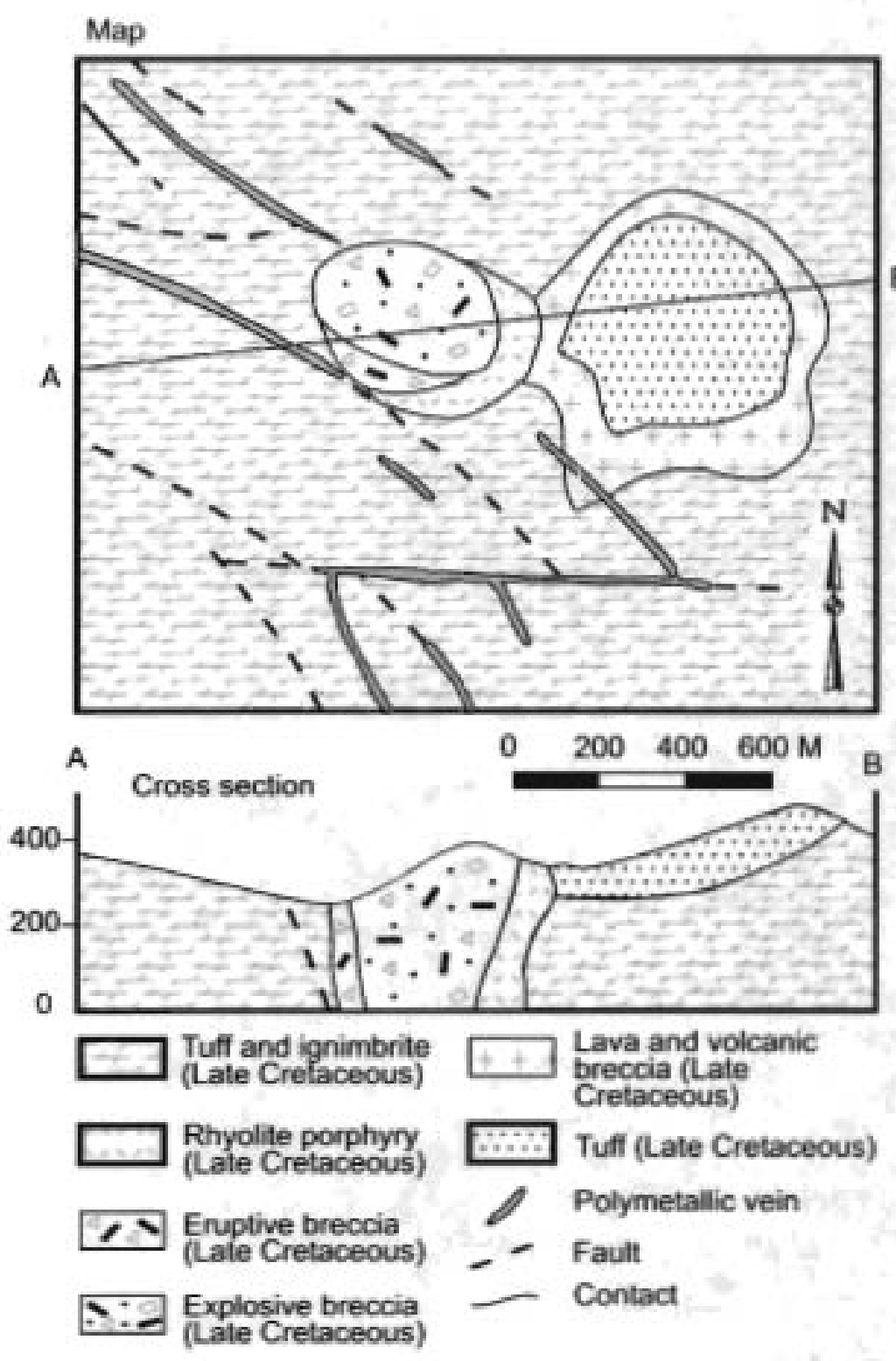

Figure 88. Krasnogorskoe Pb-Zn polymetallic vein deposit, Taukha metallogenic belt, Russian Southeast. Generaliced geologic map and cross section. Adapted from Ratkin and others (1990).

\section{Origin of and Tectonic Controls for Taukha Metallogenic Belt}

The Cretaceous granitoid rocks bosting the Taukha metallogenic belt are part of the East Sikhote-Alin volcanic-plutonic belt (fig. 79) of Late Cretaceous and early Tertiary age (Vasilenko and Valuy, 1998). The volcanic and plutonic units are widespread and are controlled by NE-trending strike-slip and pull-apart structures. The B and $\mathrm{Pb}-\mathrm{Zn}$-Ag sulfide deposits are hosted in tectonic lenses of limestone or marble which occur in the Tauka accretionary-wedge terrane. The terrane consists of mainly of Neocomian turbidite deposits and olistostromes composed Paleozoic and Mesozoic guyots, formed of limestone caps which overlying basalt pedestals, and Carboniferous through Jurnssic chert, Berriasian through Valanginian furbidite, and Permian, Triassic, and Berriasian through Valanginian shelf sandstone and turbidite deposits (Nokleberg and others, 1994c, 1997c). 
Like the Kema and Luzhkinsky metallogenic belts, the coeval Taukha metallogenic belt is hosted by East Sikhote-Alin volcanic-plutonic belt of Late Cretaceous and early Tertiary age (fig. 79) which is described in the above section the origin of the Taukha metallogenic belt. Other related, coeval metallogenic belts hosted in the East-Sikhote-Aline volcanic belt are the Kema, Luzhkinsky, Lower Amur, and Sergeevka (SG) belts (fig. 79; table 3). The differences between the coeval metallogenic belts are interpreted as due to the host igneous rocks intruding different bedrock. The Taukha metallogenic belt contains mainly B skarn, $\mathrm{Pb}-\mathrm{Zn}$ skarn, and $\mathrm{Pb}-\mathrm{Zn}$ polymetallic vein deposits, and is hosted in or near igneous rocks of the East Sikbote-Alin belt which intrude the Taukha accretionary-wedge terrane which contains a complex assemblage of abundant Paleozoic and early Mesozoic oceanic rocks and lesser Jurassic and Early Crelaceous turbidite deposits. In contrast, the Luzhkinsky metallogenic belt contains mainly Sn greisen and Sn polymetallic vein, and porphyry Sn deposits, and is hosted in or near granitoid rocks of the East Sikhote-Alin belt which intrude the Zuravlevksk-Tumnin turbidite basin terrane which contains mainly Late Jurassic and Early Cretaceous turbidite deposits.

\section{Kema Metallogenic Beit of Ag-Au Epithermal Vein, and Porphyry Cu-Mo Deposits (Beit KM) Eastern Part of Russian Southeast}

The Kema metallogenic belt of Ag-Au epithermal vein and porphyry Cu-Mo deposits (fig. 79; tables 3,4) occurs in the eastem part of the Russian Southeast. The deposits in the metallogenic belt are hosted in or near Late Cretaceous and early Tertiary granitoid rocks of the East Sikhote-Alin volcanic-plutonic belt which intrude or overlie the Kema island-arc terrane (Nokleberg and others, 1994c, 1997c).

The major Au-Ag epithermal vein deposits in the Kema metallogenic belt are at Burmatovskoe, Glinyanoe, Salyut, Sukhoe, Tayozhnoe, Verkhnezolotoe, and Yagodnoe (table 4) (Nokleberg and others 1997a, b, 1998). Porphyry Cu deposits are at Nesterovskoe and Nochnoe, porphyry Cu-Mo deposits are at Sukhoi Creek, and a porphyry Mo deposit is at Moinskoe. The Ag epithermal vein deposits, as at Tayoznoe, also occur in Early Cretaceous clastic and volcaniclastic rocks and in overlying Late Cretaceous and Paleogene, subalkalic, postaccretionary volcanic rocks of the East Sikhote-Alin igneous belt. Ag sulfosalt minerals predominate in the deposits. Concentrations of $\mathrm{Ag}$ are much greater than $\mathrm{Au}$, and $\mathrm{Ag} / \mathrm{Au}$ ratios generally are greater than 25 to 30 . Rare $\mathrm{Pb}-\mathrm{Zn}$ polymetallic vein deposits occur in the metallogenic belt, but are not economic (P.I. Logvenchev, O.L. Sveshnikova, and V.A. Pakbomova, written commun., 1994; Pakhomova and others, 1997). However, these deposits are generally of little commercial value at the present. The epithermal vein deposits generally occur mostly in or near Danian (early Paleocene) and Paleocene volcanic rocks; however, a few occur in granodiorite plutons (Khomich and others, 1989).

Porphyry Cu-Mo deposits in the Kema metallogenic belt occur mainly in the northern part of the belt at Moinskoe, Nochnoe, and Sukhoi Creek. These deposits generally consist of disseminations and veinlets in and near the intrusive rocks and coeval volcanic rocks which often contain notable amounts of $\mathrm{Pb}, \mathrm{Zn}, \mathrm{W}, \mathrm{Au}$, and $\mathrm{Ag}$ in addition to $\mathrm{Cu}$ and $\mathrm{Mo}$. The deposits occur in Late Cretaceous to Paleogene granitic and diorite intrusions. A porphyry Cu deposit occurs in the southern part of the belt at Nesterovskoe. In the westem part of the belt, in the eastem part of the adjacent Luzhkinsky terrane, are porphyry Sn deposits, as at Mopau.

\section{Glinyanoe Ag Epithermal Vein Deposit}

The rich Glinyanoe Ag epithermal vein deposit (A.N. Rodionov, written commun., 1986) consists of adularia-quartz, sericite-chlorite-quartz, and carbonate-chlorite-quartz mineralized veins and zones which contain pyrite, arsenopyrite, galena, sphalerite, chalcopyrite, argentite, acanthite, Ag-tellurides, and native gold and silver. The veins and zones occur in altered, silicified volcanic rocks which overlie Late Cretaceous (Santonian) felsic volcanic rocks. The deposit is interpreted to have occurred in four stages: (1) gold-pyrite-quartz; (2) quartz-hydromica and quartz-carbonate; (3) gold-silver; and (4) quartz-chloriteadularia with Ag-sulfosalts. The age of the deposit is interpreted as Late Cretaceous to Paleogene. The deposit is judged to be small. Average grades are $8.3 \mathrm{~g} / \mathrm{Au}$ and $122 \mathrm{~g} / \mathrm{Ag}$.

\section{Sukhoi Creek Porphyry Cu-Mo Deposit}

The Sukhoi Creek porphyry Cu-Mo deposit (Petrachenko and others, 1988) consists of stockworks which reach several hundred $\mathrm{m}$ across, and in altered zones. Polymetallic ore dominates in some stocks. The ore minerals are chalcopyrite, molybdenite, sphalerite, galena, cassiterite, scheelite, and pyrite; with significant Au and Ag contents. The deposit oecurs in Early Cretaceous sedimentary rocks which are overlain by Late Cretaceous volcanic rocks and are crosscut by ore-bearing granitic intrusions with a $\mathrm{K}$-Ar isotopic age of $73 \mathrm{Ma}$. The Porphyry Mo mineralization is related to several granodiorite and granite stocks which are intensely bydrothermally altered. Quartz-sericite alteration and medium-temperature epidote-prehnite-chlorite propylitic alteration occur at the core and grade into micaceous-chlorite-carbonate propylite at the periphery. The granite is locally altered to quartz-muscovite greisen with tourmaline and sphene, and in a few places into a peculiar garnet-phlogopite rock with apatite. The host siltstone and sandstone are altered to orthoclase-actinolite-chlorite bornfels and the felsic extrusive rocks are altered to quartz and phyllite. Average $\mathrm{Cu}$ and $\mathrm{Mo}$ contents are low, up to 0.2 and $0.01 \%$ respectively. The deposit is not explored at depth. 
The Tayozhnoe Ag epithermal vein deposit (A.N. Rodionov and others, written commun., 1976; Pakhomova and others, 1997) consists of steeply-dipping quartz veins which occur along northwest to north-south fractures which cut coarse-grained. Early Cretaceous sandstone. The veins are 100 to $500 \mathrm{~m}$ long and 0.5 to $2 \mathrm{~m}$ thick, and also occur laterally under the contact between sandstone and overlying 50-m-thick section of Late Cretaceous felsie volcanic rocks. The ore minerals oceur within the veins, and in metasomatic zones along the sub-horizontal contact between veins and overlying volcanic rocks. The major Ag* bearing minerals are Ag sulfosalts and sulfides. Pyrite and arsenopyrite are rare and formed before Ag-bearing minerals. In the upper part of veins, Ag occurs in tetrahedrite, freibergite, stephanite, pyrargyrite, and polybasite. At middle depths, Ag oecurs in acanthite and stephanite dominate, along with arsenopyrite and allargentum also oceur, whereas acanthite dominates at depth. The deposit is medium size witb an average grade of $50-2000 \mathrm{~g} / \mathrm{t} \mathrm{Ag}$ and I g/t Au. The deposit bas been mined since the 1980's, and is assumed to be related to a Paleocene rhyolite volcano-plutonic assemblage.

\section{Verkhnezolotoe Porphyry Cu Deposit}

The Verkhnezolotoe porphyry Cu deposit (Orlovsky and others, 1988) occurs at the northwest margin of a caldera which contains dike-like bodies of calc-alkaline andesite porphyry which is interpreted as tongues of a dome-like subvoleunic intrusion. A stockwork occurs in a circular aureole of hydrothermally altered rocks, with dimensions of $200 \mathrm{~m}^{2}$, occurs over the intrusive dome. Successive alterations consist of: (1) quartz-biotite-actinolite with pyroxene and epidole; (2) quartz-biotite-actinolite; (3) quartz-biotite-sericite and local chlorite; and (4) quartz-hydromica with carbonate. The stockwork includes the first three alterations and consists of a thick network of quartz-epidote-actinolite veinlets and lenses up to 2 to $3 \mathrm{~cm}$ thick with chalcopyrite, bornite, and pyrite. The stockwork is related to a diorite stock. The stockwork boundary coincides with the aureole of the biotite alteration. An intensely-fractured breccia of mineralized siliceous siltstone was encountered by drill holes which extend to $100 \mathrm{~m}$ depth. The ore minerals in breccia zones are chalcopyrite, bornite, molybdenite, pyrite, rarely pyrrhotite, cubanite, arsenopyrite, galena, and sphalerite. Carbonate-chalcopyrite veinlets also occur. A zone of oxidized ore up to 20 to $30 \mathrm{~m}$ deep caps the deposit. The deposit is small with average grades of $3 \mathrm{~g} / \mathrm{Au}, 86 \mathrm{~g} / \mathrm{t} \mathrm{Ag}, 0.35-2.27 \% \mathrm{Cu}, 0.69 \% \mathrm{~Pb}$, and $0.26 \% \mathrm{Sn}$.

\section{Origin of and Tectonic Controls for Kema Metallogenic Belt}

The Cretaceous granitoid rocks hosting the Kema metallogenic belt are part of the East Sikhote-Alin volcanic-plutonic belt of Late Cretaceous and early Tertiary age (fig. 79) which is described in the above section the origin of the Taukha metallogenic belt. Other related, coeval metallogenic belts bosted in the East-Sikhote-Aline volcanic belt are the Luzhkinsky, Lower Amur. Sergeevka (SG), and Taukha (TK)belts (fig. 79; tables 3,4). In the Kema metallogenic belt, the Cretaceous granitoid rocks of the East Sikhote-Alin belt intrude the Kema island-are terrane which consists chiefly of distal turbidite deposits, andesite and basalt flows, breccia, tuff, and interbedded shallow-marine volcaniclastic rocks which contain Aptian to Albian pelecypods (Nokleberg and others, 1994c). The volcanic rocks range mainly from tholeitic and calc-alkalic. In the Kena metallogenic belt, the volcanic rocks are mostly intermediate and moderately felsic, mainly rhyolite and lesser basalt with $\mathrm{K}$-Ar ages of about 55 to $60 \mathrm{Ma}$. In contrast to the nearby Taukiha metallogenic belt, the Kema metallogenic belt contains mainly AgAu epithermal deposits and is hosted in or near granitoid rocks of the East Sikhote-Alin belt where it intrudes the Cretaceous island-are rocks of the Kema terrane.

\section{Luzhkinsky Metallogenic Belt of Sn Greisen. Sn Polymetallic Vein, Sn silica-sulfide vein, and Porphyry Sn Deposits (Beit LZ) Southern Part of Russian Southeast}

The Luzhkinsky metallogenic belt of Sn greisen and Sn polymetallic vein, and porphyry Sn deposits (fig. 79; tables 3, 4) occurs in the southern part of the Russian Southeast (Gonevchuyk and Kokorin, 1998). The belt is hosted in the Late Cretaceous and early Tertiary granitoid rocks of the East Sikhote-Alin volcanic-plutonic belt which intrude the southern part of the Zhuravlesk-Tumnin turbidite basin terrane (Nokleberg and others, 1994c, 1997c). The Luzhkinsky metallogenic belt centains one of the major group of $\mathrm{Sn}$ mines in the Russian Southeast (Vasilenko and others, 1986; Radkevich, 1991; Gonevchuk and others, 1998). The significant deposits in the belt are Sn silicate-sulfide vein deposits at Arsenyevsoe, Khnustalnoe, and Vysokogorskoe (fig. 89). Sa polymetallic vein deposits at Dalnetayozhnoe, Iskra (fig. 90), Nizhnee, and Zimnee, a polymetallie vein deposit at Yuzhnoe, porphyry Cu and porphyry Cu-Mo deposits at Lazumoe, Malinovskoe, Verkhnezolotoe, and Zarechnoe, porphyry Sn deposits at Yantarnoe and Zvezdnoe, and Sn-W greisen deposits at Tigrinoe and Zabytoe (table 4) (Nokleberg and others 1997a, b. 1998; Gonevchuk and others, 1998).

\section{Sn greisen and Sn polymetallic Vein Deposits}

The Sn greisen and Sn polymetallic vein deposits of the Luahkinsky belt formed in the mid-Cretaceous and early Tertiary between about 90 to 100 and $60 \mathrm{Ma}$ (Gonevehuk and Korkorin, 1998). The older deposits formed in the early Late Cretaceous ( 90 
to $100 \mathrm{Ma}$ ), are typical Sn greisen deposits, and are associated with Li-F granitoid rocks. These Sn greisen deposits contain notable amounts of $\mathrm{W}$, as at the Tigrinoe deposit which occurs in the eastern part of the metallogenic belt adjacent to the Samarka W skarn accretionary metallogenic belt (fig. 79). Intermediate-age deposits, formed in the late Late Cretaceous (75-85 Ma), are Sn polymetallic vein deposits, as at Zimnee, which are interpreted as forming in coeval andesite, monzodiorite, and granodiorite intrusions. These Sn polymetallic vein deposits occur in the westem part of the Luzhkinsky metallogenic belt. The younger deposits

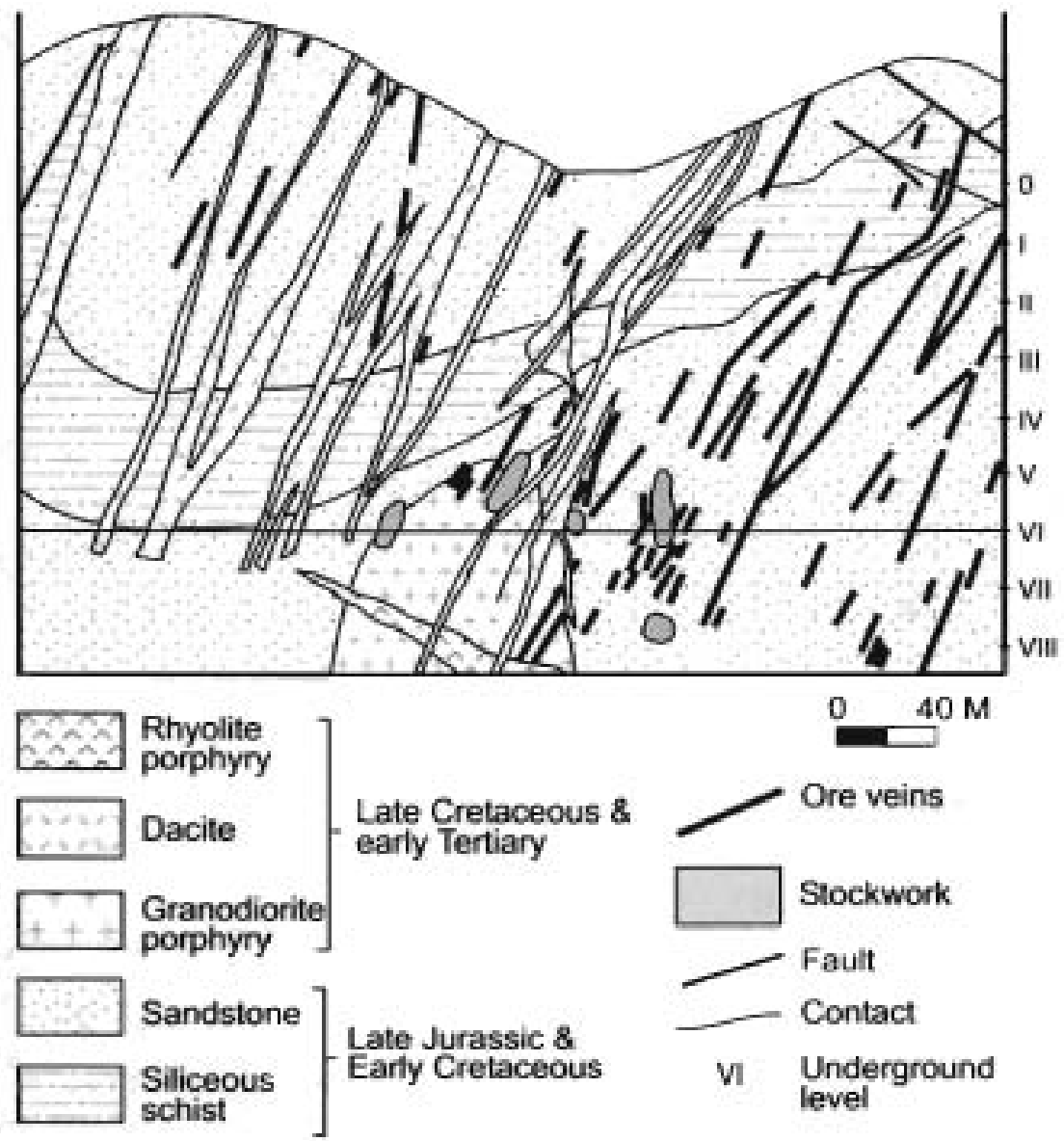

Figure 89. Vysokogorskoe Sn silicate-sulfide vein deposit, Luzhkinsky metallogenic belt, Russian Southeast. Schematic cross section. Adapted from Gonevchuk and others (1998)

formed in the Late Cretaceous and early Tertiary (70-60 Ma) and are Sn silica-sulfide vein deposits, as at Arsenyevsky which are composed mainly of cassiterite and silieate minerals. These deposits are oflen generally spatially related to the older Sn polymetallic deposits and formed simultaneously with $\mathrm{Zn}$-Pb skarn deposits of the post-accretionary Taukha metallogenic belt to the east. The Late Cretaceous and early Tertiary Sn silica-sulfide vein deposits are interpreted as related to the formation of ultrapotassic rhyolite volcanic porphyries; however, any direct relation to intrusion rocks is quite obscure.

\section{Tigrinoe Sn Greisen Deposit}

The Tigrinoe Sn greisen deposit (fig. 91) (Rodionov and Rodionova, 1980; Rodionov and others, 1984; Ruchkin and others, 1986; Rodionov and others, 1987; Korostelev and others, 1990; Gerasimov and others, 1990; Gonevchuk and Gonevchuk, 1991; Gonevchuk and others, 1998) is a complex Sn-W deposit consisting of: (1) a stockwork of quartz-topaz-micaceous greisen along the contact of a massif of Li-F granite; (2) a linear stockwork consisting of a thick network ( 5 to 10 to 70 veinlets per meter) of parallel north-south-trending quartz-topaz veins from 3 to $100 \mathrm{~cm}$ thick which are hosted in contact-metamorphosed sedimentary rocks adjacent to the granite intrusion; and (3) a sulfide breccia pipe consisting of rock fragments of the stockwork and greisen cemented by quartz with lesser carbonate, fluorite, and sulfides. Three stages of mineralization are distinguished: ( 1 ) early quartz-molybdenite-bismuthinite; (2) middle-stage REE greisen of wolframite-cassiterite with high contents of Sc, Ni, and $\mathrm{Ta}$; and (3) late hydrothermal quartz-fluorite-carbonate-sulfide veins, In, $\mathrm{Cd}, \mathrm{Ag}$, and Se are enriched in sulfides of the two last stages. A Rb-Sr age of the lithium-fluorine granite is $86 \pm 6 \mathrm{Ma}$ with an initial Sr ratio of 0,7093 , A Rb-Sr age of the greisen is 73 $\pm 18 \mathrm{Ma}$ with an initial Sr ratio of 0.7105 . The average grade is $0.14 \% \mathrm{Sn}$ and $0.045 \% \mathrm{~W}_{2} \mathrm{O}_{3}$. The deposit is of medium size. 

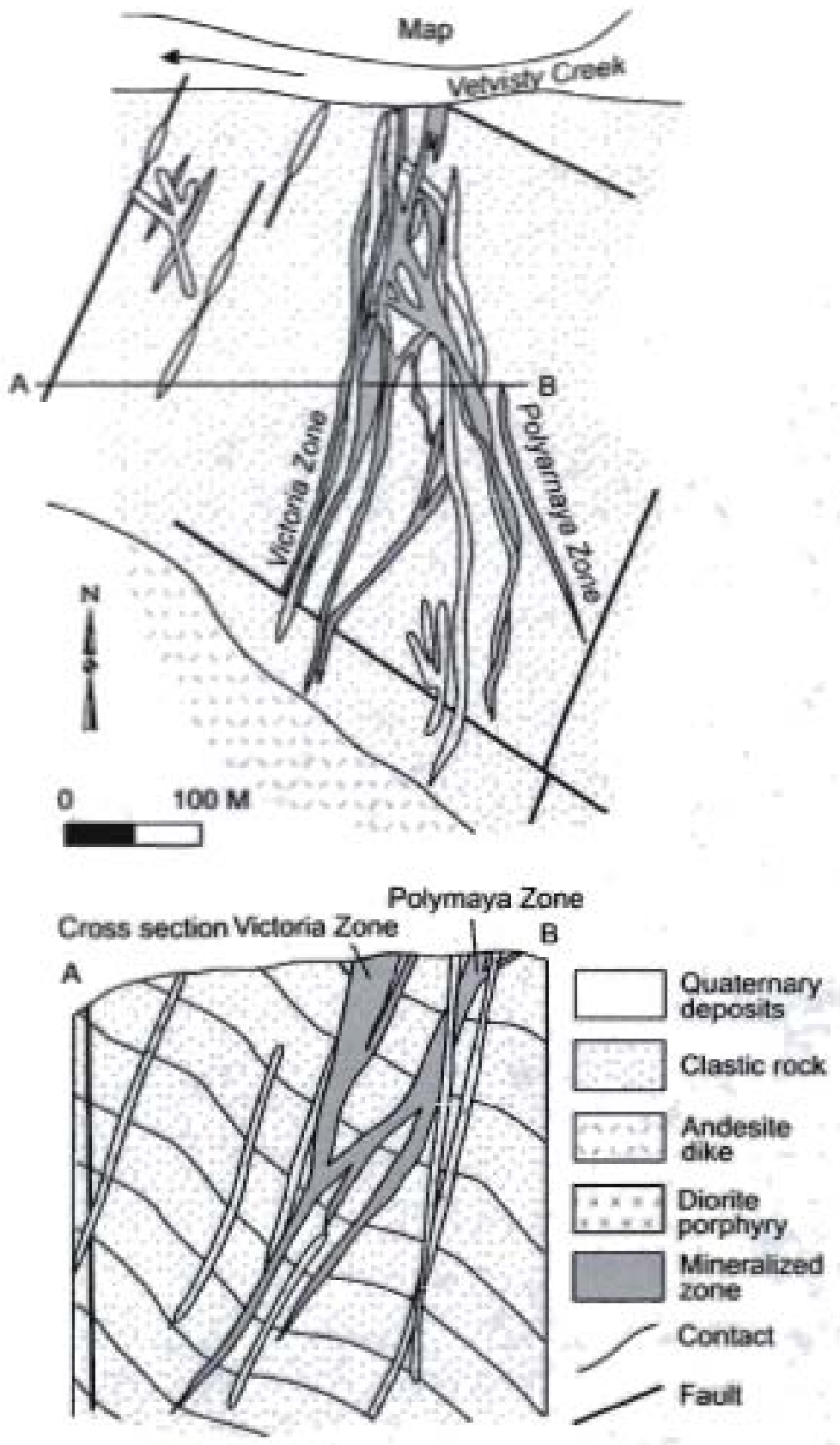

Figure 90. Iskra deposit Sn polymetallic vein deposit. Luzhikinsky metaliogenic belt, Russian Southeast. Schemafic geclogic map and cross section. Adapted from Gonevchuk and others (1998).

\section{Zimnee Sn Polymetalilic Vein Deposit}

The Zimnee Sn polymetallic vein deposit (P.G. Korostelev and others, written commun, 1980; Nazarova, 1983; Gonevchuk and others, 1998) consists of mineralized breccia, breccia- and fracture-filling veins, zones of closely spaced veinlets, and pockets which occur in fracture zones. The Sn polymetallic ore bodies have strike lengths up to $1200 \mathrm{~m}$, are extensive down dip, and vary in thickness from several tenths of a meter io several tens of meters. The deposit oceurs near a granodiorite body and consists muinly of pyrrhotite, pyrite, arsenopyrite, sphalerite, stannite, and cassiterite. Ore far from the granodiorite and in the upper part of veins is mostly galena with fine-grained cassiterite. Near the granodiorite, the ore consists of breecia-bearing fragments of tin-sulfide minerals which are cemented by a quartz-micaceous (greisen) aggregate with arsenopyrite and cassiterite. The $\mathrm{K}$-Ar age of altered rocks associated with the Sn-polymetallic ores is $75 \mathrm{Ma}$. The age of greisen assemblage is approximately $50 \mathrm{Ma}$ as determined by a $\mathrm{K}-\mathrm{Ar}$ age of $50 \mathrm{Ma}$ for the granodiorite. The deposit exhibits regional metamorphism, cataclasis, and is small. Average grades are $0.1-3.0 \% \mathrm{Cu}, 3.18 \% \mathrm{~Pb}, 0.59 \% 6 \mathrm{Sn}$, and $4.09 \% \mathrm{Zn}$. 

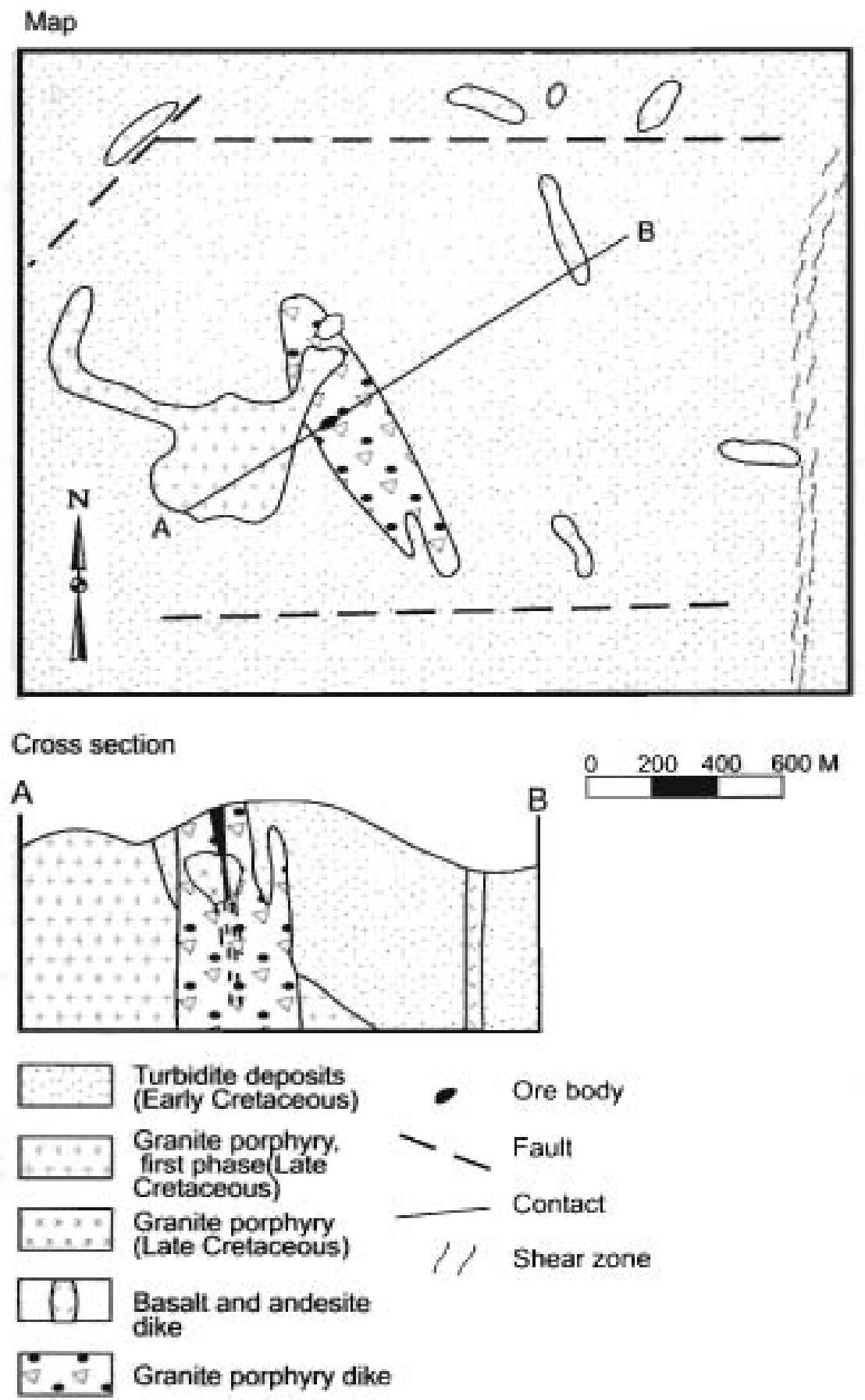

Figure 91. Tigrinoe Sn-W greisen deposit, Luzhkinsky metallogenic belt, Russian Southeast. Schematic geologic map and cross section. Adapted from Korostelev and others (1990).

\section{Arsenyevskoe Sn Sillica-Sulfide Vein Deposit}

The Arsenyevskoe Sn silicate-sulfide vein deposit (fig. 92) (Rub and others, 1974; Radkevich and others, 1980; Gonevchuk and others, 1998), one of the larger Sn vein mines in the Luzhkinsky belt, consists of a series of parallel, steeplydipping quartz veins up to $1000 \mathrm{~m}$ along strike and 600 to $700 \mathrm{~m}$ down dip. The deposit is closely associated with moderate- to steeply-dipping rhyolite dikes with K-Ar isotopic ages of $60 \mathrm{Ma}$ (early Tertiary). The ore mineral assemblage is vertically zoned. From the top downwards, the assemblages are: quartz-cassiterite, quartz-arsenopyrite-pyrrhotite, polymetallic, and arsenopyritepyrrhotite. The rhyolite exhibits quartz-sericite alteration. Local miarolithic cavities are filled with cassiterite. The deposit is of medium size. Sn content ranges from 0.1 to $20-25 \%$ and averages $2-3 \%$, $\mathrm{WO}_{3}$ content ranges from $0.1-0.5 \%, \mathrm{~Pb}$ and $\mathrm{Zn}$ from 1 $2 \%, \mathrm{Ag}$ content is about few hundred ppm. The deposit has been mined since the 1970's 


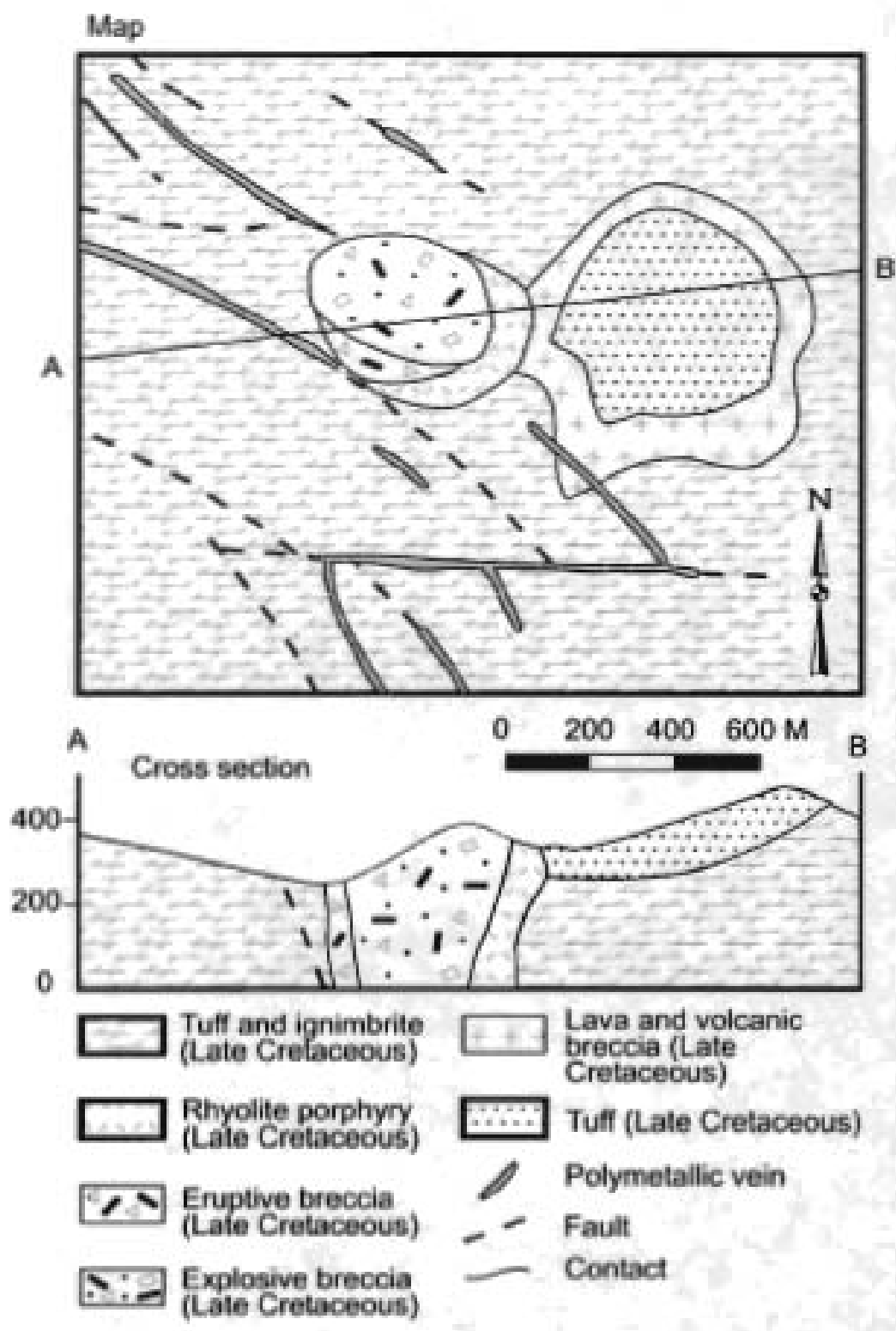

Figure 92. Arsenyevskoe Sn silicate-sulfide vein deposit, Luzhkinsky metaliogenic belt. Russian Southeast. Schematic geologic map. Adapted from Ratkin (1995).

\section{Yantarnoe Porphyry Sn Deposit}

Porphyry Sn deposits, as at Yantamoe, oceur in the northern part of the Luahkiasky belt. These deposits are poorly studied, although they are very promising economically. The Yantamoe deposit (Rodionov, 1988), consists of veiniets and disseminations of cassiterite and sulfide minerals in a pipe-like body and a volcanic breccia composed of trachyandesite and rhyolite which intrude Early Cretaceous clustic sedimentury rocks. The earliest mineralization was aasocialed with rhyolite in the pipe-like body and voleanie breccia and produced mainly pyrite-chalcopyrite. The major part formed after the intrusion of an explosive breccia and consists of metasomatic quartz-chlorite, quartz-sericite, and quartz-chlorite-sericite alterations which contain a sulfide-free cassilerite-chlorite-quartz assemblage, and a Sn-polymetallic assemblage rich with galena, sphalerite, and chalcopyrite. The host igneous rocks are spatially related to volcanie vents of Paleocene age with K-Ar isotopic ages of about 65 Ma. The deposit is small. Average grades are 0.1-2.17\% Cu, 0.03-1.02\% $\mathrm{Ph}, 7.3 \% \mathrm{Sa}$, and $0.7 .2 .22 \% \mathrm{Zn}$.

Also in the same area are younger, generally uneconomic Sn greisen occurrences with $\mathrm{K}$-Ar isotopic ages of $60-50 \mathrm{Ma}$ age. In addition to Sn deposits, the northem part of the Luahkinaky metallogenic belt includes sparse small porphyry Cu deposits, as at Verkhnezolotoe, which are associated with Senomanian and Turonian monzodiorite in the northwestern part of the belt near the Samarka accretionary-wedge terrane which contains abundant oceanic lithologies. The porphyry Cu deposits are coeval with the Sn deposits of the Luzhkinsky metallogenic belt, but presumably reflect the anomalous Cu-fich characteristics of the oceanic Samarka terrane. 
The Luzhkinsky metallogenic belt hosts the Kavalerovo ore district which has produced about $30 \%$ of the tin mined in the former USSR (Gonevchuk and Kokorin, 1998). The belt is interpreted as forming in the back-arc part of the East Sikhote-Alin volcanic plutonic belt which forms a major continental-margin arc in the Russian Southeast.

The Cretaceous granitoid rocks hosting the Luzhkinsky metaliogenic belt are part of the East Sikhote-Alin volcanicplutonic belt (fig. 79) of Late Crelaceous and early Tertiary age (Gonevchuk and Kokorin, 1998) which is described in the above section the origin of the Taukha metallogenic belt. Other related, coeval metallogenic belts hosted in the East-Sikhote-Aline volcanic belt are the Kema (KM), Lower Amur, Sergeevka (SG), and Taukha (TK) belts (fig. 79; table 3). The differences between the coeval metallogenic belts are interpreted as the result the igneous rocks which host these metallogenic belts intruding different bedrock. In contrast, to the nearby Kema metallogenic belt, the Luzhkinsky metallogenic belt occurs in the part of the East Sikhote-Alin igneous belt which intrudes the southern part of the Zuravlevksk-Tumnin turbidite basin terrane (fig. 79) (Nokleberg and others, 1994c, 1997c). Additional possible controls for the Luzhkinsky metallogenic belt are: (1) the turbidite deposits in the Zuravlevksk-Tumnin terrane are enniched in Sn; and (2) the Luzhinsky belt occurs in the back-are part of the East Sikhote-Alin igneous belt in which magnetite-series granitoid rocks predominate.

\section{Lower Amur Metallogenic Beit of $\mathrm{Au}-\mathrm{Ag}$ \\ Epithermal Vein, Porphyry Cu, and Sn Greisen \\ Deposits (Belt LA) Northern Part of \\ Russian Southeast}

The Lower Amur metallogenic belt of Au-Ag epithermal vein, porphyry $\mathrm{Cu}$, and $\mathrm{Sn}$ Greisen deposits (fig. 79; tables 3,4) occurs in the northern part of the Russian Southeast. The deposits in the metallogenic belt are hosted in or near mid-and Late Cretaceous and early Tertiary granitoid igneous rocks of the East Sikhote-Alin volcanic-plutonic belt which intrude or overlie the Amur River and Kiselyovka-Manoma accretionary-wedge terranes. The major Au-Ag epithermal vein deposits are at Belaya Gora, Bukhtyanskoe, and Mnogovershinnoe; a porphyry Cu deposit is at Tyrskoe, and a Sn greisen deposit is at Bichinskoe (table 4) (Nokleberg and others 1997a, b, 1998).

The Au-Ag epithermal vein deposits, as at Mnogovershinnoe, range from medium to large size and are generally hosted in Paleocene alkaline granitoid rocks which are closely associated with coeval andesite to dacite volcanic rocks. Some Au-Ag epithermal vein deposits are associated with Eocene and Oligocene volcanism (Khomich and others, 1989). The Au-Ag epithermal vein deposits, as at Belaya Gora and Bukhtyanskoe, are closely associated with thyolite and trachyrhyolite flows and vent rocks which are commonly hydrothermally-altered to siliceous and adularia pbases. Au is either disseminated throughout the hydrothermally-altered rocks or is concentrated in small quartz veins. The adularia phases also locally contain Au. Placer Au deposits, as at Kolchanskoe, Ulskoe, and Oemku, are associated with the Au-Ag epithermal vein deposits. In addition to the AuAg epithermal vein deposits, the Lower Amur metallogenic belt includes few small W skarn, porphyry $\mathrm{Cu}$, and $\mathrm{Sn}$ greisen deposits which are all hosted in or near Paleogene alkaline granitoid rocks.

\section{Mnogovershinnoe Au-Ag Epithermal Vein Deposit}

The large Mnogovershinnoe Au-Ag epithermal vein deposit (fig. 93) (Zalishchak and others, 1978) consists of hydrothermally altered, adularia-sericite-quartz vein-like zones up to $800 \mathrm{~m}$ long. The zones contain a series of adularia-quartz veins and veinlets. Some ore bodies consist of thodonite-carbonate veins, and lenses of skarns and sulfides. The ore minerals include pyrite, marcasite, gold, argentite, Au- and Ag-tellurides, galena, sphalerite, chalcopyrite, and freibergite. The ore minerals comprise up to $1 \%$ of veins. The Au:Ag ratio is $1: 1$. The deposit is hosted in Paleocene andesite-dacite which is genetically related to a multiphase intrusion of highly alkaline granitoid rocks. K-Ar isotopic studies indicate an age of mineralization of 49 to $69 \mathrm{Ma}$. During formation of local Au-bearing skarns, which presumably formed during intrusion of Paleogene subalkaline granites, Au was remobilized (Ivanov and others, 1989). Placer Au deposits are associated with the Au-Ag epithermal vein deposits.

\section{Belaya Gora Au-Ag Epithermal Vein Deposit}

The medium-size Belaya Gora Au-Ag epithermal vein deposit (Mel'nikov, 1978) consists of disseminated and stockworktype Au-Ag ore which oceurs in extrusive bodies of subalkalic rhyolite-dacite and explosive breccia of an Eocene-Oligocene igneous complex. Alteration minerals are quartz $(50-90 \%)$, kaolinite, dickite, sericite, hydromica, and adularia. The ore minerals are gold, silver, argentite, pyrite, marcasite, chalcopyrite, sphalerite, galena, hematite, and cinnabar. The ore assemblages are Auquartz and Au-sulfosalts-sulfide-quartz. Gold distribution is highly irregular and the ore bodies do not have clear boundaries. The deposit extends to $100 \mathrm{~m}$ deep. 


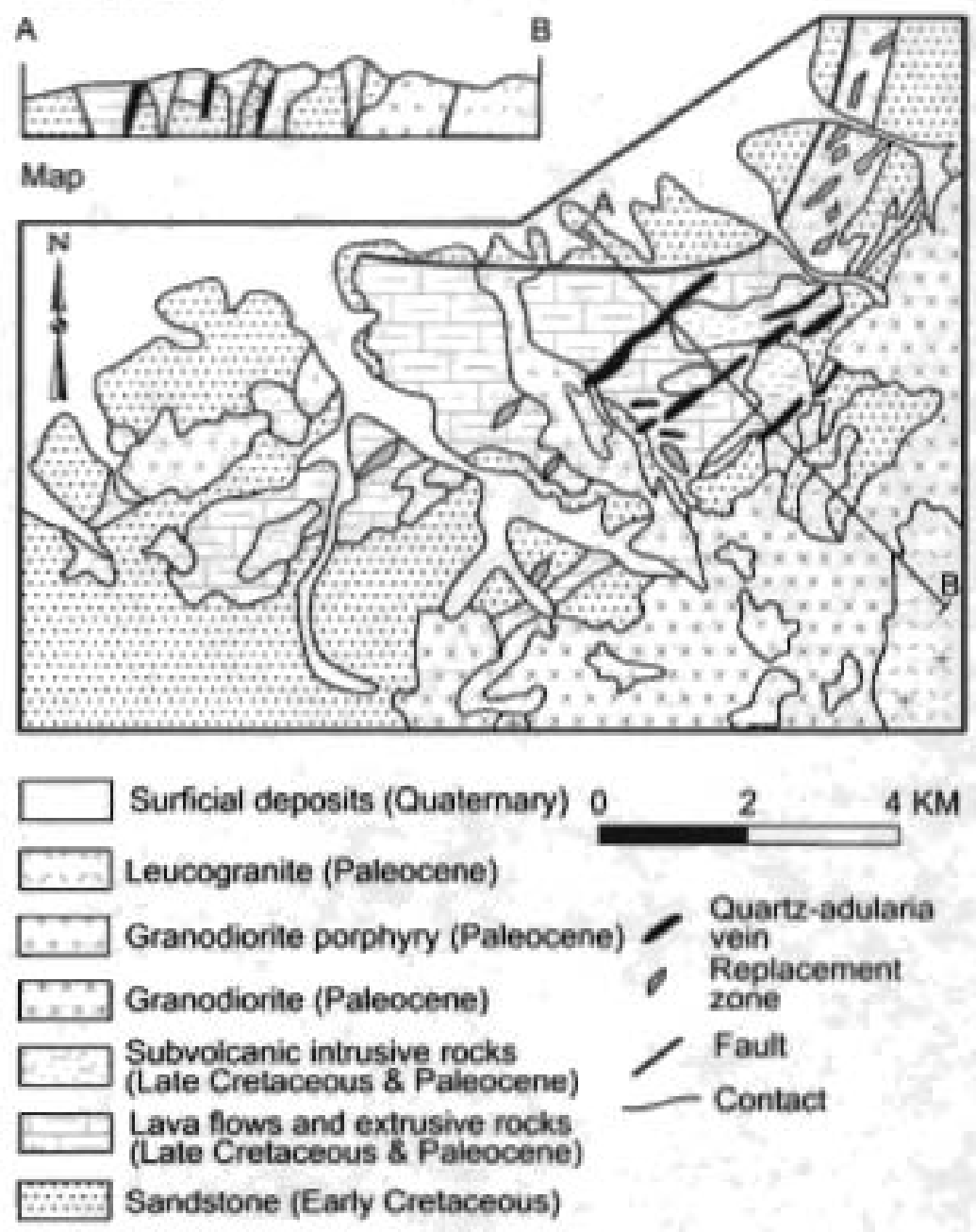

Figure 93. Mnogovershinnoe Au-Ag epithermal vein deposit, Lower Amur metallogenic belt, Russian Southeast. Schematic geologic map and cross section. Adapted from Ratkin (1995).

\section{Origin of and Tectonic Controls for Lower Amur Metallogenic Belt}

The Cretaceous granitoid rocks hosting the Lower Amut metallogenic belt are part of the East Sikhote-Alis volcanicplutonic belt (fig. 79) of Late Cretaceous and early Tertiary age which is described in the above section the origin of the Taukha metallogenic belt. Other related, coeval metallogenic belts hosted in the East-Sikhole-Aline volcanic belt are the Kema (KM). Luzhkinsky (LZ), Sergeevka (SG), end Taukha (TK) belts (fig. 79; table 3). The differences between the coeval metallogenic belts are interpreted as the result the igneous rocks which host these metallogenic belts intruding different bedrock. In contrast to these other coeval and related belts, the Lower Amur metallogenic belt occurs where Cretaceous granitoid rocks of the East SikhoteAline bell intrude the Amur River and Kiselyovka-Manoma accretionary-wedge terranes.

\section{Metallogenic Belt Formed in Late Mesozoic Oceanic Crust and Island Arc Terranes, Russian Southeast}

\section{Aniva-Nabit Metallogenic Belt of Volcanogenic $\mathrm{Mn}$ and $\mathrm{Fe}$ and Cyprus Massive Sulfide Deposits (Belt ANN) Sakhalin island, Southeastern Part of Russian Far East}

The Aniva-Nabil metallogenic belt of volcanogenic $\mathrm{Mn}$ and Fe, and Cyprus $\mathrm{Cu}$ massive sulfide deposits occurs on Sakhalin Island in the southeastern part of the Russian Far East (fig. 79; tables 3,4) (Nokleberg and others, 1997b, 1998). The belt occurs in the Aniva subduction-zone terrane and in the related Nabilsky accretionary-wedge terrane in the central part of the island 
(Nokleberg and others, 1994c, 1997c). The volcanogenic Mn deposits, as at Bereanyakovskoe and Lyukamskoe (Sidorenko, 1974), generally consist of small quartz-rhodonite lenses, with surficial pyrolusite and psilomelane, which are derived from carbonate and $\mathrm{Mn}$-oxide assemblages. Associated with the occurrences are bydrothermal quartz, sericite, and carbonate alteration. The volcanogenic Fe deposits are mainly quartz-hematite lenses which are derived from carbonate and Fe-oxide assemblages. During subsequent accretion and companion metamorphism, the carbonate-oxide assemblages recrystallized to hematiterhodonite-quartz and hematite-quartz. The Cyprus massive sulfide deposits, as at Novikovskoe and Rys'e (Sidorenko, 1974), occur in highly-deformed mafic volcanic rocks with chalcopyrite and pyrite, and subordinate galena, bornite, tetrahedrite, chalcocite and covellite.

Both the volcanogenic Mn and volcanogenic Fe deposits, occur in fuult-bounded jasper-bearing voleanic assemblages. The Cyprus massive sulfide deposits occur in fault-bounded fragments of mafie volcanic rocks. The bost rocks are highlydeformed fragments of Late Cretaceous turbidites, limestone blocks derived from oceanic crustal and island arc assemblages, including blocks of volcanic-jasper deposits, and metamorphosed gabbro and ultramafic igneous rocks. These units ure interpreted as subducted oceanic crust and island are fragments now contained in the highly deformed Aniva and Nabilsky subduction zone and accretionary-wedge terranes. These terranes are interpreted tectonically linked to the Cretaceous East Sikhote-Alin voleanicplutonic belt (Nokleberg and others, 1994c, 1997c, 2000).

\section{Metallogenic Belts Formed in Late Mesozoic and Early Cenozoic Olyutorka lsland Arc, Russian Northeast}

\section{Koryak Highlands Metallogenic Belt of Zoned Mafic-Ultramafic PGE and Cu Massive Sulfide Deposits (Belt KH) East-Central Part of Russian Northeast}

The Koryak Highlands metallogenic belt of zoned mafic-ultramafic PGE deposits occurs in the southem Koryak Highlands in the east-central part of the Russian Northeast (fig. 79; tables 3,4). The belt extends northeast for $1,000 \mathrm{~km}$ from the Sredinny Range in central Kamehatka Peninsula to the Koryak. Highlands in the northern Peninsula (Bundrzen and Sidorov, 1998; Kozin and others, 1999; Melkomukov and Zaitsev, 1999). The belt is bosted in the Olyutorka subterrane of the OlyutorkaKamchatka island-arc terrane (Nokleberg and others, 1994c, 1997c). The metallogenic belt contains several PGE and $\mathrm{Cr}$ deposits which occur in zoned, Alaskan-Uralian type plutons composed of gabbro, dunite, and clinopyroxenite. The significant deposits in the belt are the Snezhnoe zoned mafic-ultramafic Cr-PGE deposit, the Galmeononsky-Seinavsky zoned mafic-ultramafic PGE (Alaskan-Uralian PGE), and a rare gabbroic Cu massive sulfide prospect at Karaginsky (table 4) (Melnikova, 1974; Kepezhinskas and others, 1993), L.V. Melnikov, written commun., 1993; Nokleberg and others 1997a, b, 1998; Bundtzen and Sidorov, 1998). The Karaginsky deposit consists of sulfide lenses hosted in spillite and siltstone, and sulfide disseminations bosied in serpentinized ultramafic olistoliths. The sulfide minerals are chalcopyrite and pyrite, local sphalerite, and locally abundant magnetite, and. In addition to $\mathrm{Cu}$, the deposit contains $\mathrm{Ni}, \mathrm{Co}, \mathrm{PGE}, \mathrm{Zn}, \mathrm{Au}$, and $\mathrm{Ag}$.

\section{Snezhnoe Podiform Cr Deposit}

The Snezhnoe zoned mafic-altramafic Cr.PGE deposit (Kutyev and others, 1988a, b; Kutyev and others, 1991) eccurs in a small round stock, about $2 \mathrm{~km}$ wide, composed of ultramafic rocks. The stock is zoned with a core of dunite, and an outer zone of wehrlite-pyroxenites and pyroxenites. The ultramafic rocks in the stock intrude Late Cretaceous volcanogenic-sedimentary rocks which are contact metamorphosed near the stock. Chromile occurs in the dunite core and occurs as small lenses and veins in streaky and veinlet structures. These ore bodies range up to $1 \mathrm{~m}$ wide and several meters long. Femuginous chromite occurs with up to $48 \% \mathrm{Cr}_{2} \mathrm{O}_{\text {. }}$. Titanomagnetite and $\mathrm{Cu}$ sulfides occur in the peripheral pyroxenites. PGE minerals occur in association with chromite and form in chrome-spinel as small idiomorphic crystals, and as xenomorphic inclusions in interstices. Fe and P1 alloys are predominant and contain inclusions of native OS. The chrome-spinel interstices are is dominated by sperrylite and tetraferroplatinum. PGE grains range up to $1 \mathrm{~mm}$ diameter. PGE minerals are similar in composition to those in podiform $\mathrm{Cr}$ deposits in southeastem Alaska and in the Urals Mountains.

\section{Galmeononsky-Selnavsky PGE Occurrences}

The Galmeonsky-Seinaviky PGE (Alaskan PGE) occurrences are located in zoned mafic-ultramafic complexes in the geographic center of the Koryak Highlands metallogenic belt (locally in Russia called the Koryak-Kamchatka platinum beln) (Bundtzen and others, 2003a, b). The surface area of the Galmeonsky pluton is about $45 \mathrm{~km}^{2}$, and the pluton is about $16 \mathrm{~km}$ long and 3 to $4 \mathrm{~km}$ wide. An "Af" Ar isotopic age of 60-73.9 Ma has been obtained for the pluton (Bundtzen and others, 2003b). The pluton contains a dunite core which comprises about 70 percent of the body and in the periphery is dunite which is successively 
rimmed by wehrlite, olivine-magnetite pyroxenite, and gabbro. Chromite-bearing dunite zones contain up to 100 gt Pt (Kozin and others, 1999).

The Seinassky pluton occurs $7 \mathrm{~km}$ northeast of the Galmeononsky pluton, and covers an area of about $40 \mathrm{~km}$ '. Dunite constitutes about 20 percent of pluton and the rest is mainly wehrlite and pyroxenite (Melkonukov and Zaitsev, 1999). A

${ }^{*} \mathrm{Ar} /{ }^{\mathrm{t}} \mathrm{Ar}$ isotopic age of 60-73.9 Ma has been obtained for the pluton (Bundtzen and others, 2003b). Chromite-rich duaite grades up to $12 \mathrm{~g} / \mathrm{Pt}$, and pyroxenite contains up tol g/t Pd (Kozin and others, 1999). The PGE mineral the pluton and associated placer deposits is isoferroplatinum. Occurring in the region are native osmium, iridium, ruthenium, and platosmiridium which comprise a few percent of the total PGE. About $4 \%$ gold occurs in concentrates along with PGE arsenides and alloys (Melkomukov and Zaitsev, 1999; Bundtzen and Sidorov, 1998).

Since 1994, rich PGE placers have been mined in six streams which radially drain both complexes. Approximately 18.1 tonnes PGE were mined from 1994 to 1998 (Kozin and others, 1999). Production in 2000 was approximately 3.4 tonnes PGE (A. Koslov, written commun., 2000). The production from the Galmeononsky-Seinavsky district comprises a considerable percentage of total Russian PGE production.

\section{Origin of and Tectonic Controls for Koryak Highiands Metaliogenic Belt}

The zoned mafic-ultramafic plutons which host the Koryak Highlands metallogenic belt intrude the Late Cretaceous volcanogenic-sedimentary rocks of the Olyutorka subterrane of the Olyutorka-Kamchatka terrane (Nokleberg and others, 1994c, 1997e). The Olyutorka subterrane consists of a major sequence of lase Mesozoic and early Cenozoic island arc volcanic and sedimentary rocks and occurs in a large nappe which is obducted onto the Ukelayat subternane of the West Kamchatka turbidite basin terrane (Nokleberg and others, 1994c, 1997c). The Olyutorka subternane consists of: (1) a lower part composed of volcanic and siliceous oceanic rocks (Albian to Campanian Vatyn series); and (2) an upper part of Maastrichtian to Paleocene volcanic and clastic island afc deposits (Achayvayam and Ivtiginskaya formations). The subternane is locally intruded by zoned intrusives range from dunite to clinopyrokenite to gabbro. The succession from phuton cores to margins is generally dunite which grades into pyroxenite which grades into gabbro and gabbro-diabase. Intrusion occurred in the latest Cretaceous and the plutons are interpreted as the deep-level, magmatic roots of an island are (Bogdanov and others, 1987). The available geologic and petrologic and geochemical data indicate that the zoned PGE-bearing plutons formed in a marginal-oceanic basin and frontal island are during subduction of an oceanic plate (Bogdanov and others, 1987). Recent isotopic studies suggest intrusion of the zoned maficultramafic plutons in the Late Cretaceous, as young as 71 Ma (Kepezhinskas and others, 1993; Sidorov and others, 1997; Bundtzen and Sidorov, 1998). The Olyutorka-Kamchatka terrane is interpreted as an island arc rock sequence underlain by oceanic crust. The Olyutorka subterrane is intricately faulted with, and thrust over the nearly coeval, Late Cretaceous and Paleogene Ukelayat turbidite basin subtemane of the West Kamchatka turbidite basin terrane to the northwest (fig. 79). The Late Cretaceous to carly Tertiary Olyutorka-Kamchatka island-are ternane is was tectonically linked to the Vetlovskiy accretionarywedge terrane (Nokleberg and others, 2000).

Kepezhinskas and others (1993) interpret that the zoned mafic-ultramafic complexes near Epilchak Lake at the northern end of metallogenic belt were emplaced as part of cale-alkaline magmas related to Late Cretaceous subduction during a short period of crustal extension. They interpret tha the mafic Late Cretaceous lavas which crop out near Epilchak Lake and in the Galmeononsky-Scinavsky areas (part of the Olyutorka-Kamchatka island arc terrane) may be co-magmatic with the zoned maficultramafic plutions. Preliminary Ar-Ar isotopic ages from the Epilchak Lake and Galmeononsky zoned plutonic bodies range from 69 to 71 Ma (P.W. Layer, written communication, 1998).

Vatyn Metallogenic Beit of

Volcanogenic Mn and Fe Deposits (Beit VT)

Southeastern Part of Russian Northeast

The Vatyn metallogenic belt of volcanogenic Mn and Fe deposits (fig. 79; tables 3,4) occurs in the southeastern part of the Russian Northeast. The belt oceurs in several fragments, strikes east-west, is up to $680 \mathrm{~km}$ long, and ranges from 5 up to 100 $\mathrm{km}$ wide. The belt is hosted mainly in the oceanic cnistal and ophiolite rocks of the Late Carboniferous through Early Jurassic and Cretaceous Olyutorka-Kamchatka island-are terrane, and to a lesser extent in the Yanranay accretionary-wedge temane (Nokleberg and others, 1994c, 1997c). In basalt flows in the Yanrunay accretionary wedge-oceanic terrane are small occurrences of cherthosted Fe-and Mn-bearing layers and crusts which occur at the surfaces of basalt flows. The significant deposit in the belt is the lichayvayam volcanogenic Mn deposit (table 4) (Nokleberg and others 1997a, b, 1998).

\section{Itchayvayam Volcanogenic Mn Deposit}

The ltchayvayam and similar deposits in the metallogenic belt (Egiazarov and others, 1965) occur in a sequence of chent and basalt. The deposits consist of massive, patchy, and breceiated $\mathrm{Mn}$ ores which occur as concordaat, lens-like bodies I to $30 \mathrm{~m}$ long and 0.3 to $10 \mathrm{~m}$ thick which are hosted in siliceous rocks. The main ore mineral is braunite, but pyrolusite occurs locally. Mn also occurs in veins of metamorphic origin which range from 2 to $10 \mathrm{~m}$ long and contain 11 to $47 \% \mathrm{Mn}$. The deposits occur in the Albian-Campanian Vatyn Formation which contains abundant basalt and chert. 
The voleanogenic Mn and Fe deposits of the Vatyn metallogenic belt are interpreted as forming in a deep marginal-sea or oceanic basin environment during submarine basalt eruption as part of the Olyutorka subterrane of the Olyutorka-Kamchatka island-are terrane (fig. 79) which is described in the above section on the Koryak Highlands metallogenic belt. After deposition, the $\mathrm{Mn}$ and Fe deposits were metamorpbosed and locally redeposited as cross-cutting veins (Kolyasnikov and Kulisb, 1988).

\section{Eastern Asia-Arctic Metallogenic Belt Formed in Late Mesozoic Part of Okhotsk-Chukotka Continental-Margin Arc, Russian Northeast}

\section{General Setting of Metallogenic Zones in Eastem Asia-Aretic Metallogenic Belt}

The major Eastem Asia-Arctic metallogenic belt of igneous-arc-related lode deposits occurs for several thousand kilometers along the eastem margin of the Russian Northeast (fig. 79, tables 3,4). The mineral deposits of the belt occur in, and or are adjacent to the Cretaceous and early Tertiary Okhotsk-Chukotka voicanic-plutonic belt (Geiman, 1986; Nokleberg and others, $1994 \mathrm{c}, 1997 \mathrm{e}$ ). The major deposit types in the belt are porphyry Cu-Mo, Au-Ag epithermal vein, disserninated Au-sulfide, granitoid-related $\mathrm{Au}, \mathrm{Sn}-\mathrm{Ag}$ polymetallie vein, porphyry, and skarn, $\mathrm{Hg}$. Sb, and associaled deposits. The Eastern Asia-Arctic metallogenic belt includes the rear, frontal and perivolcanic zones of the Okhotsk-Chukotka volcanic-plutonic belt.

The major Eastem Asia-Arctic metallogenic belt is subdivided into smaller metallogenic zones which each exhibit a distinetive suite of felsic-magmatism-related lode deposits (fig. 79; table 4). In alphabetical order, the zones are: Anyui-Beringov, Chaun-Seward, Chukotka, Dogdo-Erikit, Koni Yablon, Okhotsk, Omusukchan, Verkhne-Kolyma, and the Verkhne-Yukonsky. These distinctive suites of lode deposits in each zone are defined or subdivided on the basis of: (1) the terrane(s) which locally underlies the zone; (2) the occurrenoe of longitudinal and orthogonal faults which trend north-south or northwest; and (3) regional magmatic zonation of the Okhotsk-Chukotka volcanic-plutonic belt (fig. 79). In some cases, the longitudinal and orthogonal faults extend several bundreds of kilometers to the northwest away from the northeast-trending mass of the Okhotsk-Chukotka volcanicplutonic belt;

\section{Origin of and Tectonic Controls for Eastern Asia-Aretic Metallogenic Belt}

The Eastern Asia-Aretic metallogenic belt is hosted in or near the Okbotsk-Chukotka volcanic-plutonic belt which constitutes a major Early Cretaceous, Late Cretaceous, and locally Paleocene age assemblage which overlaps previously-accreted terrunes. The igneous belt exiends for $3,000 \mathrm{~km}$ along western margin of Sea of Okhotsk, and across the Bering Straits into the Seward Peninsula (figs. 79, 80), and consists mainly of gently dipping basalt, andesile-basalt, andesite, dacite, thyolite, and tuff (Nokleberg and others, 1994c, 1997c). Rare beds of nonmarine clastic rocks, with conglomerate, grit, and sandstone occur at the base. The belt also contains local widespread silicic volcanic rock (mainly ignimbrites) and associated tonalite, quartz-diorite, and spar granite. To the nortbwest, into the continent, Late Cretaceous plutonic rocks grade into subalkalic and alkalic granite. The Paleocene part of the igneous belt locally consists mainly of plateau theoleitic basalt.

The Okhotsk-Chukotka belt overlies the southeastern margin of the North Asian Craton and the Kolyma-Omolon superterrane, as well as the Chukotka, Kony-Murgal, Okhotsk, Seward, South-Anyui, and Zolotogorskiy terrabes of the Russian Northeast (fig. 79). The Okhotsk-Chukotka belt is interpreled as a Pacific-facing, continental-margin are which formed the Albian through Campanian and locally Paleocene boundary of northeastem Asia. The frontal part of the Okhotsk-Chukotka volcanicplutonic belt is dominated by basalt, and the rear zone is dominated by andesite and rhyolite. Coeval granitic through gabbroic intrusions also occur in the rear zone (Bely, 1977, 1978; Filatova, 1988). The Okhotsk-Chukotka belt is equivalent to the East Sikhote-Alin volcanic-plutonic belt (unit es) in the Russian Southeast (fig. 79). Together, these two igneous belts constitute a major continental-margin are of Cretaceous and early Tertiary age which were tectonically linked subduction zone assemblages. To the north, the Okhotsk-Chukotka igneous belt was lectonically linked to the Ekonay oceanic crust, and the West Kamehatka turbidite basin and Yanranay accretionary-wedge terranes; to the sovth, the East Sikhote-Alin igneous belt was tectonically linked to the Aniva, Hikada, and Nabilsky accretionary wedge and subduction-zone terranes (Nokieberg and others, 2000). 
Eastern Asia-Auctic Metallogenic Belt:

Dogdo-Erikit Metallogenic Zone of

Au-Ag Epithermal Vein, Sn-polymetallic vein

(Southem Bolivian type?), and Volcanic-Hosted

$\mathrm{Hg}$ (Plamennoe type) Deposits (Beit DE)

West-Central Part of Russian Northeast

The Dogdo-Erikut metallogenic zone of $\mathrm{Au}-\mathrm{Ag}$ and $\mathrm{Ag}-\mathrm{Sb}$ epithermal vein, and voleanic-hosted $\mathrm{Hg}$ deposits (fig. 79; tables 3.4) extends for about $1,000 \mathrm{~km}$ and up to 50 to $70 \mathrm{~km}$ wide in a narrow band from the northwest to the southeast in the west-central part of the Russian Northeast (Goryachev, 1998, 2003). This belt is hosted in the volcanic rocks of the UyandinYasachen volcanic belt and the clastic deposits of the Inyali-Debin flysch basin (both parts of the Indigirka-Oloy sedimentaryvolcanic assemblage), and the underlying carbonate rocks of the passive continental margin Omulevka terrane of the KolymaOmolon superterrane.

The Dogdo-Erikit zone contains significant Au-Ag epithermal vein deposits, as at Kysylga, Tikhon, and Shirokoe, Snpolymetallic vein (Southem Bolivian type?) deposits at Solkuchan, and a volcanic-hosted $\mathrm{Hg}$ deposit Dogdo (table 4) (Nokleberg and others 1997a, b, 1998). The Au-Ag epithermal vein deposits are closely related to Late Cretaceous hypabyssal rhyolite bodies with $\mathrm{K}$-Ar isotopic ages of 90 to $56 \mathrm{Ma}$. The hypabyssal rhyolites crosscut contact metamorphic aureoles of older Cretaceous granitord plutons (Gamyanin and Goryachev, 1988). The Dogdo volcanic-hosted $\mathrm{Hg}$ deposit and similar deposits are hosted in Early Cretaceous (?) felsic voleanic rocks which are associated with rhyolite and andesite hypabyssal bodies with $\mathrm{K}$-Ar ages of 125 to $63 \mathrm{Ma}$ (Ganeev, 1974). The volcanic-hosted $\mathrm{Hg}$ deposits are small, uneconomic, and occur in the northwest part of the metallogenic belt which overlies the Selennyakh metallogenic belt of pre-accretionary $\mathrm{Hg}$ deposits (fig. 79). The Dogdo-Erikit metallogenic zone is interpreted as forming in a transverse (orthogonal) limb of the Cretaceous Okhotsk-Chukotka voleanicplutonic belt (Goryachev, 1998, 2003).

\section{Kysyiga Au-Ag Epithermal Vein Deposit}

The Kysylga Au-Ag epithermal vein deposit (Shoshin and Vishnevsky, 1984; Yu.A. Vladimirtseva, written commun., 1985; Nekrasov and others, 1987; Gamyanin and Goryachev, 1988) consists of veins in a zone which varies from 0.60-1.25 m thick and up to $400 \mathrm{~m}$ long. The veins are composed of quartz, ealcite, and ore minerals (1-5\%) including arsenopyrite, pyrite, $\mathrm{Ag}$ tetrabedrite, pyrrhotite, sphalerite, galena, chalcopyrite, boulangerite, Ag-jamesonite, and a low gold fineness (638). The veins strike from roughly east-west to northeast and dip steeply to south. The veins exhibit breceia or, less commonly, comb and massive structures, and often grade into stringer lodes. The deposit occurs in feathered fissures of a northwest-striking major fault and is hosted in Late Triassic sandstone and siltstone which exhibits linear folding and intense contact metamorphic alteration adjacent to a granitic intrusive. Wallrocks display sericite, chlorite, and feldspar alteration. Average grades are $3.0-84.5 \mathrm{gl}$ Au, 1 $37 \mathrm{~g} / \mathrm{Ag} ; 0.01-0.1 \mathrm{As}, 0.01-0.04 \% \mathrm{Sb} ; 0.002 \% \mathrm{Sn}$, and $0.03 \% \mathrm{~Pb}$.

\section{Solkuchan Sn-Ag Polymetallic Vein} (Southern Bolivian type?) Deposit

The Solkuchan Sn-polymetallic vein (Southem Bolivian type) deposit (S.M. Khaustova and Yu.A. Vladimirtseva, written comunun., 1987; Nekrasov and others, 1987; Shkodzinsky and others, 1992) consists of three stecply-dipping quartz-carbonatesulfide veins which occur in an Early Cretaceous subvolcanic dacite stock. The veins are up to $3.4 \mathrm{~m}$ thick and up to $900 \mathrm{~m}$ long. The ore minerals are pyrite, pyrrhotite, arsenopyrite, sphalerite, galena, Ag-ietrahedrite (31-3946 Ag), boulangerite, pyrargyrite, canfieldite, electrum (fineness 685), cassiterite, covellite, scorodite, cerussite, smithsonite, melnikovite, and Fe-bydroxides. Anomalous $\mathrm{Cu}, \mathrm{Sb}$, Ge, and Id are present. The deposit is of medium size. Average grades are $200 \mathrm{gl} \mathrm{Ag}$, from 0.04 to $2.16 \% 6.5 \mathrm{n}$, 0.03 to $2.71 \% \mathrm{~Pb}$, and 0.02 to $5.85 \% \mathrm{Zn}$.

\section{Dogdo Volcanic-Hosted Hg (Plamennoe type) Deposit}

The Dogdo voleanic-hosted Hg (Plamennoe type) deposit (Klimov, 1979, Yu.A. Vladimirtseva, written commun, 1987) consists of four lenticulat and podiform ore bodies which occur in strongly silicified Late Jurassic andesite-dacite tuff. The ore bodies are 20 to $100 \mathrm{~m}$ long and 2 to $8 \mathrm{~m}$ wide. The ore minerals are quartz, calcite, barile with disseminations and stringers of cinnabar, pyrite, arsenopyrite, sphalerite, galeoa, and chalcopyrite. The ore district is characterized by a close correlation between $\mathrm{Hg}$ content and barite. Mineralization is controlled by a northwestem thrust fault, secondary quartzite occurrences, and oceurrence of ore bodies along feathering fractures of the thrust fault. The deposit is of minot-to-medium size. Average grades are 0.35 to $0.90 \% \mathrm{~Hz}$ 
Eastem Asia-Arctic Metallogenic Belt:

Okhotsk Zone of Au-Ag Epithermal Vein

Deposits (Belt EAOH) Southeastern

Part of Russian Northeast

The Okhotsk zone of Au-Ag epithermal vein deposits (fig. 79; tables 3,4) occurs in the southeastem part of the Russian Northeast (Goryachev, 1998). The metallogenic belt is more than $1,500 \mathrm{~km}$ long and locally more than $100 \mathrm{~km}$ wide. The metallogenic belt occurs mainly in the rear of the Okhotsk-Chukotka volcanic-plutonic belt (Nokleberg and others, 1994c, 1997c). The significant deposits in the zone are (table 4) (Nokleberg and others 1997a, b, 1998): Au-Ag epithermal vein deposits at Agat, Aldigych, Burgagylkan, Druchak, Evenskoe, Irbychan, Julietta, Karamken, Kegali, Khakandzhinskoe (Khakandzha), Kolkhida, Krasivoe, Nevenrekan, Oira, Olyndja, Sentyabr, Spiridonych, Teply, Utessnoe, Verkhnenyotskoe, Vetvisty, Yurievka; a granitoidrelated Au deposit at Maltan Stock; epithermal vein and voleanic-bosted Sb vein deposits at Senon, Utro, and Serebryanoe; a Sn silicate-sulfide vein deposit at Kinzhal; and a $\mathrm{Pb}-\mathrm{Zn}$-Ag skam deposit at Skarnovoc,

The typical environments for the $\mathrm{Au}-\mathrm{Ag}$ deposits are (Goryachev, 1998): (1) volcanic fields and resurgent subvolcanic domes which are associated with calderas of 10 to $60 \mathrm{~km}$ diameter, (2) contrasting volcanic sequences with high explosive indexes and injection breccias; (3) abundant rhyolite and dacite, with less abundant latite and trachyandesite; (4) combinations of welldefined or concealed basement faults with conformal, ring, arched, and radial fractures; (5) areas of propylitic alteration; and (6) volcanic rocks with high initial Sr ratios of greater than 0.708 . Isotopic and paleontological ages for the Au-Ag epithermal vein deposits are Late Cretaceous to Paleocene. However, older deposits, such as the Albian(?) Nyavlenga deposit exist.

The epithermal Au-Ag deposits are generally characterized by (Goryachev, 1998): (1) low or moderate sulfide contents; (2) widespread Ag-Sb sulfosalts, sulfides, selenides, and sparse Ag tellurides which occur in association with electrum and other Au and Ag intermetallides; (3) veins composed of adularia, carbonate, chalcedony, and quartz; (4) wall rock alteration to adularia, sericite, and hydromica; (4) Au:Ag ratio dominated by $\mathrm{AB}_{\mathrm{B}}(1: 1$ to $1: 2$ to 1:300); (5) an obvious vertical zoning of deposits with a stage-like occurrence of ore shoots; and (6) indications of ore regeneration caused by hydrothermal temperature inversion. The major Au deposits occur in the middle parts of the Okhotsk zone at Karamken, Agatovskoc, Oira, Burgagylkan, and Julietta. The significant deposit in the northern part of the beit is at Evenskoe. The significant deposits in the southern part of the belt are at Khakandja and Yuryevka. Mining is underway at Karamken, Agat, and Oira.

\section{Karamken Au-Ag Epithermal Vein Deposit}

The Karamken Au-Ag epithermal vein deposit (fig. 94) (Krasilnikov and others, 1971; Nekrasova, 1972; Goldfrid, Demin, and Krasilnikov, 1974; Nekrasova und Demin, 1977. Sidorov, 1978; Layer, Ivanov, and Bundtzen, 1994) consists of numerous adularia-quartz and adularia-carbonale-quartz veins more than $200 \mathrm{~m}$ long and more than $0.2 \mathrm{~m}$ thick. The veins are controlled by arcuate and linear faults which define and crosscul a caldera filled with Late Cretaceous dacite, andesite-basalt, and thyolite. The Main deposit, which contains about $80-90 \%$ of the reserves, is confined to few major veins which are spatially related to a hypabyssal body cut by circular faults and composed of andesite, andesitic dacite, volcanic breccia of andesite-dacite composition, and thyolite. The most productive veins are associated with an altered zone comprised of adularia-hydromica and quartz; and explosion and hydrothermal breccia bodies. A zone of kaolinite, alunite, and quartz alteration occurs in higher parts of the ore deposit. The ore minerals are pyrite, sphalerite, chalcopyrite, canfieldite, freibergite, tennantite, naumannite ( $\mathrm{Ag}_{\mathrm{g}} \mathrm{Se}$ ), polybasite, electrum, kitstelite, native silver, and other less common sulfides, selenides, sulfostannates, and sulfosalts of silver. The Au:Ag ratio is 1:3 to 1:4 in the richest portions of the Glavnaya vein. The veins form in clusters, which converge ar depth. The gold-canfieldite-freibergite-chalcopyrile and gold-pyrite-sphalerite zones are the most productive; at depth they are succeeded by a galena-canfieldite zone with tin-silver minerals. The deposit is medium and is mostly mined. The deposit was discovered in 1964 and produced 40 tonnes Au from 1978 to 1992 . The average grade was 100 to $129 \mathrm{~g} / \mathrm{Au}$ in 1978 and $16-18 \mathrm{~g} / \mathrm{Au}$ in 1992. Ar-Ar age isotopic study of adularia in Au-Ag vein yields an age of $79 \mathrm{Ma}$ (Layer, Ivanov, and Bundtren, 1994).

\section{Julietta Au-Ag Epithermal Vein Deposit}

The Julietta Au-Ag epithermal vein deposit (S.F. Struzhkov, O.B. Ryzhov, and V.V. Aristov, written commun., 1994; Struzhkov and othen, 1994) consists of Au-Ag sulfide-carbonate-quartz veins which occur inside a large Early Cretaceous caldera. The voleanic rocks in the caldera and associated subvolcanic intrusive rocks comprised of andesite, andesite-basalt, and andesite-dacite. The veins dip sieeply and vary from $20010500 \mathrm{~m}$ length and from 1 to $4 \mathrm{~m}$ wide. The major ore minerals are native gold and silver, freibergite, polybasite, galena, sphalerite, chalcopyrite, bessite, acantite, cubanite, pyrthotite, and nuumannite. Associated minerals in adjacent metasomatically-altered volcanic rocks are ankerite, calcite, chlorite, epidote, and hydromica. The ore minerals formed in two stages, an older gold-polymetallic stage, and a younger Au-Ag-sulphosalt stage. The deposit is medium size with an average grade of $29 \mathrm{~g} / \mathrm{Au}, 325 \mathrm{~g} / \mathrm{Ag}$. Proven reserves as of 1994 were 18 tonnes Au and 200 tonnes $\mathrm{Ag}$. Estimated resources are 40 tonnes $\mathrm{Au}$ and about 1,000 tonnes $\mathrm{Ag}$. A Rb-Sr adularia isotopic age of $136 \mathrm{Ma}$ (Struzhkov and others, 1994) suggents that the Julietta deposit and host rocks may be part of an undefined pre-accretionary metallogenic belt 
which would be hosted in the early and middle Mesozoic Kony-Murgal island-are terrane. Additional isotopie studies are needed. The deposit is currently being developed by Bema Gold Corporation and other partners.
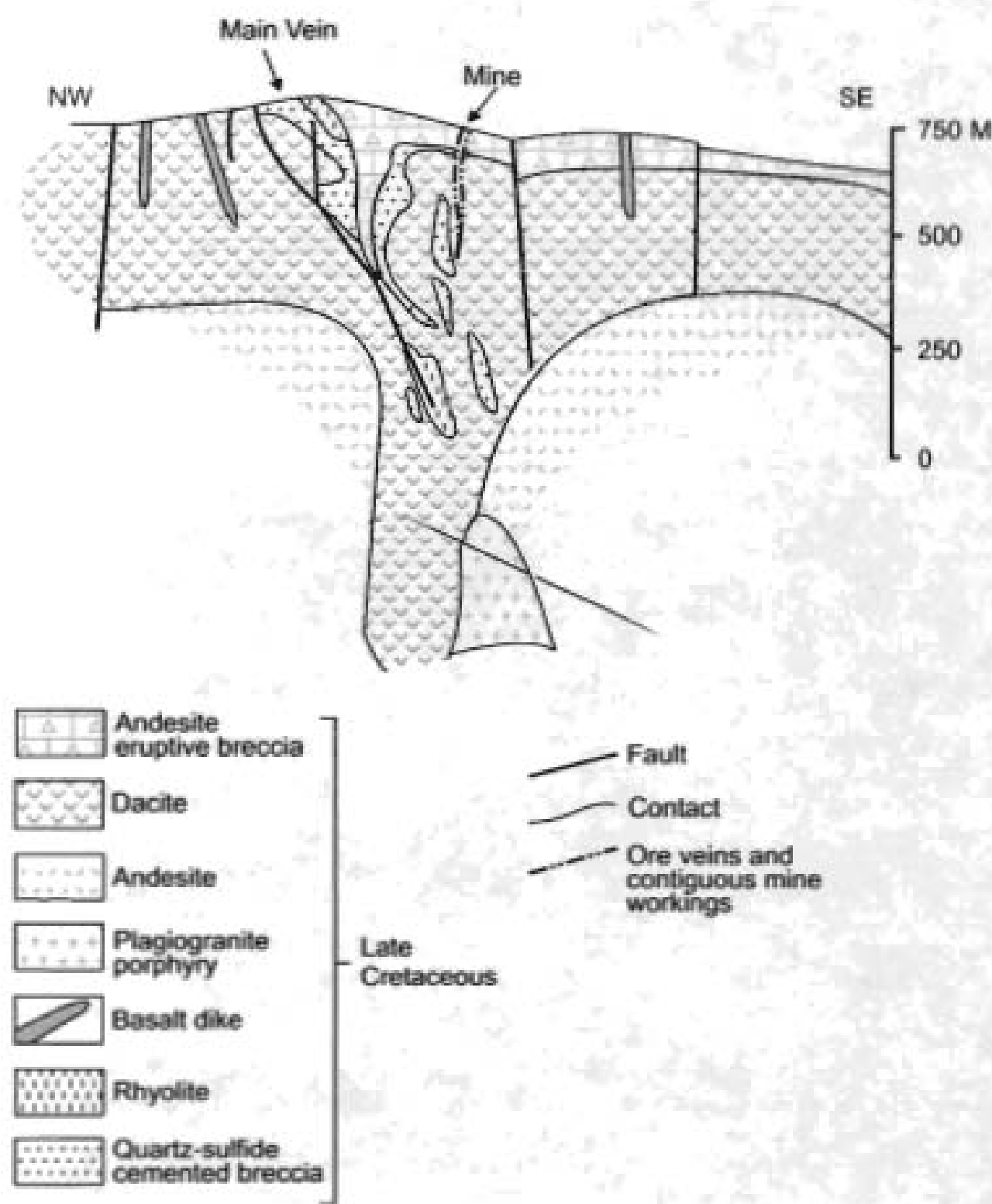

Figure 94. Karamken Au-Ag epithermal vein deposit, Okhotsk zone, Eastern Asia-Arctic metallogenic belt, Russian Northeast. Schematic cross section showing generalized geclogy of Ammanskaya volcanic structure. Adapted by N.A. Shilyaeya, using materials of R.B. Umitbeov, R.A. Eremin, G.P. Demin, and A.A. Krasilnikov, and from Sidorov and Goryachev and others (1994).

\section{Agat Au-Ag Epithermal Vein Deposit}

The Agat Au-Ag epithermal vein deposit (V.1. Naborodin, written commun, 1971, 1977) consists of several tens of quartz, carbonate-quartz, and sulfide-quartz veins which oceur in sheets of propylitically-altered Cretaceous andesite. The veins are generally simple and are controlled by northwest- to north-south-trending fissures. The ore bodies usually range from tens to hundreds of meters long, but sometimes are up to $2 \mathrm{~km}$ long; they average from $0.2101 \mathrm{~m}$ thick but are $50 \mathrm{~m}$ thick. The veins are usually altered to hydromica, chlorite, and silica; however less eroded veins display weak adularia alteration. The veins generally display a symmetrical crustification-banding and complex deformation structures. The main ore minerals are galena, sphalerite, chalcopyrite, marcasite, and pyrite. Locally present are arsenopyrite, pyrrhotite, tetrahedrite-tennantite, tellurides, Ag-sulfosalts, and other minerals. The main gangue minerals are quartz and carbonates, including calcite, dolomite, siderite, Mn-rich siderite, rhodochrosite, and kutnahorite. Barite, chalcedony, and opal occur near the periphery of the deposit. Gold occurs as electrum. The veins average 5 to $10 \%$ sulfide, but loeally ranges up to 20 to $30 \%$ sulfide. A gold-sphalerite-galena-quartz assemblage is the most productive, and is present in most veins. This assemblage also contains chalcopyrite, tetrahedrite-tennantite, Au- and $\mathrm{Ag}$ - 
tellurides, pyrargyrite, stephanite, and argentite. The Au:Ag ratio varies from 5:1 to 1:100, and averages about 1:2 to 1:5. The deposit contains estimated reserves of 3.8 tonnes $\mathrm{Au}$ and 70 tonnes $\mathrm{Ag}$. The deposit averages 6.5 to $11.8 \mathrm{~g} / \mathrm{Au}$ and 65 to $174 \mathrm{~g} / \mathrm{t}$ Ag. Bonanza ores contain up to $30 \mathrm{~kg} / \mathrm{t}$ Au.

\section{Eastern Asia-Aretic Metallogenic Belt: Koni-Yablon Zone of Porphyry Cu-Mo and Cu-Mo Skarn Deposits (Belt EAKY) Southem Part of Russian Northeast}

The Koni-Yablon zone of porphyry Cu-Mo and Cu-Mo skarn deposits (fig. 79; tables 3, 4) occurs in the southern part of the Russian Northeast. The zone occurs in the front of the Okhotsk-Chukotka volcanic-plutonic belt along the northwest margin of the Sea of Okhotsk and in plutons which intrude the Koni-Murgal island-are terrane. The significant deposits in the zone are (table 4) (Nokleberg and others 1997a, b, 1998): porphyry Mo deposits at Guan-Ti (Arkhimed), Khakandya, Molybdenitovy, Tikas, and Travka; porphyry Cu-Mo deposits at Etandzha, Gora Krassnaya, lkrimun, Osennee, Oksa, Usinskoe, Viking, porphyry $\mathrm{Cu}$ deposits at Lora, Nakhtandjin, and Yapon; a granitoid-related Au deposit at Tsirkovy; Au-Ag epithermal vein deposits at Berezovogor, Irgunei, Nyavlenga, Sergeev, and Serovskoe; a Cu skarn deposit at Maly Komui; a Mo greisen and vein deposit at Lastochka; and a volcanic-hosted $\mathrm{Hg}$ deposit at Uralskoe. The porphyry Cu-Mo deposits occur in parts of the volcanic-plutonic belt which are uplifted along major faults, as in the Okhoto-Kuhtui. Chelomdja-Yana, and Anadyr zones. Some of these zones occur along a regional gravity gradient between the front and rear zones of the volcanic-plutonic belt.

In the northeastem part of the Koni-Yablon zone, the Primagadan area, the best known part of the Koni-Yablon zone. extends along the coast of the Sea of Okhotsk for about $500 \mathrm{~km}$ and contains the Osence, Usinskoe, Nakhatandjin-Lori, lkrimum, and other deposits. These deposits occur in multiphase, large, Na-series Early Cretaceous gabbro, tonalite, granodiorite, and plagiogranite plutons which display low initial $\mathrm{Sr}$ ratios $(<0.705)$. The ore deposits occur along circular caldera structures which range from 7 to $12 \mathrm{~km}$ diameter. The porphyry deposits generally contain chaicopyrite, molybdenum, and other minerals in stringers, disseminations, veins, and stockworks (Skibin, 1982; Anorov and Mayuchaya, 1988). Across the Okhotsk-Chukotka volcanic-plutonic belt, the porphyry deposits display a zonation. From the coast into the continent, porphyry Cu deposits are successively replaced by porphyry Mo-Cu and porphyry Mo-W deposits. The zonation is correlated with a greater thickness of the granitic layer of continental crust and with the increase of leucocratic granite and granite porphyries into the continent. Ag concentrations in the porphyry deposits also increase into the continent.

In the Yablon River Basin and the Anadyr fault zone, in the extreme northeastern part of the Koni-Yablon zone, porphyry Cu-Mo deposits are associated with Cretaceous plutons of gabbro, diorite, and alkalic granite. The deposits may be controlled in part to the underlying Oloy metallogenic belt of porphyry $\mathrm{Cu}-\mathrm{Mo}$ and $\mathrm{Au}-\mathrm{Ag}$ epithermal vein deposits which is hosted in the younger (Neocomian) part of Late Jurassic-Neocomian Oloy-Svyatoy Nos volcanic belt (Nokleberg and others, 1994c, 1997c). Similar relations occur in the southwestern part of the Koni-Yablon zone where the significant deposits are the porphyry Cu-Mo deposit at Etandzha and the Cu-Mo skam deposit at Muromets. These deposits are associated with Early Cretaceous tonalite and quartz monzodiorite which intrude Cambrian dolomite and with Early Cretaceous volcanic rocks. Some deposits grade from porphyry to skarn.

\section{Nakhatandjin-Lori Porphyry Cu Deposits}

The Nakhatandjin-Lori porphyry Cu deposit (Skibin, 1982; V.B. Vorob'ev, written communication, 1986.) consists of a stockwork of sulfide, sulfide-quartz, and sulfide-chlorite-quartz veinlets associaled with disseminated sulfides occurs along east-, northeast-, and northwest-trending fault zones at the southeast and northern contacts of Srednin granitoid pluton. The pluton intrudes Triassic-Jurassic and Early Crelaceous volcaniclastic and volcanic rocks. Early Cretaceous tonalite, granodiorite, and explosive breccias which host the deposit are weakly sericitized and propylitized. Ore minerals are pyrite, chalcopyrite, and molybdenite, with subordinate magnetite and ilmenite. Deposit is closely associated with a pipe of explosive breccias. The deposits are medium to large with a probable resource of 178 million tonnes grading at least $0.5 \% \mathrm{Cu}, 0.025 \% \mathrm{Mo}$, and $2.1 \mathrm{~g} / \mathrm{Ag}$ The deposit is explored with about 100 shallow drill boles.

\section{Osennee Porphyry Cu-Mo Deposit}

The Osennee porphyry Cu-Mo deposit (L.V. Firsov and A.E. Soboleva, written comunun., 1952; S.V. Sendek, written commun. 1965) form a crescent-shaped ore body which occurs in a north-south-trending, fractured and foliated zone within the granitoid rocks of the Cretaceous part of the Magadan batholith. The deposit is more than $400 \mathrm{~m}$ long, about $30 \mathrm{~m}$ thick, and dips at $35^{\circ}$ to $65^{\circ}$. The host rocks are gabbro, granodiorite, subalkalic granite and syenite, granite porphyry, and lamprophyre. Molybdenite is accompanied by pyrite and lesset pymbotite, sphalerile, chalcopyrite, and scheelite. The molybdenite and associated minerals occur in quartz, quartz-feldspar, and quartz-lourmaline veinlets and veins, as disseminations in porphyry; and in veinlets in igneous rocks displaying silicic, sericite, chlorite, $\mathrm{K}$-feldspar, and pyrite alteration along a faulh and in adjacent areas. The deposit is small to medium, and contains from 0.1 to $0.33 \% \mathrm{Mo}$ and up to $0.1 \% \mathrm{Cu}$, and up to $5 \mathrm{~g} / \mathrm{Ag}$. Associaled, undefined amounts of $\mathrm{U}$ is also present in the porphyry deposit. 
The Etandzha porphyry Cu-Mo deposit (N.L. Kobtseva and T.G. Devyatkina, written commun., 1988) consists of stringers and disseminations of molybdenite and chalcopyrite which oceur in Cretaceous quartz dionite. The deposit oecurs along a northeast-trending zone with surface dimensions of 400 by $200 \mathrm{~m}$. Average grades are 0.02 to $2.0 \% \mathrm{Cu} ; 0.02$ to $0.74 \% \mathrm{Mo}$; up to $4 \mathrm{~g} / \mathrm{Au}$; up to $\mathrm{IS} \mathrm{g} / \mathrm{Ag}$, and unspecified amounts of $\mathrm{U}$.

The Muromets Cu-Mo skam deposit (Nikitin, Rasskazov, 1979; Krasny, Rasskazov, 1975) occurs along the contact of metasomatized Middle Cambrian dolomite and limestone which is intruded by Early Cretaceous quartz monzodiorite. The skarns occur in a zone which is I km long and dips gently $\left(20\right.$ to $\left.40^{\circ}\right)$ under the intrusion. Individual skams range from 6 to $12 \mathrm{~km}$ thick and contain disseminated, stringer-disseminated, and less common massive ore. Skarns are abundant and contain salite, diopside. scapolite, grossular, and andradite. The ore minerals are magnetite, chalcopyrite, molybdenite, scheelite, pyrthotite, bornite, pyrite, galena, and sphalerite. Magnesian skarns are less abundant and contain spinel, forsterite, phlogopite, tremolite, diopside, and serpentine. The skams developed in several stages: (1) magnesian skam with magnetite; (2) calcareous pyroxene-garnet skam with magnetite and scheelite; and (3) metasomatic quartz-feldspar rocks with molybdenite and $\mathrm{Cu}$-sulfides, Copper sulfide disseminations also oceur is altered quartz monzodiorite and form a porphyry Cu deposit. The deposit is small-to-medium size and contains up to $10 \% \mathrm{Cu}$, up to $0.92 \% \mathrm{WO}_{3}$, and up to $0.3 \% \mathrm{Mo}$.

\section{Eastern Asia-Arctic Metallogenic Belt: \\ Korkodon-Nayakhan Zone of Porphyry Mo and \\ Granitoid-Related Au Doposits (Belt EAKN) \\ East-Central Part of Russian Northeast}

The Korkodon-Nayakhan zone of porphyry Mo and granitoid-related Au deposits (fig. 79; tables 3, 4) occurs in two parts in the east-central part of the Russian Northeast. Each part is about $200 \mathrm{~km}$ long. The zone contains a small porphyry Mo deposit at Orlinoe, a granitoid-related Au deposit at Khetagchan, a Fe skarn deposit at Skarn, a Au-Ag polymetallic vein deposit at Verkhny-Koargychan, and a Fe-Pb-Cu-Ag-Au skarn deposit at Sedoi (table 4) (Nokleberg and others 1997a, b, 1998). Both types of deposits are related to subalkalic felsic and intermediate composition intrusions of granite and granosyenite. The deposits generally occur either in the apical parts of the intrusive rocks or in the adjacent wall rocks. The granitoid-related Au deposits are characterized by Ag tellurides. The deposits are generally small. Most of the lode deposits in the zone consist of sulfides disseminations and stringers. The granitoid rocks hosting the Korkodon-Nayakhan zone form a belt which is transverse or orthogonal to the Okhotsk-Chukotka volcanic-plutonic belt. The relation of the origin of the granitoid rocks to the OkhotskCbukotka volcanic-plutonic belt is unclear.

\section{Orlinoe Porphyry Mo Deposit}

The Orlinoe porphyry Mo deposit (V.N. Okhotnikov, written commun, 1957) consists of a steeply-dipping stockwork which extends for tens of melers. The stockwork consists of thin quartz veins and veinlets with disseminations and masses of molybdenite. Subordinate minerals are pyrite, chalcopyrite, wolframite, powellite, muscovite, fluorile, calcite, chlorite, and gamet. The deposit occuirs in contact-metamorphosed, Late Triassic sedimentary rocks and in Late Cretaceous granite which intrudes the sedimentary rocks. The deposit is small and averages 0.01 to $0.03 \%$ Mo, but locally ranges up to $8.5 \% \mathrm{Mo}$.

\section{Khetagchan Porphyry Granitoid-Related Au Deposit}

The Khetagchan porphyry granitoid-related Au deposit (V.A. Sidorov, written commun, 1990) consists of zones of sulfide-quartz and sulfide-chlorite-quartz veins and veinlets up to $150 \mathrm{~m}$ long and 10 to $15 \mathrm{~m}$ thick. The veins and veinlets occur along the contacts of a Late Cretaceous granodiorite; both within and adjacent to the intrusion. The ore minerals are galena, sphalerile, chalcopyrite, wolframite, pyrite, arsenopyrite, bismuthinite, native bismuth, gold, electrum, tetrahedrite-tennantite, $\mathrm{Ag}$. sulfosalts, and argentite. The deposit is judged as small and contains up to $20 \mathrm{~g} / \mathrm{t}$ Au and up to 50 to $60 \mathrm{~g} / \mathrm{Ag}$.

\section{Eastem Asia-Aretic Metallogenic Belt: \\ Verkhne Kolyma Zone of Sin-Ag Polymetallic Vein \\ (Southern Bolivian type), Sn Polymetallic Vein, \\ Rhyolite-Hosted Sn, and Granitold-Related Au Deposits \\ (Belt EAVK) Southeastem Part of Russian Northeast}

The Verkhne-Kolyma zone of Sn polymetallic vein (Southern Bolivian type), Sn-Ag polymetallic vein, thyolite-hosted Sn deposits, and granitoid-related Au deposits (fig. 79; tables 3, 4) occurs in the southeast part of the Russian Northeast. The belt trends mainly northwest-southeast, extends for about $700, \mathrm{~km}$ and ranges up to $100 \mathrm{~km}$ wide. The metallogenic belt is associated with Cretaceous plutonic rocks which intrude the North Asian Craton Margin (Verkhoyansk fold belt, unit NSV) and the Viliga passive continental-margin terrane (Nokleberg and others, 1994c, 1997e). These plutonic rocks form an orthogonal branch of the Okhotsk-Chukotka volcanie plutonic belt. Sn polymetallic vein (Southern Bolivian type) and Sn-Ag polymetallie vein deposits are 
hosted mainly in Late Cretaceous dacite and rhyolite subvolcanic dikes and stocks. The sngnificant deposits in the zone are (table 4) (Nokleberg and others 1997a, b, 1998); Sn silicate-sulfide and Sn polymetallic vein deposits at Baryllyelakh-Tsentralny.

Bogatyr, Dneprov, Kandychan, Kharan, Khenikandja. Kheta, Khuren, Kuranakh-Sala, Kyurbelykh, Porozhistoe, Svetloe, and Tigrets-Industriya; a Sn greisen deposit at Ossolony; a thyolite-hosted Sn deposit at Suvorov. Au-Ag epithermal vein deposits at Aida and Zerkalnoe; $\mathrm{Pb}-\mathrm{Zn}$-Ag vein or skam deposits at Bulunga and Tektonicheskoe, granitoid-related $\mathrm{Au}$ deposits at NetehenKhaya, Shkolnoe, a porphyry Mo deposit at Tankist; and a Co-Bi-As vein deposit at Verkhne-Seimkan. The Co and Bi deposits, as at Verkhny Seimkan, are associated with Cretaceous granitoid plutons of the Okhotsk-Chukotka volcanic-plutonic belt. The deposits are generally small, and either exhausted, partly mined, of starting to be mined, as at Shkolnoe. Local Sn deposits with $\mathrm{Ag}, \mathrm{Pb}$, and $\mathrm{Zn}$, may be of future economic interest.

\section{Tigrets-Industriya Sn Polymetallic Vein Deposit}

The small Tigrets-Industriya Sn polymetallic vein deposit (Lychagin, 1967; Plyashkevich, 1990) consists of quartzcarbonate-sulfide, quartz-sulfide, and sulfide-quartz veins, and lenticular bodies and zones of veinlets which oceur in weakly metamorphosed Late Permian sedimentary rocks intruded by a Late Cretaceous granite porphyry. The ore bodies occur along northeast-trending fractures, are 100 to $200 \mathrm{~m}$ long, and range from 0.1 to $0.8 \mathrm{~m}$ thick. Late Cretaceous siliceous lava flows occur peripheral to the mineralized area. Several Sn and Ag mineral assemblages occur in the deposit. A period of deformation separated early and late stages. The early assemblage consists of quartz-cassiterite and polysulfide containing cassiterite, ansenopyrite, pyrite, chalcopyrite, sphalerite, galena, canfieldite, Fe-freibergite, stannite, and pyrargyrite. The late seleno-canfieldite-quartz assemblage contains quartz, pyrite, sphalerite, galena, stannile, selenocanfieldite, and Mn-calcite.

\section{Kandychan Sn Polymetallic Vein Deposit}

Sn polymetallic vein deposits, as at Kandychan and Kheta, ure hosted mainly in Late Cretaceous subvolcanic and flow rocks of moderately felsic to felsic composition. The Kandychan deposit (Firsov, 1972; Lugov and others, 1974a, b; N.E. Savva, written commun., 1980) consists of groups of veins and veinlets which occur in a generally north-south-trending band more than 2 $\mathrm{km}$ long and from 500 to $600 \mathrm{~m}$ wide. The host volcanic rocks are propylitized, silicified, and argillized. The ore bodies consist of quartz-chlorite-cassiterite-sulfide veins with various carbonates (calcite, siderite, dolomite), sericite, hydromica, kaolinite, dickite, pyrophyllite, fluorite, and tourmaline. The sulfide minerals are mainly stannite, pyrargyrite, hessite, and argentite; and lesser pyrite, chalcopyrite, arsenopyrite, marcasite, pyrrhotite, sphalerite, galena, bornite, and covellite. The deposit is characterized by high Ag. Bi, Co, and Au. The sulfide veins with colloform cassiterite near the surface change with depth to low-sulfide chloritequartz veins with crystalline cassiterite. The deposit is small, is partly mined, and has produced 2,000 tonnes $\mathrm{Sn}$.

\section{Suvorov Rhyolite-Hosted Sn Deposit}

Rhyolite-hosted Sn deposits, as at Suvorov, and Sn polymetallic vein and Sn greisen deposits, as at Doeprovskoe and Khenikandja, are associated with small Cretaceous granitoid plutons. The Suvorov rhyolite-hosted Sn deposit (Lugov and othen, $1974 \mathrm{a}, \mathrm{b}$, Flerov, 1974) consists of colloform cassiterite nodules (wood tin) which occur in intensely silicified and kaolinized, fluidal thyolite, agglomerate vitric tuff flows, and tuff- and lava-breccia. The host Late Cretaceous volcanic rocks form various volcanic vent facies, Cassiterite is associated with fine-grained quartz, bematite, chlorite, kaolinite, pyrite, and ansenopyrite. The ore is characterized by high $\mathrm{Fe}$ and $\mathrm{ln}$. The deposit is small.

\section{Shkolnoe Granitoid-Related Au and Au Quartz Vein Deposit}

The Shkolnoe granitoid-related Au and Au quartz vein deposit (fig. 95) (Orlov and Epifanova, 1988; S.V. Voroshin and others, written commun., 1990; Palymsky and Palymskaya, 1990; V.A. Banin, written commun., 1993; Goncharov, 1995; Goryachev, 1998, 2003) consists of an en echelon system of quartz veins which trend generally east-west. The veins occur in a multiphase granitoid stock about $4 \mathrm{~km}^{2}$ composed mainly of granodiorite and adamellite. The stock is intruded by dikes of graniteporphyry, thyolite, pegmatite, aplite, and lamprophyre. The quartz veins are surrounded by zones of beresitic and argillic alieration, and skam and greisen alieration also locally is present. The deposit occurred in two stages separnted by intrusion of lamprophyre dikes (Goryachev, 1998): (1) an older granitoid-related Au vein deposit containing molybdenite, arsenopyrite, Wellingite, native bismuth, Bi-tellurides, and native gold (berein interpreted as part of the Yana-Kolyma metallogenic belt); (2) the most economically-important stage, a Au quartz vein deposit containing arsenopyrite, pyrite, galena, sphalerite, gold, electrum, freibergite, tetrabedrite, $\mathrm{Pb}-\mathrm{Sb}$ and $\mathrm{Ag}$-sulfosalts, argentite, and stibnite. The Au ore bodies extend to great depth into a large zone of complicated mineralogy, geochemistry, and structure. The total reserves are estimated at 32 tonnes Au averaging $29 \mathrm{~g} / \mathrm{Au}$ and $45 \mathrm{~g} / \mathrm{Ag}$. The mine at the deposit has produced $17 \mathrm{t}$ Au and 17 t Ag from 1991 to 1997. 

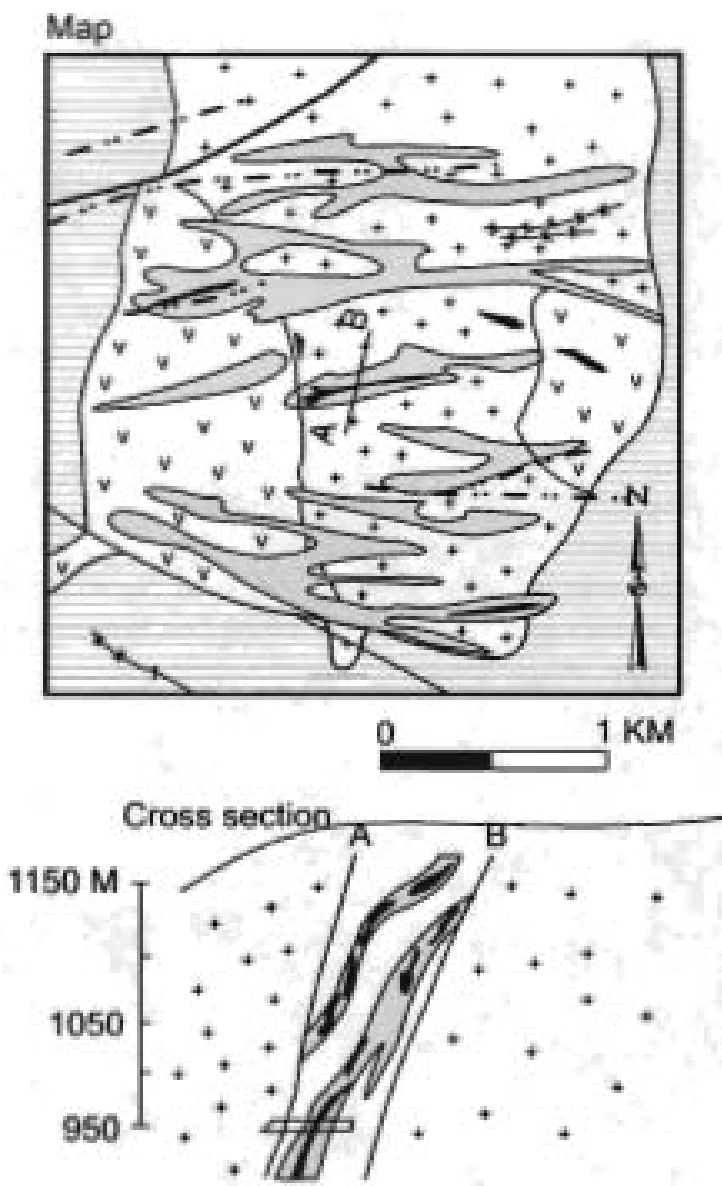

2.* Felsic dike (Late Cretaceous)

-* Mafic dike (Late Cretaceous)

\section{$\because:$ Granitic rocks (Early Cretaceous)}

V.y Quartz diorite (Late Jurassic and

r.y. Earty Cretaceous)

Sedimentary rocks (Early and Late Permian)

$\square$ Metasomatic rocks

- Granitoid-related Au veins and pods

Fault

\section{$\sim$ Contact}

Figure 95. Shkolnoe graniloid-related Au deposk, Verkhne Kolyma zone, Eastern Asia-Arctic metallogenic belt, Russian Northeast. Schematic geologic map and cross section. Adapted from Sidorov and Goryachev (1994) and Sidorov and Eremin (1995).

\section{Eastern Asia-Arctic Metallogenic Beit: Vostochno-Verkhoyansk Zone of Ag Polymetallic Vein and Clastic Sediment-Hosted $\mathrm{Hg}$ Deposits (Beit WV) West-Central Part of Russian Northeast}

The Vostochno-Verkhoyansk metallogenic zone of $\mathrm{Ag}$ polymetallic vein and clastic sediment-hosted $\mathrm{Hg}$ deposits (fig. 79; tables 3, 4) occurs in two fragments, each $250 \mathrm{~km}$ long and $20-50 \mathrm{~km}$ wide, in the west-central part of the Russian Northeast 
(Goryachev, 1998, 2003). The deposits are hosted in Carboniferous and Permian clastic rocks of the North Asian Craton Margin (Verkhoyansk fold belt, unit NSV; Nokleberg and others, 1994c, 1997c). The Vostochno-Verkhoyansk metallogenic belt is the loci of old mining which started in the 18 th century. The belt contains newly-discovered deposits which are currently being developed for mining. The significant deposits in the belt are Ag polymetallic vein deposits at Altaiskoe, Bezymyannoe, Kuolanda, Mangazeika, Prognoz, and Verkhnee Merkeche, and a Sin polymetallic vein deposit at Imtachan (table 4) (Nokleberg and others 1997a, b, 1998). Ag polymetallic vein deposits and oceurrences, as at Altaiskoe, Mangazeika, and Menkeche, oceur in longitudinal and diagonal faults which crosscut the hinges of major folds.

The age of mineralization for the Vostochno-Verkhoyansk metallogenic belt is interpreted as Late Cretaceous to Paleogene because the deposits formed prior to the development of the clastic sediment-hosted $\mathrm{Hg}$ deposits of the VerkhoyanikIndigirka metallogenic belt in the same region (Indolev, 1979; Goryachev, 1998). The Vostochno-Verkhoyansk metallogenic zone is interpreted as forming in the rear (back-arc) part of the Cretaceous and early Tertiary Okhotsk-Chukotka voleanic-plutonic belt (fig. 79).

\section{Mangazeika Ag Polymetalite Vein Deposit}

The Mangazeika deposit (N.A. Tseidler, written commun., 1985; Goryachev, 1998) consists of polymetallic veins which occur in Early Permian argillite and sandstone which occur in gently-plunging tight folds. The veins fill fissures between argillite and sandstone layers and are conformable to bedding. The veins fange from $50101,300 \mathrm{~m}$ long, and from $3 \mathrm{~cm}$ to $1 \mathrm{~m}$ thick. The main ore minerals are galena and sphalerite; minor minerals are pyrite, arsenopyrite, chalcopyrite, owyheeite, freibergite. diaphorite, boulangerite, pyrargyrite, miargyrite, cassiterite, stannite, and native gold, native silver, and argentite. Gangue minerals are manganosiderite, quartz, ankerite, sericite, chlorite, and tourmaline. This and similar deposits do not contain significant amounts of sulfide minerals; silver amalgam is locally present. Other deposits, as at Menkeche and Bezymyannoe, are associaled with Early and Late Cretaceous basaltic dikes and associated Sn polymetallic vein deposits. Wallrock alteration, including carbonization and silicification, is not significant. Estimated reserves are 62,375 tonnes $\mathrm{Pb}, 2,900$ tonnes $\mathrm{Zn}$, and 324 tonnes $\mathrm{Ag}$. Estimated total resources are more than 1,000 tonnes Ag. Average grades are $75 \% \mathrm{~Pb} ; 0.3-5 \%$ An; $500-3,938$ g/t Ag; and 0.1-0.5 g/t Au. Silver was mined from 1915-1922.

\section{Eastem Asia-Arctic Metallogenic Beit: Adycha-Taryn Zone of Au-Ag Epithermal Vein, Ag-Sb Polymetallic Vein, and Clastic Sediment-Hosted Sb-Au Deposits (Belt AT) Westem Part of Russian Northeast}

The Adycha-Taryn metallogenic zone forms a linear array of clastic sediment-hosted Sb-Au, Au-Ag epithermal vein, and $\mathrm{Ag}$-Sb polymetallic vein associated deposits (fig. 79, tables 3,4) which oceur adjacent to the Adycha-Taryn fault in the western part of the Russian Northeast (Goryachev, 1998). The Adycha-Taryn fault is a major collisional suture zone between the KularNera accretionary-wedge terrane of the Kolyma-Omolon terrane to the northeast and the North Asian Craton Margin (Verkhoyansk fold belt, unit NSV) to the southwest (Nokleberg and others, 1994c, 1997c). The metallogenic belt is about $750 \mathrm{~km}$ long and 5 to $10 \mathrm{~km}$ wide. Several groups of deposits occur in the metallogenic belt (table 4) (Nokleberg and others 1997a, b, 1998): (1) small Au-Ag epithermal vein deposits, as at Ak-Altyn; (2) small Ag-Sb polymetallic vein occurrences; and (3) highgrade clastic-sediment-hosted Au-Sb deposits, as at Billyakh, Sarylakh, Sentachan, and Uzlovoe. Many of the clastic-sedimentbosted Au-Sb deposits, as at Sarylakh, are partly mined out.

The age and genesis of the Adycha-Taryn zone is more complex than previously interpreted because some of the deposits: (1) are not evidently magmatism-felated; (2) are relatively younger than Au quartz vein and $\mathrm{Sn}$-W vein deposits which occur in the same area; and (3) locally crosscut homfels near granite intrusions which exhibit K-Ar isotopic ages of 110 to $90 \mathrm{Ma}$. Three possible origins are suggested for the genesis of the Av-Sb deposits in the Adycha-Taryn metallogenic belt. (1) A deep and possible mantle origin may be indicated by the local eccurrence of native metals in the Au-Sb deposits (Anisimova and others, 1983). (2) The clastic-sediment-bosted Au-Sb deposits, which occur in and near the major Adycha-Taryn fault, may have formed in an accretionary environment and are related to metamorphism which occurred immediately affer collision and accretion of the Kolyma-Omolon superterrane to the North Asian Craton Margin (Verkhoyansk fold belt, unit NSV, fig. 79) along the AdychaTaryn fault (Berger, 1978, 1993, Nokleberg and others, 2000). And (or; 3) the Au-Sb epithermal deposits and the polymetallic vein deposits may have formed in a post-accretional environment and are related to younger, Cretaceous and Paleogene basaltic magmatism in the region (Indolev and othen, 1980). Alternatively, the clastic-sediment-hosted Au-Sb deposits may be part of a suite of quartz vein deposits and are part of the Yana-Kolyma metallogenic belt (Berger, 1978, 1993). The epithermal and polymetallic vein deposits of the Adycha-Taryn metallogenic zone are herein interpreted as forming in the tear and transverse part of the Cretaceous to early Tertiary Okhotsk-Chukotka volcanic-plutonic belt (fig. 79) which forms a major, post-aceretionary continental-margin ares in the Russian Northeast (Nokleberg and others, 1994c, 1997e; 2000). 
The Sentachan clastic-sediment-hosted Au-Sb deposit (Shur, 1985; Indolev und others, 1980; V.V. Maslennikov, written commun. 1985) consists of two rod-like veins which vary from 85 to $200 \mathrm{~m}$ long and up to $3.1 \mathrm{~m}$ thick which occur in northweststriking shear zones in northwest-trending faults which are part of the Adycha-Taryn fault zone. The veins are hosted in Late Triassic (Norian and Rhaetian) clastic rocks which are deformed northwest-trending gently-plunging folds parallel to the fault. The main minerals are stibnite and quartz; subordinate minerals are ankerite, muscovite, pyrite, arsenopyrite, dickite, and hydromica. Rare minerals are sphalerite, gold, chalcostibnite, berthierite, tetrahedrite, zinkenite, jamesonite, aurostibnite, and chalcopyrite. The wallrocks exhibit silicic, carbonate, hydromica, and dickite alteration. The grade varies from 3.2 to $40.3 \%$ Sb. Mined and proven reserves total 100,000 tonnes Sb, making the Sentachan Au-Sb deposit one of Asia's largest Sb deposits.

\section{Ak-Aityn Au-Ag Epithermal Vein Deposit}

The small Ak-Altyn Au-Ag epithermal vein deposit (Yu.A. Vladimirtseva, written commun., 1985) consists of quartz and quartz-carbonate veins, up to 2 to $3 \mathrm{~m}$ thick and stringers which occur in a zone $10-30 \mathrm{~m}$ wide and $150 \mathrm{~m}$ long. The deposit is hosted in gently-dipping Middle Triassic (Ladinian) terrigenous rocks which are intruded by Early Cretaceous diorite porphyritic dikes. The ore is dominated by fine-grained quartz (chalcedony) with sparse sulfides (about $1 \%$ ), including galena, sphalerite, chalcopyrite, arsenopyrite, and pyrite. Gold fineness is low, Average grades are $0.2-60.4 \mathrm{~g} / \mathrm{t} \mathrm{Au}$; and $0.1-1 \%$ combined Ag. $\mathrm{Hg}$. $\mathrm{Pb}, \mathrm{Sb}, \mathrm{Zn}, \mathrm{As}$, and $\mathrm{Cu}$.

\section{Eastem Asia-Aretic Metallogenic Belt: Omsukchan Zone of Sn Polymetallic Vein, Sn Silicate-Sulfide, Porphyry Sn, Au-Ag Epithermal Vein, Porphyry Mo-Cu, and Associated Deposits (Belt EAOM) Southeastern Part of Russian Northeast}

The Omsukchan metallogenic zone (fig. 79; tables 3,4) occurs in the southeastern part of the Russian Northeast and forms an exiensive transverse (orthogonal) branch of the East Asian-Arctic metallogenic belt. The zone occurs in and near the Okhotsk-Chukotka volcanic-plutonic belt (Nokleberg and others, 1994c, 1997c), is more $150 \mathrm{~km}$ long, and ranges from 10 to 15 up to 60 to $70 \mathrm{~km}$ wide. The significant deposits in the zone are Sn polymetallic vein deposits at Maly Ken and Trood, Sn silicatesulfide vein deposits at Egorlyk, Galimoe, Khataren-Industrial, and Okhotnichie, Au-Ag epithermal vein deposits at Arylakh, Dukat, and Rogovik, porphyry Sn deposits at Ircha, Nevskoe, and Novy Djagyn, and Sb-Au and polymetallic vein deposits at Elombal, Mechta, Tidit, and Yakor (table 4) (Nokleberg and others 1997a, b, 1998). Mainly Sn and Ag polymetallic vein, and W, $\mathrm{Au}$, and $\mathrm{Co}$ vein deposits occur in the northern and middle parts of the belt, whereas mainly Au-Ag epithermal vein and porphyry Mo-Cu deposits occur in the southerm part.

The Omsukchan metallogenic belt occurs in a unique, local extensional tectonic environment in continental crust up to 52 $\mathrm{km}$ thick, which in herein interpreted as forming in the back-arc portion of the Okhotsk-Chukotka volcanic-plutonic belt. The rifttrough is filled by Early Cretaceous voleanic and sedimentary sequences of continental coal-bearing molasse which are unconformably overlain by Albian through Cenomanian andesite, rhyolite, and ignimbrite. The total thickness is greater than $3,000 \mathrm{~m}$. The lower part of the molasse includes the Aptian Ascoldin Formation which is composed of high-siliceous, ultrapotassic rhyolite. The plutonic rocks associated with the metallogenic belt are dominated by the potassic biotite granite of the Omsukchan Complex which has a K-Ar isotopic age of approximately $90 \mathrm{Ma}$, and a Rb-Sr whole-rock isochron age of $80 \mathrm{Ma}$ (Goryachev, 1998).

The significaat Sn and Sn-Ag deposits, mainly Sn polymetallic vein, Sn silicate-sulfide, and porphyry Sn deposit types, are at Nevskoe, Galimoe, Ircha, Khataren-Industrial, Trood, Novy Djagyn, and Maly Ken. Some of these deposits were recently discovered. Most of the numerous, small, but rich and quickly exploited Sn deposits were exhausted in the 1940s. Various types of $\mathrm{Sn}$ deposits are associated with the Omsukchan granite and comagmatic extrusive-subvolcanic complexes. At depths, these Sn deposits are associated mainly with granitoid plutonic rocks. At intermediate levels, the Sn deposits are associated with volcanic and plutonic rocks. Near the surface, the $\mathrm{Sn}$ deposits are associated with volcanic rocks, and consist mainly of Sn-Ag deposits, and associated $\mathrm{Ag}$-polymetallic and $\mathrm{Au}-\mathrm{Ag}$ epithermal vein deposits. The significant $\mathrm{Ag}$-polymetallic vein deposits are at Mechta and Tidit.

\section{Nevskoe Porphyry Sn Deposit}

The Nevskoe porphyry Sn deposit (Lugov, Makeev, and Potapova, 1972; Lugov, 1986) consists of fine-grained, complexly intergrown pyrophyllite, topaz, quartz, muscovite, and cassiterite. Also widespread are tourmaline, chlorite, wolframite, arsenopyrite, chalcopyrite, galena, sphalerite, pyrite, pymhotite, marcasile, letrahedrite-tennantite, stannite, rutile, and scheelite. Semseyite, guanajuatite, laitakarite, silver, zunyite, apatite, fluorite and other minerals are rare. Sn content decreases with depth, as does topaz and pyrophyllite; quartz content increases with depth. The deposit occurs in a district which extends north-northwest along a zone of intensely fractured Early Cretaceous clastic sedimentary rocks. The zone has surface dimensions of 180 by $350 \mathrm{~m}$. 
The clastic sedimentary rocks are replaced by quartz, tourmaline, pyrophyllite, kaolinite, and locally, by dumortierite and topaz. The ore bodies coineide with the most altered rocks, are pipe-like, and extend along strike for hundreds of meters. The mine at the deposit is of small to medium size and is mostly exhausted.

\section{Mechta Ag-Polymetallic Vein Deposit}

The Mechta Ag-polymetallic vein deposit (V.I. Tkachenko and others, written commun., 1976-1979; Plyashkevich, 1986; V.I. Kopytin, written commun., 1987) consists of a set of en-echelon, generally north-south-trending, arcuate fracture zones which range from 3.5 to $4 \mathrm{~km}$ wide and $10 \mathrm{~km}$ long. The zones contain quartz-chlorite-sulfide veins and veinlets. The ore bodies form a fan-like structure which branch at the upper levels and are hosted by Late Cretaceous ignimbrites with propylitic and argillic alteration. The main vein minerals are Ag-bearing galena, sphalerite, chalcopyrite, pyrite, arsenopyrite, freibergite, pyrargyrite, stephanite, famatinite, tennantite, argentite, quartz, chlorite, and hydromica. Subordinate minerals are pyrrhotite, stannite, native gold and silver, feldspar, kaolinite, and carbonate. Ores are dominated by galena-sphalerite and chalcopyrite-freibergite associations. The deposit is of medium size with average grades of about $1 \% \mathrm{~Pb}$, and $0.74 \% \mathrm{Zn}$, and up to $310 \mathrm{~g} / \mathrm{Ag}$ and $0.3 \mathrm{~g} / \mathrm{t}$ Au.

\section{Dukat Ag Epithermal Vein Deposit}

The major Ag epithermal vein deposit at Dukat (fig. 96) (Brostovskay and others, 1974; Savva and Raevskaya, 1974; Kalinin, 1975a, 1986; Raevskaya, Kalinin, and Natalenko, 1977; Sidorov, 1978; Natalenko and others, 1980; Sakharova and Bryzgalov, 1981; Sidorov and Rozenblum, 1989; Shergina and others, 1990; Goncharov, 1995) consists of numerous, extensive disseminated replacement zones, and quartz-adularia-rhodochrosite-rbodonite veins with diverse $\mathrm{Ag}$ - and base metal sulfide minerals. The estimated reserves are 15,000 tonnes silver (Natalenko and others, 1980; Konstantinov and others, 1998). The deposit occurs in ultra-potassic thyolite, part of the Early Cretaceous Askoldin igneous complex which occurs over a concealed cupola of the Omsukchan granite. This deposit differs from similar precious metal epithermal deposits by a predominance of $\mathrm{Ag}$ and multi-stage formation from the Early Cretaceous through the early Paleogene. This rich vein deposit is interpreted as forming during partial $\mathrm{Ag}$ remobilization of the disseminated sulfide minerals which were deposited during Early Cretaceous Askoldin magmatism (Milov and others, 1990). This mining district has potential for additional, undiscovered deposits, similar to Dukat, with bulk-mineable low-grade Ag deposits similar to Waterloo, and other Ag pipe-like deposits in Mexico (Natalenko and Kalinin, 1991).

\section{Eastern Asia-Arctic Metallogenic Belt: Chokurdak Zone of Granitoid-Related Sn Greisen, Sn-Polymetallic Vein, Sn Greisen, and Au-Ag Epithermal Vein Deposits (Belt EACD) Northern Part of Russian Northeast}

The Chokurdak metallogenic zone of granitoid-related Sn greisen, Sn polymetallic vein, and Au-Ag epithermal deposits (fig. 79; tables 3,4) occurs in the northern part of the Russian Northeast. The deposits are closely related to mid-Cretaceous felsic volcanic rocks and associated Late Cretaceous leucocratic granite dikes and plutons with K-Ar isotopic ages of 90 to $105 \mathrm{Ma}$ (Nokleberg and others, 1994c, 1997c). The significant deposits in the zone are Sn silicate-sulfide vein deposits at Chokurdakh, Churpunnya, and Sigilyakh, Sn polymetallic vein and Sn greisen deposits at Pavel-Chokhchurskoc, Deputatskoe, Djaktardakh, Khomustak, Odinokoe, and Ukachilkan, and $\mathrm{Sn}$ and $\mathrm{Au}-\mathrm{Ag}$ polymetallic vein deposits at Polevaya, Primorskoe, and Yuzhnoe (table 4) (Nokleberg and others 1997a, b, 1998). The Chokurdak metallogenic belt is hosted in one of the rear, mid- to Late Cretaceous parts of the Okhotsk-Chukotka volcanic-plutonic belt (Nokleberg and others, 1994c, 1997c).

The Sn polymetallic vein deposits, as at Primorskoe, Deputatskoe, and Dyaktardak, are associated with small intrusions of moderately felsic granite and quartz monzonite with $\mathrm{K}$-Ar isotopic ages of 110 to $100 \mathrm{Ma}$, and with subalkalic mafic and intermediate dikes with K-Ar isotopic ages of $100-70 \mathrm{Ma}$. These granitoid rocks constitute one of the rear parts of the OkhotskChukotka volcanic-plutonic belt. Sn greisen deposits, as at Khomustak and Odinakoe, occur in the apical portions of granitic intrusions or in subvolcanic rhyolite bodies, as at Churpunya and Odinokoe. Economic $\mathrm{Sn}$ deposits occur at Deputatskoe and Churpunnya. The Sn deposits are the sources for commercial cassiterite place deposits in the region, including a coastal belt of Sn placer deposits. 


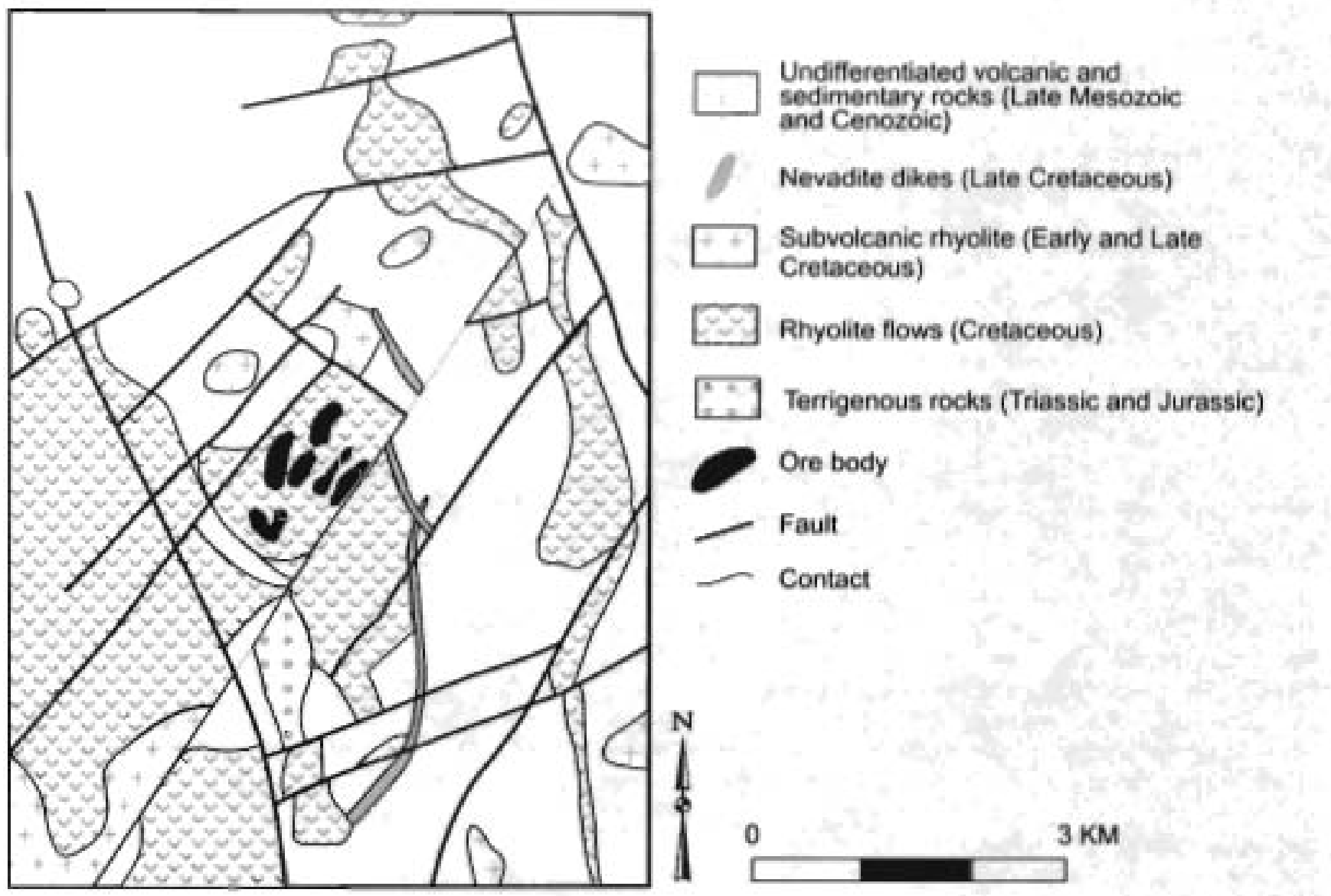

Figure 96. Dukat Au-Ag opithermal vein deposit, Omsukchan zone, Eastern Asia-Arctic metallogenic beit, Russian Northeast. Schematic geologic map of deposit and surrounding area. Adapted from Goncharov (1995a).

\section{Deputatskoe Sn Polymetallic Vein(7) Deposit}

The Deputatskoe Sn polymetallic vein(?) deposit (Flerov, 1974) includes about 150 separate ore bodies which occur in shear zones, veins, and linear stockwork zones. The main ore bodies occur in mineralized zones which are explored to depths of more than $350 \mathrm{~m}$ with adits and drillholes. The deposit ranges up $1018 \mathrm{~m}$ thick and up to $1400 \mathrm{~m}$ long. Major and minor minerals are quartz, tourmaline, chlorite, axinite, fluorite, pyrthotite, cassiterite, chalcopyrite, pyrite, siderile, ankerite, sphalerite, galena, marcasite, wolframite, stannite, franckeite, boulangerite, bismuth, bismuthine, topaz, apatite, scheelite, and sulfosalts. The walltrocks altered to silica, tourmaline, chlorite, and less common greisen and sulfides. The deposit is large with an average grade of 0.3-0.7\% Sn, and local high-grade zones with up to $10 \% \mathrm{Sn}$. The deposit hosted in contact metamorphosed Middle Jurassic shale and in an unexposed granile slock which is penetrated by drilling at $377 \mathrm{~m}$ depth. The stock exhibits a K-Ar isotopic age of 108 to $104 \mathrm{Ma}$. Pre-deposit, coeval and post-deposit dikes of mafic, intermediate, and felsic intrusive rocks are wide-spread. Many of the polymetallie veins occur in felsic and intermediate dikes. The Deputatskoe deposit has been the largest producer of Sn in the Russian Fat East.

\section{Churpunnya Sn sillicate-Sulfide Vein Deposit}

The Churpunnya Sn silicate-sulfide vein deposit (Nekrasov and Pokuovsky, 1973; Flerov and Shur, 1986; A.1. Kholmogorov, written commun, 1987) consists of shear zones, stringers, and veins with tourmaline and quartz-tourmaline; cassiterile (up to 1066), sericite, marcasite, and 1-2\% arsenopyrite, bismuth, bismuthine, wolframile, pyrnhotite, chalcopyrite, stannite, valleriite, siderite. The ore zones range from 0.1 to $0.7 \mathrm{~m}$ thick, are about one hundred meters long, and are drilled to a depth of $15010200 \mathrm{~m}$. The deposit is small and locally contains up to $10 \% \mathrm{Sn}$. The deposit hosted in intensely tourmalinized and silicified thyolite-dacile voicanic rocks and in a related Early Cretaceous granitoid stock. (Layer and others, 1999.) 
Eastern Asia-Arctic Metallogenic Beit:

Chaun Zone of Granitic-Magmatism-Reiated

Deposits (Belt EACN) Northeastem Part of

Russian Northeast

The Chaun zone of felsic-magmatism-related deposits (fig. 79; tables 3,4) occurs in the northeastem part of the Russian Northeast (Goryachev, 1998, 2003; this study). The principal deposit types in the Chaun zone are Sn silicate-sulfide vein, Sn greisen, Sn skarn, porphyry Sn, Sn and Sn-Ag polymetallic vein, and granitoid-related Au deposits. The zone occurs in the rear of the Okhotsk-Chukotka volcanic-plutonic belt and adjacent areas (Nokleberg and others, 1994c, 1997c), and extends approximately east-west for about $1,300 \mathrm{~km}$ from the mouth of the Kolyma River to Uelen. The Chaun zone is correlated across the Bering Straits with the Seward Peninsula metallogenic belt in northwestem Alaska which contains similar deposits (fig. 80). The significant deposits in the zone are (table 4) (Nokleberg and others 1997a, b, 1998); Sn silicate-sulfide vein and Sn polymetallic vein deposits at Dioritovoe, Elmaun, Enulen. Eruttin. Ichatkin, Kekur, Kukenei, Lunnoe, Mramomoe, Mymlerennet, Telekai, Valkumei, and Vodorazdelnoye; porphyry Sn deposits at Ekug and Pyrkakai; granitoid-related Au deposits at Kanelyveen and Kuekvun; porphyry $\mathrm{Cu}-\mathrm{Mo}$ and porphyry Mo deposits at Granatnoe and Shurykan; $\mathrm{Pb}-\mathrm{Zn}$ skarn and $\mathrm{Fe}-\mathrm{Pb}-\mathrm{Zn}-\mathrm{Sn}$ deposits at Chechekuyum, Enpylkhkan, Melyul, Reechen, und Serdtse-Kamen; an Au-Ag epithermal vein deposit at Pepenveem; a disseminated Au-sulfide deposit at Tumannoe; and a clastic sediment-hosted $\mathrm{Hg}$ or hot-spring $\mathrm{Hg}$ deposit at Yassnoe.

The $\mathrm{Sn}$ and associated lode deposits of the Chaun zone are generally hosted in: (1) volcanic rocks and rhyolite subvolcanic intrusions and extrusions which often have anomalous In and $\mathrm{Ag}$ : (2) major plutons of Late Cretaceous leucocratic biotite granite with K-Ar isotopic ages of $95-70 \mathrm{Ma}$; and (3) late Early Cretaceous diorite (Kanelyveen deposit). The deposits generally oceur in the apical parts of the granitic intrusions and in the intnusive domes. The typical deposit minerals are quartz, tourmaline, chlorite, and sulfide minerals. In westem Chukotka, the significant deposits are at Valkumei, currently being mined, and at Pyrkakai, Ekug, Telekai, and Kukenei, and a possible granitoid-related Au deposit at Kanelyveen. In eastern Chukotka, significant Sn-Ag skam and polymetallic vein deposits at Chechekuyum, Reechen, and Enpylhkan are hosted in Paleozoic carbonate rocks.

Also part of the Chaun zone of felsic-magmatism-related deposits is a group of Sn and complex Sn-W polymetallic vein, minor associated Sn greisen deposits which oceur in middle Paleozoic and early Mesozoic sandstone, argillite, and rare carbonate rocks of the Chauna subterrane (fig. 79). The polymetallic lode deposits are closely associated with Early and mid-Cretaceous analectic, leucocratic, potassic granitoid plutons. The main Sn-W vein deposits occur to the east in the lultin ore district. The Iultin, Svetloe, Chauntal, Tenkergin, and associated deposits of this district contain the most of the inferred tungsten reserves for the region, and the lultin and Svetloe deposits produce all of the fungsten and by-product tin in the Russian Northeast.

\section{Iultin Sn-W Polymetalike Vein and Greisen Deposit}

The lultin Se-W polymetallic vein and greisen deposit (fig. 97) (Zilbermints, 1966; Lugov, Makeev, and Potapova, 1972; Lugov, 1986) consists of quartz veins, mineralized stockwork zones, and disseminated veinlets hosied in greisen. The stockwork zones and veinlets are both steeply-dipping and gently-dipping. Some ore bodies wedge out vertically. The W ore bodies oecur over the top of a leucogranite pluton which is about $300 \mathrm{~m}$ below the surface; and the Sn ore bodies occur in the marginal zone of the leucogranite. Approximately 65 minerals are known with the most common being quartz (95\%), muscovite, fluorite, albite, cassiterite, wolframite, arsenopyrite, and loellingite. Less common are topaz, pyrite, pyrthotite, bismuthinite, stanaite, chalcopyrite, sphalerite, galena, molybdenite, scheelite, hematite, and native silvet and bismuth. Cassiterite is commonly associated with wolframite, arsenopyrite, and muscovite. Cassiterite occurs as short, columnar crystals up to $10 \mathrm{~cm}$ across. Large (up to $4-9 \mathrm{~cm}$ ) and gigantic (up to $0.5 \mathrm{~m}$ ) wolframite crystals and crystal intergrowths are present. The vertical extent of the ore bodies exceeds $900 \mathrm{~m}$. The deposit occurs along the contact of the mid-Cretaceous lultin granite with a K-Ar age of $90-110 \mathrm{Ma}$ which intrudes and contact metamorphosed and metasomatizes Early and Late Triassic sandstone and shale. The biotile granite has a Rb-Sr isotopic age of $85.1 \mathrm{Ma}$ with an initial $\mathrm{Sr}$ ratio of 0.7085 (Dudkinsky and others, 1986). The late stage of the lultin intrusive complex consists of leucocratic granite with a Rb-Sr isotopic age of $76.3 \mathrm{Ma}$ and an initial Sr natio of 0.717. The deposit is large and has been mined since 1959 with an average grade of $0.43 \%$ Sn and $1.29 \%$ wO,. The lutin deposit has produced significant $\mathrm{W}$ and $\mathrm{Sn}$ in past years, but is now inoperative.

\section{Svetloe Sn-Quartz Vein Deposit}

The Svetloe Sn-quartz vein deposit (Lugov, 1986; Kuleshov, Pristavko, and Plyashkevich, 1988) consists of en-echelon sets of quarte veins and veinlets which form two zones which diverge to the southeast. Each zone contains several tens of larger veins which vary from 0.2 to $1.5 \mathrm{~m}$ thick and are several hundreds of meters long; and about one hundred smaller veins. The ore is dominated by $\mathrm{Sn}$ minerals with abundant sulfide minerals which occur over a buried stock of greisenized granite. The veins are hosted in metamorphosed Triassic sandstone and shale and are cut by granite porphyry and aplite dikes of the Cretaceous lultin complex. Successive mineral assemblages are: (1) topaz-fluorite-muscovile greisen; (2) cassilerite-wolframite-quartz assemblage with topaz, Ioellingite, and fluorite (the most productive assemblage), (3) arsenopyrite-quartz with cassiterite and native bismuth; (4) stannite-chalcopyrite with small amounts of bismuthinite, sphalerite, galena, pyrthotite, and bornite; (5) scheelite-fluoritealbite with chlorite, pyrite, marcasite, and cassilerile; and (6) fluorile-calcile with kaolinite. A complex cassiterite-wolframite 
assemblage is dominant in the upper portion of the deposit whereas W minerals are dominant at depth. The deposit is of medium size and has been mined from 1979 to the mid-1990's.

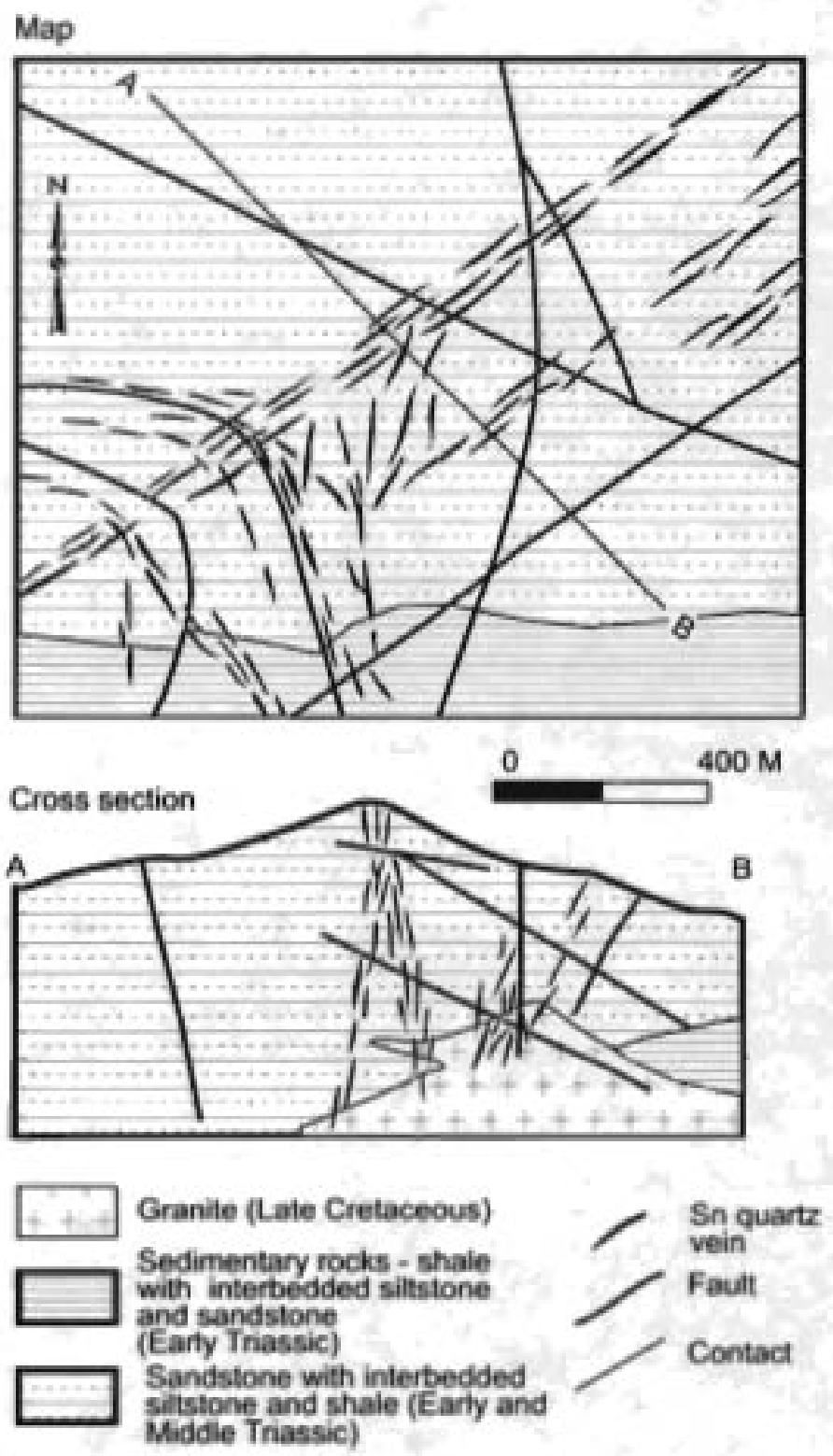

Figure 97 . Iultin Sn quartz vein deposit, Chukotica metallogenic belt, Russian Northeast. Schematic geologic map and cross section. Adapted from Lugov (1986)

\section{Valkumei Sn Silicate-Sulfide Vein Deposit}

The Valkumei Sa silicate-sulfide vein deposit (Lugov, Makeev, and Potapova, 1972; Lugov, 1986) consists of simple and complex veins, mineralized zones, and less common linear stockworks. The deposit occurs mainly within the marginal zone of the Late Cretaceous Pevek pluton, composed of granite, adamellite, and granodiorite, and to a lesser degree in Cretaceous sandstone and shale which bost the pluton. Mineralization oceurs in a north-northwest-trending zone alone the contact of the pluton. The ore bodies commonly consist of a conjugate system of: (1) major north-south veins and feathered veinlets; and (2) a zone of approximately east-west- and northwest-trending veins. Seventy minerals occur in the deposit but the majority of the veins are composed dominantly of loumaline, with quartz, chlorite, albite, arsenopyrite, cassiterite, pyrthotite, chalcopyrite, stannite, sphalerite, stibnite, fluorite, and various carbonates. The ore bodies are vertically extensive. The cassiterite-quartz-tourmaline veins are replaced by sulfide veins at depth. The deposit is large, was discovered in 1935, and has been mined from 1941 to the mid-1990's. The average grade is 0.4 to $1.2 \% \mathrm{Sn}$. 
The Chechekuyum Pb-Zn skam deposit (G.A. Zhukov and others, written commun., 1953) dips gently, is about $18 \mathrm{~m}$ thick and $30 \mathrm{~m}$ long along strike, and is composed of pyrnhotite, sphalerite, galena, chalcopyrite, magnetite, pyrite, niccolite, marcasite, calcite, garnet, diopside, and quartz. The skarn occurs along a fracture zone in Middle Devonian limestone, which is overlain by Late Cretaceous felsic extrusive rocks and intruded by granite porphyry and spessartite dikes. Massive and disseminated pyrrhotite ore occurs in the hanging wall. Massive galena, and less abundant sphalerite-galena ore, occur in the middle part of the skarn. Sparse massive sphalerite ore is prominent in the footwall. The skarn also contains sparsely disseminated ore minerals. The skarn contains anomalous $\mathrm{Sn}, \mathrm{Cd}, \mathrm{Co}, \mathrm{Bi}$, and $\mathrm{Ag}$. The deposit is judged as small.

\section{Metallogenic Belt Formed During \\ Late Mesozoic Collision and Accretion of Chukotka Superterrane, Russian Northeast}

\section{Chukotka Metallogenic Belt of \\ Au Quartz Vein and Related Deposits (Belt CH) \\ Northern Part of Russian Northeast}

The Chukotka metallogenic belt of Au quartz vein, $\mathrm{Sn}$ and $\mathrm{Sn}-\mathrm{W}$ polymetallic vein, and minor associated Sn greisen deposits (fig. 79; tables 3, 4) occurs in the nortbern part of the Russian Northeast (Goryachev, 1998, 2003) in the central and western parts of the Paleozoic and early Mesozoic Chukotka passive continental margin terrane (Nokleberg and others, 1994c, 1997c). The significant deposits in the belt are (table 4) (Nokleberg and others 1997a, b, 1998): Au quartz vein deposits at Dvoinoi, Karalveem, Lenotap, Ozemoe, Ryveem. Sredne-Ichuveem, and Svetlin; Sn quartz vein deposits at Chaantal, Svetloe, and Tenkergin; and a $\mathrm{Sn}-\mathrm{W}$ polymetallic vein and greisen deposit at lultin.

\section{Au Quartz Vein Deposits}

The Au quartz vein and associated Au shear zones deposits occur in the Anyui and Chauna subterranes of the Chukotka passive continental margin terrane (fig. 79). The significant deposits are at Karalveem, Ozernoe, Sredne-Ichuveem, Draznyaschy, Upryamy, and Lenotap. The Au-quartz vein deposits and Au shear zones deposits generally occur in anticlinal structures formed in Triassic siltstone, shale, and sandstone which are intruded by widespread Triassio gabbro-diabase sills, and by Early Cretaceous granitic dikes. The Au deposits are controlled by major, north-west-trending faults and feathering fault zones which formed during low-grade, greenschist facies metamorphism. A few Au-quartz vein deposits also occur in thrust zones in middle Paleozoic clastic and carbonate rocks, and in Late Jurassic and Early Cretaceous volcanic and sedimentary rocks. The Au quartz vein and Au shear zones deposits of the Chukotka metallogenic belt are probably the main lode source for numerous placer Au deposits of northern Chukotka. However, in detail, the known lode Au deposits do not correspond to the known large placer Au deposits. This observation suggests which undiscovered Au quartz vein or other types of undiscovered deposits may exist in the region.

\section{Karalveem Au Quartz Vein Deposit}

The only commercial Au quartz vein deposit at Karalveem (fig. 98) (Olshevsky, 1974, 1976, 1984; Davidenko, 1975 , 1980; Skalatsky and Yakovlev, 1983) consists of numerous longitudinal, transverse, and diagonal, steeply-dipping ladder quartz veins up to several meters thick which occur in Triassic gabbro-diabase sills, especially near contacts with Triassic sandstone and shale. The sedimentary rocks and sills are strongly deformed into narrow, steep, northwest-trending folds. The ore bodies are controlled by strike-slip faults associated with the folding. Host rocks exhibit greenschist facies metamorphism. The Au quartz veins consist of $95-97 \%$ quartz with segregations of arsenopyrite and lenses of scheelite, albite, ankerite, and muscovite. Also widespread are calcite, dolomite, white mica, galena, native gold, aquamarine, sphalerite, pyrite, and pyrrbotite. Gold occurs mainly in bluish-gray quartz veinlets in a matrix of coarse-grain quartz and arsenopyrite, in the upper horizons of the deposit. Silica-carbonate and sulfide alteration occur adjacent to ore zones. Near the surface, quartz veins often host druse-like intergrowths of large, well-crystallized quartz and isometric gold crystals. Coarse-grained masses of gold, and less common dendritic gold, up to I cm diameter, are characteristic of the deposit. Al depth, the gold occurs mainly as fine, dispersed masses in arsenopyrite. The deposit is of medium size, and has been prospected and developed preparatory to mining.

\section{Origin of and Tectonic Controls for \\ Chukotka Metallogenic Belt}

The Au quartz vein and Au shear zones deposits of the Chukotka metallogenic belt are herein interpreted as forming in the Late Cretaceous during regional deformation and associated metamorphism and anatectic granite magmatism (Goryachev. 1998,2003 ) which occurred during a major period of collision and accretion of the Chukotka terrane (Nokleberg and others, 2000). Preceding the accretion was: (1) Early Cretaceous opening of the Canada (Arctic Ocean) Basin; (2) migration of the Chukotka superterrane to the southwest; and (3) closure of the late Paleozoic(?) and early Mesozoic South Anyui Ocean. After 
closure, the Chukotka superternane was acereted against the South Anyui and Velmay subduction-zone terranes, and the Nutesyn island-arc terrane which in turn collided with the Kolyma-Omolon superternane farther southwest (present-day coordinates). The Au quartz vein deposits are interpreted as forming during the early stage of the accretion. Similar origin and coeval Au quartz vein deposits oecus to the east in the Southern Brooks Range metallogenic belt of Au quartz vein deposits (fig. 80). Anatexis or partial meiting is interpreted as occurring during the final stage of accretion and associated crustal thickening. The Sn polymetallic vein deposits are interpreted as forming during the final stage of accretion.

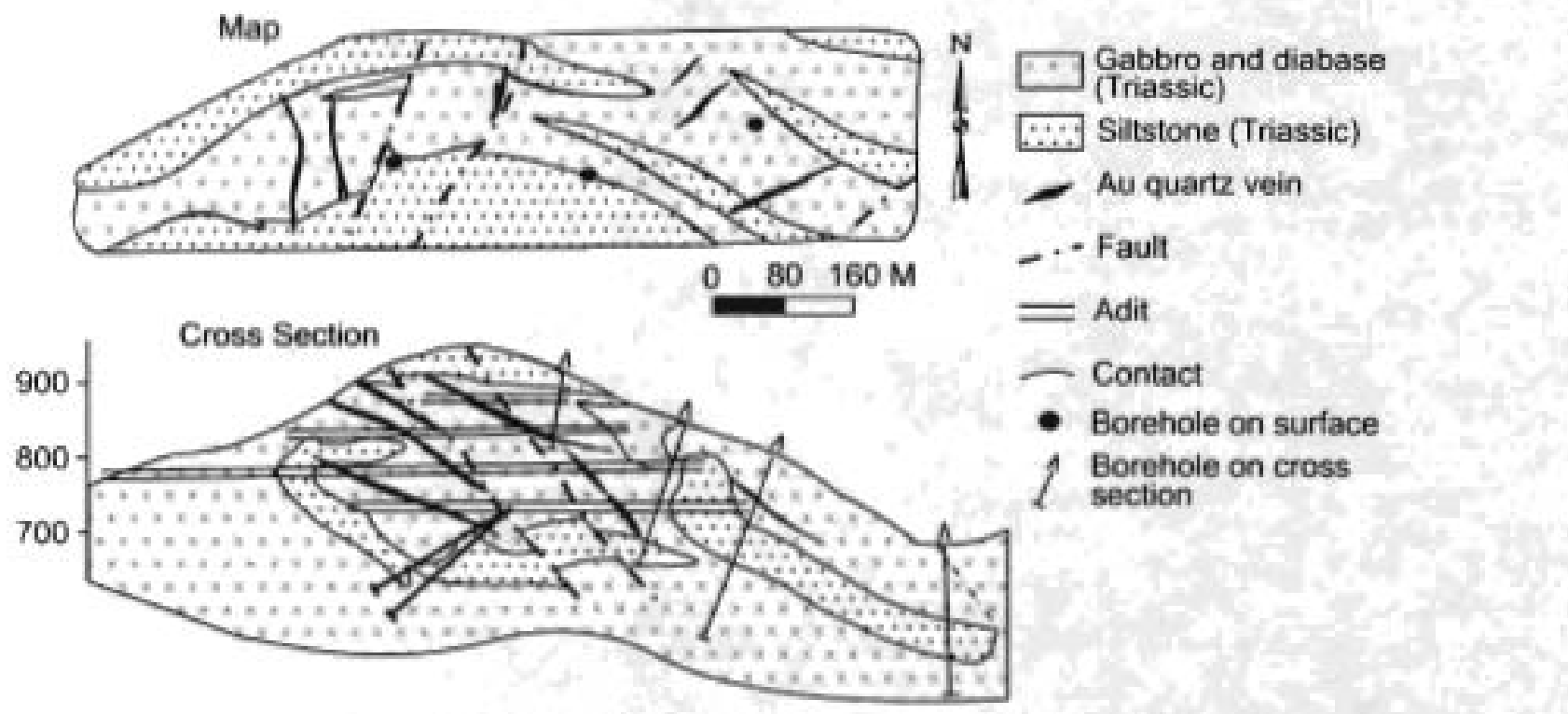

Figure 98. Karalveem Au quartz vein deposit, Chukctlca metallogenic belt, Russian Northeast. Schematic geoiogic map and cross section. Adapled from Goryachev and others (1996) and Eremin and Sidorov (1995).

\section{Metallogenic Belts Formed in \\ Late Mesozoic Collision and \\ Accretion of Wrangellia Superterrane, Southern Alaska}

\section{East-Central Alaska Metallogenic Beit of Granitic Magmatism Deposits (Older, Mid-Cretaceous Part; Belt ECA) East-Central Alaska}

The East-Central Alaska metallogenic belt of granitic magmatism deposits (older, mid-Cretaceous part) fige, 80; tables 3. 4) (Nokleberg and others, 1995a, 1996, 1997a) consists of two parts, an older, mid-Cretaceous part, described and interpreted herein, and a younger Late Cretaceous and early Tertiary part, described in a subsequent section. The mid-Cretaceous part contains a wide variety of granitoid-related $\mathrm{Au}$, Sb-Au vein, $\mathrm{Pb}-\mathrm{Ag}-\mathrm{Zn}$-Au polymetallic vein, and W-Au skam deposits (table 4). The East-Central Alaska belt is hosted mainly by mid Cretaceous granitoid rocis in the Yukon-Tanana Upland (Miller, 1994; McCoy and others, 1997) which are part of the Yukon-Tanana igneous belt (Moll-Stalcup, 1994). Recently, the name was described in a series of papers in the volume edited by Tucker and Smith (2000). However, their usage woas for both granitoidrelated Au deposits and occurrences in the East-Central Alaska metallogenic belt and in the correlative Tombstone metallogenic belt that is described above.

Three major groups of deposits oceur in the East-Central Alaska metallogenic belt (table 4). (1) In the north-central part of the belt, is the Manley and Livengood area, the significant lode deposits are a $\mathrm{Pb}$ - $\mathrm{Ag}-\mathrm{Zn}$-Au polymetallic vein deposit at Hot Springs Dome (mid-Cretaceous?), an Sb-Au vein deposit at Sawtooth Mountain (mid-Cretaceous), and Sb-Au and Au quartz vein deposits at Gertrude Creek, Griffen, and Ruth Creek (table 4) (Nokleberg and others 1997a, b, 1998). (2) In the central part of the belt are a variety of granitoid-related deposits in the Fairbanks area. And (3)in the southem part of the belt are polymetallic and Sb-Au vein deposits in the Kantishna area in the northem Alaska Range (Bundrzen, 1981; McCoy and others, 1997). Described below are the major granitoid-related deposits at Fort Knox, Democrat, and Pogo in the Fairbanks area, and vein deposits in the Kantishna district. The Fairbanks area is underlain by multiply metamorphosed and penetratively deformed, middle Paleozoic and older quartz-metasedimentary, sparse metavolcanic, and rare metagranitoid rocks of the Yukon-Tanana continental margin terrane (Nokleberg and others, 1994c, 1997c). The characteristics and origin of the mid-Cretaceous granitoid-related Au deposits in this area are described by MeCoy and others (1997). 
In the eastem and southern parts of the belt in the Fairbanks area, a wide variety of granitoid-related deposits (Table 4) are spatially associated with mid-Cretaceous plutons. These deposits are: Sb-Au vein deposits at Dempsey Pup and Scrafford; a Sn polymetallic vein deposit at Table Mountain; polymetallic vein deposits at Cleary Summit, Ester Dome (Ryan Lode), Democrat (Mitchell Lode), Blue Lead, Tibbs Creek, and Gray Lead; a major granitoid-related Au deposit at Fort Knox; a high-grade, granitoid-related Au quartz vein deposit at Pogo; and an Au-As vein deposit at Miller House. The deposits at Serafford, Cleary Summit, Gilmore Dome, Ester Dome, and Democrat are in the Fairbanks district.

\section{Fort Knox Granitoid-Related Au Deposit}

The Fort Knox granitoid-related Au deposit (fig. 99) (Blum, 1985; Robinson and others, 1990; A.A. Bakke, written commun.. 1991; Bakke, 1995; Hollister, 1992. McCoy and others, 1997) occurs northeast of Fairbanks and consists of free gold, bismuthinite, and minor to trace molybdenite and chalcopyrite which occur in a sulfide-poor, quartz vein stockwork in the Fort Knox (porphyritic granodiorite) pluton. The stockwork is preferentially emplaced along a steeply dipping fracture system which trends $290^{\circ}$. The deposit is at least $1500 \mathrm{~m}$ long by $300 \mathrm{~m}$ wide, and $250 \mathrm{~m}$ deep, and contains an estimated reserve of 186.5 million tonnes grading $1.6 \mathrm{~g} / \mathrm{t}$ Au (Bakke, 1995, 2000). The gold is remarkably pure (greater than or equal to 980 fine). The Fort Knox pluton is alkali-calcic and peraluminous. Mineralization is interpreted to have occurred either during the late stages of emplacement of the nearby Gilmore Dome stock which has a K-Ar biotite age of $92 \mathrm{Ma}$ (McCoy and others, 1997). However, a younger, early Tertiary heating event that post-dates the older porphyry Mo-Bi-Cu-mineralization may have also introduced Au (Bakke, 1995).
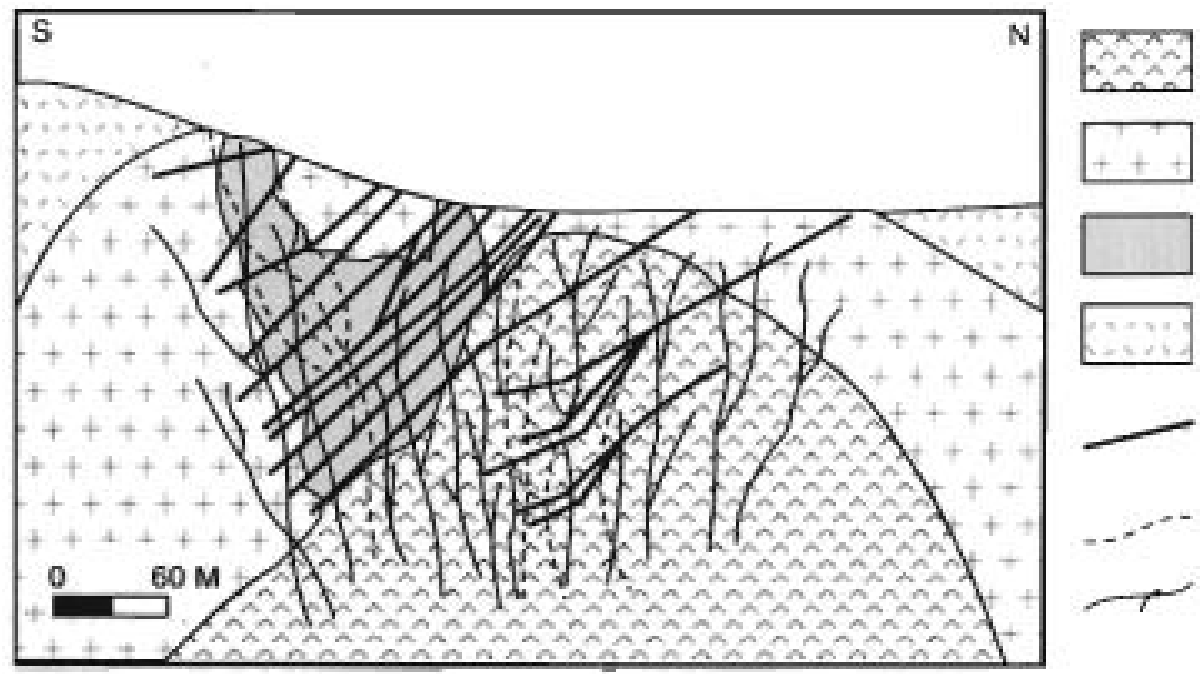

\section{Coarse-grained granile \\ Medium-grained Late granite - Cretaceous \\ Fine-grained granife \\ Schist and quartzite

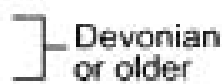 \\ Shear zone showing s ericite halos \\ Pegmatite/aplite showing mostly feldspar halos \\ Stockwork veining showing teldspar-quartz and/or white mica quartz halos}

Figure 99, Fort Knox granitoid-related Au deposit, East-Central Alaska metallogenic belt, East-Central Alaska, Schematic cross section looking west. Adapted from Bakke (1994).

\section{Democrat (Mitchell Lode) Granitoid-Related Au Deposit}

The Democrat (Mitchell Lode) granitoid-related Au deposit (fig. 100) (Bundtzen and Reger, 1977; T.K. Bundtzen and R.B. Forbes, written commun., 1990) occurs in the Richardson district south of Fairbanks, and consists of disseminated and stockwork tetrahedrite, galena, acanthite, owyheeite, other Ag-sulfosalts, free gold, and quartz in a hydrothermally altered granite porphyry. A strong sericite alteration balo surrounds the porphyry, which intrudes sillimanite-bearing metasedimentary schists of the Yukon-Tanana terrane. The granite porphyry has a K-Ar biotite age of $89.1 \mathrm{Ma}$ and is part of a 35-km-long sill complex which intruded along the Richardson lineament. Free gold occurs as interlocking alloys of native silver and gold which average $67 \%$ Au and $33 \% \mathrm{Ag}$. Silver sulfosalts are abundant locally and exhibit very high grades of up to $66,000 \mathrm{~g} / \mathrm{Ag}$. In 1989 , a pilot mill produced 88,000 tonnes grading $2.2 \mathrm{~g} / \mathrm{t} \mathrm{Au}$ and $5.0 \mathrm{~g} / \mathrm{t} \mathrm{Ag}$. The deposit is interpreted as forming during high level emplacement of a Late Cretaceous granite porphyry along the Richardson lineament. 
A

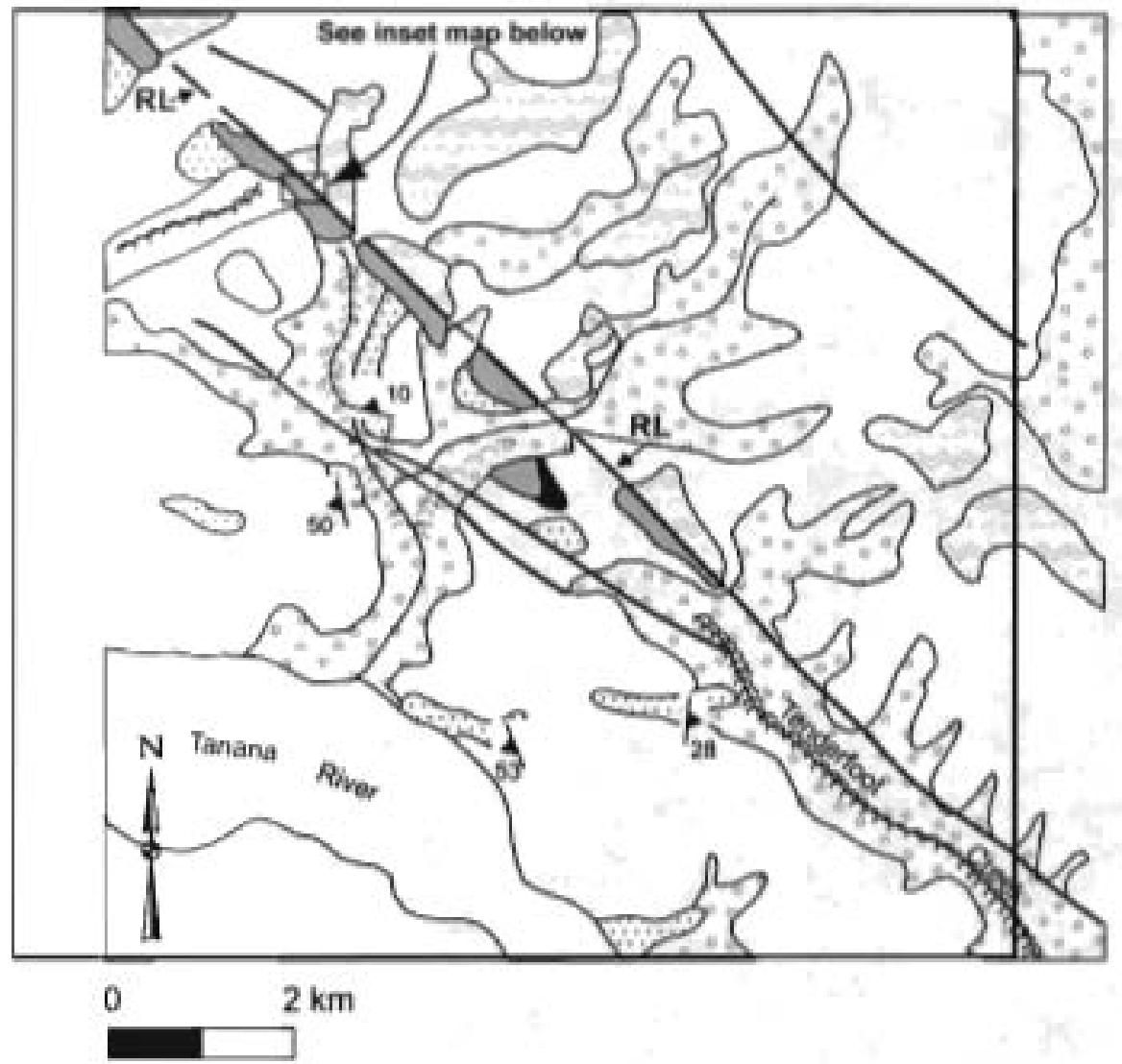

Undifferentiated bedrock (Unmapped orcovered)

$2 *$ Stream alluvium and alluvialcolluvial deposits

Epidote-hornblende skarn

Granite porphyry sill (Late Cretaceous)

.7. Granite 8 granodiorite gneiss (Devonian?)

Garnet biotite muscovite schist and meta-felsite (greenschist facies)

Sillimanite bearing schist and gneiss (amphibolite facies)

11111 Silicified zone (silicic with

..... Ag/Au pods)alteration

I: Argillic alteration

, 1, Sericite alteration with

,, Mn patina

$\equiv \equiv$ Potassic alteration

- High angle fault or prominant linear feature

RL 'Richardson Lineament' / fault

tos Placer mine tailings

Edge of open pit or mine cut

B

4. 10 Foliation

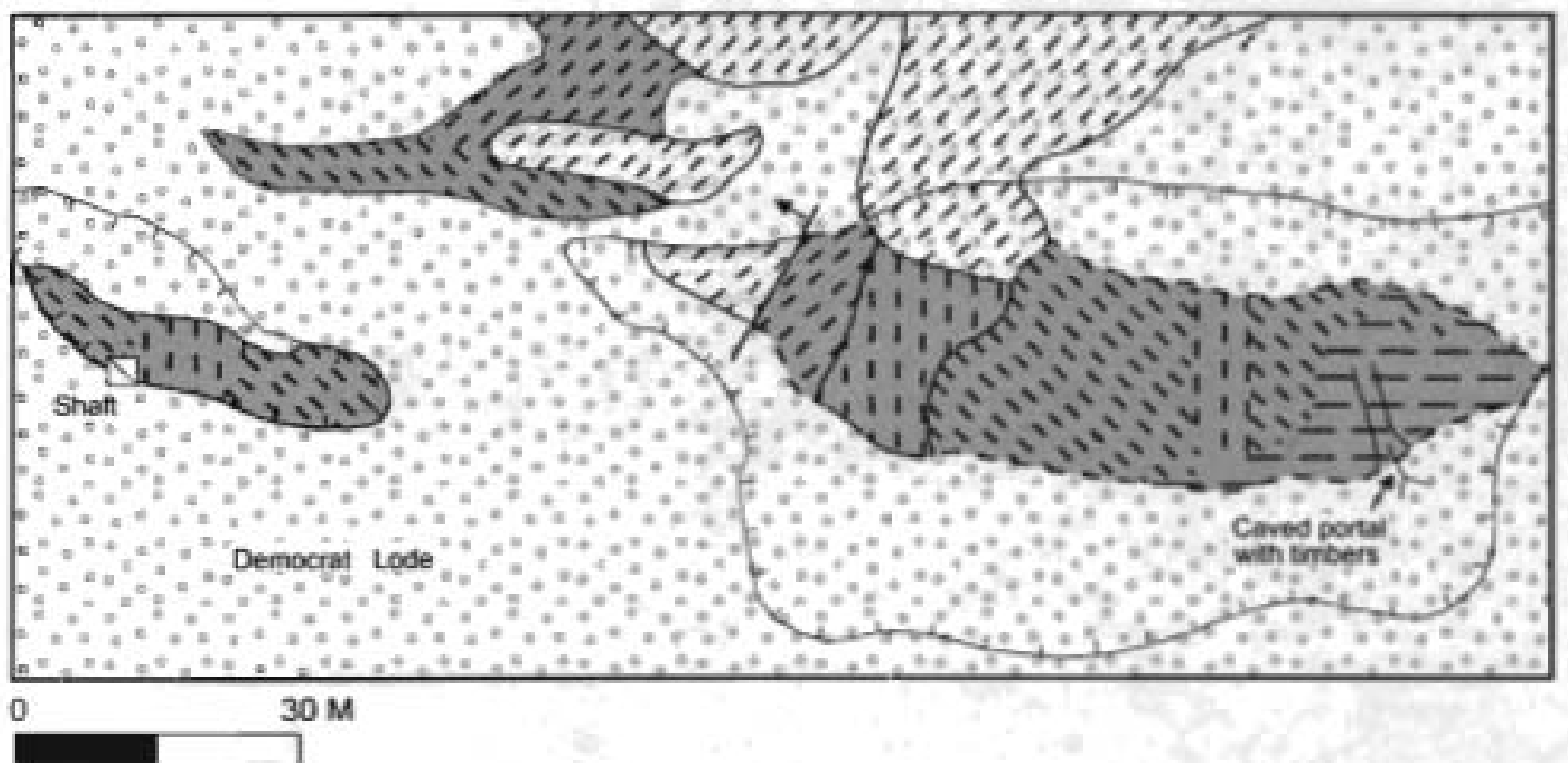

Figure 100. Democrat graniloid-related Au deposit. East-Central Alaska metallogenic belt, East-Central Alaska. A. Schematic geologic map of part of surrounding Richardson district. B. Schematic geologic map of Democrat deposit. Adapted from Bundtzen and Reger (1977). T.K. Bundtzen (written comm, 1989), and Nokleberg and others (1995). 
The Pogo deposit (Liese Zone) consists of at least two, subparallel, gently dipping tabular quartz bodies which are hosted by Proterozoic to early Paleozoic paragneiss and minot orthogneiss of the Yukon-Tanana Terrane (Lefebure and Cathro, 1999; Smith, 1999, Smith and others, 1999, 2000). The deposit contains both vein and replacements quartz bodies, and consists mainly of three or more large, tabular, gently-dipping quartz bodies at LI, L2, and L.3. The quartz bodies, none of the bodies crop out at the surface, vary from I up to 21 meters thick, and the largest at $L I$ extends at least 1,300 meters along strike. The L.2 quartz body underlies the eastem half of the LI body. The quartz bodies lie from 1 to $215 \mathrm{~m}$ apart, range from 1 to over $20 \mathrm{~m}$ thick (average 7 $\mathrm{m}$ thick), are roughly parallel, and dip from 25 to 30 degrees. The bodies cut the foliation in the host rocks and are offset by high angle faults.

The quartz bodies contain three percent sulfide minerals. The ore minerals are pyrrhotite, pyrite, loellingite, arsenopyrite, chalcopyrite, bismuthinite, various $\mathrm{Ag}-\mathrm{Pb}-\mathrm{Bi} \mathrm{S}$ minerals, maldonite, native bismuth, galena and tetradymite. Native gold typically ranges from to -25 microns in diameter, and locally up to 100 microns. Gold is often rimmed by native bismuth. The deposit grade ranges up to more than $75 \mathrm{~g} / \mathrm{Au}$ over widths of several meters. High Au values are is associated with high values of $\mathrm{Bi}, \mathrm{Te}, \mathrm{W}$, As, and possibly $\mathrm{Sn}$. Both white and gray quartz occur; the former is associated pyrrhotite and loellingite and is interpreted as early-stage, while the latter is associated with arsenopyrite and pyrite and is interpreted as late stage. As of 1999, the LI and L2 zone contained an estimated 9.05 millions tonnes grading $17.8 \mathrm{~g} / \mathrm{t}$ for a total of $147,386,400 \mathrm{gm}$ Au at a $3.42 \mathrm{~g} / \mathrm{t}$ cutoft. Median grade for Ag in the mineralized zones is $2 \mathrm{~g} / \mathrm{t}$ (Smith and others, 1999, 2000). One drill hole along steep shears and quartz-veins that average $8.6 \mathrm{~g} / \mathrm{t}$ Au for over 75 meiers. This area may be a possible feeder zone. The quartz is saccharoidal to polygonal. Biotite alteration envelopes up to 0.5 meters wide occur adjacent to veins, and are overptinted by younger, widespread, quartzsericite stockwork, and sericite-dolomite alteration.

The host rocks consist of highly deformed, amphibolite-grade, mainly metasedimentary which rocks are intruded by diorite, granodiorite pegmatite and aplite dikes and sills and a granodiorite intrusion. The deposit is younger than a granite dike which exhibits a preliminary U-Pb monazite isotopic age of $107 \mathrm{Ma}$, and is older than a cross-cutting diorite that has a preliminary U-Pb zircon isotopic age of $94 \mathrm{Ma}$. The Pogo deposit shares a number of characteristics with plutonic-related quartz veins in the Fairbanks district and Yukon, including a similar geological setting, a close association with Cretaceous granitoid rocks, low sulfide content, and similar geochemistry. The Pogo deposit may represent a deeper, higher-temperature part of a plutonic-related Au system (D. McCoy, personal communication, 1999).

\section{Kantishna District}

At least seventy polymetallic and Sb-Au vein deposits occur in the Kantishna district in the western part of the southern Yukon-Tanana terrane in the northern Alaska Range (Bundtzen, 1981: MeCoy and others (1997). The significant deposits are SbAu vein deposits at Caribou, Eagles Den, Slate Creek, and Stampede, and polymetallic vein deposits at Banjo, Quigley Ridge, and Spruce Creek (Table 4) (Nokleberg and otbers 1997a, b, 1998). The polymetallic vein deposits occur in middle Paleozoic or older, polymetamorphosed and poly-deformed submarine metavolcanic and metasedimentary rocks of the Yukon-Tanana terrane, which also hosts an extensive belt of middle Paleozoic kuroko massive sulfide deposits described previously (Aleinikoff and Nokleberg. 1985; Nokleberg and Aleinikoff, 1985). Most of the polymetallic vein deposits occur as crosscutting quartz-carbonate-sulfide veins and are confined to a $60-\mathrm{km}$-long, northeast-trending fault zone which exlends from Slate Creek to Stampede (Bundtzen, 1981). Mineralization occurred before, during, and after fault-zone movement, as illustrated by both crushed and undeformed ore shoots in the same vein system. "As-" Ar isotopic ages indicate vein formation was from 91 to $88 \mathrm{Ma}$ (McCoy and others, 1997).

\section{Origin of and Tectonic Controls for \\ East-Central Alaska metallogenic (mid-Cretaceous part)}

The mid-Cretaceous granitoid rocks of the older part of the Yukon-Tanana igneous belt (Moll-Stalcup, 1994), which host the older part of the East-Central Alaska metallogenic belt, occurs is large batholiths, and small, isolated granitoid plutons (Foster and others, 1987; Miller, 1994). The plutons range in area from smaller than I to larger than $300 \mathrm{~km}^{2}$. The irregular-shaped plutons were intruded after a period of intense metamorphism and deformation in the mid-Cretaceous. The phutonic rocks exhibit $\mathrm{K}$-Ar mineral, Rb-Sr whole rock, and U-Pb zircon ages which range from about 100 to $90 \mathrm{Ma}$ (Wilson and others, 1994; Smith and others, 1999,2000$)$.

The polymetallic, Sb-Au vein, and granitoid-related Au deposits of the mid-Cretaceous part of the East-Central Alaska metallogenic belt, and similar deposits in the Tombstone metallogenic beit to the east, are generally hosted in or near midCretaceous granitoid plutons (Nokleberg and others, 1995a; McCoy and others, 1997; Smith, 1999, 2000) and are herein interpreted as forming during the waning stages of a major mid-Cretaceous collision of the Wrangellia superternane with the previously-accreted Yukon-Tanana terrane (Stanley and others, 1990; Dusel Bacon and others, 1993; Pavlis and others, 1993; Nokleberg and others, 2000). The collision and associated metamorphism and deformation is interpreted as forming in three phases: (1) a relatively older period of collision and thrusting, associated with high-temperature and high-pressure metamorphism; (2) a slightly younger period of extension associated with lower greenschist facies metamorphism; and (3) intrusion of anatectic granitoid plutons and relatively younger Au quartz veins. The mid-Cretaceous granitoid rocks and relatively younger quartz veins 
intrude and crosscut both the relatively older. higher-grade, and relatively younger, lower grade metamorphic fabrics in the region (Dusel Bacon and others, 1993; Pavlis and others, 1993). These relations suggest that the granitoid-related Au deposits of the older part of the East-Central Alaska metallogenic belt, and the Tombstone belt to the east, formed in the waning stages of this complex deformational event (Nokleberg. 1997e, 2000). Alternatively, McCoy and others (1997) interpret the mid-Cretaceous granitoid-related Au deposits as forming in a continental-margin are relafed to subduction.

\section{Misused Name: Tintina Gold Belt}

In recent years, the name Tintina Gold Belt (as described and interpreted in a series of papers by by Goldfarb and others (2000), Flanigan and others (2000), Hart and others (2000), Mortensen and others (2000), Newberry (2000), O'Dea and others (2000), and Smith (2000) in the volume edited by Tucker and Smith (2000) has been used for granitoid-related Au deposits and occurrences in the East-Central Alaska metallogenic belt of Nokleberg and others (1995a, 1996, 1997a) and in the correlative Tombstone metallogenic belt (described below) of Nokleberg and others (1995a, 1996, 1997a) which occurs to the east in the central Yukon Territory. Because the Tintina Gold Belt actually includes a number of belts of differing ages and tectonic origins, the term is not used in this study.

Bundizen and others (2000) have introduced the term Tintia Gold Province to denote Cretaceous and early Tertiary intrusive-hosted gold deposits in East-Central Alaska and the Yukon Territory. This province includes the following metallogenic belis which are described and interpreted in this study: East-Central Alaska (older part; ECA), Kuskokwim Mountains (KM), Tombstone (TS), and metallogenic belts (table 3 ). These distinct belts are separately described and interpreted herein because they: (1) formed over a relatively long time span; (2) are hosted in a diverse array of host rocks; and (3) formed at different times in strongly contrasting tectonic environments, either collisional or subduction-related environments.

\section{Yukon-Tanana Upland Metallogenic Belt of Au-quartz vein Deposits (Belt WT) East-Central Alaska}

The Yukon-Tanana Upland metallogenic belt of Au-quartz vein deposits occurs in east-central Alaska (fig. 80; tables 3. 4) (Nokleberg and otbers, 1997b, 1998). The metallogenic belt is hosted in the Devonian and Mississippian metasedimentary and lesser metavolcanic rocks of the southern Yukon-Tanana displaced-continental margin terrane, and in the Stikinia(?) island-arc terrane (Nokleberg and others, 1994c, 1997c). The known deposits occur in parts of these terranes which display greenschist facies and associated major metarnorphism which ended in the mid-Cretaceous. The significant deposit is at Purdy.

\section{Purdy Au Quartz Vein Deposit}

The small Purdy Au quartz vein deposit (H.L. Foster, written commun., 1984; W.D. Menzie, written commun., 1985) contains a large quartz-calcile fissure vein and smaller veinlets that contain spectacular lace gold. The deposit consists mainly of this one large veis which exiends for about $2 \mathrm{~m}$ and is terminated by a fault. The large vein and smaller veinlets intrude midPaleozoic or older metasedimentary schist of the Stikinia(?) terrane. The large vein was mined out by 1960 . Small veins and veinlets were mined in 1969 and early $197 \%$ s.

\section{Origin of and Tectonic Controls for} Yukon-Tanana Upland Metallogenic Belt

The Yukon-Tanama Upland metallogenic belt is associated with a major, low-grade regional metamorphism and intense deformation of the Stikinia(?) and structurally subjacent Yukon-Tanana terranes in east-central Alaska (Dusel-Bacon and others, 1993. Pavlis and others, 1993; Nokleberg and othens, 1994c, 1997c). As with the East-Central Alaska metallogenic belt describe and inlerpreted above, the Yukon-Tanana belt is interpreted as forming during the third stage of a mid- to Late Cretaceous complex deformational event that ended with intrusion of analectic granihoid plutons and relatively younger Au quarte veins. The quartz vein crosscut a subborizontal, schistose fabric that exhibits the younger stage of greenschist facies metamorphism. This complex event occurred during final accretion of the Wrangellia superterrane to the active margin of the North American continental margin (Plafker and others, 1989, Stanley and others, 1990; Pavlis and others, 1993; Nokleberg and others, 2000).

\section{Wrangell Mountains Metallogenic Belt of Cu-Ag Quartz Vein and Kennecott Cu Deposits (Belt WR) Eastern-South Alaska}

The Wrangell Mountains metallogenic belt of $\mathrm{Cu}$-Ag quartz vein and Kennecott $\mathrm{Cu}$ deposits (fig. 80; tables 3,4) occurs in the eastem Alaska Range, Nutzotin Mountains, and Wrangell Mountains in eastern-southern Alaska. The metallogenic belt is hosted in the pan of the Wrangellia island-are lerrane underlain by Late Cretaceous and older stratified rocks, particularly the Late Triassic Nikolai Greenstone, and older late Paleozoic sedimentary and voleanic rocks (Nokleberg and others, 1994c, 1997e; MacKevet and others, 1997). The extensive suite of minor Cu-Ag quartz vein deposits occurs mainly along the northem margin of the Wrangellia sequence of Wrangellia superterrane. The major Cu-Ag quartz vein deposits are at Kathleen-Margaret, Nugget 
Creek, and Nikolai; the major Kennecont Cu deposits are in the Kennecott district at Kennecott and Westover, and a basaltic Cu deposit is at Erickson (table 4) (Nokleberg and others 1997a, b, 1998).

\section{Kathleen-Margaret Cu-Ag Quartz Vein Deposit}

The Kathleen-Margaret Cu-Ag quartz vein deposit (MacKevett, 1965) consists of quartz veins which are up to $140 \mathrm{~m}$ long and $3 \mathrm{~m}$ wide and contain disseminated to massive chalcopyrite, bornite, and malachile. The gangue is mainly quartz and minor caleite. The veins cut the Late Triassic Nikolaj Greenstone, strike east-west, and are intruded along shear zones. Grab samples from the deposit contain up to $13 \% \mathrm{Cu}_{4} 3.2 \mathrm{~g} / \mathrm{Au}, 300 \mathrm{~g} / \mathrm{Ag}$ About 1.8 lonnes of ore was produced in the 1950 's. At the nearby Nugget Creek deposit slablike copper nuggets of several lonnes weight occur.

\section{Kennecott Cu Deposits}

The large Kennecott Cu deposits (fig. 101) (Bateman and McLaughlin, 1920, MacKevett, 1976; Armstrong and MacKevett, 1982; MacKevett and others, 1997 ) consist mainly of chalcocite and covellite, and also have minor enargite, bomite, chalcopyrite, luzonite, and pyrite. Tennantile, sphalerite, and galena are extremely rare. Local surface oxidation occurs with alteration of sulfides to malachite and arurite. Sulfide minerals occur mainly as large, irregular, massive, wedge-shaped bodies, mainly in dolomitic parts of the Late Triassic Chitistone or Nizina Limessone. The bodies are generally less than $100 \mathrm{~m}$ above a disconformity over the subjacent Middle and(or) Late Triassic Nikolai Greenstone. The largest ore body (Jumbo) consists of an almost pure chalcocite and covellite mass, which is about $110 \mathrm{~m}$ high, up to $18.5 \mathrm{~m}$ wide, and which extends $460 \mathrm{~m}$ along plunge. The Kennecott Cu mines were among the largest group of mines in Alaska from 1911 until 1938, when the ore was mostly exhausted. The district contains more than $96 \mathrm{~km}$ of underground workings. The major mines in district are the Jumbo, Bonanza, Erie, Mother Lode, and Green Butte. The district produced about 544 million $\mathrm{kg} \mathrm{Cu}$ and 280 million $\mathrm{g} \mathrm{Ag}$ from 4.3 million tonnes of ore.

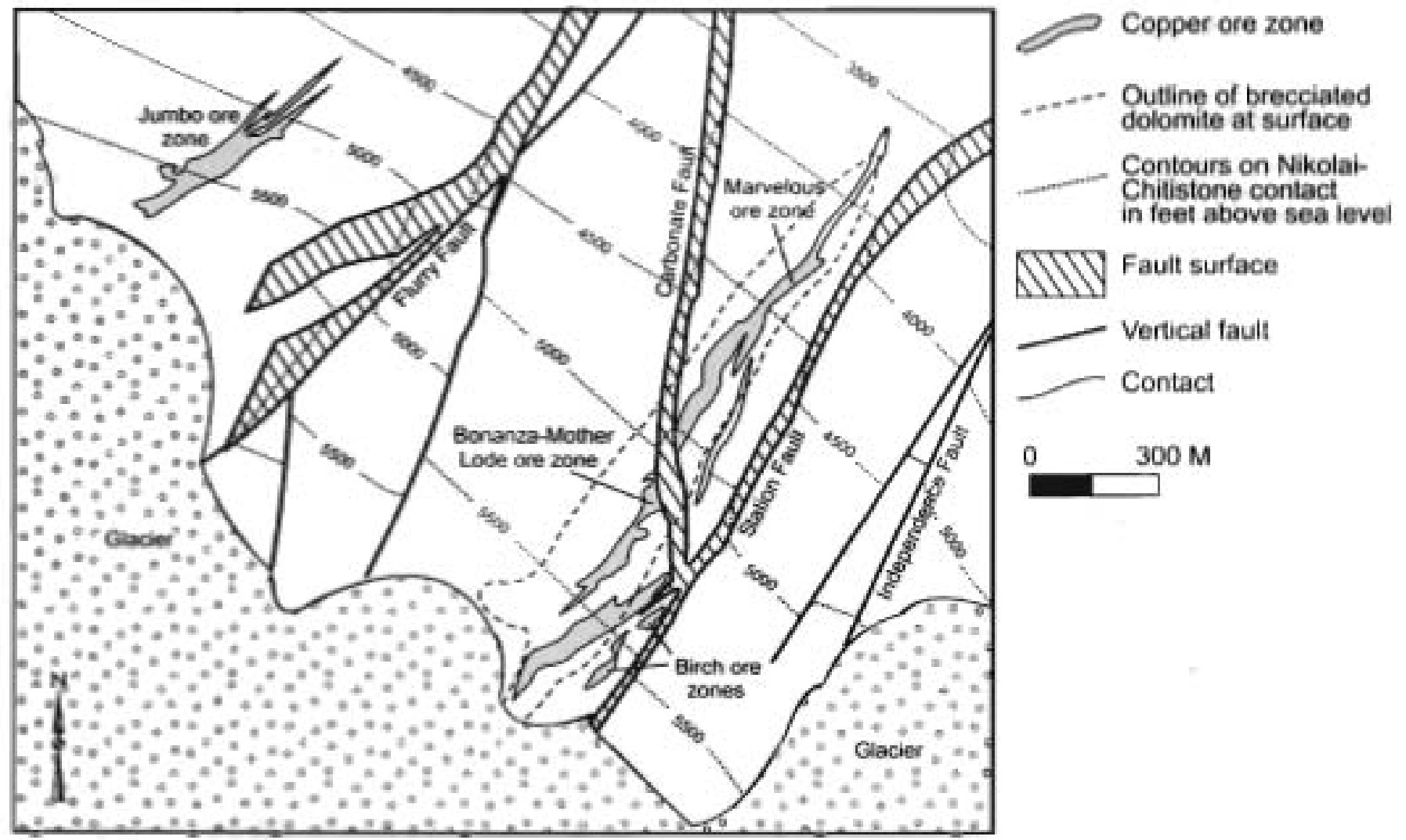

Figure 101A. Kennecott district of Kennecott Cu deposits. Wrangell Mountains metallogenic belt, Southem Alaska. Schematic geologic map showing the Bonanza-Mother Lode and Jumbo ore zones, major faults, and contours on contact between the Nikolai Greenstone and the Chitistone Limestone. Modified from MacKevett and others (1997). 


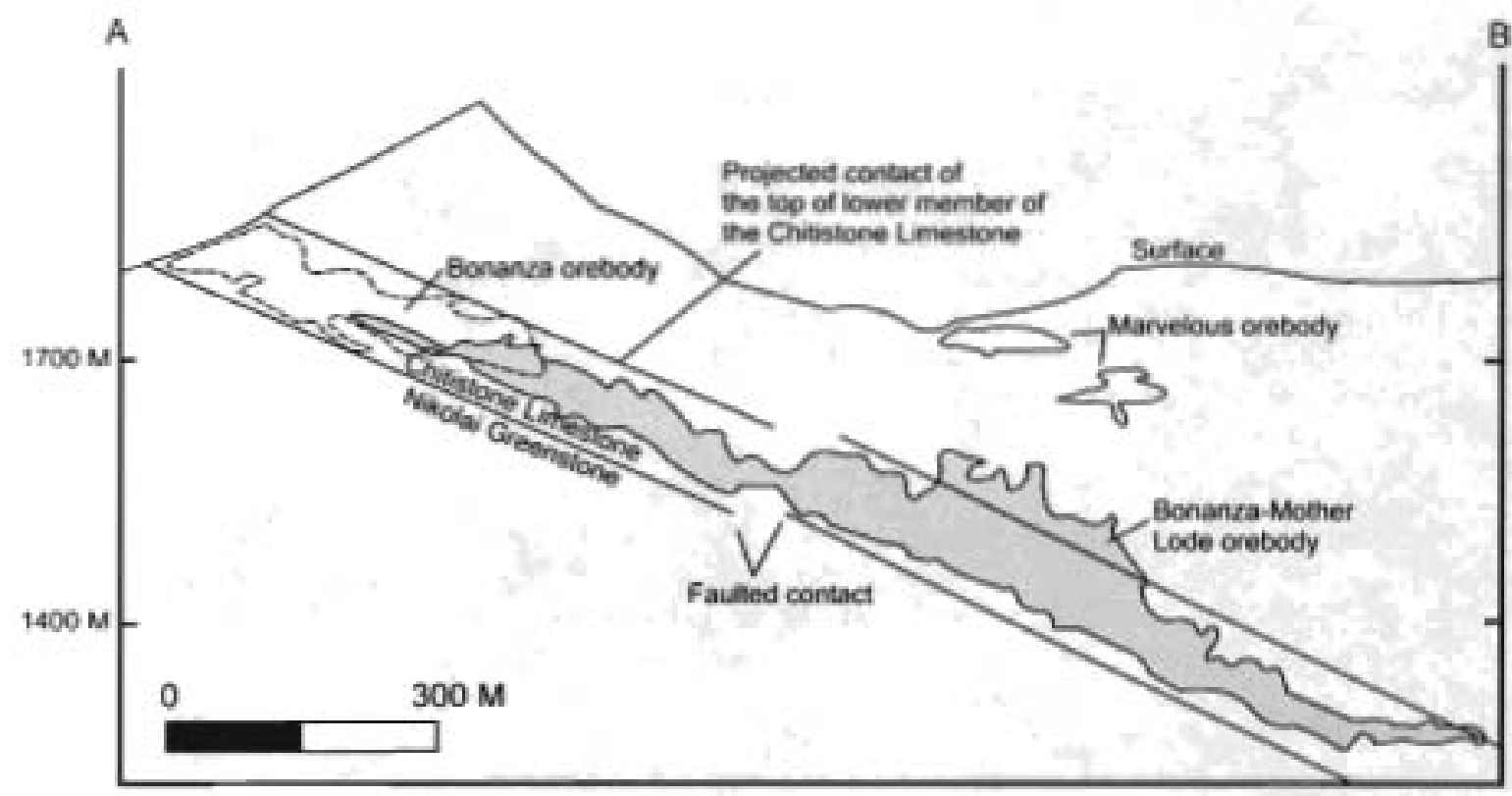

Figure 101B. Kennecott district of Kennecott Cu deposits, Wrangell Mountains metallogenic belt, Southern Aleska. Schematic cross section through Bonanza-Mother Lode ore zone. Shaded area represents the extent of Cu-rich veins and local massive sulfide bodies. Plane of section is N 35 E. Adapted from Mackevelt and others (1977).

\section{Origin of and Tectonic Controls for Wrangell Mountains Metallogenic Belt}

Throughout the Nikolai Greenstone and older rocks in the Wrangellia terrane, quartz veins, which locally contain abundant Cu sulfides, grade into clots of quartz, chlorite, actinolite, and epidote (Nokleberg and others, 1985, 1994d). This relation suggests that the $\mathrm{Cu}-\mathrm{Ag}$ quartz vein deposits formed during a period of lower greenschist facies regional metamorphism. The age of metamorphism is interpreted as mid-Cretaceous because Early Cretaceous and older units of the Wrangellia sequence were affected. The formation of the $\mathrm{Cu}$-Ag quartz vein deposits and associated regional metamorphism are berein interpreted as occurring during mid-Cretaceous accretion and deformation of the Wrangellia superterrane to the active margin North American Cordillera (Nokleberg and others, 1985, 2000; Plafker and others, 1989).

The Kennecott Cu deposits are interpreted by Armstrong and MacKevett (1982) and MacKevett and others (1997) as forming by derivation of $\mathrm{Cu}$ from the Nikolai Greenstone, followed by deposition from oxygenated groundwater in the lower pant of the overlying Chitistone Limestone along dolomitic sabkha interfaces, and as open-space fillings in fossil karsts. Armstrong and MacKevett (1982) interpreted the age of deposition as Late Triassic, but did not rule out possible later remobilization.

Subsequently, MacKevett and others (1997) interpreled the hydrothermal event associaled with formation of the Kennecot Cu and Cu-Ag quartz vein deposits in the Wrangell Mountains metallogenic belt as forming during nearby, mid-Cretaceous magmatism. In contrast, Nokleberg and others (1985, 1994d) and Goldfarb (1997) suggested that lower greenschist facies regional metamorphism of the Nikolai Greenstone, associated with mid-Cretaceous accretion of the Wrangellia superterrane, may have been the source of hydrothermal fluids which either deposited or further concentrated the Cu-sulfides in the Kennecout Cu deposits in the Kennicott district and in associaled Cu-Ag quartz vein deposits in southern Alaska.

\section{Late Cretaceous and Early Tertiary Metallogenic Belts (84 to $52 \mathrm{Ma}$ ) (Figures 102, 103)}

\section{Overview}

The major Late Cretaceous and early Tertiary metallogenic belts in the Russian Far East, Alaska, and the Canadian Cordillera are summarized in table 3 and portrayed on figures 102 and 103 . The major belts are as follows. (1) In the Russian Southeast, continuing on from the carly Lafe Cretaceous were the Kema (KM), Lower Amur (LA), Luzhkinsky (LZ), Sergeevka (SG), and Taukha (TK) belts, which contain a large array of granitic-magmatism-related deposits. The belts are hosted in or near the East Sikhote-Aline volcanic-plutonic belt and are interpreted as forming during subduction-related granitic plutonism which formed the East Sikhote-Aline continental margin are. (2) In the Russian Northeast, continuing from the early Late Cretaceous are several zones of the Eastem Asia belt, along with formation of several new zones. The zones, which are all hosted in or near the 


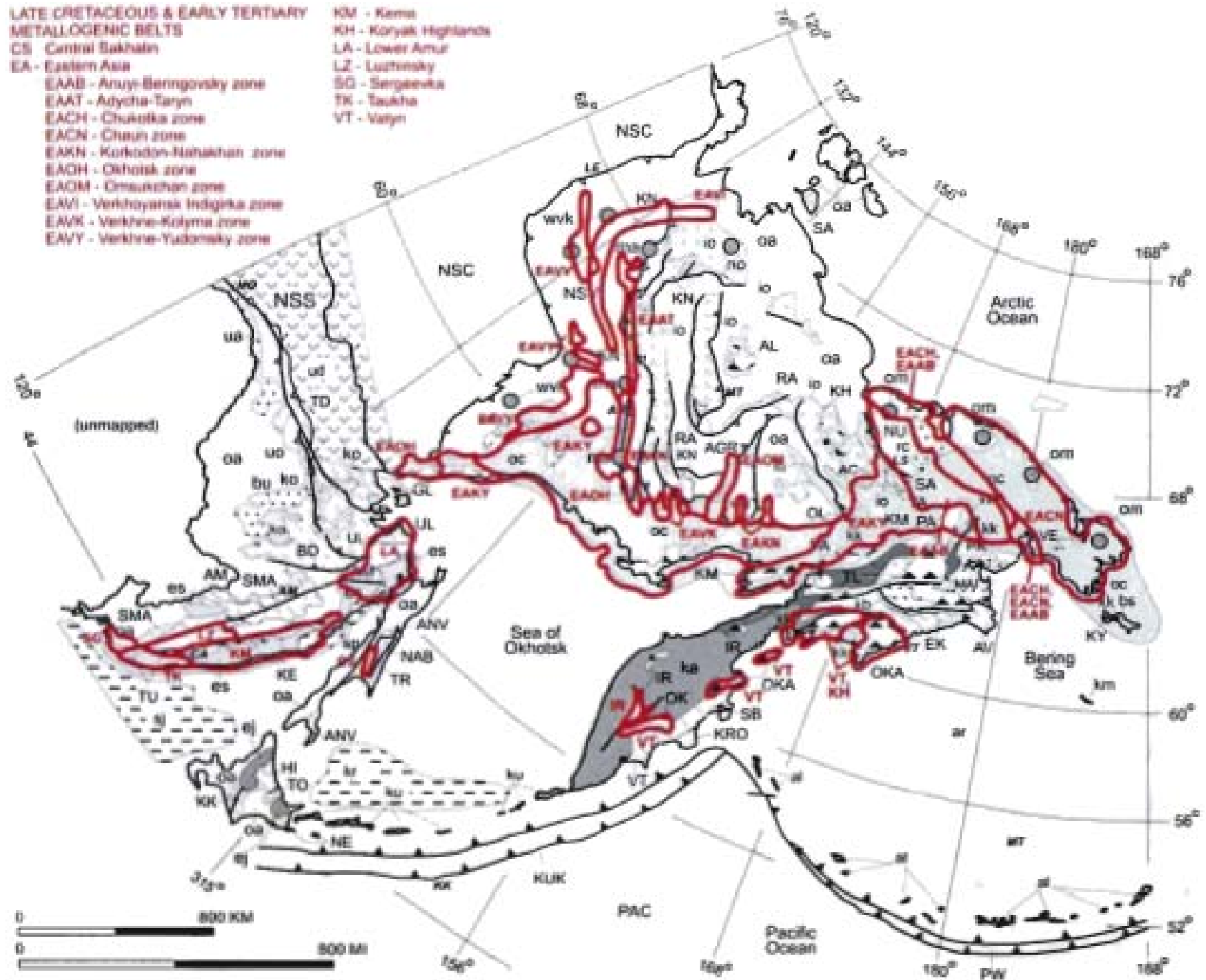

Figure 102. Generalized map of major Late Cretaceous and earty Tertiary metallogenic belts, overlap assemblages, and tectonically-linked subduction-zone or accretionary-wedge terranes for Russian Far East, northem Japan, and adjacent oflshore areas. Refer to text for description of metallogenic belts. Adapted from Nokleberg and others (1997b, 1996). Refer to figure 59 for explanation.

Okhotsk-Chukotka voleanic-plutonic belt, include the Adycha-Taryn (AT), Chaun (CN), Chukotka (CH), Korkodon-Nayakhan $(\mathrm{KN})$, Okhotsk (OH), Omsukchan (OM), and Verkhne-Kolyma (VK), Verkhne-Yudomsky (VY), and Verkhoyansk-Indigirka (VI) zones. Together, these zones and belts of grantic-magmatism-related deposits are interpreted as forming during subduction-related granitic plutonism which formed the Okhotsk-Chukotka continental-margin are. (3) Aiso in the Russian Northeast, continuing on from the early Late Cretaceous were the Koryak Highlands $(\mathrm{KH})$ belt which contains zoned mafic-ultramafic PGE and Cu massive sulfide deposits, and the Vatyn (VT) belt which contains volcanogenic Mn and Fe deposits. Both belts are bosted in the Olyutorka-Kamchatka island-are terrane and are interpeteted as forming in different parts of the Olyutorka island are. (4) Also in the Russian Nortbeast was the Inuseiskiy (IR) metallogenic belt of porphyry Cu deposits that also formed in the Olyutorka island arc. (5) In Northwestem Alaska, the Northwestern Koyukuk Basin (NWK), Seward Peninsula (SP), and West-Central Alaska (WCA) belts, which are hosted in the Alaska extension of the Okhotsk-Chukotka volcanic-plutonic belt, are also interpreted as forming during subduction-related granitic plutonism which formed the Okhotsk-Chukotka continental-margin arc. (6) In Southern Alaska, the East-Central Alaska (younger part; ECA), Soutbern Alaska (SA), and Kuskokwim Mountains (KM) belts, which are hosted in the Kuskokwim Mountains sedimentary and vokanic bels or the Alaska Range-Talkeetna Mountains igneous belt, are interpreted as forming during subduction-related granitic plutonism which formed the Kluane continental-margin arc. ( 7 ) In Southem and Southeastem Alaska, several belts are interpreted as forming during oblique subduction of the Kula-Farallon oceanic ridge under margin of Southern and Southeastem Alaska. In alphabetical order, these belts are the Baranof (BN), Chugach Mountains (CM). 


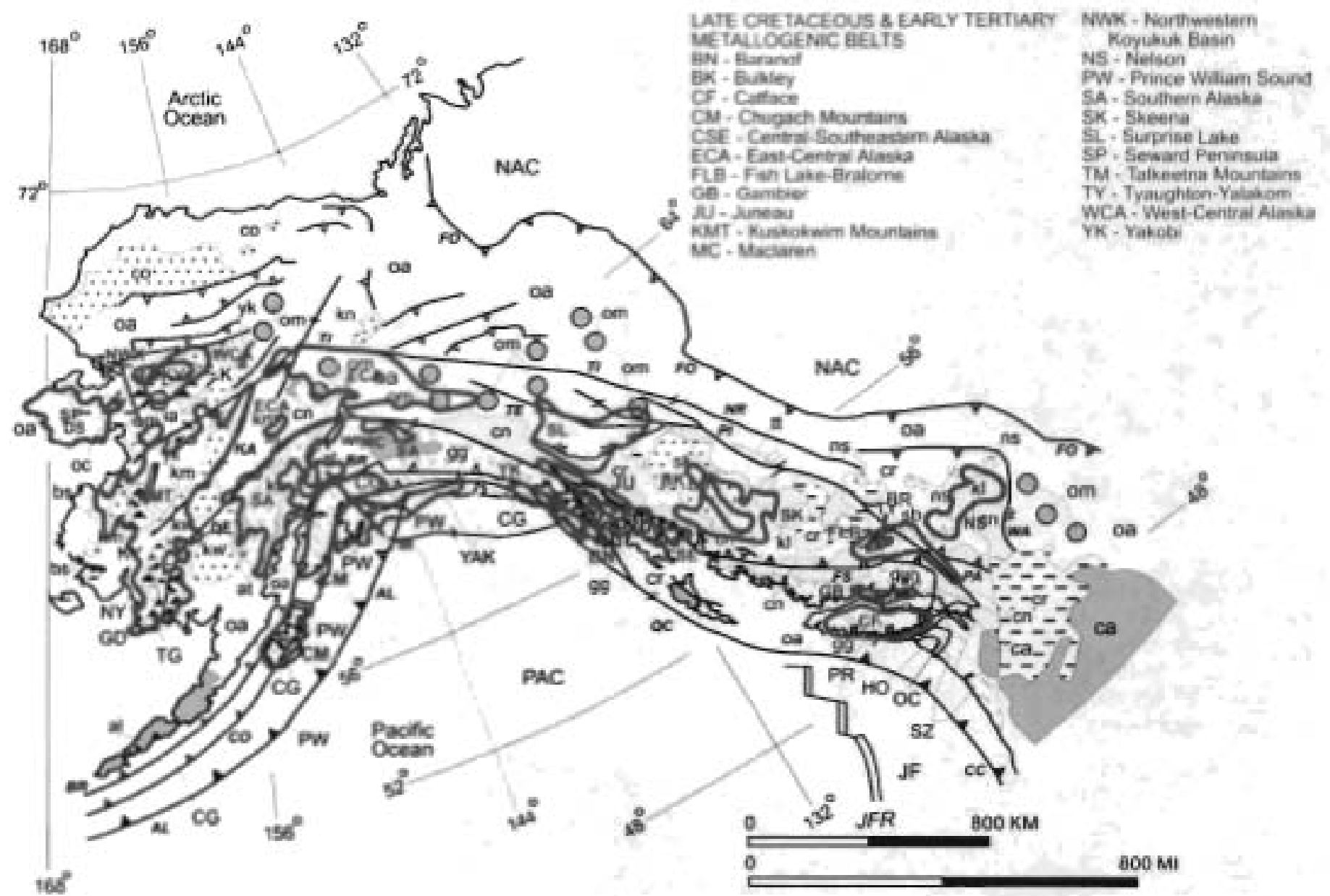

Figure 103. Generailzed map of major Late Cretaceous and early Tertiary metallogenic beits, overlap assemblages, and tectonically-inked subouction-zone or accretionary-wedge terranes for Alaska, Canadian Cordillera, and adjacent offshore areas. Refer to text for description of metallogenic belts. Adapted from Nokleberg and others (1997b, 1998). Refer to figure 59 for explanation.

Juncau (JU), and Maclaren (MC), and Talkeetna Mountains (TM) belts, which contain Au quartz vein deposits, and the Yakobi (YK) belt which contains gabbroic Ni-Cu deposits. (8) Also in the same region, the Prince William Sound (PW) belt, which contains massive sulfide deposits related to marine mafic volcanism, is interpreted as forming during sea-floor spreading along the Kula-Farallon oceane ridge before thrusting of the ridge beneath the margin of Southern Alaska, And (9) in Southeastern Alaska and the Canadian Cordillera are a large array of metallogenic belts which contain granitic-magmatism-related deposits which are hosted in or near the Coast-North Cascade plutonic belt. In alphabetical order, these belts are the Catface (CF), CentralSoutheastern Alaska (CSE), Bulkley (BK), Fish Lake-Bralome (FLB), Gambier (GA), Nelson (NS), Skeena (SK), Surprise Lake (SL), and Tyaughton-Yalakom (TY) belts. The belis are interpreted as forming during subduction-related granitic plutonism which formed the Coast continental margin arc. In the below descriptions of metallogenic belts, a few of the noteable or signficant lode deposits (table 4) are described for each belt.

\section{Metallogenic-Tectonic Model for Late Cretaceous and Early Tertiary (84 to $52 \mathrm{Ma}$; Figure 104)}

During the Late Cretaceous and early Tertiary (Campanian though Early Eocene - 84 to 52 Ma), the major metallogenictectonic events were (fig. 104; table 3): (1) the continuation of a series of continental-margin arcs, associated metallogenic belts, and companion subduction-zone assemblages around the Circum-North Pacific; (2) completion of opening of the Amerasia, Canada, and Eurasia Basins; (3) completion of accretion of the Wrangellia superterrane; (4) a change to dextral transpression in the eastern part of the Circum-North Pacific between the Kula Ocean plate and the North American continental margin; (5) oblique subduction of the Kula-Farallon oceanic ridge under the margins of Southem and Southeastem Alaska, and formation of associated metallogenic behs, and (6) northward migration of previously accreted terranes along the margin of the North American Cordillera. 


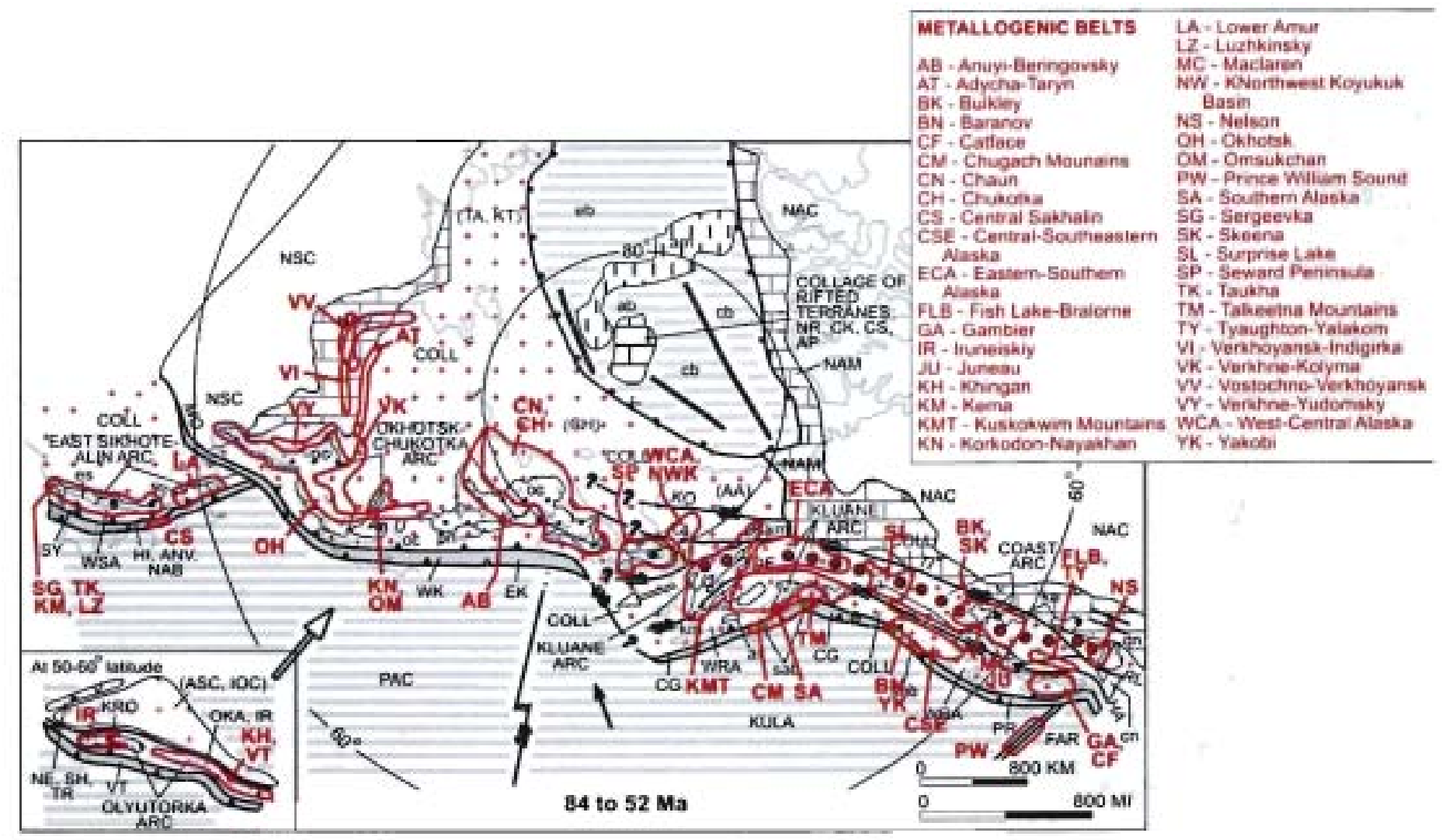

Figure 104. Late Cretaceous and early Tertiary (Campanian through early Eocene - 84 to 52 Ma) stage of metallogenic-tectonic model. Refer to text for explanation of metallogenic-tectoric events, to tables 3 and 4 for descriptions metallogenic belts and significant deposits, and to figure 18 for explanation of abbreviations, symbols, and patterns. Adapted from Nokleberg and others (1997b, 1998, 2000).

\section{Specific Events for Late Cretaceous and Early Tertiary}

(1) Far to the south, at about $50^{\circ}$ to $60^{\circ}$ paleolatitude, the extensive Olyutorka island are continued to form. Parts of the are are preserved in the Nemuro (NE), Kronotskiy (KRO), and Olyutorka-Kamchatka (OKA), and Iruneisky (IR) island-arc terranes. Continuing to form in the Olyutorka arc were the Koryak Hightands metallogenic belt, which contains zoned maficultramafic PGE and Cu massive sulfide deposits, the Vatyn (VT) metallogenic belt, which contains volcanogenic Mn and Fe deposits. Also forming in Olyutorka are was the Iruneiskiy (IR) metallogenic belt of porphyry Mo deposits. Associated with the arc was subduction of part of the adjacent oceanic plate to form the Vetlovskiy (VT) terrane. This arc and companion subduction zone migrated northward toward the Okhotsk-Chukotka continental-margin arc.

(2) Farther west, the East Sikhote-Alin continental-margin arc (es) and related deposits continued activity. Forming as part of the are was the West Sakhalin (WSA) turbidite-basin terrane, Continuing to form in the East-Sikhote arc were the Kema, Lower Amur, Luzhkinsky, Segeevka, and Taukha metallogenic belts. Associated with the are was oblique subduction of part of the Pacific Ocean plate (PAC) to form the Hikada (HI), Aniva (ANV), and Nabilsky (NAB) terranes.

(3) The Okhotsk-Chukotka continental-margin arc continued activity. Parts of the arc are preserved in the OkhotskChukotka volcanic-plutonic belt (oc) and related Penzhina (forearc) sedimentary basin (pn). Associated with the arc was subduction of part of the Pacific Ocean plate (PAC) to form the West Kamchatka (WK) and Ekonay (EK) terranes, Local plutons in the Okhotsk-Chukotka volcanic-plutonic belt intruded under extension, probably as the result of rollback of the subduction slab during the Late Cretaceous (Amato and Wright, 1997). Also in the same region, the Okhotsk-Chukotka and East Sikhote-Alin continental-margin ares were offset in a sinistral sense along the Mongol-Okhotsk fault system (MO). Continuing in the OkhotskChukotka arc was the Eastern Asia metallogenic belt of granitic-magmatism-related deposits which contained a complex array of zones. Continuing or new zones were the Anuyi-Beringovsky (AB), Chaun (CN), Chukotka (CH), Korkodon-Nayakhan (KN), Okhotsk (OH), Omsukchan (OM), Verkhoyansk-lndigirka (VY), Verkhne-Kolyma (VK), Verkhne-Yudomsky (VY) zones. Also continuing to form in the Okhotsk-Chukotka volcanic-plutonic belt and peripherally related to the Eastern Asia metallogenic belt in the Russian Far East were the Adycha-Taryn (AT), and Vostochno-Verkhoyansk (VV) metallogenic belts. Forming in the Okhotsk-Chukotka volcanic-plutonic belt in western Alaska, and peripherally related to the Eastem Asia metallogenic belt, were the Northwestem Koyukuk Basin metallogenic belt (NWK) which contains felsic plutonic U deposits, the Seward Peninsula 
metallogenic belt (SP) which contains Sn skam and related deposits, and the West-Central Alaska metallogenic belt (WCA) which contains porphyry $\mathrm{Cu}$ deposits.

(4) Between the areas of the Russian Far East and Alaska, continental-margin arcs and companion subduction zones in each region were connected by a major transform fauli. In the area of Western Alaska, tectonic escape (crustal extrusion) of terranes occurred along major dextral-slip faults, including the Denali $(D E)$, Iditarod-Nixon Fork $(N F)$, Kaltag $(K A)$, and companion faults (Scholl and others, 1992, 1994). In association with movement on these major dextral-slip faults, dexiral-wrench sedimentary basins formed, including the Kuskokwim basin (kw; Plafker and Berg. 1994; Bundtzen and Miller, 1997). The crustal extension and wrench faulting were associated with a major period of extension in Interior Alaska according to the interpretation of Miller and Hudson (1991). The middle and Late Cretaceous extension is interpreted as forming warm, thin continental crust which was favorable for crustal extrusion and dextral-wrench faulting (Scholl and others, 1992, 1994).

(5) By the early Tertiary, in the region of the Amerasia (ab), Canada (cb) and Eurasia (eb) Basins, sea-floor spreading and associated rifting was completed (Grantz and others, 1990, 1991, 1998), and sedimentation continued in the large Amerasia (ab), Canada (cb) and Eurasia (eb) Basins. The formation of the Alpha and Mendeleev Ridges (am), which are interpreted as large piles of hot-spot basalt and associated deposits, was completed (Grantz and others, 1990, 1991, 1998).

(6) In the Paleocene (about 56 to $60 \mathrm{Ma}$ ), in the area of the Bering Sea, major counter-elockwise rotation of the Pucific Ocean plate (PAC) occurred (at about $30^{\circ}$ to $50^{\circ}$ paleolatitude; Lonsdale, 1988). The rotation resulted from compression between Eurasia and North America (Plafker and Berg, 1994). At the same time, the extension of dextral-slip faults from the area of Western Alaska into the Bering Sea resulted in accretion and capture of a fragment of the Kula Oceaa plate (KULA; Scholl and others, 1992, 1994).

(7) In response to oblique subduction of the Kula Ocean plate (KULA), the major Kluane continental-margin are formed (Plafker, 1994; Nokleberg and others, 2000). Parts of the are are preserved as the Kuskokwim Mountains voleanic-plutonic belt $(\mathrm{km})$ and Alaska Range-Talkeetna Mountains igneous belt (at). The coeval Coast are fomed along the margin of the North American Cordillera. Parts of this arc are preserved in the Coast-North Cascade plutonic belt (cn) and the Kamloops magmatic belt (kj). These continental-margin ares overlapped the previously accreted Wrangellia superterrane and adjacent inboard terranes and extended for a distance of more than $3,200 \mathrm{~km}$ along the active continental margin of the North American Cordillera. Associated with the Kluane continental-margin are was the subduction of the laterally extensive Chugach terrane (CG) and the Pacific Rim terrane (PAR).

Forming in the Kluane are in Southern Alaska were the East-Central Alaska (younger parn; ECA), Southern Alaska (SA), and Kuskokwim Mountains (KMT) belts, which are hosted in the Kuskokwim Mountains sedimentary and voleanic belt or the Alaska Range-Talkeetna Mountains igneous belt. Forming in the Coast are in Southeastern Alaska and the Canadian Cordillera were a large array of metallogenic belts which contain granitic-magmatism-related deposits which are hosted in or near the CoustNorth Cascade plutomic belt. The belts include the Catface (CF), Central-Southeastern Alaska (CSE), Bulkley (BK), Fish LakeBralorne (FLB), Gambier (GA), Nelson (NS), Skeena (SK), and Surprise Lake (SL) belts. All these belts are interpreted as forming during subduction-related granitic plutonism.

(8) Along the active margin of the North American Cordallera, the rapid northward migration of the Kula Ocean plate (KULA), which started to form at about $85 \mathrm{Ma}$ (Englebretson and others, 1985), resulted in formation of major dextral-slip faults, including the Denali $(D E)$, Tintina (Th), Ross Lake (RL), and companion faults (Plafker and Berg. 1994). Oblique subduction of the Kula-Farallon oceanic ridge occurred at about 50 to $60 \mathrm{Ma}$ along the margin of Southern Alaska (Bradley and otbers, 1993 ). The subduction of the oceanic ridge, locally partly preserved in ophiolites in the Prince William Terrane (Lytwyn and others, 1997; Kusky and Young, 2000), in the early Tertiary is interpreted as causing (1) a regional metamorphic welt and formation of anatectic granites (Plafker and others, 1989b; 1994); (2) rapid changes in components strike-slip movements along the subduction zone bordering the early Tertiary contisental margin (Bradley and others, 1993); and (3) formation of belts of early Tertiary granitic and mafic-ultramafic plutonic rocks of the Sanak-Baranof plutonic belt (sab; Hudson, 1979; Moll-Stalcup and others, 1994) in Southem and Southeastem Alaska which are interpeted as forming in a near-trench environment during subduction of the Kula-Farallon oceanic ridge (Bradley and others, 1993; Kusky and others, 1997).

In Southern and Southeastem Alaska, several metallogenic belts are interpreted as forming during oblique subduction of the Kula-Farallon oceanic ridge under margin of Southern and Southeastern Alask. These metallogenic belts include the Baranof (BN), Chugach Mountains (CM), Juneau (JU), Maclaren (MC), and Talkeetna Mountains (TM) metallogenie belts, which contain Au quartz vein deposits, and the Yakobi (YK) metallogenic belt which contains gabbroic Ni-Cu deposits. (9) Also in the same region, the Prince William Sound (PW) metallogenie belt, which contains massive sulfide deposits related to marine mafic volcanic rocks, is interpreted as forming during sea-floor spreading along the Kula-Farallon oceanic ridge before subduction of the ridge beneath the margin of Southern Alaska.

(9) Regional extension occurred in the southern Canadian Cordillera and northeastern Washington. The extension is interpreted either as: (1) the result of a change from transpression to transtension at about 55 Ma (Parrish and others, 1988); (2) caused by a change of obliquity of convergence of the oceanic plate, or (3) alternatively, but likely, collapse of overthickened thrust units.

(10) The eastward thrusting of the North American Craton Margin (NAM) over the North American Craton (NAC) ended at about $60 \mathrm{Ma}$ in the Canadian Cordillera. 


\title{
Iruneiskiy Metallogenic Belt of \\ Porphyry Cu Deposits (Map Unit IR) \\ Southern Kamchatka Peninsula
}

The small Iruneiskiy metallogenic belt (IR) of porphyry Mo deposits (Vlasov, 1977) occurs in the southern part of the Kamchatka Peninsula in the Iruneiskjy island-arc terrane (fig. 102; tables 3,4) (Nokleberg and others, 1994c, 1997b, c, 1998). The one economic porphyry Cu deposit in the belt at Kirganik (Vlasov, 1977; A.V. Ignatyev, written commun., 1980) consists of steeply-dipping, metasomatically altered zones of biotite and $\mathrm{K}$-feldspar which occur in Late Cretaceous siliceous volcanic rocks. The altered zones contain veinlets and disseminations of pyrite, chalcopyrite, bornite, chalcocite, hematite, gold; the zone contain up to $0.8 \mathrm{~g} / \mathrm{t} \mathrm{Au}$. The Late Cretaceous calc-alkalic volcanic rocks hosting the zones grade upward into Maastrichtian shoshonite which is intruded by dunite-clinopyroxenite-gabbro monzonite. The porphyry Cu deposits are interpreted as being related to the monzonite intrusions. The deposit has a K-Ar isotopic age of 75 to $65 \mathrm{Ma}$ which is similar to which for the intrusion. The deposit is of medium size, and average grades are $0.1-1 \% \mathrm{Cu}$ and 0.2 to $0.4 \mathrm{~g} / 1 \mathrm{Au}$ in disseminated and veinlet ore, and up to $0.8 \mathrm{~g} / \mathrm{Au}$ in oxidized ore. The Iruneiskiy terrane is interpreted as part the Olyutorka-Kamchatka island-are terrane which was accreted in the early Tertiary onto the North Asian continental margin (Nokleberg and others, 2000).

\section{Metallogenic Belts Formed in \\ Late Mesozoic and Early Cenozoic \\ Part of Okhotsk-Chukotka \\ Continental-Margin Arc, \\ Russian Northeast and Western Alaska}

\author{
Eastem Asia-Arctic Metallogenic Belt: \\ Verkhne-Yudomsky (Yuzhno-Verkhoyansk) \\ Zone of $\mathrm{Sn}$ and $\mathrm{Ag}$ Polymetallic Vein \\ (Southem Bolivian type) Deposits (Beit VY) \\ West-Central Part of Russian Northeast
}

The Verkhne-Yudomsky (Yuzhno-Verkboyansk) metallogenic zone of Sn and Ag polymetallic vein (Southern Bolivian type) deposits (fig. 102; tables 3,4) extends north-south for $400 \mathrm{~km}$ with a maximum width of $100 \mathrm{~km}$. The belt occurs in the west-central part of the Russian Northeast, and is hosted by either the clastic sedimentary rocks of the North Asian Craton Margin (Verkhoyansk fold belt), the Okhotsk cratonal terrane, or the volcanic rocks of the Okhotsk-Chukotka volcanic-plutonic belt. The significant deposits in the zone are (table 4) (Nokleberg and others 1997a, b, 1998): Sn polymetallic vein deposits at Balaakkalakh, Diring-Yuryak, Khaardak, and Khoron; and various types of polymetallic vein deposits at Dzhaton, Kutinskoe, Nivandzha, and Zamitsa.

The metallogenic zone is associated with major hypabyssal Early and Late Cretaceous felsic intrusions which occur in the landward part of the Cretaceous to early Tertiary Okhotsk-Chukotka volcanic-plutonic belt (unit ok, fig. 102) (Nokleberg and others, 1994c, 1997c). The deposits generally consist of quartz-chlorite-sulfide veins with cassiterite, hematite, sericite, fluorite, arsenopyrite, pyrite, chalcopyrite, galena, sphalerite, stannite, tetrahedrite, and gold which occur in steeply-dipping shear zones to $20 \mathrm{~m}$ thick and in elongate (stringer) masses in dacite, rhyolite, and granite porphyry. Wallrocks are generally altered to chlorite and sericite. Also associated with the $\mathrm{Sn}$ and $\mathrm{Ag}$ polymetallic vein deposits are small $\mathrm{Sn}$ (Bi, W) greisen deposits, generally small and uneconomic, which are related to leucocratic Late Cretaceous granitoid plutons. The major Sn and Ag polymetallic vein deposit is at Zarnitsa-Kutinskoe. The Verkhne-Yudomsky metallogenic zone is interpreted as forming in the rear of the perivolcanic zone of the Cretaceous to early Tertiary Okhotsk-Chukotka volcanic-plutonic belt (fig, 102).

\section{Zarnitsa-Kutinskoe Pb-Zn-Ag \\ Polymetallic Vein Deposit}

The Zamitsa-Kutinskoe $\mathrm{Pb}-\mathrm{Zn}-\mathrm{Ag}$ polymetallic vein deposit (V.I. Korostolev, written commun., 1963) consists of two polymetallic quartz-sulfide veins which contain galena, sphalerite, pyrite, chalcopyrite, and silver minerals. The larger vein is up to $500 \mathrm{~m}$ long and $6 \mathrm{~m}$ thick. The veins cut Late Cretaceous granite-porphyry and rhyolite and have a fringe of disseminated sulfides up to $20 \mathrm{~m}$ thick. The Kutinskoe deposit consists of one vein about $3 \mathrm{~m}$ thick and $400 \mathrm{~m}$ long which is composed of quartz, pyrite, galena, sphalerite, and pyrrhotite. The Kutinskoe vein cuts contact-metamorphosed Late Permian sandstone and shale. The deposit is medium size with average grades of $4.86-7.75 \% \mathrm{~Pb}, 4.1-5 \% \mathrm{Zn}$, and $44-3,268 \mathrm{~g} / \mathrm{Ag}$. 
Eastern Asia-Arctic Metallogenic Belt:

Verkhoyansk-indigirka (Dulgalak)

Zone of Clastic Sediment-Hosted $\mathrm{Hg}$

and Sb-Au Vein Depesits (Beit EAVI)

Western Part of Russian Northeast

The Verkhoyansk-Indigirka (Duigalak) metallogenic zone of elastic sediment-hosted $\mathrm{Hg}$ and $\mathrm{Sb}$-Au vein deposits (fig. 102; tables 3,4) occurs in a narrow are in the western part of the Russian Northeast. The zone is more than $1,200 \mathrm{~km}$ long and up to $50 \mathrm{~km}$ wide. The zone mostly oecurs within the North Asian Craton Margin (Verkhoyansk fold belt, unit NSV), to a lesser amount in the Kular-Nera accretionary-wedge terrane of the Kolyma-Omolon superterrane. The significant deposits in the belt ure (table 4) (Nokleberg and others 1997a, b, 1998): clastic sediment-hosted Hg deposits at Erel, Iserdek, Kholbolok, Seikimyan, Singyami, Zagadka, and Zvezdochka; and Sb, Sb-As, Sb-Au, and Sb-Au-Hg vein deposits at Baidakh, Betyugen, Imnekan. Kyuchyuss, Selerikan, Senduchen, and Stibnitovoe. The one is locally extensively overlain by unconsolidated Cenozoic sedimentary deposits of the Primorskaya lowland. The Verkhoyansk-Indigirka metallogenic belt may be a portion of a greater Verkhoyansk-Chukchi mercury belt. The major clastic sediment-hosted Hg deposits are at Zagadka and Zvezdochka, and the major Sb-Au vein deposit is at Kyuchyuss (fig. 105). The clastic sediment-hosted $\mathrm{Hg}$, and Sb-Au vein deposits are hosted mainly in clastic sandstone and shale and generally oceur along the hinges of anticlines which are crossed by longitudinal and diagonal faults. The deposits generally are along deep faults which strike subparallel to the strike of the major folds. The Sb-Au vein deposits generally occur where the Verkhoyansk-Indigirka metallogenic zone overlies Au quartz vein deposits of aceretionary metallogenic belts, such as the Kular metallogenic belt (fig. I1). This metallogenic zone contains abundant pre-mineralization subalkalic basalt dikes of Late Cretaceous and Paleogene age with K-Ar isotopic ages of 90 to $45 \mathrm{Ma}$. The Verkhoyansk-Indigirka metallogenic zone is interpreted as possibly forming in the rear (back-arc) portion of the Okhotsk-Chukotka volcanic-plutonic belt (Nokleberg and others, 1994c, 1997c).

\section{Zagadka Clastic Sediment-Hosted Hg Deposit}

The Zagadka clastic sediment-hosted Hg and associated deposits (V.V. Maslennikov, written commun., 1977, 1985) consists of cinnabar and metacinnabarite which are relatively younger than the Sb-Au vein deposits which consist of stibnite and berthierite. The Zagadka deposit occurs in Late Permian sandstone and siltstone which is gentle folded and cut by steeply-dipping faults. The deposit is located along a linear zone about $2.4 \mathrm{~km}$ long within one of the faults, The thickness and morphology of the ore bodies is influenced by shear zones and associated feathered veins and stringers. The ore bodies, mainly cinnabar, range from 0.4 to $3 \mathrm{~m}$ thick. Subordinate minerals are galena, sphalerite, stibnite, Pb-sulfosalts, and cassiterite. Gangue minerals are quartz. dickite, and carbonate minerals. The wall rocks exhibit dickite, quartz and carbonate alteration. Average grades are $0.22-6.2 \% \mathrm{Hg}$. $0,8-20 \% \mathrm{~Pb}, 2-10 \% \mathrm{Zn}, 4-10 \% \mathrm{Sb}$, and up to $30 \mathrm{~g} / \mathrm{Ag}$. Estimated resources are 1,718 tonines mercury and 1,000 tonnes antimony.

\section{Kyuchyus Sb-Au-Hg Vein Deposit}

The Kyuchyus Sb-Au-Hg vein deposit (Ivensen and others, 1975; Indolev and others, 1980; Konyshev and others, 1993) occurs in steeply-dipping mineralized reverse shear zones up to $1 \mathrm{~m}$ thick and in veins up to $0.5 \mathrm{~m}$ thick. The shear zones and veins contain quartz-stibnite, cinnabar-stibnite-quartz, realgar-quartz and quartz, with various amounts of ankerite, calcile, kaolinite, dickite, arsenopyrite, pyrite, orpiment, berthierite, sphalerite, galena, bournonite, pyrmbotite, tetrabedrite, native mercury (up to 15\%), and gold. The veins and shear zones crosscut a Middle Triassic (Anisian and Ladinian) sequence of sandstone and siltstone flysch. Alteration types include argillaceous, silicic, carbonate, and hydromica aureoles which occur near the deposit. A verage grades are $4.5 \% \mathrm{As}$, up to $15 \% \mathrm{Sb}$, up to $0.6 \% \mathrm{Hg}$ and up to $300 \mathrm{~g} / \mathrm{Au}$. The $\mathrm{Sb}$-Au ( $\mathrm{Hg}$ ) vein deposits usually vary from small to medium in size, and are not economic.

\section{Eastern Asia-Arctic Metallogenic Belt: \\ Anuyi-Beringovsky Zone of Au-Ag \\ Epithermal Vein and Disseminated \\ Au Sulfide Deposits (Belt EAAB) \\ Northeastern Part of Russian Northeast}

The Anuyi-Beringovsky zone of and disseminated Au-sulfide deposits (fig. 102; tables 3,4) occurs in the northeastern part of the Russian Northeast. The zone extends approximately east-west for more than $1,000 \mathrm{~km}$ and ranges from 200 to $250 \mathrm{~km}$ wide. The zone is hosted in the volcanic rocks of the Okhotsk-Chukotka volcanic-plutonic belt, and in adjacent areas of coeval granitoid plutons. Most of the deposits in the zone are near-surface, Au-Ag epithermal vein deposits of Late Cretaceous and early Paleocene age. These Aw-Ag epithermal vein deposits occur mainly in volcanic rocks and are spatially related to disseminated Ausulfide deposits which oceur in clastic tocks of the Chukotka ternane which underlies the Okhotsk-Chukotka volcanic-plutonic belt. The significant deposits in the zone are (table 4) (Nokleberg and others 1997a, b, 1998): Au-Ag epithermal vein deposits at Chiseyveem, Dramyaschy, Enmyvaam, Gornostai, Maly Peledon, Promezhutochnoe, Shakh, Zhilny, Sopka Rudnaya, Upryamy, and Valunistoe; a granitoid-related Au deposit at Pelvuntykoinen; and disseminated Au-sulfide deposits at Elveney and Maiskoe. The depositional environments, ore composition, and ore chemistry of the Anuyi-Beringovsky zone are similar to those of the 
Okhotsk zone of Au-Ag epithermal vein deposits. Some post-tectonic Au-quartz vein deposits, as at Sypuchec, also occur in the Anyui-Beringovsky zone. These deposits display characteristics of mesothermal and epithermal deposition, and locally contain bonanza gold. However, their economic value is unknown.
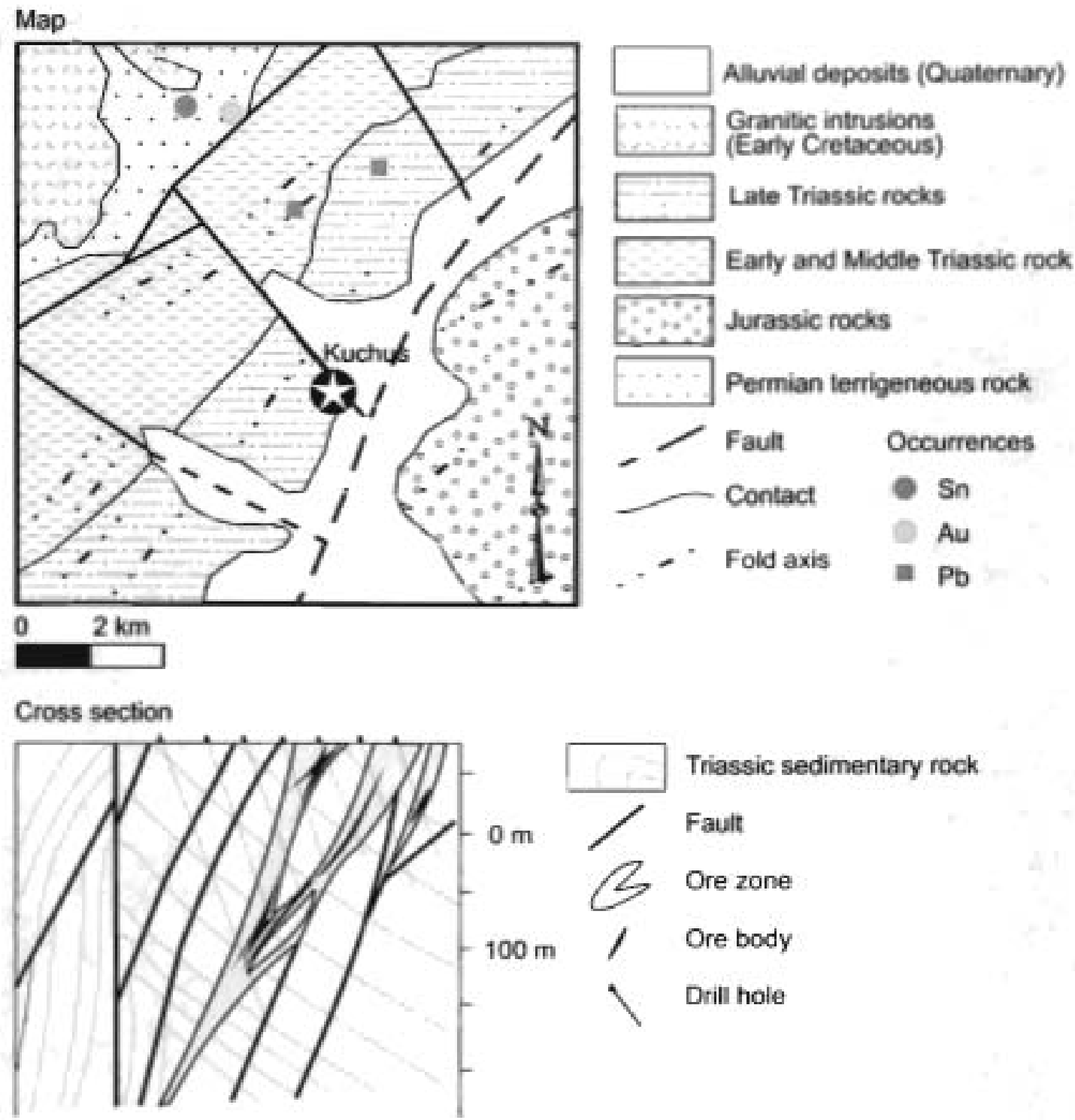

Figure 105. Kyuchyuss Sb-Au-Ho vein deposit, Verkhoyansk-Indigirka (Dulgalak) zone, Eastem Asia-Arctic metallogenic beit). Russian Northeast, Schematic rogional geologic map of Kyuchyus area and cross section of deposit. Adapted from Ivensen and others (1975) and Konyshev and others (1993).

The disseminated Au-sulfide deposits of the Anuyi-Beringovsky zone occur mainly in large shear zones which contain veinlets and disseminations of ansenopyrite, pyrite, finely-dispersed gold, and stibnite. The significant deposits are at Maiskoe, being developed for mining, and at Elvenei and Tumanoe. About ninety percent of the gold occurs as inclusions in fine needles of arsenopyrite and As-bearing pyrite, and consequently the ore is difficult to mill. The deposits are concentrated in areas where flysch units of the Chukotka passive continental margin terrane and the Jurassic and Early Cretaceous Raucha sedimentary basia, are overlain by the Okhotsk-Chukotka voleanic-plutonic belt. The disseminated Au-sulfide deposits tend to occur in areas where (Sidorov, 1987): (1) transeurrent fuults which crosscut older collisional structures, thrusts, intrusive domes and horsts; and (2) layers of clastic sediments which contain relatively high carbonaceous conients. The disseminated Au-sulfide deposits are interpreted as the roots for the Au-Ag epithermal vein deposits of the Anuyi-Beringovsky zone. 
The Valunistoe Au-Ag epithermal vein deposit (Berman and Trenina, 1968; Berman, 1969; Sidorov, 1978; P. Layer, V. Ivanov, and T.K. Bundtren, written commun., 1994) consists of more than one hundred adularia-quartz, adularia-carbonatequartz, and fluorite-quartz veins which comprise zones up to $1,500 \mathrm{~km}$ long and $400 \mathrm{~m}$ wide. The ore minerals are mainly finely disseminated electrum, argentite, aguilarite, stronieyerite, native silver, galena, sphalerite, and chalcopyrite. A gold-argentite assemblage is predominant in veins of the upper portions of the deposit. At depth, the gold-argentite assemblage is succeeded by a gold-chalcopyrite and gold-galena-sphalerite ussemblages. The ore bodies occur in Late Cretaceous volcanic rocks in a volcanic dome structure which is located at the intersection of northwest- and northeast-trending faults. The wall rocks are dominated by andesite-dacite and dacite with quartz-adularia-hydromica and propylitic alteration. The quartz veins vary from lenticular to podiform, are commonly en-echelon, and locally grade into a stockwork of veinlets associated with bydrothermal and subvolcanic breceia. Ar-Ar isotopic studies of adularia in Au-Ag vein yields an age of $72 \mathrm{Ma}$. The deposit is of medium size and ranges from 1.4 to $787 \mathrm{~g} / \mathrm{Au}$ and 2 to $6.273 \mathrm{~g} / \mathrm{Ag}$.

\section{Maiskoe Disseminated Au-Sulfide Deposit}

The Maiskoe disseminated Au-sulfide deposit (fig. 106) (Sidorov and others, 1978; Gavrilov, Novozhilov, and Sidorov, 1986; Olshevsky and Mezentseva, 1986; Sidorov, 1966, 1987; Benevolskyi and others, 1992) occurs in linear shear zones which generally trend north-south, have variable strike and dip, and are marked by distinctive cleavage, fissures, contortion, and boudinage. The deposit consists of veinlets and disseminations of Au-bearing pyrite and arsenopyrite. The veinlets and disseminations occur in the more plastic rocks such as siltsione, and silty shale, and shale which are part of a Middle(?) and Late Triassic flysch sequence. These sedimentary rocks are intruded by dikes of quartz-feldspar porphyry, granile, granosyenite porphyry, Early Cretaceous lamprophyre, Late Cretaceous rhyolite, as well as by vein-like bodies of intrusive breccia of OkhotskChukota volcanic-plutonic belt. The igneous rocks are altered to beresite, kaolinite, sericite, carbonate, graphite, and irregular silicic alteration. The carbonaceous rocks sedimentary rocks are metamorphosed to phyllite. The ore consists mainly of disseminated high-grade Au in acicular arsenopyrite and As-rich pyrite. A luter quartz-stibaite-native arsenic stage of mineralization is also widespread. Exterior to the ore zones, veins of molybdenite-quartz and REE-polysulfide-quartz oceur mainly in sandstone. These veins contain cassilerite, scheelite, wolframite, Bi-minerals, tetrahedrite-tennantite, and $\mathrm{Pb}$ - and $\mathrm{Ag}$ sulfosalts. A K-Ar adularia age for the vein is $79.4 \mathrm{Ma}$ (Ishihara and others, 1997). The Au mineralization is vertically and areally extensive. The deposit contains proven reserves of 23 million tonnes with an average grade $12 \mathrm{~g} t \mathrm{Au}$.

\section{Eastern Asia-Arctic Metallogenic Belt: \\ Chukotka Zone of Igneous-Related \\ $\mathrm{Hg}$ Deposits (Belt EACH) Northeastern \\ Part of Russian Northeast}

The Chukotka zone of igneous-related Hg deposits (fig. 102; tables 3,4) oceurs in the northeastem part of the Russian Northeast. The Chukotka zone contains numerous $\mathrm{Hg}$ deposits and occurrences, trends roughly east-west, is about $1,000 \mathrm{~km}$ long and ranges from $10010150 \mathrm{~km}$ wide. The significant deposits in the belt are (table 4) (Nokleberg and others 1997a, b, 1998): clastic sediment-hosted $\mathrm{Hg}$ deposits at $\mathrm{Kyttam}$ lai and Palyan; volcanic-hosted $\mathrm{Hg}$ deposits at Kulpolney, Omrelkai, and Plamennoe; and a silica-carbonate $\mathrm{Hg}$ deposit at Matachingai. The deposits occur both in the Okhotsk-Chukotka volcanic-plutonic belt and in the igneous rocks which intrude the Jurassic and Early Cretaceous sedimentary rocks of the Raucha Basin (Nokleberg and others, 1994c, 1997e). The Chukotka zone partly overlies the Anyui-Beringovsky and Chaun metallogenic zones (fig. 102).

The $\mathrm{Hg}_{\mathrm{g}}$ deposits in the Chukotka zone generally occur in linear belts up to several kilometers long, and are partly controlled by northwest-southeast-trending faulis. The deposits are hosted in rhyolite, andesite, and more rarely in ultramafic rocks, and show a distinctive relation basalt and lamphrophyre dikes (Obolensky and Obolenskaya. 1971). The Hg deposits oceur in faulted areas in volcanic dornes, borsts, subsiding calderas, and anticlines. The deposits generally occur in stockworks and veins, and cinnabar is the predominant mineral, generally in association with ankerite, quarts, and dickite. The major $\mathrm{Hg}$ districts are at Tsentral Chukotsky, Sredne-Anadyrsky, and Vostochno-Chukotsky (Babkin, 1975; Kopytin, 1978). The Palyavaam area (Tsentral Chukotsky district) is the best studied, contains the Palyanskoe and Plamennoe deposits. Some deposits are economic.

\section{Palyanskoe Clastic Sediment-Hosted $\mathrm{Hg}$ or Hot-Spring $\mathrm{Hg}(7)$ Deposit}

The Palyanskoe clastic sediment-hosted Hg or hot-spring Hg(?) deposit (Syromyatnikov, 1972; Babkin, 1975; Syromyatnikov, Dubinin, 1978) consists of stockworks, veinlets, and disseminations, podiform occurrences which are hosted in Late Cretaceous sandstone and shale. The sedimentary rocks overly a deeply-eroded volcanic dome now exposed as a block of volcaniclastic rocks with an intrusive core. The $\mathrm{Hg}$ deposit formed in several stages. Most parts of the deposit occur at the intersections of major north-south- and east-west-trending faults. The ore bodies tend to occur along extensive layering in the volcanic tocks and along zones of lectonic disruption and explosive brecciation. More than 30 minerals are recognized, including 
quartz, dickile, dolomile, siderite, calcite, cinnabar, marcasite, pyrite, galena, sphalerite, native arsenic, and realgar, and nickel minerals. Wall-rock alteration is not identified. The deposit contains an estimated 10,117 tonnes $\mathrm{Hg}_{\mathrm{g}}$ in ore grading $0.53 \% \mathrm{Hg}$.
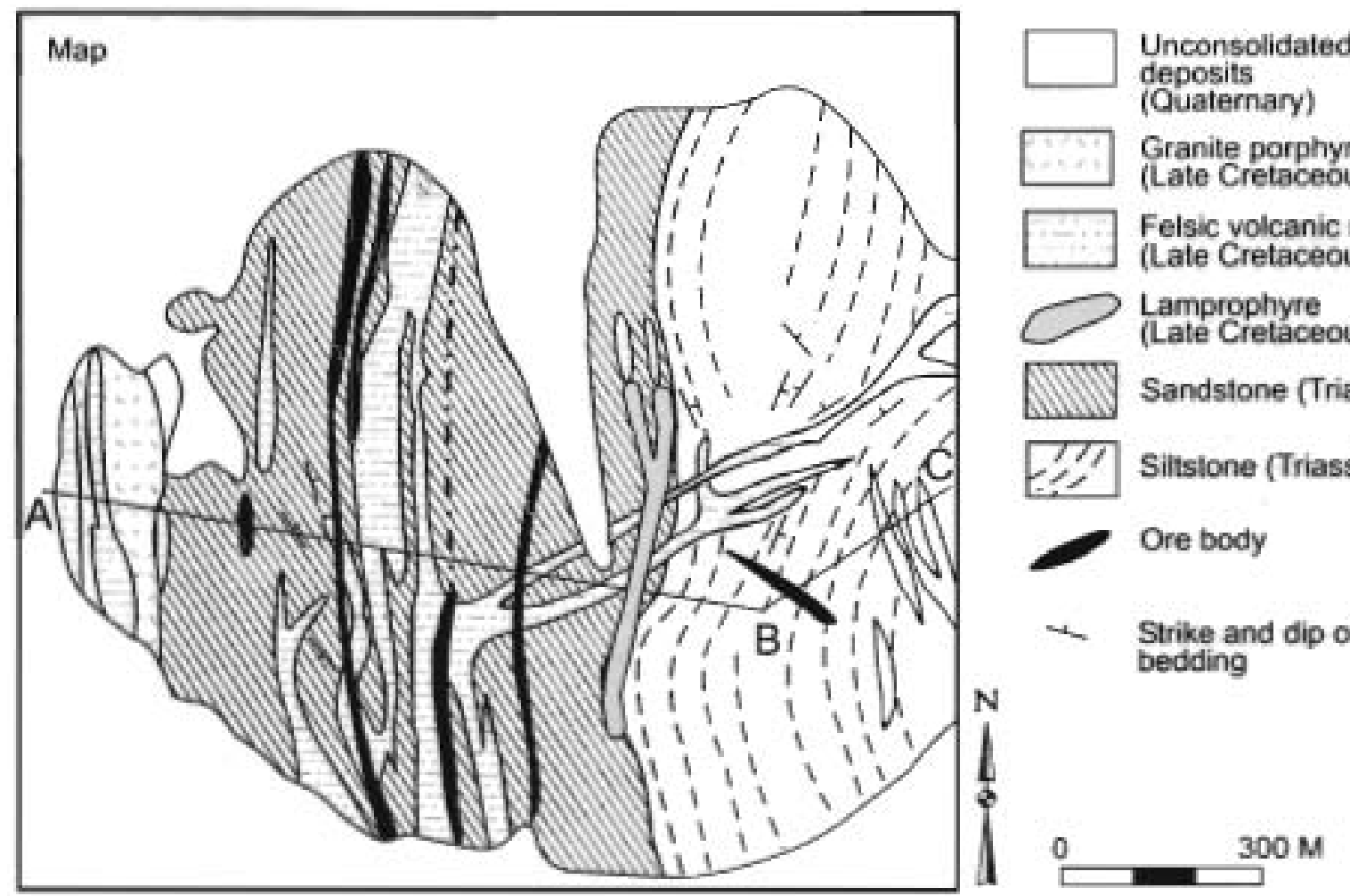

Granite porphyry (Late Cretaceous)

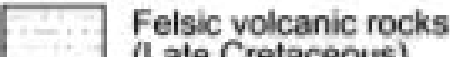

(Late Cretaceous)

Lamprophyre (Late Cretaceous)

DIDI Sandstone (Triassic)

[7/ Siltstone (Triassic)

$\longrightarrow$ Ore body

- Strike and dip of bedding
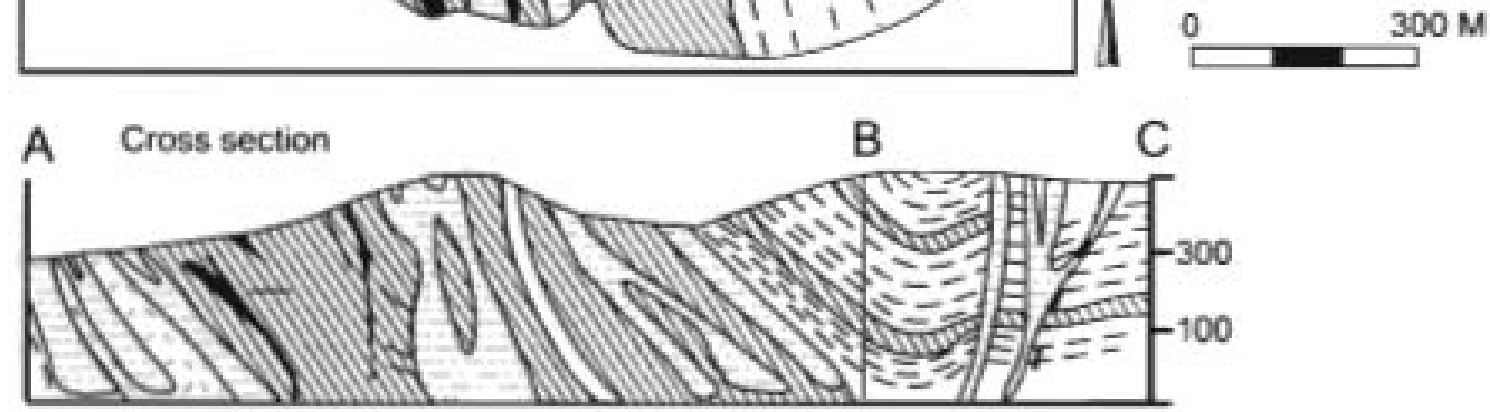

Figure 106. Maiskoe disseminated Ausulfide deposit. Anuyh-Beringovsky zone, Eastern Asia-Avctic metallogenic belt Russian Northeast. Schematic poologic map and cross section. Adapted from Sidorov and Eremin (1995).

\section{Seward Peninsula Metallogenic Belt of Granitic Magmatism Deposits (Belt SP) Northwestern Naska}

The Seward Peninsula metallogenic belt of granitic magmatism deposits (fig 103; tables 3, 4) occurs on the western part of the Seward Peninsula and St. Lawrence bland (not shown on fig. 103) in northern Alaska (Nokleberg and others, 1995a; Hudson and Reed, 1997). The metallogenic belt is hosted in the part of the region iniruded by Late Cretaceous silicic granitoid plutons (Hudson and Arth, 1983). The deposit types are mainly Sn granite, porphyry Mo, polymetallic vein, and felsic plutonic U deposits. The significant deposits in the belt are (table 4) (Nokleberg and others 1997a, b, 1998): Sn quartz vein deposits at Cape Mountain and Potaloe Mountain; a Sn skarn deposit at Ear Mountain (Winfield); a complex Sn-W skam, Sn greisen, Carbonatereplacement $\mathrm{Se}$ (7) deposit at Lost River, a Sn greises deposit at Kougarok; polymetallie vein deposits at independence, Omilak, Quartz Creek, and Serpentine Hot Springs; a porphyry Mo deposit at Windy Creek; a sediment-hosted U deposit at Death Valley; and a felsic plutonic U deposit at Eagle Creek. The deposits and host granite plutons are interpreted as the extreme northeastern end of the Cretaceous and early Tertiary Okhotsk-Chukotka volcanic-plutonic belt which extends for several thousand kilometers to the west across the Bering Straits and southwest into the Russian Far East (Nokleberg and others, 1994c, 1997c). The various Sn deposits are commonly referred to as the Cretaceous tin province of the Seward Peninsula. The origins of many of the polymetallie vein depesits are somewhat enigmatic. 
The classic Lost River Sn-W skam and Sn greisen deposit (fig. 107) (Dobson, 1982; Hudson and Arth, 1983; Reed, Menzie, and others, 1989; Newberry and others, 1997) consists of several prospects and one mine in veins, skams, greisens, and intrusion breccia formed above a shallow Late Cretaceous granite stock that intruded thick sequence of Early Ordovician limestone and argillaceous limestone. Early-stage andradite-idocrase skam and later fluorite-magnetite-idocrase vein skarns are altered to chlorite-carbonate assemblages which are contemporaneous with formation of cassiterite-bearing Sn greisen. The major ore minerals in skarn and greisen are cassiterite and wolframite, and lesser stannite, galena, sphalerite, pyrite, chalcopyrite, arsenopyrite, and molybdenite, plus a wide variety of other contact metasomatic and alteration minerals. The $\mathrm{K}$-Ar isotopoic age of the granite is $80.2 \mathrm{Ma}$. Production of 320 tonnes Sn occurred mostly from 1951 to 1956 from underground workings a few hundred meters deep along the Cassiterite dike, a near-vertical rhyolite dike which is extensively altered to greisen over the buried granite. Similar smaller deposits nearby include Sn greisen and veins near the Tin Creek Granite and various polymetallic veins and skarns near the Brooks Mountain Granite. A large beryllium deposit occurs peripheral to the skarns and consists of limestone replaced by fluorite-white mica veins which contain diaspore, chrysoberyl, and tourmaline. The Be deposit is probably associated with early stages of granite intrusion. Some placer Sn was recovered from creek below Lost River mine. A major exploration program in early 1970's drilled several large Sn-W-fluorite-Be ore bodies. The deposit contains estimated reserves of 25 million tonnes grading $0.15 \% \mathrm{Sn}, 0.03 \% \mathrm{WO}_{3}, 16.3 \% \mathrm{CaF}_{2}$ (WGM, Inc., written commun., 1975).

\section{Felsic Plutonic $U$ and Sandstone $U$ deposits}

A complex, multi-phase, felsic plutonic U deposit occurs at Eagle Creek and a sandstone $U$ deposit occurs at Death Valley, both in the eastern part of the Seward Peninsula. The felsic plutonic deposit consists of disseminated U-, Th-, and REEminerals, which occur along the margins of alkaline dikes intruded into a Cretaceous granite pluton and adjacent wall rocks (Miller, 1976, Miller und Bunker, 1976). The Death Valley sandstone U deposit consists mainly of metaautunite in Paleocene sandstone along the margin of a Tertiary sedimentary basin (Dickinson and Cunningham, 1984; Dickinson and others, 1987). The $\mathrm{U}$ in the sandstone probably was transported by groundwater from Cretaceous granitoid plutons to the west (Dickinson and Cunningham, 1984),

\section{Origin of and Tectonic Controls for Seward Peninsula Metallogenic Belt}

The felsic-magmatiam-related deposits of Seward Peninsula metallogenic belt generally occur in, or adjacent to, moderate or bighly silicic granites of latest Cretaceous age (Hudson and Arth, 1983; Nokleberg and others, 1995a). The porphyry Mo, felsic plutonic U, and polymetallic vein deposits oceur in slightly older and slightly less siliceous granites, whereas the Sn granite and associated deposits occur in slightly younger and more silicic deposits. The granites associated with both groups of deposits are interpreted as forming during assimilation of the continental, Late Proterozoic and early and middle Paleozoic metasedimentary rocks of the Seward metamorphosed continental margin terrane (Hudson and Arth, 1983; Swanson and others, 1988). Alternatively, on the basis of trace element data, the Sn granite and related deposits are interpreted as forming during crustal extension (Newberry and others, 1997b).

On the basis of similar geochemistry, age, and spatial proximity, the host Late Cretaceous granitic rocks on the Seward Peninsular are interpreted as part of the eastern edge of the Okhotsk-Chukotka volcanic-plutonic belt which hosts the Seward Peninsula metaliogenic belt extends for $3000 \mathrm{~km}$ along wesiern margin of Sea of Okhotsk (Nokleberg and others, 2000). The Seward Peninsula metallogenic belt and the nearby Northwestern Koyukuk Basin metallogenic belt of felsic plutonic U deposits, described below, are inierpreted herein as the easiem extension of the Eastem-Asian-Arctic metallogenic belt in the Russian Far Easi (figs. 102, 103). The Seward Peninsula metallogenic belt with Sn granite and related deposits, is correlated with the Chaun zone of the Eastern Asia metallogenic belt which contains similar deposits to the west in the Russian Northeast (fig. 102).

\section{Northwestern Koyukuk Basin Metallogenic Beit of \\ Feisic Plutonic $U$ and Manto-Replacement \\ (Polymetallic Pn-Zn, Au) Deposits (Belt NWK) \\ West-Centrai Naska}

The Northwestern Koyukuk Basin metallogenic belt of felsic plutonic $\mathrm{U}$ and manto-replacement (polymetallic $\mathrm{Pn}-\mathrm{Zn}, \mathrm{Au}$ ) deposits (fig. 103; tables 3, 4) occurs in the Purcell district and adjacent area in the northwestern Koyukuk Basin in west-central Alaska. The metallogenic belt is hosted in the part of the region underlain by the Late Cretaceous Hogatza plutonic belt (Miller, 1994). The significant felsic plutonic U deposits in the belt are at Clear Creek, Wheeler Creek, and Zane Hills (table 4) (Miller and Elliot1, 1969; Miller, 1976; Jones, 1977; Nokleberg and others 1997a, b, 1998). These felsic plutonic U deposits and host plutonic rocks are interpreted as the extreme northeastem end of the Okhotsk-Chukotka volcanic-plutonic belt of the Russian Far East (Nokleberg and others, 1994c, 1997c, 2000). Also occurring in the metallogenic belt is a polymetallic (Au-Pb- $\mathrm{Zn}$ ) vein and manto replacements(?) in the Illinois Creek area which produced $957 \mathrm{~kg}$ Av from 1997101999 , and is isotopically dated at $111 \mathrm{Ma}$, about the same age as the nearby Khotol pluton (Flanigan, 1998). 


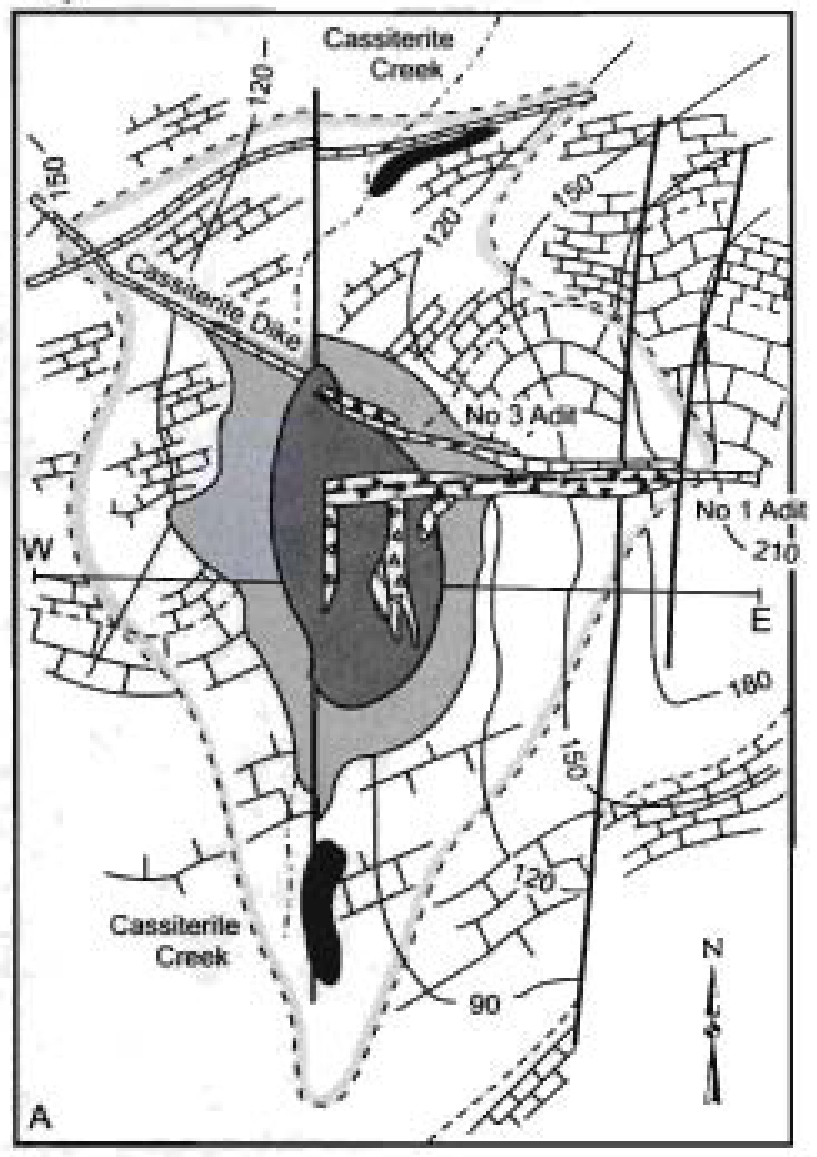

0

\section{Cross section}

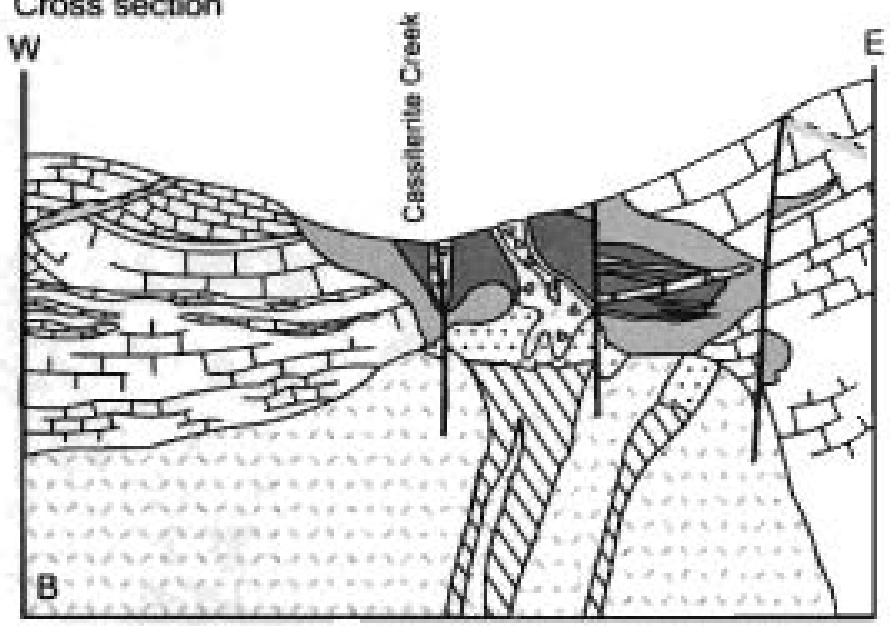

Zone of vein density $5-10 \%$; dominantly fluorite-white mica veins

Zone of vein density $10-30 \%$;

fluorite-white mica veins

Zone of vein density 10-30\%:

abundant hydrous skam

Zone of veindensity $>30 \%$ :

most early skarn and abundant hydrous skam

. I Clay-matrix breccia

$\triangle \triangle{ }_{A}$ Muscovite-matrix breccia

$\because \ldots \ldots$ Muscovite-quartz-tourmaline greisen

MIIV Quartz-topaz-tourmaline greisen

D. Quartz porphyry dike

W.:. Leucogranite

Leucogranite

Diabase dike

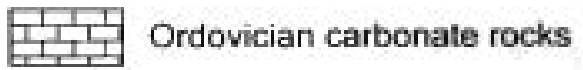

Normal fault

.....- Geologic contact

Figure 107. Lost River Sn-W skam and Sn greisen deposit, Seward Peninsula metaliogenic beit, Seward Peninsula, Alaska. Schematic geologic map and cross section. Adapted from Dobson (1982) and Hudson and Reed (1997). 
The felsic plutonic U deposits at Wheeler Creek, Clear Creek, and Zane Hills (Eakin and Forbes, 1976; Miller, 1976; Jones, 1977; Miller and Elliot, 1977) are of two main types: (1) uranothorite and gummite in quartz-rich veinlets in altered Late Cretaceous alaskite, uraniferous nepheline syenite and bostonite dikes which cut Early Cretaceous andesite; and (2) uranothorite, betafite, uraninite, thorive, and allanite in veinlets in a foliated monzonite border phuse, that locally grades to syenite. Grab samples contain up to $0.027 \% \mathrm{U}$

Minois Creek Manto-Replacement

(Polymetallic Pn-Zn, Au) Deposit

A structurally-controlled, plutonic-related epigentic deposit occurs at Illinois ereek about $70 \mathrm{Km}$ south of Galena (Flanigan, 1998; Bundtzen and others, 2000). The Illinois Creek deposit is a supergene oxidized deposit which oceurs in an east. trending, moderately dipping shear zone. The deposit has with anomalous to ore-grade $\mathrm{Au}, \mathrm{Bi}, \mathrm{AG}, \mathrm{Cu}, \mathrm{Pb}$, and $\mathrm{Zn}$. The deposit contains supergene pyrolucite, limonite, geothite, and hemetite; sulfides are rare. As/Ar isotopic age, petrologic, and microprobe studies indicate that the Illinois Creek deposit is related to emplacement of the syn-collisional, $111.3 \mathrm{Ma}$ Khotol Mountain granite (Flaniagn, 1998). The mine produced $957 \mathrm{~kg}$ gold from 1.22 million tonnes of ore prior to 1999 bankruptcy.

\section{Origin of and Tectonic Controls for Northwestern Koyukuk Basin Metallogenic Belt}

The cale-alkaline granitoid rocks which host the Northwestern Koyukuk Basin metallogenic belt extend about $300 \mathrm{~km}$ from Hughes on the Koyukuk River westward to near the Seward Peninsula. The granitoid plutonic rocks ure mainly granodiorite and lesser fonalite and high-silica granite. The granites intrude a sequence of andesitic flows, tuffs, broccia, agglomerate, conglomerate, tuffaceous graywacke, and mudstone containing local interealations of Early Cretaceous limestone which together form part of the Koyukuk island-are terrane (Patton and others, 1994). These plutons are interpreted as forming in a subductionrelated, continental-margin are on the basis of a calc-alkaline composition, high sodium content, relatively, locally abundant mafic xenoliths, and low initial Sr ratios (Miller, 1994). The Northwestern Koyukuk Basin metallogenic belt and the nearby Seward Peninsula metallogenic belt, deseribed above, are herein interpreted as the eastern extension of the Eastern-Asian-Aretic metallogenic belt which in the Russian Far East (figs. 102, 103). This major metallogenic belt, as described above, extends west and southwest for $3000 \mathrm{~km}$ along westem margin of Sea of Okhotsk.

\section{West-Central Alaska Metallogenic Belt of Porphyry Cu-Au Deposits (Belt WCA) West-Central Alaska}

The West-Central Alaska (Hogatza) metallogenic belt of porphyry Cu-Au deposits (fig. 103; tables 3, 4) (Hollister, 1978; Nokleberg and others, 1995a) is bosted in a suite of Late Cretaceous quartz monzonite plutons of the Hogatza plutonic belt which intrude oceanic crust of the Yukon-Koyukuk island-are terrane and overlapping Cretaceous flysch (Nokleberg and others, 1995a). Most of the older intrusions of the Hogatza plutonic belt exhibit K-Ar ages generally from 100 to $120 \mathrm{Ma}$, and are undersaturated, alkalic igneous complexes which tend to be barren of porphyry deposits. The significant deposits in the belt are at Indian Mountain, Purcell Mountain, and Zane Hills (table 4) (Nokleberg and others 1997a, b, 1998). All these deposits are hosted in oval-shaped, epizonal, forcefully injected plutons with K-Ar isotopic mineral ages of $80-82 \mathrm{Ma}$ (Miller and others, 1966).

\section{Indian Mountain and Purcell Mountain \\ Porphyry Cu-Au Deposits}

The Indian Mountain and Purcell Mountain porphyry Cu-Au deposits occur in the middle Koyukuk River basin. The Indian Mountain deposit consists mainly of tourmaline-bearing breceias in the center of a quartz monzonite porphyry intrusion. The breccias contain chalcopyrite and surrounding the breccias are concentric phyllic-argillic-propylitic alteration halos. The quartz monzonite porphyry intrusion is approximatly $10 \mathrm{~km}^{2}$ (Miller and Ferrians, 1968; Hollister, 1978). A pyrite halo rims the intrusion. Limited assays at Indian Mountain range from 0.07 to $0.15 \% \mathrm{~g} / \mathrm{Cu}$ and 0.1 to $1.5 \mathrm{~g} / \mathrm{Au}$. Barite, galena, and sphalerite have also been identified at the prospect. The Purcell Mountain porphyry copper deposit consists of stockwork veins in a quartz monzonite porphyry intrusion. The veins contain chalcopyrite which are also associated with concentric phyllic-argillic-propylitic alieration halos. The quarte monzonite porphyry intrusion is about $12 \mathrm{~km}^{2}$ (Hollister, 1978). A pyrite halo also rims the intrusion. The deposit contains 0.07 to $0.10 \%$ Cu but no Aw; however, placer Au has been commercially recovered from streams draining both plutons. 
The Zane Hills porphyry $\mathrm{Cu}-\mathrm{Au}$ deposit consists of a stockwork and veins containing chalcopyrite and pyrite, and trace molybdenite and covellite that occur most commonly in a quartz gangue. The stockwork und veins occur in a small, $5 \mathrm{~km}^{2}$ monzonite porphyry which intrudes older Jurassic andesite, and also in a mid-Cretaceous granodiorite pluton. The stockwork and veins oceurs in both the Jurassic andesite and in the monzonite porphyry which bas K-Ar age of BI Ma. Like the deposits at Indian and Purcell Mountains, the phyllic-argillic-propylitic alteration assemblage which is annularly distributed around the core of the monzonite porphyry (Hollister, 1978). The deposit contains up to $2.0 \% \mathrm{Cu}, 0.2 \% \mathrm{Mo}$, and $2.4 \mathrm{~g} / \mathrm{Au}$ (Miller und Ferrians, 1968). The Zane Hills deposit oceurs about $4 \mathrm{~km}$ west of the Hog River placer deposit which has yielded about $6,842 \mathrm{~kg}$ of placer Au.

\section{Origin of and Tectonic Controls for \\ West-Central Alaska Metallogenic Belt}

Isotopic trace element (initial Sr isotopic ratios) and isotopic age data reported from the Late Cretaceous and early Tertiary igneous rocks of western Alaska indicate a variety of source rocks for the parent magmas (Moll-Stalcup and Arth, 1991; Moll-Stalcup, 1994; Arth, 1994), including both contaminated enustal rocks and oceanic crust. On the besis of regional geologic relations, igneous rock composition, and ages of igneous rock, and tectonic environment, the West-Central metallogenic belt is herein interpreted as hosted in the extreme northeastern end of the Okhotsk-Chukotka volcanic-plutonic belt. Other related metallogenic belts to the west in Alaska are the Northwestern Koyukuk Basin metallogenic belt and the Seward Peninsula metallogenic belt of granitic magmatism deposits (fig. 103). To the west and southwest, the Okhotsk-Chukotka volcanic-plutonic belt, which also hosts the Northwestern Koyukuk Basin and Seward Peninsula metallogenic belts, exiends for $3000 \mathrm{~km}$ along western margin of Sea of Okhotsk(Nokleberg and others, 1994c, 1997c). The Okhotsk-Chukotka belt is interpreted as a continental-margin arc marking the Albian through Campanian and locally Paleocene active continental margin of northern Asia (Nokleberg and others, 1994c, 1997c, 2000).

\section{Metallogenic Belts Formed in Late Mesozoic and Early Cenozoic Kluane Continental-Margin Arc, Southern Alaska}

\section{Kuskokwim Mountains Metallogenic Belt of Granitic-Magmatism-Related Deposits (Belt SWK) Southwestern Alaska}

\section{Geologie Setting of Kuskokwim Mountains Metallogenic Beit}

A major Au-polymetallic metallogenic province associated with Late Cretaceous-early Tertiary granitoid plutons and associated volcanic fields occurs in the 650 long by $350 \mathrm{~km}$ wide Southwestern Kuskokwim Mountians metallogenic belt in western-southwestern Alaska (Nokleberg and others, 1995a). The metallogenic belt can be traced from Goodnews Bay in extreme Southwestern Alaska to Cosna Dome in the northeastern Kuskokwim Mountains, a distance of more than $650 \mathrm{~km}$ (fig. 103). Bundtzen and Miller (1997), have included the precious metal and related deposits of Late Cretaceous and early Tertiary age through out much of this region into the Kuskohwim Mineral Belt which is named after the Kuskokwim Mountains where most of the deposits oceur. This name has also been adopted by other authors including Lange and others $(2000)$ and Goldfarb and others (2000). Smith (2000), and Flanigan and others (2000), as stated above, regard the same area as a southwest exiension of the Tintina gold belt, a belt of granitoid-related Au plutons of mainly Mesozoic age which spans the region of central Alaska and the Yukon Territory.

During the twentieth century, lode and placer deposits derived from Cretaceous and early Tertiary igneous complexes within the Kuskokwim Mineral Belt have produced approximately $110,000 \mathrm{~kg}$ Au, $9,500 \mathrm{~kg}$ Ag. $3,842 \mathrm{~kg}$ Cu, and 1.5 million kg Hg (Bundtzen und others, 1992; Miller and Bundtzen, 1994; Nokleberg and others, 1996; Bundtzen and Miller, 1997; Bundtzen, 1999). However, some of the placer gold is interpreted as derived from older bedrock sources: (1) about 15 percent of the Au production of $16,900 \mathrm{~kg}$ has been from placer deposits containing detritus from mid-Cretaceous (108 Ma) plutonic complexes in the Nyac district; (2) one percent $(970 \mathrm{~kg})$ was mined from placers eroding Jurassic ultramafic rock complexes in the Goodnews Bay region;

The significant deposits in the belt (Nokleberg and others 1995, 1996, 1997a, 1998; Bundtzen and Miller, 1997) include; the McLeod, and Molybdenum Mountain porphyry Mo prospects; the important Donlin Creek and Vinasale Mountain porphyry Au-polymetallic deposits; the Chicken Mountain, Von Frank, and Golden Horn porphyry Cu-Au prospects; Au-polymetallic vein and replacement prospects at Fortyseven Creek south of Sleetmute; the Arnold prospect near Marshali; the Mission Creek Owhat and Headwall prospects in the Russian Mountains; $\mathrm{Cu}-\mathrm{Au}-\mathrm{Bi}$ skarn deposits in the Nixon Fork area; a small Fe skarn occurrence at Medfra; the Bismarck Creek, Win, and Won Sn-W-Ag polymetallic, greisen, veit, and skam deposits; and epithermal Hg-Sb- 
Au vein.and hots spring deposits at Red Devil, Kaiyah, Kagati Lake, Kolmakof, Snow Gulch-Donlin, Cinnabur Creek, DeCourcey, and Gemuk Mountain; and felsic-plutonic U prospects at Wolf Creek Mountain and Sichu Creek.

The lode deposits in the oceur in veins, stockworks, breccia pipes, skarns and replacement deposits which formed in upper mesothermal to epithermal environments (Bundtzen and Miller, 1991; 1997; Gray and others, 1997). A plausible metallogenic model suggests which most of these deposits are similar vertically-zoned hydrothermal systems which are exposed at various erosional levels within the late Cretaceous and early Tertiary igneous complexes and wall rocks. Selected deposits and environments include: (1) the Cirque, Tolstoi, Headwall, Mission Creek, Win, Won, and Bismarck Creek, greisen Sn-Cu-Ag-As deposits (formed in upper mesothermal environment); (2) the Golden Hom, Chicken Mountain, and Von Frank porphyry Cu-Au deposits (formed in lower mesothermal envirohment); and (3) the Red Devil, DeCoursey, Donlin, and Mountain Top Hg-Sb (Au) deposits (epithermal deposits). The important Donlin Creek and Vinasale gold-polymetallic deposits resemble porphyry Au deposits (Wilson and Keyser, 1988; Hollister, 1992), but lack metallic, fluid inclusion, and wallrock alteration more typical of porphyry Au systems (Bundtzen and Miller, 1997; Ebert and others, 2000). Unusual, U-rich, REE deposits occur in ultra-potassic felsic igneous rocks at Sischu Mountain and Wolf Creek Mountain (Patton and others, 1994; Bundtzen, 1998). The various Aupolymetallic and other mineral deposits in the are interpreted as forming in a distinctly higher, structural level than the deeper, mesothermal systems in the East-Central Alaska metallogenic belt described below. Selected examples of important deposits in the Kuskokwim Mineral Belt are described below.

The Southwestern Kuskokwim Mountians metallogenic belt is hosted in the Kuskokwim Mountains sedimentary and volcanic belt that consists of three major types of igneous complexes: (1) calc-alkalic, metaaluminous granite and quartz monzonite of Early and mid-Cretaceous age (about 109 to $98 \mathrm{Ma}$ ); (2) peraluminous to metaaluminous, alkali-calcic to quartz alkalic, volcanic-plutonic complexes which contain plutons ranging in composition from alkali gabbro to quartz syenite and average about $70 \mathrm{Ma}$; und (3) peraluminous granite porphyry sills and dikes which range from 58 to $70 \mathrm{Ma}$. The various units of the Kuskokwim Mountains sedimentary and volcanic belt intrude and overlie several major bedrock units, including the Proterozoic to Paleozoic Ruby terrane, the Paleozoic Nixon Fork terrane, the Late Paleozoic-Mesozoic Innoko terrane, the Triassic to Early Cretaceous Gemuk Group, the Ordovician to Jurassic Goodnews terrane, the Late Cretaceous Kuskokwim Group, and other basement rocks (Moll-Stalcup, 1994: Bundtzen and Miller, 1997).

\section{Kuskokwim Mountains Sedimentary and Volcanic Belt}

The Kuskokwim Mountains sedimentary and volcanic belt which hosts the Kuskokwim metallogenic belt consists of interlayered volcanic and sedimentary rocks which are intruded by coeval plutonic rocks. Geochemical and isotopic studies of the igneous rocks of the belt reveal two types of igneous complexes (Bundtzen and Miller, 1997): (1) peraluminous to metaluminous, alkali-calcic to quartz alkalic and lesser calc-alkalic, volcanic-plutonic complexes composed of plutons ranging is composition from alkali gabbro, quartz diorite, granodiorile, monzonite, to syenite; and (2) peraluminous granite porphyry sills and dikes. These two suites exhibit K-Ar crystallization ages ranging from 75 to $60 \mathrm{Ma}$ (Late Cretaceous and early Tertiary).

The volcanic suite consists chiefly of thyolite and dacite domes, flows, and tuff, and dacite, andesite, and basalu flows which exhibit K-Ar isotopic ages of 58 to $77 \mathrm{Ma}$ (Bundizen and Gilbert, 1983; Miller and Bundtzen, 1994; Moll-Stalcup, 1994; Moll-Stalcup and others, 1994). They display moderate-K, calc-alkalic to shoshonitic compositional trends with andesite and myolite being most common. REE pattems are variable, initial $\mathrm{Sr}$ ratios vary from 0.704 to 0.708 , and trace element studies suggest assimilation of small amounts of continental crust of the metamorphosed continental margin Ruby terrane (Miller, 1994; Moll-Stalcup, 1994; Moll-Stalcup and others, 1994). An unusually large range of incompatible elements occur in the igneous rocks and their significance is not well understood (Moll-Stalcup, 1994).

Sedimentary rocks underlying the Kuskokwim Mountains igneous belt include the mid- and Late Kuskokwim Group (Cady and others, 1955) and Cretaceous flysch of the Yukon-Koykuk basin (Patton and others, 1994). The Kuskokwim Group consists mainly of conglomerate to coarse-grained sandstone turbidites deposited in deep-marine conditions, and lesser sandstones and conglomerates deposited in shallow-marine lo nonmarine conditions. The Kuskokwim Mountains igneous belt and the Kuskokwim Group afe generally mildly folded and faulied, and, to the south, are interpreted to overlie the Kahiltna sedimentary and volcanic assemblage (fig. 103). To the east, the igneous belt locally overlies the Wrangellia superterrane. Bundtzen and Miller (1997) and Patton and others (1994) provide more detailed geologic frameworks for both of these areas.

\section{Origin of and Tectonic Setting for}

\section{Kuskokwim Mountains Metallogenic Beit}

The Kuskokwim Mountains metallogenic belt is hosted by the Kuskokwim Mountains sedimentary and voleanie belt which is interpreted as the back-are part of the extensive, subduction-related Kluane igneous arc which occurred along the Late Cretaceous and early Tertiary continental margin of southem and southeastem Alaska (Moll and Paiton, 1982; Bundtzen and Gilbert, 1983, Swanton and others, 1987; Plafker and others, 1989; Szumigala, 1993; Miller and Bundtzen, 1994; Moll-Staleup, 1994; Nokleberg and others, 1995a; Bundtzen and Miller, 1997). Supporting data for this interpretation include: (1) the alkalicalcic nature of the igneous rocks in the Kuskokwim Mountains igneous belt which are more alkalic than the coeval Alaska Range-Talkeetna Mountains igneous belt; (2) trans-tensional tectonism associated with the Kuskokwim Mountains igneous belt; 
and (3) the existence of peraluminous igneous rocks and the deposits in the Kuskok wim Mountains igneous belt. In a similar setting, alkalic porphyry $\mathrm{Cu}$-Au and polymetallic Sn deposits occur in back-are extensional environments in South America (Hollister, 1978), and early Tertiary peraluminous intrusions in Yukon Territory are interpreted by Sinclair (1986) as forming during extensional, wrench fault tectonism related to strike-slip faulting. This interpretation is also advocated by Miller and Bundtzen (1994) for the mineralized plutons of the Kuskokwim Mountains igneous beit.

In Alaska, the other major parts of the Kluane arc are the Alaska Range-Talkeetna volcanic-plutonic belt to the southeast, the Yukon-Kanuti igneous belt to the northwest, and the Late Cretaceous and early Tertiary granitoid rocks of the Yukon-Tanana igneous belt to the northeast (Moll-Stalcup, 1994). The Kluane are is interpreted as forming immediately after the accretion of Wrangellia superterrane in the mid-Cretaceous, and was consequently substantially dismembered by major dextral-slip faulting in the Cenozoic (Plafker and othens, 1989; Nokleberg and others, 1994d, 2000). These belts and the Kuskokwim Mountains sedimentary and volcanic belt are interpreted as a subduction-related arc that was tectonically linked to the Late Cretaceous part of the Chugach accretionary-wedge terrane (Valdez Group and equivalent units) and to the early Tertiary part of the Prince William accretionary-wedge terrane (Orca Group and equivalent units) (Nokleberg and others, 2000).

\section{Felsic Porphyry Mo Deposits * \\ Kuskokwim Mountains Metallogenic Belt, Southwestern Alaska}

A north-south-trending, linear belt of quartz monzonite to granite porphyry stocks and plutons, that host porphyry Mo deposits and prospects, intrude the Late Cretaceous flysch of the Kuskokwim Group and older metamorphic rocks of the Ruby terrane in the west-central Kuskokwim Mountains. From south to north along a linear distance of about $125 \mathrm{~km}$, these deposits and prospects inelude the MeLeod deposit in the eastern Kaiyuh Hills along the lower Innoko River Drainage and the Molybdenum Mountain deposit on the Owhat River. These two felsic porphyry Mo deposits are generally similar to the model of Lowell and Guilbert (1970). All three deposits and prospects contain concentric phyllic and argillic alteration zones, and plot in the granite field of a normative QAPF diagram, and are peraluminous.

\section{MoLeod Porphyry Molybdenum Prospect}

The McLeod porphyry Mo deposit strikes eusi-northeast and consists of a molybdenite-bearing quartz stockwork in a quartz porphyry stock about $3 \mathrm{~km}^{2}$ in area (Mertic, 1937a; Chapman, 1945; West, 1954; Nokleberg and others, 1995a). The stock intrudes undifferentiated Cretaceous greenstone of the Kuskokwim Group and is interpreted as associated with quartz latite dikes which occur bear the eastem boundary of the pluton. In addition to quartz and molybdenite, the stockwork contains pyrite, pyrnotite, and chlorite. The stockwork locally comprises up to $10 \%$ of the intrusion. Veinlets also occur in adjacent greenstone. The quartz-feldspar porphyry stock and latile dikes exhibit a phyllic alteration core flanked by silicic and argillic zones in a 300 by 1,100 $\mathrm{m}$ area. The stockwork averages $0.09 \% \mathrm{MoS}_{2}$ over a 30 by $350 \mathrm{~m}$ surface area. The quartz porphyry stock has a K-Ar biotite age of $69.3 \mathrm{Ma}$ (T.K. Bundtzen, unpublished data, 1987).

\section{Molybdenum Mountain Porphyry Molybdenum Prospect}

The Molybdenum Mountain porphyry Mo prospect (T.K. Bundtzen, unpublisbed data, 1987; Nokleberg and others, 1995a) consists of a stockwork of vein quartz with massive and disserninaled molybdenite, galena, and pyrite in the Molybdenum Mountain stock, a small, $2 \mathrm{~km}^{2}$, hypabyssal felsic intrusion which occurs about $45 \mathrm{~km}$ northeast of Aniak. Alterations are mainly silicic and sericitic. A large, elongate contact metamorphic aureole surrounds the Molybdenum Mountain stock and several smaller intrusions which occur about 4 to $6 \mathrm{~km}$ to the northeast. Selected rock samples from the Molybdenum Mountain stock contain up to $5.0 \% \mathrm{MoS}_{2}$; however, average estimates of grade are not available. The stock intrudes contact-metamorphosed, Late Cretaceous flysch of the Kuskokwim Group along a large shear zone which is a splay of the Iditarod-Nixon-Fork Fault, a major dextral-slip Cenozoic fault in west-central Alaska. A K-Ar white mica age of $60.9 \mathrm{Ma}$ is obtained from the stock.

\section{Alkalic-Calcic Porphyry Cu-Au Prospects - Kuskokwim Mountains Metallogenic Best}

Alkalic-calcic, porphyry Cu-Au deposits and prospects have only been recently identified in the central Kuskokwim Mountains. The general geology structure, and alteration features of the porphyry deposits in the southwestem Kuakokwim Mountains metallogenic belt are generally those of the alkalic porphyry Cu-Au model of Lowell and Guilbert (1970) or to the porphyry Cu-Au deposit model of $\mathrm{Cox}$ (1986b), except that the classic alteration panterns are lacking. The significant deposits are at Chicken Mountain and Von Frank Mountain. These deposits, display similar characteristics, including tourmaline-bearing breccia pipes, stockworks, metal zoning, and petrology. The host plutons for the deposits range from 66 to 71 Ma and intrude Late Cretaceous flysch of the Kuskokwim Group. 
The Chicken Mountain porphyry Au and polymetallie vein deposit (fig. 108) (Bull, 1988; Bundizen and others, 1992; Nokleberg and others, 1995a; Bundtzen and Miller, 1997) consists of a stockwork of gold-quartz sulfide and sulfide veinlets which occur in the cupola of the Chicken Mountain pluton. The pluton is zoned: older, peripheral alkali gabbro and wehrlite is successively intruded by monzonite, syenite, and local quartz monzonite. A dumbbell-shaped alteration zone of peripheral ankerite and sericite surrounds most of the known parts of the deposit. Large dolomite replacement zones fomed synchronously with a sulfide mineral assemblage which includes arsenopyrite, stibnite, cinnabar, scheelite, chalcopyrite, molybdenite, various sulfosalts. and anenopyrite. The sulfide minerals rarely comprise more than $5 \%$ of veins in the stockwork, and the veins typically are about 1 to $2 \mathrm{~cm}$ thick.

An apparent temperature-pressure zonation exists as determined by mineral assemblage, alteration, and fluid inclusion data (Bundtzen and others, 1992). A deuteric magmatic event which contained elevated $\mathrm{Ta}$ and $\mathrm{Sn}$ values was followed by formation of a black sulfide breceia rich in $\mathrm{Cu}$ and $\mathrm{Mo}$; which was in turn followed by emplacement of As-W-Au veins and stockwork and $\mathrm{Pb}-\mathrm{Au}-\mathrm{Sb}$ sulfosalts. $\mathrm{A}$ final $\mathrm{Sb}-\mathrm{Au}(\mathrm{Hg})$ quartz vein episode overprinted the older mineralizing events. $\mathrm{K}$-Ar isotopic ages for both plutonic rocks and mineral veins average about $69.5 \mathrm{Ma}$. A secondary biotite age of $63.5 \mathrm{Ma}$ from the Golden Horn deposit (Bundizen and Miller, 1997 ) may postdate the late-stage $\mathrm{Sb}(\mathrm{Hg})$ epithermal vein mineralization. A drilling program conducted in 1989 through 1990 suggests a reserve of 14.5 million tonnes grading $1.2 \mathrm{~g} / \mathrm{Au}, 0.09 \% \mathrm{Cu}$, and $0.46 \% \mathrm{Sb}$ to a depth of about $200 \mathrm{~m}$ (Bundtzen and others, 1992).

Cirque, Toistoi, Bismarck Creek, and Win

Sn-Ag Polymetallic Deposits

Sn-Ag-polymetallic deposits occur in the Beaver Mountains (fig. 109) west of MeGrath, and in other areas of the Kuskokwim Mountains (Bundtzen and Laird, 1982; Miller and Bundtzen, 1994; Nokleberg and others, 1995a; Burleigh, 1992a,b; Bundtzen and Miller, 1997). The deposit consist of vein stockworks, replacements, and tourmaline breccias with anomalous Ag. $\mathrm{Cu}, \mathrm{Pb}, \mathrm{W}, \mathrm{Sn}, \mathrm{Nb}$, and $\mathrm{As}$, and uncommonly $\mathrm{Au}$. The deposits occurs in both Late Cretaceous and early Tertiary plutons and in overlying contact-metamorphic hornfel. The significant lode prospects in the Beaver Mountains occur in a $15 \mathrm{~km}^{2}$ area centered on the Cirque and Tolstoi prospects (Bundtzen and Laird, 1982) which are is called the South Quartz Zone by Szumigala (1993). A K-Ar biotite age of $70.3 \mathrm{Ma}$ (Bundtzen and Laird, 1982) is obtained for quartz syenite near the northem margin of the Beaver Mountains pluton. The Cirque and Tolstoi deposits consist of a series of parallel tourmaline-axinite-sulfide fracture fillings and tourmaline-syenite breccia pipes which oocur in the cupola of a quartz syenite phase of the Beaver Mountains pluton. Chipchannel sumples range up to $21.0 \% \mathrm{Cu}, 1,000 \mathrm{~g} / \mathrm{Ag} .200 \mathrm{ppm} \mathrm{Sn}$, and I g/ Au (Bundtzen and Laird, 1982; Miller and Bundtzen, 1994).

The Bismarck Creek deposit occurs in an east-west to northeast-trending zone of tourmaline-axinite-cassiterite-sulfide gossan in hornfels, about $70 \mathrm{~km}$ southwest of MeGrath (Bundtzen and Miller, 1997). Secondary biotite is locally abundant and occurs in fine network veins and replacement zones in breceia. A 30-metef-wide zone extends for about 300 meters along strike. Based on exiensive surface sampling and geological modeling. Bundtzen and Miller (1997) estimate that the Bismarck Creek deposit contains about 500,000 tonnes grading 0.137 peroent $\mathrm{Sn}, 47.8$ grams/onne $\mathrm{Ag}, 0.26$ percent $\mathrm{Zn}$, and anomalous $\mathrm{Cu}, \mathrm{F}$, bi, $\mathrm{Sb}$, and In. A nearby Sn granite intrusion on Granile Mountain is radiometrically dated at $61 \mathrm{Ma}$.

The Win and Won deposits, each of which contain 5 or more individual oceurrences and prospects, are about $35 \mathrm{~km}$ apart. Both deposits occur north of MoGrath, and contain some of the most important Sn-polymetallic resources in the Kuskokwim Mineral Belt and perhaps in all of Alaska. Both groups of deposits consist of polymetallic-sulfide and quartzcassiterite assemblages in vein and breccia in quartz-tourmaline homfels (Burleigh, 1992a, b; Bundtzen and Miller, 1997; Bundtzen, 1999). Although neither the Win nor Won deposits are isotopically dated, both are spatially associated with several subvolcanic plutons which have isotopic ages ranging from 60 to $70 \mathrm{Ma}$ (Moll and others, 1981). Sulfosall-rich veins and breccias at the Win deposit contain up to $643 \mathrm{~g} / \mathrm{Ag}$, and 6.97 percent $\mathrm{Sn}$, but very little Au. The better studied Won deposit group is estimated to contain 1.94 millon tones grading 0.59 percent Sn and $42 \mathrm{gt}$ Ag. The Win and Won deposits are geologically and morphologically similar to the Bismarck Creek deposit deseribed above.

Von Frank Mountain Porphyry Cusu Prospect

The Von Frank Mountain porphyry Cu-Au prospect (1. DiMarchi, written commun., 1994; Nokleberz and others, 1995a; Bundtzen, 1999) occurs about $100 \mathrm{~km}$ northeast of McGrath and consists of stockwork in a quartz diorite and augite-biotite granodiorite. These rocks occur in a down-dropped structural block along the southern limit of a volcanic-plutonic complex exposed at Von Frank Mountain. The stockwork consists of chalcopyrite and arsenopyrite, minor molybdenite, and free gold in quarze-carbonate veins in a cupola of the intrusive system. Alterations are sericite, silica, and dolomite replacements which are similar to those in the Chicken Mountain porphyry Au deposit (Bundtzen and others, 1992). A K-Ar mineral isotopic age of 69.9 Ma was obtained from a granitoid pluton north of the prospect (Moll and others, 1981). Bundtzen (1999) indicates which Cu and Au have a correlation coefficient of 0.92 ; coefficient values between $\mathrm{Au}$ and other metals are much lower. Gndes range from 0.5 to $19.1 \mathrm{~g} / \mathrm{Au}$ and from $0.05 \%$ to $0.45 \% \mathrm{Cu}$. One drill hole intercepted about $45 \mathrm{~m}$ grading $1.2 \mathrm{~g} / \mathrm{Au}$ and $0.08 \% \mathrm{Cu}$. The Von Frank Mountain deposit is the most northeastem porphyry deposit known in the Kuskokwim Mountains metallogenic belt. 

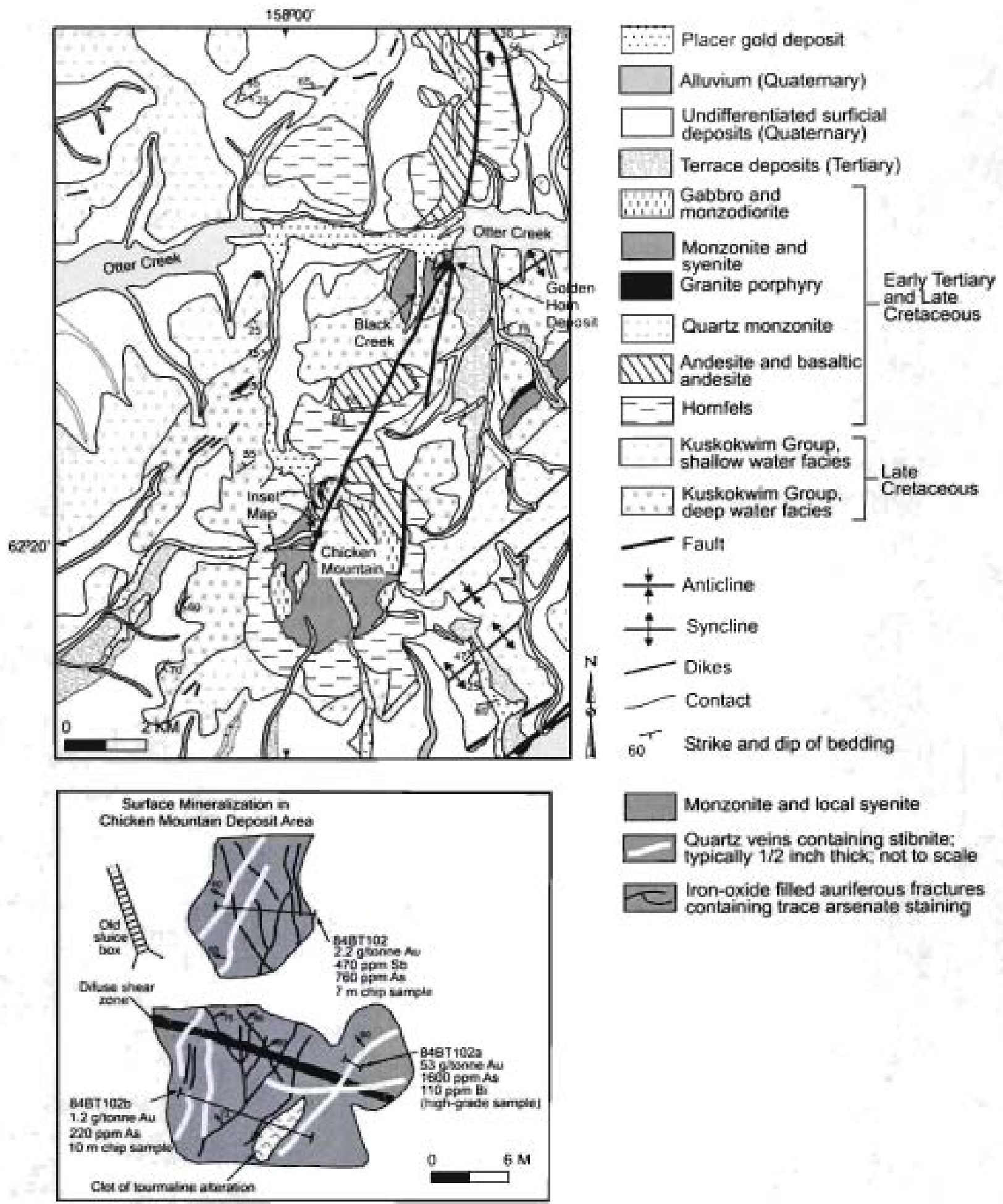

Figure 108. Chicken Mountain and Black Creek granitoid-related Au-Ag (Cu) deposits, Fiat district, Kuskokwim Mountains metallogenic belt, Southwestern Alaska. Schematic geologic map showing locations of Au-bearing plutons. Note the fadial distribution of placer gold deposits surrounding the mineralized plutons. Inset shows style of mineralization at the Chicken Mountain goid polymetallic deposit. Adapted from Bundtzen and others (1992), and Bundtzen and Miller (1997). 


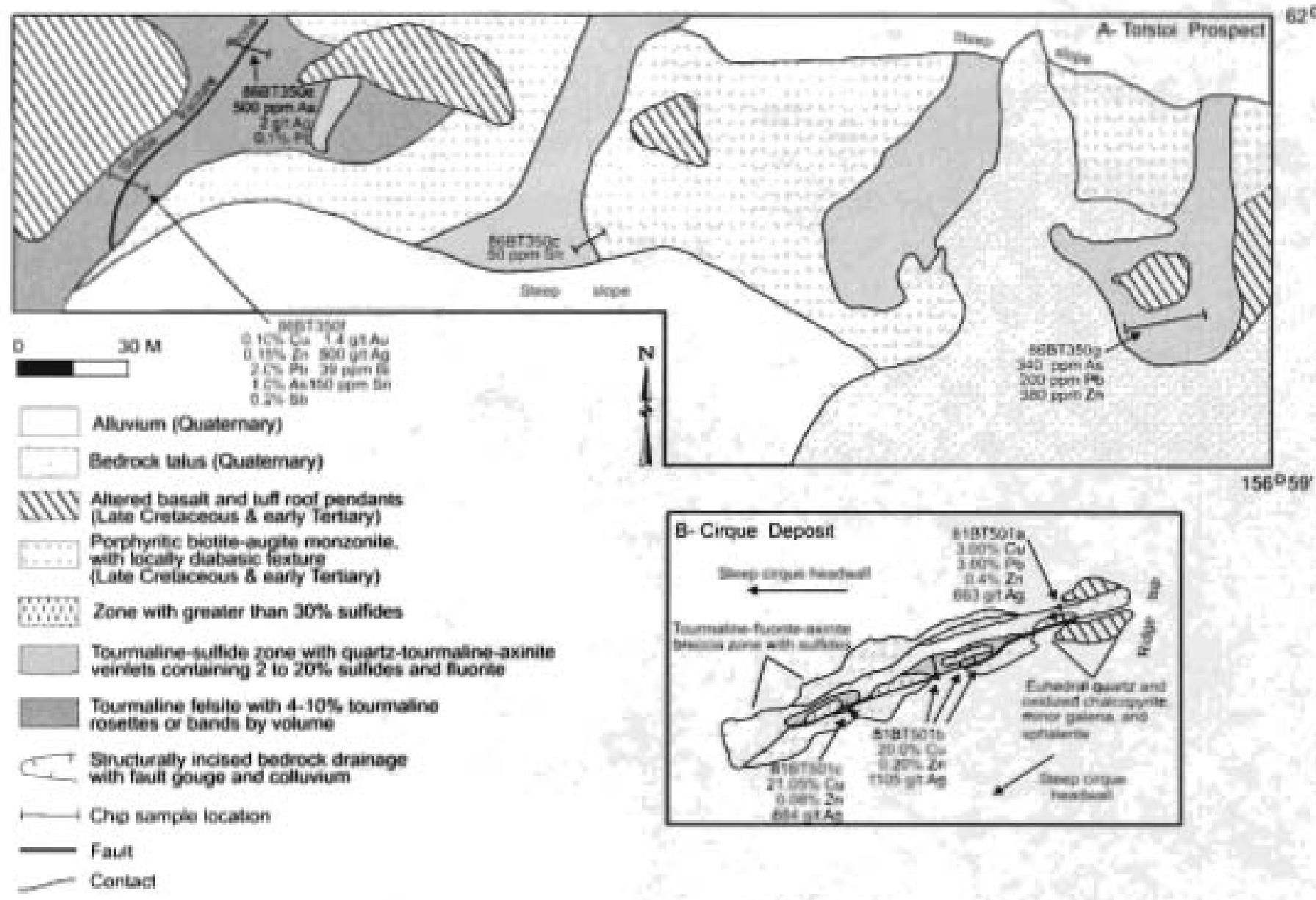

Figure 109. Beaver Mountains Ag-Sn polymetallic vein deposits, Kuskokwim Mountains metallogenic belt, Southwestem Alaska. Two examples of high-level, plutonic-related, B-enriched Ag-Sn polymetallic deposits or prospects. A - Tolstoi prospect, illustrating extensive tourmaline-sulfide breccia zones. B - Cirque Cu-Ag (Au) deposit, showing fracture zone and tourmaline-axinite-fuorite breccia zone. Both deposits occur just below roof pendants of basaltic andesite. Adapted from Bundtzen and Meiler (1997).

\section{Peraluminous Granite Porphyry Au Deposits - Kuskokwim Mountains Metallogenic Belt}

Peraluminous granite porphyry Au deposits are only recently identified in the central Kuskokwim Mountsins. Placer Au deposits in the area have been mined for many years (Mertie, 1936; Bundtren and Laird, 1980; Bundrren, 1986). The best examples of the porphyry deposits are at Donlin Creek, the Independence Mine on Ganes Creek in the Innoko District, and Vinasale Mountain, about $25 \mathrm{~km}$ south of McGrath. Nine other occurrences are located in the Iditarod Quadrangle (Bundrzen and others, 1985). K-Ar mineral ages for the igneous rock hosting all the deposits range from 69 to $71 \mathrm{Ma}$ (Bundtren and Laird, 1982 ; Solic and others, 1991: Miller and Bundtzen, 1994). A K-Ar sericite age of 68.1 Ma is reported for the Vinasale deposit by DiMarchi (1993) which within analytical uncertainty is the same age as the host pluton.

\section{Donilin Creek Porphyry Au Deposit}

The Donlin Creek porphyry Au deposit (fig. 110 ) is hosted in a porphyritic rhyodacite, granite porphyry, and minor granodiorite dike and sill complex which intruded a flysch of the Late Cretaceous Kuskokwim Group (Ebert and others, 2000; Cady and others, 1955). More than seven mineralized zones are known (Bundtzen and Miller, 1997). K-Ar isotopic ages range from 65.1 to $70.9 \mathrm{Ma}$ for granite porphyry sills at the Snow Gulch portion of the property (Miller and Bundtzen, 1994); subsequent ${ }^{40} \mathrm{Ar}{ }^{34} \mathrm{Ar}$ and U-Pb ages are similar. The Au-As-Sb-Hg deposit occurs in a 2 by $6 \mathrm{~km}$ area, and is associated with narrow, steeply-dipping, irregular, and discontinuous quartz and quartz-carbonate veins and veinlets (Ebert and others, 2000). Quartz vein teatures ranges from massive to fine-grained, and comb to bladed. Ore minerals are As sulfosalts (rare), cinnabar (rare to uncommon), stibnite (common), ansenopyrite (very common), and As pyrite (very common). The Donlin Creek deposit is structurally controlled along north-northeast-trending extensional fractures, and the deposit is best developed where mineralizing fluids intersected competent bost lithologies such as massive graywacke and porphyry dikes and sills (Ebert and others, 2000). The Donlin Creek deposit contains 127.4 million tonnes grading $2.89 \mathrm{~g} / \mathrm{Au}$ or 368.2 Au gold. The deposit may be the largest currently known in Alaska (Bundtzen and others, 2000). 


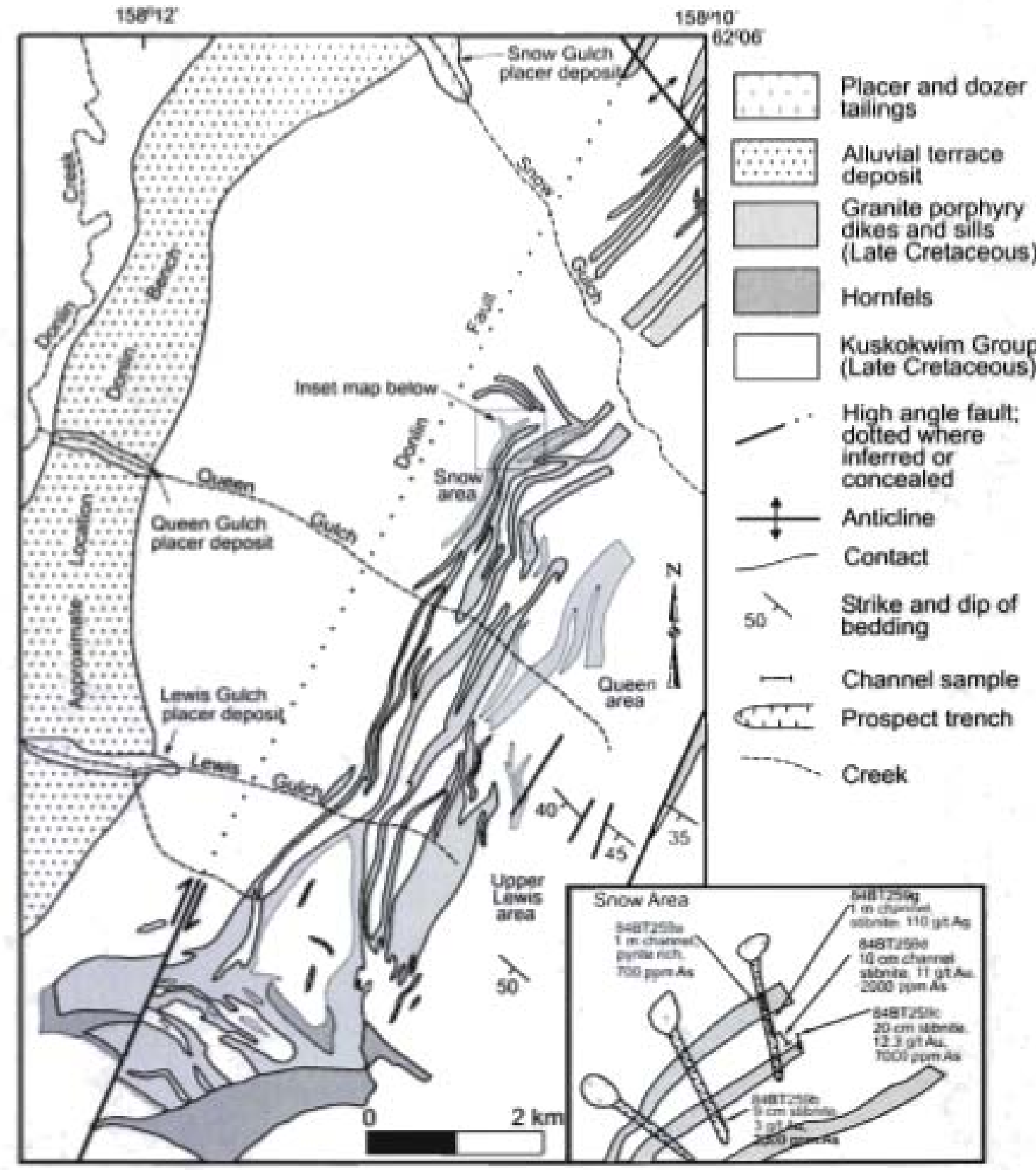

Figure 110. Donlin Creek porphyry Au deposit, Southwestern Kuskokwim Mountains metallogenic beit, Southwestern Alaska. Schematic geologic map of Donlin Creek dike swarm and adjacent units. Adapted from Retherford and McAtee (1994) and Bundtzen and Miler (1997).

\section{Vinasale Granitoid-Related (Porphyry) Au Deposit}

The Vinasale Mountain graniloid-related Au (porphyry Au) deposit (fig. 111) (DiMarchi, 1993; Nokleberg and others, $1995 \mathrm{a}$ ), which lies about $25 \mathrm{~km}$ south of McGrath, consists of Au-Ag-Sb-Pb-As sulfide minerals which occur as disseminations, in breccia, and in dolomite veins and segregations. Mafic minerals exhibit silica, sericite, and propylitic replacements. The highest Au concentrations occur in the central zone of the deposit in areas of intense sericite and silica alteration. Over ninety percent of the gold occurs in As and Sb sulfides and sulfosalts. Correlation coefficients are highest between Au and As ( 0.81 ). The deposit is bosied in various phases of the Vinasale pluton which consists of a multiphase, $6 \mathrm{~km}^{2}$ intrusion composed of monzonite, quartz monronite, and granite porphyry. The pluton intrades the Late Cretaceous Kuskokwim Group. A K-Ar biotite isotopic age of 69.0 Ma is obtained a quartz monzonite phase of the Vinasale Mountain pluton (Bundtzen, 1986). Based oo about $11,260 \mathrm{~m}$ of drilling. a central zone of the Vinasale Deposit contains reserves of about 10.3 million tonnes grading $2.40 \mathrm{~g} / \mathrm{Au}$ (24,540 kg of gold resource) and with minor $\mathrm{Ag}$ and $\mathrm{Sb}$, or about (Bundtzen and Miller, 1997). Recent industry exploration, ineluding soil surveys and geophysical and drilling programs (DiMarchi, 1993) indicate that the Vinasale Mountain as one of the most important lode gold deposits in the Kuskokwim Mineral Belt. 

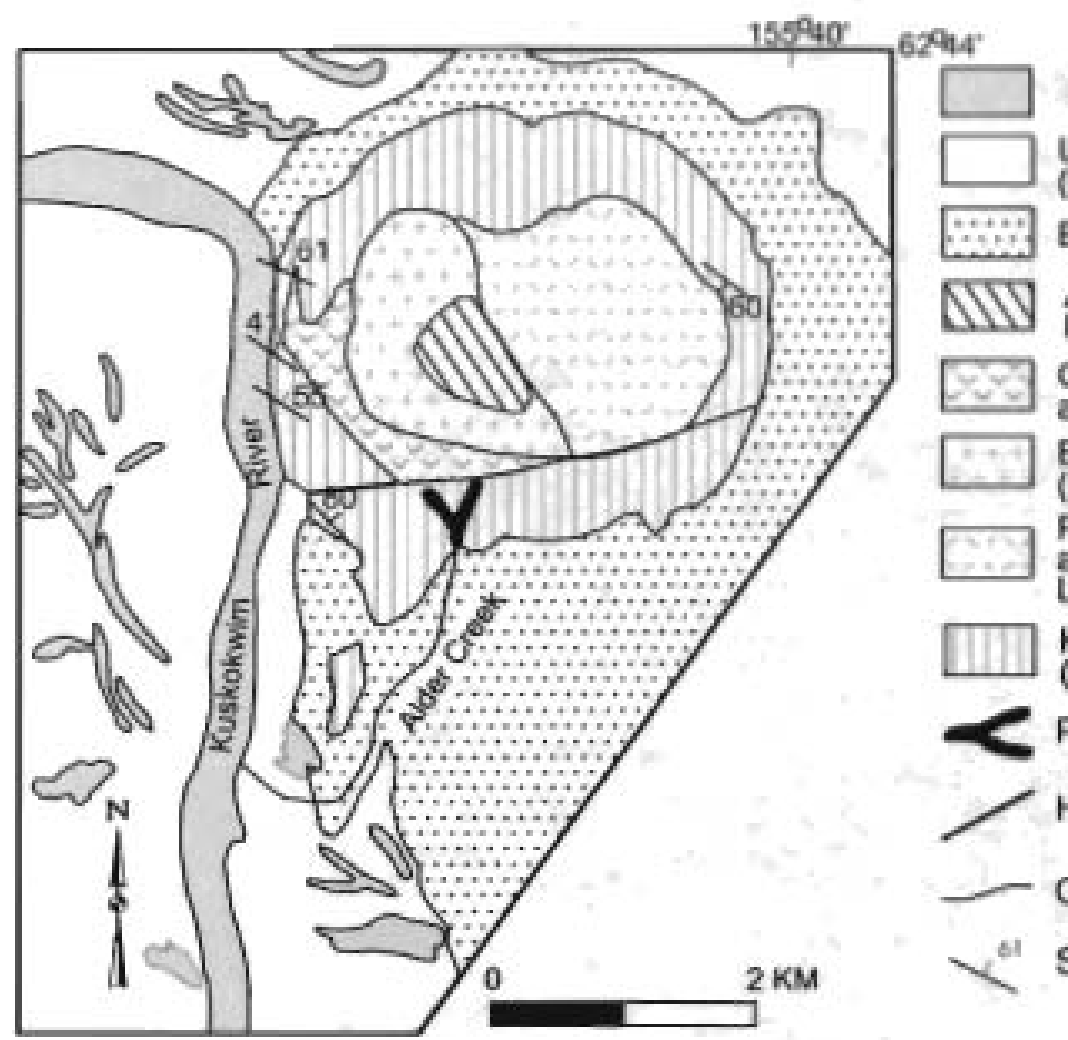

River gravel (Holocene)

Undifferentiated alluvium (Quaternary)

Eolian siltsand (Quatemary)

Approximate location of Central Mineral Zone.

Granite porphyry (Early Tertiary and Late Cretaceous)

Biotite monzonite and syenite (Early Tertiary and Late Cretaceous)

Porphyritic quartz monzonite and granite (Early Tertiary and Late Cretaceous?

III] Kuskokwim Group clastic rocks (Late Cretaceous)

$<$ Placer gold-scheelite

High-angle fault

- Contact

$x^{61}$ Strike and dip of bedding

Figure 111. Vinasale Mountain granitoid-related (porphyry) Au deposit, Kuskokwim Mountains metallogenic belt, Southwestem Alaska. Schematic geologic map showing location of Central Mineral Zone. Adapted from Bundtzen (1986), DiMarchi (1993), and Bundtzen and Miller (1997).

\section{Marshall District of Granitoid-Related Au Deposits, West-Central Alaska}

A suite of granitoid-related Au deposits of the Marshall district occur at the Amold prospect near the bead of Willow Creek is soutbwestern Alaska (Bundtzen and Miller, 1997). The deposits consist of quartz-carbonate veins which occur in, or near sheared Late Cretaceous or early Tertiary alaskite sills which intrude the Koyukuk island-are terrane (Nokleberg and others, $1994 \mathrm{c}, 1997 \mathrm{c}$ ). The significant deposits and prospects include the Arnold, Kako, and Stuyahok gold prospects.

The Amold prospect consists of an approximate east-west-trending suile of low sulfide polymetallic veins which contain gold in quartz and carbonate gangue. The sulfide minerals, which comprise less than one percent of the deposit, are disseminated chalcopyrite, molybdenite, galena, and tetrabedrite. The vein system occurs in, ot near sheared alaskite sills. A distinctive albite thyolite dike or sill parallels the main vein system. The sills intrude Neocomian (early Early Cretaceous) greenstone derived from tholeiite metabasall and metaandesite. The deposit extends along strike for least 400 meters and ranges from 0.5 to $2 \mathrm{~m}$ thick. Abundant carbonate alteration occurs adjacent to the main polymetallic veins. Mo averages about 80 ppm in the veins, Mo anomalies occur in soils. Grab samples of rocks contain up to $97 \mathrm{~g} / \mathrm{tand} 100 \mathrm{~g} / \mathrm{Ag}$.

Other significant gold-polymetallic mineralization in the Marshall district include important lode and associated placer gold occurrences at Kako Creek and Stuyahok, about $55 \mathrm{~km}$ and $75 \mathrm{~km}$ east of the Amold prospect, respectively (Miller and others, 1998). Both of the latter prospects resemble the Donlin Creek deposit described above, and are spatially related to small, Late Cretaceous sills and dikes which intrude the Koyukuk terrane.

Au-Ag-Hb-So Epithermal Deposits,

Kuskokwim Mtineral Beit

Epithermal systems of the Kuskokwim Mineral Belt are subdivided into three major types (Bundtzen and Miller, 1997; Gray and others, 1997): (1) structurally controlled (Au)-Hg-Sb deposits related to altered olivine basalt dikes; (2) low Iemperature Ay-Sb-Hg minerals in shear zones in high level portions of intrusions; and (3) chalcedony breccias hosted in subaerial voleanic piles, including stockwork veins adjacent to volcanic calderas. Although generally poorly elassified, the three epithermal deposit types probably correspond to deposit models the hot springs Au-Ag. Creede epithermal, and Sado epithermal deposit models of Cox and Singer (1986).

The structurally controlled Au-Sb-Hg deposits (type 1) are part of a well-studied Hg belt (Sainsbury and MacKeveth, 1965) which extends nearly $500 \mathrm{~km}$ from the Red Top mine near Bristol Bay to Mount Joaquin near McGrath. The principle type 1 deposit is the Red Devil $\mathrm{Hg}-\mathrm{Sb}$ mine near Sleetmute which produced more than 85 percent of the 1.5 million $\mathrm{kg}$ of past $\mathrm{Hg}$ 
production from the Kuskokwim Mineral Belt, and was the largest mercury mine in Alaska. At Red Devil, high-angle structures cut flysch of the Cretaceous Kuskokwim Group and altered mafic dikes. The fluids tht deposited cinnabar and stibnite utilized fulted mafic dikes as structural conduits; however no clear link exists between dikes and the deposil. Bundtzen and Miller (1997). Gray and others (1997), and Miller and others (1989) all report which fluid inclusion data from type I epithermal deposits in the Kuskokwim Mineral Belt which indicate shallow depths of ore deposition at less than 1,500 bars pressure, and less than $200 \mathrm{C}$. Gray and others (1997) report radiometric ages ranging from 72.5 to $76 \mathrm{Ma}$ for several deposits. Type $2 \mathrm{Au}-\mathrm{Sb}-\mathrm{Hg}$ vein deposits include the Dishna River Au-Sb prospect and Glenn and Minnie Gulch prospects, which cut high level plutonic rocks in the Flat area (Bundtzen and others, 1992; Bundtzen and Miller, 1997).

During 1998-1999, an important new epithermal Au-Ag deposit (type 3 above) was discovered at the Kaiyah prospect about $125 \mathrm{~km}$ southwest of McGrath (Bundtzen and others, 2000). The deposit occurs about $2 \mathrm{~km}$ from a curvilinear, faulted contact between the Early Cretaceous flysch of the Yukon-Koyukuk basin and andesite tuff, welded tuff, and rhyodacite domes of the Late Cretaceous and early Tertiary Poison Creek caldera. The volcanic rocks have isolopic ages of 42.5 and $65.2 \mathrm{Ma}$, and the caldera covers $75 \mathrm{~km}^{2}$ (Bundtzen and Miller, 1997). The deposit oceurs in a 4 by $2.5 \mathrm{~km}$ altered area which contains abundant silica alteration, and extensive alunite, jarosite, and sericite alterations, Individual Au-Ag veins average $30 \mathrm{~m}$ thick and extend about $450 \mathrm{~m}$ along strike. Anomalous elements are $\mathrm{Sb}, \mathrm{Hg}$, As. Te, $\mathrm{Pb}, \mathrm{Cu}$, and $\mathrm{Bi}$. Geological and geochemical data suggest that the Kaiyah deposit is a high sulfidation epithermal Au-Ag deposit with a Ag:Au ratio of about 40:1. Grades range up to $10.8 \mathrm{~g} / \mathrm{t}$ Au gold and $465 \mathrm{~g} / \mathrm{Ag}$ (Bundtzen and others, 2000).

\section{Other Significant Deposits in the Kuskohwim Mineral Beht}

The high grade Au-Bi-Cu skams at Nixon Fork (fig. 112), 45 km, northeast of McGrath, have been developed and mined since the 1920s. The ore deposits occur in irregular, and rich, pipe-like, garnet-epidote-magnetite-gold-copper-skams which rim a monzonite stock that has a K-Ar isotopic age of $68 \mathrm{Ma}$. The intrusion cuts Ordovician limestone of the Novi Mountain Formation (Patton and others, 1994). From 1920 to 1999 Nixon Fork Mining Company and previous operators produced 6,210 kg Au, and byproduct $\mathrm{Bi}$ and $\mathrm{Cu}$ from about 128,300 Ionnes of ore (Bundizen and others, 2000).

\section{East-Central Alaska Metallogenic Beit of Granitic Magmatism Deposits (Younger, Late Cretaceous and Early Tertiary Part; Beit ECA) East-Central Alaska and Northern Canadian Cordillera}

This major, long, extensive, and complex metallogenic belt of Late Cretaceous and carly Tertiary granitic-magmatismrelated deposits (belt ECA) (fig. 103; tables 3, 4) oceurs in east-central Alaska and the western Yukon Territory (Nokleberg and others, 1995a). The significant deposits are mainly various W skam, porphyry Cu-Mo deposits, polymetallic vein, Sn greisen and vein, and $\mathrm{Sb}$-Au vein deposits in the northem and eastern Yukon-Tanana terrane (table 4). Described below are the major Casino and Taurus porphyry Cu-Mo deposits, and the Road Metal tourmaline-topaz-quartz sulfide greisen deposit.

The East-Central Aluska part of the belt contains a varicty granitic magmatism deposits which are hosted in Late Cretaceous and sparse early Tentiary granitoids which intrude the northern and easlern Yukon-Tanana terrane (Table 4). Major deposits are: (1) a W skam deposit at Salcha River (possibly mid-Cretaceous); (2) porphyry Cu-Mo deposits at Mosquito, Asarco, Taurus, and Casino; (3) a Sn greisen deposit at Ketchem Dome; (4) Sn greisen and Sn vein deposits at Ketchen Dome and Lime Peak; and (5) a felsic-plutonic U deposit at Roy Creek (former Mount Prindle). For deposits in groups (1) to (4), the host rock of the Yukon-Tanna terrane consists of metarnorphosed and penetratively deformed, middle Paleozoic and older, quartz. metasedimentary, sparse metavolcanic, and rare middle Paleozoic metagranitoid rocks (Foster and others, 1987). For the deposits in group (5), the granitoid rocks hosting the felsic-plutonic $U$ deposits intrude a sequence of weakly deformed, quartz-rich sandstone, grit, shale, and slate, containing probable Early Cambrian fossils, which form part of the Wickersham passive continental margin ternane (Jones and others, 1987). Yukon Ternitory part of the belt contains porpbyry Cu-Mo deposits in the Carmacks area.

\section{Casino Porphyry Cu-Mlo-Au Deposit}

The large Casino (Patton Hill) porphyry Cu-Mo-Au deposit in the Carmacks area, Yukon Territory, is hosted in a breccia pipe and associated porphyritic dacite and granite of the Casino Intrusive Complex which has a K-Ar isotopic age 71.3 Ma, which intrudes the Early Jurassic Klotassin batholith. The deposit occurs in the center of the complex and consists of a central, conical breccia pipe, fine-grained quartz monzonite, intrusion breccia, and plagioclase porphyry intrusions (EMR Canada, 1989; Mining Review, 1992; Sinclair, 1986; Northem Miner, December 6,1993; Bower and others, 1995). An innermost zone of potassic alteration is associated with hypogene sulfides, and contains superimposed phyllic and pyrite alteration, and weakly-developed, peripheral propylitic alteration. Supergene minerals are chalcocite, digenite, and covellite which oceur as replacements of hypogene sulfides. A 70-m-thick, Au-bearing leached cap overlies a well developed supergene enrichment blanket. Estimated reserves are: (1) for a combined Au-oxide zone in the leached cap and an copper-oxide supergene zone, 28 million tonnes grading $0.68 \mathrm{~g} t \mathrm{Au}, 0.11 \% \mathrm{Cu}$, and $0.024 \% \mathrm{Mo}$, (2) for a sulfide supergene zone, 86 million tonnes grading $0.41 \mathrm{~g} / \mathrm{Au}, 0.43 \% \mathrm{Cu}$, and 
$0.031 \%$ Mo; and (3) for a bypogene zone, 445 million tonnes grading $0.27 \mathrm{~g} / \mathrm{Aw}, 0.23 \% \mathrm{Cu}$, and $0.024 \%$ Mo (Godwin, 1976 ; Bower and others, 1995).
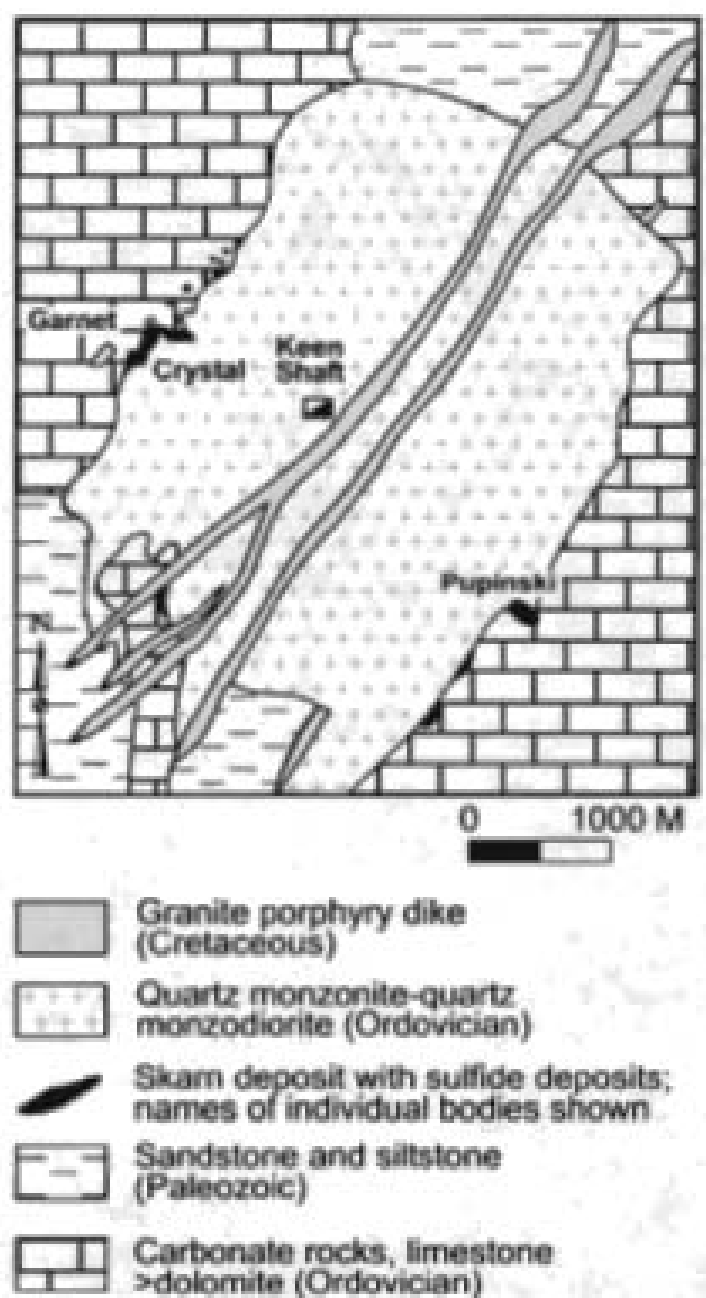

Figure 112 Nixon Fork Cu-Au skam deposit, adjacent prospects, and surrounding area, Kuskokwim Mountains metallogenic belt, Southwestem Alaska. Schematic geologic map. Porphyry dikes, alteration, and main stock all yieid identical K-Ar ages of $69 \mathrm{Ma}$. Modified from Cutler (1994) and Newberry and others (1997).

\section{Taurus Porphyry CoppenMolybdenum Deposit}

The Taurus porphyry Cu-Mo deposit (E.R. Chipp, written commun., 1984; Leriche, 1995) occurs in the eastern part of the Yukon-Tanana Upland in east-central Alaska, and consists of chalcopyrite, molybdenite, and pyrite that oceur as disseminations and in veinlets composed of quartz-orthoclase-sericite, quartz-magnetite-anhydrite, quartz-sericite-pyrite-clayfluorite, and quartz-orthoclase-biotite. The disseminations and veinlets oceur in at least three areas in a zone of hypabyssal plutons about $13 \mathrm{~km}$ long and $1.6 \mathrm{~km}$ wide. The plutons consist of early Tertiary granite porphyry, granodiorite, and quartz latite porphyry (57 Ma, T.K. Bundtzen, written commun., 1994) which intrude middle Paleozoic or older quartz-muscovite schist of the YukonTanana terrane. The core of the pluton exhibits potassic alteration whereas sericitic alteration occurs in the periphery and adjacent wall rocks. The sequence of alteration, from oldest to youngest, is hydrothermal potassic, propylitic, phyllic, and sericitic. Magnetite-rich cores of the potassic-altered granite porphyries contain sparse sulfides. Higher concentrations of Cu and Mo sulfides occur in the periphery along with phyllie alteration. Tourmaline, fluorite, and replacement of ehalcopyrite by chaleocite occur locally. Numerous faults and sbears occur in the deposit. The deposit contains a resource of 23 million tonnes grading $0.3 \%$ $\mathrm{Cu}$ and $0.039 \%$ Mo (Leriche, 1995).

\section{Road Metal Tourmaline-Topaz-Quartz-Sulfide Greisen Deposit}

The Road Metal deposit displays the classic features of a tourmaline-topaz-quartz sulfide greisen deposit (Bundtzen, Schaefer, and Dasbevsky, 2003). The deposit oceurs adjacent to the Alaska Highway in East-Central Alaska. "Ar ${ }^{\circ}$ Ar isotopic ages of $68-70 \mathrm{Ma}$ are obtained from hydrothermal sericite in veins. The Road Metal deposit consists of structurally controlled, 
sulfide-rich, tourmaline-muscovite greisen, semi-massive sulfide replacement veins, massive white mica alteration zones, and smokey-quartz-rich, potassic alteration zones that hosted in granite and quartz monzonite with a K.Ar isotopic age of $95 \mathrm{Ma}$. However, sulfide-rich quartz monzonite and white mica alteration minerals in greisen yield ${ }^{40} \mathrm{Ar} /{ }^{36} \mathrm{Ar}$ isotopic ages ranging from $7067 \mathrm{Ma}$. Sulfide and sulfosalt minerals in drill core include kobellite, boulangerite, owyheeite, galena, chalcopyrite, pyrite, and tetrahedrite. The sulfide greisens strike northeast, dip vertically, range from $40-50$ meters wide, und extend for about 1,400 meters along strike. More than twenty diamond drill holes totaling about 5,300 meters of drilling completed and significant mineralization occurs in about half of the drill holes. Up to $85.8 \mathrm{~g} / \mathrm{t} \mathrm{Au}, 4,634 \mathrm{~g} / \mathrm{Ag}, 6.00 \% \mathrm{Sb}, 2.42 \% \mathrm{Bi}$, and $3.83 \% \mathrm{Cu}$ occur in 1.5 -meterlong drill intercepts. No resource or reserve estimates are yet established. A preliminary quartz fluid inclusion study in mineralized greisen indicates primary fluid inclusions have homogenization temperatures from $322-381^{\circ} \mathrm{C}$. and contain 16.0 to 18.2 weight percent $\mathrm{NaCl}$ (Cameron Rombach and John Mair, University of Western Australia, written commun., 2001). Secondary inclusions have homogenization temperatures ranging from $277-430^{\circ} \mathrm{C}$ and contain 23.1 to 29.9 weight percent $\mathrm{NaCl}$. These results are consistent with formation in a relatively high temperature saline greisen or a porphyry Cu-Au system at pressures of 1-3 kilobars.

The Road Metal deposit shares some features with other granitoid-related deposits in the East-Central Alaska metallogenic belt (younger part) in the Yukon-Tanana Upland, including high Au and $\mathrm{Ag}$, elevated $\mathrm{Bi}$, major oxide chemistry of host intrusive rocks, and regional geologic setting. A high Bi:Au ratio of about 250:I, bigh Ag:Au ratio of about 40:1, elevated Sn and W, and intrusive and deposit isotopic ages of $67-70 \mathrm{Ma}$, collectively suggest that the Road Metal deposit is comparable with deposits hosted in the Carmacks Plutonic Suite in the western Yukon Territory, with isotopic ages of 75-55 Ma, and also with other deposits in the East-Central Alaska metallogenic belt, including the Casino, Taurus, and Mount Nansen porphyry Cu-Mo deposits. If the $400 \mathrm{~km}$ of right-lateral strike-slip along the Denali fault is restored, the area hosting the Road Metal deposit may link up with the Southern Alaska Metallogenic Belt (described below), which is near Chulitna and which contains both Aupolymetallic greisen and porphyry deposits as Golden Zone.

\section{Plutonic Rocks Hosting East-Central Alaska Metallogenic Belt}

The East-Central Alaska metallogenic belt (younger part) is hosted in Late Cretaceous (with isotopic ages of about 94 to $70 \mathrm{Ma}$ ), and in early Tertiary granitoid rocks (with isotopic ages of about 74 to $55 \mathrm{Ma}$ ) which are the younger purt of the YukonTanana igneous belt (Miller, 1994; Moll-Stalcup, 1994) and the correlative Carmacks Plutonic Suite (Mortensen and others, 1994). In East-Central Alaska, these granitoids intrude the Yukon-Tanana Upland whicb is underlain by the large Yukon-Tanana terrane, and a collage of smaller, continental-margin terranes, including the Wickershim and Manley terranes (Nokleberg and others, 1994c, 1997). In East-Ceniral Alaska, most of the Late Cretaceous granitoids are calc-alkalic and intermediate in composition, and chemical data indicate which some of the plutons formed from magmas contaminated by continental crust in areas underlain by the continental-margin Yukon-Tanana terrane (Foster and others, 1987; Miller, 1994). The younger, dominantly early Tertiary granitoids generally exhibit high initial Sr ratios and are interpreted as forming from a mixture of mantle-derived magma and continental crust (Foster and others, 1987; Miller, 1994).

The Late Cretaceous granitoid plutonic rocks which host the lode deposits in the western Yukon Territory (Carmacks area) consist of calc-alkatine granodiorite and quartz monzonite plutons of the Carmacks Plutonic Suite which intrude the YukonTanana and locally the Stikinia terranes (fig. 103) (Mortensen and others, 1994).

\section{Origin of and Tectonic Setting for East-Central Alaska Metallogenic Beft (Younger Late Crefaceous and Early Tertiary Part)}

The younger, Late Cretaceous and early Tertiary Yukon-Tanana igneous belt, and the Carmacks Plutonic Suite are herein interpreted as part of the subduction-related Kluane are which occurred along the Late Cretaceous and early Tertiary continental margin of southern and southeastern Alaska (Plafker and others, 1989, Moll-Stalcup, 1994; Nokleberg and others, 1994b, 1997a, 2000). In Alaska, the other major parts of the Kluane are (Moll-Stalcup, 1994) are the Kuskokwim Mountains sedimentary, volcanic, and plutonic belt, the Alaska Range-Talkectna volcanic-plutonic belt, and the Yukon-Kanuti igneous bell. The Kluane are is interpreted as forming immediately after the accretion of Wrangellia superterrane in the mid-Cretaceous, and was substantially dismembered by major dextral-slip faulting in the Cenozoic (Plafker and others, 1989; Nokleberg and others, 1994b, 2000). The Kluane are is tectonically linked to the Late Cretaceous part of the Chugach accretionary-wedge terrane (Valdez Group and equivalent units) and to the early Tertiary part of the Prince William accretionary-wedge terrane (Orca Group and equivalent units; Plafker and others, 1989; Plafker and Berg. 1994; Nokleberg and others, 1997e, 2000).

\section{Southern Alaska Metallogenic Beit of \\ Granitic Magmatism Deposits (Bett SA) \\ Central and Northern Part of Southern Alaska}

The major Southern Alaska metallogenic belt contains a wide variety of felsic-magmatism-related deposits (fig. 103; tables 3,4) and eccurs in the central and northern parts of Southem Alaska (Nokleberg and others, 1995a). The metallogenic belt is bosted in the Late Cretaceous to early Tertiary Alaska Range-Talkeetna Mountains volcantic-plutonic belt (Nokleberg and 
others, 1994c, 1997e). The granitoid rocks in this igneous belt range in age from Latest Cretaceous to early Tertiary; the largest events nccurred in the early Tertiary (Mnll-Staleup, 1994). The significant deposits in the helt are (tahle 4) (Nokleherg and nthers 1997a, b, 1998): a porphyry Cu deposit at Kijik River in the Bristol Bay District; a porphyry Cu-Au deposit at Pebble Copper in western-southern Alaska; and polymetallic vein, $\mathrm{Au}$-Ag breccia pipe, or porphyry $\mathrm{Cu}$-Au deposit at the Golden Zone in tbe Chulitna district (Nokleberg and others, 1993). Other deposits in the belt are: $\mathrm{Ag}$ - $\mathrm{Pb}$ - $\mathrm{Au}$ (Cu) skam deposits at Bowser, Sheep Creek, Tin Creek, and Rat Fork Creek in the Farewell District; various Au-Ag polymetallic vein, porphyry $\mathrm{Cu}$, and porphyry $\mathrm{Cu}$ Mo deposits at Nim, Nimbus, Ready Cash, and Silver King in the Chulitna district and at Treasure Creek; various polymetallic vein and porphyry Cu deposits at Bonanza Hills, Nabesna Glacier, and Partin Creek; a porphyry Mo deposit at Miss Molly (Hayes Glacier); a Cu-Au skam deposit at Zackly in the Valdez Creek district (fig. 113; table 4); a Sn greisen and Sn vein deposits at Boulder Creek (Purkeypile), Coal Creek, Ohio Creek, and Sleitat (fig. 114; table 4); and a carbonate-hosted $\mathrm{Hg}$ (?) deposit at White Mountains.
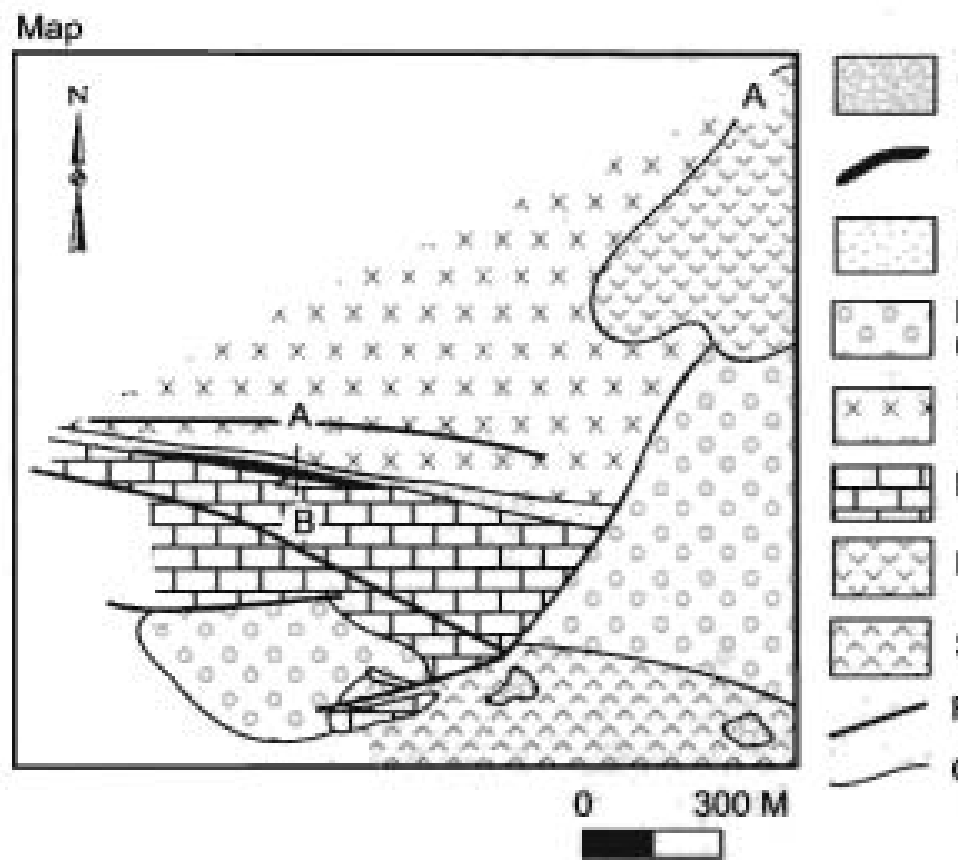

Conglomerate (Tertiary)

\section{Cross section}

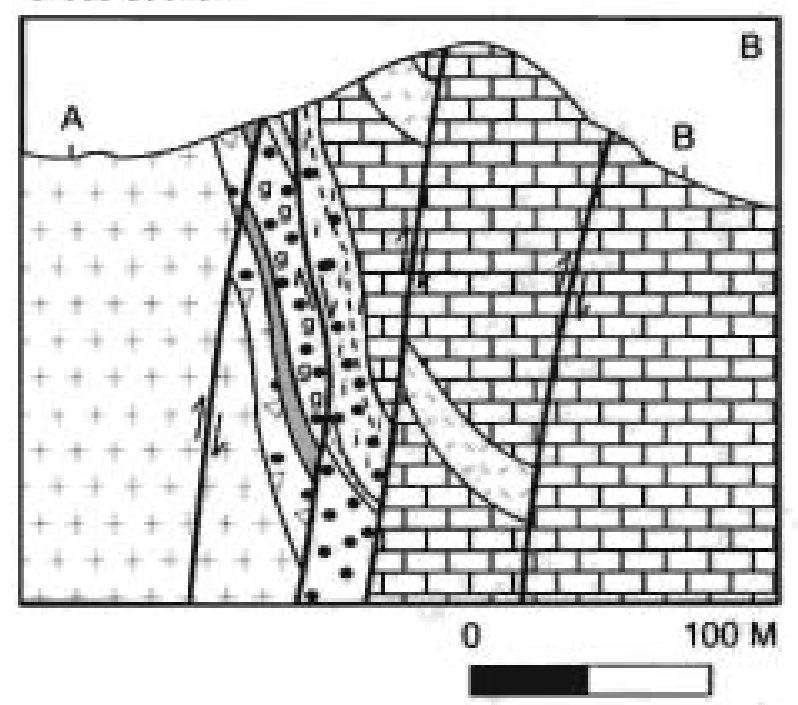

\section{Endoskarn}

W. Metabasalt (altered to endoskam)

Massive garnet

${ }_{9}^{9} 9$ Garnet-pyroxene skam

i, 1. Idocrase-wollastonite skam

G.7. Garnet-pyroxene-

wollastonite-skarn

: - Cu sulfides

.... Magnetite

++ Quartz diorite (Cretaceous)

II Marble (Triassic)

Figure 113. Zackly Cu-Au skarn deposit, Southern Alaska metallogenic belt, Southem Alaska. Schematic geologic map and cross section. Adapted from Nokleberg and others (1986), and Newberry and others (1997). 
The Tin Creek Cu-Pb-Zn skarn deposit (fig. 115) (Szumigala, 1987: Newberry and others, 1997a) consists of pyroxenerich skarn with abundant sphalerite and minor chaicopyrite, and gamet skarn with chalcopyrite and minor sphalerite; and locally abundant epidote and amphibole. The pyroxene skam is distal, and the garnet skam is proximal to an extensive Tertiary dacite to andesite poprhyry dike swarm that intrudes polydeformed, middle Palcozoic contact metamorphosed, clastic and carbonate rock. The skarn forms small, discontinuous bodies up $103 \mathrm{~m}$ wide along dikes, as manto replacement in marble, and as irregular bodies along along thrust and high-angle faults. The skarns are zoned, with garnet-chalcopyrite-rich skam proximal to the dike swarm center, and pyroxene-sphalerite-rich skarn distal to the dike swam. Garnet-rich skarn grades $0.5-1 \% \mathrm{Cu}$ and $1-2$ oz/t Ag, and negligible $\mathrm{Zn}$ and $\mathrm{Pb}$. Pyroxene-rich skam generally contains $5.20 \% \mathrm{Zn}, 0.1-3 \% \mathrm{~Pb}, 0.5-2 \% \mathrm{Cu}$, and $2-9$ owl $\mathrm{Ag}$. In a single outcrop, skarn pyroxene becomes more Fe-rich, and sulfides increase towards marble. Sulfide veins occur locally in dikes and wall rocks. Many dikes are lacking associated skarn, and many dikes possess skarn only along one contact. The deposit has a resource of an estimated 230,000 tonnes with $16 \%$ combined $\mathrm{Pb}$ and $\mathrm{Zn}$.

\section{Kijik River Porphyry Cu Deposit}

The Kijik River porphyry Cu deposit consists of a lurge area of low-grade, disseminated chalcopyrite, pyrite, and minor molybdenite which occur in and adjacent to an early Tertiary dacile porphyry (Eakins and others, 1978; Nelson and others, 1985; T.K. Bundtzen, written commun, 1984). The deposit contains a distinctive onange gossan which extends over a $3 \mathrm{~km}^{2}$ area. The gossan contains an extensive stockwork, and zones of sericite and silicic alteration and sulfides. The stockwork varies from weak to intense, consists mainly of quartz and sulfide minerals, and is developed both in the dacite porphyry and in overlying volcanic rocks. Extensive propylitic and silicic alteration occurs in the dacite porphyry. The deposit contains a possible resource of 90 million tonnes and some samples containing up to $0.25 \% \mathrm{Cu}$ and $0.17 \%$ Mo (T.K. Bubdtzen, written commun., 1984).

\section{Golden Zone Deposit}

The Golden Zone deposit exhibits features common to polymetallic vein, Au-Ag breccia pipe, and porphyry Cu deposits. The sulfide mineralogy consists of auriferous arsenopyrite and minor chalcopyrite, sphalerite, and pyrite in a quartz gangue which fills open spaces in a breccia pipe (Hawley and Clark, 1974; Swainbank and others, 1978; C.C. Hawley, written commun., 1985, 1990). The breccia pipe occurs in the highly-fractured central part of an Late Cretaceous early Tertiary quartz diorite porphyry. The ore zone is about $125 \mathrm{~m}$ in diameter. At the surface, high-grade mineralization occurs in a breccia pipe which is approximately $75 \mathrm{~m}$ wide. Abundant polymetallie veins occur adjacent to the porphyry. The breceia pipe contains an estimated 8.9 million tonnes grading $3.2 \mathrm{~g} / \mathrm{Au}$ and minor $\mathrm{Cu}$ and $\mathrm{Ag}$. The deposit contains an inferred reserve of 1.6 million tonnes grading 5.2 g/ Au, and $0.5 \% \mathrm{Cu}$. An old mine at the deposit produced $50 \mathrm{~kg} \mathrm{Au}, 267 \mathrm{~kg} \mathrm{Ag}$, and 19 tonnes $\mathrm{Cu}$. The diorite porphyry has been dated at $68 \mathrm{Ma}$ (Swainbank and others, 1978) and intrudes Permian to Jurassic sedimentary rocks of the Chulitna (ophiolite) terrane, a fault-bounded fragment within the highly-deformed Kahiltna overlap assemblage.

\section{Nabesna Glacier polymetallic vein(7) deposit}

The Nabesna Glacier polymetallic vein(?) deposit (Richter, 1975) occurs in three contiguous areas which contain: (1) quartz veins and veinlets containing pyrite and minor chalcopyrite and sphalerite; (2) a zone of disseminated malachite and azurite; and (3) a zone of intense alteration and breccia cemented by quartz, pyrite, chalcopyrite, and galena. The deposit occurs in late Paleozoic metavolcanic porphyry and metabasalt flows of the Tetelna Volcanics and may be related to nearby Late Cretaceous and early Tertiary granitoid plutons and dikes.

\section{Sn and Mo Lede Deposits Hosted by Granitoid plutons of McKinley Sequence}

A distinctive group of Sn-greisen, polymetallic vein, and porphyry Mo deposits occur in part of the southem Alaska metallogenic belt at Boulder Creek, Ohio Creek. Coal Creek, and Treasure Creek (Nokleberg and others, 1987, 1988, 1993). These and other lesser deposits occur in or near the early Tertiary McKinley sequence of granite and granodiorite plutons, which exhibit a narrow age range of 55 to $60 \mathrm{Ma}$ (Reed and Lanphere, 1973; Lanphere and Reed, 1985). Many of the MeKinley sequence plutons are peraluminous granites having high initial Sr ratios, suggesting incorporation of large amounts of crustal material (Reed and Lanphere, 1973; Lanphere and Reed, 1985). The plutons of the McKinley sequence intrude the the Wrangellia sequence of the Wrangellia supterterrane and the Kahilina overlap assemblage (Jones and others, 1987). Lanphere and Reed (1985) interpreted these granitoid rocks as forming during early Tertiary collision of the Wrangellia composite terrane with various parts of the passive continental-margin Central composite terrane to the north. However, because more recent tectonic analyses suggest this collision occurred in the mid-Cretaceous (Nokleberg and others. 1985. 1994d; Plafker and others, 19896; Plafker and Berg, 1994)., the McKinley sequence granitoid plutons are herein interpreted as forming during the crustal contamination of magmas from easly Tertiary subduction along the southern margin of Alaska. 
Map

B

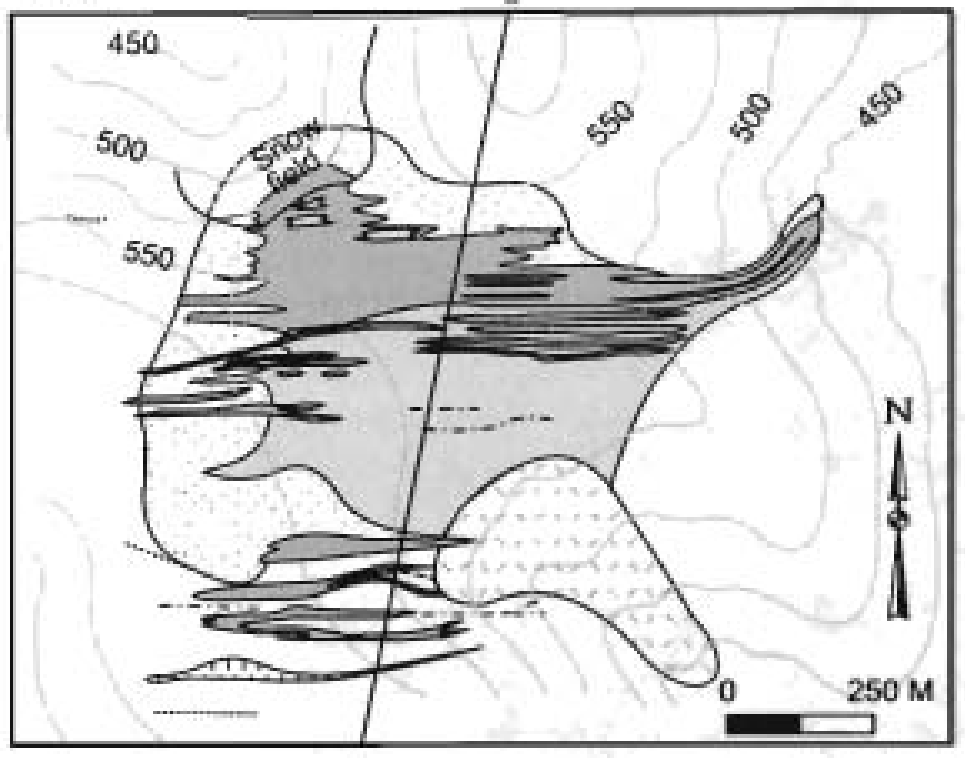

A

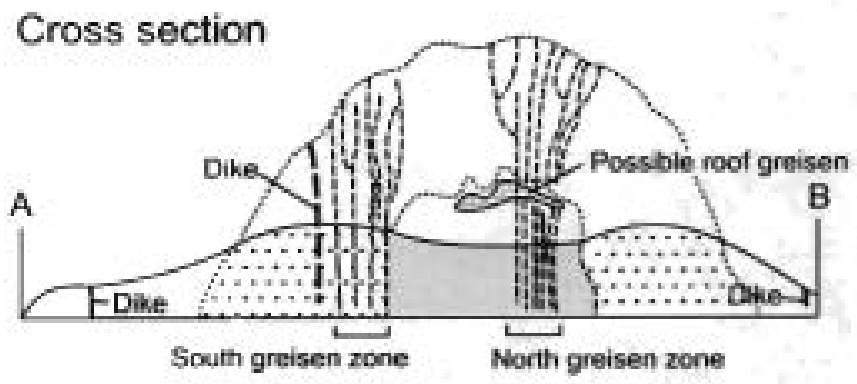

Talus and rock glacier (Quaternary). mainly muscovite granite fragments

Greisen zones comprising $50 \%$ tabular, greisen bodies and $50 \%$ granite wallrock

$\left.\begin{array}{l}\square \text { Zinnwaldite granite } \\ \square \text { Biotite-muscovite granite }\end{array}\right]$ Early

W.W.'. Muscovite quartz porphyry

Kuskokwim Group flysch Late Cretaceous), contact metamorphosed

- Contact

Quartz vein associated with greisen alteration halo

Quartz-tourmaline-topazcassiterite-wolframite veining

Granite

$\ldots . \cdots$ Hornfels

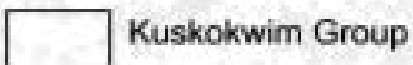

\section{$0300 \mathrm{M}$}

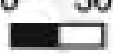

Figure 114. Sleitat Sn greisen and skarn deposit, Kuskokwim Mountains metallogenic belt, Southwestern Alaska. Schematic geologic map and cross section. Adapted from Burleigh (1991) and Hudson and Reed (1997).

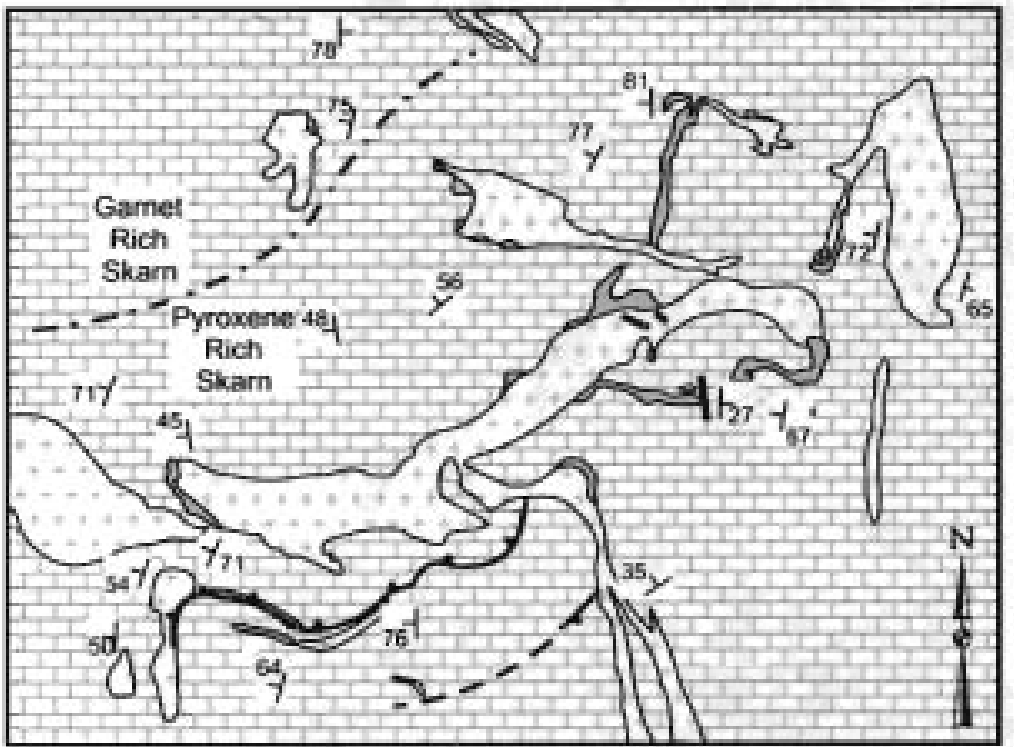

Skarn

Dacite to andesite porphyry dike (Tertiary)

Marble, calc-hornfels. and skarnoid (Paleozoic)

Vein

-. - Contact between skarn zones

L65 Strike and dip of bedding

Thrust fault

0 $60 \mathrm{M}$

Figure 115. Tin Creek Cu-Pb-Zn skarn deposit, Southern Alaska metallogenic belt, Southern Alaska. Schematic geologic map showing distribution of $\mathrm{Zn}-\mathrm{Pb}$ skarn along dikes, bedding planes, and faults. Modified from Szumigala (1987) and Newberry and others (1997) 
The Alaska Range-Talkeetna Mountains igneous belt, which hosts the southem Alaska metailogenic belt, extends for about $700 \mathrm{~km}$ in the western and central parts of southern Alaska (fig. 103). The igneous belt (unit at, fig 103) consists chiefly of (Moll-Stalcup, 1994; Moll-Stalcup and others, 1994): (1) large and small volcanic fields which are composed of rhyolite, dacite, and andesite flows, pyroclastic rocks, and interlayered basalt and andesite flows of 50- to 75-Ma age; and (2) numerous related diorite, quartz diorite, tonalite, granodiorite, and granite and locally monzonite and syenite plutons. The latter constitute the plutonic part of the Late Cretaceous to early Tertiary part of the Aleutian-Alaska Range and Talkeetna Mountains batholith. The igneous belt occurs mostly south of the Denali Fault, and is partly coeval with the Kuskokwim Mountains igneous belt to the northwest (Moll-Stalcup, 1994). The Alaska Range-Talkeetna Mountains igneous belt overlies various terranes in southern Alaska, including the Wrangellia superterrane, and the Kahiltna overlap assemblage (Jones and others, 1987; Nokleberg and others, 1994c, 1997c).

In the Farewell District, the grasitoid rocks and adjacent areas range in age from 52 to $60 \mathrm{Ma}$ (Szumigala, 1987 ; Bundtzen and others, 1988; Gilhert and others, 1990; Solie and others, 1991; Nokleberg and others, 1993). In the Chulitna District, the granitoid rocks which are associated with deposits (Golden Zone, Nim, Nimbus, Silver King), and in the Valdez Creek district (Zackly deposit) the associated ganitoid rocks range in age from 65 to 68 Ma (Swainbank and others, 1978; Newberry and others, 1997). The low temperature $\mathrm{Pb}-\mathrm{Zn}$ skams at Tin Creek and Sheep Creek replace and alter granodiorite dikes with isotopic ages of $25-30 \mathrm{Ma}$. Geochemical and isotopic data indicate that the Alaska Range-Talkeetna Mountains igneous belt has low $\mathrm{TiO}_{2}$, moderate $\mathrm{K}_{2} \mathrm{O}$, no Fe-enrichment, a calc-alkalic compositional trend, and low initial Sr ratios (Szumigala, 1987; Moll-Staicup, 1994).

\section{Origin of and Tectonic Setting for Southern Alaska Metallogenic Belt}

The Southern Alaska metallogenic belt is hosted by the Alaska Range-Talkectna Mountains igneous belt which is interpreted as central part of the extensive, subduction-related KJuane igneous are which formed along the Late Cretaceous and early Tertiary continental margin of southern and southeastern Alaska (Moll and Patton, 1982; Bundtzen and Gilbert; 1983; Swanson and others, 1987; Plafker and others, 1989; Szumigala, 1993; Miller and Bundtzen, 1994; Moll-Stalcup, 1994; Bundtzen and Miller, 1997). Supporting data for this interpretation include (Moll Stalcup, 1994; Moll-Stalcup and others, 1994): (1) the ealcic nature of igneous rocks; (2) low initial $\mathrm{Sr}$ ratios; low $\mathrm{TiO}_{2}$ and moderate $\mathrm{K}_{2} \mathrm{O}$ values; and (3) the occurrence of the $\mathrm{Alnska}$ Range-Talkeetna Mountains igneous belt along the southem margin of southem Alaska, a few kilometers north of major, coeval subduction-zone and accretionary-wedge complexes to the south which are thrust northward, under the Alaska Range-Talkeetna Mountains igneous belt to the north.

\section{Metallogenic Belts Formed During Early Tertiary Oblique Subduction of

\section{Maclaren Metallogenic Belt of}

\section{Au Quarta Vein Deposits (Belt MC)}

Northern Part of Eastern-Southern Alaska

The Maclaren metallogenic belt of Au quartz vein deposits occurs in the Maclaren contincental-margin are terrane in the central Alaska Range in the northern part of eastern-southern Alaska (fig. 103; tables 3, 4) (Nokicberg and others, 1997b, 1998; Goldfarb and others, 1997, 1998). The metallogenic bell is hosted in the Maclaren Glacier metamorphic belt which is probably derived from Late Jurassic(?) flysch composed chiefly of argillite and metagraywacke (Nokleberg and others, 1985, 1994d). The significant deposits are at Timberline Creek and Lucky Hill.

\section{Lucky Hill and Timberline Creek Au Quartz Vein Deposits}

The Lucky Hill and Timberline Creek Au quartz vein deposits (Smith, 1981; Adams and others, 1992; Goldfarb and others, 1997) consist of free gold and minor pynte, pyrrhotite, arsenopyrite, galena, and sphalerite in sheeted quartz veins which strike east-northeast and dip steeply to the northwest. The veins occur in semischist of the Maclaren Glacier metamorphic belt at Lucky Hill and in granodiorite at Timberline Creek. A distinetive, yellowish, ankerite-carbonate assemblage also oceurs in some veins. Incremental Ar isotopic ages on primary micas indicate an emplacement age of 90 to $100 \mathrm{Ma}$, whereas the age of vein formation is 57 to $63 \mathrm{Ma}$. The latter ages are the same as determined for biotite-blocking temperature in the Maclaren Glacier metamorphic belt. The deposits contain an estimated 348,000 tonnes, averaging $7.1 \mathrm{~g} / \mathrm{Au}$. One of Alaska's largest placer Au mines at Valdez. Creek occurs downstream from the Lucky Hill and Timberline Creek deposits. 
The Maclaren Glaciet metamorphic belt, which hosts the Maclaren metallogenic belt of Au quartz vein deposits, and part of the Maclaren terrane, displays classic prograde, Barrovian-type metamorphism of which the lower, greenschist facies portions are judged as highly favorable for Au-quartz vein deposits. ${ }^{40}$ Ar. ${ }^{*}$ Ar ages of metamorphic minerals in auriferous quartz veins which occur in the lower greenschist facies and have isotopic ages rangeing from about 58 to $62 \mathrm{Ma}$ (early Tertiary) (Adams and others, 1992). These ages are interpreted to indicate that Au mineralization occurred in the early Tertiary during oblique subduction of Kula-Farallon oceanic ridge under margin of southern Alaska (Bradley and others, 1993; Haeussler and Nelson, 1993; Haeussler and others, 1995; Goldfurb and others, 1995; 1997; Goldfarb, 1997).

The Maclaren terrane is interpreted as a displaced continental-murgin are fragment which was tectonically separated from the Kluane schist and the Ruby Range batholith that both occur on the northeast side of the Denali fault some $400 \mathrm{~km}$ to the southeast in the Yukon Territory (Nokleberg and others, 1985, 1994d, 2000; Plafker and others, 1989). Similar major Au quartz vein deposits occur in the Juneau metallogenic belt of southeastern Alaska (described herein) (Nokleberg and others, 1985, 1993. 1994d).

\section{Talkeetna Mountains Metallogenic Belt of Au Quartz Vein Deposits (Belt TM) \\ Northern Part of Southern Alaska}

The Talkeetna Mountains metallogenic belt of Au quartz vein deposits occurs in the Talkeetna Mountains in the northern part of southem Alaska (fig. 103; tables 3,4) (Nokleberg and others, 1997b, 1998). The metallogenic belt is hosted in the Late Triassic(?) and Early Jurassic Talkeetna Formation where intruded Jurassic and Cretaceous granitoid rocks that were deformed and metamorphosed to lower greenschist facies during the carly Tertiary (Nokleberg and others, 1994c, 1997c). The significant deposit is the Independence mine in the Willow Creek District. Other deposits in the district include those at Gold Bullion, Gold Cord, Lucky Shot, and Thope

\section{Independence Au Quartz Vein Deposit}

The Independence Au quartz vein deposit, which occurs in the Willow Creek district in the Talkeetna Mountains (Ray. 1954, Madden-McGuire and others, 1989), consists of quartz veins containing a few percent or less pyrile, chalcopyrite. magnetite, and gold, and minor arsenopyrite, sphalerite, tetrahedrite, Au-tellurides, and galena. The veins average 0.3 to $1 \mathrm{~m}$ thick, but some range up to $2 \mathrm{~m}$ thick. The veins occupy east-northeast and north-south-striking shear zones up to $7 \mathrm{~m}$ wide. Considerable alteration of wall rocks occurs marked by formation of sericite, pyrite, carbonate, and chlorite in parallel bands. The veins occur in zones in and along the southem margin of Jurassic quartz diorite, and younger Cretaceous and early Tertiary granitoid rocks of the Talkeetna Mountains batholith, and also locally in mica schist. The Willow Creek district consists of several mines and many prospects, most in an area about $12.8 \mathrm{~km}$ long and $6.2 \mathrm{~km}$ wide along southern portion of the Talkeetna Mountains butholith. The mine at the deposit contains several thousand meters of underground workings and produced about $18,400 \mathrm{~kg}$ Au from 1909 to 1950 . Ore grade ranged from about 17 to $69 \mathrm{~g} / \mathrm{Au}$.

\section{Origin of and Tectonic Controls for \\ Talkeetna Mountains Metallogenic Belt}

Hydrothermal micas from the Gold Bullion and Lucky Shot mines in the Willow Creek district exhibit K-Ar isotopic ages of 66 and $57 \mathrm{Ma}$, respectively (Madden-McGuire and others, 1989). These ages are interpreted to indicate that gold mineralization in the Talkeetna Mountains metallogenic belt oceurred in the Late Cretaceous or early Tertiary. Three different tectonic events might be the cause of mineralization: (1) Late Cretaceous and early Tertiary underthrusting of the Chugach and Prince William accretionary-wedge terranes along the Contact fault in southem Alaska; (2)as favored herein, early Tertiary underthrusting of the spreading Kula Ridge under the southern margin of coastal Alaska (Plafker and others, 1989); and (or, 3) early Tertiary deatralslip frulting along on the Castle Mountain fault system.

\section{Chugach Mountains Metallogenic Belt of Au Quartz Vein Deposits (Beit CM) Southern Alaska}

The Chegach Mountains metallogenic belt of Au quartz vein deposits (fig 103; tables 3, 4) occurs on Kodiak Island, the southeastern Kenai Peninsula, and in the central and eastern Chugach Mountains in southem Alaska. The Au quartz vein deposits occur mainly in the Late Cretaceous flysch of the Valdez Group and Kodiak Formation where these units were metamorphosed to greenschist facies (Goldfarb and others, 1986, 1997, 1998; Nokleberg and others, 1994c, 1997c, 1989b). To a lesser extent, the beli also occuns: (1) in the northern margin of the early Tertiary Orea Group of the Prince William terrane where locally metamorphosed to lower greenschist facies; (2) in metasedimentary rock of the Orca Group within a few kilometers of granitoid plutons; (3) along the southem margin of the Late Triassic through mid-Cretaceous MeHugh Complex on the Kenai Peninsula; 
and (4) in Eocene and Oligocene granitoid plutons intruding the Valdez and Orca Groups. The deposits in this belt are of small tonnage but locally high grade. For this widespread group of mines and deposits, a unique mineral deposit model for Chugachtype low-sulfide Au quartz veins has been developed by Bliss (1992). The significant deposits are at Clift, Alaska Oracle, Chalet Mountain, Crown Point, Kilpatrick, Gold King, Granite, Jewel, Kenai-Alaska, Lucky Strike (Palmer Creek), Mineral King (Herman and Eaton), Monarch, and Ramsey-Rutherford (table 4) (Nokleberg and others 1997a, b, 1998). Substantial Au production oceurred in this district until the early 1940 's, recent exploratory work has been conducted at the Cliff Mine near Valdez, the largest of the many known deposits.

\section{Clitf Au Quartz Vein Deposit}

The Cliff Au quartz vein deposit (Johnson, 1915; Pickthom, 1982; Jansons and others, 1984) consists of quartz veins, up to 3 meters thick and 515 meters long and contain gold, pyrite, galena, sphalerite, arsenopyrite, and stibnite. The veins are bosted in metagraywacke and minor phyllite of the Late Cretaceous Valdez Group. The veins occur in a complicated system of intersecting faults, Sulfide minerals compose about 3 to $5 \%$ percent of the ore. The mine contains a few thousand meters of underground workings. Production occurred mainly from 1906 to 1940 . The average grade fanged from 34 to $69 \mathrm{~g} / \mathrm{Au}$, and the mine at the deposit produced about $1,610 \mathrm{~kg} \mathrm{Au}$ from about 25,000 tonnes of ore,

\section{Origin of and Tectonic Controls for Chugach Mountains Metallogenic Beit}

The Au quartz veins generally occur in the younger of two generations of quartz fissure veins (Richter, 1963; Goldfarb and others, 1986, 1997, 1998; Nokleberg and others, 1989b). The older and mostly barren veins are approximately parallel to the regional schistosity and to axial planes of minor and major folds. Their strike varies from northwest in the east to northeast in the west. The younger Au veins generally occur in a set of tensional cross joints or fractures, and are normal to the older, barren quartz veins. Both sets of quartz veins generally dip steeply to vertically. Hydrothermal muscovite from Au-bearing veins has been dated at $53 \mathrm{Ma}$ in the Port Valdez district (Winkler and others, $198 \mathrm{Ib}$ ), at $52 \mathrm{Ma}$ in the Hope-Sunrise district (Mitchell and others, 1981), and at $57 \mathrm{Ma}$ in the Nuka Bay district (Borden and others, 1992).

These field relations and isotopic ages are interpreted as indicating that the deposits formed during early Tertiary regional metamorphism and anatectic granite plutonism. Regional tectonic and isotopic studies suggest that the As veins formed in the Orca and Valdez Groups in response to subduction of the spreading Kula-Farallon Ridge beneath the soutbern Alaska continental margin (Plafker and others, 1989; Bradley and others, 1993; Hacussler and Nelson, 1993; Haeussler and others, 1995; Goldfarb and others, 1995; 1997; Goldfarb, 1997).

\section{Baranof Metallogenic Belt of Au Quartz Vein Deposits Southeastern Alaska (Belt BN)}

The Baranof metallogenic belt of Au quartz vein deposits occurs in Southeastem Alaska and consists of a 250-km-long belt hosted in the Chugach subduction-zone terrane in soutbern and southeastern Alaska (fig. 103; tables 3, 4) (Brew, 1993; Monger and Nokleberg, 1996; Goldfarb and others, 1997, 1998). The significant deposit in the bell are Apex and El Nido, Chichagoff, Cobol, Hirst-Chichagof, and Reid Inlet (Nokleberg and others 1997a, b, 1998). The principal deposits, at Chichagoff and HirstChichagof are quartz-sulfide veins controlled by faults in metagraywacke and argillite of the Cretaceous Sitka Graywacke of the Valdez Group (Reed and Coats, 1941; Nokleberg and others, 1994a). The Baucr, Silver Bay. Cache, and Lucky Chance mines of the Sitka district have similar graywacke-hosted quartz-pyrite-pyrrhotite-arscnopyrite veins (Berg and Cobb, 1967). Located near the northern end of Chichagof Island, are the Apex-El Nido and Goldwin fissure quartz-sulfide vein mines that are bosted in Tertiary diorite plutons and armphibolite (Reed and Coats, 1941).

\section{Chichagoff and Hirst-Chichagof Au Quartz Vein Deposit}

The Chichagoff and Hirst-Chichagof Au quartz vein deposit consists of tabular to lenticular quartz veins which are a few meters thick, extend a few hundred meters along strike, and range up to a few thousand meters depth along plunge. The veins are mainly ribbon quartz containing minor pyrite, arsenopyrite, galena, sphalente, chalcopyrile, and some scheelite and tetrahedrite locally (Berg, 1984; Bundtzen, Green, Deager, and Daniels, 1987; Brew and others, 1991). Ore shoots occur mainly in shear and gouge zones along the Hirst and Chichagof faults, especially along undulations in fault planes. The deposit is hosted in metagraywacke and argillite of the Cretaceous Sitka Graywacke. The mine produced about 24.6 million $\mathrm{g}$ Au, 1.24 million $\mathrm{g}$ Ag. and minor $\mathrm{Pb}$ and $\mathrm{Cu}$ from 700,000 tonnes of ore. Average grade is $7.2 \mathrm{~g} / \mathrm{Au}$ and $2.0 \mathrm{~g} / \mathrm{Ag}$. Reserves are 91,000 tonnes of ore grading $41.2 \mathrm{~g} / \mathrm{Au}$ in several ore bodies.

\section{Apex and EI Nido Au Quartz Vein Deposit}

The Apex and E Nido Au quartz vein deposit consists of quartz fissure veins up to 2 m thick and stockworks containing sparse pyrite, arsenopyrite, chalcopyrite, galena, sphalerite, tetrahedrite, and gold (Still and Weir, 1981; Johnson and others, 
1981). The mine at the deposit produced un estimated $622,000 \mathrm{~g} \mathrm{Au}$, and $93,300 \mathrm{~g}$ Ag The host rocks are an altered Mesozoic diorite plution and an amphibolite mass within the pluton. The pluton intrudes late Paleozoic low-grade pelitic and internediate volcanic rocks. Minor sulfides oceur in the altered diorite wall rocks. The deposit also contains disseminations, veinlets, und small masses of scheelite. The vein system is symmetrical around a vertical fault which bisects the deposit.

\section{Origin of and Tectonic Controls for Baranof Metallogenic Belt}

The Au quartz vein deposits of the Baranof metallogenic belt occur mainly in the Late Cretaceous flysch of the Sitka Graywacke (part of the Valdez Group) where these units are metamorphosed to greenschist facies. The Au-quartz vein deposits also occur in early Tertiary granitoid plutons (with isotopic ages of about 51 to $\$ 2 \mathrm{Ma}$ ) which intrude the Chugach terrune; hydrothermal muscovite from Au-bearing veins bas been dated at about $52 \mathrm{Ma}$ (Taylor and others, 1994). As described above for the origin of the Chugach Mountains metallogenic belt, theAu quartz veins of the Baranof metallogenic belt are interpreted as forming in response to subduction of the spreading Kula-Farallon Ridge beneath the southem Alaska continental margin (Plafker and others, 1989; Bradley and others, 1993; Haeussler and Nelson, 1993; Haeussler and others, 1995; Goldfarb and others, 1995; 1997; Goldfarb, 1997).

\section{Juneau Metallogenic Beit of Au Quartz Vein Deposits (Belt JU) Southeastern Alaska}

The Juneau metallogenic belt (also referred to as the Juneau gold belt) of Au quartz vein deposits (fíg. 103; tables 3, 4) (Twenhofel and others, 1949; Twenhofel, 1952; Goldfarb and others, 1997, 1998) occurs in the Coast Mountains of Southeasiern Alaska. The belt, which was first defined by Spencer (1906) and redefined by Brew (1993), occurs in two areas. The northern part of the belt contains significant deposits at Alaska Juneau, Jualin, Riverside, Sumdum, and Treadwell. The southern part of the belt contains smaller deposits. The belt oceurs along strike for about $250 \mathrm{~km}$ and is hosted in the Yukon-Tanana and Stikinia terranes, the Gravina-Nutzotin Gambier overlap assemblage, and younger, early Tertiary granitoid plutonic rocks. The significant deposits in the belt ure at Alaska-Juneau, Gold Standard (Helm Bay), Goldstream, Jualin, Kensington, Riverside, Sea Level, Sundum Chief, and Treadwell (table 4) (Nokleberg and others 1997a, b, 1998). Most of the deposits oceur in the western, greenschist facies part of a belt of inverted, regional-grade metamorphic that occurs to the west of, and underneath of a extensive, foliated tonalite sill which intruded along the western edge of the Yukon-Tanana terrane and the Wrangellia superterrane (Brew, 1994; Gehrels and Berg. 1994).

\section{Alaska-Juneau Au Quartz Vein Deposit}

The Au-quartz vein deposit consists of a network of lenticular quartz veins a few centimeters to $1 \mathrm{~m}$ thick that contain sparse scattered masses of gold, pyrite, pyrthotite, arsenopyrite, galena, with minor sphalerite, chalcopyrile, and silver (Goldfarb and others, 1986, 1988, 1991, 1997; Newberry and Brew, 1987, 1988; Light and others, 1989; Brew and others, 1991; Miller and others, 1992). The Alaska-Juneau mine produced $108 \mathrm{t}$ Au, $59 \mathrm{t}$ Ag, and $21,800 \mathrm{t}$ Cu from 80.3 million tonnes of ore mined between 1893 and 1944. Reserves of 61.6 million tonnes grading $1.8 \mathrm{~g} / \mathrm{Au}$ remain (Alaska Mineral Industry, 1993, p. 13). The vein lode system is about $5.6 \mathrm{~km}$ long and $600 \mathrm{~m}$ wide. The deposit consists of a series of parallel quartz stringers that are hosted in several units in: (1) phyllite and schist near the contact between the Late Triassic Perseverance Slate; (2) amphibolite derived from late(?) Mesozoic (meta)gabbro dikes and sills; and (3) the informally named Gastineau volcanics of Permian and (or) Late Triassic age. Most of ore occurs in quartz veins; some in adjacent altered metamorphic tocks.

\section{Jualin Au Quartz Vein Deposit}

The Jualin Au-quartz vein deposit consists of four or five major quartz fissure veins and pipe-like stockworks which contain minot gold, and considerable pyrite, chalcopyrite, galena, minor sphalerite, and secondary copper minerals (Bundtzen and others, 1990; Goldfarb and others, 1991, 1997; Brew and others, 1991; Swainbank and others, 1991). Pyrite is the dominant sulfide. Gold associated with pyrite occurs as minute blebs in goethite rims and fracture fillings in corroded erystals. The gangue consists of quartz and lesser ankerite, chlorite, and sericite. The mine produced about 1.5 million $\mathrm{g}$ Alu, and reserves are estimated at 907,000 tonnes of ore grading $10.5 \mathrm{gl} \mathrm{Au}$. The age of mineralization is interpreted as $55 \mathrm{Ma}$. The deposit contains more than $5,500 \mathrm{~m}$ of horizontal workings. The deposit is hosted is Cretaceous quartz diorite which exhibits proximal ankerite, quartz, and sericite alieration adjacent to veins, and more widesperead propylitic alteration. The quartz diorite intrudes Late Triassic greenstone, graywacke, and argillite of Alecander sequence of the Wrangellia superternane.

\section{Riverside Au Quartz Vein Deposit}

The Riverside Au quartz vein deposit consists primarily of disseminated galena, pyrite, tetrahedrite, pyrrhotite, chalcopyrite, sphalerite, gold, and scheelite in two large quartz veins, but in the Lindeberg lode, part of the deposit is a combined quartz vein and epigenetic replacement deposit (Byers and Sainsbury, 1956; Smith, 1977). The mine at the deposit produced about 
27,200 tonnes, yielding $93,300 \mathrm{~g} \mathrm{Au}, 3.1$ million g Ag, 45,400 kg Cu, $113,500 \mathrm{~kg} \mathrm{~Pb}, 9,080 \mathrm{~kg} \mathrm{Zn}$, and 3,500 units $(318,000 \mathrm{~kg})$ WO$_{3}$. The veins occur in a shear zone, schist inclusion, and mylonitic gneiss derived from the Triassic Texas Creek Granodiorite of the informally named Coast plutonic-metamorphic complex of Brew and Ford (1984).

\section{Sumdum Chief Au Quartz Vein Deposit}

The Sumdum Chief Au quartz vein deposit consists of two quartz-calcite fissure veins that contain gold, auriferous pyrite, galena, sphalerite, chalcopyrite, and arsenopyrite (Brew and Grybeck, 1984; Kimball and others, 1984; Goldfarb and others, 1988. 1991, 1997). Gold is unevenly distributed and oocurs mainly in pockets where small veins intersect the main veins. Mining produced about $750,000 \mathrm{~g}$ each of $\mathrm{Ag}$ and $\mathrm{Au}$ from ore that averaged about $13.7 \mathrm{~g} / \mathrm{t}$ Au. The veins, up to $6 \mathrm{~m}$ thick, oceur in upper Paleozoic(?) or Mesozoic graphitic slate and marble of the informally named Coast plutonic-metamorphic complex of Brew and Ford (1984).

\section{Treadwell Au Quartz Vein Deposit}

The large Treadwell Au quartz vein deposit consists of disseminated sulfides in quartz and quartz-calcite vein systems in shattered albite sills and dikes. The veins contain sparse gold, pyrite, magnetite, molybdenite, chalcopyrite, galena, sphalerite, and tetrahedrite. The best ore grade is associated with abundant quartz and calcite veiniets (Light and others, 1989; Goldfarb and others, 199 I, 1997). Mining produced about 90.1 million gm Au from 25 million tonnes of ore. The albite sills and dikes are Eocene and intrude Jurassic(?) and Early Cretaceous(?) slate and greenstone derived from basaltic tuff or agglomerate (part of the Treadwell Slate in the Gravina-Nutzotin belt). Some ore forms a zone at least $1,100 \mathrm{~m}$ long in slate inclusions and in adjacent wall rock. The deposit was mined from above sea level to $790 \mathrm{~m}$ beneath sea level in Gastineau Channel from 1885 to 1922 when most workings flooded during a catastrophic influx of sea water.

\section{Origin of and Tectonic Controis for Juneau Metallogenic Belt}

The Juneau metallogenic belt is hosted in a wide variety of metamorphosed sedimentary, volcanic, and plutonic rocks which occur adjacent to a complex series of faults between the Alexander and Wrangellia sequences of the Wrangellia superterrane (Nokleberg and others, 2000), the Gravina sequence (Gravina-Nutzotin-Gambier overlap assemblage), and in syn- to post-accretionary granitoid plutonic rocks, including the foliated tonalite sill of Southeastern Alaska (Brew and Ford, 1984). Late Paleozoic and early Mesozoic metasedimentary and metavoleanic rocks bost the Jualin (Berg, 1984) and Kensington (Bundtzen and others, 1988) deposits in the Berner Bay district, and the Sumdum Chief (Kimball and otbers, 1984) and Sea Level deposits. Flysch of the Gravina-Gambier overlap assemblage bosts the Treadwell group of quartz-sulfide-gold deposits, across the Gastineau Channel from the Alaska-Juneau mine (Spencer, 1905), and the Gold Standard and Goldstream deposits. Hydrothermal muscovite from Au-bearing veins from the Alaska-Juneau mine has been dated at about 54 to $57 \mathrm{Ma}$ (Haeussler and others, 1995; Goldfarb and others, 1997). As described above for the origin of the Chugach Mountains, Baranof, and Maclaren metallogenic belts, the Au quartz veins of the Juneau metallogenic belt are interpreted as forming in response to subduction of the spreading Kula-Farallon Ridge beneath the southern Alaska continental margin (Plafker and others, 1989; Bradley and others, 1993; Haeussler and Nelson, 1993; Haeussler and others, 1995; Goldfarb and others, 1995; 1997; Goldfarb, 1997).

\section{Metallogenic Belts Formed During Early Tertiary Spreading Along Kula-Farallon Oceanic Ridge, Southern and Southeastern Alaska}

\section{Prince William Sound Metallogenic Belt of Besshi and Cyprus Massive Sulfide Deposits (Beit PW) Eastern-Southern Alaska}

The Prince William Sound metallogenic belt of Besshi and Cyprus massive sulfide deposits (fig. 103; tables 3,4) occurs in the Prince William Sound district along the eastem and northern margins in eastern-southern Alaska. The metallogenic belt is hosted in the southern margin of the Chugach and the Prince William accretionary wedge-turbidite terranes (Jones and others, 1987; Nokleberg and others, 1994c, 1997c). The significant deposits in the belt are (table 4) (Crowe and others, 1992; Newberry and others, 1997; Nokleberg and others 1997a, b, 1998): Besshi massive sulfide deposits at Beatson (Latouche), Ellamar, FidalgoAlaska, Midas, and Schlosser, and Cyprus massive sulfide deposits at Copper Bullion (Rua Cove). Knight Island (Pandora), Standard Copper, and Threeman. Many of these deposits were producing mines in the early part of the $20^{\text {th }}$ century. 
The Beatson (Latouche), and, Ellamar Besshi massive sulfide deposits (Johnson, 1915; Tysdal, 1978; Jansons and others, 1984; Crowe and others, 1992) consist of massive sulfide lenses and disseminations of muinly pyrite and pyrrhotite, and minor chalcopyrite, cubanite, sphalerite, galena, Ag-bearing minerals, and gold. Gangue minerals are quartz, sericite, and ankerite. The deposits occur in graywacke and argillite of the Paleocene and Eocene Orca Group. The deposits range up to $120 \mathrm{~m}$ thick and 300 long along strike. The Latouche and Beatson deposits produced more than 84 million $\mathrm{kg} \mathrm{Cu}$ from 4.5 million tonnes of ore. The average ore grade was about $1.7 \% \mathrm{Cu}$, and $9.3 \mathrm{~g} / \mathrm{Ag}$. The Ellamar deposit produced 7.2 million $\mathrm{kg} \mathrm{Cu}, 1,596 \mathrm{~kg} \mathrm{Au}$, and 5,960 $\mathrm{kg} \mathrm{Ag}$ from 273,760 tonnes of ore. The deposit at Beatson (Latouche) was developed and produced mainly from about 1903 to 1934, and the Ellamar deposit was mined from 1897 to 1934.

\section{Midas Besshi Massive Sulfide Deposit}

The Midas deposit consists of disseminated to massive chalcopyrite, pyrite, pyrrhotite, sphalerite, and minor galena in a folded, lens-shaped body (Moffit and Fellows, 1950; Rose, 1965; Jansons and others, 1984; Crowe and others, 1992). The sulfides occur in bighly deformed phyllite and metagraywacke of the Late Cretaceous Valdez Group in the soutbern Chugach aceretionary wedge-turbidite terrane. Mafic metavolcanic rocks crop out in the footwall within a few bundred meters of the ore body. On the basis of whole rock REE analyses, the mafic volcanic rocks in the southern Chugach terrane are interpreted by Lull and Plafker (1990) as forming in a short-lived island-arc environment.

\section{Copper Bullion (Rua Cove) Cyprus Massive Sulfide Deposit}

The Copper Bullion (Ruu Cove) Cyprus massive sulfide deposit (fig. 116) (Koski and otbers, 1985; Crowe and others, 1992) is a lens-shaped massive body of pyrrhotite with minor chalcopyrite and sphalerite which is hosted in sheared pillow basalt of the lower Tertiary Orea Group of the Prince William terrane. The lens is about $200 \mathrm{~m}$ long and is locally interlayered with pillow basalt and hyaloclastite that occur stratigraphically above sheeted dikes. The sulfides include pyrite, phrthotite, chalcopyrite, sphalerite, cubanite, galena, and marcasite. The gangue assemblage consists of abundant quartz and chlorite, which occur as fine disseminations with massive sulfides, and in pervasive and massive zones in the stockwork zone where fine-grained talc also occurs. The deposit contains a well-preserved feeder zone that underlies the massive sulfide lens is dominanted by pyrrhotile and chalcopyrile. The deposit contains reserves of 990,000 tonnes grading $1.25 \% \mathrm{Cu}$, and $<0.005$ oz/ $\mathrm{Au}$, and $<0.1$ ozh Ag.

\section{Origin of and Tectonic Controls for Prince William Sound Metallogenic Beit}

The deposits in the Prince William Sound metallogenic belt, except for the Midas deposit, are hosied in the early Tertiary (Paleocene and Eocene) Orca Group which constitutes most of the Prince William terrane and consists of a deformed, thick assemblage of Paleocene and Eocene( (?) graywacke, argillite, minor conglomerate, pillow basalt, basaltic tuff, sills, and dikes (Winkler and Plafker. 1981; Jones and others, 1987; Nokleberg and others. 1994c, 1997c; Newberry and others, 1997). On Resurrection Peninsula and on Kright Island, the lemane contains a local ophiolitic rock which is interpreted as slabs of oceanic basement formed during early Tertiary sea-floor spreading along the Kula-Farnllon oceanic ridge (Nokleberg and others, 2000). In the upper part of the ophiolite, the mafie volcanic rock of the Prince William terrane was immediately succeeded by a flood of sediment derived from uplift and erosion of the Coast Mountains (Plafker and others, 1989; Plafker and Berg. 1994; Nokleberg and others, 2000). Consequently, the Prince Willian Sound metallogenic belt is interpreted as forming in a sea-floor spreading tectonic environment. The Cyprus massive sulfide deposits are interpreted as forming during rifting without abundant covering by clastic debris whereas the Besshi deposits are interpreted as forming during sedimentation of clastic debris onto an active oceanic rif.

\section{Yakobi Metallogenic Belt of}

\section{Gabbroic Ni-Cu Deposits (Belt YK)}

Southeastern Alaska

The Yakobi metallogenic belt of gabbroie Ni-Cu deposits (fig, 103; tables 3, 4) occurs in Southeastern Alaska and is hosted in Tertiary mafic and ultramafic stocks of the La Perouse Plutonic Suite, which intrudes metagraywacke, clastic rocks, and greenstone of the Cretaceous Sitka Graywacke and the Kelp Bay Group. Both units are part of the Chugach accretionary wedge and subduction-zone terrane (Woodsworth and others, 1991; Brew, 1993; Nokleberg and others, 2000), The principal deposits are at Bohernia Basin (Yakobi Island), Brady Glacier, and Mirror Harbor (table 4) (Nokleberg and others 1997a, b, 1998). At the north end of the belt is the Mount Fairweather $\mathrm{Cu}-\mathrm{Ni}$-Co-Pt prospect which consists of mafic-ultramafic float on the southwest flank of the mountain (Plafker and MacKevett, 1970). 

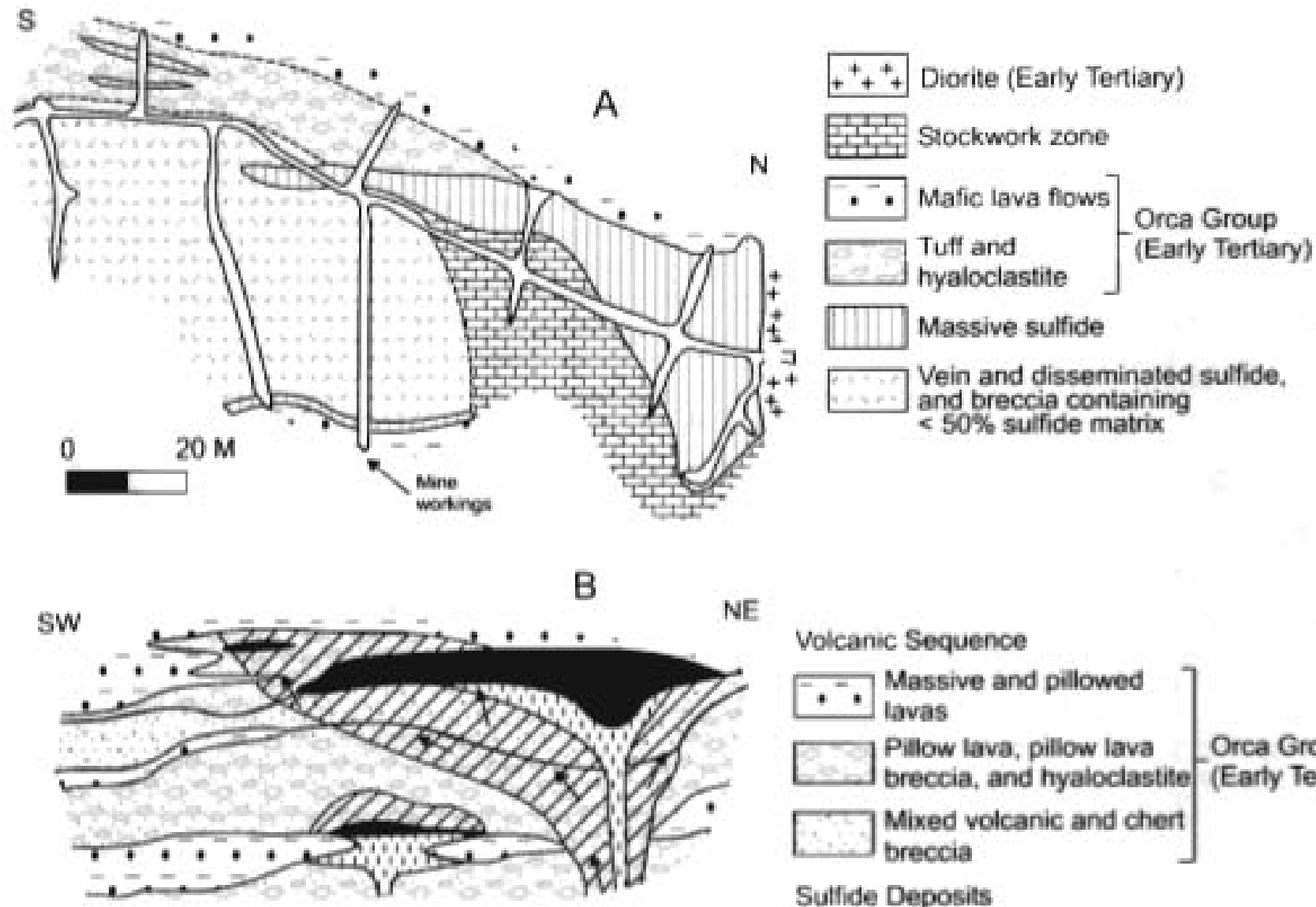

Volcanic Sequence

0

$40 \mathrm{M}$

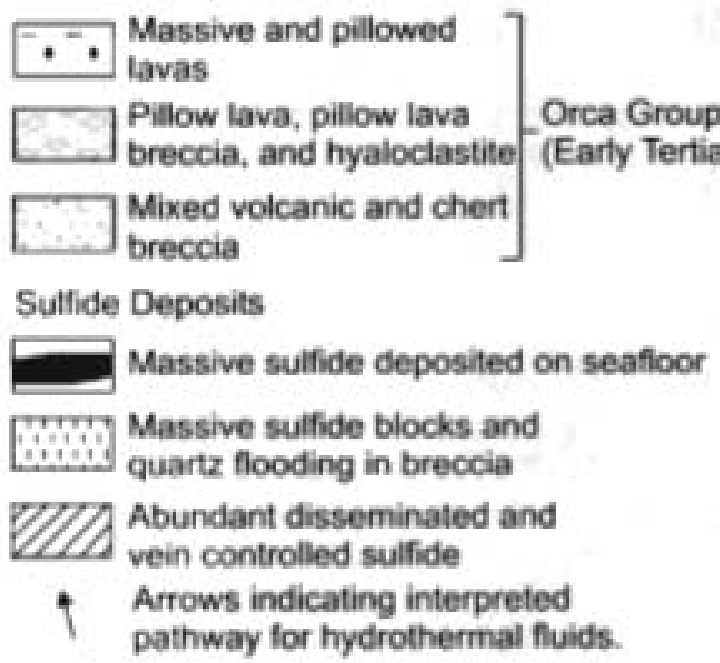

Figure 116. Copper Bullion (Rua Cove) Cyprus massive sulfide deposit, Prince Willam Sound metallogenic belt, Southem Alaska. A. Schematic geologic map of 370 level, B. Interpretive model. Modified from Koski and others (1985) and Crowe and others (1992).

\section{Bohemia Basin Gabbroic Ni-Cu Deposit}

The Bohemia Basin gabbroic Ni-Cu deposit consists of magmatic sulfide segregations, chicfly consisting of pymbotite, pentlandite, and chalcopyrite (Himmelberg and others, 1987. Still, 1988; Brew and others, 1991; Berg. 1984; Foley and others, 1997). Estimated resources are 19 million tonnes grading $0.33 \% \mathrm{Ni}, 0.21 \% \mathrm{Cu}$, and $0.01 \% \mathrm{Co}$. The deposit occurs in a trough-like body, about $45 \mathrm{~m}$ thick, near the base of a basin-shuped, composite norite of a Tertiary lopolith. The norite, which locally grades into gabbro and diorite, intrudes metagraywacke, phyllite, and greenschist of the Cretaceous and Cretaceous(7) Kelp Bay Group of the Chugach terrane.

\section{Brady Glacier Gabbroic Ni-Cu Deposit}

The Brady Glacier gabbroic Ni-Cu deposit (fie. 117) consists of disseminated and lensoid pyrthotite, pentlandite, and cbalcopyrite, with rare pyrite. The sulfide minerals occur acar the base of a large, layered Tertiary lopolith which consists mainly of gabbro and sparse peridotite, all part of the La Perouse layered gabbro (Cramanske and Calk, 1981: Himmellerg and Loney, 1981; Foley and others, 1997). The gabbro intrudes metagraywacke and phyllite of the Cretaceous Sitka Graywacke which is part of the Chugach terrane. The mafic and ultramafic rocks locally contain up to $10 \%$ disseminated sulfides. Estimated resources are 82 to 91 million tonnes grading $0.53 \% \mathrm{Ni}, 0.33 \% \mathrm{Cu}_{0} 0.03 \% \mathrm{Co}$, and minor PGE. Grab samples contain from 0.18 to $1.30 \mathrm{gt}$ PGE. The deposit occurs almost entirely beneath Brady Glacier, but exposed in small nunataks. Considerable drilling and exploration occurred in the 1970's. Exploration stopped short of development. The deposit is now part of the Wrangell-St. Elias National Park. 
The gabbroic Ni-Cu deposits and host mafic and ultramafic rocks in the Yakobi metallogenic belt formed during intrusion into the Oligocene La Perouse Plutonic Suite into highly-deformed and low-grade, regionally metamorphosed rocks of the Chugach accretionary wedge and subduction-zone terrane (Woodsworth and others, 1991; Brew, 1993, 1994; Moll-Stalcup and others, 1994). Intrusion occurred in the early Tertiary afler cessation of accretion and subduction of the Chugach terrane in the earliest Tertiary. The early Tertiary La Perouse Plutonic Suite is interpreted as forming during final spreading along the KulaFarallon oceanic ridge during ridge subduction at about 50 to $60 \mathrm{Ma}$ along the margin of southern and Southeastem Alaska (Bradley and others, 1993; Kusky and others, 1997). The early Tertiary subduction of the spreading oceanic ridge, locally partly preserved in ophiolites in the Prince William terrane (Lytwyn and others, 1997; Kusky and Young, 2000, in press), is interpreted as causing: (1) a regional metamorphic welt and formation of anatectic granites (Plafker and others, 1989b; 1994); (2) rapid change in component of strike-slip movements along the subduction zone bordering the early Tertiary continental margin (Bradley and others, 1993); and (3) intrussion of the early Tertiary granitic and mafic-ultramafic plutonic rock of the Sanak-Baranof plutonic belt (Hudson, 1979; Moll-Stalcup and others, 1994) in Southem and Southeastern Alaska. The intrusions are interpreted as forming in a near-trench environment during subduction of the Kula-Farallon oceanic ridge (Bradley and others, 1993; Kusky and others, 1997). Because of temporal and spatial proximity to subduction of the Kula-Farallon oceanic ridge along the margin of Southeastern Alaska from about 50 to $60 \mathrm{Ma}$, the Oligocene La Perouse Plutonic Suite and associated gabbroic Ni-Cu deposits of the Yakobi metallogenic belt are interpreted as forming either: (1) during the last gasp of oceanic ridge mafic plutonism (this article); or (2) possibly slightly later in association with strike-slip dismemberment of a continental-margin arc (Goldfarb and others, 1997, 1998; Goldfarb, 1997).

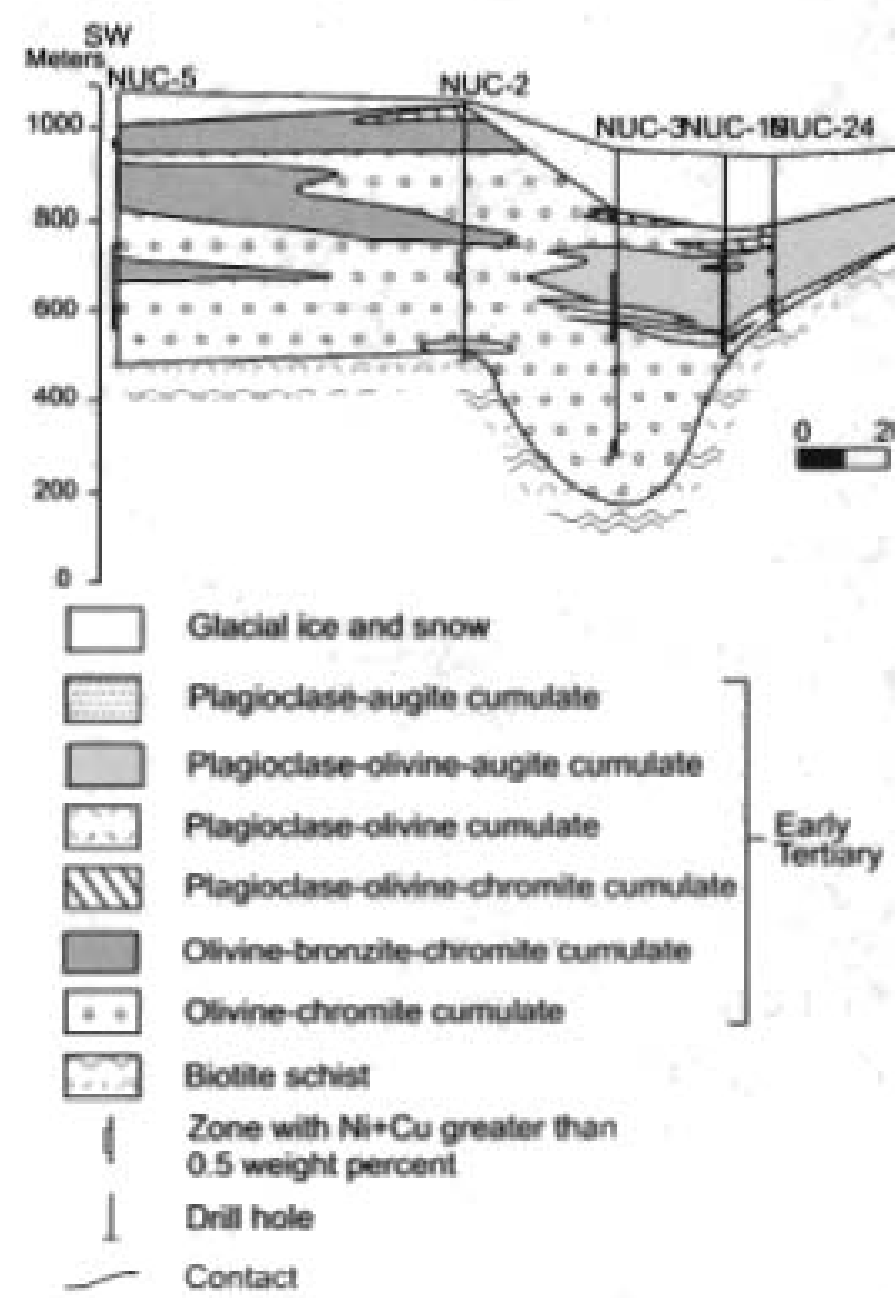

Figure 117 . Brady Glacier gabbroic Ni-Cu deposit, Yakobi metallogenic belt, Southeastem Alaska. Schematic southwest-northeast cross section. Adapted from Himmelberg and Loney (1981). 


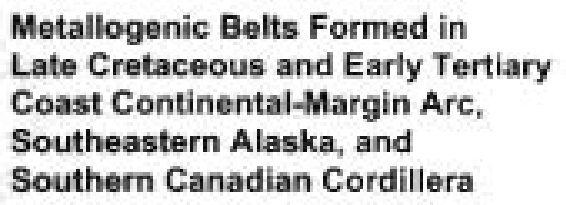

An extensive suite of Late Cretaceous and early Tertiary metallogenic belts hosting granitic-magmatism related deposits occur in Southeastern Alaska and the southern Canadian Cordillera (fig. 103; tables 3, 4). These belis are bosted mainly in the the Coast-North Cascade plutonic belt and correlative units. In alphabetical order, these metallogenic belts are the Bulkey. Carmacks, Catfish, Central-Southeastem Alaska, Fish Lake-Bralorne, Gambier, and Surprise Lake belis. The host Coast-North Cascade plutonic belt consists chiefly of quartz diorite, granodiorite, and locally more mafic or felsic plutons (Rubin and others, 1991; Gehrels and others, 1990; Wheeler and McFecley, 1991; van der Heyden, 1992; Woodsworth and others, 1992; Journeay and Friedman, 1993). The Early Late Cretaceous through early Tertiary intrusions are interpreted as forming sequentially during contraction, local(?) dextral transpression, and transtension, and accompanied by regional metamorphism (Rubin and others, I991; Journeay and Friedman, 1993). The Coast-North Cascade plutonic belt constitutes part of a laterally-extensive, Andean-type Coast continentalmargin are which overlaps the Wrangellia superterrane, and previously-accreted, more inboard terranes in Southern Alaska and coastal Canadian Cordillera (fig. 103) (Nokleberg and others, 1994c, 1997c; Monger and Nokleberg, 1996). The Early Late Cretaceous through early Tertiary intrusions were emplaced concurrently with structures formed sequentially, first during contraction, and subsequently during local(?) dextral transpression and associated regional metamorphism (Woodsworth and others, 1977; Leitch and others, 1989; Rubin and otbers, 1991; Journeay and Friedman, 1993; Schiarizza and others, 1997). The plutonic belt and associated metallogenic belts of granitic-magmatism deposits are interpreting as forming immediately after the mid-Cretaceous accretion of the Wrangellia superterrane, and the subsequent oceanward stepping of subduction and continental margin magmatism (Nokleberg and others, 1994c, 1997c; Monger and Nokleberg, 1996).

\section{Surprise Lake Metallogenic Belt of \\ Porphyry Mo-W-Cu, and \\ Au-Ag Polymetallic Vein Deposits (Belt SL) \\ Northern British Columbia}

The Surprise Lake metallogenic belt of porphyry Mo-W-Cu, and Au-Ag polymetallic vein deposits (fig. 103; tables 3, 4) occurs in northem British Columbia and is hosted in the northwest-trending Surprise Lake Plutonic Suite. The significant deposit in the belt are (table 4) (Nokleberg and others 1997a, b, 1998): porphyry Mo deposits at Adanac-Adera (Ruby Creek), Mount Ogden, Red Mountain (Bug, Fox, Boswell R.), and S.Q.E. (Storie, Casmo); a porphyry Cu-Mo deposil at Sullahine River Area (Thorn, Kay); porphyry Mo and W- and Mo skarn deposits at Mt. Haskin West (Joem, Rain, Moly Zone), and Windy (Balsam, Star, Kuhn, Dead Goat); and Au-Ag polymetallic vein deposits at Engineer Mine, Montana Mountain, Venus, and Wheaton River.

\section{Adanac-Adera Porphyry Mo Deposit}

The Adanac-Adera porphyry Mo deposit (fig. 118) consists of molybdenite with accessory pyrite, fluorite, chalcopyrite, scheelite, and wolframite, along with minor arsenopyrite which occur in a quartz-vein stockwork. Estimate reserves are 152 million tonnes grading $0.063 \% \mathrm{MoS}_{2}$ at a cutoff grade of $0.04 \% \mathrm{Mo}$ (EMR Canada, 1989; Dawson and others, 1991 ; Mining Review, 1992; Pinsent and Christopher, 1995; MINFILE, 2002). The deposit is hosted by a quartz monzonite stock which is part of the Late Cretaceous Surprise Lake Batholith (Pinsent and Christopher, 1995). The deposit exhibits silicic and potassic alteration which occur as envelopes, up to several centimetres thick, around quartz veins. Minor uranium occurs in the deposit. The Surprise Lake Batholith exhibits a K-Ar isotopic age of $70.6 \pm 3.8 \mathrm{Ma}$ as an average of six dates. This value represents a cooling age and differs significantly from a U-Pb zircon age of $83.8 \pm 5 \mathrm{Ma}$ (Mihalynuk and others, 1992). Associated W-, Cu-, and Sn-greisen vein, and $\mathrm{W}$ and $\mathrm{Sn}(\mathrm{Cu}, \mathrm{Pb}, \mathrm{Zn}$ ) skarns occur along contacts between the stock with limestone of Cache Creek Assemblage (Ray and others, 1992).

\section{Mount Ogden Porphyry Mo Deposit}

The Mount Ogden porphyry Mo deposit consists of molybdenite in an alaskite and quartz monzonite stock which intrudes amphibolite-grade, Permian and Triassic limestone, and clastic sedimentary and volcanic rocks of the Stikinia terrane (EMR Canada, 1989; MINFILE, 2002). Molybdenite occurs mainly in the alaskite as platy crystals in veins, in veinlets, as rosettes in vuggy quartz, and as interstitial grains, Some molybdenite veins range up to $10 \mathrm{~cm}$ wide and occur over 30 meters. Alteration consists of quartz-sericite, with fluorite, biotite, minor pyrite and sphalerite. Estimated reserves are 218 million tonnes grading $0.30 \% \mathrm{MoS}_{2}$. The country rocks locally contain skarns with disseminated pyrite, pyrrhotite, magnetite, and traces of sphalerite and scheelite. 


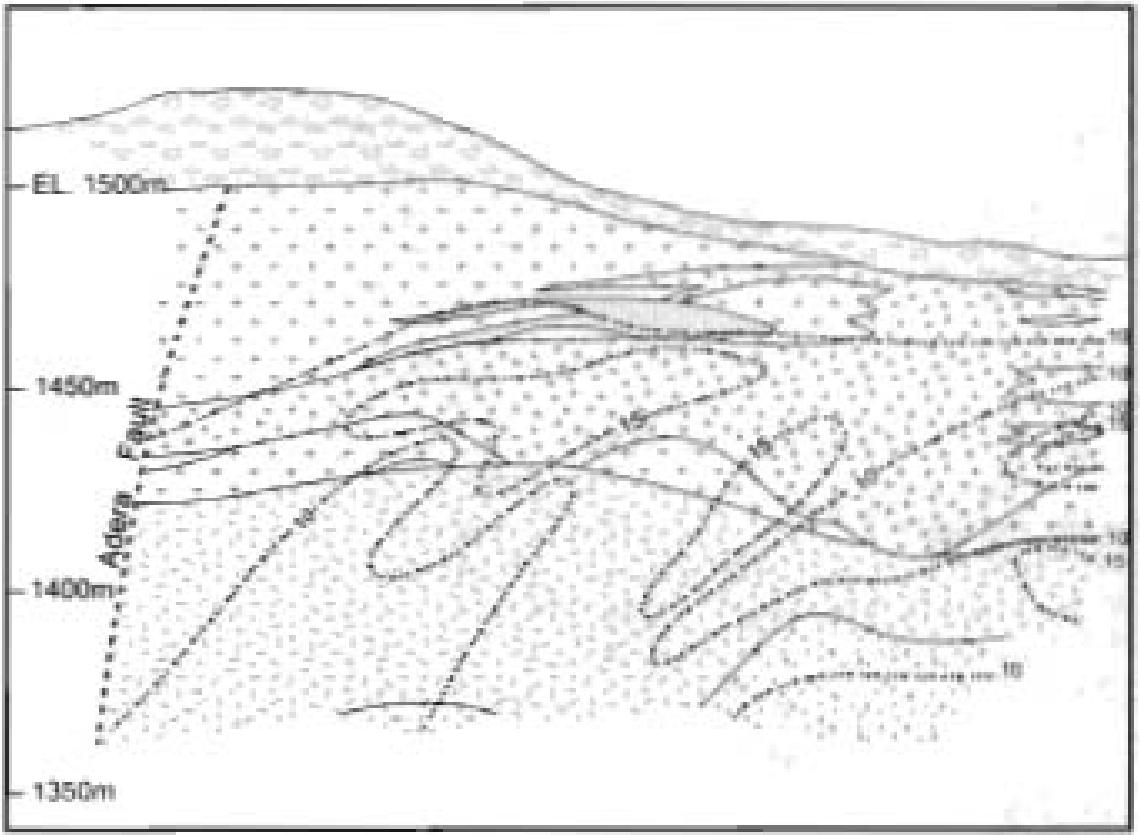

TERTIARY AND QUATERNARY

Overburden

CRETACEOUS

Mount Leonard Stock

- 1 Coarse-grained quartz monzonite

Coarse-grained to aplitic "hybrid" quartz monzonite Matic quartz monzonite porphyry

7.7 Sparse quartz monzonite porphyry

Fine-grained quartz monzonite porphyry

Din Silicified quartz monzonite porphyry

** Fault and shear

$z_{n+10}$ Molybdenum contours $-1350 m$

118. Adanac-Adera porphyry Mo deposit, Surprise Lake metallogenic belt, Canadian Cordillera. Generalized cross section through high-grade zone. Adapted from Pinsent and Christopher (1995).

\section{Red Mountain Porphyry Mo Deposit}

The Red Mountain porphyry Mo deposit consists of disseminated molybdenite which occurs in a quartz stockwork (EMR Canada, 1989; Dawson, and others, 1991; Yukon Minfile, 1992; Sinclair, 1986). Estimated reserves are 187 million tonnes grading $0.167 \%$ MoS2 (with a $0.1 \%$ cut-off), and 21.3 million tonnes grading $0.293 \% \mathrm{MoS}_{2}$ with a $0.25 \%$ cut-off. The deposit occurs in an altered Late Cretaceous quartz monzonite stock of the Surprise Lake Suite, with a K-Ar isotopic age of 87.3 Ma, and in adjacent contact-metamorphosed argillite of the early Paleozoic Nasina Assemblage of the Yukon-Tanana terrane. The stock is complex, exhibits a classical alieration pattern, and is intruded by barren quartz diorite.

\section{Surprise Lake Polymetallic and Epithermal Au-Ag Voins.}

Ag-Pb polymetallic vein deposits are associated with an Late Cretaceous pluton at Boswell River, Yukon Territory (Lees, 1936), and near the Red Mountain porphyry Mo deposit. Several Au-Ag polymetallic vein mines at Venus, Montana Mountain, and Wheaton River are hosted in or near the Late Cretaceous Carcross pluton which occurs south of Whiteborse, Yukon Territory (Hart, 1994). Au veins at the Engineer Mine, southwest of Atlin, B.C, are probably related to Eocene magmatiam which formed both the volcanic rocks and late stocks (Mihalynuk, 1990). The deposit at the Engineer Mine are cut by the major Lewellyn Fault. The Au epithermal veins at the Engineer mine are transitional between mesothermal and epithermal, low-sulphidaiton type.

\section{Origin of and Tectonic Controls for}

\section{Surprise Lake Metallogenic Belt}

The Surprise Lake metallogenic belt is associated with the Surprise Lake Plutonie Suite which consists of stocks and batholiths, comprising mainly felsic, high-level, Si- and lithophile element-rich rocks, and has K-Ar isotopic ages of 84 Ma (Woodsworth and others, 1991). Plutons in the suite intrude the Cassiar, Stikine, Yukon-Tanana, and Cache Creek terranes, The major plutonic units are the Surprise Lake batholith, near Atlin, B.C., and the Needlepoint Pluton, near Cassiar, B.C.

(Woodsworth and others, 1991). The Surprise Lake Plutonic Suite is part of the extensive Late Cretaceous and early Tertiary Coast-North Cascade plutonic belt which occurs along the westem and central parts of the Canadian Cordillera and into EastCentral Alaska (fig. 103) (Nokleberg and others, 1994c, 1997c; Monger and Nokleberg, 1996). Probable coeval, extrusive equivalents for the Surprise Lake Plutonic suite are the Windy-Table Volcanics to the east and west (Mihalynuk, 1999; Mihalynuk and others, 1992), and the Carmacks Assemblage to the north (Grond and others, 1984) and unnamned tuffaceous units in the Sustut Basin to the south (Woodsworth and others, 1991). The Coast-North Cascade plutonic belt forms the major part of the Coast continental-margin are in the region. 


\section{Central-Southeastern Alaska Metallogenic Belt of Porphyry Mo and Cu Deposits (Belt CSE) \\ Southeastern Alaska}

The Central-Southeastern Alaska metallogenic belt of porphyry Mo and Cu deposits (fig. 103; tables 3, 4) cocurs along the western coast of Southeastern Alaska and is hosted in (Nokleberg and others, 1995a): (1) a belt of lute Oligocene and younger Cenozoic grantoid stocks of the Glacier Bay magmatic belt; and (2) the Tkope-Portland Peninsula voleanic-plutonic belt. These igneous belts intrude the Wrangellia superterrane in Southeastern Alaska, and are part of the more extensive Late Cretaceous and early Tertiary Coast-Nortb Cascade plutonic belt. This belt extends along the western and central parts of the Canadian Cordillera for several thousand $\mathrm{km}$ (Nokleberg and others, 1994c, 1997c; Monger and Nokleberg. 1996). The significant deposits in the Central-Southeastern Alaska metallogenic belt are porphyry Cu-Mo deposits at Margerie Glacier, Nunatak, and Quartz Hill, a porphyry Mo deposit at Burroughs Bay, and a Fe skarn deposit at North Bradfield Canal (table 4) (Nokleberg and others 1997a, b. 1998).

\section{Margerie Glacier Porphyry $\mathrm{Cu}$ Deposit}

The Margerie Glacier porphyry Cu deposit (MacKevett and others, 1971; Brew and others, 1978; Berg and others, 1981; Berg, 1984) consists of chalcopyrite, pyrite, arsenopyrite, sphalerite, molybdenite, and minor scheelite in shear-zone-hosted quartz veins, as massive sulfide veins, and as disseminations in a propylitically altered, Tertiary(?) porphyritic granite stock and adjacent homfels. The granite stock is part of the Glacier Bay belt of middle Tertiary granitoid rocks which have isotopic ages of about 25 to $30 \mathrm{Ma}$ (Brew 1994). The stock intruded Permian(?) metamorphosed pelitic and volcanic rocks, and sparse marble of the Alexander sequence of the Wrangellia superterrane. The deposit contains estimated resources of 145 million tonnes grading $0.02 \% \mathrm{Cu}, 0.27 \mathrm{~g} / \mathrm{Au}$, and $4.5 \mathrm{~g} / \mathrm{Ag}$ (Mackevett and others, 1971; Brew and others, 1978). Parts of the deposit are higher grade.

\section{Nunatak Porphyry Cu-Mo Deposit}

The Nunatak porphyry Cu-Mo deposit (MacKevett and others, 1971; Brew and others, 1978; Berg and others, 1981; Berg, 1984) occurs in northern southeastem Alaska, and consists of numerous, closely spaced molybdenite-bearing quartz veins and stockwork, and minor disseminated molybdenite in hornfels, skarn, and a mineralized fault zone around a Tertiary granite porphyry stock. The granite porphyry stock has not yet been isolopically dated, but is part of the Glacier Bay magmatic belt of middle Tertiary granitoid rocks which range in age from about 25 to $30 \mathrm{Ma}$ (Brew and Morrell, 1983; Brew, 1988). Disseminated sulfides within the granite porphyry stock consist of varying amounts of pyrite, pyrrhotile, chalcopyrite, and sparse tetrahedrite, and bornite. The most mineralized part of the stockwork contains a resource of 2.03 million tonnes grading $0.067 \%$ Mo and $0.16 \%$ $\mathrm{Cu}$; the less mineralized part of the stockwork contains 117.5 million 1onnes grading $0.026 \% \mathrm{Mo}$ and $0.18 \% \mathrm{Cu}$ (MacKevett and others, 1971; Brew and others, 1978). Similar tonnage and grade material may exist below sea level. The granite porphyry stock intrudes tightly foided Paleozoic metasedimentary rocks of the Alexander sequence of the Wrangellia superterrane.

\section{Quartz Hill Porphyry Mo Deposit}

The Quartz Hill porphyry Mo deposit (fig. 119), which contains one of the world's largest concentrations of molybdenum (Hudson and others, 1979, P.R. Smith and J.E. Stephens, written commun., 1985; Wolfe, 1995; Ashleman and others, 1997) occurs in the southem part of eastern-southeasiern Alaska. The deposit consists of a flat-lying. tabular stockwork of molybdenitebearing, randomly oriented quartz veins and fractures, and also disseminated molybdenite, all of which are distributed throughout the multiply-altered hypabyssal Quartz. Hill composite quartz monzonite stock which crops out over an area of several square kilometers. The Quarte Hill stock is roughly ovoid in outcrop, is approximately $5 \mathrm{~km}$ long by $3 \mathrm{~km}$ wide (Brew and Ford, $1984 \mathrm{a}$, b), and is part of the Tkope-Portland Peninsula volcanic-plutonic belt. The stock is cut by a progressively younger sequence of plugs and dikes consisting of porphyritic quartz latite, igneous breccia, quartz monzonite, quartz feldspar porphyry, and latite which are abundant in the core of the Quartz Hill stock, A K-Ar isotopic age of about $27 \mathrm{Ma}$ was obtain for the stock (Ashleman and others, 1997). The host rocks are paragneiss and plutonic rocks of the Coast Plutonic Complex. The deposit contains estimated reserves of 1,600 million tonnes grading $0.127 \% \mathrm{MoS}_{2}$, at an $0.08 \% \mathrm{MoS}_{2}$ cut-off, and an estimated 210 million tonnes grading $0.22 \% \mathrm{MoS}$, (Wolfe, 1995).

\section{Origin of and Tectonic Controls for}

\section{Central-Southeastern Alaska Metallogenic Belt}

The Glacier Bay magmatic belt and the Tkope-Portland Peninsula volcanic-plutonic belt, which constitute some of the youngest, extensive igneous units in southeastern Alaska (Brew and others, 1992, 1993), hosts the Central-Southeastem Alaska metallogenic belt. The Oligocene Glacier Bay magmatic belt, which hosts the Margerie Glacier porphyry Cu and polymetallic vein deposit, and the Nunatak porphyry Cu-Mo deposat, consists of calc-alkalic, biotite granite and alkali granite plutons which are dominantly unfoliated, metaluminous, and moderately peraluminous. K-Ar isotopic ages rangefrom 31 to $42 \mathrm{Ma}$. The TkopePortland Peninsula volcanic-plutonic belt of Oligocene age hosts the Quartz Hill porphyry molybdenum deposit (Brew and Morrell, 1983, Brew, 1988). The Tkope-Portland Peninsula volcanic-plutonic belt consists of calc-alkalic and alkalic, locally 


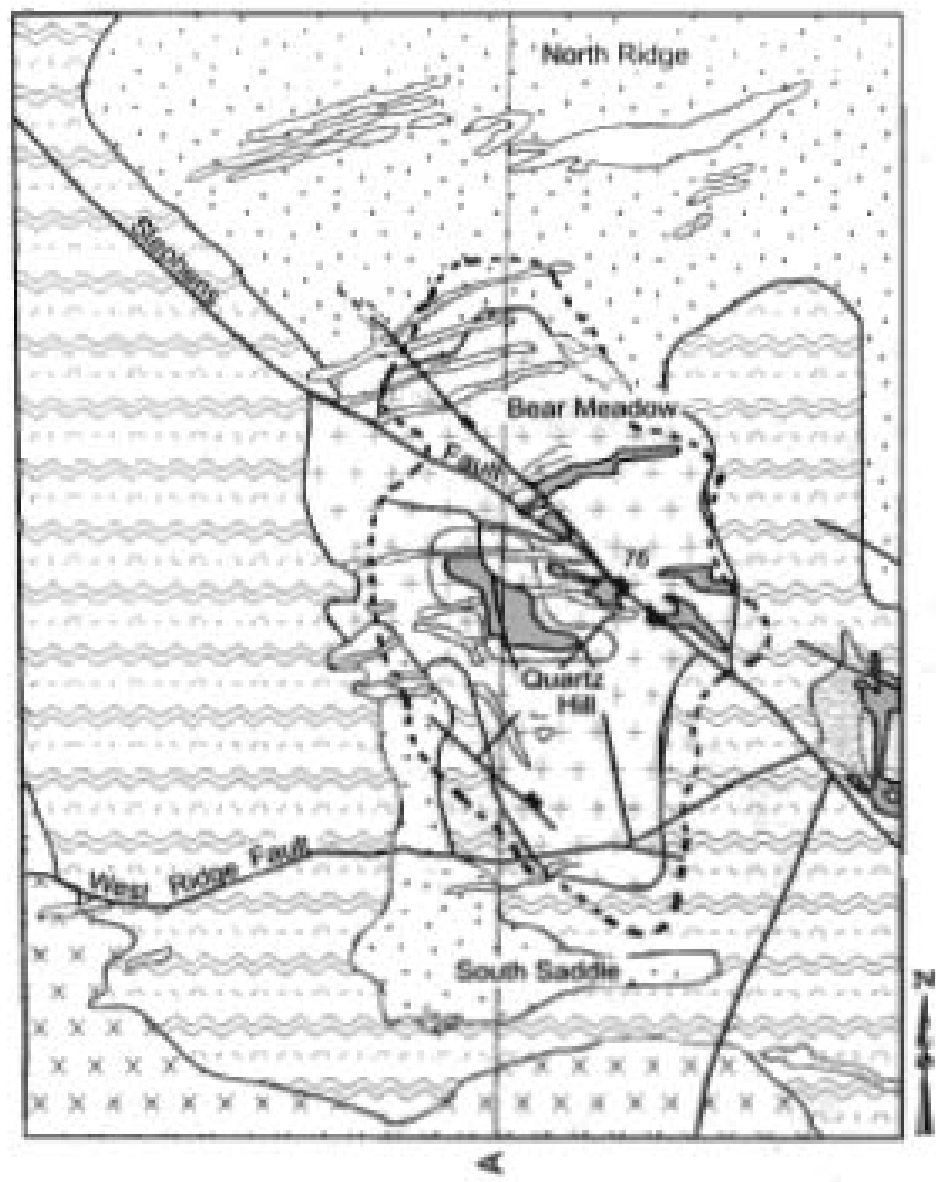

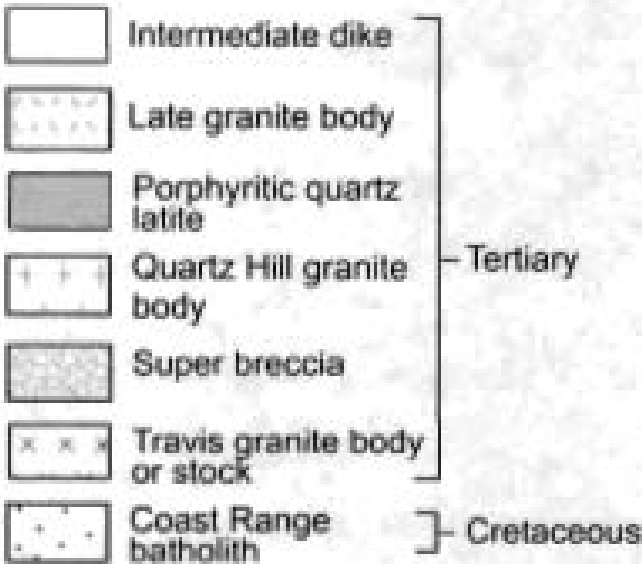

batholith

Fe्A Paragneiss, Paleozoic \&

Mesozoic

Zone averaging $0.13 \% \mathrm{MoS}$

(approximate cutoff $0.05 \%$ )

Contact

r6 Fault, locally showing strike dip, and sense of displacement

0

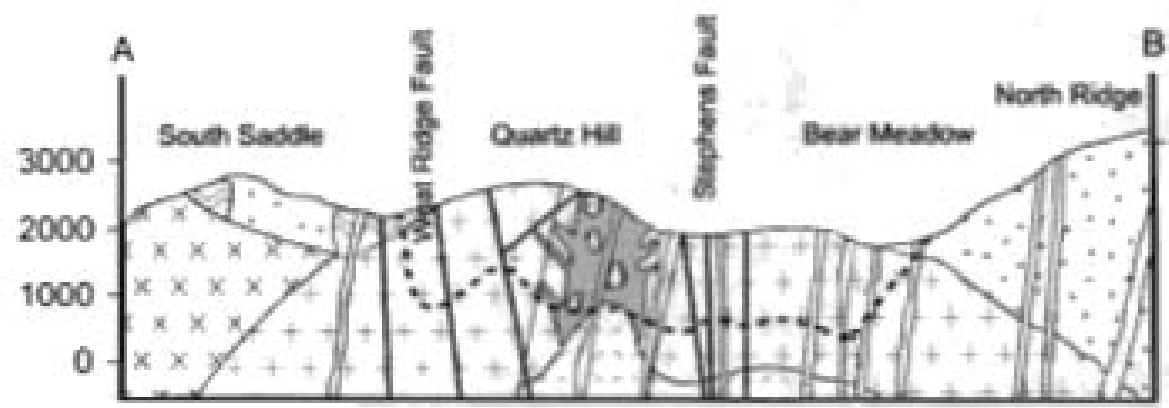

Figure 119. Quartz Hill porphyry Mo deposit, Central-Southeastem Aaska metallogenic belt, Southeastem Alaska. Adapted from and Nokleberg and others (1995)

peraluminous, homblende-biotite granite and granite poophyry, and lesser syenite and gabbro (Brew, 1988). K-Ar, Rb-Sr, and fission track isotopic ages range from 19 to $35 \mathrm{Ma}$. The belt exhibits strongly fractionated REE pattems, large Europium anomalies, and initial Sr ratios of 0.747 to 0.705 (Arth and others, 1986).

The Glacier Bay magmatic and Thope-Portland Peniniula volcanic-plutonic belts are part of the extensive Late Cretaceous and early Tertiary Coast-North Cascade plutonic belt which extends the length of the Canadian Cordillera and into East-Central Alaska (fig. 103) (Rubin and others, 1991; Gehrels and others, 1990; Wheeler and McFeeley, 1991; van der Heyden. 1992; Woodsworth and others, 1992; Joumeay and Friedman, 1993). The Coast-North Cascade plutonic belt forms the major part of the Coast continental-margin are in the region.

\section{Bulkley Metallogenic Beit of Porphyry Cu-Mo and Polymetallic Vein Deposits (Beit BK) \\ Central British Columbia}

The Bulkley metallogenic belt of porphyry Cu-Mo and polymetallic vein deposits (fig. 103; tables 3,4) occurs in central British Columbia and is hosted in a belt of small stocks and batholiths of the Late Cretaceous Bulkley Plutonic Suite which are exposed along the uplift of the Skeena Arch in the central part of the Stikinia ternune (Carter, 1982; Mihalynuk, 1992; Mihalynuk 
and others, 1999). This sute is part of the extensive Late Cretaceous and early Tertiary Coast-North Cascade plutonic belt which occurs along the westem and central parts of the Canadian Cordillera for several thousand $\mathrm{km}$ (Nokleberg and others, 1994c, 1997c; Monger and Nokleberg. 1996). The significant porphyry Cu-Mo deposits of the Bulkley metallogenic belt are associated with generally small, calc-alkaline plutons of the Bulk ley Plutonic Suite and consist mainly of biotite and hornblende granodiorite and quartz diorite whicb were emplaced at high levels along bigh-angle faults within an extensional stress field (Dawson and others, 1991). Most of the plutons hosting this metallogenic belt are toe smail to depict on figure 103. The significant deposits in the belt are (table 4) (Nokleberg and others 1997a, b, 1998); porphyry Cu-Mo and Mo deposits at Glacier Gulch (Hudson Bay Mountain), Huckleberry, and Poplar; and polymetallic vein deposits at Red Rose, Capoose Lake, and Nadina (Silver Queen).

\section{Glacier Gulch (Hudson Bay Mountain) Parphyry Mo (W, Cu) Deposit}

The Glacier Gulch (Hudson Bay Mountain) porphyry Mo (W, Cu) deposit occurs at Hudson Bay Mountain, Smithers, B.C., and consists of molybdenite and minor scheelite which occur in stockwork and quartz vein swarms formed during two periods of mineralization. The deposits are related to the intrusion of a sheet-like granodiorite body and a later quartz-porphyry plug, into rocks of the Hazelton Group of the Stikinia terrane (Bright and Jonson, 1976, EMR Canada, 1989; Aikinson, 1995; MINFILE, 2002). Most intense quartz-molybdenite-scheelite vein mineralization is related to a crudely layered granodiorite sheet. An estimated resource of 100 million tonnes grading $0.297 \% \mathrm{MoS}_{7}$ and $0.06 \% \mathrm{WO}_{3}$ is defined by surface drilling and underground exploration (Kirkham, 1967; Bright and Jonson, 1976). Hydrothermal alteration patterns are irregularly developed.

\section{Huckleberry Porphyry Cu-Mo (Au-Ag) Deposit}

The Huckleberry porphyry Cu-Mo (Au-Ag) deposit (fig 120) consisis of chalcopyrite and minor molybdenite wbich occur in a stockwork in contact-metamorphosed and ahered Jurassic Hazelton Group fuffs at a contact with a Late Cretaceous granodiorite porphyry stock of the Burkley Plutonic Suite (Sutherland Brown, 1969; Curter, 1970, Maclntyre, 1984; EMR Canada, 1989; Mining Review, 1992; Society of Exploration Geologists Newsletter, no, 20, January, 1995, p. 26; Jackson and others, 1995; MINFILE, 2002). Magnetite occasionally accompanies chalcopyrite, Potassic, phyllic, and propylitic alteration haloes surround the stock. The stockwork consists of quartz and chalcopyrite, and lesser pyrite, molybdenite which are cut by younger anhydrite veinlets. Associated with the stockwork is biotite and albite alteration. Estimated, pre-production reserves, at cut-off grade of $0.30 \% \mathrm{Cu}$, for the Main Zone, are 53.7 million tonnes grading $0.445 \% \mathrm{Cu}, 0.013 \% \mathrm{Mo}$, and $0.06 \mathrm{~g} / \mathrm{Au}$, and for the East Zone, are 108.4 millon tonnes grading $0.484 \% \mathrm{Cu}, 0.014 \% \mathrm{Mo}$, and $0.055 \mathrm{~g} / \mathrm{Au}$ ( Jackson and Illerbrun, 1995).

\section{Poplar Porphyry Cu-Mo (Ag) Deposit}

The Poplar porphyry Cu-Mo (Ag) prospect occurs $40 \mathrm{~km}$ to the north of the Huckleberry deposit and consists of disseminated chalcopyrite and pyrite which occur in a Late Cretaceous biotite-monzonite porpbyry stock (Mesard and others, 1979; EMR Canada, 1989; House and Ainsworth, 1995). Quartz-chalcopyrite-molybdenite veins are associated with gypsum gangue. The porphyry stock intrudes volcaniclastic and epiclastic rocks of the Hazelton Group in the Stikinia terrane. Estimated resources are 144.1 million tonnes grading $0.368 \% \mathrm{Cu}, 0.10 \% \mathrm{MoS}_{2}$, and $2.8 \mathrm{~g} / \mathrm{Ag}$ (Mesard and others, 1979).

\section{Red Rose W-Au-Cu-Ag Polymetallic Voin Deposit}

The Red Rose W-Au-Cu-Ag polymetallic vein deposil occurs near Hazelton, B.C, and consists of scheclite, ferberite, chalcopyrite, molybdenite and uraninile which occur in a sheared quartz vein (EMR Canada, 1989; Dawson and others, 1991). The sheared quartz vein cuts one of three northeast-trending doorite dikes which intrude contact metamorphosed argillite and siltstone of the Red Rose Formation, near the contact with porphyritic granodiorite of the Cretaceous Rocher Deboule stock. Estimated reserves are 20,000 tonnes grading $5 \%$ WO$_{3}$ tave been identified (Mulligan, 1984).

\section{Capoose Lake Ag-Au Polymetallic Vein Deposit}

The Capoose Lake Ag-Au polymetallic vein prospect occurs $110 \mathrm{~km}$ southeast of Burns Lake in central British Columbia, and consists of Ag-and Au-bearing disseminations and veinlets of galena, pyrite, pyrrthotite, chalcopyrite, arsenopyrite, and sphalerite which are bosted in contact-metamorphosed volcanic rocks of the Hazelton Group. The disseminations and veinlets which occur both as replacements of garnet in the contact-metamorphosed host volcanic rocks, and as fillings in structurallycontrolled fracture zones, are related to rhyolite sills which are coeval with, and probably satellitic to the adjacent Late Cretaceous Capoose batholith. Estimated resources are 28.3 million tonnes grading 36 g/ Ag and $0.91 \mathrm{~g} / \mathrm{Au}$ (Andrew and Godwin, 1987; Andrew, 1988). 


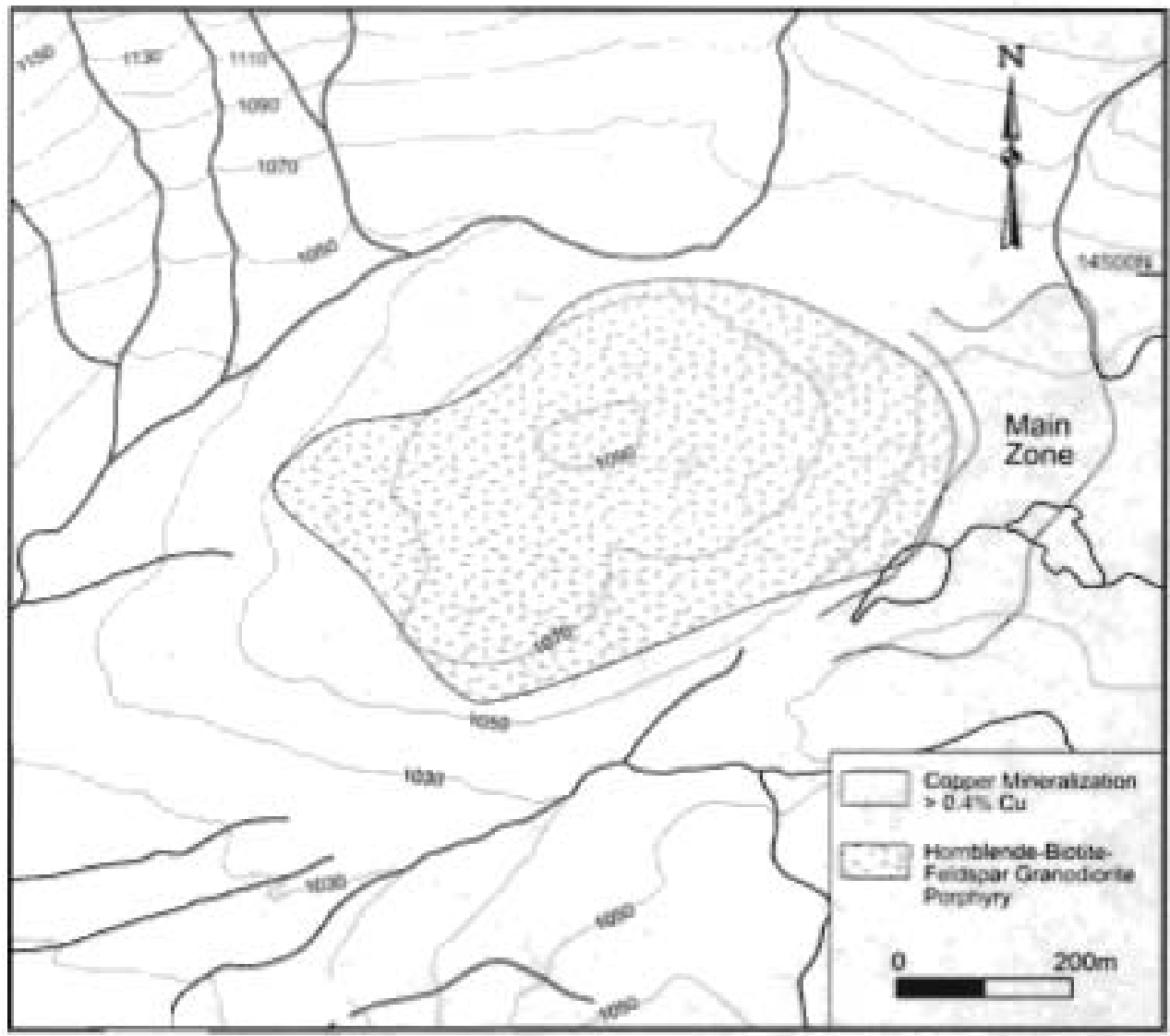

Figure 120. Huckleberry porphyry Cu-Mo deposit, Bulkiey metallogenic belt, Canadian Cordillera. Schematic map showing main ore body. Adapted from Jackson and Iliertrun (1995).

\section{Nadina (Sitver Queen) Ag Polymetallic Vein Deposit}

The Nadina (Silver Queen) Ag polymetallic vein deposit consists of sphalerite, galena, and chalcopyrite which occur in a gangue of quartz, rhodochrosite, chalcedony, and barite which are hosted in Late Cretaceous andesile and altered fragmental volcanic rocks (EMR Canada, 1989; Leitch and others, 1990; Dawsos and others, 1991). Estimated reserves are 1.72 million tonnes grading $6.19 \% \mathrm{Zn}, 328 \mathrm{~g} / \mathrm{Ag}$, and $2.7 \mathrm{~g} / \mathrm{Au}$. The deposit age is bracketed by microdiorite (with an isotopic age of $75.0 \pm 1.0 \mathrm{Ma}$ ) (MINFILE, 2002), and by younger felsite dikes and sills which are part of the Eocene Goosly Lake Intrusions.

\section{Origin of and Tectonic Controls for Buikey Mefallogenic Belt}

The Late Cretaceous Bulkley Plutonic Suite is coeval with the Surprise Lake and Carmacks Plutonic Suites, and with the volcanic rocks of the Carmacks Assemblage which all occur in the northern part of the Stikinia ternane (Woodsworth and others, 1991). Together, these plutonic rocks form part of the extensive Late Cretaceous and early Tertiary Coast-North Cascade plutonic belt that constitules the major part of the Coast continental-margin arc mainly in the western Canadian Cordillera (Nokleberg and others, 1994c, 1997c; Monger and Nokleberg. 1996). Local Late Cretaceous volcanic units interpreted to be comagmatic with the Bulkley Plutonic Suite include the Brian Boru (Sutherland Brown, 1960) and Tip Top Hill (Woodsworth and others, 1991) volcanic rocks of the Kagalka Group (Maclntyre, 1985).

Fish Lake-Bralorne Metallogenic Beit of

Porphyry Cu-Mo, Porphyry Cu-Au,

Au Quartz Vein, Au-Ag Polymetallic Vein.

and Related Deposit Types (Beit FLB)

Southwestern British Columbia

The Fish Lake-Bralome metallogenic belt of porphyry $\mathrm{Cu}-\mathrm{Mo}$, Au quartz vein, and Au-Ag polymetallic vein deposits (fig. 103; tables 3,4) oceur along the northeastern margin of the Coast Plutonic Complex in southwestern British Columbia. The belt contains the Bralome district which contains a group of major Au mines. The Bralome-and Pioneer Au deposits occur in Permian and Triassic diorite, gabbro, and greenstone, part of an ophiolite assemblage, which occurs along a shear zone along the complex tectonic boundary between Bridge River and Cadwallader terranes. The Congress polymetallic vein and Minto Ag-Au 
stibnite vein deposits in the Bridge River mining camp are related to stocks and dikes of the early Tertiary Bendor suite with isotopic ages of 70 to $65 \mathrm{Ma}$ (Leitch and others, 1989; Church, 1995). These deposits occur to the northeast of the Bralorne district. Several other Sb-Au polymetallic vein deposits occur in the mining camp and are associated with the Late Cretaceous and early Tertiary Bendor pluton, Robson stock, and related intrusions (Leitch and others, 1989). Also occurring in the belt are porphyry Cu deposits, as at Empress, which locally grade to high-sulphidation epithermal vein systems in the easternmost partr of the Coast Plutonic Complex, directly on strike from the coeval Bralorne deposit (McMillan, 1983). The belt also includes porphyry Mo and $\mathrm{Cu}$-Mo occurrences which are associated with Eocene stocks which occur along major dextral strike-slip faults.

The porphyry Cu-Mo and related deposits in the metallogenic belt are associated with Late Cretaceous porphyry dikes and stocks which are coeval with the adjacent eastero margin of the Coast Plutonic Complex and intrude metasedimentary rocks of the Methow terrane (Leitch and others, 1989). These granitoid rocks are part of the extensive Late Cretaceous and early Tertiary Coast-North Cascade plutonic belt which occurs along the western and central parts of the Canadian Cordillera for several thousand $\mathrm{km}$ (Nokleberg and others, 1994c, 1997c; Monger and Nokleberg, 1996). The significant deposits in the belt are (table 4) (Nokleberg and others 1997a, b, 1998): porphyry Cu-Mo deposits at Fish Lake, Giant Copper (Canam, A.M.), and Poison Mountain (Copper Giant); and Au quartz vein deposits at Bralome, Pioneer (Bridge River area), and Carolin. The Maggie (Bonaparte River) deposit occurs along the margin of the belt.

\section{Bralorne and Pioneer Au Quartz Vein Deposits}

The Bralome and Pioneer mines of the Bralorne district, and the smaller Wayside and BRX mines, are typically large, continuous, mesothermal Au-quariz-sulfide veins which range from 1 to $2 \mathrm{~m}$ wide, and consist commonly of quartz, calcite, free gold, arsenopyrite, pyrite, and lesser sphalerite, galena, scheelite, cbalcopyrite and molybdenite (Leitch and others, 1989). The veins are lenticular and plunge steeply within a steeply-dipping major shear zone named the Cadwallader Break. The deposits have major metals of $\mathrm{Au}-\mathrm{W}-\mathrm{Mo}-\mathrm{As}$ and $\mathrm{Au} / \mathrm{Ag}$ ratios of 2 to 5 . A district-wide mineral zoning varies from high-temperature AuAs-W-Mo through intermediate Sb-Ag-Au-As, to low-temperature Sb-Hg vein assemblages (Woodsworth and others, 1977). The southwest to northeast zonation is interpreted as forming in the thermal aureole of Late Cretaceous to early Tertiary plutons of the Coast Plutonic Complex. The Bralome deposit is associated with Late Cretaceous (86-9] Ma) porphyry dikes. The BralornePioneer district mines produced 129.96 tonnes Au between 1899 and 1978 from 7.319 million tonnes ore (Dawson and others, 1991). Proven and probable reserves for Bralorne in 1991 were 965,000 tonnes grading $9.3 \mathrm{~g} / \mathrm{t}$ Au (MINFILE, 2002).

\section{Fish Lake Porphyry Cu-Au (Ag-Mo-Zn) Deposit}

The Fish Lake porphyry $\mathrm{Cu}-\mathrm{Au}(\mathrm{Ag}-\mathrm{Mo}-\mathrm{Zn})$ deposit consists of pyrite and chalcopyrite with minor molybdenite, bornite, sphalerite and tetrabedrite which occur in stockwork veins (EMR Canada, 1989; McMillan, 1991; Taseko Mines Ltd., news release, May 4, 1993; Caira and others, 1995; MINFILE, 2002). The deposit is hosted mainly in: (1) contact metamorphosed Early Cretaceous(?) andesite flows and volcaniclastic rocks which occur in an embayment in a porphyritic quartz diorite stock; (2) an associated, east-west-elongated complex of subparallel quartz-feldspar porphyry dikes; and (3) disseminations in a Late Cretaceous quartz-diorite porphyry and in adjacent conlact-metamorphosed Early Cretaceous sedimentary and volcanic rocks (McMillan, 1991; Taseko Mines Lid., news release, May 4, 1993). The guartz dionite stock exbibits a U-Pb zircon isotopic age of about $80 \mathrm{Ma}$ (Schiarizza and Riddell, 1997), and the biotite hornfels exhibits a K-Ar whole-rock isotopic age of $77.2 \mathrm{Ma}$ (Wolthard, 1976). The principal orebody is ovoid shaped with dimensions of $1500 \mathrm{~m}$ by $800 \mathrm{~m}$ and a maximum depth of $880 \mathrm{~m}$. Estimated resource are 1,148 million tonnes grading $0.22 \% \mathrm{Cu}$ and $0.41 \mathrm{~g} / 1$ Au (Wolthard, 1976; McMillan, 1991; Caira and others, 1995).

\section{Maggie Porphyry Cu-Mo Deposit}

The Maggie (Bonaparte River) porphyry Cu-Mo deposit consists of chalcopyrite and molybdenite occurring in fine disseminations in quartz veins and in host rock, and in narrow veinlets in or bordering quartz and calcite veins. The deposit is hosted by the early Tertiary Maggie quartz monzonite stock, with a K-Ar isotopic age of $61 \mathrm{Ma}$, which intrudes metasedimentary and metavolcanic rocks of Cache Creek terrane (Miller, 1976). The stock occurs several tens of kilometers east of other plutons in the Fish Lake-Bralome metallogenic belt. Chalcopyrite and molybdenite occur in quartz veins and are disseminated in the stock. High $\mathrm{Cu}$ and $\mathrm{Mo} \mathrm{grades} \mathrm{occur} \mathrm{in} \mathrm{overlapping} \mathrm{potassic} \mathrm{and} \mathrm{phyllic} \mathrm{alteration,} \mathrm{and} \mathrm{lower} \mathrm{Cu}$ and $\mathrm{Mog}$ grades occur in phyllic and argillic alteration. Estimated resources are 181 million tonnes grading $0.28 \% \mathrm{Cu}$ and $0.029 \% \mathrm{MoS}_{2}(\mathrm{Miller}, 1976)$.

\section{Poison Mountain Porphyry Cu-Mo (Ag-Au) Deposit.}

The Poison Mountain Cu-Mo ( $\mathrm{Ag}-\mathrm{Au}$ ) porphyry deposit consists of pyrite, cbalcopyrite, molybdenite, and bornite which occur in veinlets, fracture fillings and disseminations (Brown, 1995; MINFILE, 2002). The deposit is concentrated at the contacts between a quartz diorite porphyry stock and dikes, with isotopic ages of $59 \mathrm{Ma}$, and contact-metamorphosed Early Cretaceous graywacke of the Jackass Mountain Group which is part of the Methow terrane. The deposit is surrounded by concentric zones of potassic, phyllic, and propylitic alteration. Concentric zones of copper sulfide and minor oxide minerals surround a barren granodiorite core. Estimated reserves, at $0.15 \%$ Cu cut-off, are: (1) in the oxide zone, 40.2 million tonnes grading $0.228 \% \mathrm{Cu}$ (s), 
$0.15 \% \mathrm{Cu}(0 x), 0.127 \mathrm{~g} / \mathrm{Au}$, and $0.007 \% \mathrm{Mo}$, and (2) in the sulfide zone, 768.3 million tonnes grading $0.232 \mathrm{Cu}, 0.122 \mathrm{~g} / \mathrm{Au}$, and 0.007\% Mo (Brown, 1995; Seraphim and Rainboth, 1976; MeMillan, 1991). The stock and associated dikes exhibit K-Ar isotopic ages which range from a homblende age of 61.4 for biotite-aliered quartze diorite, to a biotite-homblende age of $55.5 \mathrm{Ma}$ for contact-metamorphosed sedimentary rock in the outer part of the deposit (Brown, 1995). The deposit occurs $75 \mathrm{~km}$ southeast of Fish Lake.

\section{Origin of and Tectonic Controls for}

Fish Lake-Bralome Metallogenic Beit

The Fish Lake-Bralorne metallogenic belt is defined by the distribution of a suite of small, Late Cretaceous to Eocene, quartz monzonite and quartz diorite stocks which are part of the Coast Plutonic Complex but oceur east of the main part of the batholith. The plutons are essentially coeval with plutons marking the eastem edge of the Coast suite, and probably represent the eastem limit of Late Cretaceous-Eocene magmatism in the southern part of the continental-margin arc. The Coast Plutonic Complex is part of the Coast-North Cascade plutonic belt.

Three major pulses of mineralization are interpreted for the Fish Lake-Bralorne belt (Schiarizza and others, 1997): (1) The older, Late Cretacous deposits in the belt are interpreted as forming along early Late Cretaceous reverse to sinistral faults which are interpreted as forming during the last part of contractual deformation which was associated with subduction; (2) The younger, latest Cretaceous to Paleocene deposits in the belt oecur along dextral-slip faults, such as the Castle Pass fault and may in part be controlled by an extensional bend in the fault system (Schiarizza and others, 1997). And (3) the still younger, porphyry occurrences and associated polymetallic vein deposits are associated with Middle Eocene granodiorite plutons which oceur along dextral fault systems.

Tyaughton-Yalakom Metallogenic Belt of W-Sb Polymetallic Vein and $\mathrm{Hg}$-Sb Vein Deposits (Beit TY) Southern British Columbia

The Tyaughton-Yalakom metallogenic belt of W-Sb polymetallic vein and $\mathrm{Hg}$-Sb vein deposits occurs in southem British Columbia and consists of several belts of scheelite-stibnite and cinnabar-stibnite veins which oceur along major faults in the Methow and Cadwalleder terranes in southwestern British Columbia (fig. 103; tables 3, 4) (Nokleberg and others, 1997b, 1998). The significant deposits are at Tungsten Queen, Tungsten King, Silverquick, Manitou, Eagle, and Red Eagle.

The Tungsten Queen and Tungsten King W-Sb polymetallic vein deposits consist of banded, chalcedony-quartz-stibnitescheelite veins which occur in pervasively silica-carbonate-altered ultramafic rocks (Schiarriza and others, 1989). The Tungsten Queen deposit is hosted by listwanite-altered ultramafic rock along branched fractures in the Relay Creek-Marshall Creek fault system (Schiarrizza and others, 1990). The spatially-separated Silverquick, Manitou, and other similar Hg-Sb vein prospects consist of cinnabar which oecurs as fracture-coatings and disseminations in both the Bridge River Greenitone and a Cretaceous conglomerate. These deposits may be a later overprint (Schiarrizru and others, 1989).

The Eagle and Red Eagle prospects consist of cinnabur-carbonate veins which occur in subsidiary shears in the Bridge River Greenstone, adjacent to the Bridge River-Yalakom fault system (Schiarriza and others, 1990). The $\mathrm{Hg}_{\mathrm{g}} \mathrm{Sb}$ vein deposits of the Tyaughton-Yalakom metallogenic belt are clearly associated with the Eocene dextral-slip falts of the Talakom, Relay Creek, and Fortress Ridge fault systems (Schiarrizza and others, 1989, 1990). The W-Sb occurrences also occur along the Relay Creek fault may be related to probable laiest Cretaceous to Eocene dikes.

The vein deposits of the Tyaughton-Yalakom metallogenic belt are herein interpected as forming during intrusion of the younger part of the Coast-North Cascade plutonic belt. The Tyaughton-Yalakom metallogenic belt is related to Fish LakeBralome metallogenic belt of granitic-magnatism-related deposits.

Gambier Metallogenic Belt of Porphyry

Cu-Mo and Zn-Pb-Cu Skarn Deposits

(Belt GB) Southern British Columbia

The Gambier metallogenic belt of porphyry $\mathrm{Cu}-\mathrm{Mo}$ and $\mathrm{Zn}$-Pb-Cu skam deposits (fig. 103; tables 3,4) occurs in southem British Columbia and is associated with a linear belt of early Tertiary plutons which are part the southwestern Coast Plutonic Complex. The discordant felsic stocks intrude older, larger, concordant and more mafic plutons, and metamorphic pendants, of the Coast Plutonic Complex. These granitoid rocks are part of the extensive Late Cretaceous and early Tertiary Coast-North Cascade plutonic beit which occurs along the western and central parts of the Canadian Cordillera for several thousand $\mathrm{km}$ (Nokleberg and others, 1994c, 1997c; Monger and Nokleberg, 1996). The significant deposits in the belt are porphyry Cu-Mo deposits at Gambier Island, Hi-Mars (Lewis Lake), and O.K., and a Zn-Pb skam deposit is at Lynn Creek (table 4) (Nokleberg and others 1997a, b, 1998).

\section{Gambier Island Porphyry Cu-Mo Deposit}

The Gambiet island porphyry Cu-Mo (Zn-Pb) deposit consists of pyrite, chalcopyrite, and molybdenite which occur as disseminations, fracture fillings and veinlets (EMR Canada, 1989; Mining Review, 1990; Fox and others, 1995; MINFILE, 2002). 
Both sulfide-bearing and sulfide-free quartz veins occur in the deposit. The deposit forms a broad arcuate zone $1200 \mathrm{~m}$ long by $200 \mathrm{~m}$ wide in an elliptical-shaped, early Tertiary quartz porphyry stock of the Coast Plutonic Complex and adjacent volcanic rocks. Estimated resources are 114 million tonnes grading $0.29 \% \mathrm{Cu}$ and $0.018 \% \mathrm{MoS}_{2}$ (MINFILE, 2002). The quartz porphyry stock intrudes volcanic rocks of the Cretaceous Gambier Group which is part of the Gravina-Gambier overlap assemblage.

\section{Hi-Mars Porphyry Cu-Mo Deposit}

The Hi-Mars porphyry Cu-Mo deposit consists of a widespread occurrence of chalcopyrite and molybdenite which oecur as disseminations and fracture fillings in a small $\mathrm{Cu}-\mathrm{Mo}(\mathrm{Au}-\mathrm{Ag})$ porphyry deposit which is part of the Coast Plutonic Complex (British Columbia Department of Mines and Petroleum Resources, 1972, Geology, Exploration, and Mining, p. 272; George Cross Newsletter no, 49, March 10, 1978). The deposit, which occurs $7 \mathrm{~km}$ northeast of Powell River, contains an inferred resource of 82 million tonnes grading $0.3 \% \mathrm{Cu}$ (George Cross Newsletter No, 49, March 10, 1978); this resource may be for several zones in the deposit. The deposit probably is similar in age and genesis to the adjacent O.K. deposit.

\section{O.K. Porphyry Cu-Mo Deposit}

The O.K. porphyry Cu-Mo deposit consists of a stockwork with chalcopyrite, molybdenite and pyrite with minor sphalerite and bornite which occur in fractures, as quartz stringers, irregular veinlets, blebs and as disseminations (Meyer and others, 1976: EMR Canada, 1989; Mining Review, 1992; MINFILE, 2002). The deposit is mainly enclosed in a composite, narrow, northwest-1rending. elliptical granodiorite pluton which contains a narrowm leucogranite porphyry dike along the exis of the pluton. Although both intrusions contain a quartz vein stockwork, most of the Cu-Mo sulfides occur in the granodiorite within a few hundred meters of the contact with the leucocratic porpohyry dike. The plutonic rocks are part of the Coast Plutonic Complex (Woodsworth and others, 1991). The age of the granitoids range in the Coast Plutonic Complex range from Jurassic to Tertiary. The deposit age is interpreted as Late Cretaceous. The deposit contains a resource of 104.9 million tonnes grading $0.46 \%$ $\mathrm{Cu}$ and $0.028 \% \mathrm{MoS}_{2}$ (Meyer and others, 1976; MINFILE, 2002).

\section{Lynn Creek Zn-Pb Skam Deposit}

The Lynn Creek $\mathrm{Zn}-\mathrm{Pb}$ skam deposit consists of sphaierite, galena, pyrthotite, chalcopyrite and pyrite in quartz veins and calc-silicate skam. The deposit is hosted in shear zones in a roof pendant of Jurassic to Cretaceous metasedimentary and metavolcanic rocks of the Cretaceous Gambier Group. The plutonic rocks are part of the Coast Plutonic Complex. Poorlyestimated reserves are 272,000 tonnes grading 9\% $\mathrm{Zn}$ with variable Ag (MINFILE, 2002). Local high-grade zones contain up to $68.6 \mathrm{~g} / \mathrm{Ag}$ and up to $20 \% \mathrm{Zn}$. The deposit age interpreted as Late Cretaceous to early Tertiary.

\section{Origin of and Tectonic Controls for Gambier Metallogenic Belt}

The Gambier metallogenic belt is defined by the distribution of a suite of small, early Tertiary granitoid bodies which constitute the younger part of the Coast Plutonic Complex which is part of the Coast-North Cascade plutonic belt which forms a major granitoid plutonic belt of Late Cretaceous and early Tertiary age which extends the length of the Canadian Cordillera and into East-Central Alaska (fig. 103). The belt consists chiefly of quartz diorite, granodiorite, and locally more mafic or felsic plutons (Rubin and others, 1991; Gehrels and others, 1990; Wheeler and McFeeley, 1991; van der Heyden, 1992; Woodsworth and others, 1992; Joumeay and Friedman, 1993).

\section{Catface Metallogenic Belt of \\ Porphyry Cu-Mo-Au and \\ Au-Ag Polymetallic Vein Deposits (Beit CF) \\ Vancouver Island}

The Catface metallogenic belt of porphyry Cu-Mo-Au and Au-Ag polymetallic vein deposits (fig. 103; tables 3,4) occurs on Vancouver Island in the southern Canadian Cordillera and is associated with the middle to late Eocene Catface plutonic suite which consists of numerous, small irregular stocks, dikes and sills (Carson, 1973) which form a broad belt extending from near Nanaimo west to Ucluelet and north to Zeballos on Vancouver Island. The suite is part of the extensive Late Cretaceous and early Tertiary Coast-North Cascade plutonic belt which occurs along the western and central parts of the Canadian Cordillera for several thousand $\mathrm{km}$ (Nokleberg and others, 1994c, 1997c; Monger and Nokleberg, 1996). The significant deposits in the belt are at Catface, Domineer-Lakeview, and Privateer (table 4) (Nokleberg and others 1997a, b, 1998).

\section{Porphyry Cu-Mo and Polymetallic Vein Deposits}

The Catface porphyry Cu (Au-Mo) deposit consists of chalcopyrite, bornite, chalcocite, pyrite, pyrrhotite and molybdenite which occur in a stockwork of fractures and quartz veinlets (Dawson and others, 1991; Mining Review, 1992; Enns and McDougall, 1995; MINFILE, 2002). The stockwork is accompanied by biotite alteration. Estimated resources for the Cliff 
Zone are 188 mullion lonnes grading $0.42 \% \mathrm{Cu}, 0.014 \% \mathrm{Mo}$, and 308 million tonnes grading $0.37 \% \mathrm{Cu}, 0.12 \% \mathrm{Mo}$; potential for additional resources exists at depth (McDougall, 1976; Enns and MeDougall, 1995). The deposit is hosted in an apophysis of Eocene porphyritic quartz diorite of the Catface plutonic suite and has a $\mathrm{K}$-Ar isotope age of $48 \mathrm{Ma}$. The diorite intrudes relatively older quartz monzonite and metabasalt of the Lute Triassic Karmutsen Formation of Wrangellia.

The Domineer-Lakeview Au-Ag polymetallic vein zone occurs at Mount Washington, near Comox, and consists of a silicified vein-shear zone which cuts basaltic volcanic rocks of the Late Triassic Karmutsen Formation sedimentary rocks of the Late Cretaceous Nanaimo Group, and sills of the Catface Plutonic Suite. The Au-Ag polymetallic vein zone is interpreted as a shallow-dipping, post intresion body. The shear zone is intensely altered to kaolinite and contains tabular zones which are silicified and cut by Au veins with quartz, pyrite, and arsenopyrite. The deposit is associated with a small, previously-producing porphyry Cu-Mo deposit, and several mineralized breceia pipes. Estimated reserves are 550.298 tonnes grading 6.75 g/t Au and $32.2 \mathrm{gt}$ Ag (Muller and Carson, 1969; MINFILE, 2002).

The Privateer Au polymetallic vein deposit consists of a set of thin, ribbon quartz veins which eut contactmetamorphosed volcanic rocks of the Middle lunassic Bonanza Group, as well as the Zeballos stock of the Catfice Plutonic Suite. The Privateer is the largest and most productive of a group of small mines in and adjacent to the stock. The major ore minerals are abundant pyrite and arsenopyrite, sphalerite, less abundant chalcopyrite, galena, and pyrthotite, and rare free gold. Estimated production is 280,000 tonnes of ore containing $18.8 \mathrm{~g} / \mathrm{Au}$ along with $\mathrm{Ag}, \mathrm{Pb}$, and $\mathrm{Zn}$ (Stevenson, 1950; Dawson and others, 1991).

\section{Origin of and Tectonic Controls for Catface Metallogenic Bett}

The Middle to Late Eocene intrusions of the Catface Plutonic Suite are mainly calc-alkaline, tonalite and quartz diorite and minor granodiorite and granite, and commonly porphyritic. The plutons are roughly synchronous with Paleogene plutons in the southern Coast and Intermontane belts, were emplaced at high levels as indicated by associated breccias and diatremes, and intrude rocks as young as the Late Cretaceous Nanaimo Group (Woodsworth and others, 1991). The Catface Plutonic Suite is the southem part of the extensive Late Cretaceous and early Tertiary Coast-North Cascade plutotic belt which formed a major continental-margin arc in mainly the weslern Canadian Cordillera (Nokleberg and others, 1994c, 1997c; Monger and Nokleberg, 1996).

\section{Metallogenic Belts Formed in Backarc \\ Part of Early Tertiary Coast \\ Continental-Margin Arc, Southern Canadian Cordillera}

The Skeena (SK) and Nelson (NS) constitute two major metallogenic belts of granitic-magmatism-related deposits occur in the southern Canadian Cordillera (fig 103; tables 3,4) that are interpreted as forming during granitic plutonism occurring during back arc extension or transtension in an region continentward of the subduction-related Coast continental-margin arc. These two early Tertiary two metallogenic belts represent the last stage of magmatism in the Coast-North Cascade plutonic belt that comprises most of the Coast continental-margin arc. This period of regional extension or transtension in the southern Canadian Cordillera is interpreted as the result of either: (1) a change from transpression to transtension at about 55 Ma caused by a change of obliquity of convergence of the oceanic plate (Parrish and others, 1988), or (2) altematively, but likely, collapse of overthickened thrust units (Monger and Nokleberg, 1996; Nokleberg and others, 2000). This erigin is analogous to the occurrence of back-are magmatism forming the Columbia River basalt to the rear of the Cascade are in the Miocene (Wells and Heller, 1988; England and Wells, 1991; Nokjeberg and others, 2000).

\section{Skeena Metallogenic Belt of Porphyry Cu-Mo, Porphyry Mo: Ag Polymetallic Vein and Au-Ag Epithermal Vein Deposits (Belt SK) Central British Columbia}

The Skeena metallogenic belt of porphyry Cu-Mo; porphyry Mo; Ag polymetallic vein, and Au-Ag epithermal vein deposits eccurs in central British Columbia (fig. 103; tables 3,4), and is associated with several early Tertiary plutonic suites in the Intermontane Belt in west-central British Columbia, including the Nanika, Babine, Quanchus and Goosly (Woodsworth and others, 1991; Carter, 1982). Coeval and spatially related volcanic rocks support the interpretation which many of the plutons represent the roots of volcanic centres. The host plutonic rocks are the younger part of the Coast-North Cascade plutonic belt and the related early Tertiary Kamloops magmatic belt (Plafker and others, 1989; Nokleberg and others, 1994c, 1997c). The significant deposits in the belt are (table 4) (Nokleberg and others 1997a, b, 1998): porphyry Mo deposits at Ajax, Bell Moly (Alice Arm), Kitsault (BC Moly), Lucky Ship, Mount Thomlinson, Redbird, Roundy Creek, Serb Creek; porphyry Cu-Mo deposits at Berg. Big Onion, Dorothy, and Nanika (DW, New Nanik); polymetallic and Ag polymetallic vein deposits at Capoose Lake, Equity Silver (Sam Goosly), Nadina (Silver Queen), and Prosperity-Porter Idaho; and porphyry Cu-Au (Mo) deposits at Bell Copper (Newman), Granisle, and Morrison. However the age of the Equity Silver (Sam Goosly) deposit is unresolved. 
The Eocene Nanika Plutonic Suite, which forms the most widespread suite of post-accretionary granitoid plutons intruding the Stikinia terrane, include the Nanika Intrusions south of Bowser Basio (Carter, 1982), and the Alice Arm Intrusions west of the basin (Woodswortb and others, 1991). The small, multi-stage, calc-alkaline granitic to granodiorite stocks, dikes and sills, which were intruded along steeply-dipping faults, are interpreted to be the roots of deeply-eroded volcanic centers, perhaps of the Hazelton Group (Macintyre, 1985). Several major porphyry deposits associated with Nanika Intrusions occur northeast of Hazelton, B.C. The largest of these deposits are at Berg, Mount Thomlinson, and Redbird. Other significant deposits in the Huston district are at Lucky Ship porphyry Mo and Nanika Mountain porphyry $\mathrm{Cu}$ (Mo) deposits. The Serb Creek porphyry Mo and the Big Onion porphyry Cu-Mo deposits (Wojdak and Stock, 1995) occur east and west of Smithers, respectively

Berg Porphyry Cu-Mo (Pb-Zn-Ag-Au) Deposit

The Berg porphyry $\mathrm{Cu}-\mathrm{Mo}$ ( $\mathrm{Pb}-\mathrm{Zn}-\mathrm{Ag}-\mathrm{Au})$ deposit consists of chalcopyrite, molybdenite and pyrite with minor sphalerite, galena, and arsenopyrite (Panteleyev, 1981; EMR Canada, 1989; Dawson and others 1991). Estimated reserves are 238 million tonnes grading $0.39 \% \mathrm{Cu}, 0.05 \% \mathrm{MoS} 2,2.84 \mathrm{~g} \mathrm{Ag}$. The deposit occurs within a fine-grained stockwork of quartz veinlets which are distributed in a broad asymmetrical zone around a semicircular quartz-monzonite porphyry stock of the Eocene Nanika Suite, and within the peripheral, contact-metamorphosed volcanic rocks of the Hazelton Group. The most intense Mo concentrations occur in the stock whereas the most intense Cu concentrations occur 60 meter beyond the contact. A pyrite halo oceurs from 300 to 600 meters from the contact. Also occurring is extensive oxidation, leaching, and secondary enrichment.

Mount Thomlinson Porphyry Mo Deposit

The Mount Thomlinson porphyry Mo deposit consists of molybdenite, chaicopyrite, along with minor magnetite and scheelite which occur in a stockwork of quartz veinlets near the northwest contact of a circular, Eocene quartz monzonite porphyry stock which intrudes argillaceous Jurassic sedimentary rocks (Carter, 1982; EMR Canada, 1989). Estimated reserves are 40.8 million toanes grading $0.12 \% \mathrm{MoS}_{2}$. The deposit occurs predominantly within intrusive rocks along the northwest contact. The host sedimentary rocks are deformed and metamorphosed into biotite, muscovite, cordierite, and andalusite-bearing schists.

\section{Redbird Porphyry Mo Deposit}

The Redbird porphyry Mo deposit consists of molybdenite and pyrite which occur in a stockwork of quartz veinlets within peripheral, concentric alteration zones of a quartz-monzonite porpbyry stock of the Eocene Nanika Suite which intrudes Middle Jurassic pyroclastic rocks of the Hazelion Group (EMR Canada, 1989, Dawson and others, 1991). Estimated reserves are 63.5 million tonnes grading $0.17 \% \mathrm{MoS}_{2}$. The stock is dominantly one phase, and hosts a peripheral ring of molybdenum. Also present are potassic (K-feldspar), silica-sericite, and kaolinite alteration are present. The stock has a K-Ar isotopic age of $49.0 \mathrm{Ma}$.

\section{Porphyry Mo Deposits Associated with}

Alice Arm Intrusions of Nanika Plutonic Suite

The Alice Arm Intrusions of the Nanika Plutonic Suite, which occur along the easters margin of the Coast Plutonic Complex, consist of small granile to quartz monzonite porphyry stocks which intrude clastic rocks of the Late Jurassic Bowser Assemblage at the intersections of north-northwest and east-northeast fauls (Canter, 1982). The major porphyry deposits are the Ajax porphyry Mo, Bell Moly porphyry Mo-W, and Kitsauli (B.C. Moly) porphyry Mo (Ag. Pb, Zn, Cu) deposit.

\section{Aax Porphyry Mo Deposit}

The Ajax porphyry Mo deposit consists of molybdenum in a quartz-vein stockwork which is bosted in an Eocene quartz monzonite porphyry intrusion, and in adjacent, contact-metamorphosed Jurassic argillaceous rocks (Soregaroli and Sutherland Brown, 1976; EMR Canada, 1989, MINFILE, 2002). The deposit occurs in four small, closely-spaced plutons. Estimated reserves are 178.5 million tonnes grading $0.121 \% \mathrm{MoS}_{3}$. Total reserves ate 417.3 million tonnes grading $0.09 \% \mathrm{MoS}_{2}$ with a very high stripping ratio. The porphyry intrusion exhibits a K-Ar biotite isotopic age of $54.0 \mathrm{Ma}$ age.

\section{Bell Moly Porphyry Mo-W Deposit}

The Bell Moly porphyry Mo-W deposit consists of molybdenite and minor scheelite which occur in a quartz vein stockwork in an Eocene quartz monzonile porphyry and in adjacent biotite homfels is Jurassic metasedimentary and metavolcanic rocks (Canter, 1982; EMR Canada, 1989). Estimated reserves are 106 million tonnes grading $0.09 \% \mathrm{MoS}_{2}$. The deposit occurs in a crescent-shaped zone around the eastern portion of the stock. 
The Kitsault (B.C. Moly) porphyry Mo (Ag-Pb-Zn-Cu) deposit consists of molybdenite in quarte-vein stockworks which are related to an Eocene quartz monzonite and quartz diorite stock which intrudes Late-Jurassie and Early Cretaceous siltstone and graywacke of the Bowser Assemblage (Carter, 1982; Steininger, 1985; EMR Canada, 1989; Hodgson, 1995; MINFILE, 2002). The veinlets are cut by quartz veins, up to 3 meters wide and contain pyrite, galena, sphalerite, scheelite, chalcopyrite, tetrahedrite and pyrthotite. Molybdenum-bearing rocks form a ring structure around the stock in quartz veinlets. At least five stock phases are recognized. Several stages of ores are associated with intramineral dikes. The porphyry exhibits a K-Ar isotopic age of $53.7 \mathrm{Ma}$. Estimated combined production and reserves are 113.3 million tonnes grading $0.184 \% \mathrm{MoS}_{2}$. Between 1967 and 1972 production was 9.3 million tonnes grading $0.112 \% \mathrm{MoS}_{2}$, Estimated reserves in 1989 were 104 million tonnes grading $0.19 \% \mathrm{MoS}_{2}$.

\section{Ag Polymetallic Vein Deposits Associated with Goosly Plutonic Suite}

The Goosly Plutonic Suite consists of small alkaline gabbro, syenomonzonite, and quartz monzonite stecks which occur near the westem end of Francois Lake. The suite intrudes Late Cretaceous volcanic and clastic rocks of the Skeena Assemblage and is associated with subvoleanic to Eocene volcanic centers (Church, 1971). The major Ag polymetallic vein deposits are at Equity Silver (Sam Goosly) and Prosperity-Ponter Id.

\section{Equity Silver (Sam Goosly) Ag Polymetallic Vein Deposit}

The Equity Silver (Sam Goosly) Ag deposit is an unusual polymetallic stockwork and vein deposit which consists of pyrite, chalcopyrite, pyrthotite, and tetrahedrite, and minor sphalerite, galena, and silver sulfosalts which are accompanied by argillic alteration (Carter, 1982; Cyr and others, 1984; Northern Miner, March 28, 1988; Schsoeter and Lane, 1991; Panteleyev, 1995; MINFILE, 2002). The sulfides occur in veins, disseminations, and massive sulfide replacement bodies, ranging up to $120 \mathrm{~m}$ thick, which are located in tabular fracture zones roughly parallel to stratigraphy. Estimated combined production and reserves are 32.1 million tonnes grading $71.3 \mathrm{~g} / \mathrm{Ag}$ and $3.90 \mathrm{~g} / \mathrm{Au}$. The mine closed in 1984; estimated remaining reserves are 5,915,454 tornes grading $72.01 \mathrm{~g} / \mathrm{Ag}, 0.82 \mathrm{~g} / \mathrm{A} \mathrm{Au}$, and $0.22 \% \mathrm{Cu}$. Estimated total Au content of combined production and reserves is 16.9 tonnes. The deposit age is poorly constrained and is younger than the host Late Cretaceous units and older than the Goosly Lake intrusions. The deposit occurs between a granitic stock (with a K-Ar isotopic age of $58 \mathrm{Ma}$ ), and a gabbro-monzonite stock (with a $\mathrm{K}$-Ar isotopic age of $48 \mathrm{Ma}$ ). The plutonic rocks are part of the Goosly Lake latnusions und intrude sedimentary and pyroclastic rocks of the Cretaceous Skeena Assemblage. The deposit is interpreted by Panteleyev (1995) as a subvolcanic Cu-Au-Ag deposit which commonly oocurs near or above a porphyry $\mathrm{Cu}$ hydrothermal system.

\section{Prosperity-Porter idaho Ag Polymetallic Vein Deposit}

The Prosperity.Porter Idaho deposit, an important past silver producer, consists of a set of narrow polymetallic Ag veins hosted in volcanjic rocks of the Hazelton Assemblage which is related to the Hyder biotite granodiorite pluton. The pluton is part of an Eocene granitoid suite in the northeastern Coast Plutonic Complex (Woodsworth and others, 1991). From 1922 to 1950 the mine at the deposit produced 2.36 million ounces of Ag. Estimated reserves are 826,277 tonnes grading $669 \mathrm{~g} / \mathrm{Ag}$ and $5 \% \mathrm{~Pb}+\mathrm{Zn}$ (Schroeter and Lane, 1991). Related silver mines in the Stewart region are those at Idaho and Indian (Alldrick, 1985; Alldrick and others, 1987).

\section{Porphyry Cu-Au-Ag Deposits Associated with Babine Plutonic Suite}

The Eocene Babine Plutonic Suite, which consists of distinctive, small, biotite feldspar granodiorile to quartz diorite porphyry stocks and dikes, is associated with several porphyry Cu-Au mines and significant prospects in central British Columbia. The suite consists of a nortbwest-trending belt of multiple intrusions of stocks, dikes, and breccias which are fault-controlled (Kirkham, 1971), and interpreted as the loci of volcanic centres for equivalent extrusive rocks in the area (Carter, 1982). The major porphyry Cu-Au-Ag deposits are at Bell Copper, Granisle, and Morrison. These deposits exhibit: (a) an annular zoning of sulfide minerals and associated potassic to phyllic to argillic alteration (Carson and Jambor, 1974); and (2) high precious-metal contents which are characteristic of classic (non-plutonic) calc-alkaline porpbyry deposits (Sinclair, and others, 1982). Other deposits in the Babine Lake district (Carter and others, 1995) are the Dorothy porphyry Cu-Mo deposit which is hosted in a feldspar porphyry dike, and the Heame Hill Cu-Au breccia pipe whicb is associated with a biotite-feldspar porphyry plug (Ogryzlo and others, 1995).

\section{Bell Cooper Porphyry Cu-Au (Mo) Deposit}

The Bell Copper porphyry Cu-Au (Mo) deposit (fig. 121) consists of chalcopyrite and lesser bomite which occur as disseminations and in quartz lenses and stockwork veinlets. Estimated combined production and reserves are 71.75 million tonnes grading $0.46 \% \mathrm{Cu}, 0.23 \mathrm{~g} / \mathrm{Au}, 0.48 \mathrm{~g} / \mathrm{t} \mathrm{Ag}$, and $0.006 \%$ Mo (Carson and others, 1976; Noranda Inc., anaual report, 1990; 
Butrenchuk, 1991; Diron and others, 1995; MINFILE, 2002). The deposit is hosted in biotile-feldspar porphyry of the Eocene Babine Plutonic Suite and the adjacent Jurassic metasedimentary rocks and metavolcanic rocks of the Haxelton Group. A K-Ar biotite isotopic age of $51.0 \mathrm{Ma}$ for the porphyry is interpreted as the age of deposit. The deposit exhibits pervasive potassic (mainly biotite) alteration with a surrounding, concentric halo of chlorite and sericite-carbonate alteration. The alteration coincides with a two-km-wide pyrite halo which surrounds the deposit (Dirom and others, 1995). A supergene chalcocite zone caps the deposit and extends to depths of 50 to 70 meters. Higher Cu grades occur in a 60 to 90 m-thick, flat-lying area which is connected to a central pipe-like zone which is centered on the western contect of the intrusion. Past production was 28.7 million tonnes grading $0.46 \% \mathrm{Cu}$

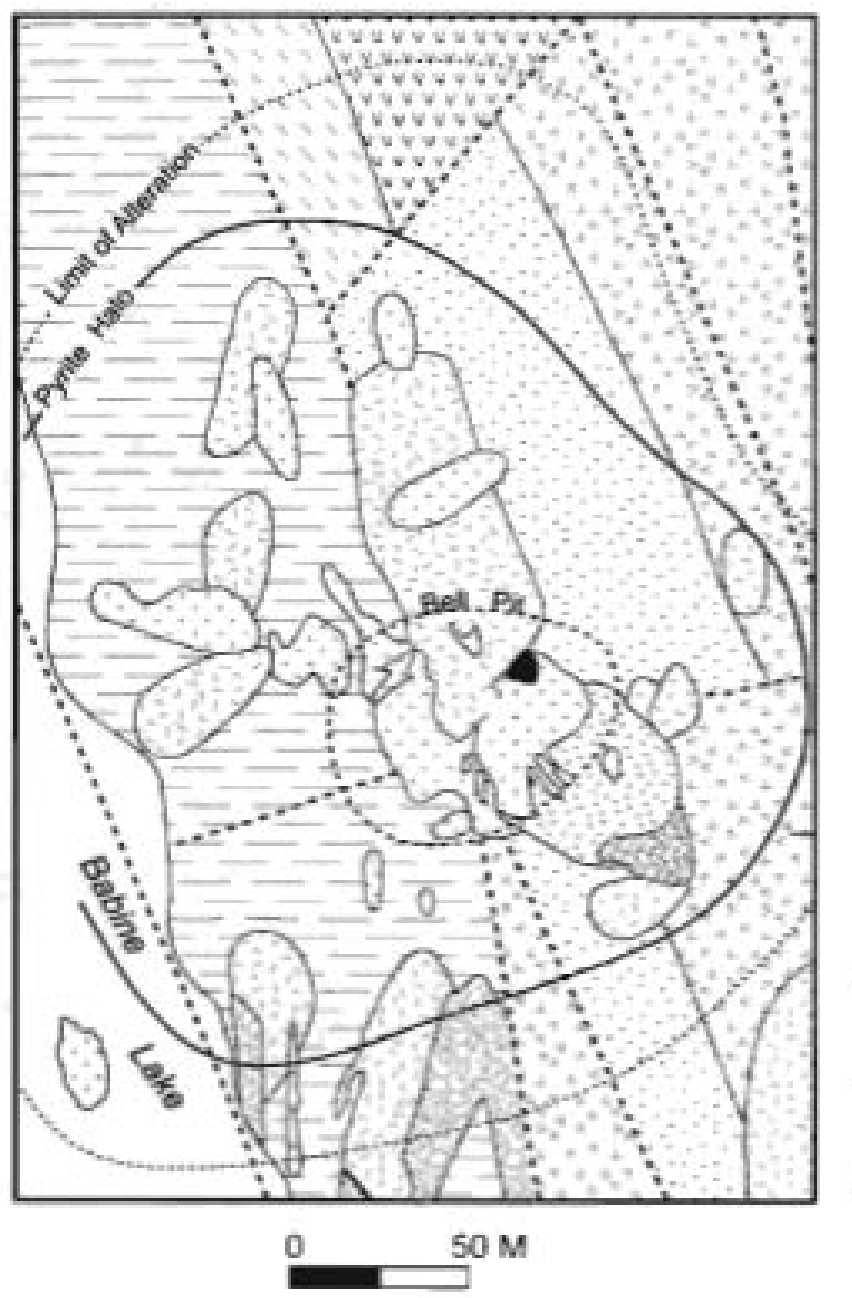

\section{EOCENE}

BABINE IGNEOUS SUTTE

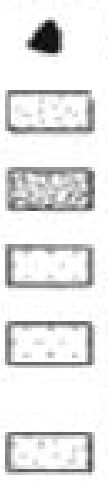

Post stockwork bioble plagioctase porphyry dive, black, navd.

Quartr biotte, plagioclase porphyry (OFP, DQFP) White. Post stockwork.

\section{Explosion brecoia. Boulders and cobbies} of BFP in a tuffaceous matrix.

Biotite plagioctase porphyry, moderate to pervasive quartz-sencite-pyrie alteration in quart2 slockwork.

\section{Eiotite plagioclase porphyry, biotite magnetie} alteration and biobte plagoclase porphyry undivided.

Renycite and hyodacite with spares plagioclase phenocrysts in dkes, plugs, and domes.

\section{CRETACEOUS}

\section{SKEENA GAOUP (AIblan?)}

Q.3 intermediate fragmental voicanic rocks.

$\square$ Btack shale, siltstone, paie green tuff.

$$
\text { JURASSIC }
$$

Hazeiton group

Smuthers Fomation (Bajocian):

2 Dark brown graywacke. highly fossiliferous.

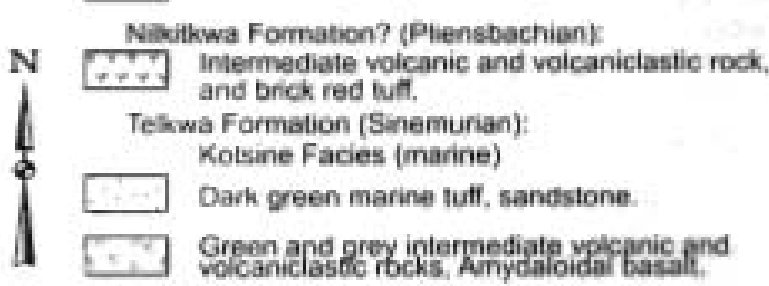

Figure 121. Bell Copper porphyry Cu-Au deposit, Skeena metallogenic belt, Canadian Cordillera. Schematic geologic map of area around open pit and alteration halos. Adapted from Butrenchuk (1991).

\section{Granisle Porphyry Cu-Au (Mo) Deposit}

The Granisle porphyry $\mathrm{Cu}$-Au (Mo) deposit consists of chalcopyrite, bornite and pyrite with low grade $\mathrm{Au}$ and $\mathrm{Ag}_{\mathrm{g}}$ and local minot molybdenite which occur in quartz-filled fractures (Carson and Jambor, 1974; Fahrni and others, 1976; EMR Canada, 1989; Dawson and others, 1991; Dirom and others, 1995). The deposit is associated with Eocene Babine porphyry intrusions (with $\mathrm{K}$-Ar isotopic ages of $51.2 \mathrm{Ma}$ ) which intrude volcanic and sedimentary rocks of the Early Jurassic Hazelton Group. Combined estimated production and reserves re 66.2 million tonnes grading $0.42 \% \mathrm{Cu}, 0.12 \mathrm{~g} / \mathrm{Au}, 1.12 \mathrm{~g} / \mathrm{Ag}$, and $0.009 \mathrm{~g} / \mathrm{Mo}$. The deposit is centered on the contact between biotite-feldspar porphyry and an earlier quartz diorite phase. A central potassic alteration zone is successively rimmed by a quartz-sericite-carbonate-pyrite alteration zone and by a chlorite-carbonate-epidote alteration zone (Dirom and others, 1995).

\section{Morrison Porphyry Cu-Au (Mo) Deposit}

The Morrison Porphyry Cu-Au (Mo) deposit consists of chalcopyrite and pyrite which occur in a stockwork of veinlets and frachures, asd as disseminations (Carter, 1982; EMR Canada, 1989; Ogryzlo and others, 1995). Estimated resources are 86 
million tonnes grading $0.42 \%, \mathrm{Cu}, 0.34 \mathrm{~g} / \mathrm{Au}, 3.4 \mathrm{gr} \mathrm{Ae}$. and $0.017 \% \mathrm{Mo}$. The deposit is hosted in biotite-hornblende-plagioclase porphyry of the Eocene Babine Suite and in adjacent Jurassic sedimentary rocks. The porphyry. sedimentary rocks, and deposit are displaced by a fault.

\section{Au-Ag Epithermal Vein Deposits Associafed with} Quanchus Plutonic Suite

The Quanchus Plutonic Suite forms an arcuate chain of large stocks in west-central British Columbia. The plutons in the suite are similat in composition to plutons in the Nanika suite to the west, but contain more hornblende and biotite; in addition, the suate contains only minor porphyry Cu-Mo prospects (Woodsworth and others, 1991). Comagmatic with the plutons of the Quanchus suite are uplifted and croded felsie volcanic centers in the Eocene Ootsa Lake Group in the Fawnie Range. The significant Au-Ag epithermal vein prospects are: (1) the Holy Cross and Uduk Lake deposits (Lane and Schroeter, 1995); (2) the Wolf prospect which is related to resurgent doming and felsic intrusion within a caldera (Andrew and others, 1986); (3) the Clisbako prospect which is bosied in felsic voleanics of the Eocene Clisbako formation, and is one of several similar deposits in a caldera with a diameter of $40 \mathrm{~km}$ (Metcalfe and Hickson, 1995), and (4) the Blackdome mine which occurs in an Eocene andesitethyolite-volcaniclastic sequence, which is coeval with the Ootsa Lake and Clisbako Volcanics to the north, and is controlled by doming and normal faulting (Vivian and others, 1987).

\section{Origin of and Tectonic Controls for Skeena Metallogenic Bett}

The Skeena metallogenic belt of porpbyry $\mathrm{Cu}-\mathrm{Mo}$; porphyry Mo; Ag polymetallic vein, and Au-Ag epithermal vein deposits occurs in central British Columbia (fig. 103) and is associated with several early Tertiary plutonic suites in the Intermontane Belt in west-central British Columbia. The plutonic suites, which consist of the Nanika, Babine, Quanchus, and Goosly Suites (Woodsworth and others, 1991; Carter, 1982), are coeval and spatially related to suprajacent volcanic rocks, indicating that the plutons were the roots of former volcanic centers. The plutonic suites are commonly controlled by high-angle faults which caused uplift and block-fuulting in the Stikinia terrane. The plutonic suites and coeval volcanic units form part of an extensive continental-margin are in the Canadiun Cordillera which consisted of the early Tertiary Kamloops magmatic belt (Plafker and others, 1989; Nokleberg and others, 1994c, 1997c) and the Late Cretaceous and early Tertiary Coast-North Cascade plutonic belt (Nokleberg and others, 1994c, 1997c). These volcanic-plutonic suites in the southem Intennontane Belt are interpreted as high-level products of deep-seated plutonism and metamorphism in the Coust Belt to the west which formed in a transpressive orogen related to an extensional stress field (Woodsworth and othens, 1991).

\section{Nelson Metallogenic Beit of \\ Ag Polymotallic Vein, Ag-Pb-Zn Manto, \\ Au-Ag Epithermal Vein, Porphyry Mo, \\ Paleoplacer U. and Related Deposits (Belt NS) \\ Southern British Columbia}

The Nelson metallogenic belt of Ag polymetallic vein; $\mathrm{Ag} \cdot \mathrm{Pb}-\mathrm{Zn}$ manto; $\mathrm{Au}-\mathrm{Ag}$ epithermal vein, porphyry Mo, paleoplacet $\mathrm{U}$ and related deposits (fig. 103; tables 3,4) occurs in southem British Columbia. The belt contains significant $\mathrm{Au}-\mathrm{Ag}$ polymetallic vein and manto deposits which occur in two settings. Some deposits occur to the east, in or near the Middle Jurassic Nelson Batholith which is part of the Nelson plutonic suite (Woodsworth and others, 1991). The significant deposits in the belt are (table 4) (Nokleberg and others 1997a, b, 1998): Au-Ag and Ag polymetallic vein deposits at Ainsworth District, Highland Bell (Beaverdeli), Milbe Mack, and Silverton District (Sandon, Silver Ridge), a porphyry Mo deposit at Carmi Moly; a Zn-Pb-Ag skarn and manto deposit at Riondel (Blue Bell); and a paleoplacer U deposit at Lassie Lake area (Blizzard).

\section{Bluebell (Riondel) Zn-Pb-Ag Skarn and Manto Deposit}

The Bluebell (Riondel) Zn-Pb-Ag skam and manto deposit (fig. 122) eonsists of sphalerite, galena, pyrrhotite, pyrite, arsenopyrite, chalcopyrite and knebelite which occur in replacement bodies and in veins controlled by bedding, fractures and open anticlinal culminations (Hoy. 1980, 1982a; Nelson, 1991; Beaudoin and others, 1992). The manto and vein deposits oceur along bedding or fractures, and is pre-deformational breccias, and anticlinal culminations in Early Cambrian limestone of the Badshot Formation, and in quartz-mica schist of the Mohican Formation. A distinctive skarn mineral assemblage includes prograde knebelise (Fe-Mn olivine) and retrograde minnesotaite ( $\mathrm{Fe}$ talc), Fe, Mn-, and Mg-carbonate, chlorite, calcite, and quartz. A K-At isotopic age of $59 \mathrm{Ma}$ for vein muscovite which cuts a gabbro dyke indicates an Eocene age of mineralization for the Riondel deposit and possibly for the district (Beaudoin and others, 1992). The mine at the deposit attained the largest production from a Canadian $\mathrm{Zn}-\mathrm{Pb}-\mathrm{Ag}$ skam mine. Between 1895 and 1971 estimated production was 4.82 million tonnes of ore, and estimated reserves are 0.35 million tontes grading $6.3 \% \mathrm{Zn}, 5.2 \% \mathrm{~Pb}$, and 45 gt $\mathrm{Ag}$. 


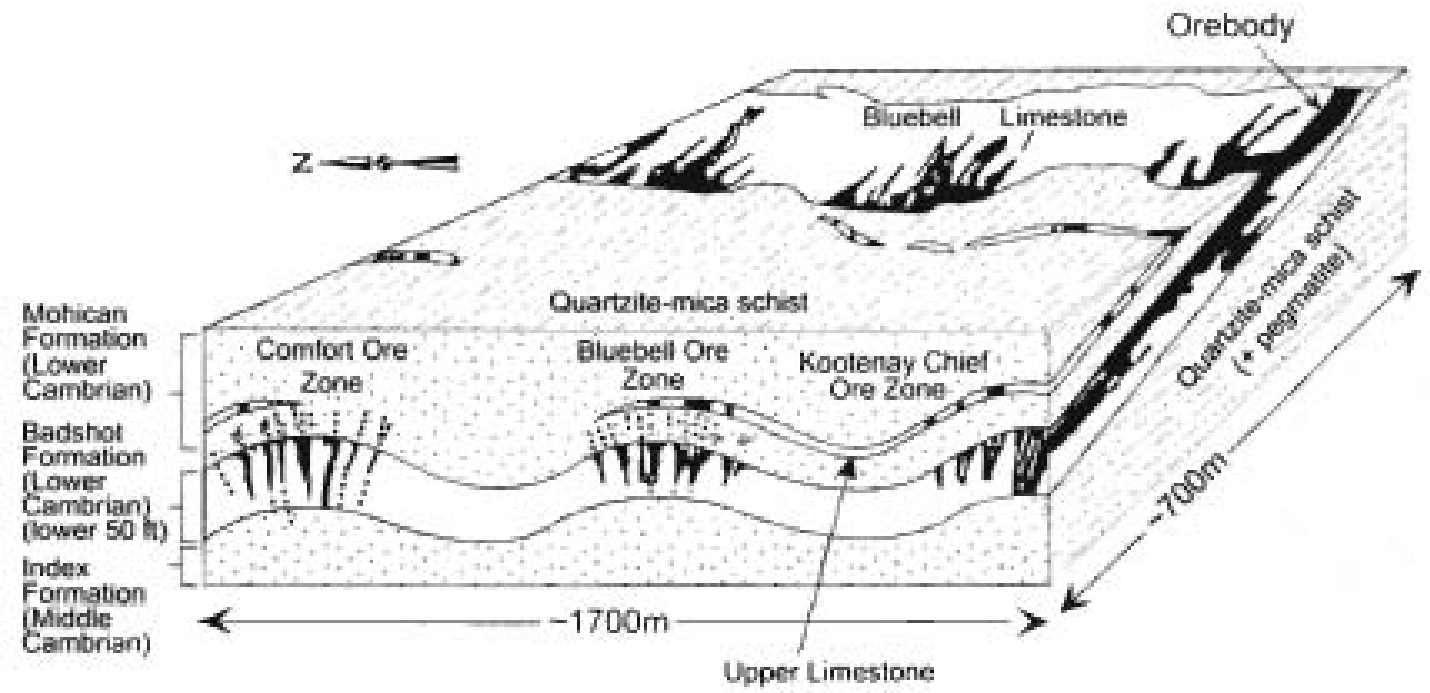

Figure 122. Bluebell (Riondel) Zn-Pb-Ag skarn and manto deposit, Nelson metallogenic belt, Canadian Cordillera. Schematic block diagram. Host Bluebell limestone occupies westem limb of a north-trending antiform. Adapted from Hoy (1980) and Dawson (1996a).

\section{Highland Bell (Beaverdell) Ag-Polymetallic Vein Deposit}

The Highland Bell (Beaverdell) Ag-polymetallic vein deposit consists of sphalerite, pyrite, galena, arsenopyrite, chalcopyrite and minor pyrargarite in quartz-calcite veins which occur along a northeast-trending, $3 \mathrm{~km}$ by 800 meter belt on the west slope of Mt. Wallace (Watson and others, 1982; MINFILE, 2002). The deposit was notably rich in Ag, and the mine at the deposit had the longest continuous operating life of any mine in British Columbia. Between 1901 and 1992, estimated production was 941,644 tonnes grading $1,060 \mathrm{~g} / \mathrm{Ag}, 1.14 \% \mathrm{~Pb}$, and $1.37 \% \mathrm{Zn}$. The majority of the production ( 1,166 tonnes of $\mathrm{Ag}$ ) was from the upper and lower Lass vein systems which occur in Jurassic granodiorite and adjacent turbiditic clastic and pyroclastic rocks of the Permian Wallace Formation. However, the Highland Bell deposit is interpreted as forming during intrusion of the Eocene quartz monzonitic Beaverdell stock which has a K-Ar isotopic age of $50 \mathrm{Ma}$ (Christopher, 1975; Watson and others, 1982).

\section{Carmi Moly Porphyry Mo-Cu (U-F) Deposit}

The Carmi Moly porphyry Mo-Cu (U-F) deposit consists of molybdenite and chalcopyrite which are disseminated in brecciated Early Jurassic granodiorite which has been intruded by a alkalic to calc-alkalic Eocene quartz monzonite porphyry Beaverdell stock with a K-Ar isotopic age of $50 \mathrm{Ma}$ (Eocene), which also contains part of the deposit (Dawson and others, 1991; MINFILE, 2002). The deposit occurs in a 2-km-diameter annular-shaped pyrite zone. The stock is part of the Coryell Plutonic Suite. Estimated reserves are 44.5 million tonnes grading $0.13 \%$ Mo.

\section{Lassie Lake and Hydraulic Lake Paleoplacer U deposits}

Lassie Lake and Hydraulic Lake paleoplacer $U$ deposits consists of autunite and saleeite which occur in paleostream channels in Paleogene continental sedimentary rocks of basins which overly quartz monzonite of Cretaceous Valhalla pluton which is part of the alkaline Coryell Plutonic Suite and calc-alkalic plutons of the Okanagan composite batholith underlie the paleoplacer U deposits. (Sawyer and others, 1981; MINFILE, 2002). Secondary U minerals, autunite and saleeite, derived from underlying uraniferous quartz monzonite of the Cretaceous Valhalla pluton, are concentrated in early Tertiary paleochannel sediments where oxidation was retarded by a capping of plateau basalt of the Pliocene Chilcotin Group. Estimated reserves are 2.1 million tonnes containing 4000 tonses of $\mathrm{U}$ and grading $0.227 \% \mathrm{U}_{3} \mathrm{O}_{3}$ (Bell, 1991; Sawyer and others, 1981). The uranium minerals occur in oxidized facies of coarse-grained fluvial sedimentary rocks and in disseminated organic material in reduced. fine-grained sedimentary rocks.

\section{Origin of and Tectonic Controls for Nelson Metallogenic Beit}

The Nelson metallogenic belt contains a wide variety of $\mathrm{Ag}$ polymetallic vein; $\mathrm{Ag}-\mathrm{Pb}-\mathrm{Zn}$ manto; $\mathrm{Au}-\mathrm{Ag}$ epithermal vein, porphyry Mo, paleoplacer U, and related deposits (tables 3,4). Some deposits occur to the east, in or near the Middle Jurassic Nelson Batholith which is part of the Nelson plutonic suite (Woodsworth and others, 1991). Other deposits occur to the west in the Okanagan Valley in, or near the Eocene alkaline Coryell Plutonic Suite which is interpreted as forming during fegional 
extension. The Coryell Suite is interpreted as the rear or back-are pan of the Coast. North Cascade plutonic belt. The vein and manto deposits which occur in, or around the Middle Jurassic Nelson Babbolith, including those in the Silverton, Ainsworth. Slocan, and Sandon districts, were originally interpreted as forming during the Middle Jurassic intrusion of the batholith and associaled granitoid dikes (Caimes, 1934; Hedley 1947, 1952). However, recent botopic studies suggest: (1) an Eocene age for mineralization for deposits in the district (Beaudoin and others, 1992), including the large Bluebell (Riondel) skam and manto; and (2) that the deposits formed during intrusion of (Eocene) mafic and lamprophyric dikes.

To the west in the Okanagan Valley several other Au-Ag epithermal vein deposits are bosted by Eocene trachyte voleanic rocks of the Marron Formation which is genetically related to the alkalic Coryell Plutonic Suite (Woodsworth and others, 1991; Church, 1973). The Au-Ag epithermal vein deposits include the Vault (Panteleyev, 1991) and Dusty Mac (Zhang and others, 1989) deposits. The igreous rocks and associated deposits are interpreted as forming during Eocene regional extension associated with the low-angle Okanagan shear zone (Tempelman-Kluit and Parkinson, 1986; Parrish and others, 1991).

\section{Early to Middle Tertiary Metallogenic Belts 52 to $23 \mathrm{Ma}$; Figures 102, 103)}

\section{Overview}

The major early Tertiary metallogenic belts in the Russian Far East and the Canadian Cordillera are summarized in table 3 and portrayed on figures 102 and 103. The major belts are as follows. (I) In the Russian Southeast, the Central Sakhalin (CS) belt, which contains Au quartz vein and tale deposits, is bosted in deformed units of the Aniva subduction zone terrane, and is interpreted as forming in collisional event during the early Tertiary(?) accretion of outboard terranes to the east. (2) On the southern Kamchatka Peninsula in the Russian Northeast, the Sredinny metallogenic belt of Au quartz vein and metamorphic REE vein(?) deposits is hosted in the Sredinny-Kamchatka terrane and is interpreted as forming during accretion of the outboard outboard Olyutorka are and generation of hydrothermal fluids. (3) Also on the southern Kamchatka Peninsula in the Russian Northeast, the Kvinumsky metallogenic belt of bornblende peridotite $\mathrm{Cu}-\mathrm{Ni}$ and gabbroic $\mathrm{Ni}$-Cu deposits, is hosted in cortlanditenorite-diorite intrusions which intrude the older metamorphic and granitoid rocks of the Sredinny-Kamchatka metamorphic terrane. The belt is interpreted as forming during backarc intrusion related to subduction beneath the Kamchatka Peninsula part of Northeast Asia continental margin arc. (4) In the Russian Northeast, the Central Koryak (CKY) belt, which contains graniticmagmatism-related deposits, is hosted in the Kamchatkak-Koryak volcanic-plutonic belt, and is interpreted as forming along a transform continental-margin are. (5) In the Russian Northeast, the Olyutor (OT) belt, which contains granitic-magmatism-related and elastic sediment-hosted $\mathrm{Hg}$ deposits, is hosted in the East Kamchatka volcanic and sedimentary basin, and is interpreted as forming during subduction-related granitic plutonism that formed the Kamchatka Peninsula part of Northeast Asia continental margis. (6) In the central Canadian Cordillera, the Pinchi Lake belt, which contains $\mathrm{Hg}$ epithermal vein, Sb-Au vein, silicacarbonate $\mathrm{Hg}$ deposits bosied in, or near shear zones, is interpreted as forming during transcurrent faulting along Cascade volcanicplutonic belt. And (7) in the southem Canadian Cordillera, the Owl Creek $(\mathrm{OC})$ belt, which also contains granitic-magmatismrelated deposits, is hosted in the Cascade volcanic-plutonic belt and is interpreted as forming during subduction-telated granitic plutonism which formed the Cascade continental margin arc. In the below descriptions of metallogenic belts, a few of the noteable or signficaat lode deposits (table 4) are described for each belt.

\section{Metallogenic-Tectonic Model for Early to Middle Tertiary ( 52 to23 Ma; Figure 123)}

During the early to middle Tertiary (middle Eocene to the early Miocene - 42 to $23 \mathrm{Ma}$ ), the major metallogenic-tectonic events were (fig. 123; table 3): (1) aceretion of the Olyutorka island are; (2) continuation of a series of continental-margin ares, associated metallogenic belts, and companion subduction-zone assemblages around the Circum-North Pacific; (3) continuation of sea-floor spreading in the Arctic and eastem Pacific Oceans; (4) establishment of a new continental margin in the northem and castern parts of the Circum-North Pacific as the result of the disappearance of the Kula Ocean plate and inception of subduction of the leading edge of the Pacific Ocean plate; (5) continuation of dextral transpression between the Pacific Ocean plate (PAC) and the North American continental margin in the eastern part of the Circum-North Pacific; and (6) a change to ortbogonal transpression between the Pacifie Ocean plate and the Southern Alaska continental margin because of counterclockwise rotation of Western Alaska.

At about $50 \mathrm{Ma}$ (Vogt and others, 1979), the Gakkel Ridge (GK; northern extension of the Atlantic mid-Ocean Ridge) was initiated and sea-floor spreading extended into the Eurasia Basin (eb) in the Arctic ocean, thereby resulting in the North American-Eurasia plate boundary in the Russian Northeast. The exact location of the Euler pole changed throughout the Cenozoic, thereby resulting in regional changes in the stress regime (Savostin and others, 1984; Harbert and others, 1990). Analysis of marine magnetic anomalies in the Eurasia Basin suggests that the region underwent extension from about 56 to $36 \mathrm{Ma}$ (Savostin and Drachev, 1988a, b; Harbert and others, 1990; Fujita and others, 1997). 


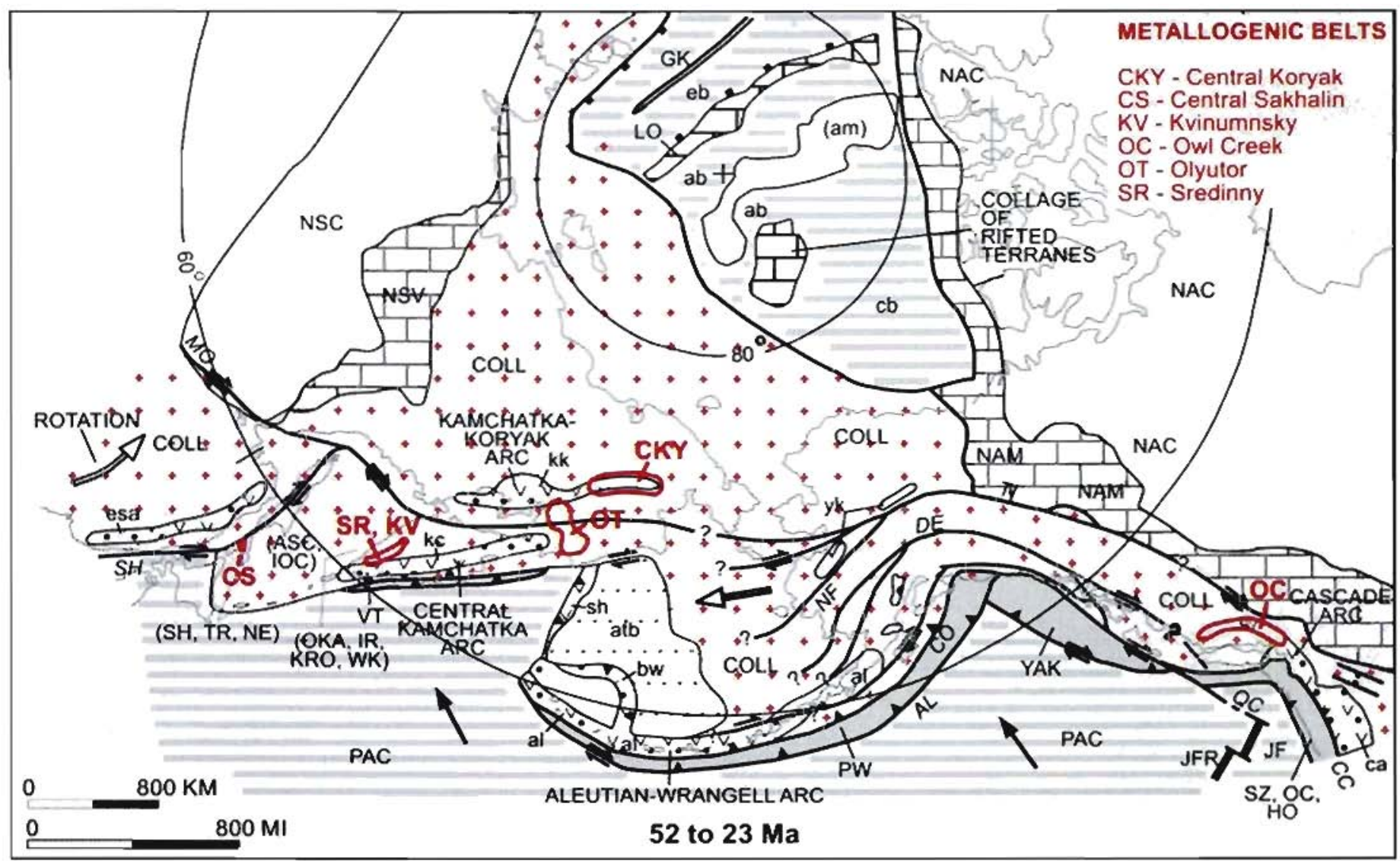

Figure 123. Early to middle Tertiary (Middle Eocene through early Miocene -52 to $23 \mathrm{Ma}$ ) stage of metallogenic-tectonic model. Refer to text for explanation of metallogenic-tectonic events, to tables 3 and 4 for descriptions metallogenic belts and significant deposits, and to figure 18 for explanation of abbreviations, symbols, and patterns. Adapted from Nokleberg and others (1997b, 1998, 2000).

\section{Specific Events for Early to Middle Tertiary}

(1) The younger, bimodal volcanic and plutonic rocks of the youngest part of East-Sikhote Alin volcanic-plutonic belt (es), mainly basalt, rhyolite, and associated granitic plutonic rocks, are herein interpreted as forming in a dextral-transpression tectonic regime. During dextral-transpression, the the Central Sakhalin (CS) metallogenic belt of Au quartz vein and talc deposits formed in the Aniva subduction zone terrane during associated hydrothermal activity.

(2) In the early Eocene, at about $50 \mathrm{Ma}$ (Heiphitz and others, 1994; Brandon and others, 1997, 1998; Garver and others, 1998; Solo'ev and others, 1998; Konstantinovskaya, 1999), the Olyutorka island arc accreted against the West Kamchatka accretionary-wedge terrane (WK; fig. 123) along the Vatyn thrust of Brandon and others (1997, 1998) which is interpreted as a low-angle, seaward-dipping zone of obduction (Brandon and others, 1997, 1998; Ramthun and others, 1997). Alternatively, Geist and others (1994) suggested that the Olyutorka arc and its companion subduction zone formed near the margin of Northeast Asia. During accretion of the Olyutorka arc was formation of the Sredinny metallogenic belt (SR) of Au quartz vein and = metamorphic REE vein(?) deposits.

(3) In the area of the central and southern Russian Far East, tectonic wedging occurred because of the accretion of the India plate against the Eurasia plate (Worall and others, 1996). The tectonic wedging resulted in sinistral displacement along the reactivated Mongol-Okhotsk fault $(M O)$ and dextral displacement along the Sakhalin-Hokkaido fault $(S H)$ parallel to the margin of the Russian Far East. A complex array of normal faults, en-echelon folds, and thrusts is interpreted as forming within and adjacent to the tectonic wedge (Worall and others, 1996). The relation of sinistral movement along the reactivated MongolOkhotsk fault and dextral movement along the Denali (DE), Tintina (TI), and related faults to the east in mainland Alaska in unclear.

(4) The bimodal volcanic and plutonic rocks of the Kamchatka-Koryak volcanic-plutonic belt (kk) are herein interpreted as forming in a sinistral tectonic regime. The Kamchatka-Koryak volcanic-plutonic belt constitutes the Cetnral Kamchatka arc. Forming in the volcanic-plutonic belt was the Central Koryak (CKY) metallogenic belt which contains granitic-magmatism- 
related deposits. Forming in the buckare part of the are was the Kvinumsky (KV) metallogenic belt of bornblende peridotite and gabbroic $\mathrm{Cu}-\mathrm{Ni}$ deposits.

(5) Rifting commenced at about $50 \mathrm{Ma}$ along the Gakkel Ridge (GK; northern exiension of the mid-Atlantic ridge) and extended into the Russian Northeast (Fujita and others, 1997). The rifting is interpreted as causing eniption of basalts in the Chersky Range at about $37 \mathrm{Ma}$ (Fujita and others, 1997). The Lomonosov Ridge ierrane (LO) is interpreted as forming during the rifting of passive continental margin units now preserved in the Barents Sea region (out of field of fig. 123) (Zonenshain and others, 1990). Sedimentation continued in the large Amerasia (ab), Canada (cb) and Eurasia (eb) Basins.

(6) A short-lived period of marine arc volcanism formed the Bowers (bw) and Shinhov (sh) Ridges in the Bering Sea. The are formed on the rear edge of the previously accreted Aleutia terrane (al), a fragment of the Kula Ocean plate (Scholl and others, 1992, 1994) The Bowers Ridge volcanic belt consists chiefly of intermediate-composition volcanic rocks, mainly altered andesite, breccia, volcaniclastic sedimentary rocks, and lesser diatomaceous silistooe (Cooper and others, 1992; Scholl and others, 1992). Analysis of sparse dredge samples and DSDP drill cores suggests a Miocene age for the volcanic rocks. The presence of a trench filled with as much as $12 \mathrm{~km}$ of sedimentary rocks located at the buse of the northern and eastem slopes of Bowers Ridge suggests that the unit formed in an early Tertiary arc-trench system which faced toward the northeast. The Shirshov Ridge volcanic belt consists chiefly of two assemblages. (1) A relatively older oceanic assemblage is coniposed of amphibolite. gabbro, diabase, basalt, and chert, Chert contains Late Cretaceous (Campanian to Maastrichtian) to early Paleogene microfauna. (2) A relatively younger volcanic-are assemblage is composed of aliered andesite, volcaniclastic sedimentary rocks, and shale of Miocene and younger age (Baranov and others, 1991; Scholl and others, 1992). Alternatively, the Bowers and Shinshov Ridges may be the northward extension of the Olyutorka-Kamchatka island are (OKA; Brandon and others, 1997, 1998). Also in the Bering Sea, a thick sedimentary prism started to form in the Aleutian-Bowers sedimentary basin (atb) which overlies the Aleutia terrane (Plafker and Berg. 1994; Scholl and others, 1992, 1994).

(7) Tectonic escape (cnustal extrusion) of terranes continued to occur along major dextral-slip faults, including the Denali $(D E)$, Nixon Fork $(N F)$, Kaltag $(K A)$, and companion faults in the area of the Western Alaska the Bering Sea (Seholl and others, 1992, 1994). Dextral-wrench basins continued to form in association with the major dextral-slip faults and were rapidly filled with continental sediments. Coincident with crustal extrusion was counterclockwise oroclinal bending of Alaska which perhaps resulted from compression between Eurasia and North America (Scholl and others, 1992, 1994; Plafker and Berg. 1994). To the east, in the aren of Southern Alaska, displacement continued along major dextral-slip faults, including the Denali, Nixon Fork, und Kaltag faults. These and similar dextral-stip faults probably extended into the area of the Bering Sea.

(8) The Pacific Ocean plate (PAC) moved towards North America as a result of sea-floor spreading along the Juan de Fuca oceanic ridge. Along the Aleutian megathrust $(A L)$, plate convergence continued to vary from oblique-orthogonal in the east to oblique in the west. Oblique-transpressive displacement occurred between the Pacific Ocean plate (PAC) and the southem Canadian Cordillera.

(9) As a result of trapping of part of the Kula Ocean plate (underlying the Aleutian-Bowers basin), and step-out of subduction, the western part of Aleutian-Wrangell are (al) was initiated at about $40 \mathrm{Ma}$. This major Andean-type arc overlapped the previously accreted Kula Ocean plate and initially extended for a distance of about $3,000 \mathrm{~km}$ along the Bering Straits and Southern Alaska. Associated with the are was subduction of part of the Pacific Ocean plate (PAC) to form the Prince William $(P W)$ and Yakutat (YA) ternanes along Aleutian megathrust (AL).

(10) At about 25 to $30 \mathrm{Ma}$, a major tectonic change occurred in the Soutbern Canadian Cordillera with tectonic overniding of the northern segment of the Juan de Fuca oceanic ridge (JFR) and resultant establishment of dextral-slip along the Queen Charlotte fault (QC). This tectonic change ended subduction of the Farallon Ocean plate (FAR) and started northward migration and subduction of the Yakutat terrane (YAK), resulting in the beginning of voleanism in the Wrangellia volcanic field (wr) in the easiern part of the Aleutian-Wrangell are (fig. 123). Total movement of the Yakutat terrane is estimated at about 600 km (Plafker and Berg. 1994; Plafker and others, 1994). Movement ceased along major dextral-slip faults in interior Canadian Cordillera, including the Tintias $(T I)$ and Fraser Creek-Straight Creek $(F S)$ faults. Between latitudes $51^{\circ}$ and $60^{\circ}$, the Queen Charlotte transform fault separaied the Cascade are and the Aleutian-Wrangell arc. This fault forms the North American plate margin between Vancouver Lsłand, Canada. and northem Southenstern Alasika.

(11) Offshore of the southem Canadian Cordillera, sea-floor spreading oceurred along the Juan de Fuca oceanic ridge (JFR). To the cast, subduction of the Juan de Fuca plate (JF) resulted in initiation of the Cascade continental-margin are (ca). Part of the subductieg plate is preserved in the Siletzia (SZ), Olympic Core ( $\mathrm{OC})$, and Hoh (HO) termanes along branches of the Cascadia megathrust (CC). Forming along transcurrent faults along the extension of the Cascade are was the Pinchi Creek (PC) metallogenic belt of $\mathrm{Hg}$ epithermal vein, Sb-Au vein, silica-carbonate $\mathrm{Hg}$ deposits. Also forming in the Cascade are was the Owl Creek $(O C)$ metallogenic belt, which also contains granitic-magmatism-related deposits and is interpreted as forming during subduction-related granitic plutonism. 


\section{Metallogenic Belts Formed in Tertiary \\ Collision of Outboard Terranes, \\ Russian Southeast}

\section{Central Sakhalin Metallogenic Beit of \\ Au Quartz Vein and Talc Deposits (Beit CS) \\ Sakhalin Island, Southeastern Part of \\ Russian Far East}

The Central Sakhalin metallogenic belt of Au quartz vein and talc deposits occurs in the Aniva subduction-zone terrane in the central part of Sakhalin Island (fig. 102; tables 3,4) (Nokleberg and others, 1997b, 1998). The major deposit at Langeriiskoe consists of Au-bearing quartz-sulfide veins in lenticular bodies of fractured and faulted Permian-Triassic spilite and graywacke, Jurassic-Early Cretaceous slate, and Cenozoic volcanic rocks and chert (Khanchuk and others, 1988; Bekhtold and Semenov, 1990). The Au-bearing quartz-sulfide veins are interpreted as forming during metamorphism associated with middle or late Tertiary folding and faulting. Also in the metallogenic belt are talc deposits, formed by hydrothermal alteration of ultramafic intrusive rocks which are also of economic interest.

The host Aniva terrane is composed of intensely deformed and metamorphosed sedimentary and voleanic rocks which locally display Late Cretaceous to Paleogene transitional glaucophane-greenschist facies metamomhism. The Aniva terrane is interpreted as a subduction zone unit which was tectonically linked to the Cretaceous East Sikhote-Alin volcanic-plutonic belt (Nokleberg and others, 1994c, 1997c). The Central Sakhalin belt of Au quartz vein and talc deposits hosted in the Aniva terrane are herein interpreted as possibly forming in a collisional environment during the early Tertiary(?) accretion of outboard termanes to the east.

\section{Sredinny Metallogenic Beit of \\ Au Quartz Vein and \\ Metamorphic REE Vein(7) Deposits \\ (Belt SR) Southern Kamchatka Peninsula}

The Sredinny metallogenic belt of Au quartz vein deposits and a single metamorphic REE vein(?) deposit occurs in the southern part of the Kamchatka Peninsula in the zoned metamorphic complexes of the Sredinny-Kamchatka terrane (fig. 102; tables 3, 4) (Nokleberg and others, 1997b, 1998). The Au quartz vein deposits occur mainly in metasandstone and metasiltstone. The major Au quartz vein deposit is at Tumannoe and a single metamorphic REE vein(?) deposit is at Anomalnoe.

\section{Tumannoe Au quartz vein deposit}

The Tumannoe Au quartz vein deposit (D.A. Babushkin and others, written commun., 1986) occurs in quartz phyllite which is interbedded with late Paleozoic metasandstone and metasiltstone. The major ore minerals are gold, arsenopyrite, and pyrite, with rare chalcopyrite and magnetite. The mineralized zones vary from $3010115 \mathrm{~m}$ long and 20 to $50 \mathrm{~m}$ thick and occur in stockworks with gold, arsenopyrite, and pyrite. The deposit consists of a stockwork which is probably remobilized from black shale. This and associated deposits are small, but are sources for placers on the western coast of Kamchatka Peninsula. The average grade of the Tumannoe deposit is $0.4-2.2 \mathrm{~g} / \mathrm{Au}$ and $3 \mathrm{~g} / \mathrm{Ag}$.

\section{Anomalnoe Metamorphic REE Vein(7) Deposit}

The small metamorphic REE vein(7)deposit at Anomalnoe (D.A. Babusthin and others, written commun., 1986) consists of an altered vein of $\mathrm{K}$-feldspar and albite which is hosted in Proterozoic(?) schist. The vein is longer than $1 \mathrm{~km}$ and varies from 1 to $12.5 \mathrm{~m}$ wide. The principal economic minerals are columbite and tantalite which contain $\mathrm{Ta}$ and $\mathrm{Ni}$. Accessory minerals are ilmenite-rutile and rare epidote. A K-Ar isotopic feldspar age for the veins is $170 \mathrm{Ma}$

\section{Origin of and Tectonic Controls for Sredinny Metallogenic Belt}

The Sredinny metallogenic belt is hosted by the by the Sredinnyi-Kamchatka metamorphic terrane which consists of several metamorphic sequences (Nokleberg and others, 1994c, 1997c). The belt is herein interpreted as forming during accretion of the outboard Olyutorka island are and generation of hydrothermal fluids. A K-Ar isotopic age of about $40 \mathrm{Ma}$ for the Tumannoc deposit is herein interpreted as a minimum time for accretion of the Olyutorka arc. The K-Ar isotopic age of $170 \mathrm{Ma}$ for the REE vein(?)deposit at Anomalnoe is uncertain. 


\section{Kvinumsky Metallogenic Belt of Hornblende Peridotite and Gabbroic \\ Cu-Ni Deposits (Belt KV) \\ Southern Kamchatka Peninsula}

The Kvinumsky metallogenic belt of homblende peridotite and gabbroic Cu-Ni deposits oceurs in the southern Kamchatka Peninsula and is associated with early Tertiary intnusive rock (fig. 102; tables 3,4) (Bundtzen and others, 2003a, b). The major $\mathrm{Cu}-\mathrm{Ni}$ deposits, at Shanuch, Kvinum, and Kuvalorog, are associated with cortlandite-norite-diorite intrusions which intrude the older metamorphic and granitoid rocks of the Sredinny-Kamchatka metamorphic terrane (Nokleberg and others, $1997 \mathrm{~b}, 1998,2000)$. An incremental ${ }^{20} \mathrm{Ar}{ }^{30} \mathrm{Ar}$ isotopic age for the host intrusive rock ranges from $60-40 \mathrm{Ma}$ (Bundtwen and others, $2003 \mathrm{a}, \mathrm{b})$. The deposits generally consists of pentlandite, $\mathrm{Zn}$-bearing chrome spinel, pyrnotite, chalcopyrite, and bormite which occur in veinlets and as disserninations in homblendite-peridotite-norile-diorite intrusions. The deposits are small and the sulfides occur mainly as disseminations in gabbro (Shcheka and Chubarov, 1984). $\mathrm{Ni}$ is less than $1.0 \%$, and $\mathrm{Cu}$ is less than $1.0 \%$. The sulfide disseminations contain up to $1 \mathrm{~g} / \mathrm{Au}$ and up to $6 \mathrm{~g} / \mathrm{Pt}$. The region containing these deposits is inaccessible and poorly explored. The Kvinumsky metallogenic belt of bornblende peridotite and gabbroic $\mathrm{Cu}-\mathrm{Ni}$ deposits is herein interpreted as forming during backarc intrusion related to subduction beneath the Kamchatka Peninsula part of Central Kamchatka continental margin arc.

\section{Central Koryak Metallogenic Belt of Igneous Arc Deposits (Beit CKY) East-Central Part of Russian Northeast}

The Central Koryak metallogenic belt of igneous-arc-related deposits (fig. 102; tables 3,4) occurs in the Koryak Highlands in the east-central part of the Russian Northeast. The belt extends from the Penzhina Inlet to the Anadyr Bay for about $1,000 \mathrm{~km}$ and is composed mainly of Sn polymetallic, Au-Ag epithermal, $\mathrm{Hg}-\mathrm{Sb}$ vein, and porphyry Mo-Cu deposits. The significant deposits in the belt are (table 4) (Nokleberg and others 1997a, b, 1998): Sn polymetallic vein deposits at Ainatvetkin, Berezovaya, Khrustal (Khrustalnoe), Parkhonai, Reznikov, and Unnei, Au-Ag epithermal vein deposits at Ametistovoe, Ivolga, Orlovka, and Sprut; volcanic-hosted $\mathrm{Hg}$ deposits at Agranai and Lamut; clastic sediment-bosted $\mathrm{Hg}$ or hol-spring Hg? deposits at Krassnaya Gorka, Lyapganai, and Neptun; silica-carbonate Hg deposits at Pervenets and Tamvatney; and porphyry Cu-Mo deposits at Kuibiveen, Lalankytap, and Rzhavy.

The metallogenic beit is hosted in or near the calc-alkaline magmatic rocks of the western part of the Kamchatka-Koryak volcanic belt (fig. 102) (Pozdeev, 1986, 1990; Filatova, 1988; Nokleberg and others, 1994c, 1997c). Various, isolated ring. volcanic-plutonic, and volcanic structures host about a third of the metallogenic belt. The Kamchatka-Koryak volcanic belt unconformably overlie nappes and thrust slices of previous-acereted flysch, island arc, and ophiolite terranes. The Sn polymetallic and $\mathrm{Au}-\mathrm{Ag}$ cpithermal vein deposits occur mainly along the southern flank of the metallogenic belt in a region underlain by a thick crust composed of a granitic and metamorphic rocks up to $40 \mathrm{~km}$ thick. The northern part of the belt consists of the Parkhonai district which contains $\mathrm{Sn}$, $\mathrm{Au}-\mathrm{Ag}$. Sb, and $\mathrm{Hg}$ polymetallic vein, and clastic-sediment-hosted $\mathrm{Hg}$ deposits. The Central Koryak metallogenic bell also has potential for undiscovered Sn lode deposits.

\section{Sn polymetallic Deposits}

The Sn polymetallic vein deposits are bosted by metasedimentary rocks, silicie and intermediate volcanic rocks, and granite porphyry and thyolite stocks and dikes which occur above concealed granitic batholiths (Lashtabeg and others, 1987). The significant Sn polymetallic deposits are at Ainatvetkin, Rernikov, Khrustal, and Unnei. The deposits tend to be enriched in Ag. In, Bi. and sometimes Au.

\section{Ainatvetkin Sn potymetalic Deposat}

The Sn polymetallic deposit at Ainatvetkin (Lugov and others, 1974; Lugov, ed., 1986) consists of cassiterite-bearing sulfide-chlorite-quartz veins and fracture zones which are up to a few hundred $\mathrm{m}$ long and range 1.0 to $6.0 \mathrm{~m}$ thick. The ore minerals are cassiterite, magnetike, pyrthotite, chalcopyrite, galena, sphalerite, arsenopyrite, wolframite, scheelite, pyrite, stannite, canfieldite, pyrarzyrite, gold, and native copper. The cassiterite-chlorite-quartz veins and fracture zones contain up to $10 \%$ sulfide minerals. Most economically important are brecciated zones with fragments of metasomatically aliered rocks and quartz-chlorite cement with sulfides. The deposit is hosted in complexly-folded Late Cretaceous (Santonian through Campanian) sandstone and shale which is overlain by Late Eocene and Oligocene rhyolite, thyodacite, thyodacite tuff, and ignimbrite. The Late Cretaceous 
clastic rocks are cut by numerous late Paleogene stocks, dikes, and hypabyssal granitoids. The deposit is of medium size and averages $0.6 \% \mathrm{Sn}$.

\section{Ag-Au and Au-Ag Epithermal Vein Deposits}

Various Ag-Au and Au-Ag epithermal vein deposits also occur in the Central Koryak metallogenic belt, as at Ametistovoe, Ivolga, and Sprut, are related to intermediate composition subvolcanic complexes (Khvorostov and Zaitsev, 1983). These epithermal deposits are vertically and lateral zoned with respect to the $\mathrm{Sn}$ and $\mathrm{Sn}$-Ag deposits.

\section{Ametistovoe Au-Ag Epithermal Vein Deposit}

The Ametistovoe Au-Ag epithermal vein deposit (fig. 124) (Khvorostov, 1983; V.P. Khvorostov, written commun., 1986; Benevolskyi and others, 1992) contains two types of ore bodies: (1) ore pipes with small subparallel veins and veinlets; and (2) steeply dipping veins and zones. The veins are hundreds of meters long and several meters thick; the zones are several tens of meters thick. The veins are composed of quartz, kaolinile-quartz, and sulfide-quartz types. The main ore minerals are gold, argentite, and küstelite, Subordinate minerals are stephanite, stibiopearcette, aguilarite, pytargyrite, miargyrite, freibergite, naumannite, and native silver. Pyrite, galena, sphalerite, and chalcopyrite are widespread and comprise up to 20 to 30 percent of some veins. The gangue minerals are quartz, kaolinite, adularia, and chlorite. The Au:Ag ratio averages 1:3. The richest ore bodies

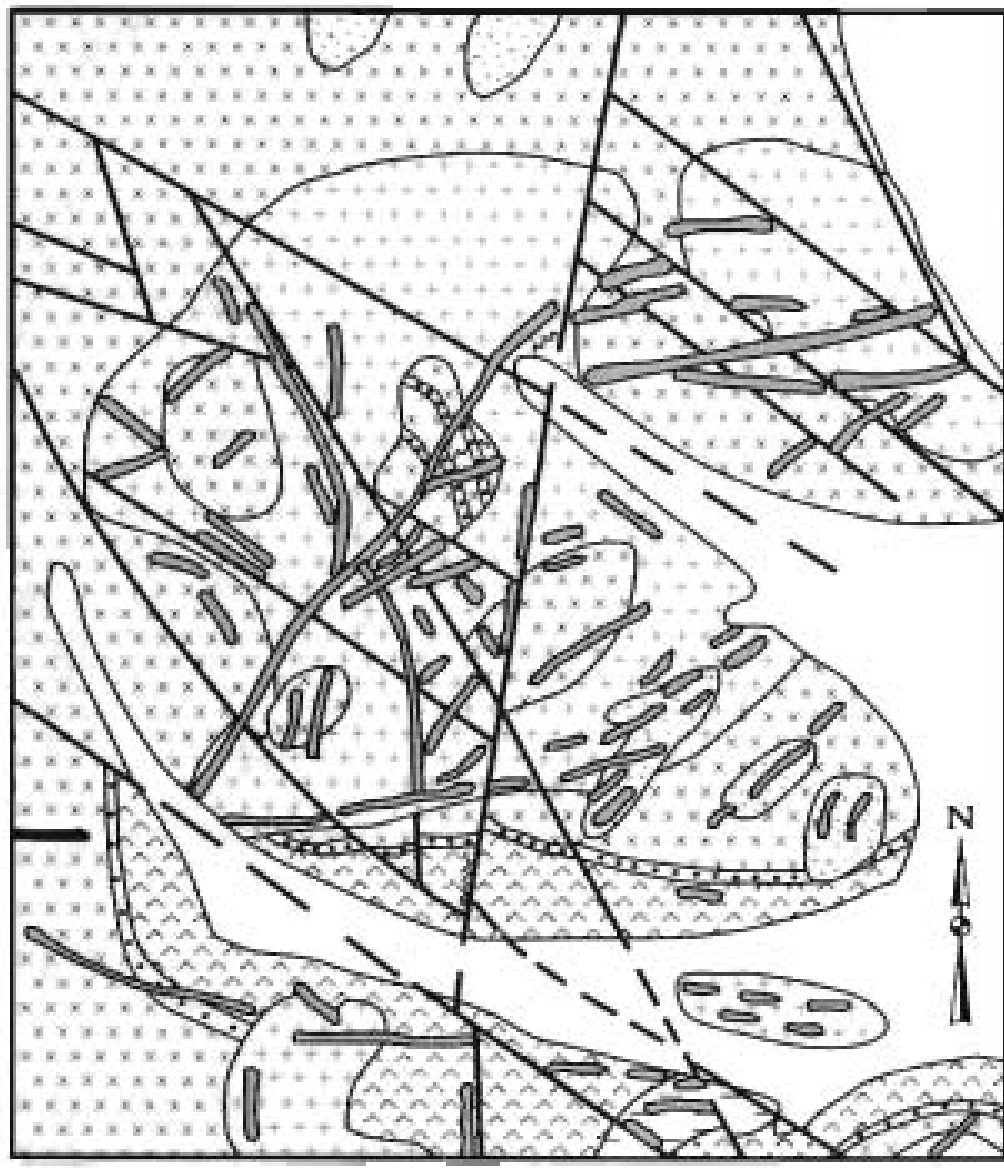

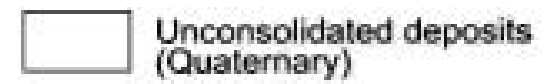
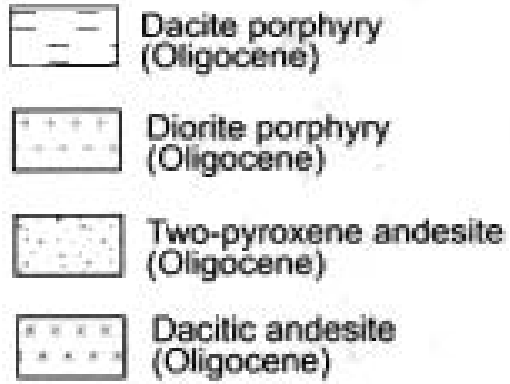

\section{Exid Dacite (Oligocene)}

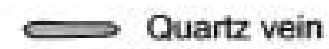

$$
\ldots \text { Tuff (Oligocene) }
$$

- Fault

Contact

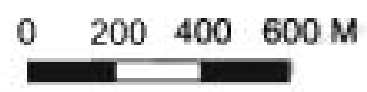

Figure 124. Ametistovoe Au-Ag epithermal vein deposit, Central Koryak metallogenic belt, Russian Northeast. Schematic geologic map. Adapted from Khvorostov (1983).

are confined to altered rocks which contain a alteration of kaolinite, illite, and quartz superimposed on widespread epidotechlorite-carbonate propylitic alteration. The deposit is centered on a magmatic structure which is about 5 to $6 \mathrm{~km}$ deep. The host volcanic rocks are Eocene and Oligocene flows with K-Ar ages of 18-24 Ma which consist mainly of andesite, andesite-basalt, andesite-dacite, and dacite. Associated are local abundant extrusive-vent and hypabyssal rocks of similar compositions. The deposit is controlled by: (1) a northwest- and nearly north-south-trending faults; (2) radial and concentric fractures; and (3) extrusive and hypabyssal bodies. The deposit is large with prove reserves of 96 tonnes Au. The average grade of the Ametistovoe deposit is $16 \mathrm{~g} / \mathrm{Au}$. The area around the Ametistovoe deposit has considerable potential for discovery of additional deposits. 


\section{Hg Deposits}

Hg deposits occur throughout the Central Koryak metallogenic belt with more abundant deposits in the southem and northem extreme parts of the beli. Extensive mineralized fault zones contain cinnabar, stibnite and realgar which are associated with intermediate-composition, small intrusions and dikes which intrude Late Cretaceous through Paleogene sandstone and shale. Significant clastic sediment-hosted $\mathrm{Hg}$ deposits are at Lyapganai, Neptun, and Krassnaya Gorka.

Lyepganai Clastic Sediment-Hosted Hg Deposit

The clastic sediment-hosted $\mathrm{Hg}$ deposit at Lyapganai (Tarasenko and Titov, 1970; Babkin, 1975; Vlasov, 1977) consists of a mineralized fracture zone in Late Cretaceous sandstone and mudstone. The fracture zone is cemented by quartz and dolomite with subordinate kaolinite and calcite. Disseminated cinnabar occurs in the vein or coats breccia clasts as thin rims. Stibnite and pyrite are minor. The ore minerals range from disseminated to massive and oceur in breceia, veinlets, and banded disseminations. The ore bodies vary in size from 0.1 to $4.2 \mathrm{~m}$ in width by $110 \mathrm{~m}$ to $420 \mathrm{~m}$ in length. The most promising ore bodies oceur in faults which trend northeast, parallel to major fold axes. The Lyapganai deposit is similar to many other clastic sediment-hosted $\mathrm{Hg}$ deposits in the Koryak upland. The deposit is of medium size and contains an estimated 1,400 tonnes of ore grading from 0.5 to $2.4 \% \mathrm{Hg}$

Both volcanic-hosted $\mathrm{Hg}$ and $\mathrm{Sn}$ deposits occur in a major, northwest-trending transverse lineament along the northeastem flank of the belt. The host rocks are rhyolite, andesite, basalt, clastic, and siliccous-volcanogenic rocks and ophiolite allochthons. The significant deposits are the volcanic-bosted $\mathrm{Hg}$ deposit at Lamut, and a major silica-carbonate $\mathrm{Hg}$ and $\mathrm{W}$ deposit at Tamvatney, Some $\mathrm{Hg}$ deposits are similar to hot-spring $\mathrm{Hg}$ deposits.

\section{Lamut Volcanic-Hosted $\mathrm{Hg}$ Deposit}

The small volcanic-bosted Hg Lamut deposit (Babkin, Drabkin, and Kim, 1967; Rozenblyum, Zincevich, and Nevreldinov, 1975) consists of lenticular occurrences and masses of quartz, opal, chalcedony, dolomite, dickite, and cinnabar. Subordinate ore minerals are metacinnabar, realgar, stibnite, and pyrite. The deposit occurs in intensely silicified, kaolinized, carbonatized, and chloritized late Puleogene rhyolite, and less commonly in basalt and tuff. The deposit oecurs along northeasttrending fracture zones.

\section{Tamvatney Silica-Carbonate $\mathrm{Hg}$ Deposit}

The major Tamvatney silica-carbonate $\mathrm{Hg}$ deposit (Rozenblum and others, 1973; Babkin, 1975; Voevodin and others 1979,1980 ) consists of cinnabar, tungstenite, wolframite, and Fe and As sulfides which occur in altered serpentinite, serpentinized peridotite, conglomerate, and coarse-grained sandstone, and argillite. The serpentinite is deformed into mylonite and displays carbonate, silica, and argillic alteration. The main ore minerals are cinnabar, tungstenite, wolframite, buebnerite, scheelite, marcasite and pyrite. Minor minerals are metacinnabar, stibnite, realgar, orpiment, arsenopyrite, sphalerile, chalcopyrite, millerite, bravoite, chalcocite, pyrhotite, and hematite. Relic ilmenite, chromite, magnetite, niccolite, and pentlandite occur in serpentinite and silica-carbonate alieration. The vein gangue minerals mainly quartz, chalcedony, magnesite, dolomite, kaolinite, dickite associated witb peculiar hard and liquid bitumens, and native sulfur. The middle part of the deposit consists of stockworks, masses of ore miserals, veins, and a dense network of sulfide veinlets. The zone of mineralization extends for about $20 \mathrm{~km}$ with an average thickness of about 20 to $30 \mathrm{~m}$. The deposit occurs along the northem tectonic contact of the Tamvatney lherzolite ophioline body which structurally overlays a clastic rocks of Early Cretaceous (Aptian and Albian) and Oligocene-Miocene age. The ultramafic tocks are intruded by Early Cretaceous gabbronorite, Late Cretaceous plagiogranite, and Neogene andesite and basalt. The age of the deposits is interpreted as Early Pleistocene. The deposit is large with estimated reserves of 30,000 tonnes $\mathrm{Hg}$ in ore which averages $0.81 \% \mathrm{Hg}$

\section{Porphyry Mo-Cu Deposits}

Av-bearing, porphyry Mo-Cu oceurrences, such as at Kuibiveen, and numerous hydrothermal vein deposits, containing $\mathrm{Au}, \mathrm{Ag}, \mathrm{Cu}, \mathrm{Mo}, \mathrm{Pb}$, and $\mathrm{Zn}$, also occur in the Central Koryak metallogenic belt. These deposits formed at varying temperatures, represent a variety of mineral deposit types. The significant deposit is at Kuibiveen.

\section{Kubeveen Porphyry Mo Deposa}

The porphyry Mo deposit at Kuibiveen consists of quartz-tourmaline breceias, altered rocks, veins, and zones of linear and stockwork quartz-sulfide veinlets which occur in a nearly east-west-trending zone which is about $25 \mathrm{~km}$ long and about $4 \mathrm{~km}$ wide (Zakharov and V.P. Vasilenko, written commun., 1977; I.S. Rozenblyum, written commun., 1991). The deposits consists of disseminated molybdenite, arsenopyrite, chalcopyrite, galena, and native gold which occur in zones from tens of meters up to hundreds of meters thick. The deposit occurs in a Neogene complex of small intrusions and dikes of internediate and felsic composition. The deposit occurs along a fault which thrusts Late Cretaceous siliceous sedimentary rocks over Oligocene and Miocene sandstone and conglomerate. The deposit is of small to medium size. 
The Kamchatka-Koryak volcanic belt, which hosts the Central Koryak metallogenic belt, is composed of lesser Late Cretaceous and mainly of Paleocene, Eocene, and Miocene age. The belt extends for $800 \mathrm{~km}$ parallel to, but mainly east of the northern part of the Okbotsk-Chukotka volcanic-plutonic belt (fig. 102) (Nokleberg and others, 1994c, 1997e). The belt oceurs in discontinuous and isolated volcanic fields and consists of gentily dipping normarine volcanic rocks of various compositions, and sandstone, gritstone, and conglomerate with flora. The lower part of the volcanic belt consists of mafie volcanic rocks, mainly Maastrichtian-Danian tholeiitic basalt, along with abundant Paleocene to Eocene alkali basalt, and associated minor diorite, monzonite, gabbro, granodiorite, and granite which yield K-Ar ages of $56-73 \mathrm{Ma}$. The upper part of the volcanic belt consiats of calc-alkaline dacite, thyolite, andesite, and basalt with late Eocene and early Miocene flora and K-Ar ages, and is associated with subvolcanic bodies and dikes of rhyolite, granodiorite, and diorite. The Kamchatka-Koryak volcanic belt is interpreted as a major, mainly early Tertiary arc which formed along a continental margin-parallel transform fault. (Khanchuk and Ivanov, 1999a, b).

\section{Motallogenic Belts Formed in Tertiary Continental-Margin Arcs, Kamchatka Peninsula, and Southern Canadian Cordillera}

\section{Olyutor Metallogenic Belt of Igneous-Arc-Related Deposits (Belt OT) Kamchatka Peninsula}

The Olyutor metallogenic belt of igneous-arc-related deposits (fig. 102, tables 3,4) oceurs in northern Kamchatka. The metallogenic belt extends for more than $600 \mathrm{~km}$ along the Bering. Sea coast and is hosted in the East and Central Kamchatka voleanic belts (Nokleberg and others, 1994c, 1997c). The little studied Olyutor metallogenic belt contains a variety of Au-Ag epithermal vein, Sn polymetallic vein, clastic sediment-hosted $\mathrm{Hg}$, and porphyry Mo-Cu deposits (table 4). Several mineable $\mathrm{Hg}_{\mathrm{g}}$ $\mathrm{Au}, \mathrm{Mo}, \mathrm{Cu}, \mathrm{Pb}$ and $\mathrm{Zn}$ deposits occur in many, slightly-eroded volcanic structures (Tarasenko and Titov, 1969). Numerous, poorly explored, porphyry $\mathrm{Cu}-\mathrm{Mo}, \mathrm{Au}-\mathrm{Ag}$ epithermal vein, sulfur-sulfide, and $\mathrm{Sn}$ polymetallic vein deposits occur along the southern flank of the belt, and a zone of $\mathrm{Hg}$-Sb and $\mathrm{Hg}$-As deposits extends for more than $100 \mathrm{~km}$ along the Olyutor Bay coast. The deposits in the Olyutor belt are hosted mainly in Tertiary sedimentary, volcanic, and hypabyssal intrusive rocks. The $\mathrm{Hg}_{\mathrm{g}} \mathrm{Sb}$ As deposits also occur in Neogene extrusive rocks, and in serpentinite melange zones. The porphyry Mo-Cu deposits occur in Tertiary diorite and granodiorite porphyry stocks and associated dikes which intrude Late Cretaceous and early Paleogene tuffaceous and clastic rocks. The porphyry Mo-Cu deposits extend more than $100 \mathrm{~km}$ in the northern part of the belt, with intrusions apparently occurring along major faults. The significant deposits in the Olyutor metallogenic belt are the Olyutor clastic sediment-bosted Hg deposit, the Lalankytap porphyry Mo-Cu deposit, and the Maletoivayam sulfur-sulfide deposit (Nokleberg and others 1997a, b, 1998).

\section{Olyutar Clastic Sediment-Hosted Hg Deposit}

The Olyutor clastic sediment-hosted $\mathrm{Hg}$ deposit (Babkin, 1975; Vlasov, 1977) consists of veins and veinlets which oceur is steeply-dipping fracture zones. The fracture zones radiate from a large northeast-trending fault which cuts Paleogene and Neogene volicaniclastic rocks which are deformed into small linear folds. Individual ore bodies extend along strike from tens of meters to $600 \mathrm{~m}$. The veins have numerous apophyses typically containing mineralized breccia which often grade into zones of veinlets. The most productive ofe bodies occur in tuff. The main ore minerals are cinnabar accompanied by stibnite and sometimes realgat. The ore also contains quartz cement and quartz-kaolinite breccia fragments. The main gangue minerals are quartz and kaolinite, and less commonly dolomite. Wall rock alteration includes weak silicification, kaolinization, and carbonatization. The deposit is large and contains an estimaled 700 tonnes $\mathrm{Hg}$ averaging $1.4 \% \mathrm{Hg}$, and up $10.4 \% \mathrm{Sb}$ and $4 \mathrm{~g} / \mathrm{Au}$.

\section{Lalankytap Porphyry Mo-Cu Deposit}

The Lalankytap porphyry Mo-Cu deposit (Brazhnik and Kolyasnikov, 1989; Brazhnik and Morozov, 1989) consists of an oval stockwork about 1.2 by $0.6 \mathrm{~km}$ in arta which contains randomly oriented quartz veinlets with irregularly disseminated pyrite, molybdenite, and chaicopyrite; and minot pymhotite, sphalerite, galena, magnetite, martite, rutile, anatase, and sphene. The ore minerals occur both in the veinlets and in disseminations. $\mathrm{Cu}$ - and Mo-minerals are related to a zone of quartz-biotite-sericitepyrite alteration which occurs in a Paleogene quartz diorite and monzodiorite pluton and in adjacent, intruded Late Cretaceous flysch. The pluton is bounded by a nearly east-west zone of pyritized altered rocks more than II km long and from I to $4 \mathrm{~km}$ wide. The deposit is of small to medium size. Small amounts of gold occur in goethite-cemented, Quatemary alluvial conglomerate near the deposit. 
The Maletoivayam sulfur-sulfide deposit (Vlasov, 1971, 1976, 1977) oceurs at the southern end of the Olyutorka volcanic belt, in the Miocene Korfovsky Formation. Two occurrences, lower and upper, are separated by a $10-50 \mathrm{~m}$ thick bed of kaolinile-montmorillonite and quartz-kaolinite rocks. Both occurrences are dip at 5 -10\% with respect to bedding orientation in the host rocks. The upper ore body can be traced for $1800 \mathrm{~m}$ along strike, is 80 to $700 \mathrm{~m}$ wide, and 3 to $115 \mathrm{~m}$ thick. The ore is disseminated in sulfide-sulfur-alunite silicified rock and in sulfuric silicified rock, which contains most of major native sulfur tonnage. The sulfide-sulfur-alunite silicified rock contains $18 \% \mathrm{~S}, 30-40 \%$ alunite, and $10 \%$ Fe sulfides. The ore contains up to $30 \%$ native sulfur. Native sulfur of $96-99 \%$ purity is separated using thermal reduction. About $60 \%$ potassium sulfate is also separated. The deposit is large and contains up to $30 \% \mathrm{~S}$.

\section{Origin of and Tectonic Controls for Olyutor Metallogenic Beit}

The East Kumchatka volcanic belt which hosts the northern part of the Olyutor metallogenic belt consists chiefly of a major chain of modem volcanoes of Pliocene and younger age (Nokleberg and others, 1994c, 1997c). The main lithologies are basalt, andesite-basalt, rare dacite, and tuff. The belt is the northward continuation of modern Kuril volcanic are which started to form in the Neogene.

The Central Kamchatka volcanic belt which hosts the central and southern parts of the Olyutor metallogenic belt extends for $1,500 \mathrm{~km}$ longitudinally the Kamchatka Peninsula (Sredinny Range). The volcanic belt contains the modern-day Kamchatka voleanic arc. The belt consists chiefly of thick, gently dipping andesite, dacite, and rhyolite strata interlayered with sandstone, siltstone, and conglomerate, and widespread large ignimbrite fields (Nokleberg and others, 1994c). The belt ranges from Oligocene to Holocene age. Shallow-marine deposits predominate in the lower part and nonmarine deposits predominate in the upper part. Formation of the bell culminated with eruptions of Pliocene to Quatemary plateau basalts which are associated with stratovoleanoes (Filatova, 1988). A minimal crustal thickness of 27 to $33 \mathrm{~km}$ occurs in the region. The Central Kamchatka volcanic belt is tectonically linked to the Kuril-Kamchatka accretionary wedge and subduction zone terrane and to the Cenozoic subduction of the Pacific Plate along the Kuril-Kamichatka megathrust (Nokleberg and others, 2000).

\section{Pinchi Lake Metallegenic Belt of $\mathrm{Hg}$ Epithermal Vein, Sb-Au Vein, and Silica-Carbonate Hg Deposits (Belt PC) Central British Columbia}

The Pinchi metallogenic belt of $\mathrm{Hg}$ epithermal vein, Sb-Au vein, und silica-carbonate $\mathrm{Hg}$ deposits occurs in central British Columbia (fie. 103; tables 3,4) (Nokleberg and others, 1997b, 1998). The belt is $100 \mathrm{~km}$ long, contains 12 or more $\mathrm{Hg}$ mines and prospects, and occurs along the faulted castern boundary of Cache Creek terrane with the Stikinia terrane. Although no known Eocene or Oligocene intrasions exist, the mercury mineralization is interpreted as early Tertiary in age. The significant deposits are at Pinchi Lake.

\section{Pinchi Lake Sillica-Carbonate Hg Deposits}

The Pinchi Lake and smaller Bralorne Takla silica-carbonate Hg deposits (Armstrong. 1949; Dawson and others, 1991) consist of cinnabar which occuns in a stockwork of thin quartz veins, replacements, lodes and breccia fillings. The deposit is hosted in marine limestone and carbonatized ultramafic rocks which occur in shears along the Pinchi Fault which separates the Mississippian to Triassic Cache Creck terrane from the Lale Triassic and Early Jurassic Quesnellia island-are terrane. The host ultramafic rocks, chert, argillise, and greenstone of the Cache Creek ophiolite are intensely altered along the fault zones to an assemblage of Fe-Mg carbonates, quartz, mariposite and talc. Mincralization postdated both the Late Triassic blueschists and Late Cretaceous-early Tentiary conglomerases. Between 1942 to 1975 , estimated production was 6000 tonnes of He. Estimated reserves are 1.1 million tonnes grading $0.32 \% \mathrm{Hg}$.

\section{Pinchi Lake District of SO-Au Vein Deposits}

The $\mathrm{Sb}$-Au vein deposits in the Pinchi Lake district oecur in the same geological settings as which of the silica-carbonate $\mathrm{Hg}$ deposits. Both types of deposits exhibit the same, distinctive, green, silica-carbonate-mariposite or listwanite alteration assemblage. The Snowbird Au-Sb prospect at Stuart Lake consists of quartz-stibaite veins is a shear zone of silica-carbonate mincrals. The shear zone occurs in sedimentary rocks of the Cache Creek terrane. Inferred reserves are 227,000 tonnes grading $6.86 \mathrm{~g} / \mathrm{Au}$ (Madu and others, 1990). The Lust Dust Au-Ag-2n-Sb deposit consists of veins and replacements composed of quartz-stibnite-boulangerite-sphalerite-pyrite. The veins asd replacements occur in a shear zone in folded sedimentary rocks of the Cache Creek Ierrane (Armstrong. 1949). The Indata Lake Au-Ag prospect is composed of quartz-pyrite-arsenopyrite-chalcopyritestibnite veins which occur in sheared and brecciated volcanic rocks of the Takla Assemblage and limestone of the Cache Creek 
terrane (Eastfield Resources Lid., News Releases of October, 28, November 4, December I, 1987). The deposit and sheared rocks oceur along a splay of the Pinchi Fault.

\section{Origin of and Tectonic Controls for Pinchi Lake Metallogenic Beft}

The deposits in the Pinchi metallogenic belt posidate the host bedrock units, both the Late Triassic blueschist of the Cache Creek terrane and overlying Late Cretaceous and early Tertiary conglomerate (Paterson, 1977). The deposits occur in shears along the Pinchi Fault which separates the Mississippian to Triassic Cache Creek terrane from the Late Triassic Quesnellia island-are terrane. The fault is interpreted as providing a zone of permenbility for mercury-bearing bydrothermal solutions (Dawson and others, 1991). Reactivation and shearing along the fault, and formation of the deposits may have oceurred during a period of uplift, magmatism, and transcurrent faulting in the Eocene and Oligocene (Gabrielse, 1985), possibly related to the Cascade volcanic-plutonic belt to the south. No known Eocene or Oligocene intrusions exist in the region.

Owl Creek Metallogenic Belt of Porphyry Cu-Mo, Porphyry Mo, and Au Polymetallic Vein Deposits (Beit OC) Southern British Columbia

The Owl Creek metallogenic belt of porphyry Cu-Mo, porphyry Mo and Au polymetallic vein deposits (fig. 103; tables 3, 4) occurs in southem British Columbia and is associated with a belt of late Tertiary plutons which extends from northern Washington into the Coast Plutonic Complex. The plutons are mostly small, circular quartz monzonite to dioirite plugs which intrude major. northwest-trending shear zones. These granitoid rocks are part of the middle Tertiary to Recent Cascade continental-margin are which occurs in the USA Pacific Northwest and southern British Columbia (Nokleberg and others, 1994c, 1997c; Monger and Nokleberg, 1996). The significant deposits in the belt are the Owl Creek district porpbyry Cu-Mo deposits, and the Clear Creek (Gem) porphyry Mo deposit (table 4) (Nokleberg and others 1997a, b, 1998). The deposits is the Ow1 Creek metallogenic belt are hosted in or near: (1) calc-alkaline, high-level plutons of the Chilliwack suite which is part Chilliwack Batholith on the British Columbia-Washington border; and (2) the Doctor's Point pluton on Harrison Lake which is coeval and probably cogenetic with the Pemberton belt of late Tertiary volcanic rocks (Souther, 1991; Woodsworth and others, 1991). The significant deposits are at: Clear Creek (Gem), Owl Creek district, and Salal Creek. Lesser deposits occur at Harrison Gold (Abo) and Doctor's Point. These mesothermal Au polymetallic vein deposits are intimately associated with $25-\mathrm{Ma}$ quartz diorite intrusions, and either consist of veins in homfels adjacent to the stiock, as at Doctor's Point, or as vein stockworks within the quartz diorite pluton, as at Harrison Gold (Ray, 1991). The veins contain quart2, pyrrbotite, and pyrite, and minor chalcopyrite, molybdenite, scheelite, and rare bismuth telluride minerals (Dawson and others, 1991). Also occurring in the metallogenic belt are Au polymetallic vein deposits at Boundary Red Mountain and Lone Jack mines which are located along the westem part of the Chilliwack Batholith in Washington (Ray, 1986).

\section{Clear Creek (Gem) Porphyry Mo Deposit}

The Clear Creek (Gem) porphyry Mo deposil consists of an arcuate zone of molybdeaite with minor pyrite and sphalerite which occur in quartz and calcite veins and as fracture filling (EMR Canada, 1989, MINFIL.E, 2002). Estimated reserves are 15.9 million tonnes grading $0.07 \%$ Mo (MINFILE, 2002). The deposit occurs in an arcuate zone around the northeast margin of an Oligocene quartz monzonite stock, named the Gem Stock, with a K-Ar isotopic age of $35 \mathrm{Ma}$. The stock intrudes quartz dionite and granodiorite of the mid-Cretaceous Spuzzum pluton, and schist and gneiss of the Cretaceous Settler Schist.

\section{Owl Creek Porphyry Cu-Mo District}

The Owl Creek porphyry Cu-Mo district consists of veins and disseminations of chalcopyrite, molybdenite, and pyrite with minor bornite which occur as blebs, disseminations and fracture fillines (Mahoney, 1977; EMR Canada, 1989; MINFILE, 2002). Estimated resources are 10 to 20 million tonnes grading 0.3 to $0.4 \% \mathrm{Cu}$ and $0.03 \% \mathrm{MoS}_{2}$ (MINFIL., 2002).The deposit is hosied in probable mid-Tertiary quartz diorite and feldspar porphyry of the Coast Plutonic Complex, and in propylitic- and argillic-aliered and voleanic rocks of the Late Triassic Cadwallader Group (Maboney, 1977).

\section{Salal Creek Porphyry Mo Deposit}

The Salal Creek porphyry Mo deposit occurs along the contact between a fine-grained granite core and a medium-grained granodiorite margin of a pluton dated which has a K-Ar isotopic age of $8 \mathrm{Ma}$ (Stephens, 1972). The deposit cxhibits in a typical ring or circular partern. To the north is the Franklin Glacier porphyry Cu-Mo prospect which has a K-Ar isotopic age of 7 Ma (Dawson and others, 1991). 
The Owl Creek metallogenic belt of porphyry Cu-Mo, porphyry Mo and Aa polymetallie vein deposits is hoated in a belt of late Tertiary plutons which approximately coincide with the Pemberion belt of late Tertiary and Quatemary volcanic rocks (Woodsworth and others, 1991; Souther, 1991). K-Ar ages of the pluton rocks progressively decrease northward, from between 35 and $16 \mathrm{Ma}$ in the south, to about $7 \mathrm{Ma}$ in the north. These relatively young plutonic rocks and associated volcanic rocks are part of the Cascade volcanic-plutonic belt of the U.S.A. Pacific Northwest and southern British Columbia (Nokleberg and others, 1994c, 1997 c. 2000).

In the Canadian Cordillera, the Cascade volcanic-plutonic belt consists of Pleistocene and Holocene basalt, andesite, and dacite eruptive centers, and late Eocene(2). Oligocene, and Miocene plutons (Chilliwack and Mount Barr batholiths). In U.S.A. Pacific Northwest, the belt consists of volcanic rocks of stratovolcanoes, mostly andesite but ranging from basalt to thyolite. The bell includes interbedded fluvial and lacustrine deposits and minor tonalite to granodiorite plutons. In Washington, parts of belt are included in the Ohanapecosh, the Fifes Peak, and the Northeraft Formations (Vance and others, 1987; Smith, 1993). The youngest active volcanoes in the belt are Mount Jefferson, Mount Hood, Mount Adams, Mount St. Helens, and Mount Rainier.

The Cascade volcanic plutonic belt and corresponding Caseade continental-margin ase is interpreted as forming in response to subduction of the Juan de Fuca Plate (Wells and Heller, 1988; England and Wells, 1991; Monger and Nokleberg. 1996; Nokleberg and others, 2000). Remnants of the subducting plate are preserved in the Siletzia, Olympic Core, and Hoh terranes along branches of the Cascadia megathrust.

\section{Middle Tertiary Metallogenic Belts (20 to $10 \mathrm{Ma}$ ) (Figures 125, 126)}

\section{Overview}

The major middle Tertiary metallogenic belts in the Russian Far East and the Canadian Cordillera are summarized in table 3 and portrayed on figures 125 and 126. The major belts are as follows. (1) In the Russian Northeast, the Central Kamchatka (CK) belt, which contains granitic-magmatism-related deposits, and the East Kamchatka (EK) belt, which contains $\mathrm{Au}-\mathrm{Ag}$ epithermal vein deposits, are hosted in the Central Kamchatka volcanic and sedimentary basin, and are interpreted as forming during subduction-related granitic plutonism which formed the Kamchatka Peninsula part of Northeast Asia continental margin arc. (3) In Southem Alaska, the Alaska Peninsula and Aleutian Islands (AP) belt, which also contains granitic-magmatism-related deposits, is bosted in the Aleutian volcanic belt and is interpreted as forming during subduction-related granitic plutonism which formed the Aleutian continental margin arc. And (3) in the southern Canadian Cordillen, continuing on from the early Tertiary was the $\mathrm{Ow}$ ] Creek $(\mathrm{OC})$ belt, which contains granitic-magmatism-related deposits and is hosted in the Cascade volcanic-plutonic belt, is interpreted during subduction-related granitic plutonism which formed the Cascade continental margin arc. In the below descriptions of metallogenic belis, a few of the noteable or signficant lode deposits (table 4) are described for cach belt.

\section{Metallogenic-Tectonic Model for Middle Tertiary (20 to10 Ma; fig. 127)}

During the middle Tertiary (Miocene - 20 to $10 \mathrm{Ma}$ ), the major metallogenic-tectonic events were (fig. 127; table 3); (1) continuation of a series of continental- margin ares, associated metallogenic belts, and companion subduction-zone assemblages around the Circum-North Pacific; (2) back-are spreading behind the major ares; (3) opening of major sedimentary basins behind major ares; (4) in the eastem part of the Circum-North Pacific, a continuation of dextral transpression between the Pacific Ocean plate and the Canadian Cordillera margin, and a continuation of orthogonal transpression between the Pacific plate and the Southem Alaska continental margin; and (5) continued sea-floor spreading in the Arctic and eastern Pacific Oceans.

\section{Specific Events for Middle Tertiary}

(1) After accretion of various terranes in the early Eocene and outward stepping of subduction, the Northeast Asia arc commenced activity. Parts of this are are preserved in the East Japan volcanic-plutonic belt (ej), Kuril volcanic arc (ku), and the various parts of the Kanchatka arc consisting of the Central Kamchatka volcanic belt (kc), Central Kamchatka volcanic and sedimentary basin (ck), and West Kamchatka sedimentary basin (wk). To the northeast, the Okhotsk-Chukotka arc ceased activity. These two major Andean-type arcs overlapped previousty accreted adjacent terranes in both the Russian Southeast and to the south and estended for a distance of about $3,000 \mathrm{~km}$. Associated with these ares was subduction of part of the Pacific Ocean plate (PAC) along the Kuril-Kamchatka megathrust (KK) to form the Kuril-Kamchatka (KUK) subduction-zone terrane. Intra-are faulting resulted in tectonic doubling of the Kamchatka-Koryak (kk) are which started to become extinct as the Central Kamchatka arc (kc) enlarged. Forming in the Kamchatka part of the Northeast Asia arc was the Central Kanschatka (CK) metallogenic belt, which contains granitic-magmatism-related deposits, and is hosted in the Central Kamchatka volcanic and sedimentary basin. 


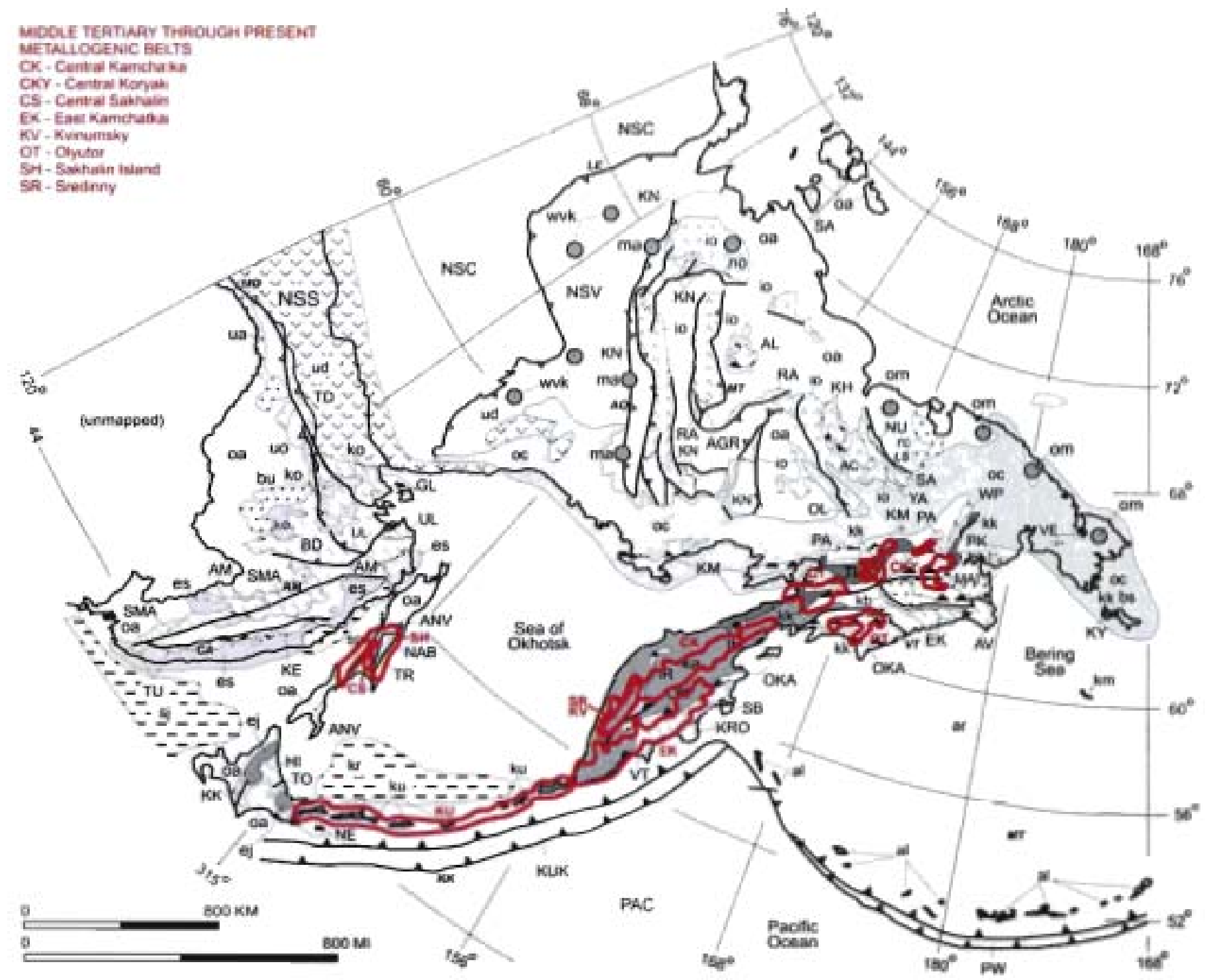

Figure 125. Generalized map of major Tertiary through Present metallogenic belts, overlap assemblages, and tectonically-linked subduction-zone or accrefionary-wodge terranes for Russian Far East, northem Japan, and adjacent offshore areas. Refer to text for description of metallogenic belts. Adapted from Nokleberg and others (1997b, 1998). Refer to figure 59 for explanation.

(2) Regional extension associated with back-arc spreading behind the northern Japan part of the Northeast Asia arc (East Japan volcanic-plutonic belt, ej), resulted in marine eruption of the Sea of Japan back-arc unit (sj) which consists of mainly tholeitic basalt and associated rocks.

(3) In the Sea of Okhotsk, back-arc spreading occurred behind the Kuril lsland and Kamchatka Peninsular part of the Northeast Asia are (B.A. Natal'in in Nokleberg and others, 1994a), resulting in marine and continental enuption of tholeiitic to alkalic basalt and associated rocks forming Sakhalin-Primorye volcanic belt (sp). This regional extension is also interpreted as the result of seaward rotation of the Kamchatka Peninsula, and in formation of major units within the Sea of Okhotsk (as discussed by B.A. Natal' in in Nokleberg and others, 1994a). Back-are spreading may have occurred simultaneously with trench roll-back and migration of the Northeast Asia are into the Pacific Ocean plate.

(4) In the Arctic Ocean, rifting continued along the Gakkel Ridge (GK) along with continued sedimentation in the Amerasia basin (as). Analysis of marine magnetic anomalies in the Eurasia Basin suggests this region underwent compression from about 36-5 Ma (Savostin and Drachev, 1988a, b; Harbert and others, 1990; Fujita and others, 1997). Geologic mapping reveals which late Miocene thrust faults and companion folds, which were associated with regional compression, occurred along the Myatisk and companion faults in the Mona and Chersky Ranges as described by Gaiduk and others (1989, 1993). Fault displacements are about 15 to $20 \mathrm{~km}$. 
(5) A major orthogonal junction formed between the westem end of Aleutian-Wrangell are (al) and Central Kamchatka arc (kc). The western leminus of the Aleutian-Wrangell arc is interpreted as having been obducted onto the Kamchatka Peninsula, thereby forming the Kamchatskiy Mys oceanic ternane ( 100 small to depict on fig. 127 , which is interpreted as the oceanic base of the ancestral Aleutian-Wrangell arc, and the Stolbovskoy island-are terrane (also too small to depict on fig. 127), which is interpreted as the older. western pan of the are (Geist and others, 1988, 1994).

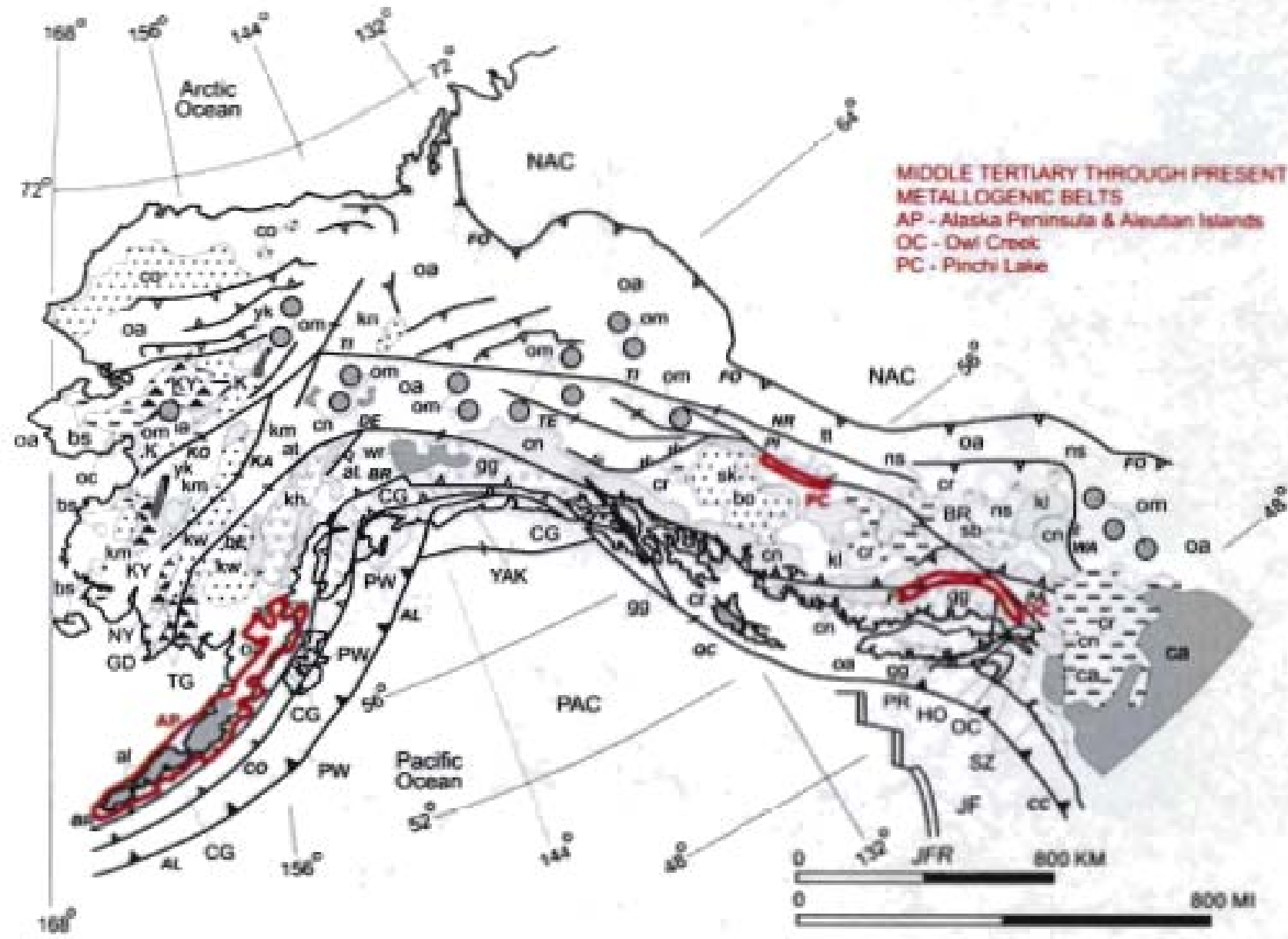

Figure 126. Goneralized map of major middle Tertiary through Present metallogenic belts, overtap assemblages, and tectonicallylinked subduction-zone or accretionary-wedge terranes for Alaska, Canadian Condillera, and adjacent olfshore aroas. Refor to text for description of metaliogenic belts. Adapted from Nokleberg and others (1997b, 1998). Refer to flgure 60 for explanation.

(6) In the early to middle Miocene, a short episode (approximately 22 to $10 \mathrm{Ma}$ ) of sea-floor spreading along the Komandorsky Ridge (KOM) formed a small pair of oceanic plates which exhibit magnetic anomalies 5 and 6. The spreading occurred after the marine-are volcanism in this area which formed the Bowers (bw) and Shirshov (sh) Ridges in the middle Eocene and early Miocene.

(7) Intense tectonic disruption occurred in the western part of Aleutian-Wrangell arc, along the western Aleutian megathrust (AL), as a result of the transform coupling between the Pacific and North American plates (Geist and others, 1988). A complex array of strike-slip, extension, and rotation structures formed in this area (Scholl and others, 1992, 1994; Vallier and others, 1994). In the area of the Bering Sea, a thick sedimentary prism continued to form in the Aleutian-Bowers basin (atb) which overlies a fragment of accreted Kula Ocean plate (Plafker and Berg. 1994; Scholl and others, 1992, 1994),

(8) Tectonic escape (cristal extrusion) of terranes continued to occur along major dextral-slip faults, including the Denali $(D E)$, Iditarod-Nixon Fork (NF), Kaltag $(K A)$, and companion faults (Scholl and others, 1992, 1994). Dextral-wrench basins continued to form in association with the dextral-slip faults and were rapidly filled with continental sediments. Dextral displacement continued farther east along major dextral-slip faults such as the Denali $(D F)$, Iditarod-Nixon Fork (NF), and Kaltag (KA) faults, Estimates of total Cenozoic displacements along the Denali and Tintina faults are between 400 and $500 \mathrm{~km}$ cuch (Nokleberg and others, 1985; Plafker and Berg, 1994; Monger and Nokleberg, 1996). These and companion dextral-slip faults probably extended into the area of the Bering Sea.

(9) The Pacific Ocean plate (PAC) continued to move northwestward. Along the Aleutian megathrust (AL) plate convergence continued to vary from oblique-orthogonal in the east to oblique to transform in the west. 
(10) The Aleutian-Wrangell continental-margin are was associated with mainly oblique subduction of the northern edge of Pacific Ocean plate (PAC) along the Aleutian megathrust $(A L)$ to form the Prince William terrane (PW). During northward migration, the Yakutat terrane (YA) started to underthrust the Prince William terrane along the eastern part of the Aleutian megathrust. Forming in the Aleutian-Wrangell continental-margin arc in Southern Alaska was the Alaska Peninsula and Aleutian Islands (AP) metallogenic belt which contains granitic-magmatism-related deposits and is hosted in the Aleutian volcanic belt.

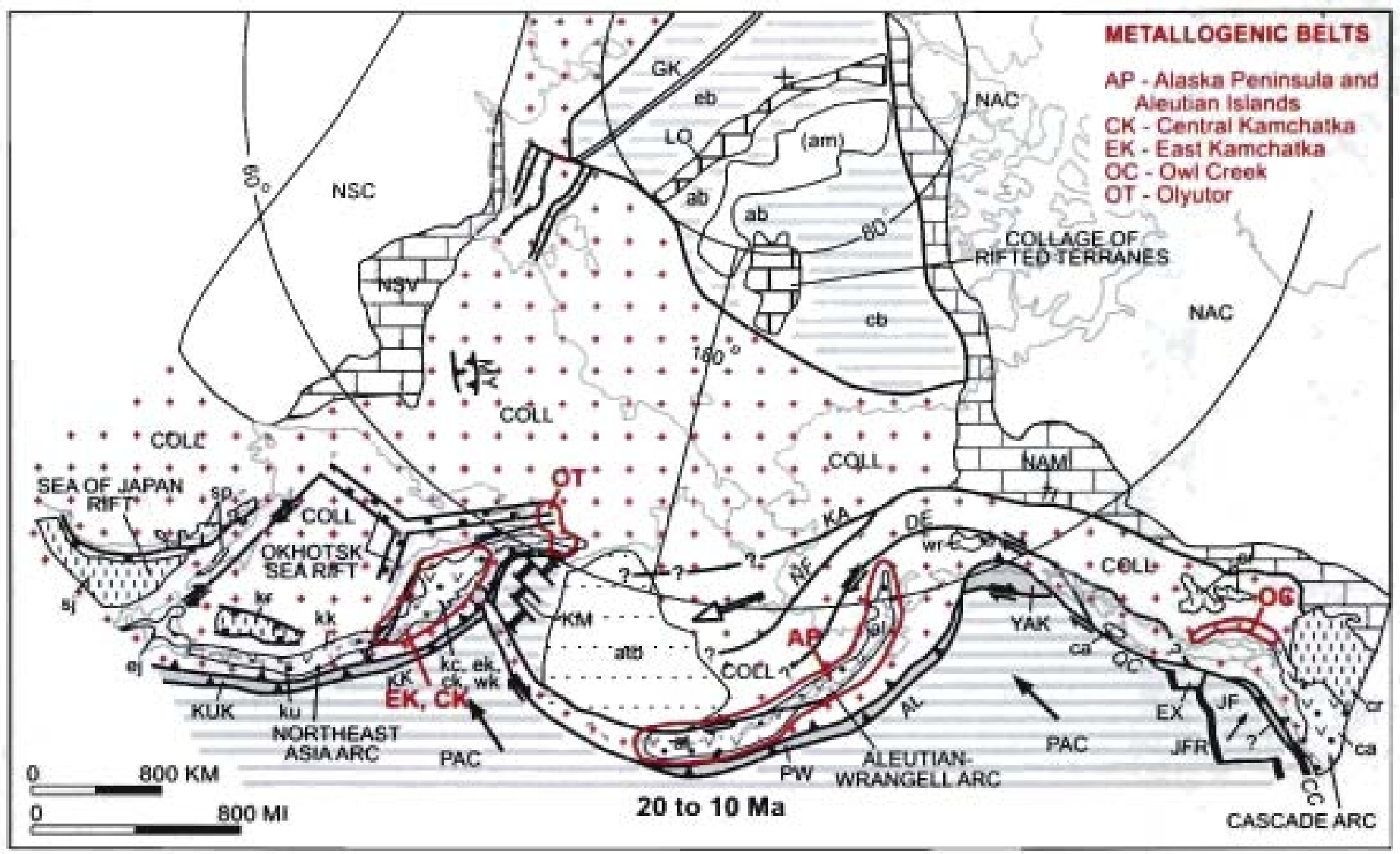

Figure 127. Middle Tertiary (Miocene - 20 to $10 \mathrm{Ma}$ ) stage of metallogenic-tectonic model. Refer to lext for explanation of metallogenic-tectonic events, to tables 3 and 4 for descriptions metallogenic belts and significant deposits, and to figure 18 for explanation of abbreviations, symbols, and patterns. Adapted from Nokleberg and others (1997b, 1998, 2000).

(11) Offshore of the southem Canadian Cordillera, sea-floor spreading continued along the Juan de Fuca Oceanic ridge (JFF). Northward movement of the Pacific Ocean plate (PAC) and associated transform displacement on the Queen Charlotte transform fault $(Q C)$ resulted in continued northward migration and subduction of the Yakutat terrane (YA) beneath the continental margin of Southern Alaska.

(12) To the south, the Cascade continental-margin arc continued activity. Associated with this are was continued subduction of part of the Juan de Fuca plate (JF) along the ancestor of the modem Cascadia megathrust ( $C C$ ). Regional extension, associated with back-are spreading the behind Cascade arc (ca ), resulting in continental eruption of the Columbia River basalt (cr; Wells and Heller, 1988; England and Wells, 1991). Continuing on from the early Tertiary in the Cascade are was the was the Owl Creek $(O C)$ metallogenic belt, which contains granitic-magmatism-related deposits, and is interpreted during subduction-related granitic plutonism. 


\section{Metallogenic Belts Formed in Tertiary \\ Continental-Margin Arcs, Kamchatka \\ Peninsula, Southern Alaska, and \\ Southern Canadian Cordillera}

\section{East Kamchatica Metallogenic Beit of Au-Ag Epithermal Deposits (Beit EK) \\ Eastern and Southern Kamchatka Peninsula}

The East Kamchakka metallogenic beit of Au-Ag epithermal deposits (fig. 125; tables 3,4) occurs in the eastern and southern parts of the Kamchatka Peninsula. The deposits are hosted in the East-Kamchatka volcanic belt which overlies late Mesozoic and Cenozoic island-are and terranes of accretionary-wedge terranes (Pozdeev, 1990). The Au-Ag epithermal deposits, most of which are economic or are potentially economic, are associated mainly with Miocene voleanoes, hypabyssal bodies, and small intrusions. The significant deposits in the belt are at Asachinskoe, Kitkhoi, Kumroch, Mutnovskoe, and Rodnikovoe (table 4) (Nokleberg and others 1997a, b, 1998).

The Au-Ag epithermal vein deposits in the East Kamchatka metallogenic belt are interpreted as forming in two stages (Petrenko, 1999), (1) In the early Miocene, Au-Ag $( \pm \mathrm{Zn}, \mathrm{Pb}$ ) epithermal vein and stockwork deposits, as at Mutnovskoe, Kumroch, and Kitkhoi, formed during enuptions of intermediate and felsic volcanic rocks and during formation of small dioritegranodiorite intrusions (Lattanzi and others, 1995), The major metals ase $\mathrm{Au}, \mathrm{Pb}$, and $\mathrm{Zn}$, along with $\mathrm{Ag}$ and sulfosalts. And (2) in the late Miocene, Au quartz-adularia epithermal vein deposits, as at Rodnikovoe and Asacha deposits, formed in andesite-basaltic piles associated with hypabyssal bodies, and in mafic, intermediate, and felsic dikes. The deposits are sulfide poor and are associated with propyllitic alteration. Some of the deposits may be Pliocene; bowever, K-Ar isotopic studies of stockworks, dikes, and adularia-quartz veins yield ages of 12 to $5 \mathrm{Ma}$, indicating a Miocene age. The association of sulfide-rich and sulfide-poor epithermal deposits in the East Kamcbatka metallogenic belt suggests diverse volcanic processes (Pozdeev, 1990; Lattanzi and otbers, 1995). A recent study by Takahashi and others (2002) presents a 4-fold classification of epithermal Au-Ag mineralization in Kamchatka: (1) Late Cretaceous Okhotsk-Chukotka Belt (Sergeevka deposit); (2) the middle Tertiary Koryak-Western Kamchatka Belt (including the Ametistovoe deposit with a K-Ar isotopic age of $41.4 \mathrm{Ma}$ ); (3) the late Tertiary Central Kamchatka belt (including the Zolotoy deposit with a K-Ar isotopic age of $17.1 \mathrm{Ma}$, and the Aginskaya deposit with a K-Ar isotopic age of $6.9 \mathrm{Ma}$ ); and (4) the Eastern Kamchatka belt (including the Asachinskoye, Mutnovskoe, Rodnikovoe, and Porozhistovoe deposits with K-Ar isotopic ages 0.9-7.4 Ma). An overview of the major Au-Ag epithermal vein deposits of the Kamchatka was published by Petrenko (1999).

\section{AsachinskoeAu-Ag Epithermal Vein Deposit}

The AsachinskoeAu Au-Ag epithermal vein deposit (Shchepotev, 1989; I.D. Petrenko, written commun, 1991; A.I. Pozdeev, written commun. 1991; Petrenko, 1999; Oknugin and others, 2002) consists of a zone of quartz-adularia veins that oceur along a north-south trending, strike-slip fault. Veins split and pinch out in tuff and andesitic lava. Ore body is a nearly flat-lying band, gently dipping to the south, and conformable to the bypabyssal host rocks. Ore exhibits colloform-banded structure. Ore minerals comprise less than $1 \%$ of the veins. Ore mineral assemblages are: gold-hydromica, gold-aaumanite-polybasite, and goldadularia-quartz. Major ore minerals are pyrite, gold, selenium polybusite, and naumanite. Deposit occurs in center of a hypabyssal dacile dome at the intersection of three large linear faults. Deposit associated with hypabyssal volcanic rocks that are inferred in cross-section. A K-Ar isotopic age for the deposit is $4 \mathrm{Ma}$ (Takahashi and others, 2001). The deposit is medium size with up 1020 $\mathrm{g} / \mathrm{Au}$ and $40.50 \mathrm{~g} / \mathrm{Ag}$. Estimated reserve are 1.56 million tonnes averaging $35 \mathrm{~g} / \mathrm{Au}$ and $62 \mathrm{~g} / \mathrm{Ag}$.

\section{Mutnovskoe Av-Ag Epithermal Vein Deposit}

The Mutnovskoe Au-Ag epithermal vein deposit (Sheheporev, 1989; L.D. Petrenko, written commun., 1991; Lattanzi and others, 1995: Petrenko, 1999, Oknugin and others, 2002) deposit occurs in the central part of a paleovolcano composed of Oligocene-Miocene mafic- and intermediate-composition volcanic rocks. Plutonic rocks consist of Miocene diorite intrusions and numerous dikes of varied composition. Major ore zone consists of a thick vein and some apophyses with zones of quartz veinlets between them. Drilling indicates which ore extends to a depth of $500 \mathrm{~m}$ below the surface. In heavily weathered zones, generally at the southern flank of the deposit, quartz veins contain from $10-18 \%$ sulfides. On the less weathered northern flank, the deposit is sulfide-poor and contains $0.2-2 \%$ base metals. The major ore assemblages are gold- tennantite-tetrahedrite, gold-argentitepearsite, and chlorite-galena-sphalerite. Canfieldite, as well as the telluride minerals, hessite and altaite, also occur. The deposit is vertically zoned, with gold, tennantite, and tetrahedrite occurring in the upper part of the veins, and chalcopyrite, galena, sphalerite occurring in the lower part of the veins. The K-Ar age of mineralization for the north flank of the Mutnovakoe deposit is 3.3 Ma and $1.1 \mathrm{Ma}$ for the south flank of the deposit (Takahashi and others, 2001). The deposit is of medium size. Average grades range up to $3 \mathrm{~g} / \mathrm{Au}$ and $10 \mathrm{~g} / \mathrm{Ag}$. Proven reserves are to the North, 1.8 million tonnes of ore averaging $16 \mathrm{~g} / \mathrm{Au}$ and $315 \mathrm{~g} / \mathrm{Ag}$, and to the South, 5.2 million tonnes of ore averaging $12.4 \mathrm{~g} / \mathrm{Au}, 1300 \mathrm{~g} / \mathrm{Ag}$, and 69,000 tonnes combined $\mathrm{Pb}$ and $\mathrm{Zn}$. The deposit contains an estimated resource of about 20 tonnes Au. 
The Rodnikovoe Au quartz-adularia epithermal vein deposit (T.D. Shchepot'ev, 1989; D. Petrenko, written commun., 1991; Petrenko, 1999) consists of a major vein and related quartz and quartz-carbonate veins and veinlets which cut the apical part of a gabbro-diorite intrusion. In addition to gold, the veins and veiniets contain goldfieldite, silver sulfosalts, and argentite. Gold fineness is 400 to 600 . Alteration includes propylitic (chlorite-carbonate and epidote-chlorite facies), kaolinitic, quartz-hydromica alteration with montmorillonite, and silicic with quartz and pyrite. The altered rocks are laterally zoned. The ore occurs in a complex vein system with several funnel-shaped ore shoots which narrow with depth. The shoots dip $30-50^{\circ}$ south. The vertical extent of mineralization is less than $150 \mathrm{~m}$. High Au concentrations (25-30 g/t Au) occur in upper levels of ore bodies. The quartzadularia veins are Late Miocene with K-Ar ages of approximately 0.9 to $1.1 \mathrm{Ma}$ (Takahashi and others, 2001). The deposit is of medium size. Average grades range up to $11.3 \mathrm{~g} / \mathrm{t} \mathrm{Au}$ and $40-50 \mathrm{~g} / \mathrm{t} \mathrm{Ag}$. The estimated reserves are 40 tonnes gold and 356 tonnes silver with an average grade of $11.0 \mathrm{~g} / \mathrm{Au}$ and $98.0 \mathrm{~g} / \mathrm{Ag}$.

\section{Origin of and Tectonic Controls for East Kamchatka Metallogenic Beit}

The Central Kamchatka voleanic belt which hosts the East Kamchatka metallogenic belt consists chiefly of Eocene to Quaternary thick, gently dipping andesite, dacite, and rhyolite strata which are interiayered with sandstone, siltstone, and conglomerate, and widespread large ignimbrite fields. Shallow-marine deposits predominate in the lower part and nonmarine deposits predominate in the upper part. The formation of the belt culminated with enuptions of Pliocene to Quaternary plateau basalts which are associated with large composite cone volcanoes. The volcanic belt is interpreted as a major post-accretionary continental-margin arc which is tectonically linked to the Kuril-Kamchatka accretionary wedge and subduction zone complex (fig. 125) (Nokleberg and others, 1994c, 1997c).

\section{Central Kamchatka Metallogenic Belt of Au-Ag Epithermal and Porphyry Cu-Mo Deposits (Belt CK) Kamchatika Peninsula}

The Central Kamchatka metallogenic belt of Au-Ag epithermal vein and porphyry Cu-Mo deposits (fig. 125; tables 3,4) occurs along the length of the Kamchatka Peninsula. The deposits are hosted in the Central Kamchatka volcanic and sedimentary basin of Oligocene to Holocene age (Nokleberg and others, 1994c, 1997c). The significant deposits in the belt are (table 4) (Nokleberg and others 1997a, b, 1998): Au-Ag epithermal vein deposits at Aginskoe (Aga), Baran'evskoe, Oganchinskoe, Ozemovskoc, Sukharikovskie Grebni, Tutkhlivayam, and Zolotoi; a porphyry Cu-Mo deposit at Krasnogorskoe; and a volcanichosted $\mathrm{Hg}$ deposit at Chempura.

The Au-Ag epithermal vein deposits are interpreted as forming mainly during two stages in the Miocene. (1) In the early Miocene (22 to $14 \mathrm{Ma}$ ), during eruption of mainly felsic volcanic rocks, low sulfide, Au-Ag deposits, as at Ozemovskoe and Tutkhlivayam, with high Te contents, formed during construction of composite cone volcanoes and associated hypabyssal intrusions. At the same time, sulfide Au deposits, as at Olgakanskoe, with high $\mathrm{Cu}, \mathrm{Pb}$, and $\mathrm{Zn}$ contents, formed in association with intermediate intrusions. However some of these deposits may have formed during the Late Eocene to Oligocene. And (2) in the late Miocene (12 to $5 \mathrm{Ma}$ ), in the final stages of Miocene volcanism, andesitic and basaltic alterations. Au ( $4 \mathrm{Ag}$ ) epithermal vein deposits formed in association with small hypabyssal bodies and dikes, as at Aginskoe, Sukharikovskie Grebni, and Baran'evskoe deposits and some ore bodies of Tutkhlivayam deposit. These deposits consist mainly of gold and minor sulfide minerals in quartz-adularia veins. In the middle and northem parts of the belt, $\mathrm{Hg}$ deposits, as at Chempura, and $\mathrm{Au}$ and $\mathrm{Au}-\mathrm{Ag}$ epithermal vein deposits occur in late Miocene hypabyssal bodies and dikes.

Porphyry Mo, Cu, and Cu-Mo deposits in the southem part of the belt occur in Miocene subalkaline granite porphyry and porphyritic diorite. These granitoid plutons intrude areas underlain by the eastern part of the Sredinny-Kamchatka metamorphic terrane. These deposits, as at Kirganik, Krasnogorskoe, and Malakhitovoe, are small to medium-size, and occur mainly in stockworks and in long fracture zones in both intrusions and adjacent metamorphic rocks. The major ore minerals are pyrite, chalcopyrite, and molybdenite. Molybdenite contains high amounts up to $600 \mathrm{~g} / \mathrm{t}$ rhenium.

\section{Ozernovskoe Au-Ag Epithermal Vein Deposit}

The large Ozernovskoe Au-Ag epithermal vein deposit (Shchepot'ev, 1989) consists of Au-bearing quartz-adularia veins along with $\mathrm{Cu}-\mathrm{Mo}$, realgar-orpiment, and $\mathrm{Au}-\mathrm{Ag}$ deposits. The $\mathrm{Au}-\mathrm{Ag}$ deposits occurs in veinlets and disseminations and is superimposed on various facies of hydrothermally-altered rocks. Ore formed in fracture-filling veins and veinlets, and as metasomatic replacement of earlier aggregates. At least four stages of mineralization are recognized: (1) gold-goldfieldite-quartz (fineness of 933-938); (2) tellurium-silvanite-goldfieldite-kaolinite-quartz gold 945 fine; (3) gold-hessite-hydromica-quartz (gold 894 fine); and (4) gold-adularia-hydromica-quartz (gold 643 to 679 fine). Host rocks exhibit several types of alteration, mainly propylitization and silicification. Argillite, displaying quartz-sericite, quartz-kaolinite, and quartz-montmorillonite-hydromica facies alteration, occurs in the central part of the ore field, near the main volcanic vent. Altered rocks consist of quartz and pyritealunite-kaolinite-quartz assemblages which form linear bodies up to $100 \mathrm{~m}$ thick along the fault zones. The largest ore bodies 
occur in these tabular, altered silicified rocks. The deposit occurs in a weakly-eroded volcano composed of basaltic andesite, andesile, and dacitic pyroclastic rocks and lava. The deposit is large and contain 0.01-0.1\% Te and Au in rare high-grade zones, up to $700 \mathrm{~g} / \mathrm{Aul}$. Most of the ore is low-grade, ranging from $2-20 \mathrm{~g} / \mathrm{Au}$.

\section{Aginskoe Au-Ag Epithermal Vein Deposit}

The Aginskoe Aa-Ag epithermal vein deposit (Shchepot'ev,1989) consists dominantly of fine-grained, chalcedony-like quartz, adularia, and hydromica with colloform banding. The ore minerals comprise 0.3 to $1.0 \%$ of veins. The major ore minerals are tellurides, including hessite, altaite, calaverite, silvanite, and petzite. A total of 55 ore minerals are identified. Gold fineness ranges from 740 to 990, and the Au/Ag ratio varies from 2:1 to 7:1. Six stages of ore deposition are recognized: (1) quartz-pyrite; (2) gold-adularia-corrensite-quartz with a gold fineness of 924 to 968 ; (3) gold-adularia-quartz with a gold fineness of 936 to 952 at upper levels, and a gold fineness of 740 to 854 at deeper levels; (4) gold-calaverite-quartz with a gold fineness 940 to 960 ; (5) gold-hessite-corrensite-quartz with a gold fineness 816 to 880 and (6) quartz-zeolite-calcite. Endogenous zoning is marked by a vertical change of ore composition, lexture, and structure. The concentration of tellurides and sulfides increases with depth. The deposit occurs in a volcanic caldera composed of Miocene basaltic andesite and basaltic andesite tuff. Ore occurs in fracture zones and zones of intense jointing. Ore-bearing structures consist of shear and breceia tectonic zones, which include numerous andesitic dikes and veins, lenses, and veinlets of udularia-quartz and quartz-carbonate composition. The main ore-bearing zones are the Aginskaya and Surpriz. In the main ore-bearing zones, short ore bodies merige at depth forming a gently-dipping mineralized band; complicated in the upper part by steeply-dipping ore shoots. Hydrothermal alteration, commonly propylitic, is common. The deposit is of medium size and contains an estimated resource of 30-50 tonnes $\mathrm{Au}$ and 70-100 tonnes $\mathrm{Ag}$. The average grade of the Aginskoe deposit is $20 \mathrm{~g} / \mathrm{Au}$. The deposit is currently under development.

\section{Kirganik Porphyry Cu Deposit}

The Kirganik porphyry Cu deposit (Vlasov, 1977; A.V. Ignatyev, written commun., 1980) consists of steeply-dipping zones of rocks with biotite-K-feldspar metasomatic alteration. The deposit is $10-15 \mathrm{~m}$ thick, up to $1200 \mathrm{~m}$ long, and occurs in Late Cretaceous siliceous volcanic rocks. The deposit consists of zones of disseminated and veinlet copper and Au minerals. The ore bodies are generally conformable with the host rocks. The oxidized zone extends deepest in heavily fractured rocks, to a depth of 100 to $120 \mathrm{~m}$, and contains up to $0.8 \mathrm{~g} / \mathrm{t}$ Au. The richest ore is in biotite-K-feldspar-metasomatically altered rocks. Altered rocks containing both pyroxene and $\mathrm{K}$-feldspar are practically devoid of ore. The ore minerals are pyrite, chalcopyrite, magnetite, bornite, chalcocite, bematite, and gold. The richest Au values oceur in rich chalcosite-chalcopyrite-bornite ore with more than $1 \%$ $\mathrm{Cu}$. The K-Ar isotopic age of the biotite-K-feldspar-aliered rocks which host the ore is $65-75 \mathrm{Ma}$. The deposit is of medium size. Average grades are $0.1-1 \% \mathrm{Cu}$ and 0.2 to $0.4 \mathrm{~g} / \mathrm{Au}$ in disseminated and veinlet ore, and up to $0.8 \mathrm{~g} / \mathrm{Au}$ in oxidized ore.

\section{Origin of and Tectonic Controls for Central Kamchatka Metallogenic Belt}

The Central Kamchatka volcanic and sedimentary basin (Nokleberg and others, 1994c, 1997c) which hosts the Central Kamchatka metallogenic belt consists chiefly of late Oligocene to Holecene volcanic and sedimentary rocks in sequences up to 5 $\mathrm{km}$ thick. The beit ranges from 20 to $70 \mathrm{~km}$ wide and is about $350 \mathrm{~km}$ long. The volcanic and sedimentary basin also contains mainly shallow-marine sedimentary rocks up to $6.000 \mathrm{~m}$ thick. and widespread tuff, basalt, and basaltic andesite. The basinal units overiy deformed Late Cretaceous to early Tertiary sedimentary rocks. The basin is interpreted as a foreare unit of the Central Kamchatka voicanic belt; both are interpreted as parts of the major, post-accretionary, Northeast Asia continental-margin arc in the Russian Far East (Nokleberg and others, 1994c, 1997c).

\section{Alaska Peninsula and Aleutian lstands Metallogenic Beit of lgneous Arc Deposits (Belt AP) Western-Southern Alaska}

The major Alaska Peninsula and the Aleutian Islands metallogenic belt of igneous arc deposits (fig 126; tables 3, 4) occurs in western-southern Alaska (Nokleberg and others, 1995a). The metallogenic belt is hosted in the area underlain or adjacent to the middle and late Tertiary granitic and voleanic rock of the Aleutian are in the easiern Aleutian Islands and the southwestern Alaska Peninsula (Nokleberg and others, 1994c, 1997c). The are is composed mainly of middle Tertiary to Holocene andesite to dacite flows and tuff, shallow intrusive rocks, small silicic stocks and sills, and associated sedimentary rocks (Burk, 1965: Wilson, 1985). Underlying parts of the southwestern Alaska Peninsula, almost as far west as Cold Bay, is the mainly Mesozoic bedrock of the Peninsular island-are ternane.

Numerous epithermal vein, polymetallic vein, and porphyry $\mathrm{Cu}$ and $\mathrm{Cu}$-Mo deposits oceur in the metallogenic belt. The significant deposits are (table 4) (Nokleberg and others 1997a, b. 1998); epithermal vein deposits at Apollo-Sitka, Aquila, Canoe Bay, Fog Lake (Pond), Kuy. Shamagin, and San Diego Bays polymetallic vein deposits at Braided Creek, Sedanka (Biorka), Cathedral Creek, and Kilokak Creek; and porphyry $\mathrm{Cu}$ and Mo deposits at Bee Creek, Mallard Duck Bay, Mike, Pyramid, Rex, and Sedanka (Biorka). The epithermal and polymetallic vein and porphyry deposits of the Alaska Peninsula and Aleutian Islands 
belt eccur over a distance of over $800 \mathrm{~km}$. This belt is related to the epithermal and bydrothermal activity associated with the latemagmatic stages of Tertiary and Quaternary hypabyssal plutonic and associated volcanic centers. These centers are along part of the Aleutian are, one of the classic continental-margin ares along the rim of the Circum-Pacific rim.

\section{Pyramid Porphyry Cu Deposit}

The Pyramid porphyry Cu deposit (Armstong and others, 1976; Hollister, 1978; Wilson and Cox, 1983; G.L. Anderson, written commun. 1984; R.L. Detterman, oral commun., 1986) occurs in the soutbwestem Alaska Peninsula and consists of disseminated molybdenite and cbalcopyrite(?) in a Fe-stained dacite porphyry stock of late Tertiary age. A zonal alteration pattern is defined by a core of secondary biotite, containing about 3 to $10 \%$ magnetite, which grades outward into an envelope of quartzsericite alteration. Fractures adjacent to the stock are filled with sericite. Local extensive oxidation and supergene enrichment by chalcocite and covellite occur in a blanket as much as $100 \mathrm{~m}$ thick. The deposit is centered on a $3 \mathrm{~km}^{2}$ area within the stock, and contains a resource of 110 million tonnes grading $0.4 \% \mathrm{Cu}, 0.03 \% \mathrm{Mo}$, and trace of $\mathrm{Au}$ (G.L. Anderson, written commun., 1984). The host stocks and dikex, and several smaller stocks which occur nearby all intrude the fine-grained clastic rocks of the Late Cretaceous Hoodoo Formation, and the Paleocene or Eocene to Oligocene Stepovak(?) or Tolstoi(?) Formation. The sedimentary rocks are contact metamorphosed adjacent to the stocks.

\section{Bee Creek Porphyry Cu Deposit}

The Bee Creek porphyry Cu deposit consists of chalcopyrite, pyrite, and traces of molybdenite in contact-metamorphosed Jurassic and Cretaceous sedimentary rocks which are intruded by a small tonalite porphyry stock of Tertiary age (Cox and others, 1981). The deposit, located on the Alaska Peninsula $25 \mathrm{~km}$ northeast of Chignik Lagoon, was discovered by Bear Creek Mining Company in cooperation with Bristol Bay Native Corporation in the late 1970's (E.D. Fields, written commun., 1977). The contact-metamorphosed sedimentary rocks and the porphyry stock exhibit strong potassic (biotite) alteration, and quartz grains in the porphyry contain abundant, high-salinity fluid-filled inclusions. The deposit is unexplored on the southwest and northeast sides and probably contains a resource of between 5 and 30 million tonnes with average grade between 0.1 to 0.4 percent $\mathrm{Cu}$. Five drill holes totaling $2,359 \mathrm{~m}$ explore the deposit; one hole intercepted $150 \mathrm{~m}$ averaging $0.25 \% \mathrm{Cu}$.

\section{Aleutian Are}

The Aleutian arc, which hosts the Alaska Peninsula and Aleutian Islands metallogenic belt, is composed of Oligocene (post-30 Ma) to Holocene andesite to dacite flows, tuff, and intrusive and extrusive breccia; bypabyssal diorite and quartz diorite and small silicic stocks, dikes, und sills; and volcanic graywacke, shale, and lahars (Burk, 1965; Wilson and Cox, 1983; Wilson, 1985; Wilson and others, 1993; Vallier and others, 1994). To the northeast on the Alaska Peninsula, magmatism apparently started in the late Miocene (about $15 \mathrm{Ma}$ ). An older Eocene and Oligocene succession of igneous rock that yields $\mathrm{K}$-Ar ages ranging from 40 to $30 \mathrm{Ma}$, is located in the northeastern Aleutian lslands and is defined as the Meshik are by Wilson (1985).

Petrologic, chemical, and isotopic characteristics of the Aleutian are (Miller and Richter. 1994) are as follows. (1) The are consists predominantly of andesite and low-silica dacite; thyolite occurs only in a few volcanic centers. (2) The axial part of the central and northeastern parts of the arc is mostly calc-alkalic, $\mathrm{SiO}_{2}$ contents fypically range between 50 to 78 percent. (3) Volcanic centers to the southwest are either tholeitic or transitional to calc-alkalic. (4) The back are contains alkalic volcanic rocks which occur in widely separated centers. And (5) initial $\mathrm{Sr}$ ratios are relatively low, in the range of 0.70305 to 0.7046 .

The lode deposits of Alaska Penunsula and Aleutian lslands metallogenic belt reflect the bedrock underlying the arc. The northeastern part of the are on the southwestern part of the Alaska Peninsula is underlain by Mesozoic bedrock of the Peninsular terrane, part of the Wrangellia superierrane (Wilsos and Cox. 1983: Nokieberg and others, 1994d). On the Alaska Peninsula, the Peninsular terrane consists of a Late Triassic(?) and Early Jurassic sequence of volcaniclastic and volcanic rocks (Talkeetna Formation), the Middle Jurassic part of the Alaska-Aleutian Range batholith (Reed and Lanphere. 1969, 1973), and younger Cretaceous sedimentary rocks. In contrast, to the southwest, the Aleutian are is interpreied to be underlain by oceanic crust (Wilson and Cox, 1983; Vallier and others, 1994). The Pyramid Bee, Creek, Rex, and Warner Bay porphyry Cu deposits in the central part of the metallogenic belf occupy a transitional zone between the parts of the magnatic are underlain by oceanic crust to the southwest and by continental crust to the northeast. Some of be deposits to the northeast are Mo-rich and contain anomalous concentrations of $\mathrm{Bi}, \mathrm{Sn}$, and $\mathrm{W}$ which may be characieristic of continental-margin deposits (Wilson and Cox, 1983). K-Ar isotopic studies indicate a variable time span of up to two million years between igneous activity and minenalization. Isotopic studies also indicate sporadic occurrences of mineralization during a long period of igneous activity (Wilson and Cox, 1983).

\section{Tectonic Setting for Alaska Peninsula and} Aleutian Islands Metallogenic Belt

The Aleutian arc, one of the classic igneous continental-margin ares along the Circum-Pacific rim, occurs structurally above the Aleutian megathrust, an active subduction zone which dips to the northwest and along which the Pacific Plate is being thrust under the southern margin of Alaska (fig. 126). The tectonic setting, and the field, petrologic, chemical, and isotopic data 
summarized above are used by analogy to infer subduction zone settings for ancient belts of igneous rocks (Vallier and others, 1994) and their associated grantoid-magmatism metallogenic belts (Nokleberg and others, 1993).

\section{Late Tertiary and Quaternary Metallogenic Belts ( 4 to $0 \mathrm{Ma}$; Figures 125,126$)$}

\section{Overview}

The major late Tertiary and Quaternary metallogenic belts in the Russian Northeast. Alaska, and the Canadian Cordillera are summarized in table 3 and portrayed on figures 125 and 126. The major belts are as follows.

(1) In the Russian Southeast, the Sakhalin Island ( $\mathrm{SH}$ ) bett, which contains Silica-carbonate, volcanic-hosted Hg deposits, is hosted in shear zones and late Tertiary volcanic rock, and is interpreted as related to backarc spreading behind the Kuril volcanic arc. (2) In the Russian Northeast, the Kuril (KU) belt, which contains granitic-magmatism-related deposits, is hosted in the Kuril volcanic-plutonic belt and is interpreted as forming during subduction-related granitic plutonism which formed the Kuril Island part of Northeast Asia continental margin arc. (3) Also in the same region, several metallogenic belts continued on from the early and middle Tertiary is the Olyutor (OT) metallogenic belt which is hosted in the East Kamchatka voleanic and sedimentary basin. (4) In Southern Alaska, also continuing on from the middle Tertiary, was the Alaska Peninsula and Aleutian Islands (AP) belt, which contains granitic-magmatism-related deposits and which is hosied in the Aleutian volcanic belt. This metallogenic belt is interpreted as forming during subduction-related granitic plutonism which formed the Aleutian continental margin arc. And (5) in the southern Canadian Cordillera, continuing on from the carly and middle Tertiary, was the Owl Creek (OC) belt, which contains granitic-magmatism-related deposits and is hosted in the Cascade volcanic-plutonic belt. This metallogenic belt is interpreted during subduction-related granitic plutonism which formed the Cascade continental margin are. In the below descriptions of metallogenic belts, a few of the noteable or signficant lode deposits are described for each belt.

\section{Metallogenic-Tectonic Model for Late Tertiary and Quaternary (4 to $0 \mathrm{Ma}$; Figure 128)}

During the late Tertiary and Quaternary (Pliocene to the present - 4 to $0 \mathrm{Ma}$ ), the major metallogenic-tectonic events were and are (fig. 128; table 3): (1) continuation of a series of continental-margin arcs, associated metallogenic belts, and companion subduction-zone assemblages around the Circum-North Pacific; (2) continuation of opening of major sedimentary basins behind major ares; (3) in the eastem part of the Circum-North Pacific, a continuation of dextral transpression between the Pacific Ocean plate and the Canadian Cordillera margin; (4) a continuation of oblique-orthogonal transpression between the Pacific plate and the Southern Alaska; and (5) continuation of sea-floor spreading in the Arctic and eastern Pacific Oceans. The modern geodynamic pattern is defined by interaction of the Eurasian, North American, and Pacific Ocean plates (Cook and others, 1986; Parfenov and others, 1989; Fujita and others, 1997). The pole of rotation between the Eurasian and North American plates is located on, or near the south coast of the Laptev sea in the Russian Northeast (Cook and others, 1986; Larson and others, 1997).

\section{Specific Events for Late Tertiary and Quaternary}

(1) The Northeast Asia continental-margin are continues activity. Parts of the are are in the East Japan volcanic-platonic belt (ej), the Kuril arc (ku), the Central Kamchatka volcanic and sedimentary basin (kc), and the East Kamchatka volcanic belt (ek). Associated with the are is subduction of the westem edge of the Pacific Ocean plate (PAC) along the Kuril-Kamchatka megathrust $(K K)$ to form the Kuril-Kamchatka (KUK) terrane. A major orthogonal junction occurs between the western end of Aleutian-Wrangell are (al) and Kamchatka are (ke). Continuing on, or forming anew in the Northeast Asia continental margin are are: (a) the Sakhalin Island (SH) metallogenic belt which is hosted in shear zones in late Tertiary and older rock, and is interpreted as forming during backarc spreading behind Kuril are. (b) the Central Kamchatka (CK) metallogenic belt which is hosted in the Central Kanchatka voicanic and sedimentary basin; (c) the East Kamchatka (EK) metallogenie belt which is hosted in the Central Kamchatka volcanic and sedimentary basin; and (d) the Olyutor (OT) metallogenic belt which is bosted in the East Kamehatka volcanic and sedimentary basin. The latter three metallogenic belts contain granitic-magmatism-related deposits and are interpreted as forming during granitic plutonism associated with subduction of the Pacifie Plate.

(2) Rifting continues along the Gakkel Ridge (GK; northern extension of mid-Atlantic Ridge) and the extension of the ridge toward the Eurasian plate. The Gakkel Ridge and its extension define the modem boundary between the North American and Eurasian plates. Analysis of sea-floor spreading anomalies in the Eurasia Basin (eb) suggest that the Russian Northeast underwent extension from about 5 to $0.5 \mathrm{Ma}$ (Moma rift episode as discussed by Fujita and others, 1990a, b, 1997; Savostin and Drachev, 1988a, b; Harbert and others, 1990; Fujita and others, 1997). The youngest change, a northward pole shift, occurred at about 0.5 $\mathrm{Ma}$, as indicated by resurgent or continued thrusting (Imaev, 1991). Focal mechanism studies indicate which parts of this region ure undergoing compression (Cook and others, 1986; Parfenov and others, 1989; Fujita and others, 1990a, b; Riegel and others, 
1993). This compression is relieved by extrusion of the Okhotsk block to the southeast (Riegel and others, 1993) and by uplift and thrusting in the CSB area (Koz'min, 1984; Imaev and others, 1990; Koz'min and others, 1996). Sedimentation continues in the Amerasia basin (ab).

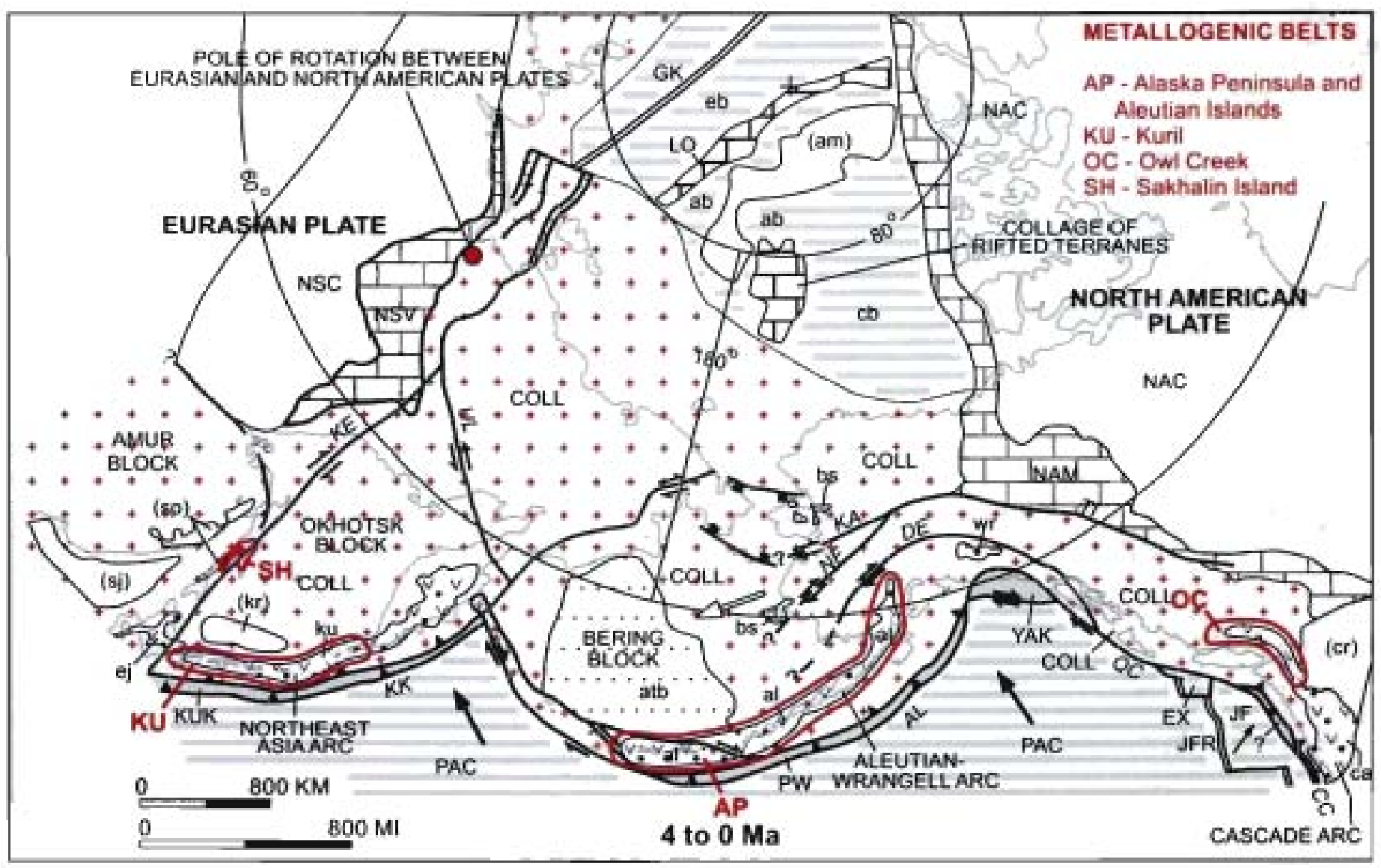

Figure 128. Late Tertiary and Quaternary (Pliocene through present - 4 to $0 \mathrm{Ma}$ ) stage of metallogenic-tectonic model. Refer to text for explanation of metaliogenic-tectonic events, to tables 3 and 4 for descriptions metallogenic belts and significant deposits, and to figure 18 for explanation of abbreviations, symbols, and patterns. Adapted from Nokleberg and others (1997b, 1998, 2000).

(3) Seismicity defines several new tectonic blocks, including the Amur, Okhotsk, and Bering blocks (Riegel and others, 1993; Fujita and otbers, 1997; Mackey and others, 1997). Boundaries between blocks are defined by epicenters located by teleseismic and regional networks (Fujita and others, 1997).

(4) Marine and continental eruption of sparse, generally small, highly dispersed flows of Bering Strait alkaline basalt (bs) occurred in the Quaternary and Recent. This volcanism may possibly be related to dextral-wrench faulting and tectonic escape in this region. Rotation of the Bering block created extension on the Seward Peninsula and on Chukotka (Mackey and others, 1997), or the Bering block may have formed as the back-arc with respect to the Aleutian-Wrangell arc:

(5) Tectonic escape (crustal extrusion) of terranes continues along major dextrai-s/ip faults, including the Denali $(D E)$, Nixon Fork (NF), Kaltag $(K A)$, and companion faults (Scholl and others, 1992, 1994) which may extend into the Bering Sea. Dextral-wrench basins continue to form in association with the dextral-slip faults and are still filling with continental sediments, A thick sedimentary prism continues to form in the Aleutian-Bowers basin (atb; Plafker and Berg, 1994). In Interior and Southern Alaska, displacement continues along major dextral-slip faults, such as the Denali $(D E)$ fault.

(6) The Pacific Ocean plate (PAC) continues to move northwestward relative to the North American plate. Along the Aleutian megathrust $(A L)$, plate convergence continues to vary from orthogonal in the east to oblique to transform in the west.

(7) Intense tectonic disruption continues in the westem part of Aleutian-Wrangell arc along the western Aleutian megathrust $(A L)$, as a result of the transform coupling between the Pacific Ocean plate (PAC) and the North American plate (Geist and others, 1988; Scholl and others, 1992, 1994). A thick sedimentary prism continues to form in the Aleutian-Bowers basin (atb) which overlies a fragment of accreted Kula Ocean plate (Plafker and Berg, 1994).

(8) Along the margin of Southern Alaska, the eastern part of the Aleutian-Wrangell arc continues activity. Associated with the are is mainly oblique subduction of the northern edge of Pacific Ocean plate (PAC) along the Aleutian megathrust $(A L)$ ), continuing the formation of the younger part of the Prince William terrane (PW). Continuing in the Aleutian-Wrangell are is the Alaska Peninsula and Aleutian Islands (AP) metallogenic belt which contains granitic-magmatism-related deposits and is hosted in 
the Aleutian volcanic beli. The Yakutat terrane (YA) continues to migrate northwestward and continues to underthrust the Prince Williarn ternane ( $P W$ ) along the eastern part of the Aleutian megathrust $(A L)$.

(9) Sea-floor spreading continues along the Juan de Fuca oceanic ridge (JFR). Northward movement of the Pacific Ocean plate (PAC) continues with transform displacement on the Queen Charlotte transform fault $(Q C)$.

(10) The Cascade continental-margin are continues to form. Continuing in the Cascade are was the Owl Creek (OC) metallogenic belt which is hosted in the Cascade volcanic-plutonic belt. Associated with the Cascade are is subduction of part of the Juan de Fuca oceanic plate (JF) and formation of a subduction-zone complex along the Cascadia megathrust (CC; Goldtinger and others, 1996. 1997; Fleuh and others, 1997).

\section{Metallogenic Belts Formed in Late Tertiary and QuaternaryContinental-Margin Ares, Kamchatka Peninsula, Southern Alaska, and Southern Canadian Cordillera}

\section{Sakhalin Island Metallogenic Beit of Silica- Carbenate or Volcanic-Hosted $\mathrm{Hg}$ Deposits (Belt SH) Sakhalin Island, Southeastem Part of Russian Far East}

The Sakhalin Island metallogenic belt of silica-carbonate and volcanic-hosted $\mathrm{Hg}$ deposits oceurs in the central and southern part of Sakhalin Island, in and adjacent to the Aniva, Nabilsky, and West-Sakhalin terranes (fig I25; tables 3,4) (Nokleberg and others, 1997b, 1998). The Russian name for the silica-carbonate Hg deposit type is listwandite. The silicacarbonate $\mathrm{Hg}_{\mathrm{g}}$ deposits occur along or adjacent to major fuults in faulted fragments of Late Cretaceous sedimentary rocks, serpentinized and altered ultramafic rocks, and in post-accretionary Neogene voleanic rocks. The significant deposits along the In' River, and at lnskoe, Svetlovskoe, Ostrinskoe, and Yasnoe consist of cinnabar and native $\mathrm{Hg}$ in fracture zones along contacts between gabbroic rocks and serpentinite, or in jasper, basalt, and shale. The $\mathrm{Hg}$ minerals either replace quartz and carbonate in listwandite or forms pods. Some of the Hg deposits, as along the In' River, occur in volcanic rocks, but display silica-carbonate alteration. Other deposits, as at Inskoe, are hosted in altered quartzite and Neogene volcanic rock.

The origin of the $\mathrm{Hg}$ deposits of the Sakhalin island belt is not clear. Silica-carbonate $\mathrm{Hg}$ deposits are classically interpreted as related to thrust faults in or near subduction zones (J.J. Rutuba, in Cox and Singer, 1986). However the nearest late Tertiary subduction zone occurred a few hundred $\mathrm{km}$ to the east, east of the Kuril are which has been active since the late Tertiary (Nokleberg and others, 1994c, 1997c). The $\mathrm{Hg}$ deposits of the Sakhalin island metallogenic bell may have multiple origins. Some of the silica-carbonate $\mathrm{Hg}$ deposits may have formed during late Tertiary back-are rifting and formation of the Sakhalin-Primorye alkali basalts and related igneous rocks. Sorne or all of the in the belt deposits may have formed in the back are portions of the late Tertiary through Holocene Kuril arc (Nokleberg and others, 2000).

\section{Kurit Metallogenic Belt of Au.Ag Epithermal Vein, Cu-Pb-Zn Polymetallic Vein, Sn sillica-sulfide vein, Sn Vein, Sulfur-sulfide (volcanic S). Kuroko Massive Sulfide, and Porphyry Mo Deposits (Belt KU) Kuril islands, East-Central Part of Russian Far East}

The Kunil metallogenic belt of Au-Ag epithermal vein, $\mathrm{Cu}-\mathrm{Pb}-\mathrm{Zn}$ polymetallic vein, $\mathrm{Sn}$ silica-sulfide vein, sulfur-uulfide (volcanic S), kuroko massive sulfide, and porphyry Mo deposits (fig. 125; tables 3, 4) oecurs in the Kuril volcanic arc in the eastcentral part of the Russian Far East. The belt contains a wide variety of volcanic and hypabyssal-related deposits (table 4) (Nokleberg and others 1997a, b, 1998): sulfur-sulfide (volcanic S) deposits at Ebeko, Golovninskoe, Krishiofovich Volcano, Novoe, Vysokoe, and Zaozernoe; Au-Ag (Zn) epithermal vein deposits at Prasolovikoe, Rifovoe, Semaya River, and Sofya; Cu$\mathrm{Pb}-\mathrm{Zn}$ polymetallic vein deposits at Dushnoe, Koshkina, and Tet'yaevskoe; Sn silica-sulfide vein and Sn vein deposits at Rudnikovikoe and Spiridonovskoe; porphyry Mo deposits at the Carpinsky caldera and Reidovskoe; and a kuroko Cu-Pb-Zn deposit at Valentinovskoe. The principal Au-Ag epithermal vein, and polymetallic, Sn, and Sn silica-sulfide vein deposits are interpreted as forming during late Neogene during aerial volcanism (Shcheglov and others, 1984). The small occumrences of kuroko-type massive sulfide deposits are interpreted as forming during early Miocene seafloor volcanism. The volcanic $\mathbf{S}$ deposits are interpreted as forming during the construction of Quaternary volcanic cones and fields. The Au-Ag epithermal vein and the volcanic $\mathrm{S}$ deposits are of potential economic interest.

\section{Novoe Sulfur-Sulfide (Voleanic S) Deposit}

The Novoe sulfur-sulfide (Volcanic S) deposit (Petrachenko, 1967) oceurs in a flat-lying sequence, about 500 to $400 \mathrm{~m}$ thick, of andesite, andesile-basalt, and related fuff. The sequence crops out in scarps of a $2 \mathrm{~km}$-wide erosional depression. Some ore bodies are controlled by faults. The sulfur ore oceurs in hydrothermally altered silicified rock, with opalite, alunite, and kaolinite. All altered rocks in the deposit contain some sulfur, but the higher-grade ores contain opalite, silicified rock, and alunite, 
Secondary minerals are barite, gypsum, marcasite, pyrite (up to $15 \%$ ), and molybdenite. The age of mineralization is Pliocene and Quaternary. The deposit is large. A verage grades are up to $20-80 \% \mathrm{~S}$ and up to $0.5 \%$ MoS. The deposit contains about 5 million tonnes sulfur.

\section{Prasolovshoe Alb-Ag Epithermal Vein Deposit}

The Prasolovskoe Au-Ag epithermal vein deposit (Danchenko, 1991) consists of ore veins which are mostly steeplydipping, and range from $2-3 \mathrm{~m}$ thick, with a few up to $10 \mathrm{~m}$ thick. The veins consist mainly of banded metacolloidal gold, telluride, and quartz veins which contain up to $1.3 \%$ ore minerals. The deposit exhibits a vertical succession of assemblages. From bottom to top the assemblages are; gold-cassiterite-quartz; polysulfide-quartz; gold-telluride-quartz; and gold-adularia (carbenate)quartz. The dominant ore minerals are pyrite, chalcopyrite, bornite, chalcocite, covellite, and sphalerite. Arsenopyrite, molybdenite, cassiterite, galena, argentite, native silver, gold, hessite, naumannite, and goldfieldite are also abundant. Limonite, covellite, malachite, and azurite occur in an oxidized zone. The ore bodies are exploted to a depth of over $200 \mathrm{~m}$. An area 1.5 by $0.5 \mathrm{~km}$ is propylitically altered and impregnated with pyrite as well as numerous quartz veinlets with epidote, sericite, adularia, chlorite, calcite, and rare barite. Earlier veinlet and disseminated ore is related to Miocene intrusions. The later Au-Ag ore is related to the Pliocene volcano-plutonic complex. The deposit is associated with Pliocene plagiogranite and quartz diorite which intrude early and middle Miocene pyroclastic green tuff deposits. The deposit is of medium size and was mined before the 1990 's.

\section{Koshkina Cu-Pb-Zn Polymetallic Vein Deposit}

The small Koshkina Cu-Pb-Zn polymetallic vein deposit (Petrachenko, 1978) consists of ore bodies up to $200 \mathrm{~m}$ long which occur hydrothermally aliered rock types outside a granodionite and diorite intrusion. The ore bodies consist of areas of closely-spaced sericitized and hydromicatized veins and veinlets with variable composition. Mineral assemblages in veins and veinlets are quartz-tourmaline, quartz-chlorite-sericite, chlorite-carbonate with zeolites, and quartz-chlorite-epidote. The ore minerals are chalcopyrite, cleiophane, galena, stibnite, realgar, orpiment, arsenopyrite, pyrite, marcasite, hematite, and magnetite. Polymetallic and antimony-arsenic ores are spatially separated and various alterations. The mineralogy and metal content of the deposit vary widely. The deposit oceurs on the sorthern part of Shumshu lsland and covers an area of approximately $5 \mathrm{~km}^{2}$. The deposit is hosted in heavily aliered early-middle Miocene volcanic rocks which are intruded by numerous extrusive and intrusive rocks, all part of a volcano-plutonic complex. Host rocks are propylitized up to epidote-chlorite facies, and are locally silicified. Propylitized granodiorite and diorite crops out in the middle part of the mineralized area. Alteration was the result of sulfate and halogene-acid hydrothernal solutions. The age of mineralization is late Miocene(?).

\section{Valentinovskoe Kuroko Cu-Pb-Zn Deposit}

The Valentinowskoe kuroko Cu-Pb-2n deposit (Neverov, 1964) consists of two steeply-dipping, thin, lens-like deposits, up to $150 \mathrm{~m}$ long. Two ore types exist. (1) The first and most conumon type consists of massive, fine-grained sphalerite, galena, chalcopyrite, chalcocite, tetrahedrite, melnikovite, barite, gypsum, quartz, chalcedony, chlorite, sericite, and calcite. This ore contains approximately $1 \% \mathrm{Cu}, 1.5-1.7 \% \mathrm{~Pb}$, and $10-13 \% \mathrm{Zn}$. And (2) the second und less common ore type consists of pyrite, sphalerite, and chalcopyrile with galena and other sulfides. This ore contains up to $4 \% \mathrm{Cu}, 10-16 \% \mathrm{Zn}$, and $1-1.7 \% \mathrm{~Pb}$. The deposit occurs in early Miocene rhyolite, dacite, andesite, and andesitic tuff with chert interbeds. The bost rocks are propylitized or sericitized and are part of a submarine tuff complex. The deposit is small with average grades of $1 \% \mathrm{Cu}, 1.5-1.7 \% \mathrm{~Pb}$, and $10-$ $13 \% \mathrm{Zn}$ in fine-grained ore, and locally up to $4 \% \mathrm{Cu}, 10-16 \% \mathrm{Zn}$, and $1-1.7 \% \mathrm{~Pb}$.

\section{Origin of and Tectonic Controls for} Kuril Metallogenic Belt

The Kuril volcanic are which hosts the Kuril metallogenic belt consists chiefly of tuff, breccia, andesite, basalt, and local hypabyssal and plutonic rocks including gabbro, diorite, and diabase (Nokleberg and others, 1994c). The are oceurs as large Quatemary active volcanoes which are tectonically linked to middle Tertiary through Holocene subduction of the westem margin of the Pacific oceanic plate (Nokleberg and others, 1994c, 1997c).

\section{Summary of Metallogenic and Tectonic History}

The preceding analysis of the metallogenesis and tectonics of the Russian Far East, Alaska, and the Canadian Cordillera reveals a series of metallogenic belts which formed during a complicated geologic hisiory. The metallogenic belts are hosted in older rock units of tectonostratigraphic terranes, along suture zones between accreted terranes, or in overlap assemblages of continental margin igneous ares. Metallogenic belts formed before accretion (pre-accretion) are interpreted as forming in the early history of terranes and are inherently linked to the older geology and lectonic history of the bost rocks. Accretionary metallogenic belts are interpreted as forming during collision of terranes with continental margins, resulting is varying amounts of regional 
metamorphism, anatectic gramites, and associated lode deposits. Post-accretionary metallogenic belts are interpreted as forming mainly in parts of continental-margin ares which overlie craton or craton margin terranes.

\section{Pre-Accretionary Metallogenic Belts}

Several major and minor metallogenic belts of deposits hosted in mafic and ultramafic rocks occur in the Russian Far East, Alaska, and the Canadian Cordillera. The principal deposits are hornblende peridotite $\mathrm{Cu}$-Ni, anorthosite-hosted apatite Ti$\mathrm{Fe}$, gabbroic $\mathrm{Ni}-\mathrm{Cu}$, hornblende peridotite $\mathrm{Cu}-\mathrm{Ni}$, podiform $\mathrm{Cr}$, serpentinite-bosted asbestos, stratiform $\mathrm{Zr}$, zoned mafic-ultramafic $\mathrm{Tt}$, and zoned mafic-ultramafic PGE deposits. These deposits and bost rocks are interpreted as forming mainly in oceanic tectonic environments, including basal island arc, ophiolite, oceanic ridge, seamount, and subduction zone environments. A few deposits are interpreted as rarely forming in continental rift environments. Subsequent to formation, most of these ocean-derived metallogenic belts and their host rocks migrated and were accreted to the margin of the North Asian Craton Margin or North American Craton Margin. Several of the metallogenic belts occur in thin, but extensive sheets of obducted ophiolites which were thrust onto the Paleozoic and early Mesozoic continental margin terranes of the Russian Northeast and northern Alaska. In island. ure terranes, these mafic-ultramafic-related deposits occur mainly in deep-level mafic to ultramafic plutons, some of which are concentrically zoned.

Several major pre-accretionary metallogenic belts of stratiform and stratabound massive sulfide and associated deposits occur in Russian Far East, Alaska, and the Canadian Cordillera. The principal deposits types are Austrian Alps W, basaltic Cu, bedded barite, Besshi massive sulfide, carbonate-hosted $\mathrm{Hg}$, carbonate-related $\mathrm{Nb}$, Ta, and REE, Cyprus massive sulfide, ironstone (Superior Fe), Kipushi Cu-Pb-Zn, Korean $\mathrm{Pb}-\mathrm{Zn}$, Kuroko massive sulfide, $\mathrm{Zn}-\mathrm{Pb}$ SEDEX, sandstone-hosied $\mathrm{U}$, sediment-hosted $\mathrm{Cu}$ deposits, sedimentary P, volcanogenic Mn and $\mathrm{Fe}$, Southeast Missouri $\mathrm{Pb}-\mathrm{Zn}$, shoshonite-hosted $\mathrm{Cu}$, and stratabound $\mathrm{Hg}$ and $\mathrm{Au}$. This wide variety of stratiform and stratabound deposits, and associated deposits are formed in a wide variety of tectonic environments, including continental margin, island arc, seamount, ophiolite, and continental rift environments. These and the other deposit types listed above also occur in accreted fragments of continental margin, cratonal, island arc, oceanic, ophiolite, and subduction-zone terranes. Major suites of stratiform and stratabound sulfide deposits also occur in the North Asian Craton Margin (unit NSV, Verkhoyansk fold belt) and in the North American Craton Margin (unit NAC).

Several major and minor pre-accretionary metallogenic belts of felsic-magmatism-related deposits occur in the Russian Far East, Alaska, and the Canadian Cordillera. The principal deposit types are Au-Ag epithermal vein, Cu-Au skam, felsic plutonic REE, Fe-Au skam, fluorite greisen, $\mathrm{Pb}-\mathrm{Zn}$ skarn, polymetallic vein, porphyry $\mathrm{Cu}$, porphyry $\mathrm{Cu}-\mathrm{Mo}$, Sn greisen, and $\mathrm{Sn}$ vein. These deposits are hosted mainly in continental margin or island are tectonic environments, Subsequent to formation, most of these metallogenic belts and their bost rocks migrated along the margin of, or were accreted to the North Asian Craton Margin or the North American Craton Margin.

\section{Accretionary Metallogenic Belts}

Several major and minor accretionary metallogenic belts occur in the Russian Far East, Alaska, and the Canadian Cordillera. The principal deposit types Au polymetallic vein, Au quartz vein, Au skarn, $\mathrm{Cu}$-Ag quartz vein, $\mathrm{Cu}$ skam, granitoidrelated $\mathrm{Au}$, Kentiecott Cu, porphyry Cu-Mo, Sn quartz vein, Sn greisen, Sn skam, Sn vein, Sn-W polymetallic vein, talc, W quartz vein, and W skam. These deposits are generally interpreted as forming from metamorphic-hydrothermal and (or) magmatichydrothermal fluids which formed in collisional zones between terranes or between terranes and craton margin units. In some regions, the deposits are interpreted as forming in lower-grade, greenschist-facies extensional zones immediately after the major period of accretion and thrusting. The various felsic-magmatism-related deposits are interpreted as forming during major periods of anatexis which occurred during or immediately after accretion. The accretionary metallogenic belis generally occur along both sides of major fault boundaries between adjacent terranes, or between terranes and craton margins.

\section{Post-Accretionary Metallogenic Belts}

Several major and minor metallogenic bels of igneous arc-related deposits, mainly porphyry, polymetallic vein, epithermal, skarn, and related deposits, occur in the Russian Far East, Alaska, and the Canadian Cordillera. The principal deposit types are $\mathrm{Au}-\mathrm{Ag}$ epithermal vein, B skam, clastic sediment-hosted $\mathrm{Hg}$. Cu skam, Cu-Mo skam, disseminated Au-sulfide, Fe-Au skam, felsic plutonic $\mathrm{U}$, granitoid-related $\mathrm{Au}$, hot-spring $\mathrm{Hg}$, kuroko massive sulfide, $\mathrm{Mo}-\mathrm{Cu}$ skam, $\mathrm{Pb}$ - $\mathrm{Zn}$ skam, polymetallic vein, porphyry Au, porphyry Cu, porphyry Cu-Au, porphyry Cu-Mo, porphyry Mo, porphyry Sn, rhyolite-hosted Sn, sandstone U. Sb-Au vein, silica-carbonate $\mathrm{Hg}_{\mathrm{g}}$, sulfur-sulfide (volcanic S), Sn greisen, Sn quartz vein, Sn silicate-sulfide vein, Sn skarm, volcanic-hosted $\mathrm{Hg}_{\mathrm{g}}$ and $\mathrm{W}$ skarn.

These deposits are mainly hosted in or near granitoid plutonic, bypabyssal siliceous, and volcanic rocks which formed mainly during younger, mainly Cretaceous and Cenozoic continental-margin are igneous activity. These post-accretionary. igneous ate deposits commonly transect several adjacent terranes and continental margin units. A general geographic and temporal pattem exists in that the older metallogenic belts and associated igneous rock belts, mainly of Cretaceous age, occur inboard, and the younger, Cenozoic belts oceurring progressively outboard towards active continental-margins. These metallogenic belts contain a most diverse spectrum of lode deposits, but also have a high potential for discovery of new deposits. Particularly in the 
Russian Far East, the metallogeny of post-accretionary, igneous-arc-related deposits depends to a great extent on the lithology and composition of the host rocks of the basement terranes. Throughout the region, in the Russian Far East, Alaska, and the Canadian Cordillera, the Cretaceous and Cenozoic the post-accretionary, igneous-arc-related deposits generally exhibit a general metallogenic zooing typical of continental-margin ares.

\section{Conclusions}

The Phanerozoic metallogenic and tectonic evolution of the Circum-North Pacific can be explained as a succession of ares and tectonically paired subduction zones which formed along the margins of the Northeast Asian and North American plates above the subducting oceanic lithosphere of mainly the Mongol-Okhotsk, Cache Creck, ancestral Pacific, and Pacific Oceans. In both Northeast Asia and in the North American Cordiliera, most of the ares formed in island ares near continental margins or along the continental margins. With respect to Northeast Asia and North America, the paleolocations of those arcs, which occur oceanward of coeval accretionary complexes, are highly suspect in the Paleozoic but are successively less so in the Mesozoic.

The complex metallogenesis and tectonics of this region are analyzed by the following steps. (1) The notable or significant lode deposits are described and classified according to defined mineral deposit models. (2) Metallogenic belts are delineated. (3) Tectonic environments for the cratons, craton margins, orogenic collages of terranes, overlap assemblages, and contained metallogenic belts are assigned from regional compilation and synthesis of stratigraphic, structurnil, metamorphic, and faunal data. The tectonic environments include cratonal, passive continental margin, metamorphosed continental margin, continental-margin arc, island arc, oceanic crusi, seamount, ophiolite, accretionary wedge, subduction zone, turbidite basin, and metamorphic, (4) Correlations are made between terranes, fragments of overlap assemblages, and fragments of metallogenic belts. (5) Coeval terranes and their contained metallogenic belss are grouped into a single metallogenic and tectonic origin, for instance, a single island are or subduction zone. (6) Igreous-are and subduction-zone ternabes, which are interpreted as being tectonically linked, and their contained metallogenic belis, are grouped into coeval, curvilinear arc-subduction-zone-complexes. (7) By use of geologic, faunal, and paleomagnetic data. the original positions of terranes and their metallogenic belts are interpreted. (8) The paths of tectonic migration of terranes and contained metallogenic belts are constructed. (9) The timings and nature of accretions of terranes and contained metallogenic belts are determined from geologic, age, and structural data; (10) The nature of collisionrelated geologic units and their contained metallogenic belts are determined from geologic data. (1I) The nature and timing of post-ikeretionary overlap assemblages and contained metallogenic belts are determined from geologic and age data. 


\section{References Cited}

Abbott, G., 1981. A new geological map of Mt. Hundere and the area north, in Yukon Exploration and Geology 1979-80: Department of Indian and Northem Affairs, Canada, p. 45-50.

Abbott, J.G., 1983, Origin of the Clinton Creek asbestos deposit: Yukon Geology and Exploration, 1982: Department of Indian and Northem Aftairs, Canada, 0.18-25.

Abbott, J.G. 1986a, Epigenetic mineral deposits of the KetraSeagull district, Yukon; in Yukon Geology. Vol. 1. Exploration and Geological Services Division, Yukon. Indian and Northem Affairs Canada, p. 56-66.

Abbott, J.G. 19866, Devonian extension and wrench tectonics near Macmilan Pass, Yukon territory, Canada; in Tumer, R.W., and Einaudi, M.Y. eds., The Genesis of Stratifom Hosted Lead and Zinc Deposits, Conference Proceedings, Stanford University Press, p. 85-89

Abbott, J.G. Thorkelson, D.J, and Wallace, C.A., 1994, Regional setting of syngenetic, epigenetic and breccia- hosted precious and base-metal occurrences in Paleozoic and Proterozoic strata of Mackenzie Platform [abs.], in Jambor. JL, ed. Recent Develogments in Yukon Metallogeny Carradian Institute of Miring and Metallurgy 1994 Arnuad Ceneral Meeting. Abstracts and Proceedings. p. 19-23.

Abel, VE, and Slezko, VA, 1989, Stratiorm goid mineraluation of the Kharaulak anticlinorium, in Yakovlev, Ya.V., Davydov, Yu.V., and Kutyrev, E.I. eds. Stratiform mineralization in Yakutia: U.S.S.R. Academy of Sciences. Seberian Branch, Institule of Geology, Yakutsk, p. 110-117 (in Russian).

Adams, D.D., Freeman, C.J., Goidtarb, R.J. Gent, C.A., and Snee, LW, 1992, Age and geochemical constraints on

mesothermal gold mineralization [abs]: Geological Society of America Abstracts with programs, v. 24, p. 2.

Aitken, JD. 1991. Two late Proterozoic glaciations, Mackenzie Mountains, northwestern Canada: Geology, v. 19, no.5. p. $445-448$

Aitken, J.D., and McMechan, M.E., 1991, Middle Proterczoic assemblages, in Gabrielse, H. and Yorath. C.J., eds. Geology of the Condilieran Orogen: Boulder, Colorado. Geological Society of America. The Geology of North America, v. G-2, p. 97-124.

Aksenova, V.D. Dovgal, Yu. M. and Sterligova, V. E, 1970, Nickel-chrome mineralization of Aluchin hyperbasite intrusion: Geologiya i Geofizika, no, 2. p 23-33 (in Russian).

Abers, JP. Fraticelli, LA., and Dawson. K.A., 1988 , Metallogenic maps of the northeast quadrant of the Circum-Pacific region, showing inferred mineral belts and distribution of oil and gas fields in accroted terranes and craton: U.S. Geological Survey Mineral Investigations Resource Map MR.95, 1 sheet, scale $120,000,000$

Alldrick, Dani J, Friedman, R M; Childe, F C, 2001, Age and geologic history of the Ecstail greenstone belt. Northwest British Columbia British Columbia Ministry of Energy. Mines and Petroleum Resources, Report: 2001 1.pp. 269.278

Aleinikof, J.N. Dusel-Bacon, C. Foster, HL and Nokleberg. W. 1967. Po-isotope fingerprinting of tectonostratigraphic terranes. east-central Alaska. Canadian Journal of Earth Sciences, v. 24, p. 2089 2098

Aleinikoff, J.N., and Nokleberg. W.J., 1985, Age of Devonian igneous arc terranes in the northern Mount Hayes quadrangle, eastern Alaska Range, Alaska, in BartschWinkler, Susan, ed. The United States Geological Survey in Alaska: Accomplishments during 1984: U.S. Geological Survey Circular 967. p. 44-49.

Alekseenko, A.V., Korobeinikov, S.V., and Sidorov, V.A., 1990. New evidence of porphyry copper-molybdenum mineralization in Omolon massit Ore formations of the U.S.S.R. Northeast: U.S.S.R. Academy of Sciences, North-Eastern Interdisciplinary Research Institute. Magadan. p. 157-162 (in Russian).

Alidrick. D.J., 1985, Stratigraphy and petrology of the Stewart mining camp (104B/1), in Geological Fleldwork 1984 British Columbia Ministry of Energy. Mines and Petroleum Resources Paper 1985-1, p. 316-341.

Aldrick, D.J., Brown, D.A, Harakal, J.E., Mortensen, J.K, and Armstrond, R.L. 1987, Geochronology of the Stewart Mining Camp (1048/1), in Geological Fielchwork 1986. British Columbia Ministry of Energy, Mines and Petvoleum Resources Paper 1987-1, p. 81-92.

Allen, D.G., Panteleyev, A, and Armstrong. A.T., 1976, Galore Creek; in Sutherland Brown, A., ed., Porphyry Deposits of the Canadian Corcillera; Canadian Institute of Mning and Metallurgy Special Volume 15, p. 402-414.

Amato, J.M., and Wright, J.E., 1997. Potassic mafic magmatism in the Kigluak gneiss dome, Northem Alaska; a geochemical study of arc magmatism in an extensional tectonic setting: Joumal of Geophysical Research, v. 102, no, 4, p. 8065-6084.

Amuzinsky, V A, 1975, Low-sulfide gold-quartz assemblage of the Verkhoyansk meganticlinorium, in Ivensen, Yu.P. ed. Gold mineral assemblages and goochemistry of gold of the Verkhoyansk-Chukchi fold belt. Nauka. Moscow, P. 121-153 (in Russian).

Anderson, HE, and Davis, 1996, U-Pb geochronology of the Moyle sills, Purcell Supergroup, southoastem British Columbia: Implicatons for the Middle Proterozoic geologic history of the Purcell (Beit) Basin: Canadian Joumal of Earth Sciences, v. 32, D. $1180-1193$.

Anderson, RG., 1963a, Geology of the Hotailuh Bathollth and surrounding volcanic and sedimentary rocks, north-centra British Columbia: Ottwes, Carleton University. Ph.D. dissertation, $669 p$.

Anderson. R.G., 1983b, Selwyn plutonic suite and its rolatonship to fungsten skam mineralization, southeastem Yukon and District of Mackenzie: Cument Research. Part B. Geological Survey of Canada, Paper 83-1B, p. 151-163.

Anderson, RG.. and Reichenbach, 1., 1991, U.Pb and K-Ar framework for Middle and Late Jurassic (172-158 Ma) and Tertiary (46-27 Ma) plutons on Queen Charlotte Islands. British Columbia in Evolution and Hydrocarbon Potential of the Queen Charlotte Basin, British Columbia; Geological Survey of Canada Paper 90-10, p. 59-87.

Ancrew, A. Godwin. C.I., and Sindair, A.J., 1983, Age and genesis of Cariboo goid mineralization delemined by isotope methods $(93 \mathrm{H})$, in Geolopical Fieldwork 1922. British Columbia Ministry of Energy, Mines and Petroleum Rescurces, paper 1983-1, p. 305-313.

Andrew, K.P.E., 1988, Geology and genesis of the Wolf procious metal epithermal prospect and the Capoose base and precious metal porphyry- style prospect. Capoose Lake area, centrai British Columbia: Vancouver, University of British Columbia, M.Sc. thesis, $334 \mathrm{D}$

Andrew, K.P. and Goowin, C.I. 1987, Capoose base and precious metal prospect, central Brtish Columbia, in Geological Fieidwork 1986. Brilish Columbia Ministry of Energy Mines and Petroleum Resources Paper 1967-1, D. $53-56$. 
Andrew, K.P.E., Godwin, C.I., and Cann, R.M., 1986, Woif epithermal precious metal vein prospect, central British Columbia, in Geological Fieldwork 1985: Brilish Columbia Ministry of Energy Mines and Petroleum Resources Paper 1986-1. p. $317-320$.

Androsov, D.V. and Ratkin, V.V., 1990, Pre-folding massive zinc-sulfide ore in the Voznesenka greisen deposit (Primorye): Geologiya Rudnykh Mestorozhdeniy, no 5. p. $46-58$ (in Russian).

Anisimova, G.V. Gamyanin, G.N., Goryacheva, E.M., 1983, Native aluminum and chromium at the Sarylak deposit: Doklady Akademii Nauk SSSR, Moscow, v. 272, p. 657660 (in Russian).

Anorow, P.N., and Mayuchaya, V.P. 1988, Features of porphyry mineralization occurrences in Magadan pluton: Magmatic and metamorphic complexes of the U.S.S.R. Northeast [abs.]: U.S.S.R. Academy of Sciences, NorthEastem Interdisciplinary Research institute, Magadan, p. 99-100 (in Russian).

Apodaca, L.E., 1992. Fluid-inclusion study of the Rock Creck area, Nome mining district, Seward Peninsula, Alaska: in Bradley, D.C. and Dusel-Bacon. Cynthia, eds., Geologic studies in Alaska by the U.S Geological Survey. 1991, U.S. Geological Survey Bulletin 2041, p. 3-12.

Archer, A., Bell, R.T, and Thorpe, R.I., 1966, Age relationships from $\mathrm{U}-\mathrm{Th}-\mathrm{Pb}$ isovope studies of uranium mineralization in Wemecke breccias, Yukon Territory: in current Research, Part A. Geological Survey of Canada, Paper 86-1A, p. 385391.

Armstrong. RL., 1988, Mesozoic and early Cenozoic magmatic evolution of the Canadian Cordillera, in Clark, S.P. Burchifel, B.C., and Suppe, J., eds., Processes in continental lithospheric deformation: Geological Society of America Special Paper 218, p. 55-91.

Armstrong, A.K., and MacKevett, E.M., Jr., 1982, Stratigraphy and diagenetic history of the lower part of the Triassic Chitistone Limestone, Alaska: U.S. Geological Survey Professional Paper 1212-A, 26 p.

Armstrong. J.E., 1949, Fort St. James map-area, Cassiar and Coast districts: British Columbia, Geological Survey of Canada, Memoir 252. 210 p., scale 1 in. equals $6 \mathrm{mi}$.

Amstrong, R. ., 1988, Mesozoic and early Cenozoic magmatic evolution of the Canadian Cordilera, in Clark, S.P.. Jr., ed., Processes in Continental Lithosperic Deformation: Geological Association of America Special Paper 218, p $55-91$.

Armstrong. R.L., Harakal. J.E, Forbes, R.B., Evans, B.W., and Thurston, S.P., 1986, Rb-Sr and K-Ar study of southem Brooks Range, in Evans, B.W., and Brown, E.H., eds., Blueschists and eclogites: Geological Society of America Memoir 164, p. 185-203.

Aurmstrong. R.L. Harakal. J.E, and Hollister, V.F., 1976, Age determinations of late Cenozoic copper deposits of the North American Cordillera: Institute of Mining and Metallurgical Engineers Transactions, Section B, v. 85, p. 239-244.

Armstrong. A.K., and MacKevett, E.M., Jr., 1982, Stratigraphy and diagenetic history of the lower part of the Triassic Chitistone Limestone, Alaska: U.S. Geological Survey Prolessional Paper 1212-A, 26 p.

Armstrong. J.E, and and Roots, E.E., 1948, Geology and mineral deposits of Aiken Lake map-area, British Columbia: Geological Survey of Canada Paper, 46 p.

Arth, J.G. 1994. Isotopic composition of the igneous rocks of Alaska, in Plafker, George, and Berg, H.C., eds., The Geology of Alaska: Boulder, Colorado, Geological
Society of America, The Geology of North America, v. G-1, p. 781-796

Arth, J.G., Barker, F., Stern, T.W., and Zmuda, C., 1986, The Coasxt batholith near Ketchikan, southeast Alaska; Geochronology and geochemistry [abs.] Geological Society of America Abstracts with Programs, v. 18, p. 529 .

Ash, C.H, Macdonald, R.W.J, and Friedman, R.M. 1997. Stratigraphy of the Tatogga Lake area, northwestem British Ciolumbia (104H/12, 13, 104G19, 16), in Geological Fieldwork, 1996: British Columbia Ministry of Energy and Mines, p. 283-290.

Ashleman, J.C. Taylor, C.D., and Smith, P.R., 1997, Porphyry Mo deposits of Alaska, with emphasis on the geology of the Quartz Hill deposit, southeastern Alaska, in Goldfarb, R.J. and Miller, L.D., eds., Mineral Deposits of Alaska: Economic Geology Monograph 9, p. 334-354.

Asher, R.R., 1969. Geologic and geochemical study, Solomon C-5 quadrangle, Seward Peninsula, Alaska: Alaska Division of Mines and Geology Report 33, 64 p.

Astmworth, Kate, 1983. Genesis of gold deposits of Little Squaw Mine, Chandalar District, Alaska: Bellingham, Washington, Western Washington University, M.S. thesis, $64 \mathrm{p}$.

Atkinson, D., 1995, The Glacier Gulch (Hudson Bay Mountain or Yorke Hardy) porphyry molybdenum-tungsten deposit, west-central British Columbia, in Schroeter, T.G., ed., Porphyry Deposits of the Northwestern Cordillera of North America: Canadian Institute of Mining and Metallurgy, and Petroleum, Special Volume 46, p. 704-707.

Atkinson, D., and Baker, D.J.,1986, Recent developments in the geologic understanding of Mactung, in Morin, J.A. ed. Mineral Deposits of Northern Cordillera: Canadian Institute of Mining and Metallurgy Special Volume 37, p. 234-244.

Babkin, P.V., 1975, Mercury provinces of the U.S.S.R. Northeast: Nauka, Nowosibirsk, 168 p (in Russian).

Babkin, P.V., Drabkin, I.E., and Kim, E.P., 1967, Volcanichosted mercury mineralization of the Magadan region: Ore Capacity of Volcanogenic Formations in the Northeast and Far East: U.S.S.R. Academy of Sciences, North-Eastem Interdisciplinary Research Institute, Magadan, p. 133-140 (in Russian).

Bakharev, A.G. Gamyanin. G.N. Goryachev, and N.A. Polovinkin, V.L., 1988, Magmatic complexes and mineral assemblages of the Ulakhan-Tas Range, the northeast Yakutia: U.S.S.R. Academy of Sciences, Siberian Branch, Institute of Geology, Yakutsk, 199 p. (in Russian)

Bakke, A.A., 1995, The Fort Knox "porphyry gold deposit Structurally-controlled stockwork and shear quartz vein, sulfide-poor mineralization hosted by a Late Cretaceous pluton, east-central Alaska, in Schroeter, T.G., ed. Porphyry deposits of the northwestern Cordillera of North America: Canadian Institute of Mining. Metallurgy, and Petroleum, Special Volume 46, p. 795-802.

Baranov, B.V., Seliverstov, N.I., Muravow, A.V., and Muzuzov, EL. 1991. The Komandorsky Basin as a product of spreading behind a transform plate boundary: Tectonophysics, v. 199, p. 237-269.

Barker, Fred, 1994, Some accreted volcanic rocks of Alaska and their elemental abundances, in Plafker, George, and Berg. H.C., eds., The Geology of Alaska: Boulder, Colorado, Geological Society of America, The Geology of North America, v. G-1, p. 555-588.

Barker, Fred, and Stern, T.W., 1986, An arc-root complex of Wrangellia, eastem Alaska Range [abs.]. Geological 
Society of America Abstracts with Programs, v. 18, no. 6. p. 534.

Barker, Fred, Sutherland-Brown, A, Budahn, J.R., and Plafker, G. 1989. Back-arc with frontal-arc component origin of Triassic Karmutsen basalt, British Columbia, Canada: Chemical Geology, v. 75, p. 81-102.

Barker, J.C., 1987, Distribution of platinum group elements in an ultramafic complex near Rainbow Mountain, Alaska: Process Mineralogy VIt: Applications to Exploration. Warren, Pennsylvlania, p. 197-200.

Barker, J.C, and Swainbank, R.C. 1986, A tungsten-rich porphyry molybdenum occurrence at Bear Mountain, northeast Alaska: Economic Geology, v. 81, p. 17531759

Bakulin, Y.I., Burak, V.A., Galuchanun, Y.H., Lowshak, N.P., and Romanovksy, N.P. 1999, Mineral resources of Khabarovsk, Amur, and Primorye Regions, Far East Economic Zone, Russian Federation: Russian Ministry of Natural Resources, Khabarovsk Office, Special Annual Publication. 213 p. (in Russian)

Barr, D.A., 1980, Gold in the Canadian Cordillera: Canadian Institute of Mining and Metallurgy Bulletin, v, 73, p. 59 76.

Barreft, T.J., and Sherlock, R.L., 1996, Voicanic stratigraphy, lithogeochemistry, and seafloor setting of the $\mathrm{H}-\mathrm{W}$ massive sulphide deposit, Myra Falls, Vancouver Island, British Columbia: Exploration and Mining Geology, v. 5, p. $421-458$

Barrie, C.T. 1993, Petrochemistry of shoshonitic rocks associated with porphyry copper-gold deposits of central Quesnellia, British Columbia: Joumal of Geochemical Exploration, v. 48, p. 225-258.

Bateman. A.M., and McLaughlin, D.H., 1920, Geology of the ore deposits of Kennecott. Alaska: Economic Geology. V. 15, D. $1-80$

Bazard, D.R.. Butter, R.F, Gehrois, G.E, 1993, Paleomagnetic and detrital zircon analysis of the Lower Devonian Karheen Formation, Alexander Terrane, southeastem Alaska [abs.]: Eos, Transactions, American Geophysical Union, v. 74, p. 213

Bazard, D.R, Buller, R.F., Gehreis, GE, and Soja, C.M., 1994, New constraints for Late Silurian-Devonian paleogeography of the Alexander terrane, southeastem Naska [abs.] Geological Society of America Abstracts with Program, v. 26, p. 384.

Bazhanov. V.A.. 1988, Major geological and metallogenic features of the Khanica massif, in Kokorin, AM., ed., Metallogeny of major tin-bearing districts of the southem Russian Far East Far East Geological Institute, Viadivostok, D. 114-133 (in Russian)

Beard, J.S. and Barker. Fred, 1989. Petrology and tectonic significance of gabbros, tonailtes. shoshonite, and anorthosiles in a late Paleozoic aro-root complex in the Wrangellia lerrane, southern Alaska: Joumal of Geology, v. 97, p. 667-683.

Beaudoin, G. Roddick, J.C., and Sangster, D.F, 1992 , Eocene ago for $\mathrm{Ag}-\mathrm{Pb}-\mathrm{Zn} \mathrm{Au}$ vein and replacement deposits of the Kokanee Range, southeastem British Columbia: Canadian Joumal of Earth Sciences, v. 29, p. 3-14

Bekchtold, A.F and Semenov, D.F 1990 , Metabasites and ultramafic rocks of the Susunai Rodpe (Sakhalin island): Tikhookeanskaya Geologiva. no. 1, p. 121-125 (in Russian)

Belasky. P, and Runnegar, B. 1994, Permian longtudes of Wrangellia, Stikinia, and eastem Kamath terranes based on coral biogeography. Goology, v. 22, p. $1095-1096$.
Beil, R.T., 1968, Proterozoic stratigraphy of northeastem British Columbia: Geological Survey of Canada Paper 67-68, 75 p.

Bell, R.T., 1991, Uranium and thorium, in Gabrielse, $H_{\text {. }}$ and Yorath, C.J., eds., Geology of the Cordilleran Orogen: Boulder, Colorado, Geological Society of America, The Geology of North America, v, G-2, p. 782-787.

Bely, V.F., 1977, Stratigraphy and structures of the OkhotskChukotka volcanogenic belt: Nauka, Moscow, 171 p (in Russian).

Bely, V.F. 1978, Formations and tectonics of the OkhotskChukotka volcanogenic belt: Nauka, Moscow, 213 p (in Russian).

Belytsky, B.V. and Krymsky, R.S., 1999, Age and genetic relationship of rare-metal ore-bearing graniles of Voznesenka ore field, Primorye: Rb-Sr and Sm-Nd isotopic data, in C.J. Stanley and others, eds. Mineral Deposits: Processes to Processing: A.A. Balkema/Rotterdam/Brookfield, v, 1, p, 313-316

Benevolsky, B.I., Migachev, I.F., and Schepotiev, Yu.M., 1992. The state and potential of gold resources of the Commonwealth of Independent States under the new market conditions: Sovietskaya Geologiya, no. 3, p. 411. (in Russian).

Berg, H.C., 1984, Regional geoiogic summary, metallogenesis. and mineral resources of southeastem Alaska: U.S. Geological Survey Open-File Report 84-572, 298 p. scale $1.600,000$.

Berg, H.C., and Cobb, E.H. 1967, Metaliferous lode deposits of Alaska: United States Geological Survey Bulletin 1246 , $254 p$.

Berg, H.C., and Grybeck, Donald, 1980, Upper Triassic volcanogenic $\mathrm{Zn}-\mathrm{Pb}-\mathrm{Ag}_{9}$ (Cu-Au)-barile mineral deposits near Petersburg. Alaska: U.S. Geological Survey OpenFile Report 80-527, 9 p.

Berg, H.C., Decker, J.E., and Abramson, B.S., 1981, Metallic mineral deposits of southeastern Alaska: U.S. Geological Survey Open-File Report 81-122, 136 p., 1 sheet, scale $1: 1,000,000$.

Berg. H.C. Elliott, RL, and Koch, R.D., 1978, Map and tables describing areas of metalliferous mineral resource potential in the Ketchikan and Prince Rupert quadrangles, Alaska: U.S. Geological Survey Open-Fle Report 78-73M, 48 p, 1 sheet, scale $1250,000$.

Berg. H.C., Jones, D.L. and Richter, D.H., 1972. GravinaNutzotin belt-Tectonic significance of an upper Mesozoic sedimentary and volcanic sequence in southorn and southeastom Alaska: U.S. Geological Survey Professional Paper 800-D, D. D1-D24.

Berger, V.L. 1978, Antimony deposits (regularities of distribution and criteria for prediction), Leningrad, Nedra. $296 \mathrm{p}$ (in Russian)

Berger, V.L, 1993, Descriptive model of goid-antimony deposits: U.S. Geological Survey Open-File Report 93194,24 p.

Berman, Yu. S. 1969, Gold-argentite assemblage as one of features of gold-silver deposits: Transactions of Central Research Geological-Exploratory institute, v. 86, part 1. p. $39-43$ (in Russian).

Berman, Yu. S. and Trenina, T1. 1968, Goid in gold-silver occurrences and related placers in Chukotka: Transactions of Central Research GeologicalExploratory institute. 79. p. 142-152 (in Russian).

Beus. V.A., and Miledin, A.K., 1990, New age data for the metamorphic complex of the Prikolymian Uplift: Reports of the U.S.S.R. Academy of Sciences, v. 311, no. 4, p. $925-928$ (in Russian). 
Binda, PL. Koopman. HT, and Koopman. ER, 1999. A stratiform copper occurrence in the Helkian Siyeh Formation of Alberta, in Boyle, R.W. Brown, A.C., Jefferson, C.W, Jowett, E.C. and Kirkham, R.V, eds., Sediment-hosted stratifom copper deposits, Geological Association of Canada Special Paper 36, p.269-286.

Bishop. S.T. Heah, T.S., Staniey, C.R., and Lang. J.R., 1995 , Alkalic intrusion hosted copper-goid mineralization at the Lorraine deposit, north-central British Columbia, in Schroeter, T.C. ed. Porphyry Deposits of the Northwostem Cordillere of North America, Canadian Insthute of Mining and Metailurgy. Special Volume 46, p. 623-629.

Biss, J.D., 1992, Grade and fonnage model of Chugach-type lowsulfide Au quartz veins, in Bliss, J.D. ed, 1992. Developments in mineral deposit modeling: U.S. Geological Survey Bulletin 2004, p. 41-46

Blss, J.D., ed., 1992, Developments in mineral deposit modeling: U.S. Geological Survey Bulletin 2004, $168 \mathrm{p}$.

Blodgett, R.B., 1998, Emsian (late Early Devonian) fossils indicate a Siberian origin for the Farewell terrane, in Clough, J.G., and Larson, F., eds., Short notes on Alaska geology 1997: Alaska Division of Geological and Geophysical Surveys Professional Report 118. p. 53-61.

Biodgett, R.B., and Boucot, A.J., 1999, Late Early Devonian (Late Emsian) eospirifernid brachiopods from Shallabarger Pass, south-Central Alaska, and theif biogeographic importance: Senckenbergiana Lethaea, $v$. 79, p. 209-221.

Blodgett, R.B. and Brease, P.F. 1997. Emsian (Early Devonian) brachiopods from Shellabarger Pass, Takeetna C-6 quadrangle, Denal National Park. Alaska, indicate Siberian origin for Farewell torrane (abs.) Geological Society of America Program with Abstracts, v 29. p. 5.

Blodgett, R.B., and Clough, J.G., 1985, The Nixon Fork terranepart of an in-situ peninsular extension of the Paieozoic North American continent [abs.] Geological Society of America Abstracts with Programs, v. 17, p. 342.

Bloodgood, M.A., 1987, Geology of the Triassic black phyllite in the Eureka Peak area, central British Columbia $(93 \mathrm{~N} 7)$; in Gelogical Fieldwork 1986, British Columbia Ministry of Energy, Mines and Petroleum Resources paper 1987-1, p. 135-142.

Blum, J.D., 1985, A petrologic and Rb-Sr isotopic study of intrusive rocks near Fairbanks. Alaska. Canadian Journal of Earth Sciences, v. 22, p. 1314-1321.

Biusson, SL., 1978, Regional geologic setting of lead- zinc deposits in Selwym Basin, Yukonc Current research, Part A, geological Survey of Canada. Paper 78-1A, p. 77-80.

Bogdanov, NA. Vishnevskaya. V.S, Kepezhinskas, P.K. Sukhov, A,N. and Fedorchuk, A.V., 1987, Geology of southem Koryak Highlands: Nauka. Moscow, 168 p (in Russian).

Bogovin. V.D., Kazanenko, G.G, Flerov, B.L. Ponamorev, V.G. Tychinsiky, A.A., and Stepanov, E.P. 1979. The geologic setling and structure of deposits and the occurrences of ore bodies, in Kuznetsov, V.A., Yanshn, A.L. eds. Stratified lead-zinc deposits occurring in Vendian sequences in the southeastern Yalutiya: Nauka, Novosibirsk, p. 106-119 (in Russian).

Bond, G.C. 1973, A late Paleozoic volcanic arc in the eastem Alaska Range, Alaska. Journal of Geology, v. B1, D 557-575.

Bond. G.C., 1976, Geology of the Rainbow Mountain-Gukana Glacier area. eastern Alaska Range, with emphasis on upper Paleozoic strata: Alaska Division of Geological and Geophysical Surveys Geologic Report 45, 47 p.

Bond, J., 1983, Geology of the Tin Granite and associated skarn at Ear Mountain. Seward Peninsula, Alaska: Fairbanks, Alaska, University of Alaska, M.S. thesis, 89 p.

Bouley, B.A.. St. George, P. and Wetherbee, P.K., 1995. Geology and discovery at Pebble Copper, a copper-gold porphyry system in Southwest Alaska, in Schroeter. T.G., ed., Porphyry deposits of the northwestern Cordillera of North America: Canadian Institute of Mining. Metallurgy, and Petroleum, Special Volume 46, p. $422-435$.

Bower, B., Payne, J., DeLong, C, and Rebagliati, C.M., 1995, The oxide-gold, supergone and hypogene zones at the Casino gold-copper-molybdenum deposit, west-central Yukon in Schroeter, T.G., ed, Porphyry Deposits of the Northwestem Cordiliera of North America, Canadian Institute of Mining and Metallurgy Special Volume 46, p. $352-366$.

Box, S.E.. 1985. Terrane analysis of the northern Bristol Bay region, southwestern Alaska, in Bartsch-Winkler, Susan, ed. The United States Geological Survey in Alaska: Accomplishments during 1984: U.S. Geological Survey Circular 967, p. 32-37

Box, S.E., Moll-Stalcup, E.J., Frost, T.P., and Murphy, J.M., 1993, Preliminary geologic map of the Bethel and southem Russian Mistion quadrangles, southwestem Alaska: U.S. Geological Survey Miscellaneous Field Studies Map MF. 2226-A, scale 1: $250,000,20 \mathrm{p}$.

Box, S.E., and Patton, W.W.4.Jr., 1989, Igneous history of the Koyukuk terrane. western Alaska: Constraints on the origin, evolution, and ultimate collision of an accreted island arc terrane: Journal of Geophysical Research, v. 94. p. $15,843-15,867$.

Box, SE., Moll-Staloup, E J., and Wooden, J.L., 1990, Kibuck terrane: Oldest-known rocks in Alaska: Geology, v. 18, p. $1219-1222$.

Boyle, H.C. and Lohth, C.HB, 1983, Geology of the Trout Lake molyodenum deposit. Brtish Columbia: Canedian insthute of Mining and Metalurgy. Bullotin, 76, no. B49, D. 115-124.

Bradiord, JA. and Godwin. C.I. 1988, Midway siver-lead-zinc manto deposit, northem British Columbia: in Gociogical Fieidwork 1987; British Columbia Ministry of Energy, Mines and Petroleum Resources Paper 1988-1.p. 353-360.

Bradiey, D.C. Haeussler. P.J., and Kusky. T.M. 1993. Timing of early Tertiary ridge subduction in southem Alaska, in Dusel-Bacon, Cynthia, and Till, A.B., eds. Geologic Stucies in Alaska by the U.S. Geological Survey, 1992 : U.S. Geological Survey Bulletin 2068, p. 163-177.

Brandon, M.T. Garver, Ji., Bullen, ME, Sokovev, A.V. Ledneva. GV., and Bogdanov, N.A. 1997, Eocone collision and obduction of the Olutornky island are, Koryak Hiphlands of northem Kamchaba, Russian Far East (abs.) Geoiogical Society of America Abstracts with Program v. 29, D. 6.

Brandon, M.T. Gaver, Ji., Bullen, ME, Sokovbr, A.V. Ledneva. G.V. and Bogdanov, N.A. 1998 . Eocene collision and obduction of the Otutorskly iatand arc, Koryak Hiphlands of northem Kamchaska, Russian Far East (abs): Abstracts of $6^{\mathrm{b}}$ Zonenshain Conference on Plate Tectonics. Russian Academy of Sciences, Moscow, v. 29. p. 172

Brazhnk, A.V, and Kolyasnikov, Yu. A., 1989, Contemporary chemogenic precipitations in one of sulfide occurrences of the Koryak Highlands: Geology. geochemistry and minerals of the Far East US.S. Academy of 
Sciences. North-Eastern Interdisciplinary Research institute, Magadan, D. 50-63 (in Russian).

Brazhnik, A.V. and Morozov. A.E., 1989, Peculiarities of metasomatic processes and ore matter balance in the Laiankytap porphyry molybdenum-copper deposit: Geochemistry and mineralogy of ore deposits of the U.S.S.R. Northeast: U.S.S.R. Academy of Sciences. North-Eastern Interdisciplinary Research Institute. Magadan, p. 142-155 (in Russian).

Bremner. T. 1990. Brewery Creek, in Yukon Exploration 1990. Exploration and Geological Services Division: Indian and Northem Affairs Canada, p. 21-23.

Bremmer, T.J. 1994, Geology and Metallogeny of southwost Yukon: Canadian Institute of Mining, 1994 General Meeting. Abstracts and Proceedings of District, p. 38-44.

Bremner. T., and Ouellette. D.1991, Matt Berry, in Yukon Exploration 1990, Exploration and Geological Services Division: Indian and Northern Affairs Canada, p, 48-49.

Brew, D.A. 1988, Latest Mesozoic and Cenozoic igneous rocks of southeastern Alaska-A synopsis. U.S. Geological Survey Open-Fle Report 88-405, 52 p.

Brew, DA.. 1993. Regional geologic setting of mineral resources in southeastem Alaska, in Godwin, L.H, and Smith, B.D. eds. Economic mineral resources of the Annette islands Reserve, Alaska: United States Department of the Interior, Bureasu of Indian Aftairs, Division of Energy and Mineral Resources Publication, p. 13-20.

Brew, D.A. 1994, Latest Mesozoic and Cenozoic magmatism in southestern Alaska, in Plafker, George, and Berg, H.C., eds. The Geology of Alaska: Boulder, Colorado, Geological Society of America, The Geology of North America, v. G-1, p. p. $621-656$.

Brew, D.A, and Ford, A.B., 1984, Tectonostratigraphic terrane analysis in the Coast plutonic-metamorphic complex, southeastern Alaska, in Reed, K. M., and BartschWinkler, Susan, eds., The U.S. Geological Survey in Alaska: Accomplishments during 1982: U.S. Geological Survey Circular 939, p. 90-93.

Brew, D.A., and Grybeck, Donald. 1984, Geology of the Tracy Arm-Fords Terror Wilderness Study Area and Vicinity. Alaska. U.S. Geological Survey Bulletin 1525-A, 52 p.

Brew, D.A. and Morrell, R.P. 1983, Intrusive rocks and plutonic belts of southeastern Alaska, U.S.A. Geological Society of America Memoir 159, p. 171-193.

Brew, D.A., Drew, L.J. Schmidt. J.M. Root, D.H. and Huber. D.F, 1991. Undiscovered locatable mineral resources of the Tongass National Forest and adjacent lands. southeastern Alaska: United States Department of the Interior, Geological Survey. Open-File Report 91-10. 369 p.

Brew, D.A. Himmelberg, G.R. Loney, R.A, and Ford, A.B. 1992, Distribution and characteristics of metamorphic belts in the south-eastern Alaska part of the North American Cordillera. Joumal of metamorphic geology, $v$. 10. p. $465-482$

Brew, D.A. Himmelberg, G.R. Ford, A. B., and Loney, R.A. 1993, Magmatic and metamorphic belts and plutonic: metamorphic complexes of southeastern Alaska [abs]. Geological Soclety of America Abstracts with Programs. V. 25, p. 13

Brew, D.A. Johnson, B.R., Grybeck, D., Griscom, A, and Bames. D.F, 1978, Mineral resources study of the Glacier Bay National Monument wildemess study area, Alaska: United States Geological Survey Open-File Report 78-494, 678 p.

Brew, DA. and Morrell, R.P. 1983, Intrusive rocks and plutonic beits of southeastern Alaska, U.S.A. Geological Society of America Memoir 159, p. 171-193.
Bright, M.J., and Jonson D.C., 1976, Glacier Gulch (Yorke-Hardy), in Sutherland Brown. A., ed., Porphyry Deposits of the Canadian Cordillera: Canadian Institute of Mining and Metallurgy Special Volume 15, p. 455-461

British Columbia Department of Mines and Petroleum Resources, 1972. Geology, Exploration, and Mining in British Columbia, p. 272.

British Columbia Department of Mines and Petroleum Resources, 1991, Report: 1991-7, 304 p.

Brosge, W.P., and Reiser, H.N., 1968, Preliminary geologic and mineral resource maps (excluding petroleum). Arctic National Wildife Range, Alaska: U.S. Geoiogical Survey Open-File Report 76-539, 4 sheots, scale 1:500,000.

Brostosvskaya, V.G., and Goncharov, V.I., Eremin, R.A., Savva, N.E., Sidorov, A.A., and Tolstikhin, Yu., V. 1974, Silver bearing deposits of the goid-argentite type: Materialy po Geologil i Polzenym Iskopaemym SeveroVostoka SSSR, U.S.S.R. Academy of Sciences, v. 21 , p. 95-100 (in Russian).

Brown, D., and MoClay, K.R., 1993, The Vangorda deposit, in Yukon Exploration and Geology, 1992: Expioration and Services Division, Yukon, Indian and Northem Affairs, Canada, p. 27-32.

Brown, R., 1995, Poison Mountain porphyry copper-goidmolybdernum deposit, south-centtral Britsh Columbia; in Schroeter, T.G. ed. Porphyry Deposits of the Northwestem Cordillera of North America, Canadian Institute of Mining and Metallurgy Special Volume 46, p. 343-351,

Bulgakova, M.D., 1986, Lithology of the Ordovician deposits in the U.S.S.R. Northeast: Nauka, Moscow, 175 p (in Russian).

Bull, K.F., 1988, Genesis of the Goiden Hom and related mineralization at Flat, Alaska: Fairbanks, Universily of Alaska unpub. M.S. Thesis, $299 \mathrm{p}$

Bundzen, T,K, 1978, The Prince of Waies Isiand Copper Mining Industry 1900-1941. Alaska Division of Geological and Geophysical Surveys Mines and Geology Bulletin, v, 27, no, 2, 6 p.

Bundtzen, T.K., 1981, Geology and mineral deposits of the Kantishna Hills, Mount McKinley quadrangle, Alaska: Fairbanks, Alaska. University of Alaska, M.S. thesis, 237 P. 4 sheets, scale 1.63.360.

Bundtzen, T.K., 1983, Overview of Alaska's strategic minerals. in Agnew, A.F, ed. International minerals, a national perspective: American Association of Advancement of Science Selected Symposium 90. Westview Press. Boulder, Colorado, p. $37-70$

Bundtzen, TK., 1983a, Mineral resource modeling KantiahnaDunkle Mine Study. Alaska: Alaska Division of Geological and Geophysical Surveys Report of Investigations 83-12, 51 p.

Bundtzen, T.K., 1963b, Overvlew of Aaska's strategic minerals. in Agnew, A.F., ed, International minerals, a national perspective: American Association of Advancement of Sclence Selected Symposium 90, Westview Press. Boulder, Colorado, p. 37-70

Bundtzen, T.K., 1986. Heavy mineral placers in Alder Gulch, Vinasale Mountain, McGrath District. Alaska: Alaska Division of Geological and Geophysical Surveys Public Data Report 66-29, $12 \mathrm{p}$.

Bundzen. T.K. 1986, Placer geology of Porcupine-mining district. Skagway B-4 quadrangle, Alaska. Alaska Division of Geological and Geophysical Surveys Public Data File Report 86-27, 22 p. scale 1;40,000. 
Bundtzen, T.K, 1999, Alaska Resource Data File (ARDF) for the Medtra Quadrangle, Alaska: U S. Geological Survey Open-File Report 99-156, 176 p.

Bundtren, T.K. Bouley, B.A., and Nodeberg. W.J., 2000. Regional metallogenesis of central Alaska: Society of Mining and Metallurgical Engineers Annual Meeting. Salt Lake City, Special Publication 00-29, p. 6-17.

Bundzen, T.K., Fonseca, A.L, and Mann, R., eds, 1995, The geology and mineral deposits of the Russian Far East: Anchorage. Alaska, Glacier House Publications and the Alaska Miners Association, 156 p.

Bundtzen, T.K., and Gibert, W.G., 1983, Outine of geology and mineral resources of upper Kuskokwim region. Alaska: Alaska Geological Society 1982 Symposium on Western Alaska, v. 3, p. 101-117

Bundtzen, T.K., and Gibert, W.G., 1991, Geology and geochemistry of the Gagaryah barite deposit, western Alaska Range, Alaska: in Reger, R.D., ed., Short Notes on Alaskan Geology-1991: Alaska Division of Geological and Geophysical Bundtzen, T.K. and Miller, M.L., 1991, Geology and metallogeny of Cretaceous. early Tertiary volcanic and plutonic rocks, Kuskokwim mineral belt, southwest Alaska: Circum-Pacific Counci on Energy and Mineral Resources, Kharbarowsk. Russian Republic, $14 \mathrm{p}$.

Bundtzen, T.K., Green, C.B., Deagen, James, and Danieis. C. L., 1987, Alaska's mineral industry: Alaska Division of Geological and Geophysical Surveys Special Report 40. $68 \mathrm{p}$

Bundtzen, T.K., Green, C.B., Pelerson, R.J., and Seward, A.F. 1988, Alaska's Mineral industry, 1987: Alaska Division of Geological and Geophysical Surveys, Special Report 41. $69 \mathrm{p}$.

Bundtzen, T.K., Harris, E.E, and Gilbert, W.G., 1997, Geology of the Eastem McGrath quadrangle, Alaska Alaska Division of Geological and Geophysical Surveys Report of Investigations 94-14, $48 \mathrm{p}$; ; scale 1:125,000.

Bundtzen, T.K., Kline, J.T., Smith, T.E., and Albanese, M.D. 1988. Geology of McGrath A-2 quadrangle: Alaska Division of Geological and Geophysical Surveys Professional Report 91, 22 p, 1 sheot, scale 1:63,360

Bundtzen, T.K., and Laird, G.M. 1980, Preliminary geology of the McGrath-Upper Innoko River area, western interior Alaska: Alaska Division of Mines and Geology Open-File Report 134, 36 p.

Bundtzen. T.K. and Laird. G.M. 1982. Geologic map of the Iditarod D-2 and eastem D-3 quadrangles, Alaska Alaska Division of Geological and Geophysical Surveys Geologic Report 72, 26 p., 1 sheet, scale 1.63.360.

Bundtzen, T.K., and Laird, G.M. 1991, Geology and minera resources of the Russian Mission C-1 Quadrangle. Southwest Alaska: Alaska Division of Geological and Geophysical Surveys Professional Report 109, 24 p. 2 sheets, scale 1.63 .360 and $1: 500$.

Bundtzen, T.K. Laird, G.M. Calutice, K.H. and Harris, E. E, 1995. Metamorphic stratigraphy and economic geology of the Nome Group, Nome mining district, westem Alaska: Geological Society of Amenca Abstracts with Programs. v. 27, p. 13.

Bundtzen, T.K. Layer, P.W., and Sidorov, E.G., 2003a, Geology, geochemistry, and new isotopic ages of PGE. Ni-Cu bearing mafic-uitramafic rocks in the Farewell and Sredinny lerranes. Alaska USA and Kamchatka. Russia (abs) Geological Sociely of America Abstracts with Programs, v. 35, p. 60.

Bundtzen. T.K. Layer, P.W., and Sidorov, E.G, 2003b. Geology, geochemistry, and new isotopic ages of selected PGE-N-Cu bearing mafo-ultramafic complexes in Alaska-Yukon and Russian far east regions, in McCarthy. PJ. ed., Geology Symposium: University of Alaska College of Scientific Engineering and Alaska Geological Society Joint Meeting. Fairbanks, Alaska, p. 9.11

Bundtzen, T.K. and Miler. ML, 1997, Precious metals associated with Late Cretaceous-earty Tertiary igneous complexes of southwest Alaska, in Goldtarb, R.J. and Miller, L.D., eds. Mineral Deposits of Alaska: Economic Geology Monograph 9. p. 242-286.

Bundtzen, TK. Miler, ML. Laird, G.M. and Buil, K.F. 1992a. Geology and mineral resources of Iditarod Mining District, Iditarod B-4 and eastern B-5 quadrangles. southwestern Alaska: Alaska Division of Geological and Geophysical Surveys Professional Report 97, 46 p., 2 plates, scale $1: 63,360$ and $1: 500,000$.

Bundtzon, TK. Miller, M. Laird, G.M., and Kline, J.T. 1985. Geology of heavy mineral placer deposits in the iditarod and Innoko precincts, westem Alaska, in Madonna, J.A., ed. 7th Arnual Conlerence on Alaska Placer Mining: Alaska Prospectors Publication Company, p. 35-41.

Bundtren, T.K. and Reger, R.D. 1977, The Richardson lineament - a structural control for gold deposits in the Richardson mining district, interior. Alaska, in Short Notes on Alaska Geology - 1977: Alaska Division of Geological and Geophysical Surveys Geologic Report 55, p. 29-34.

Bundtzen, T.K., Reger, R.D. Laird, G.M., Pinney, D.S., Calutice, K.H. Liss, S.A, and Cruse, G.R., 1994. Progress report on the geology and mineral resources of the Nome mining district: Alaska Division of Geological and Geophysical Surveys Public Data File Report 94-39. 19 p. 2 sheets, scale $1: 63,360$.

Bundzen, T.K., Schaefer, Carl, and Dashevsky, Sam, 2003. Road Metal-a new silver-goid polymetallic lode discovery at Northway Junction, Eastern-Interior Alaska [abs ]. in Reifenstuhi, R.R., ed., Alaska Geological Society 2001, Geology Symposium: University of Alaska Department of Geology and Geophysics Extended Abstracts, p. 4-5.

Bundzen, TK. and Sidorov, E.G., 1998. Overview of placer and lode platinum group element (PGE) deposits of the Russian Far East, in Walsh, D. ed. Extended Abstracts of the $16^{\text {th }}$ Biennial Conference on Alaska Mining. Alaska Miners Association Special Volume 4, p. 34-36.

Bundzen, T.K. Sidorov, E.G., and Chubarov, V., 2003. Comparisons between PGE deposits in Alaska-NW Canada and Russian Far East regions, I labs]: Abstracts with Programs; $87^{\text {th }}$ SME Annual Meeting and Exhibits. p. 44

Bundtzen. T.K., Swainbank, R.C., Clough. A., Henning. M.W. and Hansen, E.W. 1994, Alaska's Mineral Industry. 1993: Alaska Division of Geological and Geophysical Surveys Special Report 44, 100 p.

Bundtzen, T.K. Swainbank, R.C., Deagan, J.R., and Moore. J.L. 1990, Alaska's Mineral Industry, 1989: Alaska Division of Geological and Geophysical Surveys Special Report 48, $84 \mathrm{p}$.

Bundtzen, T.K., Swainbank, R.C. Henning. M.W., Clough, A.H., and Harlie, K.M., 1996, Alaska's Mineral Industry. 1995: Alaska Division of Geological and Geophysica Surveys Special Report 50, 71 p.

Bundtzen, T.K., Swainbank R. . Wood, J.E, and Clough. A.H. 1992b. Alaska Mineral Industry. 1991: Alaska Division of Geological and Geophysical Surveys Specia Report 46, $89 \mathrm{p}$. 
Burgoyne, A.A., 1966, geoiogy and expicration, McDame asbestos deposit, Cassiar, British Columbia: Canadian Institute of Mining and Metallurgy, Bulletin, v. 79 , no 889, p. 31-37.

Burk. C.A., 1965. Geology of the Alaska Peninsula - island arc and continental margin: Geological Society of America Memoir 99, 250 p., 2 map sheets, scales 1:250,000 and 1.500.000

Burleigh, RE., 1991, Geology and geochemistry of the Sleitat Mountain tin deposit, Southwestern Alaska: Alaska. Division of Geological \& Geophysical Surveys, Report: 111, p.29-39

Burleigh, R.E., 1992a, Examination of the Win tin prospect. west-central Alaska: U.S. Bureau of Mines Open File Report 92-92, 23 p.

Burleigh, RE., 1992b. Tin mineralization at the Won prospect, west-central Alaska: U.S. Bureau of Mines Open File Report 85-92, 21 p.

Burns, LE., 1985, The Border Ranges ultramafic and mafic complex, south-central Alaska: cumulate fractionates of island-are volcanics: Canadian Journal of Earth Sciences, v. 22, p. 1020-1038

Butnerchuk, S.8. and Hancock, K.D., 1997, Barite in British Columbia British Columbia Ministry of Energy and Mines Open File 1997, $145 p$

Butrenchuk, S.B., 1991, Gypsum doposis in British Columbia British Columbia Ministry of Energy. Mines and Petroleum Resources, Open File 1991-15.

Butrenchuk. S.B. 1996. Phosphale deposits in British Columbia: British Columbla Ministry of Energy. Mines and Petroleum Resources Bulletin 98, 126 p.

Byalobzhesky, S.G., Korago, E.A. Lychagin, P.P. Kolyasnikov, Yu A., and Likman, V. B, 1900, South Anyul zone: Longlived development of foided structure, in Tectonics and metallogeny of U.S.S R. Northeast: U.S.S.R. Academy of Sciences, Magadan, D. 29-31 (in Russian).

Eyers, F.M., Jf, and Sainsbury, C.L., 1956. Tungsten deposits of the Hyder district, Alaska: U.S. Geological Survey Bulletin 1024-F, D. 123-140.

Bysouth, G.D, and Wong. G.Y, 1995, The Endako molybdenum mine, central Britsh Columbia: An update; in Schroeter. T.G. ed., Porphyry Deposits of the Northwestem Cordiliers of North America. Canadian insthute of Mining and Metallurgy Special Paper 46, p. 697-703.

Cady, W.M.. Wallace. R.E. Hoaro, J.M. and Webber, E.J. 1955. The central Kuskokwim region, Alaska: U.S. Geoiogical Survey Professional Paper 268, 132 p.

Caira, N.M., Finday, A. Delong. C., and Rebagliati. CM., 1995. Fish Lake porphyry cogger-goid deposit, central British Columbia: in Schroeter, T.G., ed.. Porphyry Deposits of the Northwestem Cordiliera of North America, Canadian institute of Mining and Metalurgy Special Volume 46, p. $327-342$.

Cairnes, C.E, 1934, Slocan Mining Camp, Brtish Columbia Geological Survey of Canada Memoir 173, 137 p.

Campbell, FA., 1960, Nickel deposits in the Ouil Creek and White River areas. Yukon Canadan insthule of Mining and Metallurgy, Bulletin, v. 53, p. $953-959$.

Campbell, S.W. 1976, Nickeb-cosper sulphide deposits in the Kluane Ranges. Yukon Temtory, Department of indian and Northern Affairs, Open-File Report EGS 1976-10, 17 p.

Cant, D.J., 1989, Zuni sequence: the Foreland Basin, Lower Zuni sequence Middle Jurassic to Middle Cretaceous, in Ricketts, B D. ed. Western Canada sedimentary basin; a case history: Canadian Society of Petroleum Geologists, Calgary, p. 251-267

Carne, RC. 1979, Upper Devonian barite-lead-zinc-siver mineralization at Tom dairns, Macmilan Pass, Yukon
Territory: Vancouver, University of British Columbia, M.Sc. thesis, $149 \mathrm{p}$.

Carriere, J.J., Sinclair, W.D., and Kirkham, R.V.4 1981, Copper deposits and occurrences in Yukon Terrilory: Geological Survey of Canada Paper 81-12, 62 p.

Carson, D.J.T.4 1973, The plutonic rocks of Vancouver Island: Geological Survey of Canada Paper 72-44, 70 p.

Carson, D.J.T., and Jambor, J.L. 1974, Mineralogy, zonal relationships and ecomonic significance of hydrothermal alteration at porphyry copper deposits, Babine Lake area, British Columbia: Canadian Institute of Mining and Metallurgy Bulletin, v. 67, p. 110-133.

Carson, D.J.T. Jambor, J.L., Ogryzlo, P., and Richards, T.A. 1976, Bell Copper: Geology, geochemistry and genesis of a supergene-enriched, biotitized porphyry copper deposit with a superimposed phyllic zone, in Brown, Sutherland, A. ed., Porphyry Deposits of the Canadian Cordillera: Canadian Instliute of Mining and Metallurgy Special Volume 15, p. $245-263$

Cartor, N.C, 1970, Len, in Geology. Exploration and Mining in British Columbia 1970: British Colmbia Ministyr of Energy. Mines and Petroleum Resources, p. 104-107.

Cartor, N.C. 1982, Porphyry copper, and molybdenum deposits. west-central British Columbia: Brtish Columbia Ministry of Energy, Mines and Petroleum Resources, Buletin 64, 150 p.

Carter, N.C, Dirom, G.E, and Ogryzlo, P.L, 1995, Poophyry copper-gold deposits, Babine Lake area, west-central British Columbia, in Schroeter, T.G. ed. Porphyry Deposits of the Northwestem Cordillera of North America: Canadian Institute of Mining and Metalurgy, and Petroleum, Special Volume 46, p. 247-255.

Cassolman, MM. McMilian, W.J., and Newman, KM., 1995. Highland Valley porphyry copper deposits near Kamloops. Birttsh Columbia: A reviow and update with emphasis on the Valley deposit, in Schroeter, T.G. ed. Porphyn Deposits of the Northwestern Cordilera of North America: Canadian Institute of Mining and Metalurgy, and Petroleum, Special Volume 46, p. 161-191.

Cathcart, S.H. 1922. Metalliferous lodes in southem Soward Penineula: U.S. Geological Survey Bulletin 722. p. 163 . 261.

Cochro, M.S. 1990, Gold, silver and lead deposits of the Ketza River district, Yukon, preliminary results of field work in Abboth, J.G., and Tumer, R.J.W. eds, Mineral Deposits of the Northem Canadian Cordilera. Yukon-northeastem Brtish Columbia, Fieldtrip Guidebock No. 14, $8^{\circ}$ Sympotium International Association on Genosis of Ore Deposts (IACOD): Geciopical Survey of Canada Open Fle 2169, p. 260-282.

Cecile. M.P., 1982. The lower Paloobcic Misty Creek embayment. Setwyn Basin, Yhon and Northwest Tertiories: Geological Survey of Canada Bulvetin, v. 335,78 p.

Chapman. R.M. 1945. Molybdenum prospect in the southem part of Kaiyuh Hills, Alaska. U.S. Geological Survey Press Release, 1 p.

Chartrand, F.M. Brown, A.C. and Kikham, R.V. 1989. Diagenesis, sulphides and metal zoning in the Redstone copper deposit. Northwest Territories: Geclogical Association of Canada, Special Paper 36, p. 189-206.

Chekhov, A.D., 1982, Tectonics of the Talovka-Pekulney zone: Essays on tectonics of the Koryak Highlands: Nauka. Moscow, p. 70-106 (in Russian).

Chipp, E.R, 1970, Geclogy and geochemistry of the Chandalar area, Brooks Range, Alaska: Alaska Division of Mines and Geology Geologic Report 42, 39 p. 
Christopher, P.A., 1975, Carmi-Beaverdell area (82E/6,11), in Geological Fieldwork 1975: British Columbia Ministry of Energy, Mines, and Petroleum Resources, p. 27-31,

Church, B.N., 1971, Geology of the Owen Lake, Parrott Lakes, and Goosly Lake area, in Geology. Exploration and Mining in British Columbia 1970. British Columbia Department of Mines and Petroleum Resources, p. 119125.

Church, B.N., 1973, Geology of the White Lake Basin: British Columbia Ministry of Energy. Mines, and Petroleum Resources Bulletin 61,120 p

Church, B.N., 1986, Geological setting and mineralization in the Mount Atwood-Phoenix area of Greerwood mining camp: British Columbia Ministry of Energy. Mirnes and Petroleum Resources, Paper 1986-2, 65 p

Church, 1995, B.N., 1985, Bridge River mining camps geology and mineral Deposits, Ministry of Energy, Mines and Petroleum Resources, Report 1990-3, 95 p.

Churkin, Michael, Jr.. Nokleberg, W.J., and Huie, Carl, 1979, Collision-deformed Paleozoic continental margin, western Brooks Range, Alaska: Geology, v. 7, no. 8, p. 379-383

Collier, A.J., Hess, F.L., Smith, P.S., and Brooks, A.H., 1908, The goid placers of parts of Seward Peninsula, Alaska, including the Nome, Council, Kougarok, Port Clarence, and Goodhope precincts: U.S. Geological Survey Bulletin 328,343 p.

Collins, JA., and Smith, L., 1977, Genesis of cupriferous quartz arenite cycles in the Grinnell Formation (Spokane equivalent). Middle Proterozoic (Helikian) Belt-Purceil Supergroup, eastem Rocky Mountains, Canada; Bulletin of Canadian petroleum Geology, v. 25, p. 713-735.

Coney, P.J., Jones, D.L., and Monger. J.W.H., 1980, Cordilleran suspect terranes: Nature, v. 288, p. 329-333.

Cook, D.B., Fujita, K., and McMullen, C.A., 1986, Present-day plate interactions in northeast Asia: North American, Russian, and Okhotsk plates; Journal of Geodynamics, v. 6, p. $33-51$.

Cooper, A.K., Scholl, D.W., and Marlow, M.S., 1992, Evidence for Cenozoic crustal extension in the Bering Sea region: Tectonics, v. 11, p. 719-731

Cowan, D.S., 1994, alternative hypotheses for the midCretacecus paleogeography of the western Cordilera: GSA Today, v. 4, no. $7, p .181-186$,

Cowan, D.S., Brandon, M.T. and Garver, J.I., 1997. Geologic tests for large coastwise displacements-a critique ilustrated by the Baja British Columbia controversy: American Joumal of Science, v. 297, p. 117-173.

Cox, D.P., 1993. Estimation of undiscovered deposits in quantitative mineral resource assessments - examples from Venezuela and Puerto Rico: Nonrenewable Resources, v. 2, no. 2, p, 82-91.

Cox, D.P., Detra, D.E., and Detterman, D.L., 1981, Mineral resource maps of the Chignik and Sutwik Island quadrangles, Alaska: U.S. Geological Survey Miscellaneous Field Studies Map MF-1053-K, 2 sheets, scale $1: 250,000$.

Cox, D.P. and Singer, D.A., eds,., 1986, Mineral deposit models: U.S. Geological Survey Bulletin 1693, 379 p.

Crowe, D.E., Nelson, S.W., Brown, P.E., Shanks, W.C.. III, and Valley, J.W., 1992, Geology and geochemistry of volcanogenic massive sulfide deposits and related igneous rocks. Prince William Sound, south-central Alaska: Economic Geology, v. 87, p. 1722-1746.

Crowley, J.L., 1997, U-Pb geochronologic constraints on the cover sequence of the Monashee Complex, Canadian Cordillera: Paleoproterozoic deposition on basement:
Canadian Journal of Earth Sciences, v. 34, p. 10081022.

Csejtey, B., Jr., Mullen, M.W., Cox, D.P., Gibert, W.G., Yeend, W.E., Smith, T.E., Wahrhatig, C., Craddock, C., Brewer, W.M., Sherwood, K.W. Hickman, R.G., Stricker, G.D., St. Aubin, D.R, and Goerz, K.J., III, 1986. Geology and geochronology of the Healy quadrangle, Alaska. U.S. Geological Survey Open-File Report 86-396, 92 p., 3 sheets, scale 1:250,000.

Cyr, J.B., Pease, R.B., and Schroeter, T.G., 1984, Geology and mineralization at Equity Silver Mine: Economic Geology. v. 79, p. $947-968$.

Czamanske, G.K., and Calk, L.C., 1981, Mineralogical records of cumulus processes, Brady Glacier Ni-Cu deposits, southeastern Alaska: Mining Geology, v. 31, no. 168, p. 213-233.

Dagis, A.C., and Dagis, A.A., 1984, The Triassic system, in The Phanerozoic of Siberia, the Mesozoic and Cenozoic: Nauka, Novosibirsk, v 2, p. 4-15. (in Russian).

Dagis, A.S., Arkhipov, Yu.U., and Bychkow, Yu.M., 1979. Stratigraphy of the Triassic system in northeastem Asia: Nauka, Moscow, 243 p. (in Russian).

Dalrymple, G.B., Czamanske, G.K., Fedorenko, V.A., Simonov, O.N., Lanphere, M.A. and Likhachev, A.P., 1995, A reconnaissance ${ }^{40} \mathrm{Ar}^{35} \mathrm{Ar}^{35}$ geochronologic study of orebearing and related rocks, Siberian Russia: Geochemica et Cosmochimica Acta, v. 59, p. 2071-2083.

Danchenko, V.Ya., 1991, Gold-silver mineralization of the large Kamchatka Chain: U.S.S.R. Academy of Sciences, Institute of Marine Geology and Geophysics, YuzhnoSakhalinsk, $63 p$

Danilov, V.G., Gedko, M.I., and Shumov, V.V., 1990, Massive sulfide polymetallic mineralization of kuroko-type in the Uyandin-Yassachny volcanic belt, Eastem Yakutia: Proceedings of Higher Educational Establishments, Geology and Exploration, no. 2, p. 67-72 (in Russian).

Dasler, P.G., Young. M.J., Giroux, G., and Perello, J.A., 1995, The Hushamu porphyry copper-gold deposit, northem Vancouver Island, British Columbia, in Schroeter, T., ed., Porphyry deposits of the northwestern Cordillera of North America: Canadian Institute of Mining. Metallurgy, and Petroleum, Special Volume 46, p. 367-376.

Davidenko, N.M., 1975, Mineral assemblages and conditions of formation of goid-bearing quartz veins in Maly Anyul area, western Chukotka: Nauka, Novosibirsk, 134 p (in Russian)

Davidenko, N.M., 1987, Correlation of placer and lode gold mineralization in cryolithozone, Yakutsk: U.S.S.R. Academy of Sciences, Yakutsk Permafrost institute, 172 p (in Russian).

Davydow, Yu. V., Chiryaev, A.G., Kostin, A.V.4 and Sobolev, A.E. 1988, Stratiform mineralization of Yakutia, Yakutsk: U.S.S.R. Academy of Sciences, Yakutian Branch, p. 5-24 (in Russian).

Dawson, K.M. 1972, Geoiogy of Endako Mine:Vancouver, British Columbia, Ph.D. dissertation, University of British Columbia, $337 \mathrm{p}$.

Dawson, K.M., 1975, Carbonate-hosted zinc-lead deposits of the northern Canadian Cordilera; in Report of Activities, Part A; Geclogical Survey of Canada, Paper 75-1A, p. 239-241.

Dawson, K.M., 1983, A review of barite in the northern Canadian Cordillera: Canadian institute of Mining and Metallurgy. Symposium, Mineral Deposits of Northem Cordilera, Whitehorse, Program and Abstracts, p.18.

Dawson, K.M., 1990, Regional geologic setting of selected mineral deposits of the northem Cordilera, in Abbott, J.G., and Tumer, R.J.W, eds. Mineral Deposits of the Northem 
Canadian Cordillera, Yukon-northeastern British Columbia, $8^{\text {th }}$ IAGOD Symposium, Fieldtrip Guidebook. Field trip No. 14, Geological Survey of Canada, Open File 2169, p. 1-24.

Dawson, K.M., 1996a, Skam zinc-lead-siiver, in Eckstrand, O.R., Sinclair, W.D., and Thorpe, R.F., eds., Geology of Canadian Mineral Deposit Types: Boulder, Colorado, Geological Society of America, The Geology of North America, v. F-1, p. $432-443$.

Dawson, K.M, 1996b, Skarn gold, in Eckstrand, O.R. Sinclair, W.D. and Thorpe, R.F.. eds., Geology of Canadian mineral deposit types: Bouider. Colorado, Geological Society of America, The Geclogy of North America, v. F-1, p. $460-472$

Dawson, K.M., 1996c, Skam tungston, in Eckstrand, OR. Sinclair. W.D. and Thorpe, R.F. eds., Geology of Canadian mineral deposit types: Boulder, Colorado, Geological Society of America. The Geology of North America, v. F-1, P, 479-486.

Dawson, K.M., and Dick, L.A., 1978, Regional motallogeny in the northern Cordiliera: tungsten and base metak bearing skarns in southeastern Yukon and southwestem Mackenzie: in Current Research, Part A, Geological Survey of Canada Paper 78-1A, D. 289-292.

Dawson, K.M. and Kimura, E.T.4 1972, Endako, in Copper and Molybdenum Deposits of the Westem Cordillera: International Geological Congress, Montreal, 24th Session Gukdobook for Field Excursion A09-C09, p. 3647.

Dawson, K.M. and Kirkham, R.V., 1996, Skam copper, in Eckstrand, OR. Sinciair, W. D., and Thorpe, R.F. eds. Geoiogy of Canadian mineral deposit types: Bouider, Colorado, Geological Society of America, The Geology of North America, v. F.1, p. 444 - 459

Dawson, K.M. and Orchard, M.J., 1922, Regional metallogeny of the northem Cordiliera: biostratigraphy, correlation and metallogenic significance of bedded barite occurrences in eastem Yukon and westem District of Mackenzie: Current Research, Part C, Geological Survey of Canada Paper 82-1C, p. 31-38.

Dawson, K.M. Panteleyev, A. Suthertand Brown, A., and Woodsworth. G.J. 1991. Regional metallogeny, in Gabrielse, H. and Yorath. C.J. eds, Geology of the Cordilleran Orogen in Canada: Geological Survey of Canada, Geology of Canada, Chapter 19, no. 4, p. 707. 769.

Dawson, K.M., Shpikeman, V.L., Ratkin, V.V., and Goryachev, NA. 1994, Correlative metalogenic evonts in the Cordilleran and Siberian cratons: in Simakcov, R.V. ed. Inlemational Conference on Avctic Margins, Magadan, Russia. Abstracts Volume, p. 26.

Debari, S.M, and Coleman, RG., 1969, Examination of the deep levels of an island arc. Evidence from the Tonsina ultramafic-mafic assemblage, Tonsina, Alaska: Joumal of Gecphysical Research, v. 94, no. B, p. 4373-4391.

Decker, J. Reifenstuhl, R.R., and Coonrad. WL. 1984. Compilation of data from the Iditarod A.5 quadrangle. Alaska Division of Geological and Geophysical Surveys Report of investigations 84-17. 1 sheet. scale 1:63,360.

Decker, J. Bergman, S.C., Blodget, R. B., Box, E. E. Bundtzen, T.K. Cough, J.G., Coonrad, W.L., Gilbert, W.G., Miller, ML. Murphy, JM. Robinson, M.S., and Wallace, W.K. 1994. Geology of southwestern Alaska, in Plaker. George, and Berg. H.C., eds., The Geology of Alaska: Boulder, Colorado. Geological Society of America, The Geology of North America, v. G-1, p. 285-310.

Degenhart, C.E., Griffith, R.J., McOuat, J.F., and Bigelow, C.G. 1978, Mineral studies of the westem Brooks Range. performed under contract J0155089 to the U.S. Bureau of Mines: U.S. Bureau of Mines Open-File Report 103$78,529 \mathrm{p}$.

Delaney. G.D., 1981. The mid-Proterozoic Wernecke Supergroup, Wernecke Mountains, Yukon Territory; in Proterozoic Basins of Canada, Campbell, F.H.A., ed., Geological Survey of Canada, Paper 81-10, p. 1-23.

Delong, R.C., Godwin, C.I. Harris, M.W. Caira, N.M., and Rebagliati, C.M., 1991, Geology and alteration at the Mount Milligan gold-copper porphyry deposit, central British Columbia, in Geological Fieldwork 1990: British Columbia Ministry of Energy. Mines and Petroleum Resources Paper 1991-1, p. 199-206.

Denisova. TA., 1990, Lithology-geochemistry features of Febearing rocks of Talovskaja Mountain (Primorye), in Chudaev, O.V. ed., Lithogenes and ore formation in old and recent seas of Far East: U.S.S.R. Academy of Sciences, Far East Geological Institute, Vladivostok, p. 35-54 (in Russian).

Dekelerk, R. (compiler), 2002, Yukon MINFILE 2002 - A database of mineral occurrences: Exploration and Geological Services Division, Yukon Region, Indian and Northern Affairs, www geology.gov.yk.ca/minfilel.

Devlin, B.D., and Godwin, C.I. 1986, Geology of the Dolly Varden camp, Alice Arm area (103P/11,12), in Geological Fieldwork 1985: British Columbia Ministry of Energy, Mines and Petroleum Resources Paper 1986-1. D. 327.330 .

DeYoung. J.H.4.Ji., 1978, Mineral resources map of the Chandalar quadrangle, Alaska: U.S. Geological Survey Miscelaneous Fieid Studies Map MF-878-B, scale $1250,000,2$ sheets.

Diakow, L.J., 2001, Geology of the southem Toodoggone River and northem McConnel Creek areas, North-Central British Columbia (Parts of NTS 94E/2, 94D/15, and 94D/16): British Columbia Ministry of Energy and Mines Geoscience Map 2001-1, scale 1:50,000.

Diakow, L.J., Panteleyev, A. and Schroeter, T.B. 1991. Jurassic epithermal deposits in the Toodoggone River area. Northem British Columbia: Examples of well preserved volcanichosted, precious metal mineralization: Economic Ceology, v. 86, p. 529-554.

Diakow, L.J., Panteleyev, A, and Schroeter, T.B., 1993. Geology of the Early Jurassic Toodoggone Formation and gold-silver deposits in the Toodopgone River map area, Northem British Columbia: British Columbla Ministry of Energy and Mines Bulletin 86, 72 p.

Dickinson, K.A., and Cunningham, Kenneth, 1984, Death Valley. Alaska, uranium deposat fabs.) Geological Society of Americe Abstracts with Programs, v 16. p. 278.

Dickinson, K.A. Cunningham, K.D., and Ager, T.A, 1987. Geology and crigin of the Death Vally uranium depoeit. Seward Peninsula, Alaska: Economic Geology, v. 82, p. 1558-1574.

Dickinson. W.R, and Butler, RF, 1998, Coastal and Baja Califomia paleomagnetism reconsidered: Ceological Society of America Bulletin, v. 110, p. 1268-1280.

Dillon, J.T., 1982, Source of lode- and placer-goid deposits of the Chandalar and upper Koyikuk districts, Alaska: Alaska Division of Geological and Geophysical Surveys Open-File Report 158, 22 p.

Dillon, J.T. Tilton, G.R., Decker, J., and Kelly, M.J., 1987. Resource implications of magmatic and metamorphic ages for Devonian igneous rocks in the Brooks Range. In Alaskan North Slope Geology. Edited by L.L. Tailleur 
and P. Weimer. Pacific Section, Society of Economic Paleontologists and Mineralogists and Alaska Geological Society, Book 50, p. 173-723.

DiMarchi, J.J., 1993, Geology, aiteration, and mineralization of the Vinasale Mountain gold deposit, west-central Alaska. In Short notes on Alaskan Geology. Edited by D,N. Solie, and F. Tannian. Alaska Division of Geological and Geophysical Surveys Professional Report 113, p.17-31.

Dirom, G.E, Dittrick, M.P. McArthur, D.R., Ogryzlo, P.L., Pardoe, A.J. and Stothart. P.G., 1995, Bell and Granisle porphyry copper-goid mines, Babine region, west-central British Columbia: in Schrceter, T., ed. Porphyry deposits of the northwestem Cordillera of North America: Canadian Instlute of Mining, Metallurgy, and Petroleum, Special Volume 46, D. 256-289.

Ditson, G.M. Wells, R.C., and Bridge, D.J., 1995, Kert. The geoiogy and evolution of a deformed porphyry copper-goid deposit, northwestern British Columblax, in Schroeter. T.G. ed., Porphyry Deposits of the Northwestern Corcilera of North America, Canadian instlute of Mining and Metalurgy Special Volume 46, p. 509.523

Dmitrenko, G.G., and Mochalov. A.G., 1986, Accessory and ore-forming chromspinellids from the some duniteperidotite massifs of Koryakskoe Highland: All-Union Mineralogical Society Letters, v. 115. p. 569-581 (in Russian).

Dmitrenko, G.G., Mochalov, A.G, and Palandzhyan, S.A., 1990 , Petrology and platinum mineralization of therzolite massifs in the Koryak Highlands: U.S.S.R. Academy of Sciences, North-Eastern Interdisciplinary Research Institute, Magadan, 93 p. (in Russian)

Drnitrenko, G.G. Mochalov, A.G. Palandzhyan, S.A. and Akinin. V.V., 1987. Accessory minerals of platinum elements in Apine-type ultramafites of the Koryak Highland: Trkhookeanskaya Geologiya, no. 4. p. 66-76 (in Russian).

Dobson, D.D.. 1982, Geology and ateration of the Lost River tin-tungsten-fluorite deposit. Alaska: Economic Geology. v. 77, p. $1033-1052$

Dorofeev, A.V., 1979, Boron in Yakutia, in Arkipov, Yu.V. and Frumkin. I.M. eds. Geology of U.S.S.R. Minerals: Nedra, Moscow, p. $332-342$ (in Russian)

Downing. B.W., Webster, M.P., and Beckett, R.J. 1990. The Windy Craggy massive-sulphide deposit, northwestem Brish Columbia, Canada, in Abbott, J.G., and Turner, R.J.W., eds. Mineral Deposits of the Northern Canadian Cordillera, Yukon-Northeastern Brilish Columbia. Bth IAGOD Symposium Field Trip Guidebook No 14 : Geological Survey of Canada, Open Fle 2169. p. 25-31.

Drummond, A.D., Suthertand Bown, A, Young. R.J. and Tennant, S J. 1976, Gibratar-regional metamorphism. mineralization, hydrothermal ateration and structura devolopment in Sutherland Brown, A, ed. Porphyry Deposits of the Canadian Cordilera, Canadian Institute of minint and Metallurgy Special Volume 15, p. 195-205.

Dudkinsley, D. V. Leozlov, V.D. Mamitko, V.R, 1986, First RibSr dates for the granitoids of the lultin ore region: Soviet Academy of Sciences Reports, v. 291, p. 967-971.

Dumoulin, J.A., Bradey, D.C., Hartis, A.G, and Repetski, J.E. 1999, Lower Palecizoic deep-water tacies of the Medtra area, central Alaska, in Keliey, K.D, ed. Geologic Studies in Alaska by the U.S. Geological Survey. U.S. Geological Survey Professional Paper 1614. p. 75-103.

Dumoulin, JA., Bradley, D.C., Harris, A.G., and Repetski, JE. 1988, Sedimentology, conodont biogeography, and subsidence history of the Nixon Fork terrane, Medira quadrangle, Alaska [abs.) International Conference on Arctic Margins, ICAM III Abstracts, p. 49.

Dusel Bacon. C.. Csejtey, B.. Jr., Foster, H.L., ODoyle, E. Nokleberg. W.J., and Plafker, G.4 1993, Distribution. facies, agos, and proposed tectonic associations of regionally metamorphosed rocks in east- and southcentral Alaska. U.S. Geological Survey Professional Paper 1497-C, 73 p, 2 sheets, scale 1:1,000,000.

Dusel-Bacon. Cynthia, 1994. Metamorphic history of Alaska, in Plafker, G. and Berg. H.C., eds., The Geology of Alaska: Boulder, Colorado, Goological Society of America: The Geology of North America, v. G1, p. 495-534.

Dylevsky, EF., 1992, Magmatism of the Siversky uplit (Northeast of the U.S.S.R.) Tikhookeanskaya Geologiya, no 2, p. 95-105 (in Russian).

Dylevsky, E.F., Zuyev, S.A, and Shpikerman, V.I., 1996, The Khotoidok massive sulfide polymetallic deposit hosted in Upper Jurassic sedimentary-volcanic rocks in the central part of the Chersky Range, in Goryachev N.A. and Byalobzhesky S.G. eds., Stratiform mineralization of sedimentary and sedimentary-volcanic sequences in northeastern Asia: Russian Academy of Sciences, North-Eastern Interdisciplinary Resoarch Institute, Magadan, p. 81-96 (in Russian).

Eakins, G.R., and Forbes, R.B., 1976, Investigation of Alaska's uranium potential: Alaska Division of Geological and Geophysical Surveys Special Report 12, p. 91-110.

Eakins, G.R., Gibert, W.G., and Bundzen, T.K., 1978. Proliminary bedrock geology and mineral resource potential of west-central Lake Clark quadrangle, Alaska: Alaska Division of Goological and Geophysical Survoys Open-File Report 118, 15 p., 2 sheets, scale 1:63,360.

Ebertein, G.D., Chapman, R.M., Foster, H.L., and Gassaway. J.S., 1977, Map and table describing known metalliferous and seiected nonmetalliferous mineral deposits in central Alaska: U.S. Geological Survoy Open-File Report 77-11680, 132 p. 1 map sheet, scale 1:1,000,000

Eberiein, G.D., Churkin, M., Jr., Carter, C., Berg. H.C., and Ovenshine, A.T. 1983, Geology of the Craig Quadrangle, Alaska. U.S. Geological Survey Open-File Report 83-91 28 p.. 2 sheets, scale 1:250,000.

Ebert, Shane, Miller, L.D., Petsel, Scott, Dodd, Stan, and Kowalczyk, 2000, Geology, Mineralization, and exploration at the Dorlin Creek Project, Southwest Alaska, in Tucker, T.L., and Smith, M.T., eds., The Tintina gold belt: Concepts, Exploration, and Discoveries: British Columbia and Yukon Chamber of Mines, Vancouver, Special Volume 2, p. 99-114.

Eckstrand, O.R., 1984, Canadian mineral deponit types: A geological synopsis: Geological Survey of Canada Economic Geology Report 36.86 p.

Eckstrand, O.R. Sinclair, W.D., and Thorpe, R.J., eds, 1995. Geology of Canadian mineral deposit types: Geological Survey of Canada, Geology of Canada, No. 8., 522 p.

Eden, Karsten, 2000, Geology and gold mineralization of the Nolan Creek area, Wiseman District, Brooks Range, Aaska: U.S. Bureau of Land Management Open-File Report 78, $190 \mathrm{p}$

Efimova. M.I. Naumkin, P.A, Mahallova, V.A, and others, 1978, Temperatures of the origin of Upper Cretaceous granitic rocks, Askoid isiand, in Ermakov, N.P.y ed., Thermobarogeochemistry and Geology - Abstracts: U.S.S.R. Academy of Sciences, Far East Geological Instifute, Vadivostok $\vee .1$; p. 83-85 (in Russian).

Egiazarov, B.H. Dundo, O.P., Anikeev, L.P., Rusanov, I.M. and Degtyarenko, Yu. P, 1965, Geology and minerals of 
the Koryak Hightands: Transactions of Science Research Institute of Arctic Geology, 148, 343 p (in Russian)

Eirish, LV. 1972, Dome-like structures of the SelemdzhaKerbinsky rise and related gold mineralization: Summary of Ph.D. dissertation, U.S.S.R. Academy of Sciences, Far East Geological institute, Vladivostok, 45 p. (in Russian).

Eirish, L.V., 1991, Gold ore systems of Far East and a prognosis of deposits: Summary of Ph.D. dissertation. Far East Geological Institute, Russian Academy of Sciences, Vladivostok, 52 p. (in Russian).

Eisbacher, G.H. 1985, Late Prolerozoic rilling, gacial sedimentation, and sedimentary cycies in the light of Windermere deposition, westem Canada: Paleogeography, Palecclimatology, Paleoecology, v, 51, p. 231-254.

Elersieck, I.F., Jansons, Uldis, Mayfieid, C.F., and Tailleur, I.L.. 1982. The Story Creek and Whoopee Creek lead-zincsilver occurrences, western Brooks Range, Alaska, in Coonrad. W.L., ed., The United States Geological Survey in Alaska: Accomplishments during 1980: U.S. Geological Survey Circular 844, p. 35-38.

Elyanov, A.A. and Moralev, V.M., 1973, The age of ultramafic alkalic rocks of the Aldan and South Verkhoyansk provinces: Izvestiya Akademii Nauk, SSSR, Seriya Geologicheskaya, no: 10, p. 15-23 (in Russian).

Emond, D., and Lynch, T., 1992, Geology, mineralogy and geochemistry of tin and tungsten veins, breccias andskams, McQuesten River Region (115 P $(\mathrm{N})$ and $105 \mathrm{M}$ 13). Yukon, in Yukon Geology. Volume 3: Exploration and Geological Services Division, Yukon, Indian and Northern Affairs, p. 133-159.

EMR Canada, 1989, Canadian mineral deposits not being mined in 1989: Energy, Mines and Resources Canada, Mineral Resource Sector, MR 223, 625 p.

England, P.C., and Wells, R. E., 1991, Neogene rotations and quasicontinuous deformation of the Pacific Northwest continental margin: Geology, v. 19. p. 978-981

Engebretson, D.C., Cox, A., and Gordon, R.C., 1985, Relative molions between oceanic and continental plates in the Pacific Basin; Geological Society of America Special Paper 106, 59 p.

Engebretson, D.C.. Kelley, K.P., Cashman, H.P., and Richards, M.A., 1992, 180 milion years of subduction: GSA Today. v.2. $93-100$.

Enns, S. Thompson, JF.H, Stanley, CR, and Yarrow, E.W. 1995. The Galore Creek porphyry copper-goid deposits, northwestem British Columbia, in Schroeter, T.G. ed. Porphyry deposits of the northwestem Cordilera of North America: Canadian institute of Mining and Metallurgy, and Petroleum, Special Volume 46, p. 630-644.

Enns, S.G, and McDougal, J.J., 1995, Catface coppermolybdenum porphyry, wesi-central vancouver island, British Columbia: An updale, in Schroeter. T.G. ed. Porphyry Deposits of the Northwestem Cordiliera of North America. Canadian insttule of Mining and Metalurgy Special Volume 46, p. $322-326$.

Eromin, R.A. Voroshin, S.V. Sidorov, V.A., Shakhtyrow, V.G., and Pristavko, VA., 1994. Geology and genesis of the Nataka goid deposit, northeast Russiar. International Geology Review, v. 36, p. 1113-1138.

Emlinger, A.D. Meinert, L. D. and Ray, G.E, 1992, Goid skam mineralization and evclution of fuid in the Nickel Plate gold skam deposil. Hediey District-British Columbia: Economic Geciogy, vol. 87, p. 1541-1565.
Fadeev, A.P., 1975. Iron occurrences in southern Omolon district: Kolyma, no. 6, p. 41-43 (in Russian)

Fahmi, K.C., Kim, H., Klein, G.H. and Carter, N.C., 1976. Granisle, in Sutheriand Brown, A., ed. Porphyry Deposits of the Canadian Cordillera: Canadian Institute of Mining and Metallurgy Special Volume 15, p. 239 . 244.

Fahrni, K.C., Macauley, T.N., and Proto, V.A.G., 1976, Copper Mountain and ingerbelle, in Sutherland Brown, A., ed. Porphyry Deposits of the Canadian Cordillera: Canadian Institute of Mining and Metallurgy Special Volume 15, p. $368-375$

Fedotov, A.I. 1960a. The Maldyak goid deposit: Transactions of All-Union Science Restearch Institute-I [abs.], p. $67-69$ (in Russian)

Fedotov, A.L., 1960b, The Svetloe goid deposit Transactions of All-Union Science Research Institute-1 [abs]. p. 64-67 (in Russian)

Fedotov, A.I., 1967, On structure, mineralogy and genesis of the Svetloe gold deposit: Kolyma, no. 5, p. 39-41 (in Russian).

Fernette, Gregory, and Cleveland, Gaylord, 1984, Geology of the Miss Molly molybdenum prospect. Tyonek C.6 quadrangle, Alaska: Alasica Division of Geological and Geophysical Surveys Prolessional Repont 86, p. 35-41.

Ferri, F., Dudka, S., and Rees, C., 1992, Geology of the Uslika Lake area, northem Quesnel Trough, British Columbia $(94 \mathrm{C} / 3,4,6)$, in Geololgical Fieldwork 1991: British Columbia Ministry of Energy. Mines and Potroleum Resources Paper 1992-1. p, 127-145.

Filatova, N.I., 1988, Perioceanic volcanic beits, Nedra, Moscow, $264 \mathrm{p}$ (in Russian).

Findlay, D.C., 1969a, Mineral industry of Yukon Temitory and Southwest District of Mackenzie, 1968: Geological Survey of Canada Paper 69.55, $71 \mathrm{p}$.

Findlay, D.C., 1969b, Ongin of the Tulameen uitramafio-gabbro complex, southern British Columbia: Canadian Joumal of Earth Sciences, v. 6. p. 399-425.

Firsov, L.V., 1957a, Main structuralmorphologic types of the Yana-Kolyma belt gold deposits: Transactions of Al. Union Science Research Institute-1, Geology, 27, 25 p (in Russian).

Firsov, L.V. 1957b, Structure of host rocks and morphology of vein system in the Rodionor gold deposit: Transactions of All-Union Science Research instilute-1, Geology, 23 23 p (in Russian).

Firsov, L.V. 1972, On three-stage formation of tin-bearing veins in the Kandychan deposit: Geology and genesis of the Siberia endogenic ore formations: Nauka, Moscow, p. 153-167 (in Russian)

Firsov, L.V., 1985, Gold-quartz formation of the Yana-Kolyma belt: Nauka, Novosibirsk, 217 p (in Russian).

Flanigan, B.P., Freeman, C.J., McCoy, Dan, Newberry, R.J. and Hart. Craig. 2000, Paleo-reconstruction of the Tintina goid belt, implications for mineral exploration, in Tucker, TL, and Smith, M.T., eds. The Tintina goid beit: Concepts. Exploration, and Discoveries: British Columbia and Yukon Chamber of Mines, Vancouver. Special Volume 2, p. $35-48$

Flerov, B.L., 1974, Tin deposits of the Yana-Kolyma foid beit. Novosibirsk Nauka, 256 p (in Russian).

Flerov, B.L. 1974. Tin deposits of the Yana-Kolyma foid beit. Novosibirsk: Nauka, 286 p (in Russian).

Flerov, B.L. and Shur, VI. 1906. The geology of the tin ore districts and lode deposits of the Yana-indigirka tin region, in Lugov, S.F., ed. Geology of the lin lode 
deposits of the USSR: Nedra, v, 2, book 1, p, 43-128 (in Russian).

Flueh, E., Fisher, M., Scholl, D., Parsons, T., Brink, Uni ten, Klaeschen, D., Kukowski, N., Trehu, A., Childs, J., Bialas, J., and Vidal, N., 1997. Scientific teams analyze earthquake hazards of the Cascadia subduction zone: Eos, Transactions, American Geophysical Union, v. 78, p. $153,157$.

Foley, J.Y, 1982, Ophiolitic and other mafic-ultramafic metallogenic provinces in Alaska; west of the 141st meridian: U. S. Geological Survey, Report: Open-File Report 92-0020-B, 55 p., 1 sheet, scale 1:2,500,000.

Foley, J,Y, and Barker, J.C., 1985. Chromile deposits along the Border Ranges fault, southern Alaska: U.S. Bureau of Mines Information Circular IC-8990, 58 p.

Foley, J.Y., Barker, J.C., and Brown, L.L., 1985, Critical and strategic mineral investigation in Alaska: Chromium: U.S. Bureau of Mines Open File Report 97-85, 54 p.

Foley, J.Y., Dahlin, D.C., Mardock, C.L. and O'Connor, W.K., 1992, Chromite deposits and platinum group metals in the westem Brooks Range. Alaska: U.S, Bureau of Mines Open-File Report 80-92, 67p.

Foley, J.Y., Hinderman, Toni, Kirby, D.E., and Mardock, C.L., 1984 , Chromite occurrences in the Kaiyuh Hills, westcentral Alaska: U.S. Bureau of Mines Open-File Report 178-84, 20 p

Foley, J.Y., Light, T.D., Neison, S.W, and Harris, R.A, 1997. Mineral occurrences associated with mafic-ultramafic and related alkaline complexes in Alaska, in Goldfarb. R.J., and Miller. L.D., eds, Mineral Deposits of Alaska: Economic Geology Monograph 9, p. 396-449.

Ford, R.C., 1993, ${ }^{40}$ Ar/ ${ }^{-9}$ Ar thermochronology of white mica from the Bluff area, Alaska; the first ages for lode sources of placer gold deposits in the Seward Peninsula [abs.]: Geological Society of America Abstracts with Programs, v. 25, p.469.

Foster, H.L., and Keith, T.E.C., 1974, Uitramafic rocks of the Eagle quadrangle, east-central Alaska: U.S. Geological Survey Journal of Research, v. 2, no. 6, p. 657-669.

Foster, H.L.. Keith, T.E.C., and Menzie, W.D., 1987, Geology of east-central Alaska: U.S. Geological Survey Open-File Report 87-188, 59 p.

Fowler, B.P., and Wells, R.C., 1995, The Sulphurets gold zone, northwestem British Columbia, in Schroeter, T.G. ed. Porphyry Deposits of the Northwestem Cordillera of North America, Canadian Institute of Mining and Metalurgy Special Volume 46, p. 484-498.

Fox, P.E., Goodall, G.N., and Durfeld, R.M., 1995. The Gambier Island porphyry copper deposit, southwetern British Columbia, in Schroeter, T.G., ed., Porphyry Deposits of the Northwestem Cordillera of North America: Canadian Institute of Mining and Metallurgy, and Petroleum, Special Volume 46, p. 524-536.

Friedman, R.M. and Ash, C.H., 1997, U-Pb age of intrusions related to porphyry Cu-Au mineralization in the Tatogga Lake area, northwestern British Columbia (104G19NE), in Geological Fieldwork, 1996: British Columbia Ministry of Energy and Mines, p. 291-297.

Fritz, W.H. Cecile, M.P., Norford, B.S., Morrow, D., and Geldsetzer, H.H.J., 1991, Cambrian to Middle Devonian assemblages; in Geology of the Cordilleran Orogen in Canada, Gabrielse, H, and Yorath, C.J., eds, Geological Survey of Canada, Geology of Canada, no. 4, p.151-218.

Fryda, Jifi, and Blodgett, R.B., 1998, Two new Cirroidean genera (Vetigastropoda, Archaeogastropoda) from the Emsian (late Earty Devonian) of Alaska with notes on the early phylogeny of Cirroidea Journal of Paleontology, v. 72, p. $265-273$

Fujita, K., and Cook, D.B., 1990a, The Arctic continental margin of eastern Siberia, in Grantz, A, Johnson, L, and Sweeney, J.F. eds., The Arctic Ocean region: Boulder, Colo, Geological Society of America, the Geology of North America, v. L, p. 289-304

Fujita, K., Cook, D.B.. Hasegawa, H., Forsyth, D., and Wetmiller, R, 1990b, Seismicity and focal mechanisms of the Arctic region and the North American plate boundary in Asia, in Grantz A., Johnson, $L_{\text {, }}$, and Sweeney, J. F, eds., The Arctic Ocean Region: Geological Society of America, Geology of North America, v. L., p. 79-100.

Fujita, K., Stone, D.B., Layer, P.W., Parfenov, L.M., and Koz'min, B. M. 1997, Cooperative program helps decipher tectonics of Northeastem Russia: Eos, Transactions, American Geophysical Union, v. 7B, p. 245, 252-253.

Furduy, S.R.. 1968, Upper Precambrian tillite of the Kolyma region: Doklady Akademi Nauk SSSR, v. 180, no. 4, p. 7275 (in Russian).

Fyles, J.T., 1960, Mineral King (Sheep Creek Mine Limited); British Columbia Ministry of Energy. Mines and Petroleum Resources, Annual Report 1959, p. 74-89.

Fyles, J.T, 1970. The Jordan River area near Revelstoke, British Columbia: British Columbia Ministry of Energy, Mines and Petroleum Resources, Bulletin 57,64 p.

Fyles, J.T., 1984, Geologic setting of the Rossland Mining Camp: British Columbia: British Columbia Ministry of Energy, Mines and Petroleum Resources, Bulletin 174. $61 \mathrm{p}$.

Fyles, J.T., and Hewiett, Cecil George, 1959, Stratigraphy and structure of the Salmo lead-zinc area: British Columbia Department of Mines Bulletin, v.41, 162 p.

Gabrielse, H., 1963, McDame Map-Area, Cassiar District, British Columbia: Geological Survey of Canada Memoir 319,138 p., scale 1 in. equals $2 \mathrm{mi}$.

Gabrielse, $H ., 1985$, Major dextral transcurrent displacements along the Northem Rocky Mountain trench and related lineaments in north- central British Columbia: Geological Scciety of America Bulletin, v. 96, p. 1-14.

Gabrielse, H., and Campbel, R.B., 1991, Upper Proterozoic assemblages, in Gabrielse, $H$. and Yorath, C.J., eds., Geology of the Cordlleran Orogen: Boulder, Colorado, Geological Society of America, The Geology of North America, v. G-2, p. 125-150.

Gabrielse, H., Loveridge, W.D., Sullivan, R.W. and Stevens, R.D., 1982. U-Pb measurements of zircon indicate middle Paleozoic plutonism in the Omineca Crystalline Belt, northcentral British Columbia; in Current research, Part $c$, Geological Survbey of Canada Paper 82-1C, p. 139-146.

Gaiduk, V.V., Grinenko, O.V., and Syundyukov. I. Sh., 1993, Age of folding in the Moma Zyryanka basin. Tikhookeanskaya Geologiya: no. 3, p. 99-108 (in Russian).

Gaiduk, V.V., Syundukov, I.Sh., Grinenko, O.V., and Imaev, V.S., 1989, Structure and oil and gas potential of the Cenozoic Indigirka-Zyryanka Basin: Tectonics and Oil and Gas Prospecting in Yakutia, U.S.S.R. Academy of Sciences, Yakutian Scientific Center, p. 75-87 (in Russian).

Galkin, M.A, 1968, Structural, mineralogical, and genetic features of mercury deposits in northeastern Yakutia, in Problems of Mercury Metallogeny (According to Materials on Siberia and Russian Far East): Nauka, Moscow, p. 163-177.

Gamble, B.M. Ashley, R.P., and Pickthom, W.J., 1985, Preliminary study of lode gold deposits, Seward Peninsula, in, Bartsch-Winkler, Susan, ed., The United States Geological Survey in Alaska: Accomplishments 
during 1984: U.S. Geological Survey Circular 967, p. 27 29.

Gamyanin, G.N., and Goryachev, N.A., 1988, Near-surface mineralization in eastem Yakutia: Tikhookeanskaya Geologiya, no. 2, p. 82-89, (in Russian).

Gamyanin, G.N., and Goryachev, N.A., 1991, Gold mineralmagmatic systems of the granitoid range in the northeastem U.S.S.R., in Camyanin, G.N. Sumin, A.A. Trunilina, VA, and Yakoviev, Ya.B, eds, Ore magmatic systems of the eastern U.S.S.R: U.S.S.R. Academy of Sciences, Siberian Branch, Institule of Geology, Yakutsk, p. $37-48$ (in Russian).

Gamyanin, G.N. Silichev, M.K., Goryachev, N.A. and Belozertseva, N.V., 1985, A polystage gold lode deposh: Geologiya Rudnykh Mestorozhdeniy, no. 5. D. 86-89 (in Russian)

Gandhi, S.S., and Bell, R.T., 1996, KirunaVOlympic Dam-type iron copper, uranium, gold, siver, in Geoiogy of Canadian Mineral Deposit Types, Eckstrand, O.R. Sindair, W.D. and Thorpe, R.t. eds, Geological Survey of Canada, Geology of Canada, no. 8. p. $513-522$

Ganeev, A.Sh, 1974, Secondary quartzites of the Dogdin superimposed depression, in Grinberg. G.A. ed., New data on magmatism in Yakutia: U.S.S.R. Academy of Sciences, Siberian Branch, Institute of Geology. Yakutsk. p. 151-154 (in Russian).

Garbuzov, S.P. Sedykh, A.N., and Tarasov, G.A., 1987, The Nikolaevsiky volcano-tectonic depression, Primorye: Geology, skams, and ore: U.S.S.R. Academy of Sciences, Vladivostok, 184 p. (in Russian).

Gardner, M.C., Bergman, S.C., Mackevett, E.M., Jr., Plafker, G. Campbell, R.C., Cushing. G. W., Dodds, C.J., and Mcclelland, W D. 1988, Middle Pennsylvanian pluton staching of Wrangellia and the Alexander terrane. Wrangell Mountains, Alaska. Geology, v. 16, p. 967-971.

Gornet. JA. 1978. Goology and mineral occumences of the southem Hogem batholith; British Columbia Ministry of Mnes and Petroleum Resources, Bulletin 70,75p.

Garnett. J.A. 1978, Geology and mineral occurrences of the southern Hogem batholith: British Columbia Ministry of Energy. Mines and Petroieum Resources, Bulletin 70. 75 p.

Garver, J.L. Brandon. M.T., and Scloviev, A.V., 1998, Source of Ukelayat flysch and collison of the Olutorsky arc, northem Kamchatka, Russian Far East [abs.]: Geological Society of America Annual Meeting Program with Abstracts, v. 30. D. A269.

Gavrkov, S.I. and Zharova, V.P. 1963. The structure of the ore field and mineralization of the Zhdannoe gold deposit: Proceedings of the Alf-Union mineralogic society, part 92, v, 1, p. 26-32 (in Russian).

Gavrilov, A.M., Novozhilov, Yu. I, and Sidorov, A.A., 1986, On the relation of gold-arsenic-antimony mineralization to the formations of "impregnation sulfide ores with finedispersed gold: Takhookeanskaya Geologiya, no. 3, p. $108-111$ (in Russian)

Gehreis, G.E., 1992. Geologic map of Southern Prince of Wales isiand, southeastern Alaska. U.S. Geological Survey Map 1-2169, 1 sheet, scale 1:63,360, 23 p.

Gehrels G.E. and Berg. H.C. 1992, Geologic map of southeastem Alaska U.S Geological Survey Miscellaneous Investigations Series Map 1-1867. 1 sheot, scale 1:2.000.000, 24 p

Gehrels, G.E. and Berg. H.C. 1994, Geology of southeastern Alaska, in Plaker, George, and Berg. H.C. eds. The geology of Alaska Boulder, Colo, Geological Soclety of
America, The Geology of North America, v. G-1, P. 451468.

Gehreis, G.E., McClelland, W.C., Sampson, S.D. Patchett, P.J., and Jackson, JL. 1990, Ancient continental margin assemblage in the northem Coast Mountains, southeast Alaska and northwest Canada: Geology, v. 18. p. $208-211$

Gehreis, G.E, and Saleeby, JB., 1987, Geology of Southern Prince of Wales island, southeastern Alaska. Geological of Society of America Bulletin, v. 98, p. 123-137.

Gehrels, G.E, and Saleeby, J. B, 1987, Geologic framework, tectonic evolution, and displacement history of the Alexander terrane: Tectonics, v. 6, p. 151-173.

Geist, EL. Childs, J.R, and Schol, D.W, 1988, The origin of the summit basins of the Aleutian Ridge: Implications for block rotation of an are massit. Tectenics, v. 7, p. 327 . 341.

Geist, EL, Vallier, T.L, and Schol, D.W., 1994, Origin, transport, and emplacement of an exotic island-arc terrane exposed in eastem Kamchatka, Russia: Geciogical Society of America Bulletin, v. 106, p. 1182-1194.

Geiman. M.L., 1976, On the role of regional metamorphism in goid mineralization of the U.S.S.R. Northeast: U.S.S.R. Academy of Sciences Report 230, no. 6, p. 1406-1409 (in Russian)

Geiman, M.L., 1986, Intrusive sequences: Metallogenic map of Magadan region and contiguous areas: Sewostgeoiogiya, Magadan, 21 p. scale $1: 1,500,000$ (in Russian)

Geiman, M.L., Titov, V.A., and Fadeev, A.P.4 1974, Omolon iron-type province: U.S.S.R. Academy of Sciences Report 218, no. 2, p. 419-422 (in Russian)

Gerasimov, N.S, Rodienov, S.M., and Kompanichenico, V.N., 1990. The results of $R \mathrm{~b}-\mathrm{Sr}$ dating of tin granites of Central Sikhote-Alin: Reports of Russian Acaderny of Sciences, v. 312, no. 5, p. 1,183-1,186.

Gibert, W.G., and Bundtzen, T.K., 1979, Mid-Paleczoic tectonics, volcanism, and mineralization in north-central Alaska Range, in Sisson, A. ed. The rolationship of plate tectonics to Alaskan geology and resources: Alaska Geological Society Symposium, 1977, p. F1-F21.

Gibert, W G., Solie, D.N., Kline, J.T, and Dickey, D.B. 1990. Geologic map of the MoGrath B-3 quadrangle. Alaska Division of Geological and Geophysical Surveys Professional Report 102, 2 sheets, scale 1.63 .360$.

Glukhovsky, M.Z. Mralev, V.M. and Kukhanow, M.K., 1993. Tectonic setting of Paleo-Proterozole anothosites and granites in the Aldan Shield and zoning of thermotectonic processes: Geotectonics, no. 3, D. 69. B1.

Godwin, Cl, 1976, Casino, in Suthertand Brown, A. od., Porphyry Deposits of the Canadian Cordilera, Canadian institute of Mining, Metalurgy, and Petroleum Special Volume 15, p. 344-354.

Godwin, Cl. Gabites, JE., and Andrew, A, 1988, Leadtabie: A galena lead isctoce data base for the Canadian Cordilera: Brtish Columbia Ministry of Energy. Mins and Petroleum Resources Paper 1988-4, 188 p.

Goldtarb, RJ. 1997. Metaliogenic evolution of Alaska, in Goldfart, R.J., and Miller, L.D., eds.. Mineral deposits of Alaska: Economic Geology Monograph 9, p. 4-34.

Goldtarb, R.S. Carter Bonden, J, and Winkler, G.R., 1995, Geochemical survey of the Vaidez $1^{\circ} \times 3^{*}$ quadrangle. south-central Alaska: U.S. Geological Survoy Bulletin 2084, 77 p., 1 sheet, scale 1-250,000.

Goldfarb, R., Hart, C., Miller, M., Miller, L., Farmer, G.L., and Groves, D. 2000, The Tintina gold belt - A global 
perspective, in Tucker, T.L., and Smith, M.T., eds., The Tintina gold belt: Concepts, Exploration, and Discoveries: British Columbia and Yukon Chamber of Mines, Vancouver, Special Volume 2, p. 5-34.

Goldfarb, R.J., Leach, D.L. Pickthorn, W.J., and Paterson, C.J.. 1988, Origin of the Juneau goid belt, southeastem Alaska: Geology, v, 16, p. 440-443.

Goldfarb, R.J., Leach, D.L., Miller, M.L., and Pickthom, W.J., 1986, Geology, metamorphic setting, and genetic constraints of epigenetic lode-goid mineralization within the Cretaceous Valdez Group, south-central Alaska, in Keppie, J.D., Boyle, R.W., and Haynes, S.J., eds., Turbidite-hosted gold deposits: Geological Association of Canada Special Paper 32, p. 87-105

Goldfarb, R.J., Light, T.D., and Leach, D.L., 1986, Nature of the ore fluids at the Alaska-Juneau gold deposit, in BartschWinkler, Susan, and Reed, K.M., eds., Geologic Studies in Alaska by the U.S. Geological Survey during 1985: U.S. Geological Survey Circular 978, p. 92-95.

Goldfarb, R.J., and Miller, L.D., eds, 1997, Mineral deposits of Alaska: Economic Geology Monograph 9, 482 p.

Goidtarb, R.J., Miller, L.D., Leach, L.D., and Snee, L.W., 1997. Gold deposits in metamorphic rocks of Alaska, , in Goldfarb, R.J., and Miller, L.D., eds., Mineral deposits of Alaska: Economic Geology Monograph 9, p. 151-190.

Goldfarb, R.J., Newberry, R.J., Pickthorn, W.J., and Gent, C.A., 1991, Oxygen, hydrogen, and sulfur isotope studies in the Juneau gold belt, southeastern Alaska: Constraints on the origin of hydrothermal fluids: Economic Geology, v. 86, p. $66-80$

Goldfarb, R.J., Phillips, G.N., and Nokleberg. W.J., 1998, Tectonic setting of synorogenic gold deposits of the Pacific Rim: Ore Geology Reviews, v. 13, p. 185-218.

Goldfarb, R.J. Snee, L.W., and Pickthorn, W.J., 1993, Orogenesis, high-T thermal events, and gold vein formation within metamorpohic rocks of the Alaskan cordillera: Mineralogical Magazine, v. 57, p. 375-394

Goldfinger, C., Kulm, L.D. Yeats, R.S., McNeill, L.C., and Hummon, C. 1997. Oblique strike-slip faulting of the cetnral Cascadia submarine forearc: Joumal of Geophysical Research, v.102, no. B. p. 8217-8243.

Goidfinger, C., McNeil, L.C., Kulm, L.D.. and Yeats, R.S, 1996, Width of the seismogenic plate boundary in Cascadia: structural indicators of strong and weak coupling [abs.]: Geological Society of America Abstracts with Programs, v. 28. p. 69

Goldirid, U.D., Demin, G.P., and Krasinikov, A.A., 1974. Geologic structural peculiarities and prospecting technique of the Karamken goid-silver deposit: Materialy po Geologii i Polzenym Iskopaemym Severo-Vostoka SSSR, U.S.S.R. Academy of Sciences, v. 21, p. 75-86 (in Russian).

Golozubov, V.V., and Khanchuk, A.L., 1996, Taukha and Zhuravlevka terranes of the South Sikhote Alin-Fragments of the Early Cretaceous margin of Asia: Geology of Pacific Ocean, v. 12, p. 203-220.

Goncharov, V.L., 1996a, Geologic review of commercial mineralization types of the Okhotsk-Chukchi volcanic belt, in Bundtzen, T.K. Fonseca, A.L., and Mann, Roberta, eds., The Geology and Mineral Deposits of the Russian Far East: Alaska Miners Association, Glacier House Publications, Anchorage, Alaska, p. 134-140.

Goncharov, V.I., 1995b, Mineral resources of the Magadan region and problems of their development, in Bundtzen, T.K. Fonseca, A.L, and Mann, Roberta, eds. The Geology and Mineral Deposits of the Russian Far East:
Alaska Miners Association, Glacier House Publications, Anchorage, Alaska, p. 153-156,

Gonevchuk, V,G, Gerasimov, N.S., and Gonevchuk, G.A., 1991. The granites of the Khingan-Olonoy ore district: Pacific Geology, no. 6, p. 150-157.

Gonewchuk, V.G., and Gonevchuk, G.A., 1991, On magmatic factors of the coincidence of tin-tungsten and molibdenum mineralization in the Tigrinoe deposit (Primorye), in Khomich, V.G., ed., Relationships between different deposit types in volcanic-plutonic belts of the Asia-Pacific juncture zone: U.S.S.R. Academy of Sciences, Far East Geological Institute, Vadivostok, p. $111-120$ (in Russian).

Gonewchuk, V.G., Kokorin, A, and Popovichenko, V, 1998, The Kavalerovo ore district, in Seltmann, R., Gonevchuk, G., and Khanchuk, A., eds., International Field Conference in Vladivostok, Russia, September 1998: GeoforschungsZentrum Potsdam (GFZ), Potsdam, p. 51-76.

Gonevchuk, V.G., Semenyak, B.I., and Ishihara, S., 1998, Age of tine greisens of Primorye and other questions of tin mineralization in Russia: Geology of Ore Deposits, v. 40, no. 4 , p. $326-335$ (in Russian).

Goodfellow, W.D. and Jonasson, I.R., 1986, Enwironment of formation of the Howards Pass (XY) Zn-Pb deposit, Selwyn Basin, Yukon; in Mineral deposits of Northem Cordilera, Morin, JA., ed., Canadian Institute of Mining and Metalurgy Special Volume $37, \mathrm{p}, 19-50$.

Gordey, S.P., 1992, Geological fieldwork in Teslin map area, southern Yukon Territory, in Current Research, Part A: Geological Survey of Canada Paper 92-1A, p. 279-286.

Gordey, S.P., and Anderson, R.G., 1993, Evolution of the northem Corcileran miogeocline, Nahanni map-area (105I), Yukon and Northwest Territories: Geological Survey of Canada Memoir 428, $214 \mathrm{p}$.

Gordey, S.P., Gelidsetzer, H.H.J., Morrow, D.W., Bamber, E.W., Henderson, C.M. Richards, B.C., McGugan, A., Gibson, D.W. and Poulton, T.P. 1991, Upper Devonian to Middle Jurassic assemblages, Chapter 8, in Gabrielse, H. and Yorath, C.J., eds., Geology of the Cordilleran Orogen in Canada: Geological Survey of Canada, Geology of Canada, no. 4. p. 219-328.

Gorelova, N.N., 1990, Local metasomatism occurrences and related mineralization in one of ultramafic massifs of the Koryak Highlands: Proceedings of Higher Educational Establishments, Geology and Exploration, no. 2, p. 7378 (in Russian).

Gorodinsky, M. E., Gulevich, V.V., and Titov, V.A., 1978, Copper occurrences in the U.S.S.R. Northeast: Materialy po Geologii i Polzenym Iskopaemym SeveroVostoka SSSR, U.S.S.R. Academy of Sciences, v. 24. p. 151-158 (in Russian).

Gorodinsky, M.E., Gulevich, V.V., Neznanov, N.N., Palymsky. B.F., and Radzivill, A.Ya, 1974, On geology and metallogeny of the Anyui-Oloy interfuve: Materialy po Geologii i Polzenym Iskopaemym Severo-Vostoka SSSR, U.S.S.R. Academy of Sciences, v. 21, p. 31-41 (in Russian).

Goryachev, N.A., 1995, Mesothermal lode gold deposits of the Russian Far East, in Bundtzen, T.K. Fonseca, A.L., and Mann, Roberta, eds. The Geology and Mineral Deposits of the Russian Far East: Alaska Miners Association, Glacier House Publications, Anchorage, Alaska; p. 141152.

Goryachev, N.A., 1998, Geology of Mesozoic gold quartz veins in Northeastem Asia: Russian Academy of Sciences, 
Northeast Scientific Intergrated Research institute (NEISRI). Magadan, 210 D. (in Russian).

Goryachev, N.A, 2003. Origin of gold-quartz vein belts throughout the Northern Pacific Area. Russian Acaderny of Sciences, Far East Branch. Northeast Interdisciplinary Scientfic Research Institute, Magadan, 143 D. (in Russian)

Goryachev, N.A. and Byalobzhesky, S.G, eds. 1996, Stratiform ore mineralization of sedimentary and sedimentary-volcanogenic assemblages in northeastern Asia: Russian Academy of Sciences, Northeast interdisciplinary Scientific Research Institute, Magadan, 117 p. (in Russian).

Goryachev, N.A, and Goncharov, V.I., 1995, Late Mesozoic graniloid magmatism and related gold and tin mineralization of North-East Asia: Resource Geology Special issue, no 18, p. 111-122

Govorov. I.N. 1977. Geochemistry of Primorye ore districts: Nauka, Moscow, 251 p. (in Russian)

Gorzynski, G.A. 1986, Geology and lithogeochemistry of the Cirque stratiform sediment-hosted $\mathrm{Ba}-\mathrm{Zn}-\mathrm{Pb}-\mathrm{Ag}$ deposit, northeastem British Columbia: Vancouver, British Columbla, University of British Columbia, M.Sc. thesis, 129 p.

Gottschalk, R.R, and Oidow, J.S., 1988, Low-angle normal faults in the south-central Brooks Range fold and thrust belt, Alaska. Geology, v, 16, p. 395-399.

Govorow, IN. 1977, Geochemistry of Primorye ore districts: Nauka, Moscow, 251 p. (in Russian)

Grant, B., 1987, Magnesite, brucite and hydromagnesite occurrences in British Columbia: British Columbia Ministry of Energy. Mines and Petroleum Resources. Open File 1987-13, 68 p.

Grantz, Avthur, Moore, T.E, and Roeske, S.M. 1991, North American continent-ocean transect A-3: Gulf of Alaska to Arctic Ocean, Geological Society of America ContinentavOcean Transect No. 15: Geological Society of America, Boulder, Colorado, 3 sheets, scale $1: 500,000,72 \mathrm{p}$.

Grantz. A.. Clark, D.L. Phillips, RL., and Srivastava, S.P. 1998 , Phanerazoic stratigraphy of Northwind Ridge, magnetic anomalies in the Canade Basin, and the geometry and timing of rithing in the Amerasia basin, Arctic Ocean: Geological Socety of America Bulletin v. 110, p. 801-820.

Grantz, A. Mayh. S.D. and Hart. P., 1990. Geology of the Arctic continental margh of Naska, in Grantz. A. Johnson, L. and Sweeney, J.F, eds., The Arctic Ocean region: Boulder, Colo, Geclogical Society of America. The Geology of North America, v. L. P. 257-288.

Gray. JE. Gent. C.A. and Snee. L.W., 1997. Epithermal mercury-antimony and gold-bearing lodes of southwestem Alaska, in Goldtarb, R.J, and Miller, L.D., eds. Mineral Deposits of Alaska: Economic Geology Monograph 9, p. 287 305.

Greninger, M.L., Kemperer, S.L, and Nokleberg. W.J., 1999. Geographic information systems (GiS) compllation of geologic, geophysical, and tectonic data for the CircumNorth Pacific, in Nokdeberg. W.J., and Digoles, M.F. eds: U.S. Geological Survey Open-File Report $99-422$. CD.ROM

Grinberg. G.A., Bakharev. A.G., Gamyanin, G.N. Kukhtinsky, G.G, and Nedosekin, Yu.D. 1970, Granitoids of the South Verkhoyansk. Nauka. Moscow. 216 p. (in Russian)

Grond, H.C. Churchill. S., Amstrong. R.L. Harakal, J.E, and Niwon. G.T. 1984. Late Cretacecus age of the Hutshi, Mount Nansen, and Carmacks groups, southwestem
Yukon Temitory and northwestem British Columbia: Canadian Joumal of Earth Sciences. v. 21, p. 554-558.

Gross, G.A., 1965. Iron formation, Snake River area, Yukon and Northwest Temitcries, in Report of Activities, 1964: Geciogical Survey of Canada, Paper 65-1. p. 143.

Gross, G.A., 1996, Stratiform iron, in Geology of Canadian Mineral deposit Types, Eckstrand, O.R., Sinclair, W.D., and Thorpe, R.1, eds., Geological Survey of Canada, Geology of Canada, no, 8, p. 41-44

Grove, E.W., 1986, Geology and mineral deposits of the Unuk River-Saimon River-Anyox area: British Columbia Ministry of Energy. Mines and Petroleum Resources. Bulletin 63, $152 \mathrm{p}$.

Grybeck, Donald, 1977, Known mineral deposits of the Brooks Range, Alaska: U.S. Geological Survey Open-File Report 77-166C, 45 p., 1 map sheet, scale 1:1,000,000,

Grybeck, Donald, Berg, H.C., and Karl, S.M., 1984, Map and description of the mineral deposits in the Petersburg and eastern Port Alexander quadrangles, southeastem Alaska: U.S. Geological Survey Open-File Report 84837,86 p., 1 sheet, scale 1:250,000.

Guild, P.W., 1942, Chromite deposits of Kenai Peninsula, Alaska: U.S. Geological Survey Bulletin 931-G, p. 139 175.

Gulevich, V.V., 1974, Subvolcanic bodies and mineralization in the Baimka River basin: Materialy po Geoiogii I Polzenym Iskopaemym Severo-Vostoka SSSR, U.S.S.R. Academy of Sciences, North-Eastern Interdisciplinary Research Institute, Magadan, 62 p (in Russian).

Gurov, L.P. 1969. Gold-bearing mineral formations of the Kirovskoe deposit, in Radkevich, E.A. ed. Gold formations of the Russian Far East. Nauka, Moscow, p. 74-92 (in Russian)

Gurov, L.P. 1978. The relation of gold mineralization with Upper Mesozoic magmatism in the Upper, in Radkevich, E A. ed., Gold mineralization of the Upper and Middle Primorye: U.S.S.R. Acaderny of Sciences, Far East Geological institute, Vladivostok, p. 3-10 (in Russian).

Haeussler, P.J., Bradley, Dwight C., Goldfart, R.J., Snee, L.W. Taylor, C. D., 1995, Link between ridge subduction and goid mineralization in Southern Alaska: Geology, v. 23. p. $995-998$.

Haeussler, P.J., and Nelson, S.J, 1993, Structural evolution of the Chugach-Prince Willam terrane at the hinge of the orocline in Prince Willam Sound, and implications for ore deposits, in Dusel-Bacon, Cynthia, and TIl. A.B. eds. Geologic Studies in Alaska by the U.S. Geological Survey, 1992: U.S. Geological Survey Bulletin 2068, p. 143-162.

Hansen, VI. Radof, JK, and Hart, C.J.R., 1990. Taly Ho shear zone, southem Yukon: kinematic evolution and tectonic implications [abs]: Geological Association of Canada Annual Meeting Program with Abstracts, v. 15, p. 53-54.

Hartert, W., Frei, L, Jarrad, R. Halgedahl, S, and Engebretson, D.C. 1990 , Paieomagnetic and plate-tectonic constraints on the evolution of the Alaska eastem Siberian Arctic, in Grantz, A., Johnson, L, and Sweeney. J.F., eds., The Arcfic Ocean region: Boulder, Colo. The Geology of North America, v. L: Geological Society of America, p. 567-592.

Hardy, J.L. 1979, Stratigraphy, brecciation and mineralization. Gayna River, Northwest Temitories: Toronto. Ontario. University of Tcronto, M.Sc. thesis, 467 p.

Harms. TA, 1986, Structural and tectonic analysis of the Sytvester Allochthon, southwest McDame map-area, 
northern British Columbia: implications for paleogeography and accretion: Tucson, University of Arizona, Ph.D. thesis.

Harper, G., 1977. Geology of the Sustut Copper deposit in British Columbia: Canadian Instifute of Mining and Metallurgy Bulletin, v. 70 no. 777 , p. 97-104.

Hart, C.J.R. 1994, Gold-bearing quartz veins in southern Yukon Territory [abs.], in Jambor, J.L., ed., Recent Developments in Yukon Metallogeny: Canadian Institute of Mining and Metallurgy 1994 Annual General Meeting. Abstracts and Proceedings, p. 35-37

Hart, C.J.R., 1995, Sinistral translation of aocreted terranes: yo-yo tectonics in the Canadian Cordillera [abs.]: Geological Association of Canada Annual Meeting Program with Abstracts, v. 20, p. 43.

Hart, C.J.R., Baker, T., and Burke, M, 2000. New exploration concepts for country-rock-hosted, intrusion-related gold systems: Tintina gold belt in Yukon, in Tucker, T.L., and Smith, M.T. eds. The Tintina gold belt: Concepls, Exploration, and Discoveries: British Columbia and Yukon Chamber of Mines, Vancouver, Special Volume 2. p. 145-171,

Hawley, C.C., and Clark, A.L., 1974, Geology and mineral deposits of the upper Chulitna district, Alaska: U.S. Geological Survey Professional Paper 758-B, 47 p.

Hayes, T.S., Rye, R., Whelan, J.F., and Landis, G.P., 1989. Geology and sulfur-isotope geothermometry of the Spar Lake stratabound $\mathrm{Ou}-\mathrm{Ag}$ deposit in the Belt Supergroup, Montana, in Boyle, R.W., Brown, A.C., Jefferson, C.W. Jowett, E.C., and Kirkham, R.V., eds., Sediment-hosted stratiform copper deposits: Geological Association of Canada Special Paper 36, p. 319-338

Hedley, M.S., 1947, Geology of Whitewater and Lucky Jim Mine areas, Slocan District: British Columbia Department of Mines, Bulletin 22, 54 p

Hedley, M.S., 1952, Geology and ore ceposits of the Sandon area, Slocan mining camp. British Columbia: Britsh Columbia Department of Mines Bulletin 29, 130 p.

Heiphiz, A. Harbert, W., and Savostin, LA. 1994, Reconnalssance paleomagnetism of the Olyutorsky superterrane, northeast Russia, in Thurston, D., and Fujta, K. eds. Proceedings of 1994 International Conference on Arctic Margins: U.S. Department. of Interior, Minerais Management Service, Anchorage, p. $223-228$

Herreid, Gordon, 1968, Geological and geochemical investigations south of Farewell, Alaska: Alaska Division of Mines and Minerals Geology Report 26, $19 \mathrm{p}$

Herreid, Gordon, 1968, Progress report on the geology and geochemistry of the Sinuk River area, Seward Peninsula, Alaska: Alaska Division of Mines and Minerals Geologic Report 29. 13 p.

Herreid, Gordon, 1970, Geology and geochemistry of the Siruk area, Seward Peninsula, Alaska: Alaska Division of Mines and Geology Geologic Report 36, 63 p., 2 sheets, scale 1:63,360.

Herreid, Gordon, 1970, Geology of the Spirit Mountain nickelcopper prospect and surrounding area: Alaska Division of Mines and Geology Geologic Report 40, 19 p., 1 sheet, scale 1:20,000.

Herreid, Gordon, Bundtzen, T.K., and Tumer, D.L., 1978, Geology and geochemistry of the Craig A-2 quadrangle and vicinity, Prince of Wales Island, southeastem Alaska: Alaska Division of Geological and Geophysical Surveys Geologic Report 48, 49 p. 2 plates, scale $1: 40,000$.

Hewton, R.S., 1982, Gayna River: A Proterozoic Mississippi Valley-type zinc-lead deposit, in Hutchinson. R.W.
Spence, C.D. and Franklin, J.M., eds., Precambrian Sulphide Deposits, H.S. Robinson Memorial Volume: Geological Association of Canada, Special Paper 25, p. $667-700$

Hewton, R.S. 1982, Gayna River; a Proterozoic Mississippi Valley-type zinc-lead deposit; in Precambrian Sulphide Deposits, H.S. Robinson Memorial Volume, Hutchinson, R.W., Spence, CD., and Franklin, J.M., eds.

Himmelberg. G.R., Brew, D.A., and Ford, A.B., 1985, Ultramafic bodies in the Coast Plutonic-Metamorphic Complex near Skagway, Southeastern Alaska, in Bartsch-Winkler. Susan, ed. The United States Geological Survey in Alaska: Accomplishments during 1984: U.S. Geological Survey Circular 967, p. 92-93.

Himmelberg, G.R., and Loney, R.A., 1981, Petrology of the ultramafic and gabbroic rocks of the Brady Glacier nickel-copper deposit, Fairweather Range, southeastern Alaska: U.S. Geological Survey Professional Paper 1195,26 p.

Himmelberg. G.R., and Loney, R.A., 1995, Characteristics and petrogenesis of Alaskan-type ultramafic intrusions, southeastem Alaska: U.S. Geological Survey Professional Paper $1564,47 \mathrm{p}$.

Himmelberg. G.R. Loney, R.A., and Nabelek, P.I., 1987. Petrogenesis of gabbronorite at Yakobi and northwest Chicagof Island, Alaska: Geological Society of American Bulletin, v. 98 , p. $265-279$

Hitchins, A.C., and Orssich, C.N., 1995, The Eagle zone goidtungsten sheeted vein porphyry deposit and related mineralization, Dublin Gulch, Yukon Territary, in Schroeter, T.G. ed., Porphyry Deposits of the Northwestem Cordilera of North America, Canadian Institute of Mining and Metallurgy Special Volume 46, p. B03-810.

Hitzman, M.W., Oreskes, N., and Einaudi, M.T., 1992, Geological characteristics and tectonic setting of Proterozoic iron oxide (CU-U-Au-REE) deposits: Precambrian Research, v. 58, p. 241-287

Hitzman, M.W., Proffett. J.M. Jt., Schmidt, J.M., and Smith, T.E., 1986, Geology and mineralization of the Ambler district, northwestern Alaska: Economic Geology, v. 81, p. $1592-1618$

Hitzman, M.W., Smith, T.E., and Proffett, J.M., 1982, Bedrock geology of the Ambler district, southwestem Brooks Range, Alaska: Alaska Division of Geological and Geophysical Surveys Geologic Report 75, 2 sheets, scale 1:125,000

Hodgson, C.J. 1995, Kitsault (Lime Creek) molybdenum mine, northwestern British Columbia, in Schroeter, T.G., ed. Porphyry Deposits of the Northwestem Cordilera of North America: Canadian Institute of Mining and Metallurgy, and Petroleum, Special Volume 46, p. 708-711.

Hoffman, P.F. 1989, Precambrian geology and tectonic history of North America, in Bally, A.W., and Paimer, A.R., eds. The geclogy of North America - an overview, Boulder, Colo., Geological Society of America. The Geology of North America, v. A., p. 447-512.

Hoffman, P.F., 1991, Did the breakout of Laurentia tum Gondwanaland inside-out? Science, v. 252, p. 1409 1412

Hollister, V.F., 1978, Geology of the porphyry copper deposits of the Westem Hemisphere: Society of Mining Engineering. American Institute of Mining. Metallurgy. and Petroleum Engineers Incorporated. New York, 218 $p$

Hollister, V.F. 1992, On a proposed plutonic porphyry gold deposit model. Non-renewable resources, v, 1. p. 293302. 
House, G.D., and Ainsworth, B, 1995, The Poplar coppermolybdenum-gold porphyry deposit. central Bntish Columbia, in Schroeter, T. G. ed. Porphyry Deposits of the Northwestem Cordilera of North America Canadian Instlute of Mining and Metalungy, and Petroleum, Special Volume 46 , p. $397-400$

Howard, W.R. 1935, Salt Chuck copper-palladium mine: Alaska Territory Department of Mines Repont MR119-4, $22 \mathrm{p}$

Howell, DG, Jones, D.L., and Schermer, E.R., 19a5, Tectonostratigraphic terranes of the Circum-Pacific region: Principles of terrane analysis, in Howell. D.G. ed. Tectonostratigraphic terranes of the Circum-Pacific region. Circum-Pacific Council for Energy and Mineral Resources, Houston, Texas, p 3-31

Hay, T, 1980, Geology of the Riondel area. Central Kootenay Arc. southeastem British Columbia: British Columbia Ministry of Energy. Mines and Petroleum Resources. Bulletin 73, $89 \mathrm{p}$.

Hey. T. 1982a, Stratigraphic and structural setting of stratabound lead-zinc deposits in southeastem British Columbia; Canadian Institute of Mining and Metallurgy Bulletin, v. 75, no. 840, p. $114-134$

Hay, T., 1982b. The Purcell Supergroup in southeastern British Columbia: sedimentation,tectonics and stratiform leadzinc deposits, in Hutchinson, R.W., Spence. C.D. and Franklin, J.M., eds., Precambrian Sulphide Deposits. The H.S. Robinson Memorial Volume: Geological Association of Canada, Special Paper 25, p. 124-147,

Høy, T, 1989, The age, chemistry, and tectonic setting of the Middle Proterozoic Moyie sills, Purcell Supergroup. southeastern British Columbia Canadian Journal of Earth Sciences, v. 29, p. 2305-2317

Hay, T., 1991. Volcanogenic massive sulphide deposits in British Columbia, in McMllan, W.J., ed, Ore Deposits, Tectonics and Metallogeny in the Canadian Cordiliera: British Columbia Ministry of Energy. Mines and Petroleum Resources Paper 1991-4, p. 89-123.

Hoy, T. 1993, Geology of the Purcell Supergroup in the Fernie west-haif map area, southeastern British Columbia: British Columbia Ministry of Energy. Mines, and Petroleum Resources Bulletin 84, 157 p.

Hoy, T., 1997. Harper Creek: A volcanogenic sulphide deposit within the Eagle Bay Assemblage, Kootenay terrane. southern British Columbia: Brifish Columbia Ministry of energy and Mines. Geological Fieldwork, 1996, Paper 1997-1. p. 199-209

Hoy, T., 2001, Sodex and broken hill-type deposits, northern Monashee Mountains, southern British Columbia, in Geological fioldwork 2000: British Columbia, Ministry of Energy and Mines Report 2001-1, p.85-114.

Hey, T, Aldrick, D, and Dunne, K. 1998, The relationship between intrusion-related $\mathrm{Au}$-(Ou) sulphide veins and Mo breccias: Rossland: in Metallogeny of Volicanic Arcs, British Columbia Geological Survey, Short Course Notes, Open File 1998-5, Section K

Høy. T., and Andrew, K. 1988, Preliminary geology and geochemistry of the Elise Formation, Rossland Group, betwoen Nelson and Ymir, southeastern British Columbia (B2F/06), in Geologic Fieldwork 1991: British Columbia Ministry of Energy. Mines and Petroleum Riesources Paper 1988-1, p. 19-30

Høy. T. and Dunne. K.P.E., 1992. Tectonic and stratigraphic controls of goid-copper mineralization in the Rossland camp. southeastern British Columbia, in Geologic Fieldwork 1991: British Columbia Ministry of Energy.
Mines and Petroleum Resources Paper 1992-1, p. 261272

Hoon M. 1901, Isotopic age determinations of some metamorphic and igneous rocks from Clinton Creek area, Yukon, Yukon Geology and Exploration 1979-80: Department of Indian and Northern Affairs, Canada, p. 65. 67

Hudson, T., 1979, Mesozoic plutonic belts of southem Alaska: Geology, v. 7, p. 230-234.

Hudson, T.L., 1983, Calc-alkaline plutonism along the Pacific rim of southem Alaska, in Roddick, JA, ed. CircumPacific plutonic terranes: Geological Society of America Memoir 159, p. 159-170.

Hudson, Travis, and Arth, J.G., 1983. Tin granites of the Seward Peninsula, Alaska: Geological Society of America Bulletin, v. 94, no. 6, p. 768-790.

Hudson, T. Miller, M.L. and Pickthom, W.J., 1977, Map showing metalliterous and selected nonmetalliferous mineral deposits, Seward Peninsula, Alaska. U.S. Geological Survey Open-File Report 77-796B, 46 p.. 1 sheet, scale $1: 1,000,000$.

Hudson, T.L., and Reed, B.L., 1997. Tin deposits in Alaska, in Goldfarb, R.J, and Miller, L.D., eds., Mineral Deposits of Alaska: Economic Geology Monograph 9, p. 450-465.

Hudson, Travis, Smah, J.G., and Elliott, R. L, 1979, Petrology. composition, and age of intrusive rocks associated with the Quartz Hill molybdenite deposit, southeastem Alaska: Canadian Joumal of Earth Sciences, v. 16, p. 1805-1822.

Hulbert, L.J., 1995, Geology and motallogeny of the Kuane mafic-ultramafic beit, Yukon Territory, Canada; eastern Wrangellia, a new Ni-CU-PGE metallogenic terrane: Geological Survey of Canada Open File 3057, 407 p

Hulbert, L.J., Carne, R.C., Gregoire, D. ., and Pactunc, D. 1992 Sedimentary nickel, zinc, and platinum-group element mineralization in Devonian black shales at the Nick property, Yukon. Canada: A new bype of deposit. Exploration, Mining and Geology, Canadian insthute of Mining and Metalurgy, v. 1, no. 1, p. 3962.

Hulbert, LJ. Came, R.C., 1995. Wrangellia: a new NE-Cu-PGE metallogenic terrane: Exploration in British Columbia 1995 in Part A. Overview of exploration activity and Part B. Geological descriptions of properties: British Columbia Ministry of Mines and Petroleum Resources, Exploration in British Columbia, v. 1995, p. 179.

Hubert. LJ. Duke, JM. Edstrand, OR. Lydon. J.W. Scoates. R.F.J. Cabn, L.J and Imine, T.N. 19a8, Geciogical envionments of the platinum group elements; Cordileran Section. Geciogical Association of Canada, Short Course Notes, $151 \mathrm{p}$.

Imaev, V.S. 1991, Late Cenozoic overthrusts, reverse faults, and folded dislocations of the Chersky seismic beit (eastem Yakutia): Geotectonics, v. 25. p. 356-361.

Imaev, V.S., Imaeva, L.P. and Koz'min, B.M, 1990 . Active faults and saismotectorics of northeast Yakutia. Yakut Science Center, Yakutsk, 138 p. (n Russian).

Indolev, L.N. 1979, Dikes in mineral districts of the eastem Yakutia: Nauka, Moscow, 236 p. (in Russian).

Indoloev, LN. Zhdanov, Yu Ya, and Supletsov, V.M., 1980 Antimony mineralization in the Verkhoyansk-Kolyma province: Nauka, Novosibirsk, 232 p. (in Russian).

Insley, M.W., 1991, Modification of sedimentary barite textures during deformation, Gataga district: northeast British Columbia, Ore Geology Reviews, 6, p. 463-473.

loganson, A.K., 1988, The geologic structure of the Kurpandzha ore field and the development of copper mineralization: Stratiform mineralization in Yakutia: U.S.S.R. Academy 
of Sciences, Siberian Branch, Institute of Geology, Yakutsk, p. 87-98 (in Russian).

Irving. E, and Monger, JW.H, 1987, Prelimnary results from the Permian Asitka Group, British Columbia: Canadian Journal of Earth Sciences, v. 24, p. 1490-1497

Ivanov, O.N., Pertsev, A.N., and llchenko, L.N., 1989. Precambrian metamorphic rocks of the Anadyr-Koryak region; U.S.S.R. Academy of Sciences, North-Eastern Interdisciplinary Research Institute, Magadan, 62 p (in Russian).

Ivanov, V.V., Zinkov, A.V., and Taskaev, V.I., 1989, Mineralogy of Late Paleogene gold-silver deposits on Lower Amur region, in Khomich, V.G., ed. Mineral types of ore deposits in volcanic belts and activization zones of North-East Asia: U.S.S.R. Academy of Sciences, Far East Geological Institute, Vadiwostok, p. $87-89$ (in Russian),

Ivensen, Yu.P. and Levin, V.I., 1975, Genetic types of gold mineralization and gold mineral assemblages, in Ivensen, Yu.P., ed., Gold mineral assemblages and geochemistry of gold of the Verkhoyansk-Chukchi fold beit: Nauka, Moscow, p. 5-120 (in Russian).

Ivensen, Yu.P., Amuzinsky, V.A., and Nevoisa, G.G., 1975, The structure, history, magmatism and metallogeny of the northem Skhoyan fold belt. Nauka. Novosibirsk, 322 p. (in Russian).

Jackson. A. and Mlerbrun, K., 1995, Huckleberry porphyry copper deposit, west-central British Columbia, in Schroeter, T.G. ed. Porphyry Deposits of the Northwestem Cordillera of North America, Canadian Institule of Mining and Metallurgy Special Volume 46, p. 313-321.

Jackson, S.A, and Beales, F.W., 1967, An aspect of sedimentary basin evolution: the concentration of Mississippi Valleytype ores curing the late stages of diagenesis; Bulletin of Canadian Petroleum Geology, v. 15, p. 383-433

Jansons, Uldis, Hoekzema, R.B., Kurtak, J.M., and Fechner, S.A., 1984, Mineral occurrences in the Chugach National Forest, south-central, Alaska: U.S. Bureau of Mines Open-file Report MLA 5-84, 43 p., 2 sheets. scale $1: 125,000$.

Jefferson, C.W., and Ruelle, J.C.L., 1986, The Late Proterozoic Redstone Copper Belt, Mackenzie Mountains, Northwest Territories; in Minerai Deposits of Northern Cordilera, Morin, J.A, ed., Canadian Institute of Mining and Metallurgy Special Volume 37, p. 154-168.

Jefferson, C.W., Kilby. D.B., Plgage, L.C., and Roberts, W.J., 1983. The Cirque barite-zinc-lead deposits, northeastern British Columbia, in Sangster, D.F., ed. Short Course in Sediment-hosted Stratiform Lead-Zinc Deposits: Mineralogical Association of Canada, Short Course Handbook, v, 8, p. 121-140.

Jennings, D.S and Jilson, G.A., 1986, Geology and sulphide deposits of Anvil Range, Yukon: in Mineral Deposits of Northem Cordillera, Morin, J.A., ed., Canadian institute of Mining and Metallurgy. Special Volume 37, p. 319-361.

Johnson, B.L., 1915. The gold and copper deposits of the Port Valdez district: U.S. Geological Survey Bulletin 622, p. $140-148$.

Johnson, B.R., Kimball, A.L., and Still, J.C., 1982, Mineral resource potential of the Western Chichagof and Yakobi Islands wildemess study area, southeastem Alaska: U.S. Geological Survey Miscellaneous Field Studies Map MF-1476-B, 10 p., scale 1:125,000.

Johnston, S.T. and Mortensen, J.K., 1994, Regional setting of porphyry Cu-Mo deposits, voicanogenic massive sulphide deposits, and mesothermal gold deposits in the YukonTanana terrane, Yukon Territory [abs.], in Jambor, J.L., ed. Recent Developments in Yukon Metallogeny: Canadian Institute of Miring and Metallurgy 1994 Annual General Meeting, Abstracts and Proceedings, p. 30-34.

Jones, Brian, 1977. Uranium-thorium bearing rocks of western Alaska: Fairbanks, Alaska, University of Alaska, M.S. thesis, $80 \mathrm{p}$.

Jones, D.L. Howell, D.G. Coney, P.J., and Monger, J.W.H., 1983, Recognition, character, and analysis of tectonostratigraphic terranes in western North America, in Hashimolo, M., and Uyeda, S., eds.. Accretion tectonics in the circum-Pacific regions; Proceedings of the Ofi International Seminar on Accretion Tectonics, Japan, 1981: Advances in Earth and Planetary Sciences, Tokyo, Terra Scientific Publishing Company. p. $21-35$

Jones, DL. and Silbering, N.J., 1982, Mesozoic stratigraphy: Key to tectonic analysis of southem Alaska and central Alaska, in A.E. Leviton, ed., Frontiers of Geological Exploration of Western North America: American Association of Petroleum Geologists Pacific Division. San Francisco, Calif., p. 139-153.

Jones, D.L., Siberling, N.J., Coney, P.J., and Plafker, George, 1987, Lithotectonic terrane map of Alaska (West of 141 st Meridian): U.S. Geological Survey Miscellaneous Field Studies Map MF-1847-A, 1 sheet, scale $1: 2,500,000$

Journeay, J.M., and Friedman, R.M., 1993, The Coast Belt thrust system: evidence of Late Cretaceous shortening in souttwwest British Columbia: Tectonics, v. 12, p. 756775 .

Juras, S.J., 1987, Geology of the polymetallic volcanogenic Buttle Lake camp, with emphasis on the Price Hillside. central Vancouver Isiand, British Columbia, Canada: Vancouver, British Columbia, Ph.D. thesis, University of British Columbia, $279 \mathrm{p}$.

Juras, S., and Pearson, C.A., 1991. The Buttle Lake Camp. central Vancouver Island, British Columbia: Geological Survey of Canada, Open File 2167. Field Trip 12, Geology and regional setting of major mineral deposits in southem British Columbia. p. 145-161.

Kalinin, A.I., 1986, Structure of silver ore field and deposit occurring in high-potassium rhyolite of the OkhotskChukotka volcanic belt: Structures of ore fields and deposits in volcanic belts, Vladivostok: U.S.S.R. Academy of Sciences, Far Eastem Branch, Vladivostok, p. $56-71$ (in Russian).

Karlstrom, K.E., Wiliams, M.L., Mclelland, J., Geissman, J.W., and Ahall. K, 1999, Refining Rodinia: geologic evidence for the Australia-Western U.S. connection in the Proterozoic: GSA Today, v. 9, p. 1-7

Kazansky, V.I. 1972, Ore-bearing tectonic structures of activization zones: Nedra, Moscow, 240 p. (in Russian).

Kennedy, G.C., 1953, Geology and mineral deposits of Jumbo basin, southeastern Alaska: U.S. Geological Survey Professional Paper 251, 46 p.

Kepezhinskas, P.K., Reuber, I. Tanaka, H., and Myashita, S. 1993. Zoned calc-alkaline plutons in northeastem Kamchatka: Implications for crustal growth in magmatic arcs: Mineralogy and Petrology, v, 49, p. 147-174.

Khanchuk, A.I. 1993, Geology setting and evolution of the northwest Pacific continental framework: Summary of Ph.D. dissertation, Russian Academy of Sciences, Geological Institute, Moscow, 31 p. (in Russian).

Khanchuk, A.I. Gonevchuk V.G., and Simanenko, V., 1998, The Primorye region - the southern Sikhote-Alin accretionary fold system: geology and metallogeny, in Seltmann, R., Gonevchuk, G., and Khanchuk, A., eds., 
International Field Conference in Vladivostok. Russia. September 1998: GeoForschungsZentrum Potsdam (GFZ). Potsdam, p. 1-8

Khanchuk, A.t. and Ivanov, V.V., 1999a. Mesozoic-Cenozoic geodynamic environments and gold mineralization of the Russian Far East Geology and Geophysics, 1999, v.40. no. 11. p, 1635-1645 (in Russian).

Khanchuk, A.L and Ivanov, V.V., 1999b, Mesozoic-Cenozoic geodynamics of East Russia and goid mineralization: Geodynamics and Metallogeny. Vladivostok, Dainauka, 1999, p. 7-30 (in Russian).

Khanchuk, A.I. Ratkin, V.V., Ryazantseva, M.D., Golozuboy. V.V., and Gonckhova, N.B, 1996, Geology and mineral deposits of Primorsky Krai (territory) Far East Branch Geological Institute. Russian Academy of Sciences, Dalnauka, Vladivostok, 61 p.

Khetchikov, L.N., Goworov, I.N., Pakhomova, V.A, and other, 1992. New data on genesis of lithium-fluorite granife of the Khanka medium massif: Doklady Akademii Nauk, SSSR, v. 322, no.6, p. 1121-1127. (in Russian).

Khomich V.G., 1990. Control of shallow-depth mineralization by injection structures: Doklady Akademii Nauk, SSSR, v. 315. no. 3, p. 694-699 (in Russian).

Khomich, V.G., Ivanov, V.V., and Fatiyanov, 1.1., 1989, Types of gold-silver deposits: U.S.S.R. Academy of Sciences, Far East Geological Institute, Vladivosiok, 292 p. (in Russian)

Khomich V.G., Vanenko V.A., Sorokin A.P., Shikhanov V.V., and Lushchei A.A., 1978, Hydrothermal-metasomatic and explosive rocks of the Pokrovsky goid deposit, in Mironuk, A.F. ed. New data on mineral rescurces of the contral Baikal-Amur Railroad Zone: U.S.S.R. Acaderny of Sciences, Far East Geological Institute, Blagoveshchensk, p.119-128 (in Russian).

Khvorostov, V.P. 1983, Conditions of localization of the goidsilver deposit ore bodies: Kolyma, no. 3. p. 24-32 (in Russian)

Khvorostov, V.P, and Zaitsev, V.P. 1983, The ore-bearing magmatic complexes of Ichigan-Unneivayamsk region (Koryak Upland): Tikhookeanskaya Geologiya, no. 2, p. 42-48 (in Russian)

Kimball, A.L. Stil, J.C, and Ratai. JL., 1964, Mineral deposits and ocourrences in the Tracy Am-Fords Tenor wildemess study area and vicinity. Alaska: Uniled States Geological Survoy Buletin 1525, p. 105-210.

Kinilov. V.E., 1991, The perspectives of the prospect of REE ores, associated with volcanic rocks of Uikan depression: Proceedings of Dainedra Association, Dainedra Publishing House, Khabarovsk, v. 2, p. 111117 (in Russian).

Kunlliov, V.E. 1993. Ore hydrotermal alteration of volcanic rocks of Ulkan depression: Vladivostok. Summary of Ph.D. dissertation, Far East Geological Institute, Russian Academy of Sciences, Vladivostok. 23 p. (in Russian).

Kirkham. R.V., 1967, Glacier Gulch: British Columbia Ministry of Mines, Annual Repont 1966, p. 86-90.

Kirkham, R.V. 1971, Intermineral intrusions and their bearing on the origin of porphyry copper and molybdenum deposits: Economic Geology, v. 66, p. 1244-1249.

Kisham, RV, 1974, A synopsis of Canadian stratiorm copper deposits in sedimentary sequences: Centenaire de la Societe Geciogique de Belgique, Gisements Stratormes ef Provinces Cuprifures, Liege. D. $367-382$.

Kikham, RV., 1996a, Sedment-hosted stratiorm copper; in Geology of Canadian Minerai Deposit Types, Eckstrand, O.R. Sinclair, WD, and Thorpe, R.1., eds., Geological
Survey of Canada, Geciclogy of Canada, no. 8, p. 223240

Kirkham, R.V, 1996b, Voicanic recbed copper, in Eckstrand, O.R. Sinclair. W.D. and Thorpe, R.F., eds., Ceology of Canadian mineral deposh types: Boulder, Colorado, Geological Society of America. The Geology of North America, v. F-1, p. 473-483.

Kirkham, R.V., and Margolis, J, 1995, Overview of the Sulphurets area, northwestem British Columbia, in Schroeter, T.G. ed., Porphyry deposits of the northwestem Cordiliera of North America: Canadian Institute of Mining and Metallurgy, and Petroleum, Special Volume 46. p. 473. 483.

Klimov, N.V.4 1979, Mercury, in Arkhipov, Yu.V. and Frumkin, L.M., eds., Geology of U.S.S.R., Minerais of Yakutia: Nedra, Moscow, v. 18, p. 249-259 (in Russian).

Kolyasnikov, Yu. A, and Kulish, L.I., 1988, Manganese metamorphic concentrations in volcanic-sedimentary rocks of the Anadyr-Koryak fold beit: Metamorphogenic ore formation of low-grade facies metamorphism in Phanerozoic fold belt: Nauka, Kiev, p. 185-193 (in Russian).

Konstantinov, M.M. Natalenko, V.E., Kalinin, A.I. Strujkov, S.F. 1998, Ducat gold-silver deposit: Nedra Publisher House, Moscow, 203 p.

Konstantinovskaya, E.A. 1999 Geodyamics of isiand arocontinent collison in the westem Pacific margin: Geotectonics, v. 33, p. 15-34.

Konyshev, V O. Zhidkov, N.A., and Stepanov, VA., 1993. Gold mercury deposits in Yakutia: Kolyma, v. 3, p. 11-15 (in Russian)

Kopytin, V.I. 1978, Volcanio-hosted meroury mineralization in Chukotka: Mercury mineralization in orogenic volcanic complexes of the U.S.S.R. Northeast U.S.S.R. Academy of Sciences, North-Eastem interdisciplinary Research institute, Magadan, p. 50-119 (in Russian).

Korostelev, P.G. Gonevchuk, V.G., Gonevchuk, G.A. and others, 1990, Mineral assemblages of a greisen tungsten-tin deposit (Primorye), in Gvozdev, V.1., ed. Mineral assemblages of tin and tungsten deposits in the Russian Far East: U.S.S.R. Academy of Sciences. Far East Geological Insthute, Vladivostok, p. $17-61$ (in Russian)

Koski. Randolph Ac Siberman. M L; Nelyon, S W: Dumoslin.d A. 1985, Rua Cove; anatomy of volcanogenic Fe-Cu sulfide deposit in ophiolite on Kright Island. Naska [abs]: American Association of Petroloum Goologists Bulletin 69, p. 667.

Korostylyov V.1. 19a2. The geology and tectonics of the Southern Verkhoyan area: Nauka. Novosibirsk, 217 p. (in Russian)

Kozin, N.N., Loginov, V.A, Kozlov, A.P., Zaitsev, V.P., and Sidorov, E.G., 1999, The platinum mining activities of Koryak Geology Mining Company in Northem Kamchatka, in Schafer, Robert, and Bundtzen, T.K. eds., Session on the Mineral Current Developments in the Russian Far East: Proceedings of the Prospectors and Develcpers Association of Canada. Toronto, Ontario, p. 247-251.

Koz'min, B.M. 1984, Seismic belts of Yakutia and the mechanisms of their earthquakes: Nauka, Moscow. 125 p. (in Russian).

Koz'min, B.M., Imaev, V.S. Imaeva, L.P., Fujita, K., Chung. W.Y., and Gao, $H_{\text {, }}$ 1996, Seismicity and active faults of the eastern Siberian platform [abs.: Eos, Transactions. American Geophysical Union, v. 15, p. F521 
Koxlovsky, E.A., ed., 1988, Geology of the BAM Zone, geological structure: Nedra, Leningrad, 443 p. (in Russian).

Krasilnikov, A.A., Leibova, L.M., Khrustakeva, L. B., Nekrasova, A.N., Krasilnikova, L.N., and Demin, G.P., 1971 . Geologic-structural peculiarities and mineral composition of hydrothermally altered rocks and ore bodies of the Karamken gold-silver deposit [abs.] Metallogenic Specialization of Volcanic Belts and Volcano-Tectonic Structures in the Far East and Other Regions of the U.S.S.R.: U.S.S.R. Academy of Sciences, Vadivostok, p. 36-39 (in Russian).

Krasny, L.I., and Rasskasov, Yu.P. 1975. The new ore district in the northern Priokhotyo: Goologiya i Razvodica, v. 12. p. 5-11 (in Russian).

Kuleshov, B.A., Pristavko, V.A., and Plyashkevich, A.A., 1988. Geological-structural and mineralogical-geochemical peculiarities of the Svetly tin-tungsten deposit (Chukotka): Tikhookeanskaya Geologiya, no. 4, p. 65-76 (in Russian).

Kusky. T.M., Bradley, D.C., Haoussler, P.J., and Karl. S. 1997. Controls on accretion of flysch and melange belts at convergent margins: evidence from the Chupach Bay thrust and loeworm melange, Chugach accretionary wedge, Alaska: Tectonics, v. 16, p. 855-878.

Kusky, T.M., and Young. C.P.4 2000, Emplacement of the Resurrection Peninsula ophiolite in the southern Alaska forearc during a ridge-trench encounter: Joumal of Geophysical Research, in press.

Kutyev, F, Sh., Baikov, A. ., and Sidorov, E. G., 1988a, Platinum ore formations of the Koryak-Kamchatka region [abs.] Ore Formations in Zone of Continent-to-Ocean Transition: U.S.S.R. Academy of Sciences. NorthEastern Interdisciplinary Research Institute, Magadan. v. 1, p. 115-116 (in Russian)

Kutyev, F. Sh., Balkov, A... Sidorov, E.G.. Semenov, V.L.. Reznichenko, V.S. Simonova, L.S., and Kutyerva, G.V. $1988 b$, Metallogeny of Mafic-ultramafic compiexes of the Koryak-Kamchutka region fabs.) Magmatism and ore capacity of volcanic belts, Khabarovsk, p. 73-74 (in Russian)

Kutyer, F. Sh., Sidorov, E.G., Reznichenko, V.S., and Semenov, V.L., 1991, New data on platinoids in zonal ultramafic massits of southem Koryak Upland: U.S.S.R. Academy of Sciences Reports, 317, no, 6. p. 1458-1461 (in Russian).

Kutyrev, E.I., 1984, Geolony and prediction of conformable copper, lead and zinc deposits, Nedra, Leningrad, 248 p. (in Russian)

Kutyrev, E.I. Mikhailov, B.M. and Lyakhnitsky, Yu.S, 1989. Karst deposits: Nedra, Leningrad, 311 p. (in Russian).

Kutyrev, E.1., Sobolev. A.E., Isparavnikov. A.V.. Tolstyh, A.N.. and Shleikin, PD., 1988. Cupreous sandstones and cupreous basalts of the Sette-Daban area: Stratiforn mineralization in Yakutia: U.S.S.R. Academy of Sciences, Siberian Branch, Institute of Geology, Yakutsk, p. 74-86 (in Russian).

Kutyrev, E.1., Soboiev, A.E., Tolstyh, A.N., and Shieikin, P.D. 1986, Cupreous sandstones and cupreous basalts in the southern Bilyakchan zone: Geologiya i Razvedika, no. 11. p. 11-13 (in Russian).

Kuznetsov, V A and Yanshin, AL, 1979, Stratiform lead-zinc deposits in Vendian sequences of the southeastern Yakutia: Nauka, Novosibirsk, 206 p. (in Russian).

Lane, LS. 1994; A new plate kinematic model of Canada Basin evolution, in Thurston, D. and Fujita, K. eds., Proceedings of 1994 International Conference on Avetic
Margins: U.S. Department of interior. Minerals Management Service, Anchorage, p. 283-288.

Lane, L.S., 1997, Canada Basin, Arctic Ocean: evidence against a rolational origin: Tectonics, v. 16, p. 363-387

Lane, RA.,and Schroeler, T.G. 1995, Mineral occurrence investigations and exploration moniloring in the Nechako Plateau (93F/2,3,7,10,11,12,14,15 and 93Cig and 16), in Geological Fieldwork 1994: British Columbia Geological Survey Branch, Paper 1995-1, p. 177- 191.

Lang. J.R. Baker. Tim, Hart, Craig, and Mortensen, J.K., 2000. An exploration model for intrusion-related gold systems: Society of Economic Geologists (SEG) Newsietter, no. 40 , p. $1: 6-15$

Lange, I.M., and Nokleberg. W.J., 1984, Massive sulfide deposits of the Jarvis Creek terrane, Mit. Hayes quadrangle, eastern Alaska Range, Alaska [abs.] Goological Society of America Abstracts with Programs, v. 16. p. 294

Lange, I.M., Herberger, D.. Whipple, J.W., and Krouse, H.R. 1989. Stratabound $\mathrm{Cu}-\mathrm{Ag}$ and $\mathrm{Pb}-\mathrm{Zn}$ mineralization, in Bople, R.W. Brown, A.C. Jefferson, C.W. Jowett, E.C. and Kirkham, RV. ods., Sediment-hosted stratiform copper deposits, Geological Association of Canada Special Paper 36, p. $287-304$

Lange, I.M. Nokdeberg. W.J.4 and Zehner, R.E. 1981. Mineralization of late Paleozoic island arc rocks of Wrangellia terrane. Mount Hayes quadrangle, eastern Alaska Range, Naska [abs.]: Geological Association of Canada National Meeting Abstracts, v. 6. p. A-33.

Lange, I.M., Nokleberg. W.J. Newkirk, S.R., Aleinikoff, J.N. Church, S.E, and Krouse, H.R., 1990, Metallogenesis of Devonian volcanogenic massive sulfide deposits and occurrences, southern Yukon-Tanana terrane, eastern Alaska Range, Alaska: Proceedings of the Pacific Rim 90 Congress. Australian institute of Mining and Metallurgy, p. 443-450.

Lange, IM, Nokleberg. W.J., Newkirk, S.R., Aleinikoff, JN. Church, S.E., and Krouse, H.R. 1993, Devonian volcanopenic massive sulfide deposits and occurrences. southem Yukon-Tanana terrane, eastem Alaska Range, Alaska: Economic Geology, v. 88, p. 344-376.

Lange, IM., Nokleberg. W.J., Plahuta, J.T. Krouse, H.R., and Doe, B.R., 1985, Geologic setting. petrology, and geochemistry of stratiform zinc-lead-barlum deposits. Red Dog Creek and Drenchwater Creek areas. northwestem Brooks Range, Alaska: Economic Geology, ४. 80, D. 1896-1926.

Lanphere, MA. and Reed, B.L., 1985, The Mckinley sequence of granitic rocks: A key element in the accretionary history of southern Alaska: Journal of Geophysical Research, v. 90, p. 11413-11430.

Large, DE, 1983, Sediment-hosted massive sulphide lead-zine deposits: An empirical model, in Sangstor, D.F ed, Shont course in sedimenthosted stratiform lead-zinc deposits: Mineralogical Association of Canada. Handbock. v. 9. p.1. 29.

Larson, KM. Freymueller, J.T_, and Philipsen, S. 1997, Global piate velocities from the Global Positioning System: Journal of Geophysical Research, v. 102, no. B, p. 9961-9981

Lashtabeg. V.I. Lugov, S.F, and Pordeev, A.L. 1987, The Koryakskaya tin province: Sovietskaya Geologlya, no. 10 . p. $54-59$ (in Russian)

Lassiter, J.C., DePaolo, D.J. and Mahoney, J.J. 1994. Geochemistry of the Wrangellia flood basait province: Implications for the role of continental and oceanic 
Whosphere in flood basalt genesis: Joumat of Petrology. v. $36, p .983-1010$

Laftanzi, P., Okrugin, V.M., Corsini, F., Ignatev, A., Okrugina. A. Tchubarov, V. and Livi, S. 1995, Geology. mineralogy. and geochemistry of base and precious metal mineralization in the Mutnovsky area, Kamchatka. Russia: SEG Newsietter, no. 20, p. 1, 6-9.

Lawer, L.A., and Scotese, C.R. 1990, A review of tectonic models for the evolution of the Canada Basin, Chapter 31. in Grantz, A, Johnson, L., and Sweeny, J.F., eds., The Arctic Ocean region: Boudder, Colo, Geological Scceity of America, The Geology of North America, v, L., p. 593-618.

Layer, P.W. Ivanov, V.V., and Bundtzen, T.K., 1994, ${ }^{40} \mathrm{Ar}{ }^{\mathrm{M}} \mathrm{Ar}$ ages from ore deposits in the Okhotsk-Chukotka belt, Northeast Russia labs.) Intemational Conference on Arctic Margin (ICAM), Magadan, Russia, p. 50 (in Russian and English).

Layer, P.W., Partenov, L.M., Trunilina, V.A., and Bakharev, A.G., 1995. Age and tectonic signficance of granitic bells within the Verkhoyansk fold an thrust belt, Yakutia. Russia [abs.]: Geological Sociely of America Abstracts with Programs, v, 27, p. 60.

Layne, G.D., and Spooner, E.T.C., 1986, The JC Sn-Fe-F skarn, Seagull Batholith area, southern Yukon, in Morin, JA, ed., Mineral Deposits of the Northern Cordillera: Canadian Institute of Mining and Metallungy Special Volume 37, p. 266-273

Layne, G.D., and Spooner, E.T.C., 1986, The JC Sn-Fe-F slam, Seagull Batholith area, southem Yukon in Marin, J.A., ed., Mineral deposits of the Northern Cordilera, Canadian Institute of Mining and Metallurgy Special Volume 37, p. 266-273.Le Couleur, P.C. and Tempelman-Kluit, D.J. 1976. Rb/Sr ages and a profile of initial $S r^{n / S} / S r^{\text {ph }}$ ratios for pluanic rocks across the Yukon Crystaline Terrane: Canadian Joumal of Earth Sclences, v. 13, p. $319-330$

Leaming. S.F. 1978, Jade in Canada: Geological Survey of Canada Paper 78-19, 59 p.

Lebedev, G.S, Ivanenko, V.V. Korpenko, VI. 1994. Geochronology of volcanic-plutonic complexes in the Verkhneurmi ore field: Geology of Ore Deposits, v. 36 , p. $362-371$

LeCouteur, PC., 1979. Age of the Sullivan lead-zinc deposit in Evolution of the Cratonic Margin and related Mineral Deposits. Ceclogical Association of Canada, Cordileran Section Syrnoosium, Program and Abstracts, p. 19.

LeCouleur, PC. and Tempelman-Kout, D. J. 1976, RbiSr ages and a profile of Sr " $/ \mathrm{Sr}{ }^{\text {"s }}$ ratios for plutonic rocks across the Yukon Crystaline Terrane; Canadian Journal of Earth Sciences, v. 13, p. $319-330$.

Lees, B.j, 1936, Geology of the Tesin-Oulet Lake area, Yukon: Geological Survey of Canada Memoir 203, p. 24-25.

Lefebure, D.W. Brown, D.A. and Ray, GE, 1996, The Bntleh Columbia sediment-hosted goild project Geological Fieiowork - 1998: British Columbia Ministry of Energy and Mines Payer 1999-1. p. 165-178.

Lefebure, D., and Cathro, M, 1999, Plutonic related gold-quartz veins and their potential in British Columbia: Kamloops Exploration Group: Short Course on Plutonic Related Gold. April 9. 1999, pp. 185-221.

Leltch, C.H.B. 1991. Preliminary studies of fluid inclusions in barite from the Middle Valloy sulphide mounds, northern Juan de Fuca Ridge in Current Research, Part A. Geological Survey of Caneda Paper 91-1A, p. 27-30.

Leitch, C.H.B., Dawson, K.M., and Godwin, CI., 1989, Early Late Cretaceous-early Tertiary gold mineralization: A galena lead isotopic study of the Bridge River mining camp. Southwestem British Columbia, Canada: Economic Geciogy, v. 84, p. 2226-2236.

Leitch, C.H.B. and Turner, R.J.W., 1991. The vent complex of the Sullivan stratform sediment hosted $\mathrm{Zn}$-Pb deposit, British Columbia: preliminary petrographic and fluid inclusion studies: in Current Research, Part $\mathrm{E}$, Geological Survey of Canada Paper 91-1E, D. 33-44.

Leitch, C.H.B, and Turner, R.J.W., 1992, Preliminary fieid and petrographic studies of the sulphide-bearing network underlying the westem orebody, Sullivan stratiform sediment-hosted $\mathrm{Zn}-\mathrm{Pb}$ deposit, British Columbia: in Current Research, Part E, Geological Survey of Canada Paper 92-1E, p. 61-71.

Leitch, C.H.B, Godwin, C.A. and Dawson, K.M., 1989, Earty Late Cretaceous-earty Tertiary gold mineralization, a galena lead isotope study of the Bridge River mining camp, southwestem British Columbia, Canada: Economic Geology, v, 84, p. 2226-2236.

Leitch, C.H.B., Hood, C.T., Cheng, Xiao-lin, and Sinclair, A.J. 1990 , Geology of the Silver Queen mine area, Owen Lake, central British Columbia, in Geological Fieldwork 1989: British Columbia Geological Survey Branch Paper 1990-1, D. 287-295.

Leitch, C.H.B. Ross, K.V. Fleming. J.A. and Dawson, K.M. 1995, Preliminary studies of hydrothermal alteration events at Isiand Copper deposit. northem Vancouver island. British Columbia: Geoiogical Survey of Canada Current Research, 1995-A, p. 51-59.

Leitch, C.H.B, van der Heyden, P., Godwin, C.., Armstrong. R.L. and Harakal, J.E., 1991, Goochronometery of the Bridgo River camp, southwestem British Columbia: Canacian Joumal of Earth Sciences, v. 28, p. 195-206.

Lennan. W.B, 1986. Ray Guich tungsien skam decosit, Dublin Gulch area, centnal Yukon, in Morin, J.A. ed. Mineral Deposits of the Northem Condiliera: Canadian Institule of Mining and Metalurgy Special Volume 37, p. 245-254

Lennikov, A.M. 1979, Anothosites of the southern portion of the Aldan Shield and surrounding areas: Navka, Moscow, 345 p. (in Russian)

Lennikov, A.M., Oktyabrsky, R.A., Avdevnina, LA., 1987, Pecullarities of composition and genesis of Early Archean mafic-ultramafic intrusions of Southem Aldan Shield: Utramafic magma and its metallogony. U.S.S.R. Academy of Sciences. Far East Geological institute. Viadivostok, P. 93-118 (in Russian).

Leriche, P.D. 1995, Taurus copper-molybdenum porphyry deposit, east-central Alaska, in Schroeter, T.G. ed. Porphyry deposits of the northwestern Cordilera of North America: Canadian Institute of Mining, Metalurgy. and Petroleum, Special Volume 46, D. 451-457.

Light. T.D. Brew, D.A. and Ashley, R.P., 1989. The AlaskaJuneau and Treadwell lode gold systems, southeastem Alaska, in Shawe, D.R., Ashley. R.P., and Carter, L.M., eds., Gold deposits in metamorphic rocks-Part I: U.S. Geological Survey Bulletin 1857-D, p. D27-036.

Linen, RL. Willams-Jones, A.E, Leitch, C.HB, and Macauley, T.N. 1995, Molybdenum mineralization in a fuorine-poor system: The Trout Lake stociowork deposit, southeastem British Columbia, in Schroeter, T.G., ed. Porphyry Deposits of the Northwestem Cordillera of North Amenca. Canadian Institute of Mining and Metalurgy, Speciai Volume 46, p. 771-780.

Loney, R.A, and Himmelberg, G.R., 1984, Preliminary report on ophiolites in the Yukj River and Mount Hurst areas, west-central Alaska, in Coonrad, W.L., and Elliott, R.L., eds. The United States Geological Survey in Alaska: 
Accomplishments during 1981: U.S. Geological Survey Circular 868 , p. $27-30$.

Loney. RA., and Himmeiberg. G.R., 1989, The Kanuti ophiolite, Alaska: Journal of Geophysical Research, v. 94, p. $15,869-14,900$

Loney. R.A., and Himmelberg. G.R., 1992, Petrogenesis of the $\mathrm{Pd}-\mathrm{rich}_{\mathrm{intrusion}}$ at Salt Chuck. Prince of Wales Island: an early Paleozoic Alaskan-type ultriamafic body: Canadian Mineralogist, v. 30, p. 1004-1022.

Loney, RA., Himmelberg. G.R., and Shew, Nora, 1987, Salt Chuck palladium-bearing ultramafic body. Prince of Wales island, in Hamilton, T.D., and Galloway, J.P. eds., Geologic studies in Alaska by the U.S. Geological Survey during 1986: U.S. Geological Survey Circular 998, p. 126-127.

Lonsdale, P., 1988, Paleogene history of the Kula plate: offshore evidence and onshore implications: Geological Society of America Bulletin, v. 100, p. 755-766.

Lowell, J.D., and Guilbert, J.M., 1970, Lateral and vertical alteration-mineral zoning in porphyry ore deposits. Economic Geology, v. 65 , p. $373-408$.

Ludington, S., and Cox, D., 1996, Data base for a national mineral-resource assessment of undiscovered deposits of gold, silver, copper, lead, and zinc in the conterminous United States by U.S. Geological Survey Minerals Team: U.S. Geological Survey Open-File Report 96-96, 1 CD-ROM

Lugov, S.F., ed., 1986, The Koryak Upland - A new tin-bearing area: The geology of the tin deposits of the U.S.S.R. Northeast: Nedra, Moscow, 101 p. (in Russian).

Lugov, S.F., Makeev, B.V. and Potapova, T.M., 1972, Regularities of formation and distribution of tin deposits in the U.S.S.R. Northeast: Nedra, Moscow, $358 \mathrm{p}$ (in Russian).

Lugov, S.F., Podolsky, A.M., Speranskaya, I.M., and Titov, VA., 1974a, Tin capacity of the Okhotsk-Chukotka volcanic belt, Nedra, Moscow, 183 p (in Russian).

Lugov, S.F., Rozhkov, Yu. P., and Ivanov, A.A., 1974, The geological peculiarities of tin mineralization of the Koryak highlands and its perspectives: Geologiya Rudnykh Mestorozhdeniy, no. 3, p. 27-39 (in Russian).

Lull, J.S., and Plafker. George, 1990, Geochemistry and paleotectonic implications of metabasaltic rocks in the Valdez Group, southern Alaska, in Dover, J.H., and Galloway, J.P., eds, Geological Studies in Alaska by the U.S. Geological Survey, 1989: U.S. Geological Survey Bulletin 1946, p. 29-38.

Lychagin, P.P., 1967, Depth facies and relative temperature of formation of tin, polymetallic and gold-silver epithermal minerallzation in the Kulu River basin: Ore Capacity of Volcanogenic Formations in the U.S.S.R. Northeast and Far East: U.S.S.R. Academy of Sciences, Magadan, p. $88-93$ (in Russian).

Lychagin, P.P., 1985, The Aluchinsk Massif and the problem of ophiolite ultramafics and gabbroids in Mesozoic fold belts of the U.S.S.R. North East: Tikhookeanskaya Geologiya, no. 5, p. 33-41 (in Russian).

Lychagin, P.P.. Dylevsky, E.F., Shpikerman, V.L, and Likman, V.B., 1989, Magmatism of central regions of the U.S.S.R. Northeast: U.S.S.R. Academy of Sciences, North-Eastern Interdisciplinary Research Institute, Magadan, 120 p (in Russian).

Lydon, J.W., 1995, The Suulivan deposit and its geological environment: The Sullivan Project; GAC Mineral Deposits Division Newsietter, The Gangue, issue 49, July, 1995, p. $15-17$
Lynch, J.V.G., 1989, Larce-scale hydrothermal zoning reflected in the tetrahedrite-freizergite solid solution, Keno Hill Ag-PbZn district, Yukon: Canadian Mineralogist, v. 27, p. 383400

Lytwyn, J., Casey, J., and Gilbert, S., 1997, Arc-like mid-ocean ridge basalt formed seaward of a trench-forearc system just prior to ridge subduction: an example from subaccreted ophiolites in southem Alaska: Joumal of Geophysical Research, v. 102, no B5, p. 10,225-10,242.

Macauley, T.N., 1973, Geology of the Ingerbelle and Copper Mountain deposits at Princeton, British Columbia; Canadian Institute of Mining and Metalurgy, Bulletin, v. 66, no. 732 , p. $105-112$.

McCoy, D., Newberry, R.J., and Layer, P., 1997, Plutonic-related gold deposits of interior Alaska, in Goldfarb, R.J., and Miller, L.D., eds., Mineral Deposits of Alaska: Economic Geology Monograph 9, p. 191-241.

MacDonald, A.J., Spooner, E.T.C., and Lee, G., 1995, The Boss Mountain molybdenum deposi, central British Columbla, in Schroeter, T.G. ed. Porphyry Deposits of the Northwestern Corcilera of North America, Canadian Insthute of Mining and Metalurgy. Special Volume 46, p. $691-698$.

Macdonald, R.W.J., Barrett, T.J., and Sherlock, R.L., 1996, Geology and lithogeochemistry at the Hidden Creek massive sulphide deposit, Aryox, west-central British Columbia; Exploration and Mining Geology, v. 5, no. 4, p. 369-398.

Macintyre, D.G., 1982, Geologic setting of recently discovered barite-sulphide deposits of northeast British Columbia; Canadian Institute of Mining and Metallurgy Bulletin, v. 75, no. 840, p. 99-113.

Macintyre, D.G. 1985, Geology and mineral deposits of the Tahtsa Lake district, west-central British Columbia: British Columbia Ministry of Energy, Mines, and Pelroleum Resources Bulletin 75, $82 \mathrm{p}$.

Macintyre, D.G. 1991. Sedex-sedimentary exhalative deposits, in McMillan, W.J., and others, eds., Ore Deposits, Tectonics and Metallogeny in the Canadian Cordllera; British Columbia Ministry of Energy. Mines and Petroleum Resources, Paper 1991-4, p. 25-70.

Macintyre, D.G. Geology, geochemistry and mineral deposits of the Akie River area, northeast British Columbia: British Columbia Ministry of Energy and Minerals Divisions, Geological Survey Branch Bulletin, 91 p.

Macintyre, D.G., Mihalynuk, M.G., and Smith, M.T., 1993, Tatshenshini Project, northwestem Brish Columbia $114 \mathrm{P} / 11,12,13,14 ; 1140 / 9,10,14,15 \& 16$ ). Part D: Mineral Inventory update (114P and 1140), in Fieldwork 1992: British Columbia Ministry of Energy. Mines and Petroleum Resources Paper 1993-1, p. 217-229.

MacKevett, E.M., Jr., 1963, Geology and ore deposits of the Bokan Mountain uranium-thorium area, southeastern Alaska: U.S. Geological Survey Bulletin 1154, $125 \mathrm{p}$.

Mackevett, E.M.. Jr., 1965, Ore controls at the KathleenMargaret (Maclaren River) copper deposit, Alaska: U.S. Geological Survey Professional Paper 501c, p. C116C120.

MacKevett, E.M. Jr. 1976, Mineral deposits and occurrences in the McCarthy quadrangle, Alaska: United States Geological Survey, Miscellaneous Field Study Map, MF773-B, 2 sheets, scale 1:250,000.

MacKevett, EM. Jr., 1976, Mineral deposits and occurrences in the McCarthy quadrangle, Alaska: U.S. Geological Survey Miscallaneous Field Studies Map MF-773B, 2 sheets, scale 1:250,000. 
MacKevett, E.M. Jr., 1978, Geologic map of the Mccarthy quadrangle. Alaska U.S Geological Survey Miscelaneous investigations Series Map F-1032, scale $1: 250.000$

MacKevert. E.M. Jr. Brew. D.A. Hawley, C.C. Huit, L.C., and Smith, L.G. 1971, Mineral resources of Glacier Bay National Monument. Alaska: U.S. Geological Survey Prolessional Paper 632, $90 \mathrm{p}$.

Mackevett, EM., Jr., Cox, D.P., Potter I, Robert W, and Siberman. ML. 1997, Kennecotl-lype deposits in the Wrangell Mountains, Alaska: High-grade copper ores near a basalt-limestone contact, in Goldfarb, R.J, and Miller, L.D., eds., Mineral Deposits of Alaska: Economic Geology Monograph 9, p. 66-89

MacKevett, E.M. Jr, and Plafker, George, 1974, The Border Ranges fault in south-central Alaska: U.S. Geological Survey Journal of Research, v. 2, no. 3. p. 323-329.

Mackevett, E.M. Jr., Robertson, E.C. and Winkler, G.R., 1974. Geology of the Skagway B-3 and B-4 quadrangles, southeastem Alaska: U.S. Geological Survey Protessional Paper 832, 33 p., 1 sheet, scale 1:63.360.

Mackey, K.G., Fupta. K., Gunbina, L.V., Kovaiev, V.N., Imaev, V.S., Koz'min, B.M., and Imaeva, L.P., 1997, Seismicity of the Bering Strait region: evidence for a Bering block: Geology, v. 25, p. $979-982$

McMilian, W.J., 1973, Mount Coipeland Mine, in Geologty, Expioration and Mining in British Columbia: British Columbia Ministry of Energy. Mines and Petroleum Resources, p. 104-1123

McMillan. W.J.. 1980, Geologic fieldwork, 1979; a summary of field activities: British Columbia Geological Divison Geological Fieldwork, no. 1980-1, p.37-48.

Macqueen, R.W., and Thompson, R.I., 1978, Carbonate hosted lead-zinc occurrences in northestem British Columbia, with emphasis on the Robb Lake deposit Canadian Journal of Earth Sciences, v.15, p. 1737-1762

Madden-McGuire, D.J., Silberman, ML., and Church, S.E. 1989. Geologic relationships, K-Ar ages, and isotopic data from the Willow Creek gold mining district, southern Alaska, in Keays, R.R., Ramsay, W.R.H., and Groves, D. I. eds, The geology of gold deposits: The perspective in 1988: Economic Geology Monograph 6. p. 242-251.

Madu, BE, Nesbit. BE, and Muehlenbachs, K, 1990, A mescthermal gold-stibnile-quartz vein occurrence in the Canadian Cordiliera: Economic Geology, v.85, p. 1260 1286

Mahoney, L.R. 1977. Geology of Pemberton (92.J) map area, British Columbia: Geological Survey of Canada, Open File Map 482, scale 1250,000

Manns, F.T., 1981, Stratigraphic aspects of the Silurian-Devonian sequence hosting zinc and lead mineralization near Robb Lake, northeastem Brtish Columbia: Toronto, Ontario, University of Toronto. Ph. D. dissertation, 345 p.

Marakuchev, A.A. Emel'yanenko, E.P. and Nekrasov, LYa. 1990. The original concentric-zoned structure of the Kondyor akkali-ultramafic massit: Doklady Akademil Nauk SSSR, v. 311, no.1, p.167-170 (in Russian).

Markov, M.S., Nekrasov, G.E, and Palandzhyan, S.A. 1982, Ophiolite and melanocrafic basement of the Koryak Highlands: Essay on lectonics of the Koryak Highlands: Nauka, Moscow, D. 30-70 (in Russian).

Marriott. C. 1992. Developing the Polaris Taku gold depcsit, Abstracts of lechnical presentations: Geological Society of the CIM. Second Annual Field Conference, Sept. 28, 291992 . Kamloops, British Columbia
Martin, G C., and Katz, F.J., 1912, A geologic reconnaissance of the lilamna region. Alaska: U.S. Geological Survey Bulletin 485, $138 \mathrm{p}$

Mayfleid, C.F.. Tailleur, I.L., and Ellersieck, Inyo, 1983. Stratigraphy, structure, and palinspastic synthesis of the westem Brooks Range, northwostem Alaska: U.S Geological Survey Open-File Report 83-779, 58 p., 5 sheets, scale 1:1,000,000

McCaffrey, R., and Abers, G.A., 1991, Orogeny in arc-continent collision: the Banda arc and western New Guinea: Geology, v. 19, p. 563-566.

McClay, K.R., and Bidwell, G.E., 1986, Geology of the Tom deposit. Macmillan Pass, Yukon, in Morin, J.A., ed. Mineral deposits of Northern Corclilera: Canadian Institule of Mining and Metalurgy Special Volume 37, p. 100-114.

McClelland, W.C., Gehrels, G.E., and Saleeby, J.B., 1992a, Upper Jurassic-Lower Cretaceous basinal strata along the Cordilleran margin: implications for the accretionary history of the Alexander-Wrangellia-Peninsular terrane: Tectonics, v. 11, p. 832-835.

McClelland, W.C., Gehrels, G.E., Samson, S.D., and Patchett. P.J., 1991. Protollth relations of the Gravina belt and Yukon-Tanana terrane in central southeastem Alaska. Journal of Geology, v, 100, p. 107-123.

McClelland, W.C., Gehreis, G.E., Samson, S.D., and Patchett, P.J., 19926, Structural and geochronologic relations along the westem flank of the Coast Mountains batholith: Stikine River to Cape Fanshaw, central southeastem Alaska: Joumal of Structural Geology, v. 14, p. 475-489.

McCoy, D.. Newberry, R.d, Layer, P. DiMarch, J.J, Bakke, A, Masterman, J.S. and Minehane, DL. 1997, Plutonicrelated goid deposits of interior Alaska, in Goldtarb, R.J. and Milier, L.D., eds., Mineral deposits of Alaska: Economic Goology Monograph 9, p. 191-241.

McDougall, J.J. 1976, Cattace, in Suthertand Brown, A., ed. Porphyry Deposits of the Canadian Cordillera. Canadian Institute of Mining and Metallurgy Specia Volume 15. p. $299-310$.

McMilian, W.J., 1973, Mount Copeland Mine, in Geology. Exploration and Mining in British Columbia 1973: British Columbia Ministry of Energy. Mines and Petroleum Rescurces, p. 104-113.

McMillan, W.J., 1980, CC prospect, Chu Chua Mountainc British Columbia Ministry of energy and Mines, Geological Fieldwork 1979, Paper 1960-1, p. 37-48.

McMillan, W.J., 1985, Geology and cre deposits of the Highland Valley camp: Geolopical Association of Canada, Mineral Deposits Division, Field Guide and Reference Manual Series, No. 1, 121 p

Mctelan. W.J. 1991, Porphyry deposis in the Canadian Cordilera: in Mckiltan. W.J. and others, eds. Oro deposits, lectonics and metalogeny in the Canadian Cordilera: Brtish Columbia, Ministry of Energy Mines and Petroleum Resources Paper 1991-4, p. 253-276.

Mevillan. W.J. 19e3, Granile Creek property (920/3W), in Geology in British Columbia. 1976: British Columbia Ministry of Energy, Mines, and Petroleum Resources, D. $67-84$

Mckellan. W.J. Thompson, JF.H. Hart, C.JR, and Johnston, S.T. 1995. Regional geological and tectonic selting of porphyry deposits in British Columbia and Yukon Territory. in Schroeter. T.G. ed.. Porphyry Deposits of the Northwestem Cordiliera of North America, Canadian Institute of Mining and Metallurgy Special Volume 46. p. 20-39.

McMechan, M.E. 1981. The middle Proterozoic Purceil Supergroup in the southwestem Rocky and southeastem 
Purcell Mountains, British Columbia and the initiation of the Cordilleran miogeocline, southem Canada and adjacent United States: Buletin of Canadian Petroleum Geology, v. 29, p. 583-621.

Meinert, L.D., 19a6, Goid in skams of the Whitehorse Copper Belt. southem Yukon, in Yukon Geology, v. 1: Exploration and Geological Services Division, Yukon, Indian and Northem Alfairs Canada, p. 19-43.

Melis, A.L., and Clifford, K.L., 1987, Golden Bear - Process alternatives, testing and selection for a refractory British Columbia gold ore: Northwest Miners Association. Annual Meeting. Spokane, 1987.

Melkomukov, V.N. and Zaitsev, V.P., 1999, Platinum placers in the Gaimeononsky-Seinavsky knot, Koryak-Kamchatka Province: Platinum of Russia and Problems of Development of the Platinum Metals Resource in the $21^{\text {"t }}$ Century. Collection of Transactions, v. 3. 352 p. (in Russian)

Meinikov, B.D., and Izrailev, A.M., 1975. The stratiform leadzinc mineralization of the Verkhoyansk meganticlinorium: Geologiya Rudnykh Mestorozhdenì. no. 1, p. 101-104 (in Russian).

Mel'nikov, V.D., 1978, Hydrothermolites and ore assemblages, in Moiseenko, V.G., ed., Assemblages of hydrothermally allered rocks and their relationships with ores: U.S.S.R. Academy of Sciences, Far East Geological institule, Vadivostok, p. 28-42 (in Russian).

Mernikov, V.D., 1984, Gold-ore hydrothermal formations: Far Eastem Branch. U.S.S.R. Acaderny of Sciences. Vadivostok, 132 p. (in Russian).

Melnikow V.D., and Fatyanow I.I., 1970. The structure of a Primorye goid deposit: Ministry of High School, Proceedings of the Tomsk Polytechnical Institute, Tomsk, v. 134, p. 73-79 (in Russian)

Meinikova L.V., 1974, Mineral assemblages of gold deposits, in Petrovskaya, N.V., ed. Primorye Volcanics: Mineralogy of Gold, Abstracts for the Symposium on Mineralogy and Geochemistry of Gold: U.S.S.R. Academy of Sciences, Far East Geological Institute, Vladivostok, P. 16-17 (in Russian).

Mertie, J.B., Jr., 1936, Mineral deposits of the Ruby-Kuskokwim region, Alaska: U.S. Geological Sunvey Bulletin B64-C, p. $115-255$.

Mertie, J.B, Jf, 1937a. The Kaiyuh Hills, Alaska: U.S. Geological Survey Bulletin 868-D, p. 145-177

Mertie, J.B., Jr., 1937b, The Yukon-Tanana region, Alaska: U.S. Geological Survey Bulletin 872, $276 p$.

Mesard, P.M., Godwin, C.I., and Carter, N.C., 1979, Geology of the Poplar porphyry copper-molybdenum deposit (93L/3W;93E/15W), in Geological Fieldwork 1991: British Columbia Ministry of Energy. Mines and Petroleum Resources Paper 1979-1, p. 139-143.

Metcalfe, P. and Hickson, C.J., 1995. Volcanic stratigraphy of the Clisbako River area, central British Columbia: Geological Survey of Canada Current Research 1995-A. p. 67-73.

Meyer, W., Gale, R.E., and Randall, A.W., 1976, O.K. in Sutherland Brown, A. ed. Porphyry Deposits of the Canadian Cordillera: Canadian Institute of Mining and Metallurgy Special Volume 15, p. 311-316.

Migachev, IF Shishakov, V.B., Sapozhnikov. V.G. and Kaminsky, V.G. 1984, Ore-melasomatic zoning at the porphyry-copper deposit at the north-east of the U.S.S.R.; Geologiya Rudnykh Mestorozhdenily, no. 5, p. 91.94 (in Russian)

Mihalynuk, M.G, 1992, Geology and mineral resoutces of the Tagish Lake area (NTS 104M8, 9, 10E, 15, 104N/12W).
Northwestern British Columbia: British Columbia Minstry of Energy and Mines Bulletin 105, 217 p.

Mihalynuk, M G., Gabites, J.E., Runkle, Dita, Lefebure, Daviw, 1992. Age of emplacement and basement character of the Cache Creek Terrane as constrained by new isotopic and geochemical data: Canadian Joumal of Earth Sciences, v.29, no.11, p. 2463-2477.

Mihainyuk, M.G. Neison, J., and Diakow, L., 1994, Cache Crook terrane entrapment: Oroclinal paradox within the Canadian Cordiliera, Tectonics, 13, p. 575-595.

Mihalynuk, M.G., and Marriott C.C.4 1992, Polaris-Taku, in Exploration in British Columbia 1991: British Columbia Ministry of Energy. Mines and Petroleum Resources, p. 127-131.

Mihalynuk, M.G., Mountjoy, K.d.; Smith, M.T: Currie, L.D:; Gabites, J.E; Tipper, H.W: Orchard, M.J.; Poulton, T.P. Cordey. F 1999 , Geology and mineral resources of the Tagish Lake area (NTS 104M 18,9,10E, 15 and $104 \mathrm{~N} / 12 \mathrm{~W}$ ). northwestern British Columbia: British Columbia Ministry of Energy and Mines, Energy and Minerais Division. Geological Survey Branch Bulletin 105. $217 \mathrm{p}$.

Mihalynuk, M.G., and Mountioy, K.J., 1990, Geology of the Tagish Lake area, (104MO,9E), in Geological Fieldwork 1989: British Columbia Ministry of Energy. Mines and Petroleum Resources Paper 1990-1, p. 181-196.

Mihalynuk, M.G. Smith, M.T. Gabiles, JE. Runike, D., and Lefebure, D., 1992. Age of emplacement and basement character of the Cache Creek terrane, as constrained by new isotopic and geochemical data: Canadian Joumal of Earth Sciences, v, 29, p. 2,463-2477.

Miller, E.L. and Hudson, T.L. 1991. Mid-Cretaceous extensional fragmentation of a Jurassic-Early Cretaceous compressional orogen, Alaske. Tectonics, v. 10, p. $781-796$.

Miller, D.C., 1976, Maggie deposit, in Sutherland Brown, A. ed. Porphyry Deposits of the Canadian Cordillera: Canadian Institute of Mining and Metallurgy Speciai Volume 15, p.329-335.

Miller, J.HL, and Sinclair, A.J. 1905, Geology of the Calaghan Creek roof pendant (92.J/3), in Geology in British Columbia 1977-1981: British Columbia Ministry of Energy, Mines and Petroleum Resources, p. $98-101$.

Miller, L.D. Barton, C.C., Fredericksen, R.S, and Breseler, JR. 1992. Structural evolution of the Alaska-Juneau goid deposit. southeastem Alaska: Canadian Joumal of Earth Sciences, v. 29 , p. B65-878.

Milier, LD, Goldlart, R.J, Gehrels, GE, and Snee, LW, 1994, Genetic links among fuld cycling. vein formaton, rogiona deformation, and plutonism in the Juneau gold beit. southeastem Alaska: Ceology, v. 22, p. 203-206.

Miller, M.L, and Bundtzen. TK, 1994, Generalized geologic map of the Iditarod Quadrangle, Alaska, showing potassium-argon, major oxide, trace element, fossil, paleocurrent. and archeological sample locaities. U.S. Geological Survey Miscellaneous Field Studies Map MF2219-A, 14 p., 1 sheet, scale 1:250,000.

Miller, M.L. Bundtzen, T.K. and Keith, W.J., 1998, Geology and gold resources of the Stuyahok area, Holy Cross quadrangle, Alaska, in Gray, J.E, and Riehle, JR., eds. Geologic studies in Alaska by the U.S. Geological Survey-1996: U.S. Geological Survey Protessional Paper 1595, p. 31-50.

Miller, ML., Bradshaw, J.Y., Kimbrough, DL. Stern, T.W. and Bundtren, T.K. 1991, Isotopic evidence for earfy Proterozoic age of the idono Complex, west-central Alaska: Journal of Geology, v. 99, p. 209-223, 
Miller, M.L. Bundtzen. T.K. and Keith. W.J, 1998, Geology and gold resources of the Stuyahok area. Hory Cross quadranglo, Alaska, in Gray, JE, and Riehie, JR, eds, Geologic studies in Alaska by the U.S. Geological Survey in 1996. U.S. Geological Survey Protessional Paper 1595, p 31-50.

Miler. T.P.. 1976, Hardrock uranium potential in Alaska: U.S. Geological Survey Open-File Report 76-246, 7 D.

Miller. T.P. 1994. Pre-Cenozoic plutonic rocks in mainiand Alaska, in Plafker, George, and Berg. H.C., eds. The Geology of Alaska: Boulder, Colorado, Geological Society of America, v. G-1, p. 535-554.

Miller. T.P., and Bunker, C.M., 1976. A reconnaissance study of the uranium and therium contents of plutonic rocks of the southeastem Seward Peninsula, Alaska: U.S. Geological Survey Journal of Research, v. 4, p. 367. 377

Miller. T.P., and Elliott, R.., 1969, Metailiferous deposits near Granite Mountain, eastern Seward Peninsula, Alaska: U.S. Geological Survey Circular 614, 19 p.

Miller. T.P. and Elliott. R.L., 1977, Progress report on uranium investigations in the Zane Hills area, west-central Alaska: U.S. Geological Survey Open-File Report 77. 428, $12 \mathrm{p}$

Miller, T.P, and Ferrians, O.J., Jr., 1968, Suggested areas for prospecting in the central Koyukuk River region, Alaska: U.S. Geological Survey Circular 570, 12 p.

Milow, A.P., 1991, Results of the magmatic and metamorphic rocks geochronologic study: Geology of the continent-toocean transation zone in the Asia Northeast: U.S.S.R. Academy of Sciences, North-Eastem Interdisciplinary Research Institute, Magadan, p. 171-176 (in Russian)

Milov, A.P, Kopytin, V.I, and Sidorov, A.A., 1990, The tin-silver mineralization age and relation to calc-alkaline magmatism in the Balygychan-Sugoi thrust (U.S.S.R. Northeast) [abs.] Isotopic dating of endogenic ore formations, U.S.S.R. Academy of Sciences, Kiev, p. 201-203 (in Russian).

MINFILE, 2002, MINFILE database of Brtish Columbia Province; Geological Survey Branch. Ministry of Energy and Mines, Victoria, British Columbia, Canada: www em gov bc calminingigeolsurviminfle.

Mining Review. 1990. British Columbia and Yukon Chamber of Mines, v. 10 , no. 3. p. 28-39.

Mining Review, 1991, British Columbia and Yukon Chamber of Mines, v. 11, no. 3. p. 24-33.

Mining Review, 1992, British Columbia and Yukon Chamber of Mines, v. 12 , no. 3 , p. $23-31$.

Mitchell, P.A., Siberman, M.L and ONeil, J.R, 1961, Genesis of goid mineralization in an Upper Cretaceous turbidite sequence. Hope-Sunrise district U.S. Geological Survey Open File Report 81-103, 18 p

Motfit, F.H. and Fellows, R.E, 1950, Copper deposits of the Prince Willam Sound district, Alaska: U.S. Goological Survey Bulletin 963-B, p. 47-60.

Moiseenko, V.G, 1977, Gold geochemistry and mineralogy of Far East ore districts: Nauka. Moscow, 393 p fin Russian)

Moll, E.J., and Patton, WW., Jr, 1982. Preliminary report on the Late Cretaceous and earty Tertiary volcanic and related plutonic rocks in western Alaska, in The United States Geological Survey in Alaska: Accomplishments duning 1980 . Ediled by WL. Coonrad. U.S. Geological Survey Circular 844, p. 73-76.

Moll E.J. Siberman ML, and Patson. W.W. Jr., 1901. Chemistry, mineralogy. and K.Ac ages of igneous and metamorphic rocks of the Medtra quadrangle, Alaska.
U.S. Geological Survey Open File Report 80-811C, 18 p. 1 sheet, 1:250,000 scale

Moll-Stalcup, Elizabeth, 1994, Latest Cretaceous and Cenozoic igneous rocks of Alaska, in Plafker, George, and Berg. HC. eds., The Geology of Alaska: Boulder, Colorado, Geological Society of America. The Geology of North America, v. G-1, p. 589-620.

Moll-Stalcup, E.J. 1990, Latest Cretaceous and Cenozoic magmatism in mainland Alaska: U.S. Geological Survey Open-File Report 90-84, 108 p.

Moll-Staicup, E.J., and Arth, J.G., 1991, Isotopic and chemical constraints on the petrogenesis of the Blackbum Hills volcanic field, westem Alaska. Geochimica ef Cosmochim. Acta, v. 55, p. 3753-3776.

Moll-Stalcup, E.J. Brew, D.A. and Vallier, T.L., 1994, Map of latest Cretaceous and Cenozoic igneous rocks of Alaska, in Plafker, George, and Berg. H.C., eds., The geology of Alaska: Boulder, Colo., Geological Society of America: The Geology of North America, v. G-1. pl. 5, scale $12,500,000$.

Monger, J.W.H., and Berg. H.C., 1984, Lithotectonic terrane map of western Canada and southeastem Alaska, in Silberling. N.J, and Jones, D.L., eds., Lithotectonic terrane maps of the North American Cordillera: U.S. Geological Survey Open-File Report 84-523, p. B1-B31, 1 sheet, scale $1: 2,500,000$.

Monger, J.W.H. and Berg. H.C., 1987, Lithotectonic terrane map of westem Canada and southeastem Alaska: U. S. Geological Survey Miscellaneous Field Studies Map MF. 1874-B, 1 sheet, scale 1:2,500,000, 12 p.

Monger, J.W.H., and Nokleberg, W.J. 1996, Evolution of the northern North American Cordillere: Generation, fragmentation, displacement, and accretion of successive North American plate margin arcs, in Coyner, A.R., and Fahey, P. eds. Geology and Ore Deposits of the American Cordillera, Geological Society of Nevada Symposium Proceedings, Reno/Sparks, April 1995, p. 1133-1152.

Monger, J.W.H. and Ross, C.A., 1971. Distribution of fusulinaceans in the Canadian Cordiliera. Canadian Journal of Earth Sciences, v. 8, p. 770-791.

Monper, J.W.H. Souther, J.G, and Gabrielse, H. 1972, Evolution of the Canadian Condillera: a plate-tectonic model: American Joumal of Scionce, v. 272, p. $577-602$.

Monger, JW. H, van der Heyden, P, Joumeay, J.M, Evenchick, C.A, and Mahoney. J.B. 1994. Jura-Cretaceous basins along the Canadian Cordilera: their bearing on pre-midCrotaceous sinistral displacements: Geciogy, v. 22, p. 175 . 178.

Monger, J.W.H. Wheeler, J.O, Tpper, H.W., Gebrielse, H. Hams, T. Struk LC. Campbel, RB. Dodds, C.J. Gehrels, GE, and OBrien, J., 1991, Part B, Cordilleran Terranes in Upper Devonian to Middle Jurassic assemblages, in Gabrielse, $\mathrm{H}$, and Yorath, CJ. eds. Geology of the Cordileran Orogen: Boulder, Colorado, Geological Society of America, The Geoiogy of North America, v. G-2, p. 281-328.

Mocre, D.W., Young, L.E, Modene, J.S., and Plahuta, J.T. 1986, Geologic setting and genesis of the Red Dog zinolead-silver deposit. western Brooks Range, Alaska: Economic Geoiogy, v. 81, p. 1696-1727.

Mocre, TE, 1992, The Arctic Alaska superterrane, in Bradley. D.C. and Dusel-Bacon, Cynthia, eds., Geologic studies in Alaska by the U.S. Geological Survey. 1991: U.S. Geological Survey Bulletin 2041, p. 23a-244

Moore, T.E., Wallace, W.K. Bird, K.J., Kart, S.M., Mull, C.G., and Dilion. J.T. 1992, Stratigraphy, structure, and 
geologic synthesis of northem Alaska: U.S. Geological Survey Open-File Report 92-330, 283 p, 1 plate

Moore, T.E., Wallace. W.K., Bird, K.J., Karl, S.M., Mull, C.G. and Dillon, J.T., 1994. Geology of northem Alaska, in Plafker, George, and Berg. H.C., eds., The Geology of Alaska: Boulder, Colorado, Geological Society of America, The Geology of North America, v. G-1, p. 49140.

Moores, E.M., 1991, Southwest U.S.-East Antarctic (SWEAT) connection: A hypothesis: Geology, v. 19, p. 425-428.

Morganti, J.M. 1981, Ore deposit models - 4, Sedimentary-type strataform ore deposits: some modeis amd a new classification: Geoscience Canada, v. 8, p. 65-75

Morin, JA, 1978. A preliminary report on Hart River (116A-10) - a Proterozoic massive sulphide deposit. in Mineral Industry Report 1977, Yukon Territory, EGS 1978-79: Indian and Northem Affairs Canada, p. 22-25.

Morin, J.A., 1981, The McMillan deposit - a stratabound leadzinc-silver deposit sedimentary rocks of Upper Proterozoic age, in Yukon Goology and Exploration 1979-80: Department of Indian and Northem Affairs, p. 105-109

Morrow, D.W., 1984, Sedimentation in Root Basin and Prairie Creok Embayment-Siluro-Devonian, Northwest Terntories: Bulletin of Canadian Petroleum Geology. v. 32, p. $162-189$.

Morrison, G.W. 1981. Setting and origin of skam deposits in the Whitehorse Copper Belt, Yukon: London, Ontario. University of Western Ontario, Ph.D. dissertation, 306 p.

Mortensen, J.K., 1992, Pre-mid-Mesczoic tectonic evolution of the Yukon-Tanana Torrane, Yukon and Alaska: Tectonics, v. 11, p. 836-853.

Mortensen, J.K., Hart, C.J.R., Murphy, D.C., and Hefferman, S. 2000. Temporal evolution of earty and mid-Cretaceous magmatism in the Tintina goid beit, in Tucker, T.L., and Smih. M.T. eds. The Tintina goid belt: Concepts. Exploration, and Discoveries: British Columbia and Yukon Chamber of Mines, Vanoouver, Special Volume 2. p. $49-57$

Mortensen, J.K., and Hulber, L.J.4 1991, A U-PD age for the Maple Creek gabbro sill, Tatmagouche Creek area. southest Yukon Territory, in Radiogenic age and isotope studies, Report 5: Geological Survey of Canada Paper 91-2, p. 175-179.

Mortensen, J.K., Johnston, S.T., Murphy, D.J. and Bremner, T.J. 1994. Age and metaliogony of Mesozoic and Tertiary plutonic suites in the Yukon [abs], in Jambor, JL. ed. Recent Developments in Yukon Metalogeny: Canadian institute of Mining and Motallurgy 1994 Annual General Meeting. Abstracts and Proceedings, p. 45-47.

Mortensen, J.K, and Thompson. R. . 1990, A U.Pb zirconbaddeleyile age for a differentialed mafic sill in the Ogivie Mountains, west-central Yukon Temilory, in Radiogenic Age and isctopic Studies. Report 3: Geological Survey of Canada Paper 1969-2. D. 23-28.

Mortimer, N., 1987, The Nicoia Group: Late Triassic and eart Jurassic subduction-related volcarism in Brtish Columbia: Canadian Joumal of Earth Sciences. v. 24, p. 2521-2536.

Morton, R.D., Goble, R.J., and Fritz. P. 1974, The mineralogy. sulphur-isotope composition and origin of some copper dposits in the Belt Supergroup, southwest Aberta. Canada; Mineralium Deposita, v. 9. p. 223-241

Mull, C.G. Talleur, IL. Maylieid, C.F. Elersieck, inyo, and Curtis, Steven, 19e2. New upper Paleozoic and lower Mesozoic stratigraphic units, central and westem Brocks Range. Alaska: American Association of Petroleum Geologists Bulletin, v. 66, no. 3. p. $348-362$
Mullen, A.W., 1984, Managing exploration and development programs lor a variety of resource companies: Westem Miner, v, 57, no. 4., p. 35-36.

Muller, J.E., 1980, The Paleozoic Sicker Group of Vancouver Island, British Columbia: Geological Survey of Canada Paper 79-30, $24 \mathrm{p}$.

Muller, J.E, and Carson, D.J.T., 1969, Geology and mneral deposits of Alberni map-area, British Columbia (92F): Geological Survey of Canada, Memoir 340, 137 p.

Mulkigan, R., 1984, Geology of Canadian tungsten occurrences: Geological Survey of Canada, Economic Geology Report 32, $121 \mathrm{p}$.

Murphy, D.C., and Piercey, S.J., 1999, Finlayson Lake district: Geological evolution of Yukon-Tanana terrane and it's implications to the Campbell Range belt, southeast Yukon: Yukon Exploration and Geology - 1998: Exploration and Geological Serivces Division, p. 47-63.

Murphy, D.C. and Roots, C.F., 1992, Geology of Keno Hill, map area (105M/14) Yukon: Exploration and Geological Services Division, Indian and Northem Aftairs Canada, Open File Map 1992-3, scale 1:50,000.

Mustard, P.F Roots. C.F. and Donaidson, JA., 1990, Stratigraphy of the middle Proterozoic Gillespie Lake Group in the southem Wemecke Mountains, Yukon; geological Survey of Canada Paper 90-1E, p. 43-53.

Natalenko, V.E, and Kalinin, A.I. 1991, Geological exploration for silver in the Dukat ore district: Kolyma, no, 7. p. 6-10 (in Russian)

Nataienko, V.E., Kalinin, A.I., Raevskaya, IS, Tolstikhin, Yu.V. Khalkhalov, Yu. A., and Belkov, E.V. 1980, Geologic structure of the Dukat deposit: Materialy po Geologil i Polzenym iskopaemym Severo-Vostoka SSSR, US.S.R. Academy of Sciences, v. 25, p. 61.73 in Russian)

Natalin, B.A. 1991, Mesozoic accretionary and collisional teclonics of the southem Far East: Tikhookeanskaya Geologiya, no 5 . (in Russian).

Natal'in, BA., 1993, History and mode of Mesozoic accretion in southeastem Russia: The Island Arc, v. 2, p. 32-48.

Natapov L.M., and Shuligina W.S., eds., 1991, Geologic map of the U.S.S.R: U.S.S.R Ministry of Geology, Leningrad, scale 1:1,000,000, 111 p., (in Russian).

Nauman, C.R., Blakestad, R.A., Chipp, E.R. and Hottman, B.L. 1980, The north flank of the Alaska Range, a newhy discovered volcanogenic massive sulfide belt: Goological Association of Canada Program with Abstracts, p. 73.

Nazarova, A.S., 1983, Ores of sulfide-cassiterite deposits as a promising source of combined commodities: Nedra, Moscow, 94 p. (in Russian).

Nechaev, V.P. Markevich, P.V., Malinovsky. A.1. Philippov, A.N., and Vysotsky, S.V., 1996, Tectonic setting of the Cretaceous sediments in the Lower Amur Region, Russian Far East Joumal of Sedimentary Society of Japan, v. 43, p. 69-81.

Neimark. L.A., Larin, A.M. Ovchinnkova, G.V., and Yakovleva, S.Z. 1992. Uranium-lead ages of the Dzhugdzhur anorthosites: Report of U S. S.R. Academy of Sciences. v. 323 , p. $514-518$ (in Russian).

Nekrasov, LYa. 1959. The occurrence of gold in the northwestem Verkhoyansk-Kolyma fold belt U.S.S.R. Academy of Sciences, Siberian Branch, Institute of Geology. Yakutsk, no. 2, p. 10-16 (in Russian)

Nekrasov, I.Ya. 1962. Magmatism and mineralization in the northwestem Verkhoyansk-Chukchi fold bolt: trvestiya Akademii Nauk, SSSR, Serhya Geologicheskaya, 335 p. (in Russian) 
Nekrasov, 1.Ya. 1995, Genetic types of rare earth element (REE) mineralization in the Russian Far East. in Bundtzen, T.K., Fonseca, A.L., and Mann, Roberta. eds. The Geclogy and Mineral Deposits of the Russian Far East: Alaska Miners Association. Glacier House Publications. Anchorage, Alaska, p. 96-102.

Nekrasov, I.Ya. Gamyanin, G.N. Goryachev, N.A., Zhdanov, Yu.Ya. Leskova, N.V. and Goryacherva. Ye.M. 1987. Mineralogy and geochemistry of silver mineralization in the Verkhoyansk-Kolyma fold belt. Silver antimony and gold-silver, mineral assemblages, Mineralogic Journal. no. 9, v. $6, p, 5-17$ (in Russian)

Nekrasov, I.Ya., and Korzhinskaya, V.S., 1991, New genetic type of tungsten-zirconium mineralization: Mineralogicheskii Zhumal, v.13, p. 7.17 (in Russian)

Nekrasov, I.Ya, and Pokrovsky, V.K., 1973. Tin-bearing properties of subvolcanic rocks in the northern portion of the Polousny Range and Primorskaya lowland, in Apeltsyn. F.E., Grinberg. G.A., Nekrasov, I.Ya., and Rubick, KN., eds. Magmatism in the northeastem U.S.S.R.: Nauka, Moscow, p. 178-179 (in Russian).

Nekrasova, A.N., 1972. Peculiarities of mineral composition of the Karamken gold-silver deposit ores: Geologiya Rudnykh Mestorozhdenly, no. 3, p. 45-54 (in Russian).

Nekrasova, A.N., and Demin. G.P., 1977, On the correlation of gold-silver and tin-silver mineralization in one volcanogenic deposit: Geologiya Rudnykh Mestorozhdeniy, no. 2, p. $105-108$ (in Russian).

Neison, B.K., Neison, S.W.. and Till, A.B., 1993. Nd- and Srisotope evidence for Proterozoic and Paleozoic crustal evolution in the Brooks Range, northem Alaska. Journal of Geology, 101, P. 435-450.

Neison, J., Bellefontaine, K., Green, K., and MacLean, M. 1991. Regional geological mapping near the Mount Milligan copper-gold deposit (93K/16, 93N/1), in Geologic Fieldwork 1990: British Columbia Ministry of Energy, Mines and Petroleum Resources Paper 1991-1, p. $89-110$.

Nelson, J.L. 1991, Carbonate-hosted lead-zine ( \pm silver, goid) deposits of British Columbla, in McMillan, J.W., and others, eds., Ore Deposits, Tectonics and Metallogeny in the Canadian Cordillera: British Columbia Ministry of Energy. Mines and Petroloum Resources Paper 1991-4. p. $71-88$.

Nelson, J.L. and Bradtord. JA., 1993, Geciogy of the MidwayCassiar area, northem British Columbia (104 O, $104 \mathrm{P}$ ) Brtish Columbia Ministry of Energy, Mines, and Petroleum Resources Buletin 83, $94 p$.

Nelson, JL., Paradis, S. Christensen, J, and Gabies, J. 2002. Canadian Cordileran Mssissippi Valley-type deposits: A case for Devonian-Mississippian back-arc hydrothermal origin: Economic Geology, v. 97, p. 1013-1036

Nelson, Ji. Paradis, S. and Zantvoort. W. 1999, The Robb Lake carbonate-hosted lead-zinc deposit, northeastern Brifish Columbia; a Cordileran MVT deposit: British Columbia Ministry of Energy. Mines and Petroleum Resources, Report: 1999-1, p. 89-101.

Nelson, B.K. Neison, S.W. and Till, A.B., 1993, Nd- and Srisctope evidence for Proterozoic and Paleozoic crustal evolution in the Brooks Range, northern Alaska. Journal of Geology. 101, p. 435-450.

Nelson, S.W., and Neiscon, W.H. 1982, Geology of the Siniktanneyak Mountain ophiolite, Howard Pass quadrangle, Alaska: U.S. Geological Survoy Map MF1441. 1 sheet, scale $1,63,360$

Neison, W.H., King. H.D., Case, JE., Tripp, R. B., Crim, W.D., and Cooley. EF, 1985, Mineral resource assessment map of the Lake Clark quadrangle, Alaska: U.S. Geological Survey Miscellaneous Field Studies Map MF. 1114-B, 1 sheet, scale 1:250,000.

Nenashev, N.I. 1979, Magmatism and formation of oremagmatic districts in the eastern Yakutia: Nauka. Novosibirsk, 142 p. (in Russian).

Neverov, Yu.L., 1964, On ore types in the southern group of the Kuril Islands: Geologiya I Geoflzika, no, 7, p. 60-65. (in Russian).

Newberry, R.J., Allegro, G.L., Cutler, S.E., Hagen-Levelle, J.H., Adams, D.D. Ncholson, L.C., Weglarz, T.B., Bakke, A.A., Clautice, K.H., Coulter, G.A., Ford, M.J. Myers, G.L., and Szumigala, D.J., 1997a, Skam deposit of Alaska, in Goldfarb, R.J, and Miller, L.D., eds., Mineral Deposits of Alaska: Economic Geology Monograph 9, p. 355-394.

Newberry, R.J., and Brew, D.A., 1987, The Alaska-Juneau gold deposit; Remobilized syngenetic versus exotic epigenetic origin, in Hamilton, T.D., and Galloway, J.P., eds., Geologic studies in Alaska by the U.S. Geological Survey during 1986: U.S. Geological Survey Circular 998 , p. $128-131$.

Newberry, R.J., and Brew, D.A., 1988, Alteration, zoning, and origin of the Alaska-Juneau goid deposit, in Galloway. J.P., and Hamilton, T.D. eds., Geologic Studies in Alaska by the U.S. Geological Survoy during 1887: U.S. Geological Survey Circular 1016, p. 174-178.

Newberry, R.J., and Bums, Laurel, and Pessel, G.H., 1986a, Volcanogenic massive sulfide deposits and the "missing compliment" to the caic-alkaline trend: Evidence from the Jurassic Talkeetna island are of southem Alaska: Economic Geology, v. 81, p. 951-960.

Newberry, R.J. Craflord, T.C., Newilk, S.R. Young, LE. Nelson. S.W.. and Duke, NA., 1997b, Volcanogenic massive sulfide deposits of Alaska, in Goldtarb, R.J. and Miller, L.D. eds, Mineral Deposits of Alaska: Econornic Geology Monograph 9, p. 120-150.

Newberry, R.J., Dillon, J.T. and Adams, D.D., 19866 , Regionally metamorphosed, caio-silicate-hosted deposits of the Brooks Ranpe, northem Aaska: Economic Geology, v. 81, D. 1728-1752.

Newel, JM, and Peatfieid, G.R., 1995, The Red-Chris porphyry coppergold depost. northwestem Brtish Columbix; in Schroeter, T.G. ed. Porphyry Deposits of the Northwestem Cordillora of North Amorica. Canacian institute of Mening and Metalurgy Special Volume 46. p. $674-688$.

Nivitin, YuL. and Rasskazov, Yu.P. 19r9, Tungstenbearing skarns in the middle branch of the Mal River (Priokhtyo). The regularities of the development of endogenic mineralization in the Far East U.S.R. Acaderny of Sciances, Far East Branch, Vladivostok, P. 120-126 in Russian)

Nixon, G.T., Hammack. T.L, Ash, C.H. Cabri, L.J., Case, G. Connelly, J.N., Heaman, L.M. Leflanne, J.H.G. Natall. C. Paterson, W.P.E, and Wong. R.H., 1997, Geology and platinium-group element mineralization of Alaskatype ultramafic complexes in British Columbia: British Columbia Ministry of energy and Mines Bulletin 93, 142 p.

Noble, S.R., Spooner, E.T.C., and Harris, F.R., 1984, The Logtung large-tonnage, low-grade W (scheelite)-Mo porphyry deposit, south-central Yukon Territory: Economic Geology. vol. 79. p. $848-868$.

Nokieberg. W.J., and Aleinikotf, J.N., 1985, Summary of stratigraphy, structure, and metamorphism of Devonian igneous-arc terranes, northeastern Mount Hayes 
quadrangle, eastern Aaska Range, in Bartsch-Winkler. Susan. ed. The United States Geological Survey in Alaska: Accomplishments during 1984: U.S. Geological Survey Circular 967, p. 66-71.

Nokleberg. W.J. Bundtzen. T.K.. Berg. H.C., Brew, D.A., Grybeck, Donald, Robinson, M.S, Smith, T.E., and Yeend. Warren, 1994a, Metallogeny and major mineral deposits of Alaska, in Plafker, G. and Berg. H.C., eds. The Geology of Alaska: Boulder, Colorado, Geological Society of America: The Geology of North America, v. G1, p. 855-904.

Nokleberg. W.J. Bundtzen, T.K., Berg. H.C., Brew, D.A. Grybeck, Donald, Robinson, M.S., Smith. T.E., Yeend, Warren, 1987, Significant metaliferous lode deposits and placer districts of Alaska: U S. Geological Survey Bulletin 1786. 104 p. 2 plates, scale 1:5.000.000.

Nolileberg. W.J., Bundtzen, T.K., Berg. H.C., Brew, D.A. Grybeck. Donald. Robinson, MS, Smith, T.E., Yeend. Warren. 1988. Metallogeny and major mineral deposits of Alaska. U.S. Geological Survey Open-File Report 88 73, 97 p. 2 piates, scale $15,000.000$

Nokleberg. W.J. Bundtzen. T.K., Berg. H.C., Brew, D.A. Grybeck, Donald, Robinson, M.S., Smith, T.E., Yeend, Warren, and 54 contributors, 19940, Metallogenic map of significant metaliferous lode deposits and placer districts of Alaska, in Plafker, G. and Berg. H.C. eds. The Geology of Alaska: Boulder, Colorado, Geological Society of America: The Geology of North America, v. G1, Plate 11, scale 1:2,500,000.

Nokleberg. W.J., Bundtzen, TK. Brew, DA. and Plafker. George. 1995a. Metalogenesis and tectonics of porphyry $\mathrm{Cu}$ and Mo (Au, Ag), and granilcid-hosted $\mathrm{Au}$ deposits of Alaska, in Schroeter, T., ed., Porphyry deposits of the northwestern Cordilera of North America: Canadian Insteute of Mining. Metallurgy, and Petroleum, Special Volume 46, p. 103-141.

Nokleberg. W.J. Bundtzen, T.K., Dawson, K.M., Eremin, R.A. Goryachev, N.A., Koch, R D. Ratkin, V.V., Rozenblum, 1.S., Shpikerman, V.I., Frolov, Y.F_Gorodinsky, ME. Melnikov, V.D., Ognyanov, N.V., Petrachenko, E.D., Petrachenko, R.I. Pordeev, A.I. Ross, K.V., Wood. D.H. Grybeck, Donald, Knanchuck, A.I., Kovbas, LI. Nekrasov, 1.Ya., and Sidorov, A.A., 1996, Significant metalliferous lode deposits and placer districts for the Russian Far East, Alaska, and the Canadian Cordillera: U.S. Geological Survey Open-File Report 96-513-A, 385 p.

Nokleberg, W.J. Bundtzen, T.K, Dawson, KM., Eremin, R.A. Goryachev, N.A. Koch, R.D., Ratkin, V.V., Rozenblum, I.S., Shpikerman, V.I. Frolov, Y.F., Gorodinsky, M.E. Melnikov, V.D., Diggles, M.F, Ognyanov, N.V. Petrachenko, E. ., Petrachenko, R.I. Pozdeev, A.I. Ross, K.V., Wood, D.H., Grybeck, Donald. Khanchuk. A.I., Kovbas, L.I., Nekrasov, I.Ya., and Sidorov, A.A., 1997a. Significant metalliferous lode deposits and placer districts for the Russian Far East. Alaska, and the Canadian Cordillera: U.S. Geological Survey Open-File Report 96-513-B, CD-ROM.

Nokleberg. W.J., Bundtzen, T.K., Dawson, K.M., Eremin, R.A., Ratkin, V. ., Shpikerman, V., Goryachev, N.A., Khanchuk, A.I. Koch, R.D., Rozenblum, 1.5. Gorodinsky, M.E., Froiov, Y.F., Pozdeev, A.I., Parlenov, L.M.4 and Sidorov, A.A, 1997b: Mineral deposit and metallogenic belt maps of the Russian Far East. Alaska. and the Canadian Cordillera; Geological Survey of Canada Open File 3446, 2 sheets, scale 1:5,000,000, 5 sheots, scale 1:10,000,000.
Nokleberg, W.J., Bundtzen, T.K., Grybeck, Donald, Koch, R.D.. Eremin, R.A. Rozenblum, IS., Sidorov, A.A., Byalobzhesky, S.G., Sosunov, G. Mineral deposit maps, models, and tables, metallogenic beit maps and interpretation, and references cited: U,S. Geological Survey M., Shpikerman, V.I., and Gorodinsky. M.E., 1993. Metallogenesis of mainland Alaska and the Russian Northeast: Open-File Report 93-339, 222 pages, 1 map, scale $1: 4,000,000,5$ maps, scale 1:10,000,000.

Nokleberg. W.J., Foster, H.L., and Aleinikoff, J.N., 1989a, Geology of the northern Copper River Basin, eastern Alaska Range, and southern Yukon-Tanana Basin, southem and east-central Alaska, in, Nokleberg. W.J., and Fisher, M.A. eds. Alaska Geological and Geophysical Transect: Field Trip Guidebook T104, 28th International Geological Congress, p. 34-63.

Nokleberg. W.J. Jones, D.L., and Silberling. N.J., 1985, Origin, migration, and accretion of the Maclaren and Wrangeilia terranes, eastern Alaska Range, Alaska: Geological Sociely of America Bulletin, v. 96, p. 1251-1270.

Nokleberg. W.J., and Lange, I.M., 1985a, Metallogenetic history of the Wrangellia terrane, eastern Alaska Range, Alaska [abs.] U.S. Geological Survey Circular 949, p. 36-38.

Nokdeberg. W.J., and Lange, IM., 19850, Volcanogenic massive sulfide occurrences, Jarvis Creek Glacier terrane, western Mount Hayes quadrangle, Alaska, in Bartsch-Winkler. Susan, and Reed, K.M. eds., The United States Geological Survoy in Alaska: Accomplishments during 1983: U.S. Geological Survey Circular 945, p.77-80.

Nokleberg. W.J. Lange, IM., and Roback, R.C., 1984. Preliminary accretionary terrane model for metallogenesis of the Wrangellia terrane, southem Mount Hayes quadrangle, eastem Alaska Range, Alaska, in Reed, K.M, and Bartsch-Winkler, Susan. eds. The United States Geclogical Survey in Alaskar. Accomplishments during 1982: U.S. Geological Survey Circular 939, p. 60-65.

Nokleberg. W.J., Lange, I.M., Roback, R.C., Yeend, Warren. and Silva SR, 1991, Map showing locations of metaliferous lode and placer minera occurrences, deposits, prospects, and mines, Mount Hayes quadrangle, eastem Alaska Range, Alaska: U.S. Geological Survey Map MF-1996-C, 42 p., 1 sheet, scale $1: 250.000$

Nokieberg. W.J. Monger, JW.H. Parfonov, L.M. $1995 \mathrm{~b}$, Mesozoic and Cenozoic teclonics of the Circum-North Pacific [abs.]: Geclogical Association of Canada Program with Abstracts, v. 27, p. A-76.

Nokleberg. W.J. Partenov, L.M., and Monger, J.W.H. and Baranov. B.V. Byalobzhesky. S.G., Bundtzen, T.K. Feeney, T.D., Fuita, Kazuya, Gordey, S.P., Grantz. Arthur, Khanchuk, A.L., Natalin, B.A., Natapov, L.M. Norton. 10.. Patton, W.W., Jr. Plakeer, George, Scholl. D.W. Sokolov, S.D., Sosunov, G.M., Stone, D.B., Tabor, R.W. Tsukanov. N.V. Vallier, T.L. and Wakta, Koil, 1994c, Circum-North Pacific tectono-stratigraphic terrane map: U.S. Geological Survey Open-File Report 94-714, 221 papes, 2 sheets, scale 1:5,000,000; 2 sheets, scale 1:10,000,000.

Nokieberg. W.J., Parfenov, L.M., Monger, J.W.H., Baranov. B.V., Byalobzhesky, S. G., Bundtzen, T.K., Feeney, T.D. Fujita, K. Gordey, S.P., Grantz, A., Khanchuk, A.t. Natafin, B.A., Natapov, L.M. Norton, 1.O., Patton,Ji. W.W. Platker, G. Scholl, D.W. Sokolov, S.D. Soliunov, G.M. Stone, D.B., Tabor, R.W. Tsukanov. 
N.V., and Vallier, T.L., $1997 \mathrm{c}$, Summary Circum-North Pacific tectono-stratigraphic terrane map: U.S. Geological Survey, Open File Report 96-727, 1 sheet. scale 1:10,000,000; Geological Survey of Canada, Open File 3428, 1 sheet, scale 1:10 000,000.

Nokleberg. W.J., Parfenov, L.M., Monger, J.W.H., Norton, I.O., Khanchuk, A.I., Stone, D.B., Scotese, C.R., Scholl, D.W., and Fujita, K., 2000. Phanerozoic tectonic evolution of the Circum-North Pacific: U.S. Geological Survey Professional Paper 1626, 122 p.

Nokleberg. W.J., Platker, George, and Wilson, F.H., 1994d, Geology of south-central Alaska, in Plafker, George, and Berg. H. eds. The Geology of Alaska: Boulder, Colorado, Geological Society of America, The Geology of North America, v. G-1, p. 311-366.

Nokleberg, W.J., Platker, George, Lull, J.S., Wallace, W.K., and Winkler, G.R., 1989b, Structural analysis of the southem Peninsular, southern Wrangellia, and northern Chugach terranes along the Trans-Alaskan Crustal Transect (TACT), northern Chugach Mountains, Alaska: Journal of Geophysical Research, v. 94, p. 4297-5320.

Nokleberg. W.J., West, T.D., Dawson, K.M., Shpikerman, V.L., Bundtzen, T.K., Parfenov, L.M., Monger, J.W.H., Ratkin, V.V., Baranov, B.V., Byalobzhesky, S.G., Diggles, M.F., Eremin, R.A., Fujita, K., Gordey, S.P., Gorodinskly, M.E. Goryacher, N.A, Feeney, T.D., Frolov, Y.F., Grantz, A., Khanchuk, A.I., Koch, R.D., Natalin, B.A., Natapov, L.M., Norton, I.O., Patton, W.W. Jr., Plafker, G., Pozdeev, A.I., Rozenblum, IS. Scholl, D.W. Sokolov, S.D., Sosunov, G.M.. Stone, D.V.. Tabor. R.W., Tsukanov, N.V., and Vallier, T.L., 1998, Summary terrane, mineral deposit, and metallogenic belt maps of the Russian Far East, Alaska, and the Canadian Cordillera: U.S. Geological Survey Open-File Report 98 136, 1 CD-ROM.

Nokleberg. W.J.. and Winkler, G,R., 1982, Stratiform zinc-lead deposits in the Drenchwater Creek area, Howard Pass quadrangle, northwestern Brooks Range, Alaska: U.S. Geological Survey Protessional Paper 1209, 22 p., 2 map sheets, scale 1:20,000.

Nortord, B.S, and Orchard, M.J, 1983, Early Silurian age of rocks hosting lead-zinc mineralization at Howards Pass, Yukon Territory and District of Mackenzie: Local biostratigraphy of Road River Formation and Eam Group: Geological Survey of Canada Paper 83-18, 35 p.

Norris, D.K., 1976, Structural and stratigraphic studies in the northern Canadian Cordilera: Geological Survey of Canada Paper 1976-1A, p. 457-466.

Norris, D.K, and Yorash, C.J., 1981, The North American Plate from the Arctic Archipelago to the Romanzof Mountains, in (ed.) Naim, A.E.M., Churkin, M. Jr., and Stehli, F.G., eds., The Coean Basins and Margins, Volume 5, The Arctic Ocean: Plenum Press, New York, p. 37-103.

O'Hanley, D.S., and Wicks, F.J., 1995, Conditions of formation of lizardite, chrysotile, and antigorite, Cassiar, British Columbia: The Canadian Mineralogist, v. 33, Part 4, p. 753-774.

Obolensky, A.A, and Obolenskaya, R.V., 1971, The questions of mercury metallogeny, in Kuznetsov, V.E., ed., Magmatism-related mercury deposits and the character of mineralizing solutions: Nauka, Moscow, p. 79-100 (in Russian).

Ognyanov, N.., 1986, Geology of tin-bearing districts and deposition of the Khingan-Okhotsk tin-bearing area, in Lugov, S.F., ed., Geology of tin deposits of the U.S.S.R.: Nedra, no.1, p. 340-399 (in Russian).
Ogyzlo, P., Dirom, G.E., and Stothart, P.G., 1995, Morrison and Heame Hill copper-goid deposits, Babine region, westcentral British Columbia, in Schroeter, T.G., ed., Porphyry deposits of the northwestern Cordillera of North America: Canadian Institute of Mining and Metaliurgy, and Petroleum, Special Volume 46., p. 290-303.

OrHanley, D.S., and Wicks, F.J., 1995, Structural control of serpentine textures in the Cassiar Mining Corporations's open pit mine at Cassiar, Birtish Columbia [abs.]: Geological Association of Canada-Mineralogical Association of Canada Annual Meeting, Saskatoon, Saskatchewan, Program and Abstracts, p. 77.

Okrugin, V.M., Matsueada, Hircharu, and Ono, S., 2002, Mutnoskoe epithermal Au-polymetelic deposit, Sourthern Kamchatka, Russia [abs.]: Society of Resource Geology Abstracts with Programs, Tolyo, Japan, p. 30.

Okulitch, A.V. Loveridge, W.D., and Sullivan, R.W., 1981. Preliminary radiometric analyses of zircons from the Mount Copeland syenite gneiss, Shuswap Metamorphic Complex, British Columbia: in Current Research, Part A, Geological Survey of Canada Paper 81-1A, p. 33-36.

Olshevsky, V.M. 1974, Some regularities of gold localization in low-sulfide veins, Western Chukotka: Kolyma, no. 11, p. $39-42$ (in Russian).

Olshevsky, V.M., 1976, Mineral assemblages of gold veins in the Maly Anyui area: Kolyma, no, 6, p. $46-48$ (in Russian).

Olshevsky. V.M., 1984. Tungsten capacity of gold deposits in the Northeast mesozoid: Problems of metallogeny of the U.S.S.R. Northeast: U.S.S.R. Academy of Sciences, North-Eastern Interdisciplinary Research Institute, Magadan, p. 44-50 (in Russian).

Olshevsky, V.M., and Mezentseva, A.E., 1986, Structure of gold-sulfide deposit in terrigenous rocks of the OkhotskChukotka volcanogenic belt framework: Structures of ore fields and deposits in volcanic belt framework: Structures of ore fields and deposits in volcanic belts: U.S.S.R. Academy of Sciences, Far Eastern Branch, Vladivostok, p. $72-90$ (in Russian).

Oparin, M.I., and Sushentsov, V.S., 1988, Prospects of massive sulfide copper mineralization in Mainits zone of the Koryak Highlands [abs.]: Metallogenic Significance of Volcano-Tectonic Structures: U.S.S.R. Academy of Sciences, Khabarovsk, p. 136-137 (in Russian).

Orlov, A.G., and Epifanowa, A.P., 1988, On ore-formational position of one Central-Kolyma ore deposit [abs.]: Ore Formations in Zone of Continent-to-Ocean Transition: U.S.S.R. Academy of Sciences, North-Eastern Interdisciplinary Research Institute, Magadan, v. 1. p. 127-128 (in Russian).

Orlovsky, V.V., Gryazev, V.A., Levshuk, A.E., and others, 1988, On two porphyry mineralization types in the northem Primorye, in Vlasov, G.M., ed., Porphyry-type mineralization in the Russian Far East: U.S.S.R. Academy of Sciences, Institute of Tectonics and Geophysics, Vladivostok, p. 121-134 (in Russian).

Osatenko, M.J., and Britton, R, 1987, Geology and exploration of the Golden Bear depcosit: Canadian Instutite of Mining and Metallurgy Bulletin, v. 80, no. 904.

Ostler, J., 1979, Geological Report, Barb 9 to 15 and 16 to 32 Mineral claims, Watson Lake, Mining Division, Yukon Territory (105H/6): Sovereign Metals Corp., unpublished report, $12 p$.

Oxman, V.S., Parfenov, L.M., Prokopiev, A.V., Timofeev, V.F., Tretyakow, F.F., Nedosekin, Y.D., Lyer, P.W, and Fujita, K., 1995. The Chersky Range ophiolite beit, northeast Russia: Journal of Geology, v. 103, p. 539-556. 
Pakhomova, V., Silyanik, V., Popov, V., and Logvenchev, P., 1997. Fluid inclusions in local metallogenic research, in Abstracts/Resumes XIV ECROFI (Current European Research on Fluid Inclusions). Nancy, France: Magmatic-metamorphic processes, D. 253-254.

Palandzhyan, S.A, and Dmitrenko, G.G, 1990, Geodynamic enwironments of Alpine-type peridotite formation in the Koryak Highlands [abs.]: Tectonics and Metallogeny of the U.S.R. Northeast in the Light of Modern Tectonic Concepts: U.S.S.R. Academy of Sciences, NorthEastern Interdisciplinary Research Institute, Magadan, p. 155-157 (in Russian).

Palmer, A.R., 1983, The Decade of North American Geology. geologic time scale: Geology, v. 11, p. 503-504.

Palymsky, B.F., and Palymskaya, Z.A., 1990, Gold-sulfosalttype of gold-silver formation in Central Kolyma: Oremagmatic systems of the U.S.S.R. Northeast: Khabarowsk Polytechnic Institute, Magadan Branch, p. $64-71$ (in Russian)

Panskikh, E.A. 1978, Mineralization and petrology of anorthosite massifs of the Far East USSR: Dalgeology, Khabarovsk, Open File Report, 134 p. (in Russian).

Panskilkh, E.A., and Gavrilow, V.V., 1994, Apatite of the Geranisky anortosite massif, in Kulish, E.A. ed. Phosphate-bearing complexes of the Russian Far East: U.S.S.R. Academy of Sclences, Institute of Tectonics and Geophysics, Khabarovsk, p. 23-44 (in Russian).

Panteleyev, A., 1977, Chris, Red,Sus, Windy; in Geology in British Columbia 1975, British Columbia Ministry of Energy. Mines and Petroleum resources, p. G85-G87

Panteleyev, A., 1977, Gnat Pass deposit, in Geological Fieldwork 1977: Brilish Columbia Ministry of Energy, Mines and Petroleum Resources Paper 1977-1, p. 4546.

Panteleyev, A., 1981, Berg porphyry copper-molybdenum deposit: British Columbia Ministry of Energy, Mines and Petroleum resources, Bullotin 66, $158 \mathrm{p}$.

Panteleyev, A, 1991, Gold in the Canadian Cordillera- A focus on epithemal and deeper emvironments: in McMillan. W.J. and others, ods., Ore Deposits, tectorics and Metallogeny in the Canadian Cordillera: British Columbia Ministry of Energy, Mines and Petroleurn resources Paper 1991-4, p. $163-212$

Pantoleyev, A. 1995, Subwoicanic Cu-Au-Ag (As-SB) deposits, in selected British Columbia Mineral Deposit Profies, volume 1: British Columbia Ministry of Energy and Mines, p. 79-82.

Panteleyev, A, and Koyanag. V.M., 1994, Advanced argilic alteration in Bonanza volcanic rocks, northem Vancouver istand-Lithologic and permeability controls, in Ceological Fieldwork 1993. Brhish Columbia Geological Survey Branch Paper 1994-1, p. 101-110

Papunen, $\mathrm{H}$. 1986. Platinum group elements in Svecokarelian copper-nickel deposits, Finland: Economic Geology, vol. B1. p. $1236-1241$

Paradis, S, Neison, J., and Farmer, R, 1996, Stratigraphy and structure of the Driftple stratiform Ba-Zn-Pb deposit. Gatage area, northeastem British Columbia; in Current Research 1995-A. Geological Survey of Canada, p. 149 157

Paradis, S, Netson, JL, and inwin. S B, 1998, Age constraints on the Devorian shaie-hosted Zn-Pb-Ba deposis. Ginaga district, northeastem Brfish Columbia, Canada, Economic Geology, v. 93, no. 2. p. 184-200

Paradis. S. Neison, J.L. and Zantvoort. W. 1999, A new look at the Robb Lake carbonate-hosted lead-zinc deposit. northeastern Brtish Columbia: Current Resoarch .
Geological Survey of Canada, Report 1999-AB, p. 61. 70.

Parfenov, L.M., 1995a, Terrane analysis of the Mesozoic orogenic belis of the Russian Northeast [abs.]: Geological Society of America Abstracts with Programs. v. 27, p. $70-71$.

Parfenov, L.M., 1995b. Terranes and formation of the Mesozoic orogenic belts of eastern Yakutia: Tikhookeanskaya Geologiya, v. 14, no 6. p. $32-43$ (in Russian).

Partenov, 1995c. Tectonics and regional metallogeny of the Verkhoyansk-Kolyma region, in Bundtzen, T.K., Fonesca, A.L., and Mann, R., eds., The geology and mineral deposits of the Russian Far East: Glasier House Publications and the Alaska Miners Association, Anchorage, Alaska, p. 61-84.

Parfenov, L.M., 1995d, Tectonics and regional metallogeny of the Verkhoyansk-Kolyma Region, in Bundtzen, T.K., Fonseca, A.L., and Mann, Roberta, eds., The Geology and Mineral Deposits of the Russian Far East: Alaska Miners Association, Glacier House Publications, Anchorage, Alaska, p. 61-84.

Parfenov, L.M., Vetluzhskikh, V.G., Gamyanin, G.N., Davydov, Yu.V., Deikunenko, A.V., Kostin, A.V., Nikitin, V.M. Prokopyev, A.V., Smelov, A.P.t. Supletsov, V.M., Timofeev, V.F., Fridovsky, V.YU., Kholmogorov, A.I., Yakoviev, Ya.V., 1999, Metallogenic zonation of the territory of Sakha Republic: Tikhookeanskaya Geologiya, no. 2, p. 8-40.

Parrish, R.R., Carr, S.D., and Parkinson, D.L, 1988, Eocene extensional tectonics and geochronology of the southem Omineca Belt, Brtish Columbia and Washington: Tectorics, v.7. p. 181-212.

Parrish, R.R., Frledman, R.M., and Amstrong, R.L., 1991, Eocene extension faults, in Gabrielse, $\mathrm{H}_{4}$ and Yorath, C.J.4 eds. Geology of the Cordileran Orogen: Boulder, Colorado, Geological Society of America. The Geology of North America, v. G-2, p. 660-664.

Parrish, RR, and McNicol. V., 1992, U.Pb age deteminations from the southern Vancouver Island area, British Columbia, in Radiogenic age and isotope studies, Report 5: Geological Survey of Canada Paper 91-2, p. 97-108.

Paterson, IA., 1977. The geology and evolution of the Pinchi Fault Zone at Pinchi Lake, central British Columbia: Canadian Journal of Earth Sciences, v. 14, p. 13241342

Patrick, B.E, and MoCleland, W.C., 1995, Late Proterozoic granitic magmatism on Seward Peninsula and a Barentian origin for Arctic Alaska-Chukotka: Geology, v. 23 , p. $81-84$

Patton, W.W. Jr, and Box, S.E. 1989, Tectonic setting of the Yukon-Koyukuk basin and its borderlands, westem Alaska: Journal of Geophysical Research, v. 94, p. $15,807-15,820$.

Patton, W.W., Jr., Bor, S.E, and Grybeck, Donald, 1989. Ophiolite and other mafio-ultramafic complexes in Alaska: U.S. Geological Survey Open-File Report 89. $648,27 \mathrm{p}$.

Patton, W W, Jf, Box, S.E, Mol-Stalcup, E J., and Miller, T.P., 1994. Geology of west-central Alaska, in Plafker. George. and Berg. H.C, eds. The Geology of Alaska: Boulder, Colorado, Geological Sociely of America, The Geology of North America, v. G-1, p. 241-284.

Patton. W.W...Jr., Moll, E.J., and King. A. D, 1984. The Alaskan mineral resource assessment program: Guide to information contained in the folio of geologic and mineral resource maps of the Medfra quadrangle, Alaska: U.S. Geological Survey Circular 928, 11 p. 
Pavlis, T.L., Sisson, V.B., Foster, H.L. Nokleberg. W.J., and Plafker, G. 1993, Mid-Cretaceous extensional tectonics of the Yukon-Tanana terrane. Trans-Alaskan Crustai Transect (TACT), east-central Alaska. Teclonics, v. 12 , D. $103-122$

Payre, JG, Bratt, J.A, and Stone, B.G., 1980, Deformed Mesozoic volcanogenic Cu-Zn sulfide deposits in the Britannia district. Brifish Columbia: Economic Geology. v. 75, p $700-721$

Payne, MW. and Alison, C.W., 1981, Palecsoic continentalmargin sedimentation in east-centrat Alaska: Geciogy, v, 9 p. 274.279

Pearson. CA. 1993, Mining zincrich massive sulphide deposits con Vancouver Island, Brtish Columbia, in Proceedings of the International symposium on Zinc 1993: Australasian Instlute of Mining and Metallurgy, v. 7, p, 75-84.

Pearson, W.N. and Clark, A.H. 1979. The Minto Copper Depcsit, Yukon Territory. A metamorphosed orebody in the Yukon Crystalline Terrane: Economic Geology. v. 74, no 7. D. $1577-1599$.

Perello, J.A. Fleming. J.A., O'Kane, K.P., Burt, P.D., Clarke, G.A. Himes. M.D., and Reeves, A.T. 1995, Porphyry copper-gold-molybdenum deposits in the Island Copper cluster, northem Vancouver island. British Columbia; in Schnoeter, T. ed. Porphyry deposits of the northwestern Cordillera of North America: Canadian Insttute of Mining. Metallurgy, and Petroleum, Special Volume 46, p. 214- 238 .

Petocz. R.G. 1970, Biostratigraphy and Lower Permian Fusilinidae of the upper Delta River area, east-central Alaska Range, Alaska: Geological Society of America Special Paper 130, 94 p.

Potrachenko, E. ., 1967, Metasomatic sulfur deposits of Kamchatka Peninsula and the Kuril Islands: Summary of Ph.D. dissertation, U.S.S.R. Academy of Sciences, Far East Geological instiute, Vladivostok, 20 p. (in Russian).

Petrachenko, E D.. 1978. Tin mineralization of the Kuril Islands, in Govorov, I.N., ed. Genesis of endogenous mineralization of the Russian Far East: U.S.S.R. Academy of Sciences. Far East Geological Institute. Vladivostok, p. 111-121 (in Russian)

Petrachenko, E.D. and Petrachenko, R.I. 1965, Coppermolybdenum mineralization in the Kuri-Karnchatka arc and the East Sikhole-Alin volcanic belt: U.S.S.R. Academy of Sciences. Far East Goological Instiute. Vladivostok, 275 p. (in Russian)

Petracheniko, R.L. Oleinikov. A.V., and Petrachenko, E.D., 1988. Ore in Cretaceous to Paleocene plutonic complexes of the northern Sikhote-Alin Area, in Vlasov. G.M. ed. Porphyry-type mineralization in the Russian Far East: U.S.SR. Academy of Sclences, Institute of Tectonics and Geophysics, Vadivostck, p. 75-93 fin Russian)

Petreniko, ED. 1999. Gold-silver mineralization in Kamchatka: Kamchatka Geological Committee, Russian Ministry of Natural Resources for Kamchatka Oblast and Koryak Autonomous Oknug. and Saint Petersburg Cartographic Institute Special Publication, 115 p. (in Russian).

Philipoov. A N. 1990. Formation of West Sikhote-Alin volcanicsedimentary rocks: U.S.S.R. Acadorny of Sciences. Far East Geological Institute. Vadivostok, 143 p. (in Russian)

Pickthom, W.J., 1982. Stable isotope and fuid inclusion study of the Port Valdez goid district. southem Alaska: Los Angeies, University of California, MS thesis, 66 p.
Pigage, L C.. 1886, Geology of the Croue barle-ginotead-siver deposits, northeastem British Cotumbia in Moin, JA, od. Mineral Deposits of Northem Condilera, Canadian instaute of Mring and Metalurgy, Special Volume 37, p. 71-86.

Pirsent, RH, and Christopher, PA., 1995, Adanac (Ruby Creek) molybdenum deposit, northwestem Britsh Columbia, in Schroeter, T.G, ed., Porphyry Deposis of the Northwestem Condibera of North America. Canadian Insthue of Mining and Metalungy Special Volume 46. p. $712-717$.

Platker, George, 1990, Regional geology and tectonic evolution of Alaska and adjacent parts of the northeast Pacific ocean margin: Proceedings of the Pacific Rim Congress 90, Australasian Insitute of Mining and Metallurgy. Queensiand. Australia, D. 841-853.

Plafker, G, and Berg. H.C., 1994, Overview of the geology and tectonic evolution of Alaska, in Plafker, Georpe, and Berg. H.C., eds. The Geology of Alaska: Boulder, Colorado, Geological Society of America, The Geology of North America, v. G-1. p. 989-1022.

Plafker, G., Blome, C.D., and Siberling. N.J., 1989a, Reinterpretation of lower Mesozoic rocks on the Chilkat Peninsula, Alaska, as a displaced fragment of Wrangellia. Geology, v. 17, p. $3-6$.

Plafker, G, and Mackeveti. E.M. Jr, 1970, Mafic and ultramafic rocks from a layered pluton at Mount Fairwoather, Alaska: United States Geological Survey Professional Paper 700 B. p. B21-B26.

Plafker, G., Moore, J.C., and Winkler, G.R., 1994, Geology of the southem Alaska margin, in Plafker, Goorge, and Borg. H.C., eds. The Geology of Alaska: Bouider, Colo., Geological Society of America, The Geolopy of North America, v. G-1, p. 989-1021.

Plaker, George, Nokleberg, W.J., and Lull, J.S., 1985. Summary of 1985 TACT geologic studies in the northem Chugach Mountains and southern Copper River Basin, in Bartsch-Winkler, Susan, ed. The United States Geological Survey in Alaska: Accomplishments during 1984: U.S. Geological Survey Circular 967, p. 76-79.

Plakker, George, Nokleberg, W.J., and Lull, J.S., 1989, Bedrock geology and fectonic evolution of the Wrangelita. Peninsular, and Chugach temanes along the TransAlaska crustal transect in the Chugach Mountains and southern Copper River Basin. Alaska: Journal of Geophysical Research, v. 94, p. 4255-4295.

Plahuta, L.T. 1978, Geologic map and cross sections of the Red Dog prospect, Delong Mountains, northwestem Alaska: U.S. Bureau of Mines Open-File Report 65-78. $11 \mathrm{p}$, scale 1:24,000.

Plyashkevich, A.A. 1986. Comparative mineralogy of cassiterite-silicate and-silver-pobymetalic deposits (Magadan region, Omsukchan district): Minerals and mineral paragenesises of rocks and cres in the U.S.S.R. Northeast: U.S.S.R. Academy of Sclences. NorthEastern Interdisciplinary Research institute, Magadan. p. $115-128$ (in Russian).

Plyashikevich, A.A. 1990, On canfleidite-type tin-silverpolymetallic mineralization: Ore formations of the U.S.S.R. Northeast: U.S.S.R. Academy of Sciences. North-Eastem Interdisciplinary Research Institute. Magadan, P. 141-151.

Pokazanyev, V.P.. 1976a, Arykymbin gold-bearing volcanotectonic structure in south-western Omolon massit Kolyma, no, 3, p. $38-39$ (in Russian).

Pokazanyev, V.P., $1976 \mathrm{~b}$, On Paleozoic metallogeny of goid in Omolon massif: Kolyma, no, 4, p. $42-44$ (in Russian). 
Pollack, John, 1997. Summary report of the Lantarsky Concession, Khabarovsk Krai, Russian Federation: Amurcan Limited Status Report, 45 pages

Popeko, V.A.4 1995, Magmatic formations and mineralization in the Okhotsk-Chukotica volcanic beit, in Bundtzen, T.K. Fonseca, A.L., and Mann, Roberta, eds., The Geology and Mineral Deposits of the Russian Far East: Alaska Miners Association, Glacier House Publications, Anchorage, Alaska, p. 19-28.

Poulsen. K.H., 1996. Carlin-type gold deposits and their potential occurrence in the Canadian Corillera, in Geological Surey of Canada Current Research 1996-A. D. 1-9.

Pozdeev, A.I., 1986, Late Paleogenic stage in development of Koryak upland and some other regions of the Pacific beit: Tikhookeanskaya Geologiya, no. 4, p. 49-57 (in Russian)

Pozdeev, A.I. 1990, Volcanic epochs, volcanic belts and metallogeny of Koryak-Kamchatka region: Volcanism (evolution, geodynamics, and ores): Nedra, Moscow, D. 266-276 (in Russian).

Pratt, W.P., ed., 1981. Metalic mineral-resource potential of the Rolla quadrangle, Missouri, as appraised in September 1980: U.S. Geological Survey Open-File Report 81-518, 77 p., 11 plates, scale 1:250,000.

Preta, VA, 1972, Geology of Copper Mountain; British Columbia Department of Mines and Petroleum Resources, Bulletin $59,87 \mathrm{p}$.

Preto, V.A., and Schiarizza, P., 1985, Geology and mineral deposits of the Adams Plateau-Clearwater region, in Tempelman-Kluit, J.D., ed., Field Guides to Geology and Mineral Deposits in the Southem Canadian Cordillera: Geological Society of America, Cordilleran Section Meeting, Vancouver, Field Trip 16, p. 1-11.

Preto, V.A., and Tidsbury, A.D., 1971, Magnum Mine: in Geology. Exploration and Mining in Brtish Columbia 1971. British Columbia Depertment of Mines and Petroieum Resources, p. $81-89$.

Radkevich EA., 1984, Metallogenic zones of the Pacific ore belt: U.S.S.R. Academy of Sciences, Far East Geological Institute, Vladivostok, 192 p. (in Russian).

Rackevich, EA, ed. 1991, Pacific margin of Asia: Metallogenesis: U.S.S.R. Academy of Sciences, Far East Geological Institule, Vladivostok, 204 p. (in Russian).

Radkevich E.A. Moiscenko V.G. Molchanov P.Ya., Meinikov V.D., and Faryanov L.L., 1969, The Tokur deposit as a representative of a quartz low-sulfide formation, in Radkevich, EA, ed. Goid formations of the Russian Far East: Nauka, Moscow, p. 61-73.

Raevskaya, LS., Kalinin, A.I, and Natalenko, V.E., 1977, On mineral formation stages in gold-silver deposit Kolyma. no. 5. p. 15-20 (in Russian).

Ramthun, Alexander, Brandon, M.T, and Ring. Ewo, 1997. Preservation of sedimentary fabrics in the footwall of the large-sle vatyna thrust, Kamchatica, Russian Far East [abs]. Geological Society of America Abstracts with Program, v. 29, p. 58

Ratkin, V.V., 1991, On the rolationship of skam borosilicate and polymetalic ores of the Dalnegorsk cre district, in Shcheka, SA, ed. Ore deposits of the Russian Far East: Mineralogical criteria for prediction, prospecting. and estimation: U.S.S.R. Academy of Sciences. Far East Geological institute. Vladivostok, 112 p. (in Russian).
Ratkin, V., 1995. Pre- and post-accretionary metallogeny of the southern Russian Far East: Resource Geology, Special Issue No. 18, p. 127-133.

Ratkin, V.V , and Khanchuk, A.1., 1995, Lode mineral deposits of the southern Russian Far East, in Bundtzen, T.K., Fonseca, A.L., and Mann, Roberta, eds., The Geology and Mineral Deposits of the Russian Far East: Alaska Miners Association, Glacier House Publications, Anchorage, Alaska, p. 85-89.

Ratkin V.V., Khetchikov, L.N., and Dmitriev, V.E., 1992, On the role of colioids and paieohydrothermal cavities for the formation of rhythmically banded ore of the Dalnegorsk borosilicate deposit: Doklady Akademii Nauk SSSR, v. 325 , p. 1214-1217. (in Russian).

Ratkin, V.V. and Watson, B.N., 1993, Dainegorsk borosilicate deposits: Geology and sources of boron on the basis of isotope data: Tikhookeanskaya Geologiya, no. 6, p. 95102 (in Russian)

Ratkin, V.V., Simanenko, L.F., Kuznetsov D.N., and Korol, R.V., 1990, Tin-zinc ores of East Sikhote-Alin volcanic belt: Geologiya Rudnykh Mesiorozhdenily, no.2, p. 68-77 (in Russian)

Ratkin, V.V., Simanenko, L.F., and Logvenchev, P.I., 1991. Mineralogical and geochemical zoning of skarn and vein polymetallic deposits of the Dainegorsk district as a basis for local prediction of the vertical distribution of the deposit. in Shcheka, S.A. ed. Ore deposits of the Russian Far East: Mineralogical criteria for prediction. prospecting, and estimation: U.S.S.R. Academy of Sciences, Far East Geological Institute, Vladivostok, p. 33-35 (in Russian).

Ratkin, V.V, Watson, B.N.4. 1993, Dainegorsk borosilicate deposits: Geology and sources of boron on the basis of isotope data: Tikhookeanskaya Geologiya, no. 6, p. 95102 (in Russian)

Ray, R.G., 1954, Geology and ore deposits of the Willow Creek mining district, Alaska: U.S. Geological Survey Bulletin $1004,86 \mathrm{p}$.

Ray, G.E. 1986, Goid associated with a mid-Terfary plutonic ovent in the Harrison Lake area, southwestern British Columbia (92 G/9; $92 \mathrm{H} / 3,4,5,6,12$ ), in Geological Fieldwork 1985: British Columbia Ministry of Energy, Mines, and Petroleum Resources Paper 1986-1, p. 95-97.

Ray, G.E., 1991, Vein gold mineralzation related to mid-Tertary plutonism. Harrison Lake, Brtish Coilumbia: Economic Geology. v. 86, p. 883-891.

Ray, GE, and Dawson, G.L., 1994, The geology and mineral deposits of the Hedley goid skam district, southem British Columbia: British Columbia Ministry of Energy Mines and Petroleum Rescurces Bulletin no. 87, $156 \mathrm{p}$.

Ray, GE, and Dawson, K.M., 1996, Mineralized skams in the Canadian Cordiliera, in Lentz, D.R., ed. Mineralized intrusion-Related Skam Systemb, Mineraicgical Association of Canada, Short Course Volume 26, p. 475. 518.

Ray, Gerry E; Grond, H C; Dawson, G L; Webster, I C L, 1992. The Mount Riordan (Crystal Peak) gamet skarn, Hedley District, southem British Columbia: Economic Geology. v.87, no. 7, p. 1862-1876.

Ray. G.E., and Webster, LC.L., 1991, An overview of skam deposits, in McMilian, W.J. and others, eds. Ore Deposits, Tectonics and Metallogeny in the Canadian Cordillera. British Columbia, Ministry of Energy, Mines and Petroleum Resources Paper 1991-4, p. 213-252.

Ray, G.E, and Webster, I.C.L., 1997, Skams in British Columbia: British Columbia Ministry of Energy and Mines Bulletin 101. 260 p. 
Ray, G.E., Webster, I.C.L., Dawson G.L and Ettlinger, A.D. 1993, A geological overview of the Hedley Gold Skarn district, southern British Columbia $(92 \mathrm{H})$, in Geological Fieldwork 1992: British Columbia Ministry of Energy. Mines and Petroleum Resources Paper 1993-1, p. 269 . 280 .

Ray, R.G., 1954, Geology and ore deposits of the Willow Creek mining district, Alaska: U.S. Geological Survey Bulletin $1004,86 \mathrm{p}$.

Read, J.J., 1985, Gold-quartz mineralization at the Big Hurrah mine, Seward Peininsula, Alaska [abs.] Geological Society of America Abstracts with Programs, v. 17, no. 6. p. 402 .

Read, J.J., and Meinert, L.D., 1986, Gold-bearing quartz vein mineralization at the Big Hurrah mine, Seward Peninsula: Economic Geology, v. 81, p. 1760-1774.

Read, P.B., and Monger, JW.H., 1976, Pre-Cenozoic volcanic assemblages of the Kluane and Alsek ranges, southwestem Yukon Territory: Geological Survey of Canada Open File 381, $96 p$.

Rebagliati, C.M., Bowen, B.K., Copeland, D.J., and Niosi, D.W.A., 1995. Kemess South and Kemess North porphyry goidcopper deposits, northern British Columbia, in Porphyry Deposits of the Northwestem Cordillera of North America, Schroeter, T.G., ed. Canadian Institute of Mining and Metallurgy. Special Volume 46, p. 377-396.

Reed, J.C., and Coats, R.R., 1941, Geology and ore deposits of the Chichagof mining district, Alaska: U.S. Geological Survey Bulletin 929, 148 p.

Reed, B.L., and Eberiein, G.D., 1972, Massive sulfide deposits near Shellabarger Pass, southern Alaska Range: U.S. Geological Survey Bulletin 1342, 45 p.

Reed, B.L., and Lanphere, M.A., 1969, Age and chemistry of Mesozoic and Tertiary plutonic rocks of south-central Alaska: Geological Society of America Bulletin, v. 80, no. 1, p. $23-44$

Reed, B.L., and Lanphere, M.A., 1973. Alaska-Aleutian Range batholith: Geochronology, chemistry, and relation to Circum-Pacific plutonism: Geological Society of America Bulletin, v. 84, p. 2583-2610.

Reed, B.L., Menzie, W.D., and McDermott, M. Root, D.H. Scoth. W., and Drew, L.J., 1989, Undiscovered lode tin resources of the Seward Peninsula. Alaska: Economic Geology, v. 84, p. 1936-1947.

Reed, B.L., Miesch, A.T., and Lanphere, M.A., 1983, Plutonic rocks of Jurassic age in the Alaska-Aleutian Range batholith: Chemical variations and polarity: Geological Society of America Bulletin, v. 94, p. 1232-1240.

Reed, J.C., and Coats, R.R., 1941, Geology and ore deposits of the Chichagof mining district, Alaska: United States Geological Survery Bullebin 929, 148 p.

Reed. J.J., and Meinhart, L.D., 1986, Gold-bearing quartz vein mineralization at the Big Hurrah mine, Seward Peningula, Alaska: Economic Geology, v. 81, p. 1,7601,774 .

Reesor, JE., 1973, Geology of the Lardeau Map-area, east half, British Columbia: Geological Survey of Canada Memoir 369, p. 92-117, scale 1:250,000.

Rhys, D.A, and Godwin, C.I., 1992, Preliminary structural interpretation of the Snip Mine (104B/11); in Geological Fieldwork 1991; British Columbia Ministry of Energy, Mines and Petroleum Resources Paper 1992-1, p. 549-554.

Rhys, D.A. Sieb, M. Frostad, S.R., Swanson, C.L., Prefontaine, M.A., Mortensen, J.K. and Smit, H.Q., 1995, Geology and setting of the Red Mountain gold- silver deposits, northwestem British Columbia, in Schroeter, T.G., ed. Porphyry Deposits of the Northwestem Cordillera of North
America: Canadian Institute of Mining and Metallurgy, and Petroleum, Special Volume 46, p. 811-828.

Richards, D.R. Butler, R.F., and Harms, T.A. 1993, Paleomagnetism of the late Paleozoic Slide Mountain terrane, northem and central British Columbia: Canadian Joumal of Earth Sciences, v.30, p. 1898-1913.

Richards, G., 1976, Ox Lake, in Sutherland Brown. A., ed. Porphyry Deposits of the Canadian Corcillera, Canadian Institute of Mining and Metallurgy Special Volume 15, p. 289-298.

Richards, M.A., Jones, D.L., Duncan, R.A., and DePaolo, D.J., 1991, A mantle plume initiation model for the formation of Wrangellia and other oceanic plateaus: Science, v. 254, p. 263-267.

Richter, D.H., 1963, 1966, Geology of the Slana district, south central Alaska: Alaska Division of Mines and Minerals Geologic Report 21, 51 p.

Richter, D.H., 1963, Geology of the Portage Creek-Susitna River area, Alaska: Alaska Division of Mines and Minerals Geologic Report 3, 2 sheets, scale 1:24,000

Richter, D.H., 1970, Geology and lode-gold deposits of the Nuka Bay area, Kenai Peninsula, Alaska: U.S Geological Survey Professional Paper 625-B, p. B1B16.

Richter, D.H., 1975, Geologic map of the Nabesna quadrangle, Alaska: U.S. Geological Survey Miscellaneous Investigations Series Map 1-932, scale 1:250,000.

Richter, D.H., 1976, Geologic map of the Nabesna quadrangle, Alaska U.S. Geological Survey Miscellaneous Geological Investigations Series Map 1-932, 1 sheet, scale 1:250,000.

Richter, D.H., and Herreid, Gordon, 1965, Geology of the Paint River area, liiamna quadrangle, Alaska: Alaska Division of Mines and Minerals Geologic Report 8, 8 p., 1 plate, scale 1:31,500.

Richter, D.H., and Jones, D.L., 1973, Structure and stratigraphy of the eastem Alaska Range, Alaska: Arctic Geology. Memoir 19. American Association of Petroleum Geologists, p. 408-420

Richter, D.H. Lanphere, M.A., and Matson, N.A., Jr., 1975a, Granitic plutonism and metamorphism, eastern Alaska Range, Alaska. Geological Society of America Bulletin. v. 86, p. $819-829$.

Richter, D.H., Singer, D.A., and Cox, D.P., 1975b, Mineral resources map of the Nabesna quadrangle, Alaska: U.S. Geological Survey Miscellaneous Field Studies Map MF. 655K, scale 1:250,000.

Riegel, S.A., Fujita, K., Koz'min, B.M., Imaev, V.S., and Cook, D.B., 1993, Extrusion tectonics of the Okhotsk plate, northeast Asia: Geophysical Research Letters, v. 20, p $607-610$

Robert, F, and Taylor, B.E., 1989, Structure and mineralization at the Mosquito Creek Gold Mine Cariboo District, British Columbia, in Structural Environment and Gold in the Canadian Cordillera: Geological Association of Canada, Cordilleran Section, Short Course No. 4, p. 2541.

Robertson, E.C., 1956, Magnetite deposits near Klukwan and Haines, Alaska: U.S. Geological Survey Open-File Report, $37 \mathrm{p}$

Robinson, M., and Godwin, C.L., 1995, Genesis of the Blende carbonate-hosted $\mathrm{Zn}-\mathrm{Pb}-\mathrm{Ag}$ deposit, north-central Yukon Temitory: Geologic, fluid inclusion, and isotopic constraints: Economic Geology, v. 90, p. 369-384

Robinson, M., Godwin, C.I., and Juras, S.J., 1994, Major lithologies of the Battle zone, Buttle Lake camp, central Vancouver Island (92 F/12 E), in Geological Fieldwork 
1993: British Columbia Geological Survey Branch, Paper 9194-1, p. 319-338

Robinson, M.S., Smith, T.E., and Metz, P.A., 1990, Bedrock geology of the Fairbanks mining district Alaska Division of Geological and Geophysical Surveys Professional Report 106, 1 sheet, scale 1:63,360

Rodionow, S.M., 1988, Geology of porphyry-tin deposits of the Zvezdny ore district in Primorye: Geologiya Rudnykh Mestorozhdeniy, no. 6, p. 43-53 (in Russian).

Rodionov, A.N., and Kuznetsova, I.V., 1984, Metasomatic features of a deposit of the East Sikhote Alin Area, in Petrchenko, R.I., ed., Metasomatically altered rocks of noble metals deposits of the Russian Far East U.S.S.R. Academy of Sciences, Far East Geological Institute, Vladivostok, p. 88-92 (in Russian).

Rodionov, S.M. and Rodionova, L.N., 1980, Abot volcanicintrusive genesis of ores of Tigrinoe deposit, in Volcanogenic mineralization in Russian Far East: U.S.S.R. Academy of Sciences, Vladivostok, p.69-73 (in Russian).

Rodionow, S.M., Rodionova, L.N., and Shapenko, V.V., 1987. Cassiterite-quartz mineralization of Central Sikhote-Alin. in Mineralogy of Ore Districts of Soviet Far East: U.S.S.R. Academy of Sciences, Vladivostok, p. 4-14 (in Russian)

Rodionov, S.M., Shapenko, V.V., and Rodionova, L.N., 1984. Structure and genesis of tin-fungsten deposits of Central Sikhote-Alin: Geology of Ore Deposits, no 1, p. 22-30 (in Russian)

Roeder, Dietrich, and Mull, C.G, 1978. Tectonics of Brooks Range ophiolites, Alaska: American Association of Petroleum Geologists Bulletin, v. 62, no. 9, p. 16961702.

Roeske, S.M., Mattinson, J.M., and Armstrong. R.L., 1989, Isotopic ages of glaucophane schists on the the Kodiak Islands, southern Alaska, and their implications for the Mesozoic tectonic history of the Border Ranges fault sysem: Geological Society of America Bulletin, v, 101, p. 1021-1037.

Rose. A.W. 1965a, Geology and mineral deposits of the Rainy Creek area, Mt. Hayes quadrangle, Alaska: Alaska Division of Mines and Minerals Geologic Report 14, 51 p.

Rose, A.W., 1965b, Geology and mineralization of the Midas Mine and Sulphide Gulch areas near Valdez Alaska Division of Mines and Minerals Geologic Report 15, 21 p.

Rose, A.W., 1966, Geological and geochemicai investigations in the Eureka Creek and Rainy Creek areas, Mt. Hayes quadrangle, Alaska: Alaska Division of Mines and Minerals Geologic Report 20, 37 p.

Rose, S.C., Pickthom, W.J., and Goldfarb. R.J.. 198B, Gold mineralization by metamorphic fluids in the Chandalar district, southern Brooks Range-fluid inclusion and oxygen-isotope evidence [abs.]: Fluid Inclusion Research, v. 21, p. 328-329.

Ross, K. V., Dawson, K.M., Godwin, C.I, and Bond, L, 1992, Major Ithologies of the Ajax West pit, an alkalic copper-gold porphyry deposit, Kamloops, Bntish Columbia, in Cument Research, Part A Geological Survey of Canada Paper 92. $1 \mathrm{~A}, \mathrm{p} .179-183$.

Ross, K.V. Dawson, K.M. Godwin, C.I., and Bond, L.. 1993, Major ithologies and alteration of the Ajax East orebody, a sub-alkalic copper-gold porphyry deposit, Kamioops, south-central British Columbia; in Current Research, Part A. geological Survey of Canada Paper 93-1A, p. 87-95.
Ross, K.V., Friedman, R.M., Dawson, K.M., and Leitch, C.H.B., 1996. U-Pb zircon ages of the Island Copper deposit intrusions, northem Vancouver Island, British Columbia, in Current Research 1996-A: Geological Survey of Canada, p. 111-117,

Ross, KV., Godwin, C.I. Bond, L, and Dawson, K.M., 1995, Geology, alteration and mineralization of the Ajax East and Ajax West copper-gold alkalic porphyry deposits, southem Iron Mask bathoth, Kamboops, British Columbia; in Schroeter. T.G. ed. Porphyry Deposits of the Northwestem Cordillera of North America, Canadian Institute of Mining and Metallurgy Special Volume 46, p. 565-580

Rozhdestvensky, V.S. 1987, Tectonic evolution of the Sakhalin Island: Tikhookeanskaya Geologia, no. 3, p. $42-51$ (in Russian)

Rostovsky, F.I., Ivankin, A.N., and Nikolaeva, A.N., 1987, On polyformational skarn-scheelite-sulfide mineralization in Primorye, in Levashov, G.B., ed. Phanerozoic magmatism of the Sikhote-Alin volcanic beit: U.S.S.R. Academy of Sciences, Far East Geological Institute, Vladivostok, p. 142-154. (in Russian).

Rozenblum, I.S., Permyakov, A.P., and Makhonina, S.A., 1973, Geology and mineralogy of new mercury deposit in Koryak Highlands: Kolyma, no. 1, p. 39-41 (in Russian).

Rozenblum, I.S., Zinkevich, V.P., and Nevretdinov, E.B., 1975. New tin-mercury zone in northern Koryak Highlands: Materialy po Geologï i Polzenym Iskopaemym SeveroVostoka SSSR, U.S.S.R. Academy of Sciences, v. 22 , p. 132-140 (in Russian).

Rozhkov, 1.S. Grinberg. G.A., Gamyanin, G.N., Ipatyeva, I.S. Kukhtinsky, G.G., and Solovyev, V.I., 1971, Late Mesozoic magmatism and gold mineralization of the Verkhny-Indigirka rerion: Nauka, Moscow, $240 \mathrm{p}$ (in Russian).

Rub, M.G. Gladkov, N.G., Pavlov, V.A, and Shershakov, B.I., 1974. New data on age of igneous rocks of the western Kavalerovo district, Primorye: Izvestiya Akademii Nauk SSSR, Seriiya Geologicheskaya, no, 12, p. 36-45, (in Russian).

Rubin, C.M., Miller, M.M., and Smith, G.M., 1991, Tectonic development of Cordilleran mid-Paleozoic volcanoplutonic complexes: Evidence for convergent margin tectonism, in Harwood, D.S., and Maler, M.M., eds., Paleozoic and early Mesozoic paleogeographic relations of the Sierra Nevada, Klamath Mountains, and related terranes: Geological Society of America Special Paper 225 , p. $1-16$.

Ruchkin, G.V., Bogovin, V.D., Donets, A.L., Isakovich, IZ. Konkin, V.D. Krutty, V.M., 1977, Lead-zinc mineralization hosted by Vendian carbonates in the southeastem Yakutia: Geologiya Rudnykh Mestorozhdeniy, v. 4, p. 3-20 (in Russian).

Ruchkin G.V. Ivakin A.N. Shnayder, M.S., and Rodionov, S.M., 1986, Geological structure and genesis of tintungsten deposit of stockwork types in Primorie: Pacific Geology, no. 2, p. $68-75$ (in Russian).

Ruckmick and Noble, 1959, The origin of the ultramafic complex at Union Bay, southeastem Alaska: Geological Society of America Bulletin, v. 70, p. 981-1017.

Ryan, B., Wardel, R.J., Gower, C.F., and Nunn, G.A.G., 1995. Nickel-copper sulfide mineralization in Laborador: Voisey Bayy discovery and its exploration implications: Newfoundland Department of Natural Resources Geological Survey Report 95-4, p, 177-204.

Ryazantzeva, M.D.. 1998, The Voznesenka ore district, in Seltmann, R. Gonevchuk, G. and Khanchuk, A.s eds., 
International Field Conference in Vladivostok, Russia, September 1998: GeoforschunasZentrum Potsdam (GFZ). Potsdam, p. 9-22.

Ryazantseva, M.D., Gerasimov. N.S., and Govorov, I.N., 1994. $\mathrm{Rb}-\mathrm{Sr}$ isochrones and petrogenesis of magmatic rocks of Voznesenka ore district (Primorie): Pacific Geclogy. no. 4, p. $60-73$ (in Russian)-

Ryazantzeva, M.D. Shkurko, E... 1992, Fluorite of Prymorye: Nedra, Moscow, 156 p. (in Russian).

Sable, E.G., 1977, Geology of the westem Romanzof Mountains, Brooks Range, Alaska: U.S. Geological Survey Professional Paper 897, 84 p.

Sakharova, M.S, and Bryzgalov, I.A., 1981, Silver mineralogy of quartz-adularia-thodonite volcanogenic hydrothermal veins: Geologiya Rudnykh Mestorozhdeniy, no. 6, 36-48 (in Russian).

Sangster, D.F., 1986. Classifications, distribution and grade-class summanes of Canadian lead-zinc deposits: Geological Survey of Canada, Economic Geology Report 37, 68 p.

Savostin, L.A., and Drachev, S.S., 1988a, Some features of the geologic structure and tectonics of southern Bol'shoi Lyakhov Island (New Siberian Islands): Doklady. USSR Academy of Sciences, v. 301, p. $169-172$ (in Russian).

Savostin, L.A., and Drachev, S.S., 1988b, Cenozoic compression in the vicinity of the Novosibirskly Islands and its relationship to the opening of the Eurasia Basin: Oceanology, v. 28, p. 601-606.

Savostin, L.A., Karasik. A.M., and Zonenshain, L.P., 1984. The history of the opening of the Eurasia Basin in the Arctic: Doklady Academy of Sciences of the USSR, Earth Science Section, f. 275, p. 79-83

Savva, N.E., and Raevskaya, I.S., 1974, On beryl-mineral find in gold-silver ore: Kolyma, no, 6, p.35 (in Russian).

Savva, N.E., and Vedernikov, V.N., 1989, New type of siver mineralization in the U.S.S.R. Northeast: Geochemistry and Mineralogy of Ore Deposits of the U.S.S.R. Northeast: U.S.S.R. Academy of Sciences, NorthEastern Interdisciplinary Research Institute, Magadan, p. 86-97 (in Russian).

Savva, N.E., and Vortsephev, V.V., 1990, Features of volcanogenic mineral deposits formation in median massifs: Genesis of ore formations and practical significance of ore-formational analysis in the U.S.S.R. Northeast: U.S.S.R. Academy of Sciences, NorthEastern Interdisciplinary Research Institute, Magadan. p. $50-64$ (in Russian).

Sawkins, F J., 1990, Metal deposits in relation to plate tectonics: Springer Verlag. Berlin, 2nd edition, $461 \mathrm{p}$.

Sawyer, D.A., Tumer, A.T, Christopher, P.A. and Boyle, D.R., 1981, Basal type uranium deposits, Okanagan region, south central British Columbia, in Thompson, R.I. and Cook، D.G. eds., Fieid Guides to Geology and Mineral Deposits: Geological Association of Canada, Annual Meeting. Calgary. Alberta, p. 69-77.

Scammeil, R.J., and Brown, R.L, 1990, Cover gnelsses of the Monashee Terrane: A record of synsedimentary rifting in the North American Cordilera: Canadian Joumal of Earth Sciences, v. 27, p. 712-726.

Schiarizza, P., Gabba, R.G., Coleman, M., Garver, J.I., and Glover, J.K., 1990, Geology and mineral occurrences of the Yalakom River area, in Geological Fieldwork 1989: British Columbia Ministry of Energy. Mines and Petroleum Resources Paper 1990-1, p. 53-72.

Schiarrizza, P, Gabba, R.G., Glover, J.K, and Garver, J.I. 1989, Geology and mineral occurrences of the Tyaughton Creek area ( 92 O/2, $92 \quad \pm / 15,16)$, in Fieldwork 1988: British
Columbia Ministry of Energy. Mines, and Petroleum Resources Paper 1989-1. p. 115-130.

Schiarrizza, P., Gabba, R.G., Glover, J.K., Garver, J.1., and Umhoefer, P.J., 1997, Geology and mineral cccurrences of the Taseko-Bridge River area: British Columbia Ministry of Employment and Imvestment Bulletin 100, 291 p.

Schiarrizza, P. and Preto, VA., 1987, geology of the Adams Plateau-Clearwater-Vavenby area: British Columbis Ministry of Energy, Mines and Petroleum Resources Paper $1987-2,88 p$

Schiarrizza, P., and Riddell, J., 1997, Geclogy of the Tatlayoko Lake-Beece Creek area $(92 \mathrm{~N} / 8,9,10 ; 92 \mathrm{O} / 5,6,12)$, in Diakow. L.J, and Newell, J.M., eds., Interior Plateau Geoscience Project: Summary of Geological, Geochemical, and Geophysical Studies: British Columbia Ministry of Employment and Investment Paper 1997-2, p. 63-101.

Schmidt, J.M., 1983, Geology and geochemistry of the Arctic prospect, Ambler district, Alaska: Stanford, California, Stanford University, Ph.D. dissertation, 253 p.

Schmidt, J.M., 1986, Stratigraphic setting and mineralogy of the Arctic volcanogenic massive sulfide prospect, Ambler district, Alaska: Economic Geology, v. 81, p. 1619-1643.

Schmidt, J.M., 1988, Mineral and whole-rock compositions of seawater-dominated hydrothermal alteraton at the Arctic volcanogenic massive sulfide prospect, Alaska: Economic Geology, v, 83, p. 822-842.

Schmidt, J.M., 1993. Clastic-hosted stratiform, vein/breccia and disseminated $\mathrm{Zn}-\mathrm{Pb}-\mathrm{Ag}$ deposits of the northwestern Brooks Range, Ak: Are they different expressions of dewatering of the same source basin?: Geological Society of America Abstracts with Programs, v. 25, p. 143.

Schmidt, J.M.4 1997a, Shaie-hosted $\mathrm{Zn}_{\mathrm{n}} \mathrm{Pb}-\mathrm{Ag}_{\mathrm{g}}$ and barite deposits of Alaska, in Goldfarb, R.J.s and Miller, L.D., eds., Mineral Deposits of Alaska: Economic Geology Monograph 9, p. 35-65.

Schmidt, J.M., 1997b, Strata-bound carbonate-hosted Zn-Pb and $\mathrm{Cu}$ deposits of Alaska, , in Goldfarb, R.J., and Miller, L. D., eds., Mineral Deposits of Alaska: Economic Geology Monograph 9, p. 90-119.

Schmidt, J.M., and Zierenberg, R.A., 1988, Reconstruction of primary features and isotopic evidence for multiple sources at the Red Dog zinc-lead-silver deposit, Noatak District, Alaska, in Schindler, K.S., ed., USGS Research on Mineral Resources-1989, Programs and Abstracts: U.S. Geological Survey Circular 1035, p. 62-63.

Scholl, D.W., and Hart, P.E., 1994, Velocity and amplitude structures on sesimic reflection profiles-possible massive gas-hydrate deposits and underlying gas accumulations in the Bering Sea Basin, in Howell, D.G., ed., The future of energy gases: U.S. Geological Survey Professional Paper 1570, p. $331-351$

Scholl, D.W., Stevenson, A.J., Mueller, S., Geist, E.L. Engebretson, D.C., and Vallier, T.L., 1992, Exploring the notion that southeast-Asian-type escape tectonics and trench clogging are involved in regional-scale deformation of Alaska and the formation of the Aleutian-Bering Sea region, in Flower, M. McCabe, R., and Hilde, T, eds. Southeast Asia structure, tectonics, and magmatism: Proceedings. Geodynamics Research Institute Symposium, Texas A \& M University, College Station, Texas, p. 57-63.

Schroeter, T.G., 1983, Toodoggone River Area (94E), in Geological Fieldwork 1982 : British Columbia Ministry of Energy. Mines and Petroleum Resources Paper 1983-1. p. $125-133$. 
Schroeter, T.G., 1987, Golden Bear project, in Geological Fieldwork 1986: British Columbia Ministry of Energy, Mines and Petroleum Resources Paper 1987-1, p. 103109.

Scotese, C.R., 1997, Continental drift, Phanerozoic plate tectonic reconstructions, University of Texas, Avlington, Department of Geology, PALEOMAP Progress Report no. 36, edition 7 (CD-ROM).

Scotese, C.R., Nokleberg. W.J, Scholl, D.W., Bundtzen, T.K. Khanchuk, A.I., Monger, J.W.H., Dawson, K.M. Norton. I.O., Parfenov, L.M., 2001. Dynamic Computer Model for the Metallogenesis and Tectonics of the Circum-North Pacific: U.S, Geological Survery Open-File Report 01261, CD-ROM.

Schroeter, T.G., and Lane, R.A., 1991, A century of gold production and reserves in British Columbia: British Columbia Ministry of Energy, Mines and Petroleum Resources, Open File 1991-19, 42p.

Sebert, C., and Barrett. T.J., 1996, Stratigraphy, aiteration, and minerailzation at the Tulsequah Chief massive sulphide deposit, northwestem British Columbia; Exploration and Mining Geology, v.5, no. 4, p. 281-308

Sengōr, A.M.C., and Natarin, B.A., 1996a, Paleotectonics of Asia fragments of a synthesis, in Yin, An, and Harrison, Mark, eds., The tectonic evolution of Asia: Cambridge University Press, p. 486-640.

Sengor, A.M.C., and Natalin, B.A., 1996b, Turkic-type orogeny and its role in the making of continental crust: Annual Reviews Earth and Planetary Sciences, v. 24, p. 263337.

Seslavinskly, K.B., and Ged'ko, M.I., 1990, Ophiolitic complexes of westem Chukotka and geodynamic interpretation of their genesis, in Tectonics and mineralogy of the northeastern U.S.S.R.: U.S.S.R. Academy of Sciences, Magadan, p. 191-194 (in Russian)

Seraphim, R.H., 1975, Denali-A nonmetamorphosed stratilorm sulfide deposit: Economic Geology. v.70, p. 949-959.

Seraphim, R.H. and Rainboth, W., 1976, Poison Mountain: in Sutherland Brown, A., ed., Porphyry Deposits of the Canadian Cordillera, Canedian Institute of Mining and Metallurgy Special Volume 15, p. 323-328.

Shapowalow, V.S., 1976, Composition and temperature conditions of gold-bearing mineral assemblages formation in volcanogenic deposits (Western Chukotka): Geological and geochemical features of mineral deposits in the U.S.S.R. Northeast: U.S.S.R. Academy of Sciences, North-Eastem Interdisciplinary Research Institute, Magadan, p. 67-73 (in Russian)

Shcheglov, A.D., Khomich, V.G., and Govorov, I.N., 1984, Silver metallogeny of the Pacific segment of the Earth: Tikhookeanskaya Geologiya, v. 1984, p. 3-14.

Shcheka, S.A., and Vrzhosek, A.A., 1985, A rare-type igneous platinum-gold mineralization in mafic-ultramafic intrusives, in Shcheka, S.A., ed. Typomorphous assemblages of accessory minerals and microelements: U.S.S.R. Academy of Sciences, Far East Geological Institute, Vladivostok, p. 82-92 (in Russian).

Shcheka, S.A., and Chubarov, V.M., 1984. Homblenditeperidotites of Sredinny Ridge of Kamchatka: Izvestiya Akademii Nauk, SSSR, Seriya Geologicheskaya, no, 1, p. 23-34 (in Russian)-

Shchepot'ev, Yu.M. ed., 1989, Gold deposits of Pacific island arcs: Proceedings of TSNIGRI: (Central Research Institute of Geological Prospecting for Base and Precious Metals). 121 p. (in Russian).
Shergina, Yu. P, Kolesnikov, D.I., Shkorbatova, G.S., and Soluyanova, N.N., 1990, New data on age and genesis of the Dukat silver deposit [abs.]: Isotopic Dating of Endogenic Ore Formations: U.S.S.R. Academy of Sciences, Kiev, p. $220-222$ (in Russian).

Sherlock, R.L., Roth, T., Spooner, E.T.C., and Bray, C.J., 1999. Origin of the Eskay Creek precious metal-rich volcanogenic massive sulfide deposit. Fluid inclusion and stable isotope evidence: Economic Geology, v. 94, p. $803-824$.

Shilo, N.A., 1960. Geologic structure and lode sources of the Yana Kolyma gold placer belt: Transactions of All-Union Science Research Institute-I, Geology, 63, 108 p (in Russian).

Shilo, N.A., Gorodinsky, M.E., Gulevich, V.V., Sidorov, A.A., Senotrusov, A.G., Tilman, S.M., and Tsopanov, O.H. 1975, Gold-bearing formations of Oloi zone: Geologiya i Geofizika, no. 3, p. 43-49 (in Russian).

Shkodzinsky, V.S., Nedosekin, Yu D., and Surnin, A.A., 1992. The petrology of Late Mesozoic magmatic rocks of the eastern Yakutia: Nauka, Novosibirsk, 238 p. (in Russian).

Shkolnik, E.L., 1973, Composition, regularity of distribution, and genesis of ifon. manganese, and phosphorite deposits in the Uda - Shantary area: Ph D. dissertation, U.S.S.R. Academy of Sciences, Far East Geological Institute, Vladivostok, 200 p. (in Russian).

Shikolnik, E.L., Gvozdev, V.I., Malinko, S.V., Punina, T.A., Slukin, A.D., and Ignatyev, A.V., 2003, The origin of borosilicate mineralization of Dalnegorsk deposit, Primorye Territory. Russia: Geology of the Pacific Ocean, v. 22, no. 3, p. 122-134. (in Russian).

Shkursky, V.I., and Matweenko, V.T. 1973, Copper-zeolite formation in Range (North-Eastem U.S.S.R.): Geologiya i Geofizika, no. 3, p. 43-49 (in Russian).

Shoshin, V.V, and Vishnevsky, A.G., 1984, Tin mineralization in an ore district in the northeastern Yakutia and its relation to gold and antimony mineralization, in Flerov, B.L., Davydov, Yu.V., and Gamyanin, G.N., eds., Geology and mineralogy of ore districts of the YanaKolyma fold belt, U.S.S.R. Academy of Sciences, Siberian Branch, Institute of Geology, Yakutsk, p. 72-79 (in Russian).

Shpikerman, V.I. 1987. Polymetallic mineralization of the Omulev Uplift (U.S.S.R. Northeast), U.S.S.R. Academy of Sciences, Vladivostok, $164 \mathrm{p}$ (in Russian).

Shpikerman V.L. 1998, Pre-Cretaceous metallogeny of Northeastern Asia: Russian Academy of Sclences, Northeastern Interdisciplinary Research Institute, Magadan, 333 p. (in Russian).

Shpikerman V.I., and Shpikerman L.A., 1996, Proterozoic sediment-hosted $\mathrm{Cu}$ deposits of the Prikolymian area, in Goryachev N.A., and Byalobzhesky S.G., eds., Stratiform mineralization of sedimentary and sedimentary-volcanic sequences in northeastern Asia: Russian Acaderny of Sciences, North-Eastern Interdisciplinary Research Institute, Magadan, p. 35-44 (in Russian)

Shpikerman, V.I., Goryachev, N.A, and Merzlyakov, V.M., 1986, On new type of tungsten mineralization in the U.S.S.R. Northeast: Kolyma, no. 11, p. $25-27$ (in Russian)

Shpikerman, V.I., Merzlyakov, V.M., Lychagin, P.P.; Savva, N.E., Gagiev, M.H., and Likman, V.B., 1988, Copper mineralization in Ordovician volcanics in the east of the Yakutia, U.S.S.R: Tikhookeanskaya Geologiya, no. 4, p. 55-64 (in Russian). 
Shpikerman, V.I. Shpikerman, L.A. and Volkov, M.N., 1991, Middle Devonian cupriferous basalt of the southern Omulev Uplift Materialy po Geologii i Polzenym Iskopaemym Severo-Vostoka SSSR, U.S.S.R. Academy of Sciences, v. 27, p. 183-190 (in Russian).

Shul'gina, V.S. Tkachenko, V.I., and Kuznetsov, V.M., 1990. Geological map of the U.S.S.R.: U.S.S.R. Ministry of Geology, Leningrad, scale 1:1,000,000 (in Russian).

Shur, V.I. 1985, The structural atlas of ore feids in Yakutia: Nedra, Moscow, 155 p. (in Russian).

Shur, V.I., and Flerov, B.L., 1979, Tin and tungsten, in Geology of USSR, V. 18. Yakutian USSR minerals: Moscow, Nedra, p. $198-238$ (in Russian).

Sichermann, H.A. Russell, R.H, and Fikkan, P.R., 1976, The geology and mineralization of the Ambler district, Alaska: Spokane, Washington, Bear Creek Mining Company, 22 p.

Sidorenko, A.V., ed., 1974, Geology of the U.S.S.R. Vol. XOXXII, Sakhalin Island, Natural Resources: Nedra, Moscow, 207 p. (in Russian)

Sidorov, A.A., 1966, Gold-silver mineralization of the Central Chukotka: Nauka, Moscow, $146 \mathrm{p}$ (in Russian).

Sidorov, A.A. 1978, Gold-silver formation of East Asia volcanogenic belts: U.S.S.R. Academy of Sciences, North-Eastern Interdisciplinary Research Institute, Magadan, 370 p. (in Russian).

Sidorov, A.A., 1987, Ore formations of Phanerozoic provinces: U.S.S.R. Academy of Sciences, North-Eastem Interdisciplinary Research Institute, Magadan, 85 p (in Russian).

Sidorov, A.A. and Eremin, R.A.4 1995, Metallogeny of goidsiver deposits of northeast Russia, in Bundtzen, T.K. Fonseca, A.L, and Mann, Roberta, eds., The Geology and Mineral Deposits of the Russian Far East: Alaska Miners Association, Glacier House Publications, Anchorage, Alaska, p. 109-120.

Sidorov, A.A., and Rosenblum, 1.S., 1989, On gold-rare-metal formations in the U.S.S.R. Northeast: Geologiya Rudnykh Mestorozhdenily, no. 6. p. 95-98 (in Russian).

Sidorov. A.A. and Eremin, R.A. 1994, Metallogeny of the Russian Northeastern region and Alaska: a comparative study Geology of Pacilic Oceans, v. 11, p. 179-188.

Sidorov, A.A. Eremin, R.A., Vasilenko, V.P., Andreev, B.S. Grigorov, S.A. and Sawa, N.E, 1978, Geologicalstructural and mineralogical features of goid-arsenicantimony formation occurrences: Materialy po Geologi i Polzenym Iskopaemym Severo-Vostoka SSSR, U.S.R. Academy of Sciences, v. 24, p. $98-111$ (in Russian)

Silberling. N.J., Jones, D L., Monger, J.W.H., and Coney, P.J. 1992. Lithotectonic terrane map of the North American Cordiliera: U.S. Geological Survey Miscellanecus Investigations Series Map 1-2126, 2 sheets, scale $15.000,000$

Silkchev, M.K, and Skobelev, A.A., 1970, Nezhdanin goid lode deposit, in Data on geology and minerals of the Yakutia, USSR. v. 17: Yakutian Publishing House, p. 45-51 (in Russian)

Stkin. V.G., 1983, Chromium geology of the U.S.S.R: Nedra, Moscow, D. 45.50 (in Russian).

Simandi, G.J. and Hancock. K.D, 1991, Geology of the Mount Brussilof magnesite deposit, southeastem British Columbia, in Geciogical Fieldwork 1990: British Columbia Ministry of Energy. Mines and Petroleum Resources Paper 1991-1, p. 269-278.
Simanovich, I.M., 1978, Quartz of sandstone rocks: U.S.S.R. Academy of Sciences, Geological Instifute, no. 314. Nauka, Moscow, 156 p. (in Russian).

Sinclair, A.J., Bentzen, A, and McLeod, JA., 1979, Geology of the White River native copper deposit. Yukon Territory. Department of Indian and Northem Aflairs Canada, Publication no. QS-Y0001-000-EE-A1, 27 p.

Sinclair, A.J., Drummond, A.D., Carter, N.C., and Dawson, K.M. 1982. A preliminary analysis of gold and silver grades of porphyry-lype deposits in westem Canada, in Levinson. A.A. ed. Precious Metals in the Northem Cordiliera: Association of Exploration Geochemists Symposium Proceedings, Vancouver, British Columbia, p. 157-172.

Sinclair, W.D. 1986, Molybdenum, tungsten and tin deposits and associated granitoid intrusions in the northern Canadian Cordillera and adjacent parts of Alaska, in Morin, J.A., ed., Mineral Deposits of Northem Cordillera: Canadian Institute of Mining and Metallurgy Special Volume 37, p. 216-233.

Singer, D.A., 1993, Development of grade and tonnage modols for different deposit types, in Kirkham, RV., Sinclair, R.V.4 Thorpe, W.D., and Duke, J.M., eds., Mineral deposit modeling: Geological Association Canada Special Paper 40, 27 p. 21-30.

Singer, D.A. 1994. The relationship of estimated number of undiscovered deposits to grade and tonnage models in three-part mineral resource assessments: 1994 Intern. Assoc Math. Geology Annual Conference, Papers and Entended Abstracts, Oct. 3-5, 1994, Mount Tremblant, Quebec, Canada, p. 325-326.

Skalatsky, A.S and Yakovlev, VA., 1983, New data on geochemistry and mineralogy of goid-bearing veins in Western Chukotka: Kolyma, no. 10, p. 31-35 (in Russian).

Sketchiey, D.A., Rebagliati, C.M. and DeLong. C., 1995 , Geology, alteration and zoning patterns of the Mt. Milligan copper-gold deposits, in Schroeter, T.Q., ed. Porphyry Deposits of the Northwestem Cordiliera of North Amenca: Canadian Institute of Mining and Metallurgy, and Petroleum, Special Volume 46. p. 650-665.

Skibin, Yu. P., 1982, Copper-molybdenum mineralization of the northem Okhotsk Sea coastal area: Sovietsikaya Geologiya, no. 1, p. 78-85 (in Russian).

Smith, A.D., 1993. Geochemistry and tectonic setting of volcanics from the Anyox mining camp, British Columbia: Canadian Joumal of Earth Sciences, v. 30, P. 48-59.

Smith, J.G. 1977, Geology of the Ketchikan D-1 and Bradfield A-1 quadrangles, southeastem Alaska: U.S. Geological Survey Bulletin 1425, $49 \mathrm{p}$

Smith, M, 1999. Pogo, a new high-grade gold deposit in Alaska: labs.) Prospectors and Developers Association 1999 Annual International Convention and Trade Show Abstracts, p. 24.

Smith, M, 2000. The Tintina gold belt: An emerging gold district in Alaska and Yukon, in Tucker, T.L., and Smith, M.T. eds. The Tintina goid belt: Concepts. Exploration, and Discoveries: British Columbia and Yukon Chamber of Mines, Vancouver, Special Volume 2, p. 1-3.

Smith, M.T, and Gehrols, G.E., 1992, Detrital zircon geochronology of Upper Proterozole to lower Paleozoic continental margin strata of the Kootenay arc: Implications for the earty Paleczoic tectonic development of the eastem Canadian Cordillera: Canadian Joumal of Earth Sciences, v. 28, p. 1271-1284.

Smith, M. Thompson, J.F.H., Bressler, J. Layer, P., Mortensen, J.K. Abe, I., and Takaoka, H., 1999. 
Geology of the Liese zone, Pogo property, east-central Alaska: SEG Newsletter, Society of Economic Geologists, no. 38, p. $1,12-41$.

Smith, M. Thompson, J.F.H., Moore, K.H. Bressler, J.R., Layer, P., Mortensen, J.K., Abe, I., and Takaoka, H., 2000. The Liese zone, Pogo property: A new high-grade gold deposit in Alaska, in Tucker, T.L., and Smith. M.T., eds., The Tintina gold belt: Concepts, Exploration, and Discoveries: British Columbia and Yukon Chamber of Mines, Vancouver, Special Volume 2, p. 131-144.

Smith, T.E., 1981, Geology of Cleanwater Mountains, Alaska: Alaska Division of Geological and Geophysical Surveys Geologic Report 60, $71 \mathrm{p}$.

Solie, D.N., Bundtzen, T.K., and Gilbert, W.G., 1991, K-Ar ages of igneous rocks in the McGrath quadrangle. Alaska. Alaska. Divison of Geological and Geophysical Surveys Public Data File Report 91-23, 8 p.

Solov'ev, A.V., Brandon, M.T., Garver, Bogdanow, N.A., Shapiro, M.N., and Ledneva, G.V., 1998, Collision of the Olyutor island arc with the Eurasian continental margin: kinematic and age aspects: Doklady Earth Sciences, v. 361, p. 632634.

Soregaroli, A.E. and Nelson, W.I. , 1976, Boss Mountain, in Sutherland Brown, A., ed., Porphyry Deposits of the Canadian Cordiliera: Canadian Institute of Mining and Metallurgy Special Volume 15. p. 432-443.

Soregaroli, A.E., and Sutherland Brown, A., 1976. Characteristics of Canadian Cordilleran molybdenum deposits, in Sutherland Brown, A., ed. Porphyry Deposits of the Canadian Cordillera: Canadian Institute of Mining and Metallurgy Special Voiume 15, p. 417431.

Souther, J.G., 1991, Volcanic regimes, in Gabrielse, $H_{\text {., }}$ and Yorath, C.J., eds., Geology of the Cordileran Orogen: Boulder, Colorado, Geological Society of America, The Geology of North America, v. G-2, p. 457-490.

Southworth, D.D., and Foley, J.Y., 1986, Lode platinum-group metals potential of the Goodnews Bay ultramafic: complex, Alaska: U.S. Bureau of Mines Open-File Report 51-86, 82 p.

Spencer, A.C., 1905, The Treachell ore deposits, Douglas Island: United States Geological Survey Bulletin 259, p. 67-87.

Spencer, A.C., 1906, The Juneau gold belt, Alaska: United States Geological Survey Bulletin 287, $137 \mathrm{p}$.

Spilsbury. T.W., 1995, The Schaft Creek copper-molybdenumgold-silver porphyry deposit, nortwwestern British Columbia; in Schroeter, T.G., ed., Porphyry Deposits of the Northwestem Cordiller of North America, Canadian Institute of Mining and Metallurgy Special Volume 46, p. $239-246$

St Louls, R.M., Nesbitt, B.E., and Morton, R.D., 1986, Geochemistry of platinum group eiements in the Tulameen Ultramafic Complex, southem British Columbia: Economic Geology, v. 81, p. $961-973$.

Staniey, C.R., Holbek, P.M., Huyck, H.L.O., Lang. J.R., Preto, V.A.G., Blower, S.L., and Bottaro, J.C., 1995, Geology of the Copper Mountain alkalic copper-gold porphyry deposits, Princeton, British Columbia: Schroeter, T.G., ed. Porphyry Deposits of the Northwestem Corcillera of North America, Canadian Institute of Mining and Metalurgy. Special Volume 46, p. $537-564$

Stanley, W.D., Labson, V.F., Nokleberg. W.J., Csejtey, Béla, Jr., and Fisher, M.A., 1990. The Denall fault system and Alaska Range of Alaska: Evidence for suturing and thinskinned tectonics from magnetotellurics: Geological Society of America Bulletin, v. 102, p. 160-173.
Steefel, C.I., 1987, The Johnson River prospect, Alaska: goldrich sea-floor mineralization from the Jurassic: Economic Geology, v. 82, p. 894-914.

Steininger, R.C. 1985, Geology of the Kitsault molybdenum deposit, British Coiumbia: Economic Geology, v. 80, p. 57-71,

Stepanov, G.N., 1977. Mineralogy, petrology and genesis of scarn sheelite-sulfide ores of Far East: Nauka, Moscow, 177 p. (in Russian).

Stepanov, V.A., Shishakova, L.N., and Laipanov, H.H., 1991. Gold-silver deposits in volcanics of Kedon series: Materialy po Geologii i Polzenym Iskopaemym SeveroVostoka SSSR, U.S.S.R. Academy of Sciences, v. 27, p. $150-158$ (in Russian).

Stephens, G.C., 1972. The geology of the Salal Creek pluton, southwestern British Columbia: Bethiehem, Pennsylvania, Lehigh University, Ph D, dissertation, 177 p.

Stevens, D.L., 1971, Geology and geochemistry of the Denali prospect, Clearwater Mountains, Alaska: Fairbanks, University of Alaska, Ph.D. dissertation, 81 p.

Stevens, C.h., Davydov, V.I., and Bradley, D.C., 1997. Permian Tethyan fusilinicls from the Kenai Peninsula, Alaska: Joumal of Paleontology, v. 71, p. 985-994.

Stevenson, J.S., 1950, Geology and mineral deposits of the Zeballos area: British Columbia Department of Mines and Petroleum Resources, Bulletin 27, $145 \mathrm{p}$.

Stewart, J.H., 1975, Origin of Basin and Range structure; a review: Geological Society of America Abstracts with Programs, v. 7, no.7. p.1284.

Still, J.C., 1984, Stratiform massive sulfide deposits of the Mt. Henry Clay area, southeast Alaska: U.S. Bureau of Mines Open-File Report 118-84, 189 p.

Still, J.C., 1988a, Distribution of gold, platinum, palladium, and silver in selected portions of the Bohemia basin deposits, southeast Alaska (with an appendix section on Mirror Harbor): U.S. Bureau of Mines Open-File Report $10-88,42 \mathrm{p}$

Still, J.C., 1988b, Gold-copper mineralization of the Chilkat Peninsula and Islands: U.S. Bureau of Mines Open Fle Report OFR 49-88, 39 p.

Still, J.C., and Weir, KR., 1981, Mineral land assessment of the west portion of western Chichagof island, southeastern Alaska: U.S. Bureau of Mines Open-File Report 89-81. $168 \mathrm{p}$.

Stout, J.H., 1976, Geology of the Eureka Creek area, eastcentral Alaska Range: Alaska Division of Geological and Geophysical Surveys Geologic Report 46, 32 p., 1 sheet, scale 1:63,360.

Strona, PA., 1960, Conditions of formation ribbon structures of ores: Geology of Ore Deposits, no. 3. p. 77-87 (in Russian).

Struik, L.C., 1986, Imbricated terranes of the Cariboo gold belt with correlations and implications for tectonics in southeastern British Columbia: Canadian Joumal of Earth Sciences, v. 23. p. 1047-1061.

Struzhkov, S.F., Konstantinov, M.M., Aristov, V.V., Ryzhov, O.B., Shergina, Yu.P., 1994, New data on geology and age dates for gold and silver lode deposits in the Omsukchan area of the Okhotsk-Chukchi volcanic belt: Kolyma, no. 9-10, September-October, 1994, p. 2-15.

Sukhanov, M.K., and Zhuravlev, D.Z, 1989, Sm-Nd isotope dating of the Precambrian Dzhugdzhur anorthosites: Report of U.S.S.R. Academy of Sciences, v. 304, p. $964-968$ (in Russian).

Sutherland Brown, A, 1969, Ox (OxLake Property), in Geology. Exploration and Mining in British Columbia 1969: British 
Columbia Department of Mines and Petroleum Rescurces. p. $93-97$

Suthertand Brown, A., 1960, Geology of the Rocher Deboule Range: Brtish Columbia Department of Mines and Petroleum Resources Bulletin 43,78 p.

Sutherland Brown, A., Cathro, R.J., Panteleyev, A., and Ney, C.S., 1971 , Metallogeny of the Canadian Cordillera; in Canadian Institute of Mining and Metalurgy. Bulletin, v. 64, no. 709, D. 121-145

Sutherland Brown, A.,1968, Geology of the Queen Charlotte Islands, British Columbia: British Columbia Department of Mines and Petroleum Resources, Bulletin 54, 226 p.

Swainbank, R.C., Bundtzen, T K., and Wood, J., 1991, Alaska's mineral industry 1990: Division of Geological and Geophysical Surverys, Special Report 45, $78 \mathrm{p}$.

Swainbank, R.C., Bundtzen, T.K., Clough, A.H., Henning. M.M. and Hansen, E.W., 1995, Alaska's mineral industry 1994. Alaska Division of Geological and Geophysical Surveys Special Report 49, 75 p.

Swainbank, R.C., Smith, T.E, and Turner, D.L., 1978, Geology and $K-A r$ age of mineralized intrusive rocks from the Chulitna mining district, central Alaska. Alaska Division of Geoiogical and Geophysical Surveys Geologic Report 55. p. $23-28$

Swainbank, R.C., and Szumigla, Davo, 2000, Alaska's Mineral Industry - 1999: Alaska Division of Geological and Geophysical Surveys Special Report 54, 73 p.

Swanson, S.E.. Bull, K.F., Newberry, R.J., and Bundtzen, T.K. 1987. Late Cretaceous magmatism in the Kuskokwim Mountains bolt. southwest Alaska [abs.] Geological Society of America Abstracts with Programs, v. 19, no. 7. p. 861 .

Swanson, S.F., Bond, J.F, and Newberry, R.J., 1988, Petrogenesis of the Ear Mountain tin granite, Seward Peninsula, Alaska: Economic Geology, v. 83, p. 46-61.

Syromyatnikov, A.L., 1972. Many-storey ore shoots in Western Palyan mercury deposit (Chukotka): Problems of Ore Shoots Formation: Nauka, Novosibirsk, p. 307-312 (in Russian).

Syromyatnikov, A.L, and Dubinin, E.G., 1978, Tectonic control of mercury mineralization distribution in the Palyan dome volcano structure Mercury mineralization in orogenic volcanic complexes of the U.S.S.R. Northeast: U S.S.R. Academy of Sciences, North-Eastern Interdisciplinary Research Institute, Magadan, p. 144. 151 (in Russian)

Szumigala. D J., 1987, Geology of the zinc-lead skam deposits of the Tin Creek area, McGrath B-2 quadrangle, Alaska: Alaska Division of Geological and Geophysical Surveys Report of investigations 87-5, 21 p. 1 sheet, scale 1.5 .000 .

Szumigala. D.J. 1993, Gold mineralization related to Cretaceous-Tertiary magmatism in the Kuskokwim Mountains of west-central and southwest Alaska. Ph.D Thesis, University of Calfornia, Los Angoles, California. $301 \mathrm{p}$

Talleur, IL. 1970, Lead, zinc, and barite-bearing samples from the wostern Brooks Range. Alaska. with a section on petrography and mineralogy by G. D. Eberlein and Ray Wehy: U.S. Geological Survey Open-File Regort 445, 16 P.

Tarasenko, T.V., and Thov, LN. 1969, Main features of metallogeny of the central and southwestein Koryak Highlands: Materials on Geology and Minerals of the Koryak Nighlands, Petropavlovsk-Kamchatsky; U.S.S.R. Academy of Sciences, D. 3-20 (in Russian)
Tarasenko, T.V., and Titov, I,N., 1970, Mercury ore capacity of the Kamchatka region and prospects of mercury mining industry development: Materials of conference on Kamchatka region productive forces development up to 1980, Petropavloysk-Kamchatsky. p. 128-136 (in Russian).

Takahashi, R., Matsueda, H., Okrugin, V.M. Okrugina, A.M. and Ono, S., 2002, Outline of hydrothermal activity and related mineralization in Kamchatka, Russia [abs.] Society of Resource Geology Abstracts with Programs. Tokyo, Japan, p. 4.

Takahashi, Ryohei, Matsueada, Hiroharu, and Okrugin, V.M. 2001, Eplthermal gold and silver mineralization at the Rodnikowoe $\mathrm{Au}-\mathrm{Ag}$ deposit-related to the hydrothermal activity in the Mutnovsko-Asachinskoye geothermal area, southern Kamchatka, Russia: 2001 Intemational Symposium on Gold and Hydrothermal Systems. Fukuoka, Japan, p. 51-56.

Taylor, H.P., 1967. The zoned ultramafic complexes of southeastern Alaska, in Wyle. P.J., ed., Ultramafic and related rocks: New York, John Wiley, p. 97-118.

Taylor, C.D., Goldfarb, R.J., Snee, L.W. Gent, C.A., Kart, S.M. and Haeussler, P.J., 1994, New age data for goid deposits and granites, Chichagof mining district, SE Alaska: Evidence for a common origin [abs.]: Geological Society of America Abstracts with Programs, v. 26, p. A. 140.

Taylor, C.D., Philpotts, J.A., Sutley, S.J., Gent, C.A., Harlan, S.S., Premo, W.R. Tatsumoto, M., Emsbo, P., and Meier, A.L. 1995, Geochemistry of Late Triassic volcanic host rocks and age of alteration associated with volcanogenic massife sulfide occurrences, Alexander terrane, southeast Alaska [abs.]. Geology and Ore Deposits of the American Cordillera, Reno/Sparks, Nevada, 1995, Program with Abstracts, p. A74.

Taylor, G.C., and Stott, D.F., 1973, Tuchod Lakes map-area, British Columbia: Geological Survey of Canada Memcir $373,37 \mathrm{p}$.

Taylor, G.C. Macqueen, R.W., and Thompson, R.I. 1975. Facies changes, breccias and mineralication in Devonian rocks of Rocky Mountains, northeastern British Columbia (94B, G, K, N), in Report of Activities, Part A: Geological Survey of Canada Paper 75-1A, D. 577.585 .

Taylor, H.P. 1967, The zoned ultramafic intrusions of southeastem Alaska, in Wyllie, PJ, ed, Ultramafic and relatod Rocks: John Wiley and Sons, New York, p. 99-121.

Tempeiman-Kuat, D., 1979. Transported cataclasile, ophiolite, and granodionite in Yukon: evidence of aro-continent collision. Geological Survey of Canada Paper 79-14, 27 p

Tempeiman-10ut, D.J. and Parkinson, D, 1986, Extension across the Eocene Okanagan crustal shear in southem British Columbla: Geology, v. 14, p. 318-321.

Thompson, TB. 1997, Uranium, thorium, and rare metal deposits of Alaska, in Goldtarb, R.J., and Miller, L.D. ods. Mineral deposits of Alaska: Economic Geology Monograph 9, p. 466-482.

Thorkolson. D.J. and Walsce, C.A. 1993. Development of Wemecke breccial in Slats Creek (1060/16) map area, Wemeke Mountains; in Yukon Exploration and Geology. 1992; Exploration and Geological Services, Yukon; Indianand Northem Aftairs Canada, p. 77-87.

TE. A.B. and Dumoulin, J.A. 1994. Goology of Seward Poninsula and Saint Lawrence island, in Plafker, G. and Berg. H.C. eds. The Geology of Alaska: Boulder, 
Colorado, Geological Society of America: The Geology of North America, v. G1, p. 141-152.

Tilman, S.M., Byaiobzhesky, S.G., and Chekhov, A.D., 1982. Tectonics and history of the Koryak geosynclinal system development: Essays on teclonics of the Koryak geosynclinal system development: Essays on tectonics of the Koryak Highlands: Nauka, Moscow, p. 5-30 (in Russian).

Trunilina, V.A., Parfenov, L.M., Layer, P., and Zaitsev, A.I., 1996. Middle Paleozoic Tommot massif of alkali gabbo and syenite of Verkhoyansk-Kolyma Mesozoides and its tectonic setting: Geologia i Geofizika, no. 4. p. 71-82 (in Russian).

Tucker, T.L., and Smith, M.T., eds., 2000, The Tintina gold belt: Concepts, Exploration, and Discoveries: British Columbia and Yukon Chamber of Mines, Vancouver. Special Volume 2, 225 p.

Turner, D.L., Herroid, G., and Bundtzen, T.K., 1977. Geochronology of Southem Prince of Wales island. Alaska. In Short Notes on Alaskan Geology. Edited by F. Larsen, Alaska Division of Geological and Geophysical Surveys Geologic Report 55, p. 11-16.

Tumer, R.J.W., 1990, Jason stratiform Zn-Pb-Ba deposit, Sewyn Basin Yukon: Geological setting, hydrothermal facies and genesis, in Abbott, J.G. and Turner, R.J.W. ed., Mineral Deposits of the Northern Canadian Cordillera, Yukon-British Columbia, Fieldtrip Guidebook, Field Trip no. 14, 8th IAGOD Symposium: Geological Survey of Canada, Open File 2169

Tumer, R.J.W., and Abbott, J.G, 1990, Regional setting. structure, and zonation of the Marg voicanogenic massive sulphide deposit, Yukon, in Current Research: Geoiogical Survey of Canada Paper 90-1E, p. 31-41.

Twenhofel, W.S. 1952, Geology of the Alaska-Juneau lode system, Alaska: U.S. Geological Survey Open-File Report 52-160, $170 \mathrm{p}$.

Twenhofel, W.S., Reed, J.C., and Gates, G.O., 1949, Some mineral investigations in southeastem Alaska: U.S. Geological Survey Bulletin 953-A, p. 1-45.

Tysdal, R.G., 1978, Mines, prospects and occurrences map of the Soward and Blying Sound quadrangle5, Alaska: U.S. Geological Survey Miscellaneous Field Studies Map MF. B80A. 2 sheets, scale $1: 250,000$.

Umhoofer, P.J., 1987, Northward transiation of Baja British Columbia* along the Late Cretaceous to Paleocene margin of westem North Arnerica: Tectonics. v. 6. p. 377 . 394.

Unrug. Raphael, 1997, Rodinia to Gondwana: The geodynamic map of Gondwana superoontinent assembly: GSA Today. v. 7. p. 1.6.

Vailancourt, P.de G., 1982, Geclogy of pyrte-sphalerite-galena concentrations in Protercatic quartzite at Ouartz Lake, souttwestem Yukon: in Yukon Exploration and Geology 1982, Indian and Northem Affairs Canada, Exploration and Geological Services, Whitehorse, p. 73-77

Vallier, T. L. Wilson, F.H, von Huene, R., and Stevenson, A.J., 1994, Geologic framework of the Aleutian arc, Alaska, in Plafker, George, and Berg. H.C., eds. The Geology of Alaska: Bouldor, Colorado, Geological Society of America, The Geology of North America, v. G-1, p. 367. 388

Valuy, G., and Rostovsky. F, 1968, Intrusive magmatism and ore mineralization in the Coastal zone, the East-Sikhote Alin volcanic belt, in in Setmann, $R$. Gonevchuk. $G$. and Khanchuk, A. eds., International Fieid Conference in Vladivostok, Russia, September 1998:
GeoForschungsZentrum Potsdam (GFZ). Potsdam, p. 77-107.

Van Alstine, R.E., and Black, R.F., 1946, Copper deposits of the Kotsina-Kuskulana district. Alaska: U.S. Geological Survey Bulletin 947-G. p. 121-141.

van der Heyden, P. 1992, A Middle Jurassic to earty Tertiary Andean-Sierran arc modei for the Coast Belt of British Columbia: Tectonics, v.11, p. 82-97

Vance, JA. Clayton, G.A. Mattinson, J.M., and Naeser, C.W., 1987. Early and middle Cenozoic stratigraphy of the Mount Rainier-Tieton River area, southem Washington Cascades, in Schuster, J.E., ed., Selected papers on the geology of Washington: Wasington Division of Geology and Earth Resources Bulletin 77, p. 269-290.

Vasilenko, V.I., Ivankin, P., Scherbinin, V.A., 1966, Geology of tin-bearing districts and deposits of the Sikhote-Alin tin-bearing area: Geology of Tin Deposits of the U.S.S.R.: Nedra, Moscow, v. 1, p. 280-339 (in Russian).

Vasilenko, V.I, and Valuy, G., 1998, The Dal'negorsk ore district, in Seltmann, R., Gonevchuk, G., and Khanchuk. A., eds., International Field Conference in Vladivostok. Russia, September 1998: GeoForschungsZentrum Potsdam (GFZ). Potsdam, p. 23-50.

Vemikovsky, VV. Vernikovskaya, AE, and Chernykh, A.I. 1998, Neoproterozoic Taymyr ophiolitic belts and opening of the Paleo-Pacific Oceant International Geology Review, v. 40 , p. $528-538$

Vivian, G. Morton, R. ., Changkakot. A., and Gray, J., 1987. Biackdome Eocene epithermal Ag-Au deposit, British Columbia, Canade - Nature of ore fluids: Transactions of Institute of Mining and Metallurgy, v. 96, p. B9-B14.

Vlasov, G.M., ed. 1971, Volcanic sulfur deposits and some problems of hydrothermal mineralization: Nedra. Moscow, 360 p. (in Russian).

Vlasov, GM. ed. 1976, Sulfur-sulfide deposits of active volcanic regions: Nedra, Moscow, 350 p. (in Russian).

Vlasov, GM., ed, 1977, Geology of U.S.S.R., Kamchatka Peninsula, the Kuril and Komandor Islands, Natural Resources., Nedra, Moscow, v, 31, 351 p. (in Russian).

Voevodin, V.N. Garan, V.1. Zhitkov, N.G., Permyakov, A.P. and Tsopanov, O.H., 1979, Tungsten ore-mineralization in listvenites of the Tamvatney ore district: Geologiya Rudnykh Mestorozhdenly, no. 3, p. 43-55 (in Russian).

Voevodin, V.N. Sidorenko, G.A. Voevodina, S.A. Zhitkov. N.G. Sushentsov, V.S. and Permyakov, A.P. 1980. Mineral composition of the tungsten ores in listwanites of the Tarnvatneyan ore field: Sovietsicaya Geologlya, no. 7, p. $98-100$ (in Russian).

Vogt. P.R. Taylor, P.T., Kovacs, LC., and Johnson, G. L, 1979, Detailed aeromagnefic imvestigation of the Auctic Basin. Joumal of Geophysical Research, v. 84, no. B, p. 10711090.

Volchikov. A.G. Sokirkin, G.I. and Shishakov, V.B., 1982, Geological structure and the composition of ores of the Anyui porphyry-copper deposit. northeast of the U.S.S.R.: Geologiva Rudnykh Mestorozhdenily, no, 4, p. 89-94 (in Russian)

Volkodav, I.G. Indolev, LN, and Blanenko, V.A. 1979, Copper, lead, and zinc in Arkhipov, Yu.V.s and Frumkin, IM. eds. Geology of U.S.S. R. Minerals of Yakutia: Nedra, Moscow, v. 18, p. 134-174 (in Russian).

Volskicy, A.S., 1983. Geologic struchure and history of the Upper Prinorye Summary of Ph.D. thesis, Ministry of Geology. VSEGEl, Leringrad, $25 \mathrm{p}$. (in Russian).

Voroshin, S.V., Eremin, R.A. Tyukova, E.E, and Shakhtyrov, V.G. 1989, New evidences of structure and mineralogy of the Omchak district: Geochemistry and mineralogy of 
ore deposits of the U.S.S.R. Northeast: U.S.S.R. Academy of Sciences. North-Eastem Interdisciplinary Research Institute, Magadan, p. 67-86 (in Russian)

Vrublevsky. A.A., Mel'nikov, N.G., Golozubov, V.V., Shevelev, E.K., Yushmanov, Yu.P., and Isozov, L.A., 1988, Mixtites of the Sikhote-Ain fold belt U.S.S. Academy of Sciences, Vladivostok, $111 \mathrm{p}$.

Vulimin, M.R., Tegart, $P$, and Stammers, M.A., 1986, Lawyers goid-silver deposits, British Columbia, in Morin, J.A ed.. Mineral Deposits of the Northem Canadian Cordillera. Canacian Institule of Mining and Metallurgy Special Volume 37, p. 191-201.

Wallace, W.K., Hanks, C.L., and Rogers, J.F., 1989, The southem Kahiltna terrane: Implications for the tectonic evolution of southwestern Alaska. Geological Society of America Bulletin, v. 101, p. 1389-1407

Wamer, J.D. and Barker, J.C., 1989, Columbium- and rareearth element bearing deposits at Bokan Mountain. southeast Alaska: U.S. Bureau of Mines Open-File Report 33-89, $196 \mathrm{p}$.

Warner, L.A., and Goddard, E.N., 1961, Iron and copper deposits of Kasaan Peninsula, Prince of Wales Island, southeastern Alaska: U.S. Geological Survey Bulletin $1090,136 \mathrm{p}$

Wayland. R.G., 1943, Gold deposits near Nabesna, Alaska: U.S. Geological Survey Bulletin 933-B, p. 175-197.

Wayland, T.B., 1991, Skarn genesis of the Nabesna mine. south-central Alaska: Unpublished M.S. thesis, Fairbanks, University of Alaska, 173 p.

Watson, K.W., 1986, Silver-lead-zinc deposits of the Keno HalGalena Hill area, central Yukon, in Morin, J.A. and D.S. Emond, eds, Yukon Geology. Exploration and Geological Services Division: Department of Indian and Northern Affairs Canada, v. 1, p. 83-89.

Watson, P.H. 1984, The Whitehorse Copper Belt (105 D/11-a), Yukon: Exploration and Geological Services Division, Indian and Northern Affairs Canada, Open Fle Map, scale $1.25,000$.

Watson, P.H., Godwin, C.1, and Christopher, P.A., 1982, General geology and genesis of siver and goid veins in the Beaverdell area, south-central British Columbia: Canadian Joumal of Earth Sciences, v. 19, p. 1264-1274.

Webster. L.C.L., and Ray, G.E. 1990, Geology and mineral deposits of northem Texada Island, in Geological Fieldwork 1989: British Columbia Ministry of Energy. Mines and Petroleum Resources Paper 1990-1, D. 257. 265.

Weeks, R.M. Bradburn, R.G., Flintoff, B.C., Harris, G.R, and Malcom, G. 1995. The Brenda mine: The life of a lowcost porphyry copper-molybdenum producer (19701990 ), southern British Columbia, in Schroeter. T.G, ed. Porphyry Deposits of the Northwestem Cordilera of North Amenca: Canadian Institule of Mining and Metallurgy, and Petroleum. Special Volume 46, p. 192-200.

Wells, R.E, and Heller, PL. 1988. The relative contribution of accrotion, shear, and extension to Cenozoic tectonic rotations in the Pacific Northwest: Geological Society of America Bulletin, v. 100 , p. $325-338$ Wels, D.E, Pittrman, T.L. Brew, D.A. and Douglass, S.L. 1986, Map and description of the mineral deposits in the Juneau. Taku River, Allin and part of the Skagway quadrangles, Alaska U.S. Geological Survey Open-File Report 85$717,332 \mathrm{p}$

Wells, R.R. and Thorne, R.L., 1953, Concentration of Klukwan magnetite ore: U.S. Bureau of Mines Report of investigations 4984, 15 p.
West. W.S., 1954, Reconnaissance for radioactive deposits in the lower Yukon-Kuskokwim region, Alaska: U.S. Geological Survey Circular 328, $10 \mathrm{p}$

Whalen, J.B., Struik, L.C. and Hrudey, M.G.4 1998, Bedrock geology of the Endako map area, central British Columbia; in Current Research, 1998-A, Geological Survay of Canada, p. 113-123.

Wheeler, J.O. and McFeeley. P. 1991. Tectonic assemblape map of the Canadian Cordillera and adjacent parts of the United States of America. Geological Survey of Canada Map 1712A, 3 sheets, scale 1:2,000,000.

Wheeler, J.O. Brookfield, A.J., Gabrielse, H. Monger, J.W.H. Tipper, H.W. and Woodsworth, G.J., 1988, Terrane map of the Canadian Cordiliera: Geological Survey of Canada Open File Report 1894, scale 1:2,000,000, 9 p.

While, W.H., Sinclair, A.J., Harakal, JE, and Darwson, K.M., 1970. Potassium-arpon ages of Topiey Intrusions near Endako, British Columbia, Canadian Joumal of Earth Sciences, v. 7. p. $270-316$.

Wilson, F.H. 1985, The Meshik aro-an Eocene to earlest Miocene magmatic arc on the Alaska Peninsula: Alaska Division of Geological and Geophysical Surveys Professional Report 88, $14 \mathrm{p}$.

Wilson, F.H., and Cox, D.P., 1983, Geochronology. geochemistry, and tectonic environment of porphyry mineralcation in the central Alaska Peninsula: U.S. Geological Survey Open-File Report 83-783, 24 p.

Wilson, F.H., Detterman, R.L., and DuBois, G.D. 1993. Geologic framework of the Alaska Peninsula, southwest Alaska, and the Alaska Peninsula terrane. U.S. Geological Survey Bulletin $1969 \cdot \mathrm{B}$, in press.

Wilson, F.H. Shew, N.B, and DuBois, G.D., 1994, Map and tables showing isotopic age data in Alaska, in Plafker, Georpe, and Berg. H.C., eds. The Geology of Alaskar Boulder, Colorado, Geological Society of America, The Geology of North America, v. G-1, Plate 8, 1 sheet. scale $12,500,000$.

Wilson, M.R., and Koyser. T.K., 1905, Geochemistry of porphyry-hosted gold deposits in the Litsie Rocky Mountains Montana, Economic Geology v. 83, p. 1329. 1346.

Wiltse, M.W. 1975, Geology of the Arctic Camp prospect. Ambler River quadrangle. Alaska: Alaska Division of Geological and Geophysical Surveys Open-File Report $60,41 \mathrm{p}$.

Winkler, G.R, and Plafker, George, 1981, Geological map and cross sections of the Cordova and Middleton Istand quadrangles, southern Alaska: U.S. Geological Survey Open-File Report 81-1164, 25 p. 1 map sheet, scale 1:250,000.

Winkler, G.R., Miller, R.J., Mackevett, E M, Jr., and Holloway. C.D., 1981a, Map and summary table describing mineral deposits in the Valdez quadrangle, southern Alaska: U.S. Geological Survey Open-Fle Report 80-892-8, 2 map sheets, scale 1:250,000.

Winkler, G.R., Silberman, ML, Grantz, Arthur, Miller, R.J., and Mackevett. EM. Jr., 1981b, Geologic map and summary geochronology of the Valdez quadrangle, southern Alaska: U.S. Geclogical Survey Open-File Report 80-892-A, 1 map sheet, scale 1:250,000.

Wolfe, W.J. 1995. Exploration and geology of the Quartz Hill molybdenum depost, southeast Alaska, in Schroeter, T.G. ed. Porphyry Deposits of the Northwestem Cordillera of North America, Canadian Instate of Mining and Metallurgy Special Volume 46, p. 764-770.

Wolthard, MR, 1976. Fish Lake, in Sutherland Brown, A, ed. Porphyry Deposits of the Canadian Cordillera: Canadian 
institute of Mining and Metallurgy Special Volume 15, p. $317-322$

Wojdak, P. and Stock, G.C., 1995, Big Onion: A supergeneaitered porpohyry copper-gold deposit, west-central British Columbia, in Schroeter, T.G., ed., Porphyry Deposits of the Northwestem Cordillera of North America: Canadian Institute of Mining and Metallurgy, and Petroleum, Special Volume 46, p. 410-415.

Woodsworth, G.J.. Anderson, R.G., and Armstrong, R.L., 1991, Plutonic regimes, Chapter 15, in Gabrielse, $H$. and Yorath, C.J., eds., Geology of the Cordilleran Orogen in Canada: Geological Survey of Canada, Geology of Canada, no. 4. p. 491-531.

Woodsworth, G.J., Anderson, R.G., and Ammstrong. RL., 1992, Plutonic regimes, in Gabrielse, $\mathrm{H}_{4}$, and Yorath, C.J., eds, Geology of the Cordilleran orogen, Canada: Boulder, Colo., Geological Society of America, The Geology of North America, v. G-2, D. 493-631.

Woodsworth, G.J., Pearson, D.E., and Sinclair, A.J. 1977, Metal distribution pattems across the eastem flank of the Coast Plutonic Complex, south-central British Columbia: Economic Geology, v. 72, p. 170-183.

Worall, D.M. Kruglyak, V., Kunst, F, and Kuznetsov, V., 1996, Tertiary tectonics of the Sea of Okhotsk, Russia: far-field effects of the India-Eurasia collision: Tectonics, v. 15, no. 4. p. $813-826$

Yeo, GM., 1986, Iron-formation in th late Proterozoic Rapitan Group. Yukon and Northwest Territories, in Morin, J.A. ed., Mineral Deposits of Northern Cordillera: Canadian Institute of Mining and Metallurgy Special Volume 37. p. 142-153

Yeo, GM, 1992. Phosphontes, ironstones, and secondary phosphates in mid-Cretaceous flysch of the Blow Trough. northem Yukon, in Yukon Geology. Exploration and Geciogical Services Division, Yukon Department of Indian and Northem Allairs, Canada, v. 3. p. $27-36$.

Yole, RW. 1969. Upper Paleoroic stratigraphy of Vancouver Island: Proceedings Geological Association of Canada, v. 20. p. $30-40$.

Young. F.G. 1977. The mid-Cretacecus flysch and phosphatic ironstone sequence, northem Richardson Mountains, Yukon Territory, in Repon of Acfivities, 1977: Geological Survey of Canada Paper 77-1C, p. 67-74

Young. F.G. 19e2, The late Proterozoic Tndir Group. east: central Alaska: Evciution of a continental margin: Geciogical Young. F.G, 1977a: Stratigraphic correiation of upper Protercuoic rocks of northwestem Canada. Canadian Joumal of Earth Sciences, v. 14, D. 1771-1787.

Young. G.M. Jefterson, C.W., Delaney. G.D. and Yeo. G.M. 1979. Mode and Late Proterozoic evolution of the northem Canadian Cordilera and Shieid, Geology, v. 7, p. 125-128.

Young. GM., 1977, Stratigraphic correlation of the upper Proterozoic rocks of northwestem Canada. Canadian Joumal of Earth Sciences, v, 14, p.1771-1787

Young. LE, St. George, P.a and Bouley, B.A. 1997, Perphyry copper deposts in relation to the magmatic history and palinspastic restoration of Alaska, in Goldtarb, R.J., and Milier, L.D. eds. Mineral Deposits of Alaska: Economic Geology Monograph 9, p. 306-333

Yukon Minfle. 1962-1964, 1986-1967, 1989-1990, Mineral Resources Branch, Yukon Terntorial Government. Canada: Internet mineral deposit data base avalable at http:l/www geology. gov yk ca/publications/minfile/

Zagruzina, 1.A., and Pokazanyev, V.P., 1975, On Paleozoic ape of gold mineralization in Omolon massit: Geologya Rudnykh Mestorozhdeniy, no. 1, p. 74-80 (in Russian).
Zakharov, V.A., Ilyna, V.I., Meledina, S.V., Nakhyaeva, T.L. and Shurygin, B.N. 1984. The Jurassic system: the Phanerozoic of Siberia, the Mesozoic and Cenozoic: Nauka, Novosibirsk, p. 16-53 (in Russian).

Zalishchak, B. L. Lennikov, A.M., Oktyabresky, R.A., Nokrasov, I.Ya., Ivanov, V.V., and Mramorov, V.N., 1993, Mineralization of zoned alkalic-ultrabasic complexes of the Kondyor type, Far East Russia: Far East Geological Institute Special Paper, Vladivostok, Russia, 22 p. (in Russian)

Zalishchak, B.L., Petrachenko, R.I, Piskunov, Yu.G., and others, 1978. Major original features of the Ulsky volcanic-plutonic structure, lower Amur region), in Govorov, I.N. ed. Genesis of endogenous mineralization of the Russian Far East: U.S.S.R. Academy of Sciences, Far East Geological Institute, Vladivostok, D. 130-139 (in Russian).

Zhang, X. Nesbitt, BE, and Muehlenbachs, K, 1989, Gold mineralization in the Okanagan Valley, southem British Columbia: Fluid inclusion and stable isotope studies: Economic Geology, v. 84, p. 410-424.

Zhulanova, I.L. 1990. The Earth's crust of the Northeast Asia in the Precambrian and Phanerozoic: Nauka, Moscow, 304 $p$ (in Russian).

Zilbermints, A.V. 1966, Geology and genesis of the lultin tintungsten deposit: Nauka, Moscow, 191 p. (in Russian).

Zimin. S.S. 1985, On the genesis of the Gar deposit in the Amur Region, in Zimin, S.S., ed., Geology, magmatism, and mineralization of Primorye: U.S.S.R. Academy of Sciences. Amur Interdisciplinary Science Research Institute, Vadivostok, p. 3-7 (in Russian).

Zimin, S.S., and Konoplev, 1.1., 1989, Perspectives of the Selemdzha iron ore zone, in Moiseenko, V.G., ed., Iron ores of the Russian Far East U.S.S.R. Academy of Sciences, Far East Branch, Vladivostok, p. 76-03 (in Russian)

Zimmerman. Jay, and Soustek, P.G, 1979. The Avan Hills ultramafic complex, DeLong Mountains, Alaska: U.S. Geological Survey Circular 804-B, p. B8-811.

Zonenahain. L.P., Kuzmin, M.I., and Natapov, L.M., 1990. Geology of the U.S.S.R.: A plate-tectonic synthesis: American Geophysical Union Geodynamics Series, v. 21. 242 p.

Zubkov, Yu.A., 1984, The regular distribution of gold mineralization as related to the granitoid rock mass morphology in Yakutia, in Lazebnik, K.A.4 ed., Minerals of Yakutia: Scientific Bulletin, U.S.S.R. Academy of Sciences, Siberian Branch, Institute of Geology. Yakutsk, p. 12-15 (in Russian). 
TABLE 1. Mineral depesit models for classification of siqnificant lode deposits and for metallogenic amalysis of Russian Far East, Alaska, and the Canadian Condiliera.

\begin{tabular}{|c|c|}
\hline Deposit Group & Related Deposit Models \\
\hline $\begin{array}{l}\text { Deposits related to marine felsic to mafic extrusive } \\
\text { rocks }\end{array}$ & $\begin{array}{l}\text { Kuroko } \mathrm{Zn}-\mathrm{Pb}-\mathrm{Cu} \text { massive sulfide ( } \mathrm{Ag}, \mathrm{Au}, \mathrm{Cd}, \mathrm{Sn}, \mathrm{Sb} \text {, } \\
\mathrm{Bi} \text {, barite) } \\
\text { Besshi } \mathrm{Cu}-\mathrm{Zn} \text { massive sulfide ( } \mathrm{Cu}, \mathrm{Zn}, \mathrm{Ag}) \\
\text { Cyprus } \mathrm{Cu}-\mathrm{Zn}-\mathrm{Ag} \text { massive sulfide ( } \mathrm{Au}, \mathrm{Pb}, \mathrm{Cd}, \mathrm{Sn}) \\
\text { Volcanogenic } \mathrm{Mn} \\
\text { Volcanogenic } \mathrm{Fe}\end{array}$ \\
\hline Deposits related to subaerial extrusive focks & $\begin{array}{l}\text { Au-Ag epithermal vein } \\
\text { Volcanic-hosted } \mathrm{Hg} \text { (Plamennoe type) } \\
\text { Hot spring } \mathrm{Hg} \\
\text { Silica-carbonate } \mathrm{Hg} \\
\text { Volcanic-hosted } \mathrm{Sb} \text { ( } \mathrm{Au}, \mathrm{Ag}, \mathrm{As} \text { ) vein } \\
\text { Rhyolite-hosted } \mathrm{Sn} \\
\text { Sulfur-sulfide (S, FeS2) }\end{array}$ \\
\hline $\begin{array}{l}\text { Stratiform deposits in fine-grained clastic and siliceous } \\
\text { sedimentary rocks }\end{array}$ & $\begin{array}{l}\text { SEDEX Zn-Pb-Ag } \\
\text { Bedded barite }\end{array}$ \\
\hline $\begin{array}{l}\text { Stratabound deposits in coarse clastic sedimentary rocks } \\
\text { and subaerial basalts }\end{array}$ & $\begin{array}{l}\text { Sediment-hosted Cu (Kupferschiefer and Redbed) } \\
\text { Basaltic Cu (Dzhalkan type) } \\
\text { Clastic sediment-hosted Hg (Nikitovka type) } \\
\text { Sandstone-hosted U }\end{array}$ \\
\hline Deposits in carbonate and chemical-sedimentary rocks & $\begin{array}{l}\text { Kipushi } \mathrm{Cu}-\mathrm{Pb}-\mathrm{Zn} \\
\text { Southeast Missouri Pb-Zn } \\
\text { Korean Pb-Zn massive sulfide } \\
\text { Ironstone (Superior Fe) } \\
\text { Stratabound W (Austrian Alps-type) } \\
\text { Carbonate-hosted Hg (Khaidarkan type) } \\
\text { Stratiform } \mathrm{Zr} \text { (Algama Type) } \\
\text { Sedimentary phosphorite }\end{array}$ \\
\hline $\begin{array}{l}\text { Deposits related to calc-alkaline and alkaline granitic } \\
\text { intrusions- veins and replacements }\end{array}$ & $\begin{array}{l}\text { Polymetallic veins } \\
\text { Sb-Au veins (simple Sb deposits) } \\
\text { Sn quartz veins (Rudny Gory or Replacement Sn) } \\
\text { So silicate-sulfide veins (Cornish type) } \\
\text { So polymetallic veins (Southem Bolivian type) } \\
\text { Co-arsenide polymetallic veins } \\
\text { Carbonatite-related } T_{h}, \mathrm{Nb}, \mathrm{REE} \text { stockwork and vein }\end{array}$ \\
\hline $\begin{array}{l}\text { Deposits related to calc-alkaline and alkaline granitic } \\
\text { intrusions - skams and greisens }\end{array}$ & 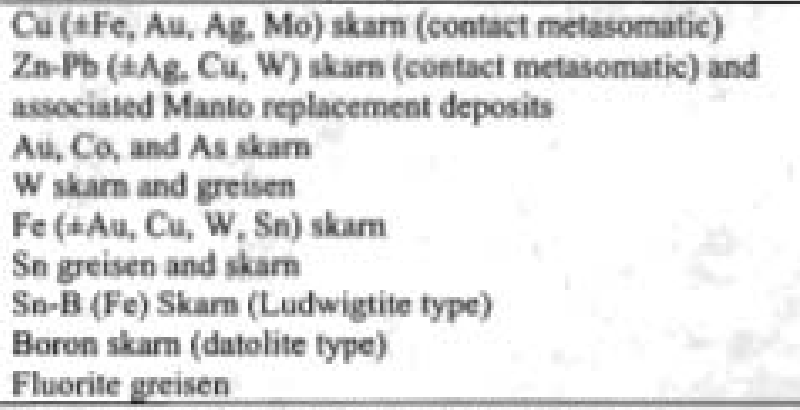 \\
\hline $\begin{array}{l}\text { Deposits related to calc-alkaline and alkaline granitic } \\
\text { intrusions }\end{array}$ & $\begin{array}{l}\text { Porphyry and Granitic Plutons-Hosted Deposits } \\
\text { Porphyry } \mathrm{Cu}-\mathrm{Mo}(\mathrm{Au}, \mathrm{Ag}) \\
\text { Porphyry Mo }( \pm \mathrm{W}, \mathrm{Sn}, \mathrm{Bi}) \\
\text { Porphyry Sn } \\
\text { Granitoid-related } \mathrm{Au} \\
\text { Felsic plutonic U-REE } \\
\text { W vein }\end{array}$ \\
\hline Deposits related to mafic and ultrumafic rocks & $\begin{array}{l}\text { Zoned mafic-ultramafic } \mathrm{Cr}-\mathrm{PGE} \text { ( } \pm \mathrm{Cu}, \mathrm{Ni}, \mathrm{Au}, \mathrm{Co}, \mathrm{Ti} \text {, } \\
\text { or Fe) (Alaskan-Uralian } \mathrm{PGE} \text { ) } \\
\text { Zoned ultramafic, mafic, felsic, and alkalic PGE-Cr and } \\
\text { apatite- } \mathrm{T} \text {. }\end{array}$ \\
\hline
\end{tabular}


Anorthosite apatite-Ti-Fe

Gabbroic Ni-Cu (PGE)

Podiform $\mathrm{Cr}$

Homblende-Peridotite $\mathrm{Cu}-\mathrm{Ni}$ (PGE)

Serpentine-hosted asbestos

Deposits related to regionally metamorphosed rocks

Au quartz vein (includes concordant vein, and sheat zone $\mathrm{Au}$ )

Disseminated Au-sulfide (Maiskoe type)

Clastic sediment-hosted $\mathrm{Sb}$-Au

$\mathrm{Cu}-\mathrm{Ag}$ quartz vein (vein $\mathrm{Cu}$ )

Kennecott $\mathrm{Cu}$ 
TABLE 2. Summary of correlations and tecnonic linkages for the Circum-North Pacific.

\begin{tabular}{|c|c|c|}
\hline \multicolumn{3}{|c|}{$\begin{array}{l}\text { CRATONAL, PASSTVE CONTINENTAL MARGIN AND REL.ATED TERRANES AND } \\
\text { OVERLAP ASSEMBLAGES IN THE RUSSIAN SOUTHEAST }\end{array}$} \\
\hline Units, correlations, and age & Tectenic envirenment(s) & Tectonie liakages and comments \\
\hline $\begin{array}{l}\text { Kabarga, Sergeevka, Kabarga, and } \\
\text { Vounesenka terranes of Khanka } \\
\text { superterrane. } \\
\text { Late Proterozoic and Paleozoic. }\end{array}$ & Passive contimental margin. & $\begin{array}{l}\text { Derived from Gondwanaland } \\
\text { supereontibent during Devonian } \\
\text { rifting and formation of bimodal } \\
\text { voleanic rocka. Costain Late } \\
\text { Paleozoic continental-margin ares. }\end{array}$ \\
\hline $\begin{array}{l}\text { Argum and Goezha terranes. } \\
\text { Archean and Paleotoic. }\end{array}$ & Cratonal. & $\begin{array}{l}\text { Derived from North Asian Craton } \\
\text { during Late Proterozoic rifting. } \\
\text { Diamembered parts of the Altaid } \\
\text { orogenic system. }\end{array}$ \\
\hline $\begin{array}{l}\text { Oldoi and Mamyn termanes. } \\
\text { Ptoterozoic to middle Paleozoic. }\end{array}$ & Passive continental margin. & $\begin{array}{l}\text { Derived from North Asian Craton } \\
\text { Margin during Late Proterozoic } \\
\text { rifting, dismembered part of Altaid } \\
\text { orogenic system. }\end{array}$ \\
\hline $\begin{array}{l}\text { Baladek terrane. } \\
\text { Archean, Paleozoic, Eariy Mesozoic. }\end{array}$ & Cratonal. & $\begin{array}{l}\text { Derived from North Asian Craten } \\
\text { during Late Proterozoic rifting. }\end{array}$ \\
\hline $\begin{array}{l}\text { Ayansk ternane } \\
\text { Palcozoic. }\end{array}$ & Passive continental margin. & $\begin{array}{l}\text { Derived from North Asian Craton } \\
\text { Margin durieg Late Devonian rifting? }\end{array}$ \\
\hline $\begin{array}{l}\text { Bureya terrane. } \\
\text { Early Paleozoic and older. }\end{array}$ & Continental-margin ars. & $\begin{array}{l}\text { Rifled fragment of North China Craton, } \\
\text { Dismembered part of Manchurid } \\
\text { orogenic system. }\end{array}$ \\
\hline \multicolumn{3}{|c|}{ LAOELIN-GRODEKOVO ISLAND ARC IN THE RUSSIAN SOUTHEAST } \\
\hline $\begin{array}{l}\text { Laoelin-Grodekovsk terrane, various back-are } \\
\text { units within Khanka superterrane, and } \\
\text { Chongjin terrane (Japan). } \\
\text { Permian. }\end{array}$ & Island are. & $\begin{array}{l}\text { Formed adjacent to Khanka } \\
\text { superterrane. }\end{array}$ \\
\hline $\begin{array}{l}\text { Spassk terrane of Khanka superterrane. } \\
\text { Early and maddle Paleozoic. }\end{array}$ & Accretionary wedge. & Linked to Laoelin-Grodekovo terrane. \\
\hline \multicolumn{3}{|c|}{$\begin{array}{l}\text { CRATONAL AND PASSIVE AND METAMORPHOSED CONTINENTAL-MARGIN TERRANES } \\
\text { IN THE RUSSIAN NORTHEAST, ALASKA. AND CANADIAN CORDILIERA }\end{array}$} \\
\hline $\begin{array}{l}\text { Chakotka terrane, Arctic Alaska superterrane, } \\
\text { Cassiar terrane. } \\
\text { Proterozoic, Paleozoic, and early Mesozoic. }\end{array}$ & Passive continental margin. & $\begin{array}{l}\text { Dismembered parts of North American } \\
\text { Craton Margin. }\end{array}$ \\
\hline $\begin{array}{l}\text { Seward terrane (both sides of Bering Straits) } \\
\text { Coldfoot, and Ruby terranes. } \\
\text { Early and middle Paleozoic (mainly) }\end{array}$ & $\begin{array}{l}\text { Metamorphosed continental } \\
\text { margin. }\end{array}$ & $\begin{array}{l}\text { Highly metarnorphosed and deformed } \\
\text { fragments of North American Craton } \\
\text { Margin. Contain Late Devonian and } \\
\text { Earfy Mississippian continental. } \\
\text { margin arc rocks. }\end{array}$ \\
\hline $\begin{array}{l}\text { Yukon-Tanana and Kootenay terranes. } \\
\text { Paleozoic. }\end{array}$ & $\begin{array}{l}\text { Metamorphosed continental } \\
\text { margin. }\end{array}$ & $\begin{array}{l}\text { Highly metamorphosed and deformed } \\
\text { rifed fragments of North Americas } \\
\text { Craton Margin. Contain Late } \\
\text { Devonian and Early Missisaippian } \\
\text { continental-margin are nocis. }\end{array}$ \\
\hline $\begin{array}{l}\text { Dillinger, Kula-Nera, Nixon Fork, Prikolyma, } \\
\text { Omulevka, Mystic, and Viliga ternanes. } \\
\text { Paleonoic and early Mesozoic. }\end{array}$ & Passive continental margin. & $\begin{array}{l}\text { Dismenbered fragments of North Asian } \\
\text { Craton Margin (Verkhoyank fold } \\
\text { and thrust beli). Late Devonian and } \\
\text { Early Mississippian rifting. }\end{array}$ \\
\hline $\begin{array}{l}\text { Kilbuck-Idono, Okbotsk, and Omolon } \\
\text { teranes. } \\
\text { Late Archean, Proteroroic, and early } \\
\text { Paleoroic. }\end{array}$ & Cratonal. & $\begin{array}{l}\text { Dismembered fragment of North Asian } \\
\text { Craton. Late Devonian and Early } \\
\text { Mississippian rifting. }\end{array}$ \\
\hline
\end{tabular}


TABLE 2. Summary of correlations and tectonic linkages for the Circum-North Pacific - Continued

\begin{tabular}{|c|c|c|}
\hline $\begin{array}{l}\text { Unit(s) and Correlations. } \\
\text { Age }\end{array}$ & Tectonic Environment(s) & $\begin{array}{l}\text { Tectoaic Linkages. } \\
\text { Comments }\end{array}$ \\
\hline \multicolumn{3}{|c|}{$\begin{array}{l}\text { MAINLY TRIASSIC TO MID-CRETACEOUS ISLAND-ARC AND CONTINENTAL-MARGIN-ARC TERRANES } \\
\text { AND OVERLAP ASSEMBLAGES, AND LINKED SUBDUCTION-ZONE TERRANES }\end{array}$} \\
\hline \multicolumn{3}{|c|}{ Monakin Continental-margin Are } \\
\hline $\begin{array}{l}\text { Monakin volcanic-pluotnic belt, granitic } \\
\text { plutonic rocks of Koréa, and volcanic- } \\
\text { plutonic belt of Southeast China. } \\
\text { Jurassic. }\end{array}$ & Igneous overlap assemblage. & $\begin{array}{l}\text { Discontinuous parts of Great Hinggan } \\
\text { arc. }\end{array}$ \\
\hline $\begin{array}{l}\text { Badzhal, Khabarovsk, and Samarka rerranes. } \\
\text { (Also Taukha, and Oshima terranes) } \\
\text { Paleozoic to Cretaceous. }\end{array}$ & Accretionary wedge. & $\begin{array}{l}\text { Linked to Monakin continental-margin } \\
\text { arc. Also linked to Umlekan are } \\
\text { (below). Remnants of subduction of } \\
\text { Ancestral Pacific Ocean plate. } \\
\text { Taukha, and Oshuma terranes linked } \\
\text { to coeval granitic plutonic rocks of } \\
\text { Korea and volcanic-plutonic belt of } \\
\text { southeast China. }\end{array}$ \\
\hline \multicolumn{3}{|c|}{ Umlekan Costinental-Margie Are } \\
\hline $\begin{array}{l}\text { Umlekan-Ogodzhin volcanic-plunonic belt. } \\
\text { Jurassic and Early Cretaceous }\end{array}$ & Igneous overlap assemblage. & Nontem extension of Monakin are. \\
\hline $\begin{array}{l}\text { Badzhai, Khabarovsk (older Jurassic part), and } \\
\text { Samarka terranes. } \\
\text { Paleozoic to Cretaceous. }\end{array}$ & Accretionary wedge. & $\begin{array}{l}\text { Linked to Umelkan are and to Monakin } \\
\text { are (above). Remnants of subduction } \\
\text { of Ancestral Pacific Ocean plate. }\end{array}$ \\
\hline \multicolumn{3}{|l|}{ Khingan continemal-margin are } \\
\hline $\begin{array}{l}\text { Khingan-Okhotsk volcanic-plutonic belt } \\
\text { Early and mid-Cretaceous. }\end{array}$ & Continental-margin are. & $\begin{array}{l}\text { Formed after collision of Anui } \\
\text { microcontinent with Samarka terrane }\end{array}$ \\
\hline $\begin{array}{l}\text { Amur River, Khabarovsk, and Kiselevka- } \\
\text { Manoma terranes. } \\
\text { Jurassic and Early Cretaceous. }\end{array}$ & Accretionary wedge. & $\begin{array}{l}\text { Linked to Khingan continental-margin } \\
\text { are. Remnants of oblique subduction } \\
\text { of Ancestral Pacific Ocean plate. }\end{array}$ \\
\hline \multicolumn{3}{|c|}{ Kerna Continental-Margin Are } \\
\hline $\begin{array}{l}\text { Kema terrane, and Early to mid-Cretaceous } \\
\text { voleanic rocks of Hokkaido Island. } \\
\text { Mid Cretaceous. }\end{array}$ & Igneous overlap assemblage. & $\begin{array}{l}\text { Transpressive continental-margin are } \\
\text { analogus to Tertiary margin of } \\
\text { California. }\end{array}$ \\
\hline $\begin{array}{l}\text { Aniva and Kamuikotan terranes. } \\
\text { Cretaceous. }\end{array}$ & Transpressional subduction zone. & $\begin{array}{l}\text { Linked to Kema arc. Remnants of } \\
\text { subduction of Ancestral Pacific } \\
\text { Ocean plate. }\end{array}$ \\
\hline \multicolumn{3}{|c|}{ Uda Continental-Margin Arc } \\
\hline $\begin{array}{l}\text { Uda voleanic-plutonic belt, Uniya-Bom } \\
\text { turbidite-basin terrane, Umlekan-Ogodzhin } \\
\text { volcanic-plutonic belt, and Upper Amur } \\
\text { sedimentary assemblage. } \\
\text { Late Jurassic and Early Cretaceous. }\end{array}$ & Igreous overlap assemblage. & $\begin{array}{l}\text { Deposited on and adjacent to, and } \\
\text { intruded into the North Asian Craton } \\
\text { and Stanovoy block of the North } \\
\text { Asian Craton. }\end{array}$ \\
\hline $\begin{array}{l}\text { Turkuringra- Dzhagdi, Galam, and Ulban } \\
\text { terranes. } \\
\text { Jurassic and Cretaceous. }\end{array}$ & $\begin{array}{l}\text { Subduction zone or accretionary } \\
\text { wedge. }\end{array}$ & $\begin{array}{l}\text { Linked to Uda arc. Remnants of } \\
\text { subduction of Mongol-Okbotsk } \\
\text { Ocean plate. }\end{array}$ \\
\hline \multicolumn{3}{|c|}{ Kony-Murgal Island Are } \\
\hline $\begin{array}{l}\text { Kony-Murgal terrane. } \\
\text { Late Triassic to Early Cretaceous. }\end{array}$ & $\begin{array}{l}\text { Continental-margin and island } \\
\text { are. }\end{array}$ & \\
\hline $\begin{array}{l}\text { Talovskiy and Penzhina-Anadyr terranes. } \\
\text { Mainly Jurassic and Early Cretaceotas. }\end{array}$ & $\begin{array}{l}\text { Subduction zone and accretionary } \\
\text { wedge. }\end{array}$ & $\begin{array}{l}\text { Linked to Kony-Murgal arc. Remnants } \\
\text { of subduction of Ancestral Pacific } \\
\text { Ocean plate. }\end{array}$ \\
\hline \multicolumn{3}{|c|}{ Pekul'ney island are } \\
\hline $\begin{array}{l}\text { West Pekul'ney terrane. } \\
\text { Late Triassic to Early Cretaceous. }\end{array}$ & Esland are. & \\
\hline $\begin{array}{l}\text { Pekul'ney verrane. } \\
\text { Mainly Jurassic and Early Cretaceous. }\end{array}$ & Subduction zone. & $\begin{array}{l}\text { Linked to Pekul'ney arc. Remnants of } \\
\text { subduction of Ancestral Pacific } \\
\text { Ocean plate. }\end{array}$ \\
\hline
\end{tabular}


TABLE 2. Summary of correlations and tectonic linkages for the Circum-North Pacafic - Contimued.

\begin{tabular}{|c|c|c|}
\hline $\begin{array}{l}\text { Unit(s) and Correlations. } \\
\text { Age }\end{array}$ & Tectosic Environment(s) & $\begin{array}{l}\text { Tectonic Linkages. } \\
\text { Comments }\end{array}$ \\
\hline \multicolumn{3}{|c|}{ Mainitskiy Island Arc } \\
\hline $\begin{array}{l}\text { Mainitskiy terrane. } \\
\text { Late Jurassic to mid-Cretaceous. }\end{array}$ & Island are. & Axial part of are. \\
\hline $\begin{array}{l}\text { Alkatvaam. } \\
\text { Late Triassic to Paleocene. }\end{array}$ & Accretionary wedge. & $\begin{array}{l}\text { Linked to Mainitskiy arc. Remnants of } \\
\text { subduction of Ancestral Pacific } \\
\text { Ocean plate. }\end{array}$ \\
\hline \multicolumn{3}{|l|}{ Uyandina island are } \\
\hline $\begin{array}{l}\text { Uyandina-Yasachnaya volcanic belt. } \\
\text { Late Jurnssic. }\end{array}$ & Island are. & Axial part of are. \\
\hline $\begin{array}{l}\text { Garbyn'ya, Debin, and Chursky Range } \\
\text { ophiolises. } \\
\text { Unknown. }\end{array}$ & Ophiolite. & $\begin{array}{l}\text { Linked to Dyandina are. Remnants of } \\
\text { subduction of Oimyakon Ocean plate. }\end{array}$ \\
\hline \multicolumn{3}{|c|}{ Oloy and Sryatov Nos Continental-Margin Ares } \\
\hline $\begin{array}{l}\text { Oloy and and Svyatov Nos Arcs volcanic } \\
\text { beles. } \\
\text { Late Jurassic. }\end{array}$ & Continental-margin are. & Axial part of are. \\
\hline $\begin{array}{l}\text { South Anyui terrane. } \\
\text { Late Jurassic and Early Cretaceous. }\end{array}$ & Subduction zone. & $\begin{array}{l}\text { Liniked to Oloy and Svyatov Nos ares. } \\
\text { Remnants of subduction of South } \\
\text { Anyui Ocean plate. }\end{array}$ \\
\hline \multicolumn{3}{|c|}{ Alazeya Island Are } \\
\hline $\begin{array}{l}\text { Alazeya, Khetachan, and Oloy terranes. } \\
\text { Late Paleozoic to Early Jurassic. }\end{array}$ & Island are. & Axial part of are. \\
\hline $\begin{array}{l}\text { Aluchin terrane. } \\
\text { Late Paleozoic to Early Jurassic. }\end{array}$ & Subduction zone & $\begin{array}{l}\text { Linked to Alazeya arc. Remnant of } \\
\text { subduction of Ancestral Pacific } \\
\text { Ocean plate. }\end{array}$ \\
\hline \multicolumn{3}{|c|}{ Nutesyn Continental-Margin Are } \\
\hline $\begin{array}{l}\text { Nutesyn terranes. } \\
\text { Mainly Late Jurnssic to Early Cretaceous. }\end{array}$ & Continental-margin are & Axial part of are. \\
\hline $\begin{array}{l}\text { Velmay terrane. } \\
\text { Upper Triassic. }\end{array}$ & Subduction zone. & $\begin{array}{l}\text { Linked to Nutesyn are. Remnant of } \\
\text { subduction of Angayucham Ocean } \\
\text { plate. }\end{array}$ \\
\hline \multicolumn{3}{|c|}{ Koyukuk Island Arc } \\
\hline $\begin{array}{l}\text { Koyukuk, Nyac, and Togiak terranes. } \\
\text { Mainly Late Jurassic to Early Cretaceous. }\end{array}$ & Island are. & Axial part of are. \\
\hline $\begin{array}{l}\text { Angayucham and Goodnews terranes. } \\
\text { Devonian to Early Jurassic. }\end{array}$ & Subduction zone. & $\begin{array}{l}\text { Linked to Koyukuk arc. Remnant of } \\
\text { subduction of Angayucham Ocenn } \\
\text { plate. }\end{array}$ \\
\hline \multicolumn{3}{|c|}{ Gravina Island Arc } \\
\hline $\begin{array}{l}\text { Kahiltna sedimentary and volcanic } \\
\text { assemblage; Gravina-Nutzotin-Gambier } \\
\text { volcanic-plutonic-sedimentary belt; } \\
\text { Cadwaller, Methow, Izee, and Wallowa } \\
\text { island-arc and turbidite-basin teranes; } \\
\text { Spences Bridge volcanic-plutonic belt; } \\
\text { Tahnsa-Three Sisters-Francois Lake } \\
\text { magmatic assemblage. } \\
\text { Juassic to mid-Cretaceous with minor Triassic } \\
\text { units. }\end{array}$ & Island are and turbidite basin. & Axial part of are. \\
\hline $\begin{array}{l}\text { Chugach (younger part, Valdez Group), } \\
\text { Pacific Rim, Bridge River, and Baker } \\
\text { terranes. } \\
\text { Jurassic to Late Cretaceous. }\end{array}$ & $\begin{array}{l}\text { Accretionary wedge and } \\
\text { subduction zone. }\end{array}$ & $\begin{array}{l}\text { Linked to Gravina arc. Remnants of } \\
\text { subduction of Cache Croek Ocean } \\
\text { plate. }\end{array}$ \\
\hline
\end{tabular}


TABLE 2. Sumanary of correlations and tectonic linkages for the Circum-North Pacific - Continued

\begin{tabular}{|c|c|c|}
\hline $\begin{array}{c}\text { Unit(s) and Correlations. } \\
\text { Age }\end{array}$ & Tectonic Envirenanent(s) & $\begin{array}{l}\text { Tectonic Linkages. } \\
\text { Commeats }\end{array}$ \\
\hline \multicolumn{3}{|c|}{ Talkeetna-Bonanza Island Are } \\
\hline $\begin{array}{l}\text { Peninsular sequence of Wrangellia } \\
\text { supserterrane (Talkeetna Formation) in } \\
\text { Alaska, Bonanza Formation and } \\
\text { Cadwallader island are and Methow } \\
\text { turbidite-basin terranes in Canadian } \\
\text { Cordilleru. } \\
\text { Late Triassic and Early Jurassic. }\end{array}$ & Island arc. & Axial part of are. \\
\hline $\begin{array}{l}\text { Chugach (older part, biueschist and MeHugh } \\
\text { Complex), Bridge River, and Baker } \\
\text { terranes. } \\
\text { Paleozoic, Triassic, and Early Jurassic. }\end{array}$ & $\begin{array}{l}\text { Accretionary wedge und } \\
\text { subduction zone. }\end{array}$ & $\begin{array}{l}\text { Linked to Talkeetna and Bonanza arcs. } \\
\text { Remnants of subduction of Cache } \\
\text { Creek and Farallon Ocean plates. }\end{array}$ \\
\hline \multicolumn{3}{|c|}{ Stikinia-Quesnellia Island Arc } \\
\hline $\begin{array}{l}\text { Stikinia and Quesnellia terranes. } \\
\text { Permian to Early hurassic. }\end{array}$ & Island arc. & Axial part of arc. \\
\hline $\begin{array}{l}\text { Cache Creek, Slide Mountain, and } \\
\text { Seventymile terranes. } \\
\text { Paleozoic and Mesozoic. }\end{array}$ & $\begin{array}{l}\text { Subduction zone and accretionary } \\
\text { wedge. }\end{array}$ & $\begin{array}{l}\text { Linked to Stikinia-Quesnellia arc. } \\
\text { Remnants of subduction of Cache } \\
\text { Creek Ocean plate. }\end{array}$ \\
\hline \multicolumn{3}{|c|}{$\begin{array}{l}\text { MAINLY LATE CRETACEOUS AND EARLY CENOZOIC CONTINENTAL-MARGIN ARCS, ISLAND ARCS, } \\
\text { AND LINKED SUBDUCTION ZONES }\end{array}$} \\
\hline \multicolumn{3}{|c|}{ East Sikhote-Alin Continental-Margin Are (Late Cretaceous) } \\
\hline $\begin{array}{l}\text { East Sikhote-Alin volcanic-plutonic belt. } \\
\text { Sorachi-Yezo, West Sakhalin terrane. } \\
\text { Cretaceous and early Tertiary. }\end{array}$ & Igneous overlap assemblage. & Axial part of arc. \\
\hline $\begin{array}{l}\text { Hidaka accretionary-wedge, younger part of } \\
\text { the Aniva, Nabilsky, and Tokoro terranes. } \\
\text { Permian to Cretaceous. }\end{array}$ & $\begin{array}{l}\text { Accretionary wedge and } \\
\text { subduction zone. }\end{array}$ & $\begin{array}{l}\text { Linked to East Sikhote-Alin are. } \\
\text { Remnants of subduction of Ancestral } \\
\text { Pacific Ocean plate. }\end{array}$ \\
\hline \multicolumn{3}{|c|}{ Okhotsk-Chukotka Continental-Margin Arc } \\
\hline $\begin{array}{l}\text { Okhotsk-Chukotka volcanic-pilutonic belt and } \\
\text { Penzhina sedimentary basin. } \\
\text { Cretaceous and early Tertiary. }\end{array}$ & Igneous overlap assemblage. & Axial part of arc. \\
\hline $\begin{array}{l}\text { West-Kamchatka, Ekonay, and Yanranay } \\
\text { terranes. } \\
\text { Upper Paleozoic, Jurassic and Early } \\
\text { Cretaceous. }\end{array}$ & Accretionary wedge. & $\begin{array}{l}\text { Linked to Okhotsk-Chukotka arc, } \\
\text { Remnants of subduction of Ancestral } \\
\text { Pacific Ocean plate. }\end{array}$ \\
\hline \multicolumn{3}{|c|}{ Olyutorka Island Are } \\
\hline $\begin{array}{l}\text { Olyutorka-Kamchatka, Iruneiskiy, Kronotskiy, } \\
\text { Shenidt, Terpeniya, and Nemuro terranes. } \\
\text { Late Cretaceous and Early Tertiary. }\end{array}$ & Esland arc. & Axial part of arc. \\
\hline $\begin{array}{l}\text { Vetiovskiy terrane, } \\
\text { Late Cretaceous and early Tertiary. }\end{array}$ & Accretionary wedge. & $\begin{array}{l}\text { Linked to Olyutorka arc. Remnants of } \\
\text { subduction of Ancestral Pacific } \\
\text { Ocean plate. }\end{array}$ \\
\hline \multicolumn{3}{|c|}{ Kluane and Coast North Cascade Contineatal-Margin Ares } \\
\hline $\begin{array}{l}\text { Kuskokwim Mountains sedimentary, volcanic, } \\
\text { and plutonic belt, Alaska Range-Talkeetra } \\
\text { Mountains volcanic-plutonic belt, Coast- } \\
\text { North Cascade plutonic belt, and Kamloops } \\
\text { magnatic belt. } \\
\text { Late Cretaceous and early Tertiary. }\end{array}$ & Igneous overlap assemblage. & Axial part of arc. \\
\hline $\begin{array}{l}\text { Chugach terrane (the Late Cretaceous Valdez } \\
\text { Group), older part of the Prince Wiiliam } \\
\text { terrane, and Pacific Rim terrane. } \\
\text { Late Cretaceous and early Tertiary. }\end{array}$ & $\begin{array}{l}\text { Accretionary wedge and } \\
\text { subduction zone. }\end{array}$ & $\begin{array}{l}\text { Linked to Kluane and Coast North } \\
\text { Cascade arcs. Remnants of } \\
\text { subduction of ancestral Pacific Ocean } \\
\text { plate. }\end{array}$ \\
\hline
\end{tabular}


TABL.E 2. Summary of carrelations and tectonic linkages for the Circum-Nonth Pacifie - Continued.

\begin{tabular}{|c|c|c|}
\hline $\begin{array}{l}\text { Unit(s) and Correlutions. } \\
\text { Age }\end{array}$ & Tecteaic E.aviroament(s) & $\begin{array}{l}\text { Teetenic Linkages. } \\
\text { Comments }\end{array}$ \\
\hline \multicolumn{3}{|c|}{$\begin{array}{l}\text { MIDDLE AND LATE CENOZOIC CONTINENTAL-MARGIN ARCS AND } \\
\text { LINKED SUBDUCTION ZONES }\end{array}$} \\
\hline \multicolumn{3}{|c|}{ Northeast Asia Continental-Margin Are } \\
\hline $\begin{array}{l}\text { East Japan volcanie-plutonic bels, Ceniral } \\
\text { Kameharka volcanic belt, Central } \\
\text { Kamchatka volcanic and sedimentary basin, } \\
\text { Eass Kamehatka voleanic beln, Eastern } \\
\text { Sakhalin sedamentary basin, and the West } \\
\text { Kamehatka sedimentary basin. } \\
\text { Early Eocene to Miocene to present. }\end{array}$ & Igneous overlap assemblages. & Axial part of are. \\
\hline $\begin{array}{l}\text { Kuril-Kamchatka terrane. } \\
\text { Miocene to presem. }\end{array}$ & $\begin{array}{l}\text { Accretionary wedge and } \\
\text { subduction zone. }\end{array}$ & $\begin{array}{l}\text { Linked to Northeast Asia are. Remnant } \\
\text { of subduction of Pacific Ocean plate. }\end{array}$ \\
\hline $\begin{array}{l}\text { Sea of Japan unit, Sakhalin-Primorye volcanic } \\
\text { belt, and Kuril unis. } \\
\text { Oltgocene to Miocene. }\end{array}$ & Back-arc units. & Linked to Northeast Asia are, \\
\hline \multicolumn{3}{|c|}{ Aleutian-Wrangell Continental-Margin Are } \\
\hline $\begin{array}{l}\text { Aleutian volcanic belt, and Wrangell voleanic } \\
\text { field. } \\
\text { Early Eocene to Miocene to present. }\end{array}$ & lgneous overlap assemblages. & Axial part of are. \\
\hline $\begin{array}{l}\text { Atru lsland part of Prince William ierrane and } \\
\text { Yakutat terrane. } \\
\text { Early Tertiary to present }\end{array}$ & Accretionary wedge. & $\begin{array}{l}\text { Linked to Aleutian-Wrangell are. } \\
\text { Remnanis of subduction of ancestral } \\
\text { Pacific Oceas plate. }\end{array}$ \\
\hline \multicolumn{3}{|c|}{ Caseade Costinental-Margin Are } \\
\hline $\begin{array}{l}\text { Cascade volcanic-plutonic belt. } \\
\text { Eocene to present. }\end{array}$ & Igneous overlap assemiblage. & Axial part of are. \\
\hline $\begin{array}{l}\text { Siletzia, Olympic Coes, and Hoh terranes, and } \\
\text { modem-day subduction zone. } \\
\text { Eocene to present. }\end{array}$ & $\begin{array}{l}\text { Subduction rene and accretionary } \\
\text { wedge. }\end{array}$ & $\begin{array}{l}\text { Linked to Cascade are. Remnants of } \\
\text { subduction of Jaan de Fuca plate. }\end{array}$ \\
\hline $\begin{array}{l}\text { Columbia River Basali Group, } \\
\text { Miocene. }\end{array}$ & Back-are unit. & Linked to Cascade arc. \\
\hline
\end{tabular}


TABLE 3. Tectonic environment of Proterozoic and Phanerozoic metallogenic belts in the Russian Far East, Alaska, and the Canadian Cordillera. Refer to Figures $4-18$ for location of metallogenic belts. For each time interval (time-stage) in the metallogenic-tectonic model, the metallogenic belts are listed in a clockwise order, according to similar tectonic environments, starting with the area of the Russian Southeast and ending with the area of the southern Canadian Cordillera. [Environment refers to metallogenic-tectonic environment of host rocks as defined and described here. Time scale is from Palmer (1983). Metallogenic belts are defined and adapted from Nokleberg and others (1997a, b, 1998b) and as modified herein. Abbreviations given for metallogenic belts as depicted on generalized maps of metallogenic belts and host rocks (figures 2-18) and on metallogenic-tectonic model for Devonian through Present (Figures 19-32).]

\begin{tabular}{|c|c|c|c|}
\hline \multicolumn{4}{|c|}{ PROTEROZOIC METALLOGENIC BELTS (2500 TO $570 \mathrm{Ma}$ ) (Figures 2, 3) } \\
\hline $\begin{array}{l}\text { Metallogenie Belt } \\
\text { (Abbreviation) }\end{array}$ & $\begin{array}{l}\text { Major Mineral Deposits Types. } \\
\text { (Significant Mineral Deposits) }\end{array}$ & $\begin{array}{l}\text { Environment. } \\
\text { Host Unit. }\end{array}$ & $\begin{array}{l}\text { Tectoaic Event. } \\
\text { Comments }\end{array}$ \\
\hline \multicolumn{4}{|c|}{ Metallogenic Belts Formed During Proterozoic Rifting of North Asian Craton or Craton Margin } \\
\hline Oroek (OK) & $\begin{array}{l}\text { Ironstone (Superior Fe), sediment-hosted } \\
\text { Cu. }\end{array}$ & $\begin{array}{l}\text { Passive continental margin. } \\
\text { Prikolyma terrane. }\end{array}$ & $\begin{array}{l}\text { Sedimentation along Proterozoic passive continental margin (ironstone deposits)- } \\
\text { Mesoproterozoic to Neoproterozoic incipient rifting of passive continental } \\
\text { margin (sediment-hosted Cu deposits). }\end{array}$ \\
\hline $\begin{array}{l}\text { Lantarsky: } \\
\text { Dzhugdzhur (LD) }\end{array}$ & $\begin{array}{l}\text { Anorthosite Apatite-Ti-Fe. } \\
\text { (Bogidenskoe, Gayumskoe, } \\
\text { Maimakanskoe, Dzhaninskoe) } \\
\text { Gabbroic Cu-Ni-Co-PGE } \\
\text { (Avlandzhinsky. Kontaktovy. Nyandomi } \\
\text { Ozerny, Odorin) }\end{array}$ & $\begin{array}{l}\text { Gabbro and anorthosite plutons. } \\
\text { and alkali granites intruding } \\
\text { North Asian Craton. }\end{array}$ & $\begin{array}{l}\text { Mesoproterozoic rifting of passive continental margin of North Asian Craton and } \\
\text { intrusion of gabbro and anorthosite plutons, relatively younger, Rapakivi-type } \\
\text { alkalic granite. }\end{array}$ \\
\hline Ulkan (UL) & $\begin{array}{l}\text { Felsac Plutonic REE and related deposits. } \\
\text { (Albititovoe, Burgundiy, Gurjanouskoe, } \\
\text { Krasnogorskoe, Mezhdurechnoe, } \\
\text { Nygvagan, Ulkanskoe, Uzhnoe, } \\
\text { Zapadnoe) }\end{array}$ & $\begin{array}{l}\text { REE granite, alkalic dikes, and } \\
\text { altered basalt in or near } \\
\text { Paleoproterozoic Ulkan } \\
\text { volcano-tectonic basin } \\
\text { overlying older units of North } \\
\text { Asian Craton. }\end{array}$ & Possible formed during Mesoproterazoic rifling? \\
\hline Bilyakehan (BI) & Sediment-hosted $\mathrm{Cu}$ and basalt $\mathrm{Cu}$. & $\begin{array}{l}\text { Passive continental margin. } \\
\text { Verkhoyansk fold belt, North } \\
\text { Assian Craton Margin. }\end{array}$ & $\begin{array}{l}\text { Sedimentation along Proterozoic passive continental margin (ironstone deposits). } \\
\text { Neoproterozoic incipient rifting of passive continental margin. }\end{array}$ \\
\hline Omolon (OM) & $\begin{array}{l}\text { Ironstone (Superior Fe). } \\
\text { (Verkhny-Omolon)) }\end{array}$ & $\begin{array}{l}\text { Marine sedimentation. } \\
\text { Omolon terrane. }\end{array}$ & $\begin{array}{l}\text { Sedimentation along Paleoprotetozoic passive continental margin. } \\
\text { Termane interpreted as a rifted fragment of North Asian Craton. }\end{array}$ \\
\hline Kilbuck (K1) & $\begin{array}{l}\text { Ironstone (Superior Fe). } \\
\text { (Canyon Creek) }\end{array}$ & $\begin{array}{l}\text { Marine sedimentation. } \\
\text { Kilbuck terrane (pre-rifting). }\end{array}$ & $\begin{array}{l}\text { Sedimentation along Paleoproterozoic passive continental margin. } \\
\text { Rifted fragment of North Asian Craton. }\end{array}$ \\
\hline \multicolumn{4}{|c|}{ Metallogenic Belts Formed During Proterozoic Sedimentation, Rifting, and Hydrothermal Activity Along Nerth American Craton or Craton Margin } \\
\hline Sinuk River (SR) & $\begin{array}{l}\text { Stratiform massive sulfide-barite. } \\
\text { (Aurora Creek, Nelson, Rocky Mountain } \\
\text { Creek, Quarry) } \\
\text { Stratabound Fe and Mn } \\
\text { (American, Bear, Cub, Monarch) }\end{array}$ & $\begin{array}{l}\text { Marine volcanism. } \\
\text { Seward terrane. }\end{array}$ & $\begin{array}{l}\text { Interpreted as forming during marine wolcanogenic rifting(?) of the North } \\
\text { American Continental Margin. }\end{array}$ \\
\hline
\end{tabular}




\begin{tabular}{|c|c|c|c|}
\hline $\begin{array}{l}\text { Metallogenic Belt } \\
\text { (Abbreviation) }\end{array}$ & $\begin{array}{l}\text { Major Mineral Deposits Types, } \\
\text { (Significant Mineral Deposits) }\end{array}$ & $\begin{array}{l}\text { Envirosmeat. } \\
\text { Host Unit. }\end{array}$ & $\begin{array}{c}\text { Tectonic Event. } \\
\text { Comments }\end{array}$ \\
\hline Gillespie (GE) & $\begin{array}{l}\text { SEDEX Zn-Cu-Pb-Au-Ag } \\
\text { (Blende, Hart River) }\end{array}$ & $\begin{array}{l}\text { Mafic plutons intruding North } \\
\text { American Craton Margin. }\end{array}$ & $\begin{array}{l}\text { Intrusion of gabbro and diorite sills during riftung of Paleoprolerozoic passive } \\
\text { continental margin? }\end{array}$ \\
\hline Wernecke (WR) & $\begin{array}{l}\text { U-Cu-Fe (Au-Co) vein and breccia } \\
\text { (lgor) }\end{array}$ & $\begin{array}{l}\text { Hydrothermal replacement? } \\
\text { North American Craton } \\
\text { Margin. }\end{array}$ & Hydrothermal activity along Paleoproterozoic passive continental margin. \\
\hline Rapitan (R.A) & $\begin{array}{l}\text { Iron formation. } \\
\text { (Crest Iron) }\end{array}$ & $\begin{array}{l}\text { Marine sedimentation. } \\
\text { North American Craton } \\
\text { Margin. }\end{array}$ & Marine exhalation along Mesoptoterozoic North American Craton Margin. \\
\hline \multicolumn{4}{|c|}{ Metallogenic Belts Formed During Proterozoic Rifting of North American Craton or Craton Margin } \\
\hline Redstone (RD) & $\begin{array}{l}\text { Sediment-hosted } \mathrm{Cu}-\mathrm{Ag} \\
\text { (Coates Lake) }\end{array}$ & $\begin{array}{l}\text { Rifted continental margin. } \\
\text { North American Craton } \\
\text { Margin. }\end{array}$ & Incipient rifting of Paleoproterozoic Norh American Craton Margin. \\
\hline Churchill $(\mathrm{CH})$ & $\begin{array}{l}\text { Cu vein } \\
\text { (Churchill (Davis Keays)) }\end{array}$ & $\begin{array}{l}\text { Rifted continental margin. } \\
\text { North American Craton } \\
\text { Margin. }\end{array}$ & Mesoproterozoic rifting of Proterozoic North American Craton Margin. \\
\hline Monashee (MO) & $\begin{array}{l}\text { SEDEX Zn-Pt-Ag. } \\
\text { (Big Ledge and Ruddock Creek) }\end{array}$ & $\begin{array}{l}\text { Rifted craton. } \\
\text { Fragment of North American } \\
\text { Craton. }\end{array}$ & Palooproterozoic rifting of North American Craton. \\
\hline Purcell (PR) & $\begin{array}{l}\text { SEDEX Zn-Pb-Ag. } \\
\text { (Sullivan, Moyie, Vine) }\end{array}$ & $\begin{array}{l}\text { Rified continental margin. } \\
\text { North American Craton } \\
\text { Margin. }\end{array}$ & Incipient rifting of Proterozoic North American Craton Margin. \\
\hline Clark Range (CR) & Sediment-hosted $\mathrm{Cu}-\mathrm{Ag}$ deposits & $\begin{array}{l}\text { Rifted continental matgin. } \\
\text { North American Craton } \\
\text { Margin. }\end{array}$ & Mesoproterozoic rifting of Proterozoic North American Craton Margin. \\
\hline \multicolumn{4}{|c|}{ CAMBRIAN THROUGH SILURLAN METALLOGENIC BELTS (570 to $408 \mathrm{Ma})$ (Figures 2, 3) } \\
\hline \multicolumn{4}{|c|}{ Metallogenic Belts Formed During Early Paleozoic Marine Sedimentation in Rifted Fragments of Gondwandaland Supercontinent } \\
\hline Voznesenka (VZ) & $\begin{array}{l}\text { Korean } \mathrm{Pb}-\mathrm{Zn} \\
\text { (Chernyshevskoe) }\end{array}$ & $\begin{array}{l}\text { Marine sedimentation. } \\
\text { Khanka superterrane. }\end{array}$ & $\begin{array}{l}\text { Rifting of early Paleozoic (Cambrian) continental margin. } \\
\text { Rifted fragment of Gondwandaland supercontinent. }\end{array}$ \\
\hline Kabarga (KA) & $\begin{array}{l}\text { Ironstone (Superior Fe) } \\
\text { (Ussuri) }\end{array}$ & $\begin{array}{l}\text { Marine sedimentation. } \\
\text { Khanka superterrane. }\end{array}$ & $\begin{array}{l}\text { Sedimentation along early Paleozoic (Cambrian) continental margin. } \\
\text { Rifted fragment of Gondwandaland supercontinent. }\end{array}$ \\
\hline \multicolumn{4}{|c|}{ Metallogenic Belts Formed During Early Paleozoic Sedimentation or Marine Volcanism in Manchurid and Altaid Orogenic Systemss } \\
\hline South Khingan (SK) & $\begin{array}{l}\text { Ironstone (Superior Fe) } \\
\text { (South Khingan, Kimkanskoe) }\end{array}$ & $\begin{array}{l}\text { Marine sedimentation. } \\
\text { Bureya superterrane. }\end{array}$ & $\begin{array}{l}\text { Sedimentation along early Paleozoic passive continental margin. } \\
\text { Part of Manchurid orogenic system. }\end{array}$ \\
\hline $\operatorname{Gar}(\mathrm{GA})$ & $\begin{array}{l}\text { Volcanogenic } \mathrm{Fe}, \mathrm{Ca} \text { massive sulfide, } \\
\text { stratiform } \mathrm{Zn}-\mathrm{Pb} \text {. } \\
\text { (Gar, Kamenushinskoe, Chagoyan) }\end{array}$ & $\begin{array}{l}\text { Continental-margin arc, } \\
\text { Khingan terrane. }\end{array}$ & $\begin{array}{l}\text { Subduction-related volcanism associated with early Paleozoic (Cambrian) } \\
\text { continental-margin are. } \\
\text { Part of Altaid orogenic system. }\end{array}$ \\
\hline \multicolumn{4}{|c|}{ Metallogenic Belts Formed During Early Paleozoic Sea-Floor Spreading, Regional Metamorphism, or During Subduetion-Related Voleanism in Russian Far East Terranes } \\
\hline Galam (GL) & $\begin{array}{l}\text { Volcanogenic } \mathrm{Fe} \text { and } \mathrm{Mn} \text {; sedimentary } \mathrm{P} \text {. } \\
\text { (Gerbikanskoe) }\end{array}$ & $\begin{array}{l}\text { Ocean floor volcanism. } \\
\text { Galam accretionary-wedge } \\
\text { terrane. }\end{array}$ & $\begin{array}{l}\text { Sea-floor spreading in early Paleozoic (Cambrian) forming part of ancestral } \\
\text { Pacific Ocean. }\end{array}$ \\
\hline $\begin{array}{l}\text { Omulevka River } \\
\text { (OR) }\end{array}$ & $\begin{array}{l}\text { Austrian Alps W, Kipushi Cu-Pb-Zn. } \\
\text { (Omulev, Vesnovka) }\end{array}$ & $\begin{array}{l}\text { Passive continental margin. } \\
\text { Ornulevka terrane (pre-rifting). }\end{array}$ & $\begin{array}{l}\text { Regional metamorphism associated with Late Silurian aceretion of Rassokha } \\
\text { oceanic crust terrane to Omulevka continental margin terrane. }\end{array}$ \\
\hline
\end{tabular}




\begin{tabular}{|c|c|c|c|}
\hline $\begin{array}{l}\text { Metallogenic Belt } \\
\text { (Abbreviation) }\end{array}$ & $\begin{array}{l}\text { Major Mineral Deposits Types. } \\
\text { (Significant Mineral Deposits) }\end{array}$ & $\begin{array}{c}\text { Environment. } \\
\text { Host Unit. }\end{array}$ & $\begin{array}{l}\text { Tectonic Event. } \\
\text { Comments }\end{array}$ \\
\hline Rassokha (RA) & $\begin{array}{l}\text { Basaltic } \mathrm{Cu} \text {, sediment-hosted } \mathrm{Cu} \text {, } \\
\text { (Agyndja), porphyry } \mathrm{Cu} \text {. }\end{array}$ & $\begin{array}{l}\text { Distal passive continental } \\
\text { margin. } \\
\text { Rassokha terrane. }\end{array}$ & $\begin{array}{l}\text { Subduction-related volcanism associated with incipient continental-margin are, } \\
\text { Possible precursor to Late Devonian Kedon arc? }\end{array}$ \\
\hline \multicolumn{4}{|c|}{ Metallogenic Belts Formed During Early Paleozoic Rifting of Continental Margins or in Continental-Margin Are Terranes } \\
\hline $\begin{array}{l}\text { Dzhardzhan River } \\
\text { (DZR) }\end{array}$ & $\begin{array}{l}\text { Southeast Missouri } \mathrm{Pb}-\mathrm{Zn} \text {, sediment- } \\
\text { bosted } \mathrm{Cu} \text {; sandstone-hosted U, } \\
\text { (Manganiler, Aga-Kukan, Kyongdyoi) }\end{array}$ & $\begin{array}{l}\text { Rifted continental margin. } \\
\text { North Asian Craton Margin. }\end{array}$ & $\begin{array}{l}\text { Incipient rifting of early Paleozoic (Cambrian) continental-margin. } \\
\text { Some deposits may have formed during late Paleozoic rilting. }\end{array}$ \\
\hline Anvil (AN) & $\begin{array}{l}\text { SEDEX } \mathrm{Zn}-\mathrm{Pb}-\mathrm{Ag} \\
\text { (Faro, Vangorda, Grum, Swim, DY) }\end{array}$ & $\begin{array}{l}\text { Rifted continental margis. } \\
\text { North American Craton } \\
\text { Margin. }\end{array}$ & $\begin{array}{l}\text { Incipient rifting of early Paleozoic (Cambrian) North American Continental- } \\
\text { Margin. }\end{array}$ \\
\hline Howards Pass (HP) & $\begin{array}{l}\text { SEDEX Zn-Pb. } \\
\text { (XY, Anniv, OP) }\end{array}$ & $\begin{array}{l}\text { Rifted continental margin. } \\
\text { North American Craton } \\
\text { Margin. }\end{array}$ & Incipient rifting of early Paleozoic (Silurian) North American Continental-Margin. \\
\hline Kootenay $(\mathrm{KO})$ & $\begin{array}{l}\text { SEDEX } \mathrm{Zn}-\mathrm{Pb} \text {. } \\
\text { (Reeves-MacDonald, HB, Duncan Lake, } \\
\text { Mastadon)) }\end{array}$ & $\begin{array}{l}\text { Rifted continental margin. } \\
\text { Kootenay terrane. }\end{array}$ & Rifting of early Paleozoic (Cambrian) Nonh American Continental-Margin. \\
\hline $\begin{array}{l}\text { Prince of Wales } \\
\text { Island (PW) }\end{array}$ & $\begin{array}{l}\text { Porphyry Cu-Mo, polymetallic vein. } \\
\text { (McLean Arm, Kassan Peninsula) } \\
\text { Zone mafic-ultramafic Cu-Au-PGE. } \\
\text { (Salı Chuck) }\end{array}$ & $\begin{array}{l}\text { Continental-margin are. } \\
\text { Alexander sequence, } \\
\text { Wrangellia superterrane. }\end{array}$ & $\begin{array}{l}\text { Subduction-related granitic plutonism associated with an Ordoviciar-Silurian } \\
\text { continental-margin arc. }\end{array}$ \\
\hline \multicolumn{4}{|c|}{ MIDDLE AND LATE DEVONIAN METALLOGENIC BELTS $(387$ to $360 \mathrm{Ma})($ Figures 4,5$)$} \\
\hline \multicolumn{4}{|c|}{ Metallogenic Belt Formed During Collision } \\
\hline Yaroslavka (YA) & $\begin{array}{l}\text { F \& Sn greisen. } \\
\text { (Voznesenka II, Yaroslavkoe) }\end{array}$ & $\begin{array}{l}\text { Anatectic plutonism. } \\
\text { Khanka superterrane (pre- } \\
\text { rifting). }\end{array}$ & $\begin{array}{l}\text { Granitic plutonism associated with collision of Voznesenka and Kabarga terranes } \\
\text { of the Khanka superterrane in early Paleozonc (Devonian). }\end{array}$ \\
\hline \multicolumn{4}{|c|}{ Metallogenic Belts Formed in a Middle Paleozoic Continental Arc Along North Asian and North American Craten Margins } \\
\hline Kedon (KE) & $\begin{array}{l}\text { Au-Ag epithermal vein, porphyry Mo, Fe } \\
\text { skam. } \\
\text { (Kubaka, Olcha, Zet) }\end{array}$ & $\begin{array}{l}\text { Continental-margin arc. } \\
\text { Omolon verrane. }\end{array}$ & $\begin{array}{l}\text { Subduction-related volcanism associated with Paleozoic (Devonian) continental. } \\
\text { margin are. Belt continued into Mississippian. }\end{array}$ \\
\hline $\begin{array}{l}\text { Eastem Seward } \\
\text { Peninsula (ES) }\end{array}$ & $\begin{array}{l}\text { Kuroko massive sulfide, } \\
\text { (Kiwatik Mountain) }\end{array}$ & $\begin{array}{l}\text { Continental-margin are. } \\
\text { Seward terrane. }\end{array}$ & $\begin{array}{l}\text { Subduction-related volcanism associated with submerged continental-margin are. } \\
\text { Arc and metallogenic belt extended into Mississippian. Arc formation succeeded } \\
\text { by continental-margin rifling. }\end{array}$ \\
\hline $\begin{array}{l}\text { Aretic (AT) (Includes } \\
\text { Ambler district) }\end{array}$ & $\begin{array}{l}\text { Kuroko massive sulfide and Kipushi } \\
\text { massive sulfide. } \\
\text { (Arctic, Ruby Creek, Sun, Smucker) }\end{array}$ & $\begin{array}{l}\text { Continental-margin are. } \\
\text { Coldfoot terrane. }\end{array}$ & $\begin{array}{l}\text { Subduction-related volcanism associated with submerged continental-margin arc. } \\
\text { Are and metallogenic belt extended into Mississippian. Arc formation succeeded } \\
\text { by continental-margin rifting. }\end{array}$ \\
\hline Brooks Range (BR) & $\begin{array}{l}\text { Porphyry Cu, Cu-Pb skarn, polymetallic } \\
\text { vein. } \\
\text { (Victor, Esotuk Glacier, Romanzof } \\
\text { Mountains) }\end{array}$ & $\begin{array}{l}\text { Continental-margin are. } \\
\text { Arctic Alaska superterrane. }\end{array}$ & $\begin{array}{l}\text { Subduction-related granitic plutonism that formed a mainly Late Devonian } \\
\text { continental-margia arc. }\end{array}$ \\
\hline
\end{tabular}




\begin{tabular}{|c|c|c|c|}
\hline $\begin{array}{l}\text { Metallogenic Belt } \\
\text { (Abbreviation) }\end{array}$ & $\begin{array}{l}\text { Major Mineral Deposits Types. } \\
\text { (Significant Mineral Deposits) }\end{array}$ & $\begin{array}{l}\text { Eavironment. } \\
\text { Host UniL. }\end{array}$ & $\begin{array}{l}\text { Teetonic Event. } \\
\text { Comments }\end{array}$ \\
\hline $\begin{array}{l}\text { Alaska Range and } \\
\text { Yukon-Tanana } \\
\text { Upland (AKY) }\end{array}$ & $\begin{array}{l}\text { Kuroko massive sulfide. } \\
\text { (WTF, Red Mountain, Sbeep Creek, } \\
\text { Liberty Bell, Andersoo Mountain, } \\
\text { Miyaoka, Haye Glacier, MeGinnis } \\
\text { Glacier, Delta distric1) }\end{array}$ & $\begin{array}{l}\text { Continental-margin arc. } \\
\text { Yukon-Tanana terrane. }\end{array}$ & $\begin{array}{l}\text { Subduction-felated voleanism associated with Late Devonian and Mississippian } \\
\text { submerged continental-margin arc. } \\
\text { Arc and metallogenic belt extended into early Mississippian. Arc formation } \\
\text { suceeeded by continental-enargin rifting. }\end{array}$ \\
\hline Dawson (DA) & $\begin{array}{l}\text { Volcanogenic } \mathrm{Pb}-\mathrm{Zn}-\mathrm{Cu} \text { Massive sulfide, } \\
\text { SEDEX } \mathrm{Pb}-\mathrm{Cu}-\mathrm{Zn}-\mathrm{Ba} \\
\text { (Lucky Joe, Mickey, Lone Star) }\end{array}$ & $\begin{array}{l}\text { Continental-margin are. } \\
\text { Yukon-Tamana terrane. }\end{array}$ & $\begin{array}{l}\text { Subduction-related volcanism associated with Late Devonian and Mississippian } \\
\text { submerged continental-margin arc. } \\
\text { Are and metallogenic belt extended into early Mississippian. Arc formation } \\
\text { succeeded by continental-margin rifting. }\end{array}$ \\
\hline Frances Lake (FR) & $\begin{array}{l}\text { Kuroko massive sulfide, } \\
\text { (Kudz Ze Kayah, Wolverine-Lynx) }\end{array}$ & $\begin{array}{l}\text { Continental-margin arc, } \\
\text { Yukon-Tanana terrane. }\end{array}$ & $\begin{array}{l}\text { Subduction-related volcanism associated with submerged continental-margin are, } \\
\text { Are and metallogenic belt extended into early Mississippian. Are formation } \\
\text { succeeded by consinental-margin rifting. }\end{array}$ \\
\hline Tracy (TR) & $\begin{array}{l}\text { Kuroko massive sulfide. } \\
\text { (Eestall, Alamo, Sweetheart Ridge, } \\
\text { Sumdum, \& others) }\end{array}$ & $\begin{array}{l}\text { Continental-margin arc. } \\
\text { Yukon-Tanana terrane (pre- } \\
\text { rifi). }\end{array}$ & Subduction-related voleanism associated with submerged continental-margin arc. \\
\hline Mount Sicker (MS) & $\begin{array}{l}\text { Kuroko voleanogenic massive sulfide. } \\
\text { (Mount Sicker (Lenora-Tyee, Twin J, } \\
\text { Lara, Copper Canyon); Myra Falls } \\
\text { (Lynx, Myra, Price, HW)) }\end{array}$ & $\begin{array}{l}\text { Island arc. } \\
\text { Wrangellia superterrane. }\end{array}$ & Subduction-related voleanism associaled with island are. \\
\hline $\begin{array}{l}\text { Kootenay-Shuswap } \\
\text { (KS) }\end{array}$ & $\begin{array}{l}\text { Kuroko, Besshi, and Cyprus massive } \\
\text { sulfide. } \\
\text { (Shuswap, Goldstream, Harper Creek, } \\
\text { Chu Chua, Adams, Liard, \& others) }\end{array}$ & $\begin{array}{l}\text { Back-are part of continental. } \\
\text { margin arc. } \\
\text { Kootenay terrane (pre-rifting) }\end{array}$ & $\begin{array}{l}\text { Subduction-related volcanism associated with submerged continental-margin are, } \\
\text { Belt extended into early Mississippian. Arc formation succeeded by continental- } \\
\text { margin rifting. }\end{array}$ \\
\hline \multicolumn{4}{|c|}{ Metallogenic Belts Formed Duriag Middle Paleozoic Rifting of North Asian Craton Margin } \\
\hline Khamna River (KR) & $\begin{array}{l}\text { Carbonatite-related } \mathrm{Nb}, \mathrm{Ta}, \mathrm{REE} \\
\text { (Khamna, Gornoe Ozero) }\end{array}$ & $\begin{array}{l}\text { Rifted passive continental } \\
\text { margin. } \\
\text { North Asian Craton Margin. }\end{array}$ & $\begin{array}{l}\text { Rifting of middle Paleozoic (Devonian) continental-margin. Hosted in Late } \\
\text { Devonian alkalic granitic rocks and carbonatites. }\end{array}$ \\
\hline Sette-Daban (SD) & $\begin{array}{l}\text { Southeast Missouri Pb-Zn, sediment- } \\
\text { hosted } \mathrm{Cu} \text {. } \\
\text { (Sardana, Urui, Kupandzha) }\end{array}$ & $\begin{array}{l}\text { Rifted passive continental } \\
\text { margin. } \\
\text { North Asian Craton Margin. }\end{array}$ & $\begin{array}{l}\text { Rifting of middle Paleozoic (Late Devonian to Early Mississippian) continental- } \\
\text { margin. Belt continued into Early Mississippian. }\end{array}$ \\
\hline $\begin{array}{l}\text { Selennyakh River } \\
\text { (SEL) }\end{array}$ & $\begin{array}{l}\text { Southeast Missouri } \mathrm{Pb}-\mathrm{Zn} \text {, stratabound } \\
\mathrm{Hg} \text {. } \\
\text { (Gal-Khaya, Kondakovskoe) }\end{array}$ & $\begin{array}{l}\text { Rifted passive continental } \\
\text { margin. } \\
\text { Omulevka terrane. }\end{array}$ & $\begin{array}{l}\text { Rifting of middle Paleozoic (Late Devonian to Early Mississippian) continental- } \\
\text { margin. Belt continued into Early Mississippian. }\end{array}$ \\
\hline Tommot River (TO) & $\begin{array}{l}\text { Carbonatite-related } \mathrm{Nb}, \mathrm{Ta} \text {, and REE } \\
\text { (Tommot) }\end{array}$ & $\begin{array}{l}\text { Rifted passive continental } \\
\text { margin. } \\
\text { Omulevka terrane. }\end{array}$ & $\begin{array}{l}\text { Rifting of middle Paleosoic (Late Devonian to Early Mississippian) continental- } \\
\text { margin. Belt continued into Early Mississippian. }\end{array}$ \\
\hline $\begin{array}{l}\text { Urultun \& Sudar } \\
\text { Rivers (URS) }\end{array}$ & $\begin{array}{l}\text { Southeast Missouri } \mathrm{Pb}-\mathrm{Zn} \text {, carbonate- } \\
\text { hosted } \mathrm{Hg} \text {. } \\
\text { (Urultun, Uochat) }\end{array}$ & $\begin{array}{l}\text { Rifted passive continental } \\
\text { margin. } \\
\text { Omalevka terrane. }\end{array}$ & $\begin{array}{l}\text { Rifting of middle Paleozoic (Late Devonian to Early Mississippian) continental- } \\
\text { margin. Belt continued into Early Mississippian. }\end{array}$ \\
\hline Yarkhodon (YR) & $\begin{array}{l}\text { Southeast Missouri Pb-Zn } \\
\text { (Slezovka, Gornoe) }\end{array}$ & $\begin{array}{l}\text { Rifted passive continental } \\
\text { margin. } \\
\text { Prikolyma terrane. }\end{array}$ & $\begin{array}{l}\text { Rifting of middle Paleozoic (Late Devonian to Early Mississippian) continental- } \\
\text { margin. Belt continued into Early Mississippian. }\end{array}$ \\
\hline
\end{tabular}




\begin{tabular}{|c|c|c|c|}
\hline $\begin{array}{l}\text { Metallogenic Belt } \\
\text { (Abbreviation) }\end{array}$ & $\begin{array}{l}\text { Major Mineral Deposits Types. } \\
\text { (Significant Mineral Deposits) }\end{array}$ & $\begin{array}{l}\text { Environmeat. } \\
\text { Host Unit. }\end{array}$ & $\begin{array}{l}\text { Tectonic Event. } \\
\text { Comments }\end{array}$ \\
\hline $\begin{array}{l}\text { Berezovka River } \\
\text { (BE) }\end{array}$ & $\begin{array}{l}\text { Kuroko massive sulfide and sulfide vein. } \\
\text { (Berezovskoe) }\end{array}$ & $\begin{array}{l}\text { Rifted passive continental } \\
\text { margin. } \\
\text { Berezovka terrane. }\end{array}$ & $\begin{array}{l}\text { Rifting of middle Palcozoic (Late Devonian to Mississippian) continental-margin. } \\
\text { Belt continued into Permian(?). }\end{array}$ \\
\hline \multicolumn{4}{|c|}{ Metallogenic Belts Formed During Middle Puleozoic Rifting of North Americun Cruton Margin or in Low-Temperature Brines Along Craton Margin } \\
\hline Mystic (MY) & $\begin{array}{l}\text { SEDEX massive bedded barite, Southeast } \\
\text { Missouri Pb- } \mathrm{Zn} \text {. } \\
\text { (Gagaryah, Reef Ridge) }\end{array}$ & $\begin{array}{l}\text { Rifted passive continental } \\
\text { margin. } \\
\text { North Asian Craton Margin. }\end{array}$ & $\begin{array}{l}\text { Rifting of middle Palecozoic (Late Devonian to Early Mississippian) continental- } \\
\text { margin. Belt continued into Early Mississippian. }\end{array}$ \\
\hline $\begin{array}{l}\text { Northern Cordillera } \\
\text { (NCO) }\end{array}$ & $\begin{array}{l}\text { Southeast Missouri Zn-Pb. } \\
\text { (Gayna River, Goz Creek, Godlin Lakes) }\end{array}$ & $\begin{array}{l}\text { Rifted continental margin. } \\
\text { North American Craton } \\
\text { Margin. }\end{array}$ & $\begin{array}{l}\text { Incipient rifting of Late Proterozoic to middle Paleozoic (Devonian-Mississippian) } \\
\text { North American Continental Margin. Belt extended from Late Proterozoic to } \\
\text { Devonian(?). }\end{array}$ \\
\hline Dempster (DE) & $\begin{array}{l}\text { SEDEX Ba, Ni-Zn-PGE-Au SEDEX, } \\
\text { Kuroko Zn-Pb-Cu massive sulfide. } \\
\text { (Rein, Marg, Nick) }\end{array}$ & $\begin{array}{l}\text { Rifted continental margin. } \\
\text { North Amserican Craton } \\
\text { Margin. }\end{array}$ & $\begin{array}{l}\text { Rifting of middle Paleozoic (Late Devonian to Early Mississippian) North } \\
\text { American Continental Margin. }\end{array}$ \\
\hline Macmillan Pass (MP) & $\begin{array}{l}\text { Sedimentary-Exhalative } \mathrm{Zn}-\mathrm{Pb}-\mathrm{Ag} \text {. } \\
\text { (Tom, Jason, Main) }\end{array}$ & $\begin{array}{l}\text { Rifted continental margin. } \\
\text { North American Craton } \\
\text { Margin. }\end{array}$ & $\begin{array}{l}\text { Rifting of middle Paleozoic (Late Devonian to Early Mississippian) North } \\
\text { American Continental Margin. }\end{array}$ \\
\hline Finlayson Lake (FL) & $\begin{array}{l}\text { Sedimentary-Exhalative Zn-Pb-Ag. } \\
\text { (Maxi, Matt Berry, Finlayson Lake) }\end{array}$ & $\begin{array}{l}\text { Rifled continental margin. } \\
\text { North American Craton } \\
\text { Margin. }\end{array}$ & $\begin{array}{l}\text { Incipient rifting of middle Paleozoic (Late Devonian to Early-Mississippian) North } \\
\text { American Continental Margin. }\end{array}$ \\
\hline Liard (LI) & $\begin{array}{l}\text { Southeast Missouri(?) Ba-F } \\
\text { (Leguil Creek, Lower Liard) }\end{array}$ & $\begin{array}{l}\text { Rifted continental margin. } \\
\text { North American Craton } \\
\text { Margin. }\end{array}$ & $\begin{array}{l}\text { Rifting of middle Paleozoic (Late Devonian to Early Mississippian) North } \\
\text { American continental-margin. }\end{array}$ \\
\hline Gatagz (GA) & $\begin{array}{l}\text { Sedimentary-Exhalative } \mathrm{Zn}-\mathrm{Pb}-\mathrm{Ag} \text {. } \\
\text { (Cirque, Driftpile Creek, Gataga) }\end{array}$ & $\begin{array}{l}\text { Rifted continental margin. } \\
\text { North American Craton } \\
\text { Margin. }\end{array}$ & $\begin{array}{l}\text { Incipient rifting of middle Paleozoic (Late Devonian to Early Mississippian) North } \\
\text { American continental-margin. }\end{array}$ \\
\hline Robb Lake (RL) & $\begin{array}{l}\text { Southeast Missouri } \mathrm{Zn}-\mathrm{Pb} \text {. } \\
\text { (Robb Lake) }\end{array}$ & $\begin{array}{l}\text { Rifted continental margin. } \\
\text { North American Craton } \\
\text { Margin- }\end{array}$ & $\begin{array}{l}\text { Rifting of middle Paleozoic (Late Devonian to Early Mississippian) North } \\
\text { American Continental Margin. }\end{array}$ \\
\hline $\begin{array}{l}\text { Southem Rocky } \\
\text { Mountains (SRM) }\end{array}$ & $\begin{array}{l}\text { Chemical-sedimentary gypsum } \\
\text { (Windemere Creek, Marysville, Mount } \\
\text { Brussilof, Parson, Brocso) }\end{array}$ & $\begin{array}{l}\text { Rifled continental margin. } \\
\text { North American Craton } \\
\text { Margin. }\end{array}$ & $\begin{array}{l}\text { Incipient rifting of middle Paleogoic (Devonian) North American Continental } \\
\text { Margin. Belt extended into Late Proterozoic with formation of sedimentary Mg } \\
\text { and Ba vein deposits. }\end{array}$ \\
\hline Ingenika ( $\mathbb{N}$ ) & $\begin{array}{l}\text { Southeast Missouri Zn-Pb-Ag. } \\
\text { Monarch (Susie, Beveley and Regent) }\end{array}$ & $\begin{array}{l}\text { Passive continental margin. } \\
\text { Cassiar terrane. }\end{array}$ & $\begin{array}{l}\text { Deposition by low-temperature brines which may have originated within an } \\
\text { adjacent shale basin. }\end{array}$ \\
\hline Cathedral (CA) & $\begin{array}{l}\text { Southeast Missoun } \mathrm{Zn}-\mathrm{Pb}-\mathrm{Ag}_{\mathrm{g}} \\
\text { Monarch (Kicking Horse) }\end{array}$ & $\begin{array}{l}\text { Passive continental margin. } \\
\text { North American Craton } \\
\text { Margin. }\end{array}$ & $\begin{array}{l}\text { Deposition by low-temperature brines which may have originated within an } \\
\text { adjacent shale basin. }\end{array}$ \\
\hline
\end{tabular}




\begin{tabular}{|c|c|c|c|}
\hline $\begin{array}{l}\text { Metallogenic Belt } \\
\text { (Abbreviation) }\end{array}$ & $\begin{array}{l}\text { Major Mineral Deposits Types, } \\
\text { (Significant Miseral Deposits) }\end{array}$ & $\begin{array}{l}\text { Environment. } \\
\text { Host Unit. }\end{array}$ & $\begin{array}{l}\text { Tectonic Event. } \\
\text { Comments }\end{array}$ \\
\hline \multicolumn{4}{|c|}{ MISSISSIPPIAN METALLOGENIC BELTS (360 to $320 \mathrm{Ma}$ ) (Figures 4, 5) } \\
\hline \multicolumn{4}{|c|}{ Continuing Metallogenic Belts } \\
\hline \multicolumn{4}{|c|}{ Metallogeaic Belt Formed During Mississippian-Pennsylvanian Back-Arc Spreading Along Nerth American Craton Margin } \\
\hline $\begin{array}{l}\text { Northwestern Brooks } \\
\text { Range (NBR) }\end{array}$ & $\begin{array}{l}\text { SEDEX Zn-Pb. } \\
\text { (Lik, Red Dog Creek) } \\
\text { Kuroko massive sulfide. } \\
\text { (Drenchwater Creek) } \\
\text { Bedded barite, sulfide vein. }\end{array}$ & $\begin{array}{l}\text { Incipient rif(?) along } \\
\text { consinental margin arc. } \\
\text { Arctic Alaska superterrane. }\end{array}$ & $\begin{array}{l}\text { Subduction-related volcanism associated with Mississippian-Pennsylvanian, } \\
\text { beck-arc spreading that was possibly associated with a shon-lived continental- } \\
\text { margin arc }\end{array}$ \\
\hline \multicolumn{3}{|c|}{ Selennyakh River (SEL) } & Belit started in Devonian. \\
\hline \multicolumn{3}{|l|}{ Sette-Daban (SD) } & Belt started in Devonian. \\
\hline \multicolumn{3}{|c|}{ Urultuin \& Sadar Rivers (URS) } & Belt started in Devonian. \\
\hline \multicolumn{3}{|l|}{ Kedon (KE) } & Beli started in Devonian. \\
\hline \multicolumn{3}{|c|}{ Northern Cordillera (NCO) } & Bclt started in Devonian. \\
\hline \multicolumn{3}{|c|}{ Dempster (DE) } & Belt started in Devonian. \\
\hline \multicolumn{3}{|l|}{ Macmillan Pass (MP) } & Belt starned in Devonian. \\
\hline \multicolumn{3}{|l|}{ Finlayson Lake } & Belt started in Devonian. \\
\hline \multicolumn{3}{|l|}{ Gataga (GA) } & Belt started in Devonian. \\
\hline \multicolumn{4}{|c|}{ PENNSYLVANIAN METALLOGENIC BELTS $(320$ to 286 Ma) (Figures 6,7 ) } \\
\hline \multicolumn{4}{|c|}{ Metallogenic Belt Formed During Mississippian-Pennsylvanian Back-Arc Spreading Along Nerth American Craton Margin } \\
\hline \multicolumn{3}{|c|}{ Northwestern Brooks Range (NBR) } & Beft started in Mississippian. \\
\hline \multicolumn{4}{|c|}{ Metallogenic Belt Formed in Late Paleocoic Island Are Terrane in the Russian Southeast } \\
\hline $\begin{array}{l}\text { Laoelin-Grodekorsk } \\
\text { (LG) }\end{array}$ & $\begin{array}{l}\text { Porphyry Cu-Mo, Au-Ag epithermal } \\
\text { vein. } \\
\text { (Baikal, Komissarovskoe) }\end{array}$ & $\begin{array}{l}\text { Island arc. } \\
\text { Lavelin-Grodekovsk terrane. }\end{array}$ & $\begin{array}{l}\text { Subduction-related granitic plutonism that formed the Lavelin-Grodekovsk isfand } \\
\text { are, part of Khanka saperterrane, a rifted fragment of Gondwandaland } \\
\text { superoontinent. Not depicted on metallogenic model because of formation } \\
\text { beyond map area. }\end{array}$ \\
\hline \multicolumn{4}{|c|}{ Metallegenic Belts Formed In Late Paleozoic Oceanic Lithosphere Preserved in Subduction Zones Terranes in Russian Northeast } \\
\hline Aluchin (AC) & $\begin{array}{l}\text { Podiform } \mathrm{Cr} \text {. } \\
\text { (Teleneut) }\end{array}$ & $\begin{array}{l}\text { Back-are rifting? } \\
\text { Aluchin subduction zone terrane }\end{array}$ & $\begin{array}{l}\text { Oceanic lithosphere preserved in Aluchin subuction zone that was tectonically } \\
\text { linked to Alazcya island are. }\end{array}$ \\
\hline Ust-Belaya (UB) & $\begin{array}{l}\text { Podiform Cr. } \\
\text { (Ulst-Belaya) }\end{array}$ & $\begin{array}{l}\text { Oceanic ridge. } \\
\text { Penzhisa Anadyr subduction } \\
\text { zone terrane. }\end{array}$ & $\begin{array}{l}\text { Oceanic lithosphere preserved in Penzhina Anadyr subuction zone that was } \\
\text { tectonically linked to Koni-Murgal continental margin and island are. }\end{array}$ \\
\hline \multicolumn{4}{|c|}{ Metallogenic Belts Formed in Late Paleozoie Skolai Island Are in Wrangellia Superterrane } \\
\hline $\begin{array}{l}\text { Alaska Range- } \\
\text { Wrangell } \\
\text { Mountains (ARW) }\end{array}$ & $\begin{array}{l}\text { Cu skarn, porphyry } \mathrm{Cu} \text {, polymetallic } \\
\text { vein. } \\
\text { (Rainy Creek, Rainbow Mountain, } \\
\text { Chistochina) }\end{array}$ & $\begin{array}{l}\text { Island are. } \\
\text { Wrangellia sequence, } \\
\text { Wrangellia superterrane. }\end{array}$ & $\begin{array}{l}\text { Subduction-related granitic plutonism in Skolai island are developed along } \\
\text { margin of Wrangellia superterrane. }\end{array}$ \\
\hline Ketchikan (KK) & $\begin{array}{l}\text { Kuroko massive sulfide } \\
\text { (Moth Bay) }\end{array}$ & $\begin{array}{l}\text { Island arc. } \\
\text { Wrangellia sequence, } \\
\text { Wrangellia superterrane. }\end{array}$ & $\begin{array}{l}\text { Subduction-related granitic plutonism in Skolai island are developed along } \\
\text { margin of Wrangellia superterrane }\end{array}$ \\
\hline
\end{tabular}




\begin{tabular}{|c|c|c|c|}
\hline $\begin{array}{l}\text { Metallogeaic Belt } \\
\text { (Abbreviation) }\end{array}$ & $\begin{array}{l}\text { Major Mineral Deposits Types. } \\
\text { (Significant Mineral Deposits) }\end{array}$ & $\begin{array}{l}\text { Environment. } \\
\text { Host Unit. }\end{array}$ & $\begin{array}{l}\text { Tectonic Eveat. } \\
\text { Comments }\end{array}$ \\
\hline \multicolumn{4}{|c|}{ LATE TRIASSIC METALLOGENIC BELTS (Carnian through Norian - 230 to $208 \mathrm{Ma}$ ) (Figure 7 ) } \\
\hline \multicolumn{4}{|c|}{ Metallogenic Belt Formed During Early Mesozoic Rifting? in Aluskan Passive Continental-Margin Terranes } \\
\hline Farewell (FW) & $\begin{array}{l}\text { Gabbroic Ni-Cu-PGE. } \\
\text { (Farewell district) }\end{array}$ & $\begin{array}{l}\text { Rifting? } \\
\text { Dillinger terrane. }\end{array}$ & Incipient rifting of Dillinger and adjacent passive continental margin terranes? \\
\hline \multicolumn{4}{|c|}{ Metallogenic Belts Formed in Middle Mesoxoic Talkeetna-Bonzana Island Are in Wrangellia Superterrane } \\
\hline $\begin{array}{l}\text { Kodiak Island and } \\
\text { Border Ranges } \\
\text { (KOD) }\end{array}$ & $\begin{array}{l}\text { Podiform Cr. } \\
\text { (Halibun Bay, Claim Point, Red } \\
\text { Mountain, Bernard Mountain, Dust } \\
\text { Mountain) }\end{array}$ & $\begin{array}{l}\text { Island arc. } \\
\text { Border Ranges mafic-ultramafic } \\
\text { assemblage }\end{array}$ & $\begin{array}{l}\text { Subduction-related intrusion of mafic-ultramafic platons into basal part of } \\
\text { Talkeetna-Bonzana island are in Wrangellia superterrane. } \\
\text { Metallogenic belt extended into Early and Middle Jurassic. }\end{array}$ \\
\hline $\begin{array}{l}\text { Eastem Alaska Range } \\
\text { (EAR) (equivalent } \\
\text { to Kluane-Nikolai } \\
\text { beli) }\end{array}$ & $\begin{array}{l}\text { Gabbroic Ni-Cu. } \\
\text { (Fish Lake, Wellgreen) } \\
\text { Besshi massive sulfide } \\
\text { (Denali) } \\
\text { Strataform gypsum } \\
\text { (Bullion Creek) }\end{array}$ & $\begin{array}{l}\text { Back-arc rifting? } \\
\text { Nikolai Greenstone, Wrangellia } \\
\text { sequence, Wrangellia } \\
\text { superterrane }\end{array}$ & $\begin{array}{l}\text { Back-are rifting associated with Talkeetna part of Talkeetna-Bonanza island arc } \\
\text { in Wrangellia superterrane. } \\
\text { Altemative interpretation of hot spot (oceanic plume). }\end{array}$ \\
\hline Alexander $(A X)$ & $\begin{array}{l}\text { Cyprus massive sulfide, Kuroko massive } \\
\text { sulfide, bedded barite. } \\
\text { (Windy Craggy, Greens Creek, Castle } \\
\text { Island, Kupreanof Island, Haines) }\end{array}$ & $\begin{array}{l}\text { Back-arc? } \\
\text { Nikolai Greenstone and } \\
\text { equivalent units, Wrangellia } \\
\text { sequence, Wrangellia super } \\
\text { terrane. }\end{array}$ & $\begin{array}{l}\text { Back-are rifting associated with Bonanza part of the Talkeetna-Bonanza island } \\
\text { are in Wrangellia superterrane. } \\
\text { Altemative interpretation of hot spot (oceanic plume). }\end{array}$ \\
\hline \multicolumn{4}{|c|}{ Metallogenic Belts Formed in Middle Mesozoic in Stikinia-Quesnellia Island Are } \\
\hline Galore Croek (GL) & $\begin{array}{l}\text { Porphyry Cu-Au. } \\
\text { (Galore Creek, Red Chris) }\end{array}$ & $\begin{array}{l}\text { Island are. } \\
\text { Stikinia \& Quesnellia terranes. }\end{array}$ & $\begin{array}{l}\text { Subduction-related granitic plutonism that formed the Stikinia-Quesnellia island } \\
\text { arc. Belt continued into Early Jurassic. }\end{array}$ \\
\hline Sustut (SU) & $\begin{array}{l}\text { Bassaltic Cu } \\
\text { (Susul) }\end{array}$ & $\begin{array}{l}\text { Island are. } \\
\text { Stikinia terrane. }\end{array}$ & $\begin{array}{l}\text { Formation in the upper oxidized parts of the Stikinia-Quesnellia island are } \\
\text { voleanic pile during shallow burial metamorphism and diagenesis. }\end{array}$ \\
\hline $\begin{array}{r}\text { Copper Mouncain } \\
\text { (Norih) (CMN) }\end{array}$ & $\begin{array}{l}\text { Porphyry Cu-Au, porphyry Cu-Mo, } \\
\text { (Lorraine, Mount Mulligan) }\end{array}$ & $\begin{array}{l}\text { Island arc. } \\
\text { Stikinia \& Quesnellia terranes. }\end{array}$ & $\begin{array}{l}\text { Subduction-felated granitic plutonism that formed the Quesnelitia island are. Belt } \\
\text { continued into Early Jurassac. }\end{array}$ \\
\hline $\begin{array}{l}\text { Copper Mountain } \\
\text { (South) (CMS) }\end{array}$ & $\begin{array}{l}\text { Porphyry Cu-Au. } \\
\text { (Copper Mountain, Ingerbelle, Iron } \\
\text { Mask, Mount Polley) }\end{array}$ & $\begin{array}{l}\text { Island are. } \\
\text { Quesnellia terrane. }\end{array}$ & $\begin{array}{l}\text { Subduction-related granitic plutonism that formed the Quesnellia is land arc. Belt } \\
\text { continued into Early Jurassic. }\end{array}$ \\
\hline Guichoe (GU) & $\begin{array}{l}\text { Porphyry Cu-Mo-Au, Au skarn. } \\
\text { (Highland Valley district, Brenda, } \\
\text { Gibraltar, Craigmont, Hedley) }\end{array}$ & $\begin{array}{l}\text { Island are. } \\
\text { Quesneltia terrane. }\end{array}$ & $\begin{array}{l}\text { Subduction-related granitic plutonism thas formed the Quessellia island are. Belt } \\
\text { continued into Early Jurassic. }\end{array}$ \\
\hline Texas Crock (TC) & $\begin{array}{l}\text { Porphyry Cu-Mo-Au, polymetallic vein. } \\
\text { (Schaft Creek, Kerr, Sulphurets, Snip. } \\
\text { Red Mountain, \& others) }\end{array}$ & $\begin{array}{l}\text { Island arc. } \\
\text { Stikinia terrane. }\end{array}$ & $\begin{array}{l}\text { Subduction-related granitic plutonism that formed the Stikinia island arc. Belt } \\
\text { continued into Early Jurassic. }\end{array}$ \\
\hline
\end{tabular}




\begin{tabular}{|c|c|c|c|}
\hline $\begin{array}{l}\text { Metallogenic Belt } \\
\text { (Abbreviation) }\end{array}$ & $\begin{array}{l}\text { Major Mineral Deposits Types. } \\
\text { (Sigaificant Mineral Deposits) }\end{array}$ & $\begin{array}{l}\text { Environment. } \\
\text { Host Unit. }\end{array}$ & $\begin{array}{c}\text { Tectonic Event. } \\
\text { Comments }\end{array}$ \\
\hline \multicolumn{4}{|c|}{ EARLY JURASSIC METALLOGENIC BELTS (Hettangian through Pleinsbachian = 208 to I93 Ma) (Figure 8) } \\
\hline \multicolumn{4}{|c|}{ Metallogenic Belts Formed in Middle Mesozoic in Talkeetna-Bonzana Island Arc in Wrangellia Superterrane } \\
\hline $\begin{array}{l}\text { Alagka Peninsula } \\
\text { (AP) }\end{array}$ & $\begin{array}{l}\text { Cu \& Fe skarn. } \\
\text { (Crevice Creek, Glacier Fork, Kasna } \\
\text { Creek, Magnetite Island) }\end{array}$ & $\begin{array}{l}\text { Island arc. } \\
\text { Granitic plutons Peninsular } \\
\text { sequence, Wrangellia } \\
\text { superterrane. }\end{array}$ & $\begin{array}{l}\text { Subduction-reiated granitic plutonism than formed the Talkeetna pan of the } \\
\text { Talkeetna-Bonanza island are in Wrangellia superterrane. } \\
\text { Metallogenic belt may have exrended into Middle Jurassic. }\end{array}$ \\
\hline $\begin{array}{l}\text { Talkeetna Mountains- } \\
\text { Alaska Range } \\
\text { (TM) }\end{array}$ & $\begin{array}{l}\text { Kuroko massive sulfide. } \\
\text { (Johnson River) }\end{array}$ & $\begin{array}{l}\text { Jsland arc. } \\
\text { Talkeetna Formation, Peninsular } \\
\text { sequence, Wrangellia } \\
\text { superterrane. }\end{array}$ & $\begin{array}{l}\text { Subduction-related marine voleanism associated with Talkectna part of } \\
\text { Talkeetna- Bonanza island are in Wrangeltia superterrane. }\end{array}$ \\
\hline Island Porphyry (IP) & $\begin{array}{l}\text { Porphyry Cu-Mo, Cu skam, Fe skam. } \\
\text { (Island Copper, Tasu, Jedway. Bumaby } \\
\text { Iron) }\end{array}$ & $\begin{array}{l}\text { Island arc. } \\
\text { Wrangellia superterrane. }\end{array}$ & $\begin{array}{l}\text { Subduction-related granitic plutonism that formed the Bonanza part of the } \\
\text { Talkeetna-Bonanza island are in Wrangellia superterrane. Belt continued into } \\
\text { early Late Jurassic. }\end{array}$ \\
\hline \multicolumn{4}{|c|}{ Metallogenic Belts Formed During Middle Mesozoic in Stikinia Island Arc } \\
\hline Klotassin (KL) & $\begin{array}{l}\text { Porphyry Cu-Au-Ag. } \\
\text { (Minto Creek, Williams Creek) }\end{array}$ & $\begin{array}{l}\text { Island are. } \\
\text { Stikinia and Yukon-Tanana } \\
\text { terranes. }\end{array}$ & Subduction-related granitic plutonism that formed the Stikinia island are. \\
\hline Toodoggone (TO) & $\begin{array}{l}\text { Au-Ag epithermal vein and porphyry Cu- } \\
\text { Au. } \\
\text { (Luwyers, Chappelle. AJ, Kemess) }\end{array}$ & $\begin{array}{l}\text { Island arc. } \\
\text { Stikinia terrane. }\end{array}$ & Subduction-related granitic plutonism that formed the Stikinia island arc. \\
\hline $\begin{array}{l}\text { Coast Mountains } \\
\text { (CM) }\end{array}$ & $\begin{array}{l}\text { Kuroko massive sulfide, Besshi massive } \\
\text { sulfide) } \\
\text { (Eskay Croek, Dolly Varden, North Star, } \\
\text { Granduc, Anyox) }\end{array}$ & $\begin{array}{l}\text { Island arc. } \\
\text { Stikinia terrane }\end{array}$ & $\begin{array}{l}\text { Subduction-related, back-are volcanism associated with Stikinia island are. Three } \\
\text { periods of deposit formation, middle and late Paleozoic, Late Triassic, and } \\
\text { Early Jurassic. }\end{array}$ \\
\hline \multicolumn{4}{|c|}{ Centinuing Metallogenic Belts } \\
\hline \multicolumn{3}{|l|}{ Texas Creek (TC) } & Belt started in Lafe Triassic. \\
\hline \multicolumn{3}{|l|}{ Galore (GL) } & Belt started in Late Triassic. \\
\hline \multicolumn{3}{|c|}{ Copper Mountain (North) (CMN) } & Belt started in Late Triassic. \\
\hline \multicolumn{3}{|c|}{ Copper Mountain (South) (CMS) } & Belt started in Late Triassic. \\
\hline \multicolumn{3}{|l|}{ Guichon (GU) } & Belt started in Late Triassic. \\
\hline \multicolumn{4}{|c|}{ MIDDLE JURASSIC METALLOGENIC BELTS (Toarcian through Callovian - 193 to 163 Ma), (Figure 8) } \\
\hline \multicolumn{4}{|c|}{ Continuing Metallogenic Belts } \\
\hline \multicolumn{3}{|c|}{ Talkeetna Mountains (TM) } & Belt started in Early Jurassic. \\
\hline \multicolumn{3}{|l|}{ Alaska Peninsula (AP) } & Belt started in Early Jurassic. \\
\hline \multicolumn{3}{|l|}{ Island Porphyry (IP) } & Belt started in Early Jurassic. \\
\hline \multicolumn{3}{|l|}{ Klotassin (KL) } & Belt started in Early Jurassic. \\
\hline \multicolumn{3}{|l|}{ Texas Creek (TC) } & Belt started in Late Triassic. \\
\hline \multicolumn{3}{|l|}{ Galore (GL) } & Belt started in Late Triassic. \\
\hline \multicolumn{3}{|l|}{ Toodoggone (TO) } & Belt started in Early Jurassic \\
\hline \multicolumn{3}{|l|}{ Coast Mountains (CM) } & Belt started in Early Jurassic \\
\hline \multicolumn{3}{|c|}{ Cogper Mountain (North) (CMN) } & Belt started in Late Triassic. \\
\hline \multicolumn{3}{|c|}{ Copper Mountain (South) (CMS) } & Belt started in Late Triassic. \\
\hline
\end{tabular}




\begin{tabular}{|c|c|c|c|}
\hline $\begin{array}{l}\text { Metallogenic Belt } \\
\text { (Abbreviation) }\end{array}$ & $\begin{array}{l}\text { Major Mineral Deposits Types. } \\
\text { (Significant Mineral Deposits) }\end{array}$ & $\begin{array}{l}\text { Environment. } \\
\text { Host Unit. }\end{array}$ & $\begin{array}{l}\text { Tectoaic Event. } \\
\text { Comments }\end{array}$ \\
\hline \multicolumn{3}{|l|}{ Guichon (GU) } & Belt started in Late Triassic. \\
\hline \multicolumn{4}{|c|}{ LATE JURASSIC METALLOGENIC BELTS (Oxfordian through Kimmerigian - 163 to 144 Ma) (Figures 9, 10 ) } \\
\hline \multicolumn{4}{|c|}{ Metallogenic Belts Formed Along Late Mesozoic Contineatal-Margin Transform Fault in Russian Southest } \\
\hline Ariadny (AR) & $\begin{array}{l}\text { Zoned mafic-ultramafic Ti. } \\
\text { (Katenskoe, Ariadnoe, Koksharovskoe) }\end{array}$ & $\begin{array}{l}\text { Transform margin. } \\
\text { Zoned mafic-ultramafic plutons } \\
\text { intrudiag Samarka tenrane. }\end{array}$ & $\begin{array}{l}\text { Transform-margin-related intrusion of mafic-ultramafic plutons along major } \\
\text { continental-margin transform faults that formed after accretion of Samarka } \\
\text { subduction zone terrane. } \\
\text { Beln may have extended into Early Cretaceous. }\end{array}$ \\
\hline \multicolumn{4}{|c|}{ Metallogenic Belts Formed in Late Mesozoic Continental Margin and Island Arc Systems in Russian Far East } \\
\hline North Bureya (NB) & $\begin{array}{l}\text { Au-Ag epithermal vein and granitoid- } \\
\text { relaied Au deposits. } \\
\text { (Pokrovskoe, Pioneer) }\end{array}$ & $\begin{array}{l}\text { Continental-margin arc. } \\
\text { Umlekan-Ogodzhin volcanic- } \\
\text { plutonic belt. }\end{array}$ & $\begin{array}{l}\text { Subduction-related granitic plutonism that formed the Umlekan continental- } \\
\text { margin arc. }\end{array}$ \\
\hline $\begin{array}{l}\text { Chersky-Argatass } \\
\text { Ranges (CAR) }\end{array}$ & $\begin{array}{l}\text { kuroko massive sulfide. } \\
\text { (Khotoidokb) }\end{array}$ & $\begin{array}{l}\text { Island arc. } \\
\text { Indigirka-Oloy volcanic- } \\
\text { plutonic assemblage. }\end{array}$ & $\begin{array}{l}\text { Subduction-related volcanism associated with Uyandina island arc. } \\
\text { Belt extended into Middle Jurassic. }\end{array}$ \\
\hline $\begin{array}{l}\text { Yasachnaya River } \\
\text { (YS) }\end{array}$ & $\begin{array}{l}\text { Pb-Zn skam, porphyry Cu. } \\
\text { (Kunarev, Terrassnoe, Datsytovoe) }\end{array}$ & $\begin{array}{l}\text { Island are. } \\
\text { Uyandin-Yassachny volcanic- } \\
\text { plutonic belt. }\end{array}$ & Subduction-related volcanism associated with Uyandina island arc. \\
\hline Oloy (OL) & $\begin{array}{l}\text { Porphyry Cu-Mo, Au-Ag epithermal } \\
\text { vein. } \\
\text { (Peschanka, Vesennee) }\end{array}$ & $\begin{array}{l}\text { Lsland arc. } \\
\text { Oloy volcanic belt. }\end{array}$ & $\begin{array}{l}\text { Subduction-relsted granific plutonism that formed the Oloy island arc. } \\
\text { Belt extended into Early Cretaccous. }\end{array}$ \\
\hline Pekulney (PK) & $\begin{array}{l}\text { Basaltic Cu. } \\
\text { (Skalistaya) }\end{array}$ & $\begin{array}{l}\text { Oceanic crust. } \\
\text { Pekuliney subduction-zone } \\
\text { terrane. }\end{array}$ & Primitive island are and neighboring sea-floor environment. \\
\hline $\begin{array}{l}\text { Tamvatney-Mainits } \\
\text { (TAM) }\end{array}$ & $\begin{array}{l}\text { Podiform } \mathrm{Cr} \text {. } \\
\text { (Krassnaya Gora) }\end{array}$ & $\begin{array}{l}\text { Island afc. } \\
\text { Zoned mafic-uliramafic plutons } \\
\text { in Mainitskiy terrane. }\end{array}$ & $\begin{array}{l}\text { Subduction-felated intrusion of mafic-ulsramafic plutons into basal pan of } \\
\text { Mainitskiy island are. Mafic-uliramafic rocks hosting deposits form part of } \\
\text { structurally-complex ophiolite at base of Mainitskiy island are terrane. Belt } \\
\text { extended into Early Cretaceous }\end{array}$ \\
\hline Mainits (MA) & $\begin{array}{l}\text { Kuroko massive sulfide. } \\
\text { (Ugryumoe) }\end{array}$ & $\begin{array}{l}\text { Island afe. } \\
\text { Maimitskiy terrane. }\end{array}$ & $\begin{array}{l}\text { Massive sulfide deposition associaned with Mainitskiy island arc. Belt extended } \\
\text { inte Early Cretaceous. }\end{array}$ \\
\hline Svyatoy-Nos (SVN) & $\begin{array}{l}\text { Atr-Ag eputhermal vein. } \\
\text { (Polevaya) }\end{array}$ & $\begin{array}{l}\text { Island are. } \\
\text { Svyatoy-Nos volcanic belt. }\end{array}$ & Subduction-related granitic plutonism that formed the Svyatoy-Nos island arc. \\
\hline Kuyul (KUY) & $\begin{array}{l}\text { Podiform Cr-PGE } \\
\text { (Talov, Tikhorechen) }\end{array}$ & $\begin{array}{l}\text { Island are. } \\
\text { Talovskiy terrane. }\end{array}$ & $\begin{array}{l}\text { Subduction-related inirusion of mafic-ultramafic plutons into basal part of Kony- } \\
\text { Murgal island are. }\end{array}$ \\
\hline \multicolumn{4}{|c|}{ Metallogenic Belts Formed in Late Mesozoic Koyukuk and Togiak Island Are Systems in Western and Soathwestern Alaska } \\
\hline $\begin{array}{l}\text { Eastern Seward } \\
\text { Peninsula and } \\
\text { Marshall (ESM) }\end{array}$ & $\begin{array}{l}\text { Podiform Cr, serpentinite-hosted } \\
\text { asbestos. } \\
\text { (No significant deposits) }\end{array}$ & $\begin{array}{l}\text { Island arc. } \\
\text { Thrust slices of mafic-ultramafic } \\
\text { rocks, upper Angayucham } \\
\text { terrane. }\end{array}$ & $\begin{array}{l}\text { Subduction-related intrusion of mafic-ultramafic plutons into basal part of } \\
\text { Koyvokuk island arc. } \\
\text { Mafic-ultramafic rocks hosting deposits form upper, thrust-slice part of } \\
\text { Angayucham subduction zone terrane. }\end{array}$ \\
\hline Kobuk (KB) & $\begin{array}{l}\text { Podiform } \mathrm{Cr} \text {, serpentiaite-bosted } \\
\text { asbestos. } \\
\text { (lyikrok Mounain, Avan, Misheguk } \\
\text { Mountain, Siniktanneyak Mountain) }\end{array}$ & $\begin{array}{l}\text { Island are. } \\
\text { Thrust slices of mafic-ultramafic } \\
\text { rocks, upper Angayucham } \\
\text { terrane. }\end{array}$ & $\begin{array}{l}\text { Subduction-related intrusion of mafic-ultramafic plutons into basal part of } \\
\text { Koyukuk island arc. } \\
\text { Mafic-ultramafic rocks hosting deposits form upper, thrust-slice part of } \\
\text { Angayucham subduction zone terrane. }\end{array}$ \\
\hline
\end{tabular}




\begin{tabular}{|c|c|c|c|}
\hline $\begin{array}{l}\text { Metallogenic Belt } \\
\text { (Abbreviation) }\end{array}$ & $\begin{array}{l}\text { Major Mineral Depesits Types. } \\
\text { (Significant Mineral Depesits) }\end{array}$ & $\begin{array}{l}\text { Environment. } \\
\text { Host Unit. }\end{array}$ & $\begin{array}{l}\text { Tectonic Event. } \\
\text { Comments }\end{array}$ \\
\hline $\begin{array}{l}\text { Southuestern Alaska } \\
\text { (SWA) }\end{array}$ & $\begin{array}{l}\text { Zoned mafic-ultramafic PGE. } \\
\text { (Kemuk Mountain, Red Mountain) }\end{array}$ & $\begin{array}{l}\text { 1sland are. } \\
\text { Goodnews terrane. }\end{array}$ & $\begin{array}{l}\text { Subduction-related intrusion of mafic-ultramafic plutons into basal part of Togiak } \\
\text { island are. } \\
\text { Mafic-ultramafic rocks bosting deposits occur in tectonically linked Goodnews } \\
\text { subduction zone terrane. }\end{array}$ \\
\hline Yukon-River (YR) & $\begin{array}{l}\text { Podiform Cr. } \\
\text { (Caribou Mountain, Lower Kanuti River, } \\
\text { Holonada) }\end{array}$ & $\begin{array}{l}\text { Island arc. } \\
\text { Thrust slices of mafic-ultramafic } \\
\text { rocks, upper Angayucham } \\
\text { terrane. }\end{array}$ & $\begin{array}{l}\text { Subduction-related intrusion of mafic-ultramafic plutons into basal part of } \\
\text { Koyukuk island afc. } \\
\text { Mafic-ultramafic rocks hosting deposits form upper, thrust-slice part of } \\
\text { Angayucham subduction zone terrane. }\end{array}$ \\
\hline \multicolumn{4}{|c|}{ Metallogenic Belts Formed in Late Mesozoic Gruvinu Island Are in Southern and Southeastern Alaska, and Canadiun Cordillera } \\
\hline $\begin{array}{l}\text { Eastern-Southern } \\
\text { Alaska (ESA) }\end{array}$ & $\begin{array}{l}\text { Porphyry Cu, porphyry } \mathrm{Cu}-\mathrm{Mo} \text {. } \\
\text { (Pebble Copper, Orange Hill, Bond } \\
\text { Creek) }\end{array}$ & $\begin{array}{l}\text { Island are. } \\
\text { Gravina-Nutzotin-Gambier belt, } \\
\text { Wrangellia sequence, } \\
\text { Wrangellia superterrane. }\end{array}$ & $\begin{array}{l}\text { Subduction-related granitic plutonism that formed the Gravina island are on the } \\
\text { Wrangellia superterrane. } \\
\text { Belt continued into Early Cretaceous. }\end{array}$ \\
\hline Klukwan-Duke (KL) & $\begin{array}{l}\text { Zoned mafic-ultramafic Ti-Cr-PGE. } \\
\text { (Union Bay, Klukwan, Haines) }\end{array}$ & $\begin{array}{l}\text { Island arc. } \\
\text { Gravina-Nutzotin-Gambier belt, } \\
\text { Wrangellia sequence, } \\
\text { Wrangellia superterrane. }\end{array}$ & $\begin{array}{l}\text { Subduction-related mafic-ultramafic plutonism associated with basal part of } \\
\text { Gravina island are on the Wrangellia superterrane. } \\
\text { Belt continued into Early Cretaceous. }\end{array}$ \\
\hline \multicolumn{4}{|c|}{ Metallogenic Belts Formed in Late Mesozoic Collision and Overthrusting in Eastern Alaska and Canadian Cordillera } \\
\hline Fortymile (FM) & $\begin{array}{l}\text { Serpentinite-Hosted Asbestos. } \\
\text { (Slate Creek, Clinton Creek) }\end{array}$ & $\begin{array}{l}\text { Collisional. } \\
\text { Alteration of ultramafic rock, } \\
\text { Seventymile terrane. }\end{array}$ & $\begin{array}{l}\text { Regional metamorphism oceurring duriag obduction and overthrusting of oceanic } \\
\text { lithosphere of Seventymile terrane onto the North American Craton Margin. }\end{array}$ \\
\hline Cassiar (CS) & $\begin{array}{l}\text { Serpentine-hosted asbestos. } \\
\text { Cassiar (MeDame) }\end{array}$ & $\begin{array}{l}\text { Collisional. } \\
\text { Alteration of ultramafie rock, } \\
\text { Slide Mountain terrane. }\end{array}$ & $\begin{array}{l}\text { Regional metamorphism occurring during obduction and overthrusting of oceanic } \\
\text { lithosphere of Slide Mountain onto the North American Craton Margin. }\end{array}$ \\
\hline François Lake (FL) & $\begin{array}{l}\text { Porphyry Mo. } \\
\text { (Endako) }\end{array}$ & $\begin{array}{l}\text { Collisional. } \\
\text { Francois Lake plutonic suite. }\end{array}$ & $\begin{array}{l}\text { Anatectic granitic plutonism associated with obduction of Stikinia-Quesnellia } \\
\text { island arc and associated subduction zone complexes onto the North American } \\
\text { Craton Margin. }\end{array}$ \\
\hline Cariboo $\langle\mathrm{CB})$ & $\begin{array}{l}\text { Au quartz vein. } \\
\text { (Cariboo Gold Quartz, Frusergold) }\end{array}$ & $\begin{array}{l}\text { Collisional. } \\
\text { Veins in Downey Creek } \\
\text { Formation of Kootenay terrane. }\end{array}$ & $\begin{array}{l}\text { Regional metamorphism occurring during obduetion and overthrusting of } \\
\text { Kootenay, Stikinia-Quesnellia arc island and associated subduction zone } \\
\text { complexes onto the North American Craton Margin. Belt continued into Early } \\
\text { Cretaceous. }\end{array}$ \\
\hline Rossland (RL) & $\begin{array}{l}\text { Au-Ag polymetallic vein. } \\
\text { (Rossland, Sheep Creek, Ymir Erie } \\
\text { Creek). }\end{array}$ & $\begin{array}{l}\text { Collisional. } \\
\text { Veins in Nelson plutonic suite. }\end{array}$ & $\begin{array}{l}\text { Anatectic granitic plutonism associated with obduction of Stikinia-Quesnellia } \\
\text { island are and associated subduction zone complexes onto the North American } \\
\text { Craton Margin. }\end{array}$ \\
\hline \multicolumn{4}{|c|}{ Continuing Metallogeaic Belt } \\
\hline Island Porphyry (IP) & - & & Belt started in Early Jurassic and ceased in early Late Jurassic. \\
\hline
\end{tabular}




\begin{tabular}{|c|c|c|c|}
\hline $\begin{array}{l}\text { Metallogenic Belt } \\
\text { (Abbreviation) }\end{array}$ & $\begin{array}{l}\text { Major Minerul Deposits Types. } \\
\text { (Significant Mineral Deposits) }\end{array}$ & $\begin{array}{l}\text { Environment. } \\
\text { Host Unit. }\end{array}$ & $\begin{array}{l}\text { Tectonic Event. } \\
\text { Cemments }\end{array}$ \\
\hline \multicolumn{4}{|c|}{ EARLY CRETACEOUS METALLOGENIC BELTS (Neocomian - 144 to $120 \mathrm{Ma}$ ) (Figures 11,12 ) } \\
\hline \multicolumn{4}{|c|}{ Metallogenic Belts Formed Along Late Mesozoic Continental-Margin Transform Faults in Russian Southeast } \\
\hline Samarka (SA) & $\begin{array}{l}\text { W skam, porphyry Cu-Mo } \\
\text { (Vosiok-2, Bencvskoe, Khvoshchovoe, } \\
\text { Kafen, Malakhitovoe) }\end{array}$ & $\begin{array}{l}\text { Transform continental-margin- } \\
\text { Samarka accretionary-wedge } \\
\text { terrane. }\end{array}$ & $\begin{array}{l}\text { Anatectic granitic plutonism occurring during subduction of Kula oceanic ridge } \\
\text { along the transform contisental margin of the Russian Southeast. Belt } \\
\text { continued into late Early Cretaceous. }\end{array}$ \\
\hline Algama (AL) & $\begin{array}{l}\text { Stratiform Zr. } \\
\text { (Algaminskoe) }\end{array}$ & $\begin{array}{l}\text { Transform-margin. } \\
\text { Alkalic igneous rock intruding } \\
\text { Stanovoy block of North Asian } \\
\text { Craton. }\end{array}$ & $\begin{array}{l}\text { Intrusion of alkali igneous rock associated with mafic-ultramafic plutons that } \\
\text { intruded along major continental-margin transform faults during subduction of } \\
\text { terranes along Mongol-Okholsk fault system. }\end{array}$ \\
\hline Kondyor (KO) & $\begin{array}{l}\text { Zoned mafic-ultramafic Cr-PGE } \\
\text { (Kondyor) }\end{array}$ & $\begin{array}{l}\text { Transform-margin. } \\
\text { Zoned mafic-ultramafic } \\
\text { intrusions intruding Stanovoy } \\
\text { block of North Asian Craton. }\end{array}$ & $\begin{array}{l}\text { Intrusion of mafic-ultramafic plutons along major continental-margin transform } \\
\text { faults during subduction of terranes along Mongol-Okhotsk fault system. }\end{array}$ \\
\hline \multicolumn{4}{|c|}{ Metallogenic Belts Formed During Late Mesozoic Closure of Mongol-Okhotsk Ocean in Russian Southeast } \\
\hline $\begin{array}{l}\text { Selerrdzha-Kerbi } \\
\text { (SK) }\end{array}$ & $\begin{array}{l}\text { Au quartz vein and granitoid-related Au, } \\
\text { (Tokur, Petrovsko-Eleninsky) }\end{array}$ & $\begin{array}{l}\text { Collisional } \\
\text { Veins and plutons intruding } \\
\text { Tukuringra-Dzhagi and Galan } \\
\text { terranes. }\end{array}$ & $\begin{array}{l}\text { Anatectic granitic plutonism associated with collision Bureya and Khanka } \\
\text { continental-margin are superterranes with the North Asian Craton and closure } \\
\text { of the Mongol-Okhotsk Ocean. Belt extended into Late Jurassic. }\end{array}$ \\
\hline Stanovoy (ST) & $\begin{array}{l}\text { Granitioid-related Au, Au-Ag epithermal } \\
\text { vein, Au quartz vein. } \\
\text { (Kirovskoe) }\end{array}$ & $\begin{array}{l}\text { Transform-margin. } \\
\text { Zoned mafic-ultramafic } \\
\text { intrusions intruding Stanovoy } \\
\text { block of North Asian Craton.. }\end{array}$ & $\begin{array}{l}\text { Anatectic granitic plutonism and regional metamorphism associated with } \\
\text { accretion of Bureya superierrane to Nont Asian Craton and closing of Mongol- } \\
\text { Okhotsk Ocean. Belt extended into Early Cretaceous. }\end{array}$ \\
\hline \multicolumn{4}{|c|}{ Metallegenic Belts Formed During Late Mesozoic Accretion of Kolyma-Omolon Superterrane in Russian Northeast } \\
\hline Kular (KU) & $\begin{array}{l}\text { Au quartz vein, granitoid-related Au, St } \\
\text { quartz vein. } \\
\text { (Burguat, Solur, Novoe) }\end{array}$ & $\begin{array}{l}\text { Collisional. } \\
\text { Veins and plutons in Northern } \\
\text { part, Verkhoyansk granite belt. }\end{array}$ & $\begin{array}{l}\text { Anatectic granitic plunonism and regional metamorphism associated with } \\
\text { accretion of Kolyma-Omolon superierrane to North Asian Craton Margin. Belt } \\
\text { continued into late Early Cretaceous (Albian). }\end{array}$ \\
\hline Allakh-Yun (AY) & $\begin{array}{l}\text { Au quartz vein, granitoid-related Au, W- } \\
\text { Sn quartz vein. } \\
\text { (Bular, Yur, Nezhdanin, Levo-Dybin) }\end{array}$ & $\begin{array}{l}\text { Collisional. } \\
\text { Verkhoyansk granite belt. }\end{array}$ & $\begin{array}{l}\text { Regional metamorphism and anatectic granitic plutonism associated with } \\
\text { aceretion of Kolyma-Omolon superterrane to North Asian Craton Margin. Belr } \\
\text { continued into Early Cretaceous. }\end{array}$ \\
\hline Yana-Polousnen (YP) & $\begin{array}{l}\text { Granitoid-related Au, Sn quariz vein, \& } \\
\text { otbers. } \\
\text { (Polyamoe, Deputatskoe, Kandidatskoe, } \\
\text { Chistoe, llin-Tas) }\end{array}$ & $\begin{array}{l}\text { Collisional. } \\
\text { Plutons and veins in Northem } \\
\text { part, Verkhoyansk granite belt. }\end{array}$ & $\begin{array}{l}\text { Anatectic granitic plutonism and regional metamorphism associated with late } \\
\text { stage of accretion of Kolyma-Omolon superterrane to North Asian Craton } \\
\text { Margin. Belt continued into early Late Cretaceous. }\end{array}$ \\
\hline Darpir (DP) & $\begin{array}{l}\text { Sn skarn, Sn greisen, granitoid-related } \\
\text { Au, porphyry } \mathrm{Cu} \text {. } \\
\text { (Titovskos, Chepak, Bastion) }\end{array}$ & $\begin{array}{l}\text { Collisional. } \\
\text { Main part, Verkhoyansk granite } \\
\text { belt. }\end{array}$ & $\begin{array}{l}\text { Anatectic granitic plutonism associated with aceretion of Kolyma-Omolon } \\
\text { superterrane to North Asian Craton Margm. }\end{array}$ \\
\hline Tompon (TO) & $\begin{array}{l}\text { Cu, W, Sn skarn, Sn quartz vein. } \\
\text { (Khunkhada, Agylki, Erikag) }\end{array}$ & $\begin{array}{l}\text { Collisional. } \\
\text { Skams and veins adjacent to } \\
\text { Main part, Verkhoyansk } \\
\text { granite belt. }\end{array}$ & $\begin{array}{l}\text { Anatectic granitic plutonism associated with accretion of Kolyma-Omolon } \\
\text { superterrane to North Asian Craton Margin. }\end{array}$ \\
\hline Shamanikha (SH) & $\begin{array}{l}\text { Au quartz vein, Cu-Ag quartz vein. } \\
\text { (Glukhariny, Opyt) }\end{array}$ & $\begin{array}{l}\text { Collisional. } \\
\text { Veins in Prikolyma terrane, }\end{array}$ & $\begin{array}{l}\text { Regional metamorphism associated with accretion of Kolyma-Omolon } \\
\text { superterrane to North Asian Cratoo Margin. }\end{array}$ \\
\hline
\end{tabular}




\begin{tabular}{|c|c|c|c|}
\hline $\begin{array}{l}\text { Metallogenic Belt } \\
\text { (Abbreviation) }\end{array}$ & $\begin{array}{l}\text { Major Mineral Deposits Types. } \\
\text { (Stgnificant Mineral Deposits) }\end{array}$ & $\begin{array}{l}\text { Environment. } \\
\text { Hest Unit. }\end{array}$ & $\begin{array}{c}\text { Tectonic Event. } \\
\text { Comments }\end{array}$ \\
\hline Verkhoyansk (VK) & $\begin{array}{l}\text { Au quartz vein, At-Sn polymetallic vein. } \\
\text { (Nikolaevskoe, Otkynoe, Chochimbal, } \\
\text { Imtandzha) }\end{array}$ & $\begin{array}{l}\text { Collisional. } \\
\text { Skams and veins adjacent to } \\
\text { Main part, Verkhoyansk } \\
\text { granite belt }\end{array}$ & $\begin{array}{l}\text { Regional metamorphism and anatectic granitic plutonism associated with } \\
\text { accretion of Kolyma-Omolon superterrane to North Asian Craton Margin. Belt } \\
\text { continued into Early Crelaceous. }\end{array}$ \\
\hline Yana-Kolyma (YA) & $\begin{array}{l}\text { Au quartz vein, Sn vein, granitoid-related } \\
\text { Au. } \\
\text { (Natalka, Svetloe, Kholodnce, Zhdannoe, } \\
\text { Utie, Alyaskitovoe,) }\end{array}$ & $\begin{array}{l}\text { Collisional } \\
\text { Veins and plutons in of adjacent } \\
\text { to Main part, Verkhoyansk } \\
\text { granite belt. }\end{array}$ & $\begin{array}{l}\text { Regional metamorphism and anatectic granitic plutonism associaled with early } \\
\text { stage of accretion of Kolyma-Omolon superterrane to North Asian Craton } \\
\text { Margin. }\end{array}$ \\
\hline \multicolumn{4}{|c|}{ Metallogenic Belts Formed During Late Mesozoic Island Arcs, Russian Northeast, Southeastern Alaska, and Southern Canadian Cordillera } \\
\hline Lefi Omalon (LO) & $\begin{array}{l}\text { Porphyry Mo-Cu, Mo-Cu skam. } \\
\text { (Bebekan, Medgora) }\end{array}$ & $\begin{array}{l}\text { Island arc. } \\
\text { Oloy-Svyatoy Nos volcanic belt. }\end{array}$ & Subduction-related granitic plutonism that formed the Oloy are island are. \\
\hline $\begin{array}{l}\text { Western-Southeastem } \\
\text { Alaska (WSE) }\end{array}$ & $\begin{array}{l}\text { Porphyry Mo, Cu-Ag skam, felsic } \\
\text { plutonic U. } \\
\text { (Baker Island, Jumba, Magnetite Cliff, } \\
\text { Bokan Mountain) }\end{array}$ & $\begin{array}{l}\text { Island arc. } \\
\text { Granitic rocks intruding } \\
\text { Gravina-Nutzotin-Gambier } \\
\text { belt, Wrangellia sequence, } \\
\text { Wrangellia superterrane. }\end{array}$ & $\begin{array}{l}\text { Subduction-related granitic plutonism that formed the Gravina are, } \\
\text { Metallogenic belt and host granitic suite formed during final accretion of } \\
\text { Wrangellia superterrane. }\end{array}$ \\
\hline Britannia & $\begin{array}{l}\text { Kuroko massive sulfide } \\
\text { (Britannia, Maggie, Northair, Nifty) }\end{array}$ & $\begin{array}{l}\text { Island arc. } \\
\text { Gravina-Nuczotin-Gambier beit, } \\
\text { Wrangellia sequence, } \\
\text { Wrangellia superterrane. }\end{array}$ & $\begin{array}{l}\text { Subduction-related granitic plutonism that formed the Gravina island arc on the } \\
\text { Wrangellia superierrane. }\end{array}$ \\
\hline \multicolumn{4}{|c|}{ Continuing Metallogenic Belts } \\
\hline \multicolumn{3}{|l|}{ Olay (OL) } & Belt started in Late Jurassic. \\
\hline \multicolumn{3}{|l|}{ Mainits (MA) } & Belt started in Late Jurassic. \\
\hline \multicolumn{3}{|c|}{ Tamvatney-Mainits (TAM) } & Belt started in Late Jurassic. \\
\hline \multicolumn{3}{|l|}{ Cariboo $(\mathrm{CB})$} & Belt started in Middle Jurassic. \\
\hline \multicolumn{4}{|c|}{ LATE EARLY CRETACEOUS METALLOGENIC BELTS (Cenomanian through Albian - 119 to 100 Ma) (Figures 11 , 12) } \\
\hline \multicolumn{4}{|c|}{ Metallogenic Beft Formed is Late Mesozoic Continental-Margin Arc, Russian Southeast } \\
\hline $\begin{array}{l}\text { Badzhal-Ezop- } \\
\text { Khingan (BZ-KH) }\end{array}$ & $\begin{array}{l}\text { Se greisen, skarn, and vein. } \\
\text { (Solnechnoe, Prvourmiiske, Ezop, } \\
\text { Khingan) }\end{array}$ & $\begin{array}{l}\text { Continental-margin arc. } \\
\text { Khingan-Okhotsk volcanic- } \\
\text { plutonic belt. }\end{array}$ & $\begin{array}{l}\text { Subduction-related granitic plutonism that formed the Khingan contineatal- } \\
\text { margin arc. Belt extended into Early Cretaceous. }\end{array}$ \\
\hline \multicolumn{4}{|c|}{$\begin{array}{l}\text { Metallogenie Belts Formed in Late Mesozoic Collision and Accretion of Island Ares, and Transform Continetnal-Margin Faulting, Russian Northwest, Western and Northern } \\
\text { Alaska, and Northern Canadias Cordillera }\end{array}$} \\
\hline Anadyr River (AD) & $\begin{array}{l}\text { Au quartz vein. } \\
\text { (Vacgi, Nutckin) }\end{array}$ & $\begin{array}{l}\text { Collison or Extensional. } \\
\text { Veins in Mainitskiy, West } \\
\text { Pekulney, or Penzhina-Anadyr } \\
\text { terranes. }\end{array}$ & $\begin{array}{l}\text { Regional metamorphism and generation of hydrothermal fluids associated with } \\
\text { accretion and collision of Mainitskiy island are onto North Asian Craton } \\
\text { margin. }\end{array}$ \\
\hline Nome (NO) & $\begin{array}{l}\text { Au quartz vein. } \\
\text { (Rock Creek, Big Hurrah, ML. Distan) }\end{array}$ & $\begin{array}{l}\text { Extensional. } \\
\text { Veins in Seward terrane. }\end{array}$ & $\begin{array}{l}\text { Regional metamorphism associated with extension that occurred after } \\
\text { overthrusting of Angayucham subduction zone terrane. }\end{array}$ \\
\hline $\begin{array}{l}\text { Southern Brooks } \\
\text { Range (SBR) } \\
\text { (Includes } \\
\text { Chandalar district) }\end{array}$ & $\begin{array}{l}\text { Au quartz vein. } \\
\text { (Mikado) }\end{array}$ & $\begin{array}{l}\text { Extensional. } \\
\text { Veins in Coldfoot terrane, and in } \\
\text { Hammond terrane of Arctic } \\
\text { Alaska superternane. }\end{array}$ & $\begin{array}{l}\text { Regional metamorphism associated with extension that oceurred after } \\
\text { overthrusting of Angayucham subduction zone terrane. }\end{array}$ \\
\hline
\end{tabular}




\begin{tabular}{|c|c|c|c|}
\hline $\begin{array}{l}\text { Metallogenic Belt } \\
\text { (Abbreviation) }\end{array}$ & $\begin{array}{l}\text { Major Mineral Deposits Types. } \\
\text { (Significant Mineral Deposits) }\end{array}$ & $\begin{array}{l}\text { Environment. } \\
\text { Host Unit. }\end{array}$ & $\begin{array}{l}\text { Tectonic Event. } \\
\text { Comments }\end{array}$ \\
\hline Fish River (FR) & $\begin{array}{l}\text { Sedimentary } \mathrm{P} \text { and Fe. } \\
\text { (Rio Alto. Fish River) }\end{array}$ & $\begin{array}{l}\text { Strike-slip fault. } \\
\text { North American Craton Margin }\end{array}$ & L.ate Mesozoic, dextral movement along the Kaltag-Porcupine fauli system. \\
\hline \multicolumn{4}{|c|}{ Metallogenic Belts Formed in Late Mesezoic Collision and Accretion of Wrangellia Superierrane, and Generation of Omineca-Selwyn Plutenic Belt, Canadian Cordillera } \\
\hline Selwyn (SW) & $\begin{array}{l}\text { W-Cu skam, } \mathrm{Zn}-\mathrm{Pb}-\mathrm{Ag} \text { skam, } \mathrm{Zn}-\mathrm{Pb}-\mathrm{Ag} \\
\text { manto. } \\
\text { (Canada tungsten, Macmillan Pass, Sa } \\
\text { Dena Hes, Quartz Lake, Prairic Creek) }\end{array}$ & $\begin{array}{l}\text { CollisionaL. } \\
\text { Cassiar plutonic suite, Omineca- } \\
\text { Selwyn plutonic belt. }\end{array}$ & $\begin{array}{l}\text { Probable anatectic granitic plutonism (Omineca-Selwyn plutonic belt) associated } \\
\text { with final accretion of Wrangellia superterrane to North American continental } \\
\text { margin. }\end{array}$ \\
\hline $\begin{array}{l}\text { Tombstone (TS) } \\
\text { (extension of Tintina } \\
\text { gold belt in } \\
\text { Alaska) }\end{array}$ & $\begin{array}{l}\text { Ag polymetallic vein, Au-Sb vein, W-Sn- } \\
\text { Au skarn. } \\
\text { (Ken Hill-Galena Hill district; Brewery } \\
\text { Creek, Ray Gulch, Eagle) }\end{array}$ & $\begin{array}{l}\text { Collisional } \\
\text { Veins and granitic plutons of } \\
\text { Omineca-Selwyn plutonic belt. }\end{array}$ & $\begin{array}{l}\text { Regional metamorphism and anatectic granitic plutonism (Omineca-Selwyn } \\
\text { plutonic belt) associated with final accretion of Wrangellia superterrane to } \\
\text { North American continental margin. }\end{array}$ \\
\hline Cassiar (CA) & $\begin{array}{l}\text { Porphyry Mo, W skam, Zn-Pb-Ag } \\
\text { manto, Sn skarn, Au skarn. } \\
\text { (Logtung, Risby, Midway Manto) }\end{array}$ & $\begin{array}{l}\text { Collisional. } \\
\text { Cassiar plutonic suite, Omineca- } \\
\text { Selwyn plutonic belt. }\end{array}$ & $\begin{array}{l}\text { Probable anatectic granitic plutonism (Omineca-Selwyn plutonic belt) associated } \\
\text { with final accretion of Wrangellia superterrane to North American continental } \\
\text { margin. }\end{array}$ \\
\hline Whitehorse (WH) & $\begin{array}{l}\text { Cu-Fe skarn, porphyry Cu-Au-Ag. Au- } \\
\text { As polymetallic vein. } \\
\text { (Whiteborse Copper Belt, Hopkins, } \\
\text { Sekulmun, Mount Nansen) }\end{array}$ & $\begin{array}{l}\text { Collisional. } \\
\text { Whiteborse plutonic suife, } \\
\text { Omineca-Selwyn plutonic belt. }\end{array}$ & $\begin{array}{l}\text { Probable anatectic granitic plutonism (Omineca-Selwyn plutonic belt) associated } \\
\text { with final accretion of Wrangellia superterrane to North American continental } \\
\text { margin. }\end{array}$ \\
\hline Bayonne (BA) & $\begin{array}{l}\text { Porphyry Mo, Cu-Mo skam. } \\
\text { (Boss Mountain, Trout Lake, Red } \\
\text { Mountain Moly, Emerald-Invincible, } \\
\text { Dodger, and others) }\end{array}$ & $\begin{array}{l}\text { Collisional. } \\
\text { Bayonne plutonic suite. } \\
\text { Omineca-Selwyn plutonic belt. }\end{array}$ & $\begin{array}{l}\text { Probable anatectic granitic plutonism (Omineca-Selwyn plutonic belt) associated } \\
\text { with final accretion of Wrangellia superterrane to North American continental } \\
\text { margin. }\end{array}$ \\
\hline \multicolumn{4}{|c|}{ Continuing Metallogenic Belts } \\
\hline \multicolumn{3}{|l|}{ Sarnarka (SA) } & Metallogenic belt started in Early Cretaceous (Neocomian). \\
\hline \multicolumn{3}{|l|}{ Kular (KU) } & Beh started in Early Cretaceous (Neocomian). \\
\hline \multicolumn{3}{|l|}{ Mainits (MA) } & Belt started in Late Jurassic. \\
\hline \multicolumn{3}{|c|}{ Tamvatney-Mainits (TAM) } & Beli started in Late Jurassic. \\
\hline \multicolumn{4}{|c|}{ EARLY LATE CRETACEOUS METALLOGENIC BELTS (Cenomanian through Santonian - 100 to 84 Ma) (Figures I3, 14) } \\
\hline \multicolumn{4}{|c|}{ Metallogenic Belt Formed in Late Mesozoic Part of East Sikhote-Aline Continental-Margin Arc, Russian Southeast } \\
\hline Sergeevka (SG) & $\begin{array}{l}\text { Granitoid-related Au. } \\
\text { (Askold, Progress) }\end{array}$ & $\begin{array}{l}\text { Continental-margin arc. } \\
\text { East Sikhote-Aline volcanic- } \\
\text { plutonic belt. }\end{array}$ & $\begin{array}{l}\text { Subduction-related granitic plutonism that formed the East Sikhote-Aline } \\
\text { conlinental margin are. }\end{array}$ \\
\hline Taukha (TK) & $\begin{array}{l}\text { B skarm, Pb-Zn skarn. } \\
\text { (Dalnegorsk, Nikolaevskoe, } \\
\text { Partizanskoc, Krasnogorskoc) }\end{array}$ & $\begin{array}{l}\text { Continental-margin are } \\
\text { East Sikhote-Aline volcanic- } \\
\text { plutonic belt. }\end{array}$ & $\begin{array}{l}\text { Subduction-related granitic plutenism that formed the East Sikhote-Alime } \\
\text { continental margin arc. }\end{array}$ \\
\hline Kema (KM) & $\begin{array}{l}\text { Au-Ag epithermal vein, porphyry Cu- } \\
\text { Mo. } \\
\text { (Glinyanoe, Sukhoi Creek, Tayozhnoe } \\
\text { Verkhnezolotoe) }\end{array}$ & $\begin{array}{l}\text { Continental-margin are. } \\
\text { East Sikhote-Aline volcanic- } \\
\text { plutonic belt. }\end{array}$ & $\begin{array}{l}\text { Subduction-related granitic plutonism that fonmed the E2st Sikhote-Aline } \\
\text { continental margis arc. }\end{array}$ \\
\hline Lazhkinsky (LZ) & $\begin{array}{l}\text { Sn polymetallic vein, Sn silica-sulfide } \\
\text { vein, porphyry Sn. } \\
\text { (Tigrinoe, Zimnee, Arsenyevskoe, } \\
\text { Yantarnoe) }\end{array}$ & $\begin{array}{l}\text { Continental-margin arc. } \\
\text { East Sikhote-Aline voleanic- } \\
\text { plutonic belt. }\end{array}$ & $\begin{array}{l}\text { Subduction-related granitic plutonism that fonned the back are part of East } \\
\text { Sikbote-Aline continental margin arc. }\end{array}$ \\
\hline
\end{tabular}




\begin{tabular}{|c|c|c|c|}
\hline $\begin{array}{l}\text { Metallogenic Bell } \\
\text { (Abbreviation) }\end{array}$ & $\begin{array}{l}\text { Major Mineral Deposits Types. } \\
\text { (Significant Mineral Deposits) }\end{array}$ & $\begin{array}{l}\text { Environment. } \\
\text { Hest Unit. }\end{array}$ & $\begin{array}{l}\text { Tectonic Event. } \\
\text { Comments }\end{array}$ \\
\hline Lower Amur (LA) & $\begin{array}{l}\text { Au-Ag epithermal vein, porphyry } \mathrm{Cu}, \mathrm{Sn} \\
\text { Greisen. } \\
\text { (Mnogovershimnoe, Belaya Ciora) }\end{array}$ & $\begin{array}{l}\text { Continental-margin are. } \\
\text { East Sikhote-Aline voleanic. } \\
\text { plutonic belt. }\end{array}$ & $\begin{array}{l}\text { Subduction-related granitic plutonism that formed the East Sikhote-Aline } \\
\text { continental margin are. }\end{array}$ \\
\hline \multicolumn{4}{|c|}{ Metallegenic Belt Formed in Late Mesazoic Oceanic Crust and Island Are Terranes, Russian Southeast } \\
\hline Aniva-Nabil (ANN) & $\begin{array}{l}\text { Voleanogenic Mn and Fe } \\
\text { (Bereznyakowskoe and Lyakamskoe); } \\
\text { Cyprus Cu massive sulfide } \\
\text { (Noyikovskoe and Rys'e) }\end{array}$ & $\begin{array}{l}\text { Oceanic crust and island are } \\
\text { rocks. } \\
\text { Aniva and Nabilskiy rerranes. }\end{array}$ & $\begin{array}{l}\text { Formation in oceanic crustal and island are assemblages that were subsequently } \\
\text { tectonically incorporated into the Aniva and Nabilsky terranes accretionary } \\
\text { wedge and subduction zone terranes. }\end{array}$ \\
\hline \multicolumn{4}{|c|}{ Metallogenic Belts Formed in Late Mesozoic and Early Cenozoic Olyutorka Island Arc, Russian Northeast } \\
\hline $\begin{array}{l}\text { Koryak Highlands } \\
\text { (KH) }\end{array}$ & $\begin{array}{l}\text { Zoned mafie-ultramafic PGE; } \mathrm{Cu} \\
\text { massive sulfide. } \\
\text { (Snezhnoe) }\end{array}$ & $\begin{array}{l}\text { Island are. } \\
\text { Olyutorka-Kamchatka terrane. }\end{array}$ & $\begin{array}{l}\text { Subduction-related intrusion of mafic-ultramafic plutons into Olyutorka island } \\
\text { are, Belt continued inte Late Cretaceous and possibly inte early Tertiary. }\end{array}$ \\
\hline Vatyn (VT) & $\begin{array}{l}\text { Volcanogenic } \mathrm{Mn} \& \mathrm{Ft} \text {. } \\
\text { (Itchayvayam) }\end{array}$ & $\begin{array}{l}\text { Island are. } \\
\text { Olyutorka-Kamchatka terrane. }\end{array}$ & $\begin{array}{l}\text { Sea floor sedimentation associated with Olyutorka island are. Belt continued into } \\
\text { Late Cretaceous and possibly into early Tertiary. }\end{array}$ \\
\hline \multicolumn{4}{|c|}{ Metallogenie Belts Formed in Late Mesozoic Part of Okhotsk-Chukotka Continental-Margin Arc, Russian Northeast } \\
\hline $\begin{array}{l}\text { Dogdo-Erikit zone } \\
\text { (EADE), Eastern } \\
\text { Asia-Arctic } \\
\text { Metallogenic Belt }\end{array}$ & $\begin{array}{l}\text { Au-Ag epithermal vein, } \mathrm{Sn} \text { polymetallic } \\
\text { vein, volcanic-hosted } \mathrm{Hg} \text {. } \\
\text { (Kysylga, Solkucban, Dodgo) }\end{array}$ & $\begin{array}{l}\text { Continental-margin are. } \\
\text { Okhotsk-Chukotka volcanic- } \\
\text { plutonic belt. }\end{array}$ & $\begin{array}{l}\text { Subduction-related granitic plutonism that formed the Okhotsk-Chukotka } \\
\text { continental-margin arc. Hosted in orthogonal branch of Okhotsk-Clsukocka } \\
\text { volcanic-plutonic belt. Zone part of Eastern Asia metallogenic belt. }\end{array}$ \\
\hline $\begin{array}{l}\text { Okhotsk zobe } \\
\text { (EAOH), Eastem } \\
\text { Asia-Aretic } \\
\text { Metallogenic Belt }\end{array}$ & $\begin{array}{l}\text { Au-Ag epithermal vein. } \\
\text { (Karamken, Julietla, Agan) }\end{array}$ & $\begin{array}{l}\text { Continental-margin arc. } \\
\text { Okhotsk-Chukotka volcanic- } \\
\text { plutonic belt. }\end{array}$ & $\begin{array}{l}\text { Subctaction-related granitic plutonism that formed the back-arc part of Okhotsk- } \\
\text { Chukotka continental-margin are. Belt continued into Late Cretaccous. Zone } \\
\text { part of Eastern Asia metallogenic belt. }\end{array}$ \\
\hline $\begin{array}{l}\text { Koni-Yablon zone } \\
\text { (EAKY), Eastern } \\
\text { Asia-Arctic } \\
\text { Metallogenic Belt }\end{array}$ & $\begin{array}{l}\text { Porphyry Cu-Mo, Cu-Mo skarn. } \\
\text { (Nakhtandjin, Osennee, Lora, Etandzha) }\end{array}$ & $\begin{array}{l}\text { Continental-margin arc. } \\
\text { Okhotsk-Chukotka volcanic- } \\
\text { plutonic belt. }\end{array}$ & $\begin{array}{l}\text { Subduction-related granitic plutonism that formed the Okhotsk-Chukotka } \\
\text { continental-margin arc. Axial part Okhotsk-Chukotka volcanjic-phutonic belt. } \\
\text { Zone part of Eastern Asia metallogenic belt. }\end{array}$ \\
\hline $\begin{array}{l}\text { Korkodon-Nayakhan } \\
\text { zone (EAKN), } \\
\text { Eastem Asia- } \\
\text { Aretic } \\
\text { Metallogenic Belt }\end{array}$ & $\begin{array}{l}\text { Porphyry Mo, granitoid-related Au. } \\
\text { (Orlinoe, Khetagchan) }\end{array}$ & $\begin{array}{l}\text { Continental-margin arc. } \\
\text { Okhotsk-Chukouka voleanic- } \\
\text { plutonic belt. }\end{array}$ & $\begin{array}{l}\text { Subduction-related volcanism associated with Okhotsk-Chukotka conatinental- } \\
\text { margin are. Onhogonal branch of Okhotsk-Chukotka voleanic-plutonic belt. } \\
\text { Zone part of Eastern Asia metallogenic belt. }\end{array}$ \\
\hline $\begin{array}{l}\text { Verkhne-Kolyma } \\
\text { zone (EAVK). } \\
\text { Eastem Asia- } \\
\text { Arctic } \\
\text { Metallogenic Belt }\end{array}$ & $\begin{array}{l}\text { Sn-Ag polymetallic vein, Rhyolite-hosted } \\
\text { Sn, granitoid-related Au. } \\
\text { (Tigrets-Industriya, Kandychan, } \\
\text { Butugychag) }\end{array}$ & $\begin{array}{l}\text { Continental-margin arc. } \\
\text { Okhotsk-Chukotka volcanic. } \\
\text { plutonic belt. }\end{array}$ & $\begin{array}{l}\text { Subdaction-related voleanism associated with Okhotsk-Chukotka continental- } \\
\text { margin are. Orthogonal branch of Okhotsk-Chukotka volcanic-plutonic belt. } \\
\text { Beli continued into Late Cretaceous. Zone part of Eastern Asia metallogenic } \\
\text { belt. }\end{array}$ \\
\hline $\begin{array}{l}\text { Vostochno- } \\
\text { Verkhoyansk zone, } \\
\text { (EAVV), Eastern } \\
\text { Asia-Arctic } \\
\text { Metallogenic Belt }\end{array}$ & $\begin{array}{l}\text { Ag polymetallic vein, clastic sediment- } \\
\text { hosted } \mathrm{Hg} \text {. } \\
\text { (Mangazeika, Menkeche) }\end{array}$ & $\begin{array}{l}\text { Continental-margin arc. } \\
\text { Back are part of Okhotsk- } \\
\text { Chukotka volcanic-plutonic } \\
\text { belt. }\end{array}$ & $\begin{array}{l}\text { Subduction-related magmatism associated with back-are part of Okhotsk- } \\
\text { Chukotka continental margin arc. Belt continued into Late Cretaceous. Zone } \\
\text { part of Eastern Asia metallogenic belt. }\end{array}$ \\
\hline
\end{tabular}




\begin{tabular}{|c|c|c|c|}
\hline $\begin{array}{l}\text { Metallogentic Belt } \\
\text { (Abbreviation) }\end{array}$ & $\begin{array}{l}\text { Major Mineral Depesits Types. } \\
\text { (Significant Mineral Deposits) }\end{array}$ & $\begin{array}{l}\text { Environment. } \\
\text { Host Unit. }\end{array}$ & $\begin{array}{l}\text { Tectonic Event. } \\
\text { Comments }\end{array}$ \\
\hline $\begin{array}{l}\text { Adycha-Taryn } \\
\text { (EAAT) zone, } \\
\text { Eastern Asia- } \\
\text { Arctic } \\
\text { Metallogenic Belt }\end{array}$ & $\begin{array}{l}\text { Clastic-sediment-hosted } \mathrm{Sb}-\mathrm{Au}, \mathrm{Au}-\mathrm{Ag} \\
\text { epithermal vein, } \mathrm{Ag} \text {-Sb polymetallic } \\
\text { vein. } \\
\text { (Ak-Altyn) }\end{array}$ & $\begin{array}{l}\text { Contiontal-margin arc. } \\
\text { Transverse extension of } \\
\text { Okhotsk-Chukotka volcanic- } \\
\text { plutonic belt. }\end{array}$ & $\begin{array}{l}\text { Subduction-related magnatism associated with back-are pant of Oahotsk. } \\
\text { Chukotka continental margin are. Beli continued into Lute Cretaceous. Zooe } \\
\text { part of Eastem Asia metallogenic belt. }\end{array}$ \\
\hline $\begin{array}{l}\text { Omsukchan zone } \\
\text { (EAOM), Eastem } \\
\text { Asia-Arctic } \\
\text { Metallogenic Belt }\end{array}$ & $\begin{array}{l}\text { Au-Ag epithermal vein, Sn polymetallic } \\
\text { vein, silicate-sulfide, porphyry } \mathrm{Sn}, \\
\text { porphyry Cu-Mo, \& others. } \\
\text { (Nevskoe, Mechta, Dukat). }\end{array}$ & $\begin{array}{l}\text { Continental-margin arc. } \\
\text { Okhotsk-Chakoska volcanic- } \\
\text { plutonic belt. }\end{array}$ & 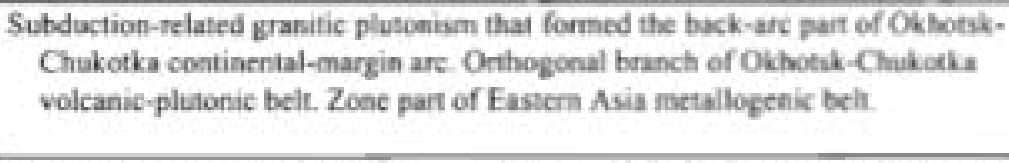 \\
\hline $\begin{array}{l}\text { Chokurdak zone } \\
\text { (EACD), Eastern } \\
\text { Asia-Arctic } \\
\text { Metallogenic Belt }\end{array}$ & $\begin{array}{l}\text { Sn polymetallic vein, Sn greisen. } \\
\text { (Deputatskoe, Churpuunaya) }\end{array}$ & $\begin{array}{l}\text { Island arc. } \\
\text { Svyatoy-Nos voleanic belt. }\end{array}$ & $\begin{array}{l}\text { Subduction-related granitic plutonism that formed the back-are part of Ok-hotsk- } \\
\text { Chukotka continental-gargia asc. }\end{array}$ \\
\hline $\begin{array}{l}\text { Chaun zone (EACN), } \\
\text { Eastem Asia- } \\
\text { Arctic } \\
\text { Metallogenic Belt }\end{array}$ & $\begin{array}{l}\text { Sn polymetallic vein, Sn greisen, Sn } \\
\text { skam, Sn porphyry, granitoid-related } \\
\text { Au. } \\
\text { (Valkumei, Chechekuyum, Kanclyveen, } \\
\text { lultin, Svelloe) }\end{array}$ & $\begin{array}{l}\text { Continental-margin arc. } \\
\text { Okhotsk-Chukotka valcanic- } \\
\text { plutonic belt. }\end{array}$ & $\begin{array}{l}\text { Subduction-related granitic plutonisn that formed the Okhotsk-Chukotka } \\
\text { continental-margin arc. Correlated with Sewasd Peninsula inctallogenic belt. } \\
\text { Belt continoed iato Late Cretaceous. Zone part of Eastern Asia metallogenic } \\
\text { belt. }\end{array}$ \\
\hline \multicolumn{4}{|c|}{ Metallogenic Belt Formed During Late Mesozeic Collision and Accretien of Chukotka Superierrane, Russian Nertheast } \\
\hline Chukotka (CH) & $\begin{array}{l}\text { Au quartz vein, Sn polymetallic vein. } \\
\text { (Karalveem, Ozernoe) }\end{array}$ & $\begin{array}{l}\text { Collisional. } \\
\text { Veins and granitic plutons in } \\
\text { Chuknotka terrane. }\end{array}$ & $\begin{array}{l}\text { Regional metamorphism and anatectic granitic plutonism associated wilh } \\
\text { accretion of riffed Chukotka passive continental-margin terrane to Northeast } \\
\text { Asia. }\end{array}$ \\
\hline \multicolumn{4}{|c|}{ Metallogenic Belts Formed in Late Mesozoic Cellisien and Accretion of Wranzellia Superterrane, Southern Alaska } \\
\hline $\begin{array}{l}\text { East-Ceniral Alaska } \\
\text { (older part) (ECA) } \\
\text { (includes major } \\
\text { part of Tintina gold } \\
\text { beli) }\end{array}$ & $\begin{array}{l}\text { Granitoid-related Au, polymetallic vein, } \\
\text { porphyry Cu, Sb-Au veio. } \\
\text { (Democrat, Fort Knox, Pogo, Kantishna } \\
\text { district, Manley-Livengood area) }\end{array}$ & $\begin{array}{l}\text { Collisional } \\
\text { Veins and granitic plutons in } \\
\text { interiot Alaska. }\end{array}$ & $\begin{array}{l}\text { Regienal metamorphism and anatectic granitie plutonism mainly in Yukon- } \\
\text { Tanana terrane associated with final accretion of Wrangellia superterrane to } \\
\text { North American continental margin. Belr started in late Early Cretaceous. }\end{array}$ \\
\hline $\begin{array}{l}\text { Yukon-Tanana } \\
\text { Upland (YT) }\end{array}$ & $\begin{array}{l}\text { Au-quariz vein. } \\
\text { (Purdy) }\end{array}$ & $\begin{array}{l}\text { Colliaional. } \\
\text { Veins in } \mathrm{Y} \text { akon-Tanana terrane. }\end{array}$ & $\begin{array}{l}\text { Regional metamorphism and anatectic granitic plusonism mainly in Yukon- } \\
\text { Tamana terrane associated with final accretion of Wrangellia superterrane to } \\
\text { North American continental margin. }\end{array}$ \\
\hline $\begin{array}{l}\text { Wrangell Mountaims } \\
\text { (WK) }\end{array}$ & $\begin{array}{l}\text { Cu-Ag quartz vein, Kennecont Cu } \\
\text { (Kathleen-Margaret, Kennecost) }\end{array}$ & $\begin{array}{l}\text { Collisional. } \\
\text { Veins and replacenacnts in Late } \\
\text { Triastic Nikolai Giscenstone } \\
\text { and Ninrima Limestane, } \\
\text { Wrangellia sequence, } \\
\text { Wrangellia supertemane. }\end{array}$ & $\begin{array}{l}\text { Regional metamorphism and vein emplacement associated with aceretion of } \\
\text { Wrangellia superternane to southem Alaska. }\end{array}$ \\
\hline \multicolumn{4}{|c|}{ Centinuing Mrtallerenic Belis } \\
\hline \multicolumn{3}{|c|}{ Badzhal-Ezop-Khingan (BZ-KH) } & Beli stanted in latc-early Cretaceous. \\
\hline \multicolumn{3}{|c|}{ Sclwyn (SW) } & Belt atarted in late Early Cretuceous. \\
\hline \multicolumn{3}{|l|}{ Cassiar (CA) } & Belt started in late Earty Cretaceous. \\
\hline \multicolumn{3}{|l|}{ Whitchorse (WH) } & Belt stanted in late Early Cretaceous. \\
\hline \multicolumn{3}{|l|}{ Bayone (BA) } & Belt started in late Early Cretaceous. \\
\hline
\end{tabular}




\begin{tabular}{|c|c|c|c|}
\hline $\begin{array}{l}\text { Metallogenic Belt } \\
\text { (Abbreviatioa) }\end{array}$ & $\begin{array}{l}\text { Major Mineral Deposits Types. } \\
\text { (Significant Miseral Deposits) }\end{array}$ & $\begin{array}{l}\text { Envirenment. } \\
\text { Host Unit. }\end{array}$ & $\begin{array}{l}\text { Tectonic Event. } \\
\text { Comments }\end{array}$ \\
\hline \multicolumn{4}{|c|}{ LATE CRETACEOUS AND EARLY TERTIARY METALLOGENIC BELTS (Campanian through early Eocege - 84 to 52 Ma) (Figures 15, 16) } \\
\hline \multicolumn{4}{|c|}{ Continuing Metallogenic Belts } \\
\hline \multicolumn{3}{|l|}{ Sergeevka (SG) } & Belt started in late Early Cretaceous. \\
\hline \multicolumn{3}{|l|}{ Taukha (TK) } & Belt started in late Early Cretaceous. \\
\hline \multicolumn{3}{|l|}{ Kema (KM) } & Belt started in Late Early Cretaceous. \\
\hline \multicolumn{3}{|l|}{ Luzhinsky (LZ) } & Belt started in late Early Crelaceous. \\
\hline \multicolumn{3}{|l|}{ Lower Amur (LA) } & Bell starled in late Early Cretaceous. \\
\hline \multicolumn{3}{|l|}{ Koryak Highlands $(\mathrm{KH})$} & Belt started in early Late Cretaceous and possibly extended into early Tertiary. \\
\hline \multicolumn{3}{|l|}{$\operatorname{Varyn}(\mathrm{VT})$} & Belt started in early Late Cretaceous. \\
\hline \multicolumn{3}{|c|}{ Okhotsk zone (E^OH). Esstem Asia metallogenic belt } & Belt stanted in early Late Cretaceous. \\
\hline \multicolumn{3}{|c|}{ Adycha-Taryn (E^AT). Eastem Asia metallogenic belı } & Belt stafted in early Late Cretacenus. \\
\hline \multicolumn{3}{|c|}{ Verkhne-Kolyma zone (EAVK), Eastem Asia metallogenie belt } & Belt started in early Late Cretaceous. \\
\hline \multicolumn{3}{|c|}{ Korkodon-Nayakhan 7one (EAKN), Eastern Asia metallogenic belt } & Belt started in early Late Cretaceous. \\
\hline \multicolumn{3}{|c|}{ Omsukchan zone (EAOM), Eastern Asia metallogenic belt } & Belt started in early Late Cretaccous. \\
\hline \multicolumn{3}{|c|}{ Chaun zone (EACN) } & Belt started in carly Late Cretaceous. \\
\hline \multicolumn{4}{|c|}{ Metallogenic Belt Formed in Late Mesozoic and Early Cenozoic Olyutorka Island Are, Russian Northeast } \\
\hline Iruneiskiy (IR) & $\begin{array}{l}\text { Porphyry Cu } \\
\text { (Kinganik) }\end{array}$ & $\begin{array}{l}\text { Island are. } \\
\text { Iraneiskiy terrane }\end{array}$ & $\begin{array}{l}\text { Subduction-related granitic plutonism that formed the Olyulorka-Kamehatka } \\
\text { island-arc. }\end{array}$ \\
\hline \multicolumn{4}{|c|}{ Metallogenic Belts Formed in Late Mesozoic and Early Cenozoic Part of Okhotsk-Chukotka Continental-Margin Are, Russian Northeast and Western Alaska } \\
\hline \multicolumn{4}{|c|}{ Continuing Metallogenic Belt } \\
\hline \multicolumn{3}{|c|}{ Vostochno-Verkhoyansk (EAVV), Eastern Asia metallogenic belt } & Belt started in early Late Cretaceous. \\
\hline $\begin{array}{l}\text { Verkbne-Yudomsky } \\
\text { (Yuzhno- } \\
\text { Verkhoyansk) zooe } \\
\text { (EAVY), Eastem } \\
\text { Asia-Arctic } \\
\text { Metallogenie Beh }\end{array}$ & $\begin{array}{l}\text { So \& Ag polymelallic veis. } \\
\text { (Zamitsa-Kutinskoe, Khasrdak) }\end{array}$ & $\begin{array}{l}\text { Continental-margin arc. } \\
\text { Back arc part of Okhotsk- } \\
\text { Chukotka volcanic-plutonic } \\
\text { belt. }\end{array}$ & $\begin{array}{l}\text { Sabduction-related granitic plutonism that formed the back-are part of Okhotsk- } \\
\text { Chukotka continental margin arc. Zone part of Eastem Asia metallogenic belt }\end{array}$ \\
\hline $\begin{array}{l}\text { Verkhoyatsk- } \\
\text { Indigirka } \\
\text { (Dulgalak) zone } \\
\text { (EAVI), Eastern } \\
\text { Asia-Arctic } \\
\text { Metallogenic Belt }\end{array}$ & $\begin{array}{l}\text { Clastic sediment-hosted } \mathrm{Hg} \text {, Sb-Au vein. } \\
\text { (Zagedka, Kyuchyus) }\end{array}$ & $\begin{array}{l}\text { Continental-margis are. } \\
\text { Back are part of Okhotsk- } \\
\text { Chukoska wolcanic-plutonic } \\
\text { belt. }\end{array}$ & $\begin{array}{l}\text { Subduction-related magmatism associated with back-are part of Okbotsk- } \\
\text { Chukotka continental margin are. Zone part of Eastem Asia metallogenic belt. }\end{array}$ \\
\hline $\begin{array}{l}\text { Anuyi-Beringovsky } \\
\text { zone (EAAB). } \\
\text { Eastem Asia- } \\
\text { Aretic } \\
\text { Metallogenic Belt }\end{array}$ & $\begin{array}{l}\text { Au-Ag epithermal vein, disseminated Au } \\
\text { sulfide) } \\
\text { (Valunistoe, Maiskoe)) }\end{array}$ & $\begin{array}{l}\text { Continental-margin arc. } \\
\text { Okhotsk-Chukotka volcanic- } \\
\text { plutonic belt. }\end{array}$ & $\begin{array}{l}\text { Subduction-related granitic plutonism that formed the Okhotsk-Chukotka } \\
\text { continental-margin arc. Zone part of Eastern Asia metallogenic belt. }\end{array}$ \\
\hline $\begin{array}{l}\text { Chukotka zone } \\
\text { (EACH), Eastern } \\
\text { Asia-Aretic } \\
\text { Metallogenic Belt }\end{array}$ & $\begin{array}{l}\text { Sediment-hosted } \mathrm{Hg} \text {, hot-spring } \mathrm{Hg} \text {. } \\
\text { volcanic-hosted } \mathrm{Hg} \text {. } \\
\text { (Palyanskoe, Plamennoe) }\end{array}$ & $\begin{array}{l}\text { Continental-margin arc. } \\
\text { Okhotsk-Chukotka volcanic- } \\
\text { plutonic belt. }\end{array}$ & $\begin{array}{l}\text { Subduction-related granitic plutonism that formed the back-are part of Okhotsk- } \\
\text { Chukotka continental-margin arc. Youngest zone in Eastem Asia metallogenic } \\
\text { belt. }\end{array}$ \\
\hline
\end{tabular}




\begin{tabular}{|c|c|c|c|}
\hline $\begin{array}{l}\text { Metallogenie Belt } \\
\text { (Abbreviation) }\end{array}$ & $\begin{array}{l}\text { Major Mineral Deposits Types. } \\
\text { (Significant Mineral Deposits) }\end{array}$ & $\begin{array}{l}\text { Environment. } \\
\text { Host Unit. }\end{array}$ & $\begin{array}{l}\text { Tectoaic Event. } \\
\text { Comments }\end{array}$ \\
\hline $\begin{array}{l}\text { Seward Peninsula } \\
\text { (SP) }\end{array}$ & $\begin{array}{l}\text { Sn skarn \& greisen, Sn granite, porphyry } \\
\text { Mo, polymetallic vein, \& others. } \\
\text { (Lost River, Eagle Creek, Death Valley) }\end{array}$ & $\begin{array}{l}\text { Continental-margin arc. } \\
\text { Westem Alaska part of } \\
\text { Okbotsk-Chukotka volcanic- } \\
\text { plutonic belt. }\end{array}$ & $\begin{array}{l}\text { Subduction-related granitic plutonism that formed the back-are part of Okhotsk- } \\
\text { Chukotka continental-margin arc. Eastem extension of Eastern Asia } \\
\text { metallogenic belt. }\end{array}$ \\
\hline $\begin{array}{l}\text { Northwestem } \\
\text { Koyukuk Basin } \\
\text { (NWK) }\end{array}$ & $\begin{array}{l}\text { Felsic plutonic U, } \\
\text { (Wheeler Creek, Clear Creek, Zane Hills) }\end{array}$ & $\begin{array}{l}\text { Continental-margin are. } \\
\text { Westem Alaska part of } \\
\text { Okhotsk-Chukotka volcanic- } \\
\text { plutonic belt. }\end{array}$ & $\begin{array}{l}\text { Subduction-related granitic plutonism that formed the back-are part of Okhotsk- } \\
\text { Chukotka continental-margin arc. Eastern extension of Eastern Asia } \\
\text { metallogenic belt. }\end{array}$ \\
\hline $\begin{array}{l}\text { West-Central Alaska } \\
\text { (WCA)(Hogatza) }\end{array}$ & $\begin{array}{l}\text { Porphyry } \mathrm{Cl} . \\
\text { (Indian Mountain, Purcell Mountain, Zane } \\
\text { Hills) } \\
\text { Manto replacoment deposit (polymetallic Pn- } \\
\text { Zn, } \mathrm{Au} \text { ) (1llineis Cresk) }\end{array}$ & $\begin{array}{l}\text { Contiaental-margin arc. } \\
\text { Westem Alaska part of } \\
\text { Okhotsk-Cbukotka volcanic- } \\
\text { plutonic belt. }\end{array}$ & $\begin{array}{l}\text { Subduction-related granitic plutonism tha1 formed the Okbotsk-Chukotka } \\
\text { continental-margin are. Eastern extension of Eastern Asia metallogenic beli. }\end{array}$ \\
\hline \multicolumn{4}{|c|}{ Metallogenic Belts Formed in Late Mesozoic and Early Cenozoic KJuane Continental-Margin Are, Southera Alaska } \\
\hline $\begin{array}{l}\text { Kuskokwim } \\
\text { Mountains (KMT) } \\
\text { (Kuskokwim } \\
\text { mineral belt) }\end{array}$ & $\begin{array}{l}\text { Sn-Cu-Ag greisen, } \mathrm{Hg} \text {-Sb-Au epithermal } \\
\text { vein, Au-As polymetallic vein, } \\
\text { porphyry Mo, porphyry Cu-Au, } \\
\text { porphyry Au, granitoid-related Au, } \\
\text { (McLeod, Fox Hills, Chicken Mountain, } \\
\text { Beaver Mountains, Cirque, } \\
\text { Tolstoi, Von Frank Mountain, Donlin } \\
\text { Creek, Vinasale, Amold) }\end{array}$ & $\begin{array}{l}\text { Continental-margin arc. } \\
\text { Kuskokwim Mountains } \\
\text { sedimentary and volcanic belt. }\end{array}$ & $\begin{array}{l}\text { Subduction-related granitic plutonism that formed the Kluane continental-margin } \\
\text { arc. }\end{array}$ \\
\hline $\begin{array}{l}\text { Easn-Central Alaska, } \\
\text { (younger part) } \\
\text { (ECA) (Includes } \\
\text { Carmacks belt of } \\
\text { porphyry Cu-Mo } \\
\text { deposins) }\end{array}$ & $\begin{array}{l}\text { Sn greisen and vein, tourmaline-topaz- } \\
\text { quartz-sulfide greisen, felsic plutonic } \\
\text { U, W skam, porphyry Cu-Mo. } \\
\text { (A sarco, Casino Ketchem Dome, Lime } \\
\text { Peak, Road Metal, Roy Creek, Taurus) }\end{array}$ & $\begin{array}{l}\text { Continental-margin are. } \\
\text { Yukon-Tanana igneous belt. }\end{array}$ & $\begin{array}{l}\text { Subduction-related granitic plutonism that formed the Kluane continental-margin } \\
\text { afc. }\end{array}$ \\
\hline Southem Alaska (SA) & $\begin{array}{l}\text { Porphyry Cu, porphyry Cu-Au, } \\
\text { polymetallic vein, Ag-Au skam, Cu- } \\
\text { Au-Ag skam. } \\
\text { (Kijik River, Golden Zone, Nabesna } \\
\text { River). }\end{array}$ & $\begin{array}{l}\text { Continental-margin are. } \\
\text { Alaska Range-Talkeetsa } \\
\text { Mountains igneous belt. }\end{array}$ & $\begin{array}{l}\text { Subduction-related granitic plutonism that formed the Kluane continental-margin } \\
\text { arc. }\end{array}$ \\
\hline \multicolumn{4}{|c|}{ Metallogenic Belts Formed During Early Tertiary Oblique Subduction of Kula-Farallon Oceanic Ridge Ubder Margin of Southern and Southeastern Alaska } \\
\hline Maclaren (MC) & $\begin{array}{l}\text { Au quartz vein. } \\
\text { (Lucky Hill and Timberline Creek) }\end{array}$ & $\begin{array}{l}\text { Extensional. } \\
\text { Veins in low-grade part of } \\
\text { Maclaren Glacier metamorphic } \\
\text { belt. }\end{array}$ & $\begin{array}{l}\text { Obliçue subduction of Kula-Farallon oceanic ridge under margin of southern } \\
\text { Alaska. }\end{array}$ \\
\hline $\begin{array}{l}\text { Talkectna Mountains } \\
\text { (TM) }\end{array}$ & $\begin{array}{l}\text { Au quartz vein } \\
\text { (Independence) }\end{array}$ & $\begin{array}{l}\text { Extensional. } \\
\text { Veins in low-grade part of } \\
\text { Talkeetna Formation. }\end{array}$ & $\begin{array}{l}\text { Oblique subduction of Kula-Farallon oceanic ridge under margin of southern } \\
\text { Alaska. }\end{array}$ \\
\hline
\end{tabular}




\begin{tabular}{|c|c|c|c|}
\hline $\begin{array}{l}\text { Metallogenic Belt } \\
\text { (Abbreviation) }\end{array}$ & $\begin{array}{l}\text { Major Mineral Deposits Types. } \\
\text { (Sigailicant Mineral Deposits) }\end{array}$ & $\begin{array}{l}\text { Environment. } \\
\text { Host Uait. }\end{array}$ & $\begin{array}{c}\text { Tectonic Event. } \\
\text { Comments }\end{array}$ \\
\hline $\begin{array}{l}\text { Chugach Mounains } \\
\text { (CM) }\end{array}$ & $\begin{array}{l}\text { Au quartz vein. } \\
\text { (Cliff, Alaska Oracle, Crown Point, \& } \\
\text { others) }\end{array}$ & $\begin{array}{l}\text { Extensional. } \\
\text { Veins in Valdez Group, } \\
\text { Chugach terrane. }\end{array}$ & $\begin{array}{l}\text { Oblique subduction of Kula-Farallon oceanic ridge under margin of southern } \\
\text { Alaska. }\end{array}$ \\
\hline Baranof (BN) & $\begin{array}{l}\text { Au quartz vein. } \\
\text { (Chichagoff, Hirst-Chichagof, Bauer, } \\
\text { Silver Bay, and cahers) }\end{array}$ & $\begin{array}{l}\text { Extensional. } \\
\text { Veins in Valdez Group. } \\
\text { Chugach terrane. }\end{array}$ & $\begin{array}{l}\text { Oblique subduction of Kula-Farallon oceanic ridge under margin of southeastem } \\
\text { Alaska. }\end{array}$ \\
\hline Juneau (JU) & $\begin{array}{l}\text { Au quartz vein. } \\
\text { (Jualin, Kensington, Alaska-Juneau, } \\
\text { Treadwell, Sundum Chief, Gold } \\
\text { Standard, } \& \text { others) }\end{array}$ & $\begin{array}{l}\text { Extensional. } \\
\text { Veins in foliated tonalite sill } \\
\text { berween Wrangellia and } \\
\text { Stikinia terrancs. }\end{array}$ & $\begin{array}{l}\text { Ohliquse subduction of Kula-Farallon oceanic ridge under margin of southeastern } \\
\text { Alaska. }\end{array}$ \\
\hline \multicolumn{4}{|c|}{ Metallogenic Belis Formed During Early Tertiary Spreading Along Kula-Farallon Oceanic Ridge, Southern and Southeastern Alaska } \\
\hline $\begin{array}{l}\text { Prince William Sound } \\
\text { (PW) }\end{array}$ & $\begin{array}{l}\text { Besshi massive sulfide, Cyprus massive } \\
\text { sulfide. } \\
\text { (Beatson (Latouche), Copper Bullion } \\
\text { (Rua Cove), Ellamar, Fidalgo-Alaska) }\end{array}$ & $\begin{array}{l}\text { Oceanie ridge. } \\
\text { Prince William terrane. }\end{array}$ & Sea-floor spreading along Kula-Farallon oceanic ridge. \\
\hline Yakobi (YK) & $\begin{array}{l}\text { Gabbroic } \mathrm{Ni}-\mathrm{Cu} \\
\text { (Bohemia Basin, Brady Glacier, Mirror } \\
\text { Harbour, Mt. Fairweather) }\end{array}$ & $\begin{array}{l}\text { Oceanie ridge. } \\
\text { Mafic-ultrumafic plutons } \\
\text { intruding Chugach terrane. }\end{array}$ & $\begin{array}{l}\text { Intrusion of mafie-taltramafie plutons during oblique subduction of Kula-Faralton } \\
\text { oceanic ridge under margin of southeastern Alaska. }\end{array}$ \\
\hline \multicolumn{4}{|c|}{ Metallogenie Belts Formed in Late Cretaceous and Early Tertiary Coast Continental-Margin Arc, Southeastern Alaska, and Southern Canadian Cordillera } \\
\hline Surprise Lake (SL) & $\begin{array}{l}\text { Porphyry Mo-Cu, Au-Ag polymetallic } \\
\text { vein. } \\
\text { (Mount Ogden, Red Mountain, Adanac- } \\
\text { Adera. Boswell River, \& others) }\end{array}$ & $\begin{array}{l}\text { Continental-margin arc, } \\
\text { Cosst-North Cascade plutonic } \\
\text { belt. }\end{array}$ & $\begin{array}{l}\text { Subduction-related granitic plutonism that formed the Cosst continental-margin } \\
\text { are. }\end{array}$ \\
\hline $\begin{array}{l}\text { Central-Southeastem } \\
\text { Alaska (CSE) }\end{array}$ & $\begin{array}{l}\text { Porphyry Mo, porphyry Cu, } \\
\text { (Margerie Glacier, Nunatak, Groundhog } \\
\text { Basin, Quartz Hill) }\end{array}$ & $\begin{array}{l}\text { Continental-margin are. } \\
\text { Coast-North Cascade plutonic } \\
\text { belt. }\end{array}$ & $\begin{array}{l}\text { Sabduction-related granitic plutonism that formed the Coast continental-margin } \\
\text { arc. }\end{array}$ \\
\hline Bulkley (BK) & $\begin{array}{l}\text { Porphyry Cu-Mo, Au-Ag polymetallic } \\
\text { vein. } \\
\text { (Huckleberry, Ox Lake, Poplar, Red } \\
\text { Rose, Dome Mountain, \& others) }\end{array}$ & $\begin{array}{l}\text { Continental-margin arc. } \\
\text { Coast-North Cascade plutonic } \\
\text { belt. }\end{array}$ & $\begin{array}{l}\text { Subduction-related granitic plutonism that formed the Coast continental-margin } \\
\text { are. }\end{array}$ \\
\hline $\begin{array}{l}\text { Fish Lake-Bralorne } \\
\text { (FLB) }\end{array}$ & $\begin{array}{l}\text { Porphyry Cu-Mo, porphyry Cu-Au, Au } \\
\text { quartz vein, Au-Ag polymetallic vein, } \\
\text { and related deposit types. } \\
\text { (Bralome, Carolin, Fish Lake, Giant } \\
\text { Copper, Pioneer, Poison Mountain) } \\
\end{array}$ & $\begin{array}{l}\text { Continental-margin are. } \\
\text { Coast-North Cascade plutonic } \\
\text { belt. }\end{array}$ & $\begin{array}{l}\text { Subduction-related granitic plutonism that formed the Coast continental-margin } \\
\text { arc. Related to Tyaughton-Yalakom metallogenic belt of } \mathrm{Hg}-\mathrm{Ab}-\mathrm{W}-\mathrm{Sb} \\
\text { polymetallic vein deposits. }\end{array}$ \\
\hline $\begin{array}{l}\text { Tyanghton-Yalakom } \\
\text { (TY) }\end{array}$ & $\begin{array}{l}\text { W-Sb polymetallic vein and } \mathrm{Hg} \text {-Sb vein } \\
\text { (Tungsten Queen) }\end{array}$ & $\begin{array}{l}\text { Continental-margie arc. } \\
\text { Veins intruding Coast-North } \\
\text { Cascade plutonic belt and older } \\
\text { units. }\end{array}$ & $\begin{array}{l}\text { Subduction-related granitic plutonism that formed the Coast continental-margin } \\
\text { are. Associated with Cretaceous to Eocene dikes intruded along Eocene } \\
\text { dextral-slip faults of the Talakom, Relay Creek, and Fortress Ridge faults. } \\
\text { Related to Fish Lake-Bralorne metallogenic belt of granitic-magnatism-related } \\
\text { deposits. }\end{array}$ \\
\hline Gambier (GB) & $\begin{array}{l}\text { Porphyry Cu-Mo, Zn-Pb-Cu skam, } \\
\text { (O.K., Gambier Island, HI-MARS) }\end{array}$ & $\begin{array}{l}\text { Continental-margin are. } \\
\text { Coast-North Cascade plutonic } \\
\text { belt. }\end{array}$ & $\begin{array}{l}\text { Subduction-related granitic plutonism that formed the Coast continental-margin } \\
\text { arc. }\end{array}$ \\
\hline
\end{tabular}




\begin{tabular}{|c|c|c|c|}
\hline $\begin{array}{l}\text { Metallogeaic Belt } \\
\text { (Abbreviation) }\end{array}$ & $\begin{array}{l}\text { Major Mineral Deposits Types. } \\
\text { (Significant Mineral Deposits) }\end{array}$ & $\begin{array}{l}\text { Eavironment. } \\
\text { Host Unit. }\end{array}$ & $\begin{array}{l}\text { Tectonic Eveat. } \\
\text { Comments }\end{array}$ \\
\hline Catface (CF) & $\begin{array}{l}\text { Porphyry Cu-Mo-Au, } \mathrm{Au}-\mathrm{Ag} \\
\text { polymetallic vein. } \\
\text { (Catface, Domineer, Privateer) }\end{array}$ & $\begin{array}{l}\text { Continental-margin are, } \\
\text { Granitic plutons intruding } \\
\text { southem Wrangellia terrane. }\end{array}$ & $\begin{array}{l}\text { Subduction-related granitic plutonism that formed the Coast continental margin } \\
\text { arc. }\end{array}$ \\
\hline \multicolumn{4}{|c|}{ Metallogenic Belts Formed in Backarc Part of Early Tertiary Coast Continental-Margin Arc, Southern Canadian Cordillera } \\
\hline Skeena (SK) & $\begin{array}{l}\text { Porphyry Cu-Mo, porphyry Mo, Ag } \\
\text { polymetallic vein, Au-Ag polymetallic } \\
\text { vein. } \\
\text { (Berg, Lucky Ship, Nanika, Red Berd, } \\
\text { Kitsault, Equity Silver, \& others) }\end{array}$ & $\begin{array}{l}\text { Continental-margin arc. } \\
\text { Coast-North Cascade plutonic } \\
\text { belt and Kamloops magmatic } \\
\text { belt. }\end{array}$ & $\begin{array}{l}\text { Granitic plutonism occurring during back afe extension or transtension occurring } \\
\text { continentward of subduction-related Coast continental-margin arc. Related to } \\
\text { Nelson metallogenic belt. }\end{array}$ \\
\hline Nelson (NS) & $\begin{array}{l}\text { Ag polymetallic vein, } \mathrm{Ag}-\mathrm{Pb}-\mathrm{Zn} \text { manto, } \\
\text { Au-Ag epithermal vein. } \\
\text { (Bluebell, Highland Bell, Vault, Dusty } \\
\text { Mac) }\end{array}$ & $\begin{array}{l}\text { Continental-margin arc. } \\
\text { Eocene plutonic rocks introding } \\
\text { Quesnellia terrane. }\end{array}$ & $\begin{array}{l}\text { Granitic plutonism occurring during back arc extension or transtension occurring } \\
\text { continentward of subdaction-related Coast continensal-margin arc. Related to } \\
\text { Skeena metallogenic belt. }\end{array}$ \\
\hline \multicolumn{4}{|c|}{ EARLY TO MIDDLE TERTIARY (Middle Eocene through early Mlocene - 52 to 23 Ma) (Figures 17, 18) } \\
\hline \multicolumn{4}{|c|}{ Metallogenic Belts Formed in Tertiary Collision of Outboard Terranes, Russian Southeast } \\
\hline Central Sakhalin (CS) & $\begin{array}{l}\text { Au quartz vein and talc } \\
\text { (Langeriskoe) }\end{array}$ & $\begin{array}{l}\text { Collisional. } \\
\text { Aniva subduction zone terrane. }\end{array}$ & $\begin{array}{l}\text { Collisional event during the early Tertiary(?) accretion of outboard terranes to the } \\
\text { east. }\end{array}$ \\
\hline Srediany (SR) & $\begin{array}{l}\text { At quartz vein. } \\
\text { (Tumannoe) } \\
\text { Metamorphic REE vein(?). } \\
\text { (Anomalnoe) }\end{array}$ & $\begin{array}{l}\text { Collisional. } \\
\text { Veins in Sredinny-Kamchatka } \\
\text { terrane. }\end{array}$ & Accretion of outboard Olyutorka are and generation of hydrothermal fluids. \\
\hline \multicolumn{4}{|c|}{ Metallogenic Belts Formed in Tertiary Backare Rifting and Continental-Margin Transform, and Transcurrent Faulting, Russian Southeast } \\
\hline Kvinumsky (KV) & $\begin{array}{l}\text { Hornblende peridotite Cu-Ni, gaboroic } \\
\text { Ni-Cu. } \\
\text { (Shanuch, Kvinum, and Kuvalorog) }\end{array}$ & $\begin{array}{l}\text { Backarc. } \\
\text { Mafic igneous intruding } \\
\text { Sredinny-Kamchatsa } \\
\text { metamorphic terrane. }\end{array}$ & $\begin{array}{l}\text { Backare intrusion related to stabduction beneath the Kamchatka Peninsula part of } \\
\text { Central Kamcharka continental margin arc. }\end{array}$ \\
\hline $\begin{array}{l}\text { Ceniral Koryak } \\
\text { (CKY) }\end{array}$ & $\begin{array}{l}\text { Sn polymetallic vein, Au-Ag epithermal } \\
\text { vein, Hb-Sb vein, porpbyry Mo-Cu. } \\
\text { (Ainatvetkin, Ametistovoe, Lyapgani, } \\
\text { Tamvatney, Kuibiveen) }\end{array}$ & $\begin{array}{l}\text { Continental-margin arc. } \\
\text { Kamchatkak-Koryak volcanic- } \\
\text { plutonic belt. }\end{array}$ & $\begin{array}{l}\text { Granitic plutonism associated with transform faulting along the margin of the } \\
\text { North Asian continent. }\end{array}$ \\
\hline \multicolumn{4}{|c|}{ Metallogenic Belts Formed in Tertiary Continental-Margin Ares, Kamchatka Peainsula, and Southern Canadian Cordillera } \\
\hline Olyutor (OT) & $\begin{array}{l}\text { As-Ag epithermal vein, Sn polymetallic } \\
\text { vein, clastic sodiment-hosted } \mathrm{Hg} \text {. } \\
\text { (Lalankytap, Maleotoivayam) }\end{array}$ & $\begin{array}{l}\text { Continental-margin arc. } \\
\text { East Kamcharka volcanic \& } \\
\text { sedimentary basin. }\end{array}$ & $\begin{array}{l}\text { Subduction-related granitic plutonism that fonmed the Kamchatka Peninsula part } \\
\text { of Northeast Asia continental margin afe. }\end{array}$ \\
\hline Pinchi Lake (PC) & $\begin{array}{l}\mathrm{Hg} \text { epithermal vein, Sb-Au vein, silica- } \\
\text { carbonate } \mathrm{Hg} \\
\text { (Pinchi Lake) }\end{array}$ & $\begin{array}{l}\text { Continental-margin arc(?) } \\
\text { Shear zone. }\end{array}$ & Transcurrent faulting along Cascade volcanic-plutonic belt. \\
\hline Owl Creek (OC) & $\begin{array}{l}\text { Porphyry Ca-Mo, porphyry Mo, Au } \\
\text { polymetallic vein. } \\
\text { (Harrison Lake, Boundary, Red } \\
\text { Mountain, Lone Jack, Clear Creek, } \\
\text { Owi Creek, \& others) }\end{array}$ & $\begin{array}{l}\text { Continental-margin arc, } \\
\text { Cascade volcanic-plutonic belt. }\end{array}$ & $\begin{array}{l}\text { Subduction-related granitic plutonism that formed the early part of Cascade } \\
\text { continental margin are. Belt extended into Miocene and Pliocene. }\end{array}$ \\
\hline
\end{tabular}




\begin{tabular}{|c|c|c|c|}
\hline $\begin{array}{l}\text { Metallogenic Belt } \\
\text { (Abbreviation) }\end{array}$ & $\begin{array}{l}\text { Major Mineral Deposits Types. } \\
\text { (Significant Mineral Deposits) }\end{array}$ & $\begin{array}{l}\text { Environment. } \\
\text { Hest Unit. }\end{array}$ & $\begin{array}{l}\text { Tectonic Event. } \\
\text { Comments }\end{array}$ \\
\hline \multicolumn{4}{|c|}{ MIDDLE TERTIARY METALLOGENIC BELTS (Miocene - 20 to $10 \mathrm{Ma}$ ) (Figures 17, 18) } \\
\hline \multicolumn{4}{|c|}{ Metallogenic Belts Formed in Tertiary Continental-Margin Ares, Kamchatka Peniasula, Southern Alaska, and Seuthern Canadian Cordillera } \\
\hline East Kamchatka (EK) & $\begin{array}{l}\text { Au-Ag epithermal vein. } \\
\text { (Asachinskoe, Mutnovskoe, Rodnikovoe) }\end{array}$ & $\begin{array}{l}\text { Continental-margin arc. } \\
\text { Central Kamehatka volcanic \& } \\
\text { sedimentary basin. }\end{array}$ & $\begin{array}{l}\text { Subduction-related granitic plutonism that formed the Kamchatka Peninsula part } \\
\text { of Northeast Asia continental margin arc. }\end{array}$ \\
\hline $\begin{array}{l}\text { Central Kamchatka } \\
\text { (CK) }\end{array}$ & $\begin{array}{l}\text { Au-Ag epithermal vein, porphyry Cu- } \\
\text { Mo. } \\
\text { (Ozernovskoe, Aginskoe, Kirganik) }\end{array}$ & $\begin{array}{l}\text { Continental-margin are. } \\
\text { Central Kamchatka volcanic \& } \\
\text { sedimentary basin. }\end{array}$ & $\begin{array}{l}\text { Subduction-related granitic plutonism that formed the Kamchatka Peninstala part } \\
\text { of Northeast Asia continental margin arc. }\end{array}$ \\
\hline $\begin{array}{l}\text { Alaska Peninsula \& } \\
\text { Aleutian Islands } \\
\text { (AP) }\end{array}$ & $\begin{array}{l}\text { Au-Ag epithermal vein, porphyry Cu \& } \\
\text { Cu-Mo, polymetallic vein. } \\
\text { (Pyramid, Bee Creek, Apollo-Sitka) }\end{array}$ & $\begin{array}{l}\text { Continental-margin arc. } \\
\text { Aleutian wolcanic belt. }\end{array}$ & $\begin{array}{l}\text { Subtuction-felated granitic plutonism that formed the } A \text { leutian continental margin } \\
\text { arc. Belt extended into Pliocene and Quatemary. }\end{array}$ \\
\hline \multicolumn{4}{|c|}{ Continuing Metallogenic Belts } \\
\hline \multicolumn{3}{|r|}{ 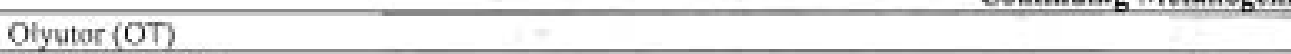 } & Belt started in late Paleogene or Miocene. \\
\hline Owl Creck $(O C)$ & & & Belt started in Eocene and extended into Pliocene. \\
\hline \multicolumn{4}{|c|}{ LATE TERTIARY and QUATERNARY METALLOGENIC BELTS (Pliocene throagh Present - 4 to 0 Ma) (Figures 17,18 ) } \\
\hline \multicolumn{4}{|c|}{ Metallogenie Belts Formed in Late Tertiary and QuaternaryCostinental-Margie Ares, Kamehatka Peninsala, Southern Alaska, and Southern Canadian Cordillera } \\
\hline Sakhalin Eland (SH) & $\begin{array}{l}\text { Silica-carbonate, volcanic-hosted } \mathrm{Hg} \\
\text { deposits. } \\
\text { (In' River, Inskoe Ostrinskoe, } \\
\text { Svetloyskoe, Yasnoe) } \\
\end{array}$ & $\begin{array}{l}\text { Rear of a continental-margin } \\
\text { are? } \\
\text { Shear zones. }\end{array}$ & Backarc spreading behind Kuril arc? \\
\hline Kunil (KU) & $\begin{array}{l}\text { At-Ag epithermal vein, polymetallie } \\
\text { vein, Sn vein, sulfur-sulfide, \& others. } \\
\text { (Novoe, Prasolovskoe, Koshkina, } \\
\text { Valentinovskoe) }\end{array}$ & $\begin{array}{l}\text { Continental-margin arc. } \\
\text { Kuril volcanic-plutenic belt. }\end{array}$ & $\begin{array}{l}\text { Subduction-related granitic plutonism that formed the Kuril Esland part of } \\
\text { Northeast Asia continental margin are. }\end{array}$ \\
\hline \multicolumn{4}{|c|}{ Continuing Metallogenic Belts } \\
\hline \multicolumn{3}{|c|}{ Alaska Peninsula \& Aleutian Islands (AP) } & Belt started in Miocene. \\
\hline \multicolumn{3}{|l|}{ Owl Creek (OC) } & Belt started in Eosene. \\
\hline
\end{tabular}


TABLE 4. Significant lode deposits, locations, and major metals for major Proterozoic and Phanerozoic metallogenic belts in the Russian Far East, Alaska, and the Canadian Cordiliera. Refer to Figures 2-18 for location of metallogenic belts. For each time interval (time-slage), metallogenic belts are listed in a clockwise order, according to similar tectonic environments, starting with the area of the Russian Southeast and ending with the area of the southern Canadian Cordillera. Attributes of lode deposits and characteristics of metallogenic belts are defined and adapted from Nokleberg and others (1997a, b, 1998b) and as modified herein. Abbreviations given for metallogenic belts as depicted on generalized maps of metallogenic belts and host rocks (Figures 2-18) and on metallogenic-tectonic model for Devonian through Present (Figures 19-32). For each metallogenic belt, mineral deposits listed in alphabetical order. Most major mineral deposits for the Yukon Territory (northwest Canadian Cordillera) have deposit numbers from the MINFILE of the Yukon Geological Survey (Dekelerk, 2002) listed in parens after the deposit name. These deposits descriptions can be accessed from the Yukon Geological Survey MINFILE Web site at: http://www,geology.gov,yk.ca/minfile/. Most major mineral deposits for British Columbia (southwest Canadian Cordillera) have deposit numbers from MINFILE (2002) listed in parens after the deposit name. These deposit descriptions can be accessed from the MINFILE Web site at www.em.gov.bc.ca/mining/geolsurv/minfile/.

\begin{tabular}{|c|c|c|c|c|}
\hline Deposit Name & Mineral Deposit Model & Major Metals & \multicolumn{2}{|c|}{ Latitude $\mathrm{N}$; Longitude $\mathrm{E}, \mathrm{W}$. } \\
\hline \multicolumn{5}{|c|}{ PROTEROZOIC (2500 TO $570 \mathrm{Ma})$} \\
\hline \multicolumn{5}{|c|}{$\begin{array}{c}\text { Oroek Metallogenic Belt of Ironstone and Sediment-Hosted Cu Deposits (Middle and Late Proterozoie) } \\
\text { West-Central Part of Russian Northeast (Belt OK) }\end{array}$} \\
\hline Orock & Sediment-hosted Cu & $\mathrm{Cu}$ & $6454 \mathrm{~N}$ & $152^{\circ} 48 \mathrm{E}$ \\
\hline Pobeda & Ironstone & $\mathrm{Fe}$ & $65^{\prime} 43 \mathrm{~N}$ & $15212 \mathrm{E}$ \\
\hline \multicolumn{5}{|c|}{$\begin{array}{l}\text { Lantarsky-Dzhugdzhur Belt of Anorthosile Apatite-Ti-Fe and Gabbroic Ni-Cu (PGE) Deposits (Mesoproterozoic), Southern } \\
\text { Part of Russian Northeast (Belt LD) }\end{array}$} \\
\hline Bogidenskoe & Anorthosite apatite $\mathrm{T}_{\mathrm{t}}-\mathrm{Fe}_{\mathrm{e}}$ & $\mathrm{Ti}_{\mathrm{i}} \mathrm{p}$ & $55^{3} 38^{\prime} \mathrm{N}$ & $133^{2} 42 \mathrm{E}$ \\
\hline Dzhaninskot & Anorthosite apatite $\mathrm{Ti}-\mathrm{Fe}$ & $\mathrm{Ti}, \mathrm{P}$ & $5531 \mathrm{~N}$ & $134^{\circ} 09^{\circ} \mathrm{E}$ \\
\hline Gayumskoe & Anorthosite apatite $\mathrm{Ti}-\mathrm{Fe}$ & $\mathrm{Ti}, \mathrm{P}$ & $55^{\prime} 43^{\prime} \mathrm{N}$ & $13415 \mathrm{E}$ \\
\hline Maimakanskoe & Anorthosite apatite Ti-Fe & Ti.P & $5537 \mathrm{~N}$ & $13430 \mathrm{E}$ \\
\hline $\begin{array}{l}\text { Avlandzhinsky, Kontaktory, } \\
\text { Nyandomi, Odocin, Ozerny. }\end{array}$ & Gabbroic Ni-Cu Cu-Ni-Co-PGE & $\mathrm{Cu}, \mathrm{Ni}, \mathrm{PGE}$ & $58^{2} 08^{\prime} \mathrm{N}$ & $13755 \mathrm{E}$ \\
\hline \multicolumn{5}{|c|}{$\begin{array}{l}\text { Ulkan Metallogenic Belt of Felsic Plutonic REE Deposits (Mesoproterozaic), } \\
\text { Southeastern Part of Russian Northeast (Belt UL) }\end{array}$} \\
\hline Ulkanskoe & Felsic plutonic REE & $\mathrm{REE}, \mathrm{B} \varepsilon_{1} \mathrm{Zr}$ & $5619 / \mathrm{N}$ & $13449 \mathrm{E}$ \\
\hline \multicolumn{5}{|c|}{$\begin{array}{c}\text { Bilyakchan Metallogenic Belt of Sediment-hosted Cu and basalt Cu Deposits (Mesoproterozoic and Neoproterozoic), } \\
\text { Southeastern Part of Russian Northeast (Belt BI) }\end{array}$} \\
\hline Dzhagdag & Basaltic $\mathrm{Cu}$ & $\mathrm{Cu}$ & $57^{\prime} 22^{\prime} \mathrm{N}$ & $13713 \mathrm{E}$ \\
\hline \multicolumn{5}{|c|}{$\begin{array}{l}\text { Omolon Metallogenic Belt of Ironstone (Superior Fe) Deposits (Archean to Early Proterozoic) } \\
\text { Central Part of Russian Nertheast (Belt OM) }\end{array}$} \\
\hline Verkhny-Omolon & Ironstone & $\mathrm{Fe}$ & $6321 \mathrm{~N}$ & $15822 \mathrm{E}$ \\
\hline \multicolumn{5}{|c|}{ Kilbuck Metallogenic Belt of Ironstone (Superior Fe) Depesits (Early Proterozoie), Southwestern Alaska (Belt KI) } \\
\hline Canyon Creek & Ironstone & $\mathrm{Fe}$ & $59^{\circ} 38^{\prime} \mathrm{N}$ & $16108 \mathrm{~W}$ \\
\hline \multicolumn{5}{|c|}{$\begin{array}{c}\text { Sinuk River Metallogenie Belt of Stratiform Massive Sulfide-Barite and Stratabound Fe and Mn Depesits } \\
\text { (Late Proterozoic or older), Western Alaska (Belt SR) }\end{array}$} \\
\hline Aurora Creek & Kuroko massive sulfide? & $\begin{array}{l}\mathrm{Zn}, \mathrm{Pb}, \mathrm{Cu}, \mathrm{Ba}, \mathrm{AB}_{\mathrm{B}} \\
\mathrm{Au}\end{array}$ & $64^{\prime} 46^{\prime} \mathrm{N}$ & $164^{7} 58^{2} W$ \\
\hline American, Bear, Cub, Monarch & Stratabound $\mathrm{Fe}-\mathrm{Mn}$ & $\mathrm{Fe}, \mathrm{Mn}, \mathrm{F}$ & $64^{\prime} 48^{\prime} \mathrm{N}$ & $16524^{\prime} \mathrm{W}$ \\
\hline \multicolumn{5}{|c|}{ Gillespie Metallogenic Belt of SEDEX Pb-Zn Deposits (Early Proterozoic), Yukon Territory (Belt GE) } \\
\hline Blende & Sedimentary exhalative $\mathrm{Pb}-\mathrm{Zn}$ & $\mathrm{Zn}, \mathrm{Cu}, \mathrm{Pb}, \mathrm{Av}, \mathrm{Ag}$ & $6425 \mathrm{~N}$ & $13430 \mathrm{~W}$ \\
\hline Hart River & $\begin{array}{l}\text { Sedimentary exhalative } \mathrm{Zn-Cu}- \\
\mathrm{Pb}\end{array}$ & $\mathrm{Zn}, \mathrm{Cu}, \mathrm{Ag}$ & $6439 \mathrm{~N}$ & $13651^{2} \mathrm{~W}$ \\
\hline
\end{tabular}




\begin{tabular}{|c|c|c|c|}
\hline Depesit Name & Mineral Depesit Model & Major Metals & Latitude $\mathrm{N}_{\text {; }}$ Longitude $\mathrm{E}, \mathrm{W}$, \\
\hline \multicolumn{4}{|c|}{ Wernecke Metallogenic Belt of U-Cu-Fe (Au-Co) Vein And Breccia Deposits (Early Proterozoic), Yukon Territory (Belt WR) } \\
\hline Dolures & $\begin{array}{l}\text { U-Cu-Fe }(\mathrm{Au}-\mathrm{Co}) \text { vein and } \\
\text { berecia }\end{array}$ & $\mathrm{Cu}, \mathrm{Co}, \mathrm{Au}$ & 6454 'N $13331 ' \mathrm{~W}$ \\
\hline Igoe & $\begin{array}{l}\text { U.Cu-Fe }(\mathrm{Atr}-\mathrm{Co}) \text { vein and } \\
\text { breccia }\end{array}$ & $\mathrm{Cu}, \mathrm{Au}, \mathrm{U}, \mathrm{Co}$ & $65^{\circ} 03 \mathrm{~N} \quad 134^{\prime 2} 38^{\prime} \mathrm{W}$ \\
\hline trene & $\begin{array}{l}\text { U-Cu-Fe }(\mathrm{Au}-\mathrm{Co}) \text { vein and } \\
\text { breccia }\end{array}$ & $\mathrm{Cu}, \mathrm{U}$ & $6505 \mathrm{~N} \quad 13415^{\prime} \mathrm{W}$ \\
\hline Pagisteel & $\begin{array}{l}\text { U. Cu-Fe }(\mathrm{Au}-\mathrm{Co}) \text { vein and } \\
\text { berecia }\end{array}$ & $\mathrm{Fe}, \mathrm{Cu}$ & $6450 \mathrm{~N} 13418 \mathrm{~W}$ \\
\hline Porphyry & $\begin{array}{l}\text { U-Cu-Fe }(\mathrm{Au}-\mathrm{Co}) \text { vein and } \\
\text { beeceia }\end{array}$ & $\mathrm{Cu}_{1} \mathrm{Au}_{3} \mathrm{U}, \mathrm{Co}$ & $64^{\prime} 55^{\circ} \mathrm{N} 133^{\prime} 15^{\prime} \mathrm{W}$ \\
\hline Slab & $\begin{array}{l}\text { Ue-Cu-Fe }(\mathrm{Au}-\mathrm{Co}) \text { vein and } \\
\text { berceia }\end{array}$ & $\mathrm{Cu}, \mathrm{Au}, \mathrm{U}, \mathrm{Co}$ & $6500 \mathrm{~N} 13402^{\prime} \mathrm{W}$ \\
\hline \multicolumn{4}{|c|}{$\begin{array}{l}\text { Rapitas Metallegenie Belt of Sedimentary Iron Fermatien Depesits (Neoproteroxoic), Central Yukon Territory } \\
\text { (Belt RA) }\end{array}$} \\
\hline Crest lron & Ironstone & Fe & $6515 \mathrm{~N} \quad 13300 \mathrm{WW}$ \\
\hline \multicolumn{4}{|c|}{ Redstone Metallogenic Belt of Sediment-Hosted Cv-As Deposits (Neoproteronoic), Ceniral Yakon Territory (Belt RS) } \\
\hline Coates Lake (Redstoee) & Sediment-hosted $\mathrm{Cu}$ & $\mathrm{Ca}_{3} \mathrm{Ag}$ & $62427 \mathrm{~N} 12638 \mathrm{~W}$ \\
\hline Juae Creek (Baldwin, Sheli) & Sediment-hosted $\mathrm{Cu}$ & $\mathrm{Cu}, \mathrm{As}$ & $6349 \mathrm{~N} \quad 12746 \mathrm{~W}$ \\
\hline \multicolumn{4}{|c|}{ Churchall Metallogenic Belt of Cu vein Deposits Deposits (Mesoproteruzoic), Central Yukon Territory (Belt CH) } \\
\hline Churchill (Davis Keays) & Cu vein & $\mathrm{Cu}$ & $58232 \mathrm{~N} 12511 \mathrm{~W}$ \\
\hline \multicolumn{4}{|c|}{ Menashee Metalletenic Belt of SFDEX Zs-Pb-Ay Deposits (Neopreterezoie), Seuthern British Celumbia (Belt MO) } \\
\hline $\begin{array}{l}\text { Big Lodge (Pingston Creck) } \\
\text { (082LSE 012) }\end{array}$ & SEDEX Zn-Ps & $\mathrm{Zn}, \mathrm{Ft}$ & $5029 \mathrm{~N} 11803 \mathrm{~W}$ \\
\hline Cotionbela & SEDEX Fb-Zn & $\mathrm{Pb}, \mathrm{Zn}, \mathrm{Ag}$ & $51^{\circ} 2 \mathrm{TN} \cdot 118^{\prime} 49 \mathrm{~W}$ \\
\hline Mount Copelasd (0k2M 022) & Porphyry Mo & Mo & $51^{\circ} 08 \mathrm{~N} 11 \mathrm{~s}^{2} 28 \mathrm{~W}$ \\
\hline River lordan (King Finsure) & SEDEX Zn-F & P. Z, A & $5 t^{\circ} 08 \mathrm{~N} \quad 11825 \mathrm{w}$ \\
\hline Ruddosk Creek $(082 \mathrm{M}$ 084) & SEDEX $\mathrm{Zn}-\mathrm{F}$ & $\mathrm{Zn}, \mathrm{Pz}, \mathrm{Ag}$ & $51^{\circ} 47 \mathrm{~N} 11857 \mathrm{~W}$ \\
\hline \multicolumn{4}{|c|}{ Purcell Metallegesic Belt of SEDEX Za-Pb-Ag Depesits (Middle Proterosoic), Seuthern British Columbia (Belt PR) } \\
\hline $\begin{array}{l}\text { Moyie (St. Eugene) (OOB2GSW } \\
025 \text { ) }\end{array}$ & As polymetallic vein & $\mathbf{F}, \mathbf{A g}$ & $4917 \mathrm{~N} 115 \mathrm{~s} 0 \mathrm{~W}$ \\
\hline $\begin{array}{l}\text { Sullivan (Kinherley) (0ok CSW W } \\
049.51)\end{array}$ & SEDEX H-2h & F, $\mathrm{Zn}, \mathrm{Ae}$ & $4943 \mathrm{~N} 11600 \mathrm{~W}$ \\
\hline Vine & As-Au polymetallic vein & H. Zn, Ag, Au & $49^{2} 24 \mathrm{~N} 11549 \mathrm{~W}$ \\
\hline \multicolumn{4}{|c|}{$\begin{array}{l}\text { Clark Range Metallogenic Belt of Sediment-Hested Ca-Az Depesits (Mesopretereroic) } \\
\text { Southern British Celumbla (Belt CR) (Varieus eccurrences: ne significant deposits) }\end{array}$} \\
\hline \multicolumn{4}{|c|}{ CAMBRIAN THROUGH SILURIAN (570 te $408 \mathrm{Ma}$ ) } \\
\hline \multicolumn{4}{|c|}{ Vomesenka Metallogenic Belt of Korean Pb-2a Deposits (Cambrian), Southem Part of Russian Southeast (Belt VZ) } \\
\hline $\begin{array}{l}\text { Chernyshevskee } \\
\text { Voumesenka-1 }\end{array}$ & $\begin{array}{l}\text { Kerean Zn massive sulfide } \\
\text { Korsan Za massive sulfide }\end{array}$ & $\begin{array}{l}Z_{n}, P b \\
Z n\end{array}$ & 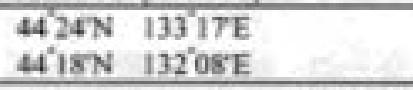 \\
\hline \multicolumn{4}{|c|}{ Kabarea Metallegenie Belt ef Ironateae (Superior Fe) Depesits (Early Cambrian), Seuthern Russian Southeast (Belt KB) } \\
\hline Ussuri deposits & Ironstone & $\mathrm{Fe}$ & $4518 \mathrm{~N} \quad 13338 \mathrm{E}$ \\
\hline \multicolumn{4}{|c|}{$\begin{array}{l}\text { Soeth Khingan Metallogenie Belt of Ironstone (Superior Fe) Deposits (Late Proterozoic and Early Paleozoie), Southern part of } \\
\text { Russian Southeast (Beir SK) }\end{array}$} \\
\hline South-Khingan & Ironstone & $\mathrm{Fe}$ & $48^{\prime} 39^{\prime} \mathrm{N} 13153 \mathrm{E}$ \\
\hline \multicolumn{4}{|c|}{$\begin{array}{c}\text { Gar Metallegenic Belts of Volcanogeaie Fe Depesits and Stratiform Cu and Pb-Zn Deposits (Late Proteroxoic) } \\
\text { Western Part of Russian Southeast (Belt GA) }\end{array}$} \\
\hline Chagoyan & Stratiforn Pb-Zn & $\mathrm{Pb}, \mathrm{Zn}, \mathrm{Ag}$ & $52^{\prime} 19 \mathrm{~N} \quad 128^{\prime} 22^{\prime} \mathrm{E}$ \\
\hline Gar & Volcanogenic Fe & $\mathrm{Fe}$ & $52^{\circ} 34 \mathrm{~N} \quad 129^{\circ} 04 \mathrm{E}$ \\
\hline Kamenushinskoe & Co massive sulfide & $\mathrm{Cu}_{2} \mathrm{FeS}$ & $52^{\circ} 43 \mathrm{~N} \quad 129^{\circ} 07 \mathrm{E}$ \\
\hline
\end{tabular}

Galam Metallegenic Belt of Voleanegenic Fe, Voleasogenie Mn, and Sedimentary P Depesits (Cambrian) Northere Part of Russian Seatheast (Belt GL)

\begin{tabular}{|c|c|c|c|c|}
\hline Galamskoe & Volcanogenic Fe & Fe & $5337 \mathrm{~N}$ & $13356 \mathrm{E}$ \\
\hline Gerbikanskee & Volcanogenic $\mathrm{Fe}$ & $\mathrm{Fe}$ & $53^{3} 29 \mathrm{~N}$ & $133^{\prime \prime} 12 \mathrm{E}$ \\
\hline Ir-Nimiiskoes: & Volcanogenic Mn & $\mathrm{Mn}$ & $54^{\circ} 09^{\prime} \mathrm{N}$ & $13436 \mathrm{E}$ \\
\hline Ir-Nimiiskoe-2 & Sedimentary phosphorite & $\boldsymbol{p}$ & $54^{\circ} 08 \mathrm{~N}$ & $134^{\prime} 38^{\circ} \mathrm{E}$ \\
\hline Itmatiaskoe & Volcanogenic Fe & Fe & $5321 \mathrm{~N}$ & $133^{\circ} 24^{\prime}$ \\
\hline Kurumskoe & Volcanogenic Fe & $\mathrm{Fe}$ & $53^{\circ} 23 \mathrm{~N}$ & $132^{\prime} 53 \mathrm{TE}$ \\
\hline Lagapskoe & Sedimentary phosphorite & $\mathbf{p}$ & $53^{\prime} 54 \mathrm{~N}$ & $13416 \mathrm{E}$ \\
\hline
\end{tabular}




\begin{tabular}{|c|c|c|c|c|}
\hline Deposit Name & Mineral Deposit Model & Major Metals & \multicolumn{2}{|c|}{ Latitude $\mathrm{N}_{\text {i }}$ Lengitude $\mathrm{E}, \mathrm{W}$. } \\
\hline Milkanskoe & Volcanogenic Fe & $\mathrm{Fe}$ & $54^{\circ} 04 \mathrm{~N}$ & $134^{\prime} 08^{\prime} \mathrm{E}$ \\
\hline Nelkanskoe & Sedimentary phosphorite & $P$ & $5418 \mathrm{~N}$ & $134^{\circ} 59^{\prime} \mathrm{E}$ \\
\hline North-Shantarskoe & Sedimentary phosphorite & $\mathbf{p}$ & $5509 \mathrm{~N}$ & $13735 \mathrm{E}$ \\
\hline \multicolumn{5}{|c|}{ Omulevka River Metallogenic Belt of Austrian Alps W and Kipushi Cu-Pb-Zn Deposits (Middle Ordovician) } \\
\hline Omalev & Austrian Alps W & W & $6413 \mathrm{~N}$ & $148^{\prime} 23^{\prime} \mathrm{E}$ \\
\hline Vesnovks & Kipushi Cu-Pb-Zn & $\mathrm{Cu}, \mathrm{Pb}, \mathrm{Zn}, \mathrm{Ge}$ & $6432 \mathrm{~N}$ & $149^{\circ} 23^{\circ} \mathrm{E}$ \\
\hline \multicolumn{5}{|c|}{$\begin{array}{l}\text { Rassekha Metallogenic Belt of Basaltic Cu and Sediment-Hosted Ca Deposits (Ordovician), } \\
\text { Westers Part of Russian Northeast (Belt RA) }\end{array}$} \\
\hline Agyndja & $\begin{array}{l}\text { Basalnic } \mathrm{Cu} \text { and sediment-hosted } \\
\mathrm{Cu}\end{array}$ & $\mathrm{Cu}$ & $6513 \mathrm{~N}$ & $148^{\circ} 02^{\prime} \mathrm{E}$ \\
\hline \multicolumn{5}{|c|}{$\begin{array}{l}\text { Dzhardzhan River Metallogenie Belt of Southeast Missouri Pb-Zn, Sediment-Hested Cu and Sandstene-Hosted U } \\
\text { deposits } \\
\text { (Late Proterozoic through late Paleozoic), Northern Part of Eastern Siberia (Belt DZR) }\end{array}$} \\
\hline Aga-Kukan & $\begin{array}{l}\text { Southeast Missouri } \mathrm{Pb}-\mathrm{Zn} \text { and } \\
\text { sediment-hosted } \mathrm{Cu}\end{array}$ & $\mathrm{Pb}, \mathrm{Zn}, \mathrm{Cu}$ & $69^{\circ} 04 \mathrm{~N}$ & $126^{\circ} 46^{\circ} \mathrm{E}$ \\
\hline Kyongdei & Sediment-hosted U & $\mathbf{U}$ & $7127 \mathrm{~N}$ & $12 \gamma^{\prime} 20 \mathrm{E}$ \\
\hline Manganiler & Southeast Missouri $\mathrm{Pb}-\mathrm{Zn}$ & $\mathrm{Pb}, \mathrm{Zn}$ & $7140 \mathrm{~N}$ & $127^{\prime} 18^{\prime} \mathrm{E}$ \\
\hline \multicolumn{5}{|c|}{ Anvil Metallogenic Belt of SEDEX Zn-Pb-Ag Deposits (Cambrian to Silurian), Seuthern Yuken Territory (Belt AN) } \\
\hline Faro (Anvil) & SEDEX Pb-Zn & $\mathrm{Zn}, \mathrm{Pb}, \mathrm{Ag}$ & $6222 \mathrm{~N}$ & $13322 \mathrm{~W}$ \\
\hline Swim (Sea, SB) & SEDEX Pb-Zn & $\mathrm{Zn}, \mathrm{Pb}, \mathrm{Ag}$ & $6213 \mathrm{~N}$ & $133^{\circ} 02^{\prime} \mathrm{W}$ \\
\hline $\begin{array}{l}\text { Vangorda Creek (Grum, Firth, } \\
\text { DY) }\end{array}$ & SEDEX Pb-Zn & $\mathrm{Zn}, \mathrm{Pb}, \mathrm{Ag}$ & $62^{\prime} 14 \mathrm{~N}$ & $133^{\prime} 02^{\prime} \mathrm{W}$ \\
\hline \multicolumn{5}{|c|}{ Howards Pass Metallogenic Belt of SEDEX Zn-Pb Depesits (Silurian), Southern Yukon Territory (Belt HP) } \\
\hline Anniv & SEDEX $\mathrm{Pb}-\mathrm{Zn}$ & $\mathrm{Zn}, \mathrm{Pb}$ & $62347 \mathrm{~N}$ & $129^{\circ} 31^{\prime} \mathrm{W}$ \\
\hline Howards Pass & SEDEX $\mathrm{Pb}-\mathrm{Zn}_{\mathrm{n}}$ & $\mathrm{Zn}, \mathrm{Pb}$ & $62^{\circ} 28 \mathrm{~N}$ & $129^{\prime 1} 10^{\prime} \mathrm{W}$ \\
\hline \multicolumn{5}{|c|}{$\begin{array}{c}\text { Kootenay Metallogenie Belt of Carbenate or Sediment-Hosted Deposits (Cambrian), } \\
\text { Southern British Columbia (Belt KO) }\end{array}$} \\
\hline $\begin{array}{l}\text { Duocan Lake Area (082KSE } \\
023)\end{array}$ & SEDEX $\mathrm{Zn}-\mathrm{Pb}$ & $\mathrm{Pb}, \mathrm{Zn}$ & $5022 \mathrm{~N}$ & $116^{2} 57^{\circ} \mathrm{W}$ \\
\hline H.B. (Zincton) & SEDEX Pb-Zn & $\mathrm{Zn}, \mathrm{Pb}, \mathrm{Ag}$ & $49^{\circ} 09 \mathrm{~N}$ & $117^{*} 12^{\prime} \mathrm{W}$ \\
\hline Jersey & SEDEX $\mathrm{Pb}-\mathrm{Zn}(?)$ & $\mathrm{Zn}, \mathrm{Pb}, \mathrm{Ag}$ & $49^{\circ} 06 \mathrm{~N}$ & $117313 \mathrm{~W}$ \\
\hline Mastadon (J\&L) (082M 005) & SEDEX $\mathrm{Pb}-\mathrm{Zn}(?)$ & $\mathrm{Zn}, \mathrm{Pb}, \mathrm{Au}, \mathrm{Ag}$ & $5115 \mathrm{~N}$ & $118^{\circ} 07^{\circ} \mathrm{W}$ \\
\hline Reeves-MacDonald (Recrmac) & Southeast Missouri $\mathrm{Pb}-\mathrm{Zn}$ & $\mathrm{Zn}, \mathrm{Pb}, \mathrm{Ag}$ & $49^{\circ} 02 \mathrm{~N}$ & $1177^{\prime \prime} \mathrm{W}$ \\
\hline \multicolumn{5}{|c|}{$\begin{array}{c}\text { Priace of Wales Island Metallogenic Belt of Continental-Margin Are-Related Deposits (Ordovician and Silurian) } \\
\text { Southeastern Alaska (Belt PW) }\end{array}$} \\
\hline Dawson & Polymetallic vein & Ats & $5528 \mathrm{~N}$ & $13242 \%$ \\
\hline $\begin{array}{l}\text { Kasaan Pentinsula (Mount } \\
\text { Andrew) }\end{array}$ & $\mathrm{Cu}-\mathrm{Fe}$ skarn & $\mathrm{Cu}, \mathrm{Fe}$ & $55^{\circ} 31 \mathrm{~N}$ & $132^{\prime} 18^{\prime} \mathrm{W}$ \\
\hline McLean Arm district & Porphyry Co-Mo & $\mathrm{Co}, \mathrm{Mo}$ & $53^{\circ} 49 \mathrm{~N}$ & $13201 \mathrm{~W}$ \\
\hline Salt Chuck & $\begin{array}{l}\text { Zoned mafic-ultramaficCu-Au- } \\
\text { PGE }\end{array}$ & $\mathrm{Cu}, \mathrm{Pd}, \mathrm{Pl}, \mathrm{Au}$ & $55^{\prime} 38 \mathrm{~N}$ & $132^{\prime} 34^{\prime} \mathrm{W}$ \\
\hline \multicolumn{5}{|c|}{ MIDDLE AND LATE DEVONIAN (387 to $360 \mathrm{Ma})$} \\
\hline \multicolumn{5}{|c|}{$\begin{array}{l}\text { Yaroslavka Metallegenic Belt of Fluerite and Se Greisen Deposits (Late Cambrian) } \\
\text { Southern Part of Russian Southeast (Belt YA) }\end{array}$} \\
\hline Voznesenka-II & Fluorite greisen & Fluocite & $44^{2} 11 \mathrm{I} \mathrm{N}$ & $132^{2} 08 \mathrm{E}$ \\
\hline Yaroslauskoe & Sn greisen & Sn & $4416 \mathrm{~N}$ & $132^{\circ} 13 \mathrm{E}$ \\
\hline \multirow{2}{*}{\multicolumn{5}{|c|}{$\begin{array}{c}\text { Kedon Metallegenic Belt of Au-Ag Epithermal Vein, Porphyry Mo, Fe Skarn, and Associated Deposits (Middle } \\
\text { Paleozoic) }\end{array}$}} \\
\hline & & & & \\
\hline Grisha & Av-Ag epithermal vein & Au, $\mathrm{Ag}$ & $63^{\circ} 48^{\prime} \mathrm{N}$ & $159^{\prime} 28 \mathrm{E}$ \\
\hline Kubaka & Au-Ag epithermal vein & $\mathrm{Au}, \mathrm{Ag}$ & $63^{\circ} 44^{\prime} \mathrm{N}$ & $160^{\circ} 01 \mathrm{E}$ \\
\hline Obyknovennoe & Au-Ag epithermal veen & $\mathrm{Au}, \mathrm{Ag}_{\mathrm{g}}$ & $6452 \mathrm{~N}$ & $158^{\prime} 39 \mathrm{E}$ \\
\hline Olcha & Au-Ag epithermal vein & $\mathrm{Au}, \mathrm{Ag}$ & $6457 \mathrm{~N}$ & $156^{\prime \prime 26 \mathrm{E}}$ \\
\hline Tumannaya & Au-Ag epithermal vein & $\mathrm{Au}, \mathrm{Ag}$ & $6416 \mathrm{~N}$ & $1600^{\circ} 02 \mathrm{E}$ \\
\hline Vechernee & Porphyry Mo-Cu & $\mathrm{Mo}, \mathrm{Cu}$ & $6329 \mathrm{~N}$ & $158^{\circ} 50 \mathrm{E}$ \\
\hline Yolochka & Au-Ag epithermal vein & $\mathrm{Au}, \mathrm{Ag}$ & $63^{\prime} 33^{\prime} \mathrm{N}$ & $159^{\circ} 38^{\circ \mathrm{E}}$ \\
\hline Zet & Au-Ag epithermal vein & $\mathrm{Au}, \mathrm{Ag}$ & $65^{\prime} 18^{2} \mathrm{~N}$ & $156^{\prime} 57 \mathrm{TE}$ \\
\hline \multicolumn{5}{|c|}{$\begin{array}{l}\text { Eastern Seward Peninsula (Kiwalik Mouatain)Belt of Kuroko Massive Sulfide Deposits (Middle Paleozoic) } \\
\text { Northern Alaska (Belt ES) (No significant deposits) }\end{array}$} \\
\hline
\end{tabular}


Aretic Metallegenic Belt of Kuroke and Klpushi Massive Sulfide Depesits (Devonian and Mississippian) Nerthern Alaska (Belt AT)

\begin{tabular}{|c|c|c|c|c|}
\hline Aretic & Kuroke massive sulfide & $\mathrm{Zn}, \mathrm{Ca}, \mathrm{Pb}, \mathrm{Ag}, \mathrm{Au}$ & $6711 \mathrm{~N}$ & $156^{\prime} 22^{\prime} \mathrm{W}$ \\
\hline BT, Jerri Creek & Kuroko massive sulfide & $\mathrm{Cl}, \mathrm{Zn}, \mathrm{Pb}, \mathrm{Ag}$ & $6708 \mathrm{~N}$ & $155^{\prime} 52^{\prime} \mathrm{W}$ \\
\hline Michigan Creek. & Kuroko massive sulfide & $\begin{array}{l}\text { As, } \mathrm{All}, \mathrm{Ag}, \mathrm{Ca}, \mathrm{Zn} \text {, } \\
\mathrm{Pb}\end{array}$ & $67^{\circ} 19 \mathrm{~N}$ & $151^{\circ} 14 \cdot \mathrm{W}$ \\
\hline Rooseveit Creek & Kuroko massive sulfide & $\mathrm{Cu}, \mathrm{Zn}, \mathrm{Pb}, \mathrm{Ag}, \mathrm{Au}$ & $67^{\prime} 10 \mathrm{~N}$ & $15230 \% \mathrm{~W}$ \\
\hline Ruby Creek, (Bornite) & Kipushi $\mathrm{Cu}=\mathrm{Pb}-\mathrm{Zn}$ & $\mathrm{Cu}, \mathrm{Co}, \mathrm{Zn}, \mathrm{Ag}$ & $67^{\circ} 04 \mathrm{~N}$ & $15659 \mathrm{~W}$ \\
\hline Smucker & Kuroke massive sulfide & $\mathrm{Cu}, \mathrm{Zn}, \mathrm{Pb}, \mathrm{Ag}$ & $6718 \mathrm{~N}$ & $157^{\prime} 12^{\prime} \mathrm{W}$ \\
\hline Sun, (Picnic Creck) & Kuroke massive sulfide & $\mathrm{Cu}, \mathrm{Zn}, \mathrm{Pb}, \mathrm{Ag}_{\mathrm{n}} \mathrm{Au}$ & $67^{\circ} 047 \mathrm{~N}$ & $155^{\circ} 01$ 'W \\
\hline \multicolumn{5}{|c|}{ Broeks Range Metallegenie Belt of Granitic Magmatism Deposits (Deveaian), Nerthern Alaska (Belt BR) } \\
\hline Ann (Emie Lake) & $\begin{array}{l}\text { Polymetallie vein } \\
\text { (metamorphosed) }\end{array}$ & $\mathrm{Pb}, \mathrm{Zn}, \mathrm{Ag}$ & $6725 \mathrm{~N}$ & $15250 \mathrm{~W}$ \\
\hline Beat Mountain & Porphyry Mo & Mo, w & $68^{\circ} 23 \mathrm{~N}$ & $142^{\prime} \mid 1 ' \mathrm{~W}$ \\
\hline Esotuk Glacier & po- $\mathrm{Zn}$ skam and fluorite vein & $\mathrm{Pb}, \mathrm{Zn}, \mathrm{Sn}, \mathrm{Cu}, \mathrm{W}$ & $69^{\circ} 18 \mathrm{~N}$ & $145^{\prime} 15^{\prime} \mathrm{W}$ \\
\hline Galena Creck & Polymetallie vein & $\mathrm{Cu}, \mathrm{Zn}, \mathrm{Pb}, \mathrm{Ag}$ & $68^{\circ} 23 \mathrm{~N}$ & $142^{\prime} 02^{\prime} \mathrm{W}$ \\
\hline Geroe Creek & Porphyry Cu-Mo & $\mathrm{Cu}, \mathrm{Mo}$ & $6741 \mathrm{~N}$ & $148^{\circ} 49^{\prime} \mathrm{W}$ \\
\hline Jim-Montana & $\mathrm{Cu}-\mathrm{Zn}_{\mathrm{n}} \mathrm{kam}$ & $\mathrm{Cu}, \mathrm{Zn}, \mathrm{Ag}_{\mathrm{g}}, \mathrm{Pb}$ & $67^{\prime} 45 \mathrm{~N}$ & $149^{\circ} 05^{\prime} \mathrm{W}$ \\
\hline $\begin{array}{l}\text { Mount Igikpak and Arrigetch } \\
\text { Peaks }\end{array}$ & $\begin{array}{l}\text { Polymetallic vein, } \mathrm{Au} \text { quartz. } \\
\text { vein, } \mathrm{Sn} \text { skam, } \mathrm{Cu}-\mathrm{Pb}-\mathrm{Zn} \text { skam }\end{array}$ & $\begin{array}{l}\mathrm{Cu}, \mathrm{Pb}, \mathrm{Zn}, \mathrm{Ag}, \mathrm{Au} . \\
\mathrm{Sn}, \mathrm{W}, \mathrm{As}\end{array}$ & $67^{\circ} 26 \mathrm{~N}$ & $15407^{\prime} \mathrm{W}$ \\
\hline Porcupine Lake & Polymetallie vein(?) & $\mathrm{Cu}, \mathrm{Zn}, \mathrm{Ag}, \mathrm{F}$ & $68^{4} 48^{\prime} \mathrm{N}$ & $14627 \mathrm{~W}$ \\
\hline Romanzof Mountains & $\begin{array}{l}\text { Polymetallic vein, } \mathrm{Pb}-\mathrm{Zn} \text { and } \\
\text { possibly } \mathrm{S}_{\mathrm{n}} \text { skam }\end{array}$ & $\begin{array}{l}\mathrm{Pb}, \mathrm{Cu}, \mathrm{Zn}, \mathrm{Mo}, \mathrm{Sn}, \\
\mathrm{Ag}, \mathrm{F}\end{array}$ & $69^{\circ} 18^{\circ} \mathrm{N}$ & $143^{2} 50 / \mathrm{W}$ \\
\hline Sukakpak Mountain & Sh-Au vein & $\mathrm{Au}, \mathrm{Sb}, \mathrm{Mo}$ & $67 / 36 \mathrm{~N}$ & $149^{\circ} 50 \mathrm{~W}$ \\
\hline $\begin{array}{l}\text { Victor, Venus. Evelyn Loe, and } \\
\text { Fbo }\end{array}$ & Porphyry $\mathrm{Cu}$ and $\mathrm{Cu}$ skam & $\mathrm{Cu}, \mathrm{Ag}, \mathrm{Me}$ & $67^{\prime} 38 \mathrm{~N}$ & $149^{\circ} 20{ }^{\prime} \mathrm{W}$ \\
\hline
\end{tabular}
Fbo

Alaska Range and Yuken-Tanana Upland Metallegenie Belt of Kuroko Massive Sulfide Deposits (Devenian and Mississippian), Ceatral and East-Central Alaska (Belt AKY)

\begin{tabular}{|c|c|c|c|c|}
\hline Anderson Mountais & Kuroko massive sulfide? & $\mathrm{Cu}, \mathrm{Pb}, \mathrm{Za}, \mathrm{Ag}$ & $6348 \mathrm{~N}$ & $14757 \mathrm{~W}$ \\
\hline Delta District & Kuroke massive sulfide & $\mathrm{Pb}, \mathrm{Zn}, \mathrm{Cu}, \mathrm{Ag}, \mathrm{Au}$ & $63^{\circ} 14^{\prime} \mathrm{N}$ & $144^{7} 10 \mathrm{~W}$ \\
\hline Liberty Bell & $\begin{array}{l}\text { Kuroko massive suifide(7) or } \\
\text { polymetallic gold vein }\end{array}$ & $\mathrm{Au}, \mathrm{Ag}_{\mathbf{g}} \mathrm{Cu}_{\mathrm{B}} \mathrm{Bi}$ & $6437 \mathrm{~N}$ & $14851{ }^{\prime} \mathrm{W}$ \\
\hline McGinnis Glacier & Kuroko massive malfide & $\mathrm{Zn}, \mathrm{Cu}_{3}, \mathrm{Fb}, \mathrm{Ag}$ & $6336 \mathrm{~N}$ & $14614^{\prime} \mathrm{W}$ \\
\hline Miyaoka, Hayes Glacier & Kuroke massive sulfide & $\mathrm{Ca}, \mathrm{Pb}, \mathrm{Zn}, \mathrm{Aa}, \mathrm{Ag}$ & $63417 \mathrm{~N}$ & $14639 \mathrm{~W}$ \\
\hline Sheep Croek & Kuroko massive sulfide? & $\mathrm{Zn}, \mathrm{Pb}, \mathrm{Ag}, \mathrm{Sn}$ & $63^{\prime} 547 \mathrm{~N}$ & $148^{\circ} 17^{\prime} \mathrm{W}$ \\
\hline WTF, Red Mountain & Kuroke massive sulfide & $\mathrm{Cu}, \mathrm{Pb}, \mathrm{Zn}, \mathrm{Ag}, \mathrm{Au}$ & $6345 \mathrm{~N}$ & $14722 \mathrm{~W}$ \\
\hline
\end{tabular}

Dawson Metallegenic Belt of Veleasegenic Pb-Zn-Cu Massive Sulfide, SEDEX Pb-Cu-Zn-Ba Deposits (Devesian and Mististippian). Central Yuken Territary (Belt DA)

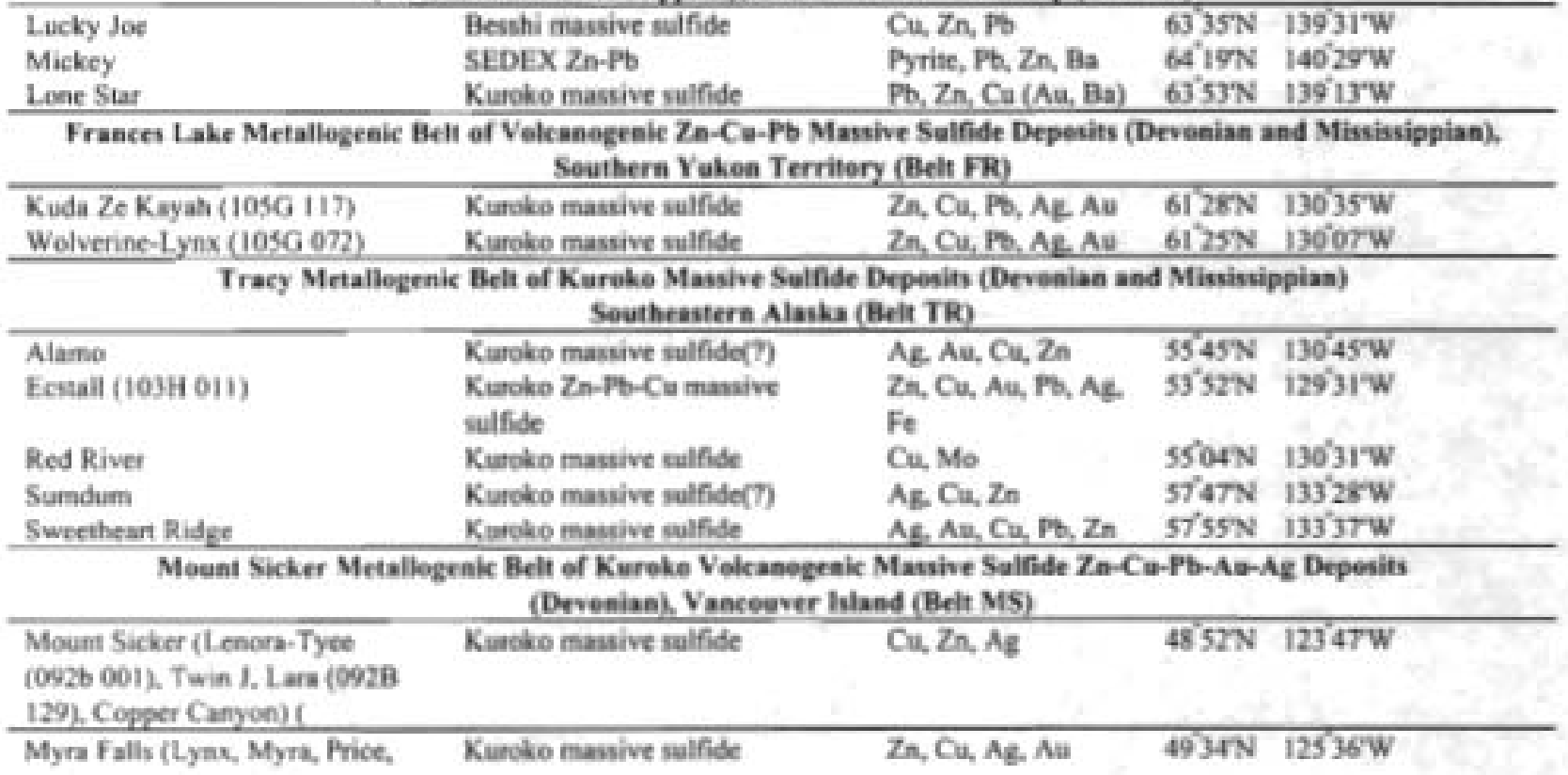




\begin{tabular}{|c|c|c|c|c|}
\hline Deposit Name & Mineral Deposit Model & Majer Metals & \multicolumn{2}{|c|}{ L.atitude $N_{\text {: }}$ Leagifude $E_{1} W_{\text {. }}$} \\
\hline HW) (092F 330) & & & & \\
\hline \multicolumn{5}{|c|}{$\begin{array}{c}\text { Kootenay-Shuswap Metallogenic Beit of Volcanogenic Zn-Pb-Cu-Ag-Au Massive Sulfide Deposits } \\
\text { (Devonian and Mississippian), Southern British Columbia (Beit KS) }\end{array}$} \\
\hline Chu Chua (082P 140) & Cyprus massive sulfide. & $\mathrm{Cu}, \mathrm{Zn}, \mathrm{Au}, \mathrm{Ag}$ & $5123 \mathrm{~N}$ & $120^{\circ} 04^{\prime} \mathrm{W}$ \\
\hline Goldstream (Pat) (082M 141) & Besshi massive sulfice & $\mathrm{Cu}_{1}, \mathrm{Zn}, \mathrm{A}$ & $51^{\prime} 38 \mathrm{~N}$ & $11826 \mathrm{~W}$ \\
\hline Harper Creek (082M 009) & kuroko massive sulfide & $\mathrm{Cu}, \mathrm{Ag}_{\mathrm{g}} \mathrm{Au}$ & $5131 \mathrm{~N}$ & $119^{\prime \prime} 49^{\prime} \mathrm{W}$ \\
\hline $\begin{array}{l}\text { Homestake (Squaam Bay) (082M } \\
025)\end{array}$ & $\begin{array}{l}\text { kuroko } \mathrm{Zn}-\mathrm{Pb}-\mathrm{Cu} \text { massive } \\
\text { sulfide }\end{array}$ & $\begin{array}{l}\mathrm{Ag}, \mathrm{Pb}, \mathrm{Zn}, \mathrm{Au}, \mathrm{Cu}, \\
\mathrm{B} \text {. }\end{array}$ & $51^{\circ} 07 \mathrm{~N}$ & $119^{\circ} 50^{\prime} \mathrm{W}$ \\
\hline Rea (Hilton) & $\begin{array}{l}\text { kuroko } \mathrm{Zn}-\mathrm{Pb}-\mathrm{Cu} \text { massive } \\
\text { sulfide }\end{array}$ & $\mathrm{Ag}, \mathrm{Pb}, \mathrm{Zn}, \mathrm{Au}, \mathrm{Cu}$ & $51^{\circ} 097 \mathrm{~N}$ & $119^{\prime} 49^{\circ} \mathrm{W}$ \\
\hline Rexspar (Birch Island) & Felsic plutonic U-REE & U, F, Sr, REE, Th & $51 " 347 \mathrm{~N}$ & $119^{\prime} 54^{\prime} \mathrm{W}$ \\
\hline
\end{tabular}

Khama River Metallogenic Belt of Carbenatite-Related Nb, Ta, and REE Deposits (Deveaian), Southern Part of Eastern Siberia (Belt KR)

\begin{tabular}{llll}
\hline Gomoe Oxero & Carbonatite-related REE & REE, Ta, Nb & $59^{\circ} 566^{\circ} \mathrm{N} 137^{\prime} 00^{\prime} \mathrm{E}$ \\
Khamna & Carbonatite-related REE & REE, Nb & $59^{\circ} 43^{\prime} \mathrm{N} 136^{\prime} 25^{\prime} \mathrm{E}$ \\
\hline
\end{tabular}

Sette-Daban Range Metallogenic Belt of Southeast Misseuri Pb-Za, Sediment-Hosted $\mathrm{Cu}$, and Basaltic $\mathrm{Cu}$ Depesits (Late Proterozoic), Southern Part of Eastera Siberia (Belı SD)

\begin{tabular}{|c|c|c|c|c|}
\hline Dzhalkan & Basaltic $\mathrm{Cu}$ & $\mathrm{Cu}$ & $63^{\prime} 38 \mathrm{~N}$ & $13638 \mathrm{E}$ \\
\hline Kurpandja & Sediment-hosted $\mathrm{Cu}$ & $\mathrm{Cu}$ & $6331 \mathrm{~N}$ & $137^{\circ} 01^{\prime} \mathrm{E}$ \\
\hline Lugun & Southeast Missouri $\mathrm{Pb}-\mathrm{Zn}$ & $\mathrm{Pb}, \mathrm{Zn}_{\mathrm{n}}$ & $59^{\circ} 08 \mathrm{~N}$ & $13639^{\circ} \mathrm{E}$ \\
\hline Sakyryr & Southeast Missouri $\mathrm{Pb}-\mathrm{Zn}$ & $\mathrm{Zn}, \mathrm{CaF}_{2}$ & $62^{\circ} 43 \mathrm{~N}$ & $138^{\prime \prime} 22 \mathrm{E}$ \\
\hline Sardana & Southeast Missouri $\mathrm{Pb} \cdot \mathrm{Zn}$ & $\mathrm{Pb}, \mathrm{Zn}$ & $6006 \mathrm{~N}$ & $136^{\prime} 45^{\prime} \mathrm{E}$ \\
\hline Segenyakh & Southeast Missouri $\mathrm{Pb}-\mathrm{Zn}$ & $\mathrm{Pb}, \mathrm{Zn}, \mathrm{CaF}_{2}$ & $63^{11} 10 \mathrm{~N}$ & 137 'S1'E \\
\hline Urui & Southeast Missourt Pb-Zn & $\mathrm{Pb}, \mathrm{Zn}$ & $59^{\circ} 52 \mathrm{~N}$ & $136^{\prime} 47^{\prime} \mathrm{E}$ \\
\hline
\end{tabular}

Selenayakh River Metallegenie Belt of Southeast Missouri Pb-Zn, Stratabound $\mathrm{Hg}$ and Au, and Pb-Zn Vein Depesits (Devonian to Permian), Nerthwestern Part of Russian Northeast (Belt SEL)

\begin{tabular}{|c|c|c|c|c|}
\hline Chistoe & $\mathrm{Pb}-\mathrm{Zn}$ vein & $\mathrm{Pb}, \mathrm{Zn}$ & $68^{\prime \prime} 12 \mathrm{~N}$ & $141^{\prime} 26{ }^{\prime} \mathrm{E}$ \\
\hline Gal-Khaya & Carbonate-hosted $\mathrm{Hg}$ & $\mathrm{Hg}$ & $68^{\prime} 53 \mathrm{~N}$ & $140^{\circ} 18^{\prime}$ \\
\hline Khatynnakh-Sala & Au quartz vein & $\mathrm{Au}$ & $68^{\prime} 18 \mathrm{~N}$ & $\left.14\right|^{\prime \prime} 24 ' E$ \\
\hline Kondakoyskoe & Southeast Missouri $\mathrm{Pb}-\mathrm{Zn}$ & $\mathrm{Pb}, \mathrm{Zn}_{\mathrm{n}}$ & $69^{\circ} 19 \mathrm{~N}$ & $149^{\circ} 49 \mathrm{E}$ \\
\hline
\end{tabular}

Tommet River Metallogenic Belt of Carbenatite-Related Nb, Ta, and REE Deposits (Devenian to Mississippian) Nerthwestern Part of Russian Northeast (Belt TO)

\begin{tabular}{|c|c|c|c|c|}
\hline Tommot & $\begin{array}{l}\text { Carbonatite-related REE (Ta, } \\
\text { Nb) }\end{array}$ & REE, $\mathrm{Ta}, \mathrm{Nb}$ & $6824 \mathrm{~N}$ & $141^{\prime} 14 \mathrm{E}$ \\
\hline \multicolumn{5}{|c|}{$\begin{array}{l}\text { Urultun and Sudar Rivers Metallogenic Belt of Seutheast Missouri Pb-Zn, Carbonate-Hosted } \mathrm{Hg}_{\mathrm{g}} \text {. Basaltic Cu } \\
\text { and Volcanegenie Mn Depesits (Devonian and Carbeniferous). West-Central Part of Russian Northeast (Belt URS) }\end{array}$} \\
\hline Batko & Basaltic $\mathrm{Cu}$ & $\mathrm{Cu}$ & $6325 \mathrm{~N}$ & $149^{\circ} 42^{\prime} \mathrm{E}$ \\
\hline Lyglykhtakh & Sedimentary $\mathrm{Mn}$ & Mn & $62^{\circ} 59^{\circ} \mathrm{N}$ & $151^{\prime 2} 20 \mathrm{OE}$ \\
\hline Prizovoe & Bedded harite & $\mathrm{Ba}$ & $63^{\circ} 29^{\circ} \mathrm{N}$ & $149^{\prime} 34^{\prime} \mathrm{E}$ \\
\hline Prolivnoe & Southeast Missouri Pb-Zn & $\mathrm{Pb}, \mathrm{Zn}_{\mathrm{n}}$ & $63^{\prime} 30 \mathrm{~N}$ & $149^{\circ} 18^{\circ} \mathrm{E}$ \\
\hline Uochat & Carbonate-hasted $\mathrm{Hg}_{\mathrm{g}}$ & $\mathrm{Hg}$ & $63^{\circ} 45 \mathrm{~N}$ & $148^{\prime} 45^{\circ} \mathrm{E}$ \\
\hline Urulnan & Southeasu Missouri Pb. $\mathrm{Zn}$ & $\mathrm{Pb}, \mathrm{Zn}$ & $63^{\circ} 407 \mathrm{~N}$ & $148^{\circ} 42^{\prime} \mathrm{E}$ \\
\hline
\end{tabular}

Yarkheden Metallogenic Belt of Southeast Missouri Pb-Zn Depesits (Late Devenian te Mississippian) Central Part of Russian Northeast (Belt VR)

\begin{tabular}{|c|c|c|c|c|}
\hline $\begin{array}{l}\text { Slezovka } \\
\text { Gomoe }\end{array}$ & $\begin{array}{l}\text { Southeast Missouri Pb-Zn } \\
\text { Southeast Missouri Pb- } \mathrm{Zn}\end{array}$ & $\mathrm{Pb}, \mathrm{Zn}$ & $\begin{array}{l}66517 \mathrm{~N} \\
66^{\circ} 36 \mathrm{~N}\end{array}$ & $\begin{array}{l}153^{2} 54^{\prime} \mathrm{E} \\
154^{\circ} 19^{\prime} \mathrm{E}\end{array}$ \\
\hline \multicolumn{5}{|c|}{$\begin{array}{l}\text { Berezovka River Metallogenic Belt of Kureko Massive Sulfide and Sulfide Vein Deposits } \\
\text { (Late Devenian te Mississippias). Central Part of Russian Nertheast (Beli BE) }\end{array}$} \\
\hline Berezovikoe & $\begin{array}{l}\text { Kuroko massive sulfide and } \\
\text { sulfide veit }\end{array}$ & $\mathrm{Pb}, \mathrm{Zn}, \mathrm{Cu}, \mathrm{Ag}$ & $6643 \mathrm{~N}$ & $15721^{\circ} \mathrm{E}$ \\
\hline \multicolumn{5}{|c|}{$\begin{array}{l}\text { Mystic Metallegenic Belt ef SEDEX Massive Bedded Barite and Southeast Misseuri Pb-Zn Depesits } \\
\text { (Deveeian and Mlississippias), West-Central Alaska (Belt MY) }\end{array}$} \\
\hline Gagaryah & SHDEX massive bedded barite & $\mathrm{Ca}, \mathrm{Ba}$ & $61^{2} 497 \mathrm{~N}$ & $15428 \mathrm{~W}$ \\
\hline Reef Ridge & Southeast Missouri Pb-Zn & $\mathrm{Zn}, \mathrm{Pb}$ & $63^{\prime} 297 \mathrm{~N}$ & $154^{\prime} 200 \mathrm{w}$ \\
\hline \multicolumn{5}{|c|}{$\begin{array}{c}\text { Nerthern Cordillera Metallogenie Belt of Southeast Mkseuri Zn-Pb Deposits (Late Proterezeic to Devenian) } \\
\text { Ceatral Yuken Territery (Belt NCO) }\end{array}$} \\
\hline Bear-Twit & Southeast Missouri Pb- $\mathrm{Zn}$ & $\mathrm{Zn}, \mathrm{Pb}$ & $64^{2} 03 \mathrm{~N}$ & $12925 \mathrm{~W}$ \\
\hline Ginyna River & Southeasa Missouri Pb- $\mathrm{Zn}$ & $\mathrm{Zn}, \mathrm{Pb}$ & $6456 \mathrm{~N}$ & $130^{\prime} 41^{\top} \mathrm{W}$ \\
\hline Gov Creek Area (Barrier Reef) & Southeast Missouni Pb-Zn & $\mathrm{Zn}, \mathrm{Pb}$ & $6423 \mathrm{~N}$ & $132^{\prime} 31^{\prime} \mathrm{W}$ \\
\hline Rusty Springs (Termuende) & Southeas Missouri Zn-Pro-Ac & $\mathrm{Ae}, \mathrm{Zn}, \mathrm{Cu}$ & $66^{6} 10 \mathrm{~N}$ & $1400^{\circ} 20 \mathrm{w}$ \\
\hline
\end{tabular}




\begin{tabular}{|c|c|c|c|c|}
\hline Depesit Name & Mineral Deposit Model & Major Metals & Latifude & $\mathrm{N}_{\text {; }}$ Lengitude $\mathrm{E}, \mathrm{W}$, \\
\hline \multicolumn{5}{|c|}{$\begin{array}{c}\text { Dempster Metallegenie Belt of SEDEX Ba, SEDEX Ni-Zn-PGE-Aa, Karoke Zn-Pb-Ca Massive Sulnde Depesits } \\
\text { (Devonian and Mississippian), Central Yukon Territory (Belt DE) }\end{array}$} \\
\hline Marg & $\begin{array}{l}\text { Kuroko } \mathrm{Zn}-\mathrm{Pb} \text {-Cu massive } \\
\text { sulfide }\end{array}$ & $\mathrm{Zn}, \mathrm{Pb}, \mathrm{Cu}, \mathrm{Ag}, \mathrm{Au}$ & $64^{2} 01^{\prime} \mathrm{N}$ & $13428^{\prime} \mathrm{W}$ \\
\hline Nick. & SEDEX Ni-Zn & $\mathrm{Ni}, \mathrm{Zn}, \mathrm{PGE}$ & $64^{\prime} 43 \mathrm{~N}$ & $13513 \mathrm{~W}$ \\
\hline \multicolumn{5}{|c|}{$\begin{array}{c}\text { Maemillan Pass Metallogenic Belt of SEDEX Zn-Pb-Ag-Ba Deposits (Devonian and Early Mississippian) } \\
\text { Central Yukon Territory (Belt MP) }\end{array}$} \\
\hline Cathy (Bar, Walt, Hess) & SEDEX Ba & $\mathrm{Ba},(\mathrm{Pb}, \mathrm{Zn}, \mathrm{Ag})$ & $63^{2} 17 \mathrm{~N}$ & $13033 \mathrm{~W}$ \\
\hline Gravity (BA) & SEDEX Ba & $\mathrm{Ba}$ & $63^{\prime} 44^{\prime} \mathrm{N}$ & $128^{\prime} 52^{\prime} \mathrm{W}$ \\
\hline Jeff (Noomi, Baroid) & SEDEX Ba & $\mathrm{Ba}$ & $6337 \mathrm{~N}$ & $12940 \mathrm{~W}$ \\
\hline MacMillan Pass (Tom, Jason) & SEDEX $\mathrm{Pb}-\mathrm{Zn}$ & $\mathrm{Pb}, \mathrm{Zn}, \mathrm{Ag}, \mathrm{Ba}$ & $6310 \mathrm{~N}$ & $130^{\prime} 12^{\prime} \mathrm{W}$ \\
\hline Moose (Spartan, Racicos) & SEDEX Ba & $\mathrm{Ba}$ & $63^{\circ} 04^{\prime} \mathrm{N}$ & $130^{\circ} 12^{\prime} \mathrm{W}$ \\
\hline Oro (Buc, Mar, Dar, Tang) & SEDEX Ba & $\mathrm{Ba}$ & $62^{\prime} 37 \mathrm{~N}$ & $129^{\circ} 46^{\prime} \mathrm{W}$ \\
\hline Tea (Brock) & SEDEX Ba & $\mathrm{Ba}$ & $63^{\circ} 017 \mathrm{~N}$ & $13037 \mathrm{~W}$ \\
\hline \multicolumn{5}{|c|}{ Finlayson Lake Metallegenic Belt of SEDEX Zn-Pb-Ag-Cu-Au Depesits (Devonian and Mississippian) } \\
\hline Mant Berry & SEDEX Pb- $\mathrm{Zn}$ & $\mathrm{Pb}, \mathrm{Zn}, \mathrm{Ag}_{\mathrm{g}} \mathrm{Cu}, \mathrm{Sb}$ & $61^{\prime 2} 29 \mathrm{~N}$ & $129^{\prime} 24 \mathrm{~W}$ \\
\hline \multicolumn{5}{|c|}{ Liard Metallegenie Belt of Southeast Missouri Ba-F Deposits (Devenian), Seuthern Yuken Territory (Belt L.I) } \\
\hline Leguil & Bedded Ba & $\mathrm{Ba}$ & $59^{\circ} 46^{\prime} \mathrm{N}$ & $12712^{\prime} \mathrm{W}$ \\
\hline Lower Liard & Southeast Missouri Ba-F & $\mathrm{F}, \mathrm{Ba}$ & $59^{\circ} 27 \mathrm{~N}$ & $126^{\circ} 05^{\prime} \mathrm{W}$ \\
\hline \multicolumn{5}{|c|}{$\begin{array}{l}\text { Gataga Metallogenic Belt of SEDEX Zn-Pb-Ag-Ba Depesits (Devenian and Mississippian), } \\
\text { Northern British Columbia (Belt GA) }\end{array}$} \\
\hline Akie & SEDEX Zn-PB & $\mathrm{Zn}, \mathrm{Pb}, \mathrm{Ag}, \mathrm{Ba}$ & $57.13 \mathrm{~N}$ & $12429 \mathrm{~W}$ \\
\hline Ciroue (Stronsay) (094F 008) & SEDEX $\mathrm{Pb}-\mathrm{Zn}$ & $\mathrm{Pb}, \mathrm{Zn}, \mathrm{Ag}, \mathrm{Ba}$ & $5731 \mathrm{~N}$ & $12509 \mathrm{w}$ \\
\hline $\begin{array}{l}\text { Driftpile Creek (Saint, Roen) } \\
(094 \mathrm{~K} 066)\end{array}$ & SEDEX $\mathrm{Pb}-\mathrm{Zn}$ & $\mathrm{Pb}, \mathrm{Zn}, \mathrm{Ba}$ & $58^{\circ} 05 \mathrm{~N}$ & $125 \mathrm{sar} w$ \\
\hline \multicolumn{5}{|c|}{$\begin{array}{l}\text { Rebb Lake Metallegenic Belt of Southeast Missouri Zn-Pb-Ag Deposits (Devonian), } \\
\text { Southern Nerthern Columbia (Belt RL) }\end{array}$} \\
\hline Robb Lake & Southeast Missouri Pb- $\mathrm{Zn}$ & $\mathrm{Zn}, \mathrm{Pb}$ & $5722 \mathrm{~N}$ & $12352 \mathrm{~W}$ \\
\hline \multicolumn{5}{|c|}{$\begin{array}{l}\text { Seathern Recky Mountains Metallogenie Beit of Strataboand Barite-Magessite-Gypsum Depesits } \\
\text { (Earty Paleozoic through Triassic), Seuthern British Columbla (Belt SRM) }\end{array}$} \\
\hline Brisco Area & Ba vein and breceia & $\mathrm{Ba}$ & $5050 \mathrm{~N}$ & $11620 \mathrm{~W}$ \\
\hline Forgetmenot Pass & Stratbound gypsum & Gypsum & $5345 \mathrm{~N}$ & $11953 \%$ \\
\hline Keotenay River Gypsum & Seratiform ippsum & Gypsum & $50^{\circ} 34 \mathrm{~N}$ & $11516 \mathrm{w}$ \\
\hline Lussiet River (United Gypsum) & Stratiform gypeum & Gypium & $50^{\circ} 03 \mathrm{~N}$ & $11531 \mathrm{~W}$ \\
\hline Marysville (082INw 001) & Stratiform magnesine & Magnesite & $49^{\circ} 36 \mathrm{~N}$ & $11558 w$ \\
\hline Mount Brussilof (Baymag) & Stratabound $\mathrm{Mg}$ & Magnesite & $50^{\circ} 4 \mathrm{TN}$ & $11541^{7} \mathrm{~W}$ \\
\hline Parson (0k2N 002) & Barite vein and gypsum & $\mathrm{Ba}$ & $5101 \mathrm{~N}$ & $11639 \mathrm{~W}$ \\
\hline $\begin{array}{l}\text { Windermere Creck ; Westem } \\
\text { Gypoum) }\end{array}$ & Stratiform Eypoum & Gypsum & $50^{\circ} 29 \mathrm{~N}$ & $11552 \mathrm{~W}$ \\
\hline \multicolumn{5}{|c|}{ Iegrenika Metallegenie Belt of Southeast Misseuri Zn-Pb-Ag Depesits (Devenian?), Seutbern Britiab Celumbla (Beit IN) } \\
\hline Susic. Beveley and Regent & Southeasit Missoun Pb-Za & $\mathrm{Pb}, \mathrm{Zn}, \mathrm{Ag}, \mathrm{Ba}$ & $5609 \mathrm{~N}$ & $12503 \mathrm{~W}$ \\
\hline \multicolumn{5}{|c|}{$\begin{array}{l}\text { Cathedral Metallegenic Belt of Southeast Misseuri Zn-Pb-Ag Depesits (Devenian?), Seuthere British Colembia (Belt } \\
\text { CA) }\end{array}$} \\
\hline Monarch (Kicting Horne) & Southeast Missourt Zn-Pb-Ag & $\mathrm{Zn}, \mathrm{Pb}, \mathrm{Ag}$ & $5125 \mathrm{~N}$ & $11626 \mathrm{~W}$ \\
\hline \multicolumn{5}{|c|}{ MISSISSIPPIAN (360 to $320 \mathrm{Ma})$} \\
\hline \multicolumn{5}{|c|}{$\begin{array}{l}\text { Northweatern Breoks Range Metallogenke Belt of SEDEX Zn-Pb, Kuroko Massive Sulfide, Bedded Barite, and } \\
\text { Vein Sulfide Depesits (Minsiasipplan and Pensylvanian), Nerthwestern Alaska (Belt NBR) }\end{array}$} \\
\hline Detnchwater & $\begin{array}{l}\text { Sedimentary } \mathrm{Zn} \cdot \mathrm{Pb} \text { and (or) } \\
\text { kuroko massive sulfide }\end{array}$ & $\mathrm{Zn}, \mathrm{Pb}, \mathrm{Ag}$ & $6834 \mathrm{~N}$ & $15841 \%$ \\
\hline Frout & $\mathrm{Cl}-\mathrm{Zn}-\mathrm{Pb}-\mathrm{Ba}$ vein & $\mathrm{Cu}, \mathrm{Zn}, \mathrm{Pb}$, barite & $67^{\prime} 28 \mathrm{~N}$ & $16135 \mathrm{~W}$ \\
\hline Hannum Creek & Metamorphosed SEDEX Zn-Pb? & $\mathrm{Pb}, \mathrm{Zn}, \mathrm{Ag}$ & $6556 \mathrm{~N}$ & $163^{2} 21 \mathrm{~W}$ \\
\hline Lis & SEDEX Zn-Pb-barite & $\mathrm{Zn}, \mathrm{Pb}, \mathrm{Ag}$, Barite & $6812 \mathrm{~N}$ & $1633^{\circ} 07 W$ \\
\hline Nimiuktuk & Bedded barite & Barite & $68^{\prime} 24 \mathrm{~N}$ & $159^{\prime} 54 \mathrm{~W}$ \\
\hline Omar & Kipuahi Cu-Pb-Zn & $\mathrm{Cu}, \mathrm{Pb}, \mathrm{Zn}, \mathrm{Ag}_{\mathrm{g}} \mathrm{Co}$ & $67 / 30 \mathrm{~N}$ & $161^{\prime} 50 \mathrm{~W}$ \\
\hline Red Dog Creek & SEDEX Zn-Pb-barite & $\mathrm{Zn}, \mathrm{Pb}, \mathrm{Ag}_{\mathrm{g}} \mathrm{Ba}$ & $6804 \mathrm{~N}$ & $162^{\prime} 50 \mathrm{~W}$ \\
\hline Story Cresk & $\mathrm{Pb}-\mathrm{Zn}_{\mathrm{n}}-\mathrm{Au}-\mathrm{Ag}$ vein & $\mathrm{Pb}, \mathrm{Zn}, \mathrm{Ag}, \mathrm{Au}$ & $68^{\circ} 22 \mathrm{~N}$ & $157^{\prime} 56 \mathrm{~W}$ \\
\hline Whoopee Creek & $\mathrm{Zn}-\mathrm{Ag}-\mathrm{A}$ u vein & $\mathrm{Zn}, \mathrm{Ag}, \mathrm{Al}$ & $68^{\circ} 14 \mathrm{~N}$ & $157^{\prime} 51 \mathrm{~W}$ \\
\hline
\end{tabular}




\begin{tabular}{|c|c|c|c|}
\hline Depesit Name & Mineral Deposit Medel & Major Metals & Latifude $\mathrm{N}$ : Longitude $\mathrm{F}_{\mathrm{a}} \mathrm{W}$. \\
\hline \multicolumn{4}{|c|}{ PENNSYLVANIAN (320 to $286 \mathrm{Ma})$} \\
\hline \multicolumn{4}{|c|}{$\begin{array}{c}\text { Laeelin-Grodekevsk Metallogenie Belt of Porphyry Cu-Mo and Au-Ag Epitbermal Vein Deposits (Permian) } \\
\text { Southern Part of Russian Southeast (Belt LG) }\end{array}$} \\
\hline Baikal & Porphyry $\mathrm{Cu}-\mathrm{Mo}$ & $\mathrm{Cu}, \mathrm{Mo}$ & $4412 \mathrm{~N} \quad 13106 \mathrm{E}$ \\
\hline Komissarovskoe (Vorob'eva plad) & Au-Ag epithermal vein & $\mathrm{Au}_{\mathrm{n}} \mathrm{Ag}$ & $4434 \mathrm{~N} \quad 13127 \mathrm{E}$ \\
\hline \multicolumn{4}{|c|}{$\begin{array}{c}\text { Aluchin Metallegenic Belt of Podiform Cr Deposits (Middle Paleozoic or elder). } \\
\text { Central Part of Russian Northeast (Belt AC) }\end{array}$} \\
\hline Teleneul & Podiform $\mathrm{Cr}$ & $\mathrm{Cr} . \mathrm{Ni}$ & $6629 \mathrm{~N} \quad 16449 \mathrm{E}$ \\
\hline \multicolumn{4}{|c|}{$\begin{array}{l}\text { Ust-Belaya Metallogenie Belt of Pediform Cr Depesits (Earty Paleozoic), } \\
\text { Northeastern Part of Russian Northeast (Belt UB) }\end{array}$} \\
\hline Ust-Belaya & Podiform $\mathrm{Cr}$ & $\mathrm{Cr}, \mathrm{PGE}$ & $6527 \mathrm{~N} \quad 17304 \mathrm{E}$ \\
\hline \multicolumn{4}{|c|}{$\begin{array}{c}\text { Alaska Range-Wrangel Mountains Metallegenic Belt of Granitic Magmatism Depesits (Pennsylvanian and Permian) } \\
\text { Central and Eastern-Seuthere Alaska (Belt ARW) }\end{array}$} \\
\hline Chistochina District & $\begin{array}{l}\text { Porphyry Cu and polymetallic } \\
\text { vein }\end{array}$ & $\mathrm{Cu}, \mathrm{Pb}, \mathrm{Ag}, \mathrm{Au}$ & $63^{\circ} 05 \mathrm{~N} \quad 14447 \mathrm{~W}$ \\
\hline Rainbow Mountain & Porphyry $\mathrm{Cu}$ & $\mathrm{Cu}, \mathrm{Ag}$ & $6320 \mathrm{~N} \quad 14541 \mathrm{~W}$ \\
\hline Rainy Crcek District & $\mathrm{Cu}-\mathrm{Ag}_{\mathrm{B}}$ skarn & $\mathrm{Cu}, \mathrm{Ag}, \mathrm{Au}$ & $63^{3} 20 \mathrm{~N} \quad 14602 \mathrm{~W}$ \\
\hline Slate Creek & Porphyry $\mathrm{Cu}(7)$ & $\mathrm{Cu}, \mathrm{Ag}, \mathrm{Au}$ & $6309 \mathrm{~N} \quad 14448 \mathrm{~W}$ \\
\hline \multicolumn{4}{|c|}{$\begin{array}{c}\text { Ketchilcan Metallogenic Belt of Kuroko Massive Sulfide Deposits (Penasylvanian? or Permian7) } \\
\text { Seutheastern Alaska (Beit KK) }\end{array}$} \\
\hline Moth Bay & Kuroko massive sulfide & $\mathrm{Cu}, \mathrm{Pb}, \mathrm{Ag}_{\mathrm{g}} \mathrm{Au}$ & $55^{\prime} 18 \mathrm{~N} \quad 13121 \mathrm{~W}$ \\
\hline \multicolumn{4}{|c|}{ LATE TRIASSIC (Carnian through Norian -230 te $208 \mathrm{Ma}$ ) } \\
\hline \multicolumn{4}{|c|}{ Farewell Metallegenic Belt of Gabbroic Ni-Cu-PGE Deposits (Lute Triassic), Western Alaska (Belt FW) } \\
\hline $\begin{array}{l}\text { Farewell District (Gargaryah, } \\
\text { River Roberts, Straight Creek) }\end{array}$ & Gabbroic Ni-Cu-PGE & $\mathrm{Ni}, \mathrm{Cu}, \mathrm{PGE}$ & $62^{\prime} 14 \mathrm{~N} \quad 15430 \mathrm{~W}$ \\
\hline \multicolumn{4}{|c|}{$\begin{array}{c}\text { Kodtak Island and Border Ranges Metallegenic Belt of Podiform Cr Depesits (Late Triassic, Early or Middle Jurassic) } \\
\text { Southern Ceastal Alaska (Belt KOD) }\end{array}$} \\
\hline $\begin{array}{l}\text { Bernard Mountain, Dust } \\
\text { Mountain }\end{array}$ & Podiform $\mathrm{Cr}$ & $\mathrm{Cr}, \mathrm{PGE}$ & $61^{\prime} 32^{\prime} \mathrm{N} \quad 145^{\circ} 09 \mathrm{~W}$ \\
\hline Claim Point & Podiform $\mathrm{Cr}$ & $\mathrm{Cr}$ & $59^{\circ} 12 \mathrm{~N} \quad 151^{\circ} 49 \mathrm{~W}$ \\
\hline Halibut Bay & Podiform $\mathrm{Cr}$ & $\mathrm{Cr}$ & $5722 \mathrm{~N} \quad 15436 \mathrm{~W}$ \\
\hline Red Mountain & Podiform $\mathrm{Cr}$ & $\mathrm{Cr}$ & $59^{\circ} 22 \mathrm{~N} \quad 151^{\circ} 30 \mathrm{~W}$ \\
\hline Spirit Mountain & Gabbroic $\mathrm{Ni}-\mathrm{Cu}$ & $\mathrm{Ni}, \mathrm{Cu}, \mathrm{Ca}, \mathrm{Ag}$ & $61^{\circ} 19 \mathrm{~N} 144^{\circ} 13 \mathrm{~W}$ \\
\hline
\end{tabular}

Spirit Mountain

Eastern Alaska Range Metallogenic Belt of Gabbroic Ni-Cu and Besshi Massive Sulfide Deposits (Late Triassic) Southern Alaska and Northwestern Canadian Cordillera (Belt EAR)

\begin{tabular}{|c|c|c|c|c|}
\hline Denali & Besshi massive sulfide & $\mathrm{Cu}$ & $63^{\circ} 09^{2} \mathrm{~N}$ & $14708 W$ \\
\hline Bullion Creek & Strataform gypsum & Gypsum & $60^{\circ} 59 / \mathrm{N}$ & $138^{\circ} 39 \mathrm{~W}$ \\
\hline Fish Lake & Gabbroic Ni-Co & $\mathrm{Cr}, \mathrm{Ni}$ & $63^{4} 13 \mathrm{~N}$ & $14648 \mathrm{~W}$ \\
\hline Wellgreen & Gabbroic $\mathrm{Ni}-\mathrm{Cu}$ & $\mathrm{Ni}, \mathrm{Cu}, \mathrm{PGE}$ & $6128 \mathrm{~N}$ & $139^{\circ} 311^{\circ} \mathrm{W}$ \\
\hline
\end{tabular}

Alexander Metallegenic Belt of Volcanegenic Cu-Pb-Za and Carbonate-Hested Massive Sulfide Depesits

(Ordovician through Triassich, Seutheastern Alaska (Belt AX)

\begin{tabular}{|c|c|c|c|c|}
\hline Castle Island, Kupreanof Island & $\begin{array}{l}\text { Bedded barite, kuroko Ba-Zn- } \\
\text { Pb-Cu massive sulfide }\end{array}$ & $\mathrm{Ba}$ & $5639 \mathrm{~N}$ & $13310 \mathrm{wW}$ \\
\hline Glacier Creek & Kuroko massive sulfide & $\mathrm{Ba}, \mathrm{Cu}, \mathrm{Zn}$ & $59^{\prime 2} 24^{\prime \prime} \mathrm{N}$ & $136^{\prime} 23 \mathrm{~W}$ \\
\hline Greens Creek & Kuroko massive sulfide & Ag. $\mathrm{Zn}, \mathrm{Au}, \mathrm{Pb}$ & $5805 \mathrm{~N}$ & $134738 \mathrm{~s}$ \\
\hline Khayyam & Kuroko massive sulfide & $\mathrm{Cu}, \mathrm{Au}$ & $5518 \mathrm{~N}$ & $132^{\circ} 23 \mathrm{~W}$ \\
\hline Lime Point & Bedded barile & $\mathrm{Ba}$ & $5503 \mathrm{~N}$ & $13238 \mathrm{~W}$ \\
\hline Moonshine & $\begin{array}{l}\text { Carbonate-hosted massive } \\
\text { sulfide }\end{array}$ & $\mathrm{Ag} . \mathrm{Pb}$ & $55^{\prime} 11 \mathrm{~N}$ & $13223 \mathrm{~W}$ \\
\hline Niblack & Kuroko massive sulfide & $\mathrm{Cu}, \mathrm{Au}, \mathrm{Ag}$ & $5504 \mathrm{~N}$ & $132^{\circ} 09 \mathrm{~W}$ \\
\hline Orange Point & $\begin{array}{l}\text { Kuroko Zn-Pb-Cu massive } \\
\text { sulfide }\end{array}$ & $\mathrm{Zn}, \mathrm{Cu}$ & $5855 \mathrm{~N}$ & $13660 \mathrm{w}$ \\
\hline $\begin{array}{l}\text { Windy Craggy (Alsek River } \\
\text { Area) (114P 002) }\end{array}$ & $\begin{array}{l}\text { Cyprus to Besshi massive } \\
\text { sulfide }\end{array}$ & $\mathrm{Cu}, \mathrm{Co}$ & $59^{\circ} 44 \mathrm{~N}$ & $13745 \mathrm{w}$ \\
\hline
\end{tabular}

Galore Creek Metallogenic Belt of Perphyry Cu-A Deposits (Late Triassic and Early Jurassic) Northern British Columbia (Belt GL)

Galore Creck (Stikine Copper) Porphyry $\mathrm{Cu}-\mathrm{Au}, \mathrm{Cu}-\mathrm{Auskarn} \quad \mathrm{Cu}$
(104G 090)




\begin{tabular}{|c|c|c|c|c|}
\hline Deposir Name & Mieeral Deposit Medel & Majer Metals & Latitude & $\mathrm{N}_{\text {: Lengitade } \mathrm{E}} \mathbf{W}$. \\
\hline Gnat Lake Area (Juhe, Stikine) & Parphyry Cu & $\mathrm{Cu}$ & $5815 \mathrm{~N}$ & $12950 \mathrm{~W}$ \\
\hline Red Chris (Money) (104H 005) & Porphyry Cu-As & $\begin{array}{l}\mathrm{Cu}, \mathrm{Au},(\mathrm{Zn}, \mathrm{Pb}, \\
\mathrm{Mo})\end{array}$ & $5742 \mathrm{~N}$ & $12948 \mathrm{~W}$ \\
\hline \multicolumn{5}{|c|}{ Sasut Metallogenic Belt of Blasaltic Cu Deposits (Late Triassic), Northern British Columbia (Belt SU) } \\
\hline Susht & Basaltic Cu & $\mathrm{Cu}$ & $5637 \mathrm{~N}$ & $12641 \mathrm{~W}$ \\
\hline \multicolumn{5}{|c|}{$\begin{array}{l}\text { Cepper Mountain (Nerth) Metallegenic Belt of Perphyry Cu-Au Deposits (Jurassic), } \\
\text { Nerthern British Columbia (Belt CMN) }\end{array}$} \\
\hline $\begin{array}{l}\text { Loeraine (Duckling Creek) }(093 \mathrm{~N} \\
602)\end{array}$ & Porphyry Cin-Mo & $\mathrm{Cu}$ & $5556 \mathrm{~N}$ & $12526 \mathrm{~W}$ \\
\hline Moun Malligan (093N 194) & Porphyry Cu-Au & $\mathrm{Cu}, \mathrm{Au}$ & $5508 \mathrm{~N}$ & $12402 \mathrm{~W}$ \\
\hline \multicolumn{5}{|c|}{$\begin{array}{c}\text { Cepper Mountain (South) Metallogenic Belt of Porphyry Cu-Au Deposits (Jurassic), } \\
\text { Southern British Columbia (Belt CMS) }\end{array}$} \\
\hline $\begin{array}{l}\text { Copper Meuntain (lngerbelle, and } \\
\text { oehers) (092HSE O04) }\end{array}$ & Porphyry $\mathrm{Cu}-\mathrm{Au}$ & $\mathrm{Cu}$ & $4920 \mathrm{~N}$ & $120^{-3} 32^{\prime} \mathrm{W}$ \\
\hline $\begin{array}{l}\text { Iron Mask Area (Aftoo (0921NE } \\
023), \text { Ajax (103P 223)) }\end{array}$ & Porplayry $\mathrm{Cu}-\mathrm{Au}$ & $\mathrm{Cu}$ & $5040 \mathrm{~N}$ & $120^{\circ} 31^{\prime} \mathrm{W}$ \\
\hline $\begin{array}{l}\text { Lodestone Mountain (092HSE } \\
\text { 034) }\end{array}$ & Zoned mafic-ultramafic $\mathrm{Fe}-\mathrm{V}$ & $\mathrm{Fe}, \mathrm{V}$ & $49^{\circ} 28^{\prime} \mathrm{N}$ & $120^{\circ} 50 \mathrm{~W}$ \\
\hline $\begin{array}{l}\text { Mt. Polley (Cariboo-Bell) (09314 } \\
\text { 008) }\end{array}$ & Porphyry Cu-Au & $\mathrm{Cu}, \mathrm{Au}$ & $52^{\prime} 34 \mathrm{~N}$ & $121^{\prime \prime} 38^{\prime} \mathrm{W}$ \\
\hline
\end{tabular}

Guichen Metallegenic Belt of Perphyry Cu-Mo-Au and Au Skarn Depesits (Late Triassie and Early Jurassic) Southern British Columbia (Belt GU)

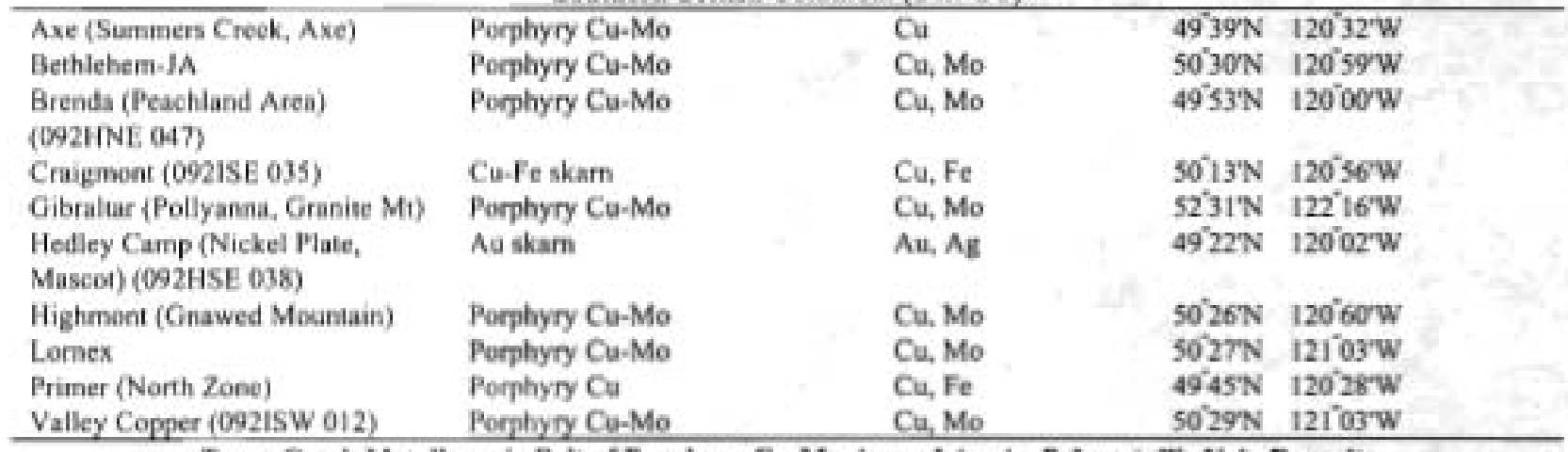

Texas Creek Metallogenic Belt of Porphyry Co-Mo-A and Aw-Ag Polymetallic Vein Deposits

(Lute Triassic te Middle Jurassic), Nerthern British Columbia (Belt TC)

\begin{tabular}{|c|c|c|c|c|}
\hline $\begin{array}{l}\text { Brucejack Lake (West Zone. } \\
\text { Shore Zone) }\end{array}$ & Av-AE polymetallic vein & $\mathrm{Alu}, \mathrm{Ag}$ & $5628 \mathrm{~N}$ & $13012 \mathrm{~W}$ \\
\hline Ken (Main Zone) & Porphyry $\mathrm{Cu}-\mathrm{Au}$ & $\mathrm{Cu}, \mathrm{Au}, \mathrm{As}$ & $5628 \mathrm{~N}$ & $130^{\circ} 16 \mathrm{~W}$ \\
\hline $\begin{array}{l}\text { Muddy Lake (Golden Bear, } \\
\text { Totem) (104K 079) }\end{array}$ & As quartz vein & Av & $5813 \mathrm{~N}$ & $13217 \mathrm{~W}$ \\
\hline $\begin{array}{l}\text { Polaris-Taku (Whitewater) (104K } \\
\text { 003) }\end{array}$ & Au quartz vein & $A=A_{g}, C_{1}, A s, S b$ & $58422 \mathrm{~N}$ & $13338 \mathrm{~W}$ \\
\hline Red Mountain (103P086) & As-Ae polymetallic vein & $A=A_{f}$ & $5557 \mathrm{~N}$ & $12942 \mathrm{~W}$ \\
\hline $\begin{array}{l}\text { Schaft Creek (Liand Copper) } \\
(104 G 015)\end{array}$ & Poephyry Cu-Mo & $\mathrm{Cu}, \mathrm{Mo}$ & $5722 \mathrm{~N}$ & $130 \% 56 \mathrm{~W}$ \\
\hline $\begin{array}{l}\text { Silbak-Premier (Premier Gold) } \\
(104 \mathrm{~B} 054)\end{array}$ & Au-Ag epithermal vein & $A \equiv, A E, F, Z n$ & $5603 \mathrm{~N}$ & $13001 \mathrm{~W}$ \\
\hline Snip (Shan) (104B 250) & Aw-Fb-Zn polymetallic vein & $A=$ & $5640 \mathrm{~N}$ & $13106 \mathrm{~W}$ \\
\hline E \& L (Snippaker Creck) & Gabbroic Ni.Cu & $\mathrm{Ni}, \mathrm{Cu}$ & $5635 \mathrm{~N}$ & $13041 \%$ \\
\hline Snow fields (Sulphurets) & Au-As polymetallic vein & $\mathrm{AB}, \mathrm{AE}$ & $5628 \mathrm{~N}$ & $1300^{\circ} 11 \mathrm{~W}$ \\
\hline Selphirets (Gold Zone) & Porghyry Cu.Au & $\mathrm{AB}, \mathrm{Cu}$ & $5630 \mathrm{~N}$ & $1300^{\circ} 16 \mathrm{~W}$ \\
\hline
\end{tabular}

EARLY JURASSTC (Hettancian threash Pleinsbachian - 208 te $193 \mathrm{Ma}$ )

\begin{tabular}{|c|c|c|c|c|}
\hline \multicolumn{5}{|c|}{ Alaska Peninsala Metallegreic Belt ef Granitie Maganatism Deposits (Jurassie), Alaska Peainsula (Belt AP) } \\
\hline Crevice Creek (McNeil) & Co-Au skam & $\mathrm{Au}, \mathrm{Cu}$ & $5908 \mathrm{~N}$ & $15440 \mathrm{~W}$ \\
\hline Glacier Fork & Cu-Zn skarn & $\mathrm{Cu}, \mathrm{Au}$ & $60^{\circ} 51 \mathrm{~N}$ & $153^{\circ} 12 \mathrm{~W}$ \\
\hline Kasna Creek (Kontrashibuna) & Cu-Fe skam & $\mathrm{Cu}$ & $60^{\circ} 13 \mathrm{~N}$ & $15405 \mathrm{~W}$ \\
\hline Magnetite island (Tuxedni Bay) & Fesham & $F_{\varepsilon}, \mathrm{Ti}$ & $60^{\circ} 14 \mathrm{~N}$ & $152^{\circ} 51^{\prime} \mathrm{W}$ \\
\hline
\end{tabular}


Talketna Mountains-Alaska Ranze Metallogenic Belt of Kuroko Massive Sulfide Deposits (Early Jurassie) Nerthern Part of Southern Alaska (Belt TM)

Johnton River Kuroke massive ualfide $\quad \mathrm{Au}, 2 \mathrm{n}, \mathrm{Cu}, \mathrm{Pb} \quad 6007 \mathrm{~N} \quad 15257 \mathrm{~W}$

Island Perphyry Metallegenic Belt of Perphyry Ca-Me; Cu Skarn, and Fe and Cu Skarn Depesits (Jurassic) Vanceuver taland (Belt IP)

\begin{tabular}{|c|c|c|c|c|}
\hline $\begin{array}{l}\text { Benson Area (Empire, Coast } \\
\text { Copper) }\end{array}$ & Cu-feskam & $\mathrm{Cu}, \mathrm{Fe}$ & $5023 \mathrm{~N}$ & $12715 \mathrm{~W}$ \\
\hline Burnaby Iton (Jib) & Fe sam & Fe & $5225 \mathrm{~N}$ & $131^{\circ} 18 \mathrm{~W}$ \\
\hline $\begin{array}{l}\text { Island Copper (Rupent lnlet) } \\
\text { (0921. 158) }\end{array}$ & Porphyry Cu-Me & $\mathrm{Cu}, \mathrm{Mo}, \mathrm{Au}$ & $5037 \mathrm{~N}$ & $127^{\prime} 31^{\prime} \mathrm{W}$ \\
\hline Hushame (0921. 240) & Porphyry Ca-Me & $\mathrm{Cu}_{0} \mathrm{Mo}_{0} \mathrm{Au}$ & $50^{\circ} 40 \mathrm{~N}$ & $127 / 50 \mathrm{~W}$ \\
\hline $\begin{array}{l}\text { Kennedy Lake (Brynnoe) (1038 } \\
\text { 026) }\end{array}$ & Feskam & $\mathrm{Fe}$ & $49^{\circ} 03 \mathrm{~N}$ & $12526 \mathrm{~W}$ \\
\hline Red Dos & Porphyry $\mathrm{Cu}$ & $\mathrm{Cu}$ & $50^{\circ} 43 \mathrm{~N}$ & $127 / 58 \mathrm{w}$ \\
\hline $\begin{array}{l}\text { Tasu Sound (Wesfrob, Taru. } \\
\text { Garnet) (103C 003) }\end{array}$ & Fe skam & $\mathrm{Fe}, \mathrm{Cu}$ & $5246 \mathrm{~N}$ & $132^{\circ} 03^{\prime} \mathrm{W}$ \\
\hline $\begin{array}{l}\text { Texada (Prescont, Yellow Kid, } \\
\text { Paxton Vananda, Marble Bay. } \\
\text { etc.) (092F 106; 092F 258; 092F } \\
\text { to7) }\end{array}$ & Cu-Au skam & $\mathrm{Cu}, \mathrm{Au}_{\mathrm{B}} \mathrm{Ag}$ & $4975 \mathrm{~N}$ & $12433 \mathrm{~W}$ \\
\hline Texada iron & Fe skam & $\mathrm{Fe}$ & $4943 \mathrm{~N}$ & $124^{\prime} 33 \mathrm{~W}$ \\
\hline Zeballos itoa (Ford) & Fe tharn & $\mathrm{Fe}$ & soogen & $12650 \mathrm{~W}$ \\
\hline \multicolumn{5}{|c|}{$\begin{array}{c}\text { Kletasin Perphyry Metallozenic Belt of Perphyry Cu-Au-Ag Depesits (Early Jurassic) } \\
\text { Seuthern Yekee Territery (Belt KI.) }\end{array}$} \\
\hline Minto Copper & Porphyry $\mathrm{Ca}-\mathrm{As}$ & $\mathrm{Ca}$ & $6236 \mathrm{~N}$ & $13715 \mathrm{~W}$ \\
\hline Williams Creck & Porphyry CasAs & $\mathrm{Ca}$ & $6221 \mathrm{~N}$ & $13642 \mathrm{~W}$ \\
\hline
\end{tabular}

Teodegeee Metallegeaie Belt of Au-Ag Epithermal Vein Deposits (Earby Jurassic), Nerthern British Columbia (Belt

\begin{tabular}{|c|c|c|c|c|}
\hline & & & & \\
\hline Toodoegone District (Lawyen) & All-Ag Giliherinal vein & $A u, A g$ & $5720 \mathrm{~N}$ & $12711 \mathrm{~W}$ \\
\hline Kemess (Kemess N, Kemess S.) & Porphyry $\mathrm{Cu}-\mathrm{Au}$ & $A w, A u$ & $5700 \mathrm{~N}$ & $12645 \mathrm{~W}$ \\
\hline
\end{tabular}

Ceast Meuntain Metallegenic Belt of Velcanegenic Cu-7n-Au-Ag Massive Sulfide Deposits (Late Triasic and Early Jurassic), Nerthern British Columbia (Belt CM)

\begin{tabular}{|c|c|c|c|c|}
\hline $\begin{array}{l}\text { Alice Amn Silver (Dolly Varden, } \\
\text { etc.) }\end{array}$ & $\begin{array}{l}\text { Kuroko } \mathrm{Zn} \text {-Pb-Cu massive } \\
\text { sulfide }\end{array}$ & Ag. $\mathrm{Pb}, \mathrm{Zn}$ & $5544 \mathrm{~N}$ & $12933 \mathrm{~W}$ \\
\hline $\begin{array}{l}\text { Anyox Area (Hidden Creek, } \\
\text { Bonarua) (103P 021, 023) }\end{array}$ & Cyprus massive sulfide & $\mathrm{Cu}, \mathrm{Ag}, \mathrm{Au}$ & $5527 \mathrm{~N}$ & $129^{\circ} 50 \mathrm{w}$ \\
\hline $\begin{array}{l}\text { Eskay Crock-2IB Zooc (104B } \\
\text { oos) }\end{array}$ & $\begin{array}{l}\text { Kutoke } \mathrm{Zn}-\mathrm{Pb}-\mathrm{Cu} \text { massive } \\
\text { sulfide }\end{array}$ & $\mathrm{Au}, \mathrm{Ag}_{\mathrm{g}} \mathrm{Pb}, \mathrm{Zn}, \mathrm{Cu}$ & $5638 \mathrm{~N}$ & $130^{\prime} 27 \mathrm{~W}$ \\
\hline $\begin{array}{l}\text { Granduc (South Leduc) (104B } \\
021 \text { ) }\end{array}$ & Besshi massive suifide & $\mathrm{Cu}$ & $5613 \mathrm{~N}$ & $13021 \mathrm{~W}$ \\
\hline $\begin{array}{l}\text { Tulsequah Chief (Big Bull) } \\
\text { (104K 002) }\end{array}$ & $\begin{array}{l}\text { Kuroko } \mathrm{Zn}-\mathrm{Cu} \cdot \mathrm{Pb} \text { massive } \\
\text { sulfide }\end{array}$ & $\mathrm{Zn}, \mathrm{Cu}, \mathrm{Au}, \mathrm{Ag}, \mathrm{Pb}$ & $5844 \mathrm{~N}$ & $13335 \mathrm{~W}$ \\
\hline \multicolumn{5}{|c|}{ MIDDLE JURASSIC (Tearcian threagh Callevian - 193 to $163 \mathrm{Ma}$ ) (All metallogenic belts started earlier) } \\
\hline \multicolumn{5}{|c|}{ LATE JURASSIC (Oxfordian through Kimmerigian - 163 to 144 Ma) } \\
\hline \multicolumn{5}{|c|}{$\begin{array}{l}\text { Ariadny Metallogenic Belt of Zoned Mafic-Ultramafic Ti Deposits (Late Jurassic), } \\
\text { Southern Part of Russian Southeast (Belt AR) }\end{array}$} \\
\hline Ariadnoe & Zoned mafic-ultramafic Ti & $\mathrm{Ti}$ & $4513 \mathrm{~N}$ & $13428 \mathrm{E}$ \\
\hline Katenskoe & Zooed mafic-ultramafic $\mathrm{Ti}$ & $\mathrm{Ti}$ & $4717 \mathrm{~N}$ & $13613 \mathrm{E}$ \\
\hline Koksharovskoe & Zoned mafic-ultramafic $T_{1}$ & $\mathrm{Ti}$ & $4428 \mathrm{~N}$ & 13408E \\
\hline \multicolumn{5}{|c|}{$\begin{array}{l}\text { Nerth Bureya Metallegenie Belt of Au-Ag Epithermal Vein and Granitoid-Related Au Depesits (Early Cretaceous) } \\
\text { Northwestern Part of Russian Southeast (Belt NB) }\end{array}$} \\
\hline Pioneer & Granitoid-related Au & Au & $5327 \mathrm{~N}$ & $12627^{\circ} \mathrm{E}$ \\
\hline Pokrovskioe & Au-Ag epithermal vein & $\mathrm{Au}, \mathrm{Ag}$ & $53^{\circ} 08^{\circ} \mathrm{N}$ & $12617 \mathrm{E}$ \\
\hline \multicolumn{5}{|c|}{$\begin{array}{c}\text { Chersky-Argatass Ranges Inferred Metallogenic Belt of Kuroko Massive Sulfide Deposits (Late Jurassie) } \\
\text { West-Central Part of Russian Northeast (Belt CAR) }\end{array}$} \\
\hline Khotoidokh & Kuroko $\mathrm{Pb}-\mathrm{Zn}$ massive sulfide & $\mathrm{Pb}, \mathrm{Zn}, \mathrm{Ag}$ & $66^{\circ} 277^{7} \mathrm{~N}$ & $14109 \mathrm{E}$ \\
\hline
\end{tabular}




\begin{tabular}{|c|c|c|c|c|}
\hline \multicolumn{5}{|c|}{$\begin{array}{l}\text { Yasachnaya River Metallogenic Belt of Pb-Zn Skara, Porphyry Cu, and Cu-Ag Vein Deposits (Late Jurassic) } \\
\text { Western Part of Russian Northeast (Belt YS) }\end{array}$} \\
\hline Cherninskee & $\mathrm{Fe}(\mathrm{Cu}, \mathrm{Pb}, \mathrm{Zn})$ skam & $\mathrm{Fe}$ & $6320 \mathrm{~N}$ & $15105 \mathrm{E}$ \\
\hline Datsytovoe & Porphyry Cu & $\mathrm{Cu}, \mathrm{Ag}, \mathrm{Bi}$ & $6329 \mathrm{~N}$ & $15101 \mathrm{E}$ \\
\hline Kunarev & $\mathrm{Pb}-\mathrm{Zn}-\mathrm{Cu}-\mathrm{Ag}$ skarn & $\mathrm{Pb}, \mathrm{Zn}, \mathrm{Cu}_{2} \mathrm{Ag}$ & $63^{\prime} 24 \mathrm{~N}$ & $150^{\circ} 55 \mathrm{E}$ \\
\hline Temassnoe & $\mathrm{Pb}-\mathrm{Zn}$ skam & $\mathrm{Pb}, \mathrm{Zn}$ & $6333 \mathrm{~N}$ & $148^{\circ} 56 \mathrm{E}$ \\
\hline Oloy $\mathrm{N}$ & \multicolumn{4}{|c|}{ Oloy Metallogenic Belt of Porphyry Cu-Mo and Au-Ag Epithermal Vein Degesits (Late Jurasic and Early } \\
\hline Asket & $\begin{array}{l}\text { Porphyry Cu-Mo and } \\
\text { Polymetallic vein }\end{array}$ & $\mathrm{Cu}, \mathrm{Mo}, \mathrm{Au}$ & $6714 \mathrm{~N}$ & $16344 \mathrm{E}$ \\
\hline Dalny & $\begin{array}{l}\text { Porphyry Cu-Mo and } \\
\text { polymetallic vein }\end{array}$ & $\mathrm{Cu}, \mathrm{Mo}, \mathrm{As}$ & $6731 \%$ & $160^{\circ} 49 \mathrm{E}$ \\
\hline Innakh & $\begin{array}{l}\text { Polymetallic vein and Porphyry } \\
\text { Cu-Mo }\end{array}$ & $\mathrm{Cu}, \mathrm{Mo}, \mathrm{Au}$ & $6717 \mathrm{~N}$ & $199^{\circ} 22 \mathrm{E}$ \\
\hline Klen & Au-Ag cpithermal vein & $A w, A g$ & $6708 \mathrm{~N}$ & $161^{\circ} 13 \mathrm{E}$ \\
\hline Peschanka & Porphyry Cu-Mo & $\mathrm{Cu}, \mathrm{Mo}, \mathrm{As}$ & $6636 \mathrm{~N}$ & $16430 \mathrm{E}$ \\
\hline Vesennee & Au-Ag cpithermal vein & Au As & $6630 \mathrm{~N}$ & $16424 \mathrm{E}$ \\
\hline
\end{tabular}

Pekulney Metallogenic Beit of Basaltic Cu Depesits (Late Jurassic), East-Central Part of the Russian Nertheast (Belt PK)

\begin{tabular}{|c|c|c|c|c|}
\hline Skalisaya & Basaltic $\mathrm{Cu}$ & $\mathrm{Cu}$ & $6525 \mathrm{~N}$ & $17408 E$ \\
\hline \multicolumn{5}{|c|}{$\begin{array}{c}\text { Tamvatney-Mainits Metallogenic Belt of Pediform Cr Depesits (Late Jurassic and Early Cretaceous) } \\
\text { East-Central Part of the Russian Nertheast (Belt TAM) }\end{array}$} \\
\hline Chirynai & Podiform $\mathrm{Cr}$ & $\mathrm{Cr}, \mathrm{PGE}$ & $6327 \mathrm{~N}$ & $17544 \mathrm{E}$ \\
\hline Krassnaya Gora & Podiform $\mathrm{Cr}$ & Cr. PGE & $63^{7} 16 \mathrm{~N}$ & $17524 \mathrm{E}$ \\
\hline \multicolumn{5}{|c|}{ Mainits Metallogenie Belt of Massive Sulfide Depesits (Late Jarassic and Early Cretaceous) } \\
\hline \multicolumn{5}{|c|}{ Easters Part of Russian Northeast (Belt MA) } \\
\hline Ugryumoe & $\begin{array}{l}\text { Kuroko } \mathrm{Cu}-\mathrm{Zn}-\mathrm{Ag} \text { massive } \\
\text { sulfide(D) }\end{array}$ & $\mathrm{Ca}, \mathrm{Zn}, \mathrm{Pb}, \mathrm{Au}$ & $6316 \mathrm{~N}$ & $17639 \mathrm{E}$ \\
\hline \multicolumn{5}{|c|}{$\begin{array}{l}\text { Svyatey-Nes Mrtallegenic Beft of Au-Ag Epithermat Vein Depesits (Beit SVN) } \\
\text { Western Part of Russian Northeast (Belt SVN) }\end{array}$} \\
\hline Polevaya & As.Ag polymetallic vein & $\mathrm{Au}, \mathrm{Ag}$ & $6908 \mathrm{~N}$ & 14906'E \\
\hline \multicolumn{5}{|c|}{$\begin{array}{l}\text { Kuyul Metallesesic Belf ef Pediform Cr, FGE and Asseciated Deposits (Middle or Late Jurassic) } \\
\text { Eant-Central Part of Russian Nertheast (Belt KUY) }\end{array}$} \\
\hline Talow & Podiform $\mathrm{Cr}$ & $\mathrm{Cr}$ & $6149 \mathrm{~N}$ & $16549 \mathrm{E}$ \\
\hline Tikorechen & Podiform Cr & $\mathrm{Cr}$ & $61^{\prime} 37 \mathrm{~N}$ & 164 SOE \\
\hline \multicolumn{5}{|c|}{$\begin{array}{l}\text { Eastern Seward Peainsula and Marnhall Metallogenie Belt of Podiferm Cr Deposits (Jurassic) } \\
\text { Nerthera Alaska (Belt ESM) (No signifieant deposits) }\end{array}$} \\
\hline \multicolumn{5}{|c|}{ Kobuk Metallogenie Belt of Pediform Cr Deposits (Jurassie), Northern Alaska (Belt KB) } \\
\hline Astbestos Mountain & Serpentine-hosted asbestos & $\begin{array}{l}\text { Asbestos, jade, } \\
\text { ssbestos, tale }\end{array}$ & $6701 \% \mathrm{~N}$ & $15650 \mathrm{~W}$ \\
\hline Avan & Podiform $\mathrm{Cr}$ & $\mathrm{Cr}, \mathrm{PGE}$ & $68^{\circ} 20 \mathrm{~N}$ & $161^{\circ} 52^{\circ} \mathrm{W}$ \\
\hline Iyikrok Mountain & Podifom $\mathrm{Cr}$ & $\mathrm{Cr}$ & $6754 \mathrm{~N}$ & $163^{\circ} 40^{\circ} \mathrm{W}$ \\
\hline Misheguk Mountain & Pediform $\mathrm{Cr}$ & $\mathrm{Cr}, \mathrm{PGE}$ & $68^{\circ} 15 \mathrm{~N}$ & $161^{\circ} 05 \mathrm{~W}$ \\
\hline Siniktanneyak Mountain & Podiform $\mathrm{Cr}_{r}$ & Cr. Ni. PGE & $6820 \mathrm{~N}$ & $158^{\prime} 30 \mathrm{rw}$ \\
\hline
\end{tabular}

Seothwestern Alaska Metallogenie Belt of Zened Mafic-Ultramafie PGE Deposits (Late Triassic and Jarassic?) Southwestern Alaska (Belt SWA)

\begin{tabular}{|c|c|c|c|c|}
\hline $\begin{array}{l}\text { Kemuk Mounlain } \\
\text { Red Mountain }\end{array}$ & $\begin{array}{l}\text { Zoned mafic-ultramafic } \\
\text { Zoned maffc-ultramafic }\end{array}$ & $\begin{array}{l}\mathrm{Fe}_{\text {, Ti, } \mathrm{PGE}} \\
\mathrm{PGE}\end{array}$ & $\begin{array}{l}59^{2} 447 \mathrm{~N} \\
59^{\circ} 007 \mathrm{~N}\end{array}$ & $\begin{array}{l}15745 \mathrm{~W} \\
161^{\circ} 10 \mathrm{~W}\end{array}$ \\
\hline \multicolumn{5}{|c|}{ Yuken River Metallegenic Beit of Pediform Cr Deposits (Jurassic), West-Central Alaska (Belt YR) } \\
\hline $\begin{array}{l}\text { Caribou Mountain, Lower Kanuti } \\
\text { River, Holonada }\end{array}$ & Podiform $\mathrm{Cr}$ & $\mathrm{Cr}$ & $6605 \mathrm{~N}$ & $15055 \mathrm{~W}$ \\
\hline Kaiyuh Hills (Yuki River) & Podiform $\mathrm{Cr}$ & $\mathrm{Cr}$ & $6410 \mathrm{~N}$ & $15640 \mathrm{w}$ \\
\hline Mount Hurst & Podiform $\mathrm{Cr}$ & Cr. PGE & $63^{\circ} 147 \mathrm{~N}$ & $15655 \mathrm{~W}$ \\
\hline
\end{tabular}

Eastern-Seuthern Alaska Metallegenic Belt of Granitic Magmatisa Depenits (Late Jarasic and Earby Cretaceous) Eastern-Seutbern Alaska (Belt FSA)

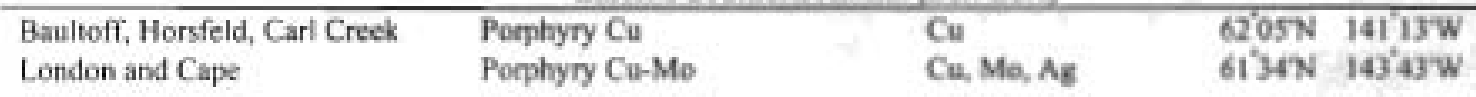




\begin{tabular}{|c|c|c|c|}
\hline Deposit Name & Mineral Deposit Model & Major Metals & Latitude $\mathrm{N}_{\ddagger}$ Longitude $\mathbf{E}, \mathbf{W}$. \\
\hline Midas (Berg Creek) & Cu-Au skam & $\mathrm{Au}, \mathrm{Cu}, \mathrm{Ag}$ & $61^{\circ} 33 \mathrm{~N} \quad 143^{4} 47 \mathrm{~W}$ \\
\hline Nabesaa, Rambler & Fe-Au skarn & As & $6223 \mathrm{~N} \quad 143^{\circ} 00 \mathrm{~W}$ \\
\hline Orange Hill, Bood Creck & $\begin{array}{l}\text { Porphyry } \mathrm{Cu}-\mathrm{Mo} \text { and } \mathrm{Cu}-\mathrm{Au} \\
\text { skarn }\end{array}$ & $\mathrm{Cu}, \mathrm{Mo}, \mathrm{Au}$ & $62^{\prime} 12^{\prime} \mathrm{N} \quad 142^{\prime} 45^{\prime} \mathrm{W}$ \\
\hline Pebble Copper & Porphyry $\mathrm{Au}-\mathrm{Cu}$ & $\mathrm{Au}, \mathrm{Cu}, \mathrm{Mo}$ & $59^{\prime} 53^{\prime} \mathrm{N} \quad 155^{\prime} 24^{\prime} \mathrm{W}$ \\
\hline
\end{tabular}

Klukwan-Duke Metallogenic Belt of Mafic-Ultramafic Ti-Fe-Cr-PGE Deposits (mid-Cretaceous) Southeastern Alaska (Belt KL)

\begin{tabular}{|c|c|c|c|c|}
\hline Duke Island & Zoned mafic-ultramafic Cr-PGE & $\mathrm{Cr}, \mathrm{PGE}$ & $5455 \mathrm{~N}$ & $131^{\prime 2} \mathrm{~W}$ \\
\hline Funter Bay & Gabbroic $\mathrm{Ni}-\mathrm{Cu}$ & $\mathrm{Cu}_{4}, \mathrm{Ni}, \mathrm{Co}$ & $58^{\prime \prime} 14 \mathrm{~N}$ & $134^{\prime} 52^{\prime} \mathrm{W}$ \\
\hline Haines & Zoned mafic-ultramafic $\mathrm{Fe}-\mathrm{Ti}_{1}$ & $\mathrm{Fe}_{\mathrm{e}} \mathrm{Ti}$ & $59^{1} 15^{\prime} \mathrm{N}$ & $13530 \mathrm{~W}$ \\
\hline Klukwan & Zoned mafic-uluramafic Fe-Ti & Fe, PGE, Ti, V & $59^{\prime} 26^{\prime} \mathrm{N}$ & $135^{\prime} 53$ 'W \\
\hline Union Bay (Cleveland Peninsula) & Zoned mafic-ultramafic Cr-PGE & $\mathrm{Fe}, \mathrm{V}, \mathrm{Th}, \mathrm{Cr}, \mathrm{PGE}$ & $554 \mathrm{~B}^{\prime} \mathrm{N}$ & $132^{\circ} 12^{\prime} \mathrm{W}$ \\
\hline \multicolumn{5}{|c|}{$\begin{array}{c}\text { Fortymile Alaska Metallegenic Belt of Serpentinite-Hosted Asbestos Deposits (Cretaceous?) } \\
\text { East-Central Alaska and Northwestern Canadian Cordillera (Belt FM) }\end{array}$} \\
\hline Clinton Creek & Serpentine-hosted asbestos & Asbestos & $6427 \mathrm{~N}$ & $140^{\prime} 43^{\prime} \mathrm{W}$ \\
\hline Slate Creek (Fertymile) & Serpentine-hosted asbestos & Asbessos & $6431 \mathrm{~N}$ & $14230 \mathrm{~W}$ \\
\hline \multicolumn{5}{|c|}{ Cassiar Metallogenic Belt of Serpentine-Hosted Asbestos Deposits (mid-Cretaceous), Central British Columbia (Beit CS) } \\
\hline Cassiar (McDame) & Serpentine-hosted asbestos & Asbestos & $5920 \mathrm{~N}$ & $12949 \mathrm{~W}$ \\
\hline \multicolumn{5}{|c|}{$\begin{array}{l}\text { Francois Lake Metallogenic Belt Porphyry Depesits (Late Jurassic to Early Cretaceous) } \\
\text { Southern British Columbia (Belt FL) }\end{array}$} \\
\hline Endako & Porphyry Mo & Mo & $5402 \mathrm{~N}$ & $12507 \mathrm{~W}$ \\
\hline \multicolumn{5}{|c|}{$\begin{array}{l}\text { Cariboe Metallogenic Belt of Au Quartz Vein Deposits (Middle Jurassic to Early Cretaceous) } \\
\text { Seuthern British Columbia (Belt CB) }\end{array}$} \\
\hline 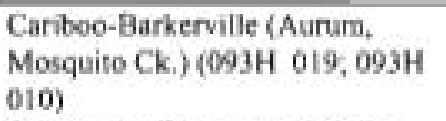 & Au quartz vein & Au & $53^{\circ} 05^{\prime} \mathrm{N}$ & $121^{*} 34{ }^{\prime} \mathrm{W}$ \\
\hline $\begin{array}{l}\text { Frasergold (Eureka Peak, Kay, } \\
\text { Mac) }(-93 \mathrm{~A} \quad 150)\end{array}$ & Au quartz vein & Aw & $5218 \mathrm{~N}$ & $12035 \mathrm{~W}$ \\
\hline
\end{tabular}

Ressland Metallogenic Belt of Au-Ag Polymetallic Vein Depesits (Middle Jurassic) Southern British Columbia (Belt RL)

\begin{tabular}{|c|c|c|c|c|}
\hline $\begin{array}{l}\text { Rossland (Le Roi. War Eagle, } \\
\text { etc.) (082FSW 093; 082FSW } \\
\text { (997; 082FSW 048; 083FSW068) }\end{array}$ & Atr-Ag polymetallic vein & $\mathrm{Au}, \mathrm{Ag}$ & $49^{\prime} 05^{\prime} \mathrm{N}$ & $11749 \mathrm{~W}$ \\
\hline $\begin{array}{l}\text { Sheep Creek Area (Kootenay } \\
\text { Belle, etc.) }\end{array}$ & Aa-Ag polymetallic vein & $\mathrm{Au}, \mathrm{Ag}, \mathrm{Pb}, \mathrm{Zn}$ & $49^{\circ} 08^{2} \mathrm{~N}$ & $11708 \mathrm{~W}$ \\
\hline Ymir-Erie Creek (Yankee Girl) & Ata-AB polymetallic vein & $\mathrm{Au}, \mathrm{Ag}$ & $49^{\prime \prime} 187 \mathrm{~N}$ & $11711 \mathrm{~W}$ \\
\hline \multicolumn{5}{|c|}{ EARLY CRETACEOUS (Neocomian - 144 to $120 \mathrm{Ma}$ ) } \\
\hline \multicolumn{5}{|c|}{$\begin{array}{l}\text { Samarka Metallegenie Belt of W Skarn, and Porphyry Cu-Mo Deposits (Early Cretaceous) } \\
\text { West-Central Part of Russian Southeast (Belt SA) }\end{array}$} \\
\hline Benevskoe & W skam & W & $43^{\prime} 06 \mathrm{~N}$ & $133^{\circ} 43 \mathrm{E}$ \\
\hline Kafen & Porphyry Ce-Mo & $\mathrm{Cu}, \mathrm{Mo}$ & $4736 \mathrm{~N}$ & $136^{\circ} 15 \mathrm{E}$ \\
\hline Khwoshchovee & Porphyry Cu-Mo & $\mathrm{Cu}, \mathrm{Mo}$ & $4758 \mathrm{~N}$ & $13611 \mathrm{E}$ \\
\hline Lermontovsky & W skam and greisen & $\mathrm{w}$ & $46577 \mathrm{~N}$ & $13427 \mathrm{E}$ \\
\hline Malakhitovee & Porphyry Ce-Mo & $\mathrm{Cu}_{3}, \mathrm{Mo}$ & $4706 \mathrm{~N}$ & $135^{\circ} \mathrm{OA} \mathrm{E}$ \\
\hline Skalistoe & Porphyry Mo & Mo & $43^{\prime} 36 \mathrm{~N}$ & $133^{*} 45 \mathrm{E}$ \\
\hline Skrytoe & W skam & w & $4505 \mathrm{~N}$ & $13435 \mathrm{E}$ \\
\hline Vostok-2 & W skarn & w & $4628 \mathrm{~N}$ & $13553 \mathrm{E}$ \\
\hline \multicolumn{5}{|c|}{ Algama Metallogenie Belt of Stratiform Zr Deposits (mid-Cretaceeus7), Nertbern Part of Russian Seutheast (Belt AL) } \\
\hline Algaminskoe & Stratiform Zt & Zr & $5848^{\circ} \mathrm{N}$ & $13534 \mathrm{E}$ \\
\hline \multicolumn{5}{|c|}{$\begin{array}{c}\text { Kendyor Metallegenie Belt ef Zoned Mafic-Ultramafic PGE-Cr Deposits (mid-Cretaceous?) } \\
\text { Northern Part of Ressian Seutbeast (Belt KO) }\end{array}$} \\
\hline Kondyor & Zoned mafic-ultramafic C $\mathrm{C}$-PGE & $P_{7}$ & $5733 \mathrm{~N}$ & $13438 E$ \\
\hline \multicolumn{5}{|c|}{ Selemitha-Kerbi Metallogenie Belt of Aw Quartz Veis Deposits (Late Jurassic and Early Cretaceous) } \\
\hline Afanas'evskoe & At quartz vein & $\mathrm{Au}$ & $52500 \mathrm{~N}$ & $13324 \mathrm{E}$ \\
\hline Ingagli & Au quartz vein & Au & $53^{\circ} 04^{2} \mathrm{~N}$ & $133^{\circ} 22 \mathrm{E}$ \\
\hline Kharga & Au quartz veia & $A=$ & $5257 \mathrm{~N}$ & $133^{*} 35 \mathrm{E}$ \\
\hline Malomyr & Au quanz vein & Au & $53^{\circ} 06 \mathrm{~N}$ & 13i"soE \\
\hline Poiskovoe & Granisoid-related $\mathrm{Au}$ & Av & $5306 \mathrm{~N}$ & $132^{\circ} 12 \mathrm{E}$ \\
\hline Sagurskoe & Av quartz vein & $A=$ & $5259 \mathrm{~N}$ & $13236 \mathrm{E}$ \\
\hline
\end{tabular}




\begin{tabular}{|c|c|c|c|}
\hline Depesit Name & Mineral Depesit Model & Majer Metals & Latitude $\mathrm{N}_{\text {i }}$ Longitade $\mathrm{E}, \mathrm{W}$. \\
\hline Talaminskoe & Sb-Au vein & $\mathrm{Sb}, \mathrm{Au}$ & $52^{\prime} 42 \mathrm{~N} \quad 133^{\prime} 24^{\prime} \mathrm{E}$ \\
\hline Tokur & Au quartz vein & $\mathrm{Au}$ & $53^{\circ} 09 \mathrm{~N} \quad 132^{\circ} 49 \mathrm{E}$ \\
\hline Zazubrinskee & Au quartz vein & $\mathrm{Au}$ & $53^{\circ} 09 \mathrm{~N} \quad 132^{\circ} 22 \mathrm{E}$ \\
\hline \multicolumn{4}{|c|}{$\begin{array}{l}\text { Stanovay Metallogeaic Belt of Granttold-related Aa Deposits (Cretaceous?) } \\
\text { Nerthern Part of the Rusian Southeast (Belt ST) }\end{array}$} \\
\hline Bamskoe (Chul'bango) & Av-Ag epithermal vein & $\mathrm{Au}, \mathrm{Ag}$ & $5559 \mathrm{~N} \quad 12354 \mathrm{E}$ \\
\hline Burindinskoe & Aw-Ag epithermal vein & $\mathrm{Au} . \mathrm{Ag}$ & $53^{\prime} 417 \mathrm{~N} \quad 124^{\prime} 54 \mathrm{E}$ \\
\hline Kirovskoe & Granitoid-related $\mathrm{Au}$ & $\mathrm{Au}$ & $34^{\circ} 27 \mathrm{~N} \quad 124^{\circ} 14^{\circ} \mathrm{E}$ \\
\hline Zolotaya Gora & Au quartz vein & $\mathrm{Au}$ & $54^{\circ} 19 \mathrm{~N} \quad 126^{\prime} 44^{\circ} \mathrm{E}$ \\
\hline \multicolumn{4}{|c|}{$\begin{array}{l}\text { Kular Metallegenie Metallogenie Belt of Au Quartz Vein, Granitoid-Related Au, Au-REE Quartz. Vein, and } \\
\text { Sn Quartz Vein Deposits (Early Cretaceous), Nerthern Part of Eastern Siberia (Belt KU) }\end{array}$} \\
\hline Burguat & Au quartz vein & $\mathrm{Au}$ & $70422 \mathrm{~N} \mathrm{13431 \textrm {E }}$ \\
\hline Dzhuorak & Au quartz vein & $\mathrm{Au}$ & $70^{\prime} 13 \mathrm{~N}$ 1341TE \\
\hline Novoe & Granitoid-related $\mathrm{Au}$ & $\mathrm{Au}$ & $69^{\circ} 36 \mathrm{~N} \quad 133^{\circ} 07 \mathrm{E}$ \\
\hline Solur & Granitoid-related $\mathrm{As}$ & $\mathrm{Au}$ & $70^{\circ} 01{ }^{\circ} \mathrm{N} \quad 133^{\circ} 24^{\circ} \mathrm{E}$ \\
\hline $\begin{array}{l}\text { Tirekhtyak district (Nagomoe, } \\
\text { Podgornoe, Poputnoe) }\end{array}$ & Sn quartz vein & $S_{n}, w$ & $69^{\circ} 58 \mathrm{~N} \quad 134^{\circ} 41 \mathrm{E}$ \\
\hline
\end{tabular}

Podgornoe, Poputnoe)

Allakh-Yun Metallogenic Belt of Au Quartz Vein Deposits and Associated W-Sn Quartz Veis Deposits

(Late Jurassic to Early Cretaceous), Southern Part of Russian Northeast (Belt AV)

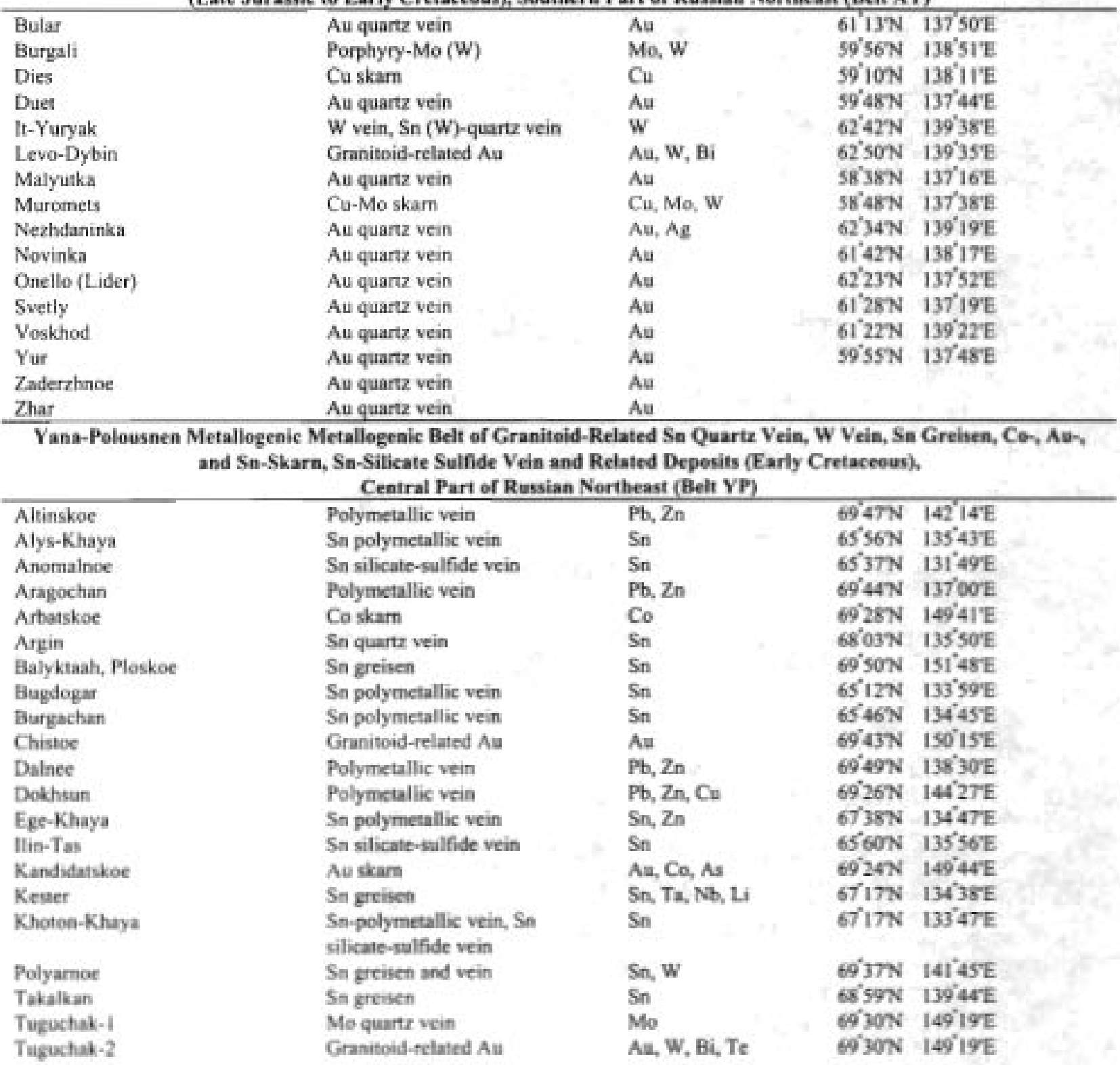




\begin{tabular}{llll}
\hline Deposit Name & Mineral Deposit Model & Major Metals & Latitude N; Longitude E, W. \\
\hline & & & \\
Ulakhan-Egelyakh & Sn silicate-sulfide vein & $\mathrm{Sn}$ & $67^{\circ}\left(09^{\prime} \mathrm{N} 134^{\circ} 21^{\circ} \mathrm{E}\right.$ \\
Ulakhan-Sala & Sn silicate-sulfide vein & $\mathrm{Sn}$ & $6^{\circ} 48^{\prime} \mathrm{N} 136^{\prime} 40^{\prime} \mathrm{E}$ \\
Verkhne-Naanchan & Polymetallic vein & $\mathrm{Pb}, \mathrm{Zn}_{\mathrm{n}}$ & $69^{\circ} 39^{\prime} \mathrm{N} 150^{\circ} 41^{\prime} \mathrm{E}$ \\
\hline
\end{tabular}

Darpir Metallogenic Belt of Sn and Associated Felsic-Magmatism Deposits (Early Cretaceous)

Western Part of Russian Northeast (Belt DP)

\begin{tabular}{|c|c|c|c|c|}
\hline Bastion & Sn greisen & Sn & $63^{2} 17 \mathrm{~N}$ & $153^{2} 13^{\prime} \mathrm{E}$ \\
\hline Bolshoy Kanyon & So skarn & Sn & $63^{\circ} 15^{\prime} \mathrm{N}$ & IST'OS'E \\
\hline Chepak & Granitoid-related Au & $\mathrm{Au}, \mathrm{W}, \mathrm{Bi}$ & $63^{\circ} 05^{\prime} \mathrm{N}$ & $152^{\prime \prime} 45^{\prime} \mathrm{E}$ \\
\hline Chibagalakh & Sn-B skam & $\mathrm{B}, \mathrm{Sn}$ & $68^{\prime} 13 \mathrm{~N}$ & I39'51'E \\
\hline Darpir & Sn silicate-sulfide vein & $\mathrm{Sn}$ & $64^{\prime} 02 \mathrm{~N}$ & 14742 'E \\
\hline Lazo & Sn silicate-sulfide vein & $\mathrm{Sn}$ & $63^{\circ} 12^{\prime} \mathrm{N}$ & I52'I3'E \\
\hline Titovskoe & Sn (B) magnesian skam & $\mathrm{B}$ & $6733 \mathrm{~N}$ & $139^{\circ} 14^{\prime} \mathrm{E}$ \\
\hline Verkhne-Seimchan & $\mathrm{Co}-\mathrm{As}$ vein & $\mathrm{Co}, \mathrm{Bi}$ & $63^{\circ} 17 \mathrm{~N}$ & $151^{\circ} 23^{\prime} \mathrm{E}$ \\
\hline
\end{tabular}

Tompon Metallogenic Metallegenic Belt of Cu, W, Sn Skarn, and Sn Quurtz Vein Deposits (Early Cretaceous)

West-Central Part of Eastern Siberia (Belt TO)

\begin{tabular}{|c|c|c|c|c|}
\hline Agylki & W skam & W. $\mathrm{Cu}$ & $64^{\circ} 17 \mathrm{~N}$ & $137^{\prime} 16^{\prime} \mathrm{E}$ \\
\hline Erikag & Sn quartz vein & $\mathrm{S} n$ & $6430 \mathrm{~N}$ & $137^{\circ} 18 \mathrm{E}$ \\
\hline Khunkhada & W-Sn skarn & W, Sn & $6434 \mathrm{~N}$ & $13449 \mathrm{E}$ \\
\hline \multicolumn{5}{|c|}{$\begin{array}{c}\text { Shamanikha Metallogenic Belt of Au Quartz Vein and Cu-Ag Quartz Vein Deposits (Late Jurassic to Early Cretaceous) } \\
\text { Central Part of the Russian Northeast (Belt SH) }\end{array}$} \\
\hline Glukhariny & Au quartz vein & $\mathrm{Au}$ & $6458 \mathrm{~N}$ & $153^{\circ} 04^{\circ} \mathrm{E}$ \\
\hline Kopach & Au quartz vein & Au & $65^{\circ} 21 \mathrm{~N}$ & $152^{\circ} 57 \mathrm{E}$ \\
\hline Opyt & $\mathrm{Cu}-\mathrm{Ag}$ quartz vein? & $\begin{array}{l}\mathrm{Cu}, \mathrm{Al}_{\mathrm{u}} \mathrm{Pb}, \mathrm{Zn}, \mathrm{Ag}_{\mathrm{g}} \\
\mathrm{Au}\end{array}$ & $63^{\circ} 54 \mathrm{~N}$ & $152^{\circ} 33^{\circ} \mathrm{E}$ \\
\hline
\end{tabular}

\begin{tabular}{|c|c|c|c|c|}
\hline \multicolumn{5}{|c|}{$\begin{array}{l}\text { Verkhoyansk Metallogenic Belt of Au Quartz Vein, Au-Sn Polymetallic Vein Depesits } \\
\text { (Late Jurassic and Early Cretaceous), Western Part of Russian Nertheast (Belt VK) }\end{array}$} \\
\hline Anna-Emeskhin & Au quartz vein & Au & $6856 \mathrm{~N}$ & $128^{\prime} 24^{\prime} \mathrm{E}$ \\
\hline Balbuk & Pb polymetallic vein & $\mathrm{Pb}$ & $6449 \mathrm{~N}$ & $130^{\circ} 37^{\prime} \mathrm{E}$ \\
\hline Bochiyskoe & Sn polymetallic vein & Sn & $6614 \mathrm{~N}$ & $129^{\circ} 58^{\circ} \mathrm{E}$ \\
\hline Chochimbal & Polymetallic vein & $\mathrm{Au}, \mathrm{Ag}, \mathrm{Pb}$ & $65^{\prime \prime} 54 \mathrm{~N}$ & $129^{\circ} 45^{\prime} \mathrm{E}$ \\
\hline Dyabkhanya & Au polymetallic vein & $\mathrm{Au}, \mathrm{Ag}$ & $65^{\circ} 30 \mathrm{~N}$ & $129^{\circ} 60^{\circ} \mathrm{E}$ \\
\hline Enchan-Tolono & Au quartz vein & $\mathrm{Au}$ & $68^{\circ} 11 \mathrm{~N}$ & $128^{\circ} 11^{\prime} \mathrm{E}$ \\
\hline Galochka & Au quartz vein & $\mathrm{Au}$ & $65^{\circ} 42 \mathrm{~N}$ & $128^{\prime \prime} 26^{\prime} \mathrm{E}$ \\
\hline Imtandzha & Sn polymetallic vein & Sn & $66^{\circ} 08 \mathrm{~N}$ & $129^{\prime \prime} 36^{\prime} \mathrm{E}$ \\
\hline Nikolaevskoe, Otkrytoe & Av quartz vein & Au & $70^{\circ} 20 \mathrm{~N}$ & $129^{\prime \prime} 33^{\prime} \mathrm{E}$ \\
\hline Syncha-I \& II & Au quartz vein & Au & $6750 \mathrm{~N}$ & $12803 \mathrm{E}$ \\
\hline Syugyunyakh-Kende & Au quartz vein & $\mathrm{Au}$ & $68^{\circ} 42 \mathrm{~N}$ & $127^{\circ} 46^{\circ} \mathrm{E}$ \\
\hline
\end{tabular}

Syugyunyakh-Kende

Yana-Kolyma Metallogenic Belt of Au Quartz Vein, So Vein and Greisen, W Vein and Clastic-Sediment-Hosted

$\mathrm{Hg}$ Deposits (Late Jurassic and Early Cretaceous), Central Part of Russian Northeast (Belt YA)

\begin{tabular}{|c|c|c|c|c|}
\hline Aleshkino & Au quartz vein & Au & $6711 \mathrm{~N}$ & $138^{\circ} 22^{\prime} \mathrm{E}$ \\
\hline Alyaskitovoe & Sn-W greisen & Sn, w & $6448 \mathrm{~N}$ & $141^{\circ} 52 \mathrm{E}$ \\
\hline Badran & Au quartz vein & $\mathrm{Au}$ & $64^{7} 12 \mathrm{~N}$ & $141^{\circ 4} 1{ }^{\prime} E$ \\
\hline Baryllyelakh & Sn greisen & Sn, w & $63^{\prime} 35 \mathrm{~N}$ & $143^{\prime \prime} 54^{\circ} \mathrm{E}$ \\
\hline Bazovskoe & Au quartz vein & At & $6442 \mathrm{~N}$ & $141^{\prime \prime} 26 \mathrm{E}$ \\
\hline Bekkem & W-Mo-Sn vein and greisent & $w$ & $6404 \mathrm{~N}$ & $142^{\circ} 37^{\prime} \mathrm{E}$ \\
\hline Bokhapcha & W vein and greisen & $w$ & $61^{3} 45 \mathrm{~N}$ & $150^{\circ} 44 \mathrm{E}$ \\
\hline Burgavli & Sn quartz vein & Sn & $66^{\prime} 28 \mathrm{~N}$ & $13739 \mathrm{E}$ \\
\hline Burkat & Se quartz vein & Sn & $65^{\circ} 35 \mathrm{~N}$ & $140^{\circ} 59 \mathrm{E}$ \\
\hline Burkhala & Au quartz vein & Au & $6236 \mathrm{~N}$ & $149^{\circ} 04^{\prime} \mathrm{E}$ \\
\hline Butugychag & Sn quartz vein & $\mathrm{Sn}$ & $6175 \mathrm{~N}$ & $149^{\circ} 05^{\prime} \mathrm{E}$ \\
\hline Chai-Yurya & Au quartz vein & $\mathrm{Au}$ & $6241 \mathrm{~N}$ & $147^{\prime} 24^{\prime} \mathrm{E}$ \\
\hline Chelbanya & Au quartz vein & $\mathrm{Au}$ & $62^{\prime} 377 \mathrm{~N}$ & $148^{\circ} 02 \mathrm{E}$ \\
\hline Daika Novaya & Au quartz vein & Au & $62^{\circ} 45 \mathrm{~N}$ & $148^{\circ} 06^{\circ} \mathrm{E}$ \\
\hline Darpir & Au quartz vein & $\mathrm{Au}$ & $65^{\prime} 30 \mathrm{~N}$ & $138^{\circ} 55^{\circ} \mathrm{E}$ \\
\hline Degdekan & Au quartz vein & $\mathrm{Au}$ & $61^{\prime} 58 \mathrm{~N}$ & $146^{\circ} 60^{\circ} \mathrm{E}$ \\
\hline Delyuvialnoe & Granitoid-related Au & Au & $66^{\circ} 17 \mathrm{~N}$ & $136^{\prime} 53^{\prime} \mathrm{E}$ \\
\hline Dirin-Yuryak & Au quarlz vein & Au & $6425 \mathrm{~N}$ & $142^{\circ} 19^{\prime} \mathrm{E}$ \\
\hline Djelgala-Tyellakh & Au quartz vein & $\mathrm{Au}$ & $62^{\prime} 19 \mathrm{~N}$ & $148^{\circ} 50^{\circ} \mathrm{E}$ \\
\hline Dorozhnoe & Au quartz vein & Au & $62^{\prime} 50 \mathrm{~N}$ & $148^{\circ} 022^{\circ} \mathrm{E}$ \\
\hline Ekspeditsionnoe & Au quanz vein & Au & $61^{\circ} 417 \mathrm{~N}$ & $150^{\circ} 33^{\circ} \mathrm{E}$ \\
\hline
\end{tabular}




\begin{tabular}{|c|c|c|c|c|}
\hline Deposit Name & Mineral Deposit Model & Majer Mefals & \multicolumn{2}{|c|}{ Latitude $\mathrm{N}$; Longitude $\mathrm{E}, \mathrm{W}$. } \\
\hline Ergelyakh & Granitoid-related Au & $\mathrm{Au}$ & $63^{\circ} 43 \mathrm{~N}$ & $143^{*} 53 \mathrm{E}$ \\
\hline Goletsov (Golets) & Au quartz vein & $\mathrm{Au}$ & $62^{\prime} 40^{\prime} \mathrm{N}$ & $15007 \mathrm{E}$ \\
\hline Igumen & Au quartz vein & Au & $6125 \mathrm{~N}$ & $148^{\prime} 21^{\prime} \mathrm{E}$ \\
\hline Imtachan & Au quartz vein & Au & $6532 \mathrm{~N}$ & $140^{\circ} 18^{\circ} \mathrm{E}$ \\
\hline Kamenistoe & Au quartz vein & Au & $62^{-1} 16^{\prime} \mathrm{N}$ & $151^{\circ} 44^{2} \mathrm{E}$ \\
\hline Kere-Yuryak & Sn-W greisen & $5 \mathrm{n}, \mathrm{w}$ & $6617 \mathrm{~N}$ & $13758 \mathrm{E}$ \\
\hline Khangalass & Au quarnz vein & $\mathrm{Au}$ & $6403 \mathrm{~N}$ & $14449 \mathrm{E}$ \\
\hline Khaptagai-Khaya & Au quartz vein & Au & $65^{\prime} 24 \mathrm{~N}$ & $142^{\circ} 60 \mathrm{EE}$ \\
\hline Kontrandya & Au quartz vein & Au & $63^{\circ} 13 \mathrm{~N}$ & $14655 \mathrm{E}$ \\
\hline Krokhalin & Sb-Au vein (simple Sb) & $\mathrm{Sb}, \mathrm{Au}$ & $6222 \mathrm{~N}$ & $15201 \mathrm{E}$ \\
\hline Kurmichan & $\begin{array}{l}\text { Clastic sediment-hosted } \mathrm{Hg} \text { of } \\
\text { bot-spring } \mathrm{Hg} \text { ? }\end{array}$ & $\mathrm{H}_{8}$ & $6218 \mathrm{~N}$ & $15239 \mathrm{E}$ \\
\hline Laryukov & Au quartz vein & Au & $62^{\circ} 06^{\prime} \mathrm{N}$ & $151^{*} 52 \mathrm{E}$ \\
\hline Lavo & Au quartz vein & $A v$ & $66^{\prime \prime} 38 \mathrm{~N}$ & $13651^{\prime} \mathrm{E}$ \\
\hline Maldyak & Au quarz vein & $\mathrm{Au}$ & $62^{\circ} 56^{\prime} \mathrm{N}$ & $148^{\prime} 14^{\prime} \mathrm{E}$ \\
\hline Mierei & Au quartz vein & Au & $6457 \mathrm{~N}$ & $144^{\circ} \mathrm{O} 1^{\prime} \mathrm{E}$ \\
\hline Nadezhda & Au quarsz vein & At & $6223 \mathrm{~N}$ & $150^{\circ} 05^{\circ} \mathrm{E}$ \\
\hline Natalka & Au quartz vein & Au & $61397 \mathrm{~N}$ & $147^{\circ} 41^{\prime} \mathrm{E}$ \\
\hline Pavlik & Au quarzz vein & Av & $6132 \mathrm{~N}$ & $14757 \mathrm{E}$ \\
\hline Pil & Au quartz vein & Au & $63^{\circ} 49^{\prime} \mathrm{N}$ & $143^{\circ} 38^{\circ} \mathrm{E}$ \\
\hline Rodionov & Au quartz vein & A & $61^{\circ} 16 \mathrm{~N}$ & $14837 \mathrm{E}$ \\
\hline Sana & Au quartz vein & At & $64^{\circ} 08 \mathrm{~N}$ & $143^{\circ} 04 \mathrm{E}$ \\
\hline Shturm & Au quartz vein & Av & $6247 \mathrm{~N}$ & $149^{\circ} 46^{\prime} \mathrm{E}$ \\
\hline Sokh & Au quarkx vein & A & $6445 \mathrm{~N}$ & $143^{\circ}$ SOVE \\
\hline Srednekan & Au quartz veis & At & $62201 \mathrm{~N}$ & $152^{\prime} 22 \mathrm{E}$ \\
\hline Stakhanov & Au quartz vein & Au & $63^{\circ} 06 \mathrm{~N}$ & $14748 \mathrm{E}$ \\
\hline Svetloe, Kholodnoe & Au quant vein & $\mathrm{Au}$ & $62^{\circ} 44^{\prime} \mathrm{N}$ & $147522^{\prime} \mathrm{E}$ \\
\hline Svetloe, Medvezhje & Sn quartz vein and greisen & Sn, w & $65^{\circ} 40 \mathrm{NN}$ & $14207 \mathrm{VE}$ \\
\hline Taboga & Au quartz vein & Au & $63^{\circ} 04 \mathrm{~N}$ & $148^{\prime \prime} 16 \mathrm{E}$ \\
\hline Talalak & Au quartz vein & $\mathrm{Au}$ & $6432 \mathrm{~N}$ & $141^{\prime} 43 \mathrm{E}$ \\
\hline Tokichan & Au quartz vein & Atu & $6201 \mathrm{~N}$ & $14645 \mathrm{E}$ \\
\hline Tumannoe & Au quartz vein & Au & $65^{\prime} 36^{\prime} \mathrm{N}$ & $13833 \mathrm{E}$ \\
\hline Tunguss & Au quarz and St vein & $\mathrm{Ab}, \mathrm{Sb}$ & $6409 \mathrm{~N}$ & $14616 \mathrm{E}$ \\
\hline Tuora-Tas & Au quartz vein & $\mathrm{Au}$ & $64^{7} 45 \mathrm{~N}$ & $14243 \mathrm{E}$ \\
\hline Uehui & Au quartz vein & Av & $6547 \mathrm{~N}$ & $13822 \mathrm{E}$ \\
\hline Utinka & Au quartz vein & Av & $62317 \mathrm{~N}$ & $151^{\circ} 04 \mathrm{E}$ \\
\hline Verkhne-Khakchan & Au quartz vein & Av & $63^{\circ} 15 \mathrm{~N}$ & $146 \mathrm{IAE}$ \\
\hline Vetrenskoe & Au quartz vein & Au & $61^{\circ} 45 \mathrm{~N}$ & $14933 \mathrm{E}$ \\
\hline Yuglet & Au quartz vein & Au & $62^{\circ} 10 \mathrm{~N}$ & $150^{\circ} 37 \mathrm{E}$ \\
\hline Yukhondja & As quartr vein & Au & $6528 \mathrm{~N}$ & $140^{\circ} 32 \mathrm{E}$ \\
\hline Zatessnoe & As quartz vein & Av & $61^{\circ} 52 \mathrm{~N}$ & $15235 \mathrm{E}$ \\
\hline Thdannes & Au guartz vein & Av & $6457 \mathrm{~N}$ & $141^{\prime 07 E}$ \\
\hline \multicolumn{5}{|c|}{ Lefl Omolen Metallegenic Belt of Granitic-Magmatism-Related Depesits (Early Cretaceous) } \\
\hline Bebeican & Forphyry Co-Mo & $\mathrm{Mo}, \mathrm{Cu}$ & $64227 \mathrm{~N}$ & $16022 \mathrm{E}$ \\
\hline Medeora & Mo-Cuskam & $\mathrm{Mo}, \mathrm{Cu}$ & $6517 \mathrm{~N}$ & $15932 \mathrm{E}$ \\
\hline \multicolumn{5}{|c|}{$\begin{array}{l}\text { Western-Seutheastern Alaska Metallegenic Belt of Granitic-Magmatism-Related Deposits } \\
\text { (Iate Jurasic and Early Cretaceous), Seatheastera Alaska (Belt WSE) }\end{array}$} \\
\hline Bokan Mountain (Ross-Adams) & Felsic plutonic U-REE & $\begin{array}{l}\text { U, Th, Bc, Nb, Pb, } \\
\text { REE }\end{array}$ & $5455 \mathrm{~N}$ & $13208 \mathrm{~W}$ \\
\hline Jumbo dustrict & Cu.Au sam & $\mathrm{Fe}, \mathrm{Ag}, \mathrm{Au}, \mathrm{Cu}, \mathrm{Mo}$ & $5515 \mathrm{~N}$ & $13237 \mathrm{~W}$ \\
\hline \multicolumn{5}{|c|}{ Britannia Metallesenic Belt of Kuroke Cu-Zn Massive Sulfie Depesits (Late Jurassic and Early Cretaceous) } \\
\hline Britannia (092GN 003) & kuroke massive sulfide & $\mathrm{Ca}, \mathrm{Zn}, \mathrm{Ag}, \mathrm{As}$ & $4967 \mathrm{~N}$ & $12308 \mathrm{E}$ \\
\hline Mapeic (092GNW 042) & kuroko massive sulfide & $\mathrm{Cu}_{\mathrm{Z}} \mathrm{Zn}, \mathrm{PB} \mathrm{Ag}$ & $49^{*} 39 \mathrm{~N}$ & $12322 \mathrm{E}$ \\
\hline Nonthair (092) W 012) & kurcko massive sulfide? & $\mathrm{Au}_{1} \mathrm{Ag}, \mathrm{Pb}, \mathrm{Zn}, \mathrm{Cu}$ & $4939 \mathrm{~N}$ & $12322 \mathrm{E}$ \\
\hline Niffy $(0930006)$ & harcko mussive sulfide & $\mathrm{Ag}, \mathrm{Cg}, \mathrm{Ag}, \mathrm{Zn}$ & $5235 \mathrm{~N}$ & $12624 \mathrm{E}$ \\
\hline
\end{tabular}


LATE EARLY CRETACEOUS (Cenomanian through Albian - 120 to $100 \mathrm{Ma}$ )

Badrhal-Ezop-Khingan Metallogenic Belt of Sn Greisen, Sn Skarn, and Sn Quartz Vein Depesits (Late Cretaceous and early Tertiary), West-Central Part of Russian Southeast (Belt BZ-KH)

\begin{tabular}{|c|c|c|c|c|}
\hline Dechalinda & Rhyolite-hosted So & Sn & $49^{\circ} 09 \mathrm{~N}$ & $13125 \mathrm{EE}$ \\
\hline Ezop & Sn polymesaltic vein & Sn & $5228 \mathrm{~N}$ & $13411 \mathrm{E}$ \\
\hline Festivalnoe & Se quarte vein & $S n$ & $50^{\circ} 41^{\prime} \mathrm{N}$ & $13621^{\prime} \mathrm{E}$ \\
\hline Ippatinskoe & Sn quartz vein & Sn & $51 " 30 \mathrm{~N}$ & $133^{\prime} 55^{\prime} \mathrm{E}$ \\
\hline Kapral & Porphyry Mo & Mo & $50^{\circ} 417 \mathrm{~N}$ & $136^{\circ} 08^{\prime} \mathrm{E}$ \\
\hline Khingan & Sn greisen & Sn & $48.59 \mathrm{~N}$ & $131^{\circ} 15 \mathrm{E}$ \\
\hline Loshadieayagriva (Main) & Se quartz vein & $\mathrm{Sn}$ & $5033 \mathrm{~N}$ & $135^{\prime} 14^{\prime} \mathrm{E}$ \\
\hline Olgakanskoe & Se greisen & $5 n$ & $52^{\prime} 21^{\prime} \mathrm{N}$ & $134^{\circ} 04^{\prime} \mathrm{E}$ \\
\hline Pravourniniskoe & Sn greisen & Sn & $50^{\circ} 26 \mathrm{~N}$ & $134^{\prime} 15 \mathrm{E}$ \\
\hline Solnechnce & Sn quartz vein & $5 n$ & $50^{\circ} 487 \mathrm{~N}$ & $136^{\prime} 16^{\prime} \mathrm{E}$ \\
\hline Verkhnebidzhanskoe & Sn quartz vein & $\mathrm{Sn}_{\mathrm{n}}$ & $48^{\prime} 37 \mathrm{~N}$ & $131^{\prime \prime} 30^{\prime} \mathrm{E}$ \\
\hline \multicolumn{5}{|c|}{ Anadyr River Metallogenic Belt of Au Quartz Vein Depesits (late Early) Cretaceeus), Russian Nertheast (Belt AD) } \\
\hline Nutekin & Au quartz vein & Au & $6325 \mathrm{~N}$ & $17652 \mathrm{E}$ \\
\hline Vacgi & Aus quartz vein & $\mathrm{Au}$ & $63^{3} 33 \mathrm{~N}$ & $171^{\circ} 09^{\circ} \mathrm{E}$ \\
\hline \multicolumn{5}{|c|}{ Neme Metallogenic Belt of Au Quartz Vein Depesits (Early to mid-Cretaceous), Seward Peninsula, Alaska (Belt NO) } \\
\hline Big Hurrah & Au quartz vein & $\mathrm{Au}$ & $6459 \mathrm{~N}$ & $16414 \mathrm{~W}$ \\
\hline Daniels Creek. (B/ufin) & Au quartz vein & $\mathrm{Am}, \mathrm{Ag}$ & $64^{4} 34 \mathrm{~N}$ & $163^{\circ} 44 \mathrm{~W}$ \\
\hline Nome district Mt. Distin & All quarlz vein & $\mathrm{Au}$ & $6440 \mathrm{~N}$ & $165^{\circ} 28 \mathrm{~W}$ \\
\hline Rock Croek & Au quartz vein & $\mathrm{As}, \mathrm{Ag}, \mathrm{W}$ & $6435 \mathrm{~N}$ & $165^{\prime} 29 \mathrm{~W}$ \\
\hline
\end{tabular}

Southern Breoks Range Metallegenic Belt of Au Quartz Vein Deposits (Early to mid-Cretaceous), Northern Alaska (Belt SBR)

\begin{tabular}{|c|c|c|c|c|}
\hline $\begin{array}{l}\text { Chandalar district (Mikado, Little } \\
\text { Squaw) }\end{array}$ & Au quartz vein & $\mathrm{Au}$ & $6732 \mathrm{~N}$ & $1 4 8 \longdiv { 1 5 W }$ \\
\hline \multicolumn{5}{|c|}{ Fish River Metallogenic Belt of Sedimentary P and Fe Depesits (Late Cretaceous), Northern Vukon Territery (Belt FR) } \\
\hline Rio Alto & Stratabound Fe & Fe & $6632 \mathrm{~N}$ & $14017 \mathrm{~W}$ \\
\hline Fish River & Sedimentary P and Fe & $\mathrm{Fe}, \mathrm{P}, \mathrm{Mn}, \mathrm{Gems}$ & $68^{\prime} 29 \mathrm{~N}$ & $13629 \mathrm{w}$ \\
\hline
\end{tabular}

Selwyn Metallogenic Belt of W-Cu Skarn, Zn-Pb-Ag Skarn, and Zn-Pb-Ag Manto Depesits (mid-Cretaceous) Seuthern Yuken Territery (Belt SW)

\begin{tabular}{|c|c|c|c|c|}
\hline Bailey (Par) & $\mathrm{W}$ skam & $\mathrm{W}, \mathrm{Cu}$ & $6046 \mathrm{~N}$ & $12851 \mathrm{~W}$ \\
\hline Cantung (Canada Tungsten) & W skam & $\mathrm{w}, \mathrm{Cu}$ & $61^{2} 57 \mathrm{~N}$ & $128^{\circ} 15 \mathrm{~W}$ \\
\hline Lened (Rudi, Godfrey) & W skam & $\mathrm{W}, \mathrm{Cu}$ & $62^{\circ} 23 \mathrm{~N}$ & $12873 \% \mathrm{~W}$ \\
\hline MacTung (MacMillan Tungsten) & W skam & $\mathbf{w}, \mathrm{Cu}$ & $63^{\circ} 17 \mathrm{~N}$ & $130^{\circ} 09 \mathrm{w}$ \\
\hline McMillan (Quartz Lake) & $\mathrm{Pb}-\mathrm{Zn}$ skam and nunte & $\mathrm{Pb}, \mathrm{Zn}_{\mathrm{n}} \mathrm{AE}$ & $60^{\circ} 30 \mathrm{~N}$ & $127 / 57 \mathrm{w}$ \\
\hline Praine Creck (Cadillac) & Pb-Zn skarn and manto & $\mathrm{Pb}, \mathrm{Zn}, \mathrm{Ag}$ & $61^{13} \mathrm{TN}$ & $124^{\circ} 48 \mathrm{~W}$ \\
\hline Sa Dena Hes (Mt. Hundere) & Pb-7n skarn and mante & $\mathrm{Pb}, \mathrm{Zn}, \mathrm{Az}$ & $60^{\circ} 31 \mathrm{~N}$ & $128^{\circ} 53 \mathrm{~W}$ \\
\hline
\end{tabular}

Tembstene Metallezenic Belt of Ag Pelymetallic Vein, Aw-Sb Vein, and W-Sh-Au Skarn and Cu Depesits (mid-Cretaceoess, Central Yuken Territery (Belt TS)

\begin{tabular}{|c|c|c|c|c|}
\hline Brewery Creek (Loki Gold) & Sb-Au vein & $A \mathrm{~A}$ & $6404 \mathrm{~N}$ & $138^{2} 14 \mathrm{~W}$ \\
\hline Craig (Tara, Nadalees Mts) & Ag polymetalike vein & $\mathrm{Pb}, \mathrm{Zn}, \mathrm{Ag}_{\mathrm{E}}, \mathrm{As}_{\mathrm{s}}$ & $6410 \mathrm{~N}$ & $133^{\prime} 22 \mathrm{~W}$ \\
\hline Keno Hill (Galena Hill) & Ag polymetalfic vein & $A_{\text {e. }} \mathrm{Pb}, \mathrm{Zn}, \mathrm{Cd}$ & $6355 \mathrm{~N}$ & $135^{\prime} 15 \mathrm{~W}$ \\
\hline Ray Gulch (Potato Hills, Mar) & W skam & w & $64027 \mathrm{~N}$ & $135^{\circ} 46 \mathrm{~W}$ \\
\hline Rusty Mountain (Ven, Val, & Ag-Pb-Zn polymetallic vein & Ag. $\mathrm{Pb}$ & $6419 \mathrm{~N}$ & $133^{\circ} 45 \mathrm{~W}$ \\
\hline
\end{tabular}
Cavey)

Castiar Metalloeenic Belt of Perphyry Mo-W; W Skarn, Zn-Pb-Ag Mante, Se Skarn, and Au Skarn Depenits (mid-Cretaceous), Seuthern Vuken Territery (Belt CA)

\begin{tabular}{|c|c|c|c|c|}
\hline IC (Viola) & Sn sam & $\mathrm{Sn}$ & $60^{1} 12 \mathrm{~N}$ & $13142 \mathrm{~W}$ \\
\hline Logan & Zn-Ag polymetallic vein & $\mathrm{Zn}_{\mathrm{n}} \mathrm{A}_{\mathrm{g}}$ & $60^{\circ} 30 \mathrm{~N}$ & $13028 \mathrm{~W}$ \\
\hline Logtung (Logjam Creek) & Porphyry W-Mo & $\mathrm{W}, \mathrm{Mo}_{\mathrm{o}}$ & $6001 \mathrm{~N}$ & $13137 \%$ \\
\hline Midway (Silver Tip) (1040 038) & $\mathrm{Pb}-\mathrm{Zn} \cdot \mathrm{A} e \mathrm{~g}$ skam and manto & Af, $\mathrm{Pb}, \mathrm{Zn}$ & $5966 \mathrm{~N}$ & $130^{\circ} 20 \mathrm{w}$ \\
\hline Risby (Cab) & $W_{3 k a m}$ & $\mathbf{w}$ & $61^{\circ} 52 \mathrm{~N}$ & $13323 \mathrm{~W}$ \\
\hline \multicolumn{5}{|c|}{ 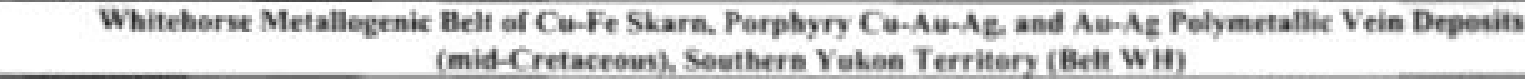 } \\
\hline Hopkins (Giltana) & Cu skam & $\mathrm{Cu}$ & $6118 \mathrm{~N}$ & $13655 \mathrm{~W}$ \\
\hline Whiteborse Copper Belt (Littie & Cu skam & $\mathrm{Cu}, \mathrm{Au}, \mathrm{Al}_{\mathrm{Z}}$ & $6037 \mathrm{~N}$ & $13503 \mathrm{w}$ \\
\hline
\end{tabular}

Bayoene Metallogenic Belt of Perphyry Me and Cu-Mo-W.7a Skarn Depesits (mid-Cretacreas). 


\begin{tabular}{|c|c|c|c|c|}
\hline Depesit Vame & Mincral Depesit Medel & Major Metals & Latitude & $\mathbf{N}$ : Longitude $\mathbf{E}, \mathbf{W}$. \\
\hline \multicolumn{5}{|c|}{ Southers British Columbia (Belt BA) } \\
\hline Boss Mountain (093A 00I) & Porphyry Mo & Mo & $5206 \mathrm{~N}$ & $120 ' 54 \mathrm{~W}$ \\
\hline $\begin{array}{l}\text { Emerald-Invincible (6825SW } \\
\text { o10) }\end{array}$ & W sam & W, Mo & $49^{\circ} 06 \mathrm{~N}$ & $117^{\prime} 14 \mathrm{~W}$ \\
\hline Mineral King & $\mathrm{Zn} \cdot \mathrm{Pb}$ skam and manto & $\mathrm{Zn}, \mathrm{Pb}, \mathrm{Ag}$ & $5020 \mathrm{~N}$ & $116^{\prime} 25 \mathrm{~W}$ \\
\hline $\begin{array}{l}\text { Phoenix-Grcettwoed District } \\
\text { (082ESE 020) }\end{array}$ & Cu-Au skarn & $\mathrm{CB}, \mathrm{AB}, \mathrm{Ag} . \mathrm{Fe}$ & $49^{\circ} 05 \mathrm{~N}$ & $118^{\circ} 36 \mathrm{~W}$ \\
\hline $\begin{array}{l}\text { Red Mountain Moly (Coxey, } \\
\text { Novelry, Nevada) (103P 086) }\end{array}$ & Moskam & Mo & $49^{\circ} 05 \mathrm{~N}$ & 117 sorw \\
\hline Trout Lake (082KN 087) & Porphyry Mo & Mo & $50^{\circ} 38^{\circ} \mathrm{N}$ & $117^{2} 36 \mathrm{~W}$ \\
\hline
\end{tabular}

EARLY LATE CRETACEOUS (Cenemanian threagh Santonian - 100 to 84 Ma)

Sergeevka Metallegenic Belt of Granitoid-Related Au Depesits (Late Cretaceous), Southern Part of Russian Southeast (Belt SG)

\begin{tabular}{|c|c|c|c|c|}
\hline Askold & Granitoid-related $\mathrm{Al}$ & $\mathrm{Au}$ & $4244 \mathrm{~N}$ & $13220 \mathrm{E}$ \\
\hline Balykovskoe & Granitoid-related Au & Au & $42^{\prime} 587 \mathrm{~N}$ & $132^{\circ} 57 \mathrm{E}$ \\
\hline Krinichnoe & Granitoid-related $\mathrm{Al}$ & $\mathrm{Au}$ & $42^{\circ} 54 \mathrm{~N}$ & $13229 \mathrm{E}$ \\
\hline Porozhistoe & Giranitoid-related $\mathrm{Al}$ & $\mathrm{Au}$ & $42^{\prime} 54 \mathrm{~N}$ & $133^{\circ} 28 \mathrm{E}$ \\
\hline Progress & Granitoid-related $\mathrm{Au}$ & An & $42^{\circ} 52 \mathrm{~N}$ & $132^{\circ} \mathrm{SOE}$ \\
\hline
\end{tabular}

Taukha Metallogenic Beit of B Skarn, Pb-Zn Skarn, Pb-Zn Polymetallic Vein, and Related Deposits (mid-Cretaceous te early Tertiary), Eastern Part of Russian Southeast (Belt TK)

\begin{tabular}{|c|c|c|c|c|}
\hline Belogorskoe & Fe skarn & $\mathrm{Fe}$ & $4352 \mathrm{~N}$ & $13512 \mathrm{E}$ \\
\hline Dalnegorsk & Boron skam & B & $44^{\circ} 29 \mathrm{~N}$ & $135^{\prime} 35 \mathrm{E}$ \\
\hline Fasolnoe & Polymetallic vein & $\mathrm{Pb}, \mathrm{Zn}_{\mathrm{n}}$ & $43^{6} 35 \mathrm{~N}$ & $134^{\circ} 42^{\circ} \mathrm{E}$ \\
\hline Krasnogorskee & $\mathrm{Pb}-\mathrm{Zn}$ polymetallic vein & $\mathrm{Pb}, \mathrm{Zn}_{\mathrm{n}}$ & $4424 \mathrm{~N}$ & $135^{\prime} 58 \mathrm{E}$ \\
\hline Lidorskoe & $\mathrm{Pb}-\mathrm{Zn}$ polymetallic vein & $\mathrm{Pb}, \mathrm{Zn}_{\mathrm{n}}$ & $44^{4} 26 \mathrm{~N}$ & $135^{2} 49 \mathrm{E}$ \\
\hline Nikolaevskoe & Pb-Zn Skarn & $\mathrm{Pb}, \mathrm{Zn}_{\mathrm{n}}$ & $44^{\circ} 35 \mathrm{~N}$ & $135^{\circ} 40 \mathrm{E}$ \\
\hline Novo-Monastyrskoe & $\mathrm{Pb}-\mathrm{Zn}$ polymetallic vein & $\mathrm{Pb}, \mathrm{Zn}_{\mathrm{n}}$ & $4421 \mathrm{~N}$ & $135^{\circ} 43 \mathrm{E}$ \\
\hline $\begin{array}{l}\text { Partizanskoe (Soviet 2, Svelliy } \\
\text { Otvod) }\end{array}$ & $\mathrm{Pb}-\mathrm{Zn}$ skam & $\mathrm{Pb}, \mathrm{Zn}_{\mathrm{n}}$ & $44^{\circ} 257 \mathrm{~N}$ & $135^{\circ} 30 \mathrm{E}$ \\
\hline Piastun & Porphyry Cu & $\mathrm{Cu}$ & $44^{\circ} 39 \mathrm{~N}$ & $136^{\prime 1} 12 \mathrm{E}$ \\
\hline Shcherbakovskoe & Polymetallic vein & $\mathrm{Pb}, \mathrm{Zn}_{\mathrm{n}}$ & $43^{\circ} 35 \mathrm{~N}$ & $13428 \mathrm{E}$ \\
\hline Soyuz & Au-Ag epishermal vein & $A E-A u$ & $43^{\prime} 25 \mathrm{~N}$ & $13420 \mathrm{E}$ \\
\hline
\end{tabular}

Kema Metallogenic Belt ef Ag-Au Epithermal Vein, and Porphyry Cu-Me Depesits

(mid-Cretaceous to early Tertiary). Eastern Part of Russian Southeast (Belt KM)

\begin{tabular}{|c|c|c|c|c|}
\hline Burmatovskoe & Au-Ag epithermal vein & An, $\mathrm{AE}$ & $4706 \mathrm{~N}$ & $13806 \mathrm{E}$ \\
\hline Glinyanoe & Au-Ag epithermal vein & $\mathrm{Au}, \mathrm{Ag}$ & $46^{6} 11 \mathrm{~N}$ & $137 / 55 \mathrm{E}$ \\
\hline Moinskoe & Porphyry Mo & Mo & $48^{\circ} 06 \mathrm{~N}$ & $138^{\prime} 38 \mathrm{E}$ \\
\hline Mopau & Porphyry Sn & Sn & $49^{\circ} 201 \mathrm{~N}$ & $13847 \mathrm{E}$ \\
\hline Nesterovskoe & Porphyry $\mathrm{Cu}$ & $\mathrm{Cu}$ & $46047 \mathrm{~N}$ & $13749 \mathrm{E}$ \\
\hline Nochnoe & Porphyry $\mathrm{Ca}$ & $\mathrm{Cu}$ & $4834 \mathrm{~N}$ & $138^{\prime} 35 \mathrm{E}$ \\
\hline Salyut & Au-Ag epithermal vein & $\mathrm{Au}, \mathrm{Al}$ & $4622 \mathrm{~N}$ & $13741 \mathrm{E}$ \\
\hline Sukhoe & Au-Ag epithermal vein & $A=A_{E}$ & $46587 \mathrm{~N}$ & I38'ort \\
\hline Sukhoi Creek & Porphyry Cu-Mo & $\mathrm{Cu}, \mathrm{Mo}$ & $48^{\prime} 12 \mathrm{~N}$ & $138^{\prime} 12 \mathrm{E}$ \\
\hline Tayozhnoe & As epithermal vein & $\mathrm{Ag}_{\mathrm{B}}$ & $45^{6} 30 \mathrm{~N}$ & $13639 \mathrm{E}$ \\
\hline Yagodnoe & Ali-Ag cpithermal vein & $A=A_{R}$ & $4709 \mathrm{~N}$ & $13855 \mathrm{E}$ \\
\hline
\end{tabular}

Luzhkinsky Metallogenic Belt of Se Greisen, Sn Polymetallie Vein, Sa silica-aulfide vein, and Perphyry Se Depesits (mid-Cretaceeus te early Tertiary). Southern Part of Russian Southeast (Belt LZ)

\begin{tabular}{|c|c|c|c|c|c|}
\hline Arsenyevskoe & Sn silicate-sulfide vein & & Sn & $4425 \mathrm{~N}$ & $13447 \mathrm{E}$ \\
\hline Dalnetayozhnoe & Sn polymetallic vein & & $\mathrm{Sn}_{\mathrm{n}} \mathrm{Pb}, \mathrm{Zn}$ & $45^{2} 40 \mathrm{~N}$ & $136^{\circ} 08 \mathrm{E}$ \\
\hline lskrs & Sn polymetallic vein & & Sn, & $4413 \mathrm{~N}$ & $13432 \mathrm{E}$ \\
\hline Khrustalnoe & Sn sillicate-sulfide vein & & Sn & $4428 \mathrm{~N}$ & $13499 \mathrm{E}$ \\
\hline Larumoe & Porphyry Ca-Mo & & $\mathrm{Cu}, \mathrm{Mo}$ & $44^{\prime} 06 \mathrm{~N}$ & $13424 \mathrm{E}$ \\
\hline Malinovskoe & Porptyry Cu & & $\mathrm{Cu}$ & $45^{\circ} 08 \mathrm{~N}$ & $135^{\circ} 02 \mathrm{E}$ \\
\hline Nizhnee & Sn polymetallic vein & & $\mathrm{Sn}, \mathrm{Pb}, \mathrm{Zn}$ & $43^{6} 37 \mathrm{~N}$ & 134ISE \\
\hline Srmimovskee & Polymetallic vein & & $\mathrm{Pb}, \mathrm{Zn}, \mathrm{Sn}$ & $4438 \mathrm{~N}$ & $13520 \mathrm{E}$ \\
\hline Tigrince & Sn-W greisen & & $\mathrm{Sn}, \mathrm{W}, \mathrm{Ta}, \mathrm{Nb}, \mathrm{In}$ & $4605 \mathrm{~N}$ & $13545 \mathrm{E}$ \\
\hline Verkhnezolotoe & Porphyry Cu & & $\mathrm{Cu}, \mathrm{Sn}$ & $4632 \mathrm{~N}$ & $13626 \mathrm{E}$ \\
\hline Vysokogorskee & So sehcate-sulfide vein & & Sn & $44^{\prime} 21 \mathrm{~N}$ & 135'10R \\
\hline Yantamoe & Porphyry Sn & & Sn & $4620 \mathrm{~N}$ & $13634 \mathrm{E}$ \\
\hline Yurehnoe & Polymetallie vein & & $\mathrm{Ph}, \mathrm{Zn}, \mathrm{Ag}$ & $4445 \mathrm{~N}$ & $135^{\prime} 21 \mathrm{E}$ \\
\hline
\end{tabular}




\begin{tabular}{|c|c|c|c|}
\hline Deposit Name & Mineral Depesit Medel & Major Metals & Latitude $\mathrm{N}$; Lengitude E, W. \\
\hline Zabytoe & W.Sn greisen & W, Sn, Bi & $45^{\prime} 39^{\circ} \mathrm{N} \quad 135^{\prime} 25^{\prime} \mathrm{E}$ \\
\hline Zarechnoe & Porphyry Cu & $\mathrm{Cu}$ & $4439 \mathrm{~N} \quad 13439 \mathrm{E}$ \\
\hline Zimnee & Sn polymetallic vein & $\mathrm{Sn}, \mathrm{Pb}, \mathrm{Zn}$ & $45^{\circ} 46^{\prime} \mathrm{N} \quad 135^{\prime} 58^{\prime} \mathrm{E}$ \\
\hline Zverdnoe & Porphyry Sn & Sn & $4610 \mathrm{~N} \quad 13630 \mathrm{E}$ \\
\hline
\end{tabular}

Lower Amur Metallogenic Belt of Au-Ag Epithermal Vein, Porphyry Cu, and Sn Greisen Deposits (mid-Cretaceous to early Tertiary), Northern Part of Russian Southeast (Belt L.A)

\begin{tabular}{llll}
\hline Belaya Gora & Au-Ag epithermal Vein & $\mathrm{Au}, \mathrm{Ag}$ & $53^{\circ} 23^{\prime} \mathrm{N} 140^{\circ} 14^{\prime} \mathrm{E}$ \\
Bichinskoe & $\mathrm{Sn}$ greisen & $\mathrm{W}, \mathrm{Sn}$ & $52^{\circ} 32^{\prime} \mathrm{N} 139^{\circ} 32^{\circ} \mathrm{E}$ \\
Bukhtyanskoe & $\mathrm{Au}-\mathrm{Ag}$ epithermal vein & $\mathrm{Au}, \mathrm{Ag}$ & $53^{\circ} 03^{\prime} \mathrm{N} 140^{\circ} 29^{\prime} \mathrm{E}$ \\
Mnogowershinoe & $\mathrm{Au}-\mathrm{Ag}$ epithermal vein & $\mathrm{Au}, \mathrm{Ag}$ & $53^{\circ} 53^{\prime} \mathrm{N} 139^{\circ} 48^{\circ} \mathrm{E}$ \\
Tyrskoe & Porphyry Cu & $\mathrm{Cg}$ & $52^{\circ} 57^{\prime} \mathrm{N} 140^{\circ} 27^{\prime} \mathrm{E}$ \\
\hline
\end{tabular}

Aniva-Nabil Metallogenic Belt of Veleanegenic Mn and Fe and Cyprus Massive Sulfide Deposits (Late Cretaceous), Eastern Part of Russian Seutheast (Belt LA)

\begin{tabular}{|c|c|c|c|c|}
\hline Bereznyakovskoe & Volcanogenic $\mathrm{Mn}$ & $\mathrm{Mn}$ & $4704 \mathrm{~N}$ & $142 \overline{56} \mathrm{E}$ \\
\hline Lyukamskoe & Volcanogenic $\mathrm{Mn}$ & $\mathrm{Mn}$ & $49^{\circ} 58^{\prime} \mathrm{N}$ & $143^{4} 35^{\prime} \mathrm{E}$ \\
\hline Novikovskoe & Cyprus massive sulfide(?) & $\mathrm{Cu}, \mathrm{Zn}, \mathrm{Pb}$ & $4618 \mathrm{~N}$ & $143^{\circ} 26^{\prime} \mathrm{E}$ \\
\hline Rys'e & Cyprus massive sulfide & $\mathrm{Ca}, \mathrm{Pb}, \mathrm{Zn}$ & $49^{+} 31 \mathrm{~N}$ & $144^{\circ} 01 ' \mathrm{E}$ \\
\hline
\end{tabular}

Koryak Highlands Metallogenic Belt of Zoned Mafic-Ultramafic PGE Deposits (Upper Cretaceous) East-Central Part of Russian Northeast (Belt KH)

\begin{tabular}{|c|c|c|c|c|}
\hline Karagin group & Gabbroic $\mathrm{Cu}$ & $\begin{array}{l}\mathrm{Cu}, \mathrm{Zn}, \mathrm{Au}, \mathrm{Pt}, \mathrm{Ni}, \\
\mathrm{Co}\end{array}$ & $58^{2} 52^{7} \mathrm{~N}$ & $164^{\prime} 02^{\prime} \mathrm{E}$ \\
\hline Snerhnoe & Zoned mafic-ulitramafic $\mathrm{Cr}$-PGE & Cr. PGE & $61^{\circ} 37 \mathrm{~N}$ & $17139 \mathrm{E}$ \\
\hline Galmeonsky-Seinavsky & Alaskan PGE & PGE, $\mathrm{Cr}$ & $61^{\prime} 34 \mathrm{\prime}$ & $16605 \mathrm{E}$ \\
\hline \multicolumn{5}{|c|}{$\begin{array}{l}\text { Vatyn Metallogeaic Belt of Voleanogenic Mn and Fe Deposits (Early Cretaceous), } \\
\text { Southeastern Part of Russian Northeast (Belt VT) }\end{array}$} \\
\hline Itchayvayam & Volcanogenic $\mathrm{Mn}$ & $\mathrm{Mn}$ & $61241 \mathrm{~N}$ & $17220 \mathrm{E}$ \\
\hline \multicolumn{5}{|c|}{$\begin{array}{c}\text { Degdo-Erikit Zone (Eastern Asia-Arctic Metallogenic Belt) of Au-Ag Epithermal Vein, Sn-polymetallic vein } \\
\text { (Southern Bolivian type?), and Velcanic-Hosted } \mathrm{Hg} \text { (Plamennoe type) Deposits (Late Cretaceous and early Tertiary) } \\
\text { West-Central Part of Russian Nertheast (Belt EADE) }\end{array}$} \\
\hline Dogdo & Volcanic-hossed $\mathrm{Hg}$ & $\mathrm{Hg}$ & $6721 \mathrm{~N}$ & $13927 \mathrm{E}$ \\
\hline Kysylga & Au-Ag epithermal vein & $\mathrm{Au}, \mathrm{Ag}$ & $6733 \times \mathrm{N}$ & $13755 \mathrm{E}$ \\
\hline Shirokoe & Au-Ag epithermal vein & $\mathrm{Au}, \mathrm{Ag}$ & $65^{\prime} 36^{\prime} \mathrm{N}$ & 14433'E \\
\hline Solkuchan (Khatys) & Sn polymetallic vein & $\mathrm{Ag}, \mathrm{Sn}$ & $65^{\prime} 15^{\prime} \mathrm{N}$ & $143^{\prime} 51 \mathrm{E}$ \\
\hline Tikhon & Au-Ag epithermal vein & $\mathrm{Ag}, \mathrm{Au}$ & $6548 \mathrm{~N}$ & $143^{\prime} 27 \mathrm{E}$ \\
\hline
\end{tabular}

Okhotsk Zone (Eastern Asia-Aretic Metallogenic Belt) of Au-Ag Epithermal Vein Deposits (mainly Late Cretaceous and early Tertiary), Southeastern Part of Russian Northeast (Belt EAOH)

\begin{tabular}{|c|c|c|c|c|}
\hline Agat & Au-Ag epithermal vein & $\mathrm{Au}, \mathrm{Ag}$ & $60^{\circ} 587 \mathrm{~N}$ & $150^{\circ} 53^{\prime} \mathrm{E}$ \\
\hline Aldigych & Ad-Ag epithermal vein & $\mathrm{Au}, \mathrm{Ag}$ & $62^{\prime} 19 \cdot \mathrm{N}$ & $159^{\circ} 58^{\circ} \mathrm{E}$ \\
\hline Burgagylkan & Au-Ag epithermal vein & $\mathrm{Au}, \mathrm{Ag}$ & $60^{\circ} 38 \mathrm{~N}$ & $146^{\circ} 45^{\prime} \mathrm{E}$ \\
\hline Drucbak & Au-Ag epithermal vein & $\mathrm{Ag}, \mathrm{Au}$ & $62^{\circ} 60 \mathrm{~N}$ & $160^{\circ} 03^{\prime} \mathrm{E}$ \\
\hline Evenskoe & Au-Ag epithermal vein & $\mathrm{Au}, \mathrm{Ag}$ & $62^{\circ} 32^{\prime} \mathrm{N}$ & $159^{*} 45^{\prime} \mathrm{E}$ \\
\hline Irbychan & Au-Ag epithermal vein & $\mathrm{Au}, \mathrm{Ag}$ & $62^{\circ} 41 \times \mathrm{N}$ & $159^{\circ} 55{ }^{\prime} \mathrm{E}$ \\
\hline Julietta & Au-Ag epithermal vein & $\mathrm{Aul}, \mathrm{Ag}$ & $61^{+} 100 \mathrm{~N}$ & $153^{\circ} 59 \mathrm{E}$ \\
\hline Karamken & Au-Ag epithermal vein & $\mathrm{Au}, \mathrm{Ag}$ & $60^{\circ} 14 \mathrm{~N}$ & $150^{\circ} 60 \mathrm{FE}$ \\
\hline Kegali & Au-Ag epithermal vein & $\mathrm{Au}, \mathrm{Ag}$ & $6323 \mathrm{~N}$ & $161^{\circ} 42^{\prime} \mathrm{E}$ \\
\hline Khakandzhinskoe (Khakandzha) & Au-Ag epithermal vein & $\mathrm{Au}, \mathrm{Ag}$ & $60^{\circ} 02^{\prime} \mathrm{N}$ & $14236 \mathrm{E}$ \\
\hline Kinzhal & Sn silicate-sulfide vein & Sn & $62^{4} 17 \mathrm{~N}$ & $151^{\circ} 58 \mathrm{E}$ \\
\hline Kolkhida & Au-Ag epithermal vein & $\mathrm{Ag}, \mathrm{Au}, \mathrm{Sn}$ & $6037 \mathrm{~N}$ & $15127 \mathrm{VE}$ \\
\hline Krasivoe & Au-Ag epithermal vein & $\mathrm{Au}, \mathrm{Ag}$ & $59^{7} 28 \mathrm{~N}$ & $140^{\circ} 22^{\prime} \mathrm{E}$ \\
\hline Maltan Stock & Granitoid-related Au & $\mathrm{Au}, \mathrm{Bi}, \mathrm{Te}$ & $61^{\circ} 281 \mathrm{~N}$ & $150^{\circ} 52^{\prime} \mathrm{E}$ \\
\hline Nevenrekan & Au-Ag epithermal vein & Ats, Ag & $62^{\circ} 14 \mathrm{~N}$ & $159^{\circ} 1 I^{\prime} \mathrm{E}$ \\
\hline Oira & At-Ag epithermal vein & $\mathrm{Au}, \mathrm{Ag}$ & $60^{\circ} 09^{\prime} \mathrm{N}$ & $149^{\circ} 45^{\prime} \mathrm{E}$ \\
\hline Olyndja & Au-Ag epithermal wein & $\mathrm{Ag}, \mathrm{Au}$ & $62^{\circ} 26^{\prime} \mathrm{N}$ & $15735 \mathrm{E}$ \\
\hline Senon, Utro, Serebryanoe & $\begin{array}{l}\text { Epithermal vein and volcanic- } \\
\text { hosted Sb vein }\end{array}$ & $\mathrm{Ag}, \mathrm{Au}, \mathrm{Sb}$ & $60^{\circ} 40 \mathrm{~N}$ & $148^{\circ} 05^{\circ} \mathrm{E}$ \\
\hline Sentyabr & Au-Ag epithernal vein & $\mathrm{Ag}_{3} \mathrm{Au}$ & $60^{\circ} 44 \mathrm{~N}$ & $149^{\circ} 22^{\prime} \mathrm{E}$ \\
\hline Skamovoe & $\mathrm{Ph}-\mathrm{Zn}-\mathrm{Ag}_{\mathrm{g}}$ skam & $\mathrm{Zn}, \mathrm{Pb}, \mathrm{Ag}$ & $60^{\circ} 46^{\prime} \mathrm{N}$ & $150^{\circ} 38^{\circ} \mathrm{E}$ \\
\hline Spitidonyeh, Teply & Au-Ag epithermal wein & Au, Ag & $61^{\prime \prime} 200 \mathrm{~N}$ & $156^{\circ} 17 \mathrm{TE}$ \\
\hline Utessnoe & Au-Ag epithermal vein & $\mathrm{Ag}, \mathrm{Au}, \mathrm{Hg}$ & $60^{\circ} 26^{\prime} \mathrm{N}$ & $150^{\circ} 41^{\prime} \mathrm{E}$ \\
\hline Verkhnenyotskoe & Au-Ag epithermal vein & Alt, $\mathrm{Ag}$ & $58^{\circ} 17 \mathrm{~N}$ & $139^{\circ} 06 \mathrm{E}$ \\
\hline
\end{tabular}




\begin{tabular}{|c|c|c|c|c|}
\hline Depesit Name & Mineral Depesit Medel & Major Metals & \multicolumn{2}{|c|}{ Latitude $\mathbf{N}$; Longitude E, W. } \\
\hline Vetvisty & Au-Ag epithermal vein & At. $\mathrm{Au}$ & $6207 \mathrm{~N}$ & 15208'E \\
\hline Yurievka & Au-As epithermal vein & Ali. Ag & $5941 \mathrm{~N}$ & $141^{\prime} 44 \mathrm{E} E$ \\
\hline \multicolumn{5}{|c|}{ Keni-Yablon Zene (Eastern Asia-Arctic Metallogenic Belt) of Porpbyry Cu-Me and Cu-Me Skarn Depesits (Cretaceous) } \\
\hline \multicolumn{5}{|c|}{ Southern Part of Russian Nertheast (Belt EAKY) } \\
\hline Betczovogor & Au-Ag epithermal vein & $\mathrm{Au}, \mathrm{Ag}, \mathrm{Pb}$ & $65^{\prime} 50^{\prime} \mathrm{N}$ & $170^{\circ} 08^{\prime} \mathrm{E}$ \\
\hline Etandzha & Porphyry Cu-Mo & $\mathrm{Co}, \mathrm{Mo}$ & $5729 \mathrm{~N}$ & $138^{\prime} 39^{\prime} \mathrm{E}$ \\
\hline Gona Krassnaya & Porphyry Cu-Mo & $\mathrm{Mo}, \mathrm{Cu}_{4} \mathrm{Au}$ & $6635 \mathrm{~N}$ & $17531 \mathrm{E}$ \\
\hline Guan-Ti (Arkhimed) & Porphyry Mo & $\mathrm{Mo}, \mathrm{W}$ & $61^{\prime \prime} 30^{\prime} \mathrm{N}$ & $\left|43^{\prime} s\right|^{\prime} \mathrm{E}$ \\
\hline Ikrimuan & Porphyry Cu-Mo & $\mathrm{Cu} . \mathrm{Mo}$ & $59^{\circ} 21 \mathrm{~N}$ & $146^{4} 59 \mathrm{tg}$ \\
\hline Irgunei & Au-As epithermal vein & $\mathrm{Au}, \mathrm{Ag}$ & $64^{\prime} 42 \mathrm{~N}$ & $166^{\prime} 50^{\prime} \mathrm{E}$ \\
\hline Khakandya & Porphyry Mo & Mo & $60^{\prime} 49^{\prime} \mathrm{N}$ & $153^{\prime} 32 \mathrm{E}$ \\
\hline Lastochka & Mo greisen and vein & Mo & $64^{\circ} 32 \mathrm{~N}$ & $165^{\circ} 07 \mathrm{E}$ \\
\hline Maly Komui & Cu skam & $\mathrm{Cu}$ & $5723 \mathrm{~N}$ & $137^{\prime} 32 \mathrm{E}$ \\
\hline Molybdenitovy & Porphyry Mo & Mo & $61^{\circ} 33 \mathrm{~N}$ & $142^{\prime} 59^{\prime} \mathrm{E}$ \\
\hline Nakhtandjin, Lora & Porphyry $\mathrm{Cu}$ & $\mathrm{Cu}$ & $59^{\prime} 25 \mathrm{~N}$ & $153^{\prime 2} 29 \mathrm{E}$ \\
\hline Nyavlenga & Au-Ag epithernal vein & $\mathrm{Au}_{\mathrm{i}} \mathrm{Ag}$ & $60^{\circ} 44 \mathrm{~N}$ & $153^{\circ} 28^{\prime} \mathrm{E}$ \\
\hline Osennee, Oksa, Usinskoe & Porphyry Cu-Mo & $\mathrm{Mo}, \mathrm{Cu}$ & $59^{\circ} 44 \mathrm{~N}$ & $150^{\circ} 16 \mathrm{E}$ \\
\hline Sergeev & Au-Ag epithermal vein & $\mathrm{Au}, \mathrm{Ag}$ & $63^{\prime} 52 \mathrm{~N}$ & $165^{\circ} 41^{\prime} \mathrm{E}$ \\
\hline Serovskoe & Au-Ag epithermal vein & $\mathrm{Au}, \mathrm{AB}$ & $65^{\prime} 17 \mathrm{~N}$ & $169^{\circ} 00^{\prime} \mathrm{E}$ \\
\hline Tikas & Porphyry Mo & Mo & $61^{\circ} 407 \mathrm{~N}$ & $161^{\circ} 211^{\prime} \mathrm{E}$ \\
\hline Travka & Porphyry Mo & Mo & $6448 \mathrm{~N}$ & $168^{\circ} 36 \mathrm{E}$ \\
\hline Tsirkovy & Granitoid-related $\mathrm{As}$ & $\mathrm{Au}, \mathrm{Ag}, \mathrm{Cu}, \mathrm{W}, \mathrm{Bi}$ & $6333 \mathrm{~N}$ & $165^{\circ} 07 \mathrm{E}$ \\
\hline Uralskoe & Volcanic-hosted $\mathrm{Hg}$ & $\mathrm{Hg}, \mathrm{Sb}, \mathrm{Au}, \mathrm{Ag}$ & $6628 \mathrm{~N}$ & $166^{\prime} 48^{\prime} \mathrm{E}$ \\
\hline Viking & Porphyry Cu-Mo & $\mathrm{Cu}, \mathrm{Mo}$ & $58^{\prime} 58 \mathrm{~N}$ & $152^{\prime} 34 \mathrm{E}$ \\
\hline Yapon & Porphyry $\mathrm{Cu}$ & $\mathrm{Cu}$ & $5925 \mathrm{~N}$ & $154^{\circ} 52 \mathrm{E}$ \\
\hline
\end{tabular}

Korkoden-Nayakhan Zone (Eastera Asia-Aretic Metallegenic Belt) of Perphyry Me asd Graniteid-Related At Depesits (Late Cretaceous), East-Central Part of Russian Northeast (Blelt EAKN)

\begin{tabular}{|c|c|c|c|c|}
\hline Khetagchan & Granitoid-related $\mathrm{Au}$ & $\mathrm{Au}, \mathrm{W}, \mathrm{Bi}$ & $6324 \mathrm{~N}$ & $15704 \mathrm{E}$ \\
\hline Orlinoe & Porphyry Mo & Mo & $6235 \mathrm{~N}$ & $157^{\prime} 16^{\prime} \mathrm{E}$ \\
\hline Sedoi & $\begin{array}{l}\mathrm{Ag}-\mathrm{Co} \text { arsenide vein and } \mathrm{Fe}-\mathrm{Pb} \text { - } \\
\mathrm{Cu} \mathrm{Ag} \text {-Au skarn }\end{array}$ & $\mathrm{Ag} \mathrm{Co}_{0}$ & $63^{\circ} 49 \mathrm{~N}$ & $158^{\circ} 25 \mathrm{E}$ \\
\hline Skarn & $\mathrm{Fe}( \pm \mathrm{Au}, \mathrm{Cu}, \mathrm{W}, \mathrm{Sn})$ skam & Fe & $63^{\circ} 29 \% \mathrm{~N}$ & $15832 \mathrm{E}$ \\
\hline Verkhny-Koargychan & Au-Ag Polymetallic vein & $\mathrm{Au}, \mathrm{Ag}, \mathrm{Pb}, \mathrm{Zn}$ & $63^{\circ} 07 \mathrm{~N}$ & $159^{\circ} 19^{\circ} \mathrm{E}$ \\
\hline
\end{tabular}

Verkhne-Kelyma Zone (Eastern Asia-Arctic Metallogenie Beit) of Sn-Ag Pelymetallie Vein, (Seuthera Belivian type). Sn Polymetallic Vein, Rhyolite-Hested Sn, and Graniteid-Related Au Depesits (Cretaceous). Southeastern Part of Ressian Nertheast (Belt EAVK)

\begin{tabular}{|c|c|c|c|c|}
\hline Aida & Au-Ag epithermal vein & $A_{\mathrm{E}}, A_{u}$ & $6336 \mathrm{~N}$ & 14401E \\
\hline Baryllyelakh-Tsentralny & Sn polymetallic vein & $\mathrm{Sn}, \mathrm{Ar}$ & $6326 \mathrm{~N}$ & $143^{\circ} 45 \mathrm{E}$ \\
\hline Bogatyr & Sn silicate-sulfide vein & Sn & $61^{\circ} 027 \mathrm{~N}$ & $14555 \mathrm{~F}$ \\
\hline Bulungs & $\mathrm{Pb}-\mathrm{Zn}-\mathrm{Ag}$ vein or skarn & $\mathrm{Pb}, \mathbf{Z a}, \mathrm{Ag}_{\mathrm{g}}$ & $62^{\prime} 18 \mathrm{~N}$ & $14542 \mathrm{E}$ \\
\hline Dneprov & $\begin{array}{l}\text { Sn silicate-sulfide vein and Sn } \\
\text { greisen }\end{array}$ & Sn & $61^{\circ} 20 \mathrm{~N}$ & $151^{\circ} 36 \mathrm{E}$ \\
\hline Kandychan & Sn polymetallic vein & $\mathrm{Sn}, \mathrm{Ag}_{\mathrm{g}}$ & $60^{\circ} 36 \mathrm{~N}$ & $15020 \mathrm{E}$ \\
\hline Kharan & Se polymetallic vein & Sn & $61^{\prime} 56 \mathrm{~N}$ & I46'03E \\
\hline Khenilandja & $\begin{array}{l}\text { Sn silicate-sulfide and Sa } \\
\text { polymetallic vein }\end{array}$ & Sn & $61^{\circ} 497$ & $14631 \mathrm{E}$ \\
\hline Kheta & Sn polymetallic vein & $\begin{array}{l}\mathrm{Sn}, \mathrm{Zn}, \mathrm{Pb}, \mathrm{Ca}, \mathrm{Bi}_{i} \\
\mathrm{As}_{\mathrm{g}}\end{array}$ & $61^{\circ} 06 \mathrm{~N}$ & IS1'47E \\
\hline Khuren & Sn polymetallic vein & Sn & $60^{\circ} 54 \mathrm{~N}$ & I47'IOFE \\
\hline Kuranakh-Sala & Sn silicate-sulfide vein & Sn & $6303 \mathrm{~N}$ & $14419 E$ \\
\hline Kyurbelykh & $\begin{array}{l}\text { Sn silicate-sulfide vein and Sn } \\
\text { polymetallic vein }\end{array}$ & Sn & $6246 \mathrm{~N}$ & $14529 \mathrm{E}$ \\
\hline Netchen-Khaya & Granitoid-related Au & $\mathrm{Al}, \mathrm{Mo}, \mathrm{Bi}$ & $61^{\circ} 42 \mathrm{~N}$ & $151^{\circ} 32 \mathrm{E}$ \\
\hline Ossolonyn & Sn greisen & Sa & $61^{\prime} 43 \mathrm{~N}$ & I53'19E \\
\hline Porozhistoe & Sin polymetallic vein & Sn & $61736 \mathrm{~N}$ & $14628 \mathrm{E}$ \\
\hline Shkolnoe & Granitoid-related Au & $\mathrm{A}=$ & $61^{\prime} 28 \mathrm{~N}$ & $14848 \mathrm{E}$ \\
\hline Suvorov & Rhyolite-hosted Sn & Sin & $61^{\circ} 007 \mathrm{~N}$ & I52'09E \\
\hline Svetloe & Sn polynnetallic vein & Sin & $60^{\circ} 46 \mathrm{~N}$ & $150^{\circ} 16 \mathrm{E}$ \\
\hline Tankist & Porphyry Mo & Mo & $6121 \mathrm{~N}$ & $147.56 \mathrm{E}$ \\
\hline Tektonicheskoe & $\mathrm{Pb}-\mathrm{Zn}-\mathrm{Ag}$ vein & $\mathrm{Pb}, \mathrm{Zn}, \mathrm{Az}, \mathrm{Sn}$ & $6226 \mathrm{~N}$ & $14515 \mathrm{E}$ \\
\hline Tigrets-industriya & Sn polymetallic vein & $\mathrm{Sn}, \mathrm{Ag}, \mathrm{Pb}, \mathrm{Zn}$ & $62^{\prime} 16 \mathrm{~N}$ & $14631 \mathrm{E}$ \\
\hline
\end{tabular}




\begin{tabular}{|c|c|c|c|c|}
\hline Deposit Name & Mineral Depesit Model & Major Metals & \multicolumn{2}{|c|}{ Latitude N; Lengilude E, W. } \\
\hline $\begin{array}{l}\text { Verkhne-Seimkan } \\
\text { Zerkalnoe }\end{array}$ & $\begin{array}{l}\text { Co-Bi-As vein } \\
\text { Au-Ag epithermal vein }\end{array}$ & $\begin{array}{l}\mathrm{Co}, \mathrm{Bi} \\
\mathrm{Au}, \mathrm{Ag}, \mathrm{Bi}, \mathrm{Te}\end{array}$ & $\begin{array}{l}60^{2} 31 \mathrm{~N} \\
60^{\prime} 58^{\prime} \mathrm{N}\end{array}$ & $\begin{array}{l}149^{\circ} 60^{\prime} \mathrm{E} \\
151^{\circ} 10 \% \mathrm{E}\end{array}$ \\
\hline \multicolumn{5}{|c|}{$\begin{array}{l}\text { Vostechno-Verkhoyansk Zone (Eastern Asis-Aretic metallogenic belt) of Ag Polymetallic Vein Deposits } \\
\text { (Late Cretaceous and early Tertiary), West-Central Part of Russian Northeast (Belt EAVV) }\end{array}$} \\
\hline Altaiskoe & Ag polymetallic vein & $\mathrm{Pb}, \mathrm{Zn}, \mathrm{Ag}$ & $6301 \mathrm{~N}$ & $14043^{\prime} \mathrm{E}$ \\
\hline Bezymyannoe & Ag polymetallic vein & $\mathrm{Ag}, \mathrm{Pb}$ & $65^{\prime} 39 \mathrm{~N}$ & $13036 \mathrm{E}$ \\
\hline Imtachan & Sn polymetallic vein & $\mathrm{Pb}, \mathrm{Zn}, \mathrm{Sn}$ & $62577 \mathrm{~N}$ & $13944 \mathrm{E}$ \\
\hline Kuolanda & Ag polymetallic vein & $\mathrm{Pb}, \mathrm{Zn}, \mathrm{Ag}$ & $6711 \mathrm{~N}$ & $127^{\prime} 45 ' \mathrm{E}$ \\
\hline Mangazeika & Ag polymetallic vein & $\mathrm{Pb}, \mathrm{Ag}$ & $6546 \mathrm{~N}$ & $130^{-1} 35 \mathrm{E}$ \\
\hline Prognoz & Ag polymetallic vein & $\mathrm{Ag}, \mathrm{Pb}$ & $65^{\circ} 41^{\prime} \mathrm{N}$ & $13329 \mathrm{E}$ \\
\hline Verkhnee Menkeche & A\& polymetallic vein & $\mathrm{Pb}, \mathrm{Zn}, \mathrm{Ag}$ & $6256 \mathrm{~N}$ & $13927 \mathrm{TE}$ \\
\hline \multicolumn{5}{|c|}{$\begin{array}{l}\text { Adycha-Taryn Zene (Eastern Asia-Arctic Metallogenic Belt) of Clastic Sediment-Hosted Sb-Au, Au-Ag Epithermal Vein, } \\
\text { and Ag-Sb Polymetallic Vein Deposits (Cretaceous and early Tertiary), Western Part of Russian Northeast (Belt EAAT) }\end{array}$} \\
\hline Ak-Altyn & $\mathrm{Au}-\mathrm{Ag}$ epithermal vein & Av & $67^{\circ} 02^{\prime} \mathrm{N}$ & $133^{\circ} 60 \mathrm{E}$ \\
\hline Billyakh & Au-Sb polymetallic vein & $\mathrm{Sb}, \mathrm{Au}$ & $6735 \times \mathrm{N}$ & $13406 \mathrm{E}$ \\
\hline Maltan & Sb-Au vein & $\mathrm{Au}, \mathrm{Sb}$ & $6403 \mathrm{~N}$ & $143^{*} 19 \% \mathrm{E}$ \\
\hline Sarylakh & Sh-Au vein & $\mathrm{Au}, \mathrm{Sb}$ & $6417 \mathrm{~N}$ & $142^{\circ} 46^{\prime} \mathrm{E}$ \\
\hline Sentachan & $\begin{array}{l}\text { Sb-Au vein or clastic sediment- } \\
\text { hosted Sb-Au }\end{array}$ & $\mathrm{Sb}$ & $66^{\prime 2} 29 \mathrm{~N}$ & $137^{\circ} 03 \mathrm{E}$ \\
\hline Uziovoe & $\begin{array}{l}\text { Sb-Au vein or clastic sediment- } \\
\text { hosted Sb-Au }\end{array}$ & $\mathrm{Au}, \mathrm{Sb}$ & $66^{\circ} 06^{\prime} \mathrm{N}$ & $137^{\circ} 48 \mathrm{E}$ \\
\hline \multicolumn{5}{|c|}{$\begin{array}{l}\text { Omsukehan Zone (Eastern Asia-Aretic Metallogenic Belt) of Sn Polymetallic Vein, Sn Silicate-Sulfide, Porphyry Sn, } \\
\text { Ag Epithermal Vein, Porphyry Mo-Cu, and Associated Deposits (Late Cretaceous) } \\
\text { Southeastern Part of Russian Northeast (Belt EAOM) }\end{array}$} \\
\hline Arylakh & Au-Ag epithermal vein & $\mathrm{Ag}, \mathrm{Au}$ & $63^{\circ} 08^{\prime} \mathrm{N}$ & $154^{\circ} 58^{\circ} \mathrm{E}$ \\
\hline Dukat & Au-Ag epithermal vein & $\mathrm{Ag}, \mathrm{Au}$ & $62^{\circ} 36^{\prime} \mathrm{N}$ & $155^{\circ} 11 \mathrm{E}$ \\
\hline Egorlyk & Sn silicate-sulfide vein & $\mathrm{Sn}$ & $6327 \mathrm{~N}$ & $154^{\circ} 55 \mathrm{E}$ \\
\hline Elombal, Yakor & Sb-Au vein? & Au, As, Sb & $67^{\circ} 45 \mathrm{~N}$ & $165^{\circ} 27 \mathrm{E}$ \\
\hline Galimoe & Sn silicate-sulfide vein & $\mathrm{Sn}, \mathrm{Ag}$ & $6221 \mathrm{~N}$ & $155^{\circ} 49 \mathrm{E}$ \\
\hline Ircha & Porphyry Sn & $\mathrm{Sn}, \mathrm{Ag}$ & $61^{\circ} 511 \mathrm{~N}$ & $155^{\circ} 39 \mathrm{E}$ \\
\hline Khataren-Industrial & Sn silicate-sulfide vein & $\mathrm{Sn}$ & $62^{\circ} 33 \mathrm{~N}$ & $155^{\circ} 34^{\prime} \mathrm{E}$ \\
\hline Maly Ken & Sn polymetallic vein & $\mathrm{Sn}, \mathrm{Ag}$ & $62^{\circ} 44^{\prime} \mathrm{N}$ & $15460 \mathrm{E}$ \\
\hline Mechta & $\begin{array}{l}\mathrm{Ag}-\mathrm{Pb}-\mathrm{Zn} \text { vein, Polymetallic } \\
\text { vein(?) }\end{array}$ & $\mathrm{Ag}, \mathrm{Pb}, \mathrm{Zn}$ & $62^{4} 48 \mathrm{~N}$ & $155^{\circ} 05^{\prime} \mathrm{E}$ \\
\hline Nevskoe & Porphyry Sa & $\mathrm{Sn}, \mathrm{W}, \mathrm{Se}$ & $62^{\circ} 16^{\prime} \mathrm{N}$ & $155^{\prime} 26 \mathrm{E}$ \\
\hline Novy Djagyn & Porphyry Sn & $\mathrm{Sn}$ & $62^{\circ} 48 \mathrm{~N}$ & $155^{*} 25 \mathrm{~K}$ \\
\hline Okhotnichie & Sn silicate-sulfide vein & $\mathrm{Sn}$ & $62^{\circ} 04^{\prime} \mathrm{N}$ & $155^{\circ} \mid 4^{\prime} \mathrm{E}$ \\
\hline Podgomoe & Au-Co-As vein & $\mathrm{Au}, \mathrm{Co}, \mathrm{Bi}, \mathrm{Te}$, (As) & $62^{\circ} 377^{\prime} \mathrm{N}$ & $155^{\circ} 48^{\circ} \mathrm{E}$ \\
\hline Rogovik & Au-Ag epithermal vein & $\mathrm{Ag}, \mathrm{Au}$ & $64^{4} 18 \mathrm{~N}$ & $153^{4} 58^{\prime} \mathrm{E}$ \\
\hline Tidit & $\begin{array}{l}\mathrm{Ag}-\mathrm{Pb}-\mathrm{Zn} \text { vein, Polymetallic } \\
\text { vein(?) }\end{array}$ & $\mathrm{Ag}, \mathrm{Pb}, \mathrm{Zn}$ & $62^{\circ} 51 \mathrm{~N}$ & $155^{*} 1 I^{\prime} \mathrm{E}$ \\
\hline Trood & Sn polymetallic vein & $\mathrm{Sn}, \mathrm{Pb} \mathrm{Zn}_{\mathrm{n}} \mathrm{Ag}$ & $6204 \mathrm{~N}$ & $155^{\circ} 42^{\prime} \mathrm{E}$ \\
\hline
\end{tabular}

\begin{tabular}{|c|c|c|c|c|}
\hline \multicolumn{5}{|c|}{$\begin{array}{l}\text { Chokurdak Metallogenic Belt of Granitoid-Related Sn Greisen, Sn-Polymetallic Vein, Sn Greisen, and } \\
\text { u-Ag Epithermal Vein Depesits (Early and mid-Cretaceous), Northern Part of Russian Northeast (Belt CD) }\end{array}$} \\
\hline Chokurdakh & $\begin{array}{l}\text { Sn silicate toumaline, Sn } \\
\text { silicate-sulfide vein }\end{array}$ & $\mathrm{Sn}$ & $72^{\prime} 144^{\prime} \mathrm{N}$ & $140^{\circ} 18 \mathrm{E}$ \\
\hline Churpunnya & Sn silicate-sulfide vein & Sn & $7106 \mathrm{~N}$ & $141^{\circ} 43^{\prime} \mathrm{E}$ \\
\hline Depunatskoe & Sn polymetallic vein(?) & $\mathrm{Sn}$ & $69^{\circ} 15^{\prime} \mathrm{N}$ & $139^{\circ} 58^{\prime} \mathrm{E}$ \\
\hline Djaktardakh & Sn polymetallic vein & Sn & $69^{\circ} 10 \mathrm{~N}$ & $141^{\prime \prime 20 E}$ \\
\hline Khomustak & Sn greisen & Sn & $70^{\circ} 05^{\prime} \mathrm{N}$ & $152^{\circ} 28^{\prime} \mathrm{E}$ \\
\hline Odinokoe & Sn greisen & Sn & $69^{\circ} 42^{\prime} \mathrm{N}$ & $142^{\circ} 01 \mathrm{E}$ \\
\hline Pavel-Chokhchurskoe & Si polymetallic vein and greisen & $5 n$ & $70^{\prime \prime} 10 \mathrm{~N}$ & $140^{\circ} 48^{\prime} \mathrm{E}$ \\
\hline Primorskoe & Sn polymetallic vein & Sn & $69^{\circ} 566^{\prime} \mathrm{N}$ & $153^{\prime} 22 \mathrm{E}$ \\
\hline Sigilyakh & Sn silicate-sulfide vein & Sn & $69^{\circ} 547 \mathrm{~N}$ & $13647 \mathrm{E}$ \\
\hline Ukachilkan & Sn polymetallic vein & Sn & $69^{\circ} 55^{\prime} \mathrm{N}$ & $139^{\circ} 19 \mathrm{E}$ \\
\hline Yuzhnoce & Polymetallic vein & $\mathrm{Pb}, \mathrm{Zn}$ & $69^{\circ} 311 \mathrm{~N}$ & $150^{\circ} 42^{\prime} \mathrm{E}$ \\
\hline
\end{tabular}


Chaun Zoae (Eastern Asia-Aretic Metallegenic Belt) of Granitic-Magmatism-Related Depesits (Late Cretaceous) Northeastern Part of Russian Northeast (Beit E.ACN)

\begin{tabular}{|c|c|c|c|c|}
\hline Barin & $\begin{array}{l}\text { Ag polymetallic vein and } \\
\text { replacement }\end{array}$ & $\mathrm{Ag}, \mathrm{Zn}$ & $6622 \mathrm{~N}$ & $172^{\prime} 04^{\prime} \mathrm{W}$ \\
\hline Chechekuyum & Pb-Zn skam & $\mathrm{Pb}, \mathrm{Zn}, \mathrm{Cu}_{4} \mathrm{Ni}$ & $6436 \mathrm{~N}$ & $172^{\circ} 45 \mathrm{~W}$ \\
\hline Diontover & Sn polymetallie vein & Sn & $65^{\circ} 40 \mathrm{~N}$ & $174^{\circ} 06 \mathrm{~W}$ \\
\hline Ekus & Porphyry Sn or Sn greisen & Sn, W & $67^{\prime} 34 \mathrm{~N}$ & $178^{\circ} 04^{\circ} \mathrm{W}$ \\
\hline Elmaun & Sn silicale-sulfide vein & Sn & $66^{\prime} 19 \mathrm{~N}$ & $179^{\circ} 46^{\circ} \mathrm{W}$ \\
\hline Enpylkhkan & $\mathrm{Pb}-\mathrm{Zn}$ skam & $\mathrm{Pb}, \mathrm{Zn}, \mathrm{Cu}_{3}, \mathrm{Ag}$ & $65^{\prime} 20 \mathrm{~N}$ & $174^{\circ} 16 \mathrm{~W}$ \\
\hline Erulen & Se silicate-sulfide vein & Sn & $66097 \mathrm{~N}$ & $173^{\circ} 17 \mathrm{~W}$ \\
\hline Eruttin & Se silicate-sulfide vein & Sn & $6624 \mathrm{~N}$ & $178^{\circ} 55 \mathrm{~W}$ \\
\hline Granatnoe & Porphyry Mo & Mo & $67^{\prime} 12 \mathrm{~N}$ & $179^{\circ} 09 \mathrm{~W}$ \\
\hline Ichatkin & Se silicate-suifide vein & Sn & $69^{\circ} 41 \mathrm{~N}$ & $163^{\circ} 11 \mathrm{E}$ \\
\hline Kekur & Sn silicate-sulfide vein & Sn & $69^{\circ} 497 \mathrm{~N}$ & $171^{\circ} 52 \mathrm{E}$ \\
\hline Kuekvun & Granitoid-related $\mathrm{Au}$ & $\mathrm{Au}, \mathrm{Bi}, \mathrm{Te}, \mathrm{Sn}, \mathrm{W}$ & $68^{\circ} 467 \mathrm{~N}$ & $178^{\prime} 53 \mathrm{E}$ \\
\hline Kukenei & Sn polymetalie vein & $\mathrm{Sn}, \mathrm{Ag}$ & $69^{\circ} 08 \mathrm{~N}$ & $174^{\circ} 05 \mathrm{E}$ \\
\hline Lunnoe & Sn silicate-sulfide vein & Sn, W & $68497 \mathrm{~N}$ & $174^{\circ} 49^{\prime} \mathrm{E}$ \\
\hline Melyul & $\mathrm{Pb}-\mathrm{Zn}-(\mathrm{Cu})-\mathrm{A}_{\mathrm{g}}$ skam & $\mathrm{Pb}, \mathbf{Z n}, A_{\mathrm{g}},(\mathrm{Cu})$ & $66^{\prime} 16 \mathrm{~N}$ & $172^{\circ} 04 \mathrm{~W}$ \\
\hline Mramornoe & Sn polymetallic vein & $\mathrm{Sn}, \mathrm{A}_{\mathbf{B}}$ & $68^{\circ} 06 \mathrm{~N}$ & $176^{\prime} 30^{\circ} \mathrm{E}$ \\
\hline Mymlerennet & Sn silicate-sulfide vein & Sn & $6747 \mathrm{~N}$ & $179^{\prime} 46^{\circ} \mathrm{E}$ \\
\hline Pepenveem & Au-Ag epishermal vein & $\mathrm{Au}, \mathrm{Ag}$ & $65^{\circ} 527 \mathrm{~N}$ & $175^{\prime} 37 \mathrm{~W}$ \\
\hline Pyrkakai & Porphyry Sn & Sn, w & $6933 \mathrm{~N}$ & $17157 \mathrm{E}$ \\
\hline Reechen & $\mathrm{Fe}-\mathrm{Pb}-\mathrm{Zn}-\mathrm{Sn}$ skam & $\mathrm{Fe}, \mathrm{Pb}, \mathrm{Zn}_{,}, \mathrm{Sn}$ & $64577 \mathrm{~N}$ & $17229 \mathrm{~W}$ \\
\hline Serduse-Kamen & $\mathrm{Pb} \cdot \mathrm{Zn}$ skam & $\mathrm{Pb}, \mathrm{Zn}, \mathrm{Cu}, \mathrm{Se}, \mathrm{Ag}$ & $6650 \mathrm{~N}$ & $171^{\circ} 44 \mathrm{~W}$ \\
\hline Shurykan & Porphyry Ca-Mo & $\mathrm{Mo}, \mathrm{Cu}$ & $68^{2} 447 \mathrm{~N}$ & $174^{\circ} 23 \mathrm{E}$ \\
\hline Telekai & $\begin{array}{l}\text { Sn silicale-sulfide vein and Sn } \\
\text { greisen }\end{array}$ & $\mathrm{Sn}$ & $6759 \mathrm{~N}$ & $178^{\circ} 05 \mathrm{E}$ \\
\hline Tumannoe & Disseminated Av-sulfide & Au, As, Sb & $67^{\prime} 40 \mathrm{~N}$ & $178^{\prime} 06 \mathrm{~W}$ \\
\hline Vaikumei & Se silicate-sulfide vein & Sn & $69^{\circ} 397 \mathrm{~N}$ & $170^{\circ} 12 \mathrm{E}$ \\
\hline Vodorazdeinoye & Sn silicate-sulfide vein & Sn & $6755 \mathrm{~N}$ & $178^{\prime} 51^{\prime} \mathrm{E}$ \\
\hline Yassnoe & $\begin{array}{l}\text { Clastic sediment-hosted } \mathrm{Hg} \text { or } \\
\text { hot-spring } \mathrm{Hg} \text { ? }\end{array}$ & $\mathrm{Hg}$ & $6823 \mathrm{~N}$ & $167^{\prime} 48 \mathrm{E}$ \\
\hline
\end{tabular}

Chuketka Metallogenic Belt of As Quarta Vein asd Se asd Se-W Polymetallie Vein Depesits (Early Cretaceoes)

Nerthern Part of Russian Northeast (Belt CH)

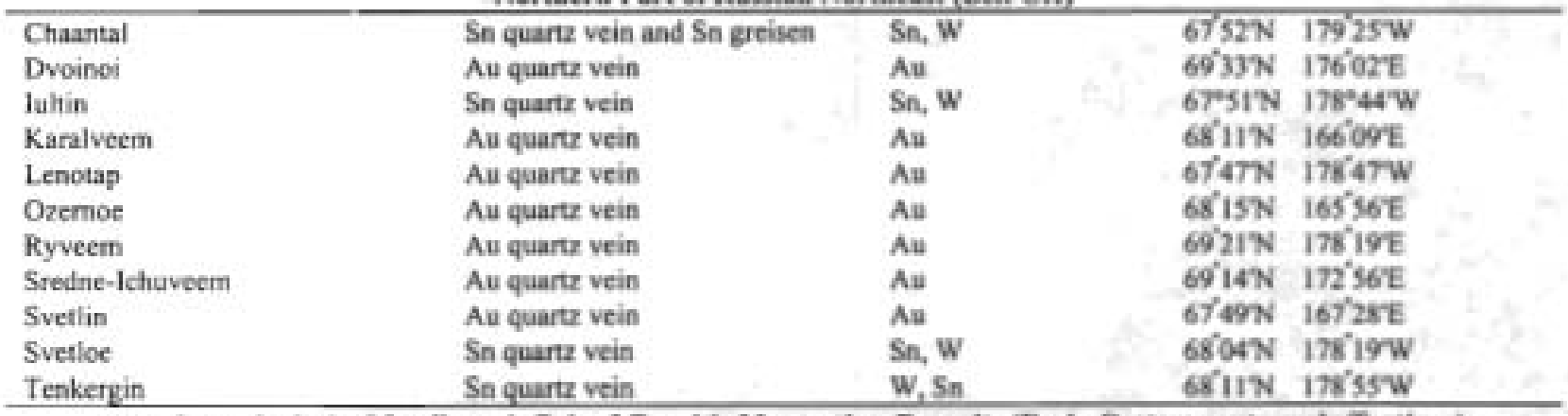

East-Central Alaska Metallegenie Belt of Grasitic Magmatisn Depesits (Earty Cretaceous te early Tertiary)

East-Central Alaska (Belt ECA) (Older Part)

Avnet (Burby)*
Banjo (Kantishna district)
Bedrock Creck*
Blae Lead, Tibbs Creek, Gray
Lead
Bluff*
Caribou Creek, Eagles Den, Slate
Creek (Kantishna district)
Cleary Sumnit
Democrat (Mrtchell Lode)
Dempscy Pup

\section{Mn-Ag vein}

Polymetallic vein

Porphyry Cu(?)

Polymetallic vein or Sb-Au vein

Porphyry Cu-Mo

Sb-Au vein

Polymetallic vein, Atequarte

vein

Granitoid-related Au

Sb-Aw vein or polymetallic vein(?)

\section{$\mathrm{Mn}, \mathrm{Ag}$}

$\mathrm{Au}_{\mathrm{A}}, \mathrm{A}_{\mathrm{G}} \mathrm{Pb}, \mathrm{Zn}, \mathrm{Sb}$

Cu, W, Th

Aw, Ag, Sb

$\mathrm{Cu}, \mathrm{Mo}$

$\mathrm{Sb}$

$6516 \mathrm{~N} 15025 \mathrm{~W}$

$63^{\prime} 34 \mathrm{~N} 150^{\circ} 44 \mathrm{~W}$

$65^{\prime} 27 \mathrm{~N} 144^{\prime} 50 \mathrm{~W}$

$6420 \mathrm{~N} 146^{\prime} 147 \mathrm{~W}$

$63^{\circ} 38 \mathrm{~N} 141^{\circ} 29 \mathrm{WW}$

$63^{\circ} 25 \mathrm{~N}$ 151'12

Av, Ag

$65^{\circ} 04 \mathrm{~N} 147^{\prime} 25 \mathrm{~W}$

Aw, Ag, Pb, Sb

Sb, Au(?)
$6420 \mathrm{~N} 146227 \mathrm{~W}$

$6521 \mathrm{~N} 14633 \mathrm{~W}$ 


\begin{tabular}{|c|c|c|c|c|}
\hline Depesit Name & Mineral Depesit Model & Major Metals & \multicolumn{2}{|c|}{ Latitude $\mathrm{N}_{\text {: }}$ Lengitude $\mathrm{E}_{4} \mathrm{~W}$. } \\
\hline Ester Dome (Ryan Lode) & Polymetallic vein(?) & $\mathrm{Au}, \mathrm{Ag}$ & $64^{\prime} 52 ' \mathrm{~N}$ & $148^{\circ} 05 \mathrm{~W}$ \\
\hline Fort Knox & Granitoid-related $\mathrm{Au}$ & $\mathrm{Au}, \mathrm{Ag}, \mathrm{Mo}$ & $65^{\circ} 07 \mathrm{~N}$ & $14723 \mathrm{~W}$ \\
\hline $\begin{array}{l}\text { Gertrude Creek, Griffen, Ruth } \\
\text { Creek }\end{array}$ & Sb-Au vein & $\mathrm{Au}, \mathrm{Sb}$ & $65^{\circ} 31 \mathrm{~N}$ & $148^{*} 100 \mathrm{~W}$ \\
\hline Granite Mountain* & Porphyry Cu-Mo & $\mathrm{Cu}, \mathrm{Mo}$ & $62^{\circ} 19 \mathrm{~N}$ & $136^{\circ} 58 \mathrm{~W}$ \\
\hline Hot Springs Dorne* & Polymetallic vein & $\mathrm{Pb}, \mathrm{Ag}_{\mathrm{E}} \mathrm{Zn}, \mathrm{Au}$ & $65^{\circ} 02 \mathrm{~N}$ & $150^{\circ} 45 \mathrm{~W}$ \\
\hline Hudson Cinnabar & Hg quartz vein & $\mathrm{H}_{\mathrm{g}}$ & $65^{\prime} 30 \mathrm{~N}$ & $148^{\circ} 22 \mathrm{~W}$ \\
\hline Miller House* & As-As polymetallic vein & $\mathrm{Au}$ & $6533 \mathrm{~N}$ & $145^{\circ} 15 \mathrm{~W}$ \\
\hline Pogo & Granitoid-related Au & $\mathrm{Au}, \mathrm{As}, \mathrm{Cu}, \mathrm{Bi}$ & & \\
\hline $\begin{array}{l}\text { Quigley Ridge (Kantishna } \\
\text { district) }\end{array}$ & Polymetallic vein & $\mathrm{Ag}_{\mathrm{B}}, \mathrm{Av}, \mathrm{Pb}, \mathrm{Zn}$ & $6333 \mathrm{~N}$ & $150 \% 45 \mathrm{~W}$ \\
\hline Salcha River" & W skam & W & $6507 \mathrm{~N}$ & $144^{\prime \prime} 38 \mathrm{~W}$ \\
\hline Sawtooth Mountain & Sb-Au vein & Sth & $65^{\prime} 23 \mathrm{~N}$ & $149^{\prime} 30 \mathrm{~W}$ \\
\hline Serafford & Sb-Au vein & Sb, Au & $65^{\circ} 00 \mathrm{~N}$ & $147^{\prime} 49 \mathrm{~W}$ \\
\hline Spruce Creek (Kantishna đistrict) & Polymetallic vein & $\mathrm{Au}, \mathrm{Ag}, \mathrm{Pb}, \mathrm{Zn}, \mathrm{Sb}$ & $6335 \mathrm{~N}$ & $15135 \mathrm{~W}$ \\
\hline Stampede (Kantiahna district) & Sb-Au vein & Sb & $6345 \mathrm{~N}$ & $150^{\prime} 25 \mathrm{~W}$ \\
\hline Stepovich Lode & W skarn & W, Au & $6459 \mathrm{~N}$ & $147^{\prime} 21 \mathrm{~W}$ \\
\hline Table Mountain & Se polymetallie vein & Au & $652 \% \mathrm{~N}$ & $145^{\prime} 53 \mathrm{~W}$ \\
\hline \multicolumn{5}{|c|}{$\begin{array}{l}\text { - Age net well established; depesit could be part of younger part of East-Ceniral Alaska metallogenie belt (Late } \\
\text { Cretaceous and early Tertiary) }\end{array}$} \\
\hline \multicolumn{5}{|c|}{ Yukeo-Tanana Upland Metallegenic Belt of Au Quartz Vein Deposits (Late Cretaceous), East-Central Alaska (Belt YD } \\
\hline Pundy & Alu-quartz vein & Al & GOTN & 141 'S5E \\
\hline \multicolumn{5}{|c|}{$\begin{array}{c}\text { Wrangell Mountains Metallogenic Belt of Cu-Ag Quartz Vein and Kennecett Ca Depesits (atid-Cretaceous) } \\
\text { Eastern-South Alaska (Belt WR) }\end{array}$} \\
\hline Erickson & Basaltic $\mathrm{Cu}$ & $\mathrm{Cu}$ & $6125 \mathrm{~N}$ & $142^{\prime} 15 \mathrm{~W}$ \\
\hline Kathleen-Margaret & $\mathrm{Cl}-\mathrm{Ag}$ quartz vein & $\mathrm{Cu}_{\mathrm{u}} \mathrm{Ag}, \mathrm{Au}$ & $63^{\circ} 17 \mathrm{~N}$ & $146^{\circ} 33 \mathrm{~W}$ \\
\hline Kennecott District & Kennecott $\mathrm{Cu}$ & $\mathrm{Cu}, \mathrm{Ag}$ & $61^{\circ} 31 \mathrm{~N}$ & $142^{\prime} 50 \mathrm{~W}$ \\
\hline Nelson (Glacier Creek) & Kennecon $\mathrm{Cu}$ & Cu. Ag & $61^{4} 27 \mathrm{~N}$ & $142^{\prime 2} 23 \mathrm{~W}$ \\
\hline Nikolai & $\mathrm{Cu}$-Ag quarta vein & $\mathrm{Cu}_{\mathrm{u}} \mathrm{A}$ & $6128 \mathrm{~N}$ & $142^{\circ} 411 \mathrm{~W}$ \\
\hline Nugzet Creek & $\mathrm{Ce}$-Ag quartz vein & $\mathrm{Cu}, \mathrm{Ag}$ & $6139 \mathrm{~N}$ & $143^{\prime} 43 \mathrm{~W}$ \\
\hline Westover & Kennecort $\mathrm{Cl}_{4}$ & Cu. Ag & $61247 \mathrm{~N}$ & $142^{\prime}$ yorw \\
\hline \multicolumn{5}{|c|}{ LATE CRETACEOUS AND EARLY TERTIARY (Campaaian throagh early Eocene - 84 to $52 \mathrm{Ma}$ ) } \\
\hline \multicolumn{5}{|c|}{ Iruseisky Metallorenic Belt of Porphyry Mo Depesits (Late Cretaceoss), Seuthern Kamehatka Peainsula (Beit IR) } \\
\hline Kinganik & Porphyry Mo & Mo & $5501 \mathrm{~N}$ & $15738 \mathrm{E}$ \\
\hline \multicolumn{5}{|c|}{ 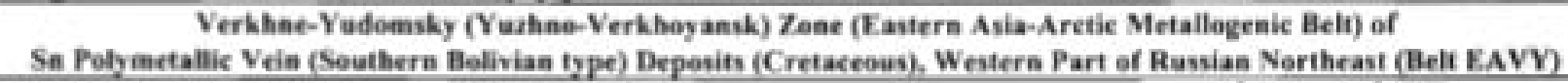 } \\
\hline Balaakbalakh, Diring-Yuryak & Sn polymetallic vein & Sn & $59 \cdot 51 \mathrm{~N}$ & $139^{\circ} 01 \mathrm{E}$ \\
\hline Dahaton & Pb-Zn polymetallic vein & $\mathrm{Pb}, \mathrm{Zn}, \mathrm{Ag}$ & $61^{\circ} 49 \mathrm{~N}$ & $140^{\circ} 15 \mathrm{E}$ \\
\hline Khaardak & Sn polymetalle vein & Se & $62^{\prime} 03 \mathrm{~N}$ & $140^{\circ} 44 \mathrm{E}$ \\
\hline Khoron & Se polymetallic vein & Sn & $6239 \mathrm{~N}$ & $140^{\circ} 49 \mathrm{E}$ \\
\hline Nivandaha & Polymetallic vein & $\mathrm{Pb}, \mathrm{Zn}, \mathrm{Ag}$ & $61^{4} 33 \mathrm{~N}$ & $141^{\prime} \mid 4 \mathrm{E}$ \\
\hline Zamitsa, Kutinskor & Polymetallic vein & $\mathrm{Pb}, \mathrm{Zn}, \mathrm{Ag}$ & $62^{\circ} 27 \mathrm{~N}$ & 140'1B'E \\
\hline \multicolumn{5}{|c|}{$\begin{array}{l}\text { Verkheyansk-Indigirka (Dulgalak) Zeee (Eastern Asia-Arctic Metallegenic Beit) of Clastic Sediment-Hested Hg and } \\
\text { Sb-Au Vein Depesits (Late Cretaceeus and early Tertiary). Western Part of Russian Nertheast (Belt EAVI) }\end{array}$} \\
\hline Baidakh & Sb-Au vein & $\mathrm{Sb}$ & $7005 \mathrm{~N}$ & $13532 \mathrm{E}$ \\
\hline Beryugen & $\mathbf{S b}$ vein & $\mathrm{Sb}$ & $67^{\prime} 06 \mathrm{~N}$ & $131^{\prime} 36 \mathrm{E}$ \\
\hline Erel & Clastic sediment-hosted $\mathrm{H}_{\mathrm{g}}$ & $\mathrm{Hg}_{\mathrm{g}}$ & $6430 \mathrm{~N}$ & $138^{\prime} 25 \mathrm{E}$ \\
\hline Imnckan & \$b vein & $\mathrm{Sb}$ & $6446 \mathrm{~N}$ & $13544 \mathrm{E}$ \\
\hline lserdek & Clastic sediment-hosted $\mathrm{Hg}$ & $\mathrm{Hg}_{\mathrm{g}}$ & $67087 \mathrm{~N}$ & $130^{\circ} 4 I^{\prime} \mathrm{E}$ \\
\hline Kholbolok & Clastic sediment-hosted $\mathrm{Hg}_{\mathrm{g}}$ & $\mathrm{Hg}_{\mathrm{g}}$ & $66^{\prime} 15 \mathrm{~N}$ & $131^{\circ} 48 \mathrm{E}$ \\
\hline Kyochyus & Sb-Au. $H_{E}$ vein & $\mathrm{Am}, \mathrm{Hz}, \mathrm{Sb}$ & $69^{\circ} 48^{\circ} \mathrm{N}$ & I3445'E \\
\hline Seikimyan & Clastic sediment-hosted $\mathrm{Hg}$ & $\mathrm{Hg}$ & $64^{\circ} 0 \sin ^{2}$ & $139^{\prime} 52 \mathrm{E}$ \\
\hline Selenkan & So vein & $5 b$ & $6413 \mathrm{~N}$ & $140^{\circ} 25 \mathrm{E}$ \\
\hline Sendachen & $\$ b-A$ s vein & As, Sb & $6321 \mathrm{~N}$ & $138^{\prime} 24 \mathrm{E}$ \\
\hline Singyani & Clastic sediment-hosted $\mathrm{Hg}$ & $\mathrm{Hg}$ & $6442 \mathrm{~N}$ & I37'40VE. \\
\hline Stibnitevoe & Sb vein & $\mathrm{Sb}$ & $63^{*} 14 \mathrm{~N}$ & $138^{\prime} 30 \mathrm{E}$ \\
\hline Zapadka & Clastic sedimcnt-hosted $\mathrm{H}_{\mathrm{g}}$ & $\mathrm{H}_{\mathrm{g}}, \mathrm{Sb}$ & $66^{6} 55 \mathrm{~N}$ & 13101'E \\
\hline Zverdochis & Clastic sediment-hosted $\mathrm{H}_{\mathrm{g}}$ & $\mathrm{He}_{\mathrm{e}}$ & $6643 \mathrm{~N}$ & Bitos'E \\
\hline
\end{tabular}


Anayi-Beringovsky Zeee (Eastern Asla-Arctic Metallogenic Bel1) of Aw-Ag Epithermal Vein and Dinseninated Gold Sulfide Depesits (Late Cretacesus). Nertheastern Part of Russian Nertheast (Belt EAAB)

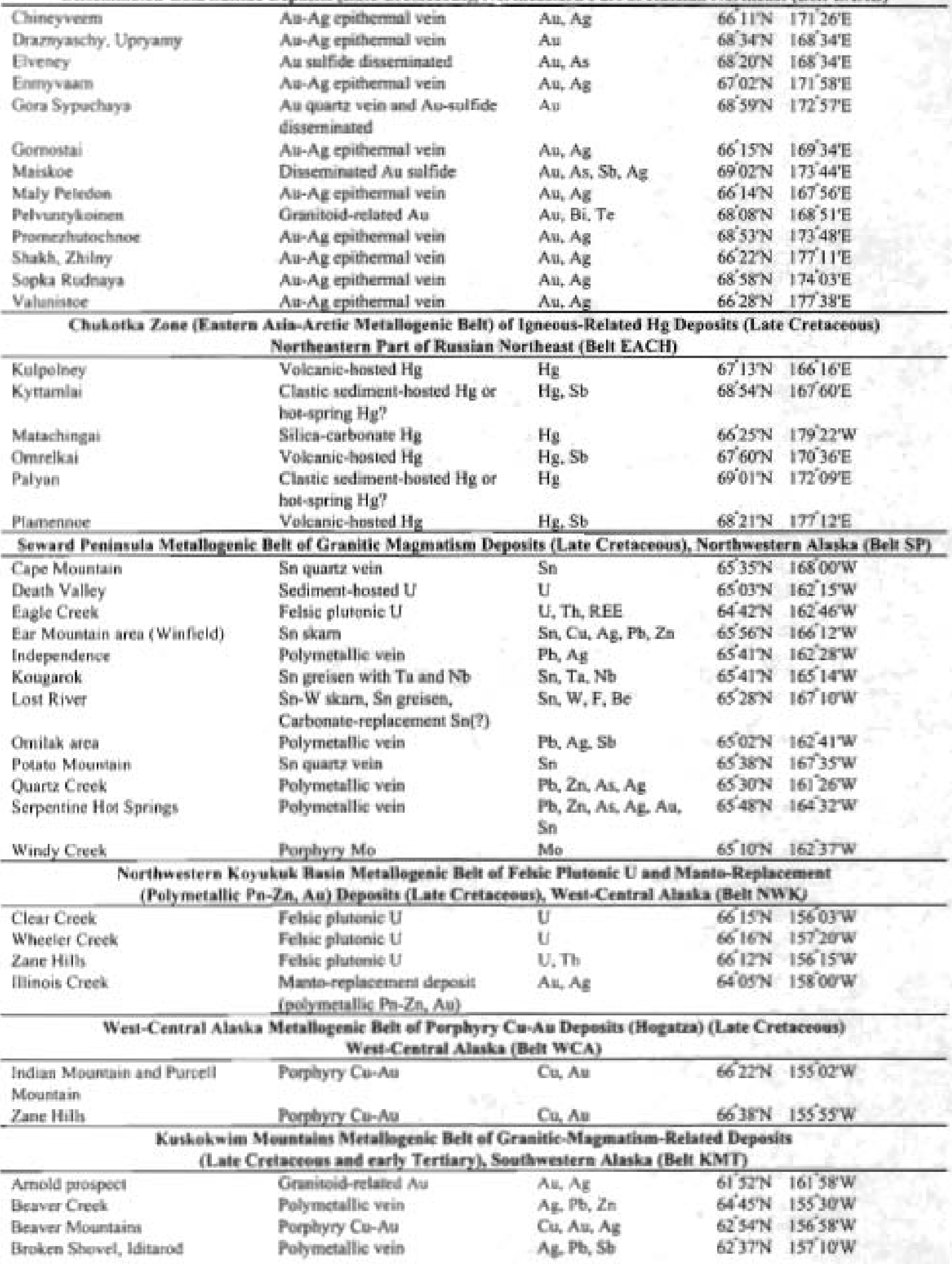




\begin{tabular}{|c|c|c|c|c|}
\hline Deposit Name & Mineral Deposit Model & Major Metals & Latitude: & N: Longitude E, W. \\
\hline Candle & $\begin{array}{l}\text { Polymetallic vein of porphyry } \\
\text { Cu? }\end{array}$ & $\mathrm{Cu}, \mathrm{Pb}, \mathrm{Ag}$ & $62511 \mathrm{~N}$ & $155^{\prime \prime} 48 \mathrm{~W}$ \\
\hline $\begin{array}{l}\text { Chicken Mountain, Black Creck } \\
\text { (Flat District) }\end{array}$ & Granitoid-related $\mathrm{Au}-\mathrm{A}_{\mathrm{B}}(\mathrm{Cu})$ & $\begin{array}{l}\mathrm{Au}, \mathrm{As}, \mathrm{Hg}, \mathrm{Sb}, \mathrm{Cu} \text {, } \\
\text { Mo }\end{array}$ & $62^{\circ} 30 \mathrm{~N}$ & $158^{\circ} 00^{\circ} \mathrm{W}$ \\
\hline Cinnabar Creek & Hot-spring $\mathrm{Hg}$ & $\mathrm{Sb}, \mathrm{Hg}$ & $60^{\circ} 46 \mathrm{~N}$ & $158^{\circ} 46^{\prime} \mathrm{W}$ \\
\hline Cirque, Tolstoit & $\begin{array}{l}\text { Polymetallic vein and porphyry } \\
\mathrm{Cu}\end{array}$ & $\mathrm{Cu}, \mathrm{Ag}, \mathrm{Sm}$ & $62 \% 33 \mathrm{~N}$ & $156^{\circ} 59 \mathrm{~W}$ \\
\hline DeCourcey Mountain & Hot-spring $\mathrm{Hg}$ & $\mathrm{Hg}, \mathrm{Sb}, \mathrm{As}$ & $6215 \mathrm{~N}$ & $158^{\prime \prime} 30 \mathrm{~W}$ \\
\hline Donlin Creek & Porphyry At & $\mathrm{Au}$ & $6218 \mathrm{~N}$ & $158^{\circ} 24^{\prime W}$ \\
\hline Fortyseven Creek & Polymetallic vein(?) & $\mathrm{Au}, \mathrm{W}$ & $61^{\circ} 0 T \mathrm{~N}$ & $158^{\prime 1} 15 \mathrm{~W}$ \\
\hline $\begin{array}{l}\text { Golden Horn, Minnie Gulch, } \\
\text { Malemute, Iditarod (Flat District) }\end{array}$ & Polymetaltic vein or Sb-Au vein & $\mathrm{Au}, \mathrm{Ag}, \mathrm{Sb}, \mathrm{Hg}, \mathrm{W}$ & $62^{\prime} 311^{\prime} \mathrm{N}$ & $157^{\circ} 55 \mathrm{~W}$ \\
\hline Independence & Porphyry Au & Au & $625 T N$ & $156^{\prime} 59 \mathrm{~W}$ \\
\hline Kagati lake & Sb-Hg vein & $\mathrm{Sb}, \mathrm{Hg}$ & $59^{\prime} 52 \mathrm{~N}$ & $159^{\prime \prime} 54 \mathrm{~W}$ \\
\hline Mcleod & Porphyry Mo & Mo & $63^{\circ} 16 \mathrm{~N}$ & $159^{\circ} 16 \mathrm{~W}$ \\
\hline Medfra & Fe skam & $\mathrm{Fe}, \mathrm{Cu}, \mathrm{Zn}, \mathrm{Au}$ & $63^{\circ} 40 \mathrm{~N}$ & $15404 \mathrm{~W}$ \\
\hline $\begin{array}{l}\text { Mission Creek, Headwall, Louise, } \\
\text { and Owhat Prospect }\end{array}$ & Polymetallic vein & $\mathrm{Au}, \mathrm{Ag}, \mathrm{Cu}, \mathrm{As}$ & $61^{\prime} 46 \mathrm{~N}$ & $158^{\circ} 32 \mathrm{~W}$ \\
\hline Molybdenum Mountain & Porphyry Mo & Mo & $62^{\circ} 05 \mathrm{~N}$ & $158^{\circ} 48^{\prime} \mathrm{W}$ \\
\hline Nixon Fork-Medfra & Cu-Au skarm & $\begin{array}{l}\mathrm{Au}, \mathrm{Cu}, \mathrm{Ag}, \mathrm{Bi}, \mathrm{Sn} \text {, } \\
\text { w, Th }\end{array}$ & $63^{\prime} 14 \mathrm{~N}$ & $15447 \mathrm{~W}$ \\
\hline Perseverance & Polymetallic vein(?) & $\mathrm{Pb}, \mathrm{Ag}, \mathrm{Sb}$ & $6445 \mathrm{~N}$ & $157^{\prime} 30 \mathrm{~W}$ \\
\hline Red Devil & Clastic sediment-hosted $\mathrm{Hg}$ & $\mathrm{Hg}, \mathrm{Sb}$ & $61^{\circ} 45 \mathrm{~N}$ & $157^{\circ} 23 \mathrm{~W}$ \\
\hline Sischu Creek & Felsic plutonic U & U, Th & $63^{*} 58 \mathrm{~N}$ & $153^{\circ} 17 \mathrm{~W}$ \\
\hline Sleitat & Sn greisen and $3 \mathrm{kam}$ & $\mathrm{Sn}, \mathrm{Ag}_{\mathrm{g}} \mathrm{W}, \mathrm{As}$ & $60^{\circ} 03 \mathrm{~N}$ & $157^{\circ} 05 \mathrm{~W}$ \\
\hline Snow Gulch-Donlin & Sb-Au vein & $\mathrm{Sb}, \mathrm{Au}, \mathrm{As}, \mathrm{Hg}$ & $62^{\prime} 13 \mathrm{~N}$ & $158^{\circ} 15 \mathrm{~W}$ \\
\hline Taylor Mountains & $\mathrm{Hg}-\mathrm{Ag}$ epithermal veinc?) & $\mathrm{Hg}, \mathrm{Au}$ & $60^{\circ} 52 \mathrm{~N}$ & $157^{\prime} 40^{\circ} \mathrm{W}$ \\
\hline Vinasale Mountain & $\begin{array}{l}\text { Granitoid-Related (Porphyry) } \\
\text { Au }\end{array}$ & $\mathrm{Au}$ & $62^{\circ} 36 \mathrm{~N}$ & $156^{\circ} 08^{\prime} \mathrm{W}$ \\
\hline Von Frank Mountain & Porphyry $\mathrm{Cu}-\mathrm{A}_{\mathrm{g}}$ & $\mathrm{Cu}, \mathrm{Ag}$ & $63^{\prime \prime} 38 \mathrm{~N}$ & $155^{\circ} 04^{\prime} \mathrm{W}$ \\
\hline Win-Won or Cloudy Mountain & Sn polymetallic vein & $\mathrm{Sn}, \mathrm{Ag}_{\mathrm{B}} \mathrm{Cu}$ & $63^{\circ} 13 \mathrm{~N}$ & $156^{\circ} 04^{\prime} \mathrm{W}$ \\
\hline Wolf Mountain & Felsic plutonic U & $\begin{array}{l}\mathrm{U}, \mathrm{Th}, \mathrm{As}, \mathrm{Nb}, \mathrm{Mo} \text {, } \\
\text { REE }\end{array}$ & $62^{\prime} 20 \mathrm{~N}$ & $16129 \mathrm{~W}$ \\
\hline
\end{tabular}

East-Central Alaska Metallogenic Belt of Granitic Maguatism Deposits (Younger, Late Cretaceous and Early Tertiary Part) (East-Central Alaska and Western Yuken Territory Carmacks area) (Belt ECA)

\begin{tabular}{|c|c|c|c|c|c|}
\hline \\
\hline Asarco & Porphyry $\mathrm{Cu}-\mathrm{Mo}$ & $\mathrm{Cu}, \mathrm{Mo}_{0}$ & $6322 \mathrm{~N}$ & $142^{\circ} 30^{\circ} \mathrm{W}$ & \\
\hline Cash (Klazan, Johnny) & Porphyry $\mathrm{Cu}-\mathrm{Mo}_{0}$ & $\mathrm{Cu}, \mathrm{Mo}$ & $6226 \mathrm{~N}$ & $137^{\prime 3} 37^{\prime} \mathrm{W}$ & \\
\hline Casino (Patton Hill) & Porphyry $\mathrm{Cu}-\mathrm{Mo}$ & $\mathrm{Cl}, \mathrm{Mo}$ & $62^{\circ} 44 \mathrm{~N}$ & $138^{\circ} 49^{\circ} \mathrm{W}$ & \\
\hline Ketchem Dome & Sn greisen & $\mathrm{Sn}$ & $6529 \mathrm{~N}$ & $144^{\circ} 53 \mathrm{~W}$ & \\
\hline Lime Peak & Sn greisen and $S n$ vein & $5 \mathrm{n}, \mathrm{Ag}, \mathrm{Zn}, \mathrm{U}, \mathrm{W}$ & $65^{\circ} 37 \mathrm{~N}$ & $146^{\circ} 43 \mathrm{~W}$ & \\
\hline Mosquito & Porphyry $\mathrm{Cu}-\mathrm{Mo}$ & $\mathrm{Cu}, \mathrm{Mo}$ & $63^{\circ} 537 \mathrm{~N}$ & $143^{\circ} 28 \mathrm{~W}$ & \\
\hline Roy Creek (former Mt. Prindle) & Felsic plutonic U & U, Th & $65^{\circ} 29 \mathrm{~N}$ & $147^{\circ} 05^{\circ} \mathrm{W}$ & \\
\hline Road Metal & $\begin{array}{l}\text { Tourmaline-topaz-quartz-sulfide } \\
\text { greisen }\end{array}$ & $\mathrm{Au}, \mathrm{Ag}, \mathrm{Cu}, \mathrm{Bi}$ & $63^{\circ} 02 \mathrm{~N}$ & $141^{\circ} 20 \mathrm{~W}$ & \\
\hline Taurus & Porphyry $\mathrm{Cu}-\mathrm{Mo}$ & $\mathrm{Cu}, \mathrm{Mo}_{\mathrm{o}}$ & $63^{\circ} 397 \mathrm{~N}$ & $141^{\circ 1} 19 \mathrm{~W}$ & \\
\hline \multicolumn{6}{|c|}{$\begin{array}{l}\text { Southern Alaska Metallegenic Belt of Granitic Magmatism Depesits (Late Cretaceous and early Tertiary) } \\
\text { Central and Northern Part of Southera Alaska (Belt SA) }\end{array}$} \\
\hline Bonanza Hills & $\begin{array}{l}\text { Polymetallic vein and Porphyry } \\
\mathrm{Cu}\end{array}$ & $\mathrm{Ag}, \mathrm{Cu}, \mathrm{Pb}, \mathrm{Au}$ & $6045 \mathrm{~N}$ & $154^{2} 30 \mathrm{~W}$ & \\
\hline Bouider Croek (Purkeypile) & Sn greisen(?) & Sn & $62^{*} 53 \mathrm{~N}$ & $152^{\circ} 08^{\circ} \mathrm{W}$ & \\
\hline Bowser Creek & $\mathrm{Pb}-\mathrm{Zn}$ skam & $\mathrm{Ag}, \mathrm{Pb}, \mathrm{Zn}$ & $6211 \mathrm{~N}$ & $1533^{\circ} 40 \mathrm{~W}$ & \\
\hline Coal Creek & Sn greisen(?) and $\mathrm{Sa}$ vein & $\mathrm{Sn}, \mathrm{Ag}, \mathrm{W}, \mathrm{Zn}$ & $63^{\prime \prime} 15 \mathrm{~N}$ & $149^{\prime \prime} 14 \mathrm{~W}$ & \\
\hline Golden Zone & $\begin{array}{l}\text { Polymetallic vein and } \mathrm{Au}-\mathrm{Ag} \\
\text { breccia pipe or } \mathrm{Cu}-\mathrm{Au} \text { porphyry }\end{array}$ & $\begin{array}{l}\mathrm{Au}, \mathrm{Cu}, \mathrm{Zn}, \mathrm{As}, \mathrm{Sb} \\
\mathrm{Ag}, \mathrm{Pb}\end{array}$ & $6313 \mathrm{~N}$ & $149^{\circ} 39^{\circ \mathrm{W}}$ & \\
\hline Kijik River & $\begin{array}{l}\text { Polymetallic vein and porphyry } \\
\mathrm{Cu}\end{array}$ & $\mathrm{Cu}, \mathrm{Mo}_{0}$ & $60^{\circ} 17 \mathrm{~N}$ & $15415 \mathrm{~W}$ & \\
\hline Miss Molly (Hayes Glacier) & Porphyry Mo & Mo & $6051 \mathrm{~N}$ & $151^{\circ} 48 \mathrm{~W}$ & \\
\hline $\begin{array}{l}\text { Nabesna Gilacier and adjacent } \\
\text { areas. }\end{array}$ & Polymetallic vein(?) & $\mathrm{Cu}, \mathrm{Zn}, \mathrm{Au}$ & $62^{\circ} 0 T \mathrm{~N}$ & $142^{\circ} 50 \mathrm{~W}$ & \\
\hline Nim, Nimbus, Silver King & Polymetallic vein and Porphyry & $\mathrm{Au}, \mathrm{Ag}, \mathrm{Cu}$ & $63^{\circ} 17 \mathrm{~N}$ & $149^{\circ} 27 \mathrm{~W}$ & \\
\hline
\end{tabular}




\begin{tabular}{|c|c|c|c|c|}
\hline Deposit Name & Mineral Deposit Model & Majer Metals & \multicolumn{2}{|c|}{ Latifude $\mathrm{N}$; Longitude E, W. } \\
\hline \multicolumn{5}{|c|}{$\operatorname{Cot}(?)$} \\
\hline Othio Creek & Sn greisen and $S n$ vein & $5 n$ & $63^{\circ} 11 \mathrm{~N}$ & $149^{\prime} 59 \mathrm{~W}$ \\
\hline Partin Creek & $\begin{array}{l}\text { Polymetallic vein or } \mathrm{Cu}-\mathrm{Ag} \\
\text { quartz vein }\end{array}$ & CH. Au. Ag & $6254 \mathrm{~N}$ & $14957 \%$ \\
\hline Rat Fork, Sheep Creek & $\mathrm{Cu}-\mathrm{Pb}-\mathrm{Zn}$ sham & $\mathrm{Cn}_{n}, \mathrm{Zn}, \mathrm{Ph}$ & $62^{*} 14 \mathrm{~N}$ & $153^{\circ} 48 \mathrm{~W}$ \\
\hline Ready Cash & Polymetallie vein(?) & $\begin{array}{l}\mathrm{Au}, \mathrm{Cu}, \mathrm{Pb}, \mathrm{Ag}, \mathrm{Sn}, \\
\mathrm{Zn}\end{array}$ & $6309 \mathrm{~N}$ & $149^{\circ} 52 \mathrm{~W}$ \\
\hline Tin Croek & $\mathrm{Cu}-\mathrm{Pb}-\mathrm{Zn}$ skam & $\mathrm{Pb}, \mathrm{Zn}, \mathrm{Cu}$ & $6223 \mathrm{~N}$ & $15338 \mathrm{~W}$ \\
\hline Treasure Creek & Porphyry Cu-Mo & $\mathrm{Mo}, \mathrm{Cu}$ & $6253 \mathrm{~N}$ & $149^{\circ} 18 \mathrm{~W}$ \\
\hline Zackly & Cu-Au skam & $\mathrm{Au}, \mathrm{Cu}_{1} \mathrm{Ag}$ & $63^{\prime} 13 \mathrm{~N}$ & $14642 \mathrm{~W}$ \\
\hline \multicolumn{5}{|c|}{ Baranof Metallogeaic Belt of Au Quartz Vein Depesits (early Tertiary). Seutheastern Alaska (Belt BN) } \\
\hline Apex and E. Nido & Au quartz vein & Au. $\mathrm{Ag}$ & $5757 \mathrm{~N}$ & $13616 \mathrm{~W}$ \\
\hline Chichagoff, Hirst-Chichagof & Au quarz vein & Au & $57^{\circ} 40^{\circ} \mathrm{N}$ & $13606 \mathrm{~W}$ \\
\hline Cobol & Au quartz vein & Av & $5751 \mathrm{~N}$ & $136^{\circ} 13 \mathrm{~W}$ \\
\hline Reid Inlet & Au quartz vein & $\mathrm{Au}, \mathrm{Pb}$ & $5852 \mathrm{~N}$ & $136^{\circ} 52 \mathrm{~W}$ \\
\hline \multicolumn{5}{|c|}{$\begin{array}{l}\text { Maclaren Metallegenic Belt of Au Quartz Vein Depesits (Early Tertiary), } \\
\text { Central and Nerthern Part of Southern Alaska (Belt MC) }\end{array}$} \\
\hline Lucky Hill and Timberline Creek & Au quartz vein & An & $6311 \mathrm{~N}$ & $14716 \mathrm{~W}$ \\
\hline \multicolumn{5}{|c|}{$\begin{array}{l}\text { Talkeetna Mountains Metallogeaic Belt of Au Quartz Veis Deposits (early Tertiary), } \\
\text { Nerthern Part of Seuthern Alaska (Belt TM) }\end{array}$} \\
\hline $\begin{array}{l}\text { Independence (Willow Creek } \\
\text { District that also includes Gold } \\
\text { Bullion, Gold Cord, Lucky Shot. } \\
\text { Thope) }\end{array}$ & Au quartz vein & $\mathrm{Az}$ & $6145 \mathrm{~N}$ & $149^{\prime} 30 \mathrm{~W}$ \\
\hline \multicolumn{5}{|c|}{ Cbugach Mountains Metallogenie Belt of Au Quartz Vein Deposits (early Tertiary). Seuthera Alaska (Belt CM) } \\
\hline Alaska Oracle, Gilpatrick & An quartz vein & Au & $6037 \mathrm{~N}$ & $149^{\prime} 34 \mathrm{~W}$ \\
\hline $\begin{array}{l}\text { Chalet Mountain (Comelius. } \\
\text { Creek) }\end{array}$ & Au quartz vein & $\mathrm{W}, \mathrm{Au}, \mathrm{Ag}$ & $57487 \mathrm{~N}$ & $15220 \mathrm{~W}$ \\
\hline Cliff (Port Valdez) & Au quarte vein & $A=$ & $61^{\circ} 07 \mathrm{~N}$ & $146^{\circ} 33 \mathrm{~W}$ \\
\hline Crown-Point, Kenai-Alaska & Au quartz vein & $\mathrm{Aa}$ & $60^{\circ} 27 \mathrm{~N}$ & $149^{\circ} 18 \mathrm{~W}$ \\
\hline Gold King & Av quartz vein & Alu & $61^{\circ} 127 \mathrm{~N}$ & $14644 \mathrm{~W}$ \\
\hline Granite & Au quare vein & $A=$ & $60587 \mathrm{~N}$ & $148^{\prime} 13 \mathrm{~W}$ \\
\hline Lucky Strike (Palmer Creek) & An quartz vein & A & $60^{\circ} 46 \mathrm{NN}$ & $140^{\circ} 33 \mathrm{rW}$ \\
\hline $\begin{array}{l}\text { Mineral King (Herman and } \\
\text { Eaton) }\end{array}$ & An quartz vein & Al & $6057 \mathrm{~N}$ & $148^{\circ} 21 \mathrm{~W}$ \\
\hline Monarch, Jewel & Aw quartz vein & Av & $61027 N$ & $149^{\circ} 06 \mathrm{~W}$ \\
\hline $\begin{array}{l}\text { Nuka Bry District (Nualaska, } \\
\text { Lost Creek, Alaska Hills) }\end{array}$ & Au quartz vein & $\mathrm{Aa}$ & $5933 \mathrm{~N}$ & $150^{\circ} 35 \mathrm{~W}$ \\
\hline Ramsay-Rutherfood & Au quarte vein & All & $61^{\circ} 12 \mathrm{~N}$ & $146^{\circ} 06 \mathrm{~W}$ \\
\hline \multicolumn{5}{|c|}{ Juneau Metallogenic Belt of Au Quartz Vein Deposits (early Tertiary), Southeastern Alaska (Belt JU) } \\
\hline Alakka-luneau & Av quartz vein & An & $5818 \mathrm{~N}$ & $13420 \mathrm{~W}$ \\
\hline Gold Standand (Helm Bay) & Au quarte veie & Au & $5539 \mathrm{~N}$ & $13200 \mathrm{~W}$ \\
\hline Goldstream & Ale quartz vein & $\mathrm{Au}, \mathrm{Cu}, \mathrm{Fb}, \mathrm{Zn}$ & $5518 \mathrm{~N}$ & $131^{12} 39 \mathrm{w}$ \\
\hline halin & An quartz vein & Au & $5852 \mathrm{~N}$ & $135^{\circ} 05 \mathrm{w}$ \\
\hline Kensington & Av quartz veis & $\mathrm{Au}$ & $5852 \mathrm{~N}$ & $13505 \mathrm{~W}$ \\
\hline Riverside & $\begin{array}{l}\text { As quartz vein or polymetallic } \\
\text { vein }\end{array}$ & $\begin{array}{l}\mathrm{Ag}_{\mathrm{g}} \mathrm{Au}, \mathrm{Cu}, \mathrm{Pt}, \mathrm{W} \text {, } \\
\mathrm{Zn}\end{array}$ & $56 \mathrm{con}$ & $130^{\circ} 0 \mathrm{rw}$ \\
\hline Sea Level & Au quartz vein & $\mathrm{Au}, \mathrm{Ag}$ & $5522 \mathrm{~N}$ & $13112 \mathrm{~W}$ \\
\hline Sumdum Chief & Au quartz vein & $\mathrm{Au}, \mathrm{Ag}, \mathrm{Cu}, \mathrm{Pb}, \mathrm{Zn}$ & $5739 \mathrm{~N}$ & $13327 \mathrm{~W}$ \\
\hline Treadwell & Alu quanz vein & $\mathrm{Au}, \mathrm{Ag}, \mathrm{Cu}$ & $58^{\prime} 15 \mathrm{~N}$ & $13421 \% \mathrm{~W}$ \\
\hline
\end{tabular}

Prince William Sound Metallogenie Belt of Besshi and Cyprus Massive Sulfide Depesits (early Tertiary) Eastern-Southera Alaska (Belt PW)

\begin{tabular}{|c|c|c|c|c|}
\hline Copper Bullion, Rua Cove & Cyprus massive sulfide & $\mathrm{Ca}$ & $6021 \mathrm{~N}$ & $14739 \mathrm{~W}$ \\
\hline Ellamar & Besshi massive sulfide & $\mathrm{Ca}, \mathrm{At}, \mathrm{Ag}$ & $60^{\circ} 547 \mathrm{~N}$ & 14642 W \\
\hline Fidalgo-Alaska, Schlosser & Besshi massive sulfide(?) & $\mathrm{Cu}_{\mathrm{n}}, \mathrm{Zn}$ & $60^{\circ} 46 \mathrm{~N}$ & $146^{\prime} 25 \mathrm{~W}$ \\
\hline Knight Island, Pandona & Cyprus massive sulfide & $\mathrm{Cu}$ & $6020 \mathrm{~N}$ & $147^{\prime} 42^{\prime} \mathrm{W}$ \\
\hline Latouche, Beatson & Besshi massive sulfide( $\eta)$ & $\mathrm{Cu}, \mathrm{Ag}, \mathrm{Zn}$ & $60^{\circ} 02 \mathrm{~N}$ & 14751 'W \\
\hline Midas & Besshi massive sulfide( (7) & $\mathrm{Cu}_{\mathrm{a}} \mathrm{Ag}, \mathrm{Aa}, \mathrm{Zn}$ & $61^{\circ} 01 ' \mathrm{~N}$ & $14616 \mathrm{~W}$ \\
\hline Thrceman, Standard Copper & Cyprus massive sulfide & $\mathrm{Cu}, \mathrm{Au}, \mathrm{Ag}$ & $60^{\prime} 51 \mathrm{~N}$ & $14633 \mathrm{~W}$ \\
\hline
\end{tabular}




\begin{tabular}{|c|c|c|c|c|}
\hline Deposit Name & Mineral Deposit Medel & Major Metals & \multicolumn{2}{|c|}{ Latitude $\mathrm{N}_{\text {; }}$ Longitude $\mathbf{E}, \mathbf{W}$} \\
\hline Bohemia Basin (Yakobi lsland) & Gabbroic $\mathrm{Ni}-\mathrm{Cu}$ & $\mathrm{Ni}, \mathrm{Cu}$ & $5759 \mathrm{~N}$ & $136^{\prime \prime} 25^{\prime} \mathrm{W}$ \\
\hline Brady Glacier & Gabbeoic $\mathrm{Ni}-\mathrm{Cu}$ & Cu, Ni, PGE & $5833 \mathrm{~N}$ & $13656 \mathrm{~W}$ \\
\hline Mirror Harbor & Gabbroic $\mathrm{Ni}-\mathrm{Cu}$ & $\mathrm{Ni}, \mathrm{Cu}$ & $57^{\prime} 47^{\prime} \mathrm{N}$ & $13619^{\prime} \mathrm{W}$ \\
\hline \multicolumn{5}{|c|}{$\begin{array}{l}\text { Surprise Lake Metallogenic Belt of Porphyry Mo-W-Cu, and Au-Ag Polymetallic Vein Deposits } \\
\text { (Late Cretaceous and early Tertiary), Nerthern British Columbia (Belt SL.) }\end{array}$} \\
\hline $\begin{array}{l}\text { Adanac-Adera (Ruby Creek) } \\
(104 \mathrm{~N} 052)\end{array}$ & Porphyry Mo & Mo, W & $59^{\prime} 437 \mathrm{~N}$ & $133^{\prime \prime 2} 4^{\prime} \mathrm{W}$ \\
\hline Mount Ogden (Nan, Moly-Taku) & Porphyry Mo & Mo & $5826 \mathrm{~N}$ & $133^{\prime 2} 22^{\prime} \mathrm{W}$ \\
\hline $\begin{array}{l}\text { Mt. Haskin West (Joem, Rain, } \\
\text { Moly Zone) (104P 059) }\end{array}$ & Porphyry Mo-W, Mo skarn & Mo, w & $5921 \mathrm{~N}$ & $12931 \mathrm{~W}$ \\
\hline $\begin{array}{l}\text { Red Mosotain (Bug, Fox, } \\
\text { Boswell River) }\end{array}$ & Porphyry Mo & Mo & $60^{\prime \prime} 597 \mathrm{~N}$ & $133^{\circ} 44 \mathrm{~W}$ \\
\hline $\begin{array}{l}\text { S.Q.E (Storic, Casmo) (104P } \\
069)\end{array}$ & Porphyry Mo & Mo & $59^{\circ} 15 \mathrm{~N}$ & $129^{\prime} 52^{\prime} \mathrm{W}$ \\
\hline $\begin{array}{l}\text { Sutlahine River Area (Thom, } \\
\text { Kay) (094D 005) }\end{array}$ & Porphyry Cu-Mo & $\mathrm{Cu}, \mathrm{Mo}, \mathrm{Ag}$ & $58^{\prime} 32 \mathrm{~N}$ & $132^{\prime} 47^{\prime \prime W}$ \\
\hline $\begin{array}{l}\text { Windy (Balsam, Star, Kuhn, Dead } \\
\text { Goat) (104P 071; 104P 003; } \\
\text { 104P 079) }\end{array}$ & W skam & W, Mo & $59{ }^{\circ} 21 \mathrm{~N}$ & $129^{\circ} 52^{\prime} \mathrm{W}$ \\
\hline Engineer Mine (104M 014) & Au-Ag Polymetallic Vein & $\mathrm{Au}, \mathrm{Ag}$ & $5429 \mathrm{~N}$ & $134^{\prime \prime} 14^{\prime} \mathrm{W}$ \\
\hline Venus (082FSW 166) & Au-Ag Polymetallic Vein & $\mathrm{Au}, \mathrm{Ag}$ & $49^{\prime} 27^{\prime} \mathrm{N}$ & $117^{\circ} 20^{\prime} \mathrm{W}$ \\
\hline \multicolumn{5}{|c|}{ Central-Southeastern Alaska Metallogenie Belt of Porphyry Mo and Cu Deposits (Oligocene) } \\
\hline Groundhog Basin & $\begin{array}{l}\text { Polymetallic vein(?), Sn granite, } \\
\text { Porphyry Mo }\end{array}$ & $\mathrm{Ag}, \mathrm{Pb}, \mathrm{Zn}$ & $5631 \mathrm{~N}$ & $132^{\circ} 04^{\prime} \mathrm{W}$ \\
\hline Margerie Glacier & $\begin{array}{l}\text { Porphyry } \mathrm{Cu} \text { and lesser } \\
\text { polymetallic vein }\end{array}$ & $\mathrm{Cu}, \mathrm{Ag} . \mathrm{Au}$ & $59^{\circ} 01 \mathrm{~N}$ & $137^{\circ} 05 \mathrm{~W}$ \\
\hline North Bradfield Canal & Fe skam & $\mathrm{Fe}, \mathrm{Cu}$ & $5623 \mathrm{~N}$ & $131 ' 231 \mathrm{~W}$ \\
\hline Nunatak (Muir Inlet) & Porphyry Mo-Cu & Mo & $58^{\circ} 59^{\prime} \mathrm{N}$ & $136^{\circ} 06^{\prime} \mathrm{W}$ \\
\hline Quartz Hill & Porphyry Mo & Mo & $55^{\circ} 24 \mathrm{~N}$ & $130^{\circ} 29^{\prime} \mathrm{W}$ \\
\hline \multicolumn{5}{|c|}{ Bulkley Metallogenic Belt of Porphyry Cu-Mo and Polymetallic Vein Deposits (Late Cretaceous) } \\
\hline $\begin{array}{l}\text { Glacier Gulch (Hudson Bay } \\
\text { Mountain) (093L 110) }\end{array}$ & Porphyry Mo & Mo & $5449 \mathrm{~N}$ & $12718 \mathrm{~W}$ \\
\hline Huckleberry (093E 037) & Porphyry Cu-Mo & $\mathrm{Cu}, \mathrm{Mo}$ & $53^{\circ} 41^{\prime} \mathrm{N}$ & $127^{2} 10^{\prime} \mathrm{W}$ \\
\hline Ox Lake (093E 004) & Porphyry Cu-Mo & $\mathrm{Cu}, \mathrm{Mo}$ & $53411 \mathrm{~N}$ & $127^{\circ} 03^{\prime} \mathrm{W}$ \\
\hline Poplar (0931 239) & Porphyry Cu-Mo & $\mathrm{Cu}, \mathrm{Mo}, \mathrm{Ag}$ & $54^{\prime} 01 \mathrm{~N}$ & $12659 \mathrm{~W}$ \\
\hline Red Rose (093M 067) & W polymetallic vein & $\mathrm{W}, \mathrm{Au}, \mathrm{Cu}, \mathrm{Ag}$ & $55^{\circ} 08^{\prime} \mathrm{N}$ & $12736 \mathrm{w}$ \\
\hline Capoose Lake (093F 040) & Polymetallic vein & $\mathrm{Au}, \mathrm{Ag}, \mathrm{Cu}, \mathrm{Pb}, \mathrm{Zn}$ & $55^{\circ} 08^{\prime} \mathrm{N}$ & $127^{4} 36^{\prime} \mathrm{W}$ \\
\hline $\begin{array}{l}\text { Nadina (Silver Queen) (093L } \\
083 \text { ) }\end{array}$ & Ag polymetallic vein & $\mathrm{Zn}, \mathrm{Pb}, \mathrm{Ag}, \mathrm{Au}, \mathrm{Cu}$ & $54^{\circ} 05 \mathrm{~N}$ & $126^{\prime \prime} 44^{\prime} \mathrm{W}$ \\
\hline
\end{tabular}

Fish Lake-Bralorne Metallogenic Belt of Porphyry Cu-Mo, Porphyry Cu-Au, Au Quartz Vein, and Polymetallic Ag-Au Vein and Related Deposit Types (Late Cretaceous and early Tertiary) Southera British Columbia (Belt FLB)

\begin{tabular}{|c|c|c|c|c|}
\hline $\begin{array}{l}\text { Bralome (092JNE 001), Pioneer } \\
\text { (092JNE 004) (Bridge River } \\
\text { Area) }\end{array}$ & Au-Sb polymetallic vein & Au & $50^{\circ} 477 \mathrm{~N}$ & $122^{\prime} 49^{\prime} \mathrm{W}$ \\
\hline Fish Lake $(0920041)$ & Porphyry Cu-Mo & $\mathrm{Cu}, \mathrm{Au}$ & $5128 \mathrm{~N}$ & $123^{\circ} 38^{\prime} \mathrm{W}$ \\
\hline Giant Copper (Canam, A.M.) & Porphyry $\mathrm{Cu}-\mathrm{Mo}$ & $\mathrm{Cu}, \mathrm{Mo}$ & $49^{\prime \prime} 10^{\prime} \mathrm{N}$ & $121^{\circ} 01 \mathrm{~W}$ \\
\hline Maggie (Bonaparte River) & Porphyry Cu-Mo & $\mathrm{Cu}, \mathrm{Mo}$ & $50^{\circ} 55^{\prime} \mathrm{N}$ & $1211^{\prime 25} \mathrm{~W}$ \\
\hline Poison Mountain (Copper Giant) & Porphyry Cu-Mo & $\mathrm{Cu}, \mathrm{Mo}$ & $51^{\circ} 08 \mathrm{~N}$ & $12237 \mathrm{~W}$ \\
\hline
\end{tabular}
$\frac{(0920046)}{\text { Tyaughton-Yalakem Metallogenic Belt of W-Sb Polymetallic Vein and Ho-Sb Vein Deposits (early Tertiary) }}$ Southern British Columbia (Belt GB)

$\begin{array}{lllll}\text { Tungsten Queen } & \text { W-Sb polymetallic vein and } \mathrm{Hg}- & \mathrm{Hg} & 51^{\prime} 03^{\prime} \mathrm{N} & 1222^{\prime} 49^{\prime} \mathrm{W}\end{array}$
Sb vein 
Gambier Metallogenic Belt of Porphyry Cu-Mo and Ze-Pb-Cu Skarn Deposits (early Tertiary) Seuthern British Columbia (Belt GB)

\begin{tabular}{|c|c|c|c|c|}
\hline Gambier Island (092GNW 025) & Porphyry Cu-Mo & $\mathrm{Cu}, \mathrm{Mo}$ & $4931 \%$ & $12322 \%$ \\
\hline Hi-Mars (Lewis Lake) (092F 292) & Porphyry Cu-Mo & $\mathrm{Cu}_{\mathrm{u}} \mathrm{Mo}$ & $49.57 \mathrm{~N}$ & $124217 \mathrm{~W}$ \\
\hline Lynn Creek (092GSW 003) & $\mathrm{Zn}-\mathrm{Pb}$ skam & $\mathrm{Zn}, \mathrm{Pb}$ & $4925 \mathrm{~N}$ & $123^{7} 047 \mathrm{w}$ \\
\hline O.K. $(092 \mathrm{~K} \quad 00 \mathrm{~B} ; 092 \mathrm{~K}$ 057) & Porphyry Cu-Mo & $\mathrm{Cu}_{1} \mathrm{M}_{0}$ & sofos & $12439 \mathrm{rw}$ \\
\hline
\end{tabular}

Catface Metallogenic Belt of Porphyry Cu-Me-Au and Au-Age Pelymetallic Vein Depesits (Eecene) Vancouver Island (Belt CD)

\begin{tabular}{|c|c|c|c|c|}
\hline Canface $(092 \mathrm{~F} \quad 120)$ & Porphyry Cu-Mo & $\mathrm{Cu}$ & $4915 \mathrm{~N}$ & $12559 \mathrm{~W}$ \\
\hline Domineer-Lakeview (092F 117) & Porplayry Cu-Mo & $\mathrm{Cu}_{1} \mathrm{Mo}_{\mathrm{o}}$ & $4946 \mathrm{~N}$ & $12518 \mathrm{~W}$ \\
\hline Privateer (0921. 008 ) & Polymetallic vein & $\mathrm{Au}, \mathrm{Ag}, \mathrm{Zn}, \mathrm{Cu}, \mathrm{Pb}$ & $5002 \mathrm{~N}$ & $12649 w$ \\
\hline \multicolumn{5}{|c|}{$\begin{array}{l}\text { Skeena Metallogenic Belt of Porphyry Cu-Mo; Porpbyry Mo; Ag Polymetallie Vein and } \\
\text { Au-Ag Epithermal Vein Deposits (carly Tertiary). Central British Columbia (Beit SK) }\end{array}$} \\
\hline Ajax (103P 223) & Porphyry Mo & Mo & $5535 \mathrm{~N}$ & $12924 \mathrm{~W}$ \\
\hline $\begin{array}{l}\text { Bell Copper (Newman) (093M } \\
001)\end{array}$ & Porplayry $\mathrm{Cu}-\mathrm{Au}(\mathrm{Mo})$ & $\mathrm{Cu}, \mathrm{Au}, \mathrm{Ag}$ & $5500 \mathrm{~N}$ & $126^{\circ} 14 \mathrm{~W}$ \\
\hline $\begin{array}{l}\text { Bell Moly (Alice Arm) (103P } \\
\text { 234) }\end{array}$ & Porphyry Mo & Mo, W & $55^{\prime} 28 \mathrm{~N}$ & $129^{\prime} 20 \mathrm{~W}$ \\
\hline Bert (093E 046) & Pooptryry Co-Mo & $\mathrm{Ce}, \mathrm{Mo}_{\mathrm{o}}$ & $5348 \mathrm{~N}$ & $12726 \mathrm{~W}$ \\
\hline Big Onion (093L 124) & Porphyry Cu-Mo & $\mathrm{Cu}, \mathrm{Mo}_{0}$ & $5449 \mathrm{~N}$ & $12654 \mathrm{~W}$ \\
\hline Capoose Lake (093F 040) & Ag-Au polymetallic vein & $\mathrm{Ag}$ & $53^{7} 17 \mathrm{~N}$ & $12510 \mathrm{w}$ \\
\hline Dorothy (093M 009) & Porphyry Cu-Mo & $\mathrm{Ce}, \mathrm{Mo}$ & $55^{\prime} 15 \mathrm{~N}$ & $12610 \mathrm{w}$ \\
\hline $\begin{array}{l}\text { Equity Silver (Sam Goosly) } \\
\text { (093L 00I) }\end{array}$ & Ag polymetallic vein & $\mathrm{Ag}, \mathrm{Cu}$ & $54^{\prime} 11 \mathrm{~N}$ & $12616 \mathrm{~W}$ \\
\hline Granisle (093L 146) & Perplayry Cu-Au (Mo) & $\mathrm{Cu}, \mathrm{Au}, \mathrm{Ag}$ & $5457 \mathrm{~N}$ & $126^{\circ} 09 \mathrm{w}$ \\
\hline Kitsault (BC Moly) (103P 120) & Porphyry Mo & Mo & $55^{\prime} 25 \mathrm{~N}$ & $129^{7} 25 \mathrm{~W}$ \\
\hline Lucky Ship (093L 053) & Porphyry Mo & Mo & $5402 \mathrm{~N}$ & $126^{\prime} 59 \mathrm{w}$ \\
\hline Morrison & Porphyry Cu-Au (Mo) & $\mathrm{Cu}, \mathrm{Ag}, \mathrm{Au}$ & $5511 \mathrm{~N}$ & $12619 \mathrm{~W}$ \\
\hline Mount Thomlioson (093M 050) & Porplryry Mo & Mo & $5535 \mathrm{~N}$ & $127^{\prime} 29 \mathrm{w}$ \\
\hline $\begin{array}{l}\text { Nanika (DW, New Nanik) (09yE } \\
\text { 055) }\end{array}$ & Porphyry Cu-Mo & $\mathrm{Cu}$ & $5345 \mathrm{~N}$ & $12741^{\prime} \mathrm{W}$ \\
\hline $\begin{array}{l}\text { Prosperity-Ponter ldaho (10נP } \\
089 \text { ) }\end{array}$ & $A g-\not b-Z n$ polymetallic vein & $\mathrm{Ag}, \mathrm{Pb}, \mathrm{Zn}$ & $55^{\circ} 55^{\circ} \mathrm{N}$ & $129^{\prime} 56^{\prime} \mathrm{W}$ \\
\hline Redbind (093E 026) & Porphyry Mo & Mo & $53^{\prime 1} 18^{\prime} \mathrm{N}$ & $127^{\circ} 00 \mathrm{w}$ \\
\hline Roundy Croek (tosp |13) & Porphyry Mo & Mo & $55^{\prime} 25^{\prime} \mathrm{N}$ & $129^{\prime} 26^{\prime} \mathrm{W}$ \\
\hline Serb Creck $(0931.083)$ & Porplyry Mo & Mo & $54^{\circ} 39^{\prime} \mathrm{N}$ & $127^{\prime} 45^{\prime} \mathrm{W}$ \\
\hline
\end{tabular}

Neluen Metallogenic Beit of Ag Polymetallic Veie; Ag-Pb-Zn Maate; Au-Ag Epithermal Vein, Perphyry Me, Paleeplacer U sad Depesits (Eecene), Seuthern British Columbia (Belt NS)

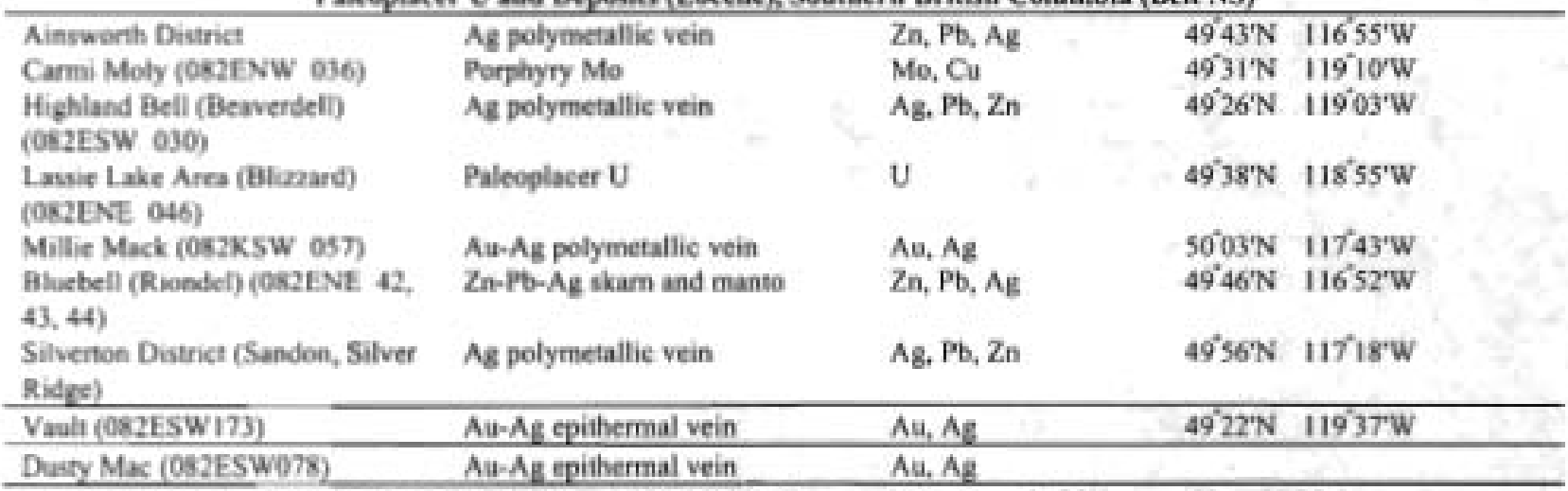

EARLY TO MIDDLE TERTIARY (Middle Eecene through early Miocene - 52 to $23 \mathrm{Ma}$ )

Central Sakhalin Metallegenic Belt of Au Quartx Veie and Tale Deposits Cu Depesits (early Tertiary) Russian Southeast (Belt CS)

\begin{tabular}{|c|c|c|c|c|}
\hline Langeriiskoe & Au quartz vein & $\mathrm{Au}$ & $5011 \mathrm{~N}$ & $14304 \mathrm{E}$ \\
\hline Sredian & $\begin{array}{l}\text { A wo Quartz Veis and Met } \\
\text { East-Ceatral Part ef Res }\end{array}$ & $\begin{array}{l}\text { ic REE } \\
\text { rtheast }\end{array}$ & Deposits & \\
\hline Temannoe & Au quartz vein & Au & $54211 \mathrm{~N}$ & $15723 \mathrm{E}$ \\
\hline Anomalnoe & Meramorphic REE vein(7) & $\mathrm{Ta} . \mathrm{Nb}$ & $5404 \mathrm{~N}$ & $15724 \mathrm{E}$ \\
\hline
\end{tabular}


Kvinumsky Metallogenic Belt of Hornblende Peridotite and Gabbroic Ni-Cu Deposits (early Tertiary) Russian Southeast (Bell KV)

\begin{tabular}{|c|c|c|c|c|}
\hline $\begin{array}{l}\text { Kuvalorog } \\
\text { Kvinum } \\
\text { Shanuch }\end{array}$ & $\begin{array}{l}\text { Homblende peridotite } \mathrm{Cu}-\mathrm{Ni} \text {. } \\
\text { Gabbroic } \mathrm{Cu}-\mathrm{Ni} \\
\text { Homblende peridotite } \mathrm{Cu}-\mathrm{Ni} \text {. }\end{array}$ & $\begin{array}{l}\mathrm{Cu}, \mathrm{Ni} \\
\mathrm{Ni}, \mathrm{Cu}, \mathrm{Co}, \mathrm{Au}, \mathrm{Pt} \\
\mathrm{Ni}, \mathrm{Cu}, \mathrm{Co}, \mathrm{Au}, \mathrm{Pt}\end{array}$ & $\begin{array}{l}53^{\prime} 28 \mathrm{~N} \\
53^{2} 38 \times \mathrm{N} \\
55^{\prime} 09 \mathrm{~N}\end{array}$ & $\begin{array}{l}157^{\circ} 24 \mathrm{E} \\
157^{\circ} 02 \mathrm{E} \\
157^{\circ} 12 \mathrm{E}\end{array}$ \\
\hline \multicolumn{5}{|c|}{$\begin{array}{c}\text { Central Keryak Metallegenic Belt of Igneous Are Deposits (Late Cretaceous and early Tertiary) } \\
\text { East-Central Part of Russian Northeast (Belt CKY) }\end{array}$} \\
\hline Agranai & Volcanic-hosted $\mathrm{Hg}$ & $\mathrm{Hg}$ & $6353 \mathrm{~N}$ & $173100 \mathrm{E}$ \\
\hline Ainatvetkin & Sn polymetallic vein & $\mathrm{Sn}, \mathrm{Ag}$ & $6058 \mathrm{~N}$ & $165^{\prime} 17 \mathrm{E}$ \\
\hline Ametistovoe & Au-Ag epithernal vein & $\mathrm{Au}, \mathrm{Ag}$ & $6179 \mathrm{~N}$ & $16449 \mathrm{E}$ \\
\hline Berezovaya & Sn polymetallic vein & $\mathrm{Sn}$ & $63^{\circ} 600 \mathrm{~N}$ & $173^{\prime} \mathrm{S} 2 \mathrm{E}$ \\
\hline Ivolga & Epithermal vein & $\mathrm{Ag}, \mathrm{Sn}$ & $61^{\circ} 16 \mathrm{~N}$ & $165^{\circ} 21 \mathrm{E}$ \\
\hline Khrustal (Khrustalnoe) & Sn polymetallic vein & $\mathrm{Sn}$ & $6128 \mathrm{~N}$ & $167^{*} 10 \mathrm{E}$ \\
\hline Krassnaya Gorka & $\begin{array}{l}\text { Clastic sediment-bosted } \mathrm{Hg} \text { of } \\
\text { bot-spring } \mathrm{Hg} \text { ? }\end{array}$ & $\mathrm{Hg}$ & $6 \mathrm{l}^{\prime} 54 \mathrm{~N}$ & $168^{\circ} 48 \mathrm{E}$ \\
\hline Kuibiveen & Porphyry Cu-Mo & $\mathrm{Mo}, \mathrm{Cu}, \mathrm{Au}$ & $62^{\prime \prime} 437 \mathrm{~N}$ & $1700^{\circ} 06^{\prime} \mathrm{E}$ \\
\hline Lalankytap & Porphyry Cu-Mo & $\mathrm{Mo}, \mathrm{Cu}$ & $6209 \mathrm{~N}$ & I73"11'E \\
\hline Lamut & Volcanic-bosted $\mathrm{Hg}$ & $\mathrm{Hg}$ & $6405 \mathrm{~N}$ & $172^{\circ} 60 \mathrm{E}$ \\
\hline Lyapganat & $\begin{array}{l}\text { Clastic sediment-hosted } \mathrm{Hg} \text { or } \\
\text { hot-spring } \mathrm{Hg}_{\mathrm{g}}\end{array}$ & $\mathrm{Hg}, \mathrm{Sb}$ & $61^{\prime} 34 \mathrm{~N}$ & $168^{\circ} 0 I^{\circ} \mathrm{E}$ \\
\hline Neptun & $\begin{array}{l}\text { Clastic sediment-hosted } \mathrm{Hg} \text { of } \\
\text { bot-spring } \mathrm{Hg}_{\mathrm{g}} \text { ? }\end{array}$ & $\mathrm{Hg}, \mathrm{Sb}, \mathrm{As}$ & $61400 \mathrm{~N}$ & $168^{\prime \prime} 16^{\prime} \mathrm{E}$ \\
\hline Orlovka & Epithermal vein & $\mathrm{Au}, \mathrm{Zn}, \mathrm{Cu}, \mathrm{Hg}$ & $6400 \mathrm{~N}$ & $168^{\prime \prime} 34^{\prime} \mathrm{E}$ \\
\hline Parkhonai & $\begin{array}{l}\text { Sn polymetallic vein and Sn } \\
\text { silicate-sulfide vein }\end{array}$ & $\mathrm{Sn}$ & $6404 \mathrm{~N}$ & $1733^{\circ} 18^{\prime} \mathrm{E}$ \\
\hline Pervenets & Silica-carbonate $\mathrm{Hg}_{g}$ & $\mathrm{Hg}, \mathrm{As}_{3}, \mathrm{Sb}$ & $63^{\prime} 28 \mathrm{~N}$ & $173^{\circ}$ SI'E \\
\hline Reznikov & Sn polymetallic vein & $\mathrm{Sn}, \mathrm{Ag}, \mathrm{Au}$ & $6050 \mathrm{~N}$ & $164^{\prime \prime} 39^{\prime} \mathrm{E}$ \\
\hline Rzhavy & Porphyry Cu-Mo & $\mathrm{Cu}, \mathrm{Mo}, \mathrm{Au}$ & $65^{\circ} 47 \mathrm{~N}$ & $165^{\circ} 06^{\prime} \mathrm{E}$ \\
\hline Sprut & Au-Ag epithermal vein & $\mathrm{Ag}, \mathrm{Au}$ & $61^{\circ} 2 \mathrm{LN}$ & $165^{\circ} 07^{\circ} \mathrm{E}$ \\
\hline Tamvatney & Silica-carbonate $\mathrm{Hg}$ & $\mathrm{H}_{2}, \mathrm{~W}, \mathrm{As}$ & $6329 \mathrm{~N}$ & $17413{ }^{\prime} \mathrm{E}$ \\
\hline Unnei & Sn polymetallic vein & $\mathrm{Sn}, \mathrm{Ag}, \mathrm{Au}$ & $61^{1} 31 \mathrm{~N}$ & $166^{\circ} 07^{\prime} \mathrm{E}$ \\
\hline
\end{tabular}

Olyuter Metallogenic Belt of Ignenus-Are-Related Deposits (late Paleogene, Miocene, and Pliocene) Kamchatka Peninsula (Belt OT)

\begin{tabular}{|c|c|c|c|c|}
\hline $\begin{array}{l}\text { Maletoivayam } \\
\text { Olyutor }\end{array}$ & $\begin{array}{l}\text { Sulfur-sulfide } \\
\text { Clastic sediment-hosied } \mathrm{Hg} \text { or } \\
\text { hot-spring } \mathrm{Hg} \text { ? }\end{array}$ & $\begin{array}{l}\mathrm{S} \\
\mathrm{Hg}, \mathrm{Sb}, \mathrm{As}\end{array}$ & $\begin{array}{l}60 \% 26 \mathrm{~N} \\
6035 \mathrm{~N}\end{array}$ & $\begin{array}{l}164^{\prime} 23^{\prime} \mathrm{E} \\
167^{\prime} 49^{\prime} \mathrm{E}\end{array}$ \\
\hline \multicolumn{5}{|c|}{$\begin{array}{c}\text { Pinchi Lake Metallogeaic Belt of Hg Epithermal Vein, Sb-Au Vein, Stica-Carbonate } \mathrm{Hg}_{\mathrm{g}} \text { Deposits } \\
\text { (Oligocene and Miocene), Central British Columbia (Belt PC) }\end{array}$} \\
\hline Pinchi Lake & Silica-carbonate $\mathrm{Hg}$ & $\mathrm{Hg}$ & $5438 \mathrm{~N}$ & $12426 \mathrm{~W}$ \\
\hline \multicolumn{5}{|c|}{$\begin{array}{l}\text { Owl Creek Metallogenic Belt of Porphyry Cu-Mo; Porphyry Mo and Au Polymetallie Vein Deposits } \\
\text { (Oligocene and Miocene), Southern British Columbia (Belt OC) }\end{array}$} \\
\hline $\begin{array}{l}\text { Clear Creek (Gern) (092HNW } \\
\text { 001) }\end{array}$ & Porphyry Mo & Mo & $49^{\circ} 437 \mathrm{~N}$ & $\left.12\right|^{\prime} 43^{\prime} \mathrm{W}$ \\
\hline $\begin{array}{l}\text { Owl Creek district (092)SE } 004 \text {, } \\
006,007)\end{array}$ & Porphyry Cu-Mo & $\mathrm{Cu}_{\mathrm{u}} \mathrm{Mo}_{\mathrm{O}}$ & $5023 \mathrm{~N}$ & $122^{\circ} 45^{\circ} \mathrm{W}$ \\
\hline Salal Creek (092JW 005) & Porphyry Mo & Mo & $50^{\circ} 46 \mathrm{~N}$ & $123^{\circ} 24 \mathrm{~W}$ \\
\hline \multicolumn{5}{|c|}{ MIDDLE TERTLARY (Miocene - 20 to $10 \mathrm{Ma}$ ) } \\
\hline \multicolumn{5}{|c|}{$\begin{array}{c}\text { East Kamchatka Metallogenic Belt of } A u-A g \text { Epithermal Deposits (Miocene) } \\
\text { Central and Southern Kamehatka Peninsula (Belt EK) }\end{array}$} \\
\hline Asachinskoe & Au-Ag epithermal vein & $\mathrm{Au}_{,} \mathrm{Ag}, \mathrm{Se}$ & $5208 \mathrm{~N}$ & $157^{\prime} 54^{\prime} \mathrm{E}$ \\
\hline Kitkhoi & Au-Ag epithermal vein & $\mathrm{Au}, \mathrm{Ag}, \mathrm{Zn}, \mathrm{Ph}$ & $53^{\circ} 26 \mathrm{~N}$ & $158^{\circ} 17^{\prime} \mathrm{E}$ \\
\hline Kumroch & $\mathrm{Au}-\mathrm{Ag}$ epithermal vein & $\mathrm{Au}, \mathrm{Ag}, \mathrm{Cu}, \mathrm{Pb}, \mathrm{Zn}$ & $55^{\circ} 40 \mathrm{~N}$ & $161^{\circ} 10^{\prime} \mathrm{E}$ \\
\hline Mumovskee & Au-Ag epithermal vein & $\mathrm{Au}, \mathrm{Ag}, \mathrm{Ca}, \mathrm{Zn}, \mathrm{Pb}$ & $52447 \mathrm{~N}$ & $158^{\circ} 24 \mathrm{E}$ \\
\hline Rodrikowpe & $\mathrm{Au}-\mathrm{Ag}$ epithermal vein & $\mathrm{Au}, \mathrm{Ag}$ & $52^{\prime \prime} 50^{\prime} \mathrm{N}$ & $158^{\prime} 16^{\prime} \mathrm{E}$ \\
\hline
\end{tabular}


Central Kamchatka Metallogeale Belt of All-Ag Epithermal and Porphyry Cu-Me Depesits (middle and late Tertiary) Kamehatka Peainsula (Belt CK)

\begin{tabular}{|c|c|c|c|c|}
\hline Aginskoe (Aga) & Atb-Ag epithermal vein & Ail, Ag. Te & $5531 \mathrm{~N}$ & $157^{\prime} 52^{\circ} \mathrm{E}$ \\
\hline Baran'evskoe & Au-Ag epithermal vein & Au, AE & $55^{\circ} 06 \mathrm{~N}$ & $158^{\circ} 13 \mathrm{E}$ \\
\hline Chempura & Volcanic hosted $\mathrm{Hg}$ & $\mathrm{Hg}$ & $5612 \mathrm{~N}$ & $15918 \mathrm{E}$ \\
\hline Krasnogorskoe & Porphyry Cu-Mo & Mo & $53^{2} 58 \mathrm{~N}$ & $157^{\prime} 28^{\prime} \mathrm{E}$ \\
\hline Oganchinskee & Al-AE epithermal vein & $\mathrm{Au}, \mathrm{Ag}$ & $5457 \mathrm{~N}$ & $157^{\circ} 46 \mathrm{E}$ \\
\hline Ozernovskoe & As-Ag epithermal vein & Au, AE, Te & $5735 \mathrm{~N}$ & $160^{\prime} 47 \mathrm{E}$ \\
\hline Sukharikovskie Grebai & Au-Ag epithermal vein & $\mathrm{Au}, \mathrm{Ag}$ & $5540 \mathrm{~N}$ & $158^{\prime} 39^{\prime} \mathrm{E}$ \\
\hline Tutkhlivayam & Au-Ag epithermal vein & $\begin{array}{l}\mathrm{Au}_{1} \mathrm{Ag}, \mathrm{Cu}_{2} \mathrm{~Pb}, \mathrm{Zn}_{4} \\
\mathrm{Te}, \mathrm{Cd}\end{array}$ & $59^{\circ} 04^{\prime} \mathrm{N}$ & $161^{\circ} 44 \mathrm{E}$ \\
\hline Zolotoi & At-Ag epithermal vein & $\mathrm{Ali}_{2} \mathrm{Ag}$ & $55^{\prime} 03^{\prime} \mathrm{N}$ & $158^{\prime \prime} 21^{\prime} \mathrm{E}$ \\
\hline \multicolumn{5}{|c|}{$\begin{array}{l}\text { Alaska Peainsula and Aleutian Islands Metallegenie Beit of Igneous Are Deposits (middle Tertiary) } \\
\text { Western-Southern Alaska (Belt AP) }\end{array}$} \\
\hline Apollo-Sitka & Atr-Ag epithemal vein & $\mathrm{Au}_{\mathrm{s}} \mathrm{A}_{\mathrm{H}}, \mathrm{Pb}_{\mathrm{b}}, \mathrm{Zn}, \mathrm{Cu}_{\mathrm{u}}$ & $55^{\prime} 12^{\prime} \mathrm{N}$ & $160^{\prime} 37^{\prime} \mathrm{W}$ \\
\hline Aquila & Au-Ag epithermal vein & $\mathrm{Au}, \mathrm{Ag}$ & $5511 \mathrm{~N}$ & $160^{\prime} 40^{\prime} \mathrm{W}$ \\
\hline Bee Creek & Porphyry $\mathrm{Cu}$ & $\mathrm{Cu}, \mathrm{Au}$ & $5631^{\prime} \mathrm{N}$ & $158^{\circ} 24^{\circ} \mathrm{W}$ \\
\hline Canve Bay & Atu-Ag epithermal vein & $\mathrm{Au}_{\mathrm{B}} \mathrm{A}_{\mathrm{B}}$ & $55^{\prime} 35^{\prime} \mathrm{N}$ & $1611^{\circ} 16 \mathrm{~W}$ \\
\hline Cathedrai Creek, Braided Creek & Polymetallic vein & $\mathrm{Cu}, \mathrm{As}, \mathrm{Zn}, \mathrm{Pb}$ & $5630 \mathrm{~N}$ & $158^{\circ} 44^{\prime} \mathrm{W}$ \\
\hline Fog Lake (Pond) & As-Ag epithemal vein & $\mathrm{Au}_{4} \mathrm{Cu}_{3} \mathrm{Ag}$ & $5931 \mathrm{~N}$ & $15423 \mathrm{~W}$ \\
\hline Kawisgag (Ivanof) & $\begin{array}{l}\text { Porphyry } \mathrm{Cu} \text { and (or) } \\
\text { polymetallic vein }\end{array}$ & $\mathrm{Cu}, \mathrm{Mo}, \mathrm{As}$ & $55^{\circ} 57 \mathrm{~N}$ & $15924^{\circ} \mathrm{W}$ \\
\hline Kilokak Creek & Polymetallic vein( 7$)$ & $\mathrm{Pb}, \mathrm{Zn}$ & $5711 \mathrm{~N}$ & $15624^{\prime} \mathrm{W}$ \\
\hline Kuy & Au-Ag epithermal veis & $\mathrm{Au}_{\mathrm{A}} \mathrm{A}_{\mathrm{H}} \mathrm{CH}$ & $59^{\circ} 16^{\prime} \mathrm{N}$ & $15438 \cdot \mathrm{W}$ \\
\hline Mallard Duck Bay & $\begin{array}{l}\text { Porphyry Cu-Mo and(or) } \\
\text { polymetallic vein(?) }\end{array}$ & $\mathrm{Cu}_{\mathrm{a}} \mathrm{Mo}$ & $5614 \mathrm{~N}$ & $15830 \mathrm{~W}$ \\
\hline Mike & Porphyry Mo & Mo & $5703 \mathrm{~N}$ & $157^{\circ} 13^{7} \mathrm{~W}$ \\
\hline Pyramid & Porphyry $\mathrm{Cu}$ & $\mathrm{Cu}, \mathrm{Au}$ & $55^{\prime} 37 \mathrm{~N}$ & $160^{\circ} 41^{\prime} \mathrm{W}$ \\
\hline Rex & Porphyry $\mathrm{Cu}$ & $\mathrm{Cu}, \mathrm{Au}$ & $5712 \mathrm{~N}$ & $15700 \mathrm{~W}$ \\
\hline San Diego Bay & Atr-Ag epithermal vein(7) & $\mathrm{Al}, \mathrm{Au}, \mathrm{Cu}, \mathrm{Pb}, \mathrm{Zn}$ & $5534 \mathrm{~N}$ & $160^{\circ} 27 \mathrm{~W}$ \\
\hline Sedanka (Biorka) & Polymetallic vein & $\mathrm{Zn}, \mathrm{Pb}, \mathrm{Cu}$ & $5345 \mathrm{~N}$ & $16610 \mathrm{w}$ \\
\hline Shamagin & Au-Ag epithermal vein & $A u, A_{g}$ & $5512 \mathrm{~N}$ & $16035 \mathrm{~W}$ \\
\hline Warner Bay (Prospect Bay) & Porphyry $\mathrm{Cu}$, Polymatallic vein & $\mathrm{Cu}, \mathrm{Ma}, \mathrm{Pb}, \mathrm{Za}$ & $5610^{\prime} \mathrm{N}$ & $15820 \mathrm{~W}$ \\
\hline \multicolumn{5}{|c|}{ LATE TERTIARY and QUATERNARY (Pliecese through Present -4 to $0 \mathrm{Ma}$ ) } \\
\hline \multicolumn{5}{|c|}{$\begin{array}{l}\text { Sakhalin Island Belt of Silica-Carbenate and Velcanic-Hested } \mathrm{Hg} \text { Depesits (late Tertiary) } \\
\text { Kuril Islands, Sakhalin Island, Russian Far East (Belt SH) }\end{array}$} \\
\hline In' River & Volcanic-hosted $\mathrm{H}_{\mathrm{s}}$ & $\mathrm{W}, \mathrm{Hg}, \mathrm{Cu}$ & $5033 \mathrm{~N}$ & $14232 \mathrm{E}$ \\
\hline Invkoe & Voleanic-bosted $\mathrm{He}$ & $\mathrm{He}$ & $4852 \mathrm{~N}$ & $14238 \mathrm{E}$ \\
\hline Ostrinskoe & Silica-carbonate $\mathrm{Hg}_{\mathrm{g}}$ & $\mathrm{Hg}$ & $4944 \mathrm{~N}$ & $143^{7} 12 \mathrm{E}$ \\
\hline Svetlowioe & Silica-cartomate $\mathrm{Hg}$ & $\mathrm{Hg}_{\mathrm{g}}$ & $5009 \mathrm{~N}$ & $143^{\prime} 23 \mathrm{E}$ \\
\hline Yaunoe & Silica-carbonate $\mathrm{Hg}$ & $\mathrm{H}_{2}$ & $500387 \mathrm{~N}$ & $14227 \mathrm{E}$ \\
\hline
\end{tabular}

Kuril Metallozenic Belt of Aa-Az Epithermal Vein, Cu-Pb-Zn Polymetallic Vein, Sn silica-sulfide vein, Se Vein, Sulfar-sulfide (Velcanic S), Kareko Massive Sulfide, and Perphyry Mo Depesits (middle Tertiary te Helecene) Kuril Islands, Fast-Central Part of Russian Far East (Belt KU)

\begin{tabular}{|c|c|c|c|c|}
\hline Carpiniky Calden & Porphyry Mo & Mo & $5010 \mathrm{~N}$ & $15528 \mathrm{E}$ \\
\hline Dushnoe & Cu-Pb-Zn polymetallic vein & $\mathrm{Ca}, \mathrm{Zn}, \mathrm{Pb}$ & $46587 \mathrm{~N}$ & $152^{\circ} 04 \mathrm{E}$ \\
\hline Ebeko & Selfirr-sulfide & $\mathrm{S}, \mathrm{FeS}_{2}$ & $50^{\circ} 38 \mathrm{~N}$ & I56 O3E \\
\hline Ciolovninukee & Sulfur-sulfide. & S, FeS & $43^{\prime} 53 \mathrm{~N}$ & $145^{\prime} 36 \mathrm{E}$ \\
\hline Koshkina & Polymetallic vein & $\mathrm{Cu}, \mathrm{Zn}, \mathrm{Pb}$ & $50 \% 44 \mathrm{~N}$ & $15616 \mathrm{E}$ \\
\hline Krishtofovich Volcano & Selfur-sulfide & S, $\mathrm{FeS}_{2}$ & $4547 \mathrm{~N}$ & $149^{\circ} 43 \mathrm{E}$ \\
\hline Novee & Sulfur-sulfide & S, $\mathrm{FeS}_{l}$ & $4456 \mathrm{~N}$ & $147 / 30 \% \mathrm{E}$ \\
\hline Prasolovskoe & Au-As epithermal vein & $A=A B$ & $4419 \mathrm{~N}$ & $146^{\circ} 05 \mathrm{~V}$ \\
\hline Reidovike & Porphyry Mo & Mo & $45^{\prime} 12 \mathrm{~N}$ & $148^{\prime} \mid 2 \mathrm{E}$ \\
\hline Rifovee & Au- $\mathrm{Pb}-\mathrm{Zn}$ epithermal vein & $\mathrm{Au}, \mathrm{Zn}, \mathrm{Pb}$ & $5024 \mathrm{~N}$ & $156^{\circ} 02^{\prime} \mathrm{E}$ \\
\hline Rednikovskoe & Sn silicate-sulfide vein & $\mathrm{Sn}, \mathrm{Pb}, \mathrm{Zn}_{\mathrm{n}}$ & $44^{\prime} 37 \mathrm{~N}$ & $147^{\prime} 22^{\prime} \mathrm{E}$ \\
\hline Sernaya River & Au epithermal vein & $\mathrm{Au}, \mathrm{Zn}, \mathrm{Cu}$ & $45^{1} 10 \mathrm{~N}$ & $148^{\circ} 02^{\prime} \mathrm{E}$ \\
\hline Sofya & Au epithermal vein & $\mathrm{Al}$ & $4527 \mathrm{~N}$ & $148^{\prime} 431 \mathrm{E}$ \\
\hline Spiridonovikoe & Sn polymetallic vein & $\mathrm{Sn}, \mathrm{Pb}, \mathrm{Zn}$ & $4401 \mathrm{~N}$ & $14545 \mathrm{E}$ \\
\hline Tet'yaevskoe & $\mathrm{Cu}-\mathrm{Pb}-\mathrm{Zn}$ polymetallie vein & $\mathrm{Cu}, \mathrm{Zn}, \mathrm{Pb}$ & $4541^{\prime} \mathrm{N}$ & $149^{\prime} 35^{\prime} \mathrm{E}$ \\
\hline
\end{tabular}




\section{Deposit Name}

Valentinovskoe

Vysokee

Zaonernoe

\section{Mineral Depusit Medel}

Kuroko $\mathrm{Cu}-\mathrm{Pb}-\mathrm{Zn}$ massive sulfide

Sulfur-sulfide

Sulfur-sulfide
Major Metals

$\mathrm{Cu}, \mathrm{Pb}, \mathrm{Zn}$

5, $\mathrm{FeS}_{2}$

S, FeS
Latitude N; Longitude E, W.

$44^{\prime} 12 \mathrm{~N} \quad 145^{\prime} 58^{\circ} \mathrm{E}$

$45^{\circ} 017 \mathrm{~N} \quad 147^{\prime} 54^{\prime} \mathrm{E}$

$50^{\prime \prime} 30 \mathrm{~N} \quad 156^{\circ} 02 \mathrm{E}$ 